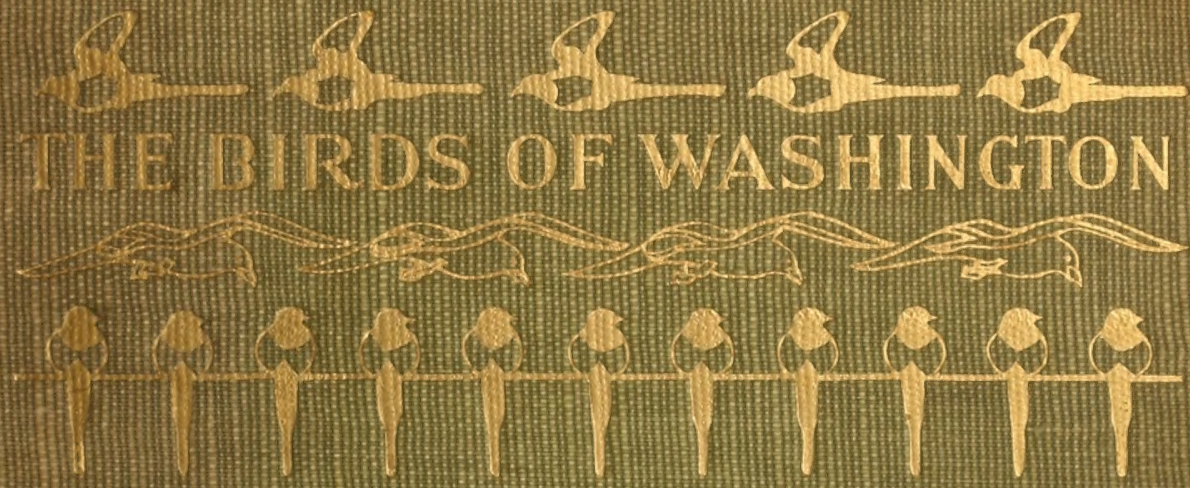




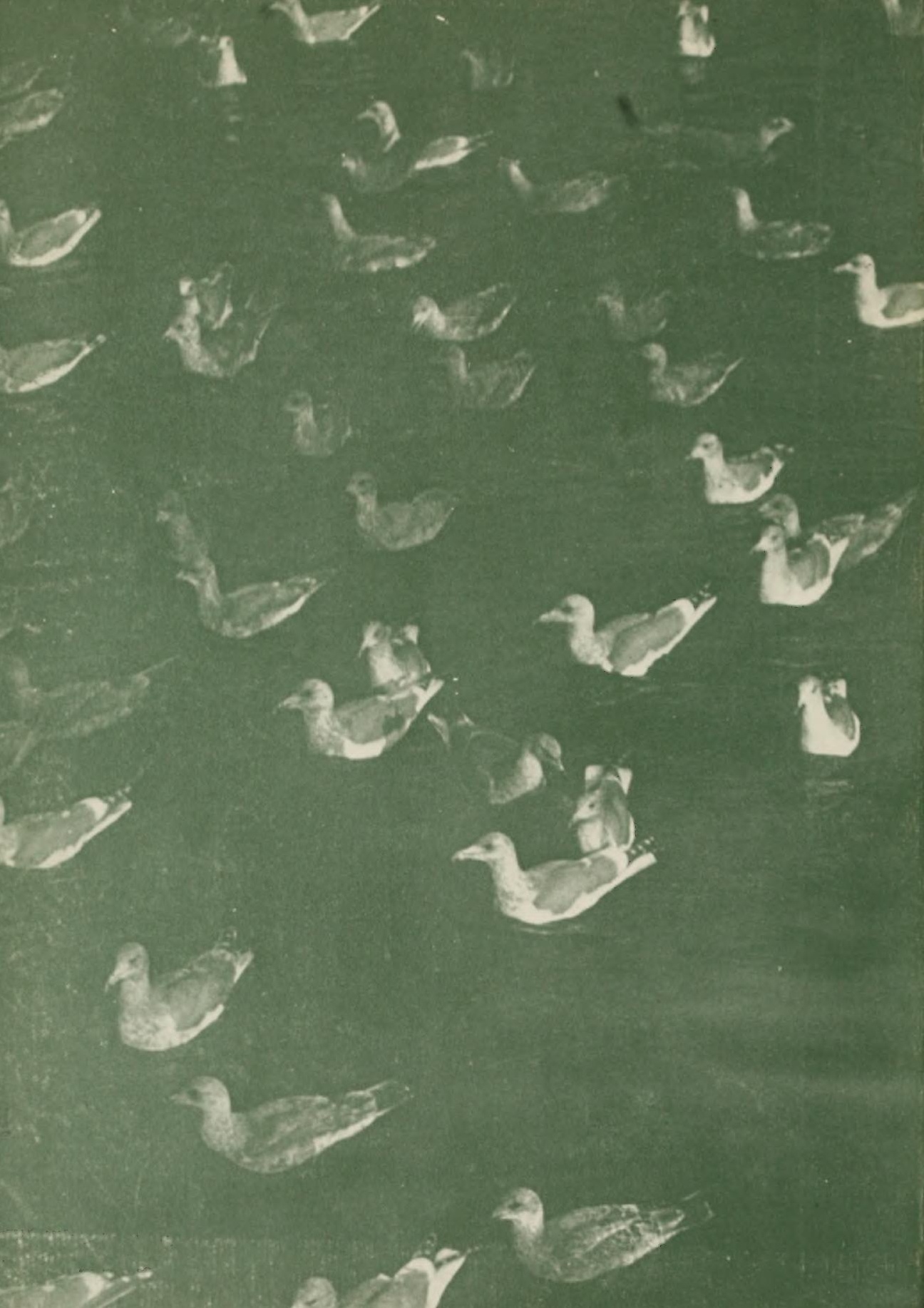




$$
33.5^{5}
$$






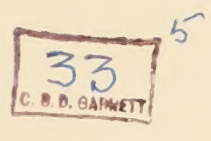

The Birds of Washington 

Of this work in all its editions 1250 copies have been printed and the plates destroyed.

Of the British Columbia Edition 55 sets have been printed and bound, of which this copy is No. 8 . 




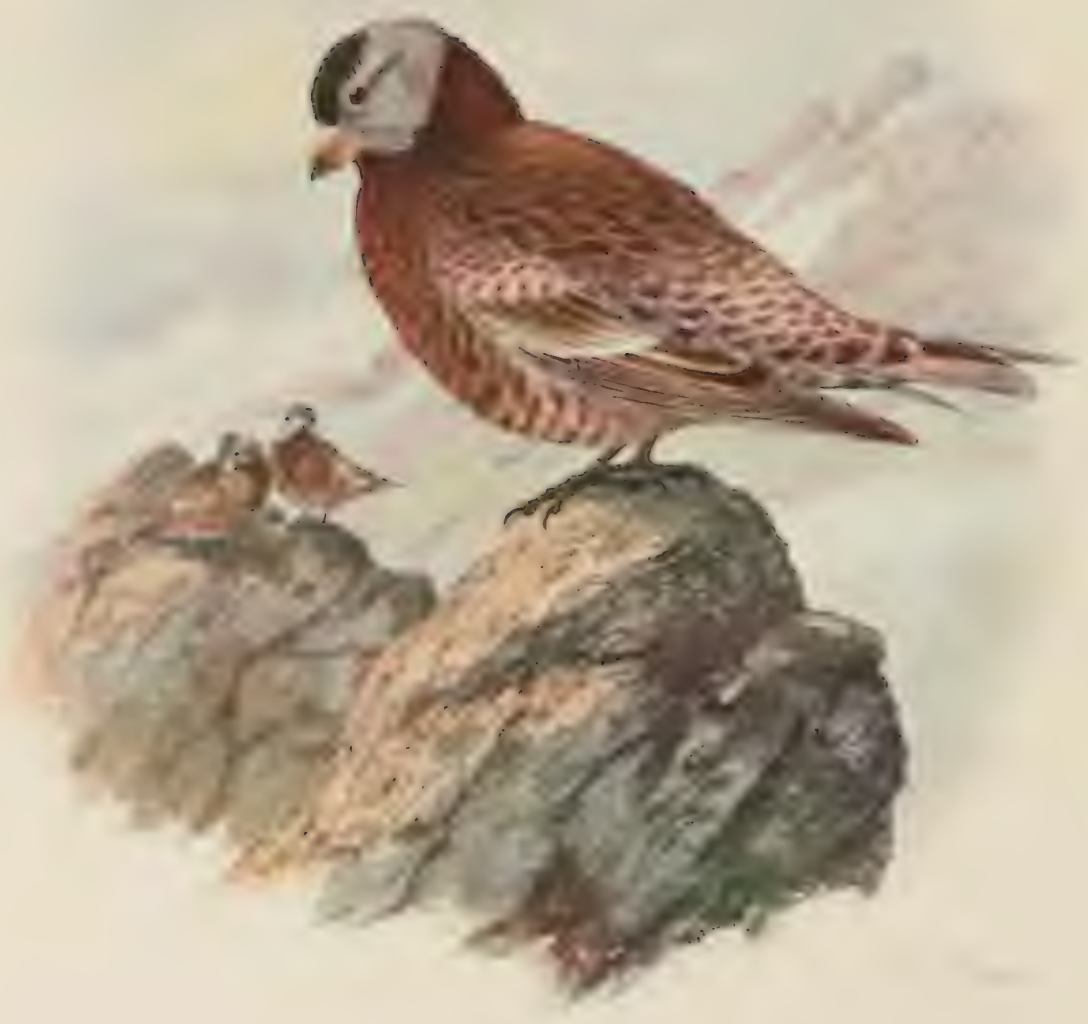




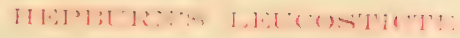

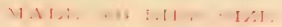

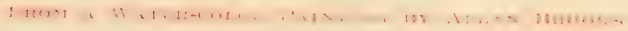




\section{THE BIRDS OF WASHINGTON}

A COMPLETL. SCIENTIFIC AND

POPLLAR ACCOLNT' OF THE 3T2 SPECIES OF IBIRDS

FOUND IN THE STATE

BY

WILLIA.M LEON I)AWSON, A. M., B. D., of Seattle AUTHOR OF "THE BIRDS OF OHIO"

ASSISTED BY

JOHN HOOPER BOWLES, of Tacoma

ILLUSTRATID WY MORE THAN 300 ORIGINAL, HALF-TONFS OF IHRIOS TA LIFE. NESTS,

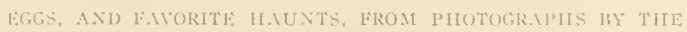
IUTHOR AND OTHERS.

TOGETHIR WITH tO DRAWIXGS IN THE THAT AND A SLRIES OF
LELL-LAGL COLOR-PLATFS.

BY

ALLAN BROOKS

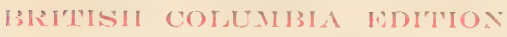

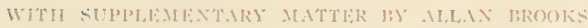

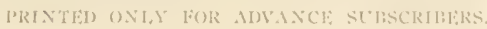

VOLUME I

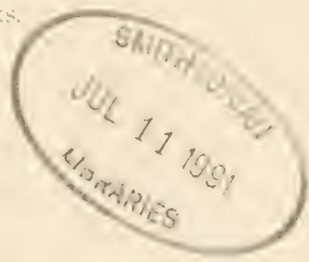

SIEAT'TIE

THE OCCIDENTAL PUBLISHING CO.

1909

A1.T. RIGIITS RFSFRVID 


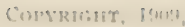

แบ

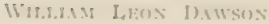

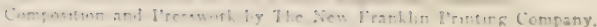

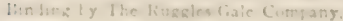


To the

\section{Bembers}

of the

\section{caurinus club,}

in grateful recognition of their friendly

services, and in expectation that

under their leadership the interests

of ornithology will prosper in

the Pacific Northwest,

this work is respectfully

\section{Dcoicatco}





\title{
EXPLANATORY.
}

\author{
T:ABLE OF COMPARISONS.
}

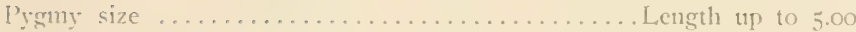

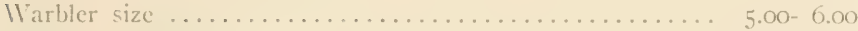

Sparrow size ............................ $6.00-7.50$

Chewink size ....................... $7.50-9.00$

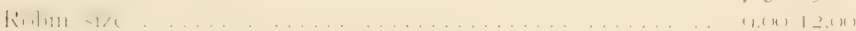

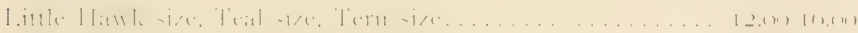

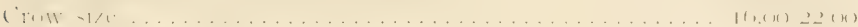

Gull size, lirant size...................... 22.00-30.00

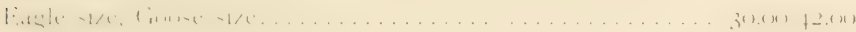

Giant size . . . . . . . . . . . . .

Ileasurements are given in inches and hundredths and in millimeters, the latter enclosed in parcntheses.

\section{KEL OF ABLREVIATIONS.}

References under Authorities are to faunal lists, as follows:

"1. Townend, Catalog of 13ircls, Narrative, I830. pp. 331-335.

cis. Cooper and Suckley, Rep. Pac. R. R. Surv. Vol. Xil., [1t. II., i\&6o, pp. 140-287.

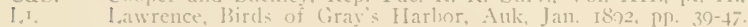

1.2. Iawrence, Finther Notes on Bircls of Giray's Harbor, Ank. Oct. I8n2, pp. 352-357.

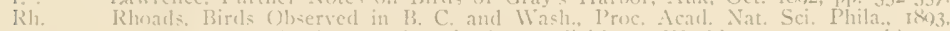
pp. 21-t5. (Only records referring explicitly to Washington are noted.)

Di. T)awson, Bircls of Okanogan County, Auk. Apr, I89\%, Jp, 1(8-182,

Sr. Suyder, Notes on a Few Species. Auk, July Io00, pp, 242-245.

Kl). Kohbe, Birds of Cape Disappointment, Auk, Oct. I900, pp. 349-358,

Ra. Rathlin, Iand Birds of Seattle, Auk, Apr. 1002, pp. 131-T.4.

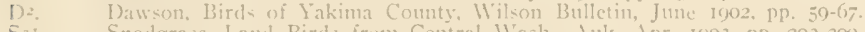

Sis. Smodgrass, I, and Birds from Central Wash., Auk. Apr. roo3. pp. 202-200.

Si2. Snodgrass, I,and Birds Central and Southeasicrn IVash., Ank, Apr. 1004. pp. 223-

Kk. Keck. Birds wi Olympia. Nilson 13ulletin, June I904, pi). 33-35.

J. Johnson. Birds of Cliency. Condor. Jan. 1906. [P]. 25-28.

B. Howles, Birils of Tacoma. Auk, Apr. 1000, pp. I38-1 fo

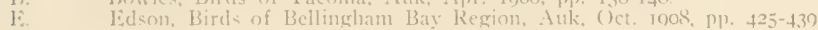

For fuller account of these lists see Bibliograply in Vol. II.

References under Specimens are to collections, as follows:

L. of IV. Luiversity of 11 ashineton Collection: (U. of 11 .) indicates lack of Incality dam. I'. Pullman (State College) Collection. P'x indicntes local specimen.

Prov. Collecton Provincial Museum. Victoria, B. C.

D. Collection C. IV \& J. H. Bowles. Only Washington specimens are listed.

C. Cantwell Collection.

BN. Collection Bellingham Normal School.

E. Collection J. M. T:d=on. 



\section{PREFACE.}

Love of the bircls is a natural passion and one which refuires neither analysis nor defense. The birds live, we live: and life is sufficient answer tmo iife. Int humanity, unfortunately, has had until recently other less justifiable interests-that of lighting pre-eminent among them-so that ont of a gory past only a few shadowy names of lirrl-lovers emerge. Aristotle. I'Jiny the Eilcler, . Tilian. (Ornithology as a science is modern. at best not over two centuries and a lualf old. while as a pojular pursuit its age is better reckoned by decales. It is, therefore, highly gratifying to those who feel this primal instinct strongly to be able to note the rising ticle of interest in their favorite stucly. () ruithology has received nnwonted attention of late, not only in scientific works but also in popular literature, and it has taken at last a cleserved place upon the curriculum of many of on colleges and seconclary schools.

We of the West are just waking not too tardily we hope, to a realization of cur priceless heritage of friendship in the birds. Our homesteads have been chosen and our rights to them established: now we are looking about us to take acconnt of our situation, in see whether indeed the lines have fallen unto us in pleasant places. and to reckon up the forces which make for happiness, welfare. and peace. Ind not the least of our resources we tind to be the bircls of 11 as hingerton. 'They are here as econonnic allies, to hear their part in the distribution of plant life, and to wage with ths unceasing warfare against insect and rosfent foce, which woukd threaten the beneficence of that life. They are here, some of theme. to supply our larder and to furmish excupation for us in the preclatory mood. lint above all, they are bere to add zest to the enjoynent of life itself: to please the eye hy a display of graceful form and picpuant color: 10 stir the clepths of Inman comotion with their marvelous gift of song; to tease the imagination lex their exhibitions of flight: or to goad aspiration as they seck in their migrations the mysterious, alluring and ever insatiable beyond. Indecel, it is seatrecly too much to say that we may learn from the bircls namers which will correct om nwy; that is, stmulate us to the full realization in our own lises of that ethical program which their tender fomestic relations so clearly foreshackus. 


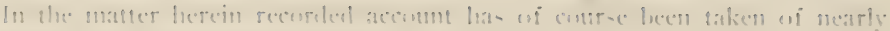

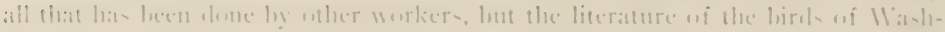

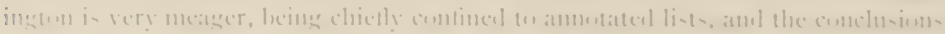

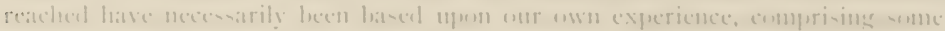

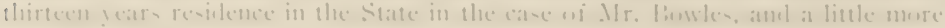

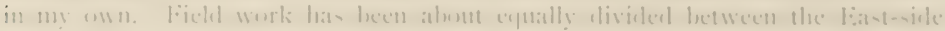

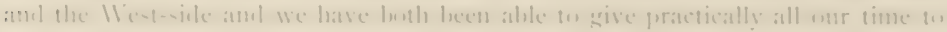

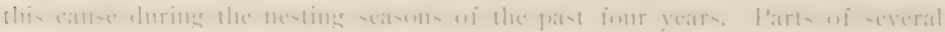

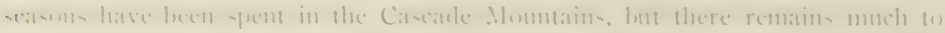

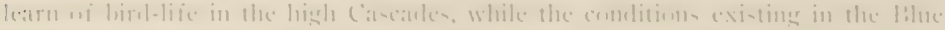

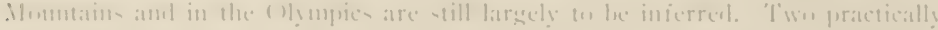

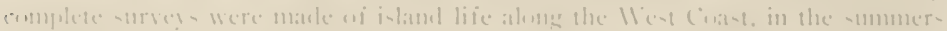

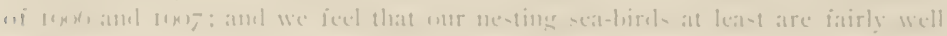
tsmiter-lenul.

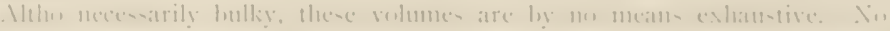

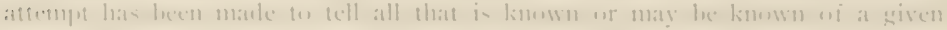

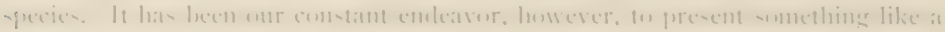

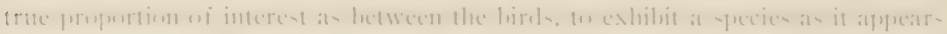

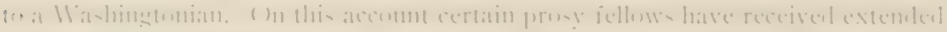

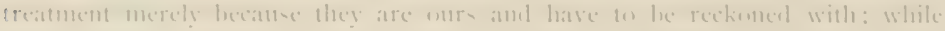

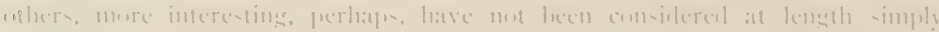

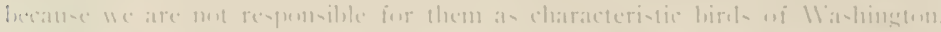

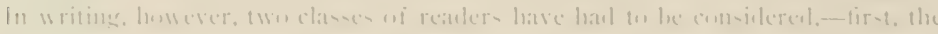

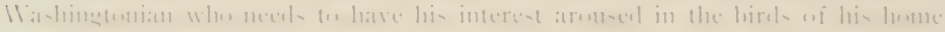

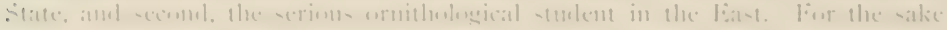

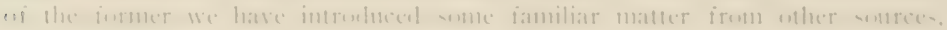

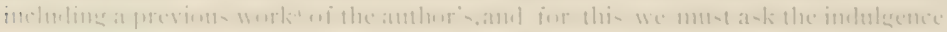

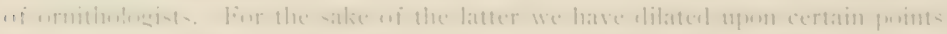

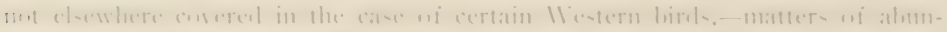

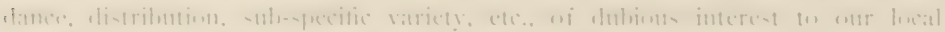

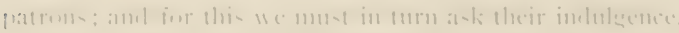

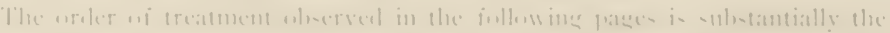

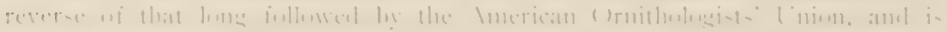

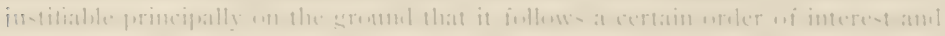

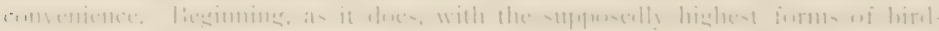

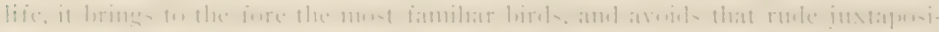

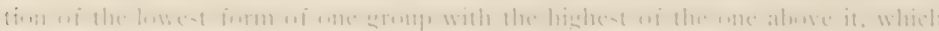

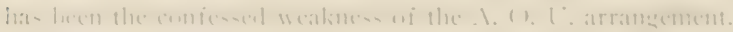

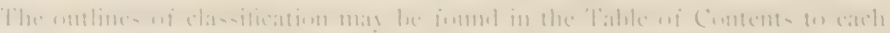

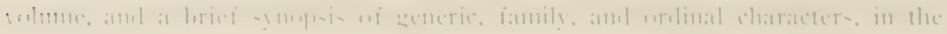

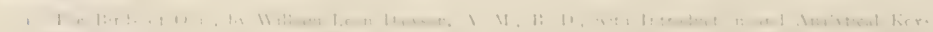

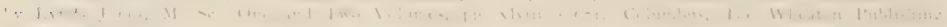
$1, \ldots, x+1$
} 
vii.

Analytical Key prepared by I'rofessor Jones. It has not been thought best to give large place to these matters nor to intrurle them upon the text, because of the many execllent manuals which already exist giving especial attention to this fictel.

The mumenclature is chiefly that of the A. O. L. Check-List. Secomel Exdition, revised io include the Fourteenth Supplement, to which reference is marle ly number. Departures lave in a few instances been made, clonges sanctioned by Rieigway or Cones, or justified by a consideration of local material. It is, of course, unfortunate that the publication of the Third Edition of the A. (). L Cleck-l.ist has been so long delayed, insomuch that it is not eren yet atvalable. (O) this accomt it has not been deemed worth while to provide in these volumes a separate check-list, hased on the A. O. L'. order, as had been intencled.

Care has been exercised in the selection of the English or vernacular name uf the bircls, to nffer those which on the whole seem hest fitted to survive locally: Linecessary departures from eastern nsage have been aroidecle and the chances made have been carefully considered. As matter of fact, the lenglish nomenclature has of late heen much more stable than the I,atin. For instance. no one has any difficulty in tracing the Western Winter IV ren thru the literature of the past half entury: but the bird referred to has, within the last ilecade. poserl successively under the following scientific names: Troylodytes hicmalis

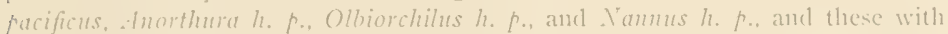
the sanction of the 1 . O. U. Committee-certainly a striking example of how not to secure stability in nomenclature. Writh such an example before us we may prerlaps he partoned for having in instances failed to note the latest discovery of the name-hunter. lut we have humbly tricel to follow our agile leaders.

In the preparation of plumage descriptions, the attempt to derive them from leail collections wats partially abandoned because of the meagerness of the materials offeres. If the work had been purely British Colmmbian, the excellent collection of the Provincial Mltsem at Victoria would have heen nearly sufficient: but there is crving need of a large, well-kejt, central collection of skins and motnterl hircls here in Washington. A ereditable showing is being mate at Poullman under the eneretic learlership of I'rofeseor II. T. Shaw, and the state College will always repure a representative working collection. The Lniversity

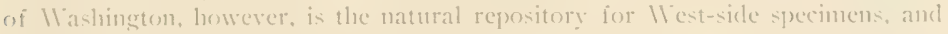
perhaps for the official collection of the State, and it is to be devonty hoped that its present ill-assorted and ill-homserl accmulations may early give place to a worlly and complete display of Whathmeton bircls. Among private collections that of .Ir. I. .I. TElson, of l'ellinglam, is the most notable, representing, ats it does, the patient excupation of extra hours for the past eighteen years. I am

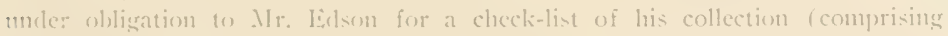
(meirely local species). ats also for a list of the hirds of the Museum of the liellinginam dromal selool. 'l'he small but well-selectod assortment of birl-skins belong-

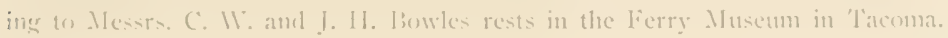




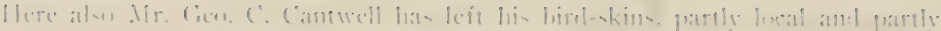
Dlaskims, an vicks.

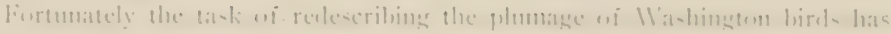

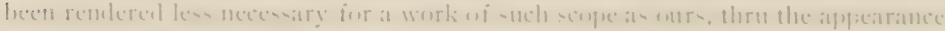

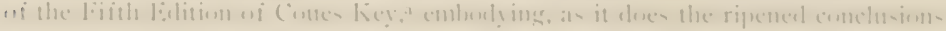

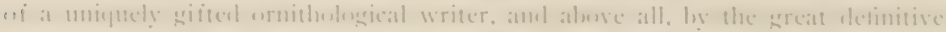

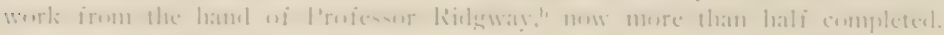

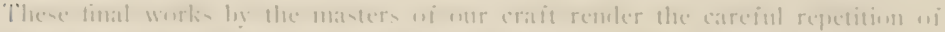

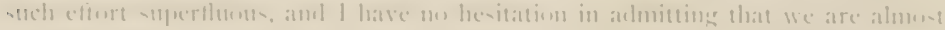

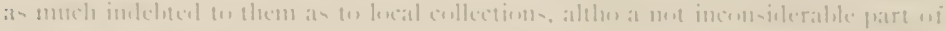

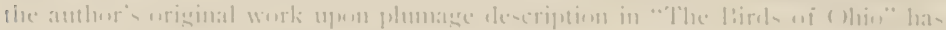

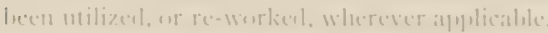

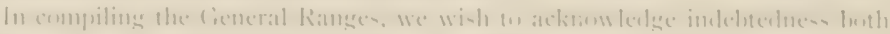

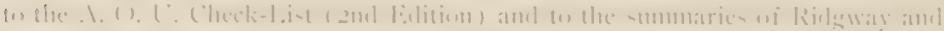

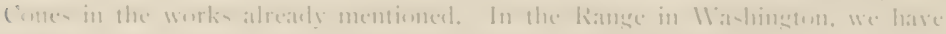

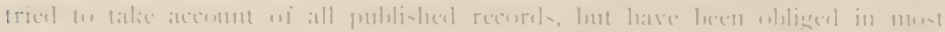

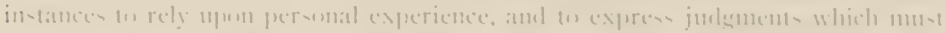
vary in acourater wilh sach imlividual cance.

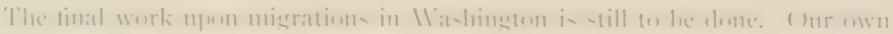

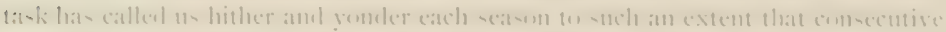

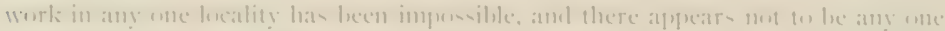

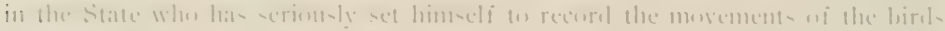

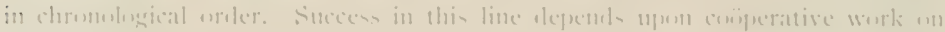

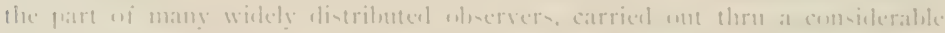

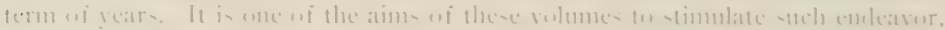

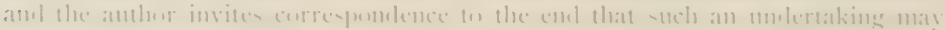

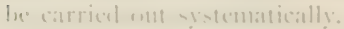

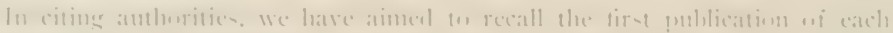

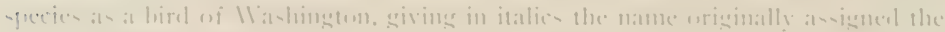

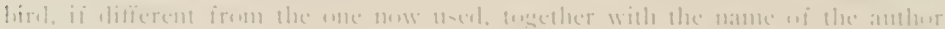

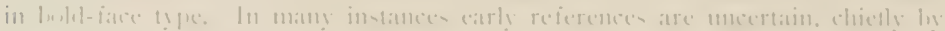

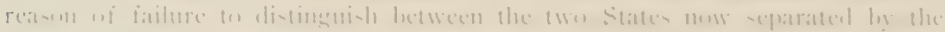

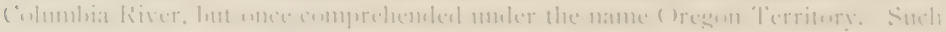

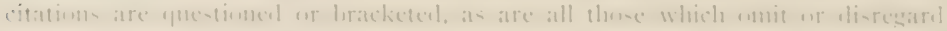

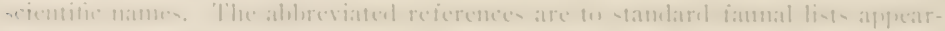

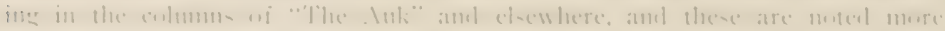

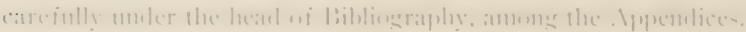

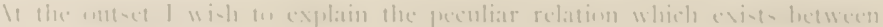

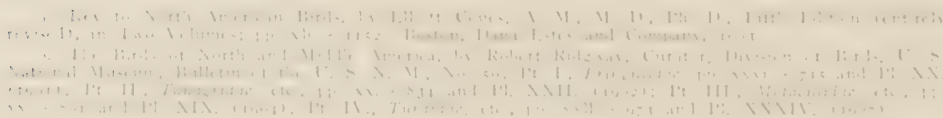


myself and the jumior author, Mr. J. If. Bowles. Fach of us had long had in mind the thought of preparing a work upon the bircls of Washington; but . Mr. liowles, during my residence in (Ohio, was the first to undertake the lask, and had a book actually half written when I returned to the scene with friendly: overtures. Since my plans were rather more extended than his, and since it was necessary that one of ths shonld devote his entire time to the work. Ar. Bowles. with mbonmed generosity, placed the result of his labors at my disposal and declared his willingness to further the enterprise meler my leadership in every possible way. lixecpt, therefore, in the case of signed articles from his pen, and in most of the unsigned articles on Cirouse and Ducks, where our work has been a strict collaboration. the actual writing of the book has fallen to my lot. In practice, therefore. I have fomd myself under every degree of indehtednesis to Mr. lowles, aceording as my own materials were abmelant or menger, or as his information or minc was more pertinent in a given case.

Mr. linwles has becn as geod as his worl in the matter of cöpperation, and hat lavished his time in the quest of new species, or in the discovery of new nests. or in the location of cheice subjects for the camera, solely that the book might prolit thereby: In several expeditions he has accompanied me. ()n this account, therefore, the text in its pronouns. "I," "we," or "le," hears witness to a sort of slicling seale of intimacy, which, mesess explaines, might be pruzzling to the castal reacler. I am especially inclehted to Mr. liowles for extended material upon the nesting of the birds: and my only regret is that the varying repurenents of the task so often enmpelled me to condense his excellent sketches into the meager sentences which appear moler the head "Nesting." Not infrequently, however. T have thrown a fell aljectives into Mfr. liowles's paragraphs and incorporated them without distinguishing comment, in expectation that our joint indelatedness will harlly excite the curiesity of any clisengaged "higher critic" of omithology: Let me. then, express my very deep gratitule to Mr. Isowles for lis generosity and 113 sibere appreciation of his abilities so imperfectly exhibited. I foar, in the following pages, where I have neessarily nsurped the opportunity

It is matter of regret on the anthor that the size of these volumes, now comsiderably in exeess of that originally contemplaterl. has precheder the possihility of an extended physical and climatic survey of Ilashington. The striking dissimilarity of conditions which olstain as between the eastern sicle of the state and the western atre familiat on its citizens and may be easily inferted by others from a pertatil of the following pages. Ont State is excelled by mone in it

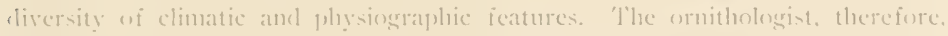

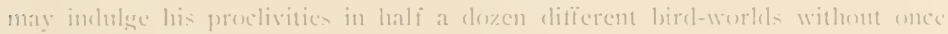

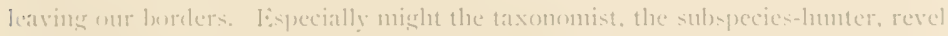
in the minte shates of difierence in plumage which characterize the representadives of the same species an they appear in diflerent sections of on state. Ile

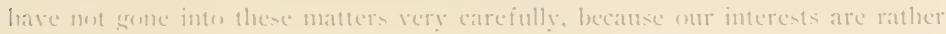




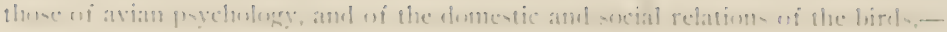
in slurt, the life interent?

While the atuther' proint of view has been that of a bire-fover, wne thinge

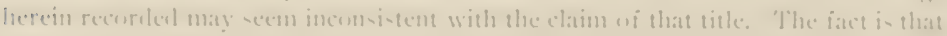

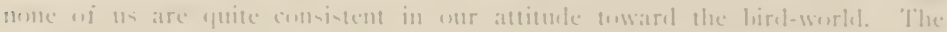

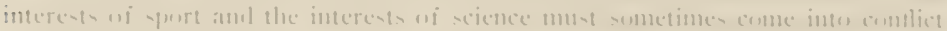

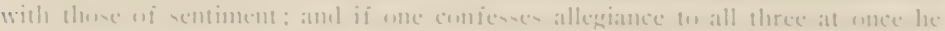

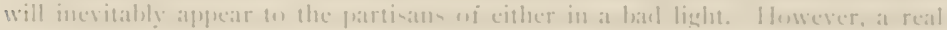

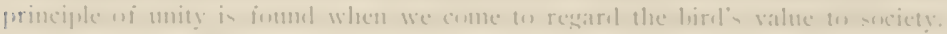

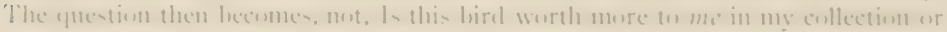
mpon my plate than as at living acter in the drantat wi life: hut, In what capacity

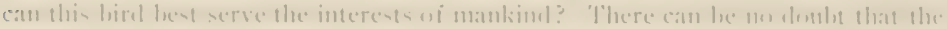

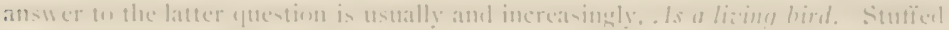

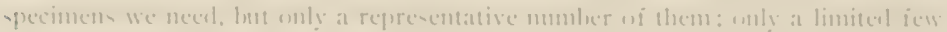

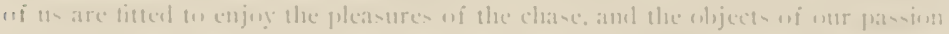

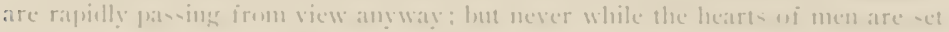

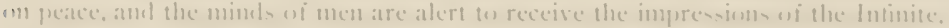

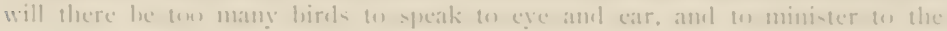

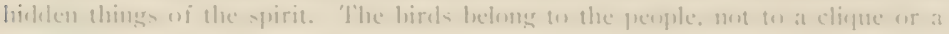

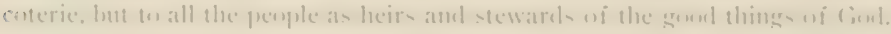

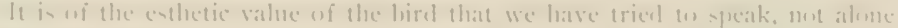

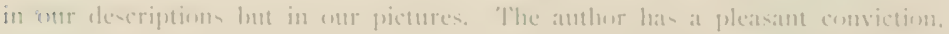

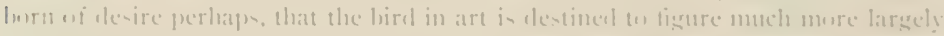
in future year than heretofore. We have learnes something from the Japane-e

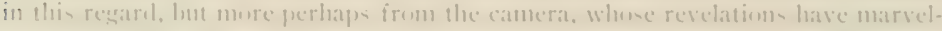

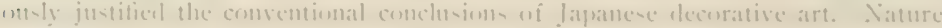

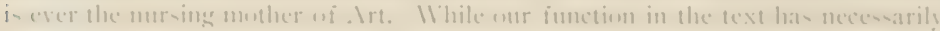

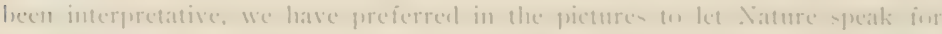

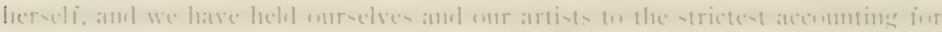

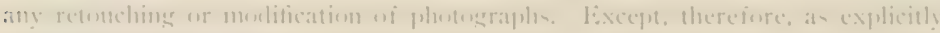

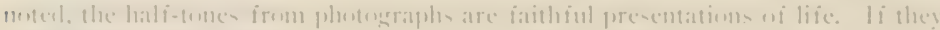

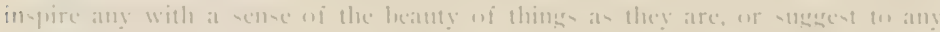

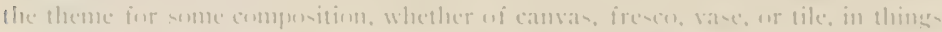
as they might he, then whe laber shall met have lecen in vain.

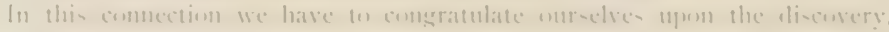

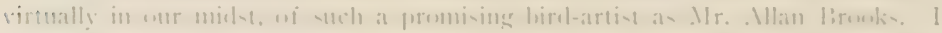

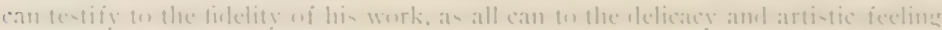

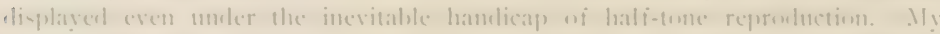

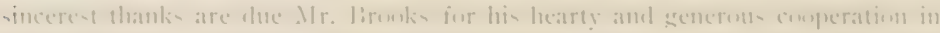

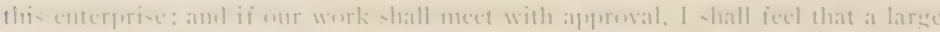

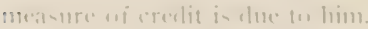

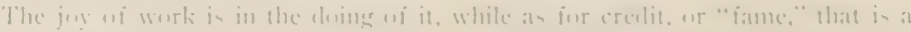

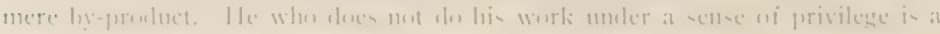


hireling, a clock-watcher, and his suflicient as coveted meed is the pay molope. liut those of us who enjoy the work are sufficiently rewarded alrearly. What tho the envelope be empty! Weve had our fun and-well, yes, We d do it again, esprecially if you thought it worth while.

But the chief reward of this labor of love has been the sense of fellowship engendered. The progress of the work under what seened at times insuperable difficulties has been, nevertheless, a continuons revelation of good will. "Eiveryhody helps" is the motto of the Seattle spirit, and it is just as characteristic of the entire Pacilic Northwest. Everyboly has helped and the result is a composite achicrement, a monument of patience, lidelity, and generosity far other than m11 uwn.

I sratefully acknowledge indebtedness to Professor Robert Ridgway for counsel and assistance in determining State recorels: to Dr. 1. K. Fisher for recorcls and for comparison of specimens: to Dr. Chas. 1I: Richmond for conlirmation of records: to Messrs. William L. Finley, Herman 'I'. Bohlman, A. WV. Anthony. II. H. II right, Fired. S. Merrill, Warburton Pike, Walter I. Burton, A. Gordun liowles, and Walter K. Fisher, for the use of photograplis; to Messrs. T. M. Exlson, D. E. Lirown, A. B. Reagan, E. S. Wloodeock, and to a score of others beside for hospitality and for assistance afield; to Samuel Rathbum. Jrof. E. S. Meany. Prof. O. B. Johnson, Prof. IV. 'T. Shaw. Miss Aclelaide Pollock, and . Viss Jennie l: Cietty, for generous coöperation and courtesies of many sorts: to Irancis Kemode. Lisq.. for use of the Provincial Museum collections, and to I'rof. 'l'revor Kincaid for similar permission in case of the University of IVashington collections. My special thanks are due my friend, Prof. Lynds Jones, the proven comrade of many an ornithological cruise, who upon brief notice and at no little sacrifice has prepared the Analytical Key which accompanies this work.

Mr wife has rendered invaluable service in preparing manuscript for press, and has shared with me the arduous cluties of proof-rearling. My father, Rer. II. E. Dawson, of IBlane, has gone over most of the manuscript and has offereri many highly esteemed suggestions.

To our patrons and subscribers, whose timely and indulgent support has made this enterprise possible, I offer my sincerest thanks. To the trustees of the ()ecidental P'ublishing Company 1 am under a lasting (lel)t of gratiturle, in that they have planned and comselled freely, and in that they have so heartily seconded my efforts to make this work as beatiful as possible with the funds at command.

Onc's roll of obligations camnot he reckoned complete withont sone recognitim also of the rlumb things, the products of stranger hearts and brains, which lave faithfully serverl their uses in this undertaking: my Varner-and-Swasey binoculars ( 8 -power) - l would not undertake to write at bird-book without them; the Gratlex camera, which has taken most of the life portraits: the King canvas boat which has mate stucly of the interior lake life possible: all deaerve honwrable mention.

Then there is the pluysical side of the book itself. ()ne cannot reckon up the 
.11.

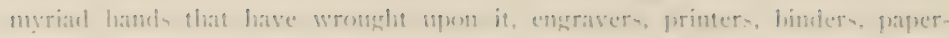

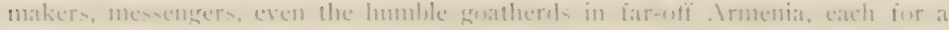

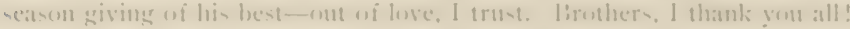

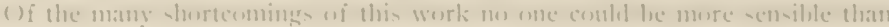

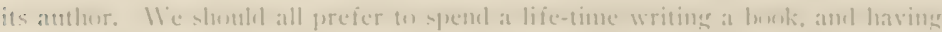

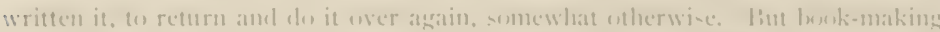

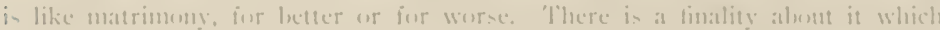

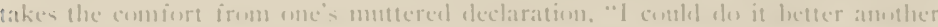
time." What I have writfen I have written. I ger mese to spent a puice daywith line liris.

MII.I.MM I.1Mx 1), MW:- 


\section{CONTENTS OF VOLUME I.}

[). 111111111

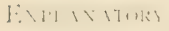

PRE:IEICI

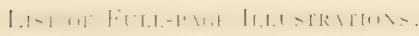

D):SCRIPTION OF SPECTES NOS. I-I8I.

Order Passeres-l'erching birds.

Suborder OSCLIES-Song Birds, NoS.

Family Coraide-The Crows and Jays........... I-It I

Ietcride -The Trompials .............. I5-22

Fringillide-The linches ...................

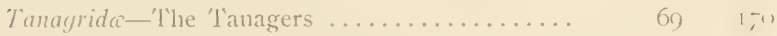

Mniotiltida-The Nood Warblers .......... T0-86 T.,

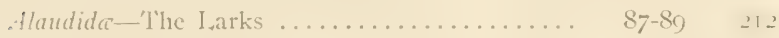

Motacillide-The Wagtails and Pipits........ go _.1

Turdide-The 'Thrushes .............. 9I-IO2 프.

Syläide-The Old Viorld Warblers, Kinglets,

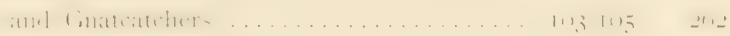

Paride-T'he 'litmice ................ IO6-I I0 2, ;

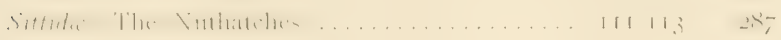

Certhida-lie Creepers .............. I I4. I I5 25

Troglodytide The IV rens ............ IIf-r22 ;il

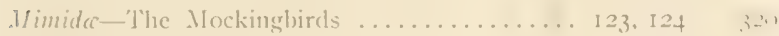

Cinclide-'he Dippers ............... I25 i-

Minundinide the Swallows ............ I26-1.32 i2"'

Ampelide-1'he 11 axwings .............. I3.3.134 ;4

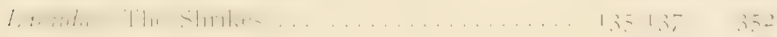

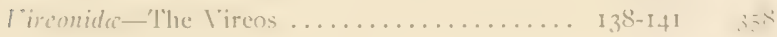


siv:

vis. Inil:

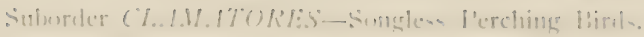

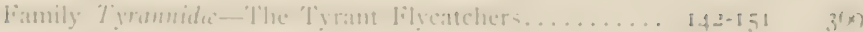

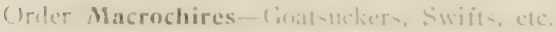

suburder Ther

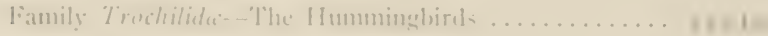

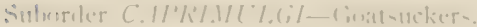

lamily caprimuluda-the Sighthawks renatoncker-

100174 4is

Subureler (')\%'Sl:1.1-swiik

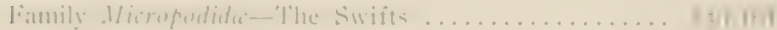

()riter Pici-l'icarian libal-

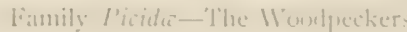

Urefer Cocoges-cuculiorm lirals.

Sulwriter ( 7 ' $\%$ \% I-C (utkms.

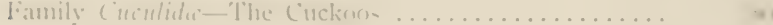

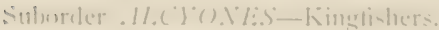

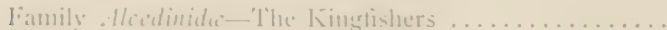




\section{LIST OF FULL-PAGE ILLUSTRATIONS.}

PAGE OR FACING PAGE.

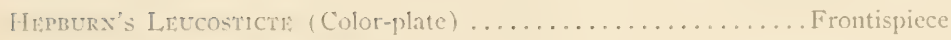

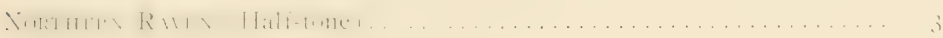

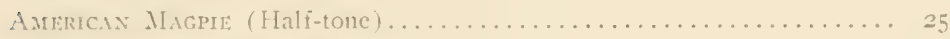

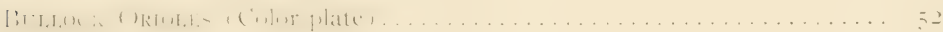

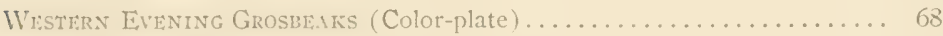

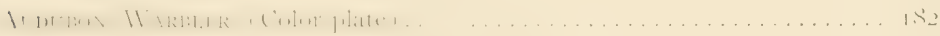

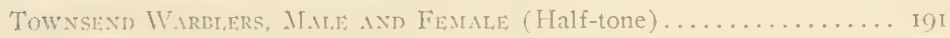

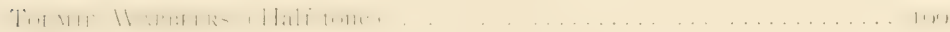

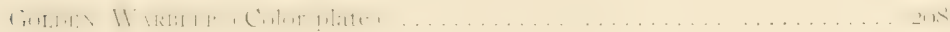

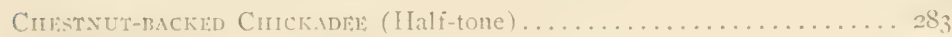

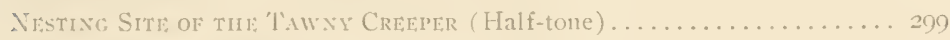

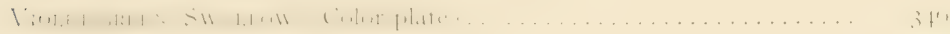

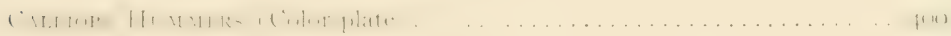

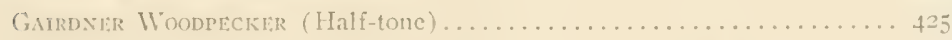

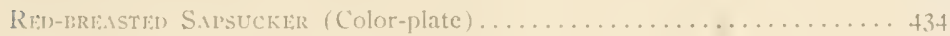





\section{The Birds of Washington VOL. I.}

Description of Species Nos. I-I 81 



\section{THE BIRDS OF WASHINGTON}

No, $\mathbf{r}$.

\section{NORTHERN RAVEN.}

A. O. U. No. $486 a$. Corvus corax principalis Ridgw.

Synonym.-Formerly called the AMLRICAN RAVEN.

Description.-Color uniform lustrous black; plumage, especially on breast, scaptulars and back, showing steel-blue or purplish iridescence; feathers of the throat long, narrow, pointed, light gray basally; primaries whitening at base. Length two feet or over, female a little smaller; wing $17.00-18.00$ ( 438$)$; tail $10.00(2.77)$; bill $3.20(-6.5)$; clepth of bill at nostril I.0O $(28.5)$; tarsus 2.68 $(1,8)$.

Recognition Marks.-Large size,-about twice as big as a Crow; long rounded tail; harsh croaking notes; uniform black coloration. Indistinguishable afielel from simatus.

Nesting.- lest: a large but compact mass of sticks, lined with grass, wool, cow-hair, etc., placed ligh in lir trees or upon inaccessible cliffs. Liggs: - $^{-7}$ ( 8 of record), usually 5, pale bluish green or olive, spotted, blotehed, and dashed with greenish brown and obscure lilac or purple. Iv. size, $1.00 \times 1.33(48.26 \mathrm{x}$ 33.78). Season: April I5; one brood.

General Range.-"Arctic and lioreal Provinces of North America; sunth to Eastern Iritisli I'rovinces, portions of New England, and Atlantic Coast of United States, higher Alleghenies, region of the Great Lakes, western and northern Washington, etc." (Ridgway).

Range in Washington.-Found sparingly in the Cascade and Olympic Somtains, more commonly along the l'acific Coast.

Migrations.-Resident but wide ranging.

Authorities.-|Lewis and Clark, Hist. lix. (ISI, ), Lid Bidklle: Cones, Vol.

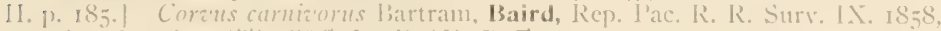

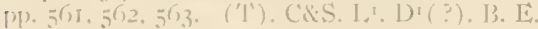

Specimens.-(U. of. II.) I'rov. C. 


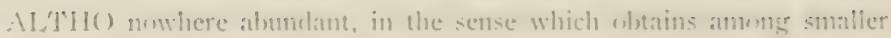
species, nor ats wielely distributed ats sume, there is probably now other hird which lats attracted such universal attention, or has left sn deep an impress upon histury and literature as the kaven. P'rimitive man has always ielt the spell of his sumbre presence, and the Raven was as deeply imberleted in the inlklore of the matritme (irecian tribes as he is torlay in that wi the Makahs and Ouillayntes upun onr wwn const. Kurat, the Greets called him, in imitation wi

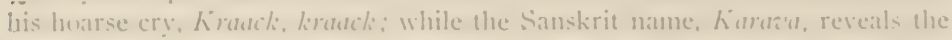

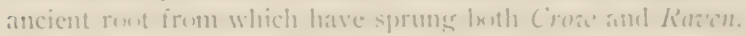

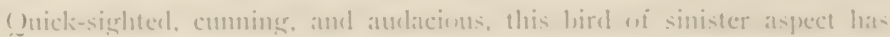
lecen invested ly perples of all ages with a mysterims and semi-sacred character. His m minns erobkings were thought to hase prophetic import, while his preternatual shrewelness has make him, with many, at symbel of divine

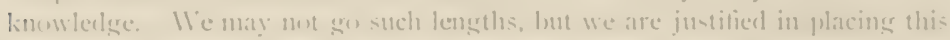

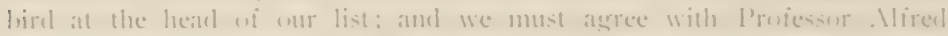
Newton that the Raven is "the latrest uf the birrls wi the ()reler l'averere and probalsly the mont highly developeel of all birds."

The katen is a birel wi the willerness: and, in spite of all his cumbing.

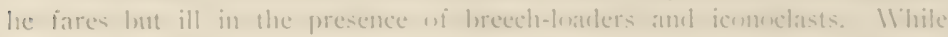

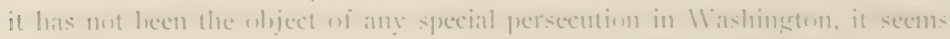
(1) share the bate reserved fors all whe lift their heats alswe the commont

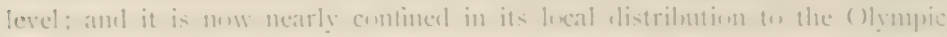
peninsulat; anel is mowhere crmmun, save in the veinity of the Indian villages which still cling to wne western slore.

In appearance the Raven presents many points of difference fom the Cemmmon Crom, espectally when contratsterl with the dwari examples of the

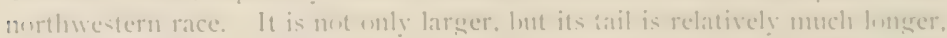
amel fully rumbled. The heat, towe is fuller, and the hill fropurtionately

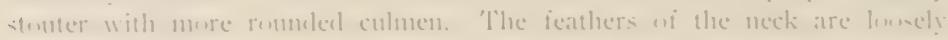

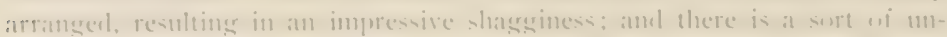

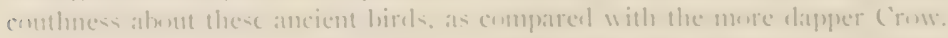

Ravens are unecrupulents in rliet. and thereirom has arisen much of the

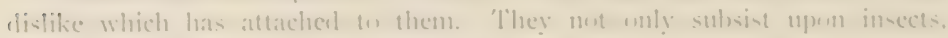

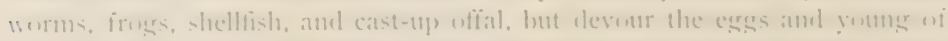

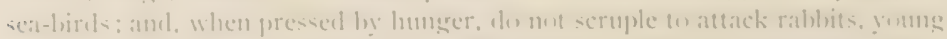

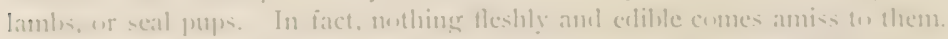
In collecting alung the seatenst I wne lost some sandpipers, - which I had

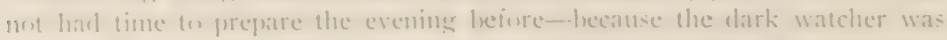
"mp first". I.ike the loish Crom, they lames abent the lmelian villages to some 



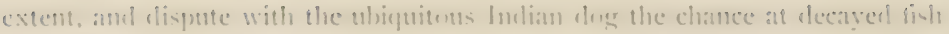
ancl ufial.

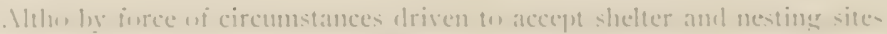
in the dense foreste of the western ()lympic slope, the kasen is a esreat lower wi the seatelifts and wi all wild scenery. Stormy days are his especial delight

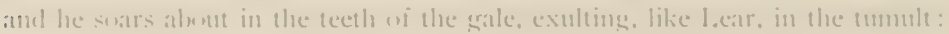

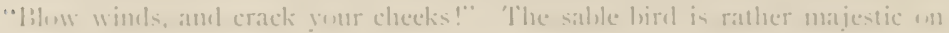
the wing, and he stars aloft at times with smmething wi the metion and dignity wi the latgle. l'ut the cirvine character is complex: and its eravest represen-

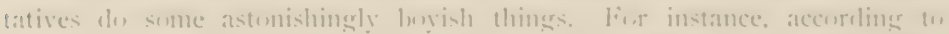

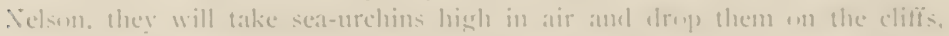

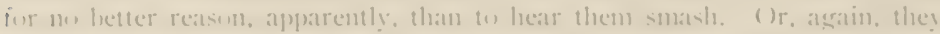

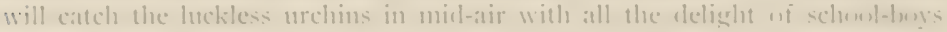
il 1 im-|uill|.

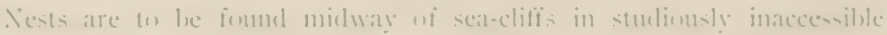

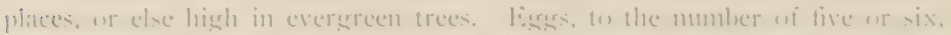

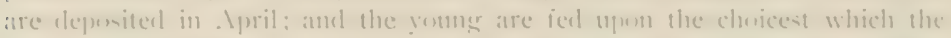

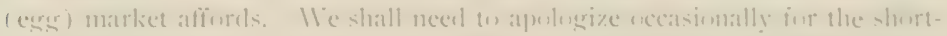

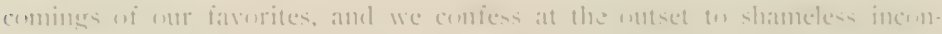

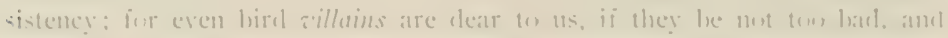

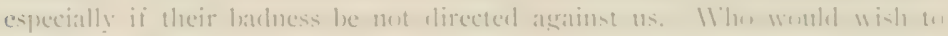

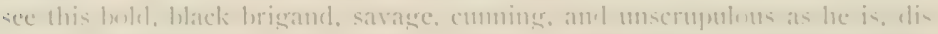

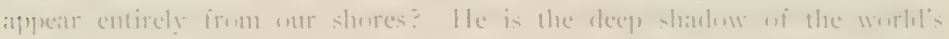

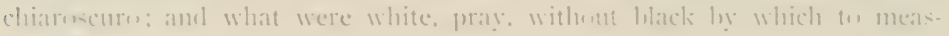
19re it :

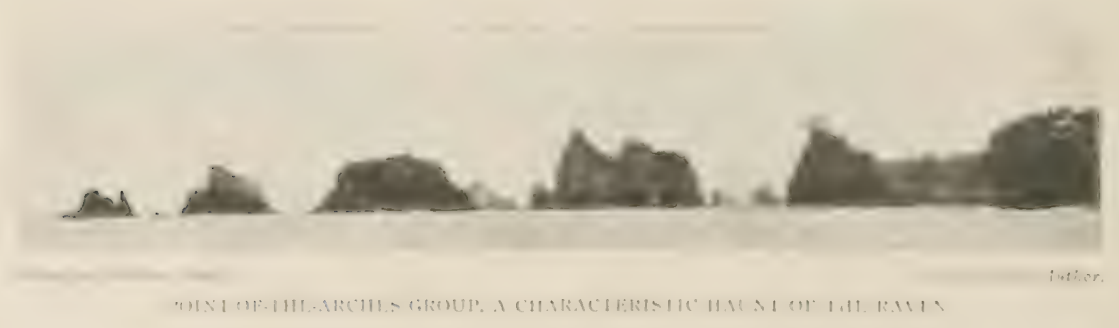


No. 2.

\section{MEXICAN RAVEN.}

1. O. L. No. 486 . Corvus corax sinuatus (Thagler).

Synonyms.- IMIRTCAN RAVEN, SOLTAERN RAVEN.

Description.-Like preceding but averaging smaller; bill relatively snaller and narrower; tarsus not so stout. Length up to 26 inches, but averaging less. Culmen $2.85(72)$.

Recognition Marks.-As in preceling-distinguishable only by range.

Nesting.- lest: placed on ledge or in crannies of basalt cliffs, more rarely in pine trees.

General Range.-Western United States chiefly west of the Rocky Mountains: in its northerly extension nearly coincident with the Upper Sonoran life zone, sonth to Honduras.

Range in Washington.-May be arbitrarily defined as restricted to the liast-sile, but common only on the treeless plains and in the IBlue Mlonntain region. Resiclent.

Authorities,-Corens cumizorus Bart., Cooper and Suckley, Rep, l'ac. R. R. Surv. NIl. pt. II. 1860, p. 210. Bendire, Life Hist. A. A. Birds, Vol. II. P. $396 \mathrm{f}$.

I'l' is mo mere association of ideas which has made the Raven the bircl of ill omen. Black is his wing, and black is his heart, as well. While it may be allowed that he works no direct damage upon the human race, we cammot but share in sympathy the burden of the bird-world which regards him as the bete noir, diatuslical in cumning. patient as fate, and relentless in the hour of (1)prortunity.

As 1 sit on an early May morning lyy the water's edge on a lonely island in the Colmmbia River, all nature seems harmonions and glad. The Meadowlarks are pricking the atmosphere with goads of good clicer in the sage belind; the Dore is pledging his heart's affection in the cottonwood hard by: the river is singing on the rapids: and my hear is won to follow on that buryant tide-when suddenly a mother Goose cries out in terror and I leap to $m$ feet to learn the canse. I have not long tis wait. Like a death knell cones the guttural croak of the Raven. He has spied upon her, learned her secret, swept in when her precious eggs were nucorered: and he bears one off in trimmpl, - a feast for lis carrion hroxd. When one has seen this sort of thing at domen times, and heard the wail of the wild things, the croak of the Raven eomes to be franght with menace, the veritable voice of doom.

To be sure, the kaven is not really worse than his kin, but he is distinguished by at hass voice: and dees not the villain in the play always sing bass? Somehow, one never helieves the ilt he hears of the sumful tenor, even tho he sees him clo it: hut heware of the hird or man who croaks at low (C. 


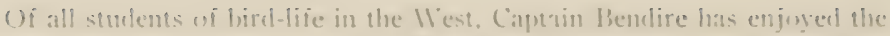

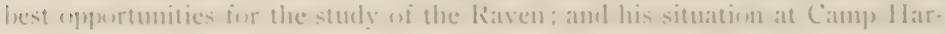
ney in eatstern () regum was very similar to such ats maty fo fomel in the sumth eastern part of our own Sitate. Of this species, ats observed at that puint, he says:

" "lhey are stately and rather serlate-lexking hirels, remain mated shru life, and are seenningly very much attached on each other, hut apparenty more unsucial on others of their kind. () n the gronum their movements are delil)-

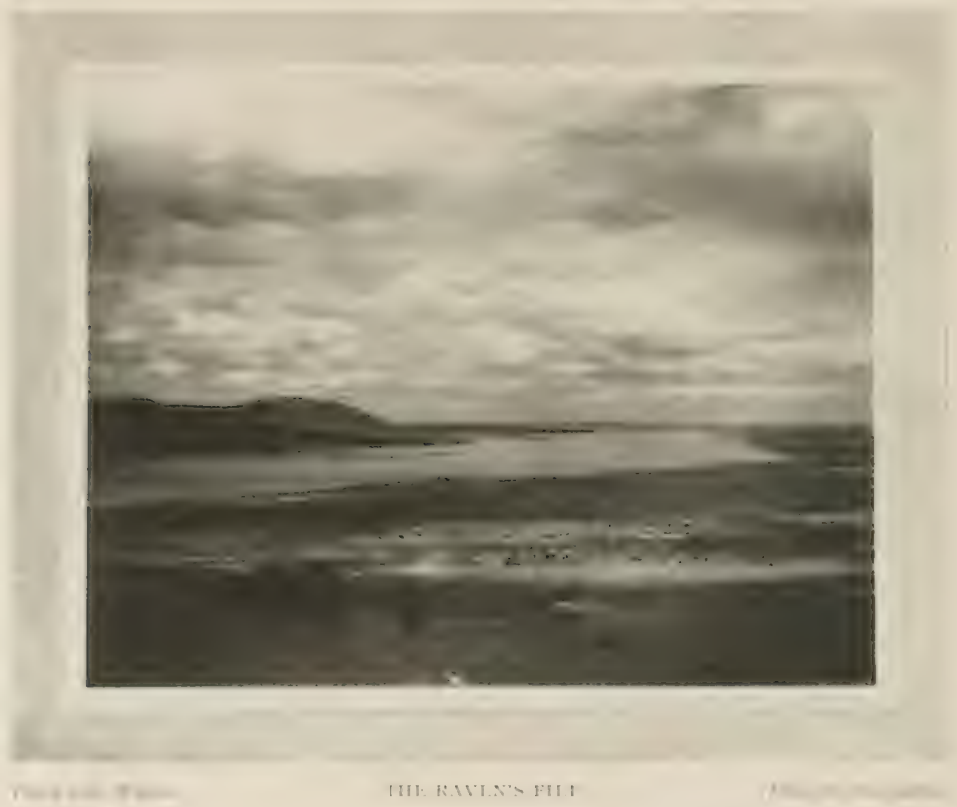

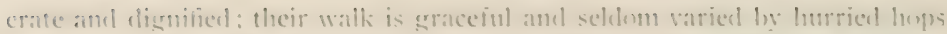
- immp. They appear te still letter arlvantage on the wing. especially in

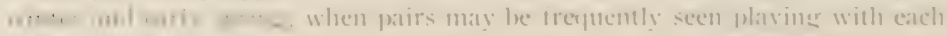

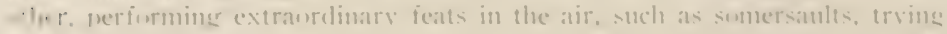

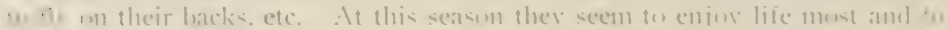

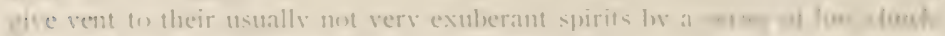

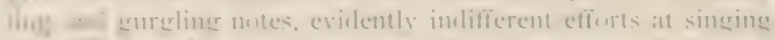

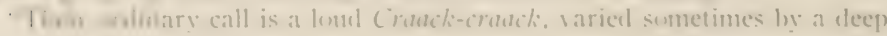


grunting koer-kverr, and again by a clucking, a sort of self-satistied sound, difficult to reproduce on paper; in fact they utter a variety of notes when at ease and undisturbed, among others a metallic sounding klunk, which seens to cost them considerable effort. In places where they are not molested they become reasonably tame, and I have seen Ravens occasionally alight in my yard and feed among the chickens, a thing 1 have never seen Crows do. * * *

"Ont of some twenty nests examined only one was placed in a tree. It was in a good sized dead willow; twenty feet from the ground, on an island

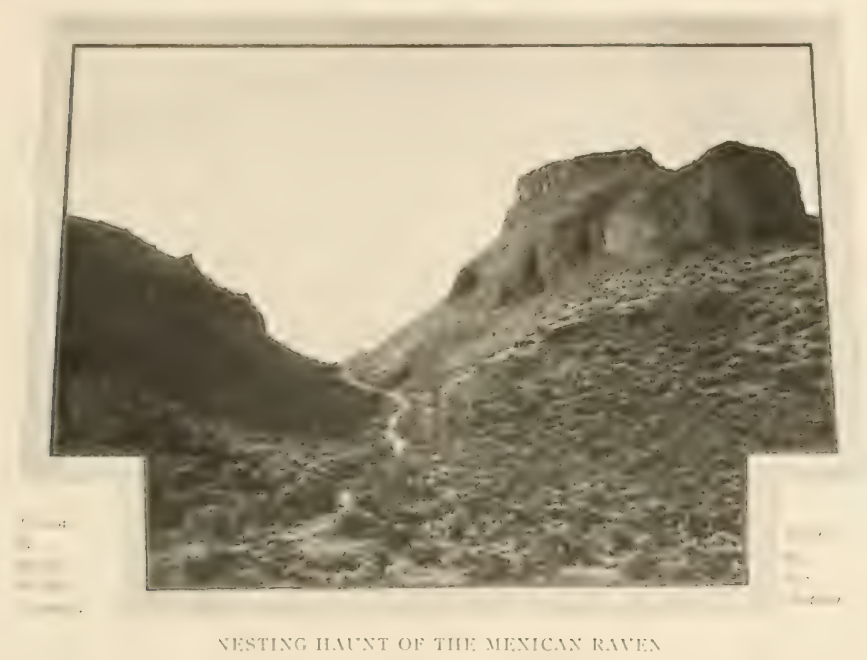

in Sylvies River. Oregon, and easily reached; it contained five fresh eggs on April 13,1875 . The other nests were placed on cliffs, and, with few exceptions, in positions where they were comparatively secure. Ustally the nest could not be seen from above, and it generally took several assistants and strong ropes to get near them, and even then it was frepuently impossible to reach the eggs without the aid of a long pole with a dipper attached to the end. A favorite site was a cliff with a southern exposure, where the nest was completely covered from alove by a projecting rock."

I Iaving once chosen a nesting site, the kavens evince a great attachment for that particular locality: and, rather than desent it, will avoid notice by deferring the nesting season, or lyy visiting the exgs or youmg only at night.

II e have no records of the taking of Raven's eggs in Washington, but it 


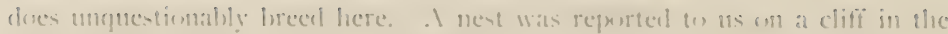

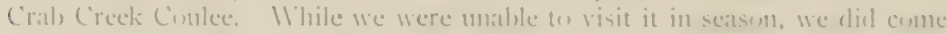
upon a tanily (romp) smme weeks later, comprising the two andults and five srown younge. 'This is pessibly the morthermunst breeding station wi the Mexican kitien yet repurterl.

No. 3.

\section{WESTERN CROW'}

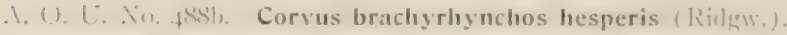

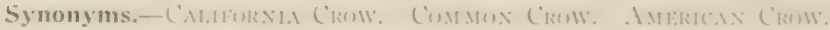

Description. - Jintire plumage ghess black, for the most part with ereenish bine, sect-blue, and purplish reflections ; feathers of the nerti normal, rumbleal.

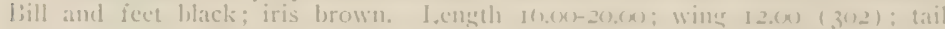

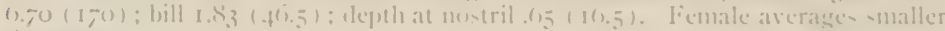
th:mll mile:

Recognition Markso-l)istingui-hable from Northwest (row be larger size imel cleatrer mice:

Vesting.- lest: a neat hemisplere of stick and twig-carefully lined with hark, roots and trash, and placed 10 - $(x)$ feet high in trees, - willow, aspen. prine.

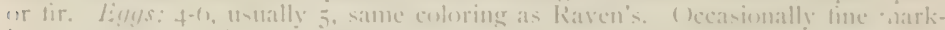

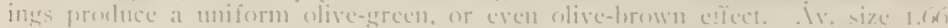

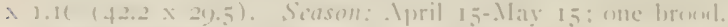

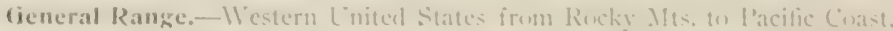

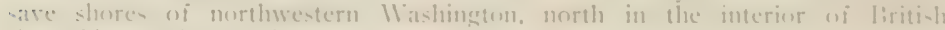
(i)hmiluiz, senth to . Irizons.

Range in Washington.-() fi general distrihntion along streams and in settlet portions of State. save aloner shores of l'uect Somml, the Straits and the Pacilie

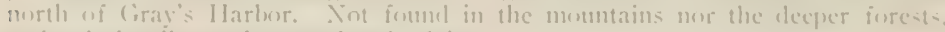
amel only lencally on the sage-brush plains.

Migrations.- Resilent hut gregarient and lecalized in winter. The winter "ronsts" lireak up) late in lieloruary.

Authorities.-Cirats americanus -Imel. Baird, Rep. l’ae. R. R. Sury. IX.

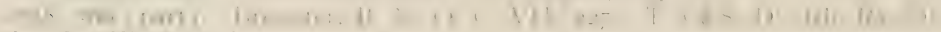
$\therefore$ S S Kk. I. I. I:

specimens.- l?: (?).

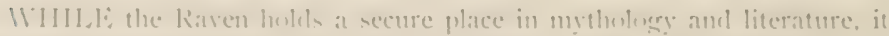

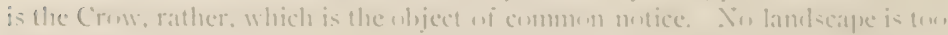

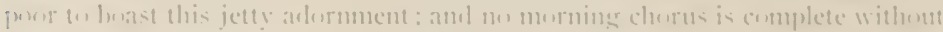

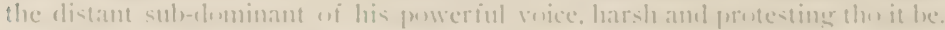

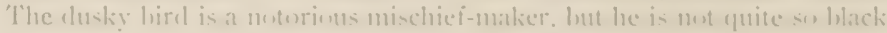

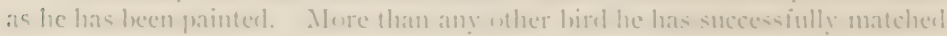
his wits agramit these ni man, and his frequent easy victuries and consedpent 
boastings are responsible in large measure for the unsavory reputation in which he is held. It is a familiar adlage in ebony circles that the proper sturly of Crow-kinel is man. and so well has he pursued this study. that he may fairly be saicl to hold his ow's in spite of fierce ancl ingenious persecution. He rejoices in the name of

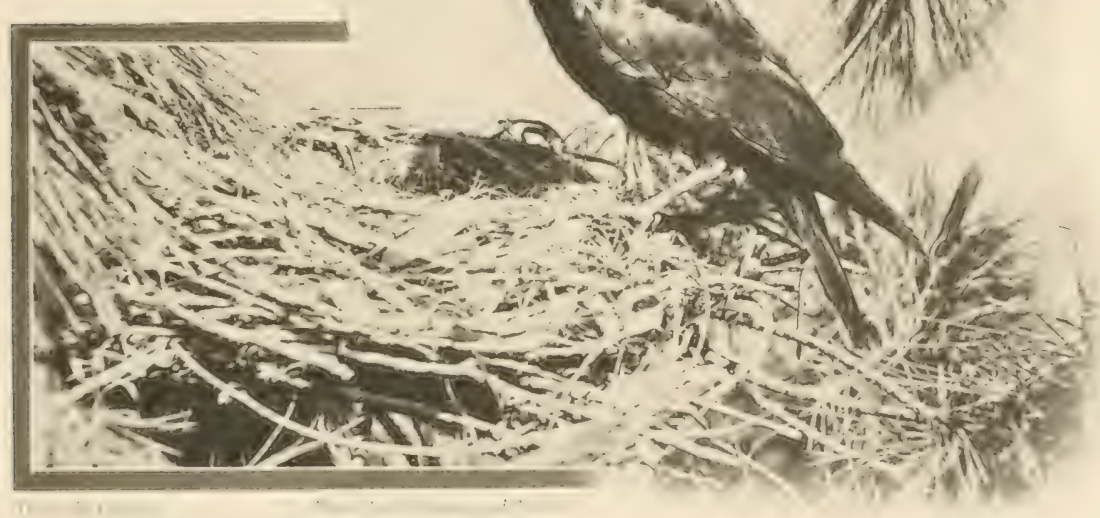

III:

(antaw, and ages of ill-treatment have only served to shapen his wits and intensify lis cumbing.

That the warlare waged against him is largely unnecessary, and partly umjust, has been pretty clearly prowen of late hy scientists who have investi sated the Crow's ford habits. It is true that he destroys large numbers of egres and nestlings, and, if allowed to, that he will ocensionally invade the poultry yard-and for sucle conduct there can be no apology. It is true, alson. that some damage is inflicted mon corn in the "rasting-ear stage, and that corn left mut thru the winter constitutes a staple article of Crom diet. Pur it is estmated that birds and egess form only alont one-lialf of one per cent of their to tal diet : and in the case of grain, certainly they perform conspicuns services in rasiug the crop). liesicles the articles of fourl mentioned, greal 
quantitics wi crickets, feetles, gratsiluppers, caterpillars, cut-morms, and spul-

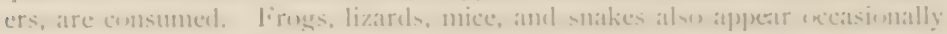

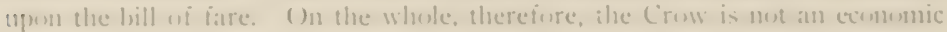

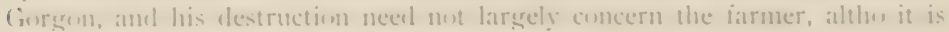
always well to feach the hirel a proper reverence.

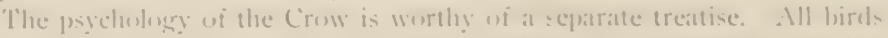
have a certain fitculty of direct pereeption. Which we are pleatsect to call in-

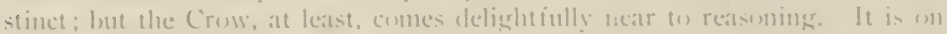
aceount of his plenomenal brightness that a young (row is anumer the most interesting of pets. If taken from the nest and well treated, a young C'Tow cam le given such a large meatsure of ireedom as fully to justify the experiment irmm a humanitarian standpent. Oi course the sure end wi such at pet is eleath

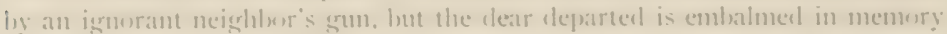
in such a degree that all Conws are thereatiter regarded ats upoul a higher plane.

Fireryone knows that ('roms talk. Their ery is msually represented by

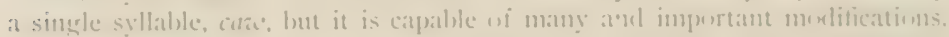

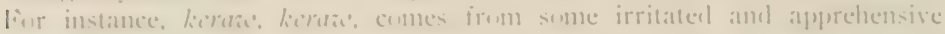

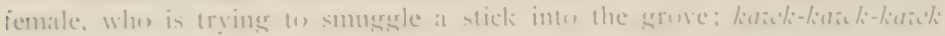
proclaims sudfen danger, and put the thek inte instant commotion: while

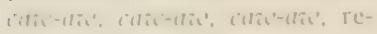

agraill. ()nce, in winter

lirrl-mian, for spert, was

lifying the local hirel perpulation by repronlueing the netes of the sereerts ()w\%. : (c) 111 | $: 1111$ y af ('rours settleds in the tops ai neierloberine frees. and earn etly disensical the probatisle mature wi the "nject hialienemeaterl muler it camera cleth limally. thes Eisce it up and nithlow - as I suppuseal. It assures them when the

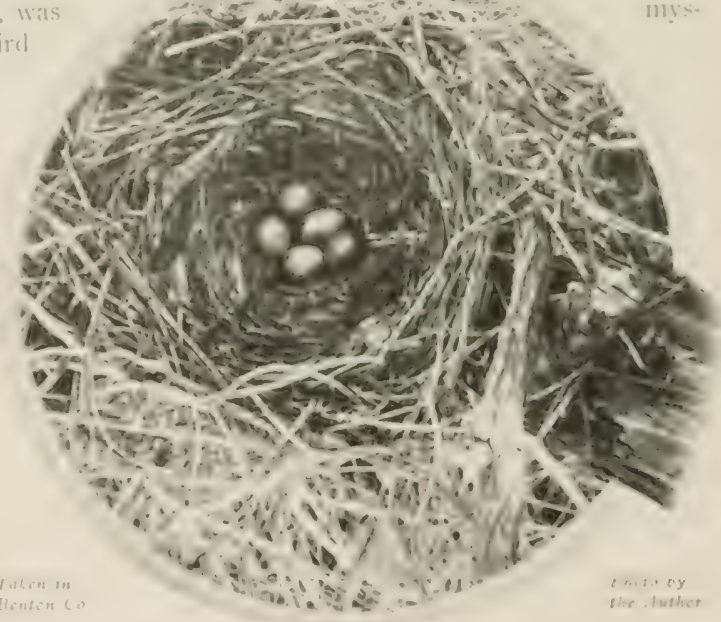

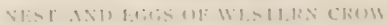


seems that one old fellow was not satisfied, for as I ventured to shift ever so little from my straned position, he set up) a derisive Ca-a-a-arc from a branch over my head, - as who should say, "Aw, ye can't fool me. Y're just a ma-a-an," and flapped away in disgust.

Crows attempt certain musical notes as well; and, unless I mistake, the western bircl has attained much greater proficiency in these. These notes are deeply guttural, and evidently entail considerable effort on the bird's part. Hunger-o-ope, hunger-(1)-ope, one says; and it occurs to me that this is allied to the delary, delary, or springloard cry, of the Blue Jay (Cyonocitta cristata).--plunging notes they have also been called.

Space fails in which to describe the elalorate structure of Crow society; to tell of the military and pedagogical systems which they enforce; of the courts of justice and penal institutions which they maintain; of the vigilantes who risit vengeance upon evil-minderl owls and other offenders: or even of the games which they play, - tag, hicle and seek, blind-man's-buff and pull-away. These things are sufficiently attested by competent observers; we may only spare a word for that most serious business of life, nesting.

A typical Crow's nest is a very substantial affair, as our illustration shows. Upon a basis of coarse sticks, a mat of dried leaves, grasses, bark-strips, and clirt, or mud, is impressed. The deep rounded bowl thus formed is carefully: lined with the inner bark of the willow or with twine, horse-hair, cow-hair, rabbit-fur, wool, or any other soft substance available. W'hen completed the nesting hollow is seven or eight inches across and three or four deep. 'The expression "Crow"s nest," as used to inclicate disarray, really arises from the consideration of old nests. Since the hirds resort to the same locality year after vear, but never use an old nest, the neighboring structures of successive years come to represent every stage of dilapidation.

IVest of the mountains nests are almost invariably placed well up in fir trees, hard against the trunk, and so escape the common olservation. L Lon the East-sicle, however, nests are usually placed in aspen trees or willows; in the former case occurring at heights up) to fifty icet, in the latter from ten to twenty feet up. Escape ly mere elevation being practically impossible, the Crows resort more or less to ont-of-the-way places, - spring draws, river islands, and swampy thickets.

Notwithstanding the fact that the spring season opens much earlier than in the East, the Crows, true to the traclitions of a northern latitude, commonly defer nesting till late in April. Firesh eggs may be found by the 20 th of April, but more surely on the Ist of May. Incubation lasts from fourteen to eighteen days; and the young, commonly five but sometimes six in number, are born nakerl and blind.

It is when the Crow children are latched that Nature becrins to groan. It is then that hirds' eggs are quoted by the crate: and heetles by the hecatomb) 


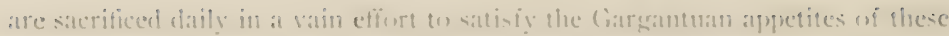

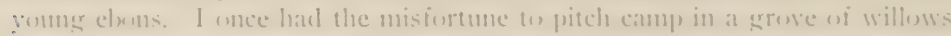

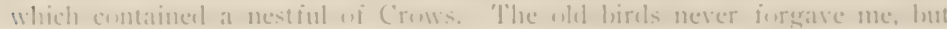
uphraihled me in bitter language irom early morn till dewy eve. 'The youngsters also suffererl sumewhat, I fear, iur as witen as a parent lirel apporatcherl.

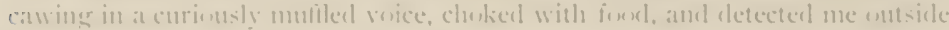
the fent, it swallemed its burden withent compunetion, in oreler that it might the mere fincibly lerate me.

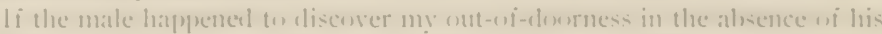
mate, he would rush at her when sle buse in sight, in atu officims, blustering

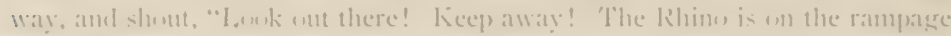
an $\cos )^{-}$

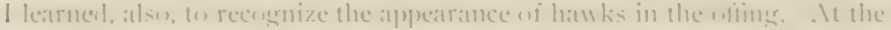

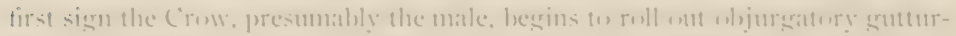

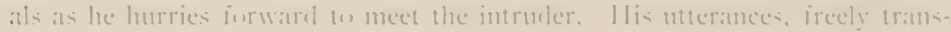

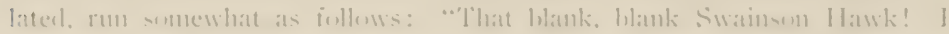

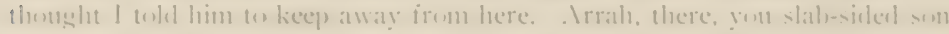

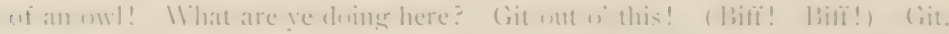

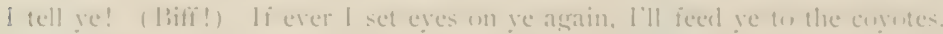

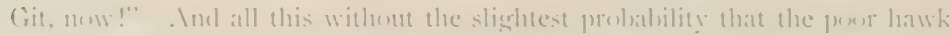

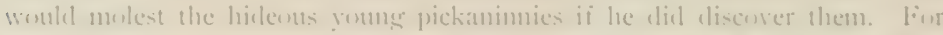
when was it self-respeeting hawk su host te decency as to he willing to "eat crow :

No. \&.

\section{NORTHIVEST CROW.}

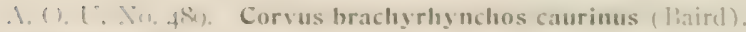

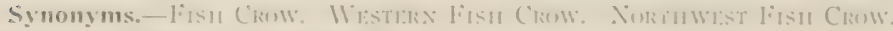

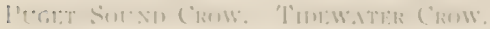

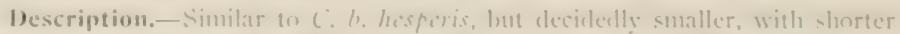

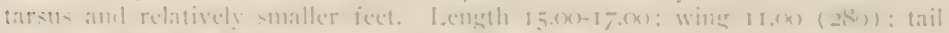

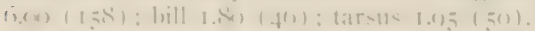

Recognition Marks.- In meler-jzed (rom. Vince luar-e and llat as enm-

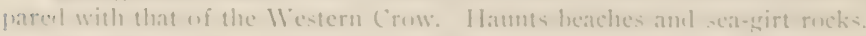

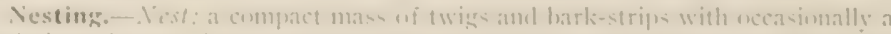

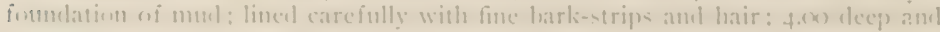

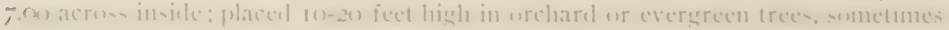

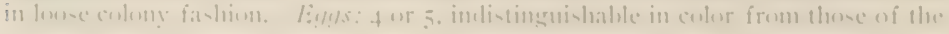


Common Crow, but averaging smaller. A typical set averages $1.56 \times 1.08$ $(39.6 \times 27.4)$. Scason: April 15 -June 1 ; one brood.

General Range.-American coasts of the North l'acific Occan and its estuaries from Olympia and the mouth of the Columbia liver north at least to the Alaskan peninsula.

Range in Washington.-Shores and islands of I'uget Sound, the Straits of Juan de Fuca, and the West Coast (at least as far south as Moclips, presumably to Cape Disappointment). Strictly resident.

Authorities.-ILewis and Clark, Hist. Ex. (I\&It), ed. Bicllle: Cones, Vol. I1. 1) 185.] Corrus cauminus Baird, Baird, Rep). Lac. R. R. Surv. IX. June 29, IS $58,569,550$. T. C\&S. L. Rh. Kb. Ra. Kk. B. E.

Specimens.- L. of WT. P'rov. E. B.

AFTER lengthy discussion it is pretty well settled that the Crow of the northwestern sea-consts is merely a dwarfed race of the Cormus brachyrhynchos sroup; and that it shades perfectly into the prevailing western type, $C$. b. hesperis, wherever that species occupies adjacent regions. This area of intergradation lies chiefly south and west of Puget Sound, in WVashington; for the Crow is ever fond of the half-open comntry, and does not take kindly to the ummitigated forest depths, save where, as in the case of the Fish Crow, he may find relief upon the broad expanses of shore and tide-flats. 'The case is quite analogous to that of native man. 'The larger, more robust types were found in the eastern interior, while those tribes which were confined exclusively to residence upon the sea-shore tended to become dwarfed and stunted: and the region of intergradation lay not chiedy along the western slopes of the Cascades with their crushing weight oi tall timber, but in the prairie regions bordering Pruget Sound upon the soutl.

It is impossible, thereiore. to pronounce with certainty upon the sulbspecific identity of Crows seen near shore in Mason, Thurston, Pierce, or eren King County; but in Clallan, Jefferson, San Juan, and the other comties of the Jorthwest, one has no dilticulty in recognizing the dwart race. Vot only: are these Crows much smaller in point of size, but the voice is weatier, flatter. and mure hoarse, as tho affected by an ever-present fog. So marked is this menl change, that one may note the difference between bircls seen along shore in I'ierce County and those which frextent the uplands. Itowever, - and this caution must be noted-the upland hirds (h) visit the shore on occasion: and the regular shore dwellers are by no means entined thereto, ats are the more tyjpical birds fouml further north.

The early uloservers were feeling for these differences, and if Nature dicl not afford sulficient ground for easy discrimination, imagimation could supply. the details. 'The following paragraph from the much quoted workia of John Keast Lord is interesting lecause deliciously untrue. 


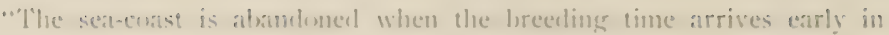
Iny, when they resert in pairs w the interior: selecting a patele of upen prairie. where there are streams and lakes and where the wihl crabl) alpple and whitethorn grows, in which they lowild nests precisely like that wi the Magpie, arched wer the top with sticks. The birel enters by a hole on une side lmat leatses loy an exit lode in the eppresite. The inside is plastered with mud a few grass

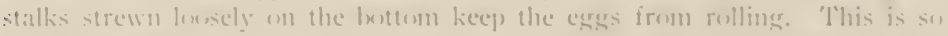

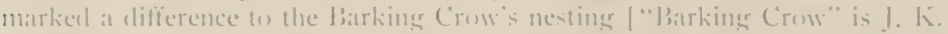

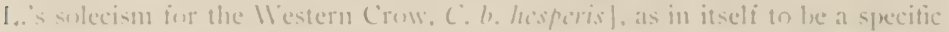
distinction. The eges are lighter in bhtehing and much smaller. I examined

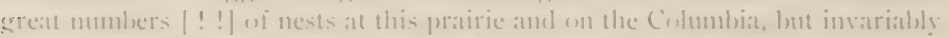
foumd that the same halpit of doming prevailed. Viter nesting. they return

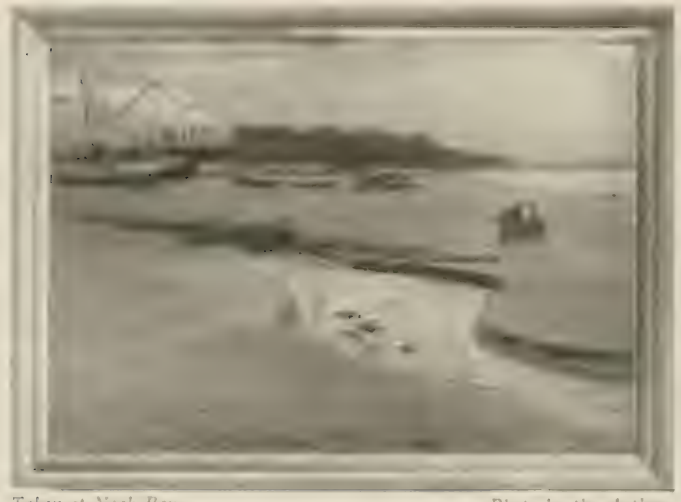

Taben at Wouth May with the voung to the seat-cosists. and remain in lat $\mathrm{r}$ e Aluck: witen asiciated with larkine Croms until nesting time comes again." - Xo single penint if which has lecen contfimeel lo succeerling (h) berrers.

1)r. (inples wrote with exact truthiulnew: "'llhis lisheristi irecutuents the onist and inlets wi this 'lerrimery in large mmuluers. and

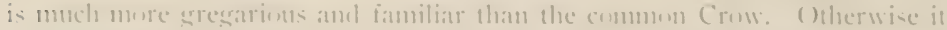

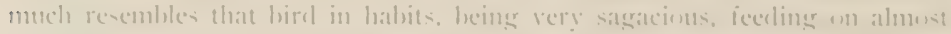
everything animal and regetable, and having nearly the same cries, ditferiner

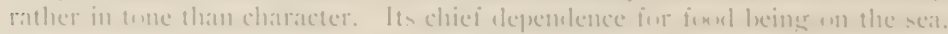

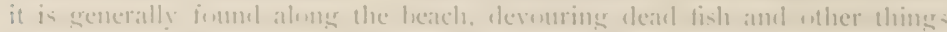

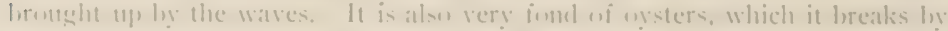
carrying then mpward and droppling asain on a rock or other laard material. When the tide is inll they resort to the diekls or dwellings near the slone and

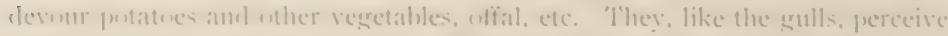
the im-tant wi change wi the sicke, and flecks will thens start wif tuerether for a

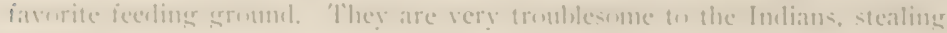


their dried fish and other things, while from superstitions feelings the Indians never kill them but set a child to watch and drive them away. They build in trees near the shore in the same way as the common crow and the young are fledged in May."

Mr. J. F. Edwards, a pioneer of ${ }^{\prime} 67$, tells me that in the early days a small drove of pigs was an essential feature of every well-equipped saw-mill on Puget Sound. The pigs were given the freedom of the premises, slept in the saw dust, and dined behind the mess-house. Between meals they wandered down to the beach and rooted for clams at low tide. The Crows were not slow to learn the advantages of this arrangement and posted themselves promptly in the most commanding and only safe positions; viz., on the backs of the pigs. 'The pig grtunted and squirmed, but Mr. Crow; mindful of the blessings ahead, merely extended a balancing wing and held on. The instant the industrious rooter turned up) a clam, the Crow darted down, seized it in his beak and made off; resigning his station to some sable brother, and leaving the porker to reflect discontentedly upon the rapacity of the mpper classes. Mr. Eilwards declares that he has seen this little comedy enacted, not once, lut a huncled times, at Port Madison and at Allserni, V. I.

The Fish Crows have learned from the gulls the delights of sailing the main on clriftwood. I have seen numbers of them going ont with the ticle a mile or more from shore, and once a Crow kept company with thee gulls on a forat so small that the gulls had continually to strive for position: lut the Crow stoud mudisturlued.

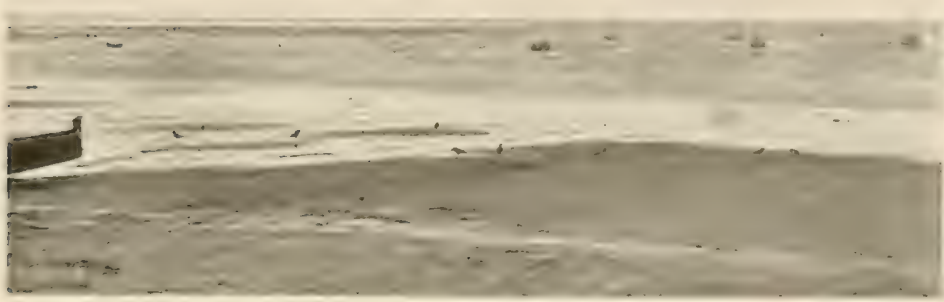




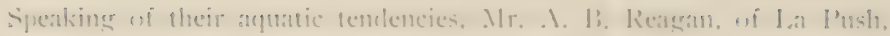
assures me that le hats repeatedly secon them catch smett in the exean near

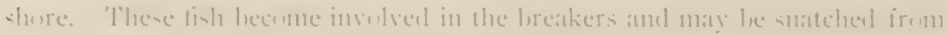
alese be the elextrens hiril without any severe wetting.

Crums are still the must familiar jeature of Indian village life. 'The

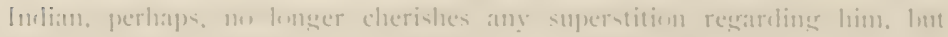
he is refuctant to hamish such a familiar esil. The (Jullatules call the hirel

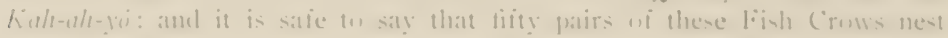
within half a mile of the village of l,at l'ush. 'lhey nest, indifferenty, in

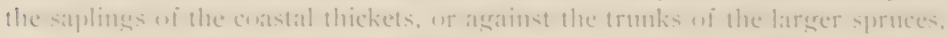

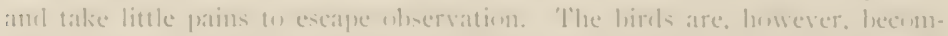

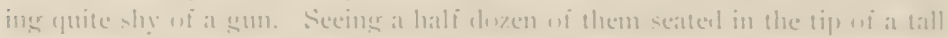

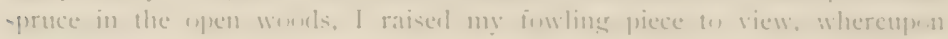

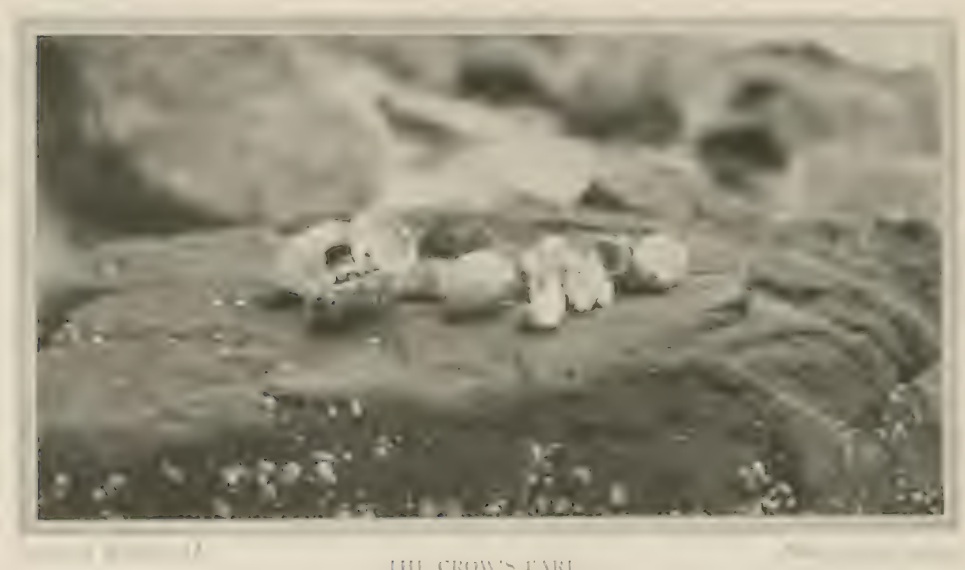

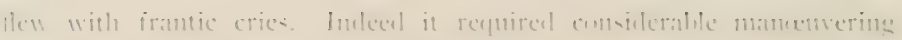

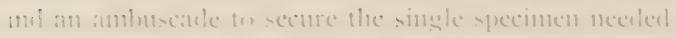

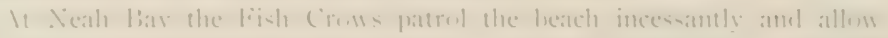

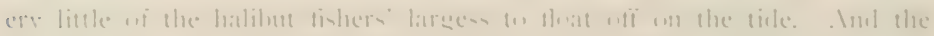

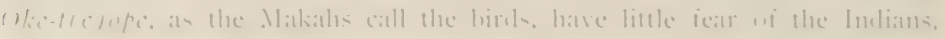

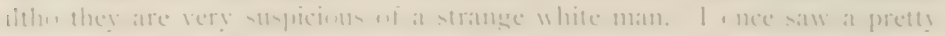

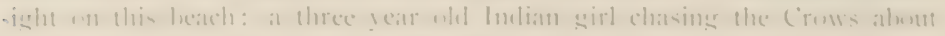

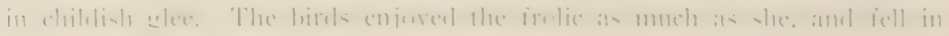


behind her as fast as she shooed them away in front-came within two or three feet of her, too, and made playful dashes at her chubby legs. But might I be permitted to photograph the scene at, say, fifty yarls? Mit nichten! Arragh! To your tents, O Israel!

In so far as this Crow consents to perform the office of scavenger, he is a useful member of society. Nor is his consumption of shell-fish a serious matter. But when we come to consicler the quality and extent of his depredations npon colonies of nesting sea-birds, we find that he merits unqualified condemmation. For instance, two of us bird-men once visited the west nesting of Baird Cormorants on Filattop, to obtain photographs. As we retired down the cliff, I picked up a broken shell of a Cormorant's egg, from which the white, or plasma, was still dripping. As we pulled away from the foot of the cliff a Crow Hashed into view, lighter on the clge of a Shag's nest, seized an egg, and bore it off rapidly into the woods above, where the clamor of expectant young soon told of the disposition that was heing made of it. Immediately the marauder was back again. seized the other egg, and was off as hefore. All this, mind you, in a trice. hefore we were sufficiently out of range for the Cormorants to reach their nests again, altho they were hastening toward them. Back came the Crow; but the first nest was exhatisted; the second had nothing in it; the Shags were on the remainder: moments were precions-he made a dive at a Gull's nest, but the Gulls made a dive at him: and they too hastened to lineir eggs.

Subserprent investigation discovered rifled egg-shells all over the island. atnd it was an easy matter to pick up at hatful for evidence. As he is at litattop, so he is everywhere, an indefatigable robluer of birds nests, a sneaking, thieving, hated, black marander. It is my deliberate conviction that the successful rearing of a nestful of young Crows costs the lives of a hundred sea-luirls. 'l'he Bairrl Cormorant is, doubtless, the heaviest loser: and slie afpears to have no means of redress after the mischief is done, save to lay more eggs, - more eggs to feed more Crows, to steal more exgs, etc. 
No. 5.

\section{CLARK'S NUTCRACKER.}

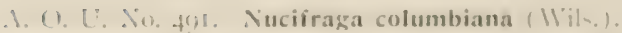

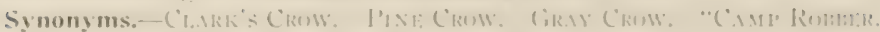
('Thru confusion with the (iray Jay, l'orisoreus sp).).

Description.- - Idults: Cieneral plumage smoky gray, lightening on heaul. lecoming serelid white on iorcheasl. lores, eveliels, malar region and chin: wingglossy lilack, the secondaries lornally tipuerl with white: muler tail-ewerts amel funt entermont pairs of rectrices white, the lifth pair with outer weds chetly white and the inner web chictly black, the remaining (central, pair wi rectice and the upper tail-coverts black; bill and feet bleck: iris brown. Shate of eray in plumage of alults variable-bluish ash in ireshly moulted specimen- darker and browner, or irregrularly whitening in worn plunage. lomme like aulults. hut

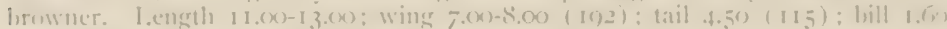

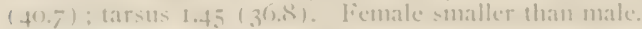

Recognition Marks. - Kinglisher size: gray plunage with abruptly contranting black-ame-white of wings and tail : harsh "iturt-1" lante.

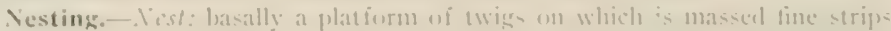

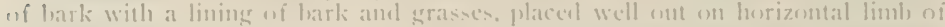

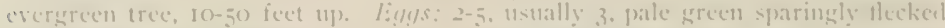

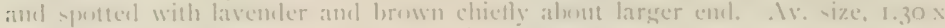

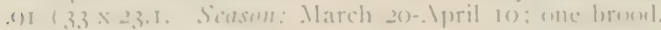

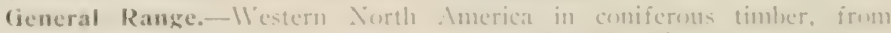

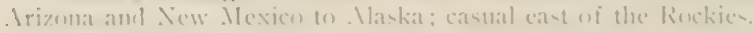

Range in Washington.-()i rewlar necurrence in the mentante thrumut the State. Resiclent in the main lut vinits the fomthills and tower pine-clat lesele

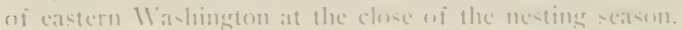

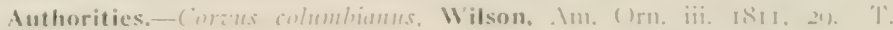

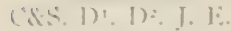

Specimens, - 1 ( . w 11 .). I'rox. I:. C.

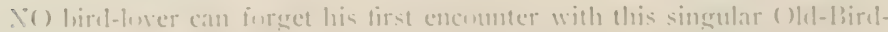

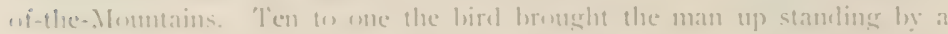

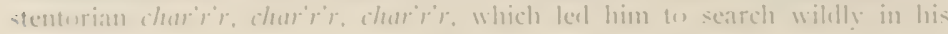
menury whether kics are credited with vrices. li the bird was particularly

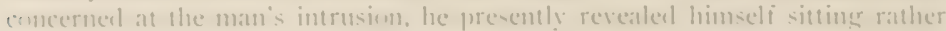
endidly on a high pine branch, repeating that harsh and deatening ery. 'The

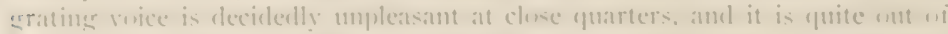

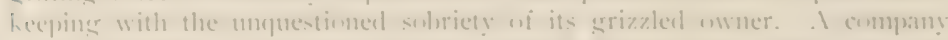

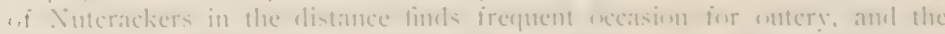
fin is onle leatrable as it is soffened and mulified by the re-echomer walle

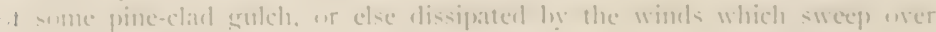
the listenine elaciers. 
Clark's Nutcracker is the presiding genius of the Eiast-side stopes and light-forested foothills, as well as of the rugged iastnesses of the central Cordilleras. His presence, during fall and winter, at the lower altitndes lepends in large meastre apon the pine-cone crop, since pine seeds are lis staple, tho by mo means his exclusive diet. This black and white and gray

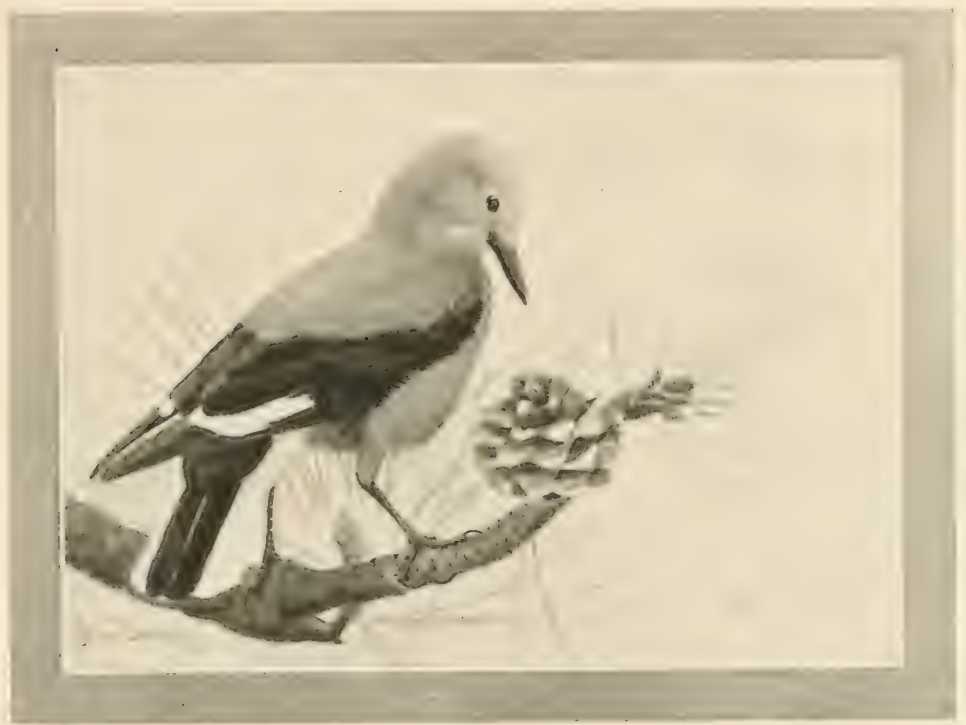

CI.ARK'S XUTCRACKIR.

"Crow" curiously cumbines the characteristics of Woodpecker and Jay as ivell. Like the Lewis Woolpecker, he sometimes hawks at passing insects, eats lerries from bushes, or alights on the gromud to glean grubs, grasshoppers, and black crickets. In the mnuntains it shares with the Jays of the P'risoreus erronp the names "meat-bircl" and "camp-robluer," for nothing that is edible comes amiss to this bird, and instances are on record of its foring invaded not only the open-air kitchen, brit the tent, as well, in search of "stipplies."

Of its favorite fool, John Keast Lord says: "Clark's 'Crows' have, like the Cross-bills, to get out the seeds from underneath the scaly coverings constituting the nutward side of the fir-cone: nature has not given them 


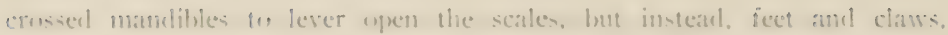
thate serve the pmopese of hames, and a proweriul bill like at small ermwar.

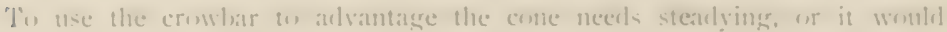
smay, at the stem and fall: to accomplish this one find clasps it. and the peweriul claws holal it firmly, whilst the uther font encircling the loranch.

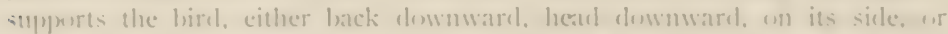

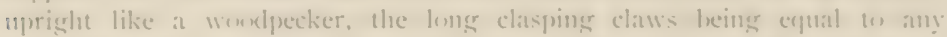
emergency: the enme thus lixed and a lim lowh maintaines on the branch. the seeds are enomged out from numler the scales."

These Nutcracters are amomer the earliest amel most hardy nesters. these are practically independene of climate. lut are fomml during the

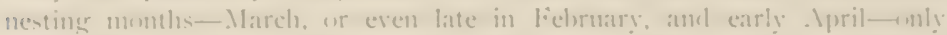
where there is a lecal abumbance of pise (or fir) seeds. They are artiully silent at this seatson, and the impression prevails that they have "erme to

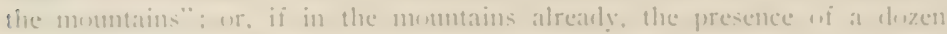
feet of snm serves to allay the wölegist's suspicions.

Tlye nest is a lery stubstantial affair of twigs and bark-strips. heavily

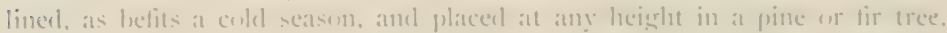
witlunt moticealile attempt at concealment. 'The lirels take turns inculating

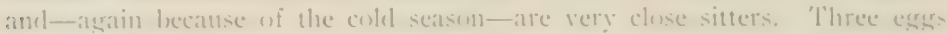

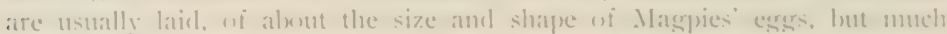
nure lightly colored. Inculation, liemelire thinks, latsts sixteen or seventeen tays. and the young are fed silely on hulled pine seeds, at the first. presumal,l: regurgitated.

If the Corvine affinties of this lird were mowlere else letrated. they

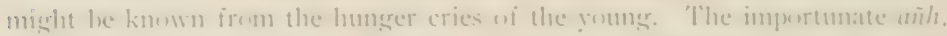

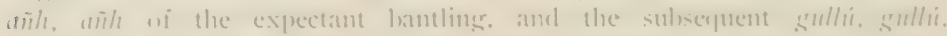
sulli of meelian elentutition (anel lenumlless sattisfaction) will always serve

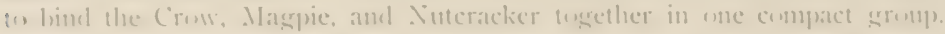

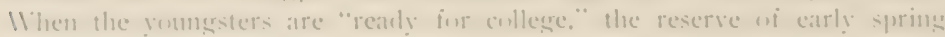
is set asile and the hillsieles are mate to resemel with much pratetice of

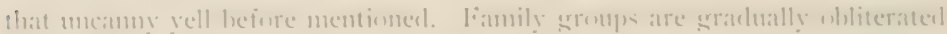

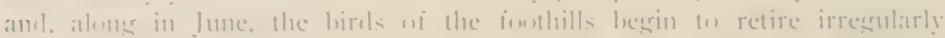

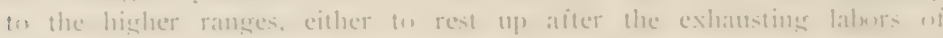

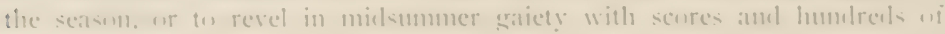
their ielliws 
No. 6.

\section{PINON JAY.}

A. O. U. No. 492. Cyanocephalus cyanocephalus (Maxim.).

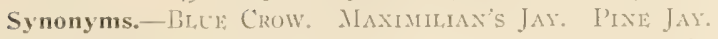

Description.-Adults: P'lmage dull grayish blue, cleepening on crown and nape, brightening on cheeks, paling below posteriorly, streaked and grayish white on chin, throat and chest centrally; bill and feet black; iris brown. Young birds duller, gray rather than blue, except on wings and tail. Length of adult males I1.00-12.00: wing 6.00 (I5.); tail 4.50 (II.4); bill I.f2 (36); tarsus I.50 (38). iemale somewhat smaller.

Recognition Marks.-Robin size; bltte color; crow-like aspect.

Nesting.-Not supposed to nest in State.

General Range.-I'iñon and juniper woods of western United States; north to southern British Columbia (interior), Idaho, etc.; south to Northern Lower California, Arizona, New Mexico, and western Texas; casually along the eastern slopes of the Rocky Mis.

Range in Washington.-One record by Capt. Benclire, liort Simcoc, Fakina Co., June, I88I, "quite numerous." Prestmably casnal at close of nesting season.

Authorities.-["Maximilian's Nutcracker," Johnson, Rep. Gov. IV. 'T. I884 (1885), 22.] Cianocephahus cyanocephahus (Wied), Bendire, Life Hist. N. A. Birds, Vol. II. p. 425 (I895).

\section{Specimens.-C:}

C.II'TYIIN BENDIRE who is sole authority for the occurrence of this hird in Washington may hest be allowed to speak here from his wide experience :

"The I'iñon Jay, Jocally known as 'Nutcracker, 'Maximilian's Jay, 'Blue Crow; and as 'I'monario' by the Mexicans, is rather a common resident in suitable Iucalities throughout the southern portions of its range, while in the northern parts it is only a summer visitor, migrating regularly. It is most aloundantly found thromghont the pinon and cedar-covered foothills abounding between the western slopes of the Rocky Mountains and the eastern bases of the Sierra Nevala and Cascade ranges in California, Nevada. and Oregun.

"It is an eminently socialsle species at all times, even during the loreerling season, and is usually seen in large compact llocks, moving alont from place to place in search of ieeding grounds, being on the whole rather restless and erratic in its movements: you may meet with thousands in a place in-rlay and perhaps to-morrow you will fail to see a single one. It is rarely met with at altitudes of over 9.000 feet in summer, and scarcely ever in 
the higher enniferents furests: its faserite haums are the piomm-ensered fouthills wi the minor muntain regions, the sweet and very palatable seeds

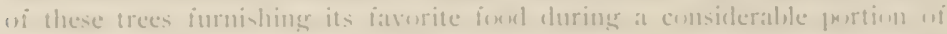
the year. In stmmer they fecel largely an insects of all kinels, especially eratsihnpers, and are yute expert in catching these on the wing: cedat

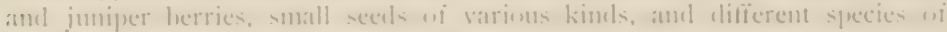
will berries ales enter larecly inter their hill wi fare. A great deal wi time

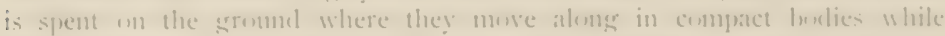

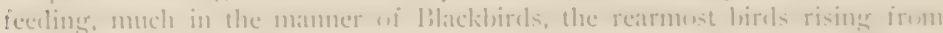

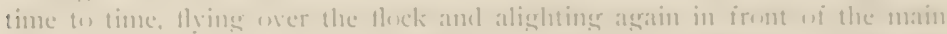
ixuly: they are rather shy and alert while engaged in feethes. I followeel a fleck numbering several thusands which was feceling in the open pine forest hordering the Klamath lialley, ()regrn, for more than hali a mile.

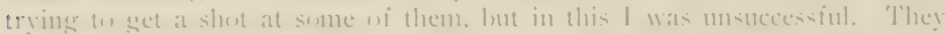

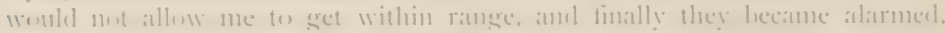
temk wisge. and flew ont of sight down the valley. ()n the mext daty.

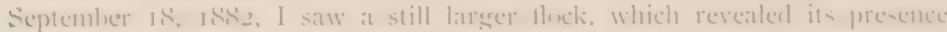

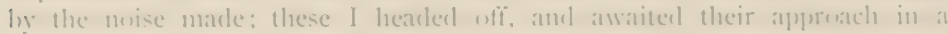

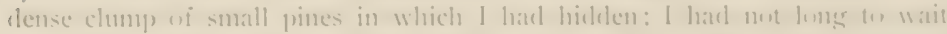

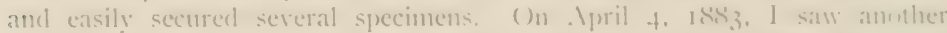
laree fleck feerling in the open wousls. evidently on their retures to their

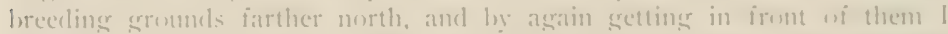
secured several fine males. These bivels atre said to loreed in laree mumber in the juniper groves near the eastern stepes of the (ascaule Mentutins, on the head waters of the l)es (hutes kiver. ()regond. I hase also seen them

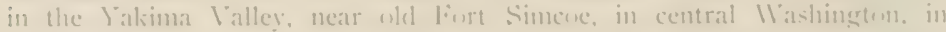

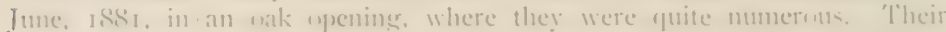
conter of almulance, however, is in the piñn or mut-pine lielt. which due not extend morth of latiturle for $)^{5}$ if so far. and wherever these trees atre

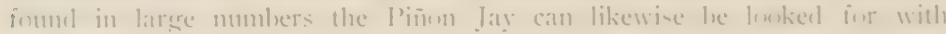
centivlence.

"Their call motes are quite variable: sume of them are almont as harsh

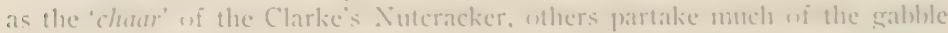
of the Magpie, and still whers resemble more these wi the Jays. A slarill.

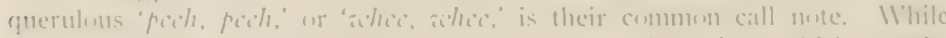
feerling on the erromul they kept up at comstant clattering, which can lie leard for quite a distance, and in this waty witen lectray their whereahuts." 


\section{No. 7.}

\section{AMERICAN MAGPIE.}

A. O. U. No. 475. Pica pica hudsonia (Sabine).

Synonym.-BLACK-BILLED MAGIIF.

Description.-Adults: Lustrons black with violet, purplish, grecn, and bronzy iridescence, brightest on wings and tail; an elongated scapular patch jure white; lower breast, upper abdomen, flanks and sides broadly pure white; primaries extensively white on inner web; a broad band on rump with large admixture of white: tail narrowly graduated thru terminal three-lifths; bill and feet black; iris black. Joung birds lack iridescence on head and are elsewhere duller; relative length of tail sure index of age in juvenile specimens. Length of aclults $15.00-20.00$, of which tail 8.00-12.00 ( $\mathrm{N}$. 265); wing 7.85 (200); bill I.35 (35.); tarsus $1.85(+7)$.

Recognition Marks.-Black-and-white plumage with long tail ummistahable.

Nesting.-Nest: nommally a large splere of interlaced sticks, "as big as a bushel basket," placed 5-40 feet high in willow, aspen, grease-wood or pine. The nest proper is a contained hemispliere of mud 8 -Io inches across insikle, and with walls $x-2$ inches in thickness, carefully lined for half its clepth with twigs surmounted by a mat of fine rootlets. Eggs: 7 or 8 , rarely 10 , pale grayish green, guite uniformly freckled and spotted with olive green or olive brown. Occasionally spots nearly confluent in heavy ring about larger end, in which case remainder of egg likely to be less heavily marked than usual. Shape variable, rounded ovate to elongate ovate. Ar. size, $1.20 \times .88$ (30.5 ×22.3). Season: March 20May I; one brood.

General Range.-llestern North America chicfly in treeless or sparsely timbered areas from southern Arizona, New Mexico, and western 'lexas north to northwestern Alaska. Straggles eastward to west shore of Hudson liay, and occurs casually in Nortli Central States, Nebraska. etc. Replaced in California west of the Sierras by l'ica nuttalli.

Range in Washington.-Confined to East-side cluring breeding season, where of nearly universal distribution. Disappears along east slope of Cascades and does not deeply penetrate the mountain valleys. Nigrates regularly but sparingly thrt motmintain passes to 11 est-sicle at close of breeding season.

- Authorities,-[I,ewis and Clark, Itist. Ex. (ISI4) Ed. Biddle: Cones, Yool. II. p. I 5.] P'ica hudsonica Tonap.. Baird, Rep. Pac. R. R. Surv. IX. pt. II.

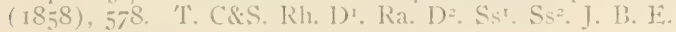

Specimens.-( L. of II:) I'. I'rov. I). Li. I3,

HERE is another of those rascals in feathers who keep one alternately grumbling and admiring. Is an abstract proposition one would not stake a sou marquec on the virtue of a Magpie; hut taken in the concrete, with a sly wink and a satucy tilt of the tail, one will rise to his feet, excitedly. slonting, "Go it, Jackity," and place all his earnings on this pie-loald steed in the race for avian honors. It is impossible to exaggerate this curious contradiction in Magpie nature, and in our resulting attitude towards it. It is much the same with the mischievons small boy. He has sumpassed the 


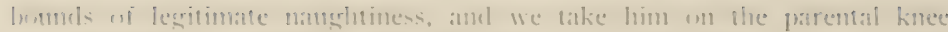

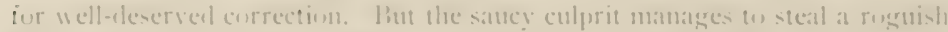

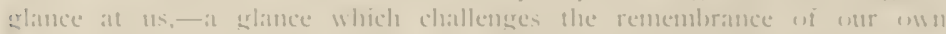
lonish pranks, and hids th ask what difference it will mate twenty years after; ant it is all uff with discipline fur that excension

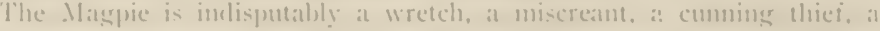

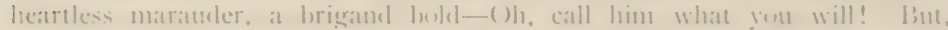

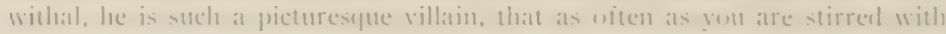

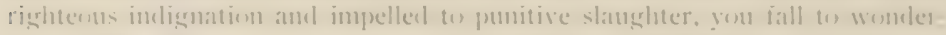
ing if yom commission ats alenger is properly commersigned, and-shirk the lask untrieght

The cattle men have it in for him, lecanse the persecutions wi the Magpie smmetimes prevent scars mate by the loranding from irom healings amel calse-

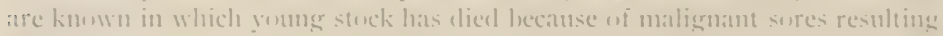
This is, of course, at arave mistemeanur: lut when the wse of fences shall hate inlly displaced the present custem of hrandinge we shall probaldy hear ne more of is

liegund this it is imlisputalyly true that Magpies are professional nest roblers. It times they organize systematic seatrehing parties, and andrance

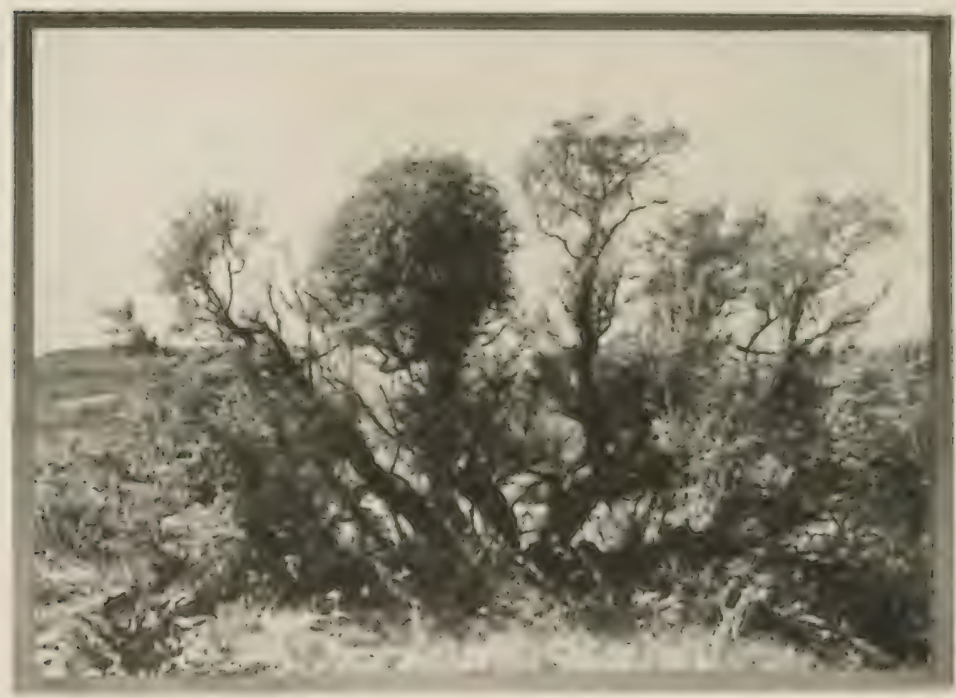




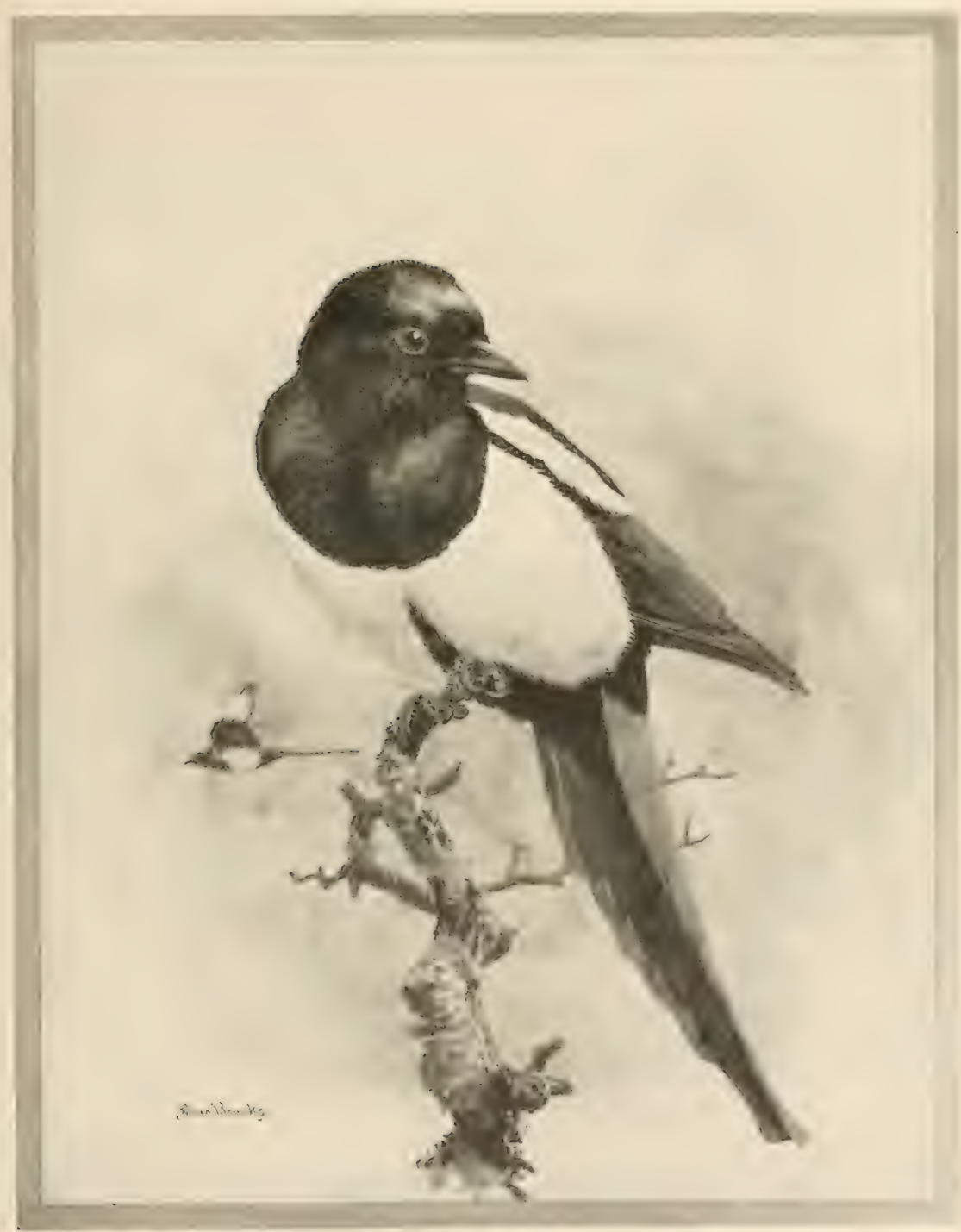

+1 14 , 1 :11 
thru the sage-brush, peking, prying, spying, and devenring, with the ruth-

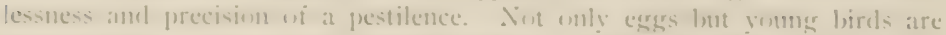
alpumpriated. I nnee saw a Magpie scize a hali-errown . Meatewlark from 11- nest. carry it to its own demicile, and parcel it ont amome its clamoring

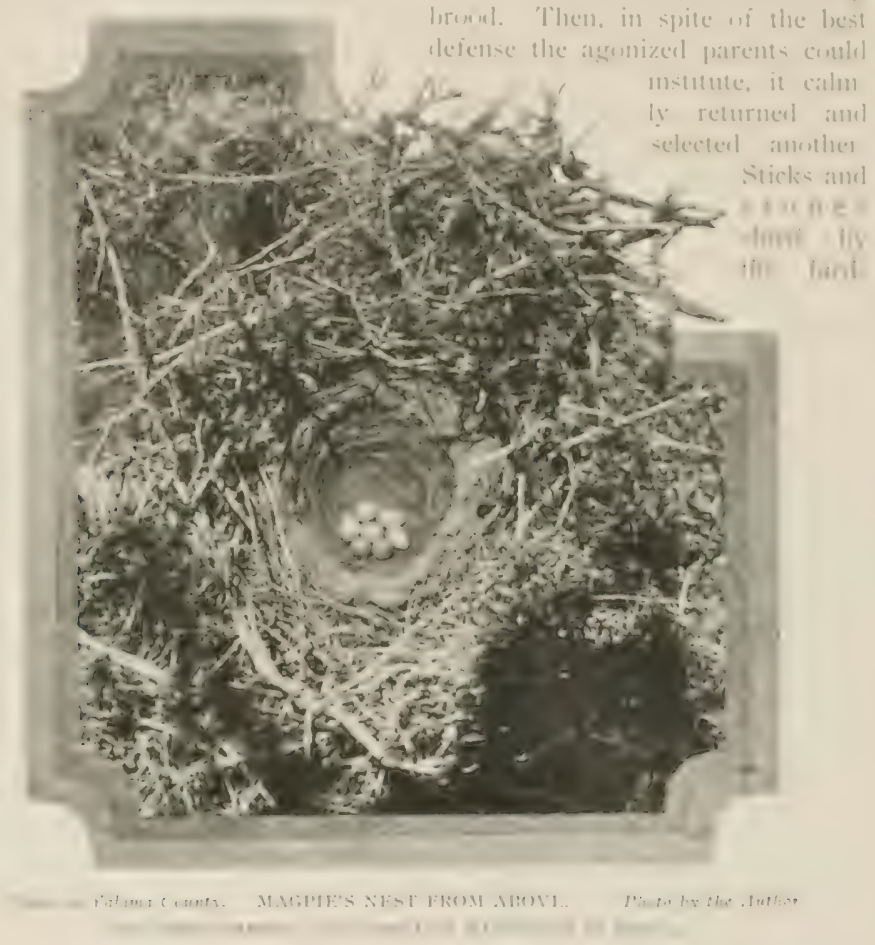

man merely deferrerl the dimm of the remaining larks. The dlagrie was not likely fo forecet the wherealumes of streh easy meat

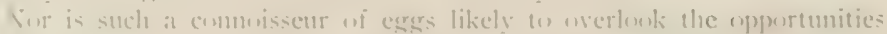

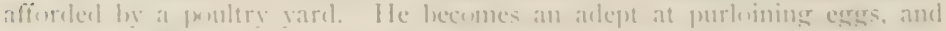
malie off with his lomes with astenishingr ease. ()ne carly morning. secine a Magric fis mer the corral with something larere and white in his

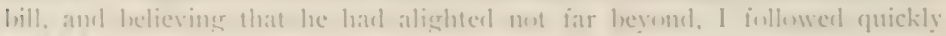
ant wohtened him from a larece hen's eger, which hore externally the marks 
of the bird's bill, but which was unpierced. Of course the only remedy for such a liabit is the shot-crm.

'Jo say that Magpies are garrulons would be as trite as to say hens cackle. and the adjective conld not be better defined than "talking like a Magpie." The Magpie is the symbol of loquacity. The very type in which this is printed is small picat; that is small . Hagpic. Mluch of this bird's conversation is undoubtedly unfit for print, but it has always the merit of vivacity. A party of Magpies will keep tup a ruming commentary on current events, now facetinus, now veliement, as ther move about; while a comparative cessation of the racket means, as likely as not, that some favorite racontem is holkling forth. and that there will be an explosion of riotous laughter when his tale is done. The pie. like Nero, aspires to song; but no sycophant will he found to praise him, for he intersperses his more tuneful musings with chacks and barks and harsh interjections which betray a disordered taste. In modulation and quality, howerer, the notes sometimes verge upon the luman: and it is well knowin that Magpies can be instructed until they acquire a handsome repertoire of speech.

In order that their double quartet of youngsters may be lined up for the egg harvest, the Magpies take an early start at home building. April is the nesting month. but I lave two records for March $30 t h$, - one of five eggs at Chelan, and one of cight in Yakima County. In the latter instance the first egg must have heen deposited not later than March 18th. Ancl becatise the season affords him 110 protection, the Nagpie resorts to two expedients in nest building in lien of concealment: he first seeks retirement, the depths of some lonesome swamp, an unfrequented chaw, or wooded spring, in the foothills, and then he erects a castle which would do credit to a fendal baron. 'The nest is a ball of interlacing sticks set about a hollow half-sphere of dried muk. 'The amomnt of labor expended upon one of these structures is prodigious. 'The greasewood nest shown in the accompanying cut is three feet (leep and two feet thru, and the component sticks are so firmly interwoven that no ordinary agency, short of the human hand. can effect an entrance. 'The bird enters thru an obscure passage in one side. and, if surprised upon the nest, has always a way of escape plamned thru the opposite wall. 'The mud cup' is carefully shaped with walls an inch or two in thickness, a total breath of eiglit or ten inclies, and a like depth. In the best construction this cavity is filled to a depth of three or four inclies with a loose mat of fine twigs of a miform size. Upon this in turn is placed a coniled mattess of fine, clean rootlets, the whole affording a very sanitary arrangement.

Another fortress, of single construction. was four feet leep and three and a half feet thru; and that, too, after making liheral allowance for clance projections. The component sticks measure up to three feet in length and 


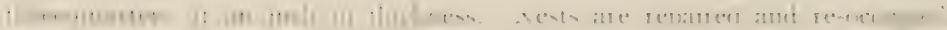

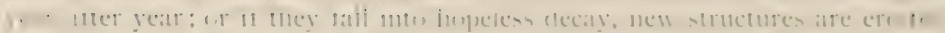

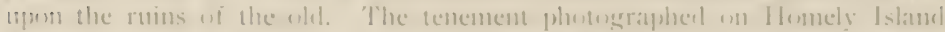
is a cholble nest tit laklis

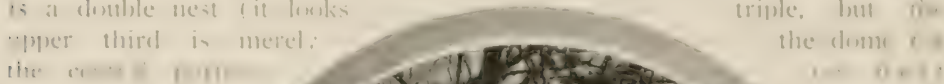
[roper), and nuciv-

teet trim toin tit

|1 () 111 in incel

them

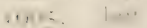

the wilugist

is verty |untel

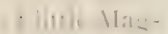

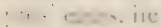

iit) il, ... . n

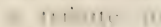

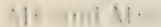
1. . .

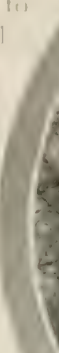

(1) $(1,+1)$ 1. en of: (n)

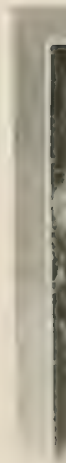

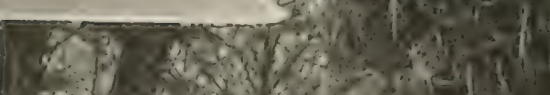


'This historic pile is in marked contrast to one sighted in a willow on the banks of Crab Creek near Odessa. My attention was attracted to the spot by a scuftle, which took place letween a Nagpie and a pair of Kinghirds: and when I started to examine the nest. I was in lonest dould whether it might not belong to the Kingluirls. 'The foundation was of mud, but this came near constituting the ontside of the nest instead of the inside. The action of the wind wyon the willows had compressed the mud bowl to a boatshaped receptacle wherein lay five brown beaties, unmistakable Magpies" eggs. There was a copious lining of rontlets, and a light half-cover of thorn twigs: but the whole structure was not over a foot in cliameter and scarcely that in depth.

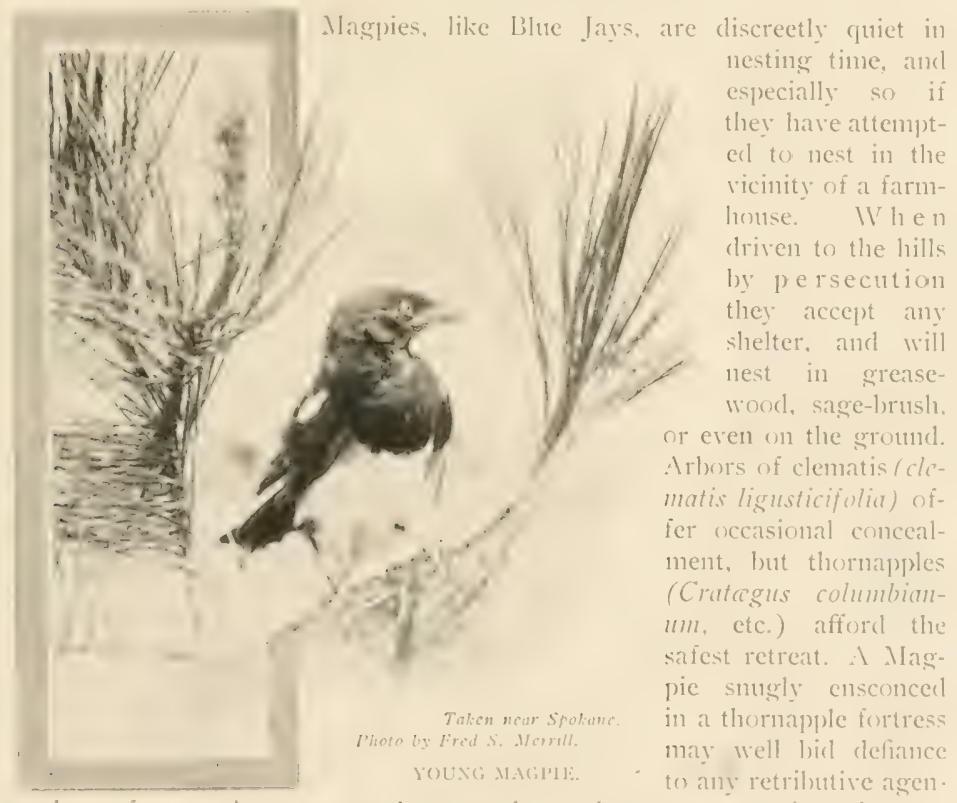

cy sluert of man. Among several seores of nests 1 never saw one in a pine tree in the Jakima conntry, yet these are freely utilized in Chelan, Okanogan, and Spokane connties. Incleed, in these latter localities there is a suspicion oi dawning preference for the tree-tros and cliffeult climbs. On the Columbias liver I once foumd a fanty of Magpies occupying the hasement of a hure 


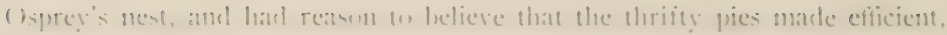
ii muselente, janims.

lonug .latgpies are unsightly when hateheel, - "worse than nakerl," and

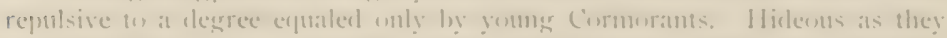
unfuestionathy are, the devoted patrents dectatre them angels. and are reaty

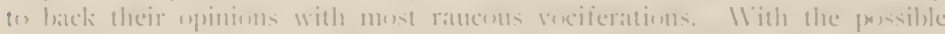

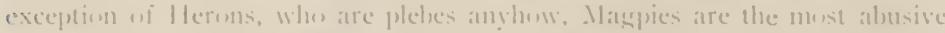
ambl profane wi hirels. When a nest wi young hirds is threatened, they met cunly expresis stach reasmable anxiety as amy parent might feel. but they demunce, mplorabl, anathematize, and vilify the in rusler, and deery his lineage

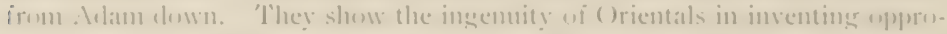
hrions epithets, and when these rmo dry, they fall to tearing at the leaves, the twigs, the bratsches, ar even light on the gromml ancl rip up the suil with their leaks, in the mat extremity ai their rage.

I patir witlo whun I experimented near Wallula rather fell into the lumor of the thing. 'lhe Magpie is ever at was. and these must have kumbn that repeated visits could mean me larme. Severtheless, as often as I ratted the nest frum my favorite perch on the willum tree, the whl pies npened fresh vials of wrath and emptied their entents upun my devented heal. When mere utterance hecame inaterpute, the male birel fell to hewing at the end of a moken branch in most eloguent indignation. He were this down inur inclues in the contre of my three visits. ()nee, when my attention was cliverted, he touk a sly crack at my ontstretched fingers. which were hastily withulrawn: and. Believe me, we buth langhed.

The lblatek-billed Alagpie winters practically thruent its breeling range, lute it alse indulges in irregular migratery mowements, which in IVashingen take the form of excursions to the enast. While never common on I'uget

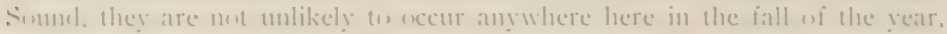
and are almost certain to be fomml somewhere alont the sonthern praties. They return early in spring hy way of the major passes, and are nut anain ecen within the heavily timberes areas during the loreeding season. Mr. I).

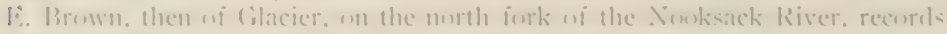
umber date of March to Ino5. the appearance of several hands of Magpies passing eastwaril at a consielerable height, perhaps something hetween three and five thousand feet. He says they were unrecongizable until grlasses were traned un them, and he thinks he must have seen at least fifty hirels, with diances for many more o have passed molserved.

Fast or west the Magpie becomes a pensiuner wi the slatghter hense in winter, and his fondness ior ment has witen prosed his molumer in the cattle

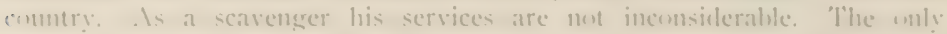
trouble is as has leen sait, that he sometimes kills his oms meat.

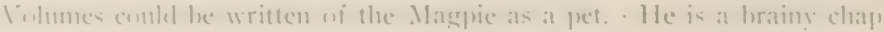


as well as a wag, and infinitely more interesting than a stupid parrot. Mischief is his special forte: the untying of shoe-strings, the investigation of carities, the secreting of spoons, and the aimless abstraction of gold teeth are his mending delight. Once when the writer was shelling seer peas in the garden, a spoiled "Jackity" assayed to fill his (the man's) ears with these innocent pellets; and when he discovered a rent in the knee of the man's trousers, he fairly chortled, "Well; I see myself busy for a week filling that liole!"

Cage life is irksome for bird or beast: but, if we numst be amused, and, above all, if we feel called upon to pass adverse judgment upon this gifted bundle of contradictions, as he exists in a state of nature, let our harshest sentence be sociable confinement with occasional freedom on parole. A birel in the cage is worth two in the obituary columms.

No. 8 .

\section{CALIFORNIA JAY.}

A. O. U. No. 48 I. Aphelocoma californica (Vigors).

Description.-Adults: In general blue, clianging to brownish gray on back (scapulars and interscapulars), whitening variously on underparts; crown, hind neck and sides of neck dull cobalt blue, nearly uniform; wings, tail, and upper tail-coverts dull azure blue; cheeks and auriculars cobalt blue and dusky; chin. throat, and chest, centrally, white, the last-named with admixture of blue in streaks, and passing into the clear blue of its sides; breast sordid gray; passing into dull white of remaining underparts; shorter under tail-coverts pure white, the longer ones tinged with pale blue; bill and feet black; iris brown. In young birds the blue of adults is supplanted by monse-gray on head and lower neck. rump, etc., save that crown is tinged with blue; the gray of back is of a decper shade; the underparts are white, save for light brownish wash across breast and sidles. Length of adult males I I.50-12.25; wing 5.00 (I 27 ); tail 5.60 ( $\left.\tau_{4}+3\right)$; bill I.00 (25.4); tarsus I.6o (4I). Females slightly smaller.

Recognition Marks.-Robin size; blue coloration without crest: whitish minlerparts.

Vesting.-Nest: a bed of small twigs withont mud ant heavily lined with line dead grass; 8 inches across outside by $3^{\mathrm{T} / 2}$ in depth-thus much smaller and lighter than that of the Steller Jay-placed at moderate elevition in tree or bush in thicket near water. Liggs: $3-6$, ustally + or 5 , deep green of varving shades, spotted with redklish browns. Av size, 1.II x .82 (28.2 x 20.8). Season: first week in . May; one brood.

General Range.-Pacific Coast district of United States, including eastern slopes of the Sierra Nevarla and the Ciscade Range in Oregon, north to sonthwestern Washington. 
Range in Washington.--(1) limited loue regular weenrence alonge the bank:

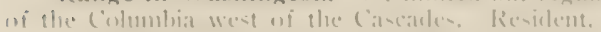

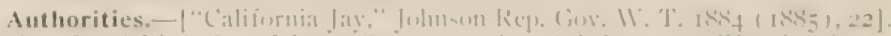

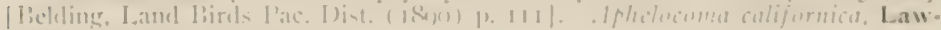
rence, Iuk, |uly, $1,4,2, \mid), 3(1)$

Specimens.-C:

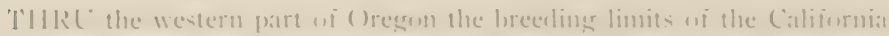
lay elo met extemel ats far north at the chimmbia liver. I have never

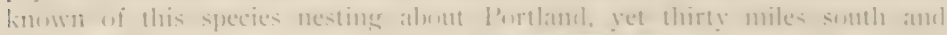
innthwest it is 1101 all all uncommmin l'hets the 11 illam efte lalley me meets this limel alume at witen as the siteller Ja! The lathits wi the nwo iavs are much the same, vet the hirals are easils rlistinguisheel lo their dresse the Califurnia I al ! bavinge more re somblanee to the lilue lay wi the $1 \cdot 11$ whe bin lackine the onet. while: the siellev Jay las a dath blue and blackisla wat with the lome mens

becorrlines mepular comen. the Califumia I, as a himel uif hal wemant an 4 mo

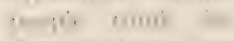
. 1110 . $\therefore 111010$

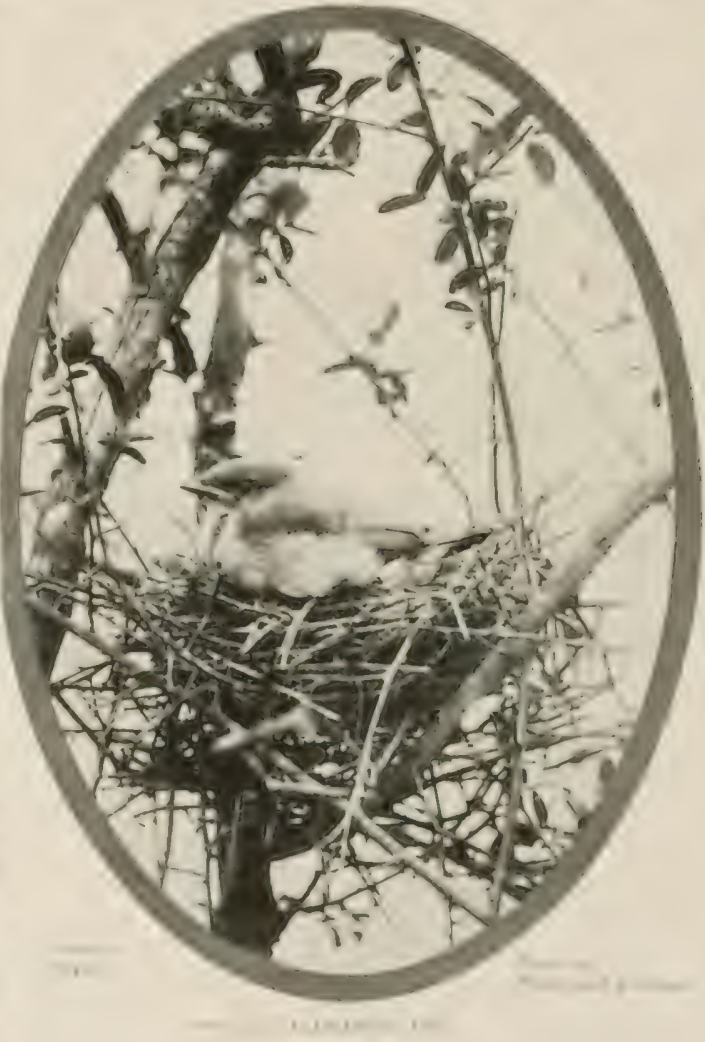


other birds and feasting on their eggs. 'This is not true, altho occasionally a Jay will destroy the home of another bird. In Oregon I have often seen this bird feeding on wheat about the edge of the fields after the grain has been cut. Iiruit, grain, grasshoppers and other insects make up a large part of lis foorl.

Several years ago I sall a small flock of California Jays along the Columbia River in the clead of winter. During the nesting season the jay is too quiet to show his real character. During the attumn and winter he throws off all restraint, picks up a few mates and goes wandering about from place to place in search of food. The bold and boisterous squawk of the Blue Jay always comes to my ear as a welcome and fitting note to relieve the cold quiet of the winter wouls.

One clay I was watching several English Sparrows that were feeding on the gromel under an oak when a pair of California Jays came flying thru the trees. IVith a lourl squawk one swonped down, with his wings and tail spread and his feathers puffed out as much as possible, evidently expecting to scare the sparrows. He clropped right in their midst with a screech which plainly. said, "Get out of here or I'll eat you up alive!" The bluff might have worked with any hird except an Englisher. The Sparrows sputtered in contenpt and were ready to fight but the Jay's attitude changed in a second. He took on an air of meekness and mnenncern and hopped off looking industrionsly in the srass for something he had no idea of finding. I thought it a good touch of Jay character.

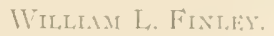

No. 9.

\section{STELLER'S JAY.}

A. O. U. No. 478. Cyanocitta stelleri (Gmelin).

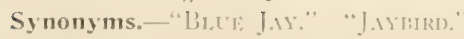

Description.-Idults: Head and neck all around, and back, sooty black, tonched with streaks of certean blue on forehead, and pale gray on chin and throat, this color passing insensibly into clull blue on breast and rump and richer blue on wings and tail : terminal portion of tail and wings crossed with fine black bars, sharply on secondaries and tertials, faintly or not at all on greater coserts. Bill and feet black; iris brown. Joung birds are more extensively soots, and wing-bars are faint or wanting. I, ength of adults about 12.00 : wing 5.00 ( $(5,5)$ : tail 5.43 ( 138 ) ; bill 1.18 (.30) : tarsus $1.80(46)$.

Recognition Marks.-Robin size; harsh notes: blue and black coloration Immistakahle. 
Nesting. - Vist: a bulky mass of the twigs thickly plastered centrally with mmel and lined with line rootlets, placed (2-30 iece high in evergereen tree of thictect. ur near celge of clearing. Litgls: 3-5, usually to pale bluish green, uniformly lut molerately spoted with olive brown and prale rofous and with numerous "sledl-

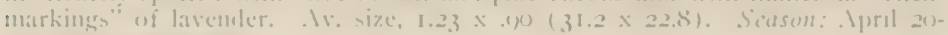
May 10: one broxel.

General Range.- North l'acific Const district from liray's Harbur and

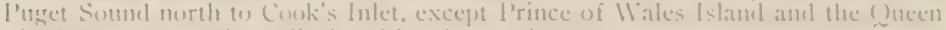
Charlotee groug) (where displaced hy $($. s. corlothe ).

Range in Washington.- lintire Western portion from -ummit of Cancalles.

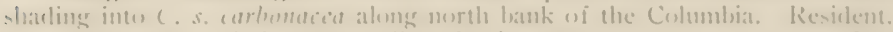

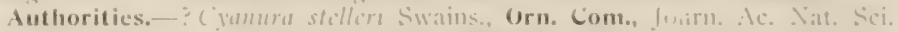

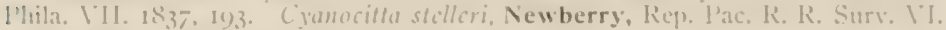

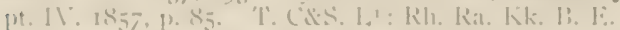

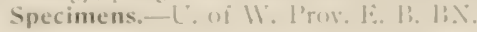

Mlscllllil" and the "lilue Jay" are synomymms. Nlert, restless, saney. inpusitive, and prowhing, yet ahways interesting, this handsonte hrigand keeps his human critics in al perpetual see-saw letween wrath and aldmirattion. . Is a sprightly prece of Nature, the stefler Jay is am ungualitied success. As the hero-subject of a guesing contest he is withont at peer, for one never knows what he is doring tutil he has done it, and nome may predict what he will in next.

The pioneers are espectally bitter asainst him, and they are unamimous in aceusing the hirl wi malicinus destructiveness in the gardens, which are dearer than the apple of the eye during the lirst years of wilelerness life. The birds will eat anything, and so, tiring of bugs and slugs, are not averse fo tryine

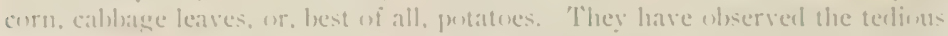
uperation of the gardener in planting, and know precisely where the coneted

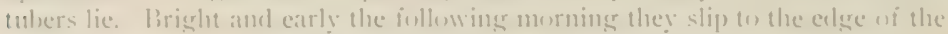
clearing. pust ane of their number as lemkent, then silently depley upen their grumlish task. If they weary of potatues, spromting peas or corn will do. (or

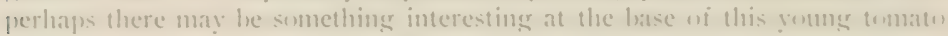
plant. And when the irate farmer applears npou the secue. the maramlers retire (1) the forest shrieking with laughter at the diseomlited swain. . Iy! there's the rub! Ile may enclure injury lut not insult. liang! lamer!

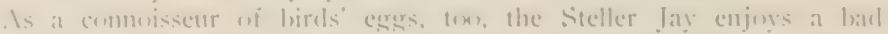
cminence. The sufferers in this case are chiefly the lesser song hirels : but mo

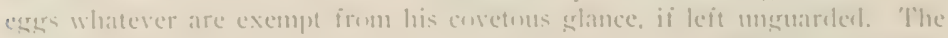
Jay has lecome especially proficient in the discowery and sacking of linsh-tits

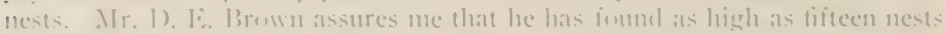
uf this hirel in a single swamps, all gutferl hy days. When it is rememberes that these luss litele workers make une of the handsomest nests in the worlel. the shame of this piracy gets upun the nerves. The investigation of this: nests has something of the fascination of the gamber table fur the lay, since 
he never knows what the wonder pouches may contain, until he has ripped a hole in the side and inserted his piratical beak.

The dense forests of Puget Sound are not so well patrolled by these feathered grafters as are the forests of the East by the true Blue Jay (Cyanocitta cristata). But then our bird has the advantage of denser cover, and we do not know how often we have been scrutinized or shadowed. Upon discovery the Steller Jay sets up a great outcry and makes off thru the thickets shricking lustily. A favorite method of retreat is to flit up into the lower branches of a fir tree and, keeping close to the trunk, to ascend the succeeding limbs as by a spiral staircase. The bird, indeed, takes a childish delight in this mad exercise, and no somer does he quit one tree-top than he dashes down to a neighboring tree to run another frenzied gamut.

Owls have abundant cover in western Washington, but should one of them be startled by clay, the Steller blue-coat is the first to note the villain's flight. The alarm is sounded and an animated pursuit begins. When the Ow] is brought to bay, the deafening objurgation of the Jays is not the least indignity which he is made to suffer. The Jay, in fact, seeks to make the world forget his own offenses by heaping obloquy upon this blinking sinner.

The notes of the Steller Jay are harsh and expletive to a clegree. Shaack, sharack, shaack is a common (and most exasperating) form; or, by a little stretch of the imagination one may hear jay, jay, jay. A mellow klook, klook, klook sometimes varies the rasping imprecations and serves to remind one that the Jay is cousin to the Crow. Other and minor notes there are for the lesser and rarer emotions, and some of these not 1 mmusical. Very rarely the bird attempts song. and succeeds in producing a medley which quite satisfies her that he could if he would.

C. stelleri, like $C$. cristata again, is something of a mimic. The notes of the II estern Red-tail (Buteo borealis calurus) and other hawks are reproduced with especial fidelity. For such an effort the Jay conceals limself in the depths of a large-lea ferl maple or in a fir thicket, and his sole olject appears to be that of terrorizing the neighboring song-bircls. One such I heard holding forth from a shade tree on the Asylum gromels at Steilacoom. Uncanny sounds are, of course, not unknown here, but an exploratory peblule servect to ummask the cheat, and drove forth a very much chastened Blue Jay before a company of applauding Juncoes.

It is well known that the gentleman hurglar takes a conscientious pricle in the safety and welfare of his own home. Nothing shall molest his dear mes. 'I'le Jay becomes secretive and silent as the time for nest-building approaches. The nest is well concealed in a dense thicket of fir saplings, or else set at various lieights in the larger fir trees. If one but looks at it before the complement of eggs is laid the locality is rleserted forthwith. If, however. the enterprise is irretrievably. launched, the birds take care not to be seen in 
the vicinty wif their nest meth they are certain wi its diecuery, in wheh case they call heaven and earth to witness that the man is at menster of indquity, and that he is plotting atgininst the innocent.

In wur experience. Siteller's lay is not, ats has leeen sometimes repurted, at

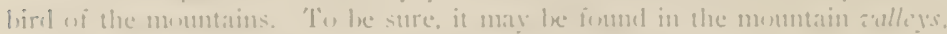

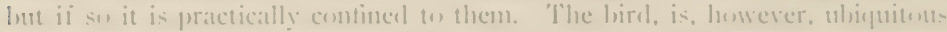

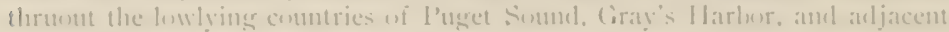
regrions, giving way only upon the somth to the duhions Cirimell Jay (S. s. (arbuitucial).

Nin. I0.

\section{GRINNELL'S JAY.}

1. (). I i. No. f-Sic. Cyanocitta stelleri carbonacea I. Cirimell.

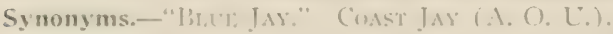

Description.-"Similar u C. s. stilleri, Int paler thront, and averaging vighty smaller; color of head very nearly as in $($. s. stelleri, lout averaging

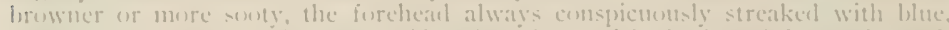
amel throat more extensively or uniformly pale srayish: back and forencele much paler, slaty hrown or brownish slate, insecal of deep sonty; blue of rumy, upper titil-coserts, and under parts of heoly light dull cerulean wr verditer blue, advancins more over cle-t. where more abrupdly detined againet the souty or lorewni-h

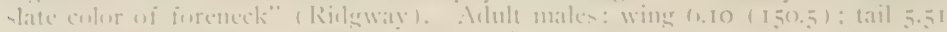
$(140)$ : lill $1.15(24) .1)$ : tarsus $1.75(4.5)$.

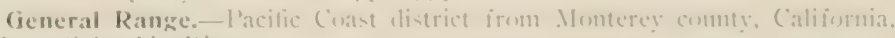
morth to ('nlumblat kiver.

Range in Washington,- Hats only theoretical stafus in state, Int specunens

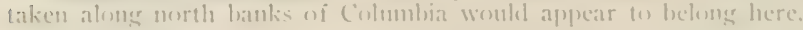

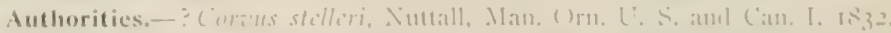

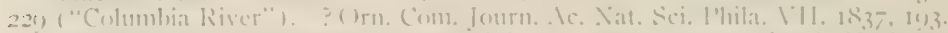

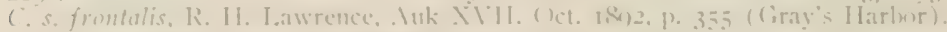

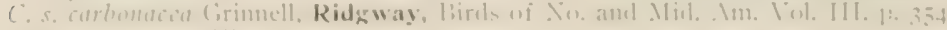
(ientmote). I.. Kh.

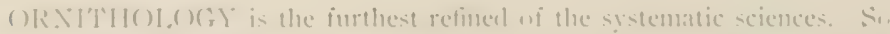

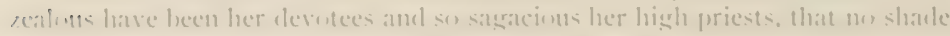

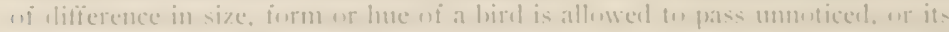

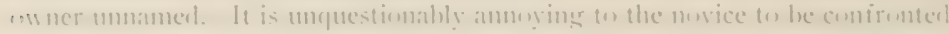

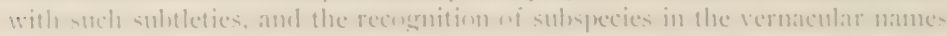

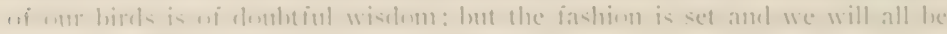
indi-h together-ent that mone may langh.

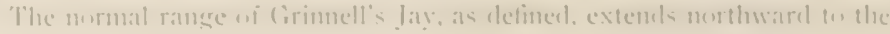


Columbia River: and since the district lying between the Columbia and I'nget Sound presents intergrades between $C$. stclleri and C. s. carbonacea, obviously, those lays which inhabit the sonthern portion of this debatable ground are better entitled to be called carbonacea than stelleri.

No. I I.

\section{BLACK-HEADED JAY.}

1. O. U. . No. $478 \mathrm{C}$. Cyanocitta stelleri annectens (Baird).

Synonyms.- "BlLL: JAY." PINE: JAY. Moc NTAIX JAY.

Description.-Adults: Similar to C. stcllcri, but marked with a small lengthened white spot over eye; streaks on forehead (when present) paler bluc or whitish: streaks on chin and upper throat whiter and more distinct; blue areas slightly paler and rather more greenish in tone. Size indistinguishable.

Recognition Marks. - Is in C. stelleri. White spot over eye distinctive.

Nesting.-As in C. stclleri.

General Range.-Eastem British Columbia and the northern Rocky Monntains, south to Wahsatch Range in Utah, west to eastern slopes of Cascade Range in Washington and Oregon.

Range in Washington.-Forests of eastern Washington, shading into typical stelleri in Cascade Range. Nearly confined to pine timber.

Authorities.-C Canocitta stelleri annotons, Brewster, liull. Nutt. Orn. $(\because 11,111,1,2,2,1,1,-1), 1,1$.

THERE is no stoch difference of plumage between $C$. stelleri and $C$. $s$. ammechens as is sugested by the name "Iblack-headed": but in encleavoring to mark eight shades of difference letween tweedledim and tweedledee within the limits of a single species, we are naturally pretty hard put to it for appropriate names. Annetens marks the annexion, or welding together, of two branching lines in the C. stelleri group). It is the hearl of the wish-bone. whose divergent arms rum down the Sierras to Lower California and along the Ruckies to Guatamala respectively.

With a lypothetical center of distribution somewhere in sontheastern Britisl, Colmulia, this subspecies inosculates with stolleri in the mountains of that province, and is roughly separated from the western stock by the central rielege of the Cascacles, in W'ashington.

Black-heacled Jays in IVashington are normally confined to the limits uf coniferous timber, heing therefore most alundant in the northem portion, in the Blue Ofountains, and along the eastern slopes of the Cascades. IVe lave, however, like lienclire, diservered then on occasion skulking in the 
willows along creek buttums some twenty miles from pine timber. ( )n the cother hand, they do not assert, with the (iray Jays and Clark Cirsws, the right to range the mumbain heights: lout are qunte content tn maintan qheir tubuly inquisition amiclst the growes and thickets of the valley flemers.

They are, perhaps, not sn mosis as the Steller lays, being less entident wi their coser: and their nutes are rather mure musical (breath wi pines is leetler than fog for the veree): lout for the rest they are the same vivations. intrepid, resurechl mischiei-makers ats their kin-folle everywhere.

Nio. 12.

\section{WHITE-HEADED JAY.}

1. (1. L. . . (1) \& fa. Perisoreus canadensis capitalis Rirlgw:

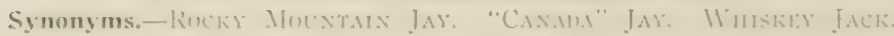

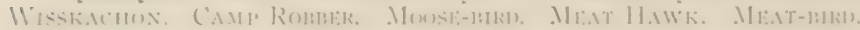

Description.- Adults: General color plumbeots ash liglatening helow: whole heacl white save space alout and behind eye connected with broad nuelral patch uf slaty gray; wisge and tail blackish owerlaid with silver gray; tail tipped with white and wings more or less edged with the sane. Pill and feet black: iris brown. Jomng birds much clarker and more miform in coloration than athitsslaty gray to sooty slate with lighter crown and some whitish edging on umlerpartic. I.ength r 2.00-13.00: wing (1.00 (152): tail 5.75 (145): bill . 82 (21): tarsils $1.38(3.5)$.

Recognition Marks.- Rolin size: slaty eray coloration. White ni head with its aliruptly defined patch of slate on himil neck distinctive as compared with related sprecies of the genus Perisoreus.

Nesting.-Has not been reported for Washington hut bird muloubtedly breeds in the Kalispell range. Nesl: in enniferous tree, a large compacted mass of the softest and warmest substances, - twigs for a foundation, then grasses. abundant moss, plant-down and feathers. liggs: 3-5, usualiv \& gravish in hite, spontted and blotehed with hrown having a tinge of purplish. Ar. size $1.15 \times$. s's

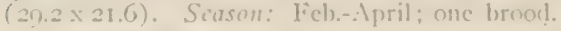

General Range- - lligher ranges of the kncky . Inuntain district from liritich Columbia in Arizona.

Range in Washington.-Momntains of northeavern corner of State amb (probably) the Bhe Mountains.

Authorities.-|"White-hemed Jay," Inlmson, Rep. Cox. WT. 'T., 1884

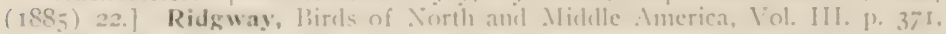
("Sinzoknoteen Dejust, cte.").

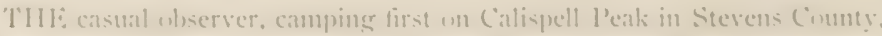
and later on Mt. Stuart, in snuthern Chelan Connty, might fail for note any 
difference in the soberly-dressed Jays, who are the self-appointed overseers of camp economics. For while the birds of the two localities really represent two species, the resemblance in general appearance and behavior is so close as to be virtually negligible afield.

Of this bird in Colorado, Mr. Frank M. Drew has observed" : "In antumn when on his first tour of inspection around the house he hops along in a curious siclelong manner, just like a school-girl in a slow hury. Whiteheaded. arave, and sedate, he seems a very paragon of propriety, and if you

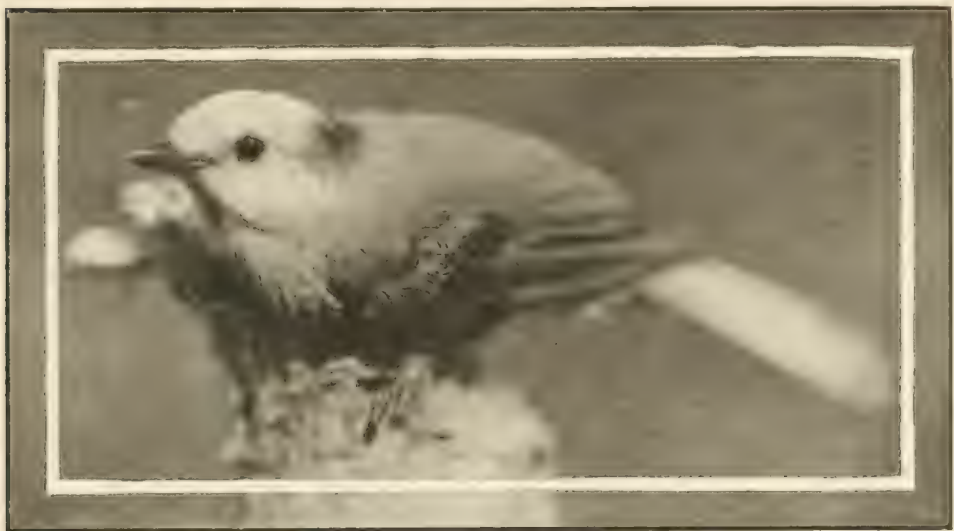

Taken near Spolane.

WIITT:IIF, IDE, I) JAY

Photo by H'. II Wright

appear to be a suitable personiage, he will be apt to give you a bit of advice. Becoming conficlential he sputters out a lot of nonsense in a manner which causes you to think lim a veritable "Whisky Jack': yet, whenerer he is clisposed, a more bland, mind-his-own-business-appearing bird will be hard to fund, as will also be many small articles around camp after one of his risits, for his whimsical brain las a great fancy for anything which may he valuahle to vou, but perfectly useless to him."

a. liull, Nure, Orn, Club, Vol, VI., p. 140 
ํ.. 1,3 .

\section{OREGON JAY.}

1. (). (i. . Xo firs. Perisoreus obscurus (Kicluway).

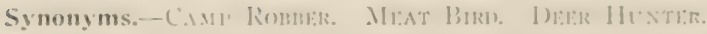

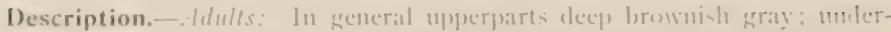
parts white tinged with brownish; forcheal and nasal plumules mose nearly elear

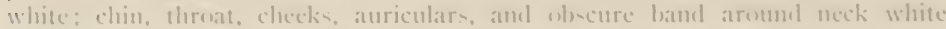
mere or less tinged with brownish; crown and naje sonty lorewn, nearly black: feathers of back with white slafts more or less exposed: whers and tail drab orsay. the former with whitim elginer on midelle and greater coverts and tertials. Lill amel feet lilack: iris brown. Jemng livels are nearly moifurm sonty brown lightening letow: l.ength $(0,(x)-11 .(x)$ : wing $5.30(1,35)$ : tail $5 .(x)(127)$ : lill .71 (18): tatsus $1.30 \quad(1,3,3)$.

Recognition Marks,-Kobin size: hrownish gray coloration, fambliar, fearless ways. Not extainly distinguishable aliedel from the next form.

Nesting.- Vest: a lublky compacted structure of twigs, slant-filers and treemose with watrm lining of fine nosses and feathers, placed well mp in fir tree. liges: $f$ or 5 , light gray or pale greenish gray spotted with grayi-h hrown and

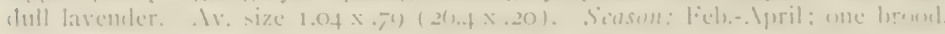

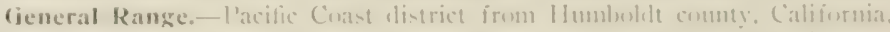

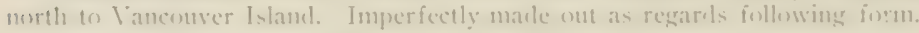

Range in Washington.-I'robably the ()ympic Mommans and irregularly thru the heavier forests of somthwestern IIa-hington.

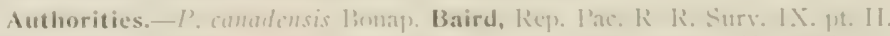

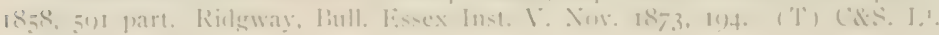
Ril. Ka. 1: l:1 ? ?.

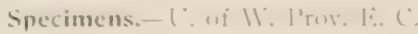

Tll1: relative distribution of the ()regens laty and the more recenty dis-

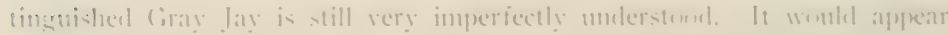

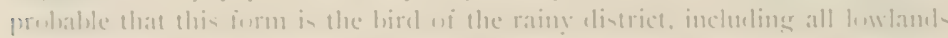

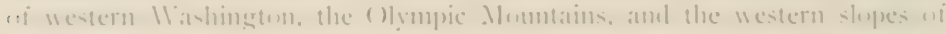

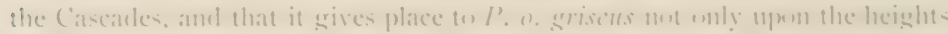
and eastern shopes of the (ascales. but in the deep valleys which penetrate these momatim irum the west.

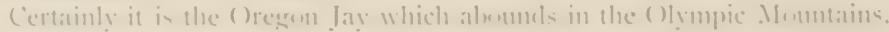

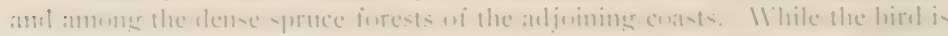

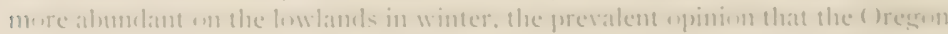

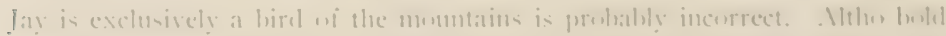

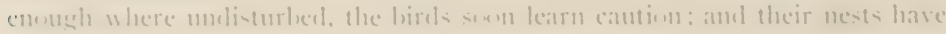


been found near Renton where their presence during the breeding season would otherwise have gone unsuspected. 'The depths of the forest have no terrors for this quiet ghost, and there are other reasons hesides color why he remains the obscure one.

\section{No. 14 .}

\section{GRAY JAY.}

A. O. U. No. 485 a. Perisoreus obscurus griseus Ridgw.

Synonyms.-CAMP Rotrim, etc.

Description.- "Similar to l'. o. obscumus, but decidedly larger (except feet), and coloration much grayer; back, etc., deep monse gray, instead of brown, remiges and tail between gray ( $\mathrm{No}, 6$ ) and smoke gray, inctead of drab gray, and under parts grayisi white instead of brownish white." ( Ridgway). I_ength (. Iv: of three (Blacier specimens) II.16 $(283.5)$ : wing $5.82(147.6)$; tail 5.48

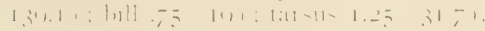

General Range-Central monntain ranges of central California, Oregon, Washington, and British Columbia.

Range in Washington.-Thruout the Cascade Monntains and irregularly along their lower slopes west (?) to ticlewater.

Authorities.-? '?. candensis Bonay,. Baird, Rep. Pac. R. R. Sury., Vol. IX, pt. II, I858, p. 50I (Cascade MIts. IV. T.). Ridgway, Auk, Vol. XVI., July, I890, 225. Kk. ?

'flli "Camp-Robber" appears promptly as interested neighbor and smell-feast before all who invale the precincts of the momtains. The hunter, the trapper, the prospector, the timber cruiser, the mere camper-ont, all know fim, and they speak well or ill of him according to their kincl. T'lue Gray Jay appears to have forsworn the craftiness of his race, and he wins lyy an exhibition of artless simplicity, rather than by wiles. 'The bird is mildly curious and humgry-oh, very hungry-hut this is Arcadia, and the shepherds draw nigh with never a cloubt of their welcome. There is a clildlike insonciance alout the way in which the hircl annexes a piece of frizzled bacon, lumbly intencled for the man. ". Shoo, did you say? IVhy, what do you mean? Cant I lave it?" And the bird retires before at flying chip, bafiled and injured by such a manifest token of ill-breeding. He complains mildly to his fellows. 'They discuss the question in gentle ofluris; generously cunclucle you didnt mean it, and return unabashed to the quest.

Hunger is the chief characteristic of these docile birds, and no potential food is refuserl, nuts, acoms, insects, herries, or even, as a last resort, the hucls of trees. Meat of any sort has an especial attraction to them: and they are the clespair of the trapper because of their propensity for stealing hait. 


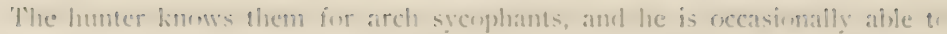

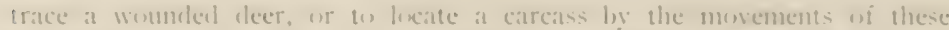
expectant heirs. Says Mr. A. W1. Anthomy" "While dressing deer in the thick timler I have been almost cosered with Jays fyimg down irom the neighboring trees. 'They wombl settle an my back, head, or shouklers, tugering and pulling at each lense shreel of me coste until one would think that their whly whect was to lielp me in all watys pessible."

In the higher latitudes "Ithisky lack," in spite of carefully secreted sfores, witen lecomes very enaciated in winter, a mere lumch of lunes a 11 al ienthers. nu heswer than it kel [xill. While the Jatys uf our kimblier elime in mot feel sis keenils the belly jumch wi winter, they hatse the same thrifly hat it= as their morthern kininlk. [innd is never refuserl. and a well-stulfel speci men will still carrs (rrub) from camp and arovete it in larki arevice or hollow. aesanit the unkmoss hisur wi neel

I have never heard

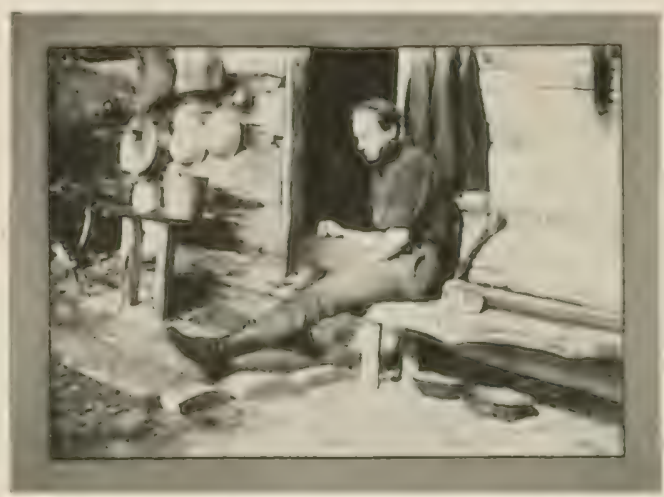

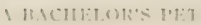

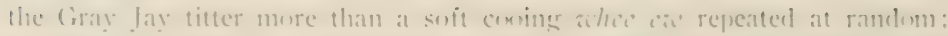

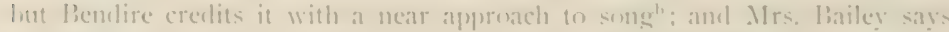
ef the lays an .Mr. Herofe: "'Their motes were pleasantly varierl. ()ne

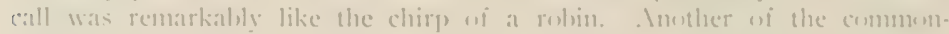
est was a weak and rather complaining ery repeated several times. I sharply comtrasting me was a pure clear whistle of one mete followed

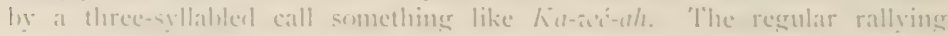

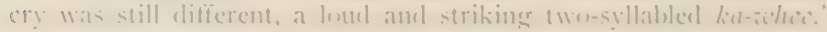

The enges of the (iray laty hate nen yet lecen regurted from this state.

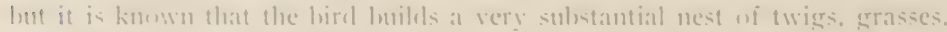
plant fihre, and monses withont mul, and that it provides a heary lininge of

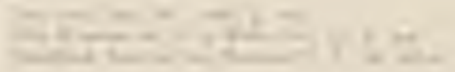


soft gray mosses for the eggrs. The nest is usually well concealed in a fir tree, and may be placed at any height from ten or fifteen feet upward, altho usually at sixty or eighty feet. Only one brood is reared in a season, and family groups hunt together until late in the stmmer.

\section{No. 15. \\ COWBIRD.}

A. O. L. No. 405. Molothrus ater (Bodd.).

Synonyms.-Cow liLACKBRD. CuCKord.

Description.- Idwlt malc: Head and neck wood-, seal-, or coffec-brown (variable); remaining plumage black with metallic greenish or bluish iriclescence. licmale: Dark sravish hrown, showing slight greenish reflections, darkest on wings and tail, lightening on breast and throat. Yonng in first plumage: I,ike female but lighter below and more or less streaky; above somewhat mottled by luffy edgings of feathers. The young males present a striking appearance when they are assuming the adult black, on the installment plan, by clitnks and blotches. Length 7.50-8.00 (I)0.5-203.2); wing 4.40 (III.8); tail 3.00-3.40 (76.2-86.4); bill .65 (I6.5); tarsus .95-1.10 (24.I-27.9). Female, length, wing, and tail one-half inch less.

Recognition Marks.-Chewink size; brown head and black body of male; lorown of female.

Nesting. - The Cowbird invariably deposits her eggs in the nests of other birds. ligys: I or 2 , rarely 3 or 4 , with a single hostess, white, often faintly tinged with bluish or greenish, evenly speckled with cinmamon, brown or umber. Av. size, $.85 \times .05(21.6 \times 16.5)$, but quite variable. Season: April-June.

General Range.- - United States from the Atlantic to the Pacific, north into sonthern liritish Anerica, south in winter, into Mexico.

Range in Washington.-Of linited but regular occurrence cast of the Cascades, increasing; rare or casual in western Vashington. Summer resident.

Authorities.-Bendire, Life Histories of N. A. Birds, Vol. II., p. 434. D). D $)^{2} \cdot S^{2} \cdot$ J. B. E.

Specimens.-C. I'.

WHIILE: I was chatting with my host at milking time (at the head of Lake Chelan in the ante-tourist (lays), a dun-colored bird with light underparts flew down into the corral, and began foraging as tho to the manor born. One by one the cows sniffed at the stranger and nosed. it about, following it up curiously. But the bird only side-stepped or walked unconcernedly alsearl. When I returned with the gum, a moment later, I found a calf investigating the newcomer, and it was difficult to separate the creature from bossikin's nose. The date was August $3 \mathrm{rd}$; the bird proved to be a young male 


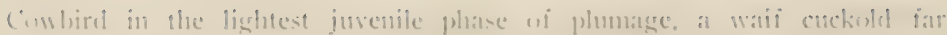
irom any of his kin, lut shifteng for himseli with the nenchalance which dhatacterizes his worthlesis kimel.

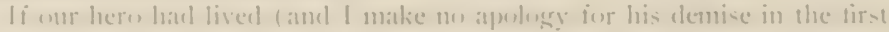
act ). he would have exchanged his incenspienous livery for the rich, irilesent

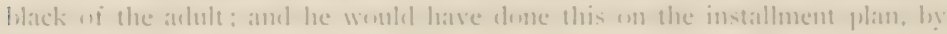

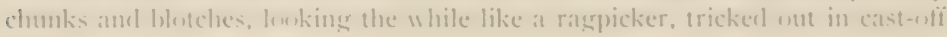
linery.

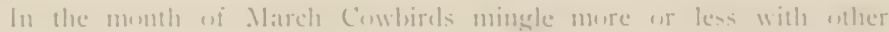

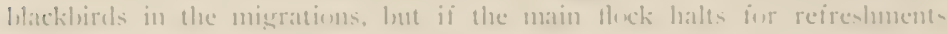
and discussion on romle a gromp of these rowlies will hunt up sume dis-

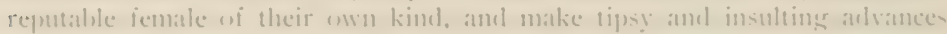
(1) her alomg smome hurizontal limb or fence rail. 'laking a pesition alum a fint away from the ens trah, the male will make two or three atecelerating

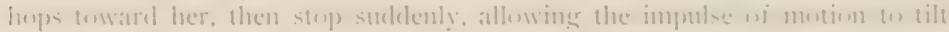
him vinfently ferwarel and threm his tail mp perpendicularly, while at the

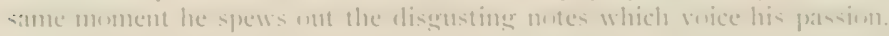

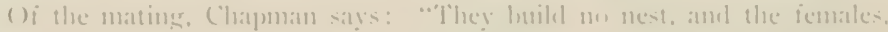

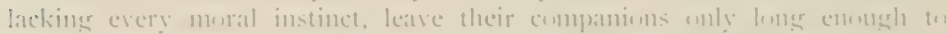

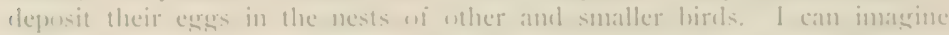
nos sight more strongly sugrestive of a thusuly despicable nature than at

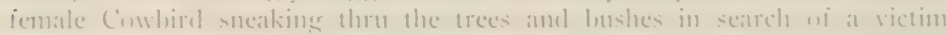
mpen 11 hem to shift the dutics uf mutherhenel."

The exer. thus surreptitionsly placed in another biral's nest. Msually

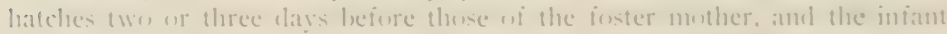

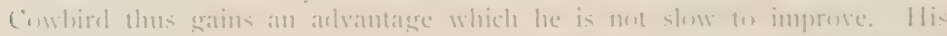

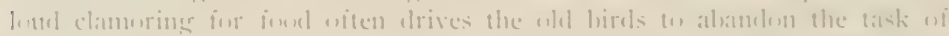

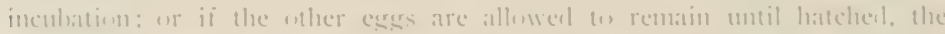

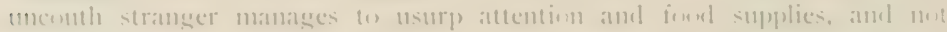

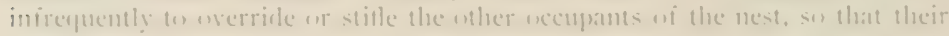

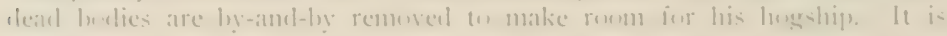

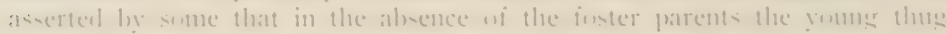

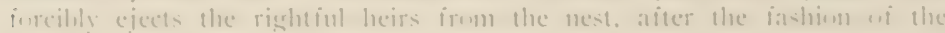

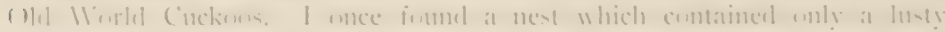

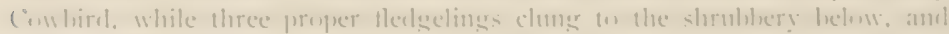

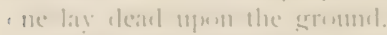

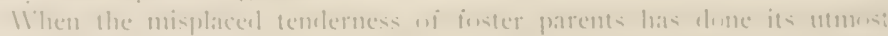

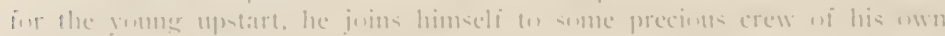
bluevl, and the evele of a changeling is complete.

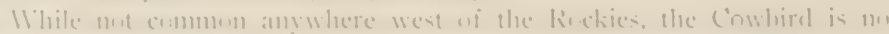

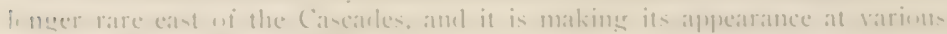

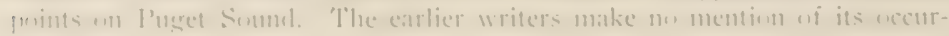


rence in Washington, and it seems probable that its presence has followed tardily upon the introduction of cattle. Bendire was the first to reprort it from this State, having taken an egg near Palouse Falls on June is, is 78. from a nest of the Slate-colored Sparrow (Passerclla iliaca schistacea).

Its presence among us is, doubtless, often overlooked because of the superficial resemblance which it bears in note and appearance to Brewer's Blackbircl (Euphagus cyanoccphalus). The note of the former is distinctive, - a shrill, hissing squeak in two tones with an interval of a clescending third, uttered with wreat effort and apparent nausen-honestly, a disgusting souncl.

No. 16.

\section{BREWER'S BLACKBIRD.}

\section{A. O. [. No. 510. Euphagus cyanocephalus (Vagler).}

Description. - Idult male: Glossy black with steel blic and violet reffections on head, with fainter greenish or bronzy reflections elsewhere; bill and feet black: iris pale lemon yellow or light cream. Adult female: Head and neck all around (leep brownish gray with violet reflections; melerparts brownish slate to lhackish with faint greenish iriclescence; upperparts blackish, or ontriglit black on wings and tail, which are glossed with bluish-erreen: bill and feet as in male, but iris brown, Immature males in first ainter plumage resemble adults but have some elging of pale grayish brown. Length of adult males: 10.00 (254); wing $5.00(128)$; tail 3.00 (99); bill .80) $(22.6)$; tarsus $1.27(32.3)$. Adult female: length $9.25(235)$; wing +.50 ( 117 ) ; tail $3.50(89)$ bill .79 (20) ; tarsus 1.20 $(30.5)$.

Recognition Mlarks.-Robin size; pure black coloration and whitish eye of male. Larger than Cowbird (Molothrus atcr) with which alone it is likely to he confuserl.

Nesting.- Nest: placed at moderate height in bush clump or thicket, less frequently on gromel at base of loush, more rarely in cramny of cliff or cavity of decayed tree-trunk, a sturdy, tidy structure of interlaced grasses, strengthened by a matrix of mul or clried cow-clung and carefully lined with coiled rootlets or horsehair. Nests in straggling colonies. Liggs: $4-7$, 11 sually 5 or 6 , presenting two divergent types of coloration with endless variations and internediate phuses. Light type: ground color light gray or greenish egray, spotted and blotelied with brown of varying sharles, wahnt, russet, and sepia. (In some examples there is purplish brown seratwling, which suggests the Redwing type. (One egg in the writer's collection is indistingusishable from that of a Cowhurl. save for size.) Darl: type: ground color completely obscured by overlay of tine brow'n dots resulting in nearly uniform shacle of mummy brown or landyke brown. Av. size $1.03 \times .72(26.2 \times 18.3)$. Scason: April 20 - May 10 : one or two broods.

General Range- - Il estern Anth Anerica from the phains to the l'ilcific, and from the Saskatchewan region south to the highlands of Mexico to ()anaca. 
Range in Washington.-() i general distributum thrums the siate lut ionnel chiclly in more ufen situations in vicinity of streame and permels and in enleivated

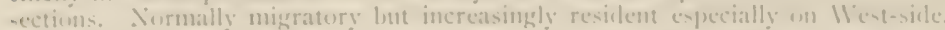

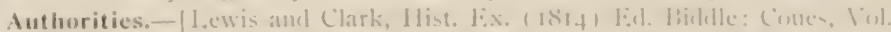

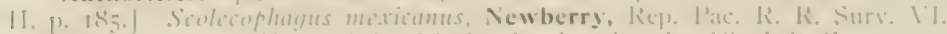

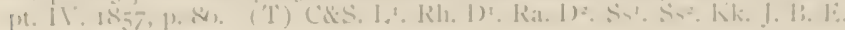

speicmens.-Li, of II: I'rov. I! E. I'.

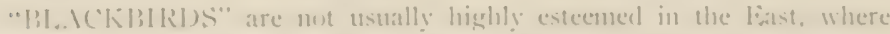
the memory of devastated cornlielels keeps the wrath of the farmer warm: but if all species were as indiensive as this enthling pensinner wi the

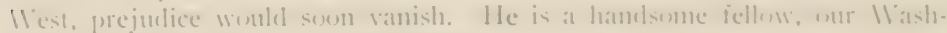
inertens eratckle, sleck, vivacinus, inter esting. and serviceable withal. $11 \mathrm{e}$ kmow him lest, perlaps, as an incluirous gleaner uf pastures, corrals. streets. and "made" lands. Ile is not mly the farmer"s "hired man," watging increasing wartare against insect life. especially in its noxions larval forms. but he has an aceepted place in the exmonmy of eity and village as well.

As une alpuruaches a feerling fleck. he motes the eagerness with which the firrls run forwarel, or rise and tlit pass their fellows, mow diving at a mimble wevil, nuw leaping $(1)$ catch at passing lumer hut alwats pusluing on entil me perceives al corions rollinge effect in the intal movement.

Le we dratw near. some timid in dividual takes alarm, amb instantly all are tp, tw alight again typus the fence or slurubluers where they clack and whistle, mot so much by way of apprehencion as thru sheer exuberanece of

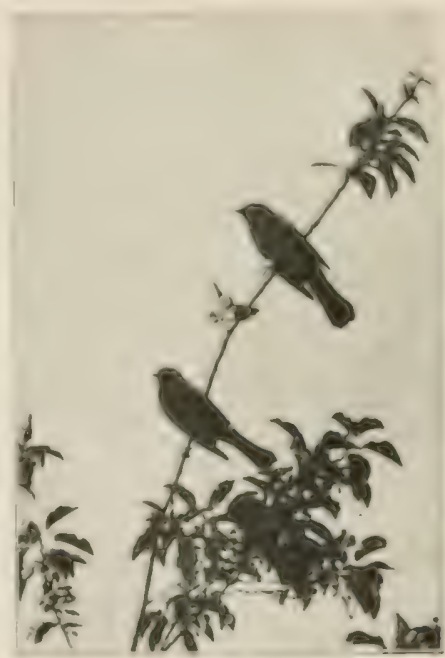

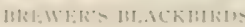
nerouts force. As we pass (we must not stup short, in they resent expresi attention) we mote the droll white eyes of the males, as they torist amel perts

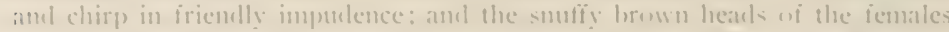
with their soft hazel iristes, as they give a motherly thaff of the feathers. or yawn with impatience ower the intermpterl meal. Ithen we are fatrl!

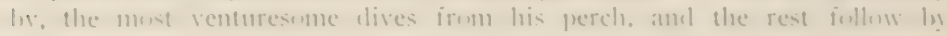

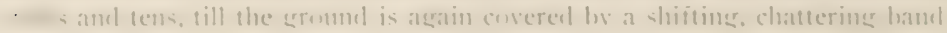


Like all Blackbirds, the Brewers are gregarious; but they are somewhat more independent than most, flocks of one or two score being more frequent than those of a hundred. During migrations and in antumnal flocking they associate more or less with liedwings; but, altho they are devoted to the vicinity of water, they care nothing for the fastnesses of reed and rush, which are the delight of Redwing and Yellowhead. Their preference is for more open sitnations, so that they are most abundant upon the East-side. Here a typical breeding hatunt is a strip of willows fringing a swamp; or, better still, a line of clark green thorn-bushes clinging to the bank of the rolling Columbia.

Altho isolated nests may now and then be found, colonies are the rule: and I have found as high as forty nests in a single patch of greenery. There is room, of course. for individual choice of nesting sites, but the community cloice is the more striking. Thus, one recalls the greasewood nesting, the rose-briar nesting, the thorn-bush nesting, where all the mombers of the colony conformed to the locally established rule in nest position. Mr. Bowles records the most remarkable instance of this: One season the nests of the South T'acoma colony were all placed in small bushes, the highest not over four feet from the ground; but in the season following the birds were all found nesting in cavities near the top of some giant fir stulos, none of them less than i 50 feet from the ground. On the other hand, in the Usk nesting of I906, on the placid banks of the Pend d'Oreille, one pair had recessed its nest in a stump at a height of eighteen feet, while three other pairs had sunk theirs into the ground at the base of bushes.

In construction the nest of the Brewer Blackbircl varies consiclerably, but at its best it is quite a handsome affair. Composed externally of twigs. weed-stalks, and grasses, its characteristic feature is an interior mould, or matrix, of dried cow-dung or mud, which grives form and stability to the whole. The lining almost invariably includes fine lrown rootlets, but horsehair is also welconed wherever available.

'The eggs of Brewer's Blackbird are the admiration of oölogists. Ranging in color from clear greenisl gray with scattered markings thru denser patterns to nearly uniform umber and chocolate, they are the natural favorites of "series" hunters. The range of variation is, indeed, curious, but it proves to be entirely individual and casual without trace of local or constant differences. Liggs from the same nest are ustally uniform in coloration, but even here there is notalble cliversity. In some instances, after three or four eggs are laid. the pigment gives out, and the remainder of the set is lighter colored. Igain, single eggs are heavily pigmented half way, and finished with a clear sreen ground-color. 


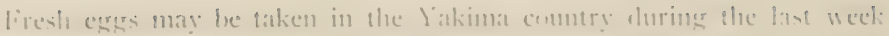

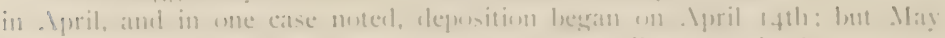

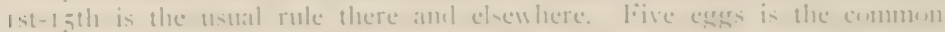
$-e$, lute six to at eluteh is mot rare. (Ji twenty-eight nests examined in

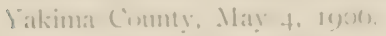
eleven contained six egers eath: while, wi somethings wer two hmmirecl seen altwesher. Imo nente emulained seren exich.

It is in his moter thatt the Brener llacklinel hetrass hiathinites lest wi all. 'The meludimusly stueaking chatter wi matiner time is, wi enmse, must Jike that wi the linsty lilack himel (.5) omolimus). Inte it lacks the bubliner claratere. He has then the silellines mote of the Brackles proper. fif-itot. the latter patt remelereil with smme thinge wi at trill, the fommer merely as at aspirate: and the whole acemplamied lu expan sinut af landy, slight libing wi wings amel partial spreating wi sail. This mete is attereal mot moly during the contrting se:i sen. Int on the aceasion fif ex citement uf anty kimel. Kenrat las at fine inctallic qualit! which promply links it on the

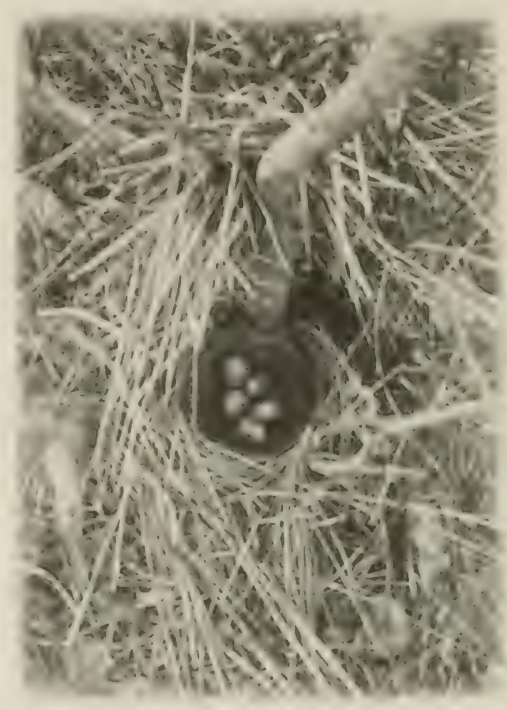

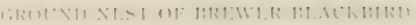

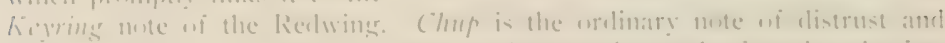

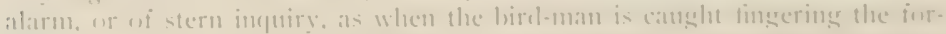

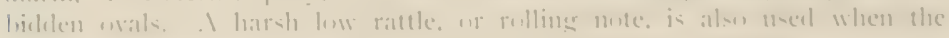

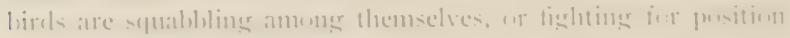

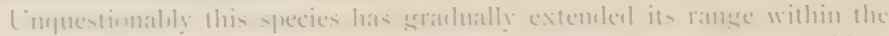

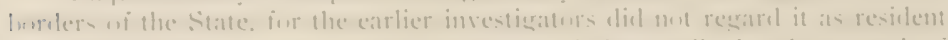

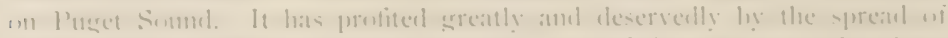

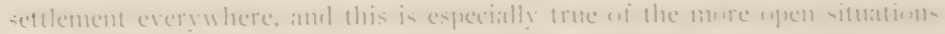

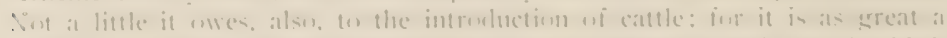

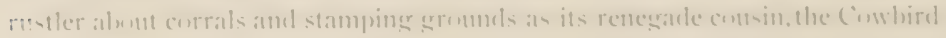


No. 17 .

\section{BULLOCK'S ORIOLE.}

\section{A. O. L. No. 508. Icterus bullockii (Swainson).}

Description.-Idult male: Black, white, and orange; bill, lore, a line thru eve, and throat (narrowly) jet black; pilemm, back, scapulars, lesser wing-coverts, primary coserts, and tertials chicfly black, or with a little yellowish skining; remiges black edged with white; middle and greater coverts continuous with edging of tertials and secondaries, white, forming a large patch; tail chicfly yellow but central pair of rectrices black teminally, and remaining pairs tipped with blackish; remaining plumage, including stupraloral areas continuous with stiperciliaries, orange vellow, most intense on sicles of throat and chest, shading thru cadmium on breast to chrome on rump, tail-coverts, etc. In young adults the orange is less intense and, encroaclies upon the black of forchead, hind-neck, etc., altho the tail is more extensively black. Idult female: Above (lrab-gray, clearest on rump ancl upper tail-coverts; wings fuscous with whitish edging; pattern of white in coverts of male retained but much reduced in area; tail nearly uniform dusky chrome; molerparts in general sordid white; chin and lores white; forehead, superciliary, (inclistinct), checks, hincl-neck and chest more or less tinged with chrome yellow. Young males resemble the female but soon gain in intensity of yellow on the foreparts, gradually acpuiring adtult black along median line of throat and in streaks on pilemm. Length of adult male about 8.25 (209.5); wing $3.89(99)$; tail 3.07 (78); bill .73 (18.5); tarsus .98 (25). Ficmale a little smaller.

Recognition Marks.-Chewink size; black, white, and orange of male distinctive: slencler blackish bill of female strongly contrasting with the heavy lightcolored bill of fenale llestern 'lanager with which alone it is likely to be confused by the novice. (ieneral coloration of female ashy or drab rather than olivaceous, yellow of tail contrasting with whitish or light drab of tail-coverts.

Nesting.-. Vest: a pouch of cumingly interwoven grasses, vegetable fibers. string, ete. 5 to 9 inches deep and lashed by brim to branches of deciduous tree. Egys: usually 5, smoky white as to ground color, sometimes tinged with pale Bluc, more rarely with faint claret, spotted, streaked and elaborately scrawied with purplish black or dark sepia, chiefly about larger end. Elongate ovate: av, size $.04 \times .03(23.9 \times 16)$. Season: May 20-June 15 ; one brood.

General Range.-Western United States, southern Pritish Provinces and platean of Mexico; breeling north to southern British Columbia, Alberta and sonthern Assiniboia east to eastern border of Great P'lains in South Dakota, Vebraska, etc., south to northern. Mexico; in winter south to central Mexico.

Range in Washington.-Kegular summer resiclent in eastern IVashington thruout setted sections and along water courses; rare or casual west of Cascarles.

Migrations.-Spring: Iakima Connty, May 2, 1no0; Moses Iake, May 15 , r(jor): Chelan, May 21, 1806. 


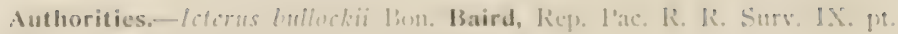

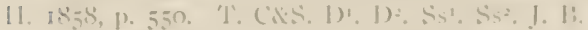

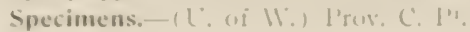

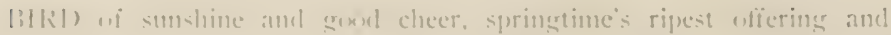
cmblem wi smmmer achieved, is this happy-hearted creature whe flits aleuti the orchards and timber cultures of eastern Washingtum. The willows af

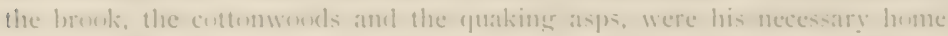
until the hamel of the pinneer mate rearly the lexust, the maple and the lon-

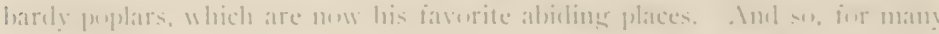

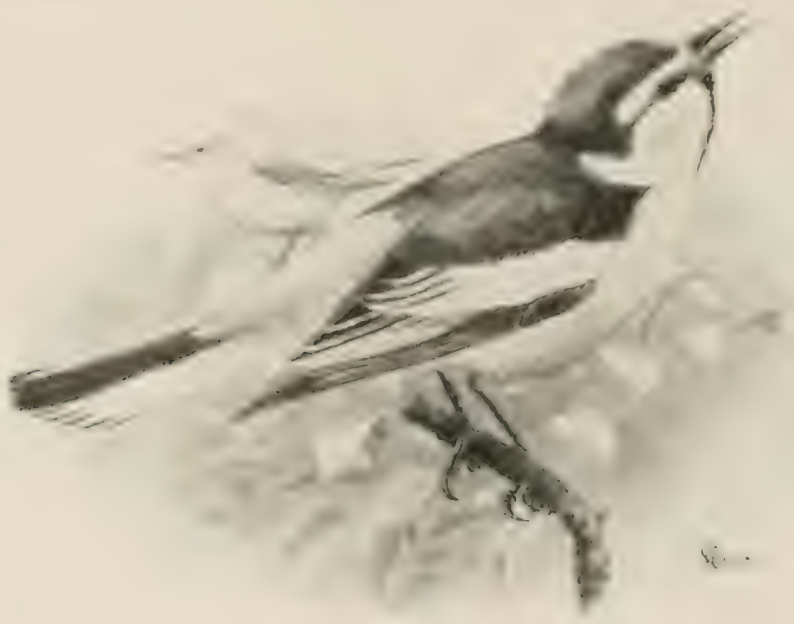

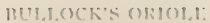

years, the droming of hees, the heavy-sented breatl of the acacia, and the high. ciear whistling of the Oriole have leen assenciated memories.

I litule less daudified than his eatstern enusin, the leodly bird of Baltimere, the linlhek ()riole fultils much the same ecumum in habit, sung, and nesting as that well-knmon bird. He is, if anything. a little less muscial. alsen, ansl mut se conspicums.

The males arrive a week or two in alvance of their mates, aml appear quite ill at ease until jomed by their sly emmaninns. Marriage compacts have to 


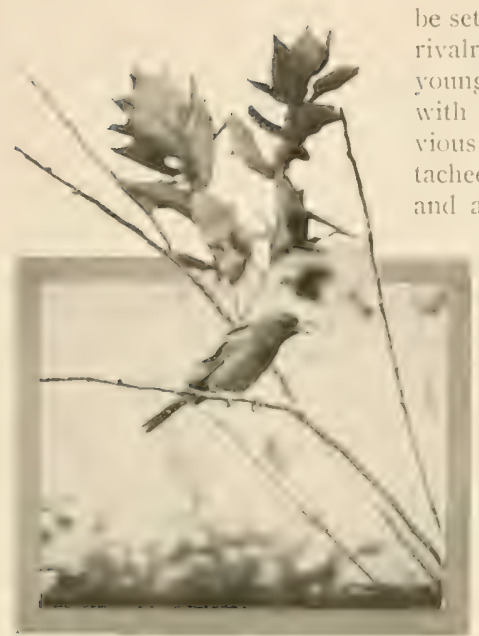

Taken new Spokane.

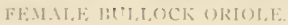

be settled at the beginning of the season, but rivalry is chiefly between the under-colored yomm blades who must make their peace with the sweet girl graduates of the previuus year. Orioles are very closely atlached to a suitable locality, once chosen. and a sroup of nests in a single tree presenting successive ammual stages of preservation, is fairly eloquent of conjugal fidelity.

The purse-shaped nest of the Bullock Oriole is a marvel of inchustry and skill, fully equal in these respects to that of the Baitimore Bird. A specimen before me, from a small willow on Cral, Creek, in Lincoln Connty, taken just after its completion, is composed entirely of vegetable fibers, the frayed inner hark of dead willows being chiefly: in evidence, while plant-downs of willow, poplar, and clematis are felted into the interstices of the lower portion. 'This putch is lashed at the brim by a hundred tiny cables to the sustaming twigs, and hangs to a depth of six inches, with a mean diameter of nearly three, yet so delicate are the materials and of fine the workmanship. that the whole structure weighs less than half an onnce.

A more bulky, loose-mesled affair, taken at Brook Lake No. 4, in Donglas County, has a maximum depth of nine inches outside, a mean depth of six and a half inches inside, and a greater diameter of five inches.

Vear farm lrouses of in town the birds soon learn the value of string. thread, frayed rope, and other waste materials, and nests are made entirely. of these less romantic substances. Occasionally a bird becomes entangled in the coils of a refractory piece of string or horse-hair, and tragedies of Orioles hangerl at their own doorstep are of record.

The eggs of this species, four to six in number, are usually of a pale smoky gray color, and upon this gromol appear curious and intricate scrawlings of purplish black, as tho made by a fine pen, held unsteadily while the ecre was twirled. The purpose of this bizarre ormamentation, if indeed it has any, may be thought to appear where scanty coils of black horse-hair in the lining of the nest show up in high relief against the normal white back- 


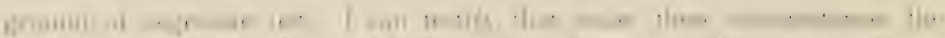

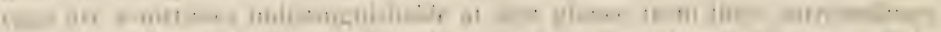

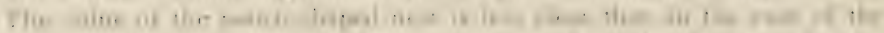

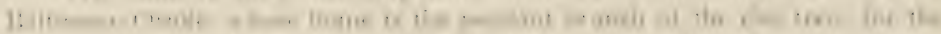

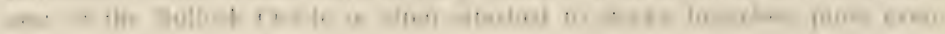

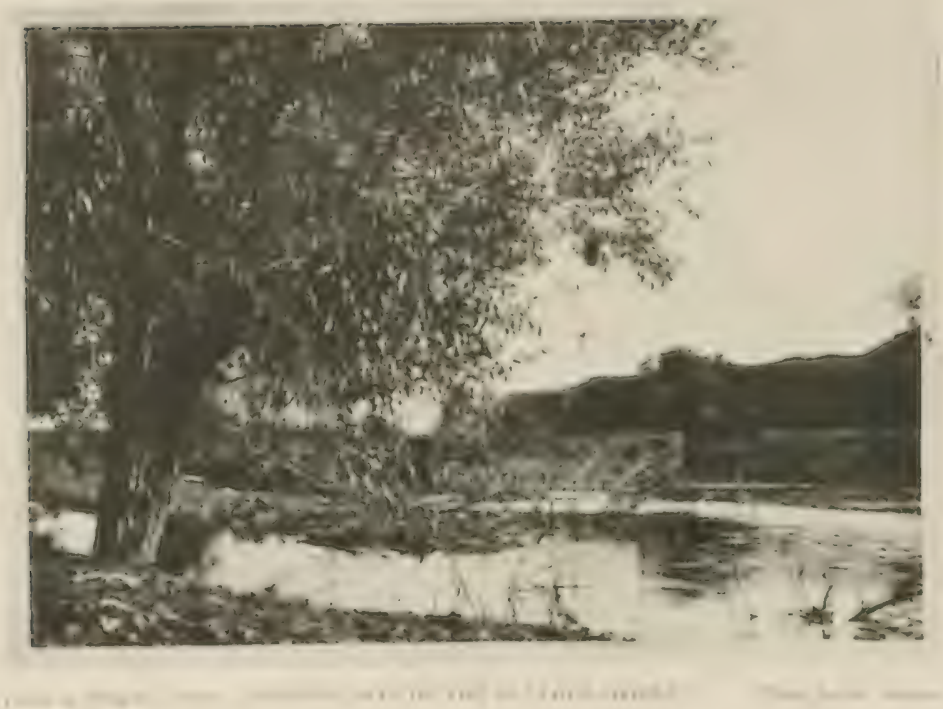

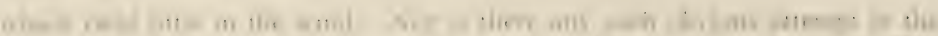

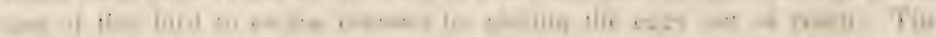

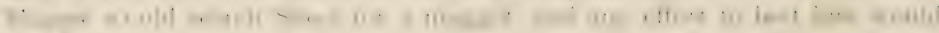
I

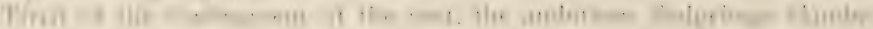

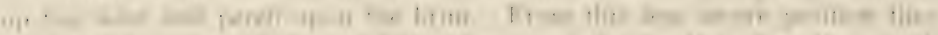

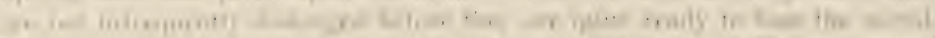

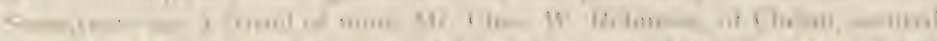

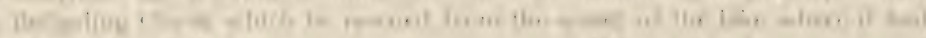

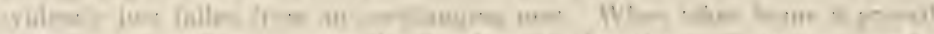

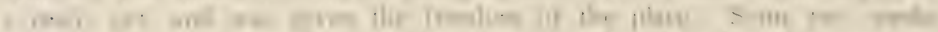

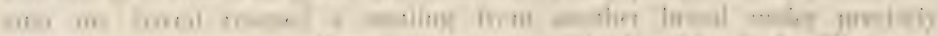

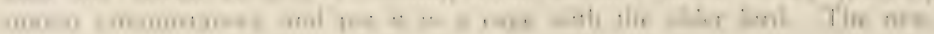




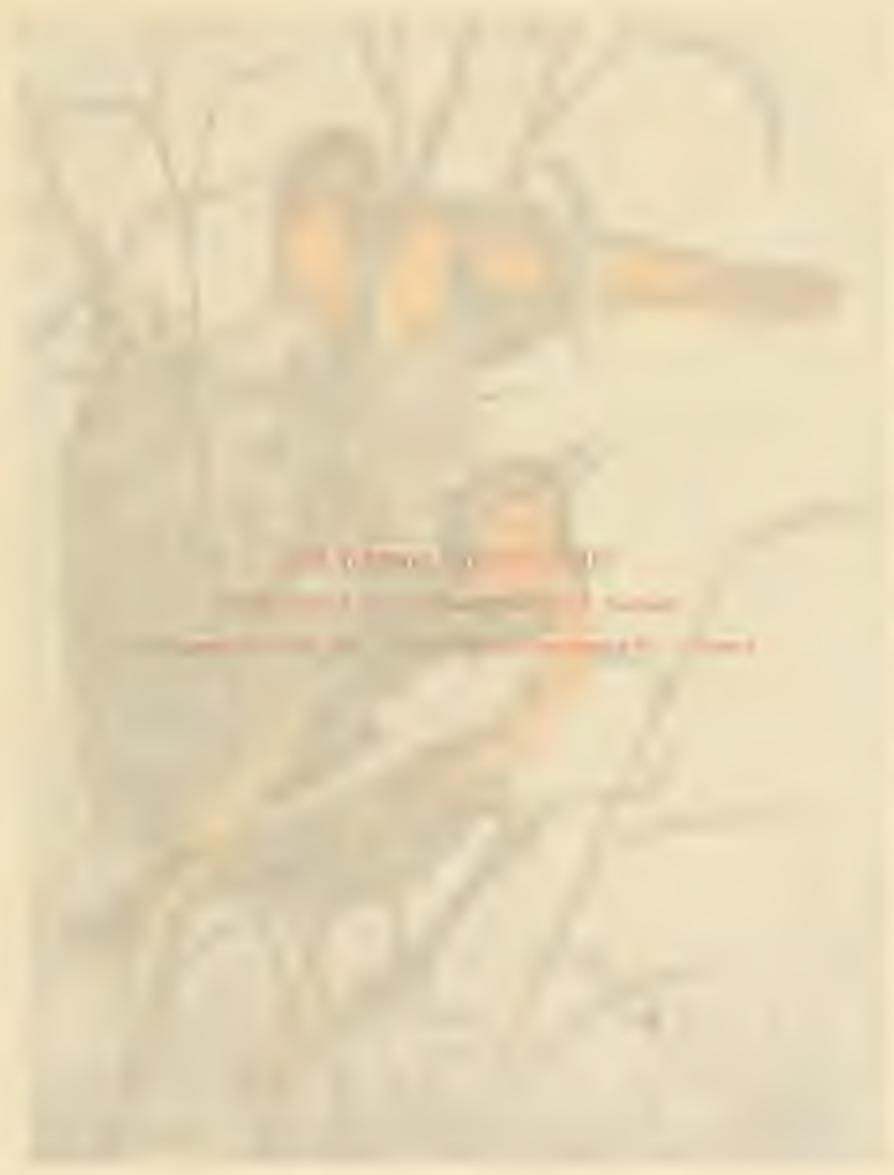




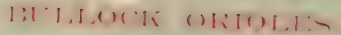

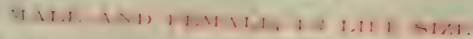

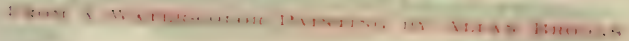




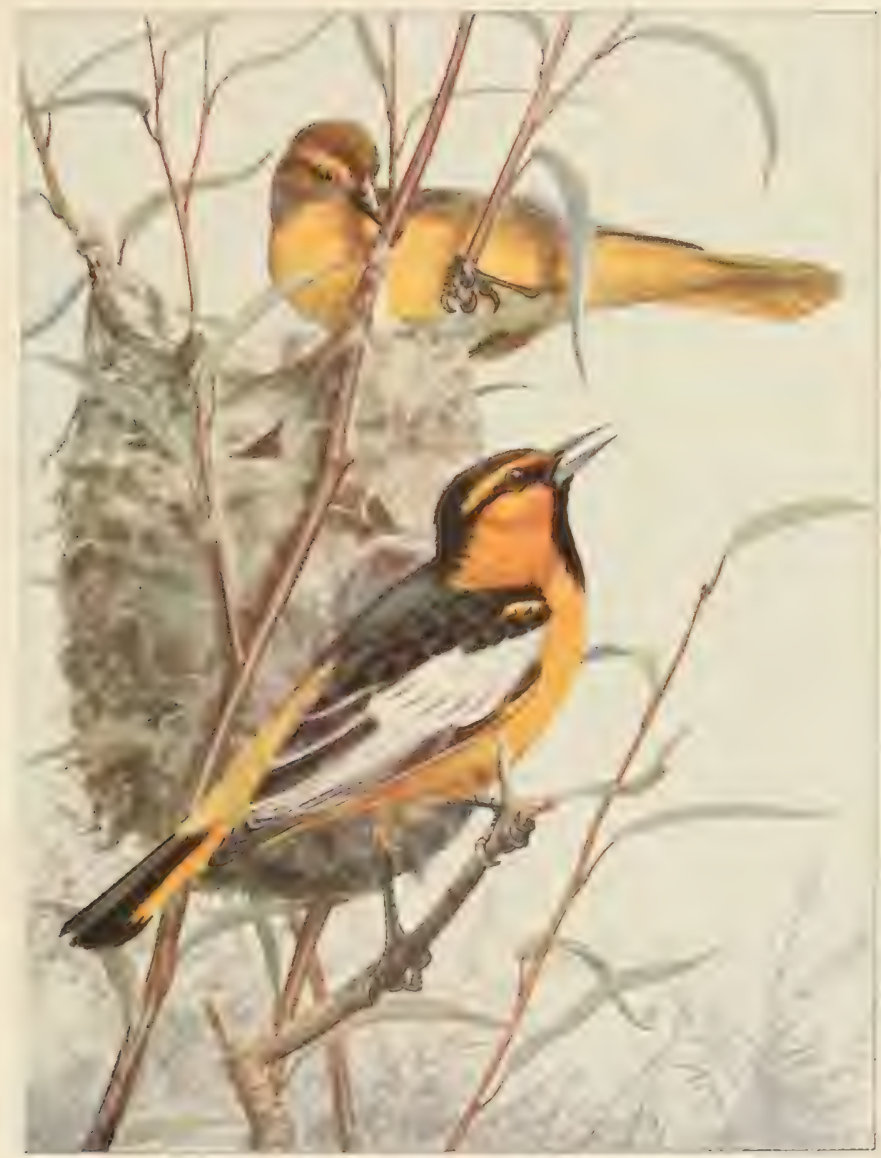



enmer had not yet learned to feed himself, but only opened his munti and called with childish insistence. Judge of the owner's delight, and mine as a witness, when the older bird, himself little more than a fledgeling, began to feed the orphan with all the tender solicitude of a parent. It was irresistibly cumning and heartsome too, for the bird to select with thougliful, brotherly kindness, a morsel of food, and hop over toward the clamoring stranger and drop it into his mouth; after this to stand back as if to say. "There, baby! how did you like that?" 'This trait was not shown by a clance exhibition alone, but became a regular habit, which was still followed when the older bird had attained to fly-catching. It upset all one's notions about instinct, and made one think of a golden rule for lirds.

No. 18.

\section{CALIFORNIAN BICOLORED BLACKBIRD.}

A. O. U. No. 409. Agelaius gubernator californicus Nelson.

Description.- - tdult male: "Uniform cleep black, with a faint bluish green gloss in certain lights; lesser wing-coverts rich poppy red or vermilion; mulde coserts black, or (if not entirely black) at least broarlly tipped with black, the basal portion tawny buff or ochraceons; bill, legs, and feet black; iris brown" (Riclgway). Adult female in brecding plumage: Dark sooty brown more or less streaked on crown and back; clnin and throat whitish or pinkish buff streaked with brown: faint superciliary stripe composed of narrow whitish streaks on sooty ground. Adult female in ainter: lieathers more or less edged with rusty: Immature male: Lesser wing-coverts partly black, the remaining red not clear. ocliraccous-rufous or orange-tawny: l,ength of adult male: (skins) 8.62 (219): wing 5.78 (136.9); tail 3.67 (93.2); bill .8. (21.3); tarsus 1.28 (32.5). Adult female $6.93(176)$; wing $4.27(108.5)$; tail $2.82(71.6)$; bill .72 (18.3) ; tarsus $1.10(27.9)$.

Recognition Marks.-Like Redwing Blackbird but epaulets fure red withont exposed luff.

Nesting.--Nest and liggs like those of the Northwestern Red-wing. Said to be less prolitic.

General Range,-Central and northern coast districts of California north to IIaslington; straggles irregularly eastward and southward in California in winter.

Range in Washington.--Recorded breeding at Cape Disappointment and maty possibly extend north to (iray's I larbor.

Authorities.-Ageluius gubernutor Bonaparte, Baird, Rep. Lac. R. R. Surs. IA. 1858, 1). 530 (Columbia River ly J. K. 'Townsend). Allen, I?. N. (). C. II. 1). 128. R. H. I.awrence, Iuk IX. isig2, 45. Kobbé. 


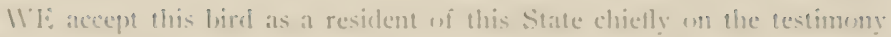

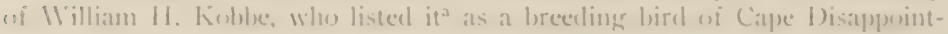
ment. He foumel it closely assexiated with the Sorthwestern Reel-wing (.A. phumicus comrims) atthe the latter irepuently pursued it in the attempt to expel it from the small swamp which lesth were compelled to necups. 'This polnthly represents the mothermmost extension wi this species, the (iray Harluer record of . Mr. Lawrence lesing at least opeen to gutestion in the matter uf islentifications.

The habits of the liculored blacklsirel des wot differ in any kmmwn particular from those of the familiar leed-wing. wi which it is a discomtinums iffshout.

No. 19 .

\section{COLUMBIAN RED-IVING.}

1. (). U. No. for. Agelaius pheniceus neutralis lidlyway.

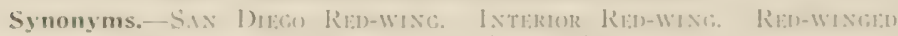

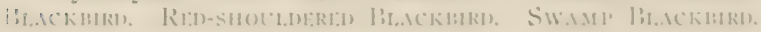

Description.-Idult male in summer: Cilossy black: lenser wing-coserts loright red (poppy-red, vermilion or scarlet ): midelle cowerts buffy or echraceousbuft-ele two forming thus a conspicuens epaulet, or shombler patch. Lill, legs, and feet horn black: irides brown. Idult mole in sinter: Midelle wing-coverts more deeply buffy; scapulars and feathers of black more or less exlged with rusty. In immoture moles the black of the phumage is more or less extensively marrined with rusty-huffy or whitish: the wing-coverts have an admixture of black and the "real" of the lesser coserts is wi a sickly lue forange-tawny, etc.). Adult femule in summer: lirownish gras, everywlere mottled and streakerl, or stripul, with dusky, linely on chin, clectis, and stupereiliaries, where also more or less rubescent, lecavily below, less distmetly alowe; lesser coserts brownisle-gray

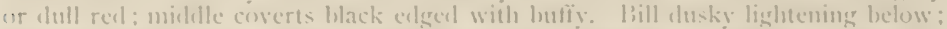
feet and lege dusky. Adult fomale in ainter: l'lumage wi lipperparts more or less margined with rusty or ochraceens: sides of heat and umlerparts tinged with

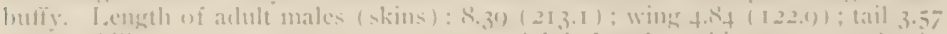

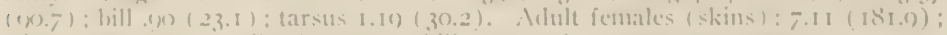

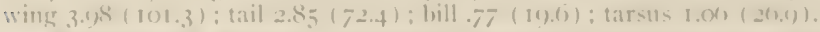

Recognition Marks.-('hewink to konhin size: bright red epaulets of male: Eeneral streakinces of female. Female lighter-colored and not on heavily streaked as in . I. r. caminus.

Vesting. - Vost: a neatly woren lnut rasher lublky lasket of gerasses, cat-tail

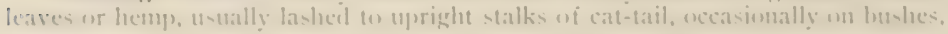

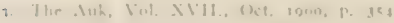

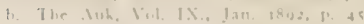


as willow and the like; lining of fine grasses of miform size. Eiggs: $4-7$, ustally f. light blue to clull grayish blue, scrawled, blotched or cloucled with dark purple, purplish brown or black, chiefly about the large end. Av, size I.O4 $x$.70 (26.4 $x$ 17.8). Scason: last week in April, June; two broods.

General Range.- IVestern United States in the interior north to castern British Columbia, restricted by Rocky Mountains and Cascades in northern portion of range but reaching coast in San Diego and Los Angeles Counties in California and breeding as far east as western 'l'exas, southward to northern Chiluahua and northern Lower California; displaced in Lower Colorado V'alley and sonthern Arizona by $\%$. p. sonoriensis; sonth in winter to sonthern l'exas, etc.

Range in Washington.--Found in all suitable localities east of the Cascales.

Migrations.-Irregularly resident but numbers always greatly augmented about . Narch ist.

Authorities.-Agclains phanicens Vicil, Cooper and Suckley, Rep. Pac. R. R. Surv, XII. pt. II. I860, 207. Allen, Bull. Nutt. Orn. Club, VI, I88I, iz8. $\mathrm{D}^{\mathrm{T}} \cdot \mathrm{D}^{2} \cdot \mathrm{Ss}^{\mathrm{T}} \cdot \mathrm{Ss}^{2} \cdot \mathrm{J}$.

Specimens.-U, of IV. C. P.

A MEADOWLARK may pipe from a sumy pasture slope in early February, and a Merrill Song Sparrow may rehearse his cheerful message in midwinter, but it takes the chorus of returning Blackbirds to bring boisterous tidings of awakening spring. What a world of jubilation there is in their voluble whistlings and chirpings and gurglings, a wild medley of March which strikes terror to the faltering heart of winter. A sudden hush falls upon the company as the bird-man draws near the tree in which they are swarming; lut a dusky maiden pouts, "Who cares?" and ther all fall to again, hammer and tongs, timbrel, pipes, and hauthoy. Brewer's Blachbirds and Cowhirds occasionally make common cause with Red-wings in the northern migrations, but it is always the last-named who preponderate, and it is they who are most rivacions, most resplendent, and most nearly. musical. 'The Red-wing's mellow kongquerec or necasional tipsy whoop-eractulup is the life of the party.

Amost before we know it our friends, to the number of a dozen pairs (11 more, lave taken up their residence in a cat-tail swamp-nowhere else. if you please, unless driven to it-and here, about the third week in April. a dozen haskets of matchless weave are swung, or lodged miclway of the growing plants. Your clistant approach is commented upon from the tups uf borklering willows by lecrings and other notes. At close range the lordly male, he of the brilliant epaulets and the proper military swagger, shakes out his fine clothes and says, Kongquer, in a voice wherein anxicty is quite ontweighed ly vanity and proffered good-fellowship withal. But if you push roughly thru the ontlying sedges, anxiety obtains the mastery. There is a iublubl in the marsh. Pustling, frowsy females appear and sond you roumblly: 'The lazy' gallants are all fathers now, and they join clireful threats 


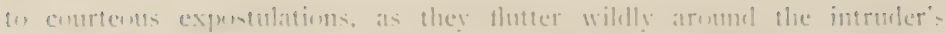

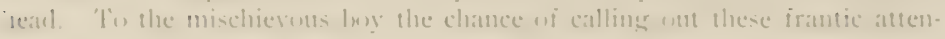
tions is very allurings. even when mo harm is intenderl.

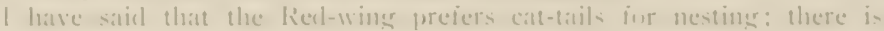

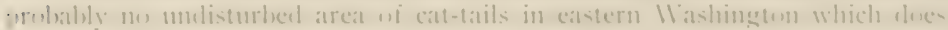

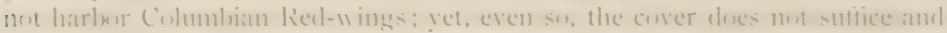

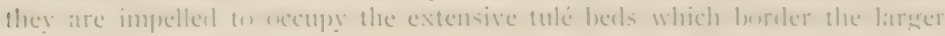

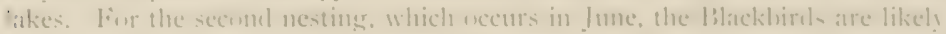

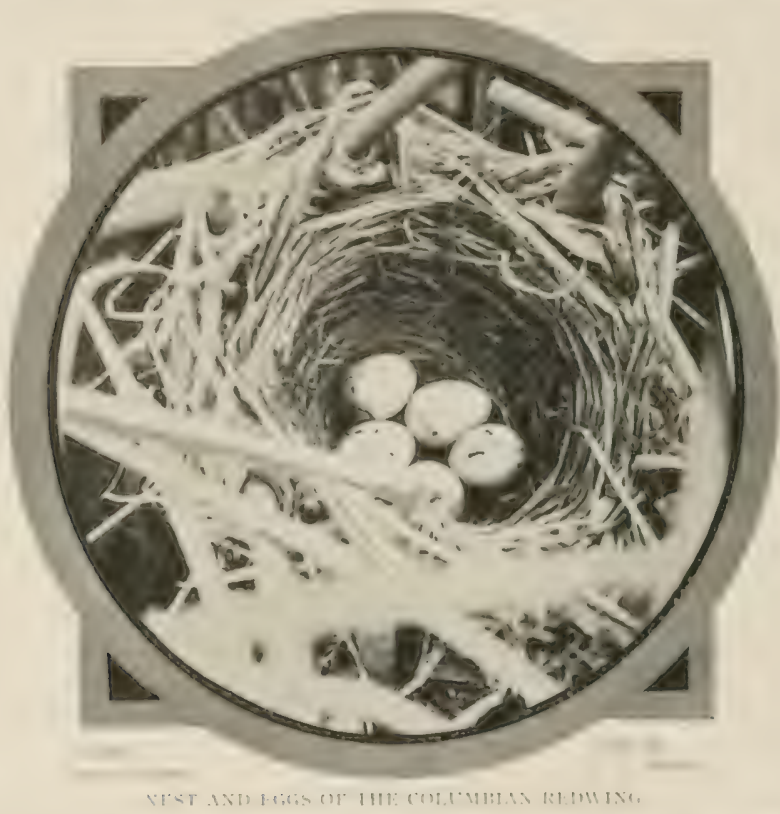

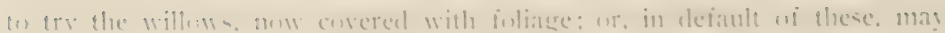
renture intu ans contse vegetation which lines the swasup

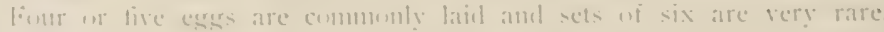

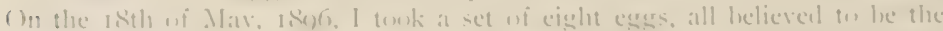

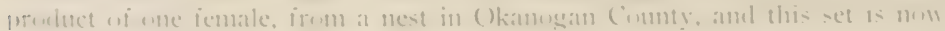
in the ()herlin (iollere Muréum

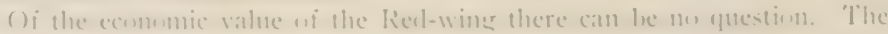
hirel is eliefly insectivoroms and destrovs an immense amotme of insed lite. 
particularly in the larval state, injurious to vegetation. Its single fatt is a weakness for young corn, but as corn is not a staple crop in Washington, this fault may be readily condoned in view of the bird's valuable services to stockman and orcharclist.

No. 20.

\section{NORTHWESTERN RED-WING.}

A. O. U. No. 498f. Agelaius phuniceus caurinus Ridgway.

Synonyms.-RED-IVINGED BLACKBRD. RED-SIOULDERED IBLACKBIRI). MARSH

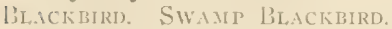

Description.- Similar to. . p. ncutralis but female much darker, heavily streaked with black below; in winter feather skirtings of female more extensively rusty. Measurements not essentially different.

Recognition Marks. - Is in preceding. Female darker and more heavily streaked than in 4. p. neutralis.

Nesting. - Vest: as in preceding; dimensions 5 in. wide by 6 in. deep outside, $3 \times 3$ inside. Eggs: 3 or 4 , rarely 5 . colored as before; dimensions varying from $1.05 \times .76(26.6 \times 19.3)$ to $1.00 \times .06(25.4 \times 16.7)$. Scason: second to last week in April, June ('Tacoma, April 6, Igor, 3 eggs); two broods.

General Range,-Northwest coast district from northern California north to British Columbia on Tanconver Island and mainland.

Range in Washington.-Common in suitable localities west of the Cascades. Irregularly resiclent.

Authorities.-Agclains phanicens Vicil, Baird, Rep. Pac, R. R. Surv. IX. I858, 528. T'. C\&S. Rh. K1, Ra. Kk. L. E.

Specimens.-( U. of II.) Prov. B. E.

THE bird-man was sitting 'I'urk-fashion on a great mossy log which ran far out into the rustling lepths of the South 'lacoma swamp. 'The April sun flooded the scene with warm light and made one blink like a blisstul clrowsy frog, while the marsh sent up a grateful incense of curling vapor. A pocket lunch of bread and clieese was the ostensible occasion of this noonticle bliss, lout victuals had small chams beside those of the sputtering 'Tulé Wrens win played hide and seek among the stems, or the dun Coots, who sowed their pulque pulque pulque notes along the reerly depths.

Lpon this scene of marshy content burst a vision of Phonician splendor. Caurinus I., the military satray of South Tacoma, the authentic tyee of lalackbirds. Ife was a well-aged bird, and as is the proper way with feathered folk, resplendent in propertion to his years. I Iis epanlets seemed a half larger again than others, and their scarlet was of the brightest 
Ine, comerasting with a black mantle which fairly slune. He appeares an amiable old fellow, and as he lighterl pronderously on an uplifted hranch

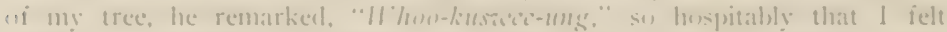
impelled to mumur, "'llanks," and assured him wi my unhestile inteme.

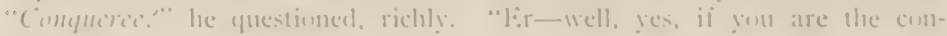
tplerut."

fiut the areneral hat wher interests (n) watch. In mpitart male wi the second year with shoulder-stratps of a sickly orange hue, was descried a rod away climbing hand-eser-latmel up a cat-tail stem. heyring, heyring.

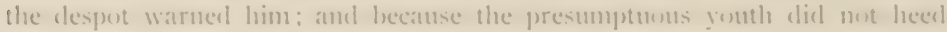
him quickly enongh, he laturehed his splement ower the spot, whereat the routh sank in dire confusion. . Ind next. nur heru caught sight wi at female fatir to lexk thron peeping at him furtively from lehind her lattiec

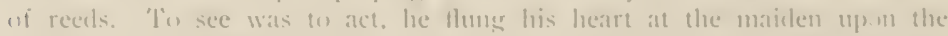

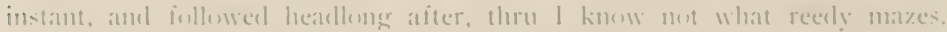
() 1, lestrt ever young, and pursuit never wearving!

Durthwestern lied-wings fund rather restricted range thrumut western Ilashingtom, lont they appear wherever there are fresh-water marshes of reed-lowrered lakes. In debult of cat-talils they will accept the shelter wi dwari willows, or coarse dense erass of any smet.

Nesting is molertaken at l'acomat at least log the third week in . Lpril. amel we have fommlesers as early as the sixth of that momth. The nest of the accompanying illustration (phentegravure) is compersed solely of dhe coiled stems of the dried hulrusles, ammugst which it is placed. with a lining of clean dried erass-stems.

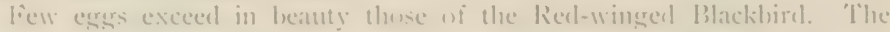

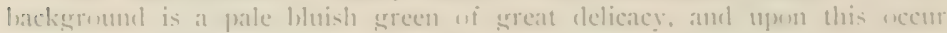

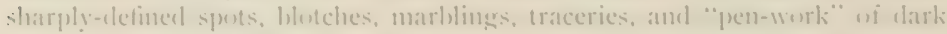
sepra, purplish black, drath, and helietrope purple. () al sput wi color appears Io he eleeply imberled in the fine. strome texture of the shell, and carries

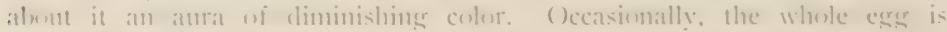

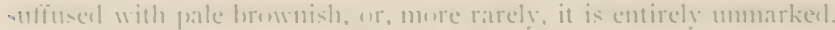

Incubation lasts inurten days and the young are realy to leave the nest in at litte wer two weelis more. 'lhey are frizzly, helpless, complaining litte creatures, lnt if they cammet fly well they can clamber, and they cling with the grip of terrified mentieys.

()ur Vorthwestern Rerl-wings are mormally migratory. Int they alson

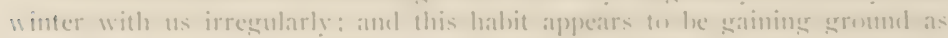

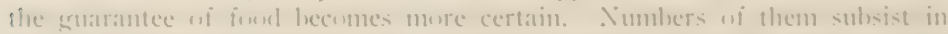
lesth Seattle and latema in the vicinity of grain chesators. where they will have comfortable sustenance until stect time as the angmented English sparmoss decree death to all mative hirels. 
No. 21.

\section{YELLOW-HEADED BLACKBIRD.}

\section{A. O. U. No. 497. Xanthocephalus xanthocephalus (Bonap.).}

Description.- Adult male: Head, neck all around, and breast orange yellow; lores and feathers skirting eyes and bill, black; a double white patch on folded wing formed by greater and lesser coverts, but interrupted by black of bastard wing; usally a little yellow about vent and on tibix; the remaining plumage black, dull or subdued, and turning brown on wing-tips and tail. Female: Dark brown; line over eye, throat, and upper breast dull yellow. Length ro.ooII.OO (25t-279.4); wing 5.30-5.60 (134.6-1.42.2); tail 4.00-4.50 (101.6-1 1.4.3); bill .90 (22); tarsus 1.25 (31.8). Fiemale smaller, length 8.00-9.50 (203.2-241.3). patches.

Recognition Marks.-Robin size; yellow head and breast; white wing-

Nesting.-Nest: a bulky but ustrally neat fabric of dried grasses, reeds or cat-tails lashed to growing ones; 5-7 inches in diameter outside by 5-8 deep; inside deeply cupped. Liggs: $3-6$, ghayish green spotted or clouded with reddish brown, rarely scrawled as in Agclains; elongate ovate in shape. Av. size, I.IOx.75 27.9x 19). Season: Mlay or June; one brood.

General Range.-Western North America from Wisconsin, Illinois and 'T'exas to the Pacific Coast, and from British Columbia and the Saskatchewan River sonthward to the Valley of Mexico. Accidental in Middle and Atiantic States.

Range in Washington.-Of local distribution in eastern Washington chiefly east of the Columbia River. Rare or casual west of the Cascades. Summer resirlent.

Authorities.-["Yellow-headed Blackbird," Johnson, Rep. Gov. IV. T. I 884 (1885). 22.] Bendire, Life Ifist. N. A. Birds, Vol. II. I895, p. 447. Ss ${ }^{T}$. J.

Specimens.-Prov. C. P.

OII, well for the mntried nerves that the Yellow-headed Blackbird sings by day, when the sum is shining brightly, and there are no supporting signs of a convulsion of Nature! Verily, if love affected us all in similar fashion, the world would be a merry mad-house. 'T'he lellow-head is an extraordinary person-you are prepared for that once you catch sight of his resplendent gold-nupon-black livery-but his avowal of the tender passion is a revelation of incongruity. Grasping a reed firmly in both fists, he leans furward, and, after premonitory gulps and gasps, succeeds in pressing out a wail of desparing agony which would do credit to a dying catanount. When you have recovered from the first shock, you strain the eyes in astonishment that a mere bird, and a bird in love at that, should give rise to such a cataclysmic sound. But he can do it again, and his neighbor across the way can do as well-or worse. When your nerves have somewhat recovered, morlesty 


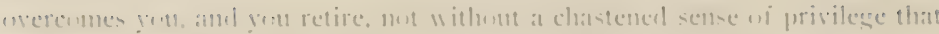

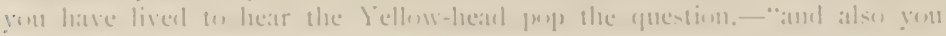
lived after."

The expiring kemen ery is ynite the linest of the dinthecphlatine reper-

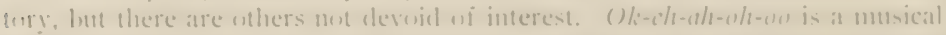

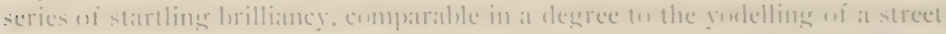

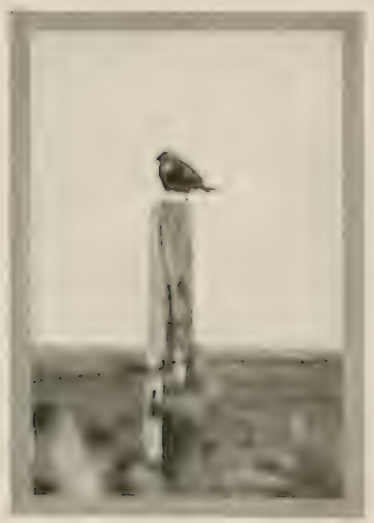

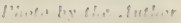

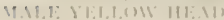
urchin,-il succession uf sumbls of varving pitches, probleced as tho hy altering the oral capacily. It may he muted ilous: The list unte is especially mellom aunl pleatsinger recalling 1 , sume

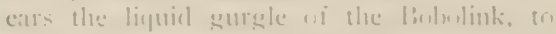
which, wi ceurse, set:r hirel in elintimetly related.

. Ulermather with the latst mamerl, and mure frecpuenty hearel from the elejules uf the nesting swamp is gur, surrl; or, as nitenest. veailuk). gevi(nk), gur-gurml. In this phrase the guml is drawn out with comical effect, at thut the gallant were down on his

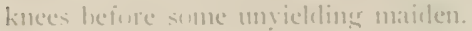

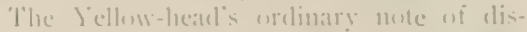

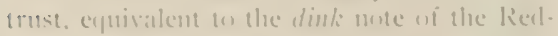
wing, is liluck ar liolucli. In thight this iecomes almost invariably orkluk, ocikluk. At rest, agrain. this is sometimes probonged into a thrilling passige of resmant "l" notes, pmoblhly remomstratery in charater. The alarm cry is lunilt upon the same hasis, and is uttered with

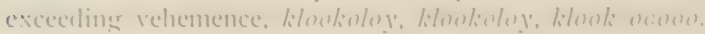

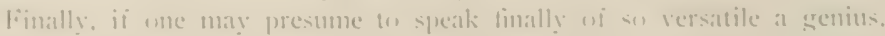

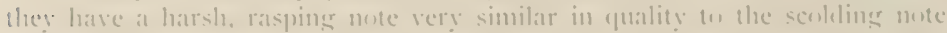

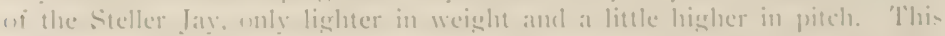
is the ante of fieree altereatim. or the distress ery in imminemt danger.

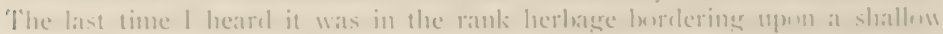

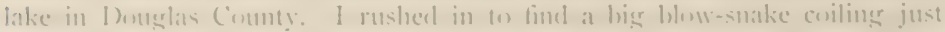
lelow a mentful wi voung birds, while the agonized parents amel sympathetic

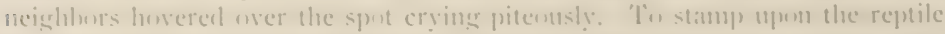

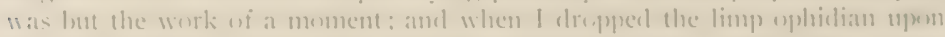

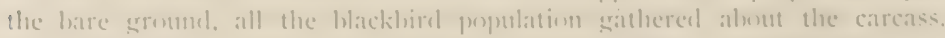
-humlering lut exultant, and-perhaps it was only fancy-errateful tom.

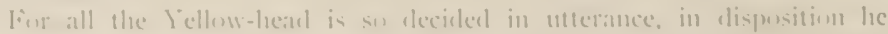
is semewhat phlemmatic, the male hirel especially lacking the vivacity which characteriges the agile Brewer blacklirel. lixcept when lumerys or im- 
pelled by passion, he is quite content to mope for laours at al time in the deptlis of the reeds: and even in nesting time, when his precincts are invaded, he oftener falls to admiring his own plumage in the flockling sum shine than tries to drive off the intruder. Let the homely and clistrat female attend to that.

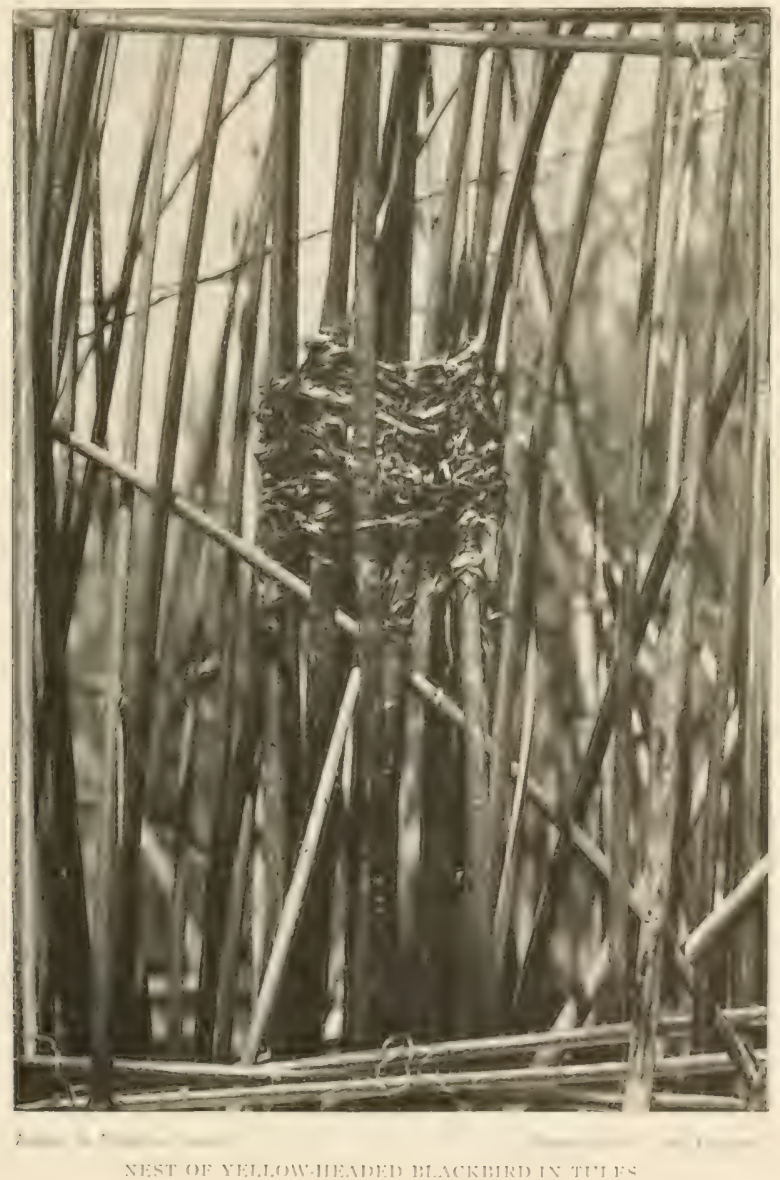




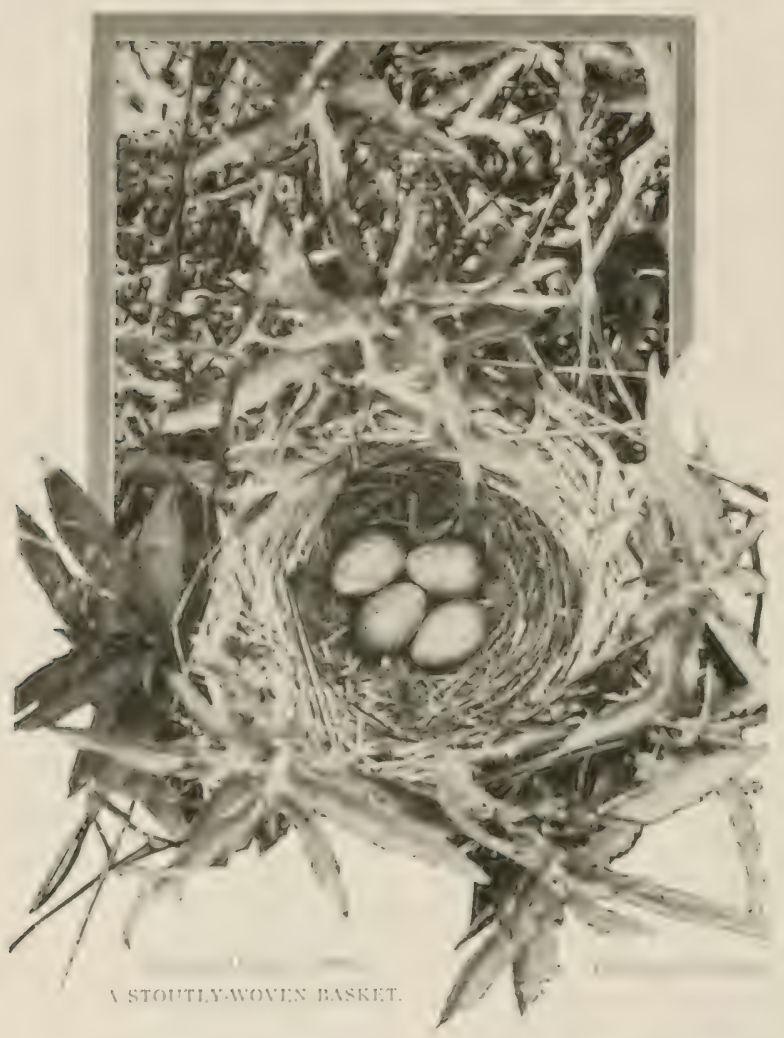

'llois lived is e: sentially at plainslowing specters, and its iasorite hamuwith us are the recely |mirclers wi the ereeleses lakes. amel the mplamel semeghs ui eastern Ilistingente It in highly erexartions. especially in the iall and earl fprings. hut cons iesses tor almont the sitme deerree wi denterticity ats the Reel-winer in late epring and earl! -

l'he nests ari stemely-useren has kets on reeels amel erratsecs, light amet dry and lamel sime. Nom mutel or inther matrix material is nserl in cumstructisul. :แx\} the interior is al. w a y careiully lined with fine dry erass. 'l'he

illimitable bulrushes are the faverite cover, but rank herlatere of ans sort

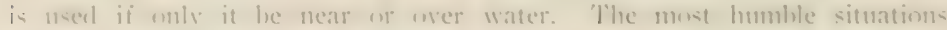
anfice: and the nest is offen placert within a fow of the water, or its erpuisalent wi black mence. 
No. 22.

\section{WESTERN MEADOWLARK.}

A. O. U. No. 501.1. Sturnella neglecta Audubon.

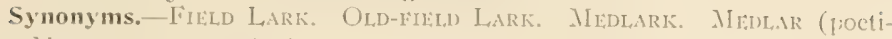
cal). MIUDL.ARK (corruption).

Description.- Hdult male: General color of upperparts brownish black modified by much tawny and buffy-gray edgings of the feathers which throw the black into stripes and bars with suggestion of herring-bone pattern; the tawny heaviest on secondaries and upper tail-feathers where taking the form of partial bands, a median crow'n stripe and posterior portion of superciliary sordid white or buffy; anterior portion of superciliary, cheeks, chin, upper throat, loreast (broadly) and middle belly rich lemon yellow (inclining to orange in viler specimens); a large black crescent on upper breast; sidles and Hanks blackstreaked and spotted with pale brown on a buffy or whitish ground. Bill variegated, tawny, black and white. Ficmalc: Like male but smaller and paler witl some substitutions of brown for black in streaking; black of jugulum veiled by grayish tips of feathers; yellow of breast duller. etc. The plumage of both sexes is duller in fall and winter, the normal colors being restraned by buffy: nverlay. J.ength of adtult male: $10.00-11.00(254-279.4)$; wing 4.85 (123.2); tail $3.00(-6.2)$; bill $1.30(33)$; tarsts 1.46 (37.1). Female smaller.

Recognition Marks.-Robin size; yellow breast with black collar distinctive; general streaky appearance above; yellow cheeks as distinguished from the Eastern Meadowlark (Stumella mayna).

Nesting.-. Vest: on the gromul in thick grass or weeds; a slight depression lined (carefully or $10 \mathrm{t}$ ) and usually overarched with dried grasses. ligys: $4^{-6}$. white, speckled and spotted, sometimes very sparingly; with cinnamon brown or purplish; very variable in shape, elliptical ovate to almost round. Av, size, I.12 X $.80(28.5 \times 20.3)$. Season: April and June; two broods. 'lacoma, April 5, I906. + fresh eggs.

General Range,- Western United States, sonthwestern British Provinces, and northwestern Mexico, east to prairie districts of Mississippi Valley, Minnesota, Iowa, Missouri, etc., occasionally to lllinois and Michigan; breeding thruout its range.

Range in Washington.- - Dundant east and west of the Cascades; largely resident on the West-side, partially on the liast-side: numbers angmented from the south during last week in lichruary.

Authorities.-[Lewis and Clark, Hist. Ex. (18I4), Ed. Biddle: Cones. Vol I1. p. 186.] Stumella neglecta Aud., Baird, Rep. Pac. R. R. Surv. 1A. I858,

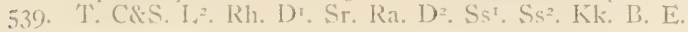

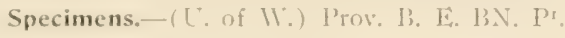

SL:MLMIR silences the birds so gradually and we ourselves have become so much absorbed in business during the prosy days of September that we 


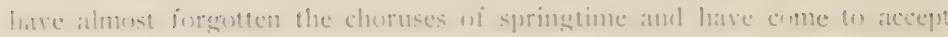

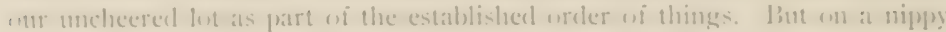
fetoler morning, as we are lemeling aner some dull task, there comes a

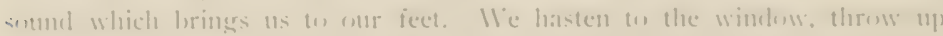

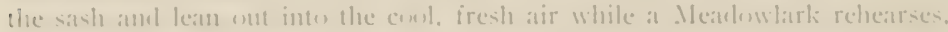

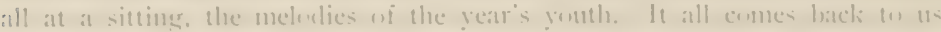
with a ru-h: the susell wi lush gratses, the splender af apple blessumes the

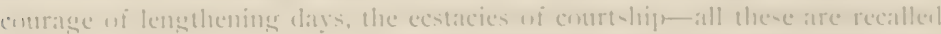

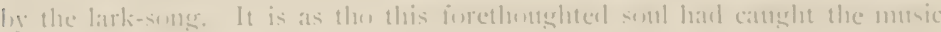

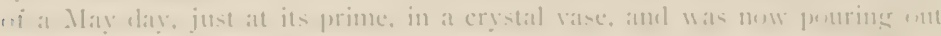

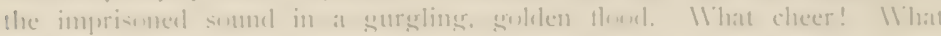

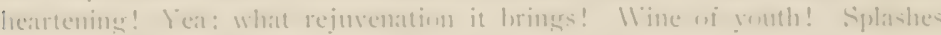
wi colus and gay delight

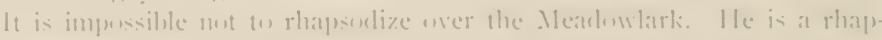

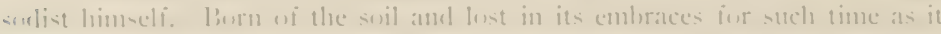
pleases him, he yet quits his lowly station ever and agatin, mumts smone ience-

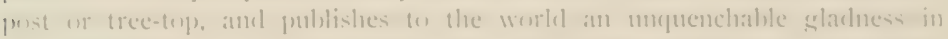

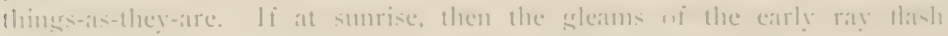

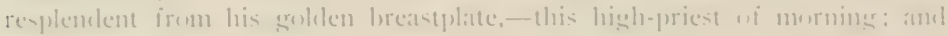

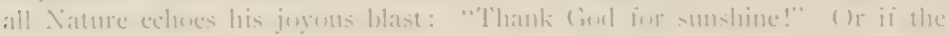

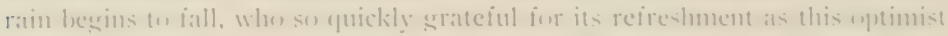

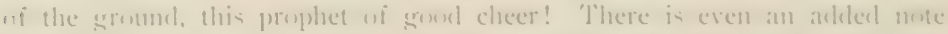

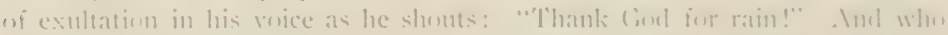

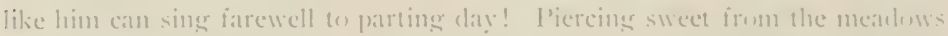

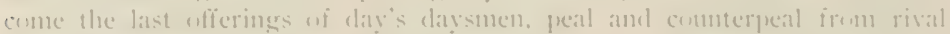

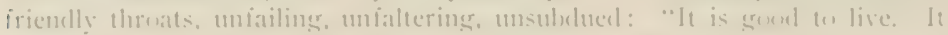

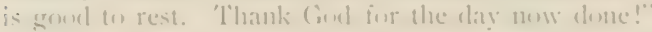

The Meadowlark of the bast has a puet's sombl lut le lacks an anlerpuate

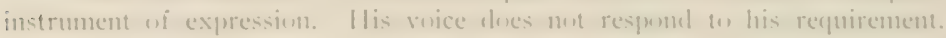
l'erhaps his early colucatinn, ats a species. was neglecterl. Certain it is that

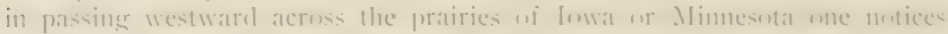
an instant change in the voices of the Meathwlarks. 'lhe soms wi the western lisel is sweeter, clearer, losuler. fonerer and more varied. 'The difference is se striking that we can explain it only upon the suppesition of an inclependent development. 'The western hire got his carly eraining where

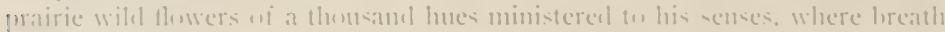

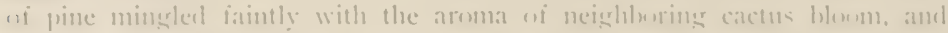
where the sight of distant monntains fired the imagriation of a puet race.

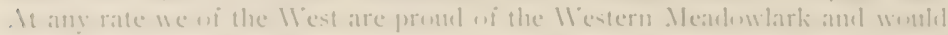

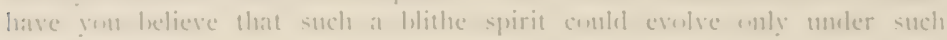
viremustances. 
Bird song never cractly conforms to our musical notation, and there is no instrument save the luman "whistle" which will even passably reproduce the quality of the Meadowlark's song. Nevertheless, many interesting experiments lave been made in recording these songs and a little attention will convince the least accomplished musician that there is a fascinating field for study here.

A formal song of the Western Meadowlark comprises from four to a dozen notes, usually six or seven. The song phrases vary endlessly in detail, yet certain types are clearly distinguishable, types which reappear in different parts of the country, apparently without regard to local traditions or suppositional schools of song. Thus a Chelan singer says, "Oku whecl'cr, ku whecl'cr, and he may not have a rival in a hundred miles; yet another bird on the University campus in Seattle sings, Eh heu, whecliky, ahecliky, or even E/ hou zihceliky, whecl'iky, whed'iky, and you recognize it instantly as belonging to the same type. In like manner Oruy'lee, recitative was heard with perfect distinctness both at Wallula and in Okanogan County.

Each bird has a characteristic song-phrase by which he may be recognized and traced thru a season, or thru succeeding years. One boisterous spirit in Chelan I shall never forget for he insisted on shouting, hour after hour, and day after day, "Hip! Hip! Hurrah! boys; three checrs!" Yet, while this is true, no bird is confined to one style of song. An autumnal soloist in Ravenna Park rendered no less than six distinct songs or song-phrases in a rehearsal lasting five minutes. He gave them without regard to sequence, now repeating the same phrase several times in succession, now hurrying on to new forms, pausing only after each utterance for breath.

Nor is the effort of the Western Meadowlark confined to the formal song for he often pours out a flood of warbling, chattering and gurgling notes which at close range are very attractive. Not infrequently he will interrupt one of these meditative rhapsodies with the clarion call, and return immediately to his minor theme.

In the presence of a stranger the lark serves frequent notice of intended departure in a vigorous toop, or toob, accompanving the sound with an emphatic flirt of the wings and jerk of the tail. Now and then the actual departure is accompanied by a beatiful yodelling song. After several preliminary tools the bird launches himself with fantastic exaggeration of effort and rolls ont. O'ly' o'ly o'ly o'ly o'ly', with ravishing sweetness.

At nesting time the parent birls have many causes for apprehension. and as they move about in search of food they give vent to the toob note of distrust in a fashion which soon becomes chronic. In Douglas County this note is ifoubled, trio' bit, or ta'n' ahit, and one camnot recall the varied life of the sage in June without hearing as an molertone the half melaneloly tavo' bit of a mother Meaclowlark as she works her way homeward by fearful stages. 


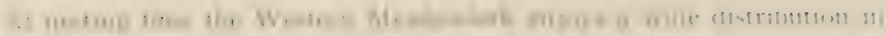

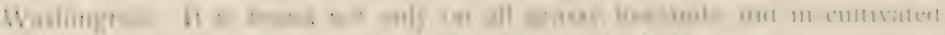

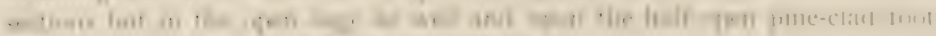

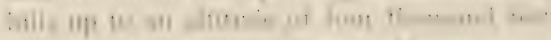

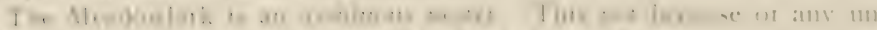

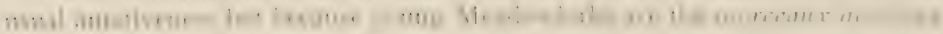

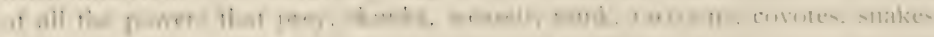

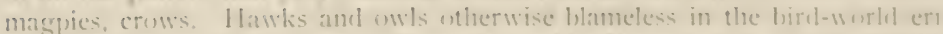

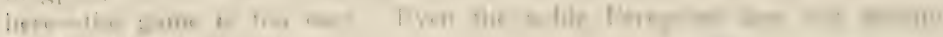

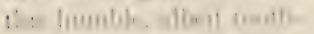
- III. .

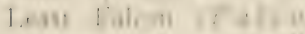

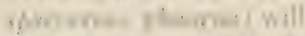

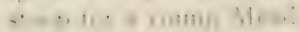

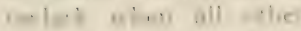
avt. Hetmon th then ... ir . . 11

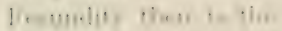

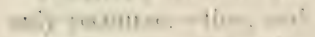
$\cdots+\cdots+15$ m. $, \cdots, \cdots$, 11

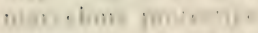

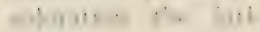

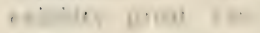

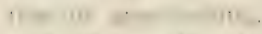
a. if in ili it

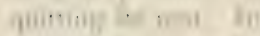
, . li,

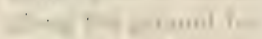

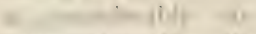
* in in in wh th $:$ ale I in il

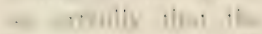

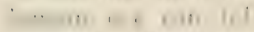

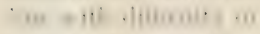

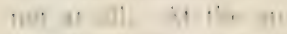

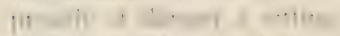

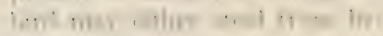

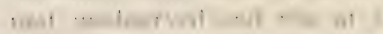

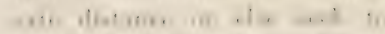

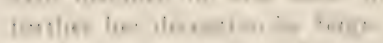

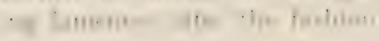

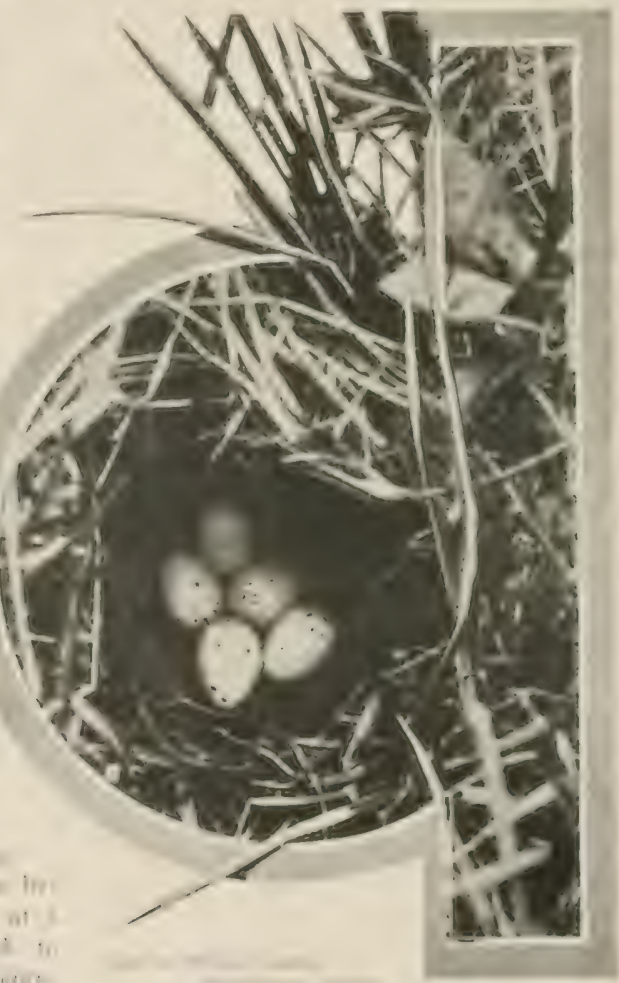

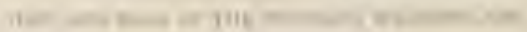


of the Shore-birds. Or, again, she may cling to her charge in desperation hoping against hope till the last possible moment and taking chances of final mislap. In this way a friend of mine once discovered a brooding Aleadowlark imprisoned underneath his boot-iortmately without clamage for she occupied the deep depression of a cow-track.

'To further concealment the grass-lined depression in which the Neadowlark places her four or five speckled eggs is almost invariably over-arched with dried grasses. 'This renders the eggs practically invisible from above, and especially if the nest is placed in thick grass or rank herbage, as is customary. Touching instances of blind devotion to this arch traclition were, however, afforded by a sheep-swept pasture near Adrian. Here the salt-grass was cropped close and the very sage was guawed to stulss. But the Meadowlarks, true to custom, had imported long, dried grasses with which to overarch their nests. As a result one had only to look for knobs on the landscape. By eye alone we located six of these pathetic landmarks in the course of a half-hour's stroll.

One brood is usually brought off by May ist and another by the middle of June. Nltho Meadowlarks are classed as altricial, i. e. having young helpless when hatched and which require to be nurtured in the nest, the young Meadowlarks are actually very precocious and scatter from the nest four or five days after hatching, even hefore they are able to fairly stand erect. 'This arrangement lessens the chances of wholesale destruction but it would appear to complicate the problem from the parental standpoint. How would you. for instance, like to tend five babies, each in a separate thicket in a trackless forest, and that hatmted by congars, and lynxes, and boa-constrictors and things?

We cannot afford to be indifferent spectators to this early struggle for existence. for it is difficult to nverestimate the economic value of the XIeadowlark. 'The hird is by choice almost exclusively insectivorous. If, however. when hard pressed, he does take toll of the fallen wheat or alfalfa seed, he is as easily justifiable as is the hired man who consumes the farmer's biscuits that he may have the strength to wield the hoe against the farmer's weeds. Being provided with a long and sensitive bill, the Meadowlark not only gleans its insect prey from the surface of the sround, but works among the grass ronts, and actually probes the earth in its search for wire- and cutworms, those most dreaded pests. Besides devouring injurious gruls and insects of many kinds, the Lark has a great fondness for grassloppers, sul)sisting almost entirely upon these in the season of their greatest abundance. In the matter of graschopper consumption alone Nendowlarks of average distribution, are estimated $\mathrm{w}$ no less an anthority than Professor Beal, to be worth alonst twenty-four inllars per month, per township, in saving the hay crojs. 'I'o the individual farmer this may seem a small matter, but in 
ale agreregate the saving to the nation amenuts (1) some lumelreds of thousands of cloflats each year. liven in winter, when a iew individuals or accasional companies of latrks are still to fe fomul, a large progurtion wi their furd consists of hardy feetles and other insects, while weed-seed and scattering grain is litid under trilute, as it were, reluctantly.

It gues withut saying that we cammet regard this hird ats lawinl game. IVe exemut the horse from slaughter mot because its flesh is unfit for forelit is really very saphel-lunt because the animal has endeared itselt to our race In erenerations of faithiful service. We place the horse in another category, that of anmal iriend. Ind the luman race, the best of $\mathrm{it}$, has some time since discosered compunctions alxut eating its friends. Make friends with

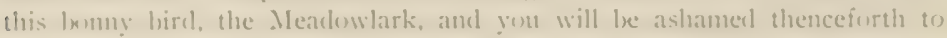
even discuss assassination. Foricassee of prima demna! Voice of merning ilf brochelle! Bircl-of-merry-cheer on tonst! Faugh! And yet that sore of thing passed muster a generatiun ago-does yet in the darker parts of liurope!

No. 2.3 .

\section{IVESTERN EVENING GROSBEAK.}

\section{A. (). (i. Xo. 514a. Hesperiphona vespertina montana Richway.}

Description.-Idulf mak: forchead and strperciliaries gamboge yellow; feathers alout base of bill. lores, and crown black: wings black with large white fatch formed by tips of imner secomelaries and tertials; tail black: remaining plumage souty cilive brown aloust head and neck, shacling thru slive and olive-

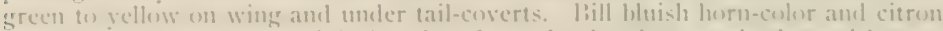
vellow: feet hrownish. Adult fomale: General color deep smoky brownish gray or buffy lorusn, clarker nu the lecal, lighter on wings, lighter, mere butfy, an sieles. shading wo dull whitish on throat and alelomen, tinged with yellowish green on limel-neck, clearing to light yellow on axillars and moler wing-coverts: a small clear white patch at base of inner primaries: white blotches on tips of upper tail-coserts and imoer weles of tail-feathers in varvine presportions. I.ength aluent

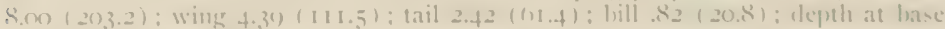
(1) $2(15,1)$ : tars 11 - Si $12(0,3)$. Female very slightly -maller.

Recognition Marks. - Chewink size: olive-lorown coloration with black and

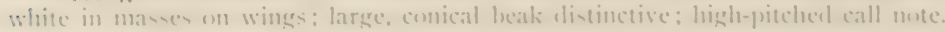

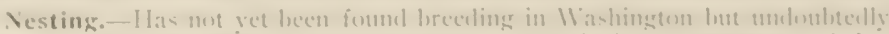

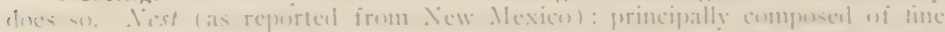

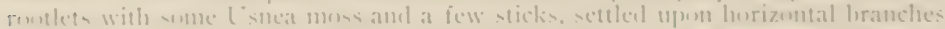

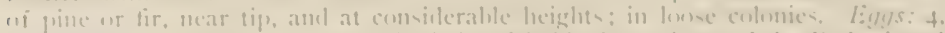
"in contur, size, form, and texture indistimgui-hable from these of the licel-winged lilakhiril" ( Itirtwell). 


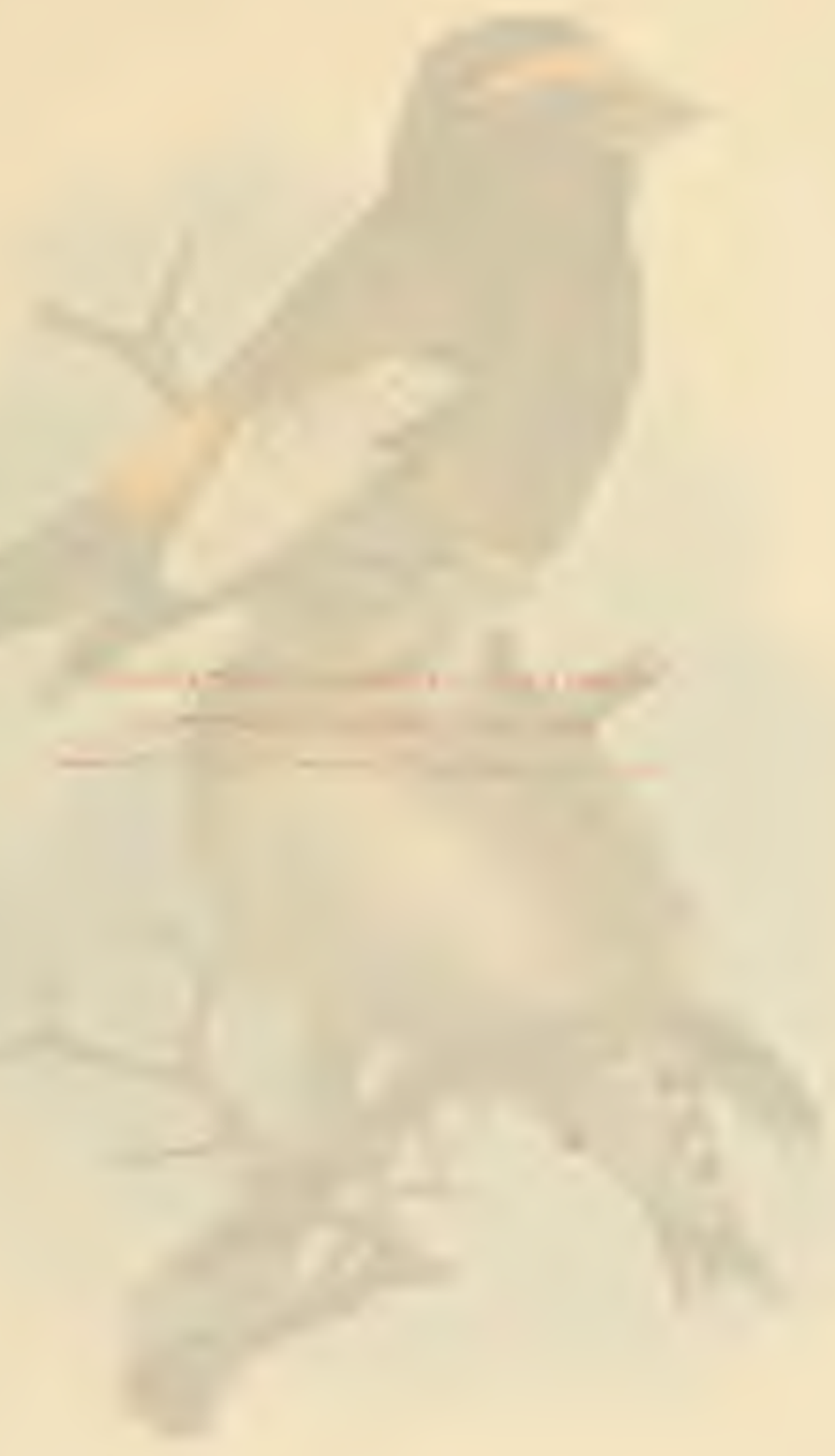




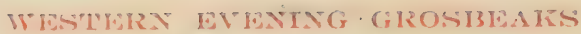

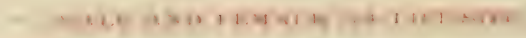

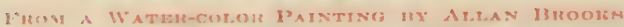




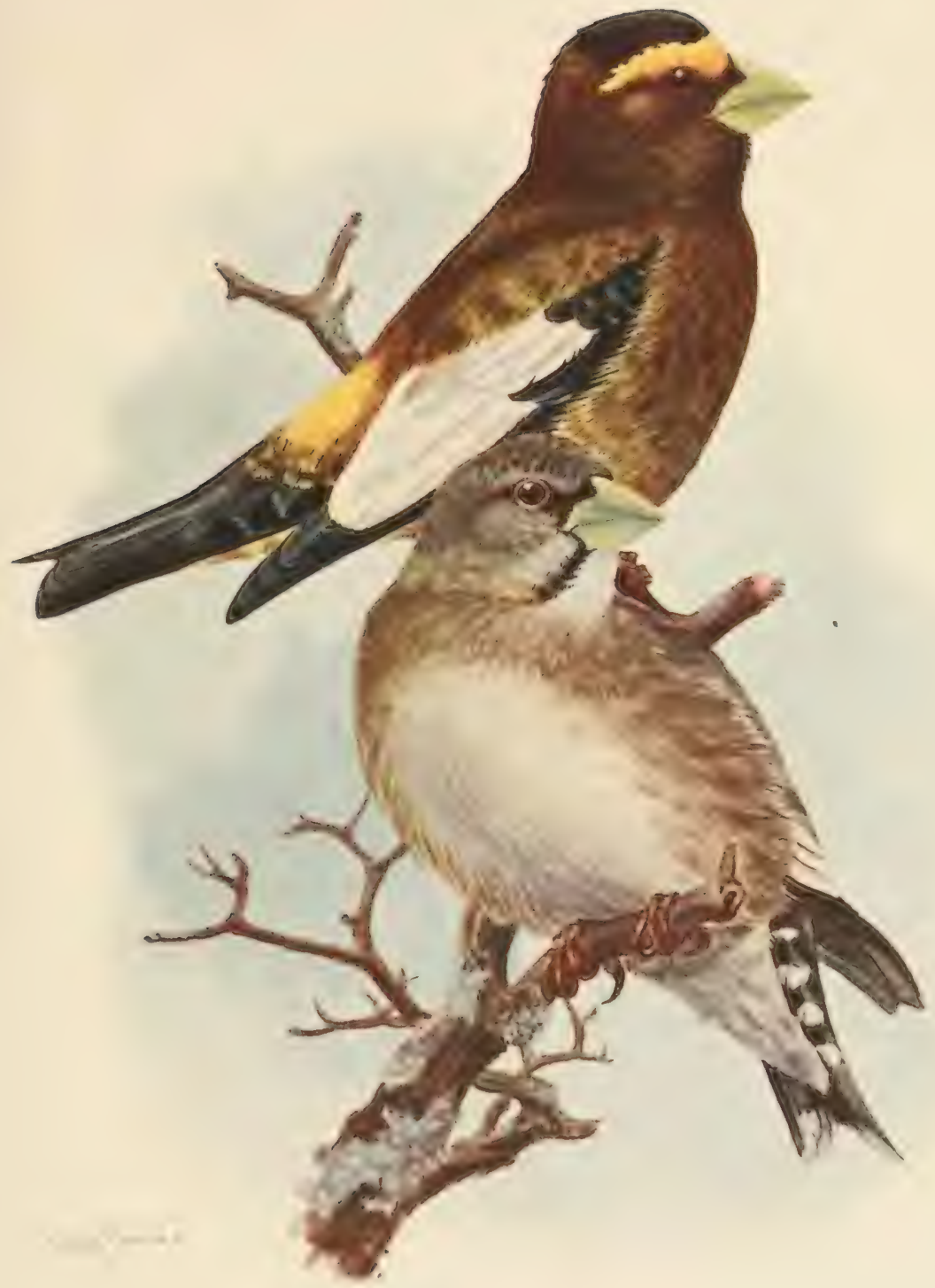



General Range.-Western United States and Northern Mexico; cast to and including Rocky Mountains; north to British Columbia.

Range in Washington.-Co-extensive with evergreen timber and appearing irregularly elsewhere. Resident within State but roving locally. Winters regularly in parks of the larger cities.

Authorities. - ? Fringilla iespertina 'Townsend, Journ. Ac. Nat. Sci. Phila. VIH. IS39, I5t (Columbia R.). Hesperiphona vespertina Baird, Rep. Pac. R. R. Surv. IX. I858, 409. 'T'. C\&S. Ra. Kk. B. E.

Specimens.-U. of W. Pr. Prov. I3. E.

SPARROIVS are also called Cone-bills; it is, therefore, fair that the bird with the biggest cone should take precelence in a family listory. But for this primacy there are damaging limitations. The Grosbeak is neither the most beatiful nor the most tuneful of the fringillida, if he is by conmon consent rated the oddest. His garb is a patchwork; his song a series of shricks; his motions eccentric; his humor pllegmatic; and his concepts beyond the ken of man. Altho at times one of the most approachable of birds, he is, on the whole, an avian freak, a rebus in feathers.

Perhaps we make too much of a mystery of him, just as we rate the owl highest in wisclom for the single discretion of silence, which any dunderhead may attain. But now take this group in the park; just what are they at? They sit there stolidly in the rowan tree where all the passersby may take note of them, giving vent ever and anon to explosive yelps, but doing nothing by the hour, until an insane impulse seizes one of their number to be off to some other scene no better, be it near or far, and the rest yield shrieking consent by default of alternative idea. It is all so umeasonable, so uncanny, that it irritates 11 .

Eivening Grosbeaks are semi-gregarions the year around, but are seen to best advantage in winter or early spring. when they flock closely and visit city parks or wooded lawns. One is oftenest attracted to their temporary quarters by the startling and disconnected noises which are flung ont broadcast. It may be that the flock is absorbed in the clepths of a small fir, so that one may cone up near enough to analyze the sound. Three sorts of notes are plainly distinguishable: a low mumuring of pure tones, quite pleasant to the ear; a harsh but staludued rattle, or alam note, aciszt or ai: $\approx \approx p$. familiarly. similar to that of the Crosslill: and the high-pitelied shriek, which distinguisles the bird from all others, dimp. A little attention brings to light the fact that all the birds in the flock bring out this astonishing note at precisty the sume pitch. Once distinguished, this note will serve again and again to (lraw attention to this uncanny fowl, as it passes overhead or loses itself in the bosom of some giant conifer. 
It is ant a liule surprising at first thenght, that the lathits of these birels

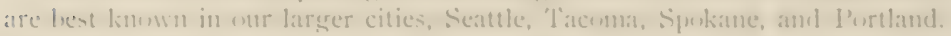
Why they shombl he especially attracted to them, it is hard on say, moless it he

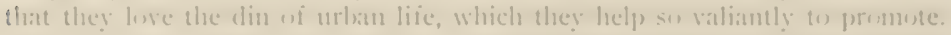
Lint it is easy to see why they are more moticeathle there; for their showy and patchy cohration matks them ats distinguished visiturs in fomm, whereas in the furest their colnes so melt inte and harmenize with their surromentings that it is distionlt to follows their movements.

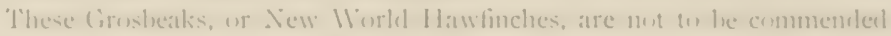
as horticulturists. In winter they feed largely upon the groumb, sheaning ballen secels and iruits: and are especially fomd wi the winged liey of the larese-

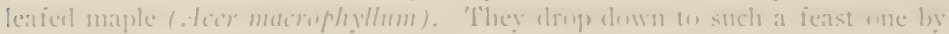

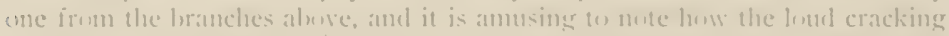
of seerls is interspersed with music. I litte later the hirds dewote themselses (1) swelling huls, ambl lere ton the maple is a fatwrite: the ash, alder. fluwering

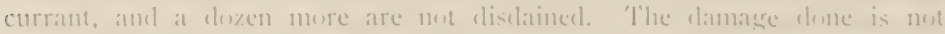
comsislerable: for the lirels, vieweel in the large, are not mumeroms emough, all

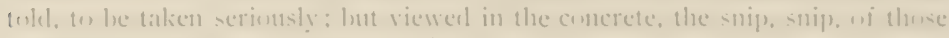
mandibles in the lilac busles is mo jelle juy.

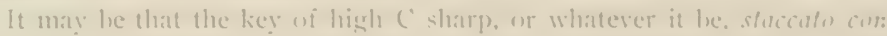
mofo, is the acepted lowe note, and that the green-liveried swain hurls declarations at his commonats, like samente in llandel's oraterin, the live-fong

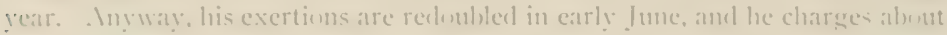
in a reckless frenzy which should make the eity gape. Jume. monf, was

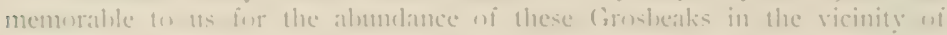

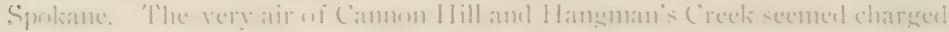

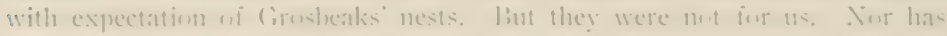
the nest yet been talien in 11 ashington.

No. 21.

\section{AIASKAN PINE GROSBEAK.}

1. 11. 1: .10.5150. Pinicola enucleator alascensis liulgway.

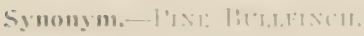

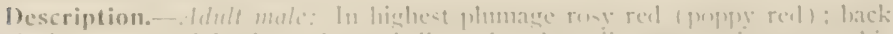

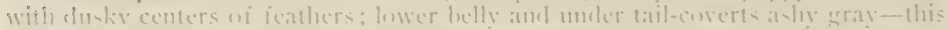

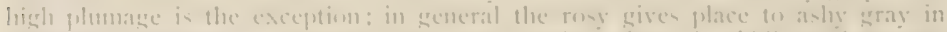

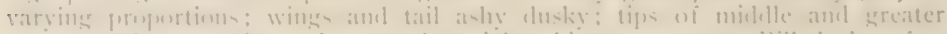

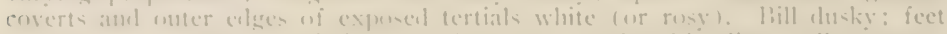

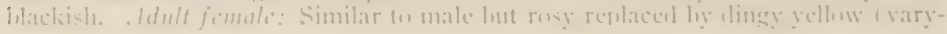


ing from olive-yellow, olive-tawny and ochraceous to bricky red) and chicfly confined to head, hind-neck and upper tail-coverts (where brightest); feathers of back frequently tipped with ochraccous and breast with an ochrey wash. Length abont 8.60 (218.4) ; wing 4.60 (II ) ; tail 3.66 (93); bill .57 (I 4.5 ); tarsus .89 $(22.7)$.

Recognition Marks.-Chewink size; large, rounded conical heak; red and sray coloration for size distinctive.

Vesting.-.". Iest, composed of a basement of twigs and rootlets within which is a more compact faluric of finer materials. Eiggs, usually 4 , pale greenish blue. spotted and blotched with dark brown surface markings and lilac shell-spots." Ar. size $1.05 \times .7+(26.7 \times 18.8)$. Season: About June ist; one brood.

General Range.-"Northwestern North America, except Pacific Coast. breeding in interior of Alaska; sonth, in winter; to eastern british Columbia. Montana (liitterroot lalley), etc." (Riclsway).

Range in Washington.-Reported by Allan Brooks as breeding in the MIt. Baker district (as below) ; should occur upon the timbered lowlands in winter. p. 482.

Authorities.-Allan Brooks in cpist. Dawson, Auk Vol. XXY. Oct. IgoS,

\section{Specimens.-P'rov:}

THIS large and handsome Fincl is of very irregular occurrence in southern British Columbia excepting the higher mountain ranges, where it breels. During some winters it is present in-large numbers, while in others, equally severe, none are seen. l'he species was very common throughout the winter of 1906-1907, a very severe one; lut in that of I90I-1902, which was notably mild, Pine Grosbeaks were noticed in considerable numbers as far sonth as Penticton, fo miles nortl of the international boundary, and they unchenbtedly occurred much farther south.

'Their food in the winter months is principally berries, but, strange to say, they altogether refuse those of the mountain ash, both the introduced and incligenous species. The former is the favorite food of the Easten Pine Grosleak thrunut the winter in Ontario, but trees loaded with fruit were passed by at Okanagan Landing in the winter of Igo6-1907. eren after the hirds lati eaten all the rose hips and snow herries and were reduced to eating weerl seeds with the lowerstictes.

Either this sub-species or muntanu breeds on all the higher mountain ranges in Iritish Columbia, cecupying a zone from timber line dowmwards alont 2.000 feet.

My first acpuantance with the l'ine Grosheak at its breeding grounds. was in the Cascarle .romntains due north of .It. Baker. on both sicles of the Forty-minth l'arallel. Here the species was a somewhat sparing breeder close to timber line amoner the hemlock and balsam timber. 'lhey were fecting youmg on the 17 th of July: at the same time Crossbills hat fully 
gromn young in lixks. No red males were seen, through many gray males were singring in the early mornings from the topmest spray of some halsant.

In the uriter's opinion the red plumage in the mate is acepureel at the first monlt or inmediately atter the juxenal dress, and is usually anly retaned for one seatson; in some males a duller red dress is carried floromgh the second summer, or mure rarely at salmon-pink one: lout in mest cases the dress of the second summer is a gray one like the females, with yellom heand and rump. Females may sometimes be seen with decidedly red heats and rumps, -irom the size and shape of the bill these seem whe very ohl hirds. The alone remarks as to the red dress in the male apply also, in the writer's experience, to the genera Loxia, Carpodacus and Acomihis.

Ar.I.IX Bknoks.

No. 25.

\section{AMERICAN CROSSBILL.}

A. O. L. . .o. 521. Loxia curvirostra minor (Iirelum.).

Synonym.-Rrit) (kossut.t.

Description. - Alult male: 'Tips of mandibles crossed cither way : plumage ret, brightest on rump) feathers of loack with lorownish centers: wings and tail fuscous. Shade of red very variable, - orange, cinnabar, even vermiliom, sometimes toned down by a saffrom suffusion. Immature males sometimes present a curiously mottled appearance with chronse-green and red intermingled. Fimale and young: Dotl nlive-green, lorighter and more yellow on heal and rump: below gray overcast by thingy yellow. Arlult male, length 5.50-12.25 (1 39.-7158.8); wings $3.40(86.4)$; tail $2.05(52.1)$; hill $.70(8.8)$ or meler.

Recognition Marks. - Sparrow size: crosserl manlibles; male red and fomale olive-ereen: both aitheut white wing-bars.

"Nest: in forks or among twigs of tree, founded nn a mass of twige anul bark-strips, the inside felted of ther materials, including small twigs. rondets, grasses, hair, feathers, etc. Ligys: $3-4.0 .75 \times 0.57$, pale greenish, spotted and dotted alsut larger end with clark purplish hrown, with lasender shell-markings"

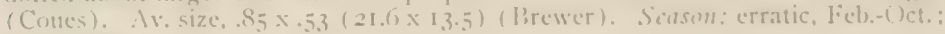
nile bront.

General Range.-Northern North America, resident sparingly south in the

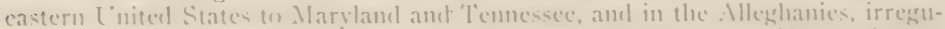
larly abundant in winter. Of irregular distribution throsut the coniferous forests of the 11 ent, save in sonthern California, Arizona, and dew .lexien, where replacerl by I.. c. stricklundi.

Range in Washington.- Finut thruout the enniferous forests of the State: of irregular f cenrence lecally. Nom-migratery lut memalic.

Authorities, - (urimstrit amerioma Wils. Baird. Rep. lace. K. R. Surs.

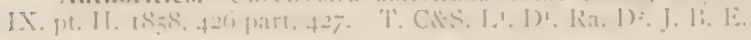

specimens.- L'. of 11 . I'rom. H. I3. 
IVHEN a bird's pastures are the tree-tops it is possible for it to live a quite secluded life here in Washington. And, indeed, we know the Crossbill chiefly as a wandering voice or, rather, a vocal babel, passing from summit to summit in the grim fir forest. But on a rare day, it may be in Spokane, or it may be in Tacoma, the birds descend to human levels and are discovered feeding busily on their favorite pine cones. The birls are perfectly indifferent to equilibrium, and feed any side up without care. While thus engaged they may exhibit little fear of the beholder and sometimes venture within reach; but as often, for some whimsical reason they are up and away again as tho seized by evil spirits.

The Crossbill owes its peculiar mandibles to an age-long hankering for pine-seeds (using that word in the generic sense), a desire fully satisfied according to the fashion of that Providence which works so variously thru Nature, and whose method we are pleased to call evolution. The bill of the bird was not meant for an organ of prehension, and Buffon, the Deist, once won a cheap applause by railing at the Almiglity for a supposed oversight in this direction; but as matter of fact, its wonderful crossed mandibles enable the Crossbill to do what no other bird can; viz., pry and cut open the scales of a fir cone, in order to extract the tiny seed with its tongue.

These birds are not entirely confined to a vegetable diet, for I once detected a group of them feeding industriously in a small elm tree which was infested with little gray insects, plant-lice or something of the sort. The presence of these insects, in colonies, caused the edges of the leaves to shrivel and curl tightly backward into a protective roll. Close attention showed that the Crosslills were feeding exclusively upon these aphicles. They first slit open a leaf-roll with their scissor-bills, then extracted the insects with their tongues, taking care apparently to secure most of the members of each colony before passing to the next.

Crosshills also feed to some extent upon the ground, where they pich up fallen seeds and other tidbits. Mr. J. F. Galbraith, a ranger of the IVashington Forest Reserve, first called my attention to another purpose which the birds have in visiting the ground. He had noticed how at certain places, and notably where dish-water was habitually thrown, the Crossbills were wont to congregate, and, turning the hend sidewise, to thrust out the tongute along the bare ground in a most puzzling manner. Suspecting at last the real state of affairs, he sprinkled the ground with salt, and mpon their return. the birds licked it up with great avidity. Mr. Galloraith claims to have tried this experiment successfully upon numerous occasions. 'The birds do not appear to recognize the salt at first sight, but soon learn to resort to established salt-licks in open places. Rev. lired MI. McCreary also reports similar habits in connection with certain mineral springs in the Suiattle country. 
When we recall that the nermal foud wi the Cirusbill is pine-secels, this cratving for daturés smlent is reatlily understandable.

C'rumblills grive ont an intermittent rattling ery, or excited titter, feat.

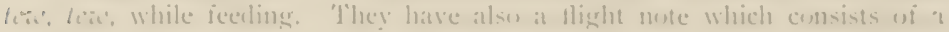
short, clear whistle: and a thek compuacel wi separately molubang indi-

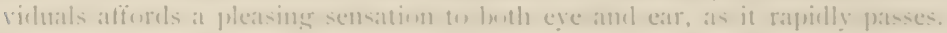
Jhe male is saise to hatve sprightly whistling motes of a ment agreeable char-

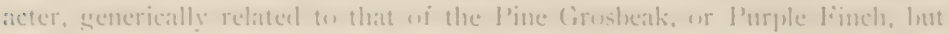
lleeir exhibition munt lee rather rare.

Diter all, there is somethine a hit uncammy almout these cross-billed ereatures, and their eceentricities shum nowhere in sreater relief than in their nesting hathits. The quasi migrations of the hiral are determineel by the heat

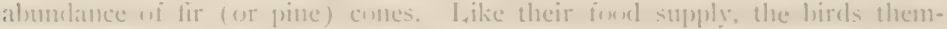

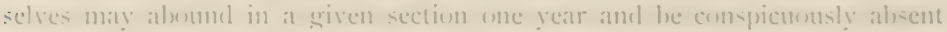
the next. Mnemer, lecause there is no choice of season in gathering the secel crop, the bircls may nest wheneser the whim seizes them: ame this they

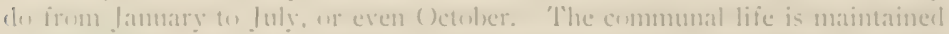

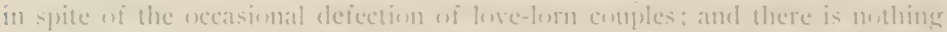

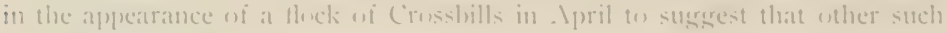
are elutifuily nesting.

Mr. Liemles has never taken the egres near flacuma, altho he has encountered half a domen wi their nests in twelve vears, the moly acenpied one af

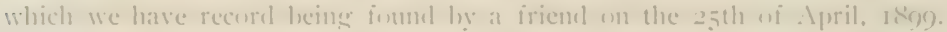
It contained thee hali-incubated exges, and was placed in one of a gromplof small lirs in the pratric comntre, at an elesation of some twenty feet. The nest rather clesely resembles that wi the (aldifornia l'urple lineh. lout is more

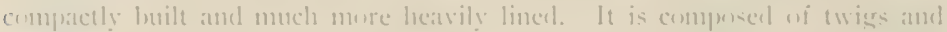

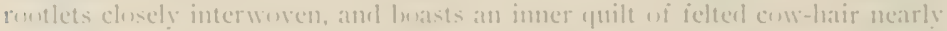
hali an inch in thichness. 'lle female ('russhill exhibits a singular devotion

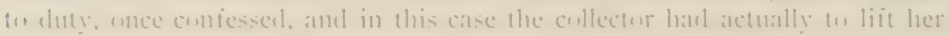
from the exgs in ureler that he might examine them.

No. 26.

\section{WHITE-WINGED CROSSBILL.}

1. (1) 1. An 522. Loxia leucoptera (imel.

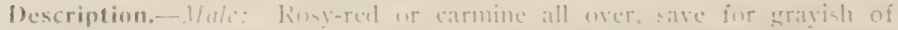

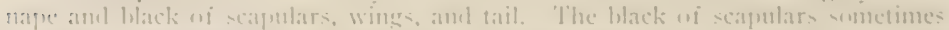
meet on lower hack. Two censpiemons white wing-bars are formed he the tips

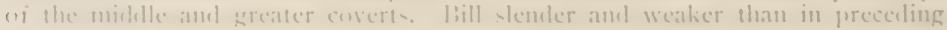


species. Female and young: Light olive-yellow, ochraceons, or even pale orange over gray, clearer on rump), duller on throat and belly; most of the feathers with dusky centers, funer on crown and throat, broader on back and breast; wings and tail as in male, but fuscons rather than black; feather-edgings olivaccous. Very variable. Lengtl $6.00-6.50$ ( $152.4-165.1)$; wing 3.50 (88.9); tail 2.25 $(57.2)$; bill .67 (I7).

Recognition Marks.-Sparrow size; crossed bill; consuicuons white wingbars of both sexes.

Nesting. - Nest has not yet been taken in Washington but bird undoubtedly breeds here. "Nest: of twigs and strips of birch-bark, covered exteriorly with moss (L'snca) and lined with soft moss and hair, on the fork of an evergreen, in deep forests. Egys: $3($ ?), pale blue, spotted and streaked near larger end with recklish brown and lilac, $80 \times .55$ (20.3 $\left.\times \mathrm{r}_{4}\right)$ " (Chamberlain). Scason: Fel).March.

General Range.-Northern parts of North Anerica and sonthern Greenland, soutl into the United States in winter. Resident in coniferous timber thru the entire northern tier of states and irregularly south in the mountains at least to Coloralo. Casual in western Europe.

Range in Washington.-Several records of occurrences in northern Cascade Nonntains. Doubtless regular and resident.

Authorities.-Dawson, Auk, Vol. XVII. ()ct, IgoI, p. 403. D².

Specimens.-(L. of II.) Prov. C. B.

'I'O 'l'ELL, the truth, no one hereabouts appears to know much about the White-winged Crossbill. It is presumed to be common in the Cascade dountains, lut I lawe only thrice encomntered it: once, May I5, I89 I, in the monntains of Yakima County; again, July 23. I900, on the slopes of IV right's l'eak near the head of Lake Chelan; and lastly, on the summit of Cascade l'ass, June 25, igo6. 'There are no other records. 'l'his species is quite as erratic as its more common cousin; ancl while it is, perhaps, more nearly confined to the mountains, it should be looked for wherever $C$. minor vecurs, and especially in flocks of the latter species.

Of the hird's occurrence in Alaska, where it is much more alumdant. Delson says": "It is more familiar than the Grosbeak [i. e., P'inicola enncleator alusconsis ], frequently coming low down among the smaller growth, and it is a common sight to see partics of them swinging about in every conceivable position from the twirs on the tops of the cottonwoosls or birch trees, where the birds are busily engaged in feeding upon the buds. They pay no lreed to a passing party of sleds, except, perhaps, that an incliviclual will fly down to some convenient bush, where he curinusly examines the strange procession, and, his curiosity satisfied or conlidence restored, back he groes (1) his companions and contimes feeding. When fired at ther ntter

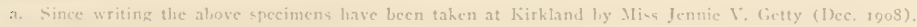

1). Keg. Xat'l Hist. Cinl. in Alasha, pp, 17\$, 175. 
chirps of alarm and call to each ofler with a hong, sweet mote, something simbilat to that of the (ioldlinch (Spinns tristis). They keep up a comstant cherping repetition wi this mote when feeding in parties, and if me ni their number is stut the others approach closer and cluser to the hunter, and graze with mingled cursusty and sympathy upun their fluttering companion."

ํo. 27.

\section{GRAY-CROWNED LEUCOSTICTE.}

A. (1. [. . No. 524. Leucosticte tephrocotis Swains.

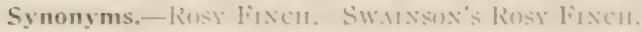

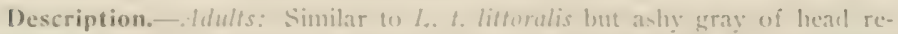
stricterl to sides of crows and occiput-in worn plumages lilack of crown pronduced hackwarel to meet hrown of hind neck. Seasumal changes as in suceceding. Size wi next.

Recognition Marks.-Sparrow size; warm brown plumage; aslyy gray not encroaching upon siles of heal ats distinguisheal from l.. t. lithoralis.

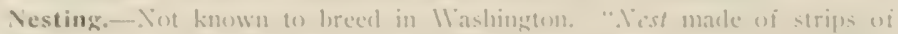
bark and grass, huilt in a fissure of a ruck at the side of at hunch of grass" (Recel). Eous: 4 or 5. white. Sioson: lane; one broud.

(ieneral Range.-Imperfectly mate out-probably discontinuous. Rejortesl

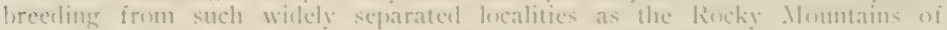

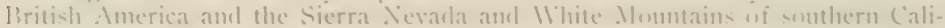
fornia: winters on the eastern slopes of the Rexkies and irregularly castward to western debrasta. Manitola, de. westwarel on Cascale and Sierra devala ranges (C'amp, llarvey, ()re. I'ullman, IIash. C'hilliwhack. Ii. C'.).

Range in Washington.-I'robably of regular oceurrence during migrations and in winter east of the Cascade Monntains only. inos.

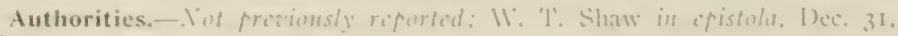

Specimens.-I'ullman.

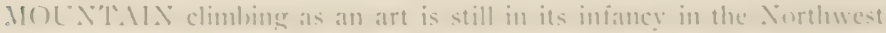
and altho the Monmtaineers and the Mazamats are attacking the situation vigerously we have yet much to learn of the wild life upene our IVashington

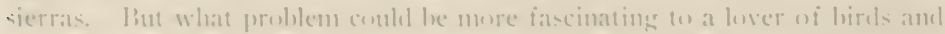

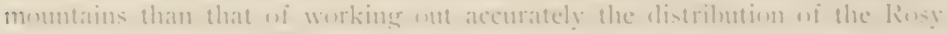

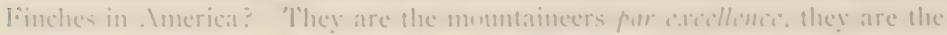
Jelusiles of the untaken citalels, and mut igmorance uf their ways will ere

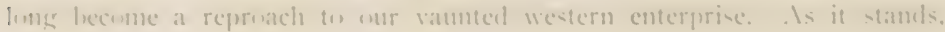


however, only scanty crumbs of information have cone to us concerning this most interesting and widely distributed race of Highlanders.

The Gray-crowned Leucosticte is considered the central figure of the genus, shading ${ }^{2}$, as it does, into $L$. atrata of the Bitterroots and $L$. australis of Colorado, into L. t. littoralis of southern British Columbia, WVashington and Oregon, and (perhaps thm littoralis) into grisconuclia of the Nlentians. 'This assumes for the species a center of distribution in the Rocky MIountains of British Columbia, Alberta and Saskatchewan where the hird is known to occur. And so because of the greater severity of the winters in its normal haunts this form is found to be the greatest wanderer of its group, being irequently driven in the fall far ont upon the central eastern plains or down the "inside passage" between the Rockies and Sierras.

It was in this fashion, probably, that a colony of this species became established in the southern Sierras of California, where it now maintains a vigorous existence separated, as we suppose, by at least a thousand miles from the parent stock in British Columbia.

\section{No. 28 .}

\section{HEPBURN'S LEUCOSTICTE.}

\section{A. O. U. No. 524a. Leucosticte tephrocotis littoralis (Baird).}

Synonyms.-Rosy Fixch. Herpury's Rosy Fixcir. Barrís Rosy Fixch.

Description.-Adult male in sumer: Forehead and fore-crown black: occiput, broadly; and sides of head, clear ashy gray, color sometimes encroaching on chin and throat; nasal plumules grayish white; remaining plumage in general chestnut, chocolate, or rich vandyke brown, sharply contrasting with ashy gray on hind-neck and sides of head, inclining to blackish on throat, streaked with disky. on back and with more or less admixture of dusky on feather tips, especially on wings and flanks; feathers of npper and under tail-coverts, rump and llanks broadly and distinctly tipped with pink (of variable shade); wings and tail blackish; lesser and middle coverts broadly tipperl with pink, the greater coverts. [primary coverts and part of the flight feathers elged with pink or light carmine: rectrices with more or less edging of pinkish gray or light brown; bill black; feet and legs black. Adult femule: of somewhat paler and duller coloration. Adults in winter: Feathers of hack and scaptulars exlged with light brown; pink elgings of wings, etc., paler, and body plumage, especially on breast, with more or less pale skirting; lill yellow with dusky tip) (this character is assumed as early as september). I,ength of adlult male: 6.15 ( I 56.2); wing 4.00 (IOI.6); tail 2.60 (66) ; bill .45 (11.4); tarsus . 75 (I0).

Recognition Marks.-Siparrow size; plumage warm brown with rosy skirtingrs; ashy gray on sides of heal as distinguished from $I_{\text {. }}$ tephrocotis.

a. Iiy "-hating" liere is nut meant sub-fecitic relatiunahis, altho this does nheain as regarding both

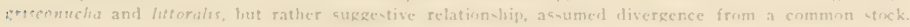




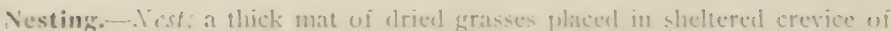

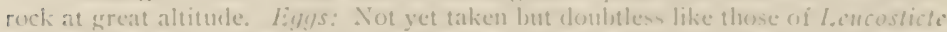

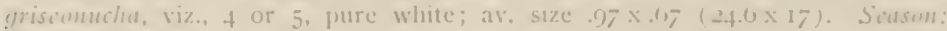
junc ; one lorиul.

General Range- - Summer haunts include the higher momtanin ranges of

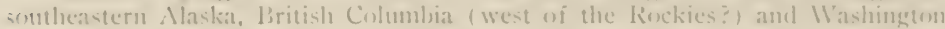
(gussibly ()rewon als well); " in winter south to . Vevada, Liah, and Colorato, andi east (u) castern hase of hecky Momntains (casually (o) Minnesutat), and aleng the l'acitic cosist to Kixliak, Sitka, l'atncouver Island, etc," (Ridgway).

Range in Washington.-Freeds thruent the higher Cascates (IVright:

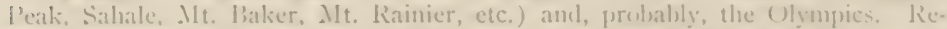
treats in winter to the lowlands, cliefly east of the Cascale. Mromtains.

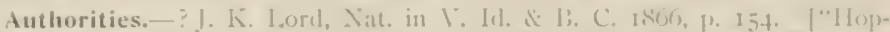
burn's (sic) rusy finch," lohnson, Rep. (iov. 11. 'T. 1884 (1885), 22.| Dawson. luk, $111,18(1), 1) 2,177,1.1 \%$

Specimens.-1'. I'rov. L. C.

1.IVlis there a mam so brutish that his heart dees not kindle when he sees Rainier lit up with the rudedy glow of the evenings sacrifice? li such there les he is an birel-hover.

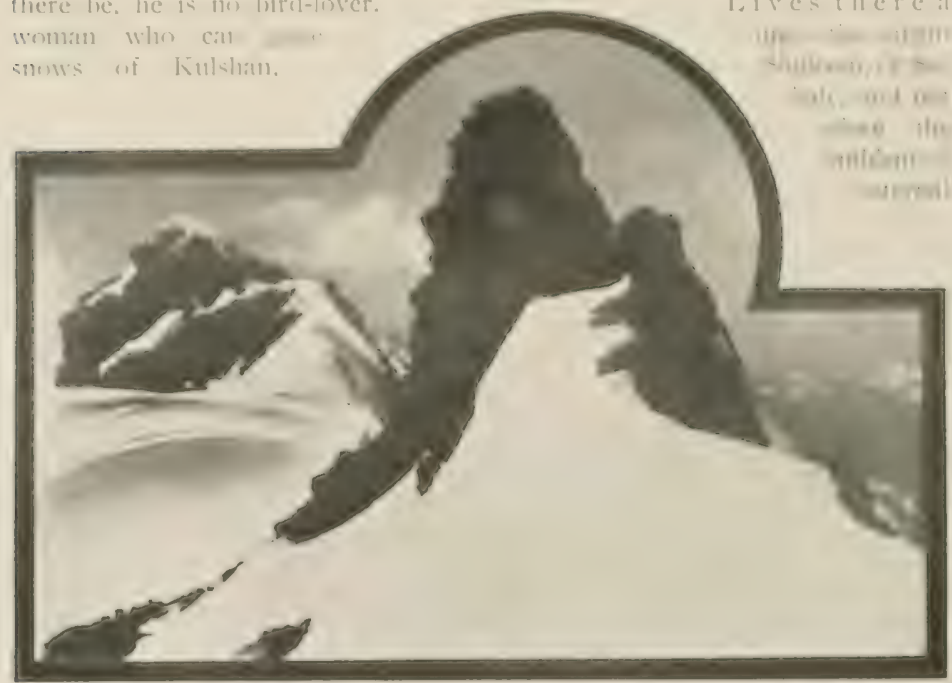

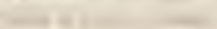


purity thereon displayed? If so, she will not appreciate the Lencosticte. 'This bircl is the vestal virgin of the snows, the attendant minister of Nature's loftiest altars, the guardian of the glacial sanctuaries.

One who loves the mountains camnot measure his praise nor bound his enthusiasm. Their sublimity bids him forget his limitations; and if one happens also to care for hirds, it is matter of small justice to laucl a bird whose devotion to the peaks appears as boundless as his own, besides knowine ncither aclmixture of caution nor limitation of opportunity. Tere is the patron saint of monntainecrs! He alone of all creatures is at lome on the heights, ancl he is not eren dependent upon the scanty vegetation which follows the retreating snows, since he is able to wrest a living from the verv glaciers. Abrsses do not appall him, nor do the tlower-strewn mearlows of the lesser heights alienate lis snow-centered affections.

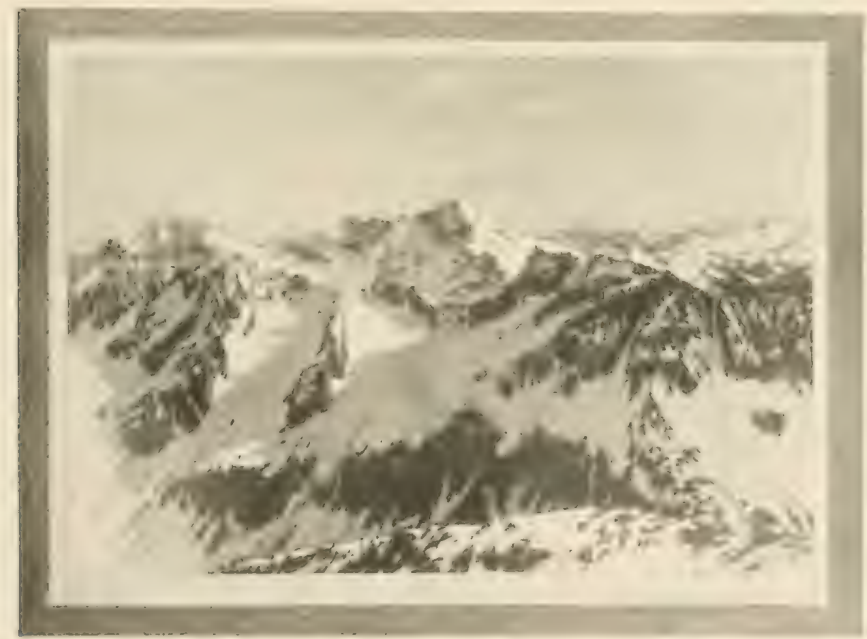

Faken in Cliclun County.

Photo by the Altien

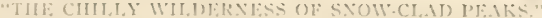

Looking out on the chilly wilderness of snow-clad peaks which confronts Lencosticte on an early day in June, one wonders what the bircl sees to justify the assumption of family cares. Save for a few dripping sonth exposures of inhospitalsle rock. there is nothing visible which affords promise of fond mmess it be the snow itself. Ancl when one sees a little company of the 
linches moving alsut iemurely upen the face of a cheppys snowelrift, pecking at the suriace lere and there, he hegins to harlore an uncamy suspicion that the hirds de eat snow. Closer examination, however, shows that the suriace of all smow-bunks, not ireshly covered, is sprinkled with insects, - midges, beetles, waspes, and the like-insects which the spring gales have swept up (1) uncongenial leeights and dropped, lenumbed or dead with cold. These battered waifs the I.eterstictes gather with untiring patience, and they are thus able to subsist as no other species can, up to the very summits.

The exgs of the llephurn lencosticte have not to our knowledge yet been taken. Mr. 1). Li. Brown, then of Glacier, found these birds sconping hollows under grass tussocks on the micldle slopes of Baker, alone timber line, on the 7 th of June, 1905. On the zoth of July, I900, l'rofessor Lynds Jones and myself found a thick-walled grass nest setted upon bare rock without protection, on the south slope of the aiguille of Wright's I'eak, at an elevation of some 9.000 feet, and within a hundred yards of the summit: this could hardly have belonged to any other species.

In July, 190\%, knowing that it was too late for eggs, I yet spent several days searching the precipitous wall which separates the upper Horseshoe Basin from the gracier which heads 'Thumber Creek. Adult hirds to the number of a dozen gleaned scraps from the dump of the Cascarle Mine louse: lut, altho each made off in business-like fashion when "loarlecl," the stretch of the wall was $(x)$ vast and its recesses $(x)$ mazy to permit of exact work in tracing. I therefore examined carefully but with difticulty several of the weathered fissures, or couluirs, which ran perpendicularly up the face of the cliff. Ilere, under cower of rocks which had Inlged in the throat of the hissure, or which had weathered out unevenly, old nests were foumbl, simple affairs of coiled grasses, and tom dilapidated for exact measurement. Firom une wi these sites a pebble snapperl from the finger must have fallen three humeleed feet before striking the glacier helow:

Nim and then a passing hirel, suspicions of my intent. stopped on some mojecting pesint of reck, to utter the sole note which denes duty for every momel, churlk or scththub, a somel comparable only to the concussion of a small taut rope un a thas-pole. Finally, near the top of the sabale cilacier.

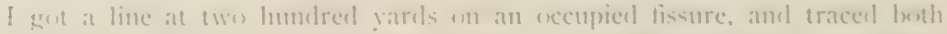

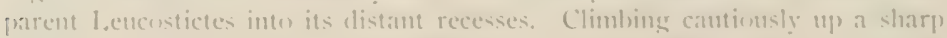

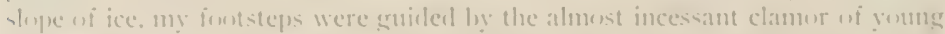
hirels. Arrived at the upper lip of the glacier. lemwever. I fomm that it stend away irum the reck-wall some fifteen feet, and that a chasm sume furty feet

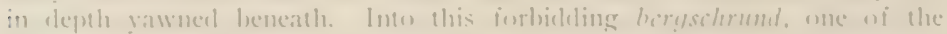

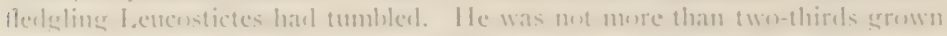
(July ISth) and down feathers still thuttered from his checks. Int he was a

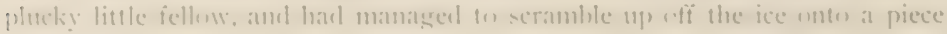


of flat rock which caught a bit of the atternoon sum. Here, to judge from his lusty yelping, there could be no doubt that his parents would notice him. altho they would be powerless to secure his further release until his wings were grown. A Carnegie medal hovered suggestively over the spot, I know; but pray, consider,-the rock wall was perpendicular and smooth as glass, the ice-wall I stood on was melercut. No; even philornithy has its limits!

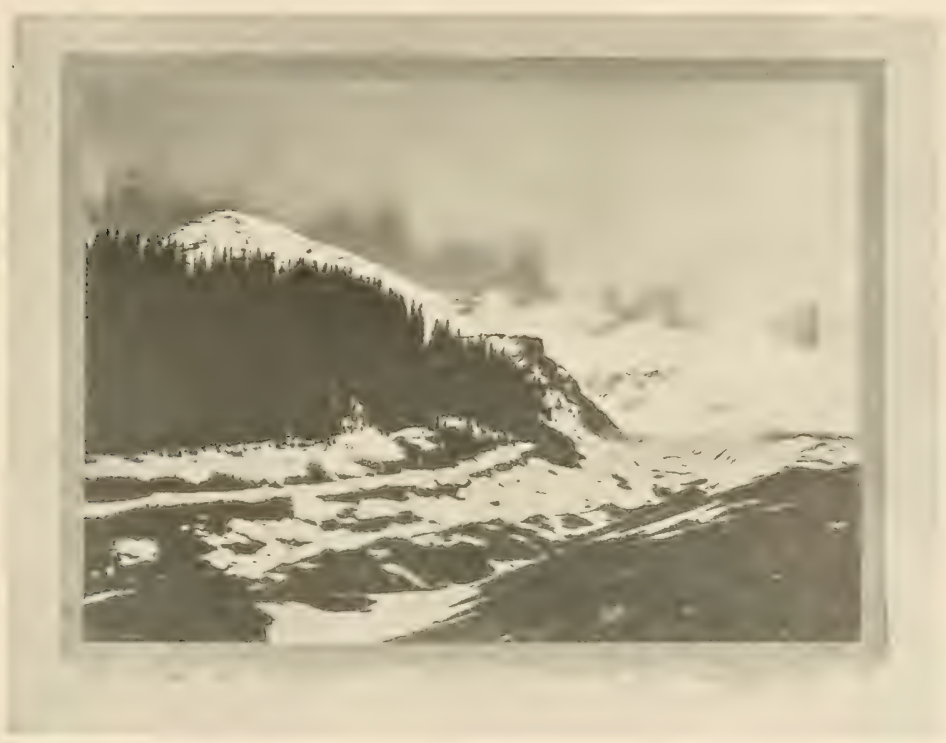

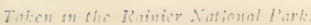

From e Plosegraph Copyrisht, 100s, by 11. I

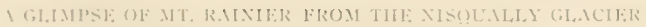

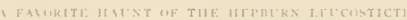

The nest containing the remaining youngsters was set well hack in a rock lissure, concealed by projections eighty feet abore the fallen first-born. and inacessible to man from ahove or helow. Ilith the possible exception of the IBlack Cloud Swifts (Cypsolndes niger borealis), who are reperted th share at thines these sume cliffs, it is saie to saty that the J.encostictes are the highest nesters on the continent. 
No. 29).

\section{REDPOLL.}

1. (). L. Xio. 524. Acanthis linaria (I.imm.).

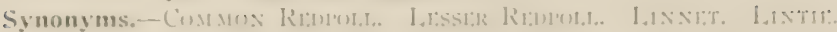

Description.- Whal male: Crown crimson; breant and shomleters criman

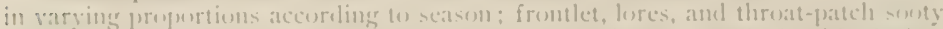

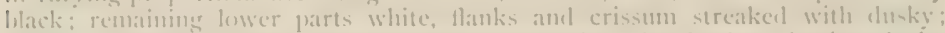
alnove, variugated dosky, flaxen-brown and whitish, the feathers having dusky enters and llaxen ederings ; rump dosky and white in streaks, tingerl with rony; wings and tail dosky with flaxen or whitish edgrings; two incon-picum wing-hare

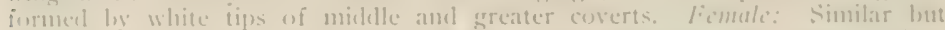
without red on romp and breast, the litter suftused with ludïy insteat: siles heavily streakerl with dusky. Immature: Like female but without crianem

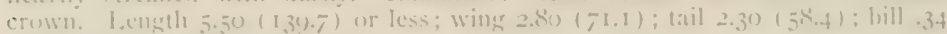
$(8.6)$ : elepth at hise $23(5.8)$.

Recognition Marks. - Warliler to Sparrow size: crimson crown-patoh in alults: net dusliy spot on breast.

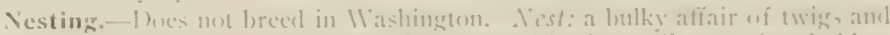

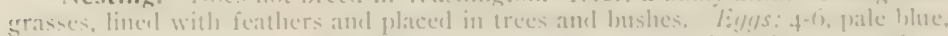

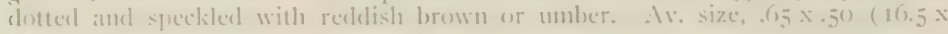
$: \cdot-$

General Range- - Vorthern portions nf northern hemisplere, smmah irregularly in winter, in North. Inerica on the Middle States, and southern () regents.

Range in Washington. - IV inter resident, alumbant on liast-side, infrepuent ne castail went of the citcearles.

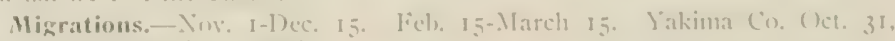

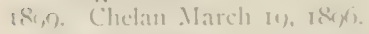

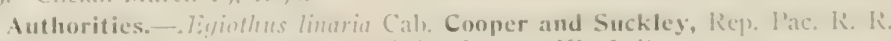

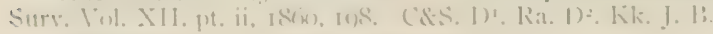

Specimens.-1 ('. of II:) ]'rom: I:. C. I'.

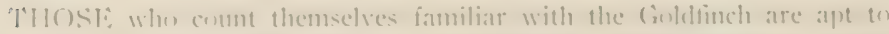

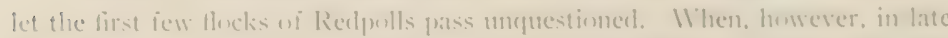

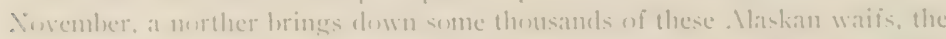
birel stulent is muserl to attention. 'llhe resemblance letween the two species is most striking in form anel appearance as well ats in latbit and mote. lint

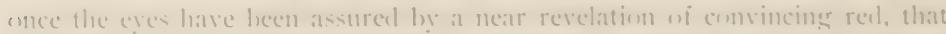

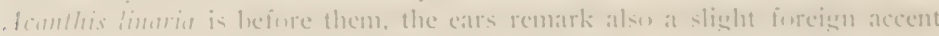
in the sivefte call amel in the rattling thieght motes.

liedpells sumumer abmulanely along the coasts wi . Maska, and alone the

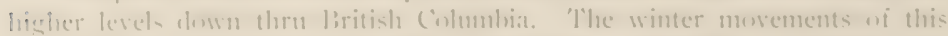

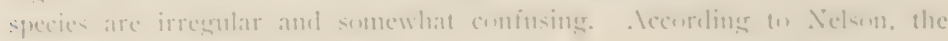


western residents retire into the interion of Alaska to winter, where they are able to withstand the fiercest cold. The interior birds retire largely to the south, and under the urgency of bad weather sweep into or thru eastern 1 ashington in immense numbers. 'There is also a small movement setting in a southwesterly direc-

tion, so that some birds winter

regularly on Vanconver Is-

land, and a few straggle thru

the Puget Sound country.

While with us, the Redpoll is nowise dependent upon the forests, but appears to seek the more open country by preference. It subsists chicfly upon sceds, gleaning them from the gromucl with much pleasant cliatter, or seeling them in their winter receptacles. Redpoll again proves kinslip) with Goldfinch by eating thistle seecls. and with Siskin by his extravagant fonchess for the alder catkin. Liedpoll's manner is very confiding; and wC are sure that he would not begrudge us a share of his winter viands, if $\mathrm{wc}$ cared for them. 'l'he author is no vecre-

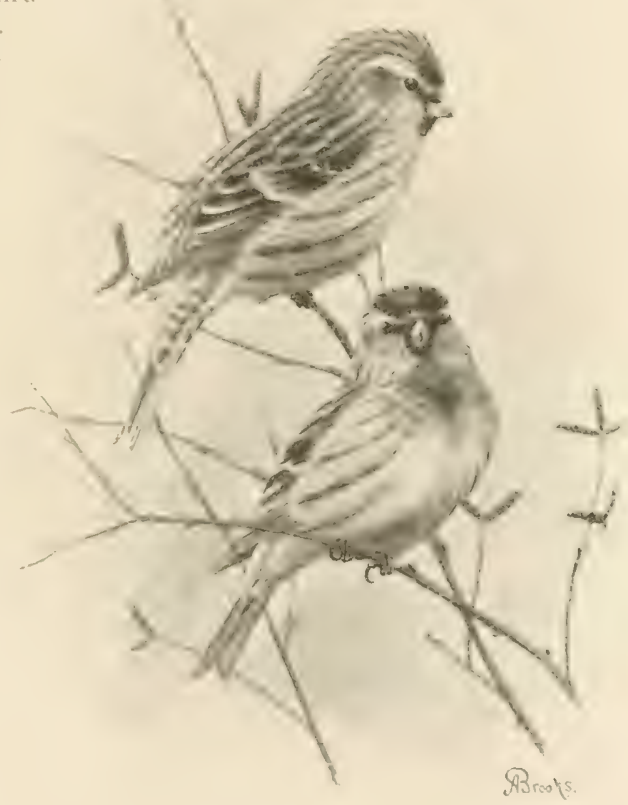

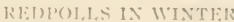
tarian, but he is lonum to admit that a "simple diet of grains, fruits and nuts" makes for contentment among the bircls, even at forty below zero.

As spring comes on, and the gentle hyperboreans prepare to return to their native lieather, we see the deep-dver crimson of full regalia on crown and hreast. liut during the actual breeding season, we are told by a com- 


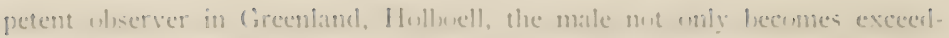

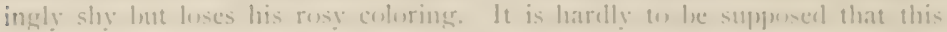
luss of collor is a protective measure, lunt rather that it is the result of the exhaustive labors incirlent to the senson. Cature, in that inthileling clime. camnot affurd to dress a lutsy worlinan in tine cluthes. It is moneworty in this enmectum, also, that caged Redpulls lose their rong tints never to regain thems.

No. 30.

\section{PINE SISKIN}

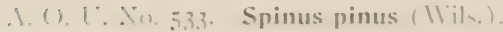

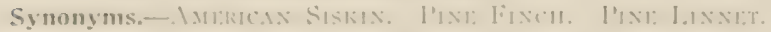

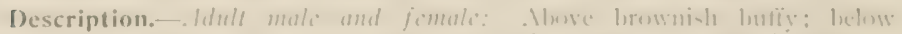
creamy-bulf and whitish: everswhere streakecl with duske or dark nlive-lorown:

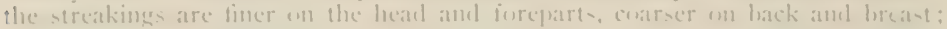

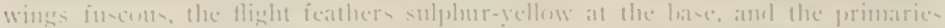

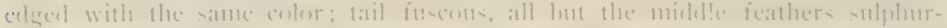

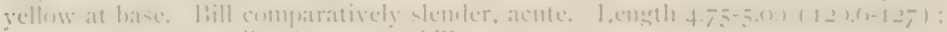

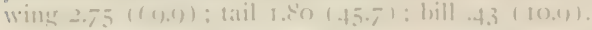

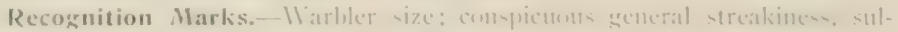
plus-yellow markings oi wings amel tail, mone noticealste in Hight.

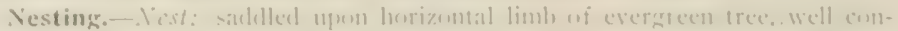

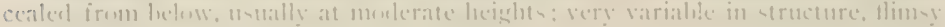

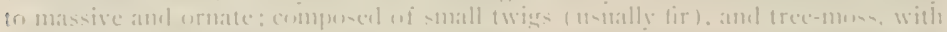

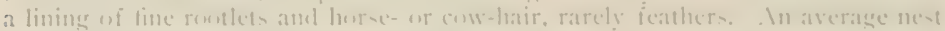

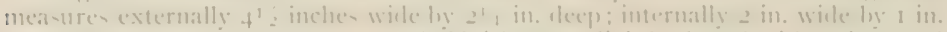

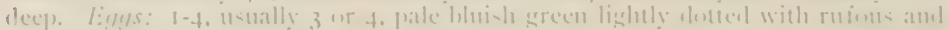

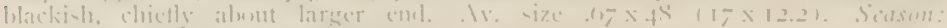
March-soptemlier, but most alumelant in . Ipril; ane hronel.

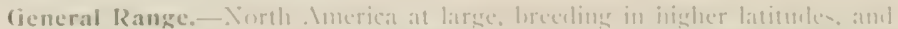

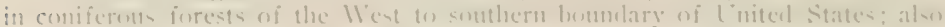

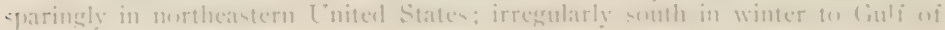
Mexicu

Range is Washington.-In smance coestensive with eversteen timber, but

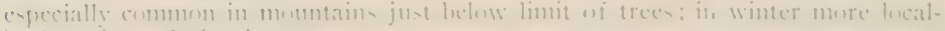
ized, or irresularly ah-ent.

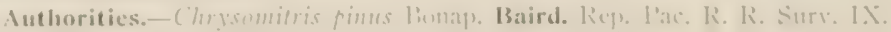

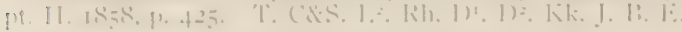

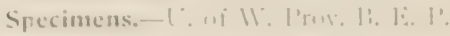

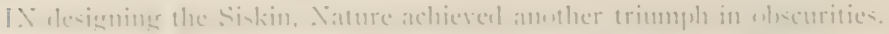

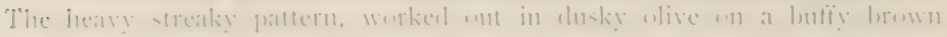




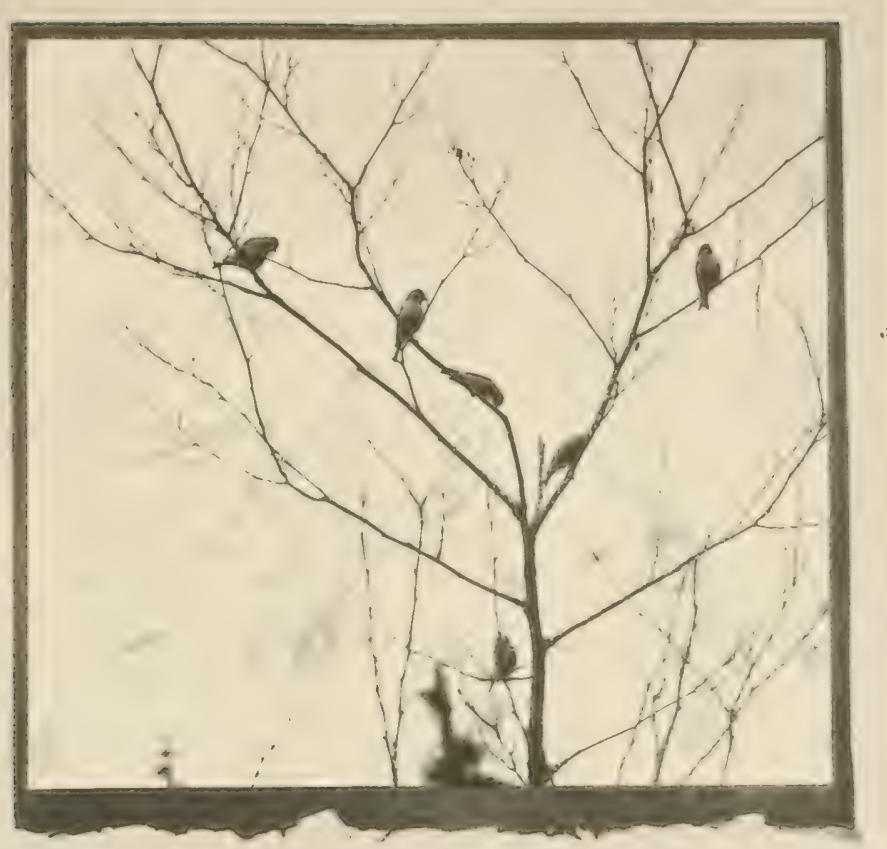

Tolien of iongmirc's springs.

From a Photograph Copyright, 1008, by IV. L. Dasuson.

SIX J.ITTI,E: SISKINS

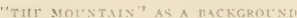

hase, prepares the bird for self-effacement in any enviromment: while the sulphur-colnred water-mark of the outspread wings barely relecms its owner from sheer olblivinn. This remark applies, however, only to plumage. In behavior the siskin is anvthing but a forgettalole bircl-person

Whatever be the time of year. Siskins roan about in happy, rollicking bands, comprising from a seore to several hundred individuals. They move with energy in the communal flight. while their incessant clange of relative positions in flock suggests those intramolecular vibrations of matter, which 


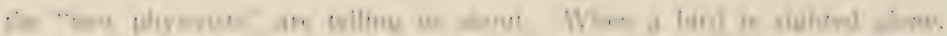

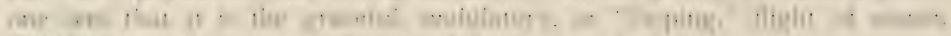

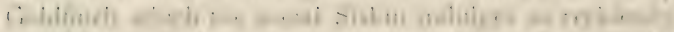

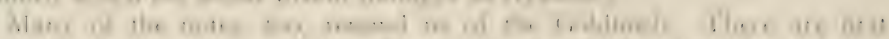

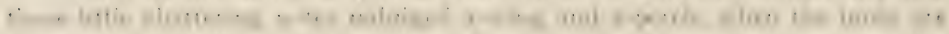

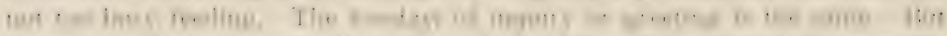

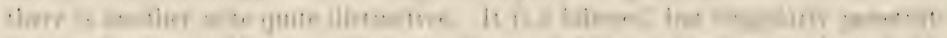

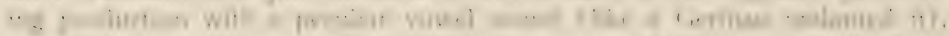

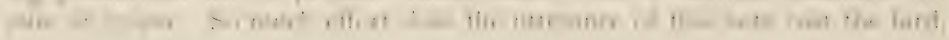

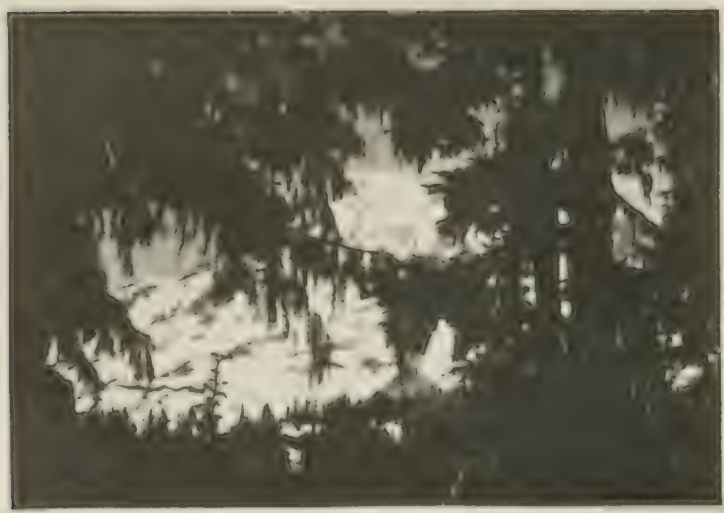

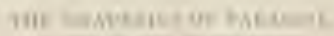

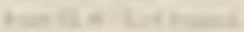

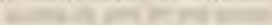

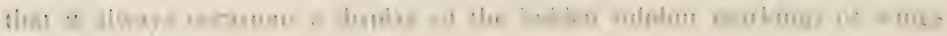
an: 1 in:

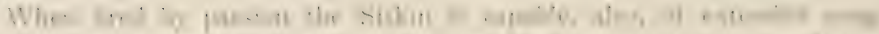

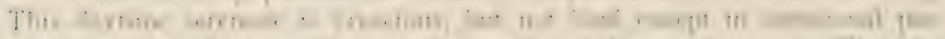

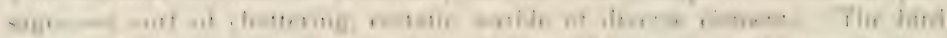

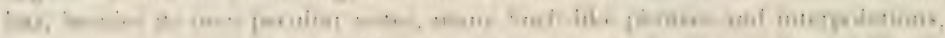

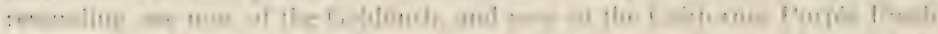

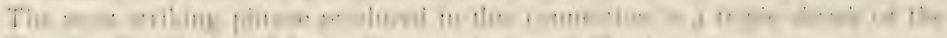

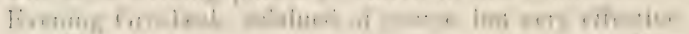

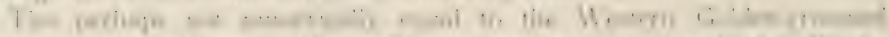

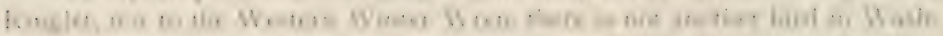

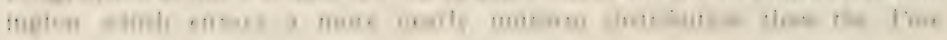


Siskin. Its breeding range coincicles with the distribution of evergreen timber; its feeding forays include all alder trees; and roving bands are likely to turn up anywhere in eastern Washington, if there is shrubbery. larger or greener than sage-brush at hand.

Much of Siskin's food is olntained mpon the ground. City lawns are favorite places of resort; these birds, together with California P'urple Finches, appearing to derive more bencfit from grass plots, whether as granaries or insectaria, than does any other species. 'I'hey share also with Crosshills a strong interest in the products of fir trees, whether in cone or leaf. Their peculiar province, however, is the alder catkin, and the tiny white seeds obtained from this source are the staple supply of winter. Mr. Brown, of Glacier, has examined specimens in which the crops were distended by these seeds exclusively. While the olserver is ogling, it may be an overmodest 'l'ownsend Sparrow; a flock of Pine Siskins will charge incontinently. into the alders above his very head. With many zer's and zeems they fall to work upon the stublorn catkins, poking, twisting, prying, standing on their heads if need he, to dig out the dainty dole. Now and then, withont any apparent reason, one detachment will suddenly desert its claim and settle upon another, precisely similar, a few feet away; while its place wil? be taken, as likely as not, by a new band, charging the tree like a volley of spent shot.

Vesting time with the Siskin extends from March to September, and the parental instinct appears in the light of an individual seizure, or decimating epiclemic, rather than as an orderly taking up of life's duties. Smitten couples drop out from time to time from the communal groups, and set up temporary establishments of their own; but there is never any let-up in the social whirl on the part of those who are left; and a roistering company of care-free maids and bachelors on fete may storm the very tree in which the first lullabies are being crooned by a hapless sister. Once in a while congenial gromps agree to retire together, and a single tree or a clump of neighbors may loast a half-a-clozen nests; tho which is which and what is whose one cannot always tell, for the same intimacy which suggested simultaneons marriage. allows an almost unsecmly interest in the private affairs of a neighbor.

Once embarked mpon the sea of matrimony, the female is a very cletermined sitter, and the male is not inattentive. In exanining the nest of a sitting bird one may expect the mother to cover her eggs at a foot's remore. without so much as by-your-leave.

'The nest, in our experience, is invariably built in an evergreen tree, usually a Douglas spruce (Pscudotsuga mucronata), and is commonly saddled upon a horizontal or slightly ascending limb at some distance from the tree trunk. Viewed from below; it appears merely as an accumulation of material at the base of divergent twigs, where moss and waste is wont to gather. 


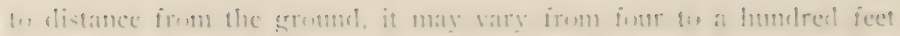

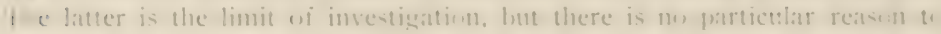

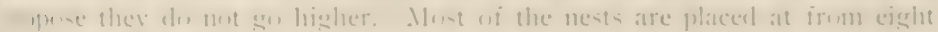
tavents acet up

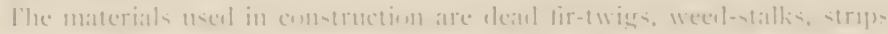

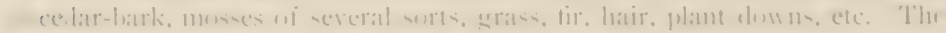

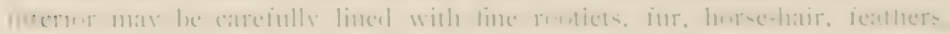

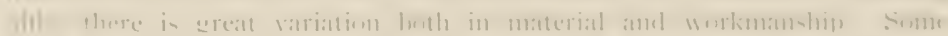

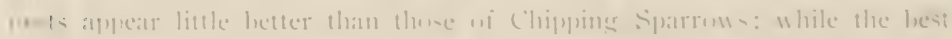

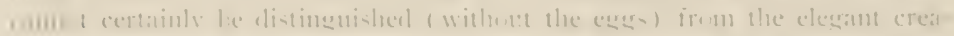

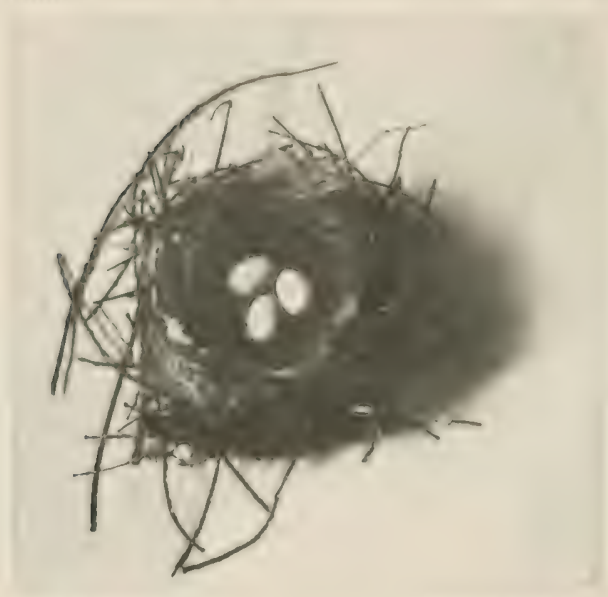

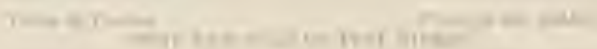

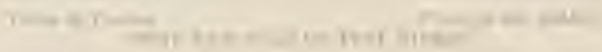

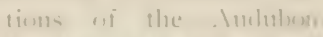

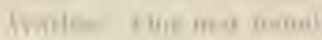
i) yoven= I. in ilis. $+W_{1}, \ldots+1$.

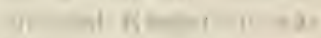

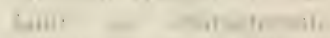
It lir - $\operatorname{limi}$

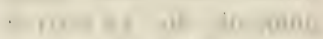

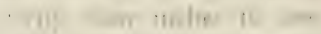
a. I f. w it, . im

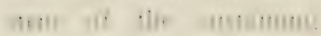

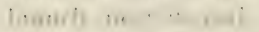

The , ifle

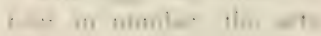
If une ine! wh nt ine

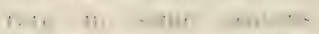

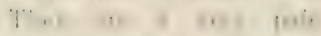

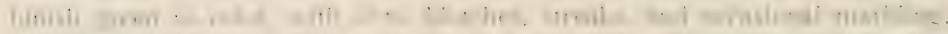

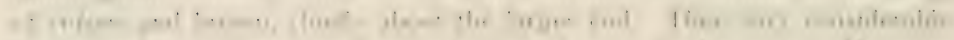

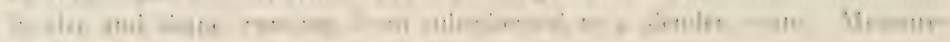

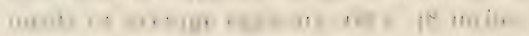

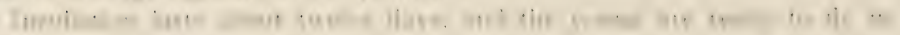

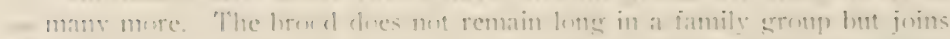

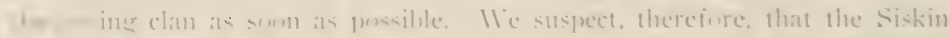

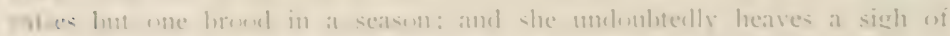

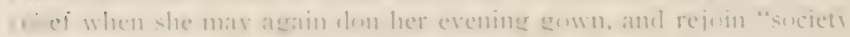


No. 31 .

\title{
IVESTERN GOLDFINCH.
}

\author{
1. O. U. No. 529a. Astragalinus tristis pallidus (Mearns). \\ Synonyms.-I'Ale Goldinch. "WhL CANARY:" "Summer Yellow- \\ nIRD," 'T'HISTT,E-BIRD,
}

Description.-- Adult male in summer: General plumage clear lemon or canary yellow; crown patch, including forchead and lores, black; wings black, varied by white of middle and lesser coverts, tips of greater coverts and edges oi seconclaries; tail black, each feather with white spot on inner web; tail coverts broadly tipped with white: bill-orange, tipeed with black; feet and legs light brown; iriles brown. Adult female in summer: Alove grayish brown or olivaceous; wings and tail dusky rather than black, with white markings rather broader than in male; below whitish with buffy or yellow suffusion brightest on throat and sides. Adult male in sinter: Like adult female but brighter by virtue of contrasting black of wing and tail; white markings more extended than in smmmer. licmale in winter: not so yellow as in summer, grayer and browner with more extensive white. Ioung: Like winter adults but browner, no clear white anywhere, cimnanomeus instead. Length of adult male: (skins) 4.7I (120); wing 2.95 (75); tail 1.97 (50); bill .4I (10.4); tarsuls .55 (I 4.I).

Recognition Marks.- IIarbler size; black and yellow contrasting, witl conical bill, distinctive; undulating flight; canary-like notes. liceds on thistle seed as does also Spinus pinus, a closely related but much less landsome species.

Nesting.-Nest: A beautiful compact structure of vegetable tihers, "hemp," grasses, etc., lined with regetable cotton or thistle-clown, and placed at varying heights in trees or bushes, usually in upright crotches. Eggs: 3-6, pale bluish white, unspotted. Av. size, $.65 \times .52$ (I $) .5 \times 13.2$ ). Scason: July and August; are brood.

General Range-- IVestern Lnited States, except the Pacific coast district, north to Litish Columbia and Manitoba, south to northern and eastern Mexico.

Range in Washington.-East-sicle, not common resident in lialf-open situations and along streans; resident but roving in winter.

Authorities.-Chrl'somitris tristis, Brewster, B. N. O. C. VII. Oct. 1882,

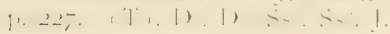

Specimens.-P'. Prov. C.

"IIANI)SOME is that handsome does," we are told, but the Goldfinch fulfils both conditions in the proper sense, and does not require the doubtful apology of the proverb, which was eviclently derised for plain folk. One is at a loss to decirle whether Vature awarded the Goldfincli his suit of fine clothes in recognition of his clatutless cheer or whether he is only happy because of his panoply of jet and gold. At any rate he is the birel of sunshine the year around, happy, careless, free. Rollicking companies of them rove the comutry-side. now searching the heads of the last year's mullein 
stalks and enlivening their yuest with much pleasint chatter, now seattering in oberlience to some whimsical commanel and soming the atr with their

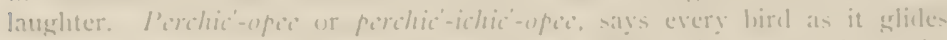
down each suecesive billow of its undulatiner tlight. Su emamererl are the

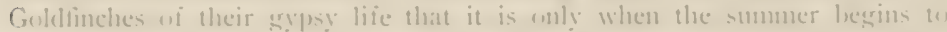
wane that they ate willing to nake particular chuice wi mates and nesting

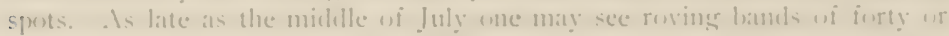
fifty individuals, lut loy the first of Angust they are usually settled to the

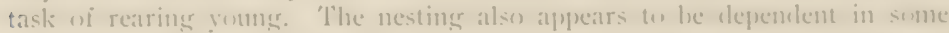
measure upun the thistle cropr. When the weeds are commen and the seasom forwarel, nesting may commence in June: but so long as thistle demon is scarce or wanting, the hirds seem lonth to hegin.

Dests are placed in the upright forks of variuns kinds of saplingse or even of erowing plants, in which latter calce the thistle, agatin, proses first

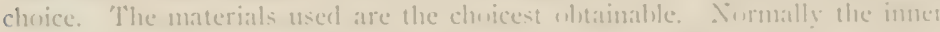

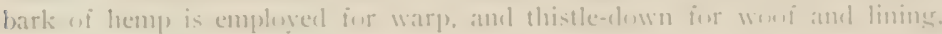
so that the whole structure lileatses (1) a claracteristic silver-graty. In the

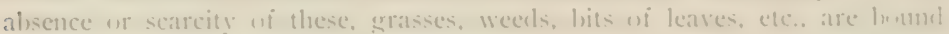
togrether with colvwels, and the whole felted with other sift planterbums.

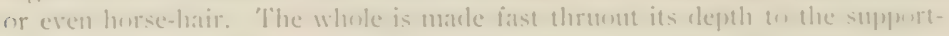
ing loranches, and forms one of the most clurable of summer's trephies.

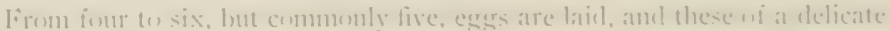
greenish halue. Fonteen dats are required for hatching: and from the time

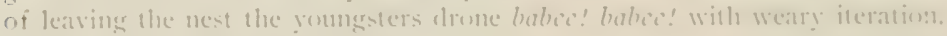
all thru the stifling summer day.

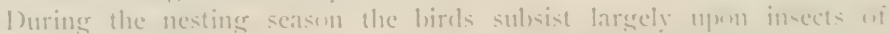
varions kimls, especially plant-lice, thes, and the smalley grastheppers: lut at other times they feed almost exclusively upon seeds. 'They are very hut of smuflower seerls, returning on a favorite heat day after day matil the con is harvesterl. Seerls of the lettuce, turnips, and other warten plants are levied upion freety where eccasion offers: lnt thistle seed is a staple article.

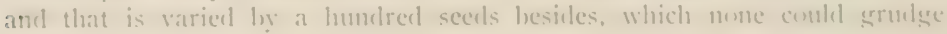
them.

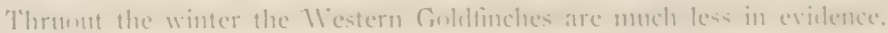
the majority of them having retired to the stuthland at thate seasom. 'l'hese which remain are somewhat altered on appearance: the wings amb tat show much pure white. and the yellow proper is mom confined to the throst and the sides of the leat and neek. Te is thus a lighter and a lorigher hiral than his enetern lowther. Put the western hirel has the sane merry metes and

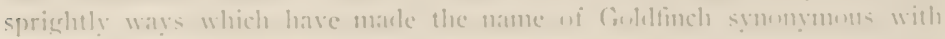
sminchine. 


\section{No. 32. \\ WILLOW GOLDFINCH.}

A. O. L. No. $529 \mathrm{~b}$. Astragalinus tristis salicamans (Grinnell).

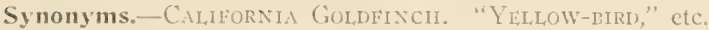

Description.-Similar to A.t. pallidus, but wings and tail shorter and colorattion very much larker; adult male in summer plumage has tinge of pale olivegreen on back, while winter adults and young are decidedly darker and browner than corresponding plumage of $A$. $t$. pallidus. Wing (of adult male) 2.75 ( 70 ); tail $1.73(44)$.

Recognition Marks.-As in preceding but decidedly darker and browner. especially in winter.

Nesting.-As in 1 . t. pallidus.

(ieneral Range.-Pacific coast district from Lower California (Cerros 1d.) north to British Columbia. Jas been taken at Okanagan Landing, B. C. (Brooks).

Range in Washington.-Not common resident on West-side only; cliefly in cultivated valleys.

Authorities. - Chrysomitris tristis Bon, Baird, Rep. Pac. R. R. Surv. IX. $1858,421,422$, part. C\&S. L 2 . Kb. Ra. Kk. R. E.

Specimens.-(U. of W.) Prov. B. E.

GOLDFINCHES are a bit of a rarity on Puget Somnd. Of contse we see them every season, and one may see a great deal of a particular troop. once its general range is ascertained; but, taken all in all, the bird is not common. Neither Cooper nor Suckley saw this Goldfinch, altho particularly: wondering at its absence. 'The clearing of the forests and the cultivation of the soil is conducive to its increase, however; and there is every reason to believe that we are seeing more of it year by year.

'There has been a warm cliscussion as to the subspecific valiclity of the Nillow Goldfunch, but those who see birds of this form in late winter or early spring cannot but be impressed with the striking brownness of its plumage. as well as by the more extensive white upon the wings, as compared with the eastern bird. Beyond its partiality for willow trees, it has no further distinguishing traits, unless, perhaps, it may be reckoned less tuneful, or noisy. 
No. 3.3 .

\section{CASSIN'S PURPLE IINCH.}

1. (). 1. . (in. 518, Carpodacus cassinii liaircl.

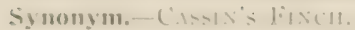

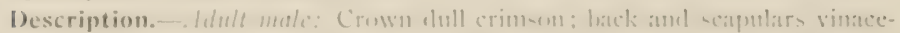

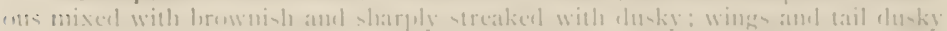

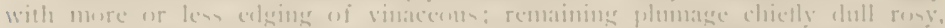

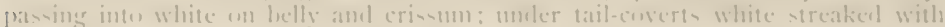

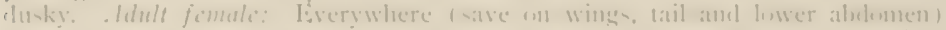

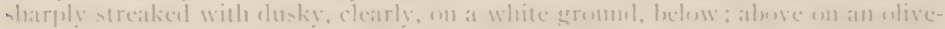

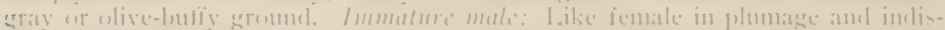

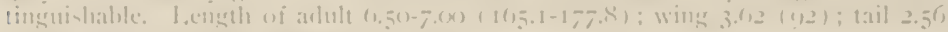

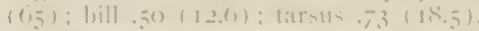

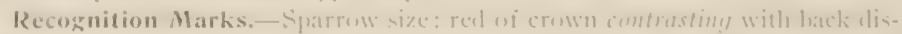

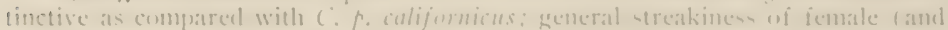
male in mere conmmon plumatges.

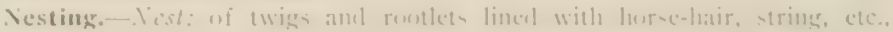

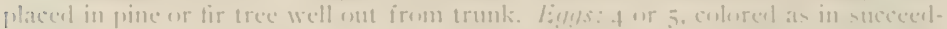

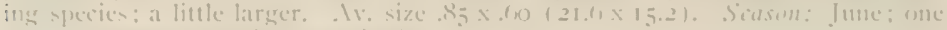
ur enor) bromels accorreling to altitucle.

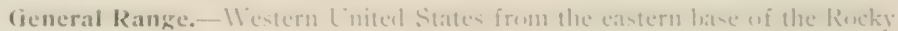

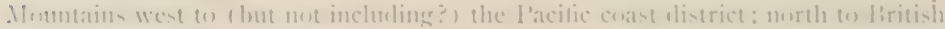

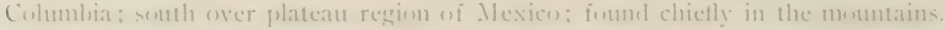

Range in Washington.- Ie least eocetensive with pine timber in ca-tern

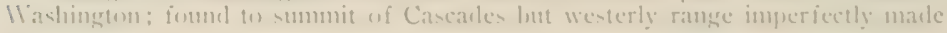
mit.

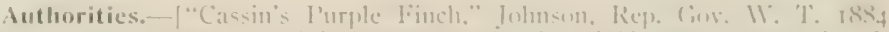

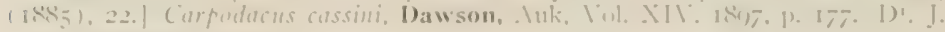

specimens.-I'row. (C.

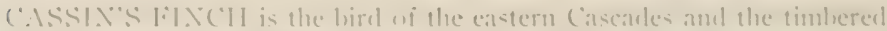

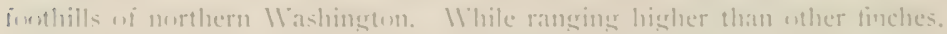
it slares with them an inclination to urlan life, and a full realization of the

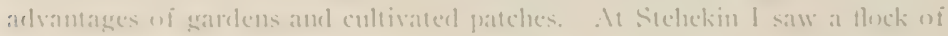
them erleaning crumbs as complacenty as spartens, in the yarel at the rear uf the luntel. It Chelan they hame she lenesene pine trees which still dot the slunes of the lake, seemingly regareling their smarled recesses as citatels where allene they may he safe from the termors of the open combery.

Is the bird-man lay sprawling in the eratedul shatew of ene wi these erime-entinels, munching at mumblay lunch, and remenstratine with l'rovidence

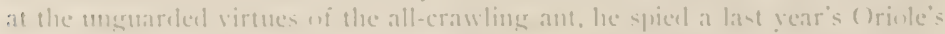
nest hameing just wer his heal. while an acommolating (assin fönch 
called his attention to this year's nest in process of construction, ly going over and helping herself to a beakful of material, which she pulled out of the structure by main force. She evened things up, however, (for the bircl-man) by immediately visiting her own nest, pitched on the upper side of a horizontal branch near the end.

This female Cassin was a wearisome bird. for she sat and twittered inanely, or coaxed. every minute her husband was in the tree. He, poor soul, was risibly annoyeci at her indolence, not to say her wantonness, and had as little to do with her as possible. However, he was a young fellow, without

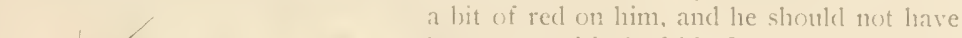
been over-critical of his first mate in honey-

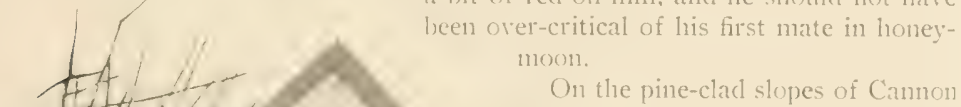
I Iill in Spokane, there is no more familiar sound in June than the wanton rote of the female

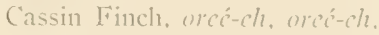
delivererl as often as not with quivering wings, and ummistakably inviting the attentions of the male. Perhaps it is fair to call this a love note. lut it is rlelivered with the simpering insistence of a spoiled chilcl.

The sight of a singing male in ligh plumage is memorable. He selects a position at the tip of a pine branch, or" perliaps nn a lounch of entues at the very (o) of the tree, and throws himself into the work. Ilis color, crimsom, not purple, is pure and clear upon the croun onle: elsewhere, ngon nape, shoulelers, and breast, it presents merely a suffusion of rel. A song hearel near Chelan was murch like that of a California I'urple linach in character, but less musical and more chatter ing. with the exception of one stronge note thrown in near the cluse. This ante was very like the characteristic squeal of the Fiening Grostreak. gimp, or thkimp. ont of all keeping with the remainder-mentestionalsly: borrowed.

The Cassin finch is quite ats stucessful as a mimic as his consin from 


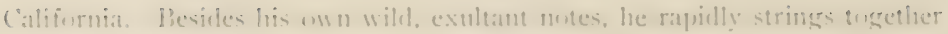

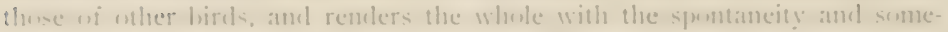
thing of the aceent of the lark Siparrom: Indeed, when I lirst heard one

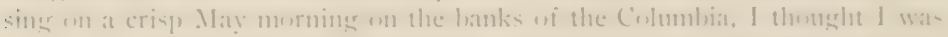

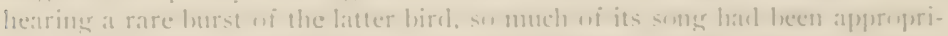

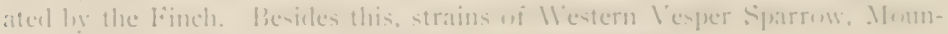
tain lihelsml. and I endianal l'anager were recongnized.

\section{CAIIFORNIA PURPLE FINCH.}

No. 3.

1. (1) L. Ne. 517a. Carpodacus purpureus californicus laairl.

Description.-- Idult male: (ieneral buly plumage rich crimson or reng reel.

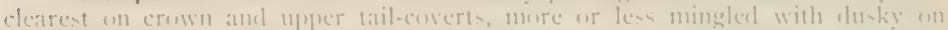

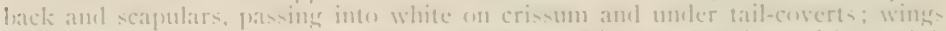

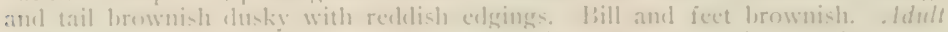
female: Almoe olive dusky in streaks, with edging or ghoss of hrighter olivaceons: mulerparts whiti-h, everywhere, save on midelle abufonen, crissum and muler tailerserts, streaked with olive dusky, fincly on throat, broblly on breast and siles, shaling into pattern of upperparts on siles of head, neck and chest. Immature

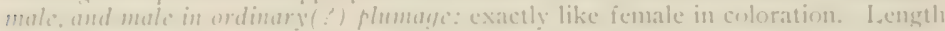

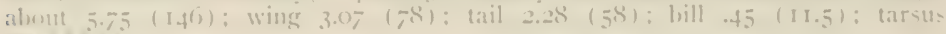
$\therefore$, wh

Recognition Marks. - "Warbler size" but sturelier, an ummistakable sparrow: rus coloration of male dintinctive (without crossed mamelibles) lout streaky pattern offenest seen. Distingtishable from the I'ine Siskin (Spinus pinus) by larger -ize, mere serlate ways and alrence of sulphury wing-and tail-markings.

Vesting.-. lest: well hoult, of lir twies, heavily lined with green mos.

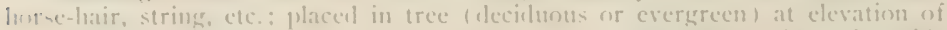
$5-40$ feet and usually at some distance from trunk: measures om-inle 5 in. wide

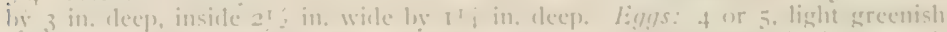
lilue, spotted and streaked with violacenus amel black, chictly almot the larger enel.

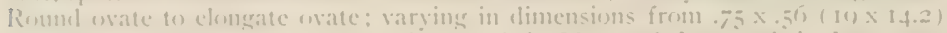

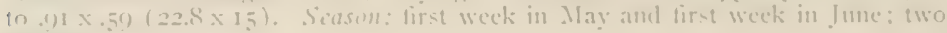
liringils.

General Ranke.- T'acific coast district from snuthern (ablifornia nerth to

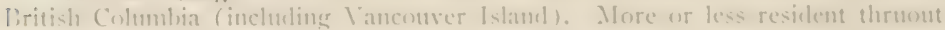
range hut drifts (casually?) to sontheastwared in Arizona during migralions.

Range in Washingen.-Went-vile, chichly at lower levels; enpecially partial in orvharils and cultivated cections. Irregularly resielent hut mumbers angmented in spring.

Authoritics.-Carpolacus califumions latird, Baird, Rep. I'nc. K. K. Surs.

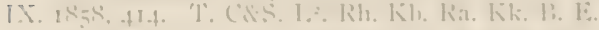

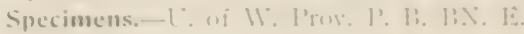


Of the streaked, streaky is this demure and inoffensive bird in the olivaceus plumage, in which we usually see him, and always see her. But the sharpmess and mannitude of the dusky streaks above and below confer a measure of clistinction, even when there is no trace of the adult crimsons, miscalled purple. 'This finch is a familiar object about the gardens, orchards, and parks in $1 /$ estern 11 ashington. It moves about for the most part silently, inspecting birds and flowers, sampling fruit, or gleaning seeds from the gromed in company with its own kind, or with the humbler and equally streaked Siskins. While not altogether dependent upon human hounty, it probably owes more to man than does any other native sjecies.

11 right's Park, in 'Tacoma, appears to lead the state by two weeks in the early budding of its flowering plants, and here Purple linches appear to the best advantage. In the luxuriant bushes of the red flowering currant (Ribes sungmincum) one may see them feeding cluring the last week of Narch. The linches pluck the flowers assiduously; and either eat the fleshy part at the base, the tender ovary, or else press out the nectar just above, or hoth. A fluwer is first plucked off whole and held in the bill, while the bird appears to smack its lips several times; then the crimson corolla is allowed to drop upon the ground, which thus becomes carpeted with rejected beaty. Like many related species, the California Finch is rather muary, so that one may study his belavior at close range.

Because the I'unple Finch is usually so unobtrusive, we are startled at the first ontburst of spring song. Nothing more spontaneous could be desired, and the mellow; musical yodelling of this bird is one of the choicest things allowed us on the WVest-sicle. 'The song is niclway between a trill and a carol, and has a wild quality which makes it very attractive. 'The notes are so limpicl and penetrating that one is sometimes deceived as to the distance of the singer, supposing him to be in a neighboring copse when, in truth, he occupies a distant far-tup). Checeloorcédooré doorcé dooréé dooré dooré doorec drecetoret may afford an iclea of the rolling, rollicking character of the song, but is, of course, alssurdly inadequate.

A master singer among the Purple Finches once entertained us from the top of a fir tree a hundred fect high. He was in the dull plumage, that is, without red; and altho he sang briskly at intervals we were not prepared for any unusual exhibition of vocal powers on his part. It was a long time, therefore, before we put the ery of a distant Steller Jay uy to him. Our strppicions once aroused, howerer, we canght not only the Steller Jay cry. ummistakalsly, lut also half a dozen others in swift and dainty succession, atfer the ustual l'urple finch prelude. I clearly recognized nutes of the Flicker, Steller Jay, Cancory, American Crossbill, and Seattle Wren. These imitative efforts varied in correctness ni execution, and came to 11 s with the 
distance of the uriginal singer plus that wi the lineh, so that the restile was mot a litele confusing, the very delighteul when explatined.

During courtship this binch will execute an aterial somgr-tance, comsisting wi sumlry jerks and crazy antics, juterspersed with a menlley wi eestatic motes : at the conclusion of which he will make a sugeretive dive at lis fianced when meanwhile has leen poking iun at him.

for some reason nests have leen exceelingly barel an find. Mamy lirds are always pottering athent with ne apparent concern for nesting time, and

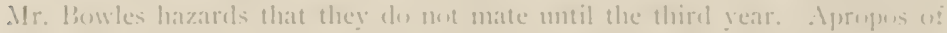
this, one remarks the scarcity of highly plumaterel males at all seasons. I have gone six monels at a time, where linches were mot unemmum, withum secing a single red hird. In fact, I never fumbl the latter common execpt in the vicinity wi lacuma.

Cests are placed, preferably, near water, in evergreen or decielumes trees.

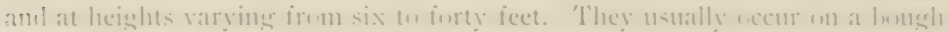

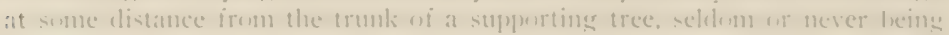

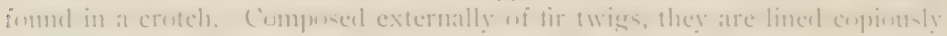

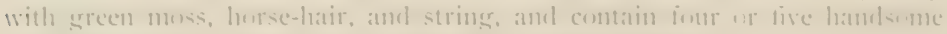

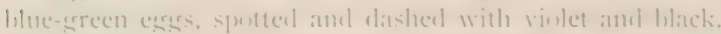

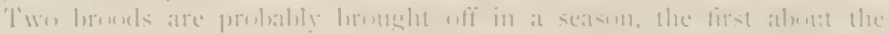

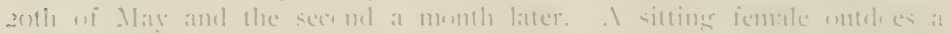

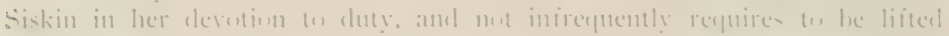

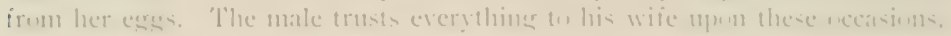

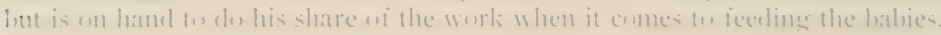

Nin. 35.

\section{ENGLISH SPARROW. \\ [WTrumeren, Passer domesticus (I.imn.).}

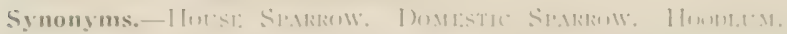

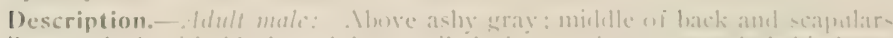

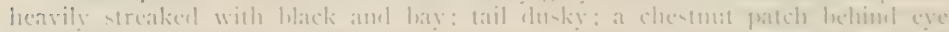

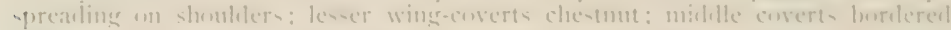

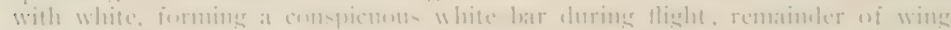

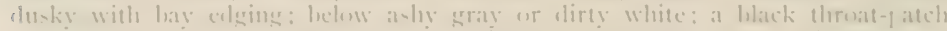

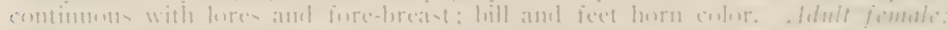

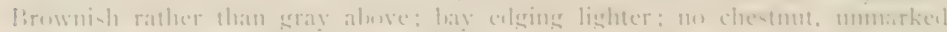

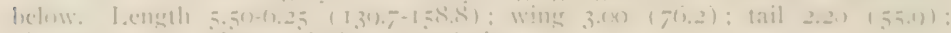
bill .51) (12.7). Sieses if alumt equal size.

Recognition Marks.-"Sparrow -ize," hack throat amel hreast wi rale:

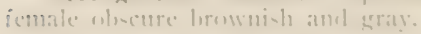

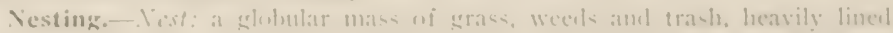

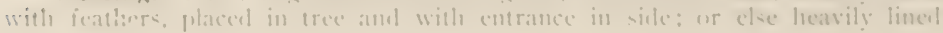


cavity anywhere. Holes in trees and electric lamps are alike favored. Liggs: $4-7$, whitish, heavily dotted and speckled with olive-brown or dinll black. 'The markings often gather about the larger end ; sometimes they entirely obscure the ground color. Av. size, $.86 \times .62$ (21.8 x 15.8). Season: March-September; several broods.

General Range. - "Nearly the whole of Litrope, but replaced in Italy by $P$. italice, extending eastward to Persia and Central Asia, India, and Ceylon" (Sharpe). "Introduced and naturalized in America, Australia, New Zealand, etc." (Clapman).

Range in Washington,- Is yet chiefly confined to larger cities and railroad towns, but spreading locally in farming sections.

Authorities.-Rathbun, Atk, Vol. XIX. Apr. 1902, p. I 40. Ra, Kk. B. Ë.

Specimens.-B. C.

IIH.LT a piece of mischief is the Sparrow! how depraved in instinct! in presence how unwelcone! in habit how unclean! in voice low repulsive! in combat how moblike and despicalle! in courtship how wanton and contemptible! in increase how linitless and menacing! the pest of the farmer! the plague of the city! the bane of the bird-worly! the despair of the philanthropist! the thrifty and insolent beneficiary of misguided sentiment! the lawless and defiant object of impotent hostility too late aroused! Out nipon thee, thou shapeles;, senseless, heartless, misbegotten tyrant! thou tedious and infunite alien! thou myriad cuckoo, who dost by thy consuming presence bereave us daily of a million dearer children! Out upon thee, and we the day!

IVithout question the most deplorable event in the history of American ornithology was the introduction of the English Sparrow. 'The extinction of the Great Ank, the passing of the IVild Pigen and the Turkey,-sad as these are, they are trifles compared to the wholesale reduction of our smaller birds, which is due to the invasion of this wretched foreigner. To be sure he was invited to come, but the offense is all the more rank because it was partly human. His introduction was effected in part by people who ought to have known better, and would, doubtless, if the science of ornithology had reached its present status as long ago as the early lifties. 'The maintenance and prodigrinus increase of the pest is still due in a measure to the imbecile sentimentality of people who build bird-houses and throw out crumbs for "the dear little birdies," and then care nothing whether lionest birds or scalanags get them. Such people helong to the same class as those who (rop) kittens on their neighbors' donr-steps because they wouldn't have the heart to kill them themselves, you know.

The increase of this bircl in the United States is, to a lover of hirds. 


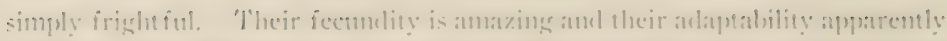
limitless. Mr. Marruws, in at special report prepared under the direction of

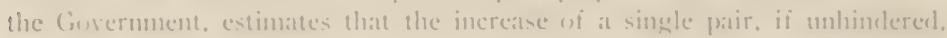

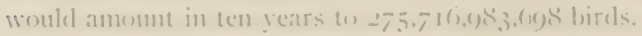

As to its ranger. We toste that the subjugation of the listst hats homg leen acemplisheel, and that the conduest of the llest is suceceelinger rapidly. It is not pusible te tell precisely when the first Sparrows arrivenl in llashingten,

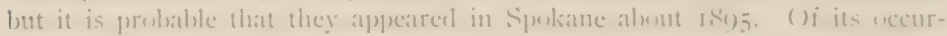

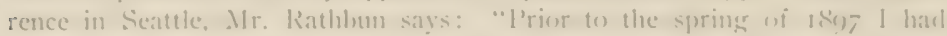
never seen this species in seattle. but in lune of that vear I nuterl at pair.

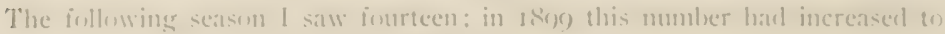
about seventy, associating in smatl flucks."

The favorite means of discemination hats leen the hux car, and especially the grain car. 'Tle sparrows, leiner essentially grain and seel eaters, irepuent the grain cars as they stand in the railenal yards, and are oceasionally imprisoned in them. lupeful stowaways and "gentlemen of fortune." () ne this account, alsis, the larger cities and ratilnat towns are first colonized, and at this time of writing (Jan.. Igos') the birds are practically confined to them, Tacoma havins an especial motoriety in this respect lecanse of its immense grain-shipping interests.

Difficult ats it may seem, it is true that the binglish sparrow arlopts the policy of Crial, Heep ujum lirst entering a town. Witle all the unctunsts humility of a hamel of Jormon apostles, the newermers talk soltly, walk

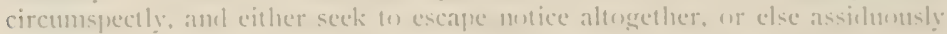

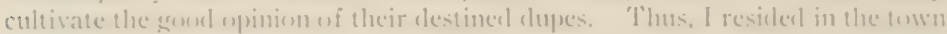

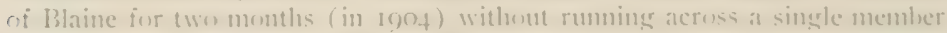
of the puncer land of nine Enclish Sparrows, althe I was assured on gernel atutherity that the hires had been there for at least two years previons.

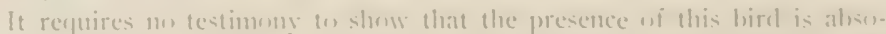

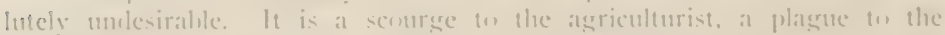
architect. and the atomerl and determined enemy af all other hirels. Its nests are mot unly unsighty hut unsanitary, and the mandlin racket wi their moners

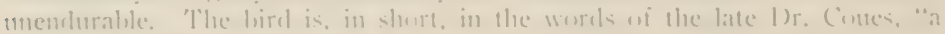

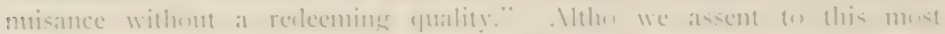

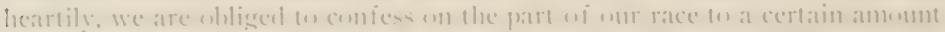

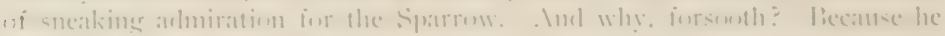

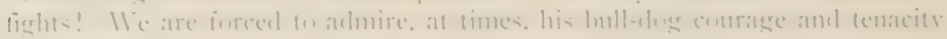

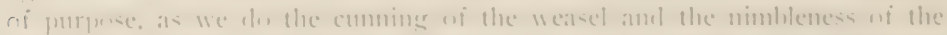

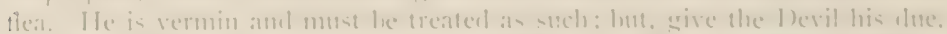

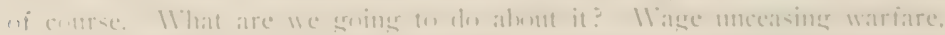

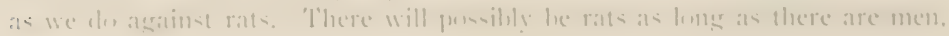


but a bubonic plague scare operates very effectually to reduce their numbers. No doubt there will be English Sparrows in cities as long as there are brickbats, but a clear recognition of their detestalle qualities should lead every sensible person to deny them victuals and shelter. 'The House Sparrow is no longer exterminable, but he may be, must be kept within bomels.

No. 36 .

\section{SNOWFLAKE.}

\section{A. O. U. To. 534. Plectrophenax nivalis (Linn.)}

\section{Synonym.-Sxow Buxisc.}

Description,-Adult male in summer: Pure white save for bill, feet, middle of back, scaptulars, bastard wing, the end half of primaries and inner secondaries. and the milclle tail-feathers, which are black. Female in summer: Similar, but upperparts streaked all over with black, and the black wings largely replaced by fuscons. Adults in winter: Entire upperparts overcast with browns-rusty: or seal brown-clear on crown, grayish and mottled with dusky centers of feathers on back, scapulars, etc. ; also rusty ear-patches, and a rusty collar, with faint rusty wash on sides. The black of wing and tail-feathers is less pure (fuscous in the female) and edged with white or tawny. Length 6.50-7.00 (165.1-177.8); wing 4.12 (10.4.6); tail 2.54 (6.4.5); bill .40 (10.2).

Recognition Marks.-Sparrow size; conspictuonsly and uniquely white, with blacks and browns above.

Nesting.-Does not breed in Washington. "Nest: on the gronnd in the sphagnum and tussocks of Arctic regions, of a great quantity of grass and moss, lined profusely with feathers. Liggs: $4-6$, very variable in size and color, about $.00 \times .65$ (22.) $\times$ I6.5), white or whitish, speckled, veined, blotched, and marbled with deep browns and nentral tints" (Cones.).

General Range.- "Northern parts of the northern lemisphere, breeling in the Arctic regions; in North America south in winter into the northern United States, irregularly to Georgia, sonthern Illinois, Kansas and Oregon."

Range in Washington.-East-side, of regular occurrence in open country: casual west of the Cascarles. County).

Migrations.-Xov. 4, I8g9 (Yakima Connty). March 17. 180 6 (Okanogan

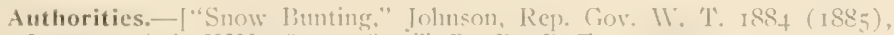

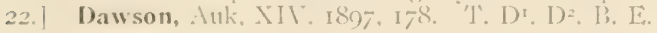

Specimens.-( L. of IV.) I'ros: l3. E.. I'.

I Wibl, remember my first meetine with this prince of storm waifs. the Snowflake. It was in Chelan County on a chilly day in J)ecember. A clistant-iaring. feathered stranger harl tempted me acrosis a lifeals pasture. when all at ince a fluttering snowelrift, enntrary to Natures wont, rose from 


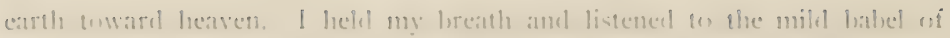

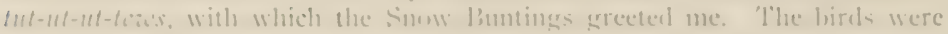
loath to leave the place, and lowered indecisively while the hirel-man dewared them with his eyes. Is they moved elit slowly, eateh hird seemed altermately fo iall and strugrgle upward thru an are of five or six feet, imlependemely of

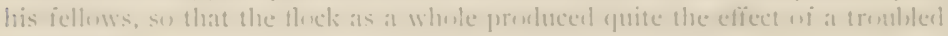
घाओ

Sunwflakes thek indifferently in winter amel may aceur in mumbers up

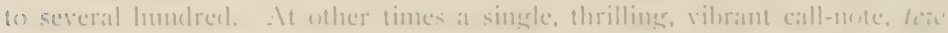

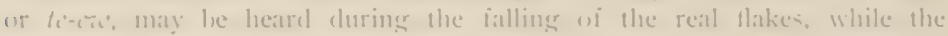

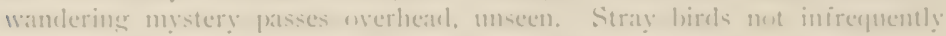

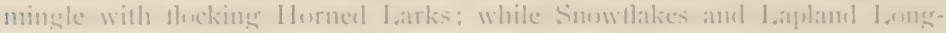
fours are fast friends in the regions where the latter are comment.

l'robably these birds are of resular the sparing aceurrence in the bign

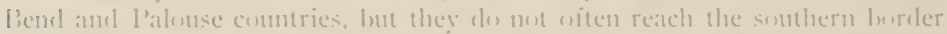
of the Siate: and their appearance on l'uget Somncl, as upun the pratries of Pierce cinuty, is quite unusual. While with us they mese amosesty irom field an field in apen situations, wr glean the weerl-seed, which furms their

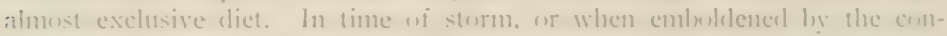
timnance of winter, they may make their apjearance in the barmyarel, wr atent

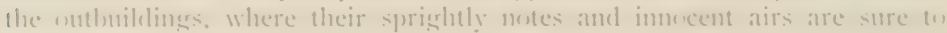
make them weleome.

It is dificult th conceive how these hirds may withstamel the frightoul temperatures to which they are sulyected in a winter mpon the saskitelewan plains, and yet they enclure this by preference to the elfeminizing influences which are ledieverl to preval senth of "lourty-nine," anel especially west wf the linclies. Chese-knt feathers. the warmest cosering kmown. fortitied hy lavers of fate, render them quite impersiunts to colds and as for the raging higzard, the hirds have only to sit quietly under the snome and wait till the lilist has lowem itseli out.

The smo alone mesails, as in the catse wi the man with the cloaks and at the first hint of the sun's return to prower. Alese iece-children hasten back

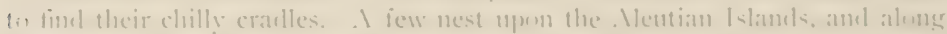

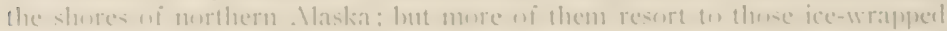

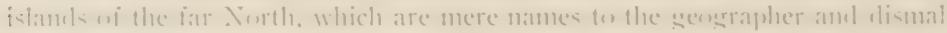

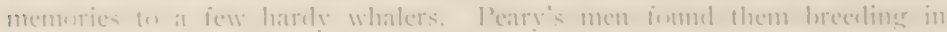

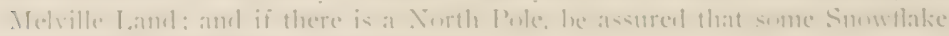
is ne-tline conterstedly at the hase of it. 


\section{ALASKAN LONGSPUR.}

A. O. U. 536a. Calcarius lapponicus alascensis Ridgw.

Description.- Idult male in summer: Head, throat, and fore-breast iblack; a buffy line behind eye and sometimes over eye; a broad nuchal patch, or collar, of chestnut-rufous; remaining upperparts light grayish brown, streaked with black and with some whitish edging; below white; heavily streaked with black on sides and thanks; tail fuscous with oblique white patches on the onter rectrices; feet and legs black: bill yellow with black tip. Adult male in winter: Lighter above; the black of head and chestnut of cervical collar partially overlaid with buffy or whitish edging; the liack of throat and breast more or less obsenred by whitish edging. Adult female in summor: Similar to male in summer, but no continuons black or chestnut any-here; the black of head mostly contined to centers of feathers,-these elged with buffy; the chestnut of cervical collar only: faintly indicated as exlging of feathers with sharply outlined clusky centers ; black of throat and chest pretty thoroly obscured by grayish edgmg, but the generat pattern retained; sides and flanks with a few sharp dusky streaks. Adult female in winter: [Description of October specimen taken in Seattle] Above buffy: grayish brown streaked (centrally tipon featlers) with black, wing coverts and tertials with rusty areas between the black and the buffy, and tipped with wisite; underparts warm buffy brownish, lightening on lower breast, abdomen, and under tail-coverts (where inmaculate), lightly streaked with black on throat, chest, and sides, sharply on sides and flanks. Length of adult males about 6.50; wing $3.77(95.8)$; tail $2.50(63.3)$; bill .46 (II.7) ; tarsus .86 (21.8). Female smaller.

Recognition Marks.-Sparrow size; terrestrial haloits; black head and breast of male. The bird may be distinguished from the Horned Lark, with which it sometimes associates, by the greater extent of its black areas, and by the chirruping or rattling cry which it makes when rising from the ground.

Vesting.-Does not breed in II ashington. Vest: in grass tussock on ground, flimsy or lulky, of grasses and moss, frequently water-soaked, and lined carefully with fine coiled grass, and occasionally feathers. Eggs: 4-6, light clay-color with a pale greenish tinge, variously marked,-speckled, spotted, scrawled, blotched, or entirely overlaid with light brown or chocolate brown. Av. size $80 \times .62(20.3 \mathrm{x}$ 15.7). Scason: first weck in June: one brood.

General Range.-"The whole of Naska, including (and breeding on the Pribilof and Alentian Islands, Lnalaska, and the Shumagins; east to Fort Simpson, south in winter thru more western parts of North America to Nevada (Carson City), eastern Uregon, Colorado, western Kansas, etc." (Ridgway).

Range in Washington.-I'resumalbly of more or less regular occurrence in winter on the liast-cicle. Casual west of the Cascades.

Authorities.-["I apland I.ongspur," Johnson, Rep. Gov. IV. 'I'. 1884 (1885) 22.] Dawson, Ank, Vol. XXV. Oct. I008, 1). 483.

[3) all the rules this bird should be abundant in winter in the stubble fields of the l'alouse country, if not upon the prairies of I'ierce, 'l'hurston, and 


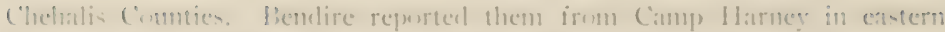

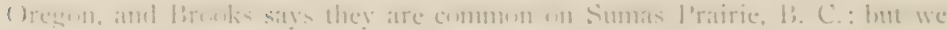

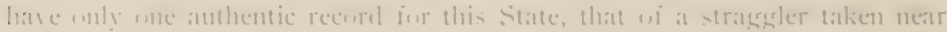

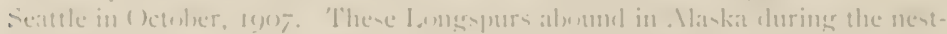

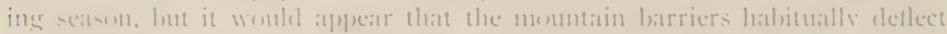
their antummal llight fo the castwatrel, and that the few which reach us stragegle dow11 the (a):at.

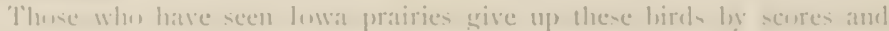
humberls every few rods, hate leen able to form some cunception of their vast

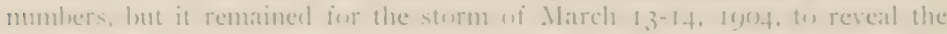
real wreler wi matenitule of their abumbance. An entserver detaited by the Minnestat state . Natural llistory Survey estimates that a millon and a hali

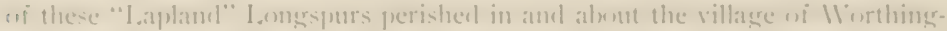
fon aldene: and he found that this destructions, the not elsewhere sin interse. extented wer an atreat of fifteen humberl square miles.

In syife wi such luffutings of fortune, these hirels which du reach . Maska bring at mighty eleer with them w the stlitures. As Velsum sates: "llhen they arrive early in . May the errombl it still largely cowered with smow with the

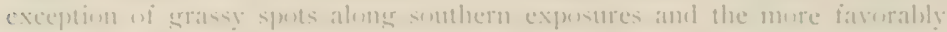
situated purtions if the tumlrat, and here may le fomel these hirels in all the feamly wi their elegrant summer dress. The males, as if comecioms of their

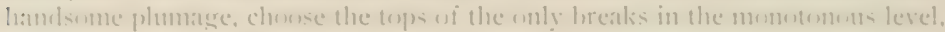

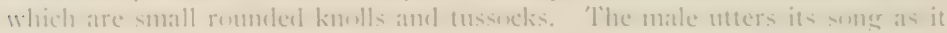

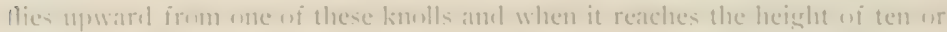
liftern yards, it extende the prints of its wings mpwarels, forming a large

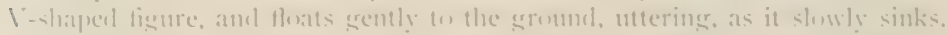
it: liefuid tumes, which fall in tinkling succesiun upon the ear, and are perhaps the sweetest motes that one hears during the entire spring-tine in these regions.

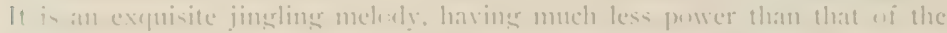

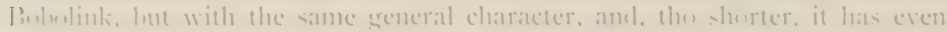
mere metrely than the strige of that well known lirel."

No. 3 s.

\section{WESTERN I,ARK SPARROW.}

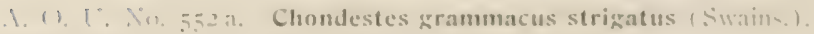

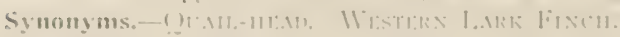

bescription.- ldult: Heal varicgated, black, white, and che-timet lateral

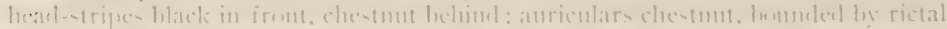

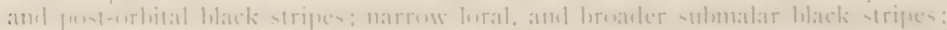

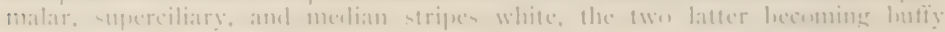


belind: upper parts buffish gray brown, clearest on sides of neck, streaked by blackish brown centers of feathers on miclle lack and scapulars, persisting as edging on the fuscous wings and tail; tail-feathers, except midelle pair, broadly tipped with white; below white, purest on throat and belly, washed with grayish buff on sides and crissum, also obscurely across fore-breast, in which is situated a central black spot. I.ength 6.25 ( 158.8 ); wing 3.35 ( 85 ); tail 2.68 (68); bill .77 (12); tarsus .80 (20.3).

Recognition Marks.- Sparrow size; head variegated black, white, and chestnut: fan-shaped tail broally tipened with white and conspicuous in flight (thus

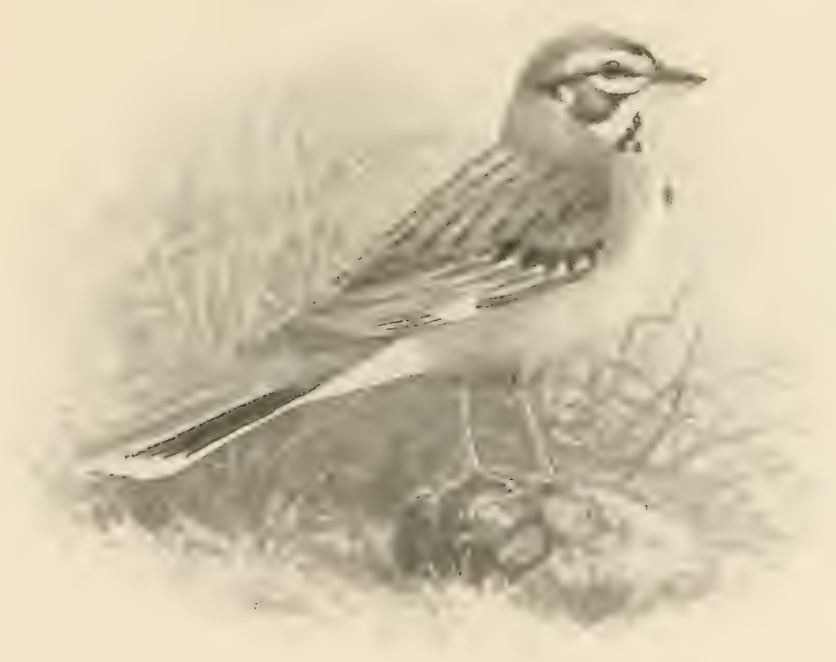

WESTIRN I.MRK SIMRROM

easily distinguished from the IV estern Vesper Sparrow with square tail and lateral white ienthers).

Nesting.-West: of grasses, lined with finer grass, rootlets and occasionally horse-hair, on the ground or, rarely, in low bushes or trees. Liggs: 5, white, pinkish or bluish white, spotted and scrawled in zigzags and scrolls with elark 


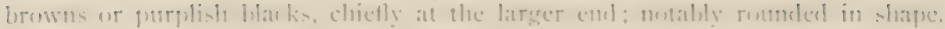
Ax. 420 .

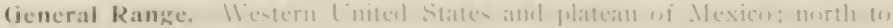

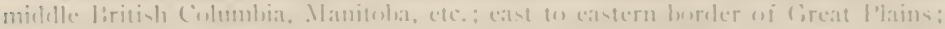

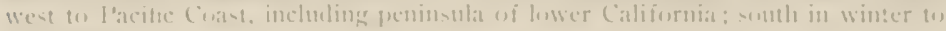
fivatemala.

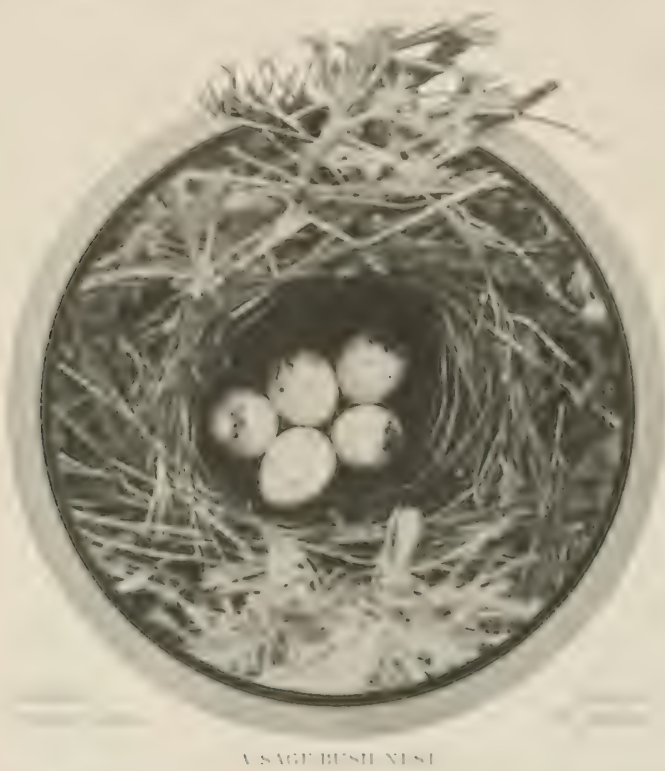

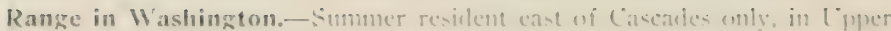
Sonoran and . Irid Transition zonk

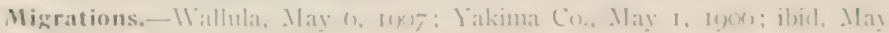
3. I000) Chelan, Ma! M, rivin

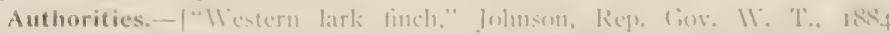

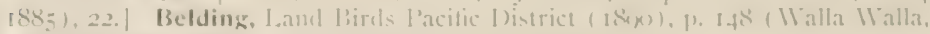

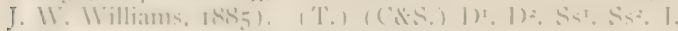

specimens, $-($ L. ni 11 .) ('. I'.

Is in the case wi the Samelwich and Savama Suarrows the curtems!

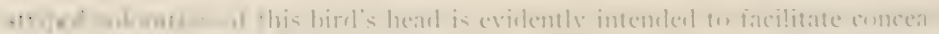

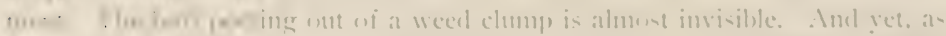

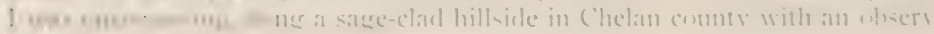


ing young rancher, my companion halted with a cry. He had canght the gleam of a Lark Sparrow's eye as she sat brooding uncler a perfect mop of dead broom-sage. The camera was brought into recuisition, and the lens pointed downward. 'l'he camera-cloth bellied and flapped in the breeze, yellow tripod legs waved belligerently, and altogether there was much noise of photographic commerce, but the little mother clung to her eggs. The stupid glass eye of the machine, spite of all coaxing, saw nothing but twies, ancl we were obliged to forego a picture of the sitting hird. T' get the accompanying picture of eggs. I was obliged to hack away the protecting brush, liaving first slipped in a handkerchief to protect the nest and contents it nu showering debris.

'The dlesert harlon's many choice spirits, but none (save the incomparable sage Thrasher ) more joyous or more talented than the Lark Spar. row. Whether it is romning nimbly.

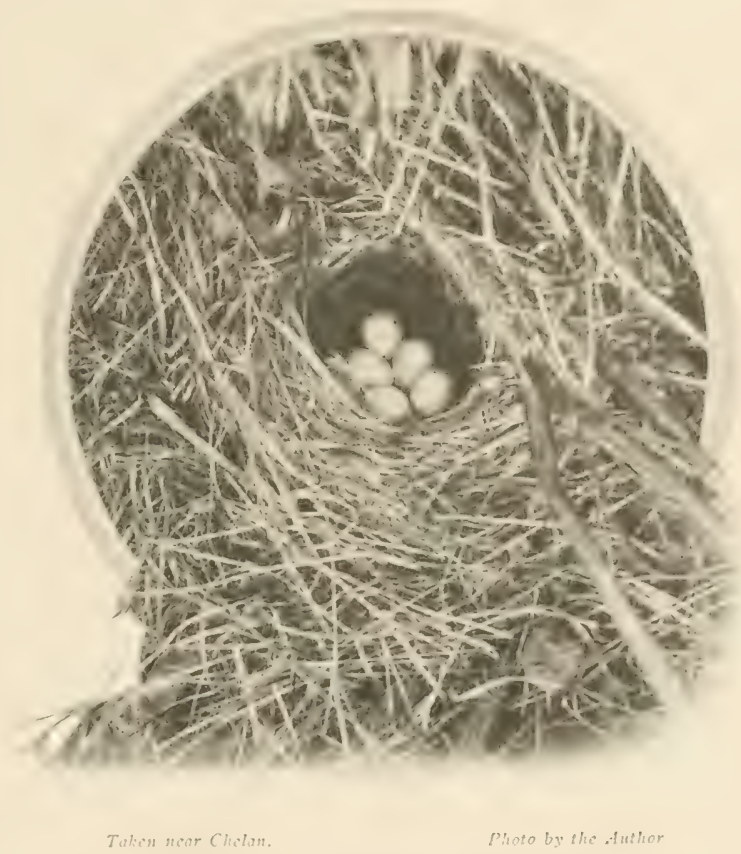

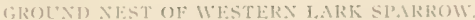

along the grotund of leaping into the air to catch a risen grasshopper, one feels instinctively that here is a clainty breed. The birel loves to trip alhead corpuettishly along a dusty road, only to yield place at last to your insistent steed with an air of gentle reproach. As it flits away you catch a glimpse of the romeled tail, held half open, with its terminal rim of white, and you know you have met the aristocrat of the sage.

Lark Sparrows are somewhat irregular in distribution, but their range 


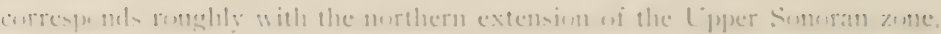

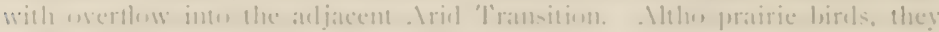

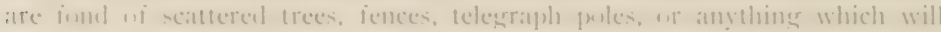

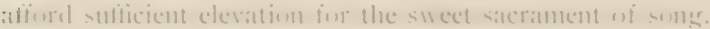

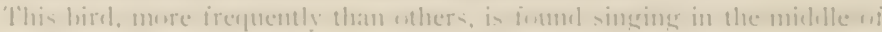
the very luttent datys in stmmer, and at steh times his tremulmas motes come

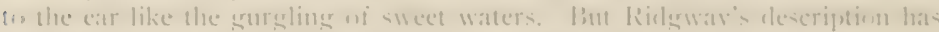

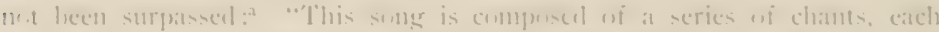
s.llable rich, lomel, anul clear, interspersed with emmental trill. It the

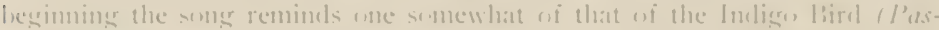

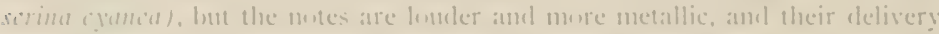

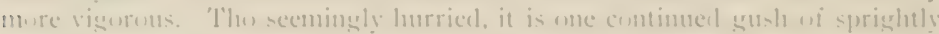

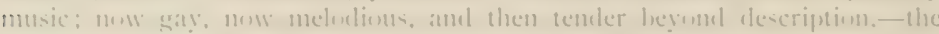

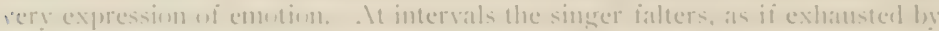

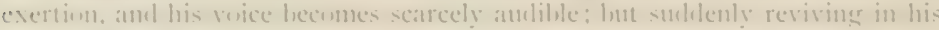

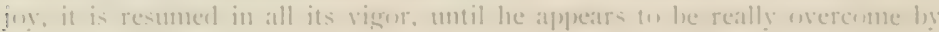
the elint.

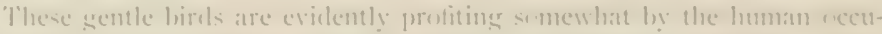

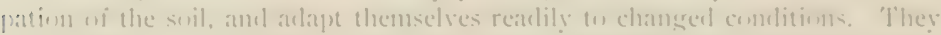

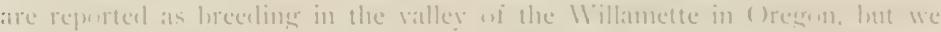

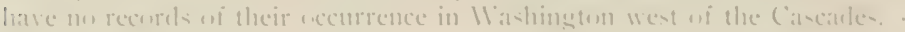

No. 3\%.

\section{WESTERN VESPER SPARROW.}

1. (1) $1^{\circ}$. Xir. 5 fon. Ponectes gramineus continis Matird.

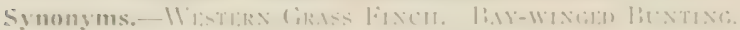

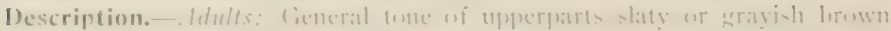

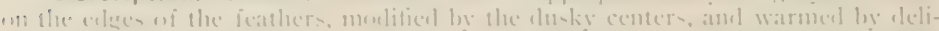

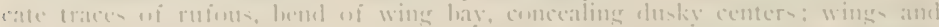

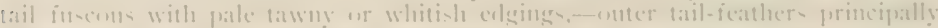

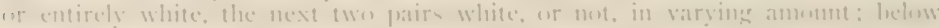

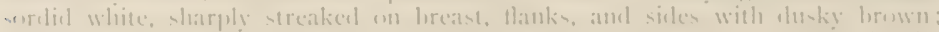

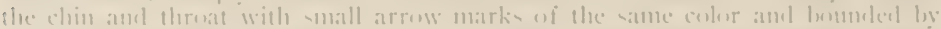

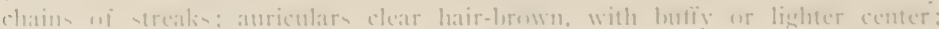

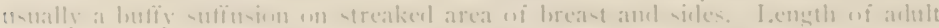

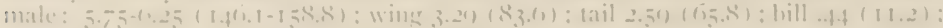

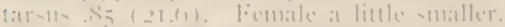

Recognition Marlis.- Sparrow -ize: general -trealied appearanee: white

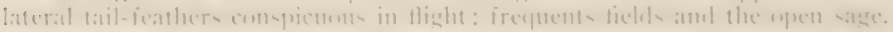

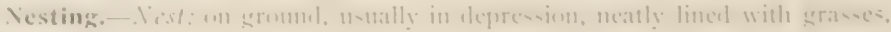


rootlets, and horse-hair. Figys: f or 5 , pinkish-, grayish-, or bluish-white, speckled, spotted and occasionally scrawled with reddish-brown. Ar. size, $82 \times .60$ $(20.5 \times 15.2)$. Season; lirst week in Mlay, second week in June; two broods.

General Range.- Western Linited States (except P'acific coast district) and Canada north to Saskatchewan east to Manitoba, the Dakotas (midway), western Nebraskiz, etc.; breeding from the highlands of Arizona and New Mlexico nortl. warcl; in winter from sonthern California east to Texas and sonth to sonthern Mexico.

Range in Washington. East-side, sparingly distributed in all open situations.

Migrations.-Spriny: Yakima Co. March I5, I900; Chelan Co. March 3I, 1896.

Authorities.-Dawson, Auk, XIV. April I897, p. I78. Sr. Dz. Ss'. Ss². J. Specimens.-P. I'rov. C'.

$\therefore$ SOBER (arl) camnot conceal the quality of the wearer, even tho Onaker gray be made to cover alike saint and sinner. Plainness of dress, therefore, is a fault to be realily forgiven, even in a bird, if it be accompanied by a wice of sweet sincerity and a manner of self-forgetfulness. In a family where a modest appearance is no reproach, hut a warrant to health and long life, the Vesper Sparrow is pre-eminent for modesty. Yon are not aware of his presence until he disengages himself from the engulfing grays and browns of the stalk-strewn ground or clusty roadside, and mounts a fence-post to rhine the commes or the parting day.

The arrival of Vesper Sparrow, late in \arch, may mark the supreme effort of that particular warm wave, but you are quite content to await the further travail of the seatson while you get acquainted with this amiable newcomer. Lnder the compulsion of the sum the bleary fields have been trying to muster a decent green to livele the ugliness of winter"s devastation. But wherefore? 'llhe air is lonely and the sage untenanterl. The Meadowlarks, to be sure, have been romping about for several weeks and getting bolker every day: but they are roisterous fellows, drunk with air and mad with sunshine. 'Tlie winter-sharpened ears wait humgrily for the poet of common day. 'The morning he comes a low sweet murmur of praise is heard on every side. You know it will ascend unceasingly thenceforth, and spring is different.

lesper Sparrow is the typical ground bird. He eats, rums, sleeps, and rears his family upon the ground : but to sing-ah, that is different!-nothing less than the tip of the highest sage-lutsh will do for that: a telegraph pole or wire is lotter: and a lone tree in a pasture is not to be despised for this one purpose. 'The males eather in spring to engage in decurous concerts of rivalry. 'The sung comsists of a variety of simple, pleasing notes, each utterest twe sir tluce times, and all strung together to the number of four or five. The characteristic introduction is a mellow whistled he-ho, a little softer in tone 


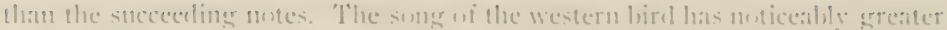

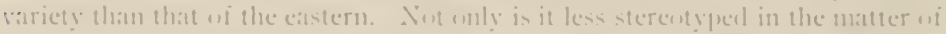

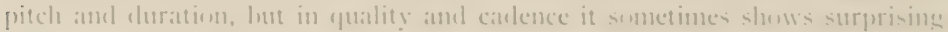

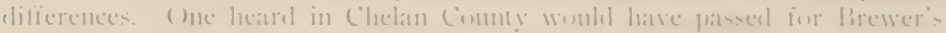

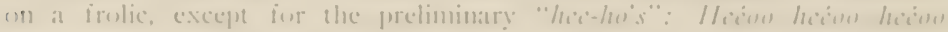

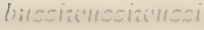

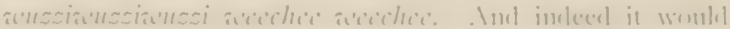

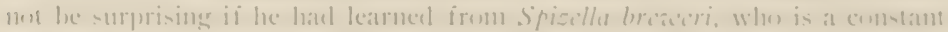

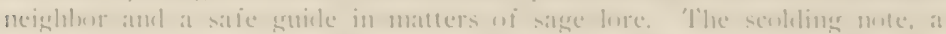

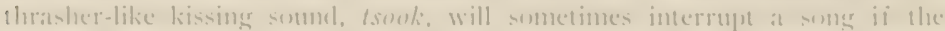

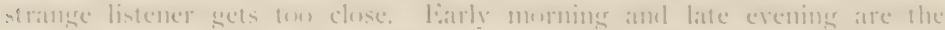

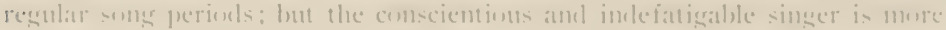

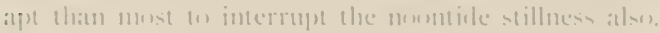

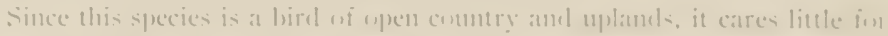

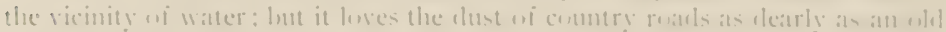

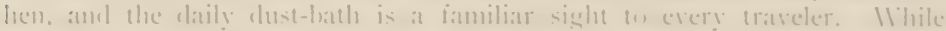

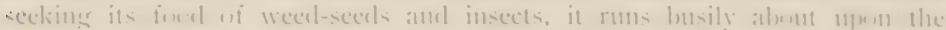

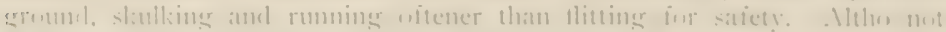

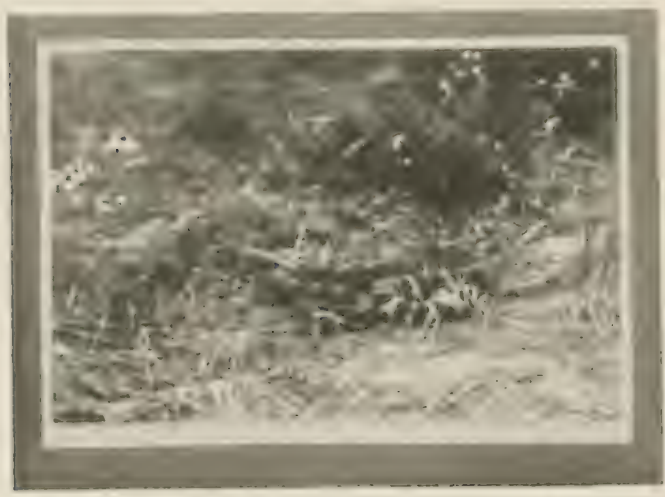

[III: I:TIY)

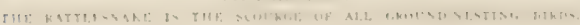

especially timiel i: sectuls to take at writ: of profesimal priske in leciner alle to slip? alunt ammone the

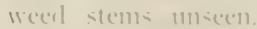

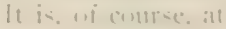
nesting time that the sneak-iblility wi the limel is must severels testerl. 'lhe nest, a simple alfair wi

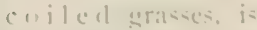
mstailly $\& 1111 \mathrm{k}, 4 \mathrm{~T}^{\circ}$ chambereet in the (rroumel, sis that its lrim comes llu-h with the stritice. lior the resit. the

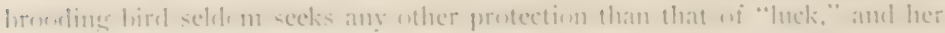

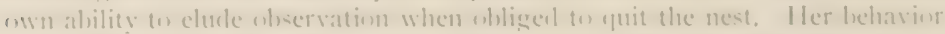

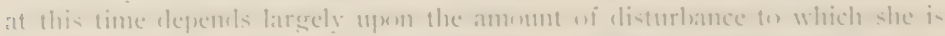

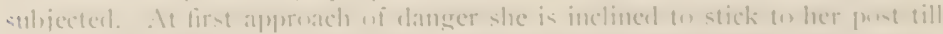

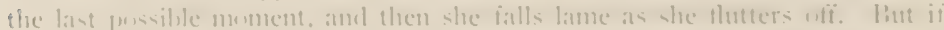

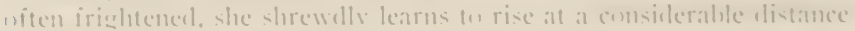


Two and sometimes three broods are raised in a season, the first in late April, the second in late June or early July. Pastures and fallow grounds are favorite spots for home building, but I have frequently come upon the nests in the open sage, and here oftenest upon hillsides or tops of low ridges.

Altho not averse to the wilderness, there is reason to believe that this bird profits by the advent of civilization, and that its numbers are slowly increasing.

\section{No. 40.}

\section{OREGON VESPER SPARROW.}

A. O. U. No. 540 b. Ponecetes gramineus affinis Miller.

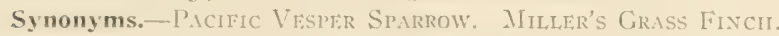

Description.-Similar to $I^{P}$. g. confunis but smaller and coloration darker. browner above, more distinctly buffy below. Length of adult male about 5.75 ( I.46); wing 3.04 (77.2); tail 2.28 (57.9); bill .43 (I0.9); tarsus .8I (20.6). Fiemale a little smaller.

Recognition Marks. - Is in preceding, less liable to confusion because of absence of lirewer Sparrow, Western Lark Sparrow, etc, from range,

Nesting.-. Nest: on plonghed ground or tnder shelter of fern-stalk, fallen branch, or the like : of grasses fined with hair; measures externally 3 inches across by 2 in clepth, insicle $2^{1 / 4}$ across by $1 \frac{1}{4}$ in depth. Eggs: 3 or 4 , size and color as in preceling. Season: May; one brood, rarely two.

General Range.- Pacilic coast district from northern California north to British Columbia (including Vancouver Island); sonth in winter thru southern California to Cape St. Lucas.

Range in Washington.-Of local occurrence on prairies and in cultivated valleys west of the Cascades-not common.

Migrations.-Spring: 'Tacoma April 9, Ino6; April 13, 190\%.

Authorities.-Poncetes yramineus lia|i|rd, Baird, Rep. Pac. R. R. Surv. 1.1. $1858, p+47$ (part). ('T). CiS. Ra. B'.

Specimens.-(L. of II.) P'. I'rov. I3. IE.

TIII: appearance of a Vesper Spartow where trees are the rule is something of an anomaly. Vevertheless, this plains-loving birel seems to do very well in the pratice region sonth of 'lacoma; and it has been here at least long enomgh to begin to assume the clarker garb which characterizes old residents of the soment rexion.

The bird is hecming fairly common wherever conditions in the large are suitalble for it. I found it in mumbers at Dungeness in the spring of 10)o: and the agricultural lands of the Skagit are being accepted by this gentle sonester als tho duly made and provicled.

Mr. Bowles funds that egrgs may not be lookerl for in the vicinity of 


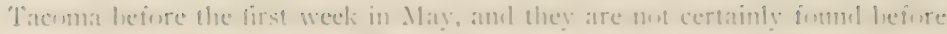

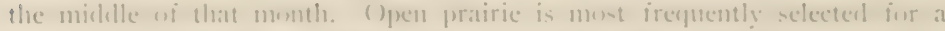

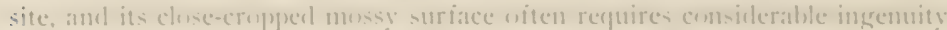

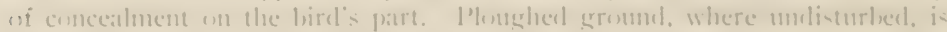

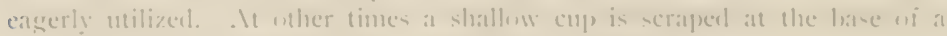
small fern, or the protection of at billen limb is semghte.

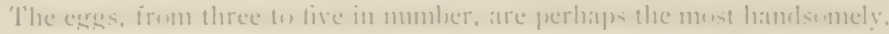

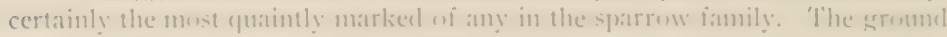

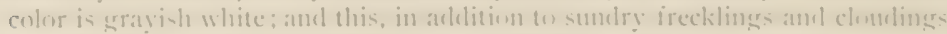

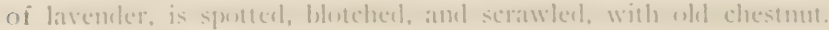

'The iemale sits closely and sometimes will nut leave the nest until

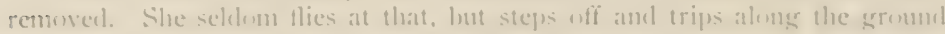
for some distance. 'Then sle walks almont measily or pretemels to feerl. venturing litte expression of eoncern. Curbusly, her liege forst never appears. either, in defense of his home, but atter the young are hatcheel he deres his iatr share in feeding them.

No. 41.

\section{SANDWICH SPARROIV.}

1. (1) 2 . . Di1. 5.2. Passerculus sandwichensis ( (imelin).

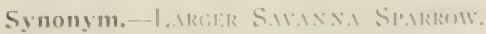

Description.-- Idults: Cieneral tune of upper plumage grayish brown-the feathers hlackish centrally with much erlging of grayish-loriws fometimes bay). llaxen and whitish; a mesial comw-strige dull lowfly, or tingerl anterivirly with vellowish: lateral stripes with gravish lomwa chlging reduced:

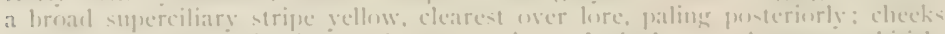
buffy with some mingling and onteropping of dosy: molerparts whitish. cleares on throat, washed with hoify on siles. heavily amel sharply streaked

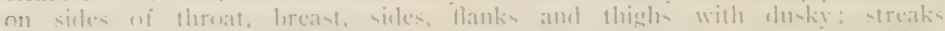
nearly ennfluent on sides of throat, thus defining sulmalar area ni whitish:

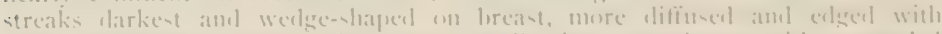

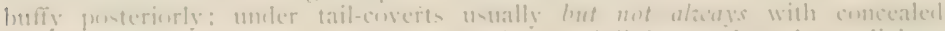

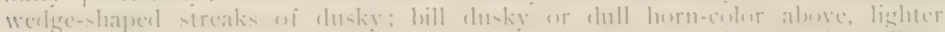

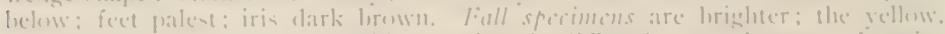

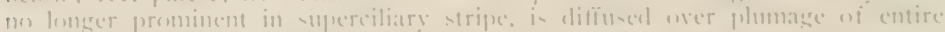

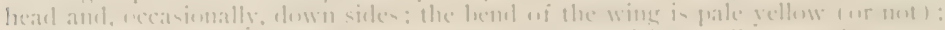

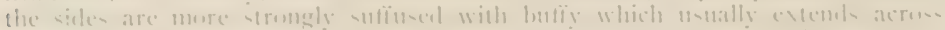

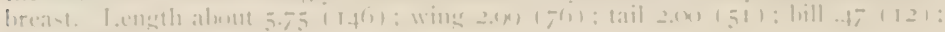
tar-11- ses 12251 .

Recognition Marks. - Ilarbler -ize hut much moge rolust in appearance

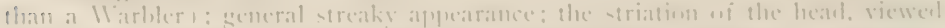

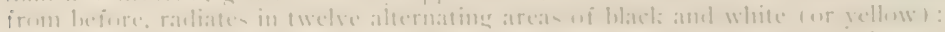

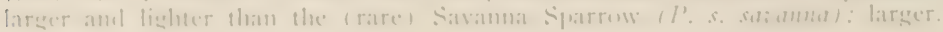


darker and browner than the common Western Savanna Sparrow (I). s. alandimus).

Nesting.- Not yet reported breeling in Mashington. Nest and cygs as in P. s. alaudinus.

General Range.- - Unalaska Island (also Shmmagin islands and lower portion of Alaska peninsula?) in summer: in winter, eastward and southward aloner the coast to British Columbia, more rarely to Northern California" (Ridgway). Also breeds extensively in western Iiritish Columbia and on Vancomer Island (Auct. Famin, Kermocle, Dawson).

Range in Washington.-Spring and fall migrant on both sides of the Cascades (sparingly on liast-side); (prestmably) resident in winter west of the range: possibly summer resident in northwestern portion of State.

Migrations.-Spring: April (IVest-sicle); Sonth Park April 24. 25, 29, I804; May (East-side); Yakima Co. May 8, Io, I80t; Fall: September.

Authorities.-P'asserculus sandrichensis Bairl, Baird, Rep. P'ac. R. R. Surv. IX. 1858, p. 445. C\&S. Rh. Kb.

Specimens,-U. of IV. I'rov. C.

THE interrelations and distributions of the Passerculus sundarichensis group are not at all clear as yet, but the migrant birds of spring and middle fall are ustally of this form, and hail from or are bound for the coast of Britisl Columbia and Mlaska. At Blaine I have found them skulking about the fish-trap timbers of Semiahmoo spit, during the last week in September; or hiding in the rank grass which lines the little waterways draining into Camploll Creek. At such times they keep cover until one is almost upon them, and then break out with a frightened and protesting tss, only to seek shelter again a dozen teet away.

No. 42 .

\section{SAVANNA SPARROW.}

A. O. U. oo. 542 a. Passerculus sandwichensis savanna (Wilson).

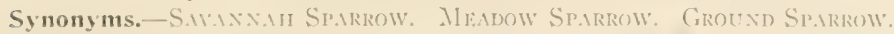

Description.- Idult: Similar to $P$. samdachensis but decicledly smaller and darker (usually browner as well), with bill both relatively and absolutely smaller. and with less or less conspicuons yellow in superciliary stripe. Length about 5.0

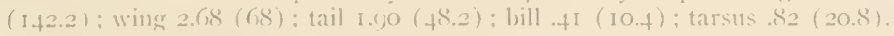

Recognition Marks.- Warbler size: I2-meliant pattern of head: cencral streakinesi of upperparts; sharply streaked on breast and sides : darker.

Vesting.- Has not lecen discovered breeding in IVashingtom hut probably doeseso. . lest and lings as next. 


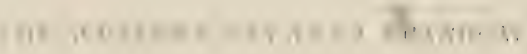

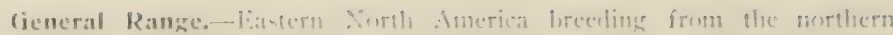

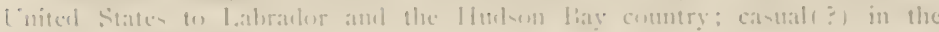
Ilevern [ niterl Sitater.

Range in Washington.-lmperfectly made unt: many lirels resident on

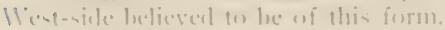

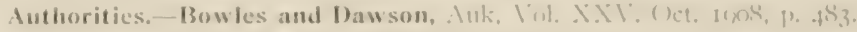

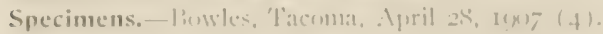

So 181 s specimens we get an l'meret Sinmel are nu larger than typical II estern Sasanna, hut are more strongly and brightly colured-hamblome

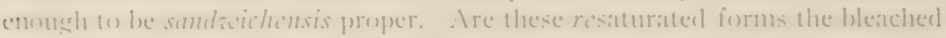

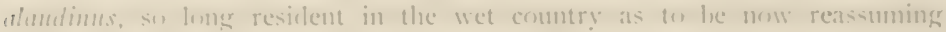
the discarded tints of uld? Are they, rather, intergrales letween l's s. sumb-

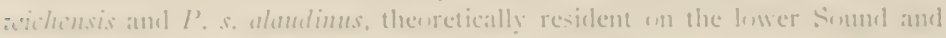

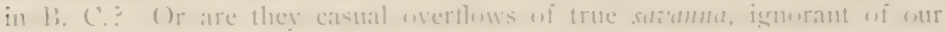

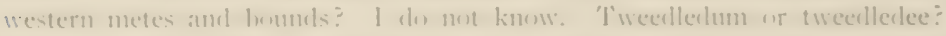
llere is a finc problem for the man with a grm, to whom a new stabspecies is mere than the lives of at thusand inmeents. Lat I disclam all respunsiliility in the matter.

No. 43.

\section{IVESTERN SAVANNA SPARROW.}

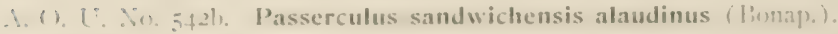

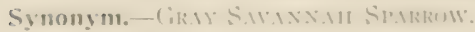

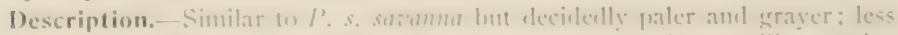
hay or mone in caleing of featlers of mple rparte: yellow of superciliary stripe unvally paler, smbetines nearly white: bill lemger and relatively weater. (nher

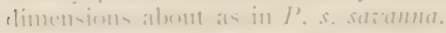

Recognition Marks.- Is in preceling-pulir.

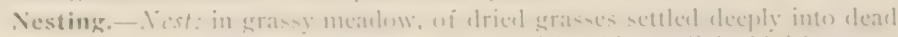

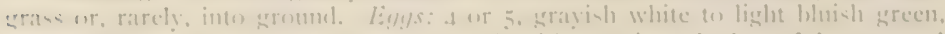

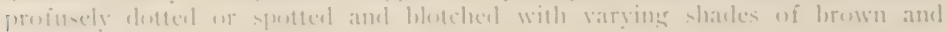

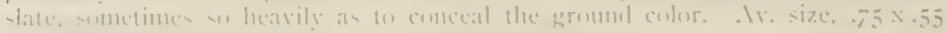

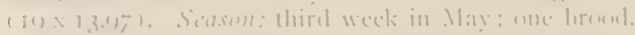

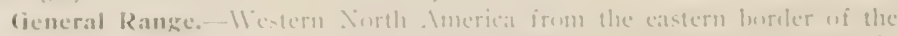

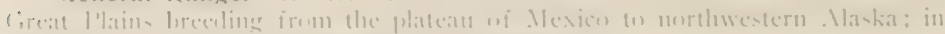

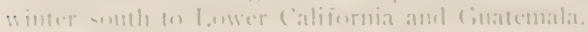

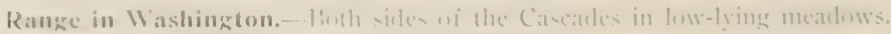
f'erhape-paringly re-ilent in winter an 11 est-sile. 
Migrations.-Spriny: About April 1st; Bremerton March 23, Igo6.

Authorities.-Passerculus alandinus bonap. Baird, Rep. I'ac. R. R. Surv. II. 1

Specimens.- $L$. of $\mathrm{IV}, \mathrm{I}^{1}$. I'rov. I'.

VO' every bird ean he a beatty any more than every soldier can be a colonel; and when we consider that ten times as many shot-guns ate in commission in time of peace as rifles in time of war, we cannot blame a bird for rejoicing in the virtue of humility, envying neither the epaulets of General Blackbird nor eren the pale cherrons of Sergeant Siskin. A Saranna

Sparrow, especially the washed-out western va-

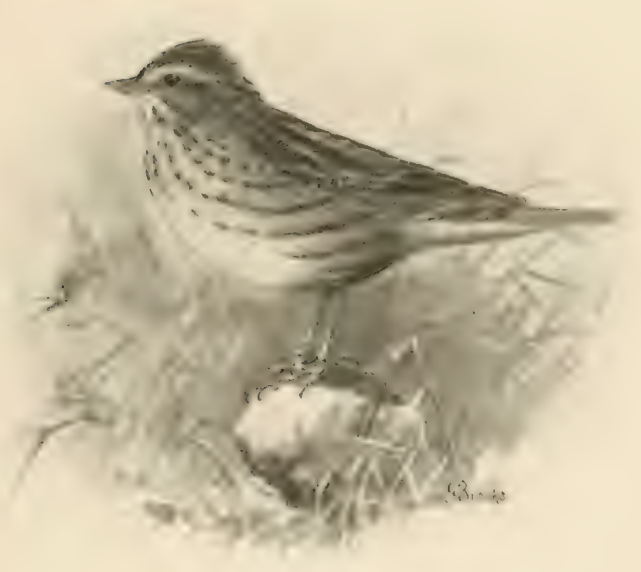

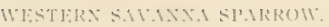
riety, is a mere detacherl lit of lirown earth done up in elried grasses; a feathered

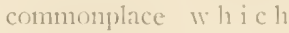
the landscape will swallow up the instant you take eves off it. 'To be sure, if your can get it quite alone and icry near, you see enotigh to arlmire in the twelveradiating pattern of the head, and you may even perceive a wan tint of vellow in the superciliary region; but let the birclling clrop mpon the gromel and sit motionless amidst the grass, or in a crisscross litter of weed-stalks, and sooner far will you catch the gleam of the needle in the hastack.

Savannas are birls of the meaklows, whether fresh or salt, and whereve: well-watered grasses and weeds abound, there they may he looked for. During migration, indeed, they may appear in most mexpected places. I sau one last vear, at bremerton, which haunted the vicinity of a timy cemented pond in the center of a well-kejut lawn. 'T'his birt hopped alunt coyly, peering behind blades of erass, and affecting a clainty fright at the sight of wate: very mucli ats a Chippong Sparrow might have done. In their nesting 


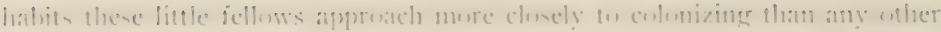

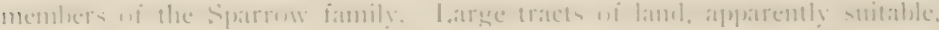

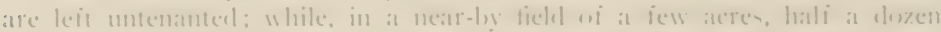

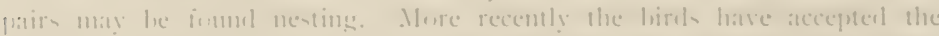
shelere of irrigaterl trated

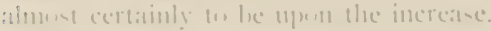

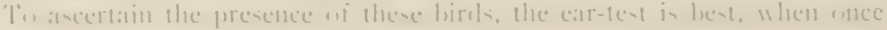

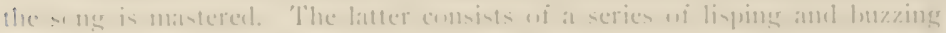

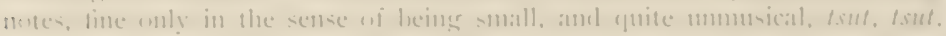

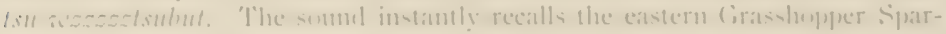

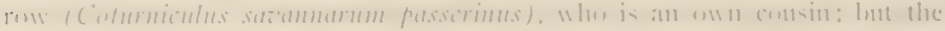

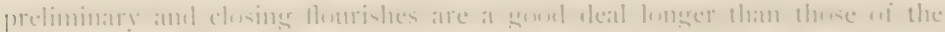

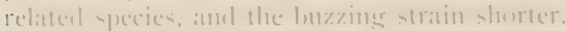

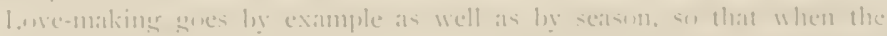

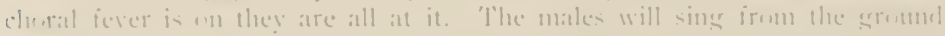

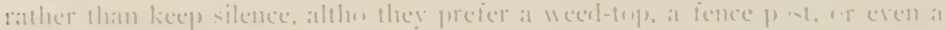

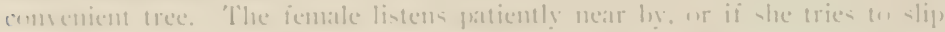

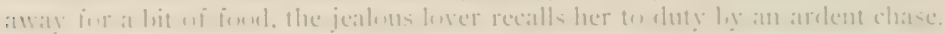

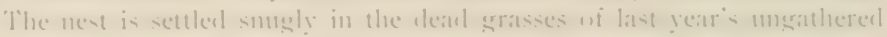

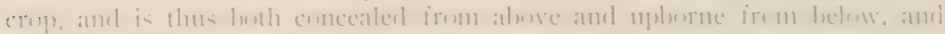

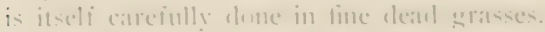

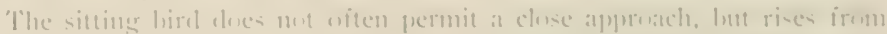
the nest at mot lese than thirty icet. The precise spot is therefore. very

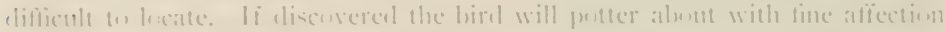

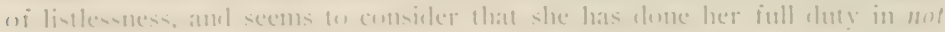
- homing the ceress.

No. 1.1.

\section{DESERT SPARROW}

1. (). (i. Xio. 57.3 a. Amphispiza bilineata deserticola liulgw:

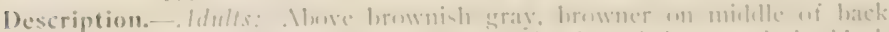

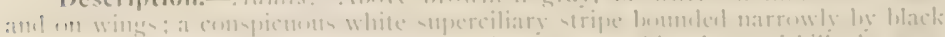

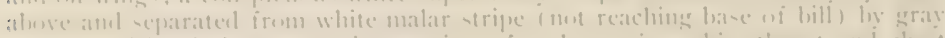

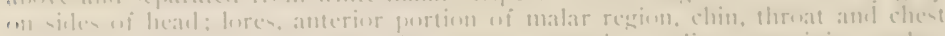

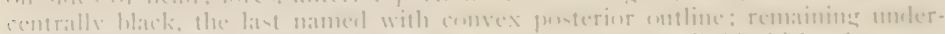

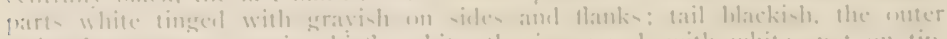

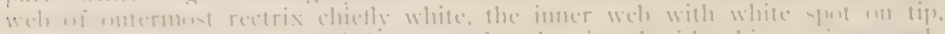

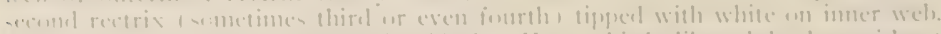

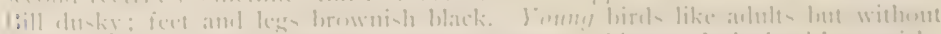

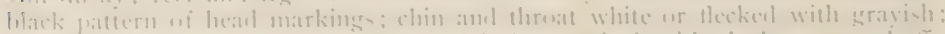

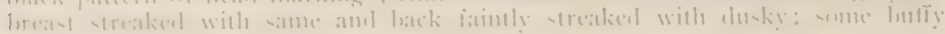


elging on wing. Length of adults about 5.35 (135.9); wing 2.55 (65); tail $2.48(63)$; bill .40 (10); tarsus .75 (19).

Recognition Marks.- Marbler size; grayish coloration; strong white superciliary; black throat distinctive.

Nesting.- Not yet reported from Washington. "Nest in bushes, slight and frail, close to the ground; $\operatorname{cgggs} 2-5,0.72 \times 0.58$ ( $18.3 \times 14.7$ ), white with a pale sreenish or bluish tinge, mmarked; laid in May, June and later" (Cones).

General Range.-Aricl districts of southwestern Lnited States and northwestern Mexico west from western 'l'exas to California north probably to southern Inlaho and II ashington; south, in winter to Chihuahna, Sonora and Lower California.

Range in Washington.-P'robably stmmer resident in Lpper Sonoran and Arid 'Transition life-zones; believed to be recently invading State from sonth.

Authority.-Dawson, tuk, lol. XXV. Oct. Igos, p. 483.

If one happens to be fairly well acquainted with the licensed musicians of the sage, the presence of a strange voice in the morning chorus is as noticeable as a scarlet golf jacliet at church. The morning light was gilding the cool gray of a sage-covered hillsicle in Douglas County, on the 3Ist dlay of May, Igos, and the bird-man was mechanically checking off the members of the desert choir, Brewer Sparrow, Lark Sparrow, Vesper Sparrow and the rest, as they reported for duty, one by one, when suddenly a fresh voice of inquiry, Blew chee tee tec, burst from the sage at a stone's cast. The binoculars were instantly levelled and their nse alternated rapidly with that of note-book and pencil as the leading features of the stranger's dress were seized upon in order of saliency: Black chin and throat with rounded extension on chest ontlined against whitish of underparts and separated from grayish clusky of cheeks by white malar stripe; lores, apparently including eye, black; brilliant white superciliary stripe; crown and back warm liglit brown.

The newcomer was a male Desert Sparrow and the interest aroused by his appearance was considerably heightened when it was recalled that he was venturing some five humbled miles north of his furthest previously recorded range. 'This bird, probably the same individual, was seen and heard on several occasions sulseequent thruout a stretch of half a mile bordering on Brook I.ake. Once a female wats glimpsed in company with her liege lord, flitting creptettishly from bush to bush: but the most diligent search failed to rliscover a nest, if such there was. Nesting was most certainly on the gallant's mind for he sang at faithful intervals. The motes of his brief but musical wffering had something of the sushing and tinkling quality of a lark Sparrow's. A variant form, whewe, altea', atherer, began nicely but decrencrated in the last member into the metallic clicking of 'Towhee.

IVe have here, in all probability, another and a very conspicuns example 


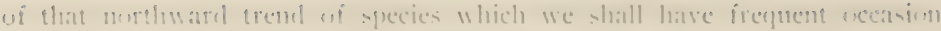

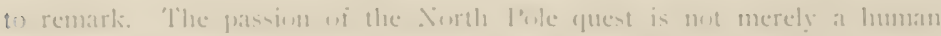
weakines: it in at deep-ronted instinct which we onty shatre with the birsts.

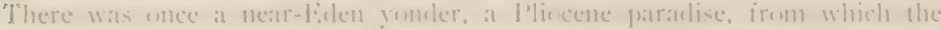

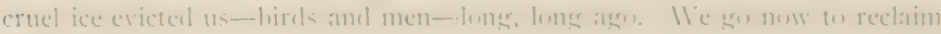
(1)1 +11 11 .

No. 45 .

\section{SAGE SPARROW.}

\section{A. (). L: No. 57 f. Amplospiza nevadensis (Riclew.).}

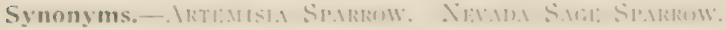

Description.- Idulls: Liperparts (incluting auricular and sicles of neck ashy gray to ashy brown, clearer and grayer anteriorly, browner puseriorly : pilem, back and seapulars sharply and narrowly streaked with latek: wings amel tail dull black with light brownish or pale gravish elgingr : the rectrices markeal with white much as in precesling species: a supratural spot, an orhital ring and (ustally) a short median line on forchead white: siden wi head slaty gray ; lore dusky: underparts white, clearest on throat where lwounded ansl set off from white of malar area hy interrupterl chain of dusky steaks, occastumally with dusky spont nn eenter if hreast, markerl on sides and flasks with lufï̀ and streatient with dusky; celge of wing pale yelhow or yellowish white. liall hackish alowe. lighter below: lege dark brown, toes darker: iris brown. Jomne: "l'ilemm, himelneck, chest and siles, as well as back, streakerl with clusky: otherwise esiontially as in arlules" (Ridgway). ("nelerparts save on throat sometimes tinged with

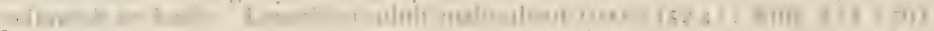

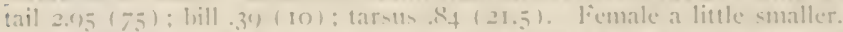

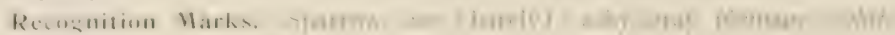
throat elelineal hy dusky streaks.

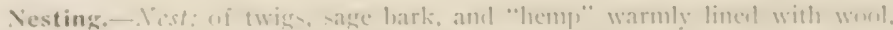

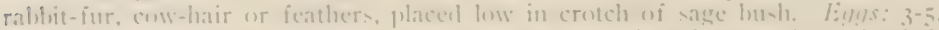

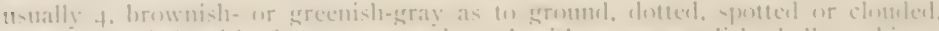
rarely wrawled, with chentmut or sepia and with sme purpliah chell markings.

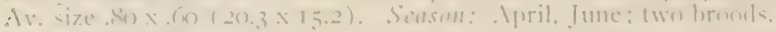

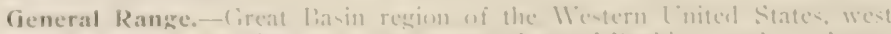

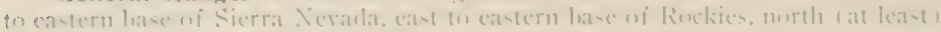

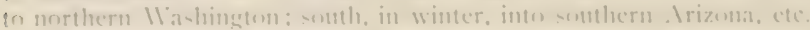

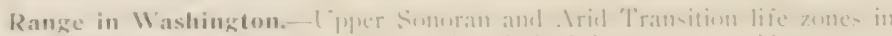

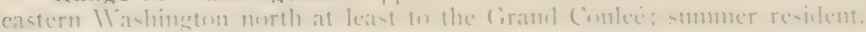

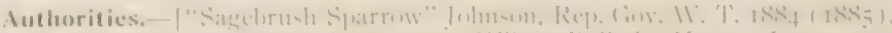

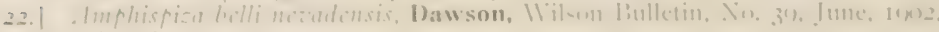
1) 615.50 .25

specimens - $l^{\circ}$, wi 11 , I'. 
11IXK God for the sage-lorush! It is not merely that it clothes the desert and makes its wastes less arid. No one needs to apologize for the manclad open, or to shum it as tho it were an unclean thing. Only little souls do this, - those who, being used to small spaces, miss the support of crowding ellows, and are frightened into peevish complaint when asked to stand alone. 'To the manly spirit there is extltation in mere space. The ground were enough, the mere lixpanse, with the erer-matehing bitue of the hopeful sky. but when to this is ackled the homely verdure of the untilled gromel, the cup of joy is filled. One snatches at the sage as tho it were the symbol of all the wikl openness, and buries his nostrils in its pungent branches to compass at a whiff this realm of unpent gladness. Prosy? Monotonous? I'angh! Back to the city with you! You are not fit for the wilderness unless you love its very worm-

wood.

The sage has interest or not. to be sure. according to the levei from which it is vi w w ed. Regarded from the supercilious level of the man-onhorseback, it is a mere hindrance to the purstiit of the erring steer. The man a-foot has some dim perception of its lseauties, but if lis errand is a long one he, ton. wearies of his devious course. Those who are lest of all

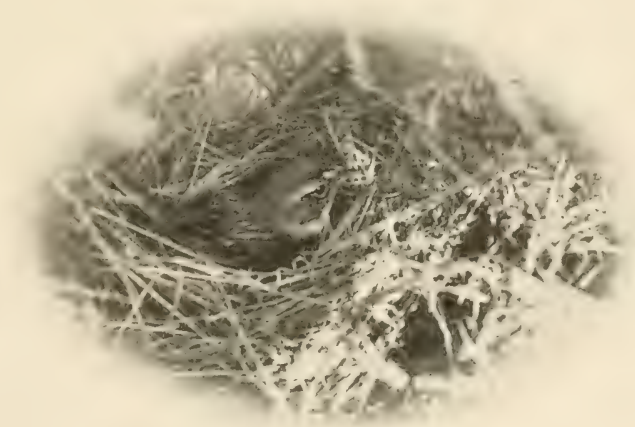

Tutien in Douglus County. Photo by H". Leon Dawson. S.1GE SP.IRRON ON XEST,

TIIS RIKD WAS SRT THI: VICTIM OF TIF, MISFORTUNE MFNTIONFD I. THE TEXT.

fitted to appreciate its infinite variety of gnarled branch and velvet lea $f$, and to revel in its small mysteries, are simple folk,-rabbits, lizards, and a few bircls wh have chosen it for their life portion. Of these, smme look up to it as to the trees of an ancient forest and are lost in its mazes: hut of those who know it from the gromul wp, none is more loyal than the Sage Sparrow. Whether he gathers a breakfast, strewn upon the gromel, among the red, white, and blue, of storkbill, chickweed, and fairy-mint, or whether he explores the crevices of the twisterl sage itself for its store of shrinking heetles, his soul is filled with a vast content.

Ifere in the springtime lie sonn gets full enough for utterance, and mounts the topmost sprig of a sage lush to voice his thanks. In general character 


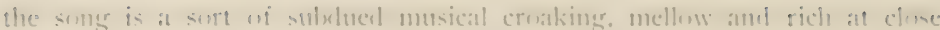

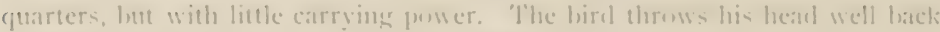
in singing, and the tatil is carricel mose nearly lorizontal than is the abe with

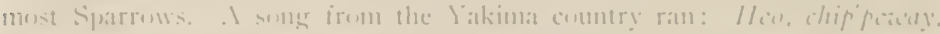

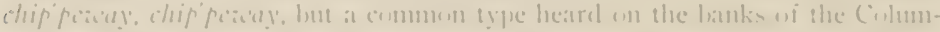

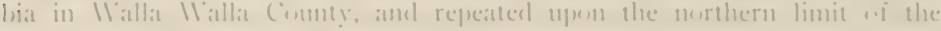

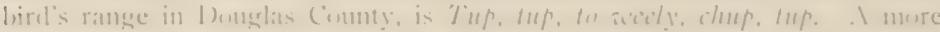

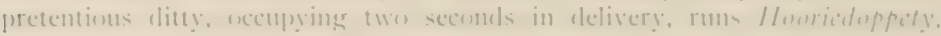

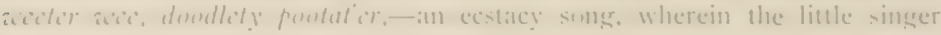
secms (1) be intexicaterl with the atomat of his favorite sage.

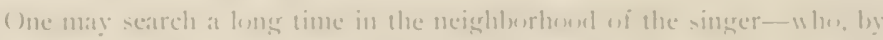
the way, cheses the comeert aldruptly when le realizes that loe is likely to give his secret anaty-lechere linding the lumble domicile at fout or two mp in al sage busth. I nest which contaned five egress wats compused extermally ef sage

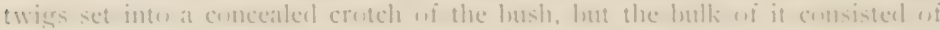
weed-hark and "lempl" of at quite miform quality: while the lininge contaneel tufts of woul, rablut-fur, cow-latir, feathers, and a few coiled lurse-hairs

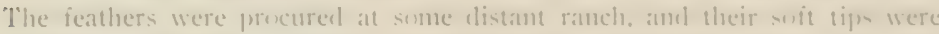

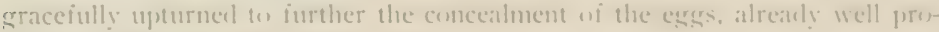
tected lyy their gravish green tints.

Annther nest, sighted sume forty paces awaly, contained one eures. and wo hat high hopes of heing able to secure plustugraphls upen sur return with the

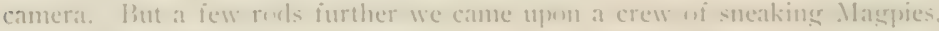
scouring the sane with a dozen leably eyes, and patssing sneering or vulgarly jexene remates upon what they found. When we returnet, therefore, a day or two later, we were mot surprised to learn that the feathered matratulers had preferrel exg-in-the-hill th sumenir photographs.

No. f(5,

\section{SI,ATE-COI,OREI) JUNCO.}

\section{1. (). L: Xi). g(i-. Junco hyemalis (1 imm. I.}

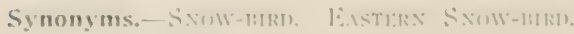

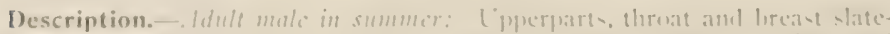

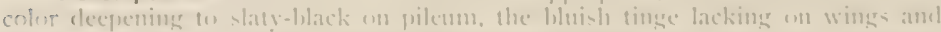

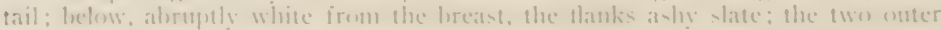

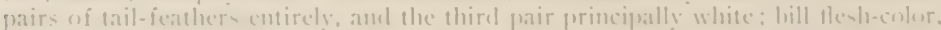

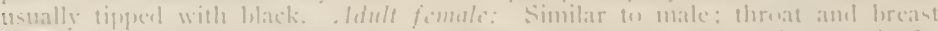

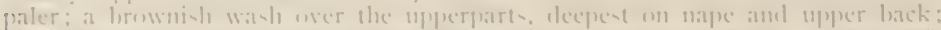

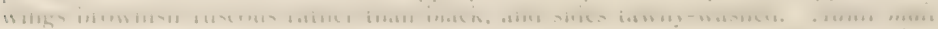

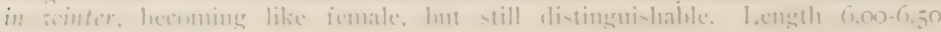


(152.4-165.I); wing 3.07 (78); tail 2.80 (7I.I); bill .49) (12.5). Ficmale averages slightly smaller than nale.

Recognition Marks.-Sparrow size; white lateral tail-feathers; hood slaty as compared with $J$. oregumus and $J$. o. shufeldti.

Nesting.-Not known to breed in Washington. Nest and cgys as next.

(ieneral Range.-North America, chiefly east of the Rocky Momtains, brecling in the hilly portions of the Northern States (east of the Rockies) north to the Arctic Coast and west to the valleys of the Yukon and Kowak Rivers, Alaska; south in winter as far as the Gulf States and sparingly over the IVestern States to California, Arizona, etc.

Range in Washington.-Casual during migrations; may winter rarely in company with $J$. orcganns.

Authorities.-Not preziously published: II. 'I. Shaw in cpist. Dec. I, I0o8. J. 11. Bowles in epist. Jan. 19, I909.

Specimens.- $\mathrm{P}^{\mathrm{T}}$.

'THIS the familiar Snow-bird of the East is occasionally secn west of the Rocky Mountains in winter and during migrations, specinens having been taken at Stmas, B. C., by Mr. Allan Brooks, and at Corvallis, Oregon, by Mr. A. R. Woodcock, in adclition to the one reported from Pullman. It is not impossible that the birl is more common than we have heen supposing. because, when fonnd, it appears to be mingling freely with flocks of allied species, quite unaware of the fact that such actions are of interest to inquisitive bird-men.

No. 47.

\section{OREGON JUNCO.}

A. O. U. N†o. 567 a. Junco oreganus ('Jowns.).

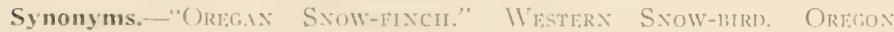

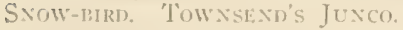

Description.-- Adult malc: Head and neck all aronnd and chest (abruptly defined along convex posterior edge) sooty black; back and scapulars and edemg of tertials warm reddish brown (nearly walnut brown); rump, upper tail-coverts and midclle and greater wing-coverts slaty gray or ashy gray, sometimes glossed with olivaceous; wings and tail dusky, edged with ashy; the ontermost rectrix wholly and the second chiefly touched with white, the third pair toucher with white near tip): sickes of breast. sides and flanks strongly washesl with pinkish brown (vinaceous cinnamon) : remaining underparts (below chest) white. IBill pinkish white with dusky tip; iris claret recl. Adult fomale: Ilead and neck all arouncl and chest scarcely contrasting in color with upperparts but changing from warm brown (bister) above to dull slaty overlaid with brownish on throat and chest: brown of lack (bister or clull sepia) without reddish tinge: white on second rectrix not so extensive as in male: wash of sides duller. not so vinacents. 


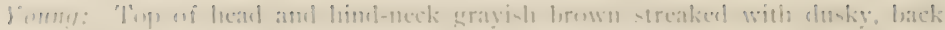
and scapulars warmer hrown streaked wih hlack: throal, che-t, siles and hanks

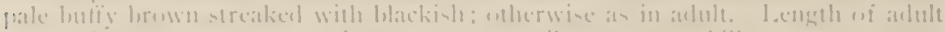

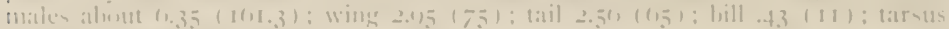
$\$ 3(21)$. liemater smaller.

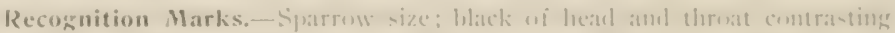

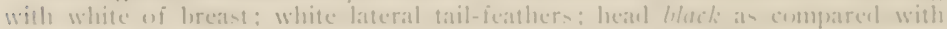

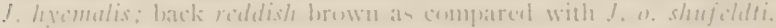

Nesting.- Vest: on groumel at balee of small bus or maler fallen branch.

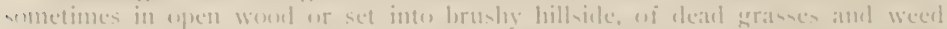

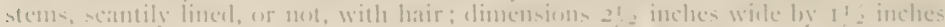

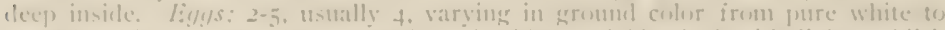

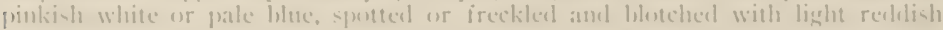

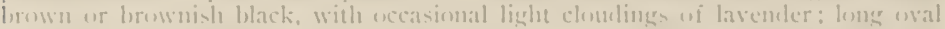

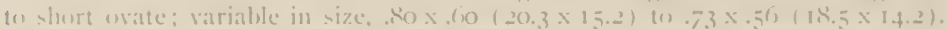
Siosen: fourth week in . Ipril to lirst week in fuly or Augu-t according to altiturle; two or thee bromks.

General Range- -l'acilic Coast district: in summer from southern liritish

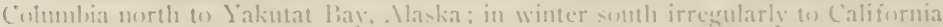
(santa ('ruz and san Matee counties), straggling across the Caceale-sierras inter interior.

Range in Washington.-Formerly stmmer resident, now chictly migrant and winter resident west of the Cascailes: winter resident and migrant east of C'ascates.

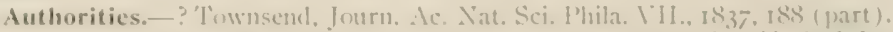

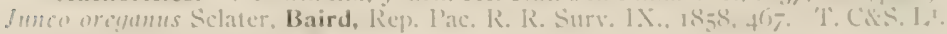
Kh, I). Kh, Ra. 1): Kk. I\}.

specimens,-Li, of 11 . 1'! I'rov. B.

IX speaking of Juncoes it is necessary to distinguish hetween the rufutsbacked hirel of winter, the Oregen Junew proper, and the brownish-gray-

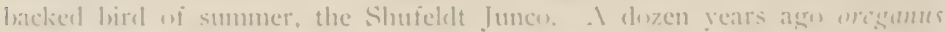

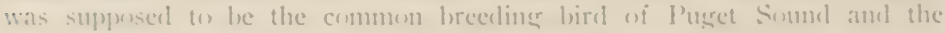
neigliburing fouthills, altho shufeldt's was well homwn in the more open siluations. Intterly, however, there has mot been any authentic aceount of the nestinge of the real-backed birel within the State. ino, 3 witnessed its last appearance as a smmmer bircl, and that only in the lighlamels. Recent specimens taken during the breeding seasom at places so remote from esteh wher ats the pratiries of l'ierce Comnty, the lanks of the l'end d'o reille in stevens

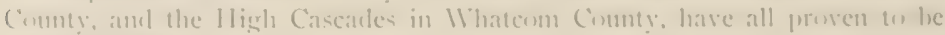
I. 1. shufiliti.

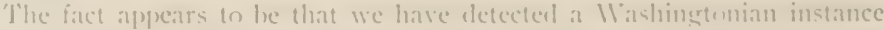
uf that nurthward trend uf species clearly recognizable in the liast, lut

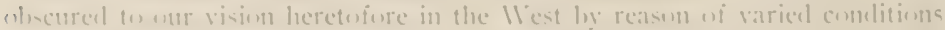
and insufficient data. The theory is that the hires are still following the

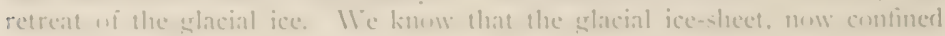


w. Geenland and the high Jorth, once covered lalf the continent. In our own momntains we see the restigial traces of glaciers which were once of noble proportions. We know that the southward advance of the continental icesheet must have driven all animal life before it ; and, likewise, that the territory since relinguished by the ice has been regained by the animals. What more natural than that we should witness thru close observation the northward adrance of those varieties of birds which are best suited to withstand cold, and the corresponding occupation of abandoned territory on the part of those next south?

Juncoes, moreover, are erratic in their migrations, and in the IVest, at least, tend to become non-migratory. While Oregon Juncoes are the common winter birds of I'nget Suml. Shufeldt's are not entirely absent at this season, and we may even look to see them hold their own thruout the year. T'le problem is further complicated by what we call vertical migration, by which is meant that monntain birds descend to the valleys in winter instead of flying southward. Our winter Shufeldts, therefore, may or maty not be strictly resident on, say, Steilacoom Prairie. 'The summer birds may retire to California: the winter bircls may have descended from the Olympics or Momut Rainier.

No. 48.

\section{SHLFELDT"S JU N(O).}

1. O. U. No. 567b. Junco orexanus shufeldti (Coale).

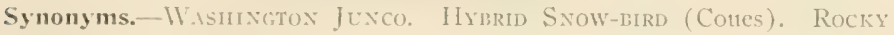
Moumtan Junco (Cones).

Description.-Idults: Similar to J. orcganus but back (in males) grayish, or erayish-brown to sepia; in females sepia to (lrab; black of head and throat more slaty; also averaging larger. Length: 6.00-6.50 (152.4-I65); wing 3.I5 $(80)$; tail $2.72(60)$; bill .43 (II) : tarsus .83 (2I).

Recognition Marks. - Sparrow size: black of head and throat contrasting with brownish-gray of hack and with white of breast; grayer on back than prececling.

Vesting.- Nest: much as in preceding, occasionally placed at molerate heights in trees, liggs: tor 5. pale bluish white, spotted and blotehed with light recklish brown and lavender, usually in light ring, occasionally in confluent mass

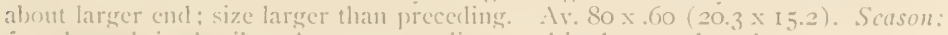
fourth week in April to August according to altitukle; two broods.

General Range.-lirecling from northern Oregon north into liritish Columbia east to mountains of Allerta and Idalon: sotuth in winter over Rocky Iountain plateau region to Mexico,-northern California. 


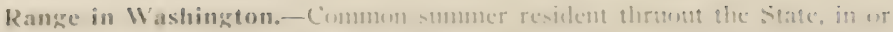

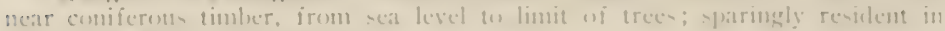
winter ehicfly west wi ciacialest

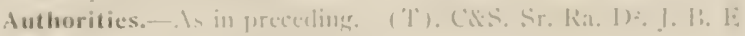

Specimens.-1'. wi 11: 1'. 13. l'n.

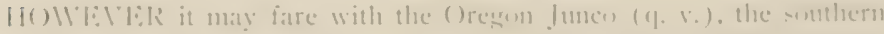

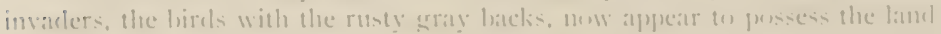

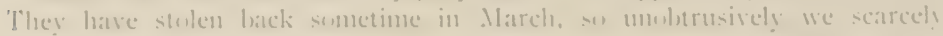

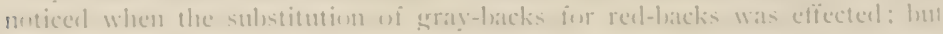
sons we do motice that the yarels and clearings are frepuented ly happ!

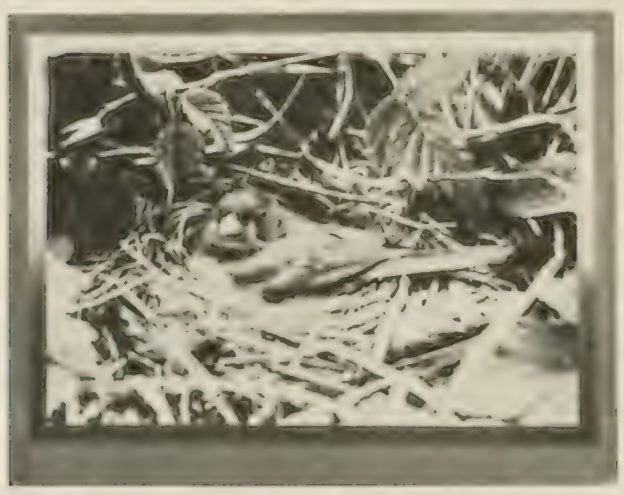

r.

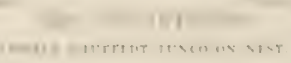
rollicking irmps at

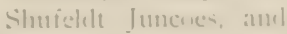
we mitice tow that a sme pronomeerl tlirtationare leeine catrricel in

fliere is a invial reatlessuess alwent there hirrlis in thek which is contagenus. 'Their el (ery monement is ate complanienl ly a happ? titere and the purstuil bi neressities is never (1) stern that a satte dare irom one wi theis numbler will mot semol lle whole company wt pell-mell like at romece an schumbloss. Whenewer it Junce starts to wing. it thathes a white semal in the lateral tali-fenthers: amel this comsentemt

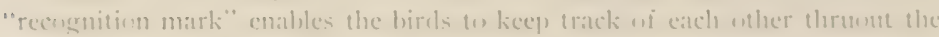
marlilest gambuls in brusli-lot or tree-tent

( ) n a stmmy day in March the Jumeres satleer for a smanel concert. The males mount the bush-tups and hold forth in rival strains, while the females

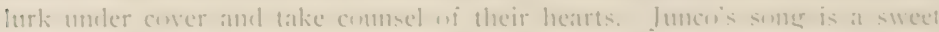

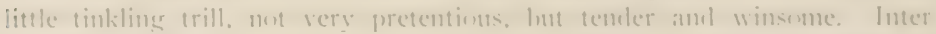

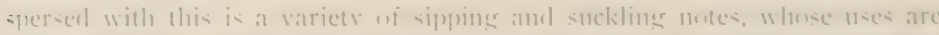

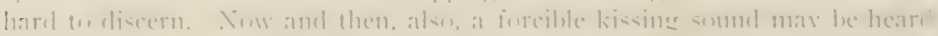

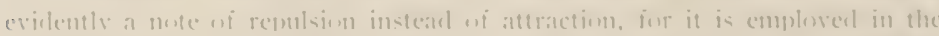

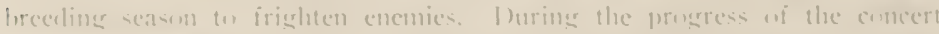

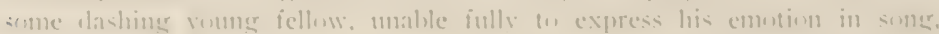


runs amuck, and goes charging about thru the woodsy mazes in a fine frenzy-withont, however, quite spilling his brains. Others catch the excitement and the company breaks up in a mad whirl of amorous pursuit.

At the end of the lorief song period, Juncoes deploy thruotit the li a $] \mathrm{f}-0 \mathrm{p}$ en woods or prairic borders of the entire State. from sea-level to timber-line. 'llhe v"nriety and interest of their nesting habits are scarceIy exceeded by those of any othe: bird. In general they appear to be guided by some thought of seclusion or protection in their choice of nesting sites. Steep hillsides or little bants are. therefore, favorite places, for liere the bird may excavate a coo? srotto in the earth. and allow the drapery of the hillsicle. mosses

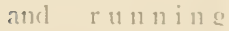
vines, in festonn and guard the ay)proaclices. It

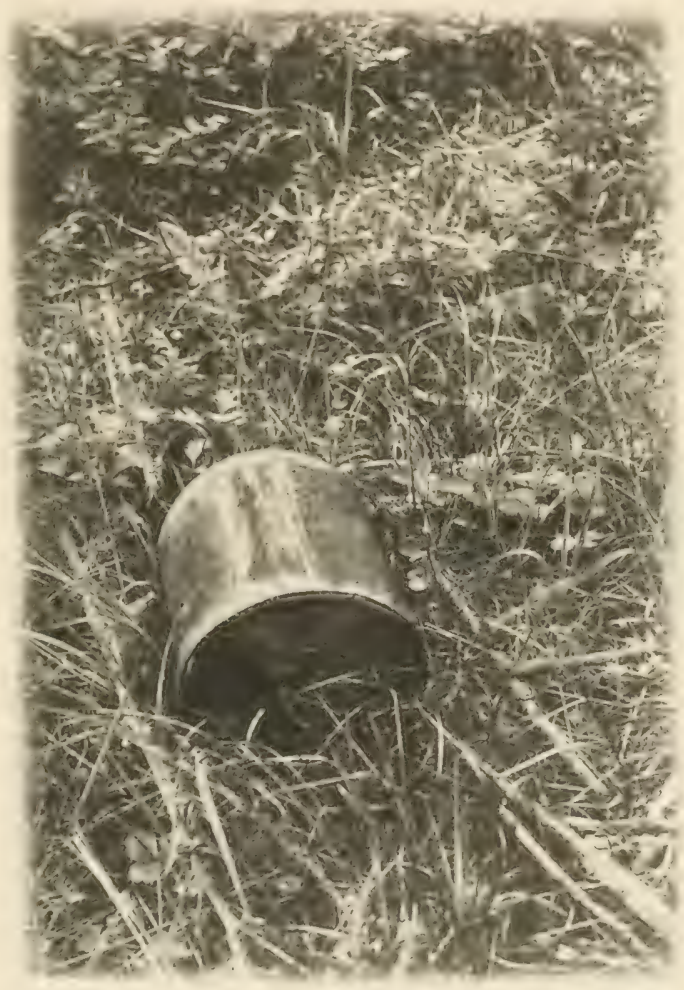

Taton in Tecoma. Plinto by the itution

CNUEk I TL LOO

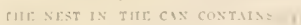

Vewport we found them nesting in the road-cuts. At Snopualmie the side of a haystack sheltererl a conficling pair. At lacoma the bircls nest at the base of tiny clumps of oak, or under the shelter of brush-piles. Sereral 


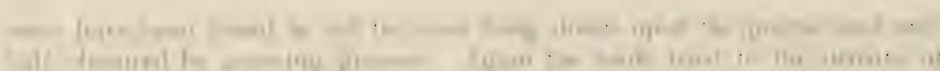

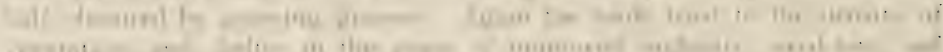

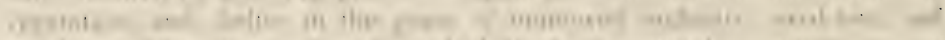

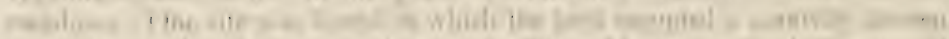

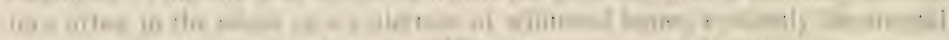

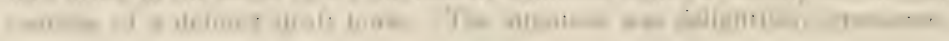

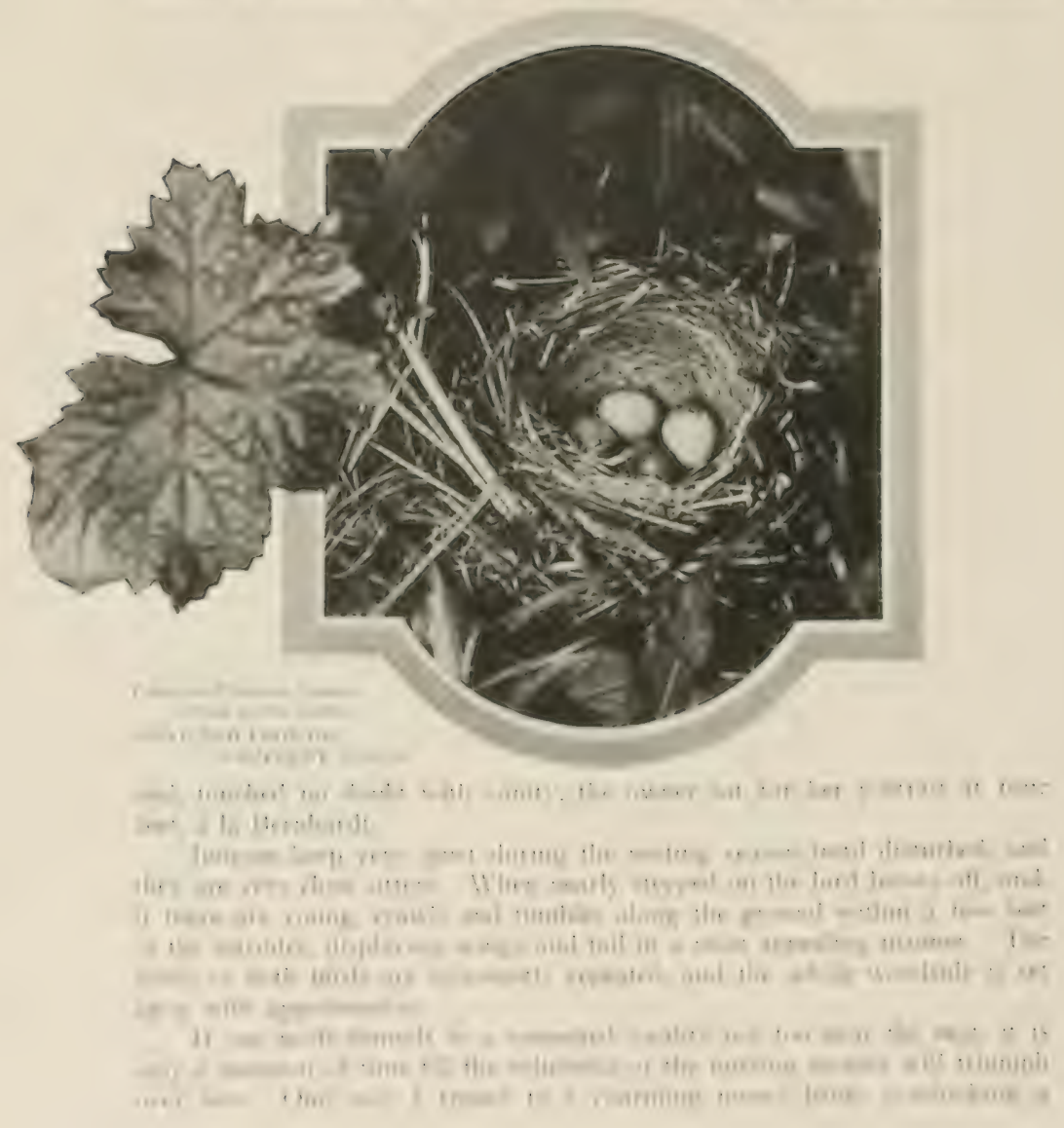


woodland pool; but on the first occasion it took the parent bird exactly half an hour to go thru all the feints and preliminaries before she ventured on the final plunge. 'There were half-grown babies in this nest, and since we were in summer camp (at Glacier, near the foot of Mt. Baker), 1 resolved to make friends of this promising family with a view to portraiture.

is I sat next day watching my Juncoes, and waiting for the sun to get around and light up the vicinity of the nest, the call to dinner sumnded. The mother bird, not without much misgiving and remonstrance, had just visited her babies, so 1 rose to go; but as 1 did so, caught sight of a stont garter snake, who lay watching the scene from a distance of fully twenty feet, a wicked gleam of intelligence in his eye. With quick suspicion of his purpose, I seized stones and hurled at his retreating form; but the grotund was rough and he managed to escape into a large brush-pile. At table I ate hurriedly, listening the while for the faintest note of trouble. When it came. a quick outcry from both parents, instead of premonitory notes of discuvery, I sprang to my feet, clutched a stick, and rushed down to the spring. Alas for us! Satan had found our Eden! The nest was emptied and the snake lay coiled over it in the act of swallowing one of the little birds. Not daring to strike, I seized him by the throat and released the balyy Junco, whose rump only had disappeared into the devouring jaws. 'Then with the stick I made snake's-head jelly on a rock and flung the loathsome reptile away. But it was all too late. One young bird lay drowned upon the bottom of the pool, and the other (I think there were only two) soon died of fright and the laceration of the hincler parts attendant upon ophidian deglutition. It was all so horrible! the malignant plan, the stealthy approach, the suclclen alam, the wanton destruction of the fledglings, the grief of the agonized parents, the remorse of the helper who came too late! Is it any wonder that our forbears have pictured the arch-enemy as a serpent:

No. 49 .

\section{IVESTERN TREE SPARROW.}

\section{A. O. (. . No. 559) a. Spizella monticola ochracea Prewster.}

Description.- Idults: l'ilem, a streak behinel eye and a small patch on side of chest cinnamon-rufous or light chestnut ; superciliary stripe and remaining portions of head and neck clear ashy gray; throat and chest of same shacle superficially lut duller by virtue of ernecaled dusky; an ill defined spot of dusky in center of lower chest; remaining underparts dell white washed on sirles with brownish: general erotor of upperparts light buffy gravish brown, much outcropping black on back, seapulars and tertials: some rusty edgingen back featlers, scapulars aml greater wing-erverts: midelle and greater wing-coserts 


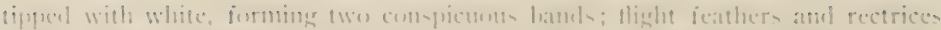

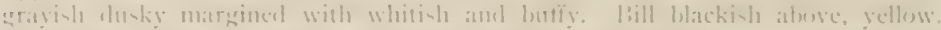

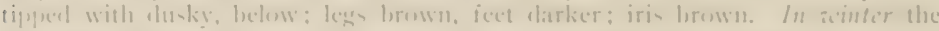

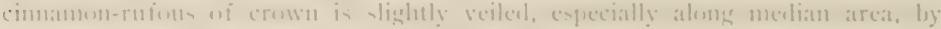

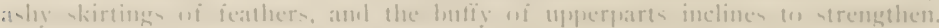

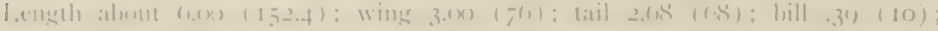

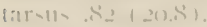

Recognition Marks. - Sparrow -ize; re-cmblen 11 estern Chipping Sparrow luse muth latrger: white wing-hars with chestum of erown distinctive.

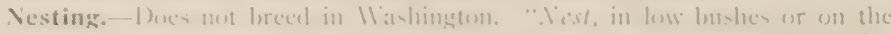

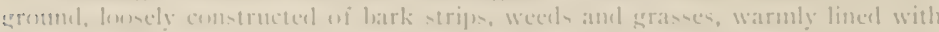

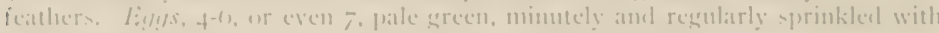

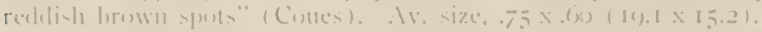

(ieneral Range.-lirecting from the valley of Ambersm Kiver, near the

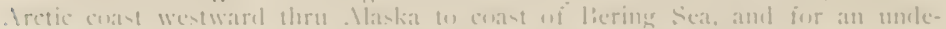

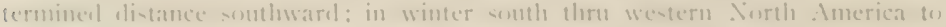

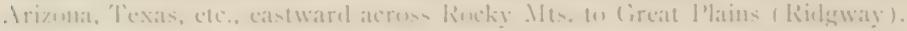

Range in Washington.- - Dit common winter revident amel migrant. Has met recently leen repurteal west of the ciacailes.

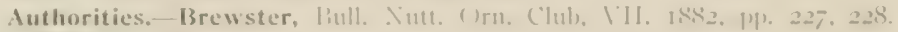

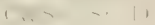

Specinens.-1 (l丷, wi II:). I", I'rus:

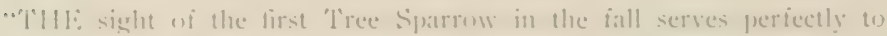
call up at vision of impending winter. Here atre the hurrying blasts. the leaten skics, the pilines smow-ilrifts, all reaty to make the heholder shiver.

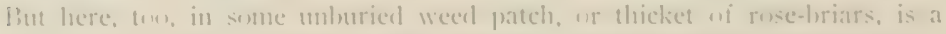

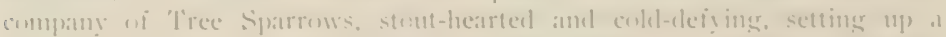

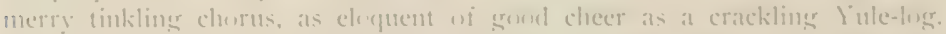

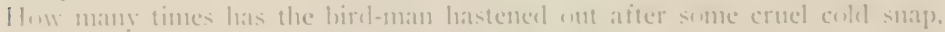

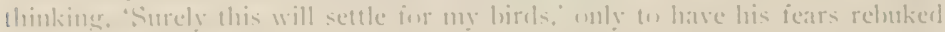

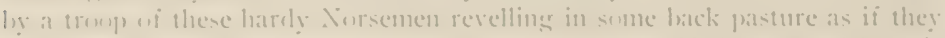

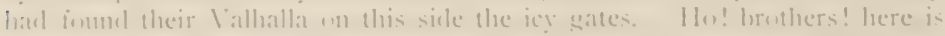

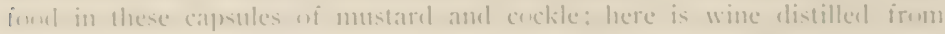

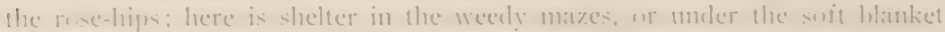

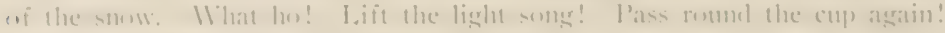
I.et mighty cheer prevail!" ( Birds of ( )hin).

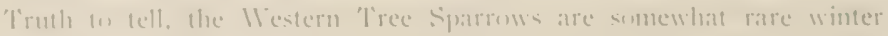

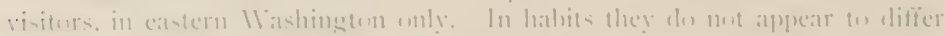

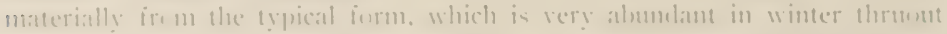

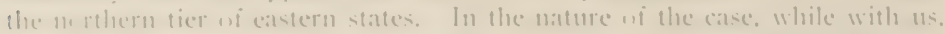

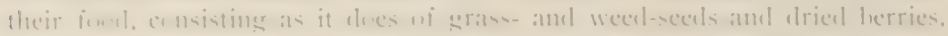

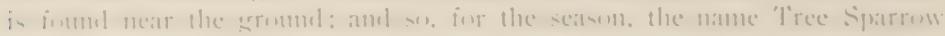

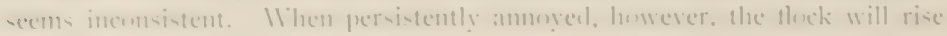


to the tree-tops in straggling fashion, and there either awat the withdrawal of the intruder, or else make off at a good height.

The song of the l'ice Sparrow is sweet and tuneful, affording a pleasing contrast to the monotonous ditty of the V' Snatches of song may be heard, incleed, on alnost any mild clay in winter: but the spring awakening assures a more pretentious effort. A common form rums. Sicielto, sacet. sacet, sacel, with notes of a most flattering tenclerness. But we may only gruess at the hird's full powers, for the homemaking is in Mlaska.

No. 50.

\section{WESTERN CHIPPING SPARROW.}

\section{A. O. U. Xo. 560 a. Spizella passerina arizona (Cones).}

\section{Synonyms.-Cirspr: HALR-IBIRD.}

Description.- idult: Crown bright chestnut; extreme forehead black with ashy median line: a light ashy superciliary stripe; lore and postoculat streak black: mulerparts and sides of head and neck ashy gray, dullest on breast and sicles, clearest on throat where nearly white: lind-neck and wings bluish ash, the former more or less streaked with blackish: back and scapulars light brown (isabella color) heavily streaked with black; wings and tail fuscons. I3ill dark; ieet light: iris brown. Joung birds are streaked with clusky above and below: and lack the chestnut of crown. Length of adult males: $5.00-5.50$ (127-I 39.7): wing 2.83 (72): 1ail $2.36(60)$; bill .39 (10) : tarsus .67 (17). "iemales smaller.

Recognition Marks.- Warbler size; chestnut crown and whitish stuperciliary distinctive.

Nesting.- Vest: A compract or eareless structure of fine twigs, grasses, and (most commonly and often exclusively) rootlets, heavily lined with horse-latir: placed in sage-bush, wild rose thicket or shrubbery, or else on horizontal branch of apple tree or evergreen. Liygs: 3-5, msually 4 greenish blue speckled freely. or in narrow ring about larger end with redelish brown and black. Av. size,

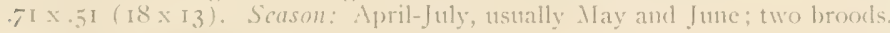

(ieneral Range.- Ilestern North Anerica fron the Rockics to the Coast breeding from the sonthern border of the Lnited States north to the lukon lalley in Alaska, cast over the western provinces of Canada; soutl in winter to .11exico anel Ionser California.

Range in Washington.-Common summer resiclent thruont the State clichly in setted prortions and more open situations.

Migrations.-Spring: Jakima, April 12, r600; Chelan, April 2.4. 1896: 'lacoma. April I2, Icg05. April in, Ionf.

Authorities.-Spiadla socialis lionap. Baird, Rep. l'ac. R. R. Surv. IX.

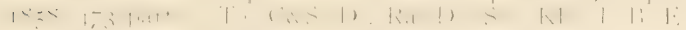

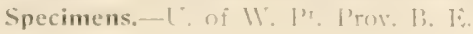




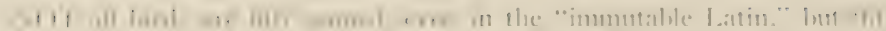

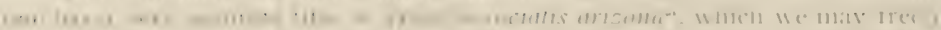

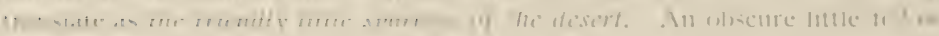

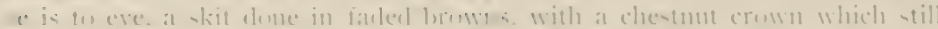

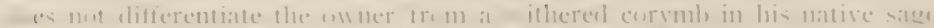

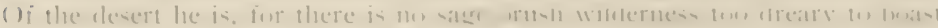

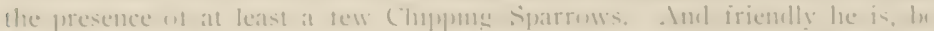

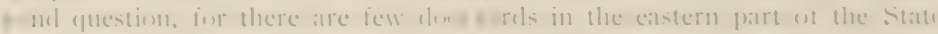

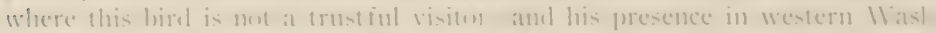
ingtum is nearly corextennive with thatl t man. low althes the chi onme

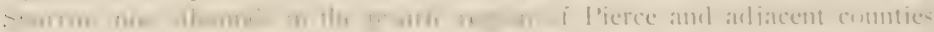

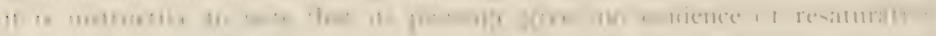

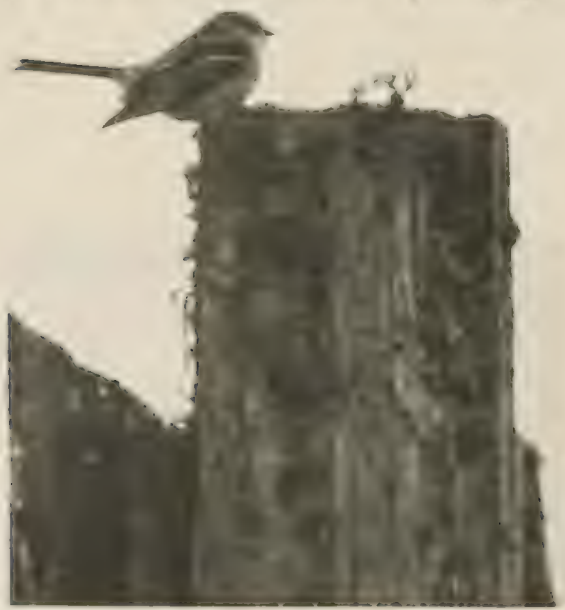

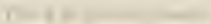

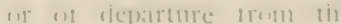
bileacleel type, as would bx

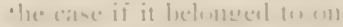

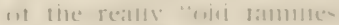

\section{I lillit. - ..}

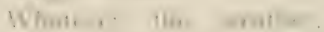

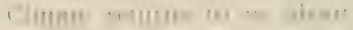

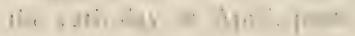
himself on the trp) (1) at til loranch. like a lrave litth Cloristmas camble. and int eecels to spmtter, in the sam part. ()i all homely - thilil the tmomotemens trill wi the II estern (hippoines Spartum is the most homels:- - ant the must casily forerioalse Is nusic it scareels rankalume the rattle wi cas tances: lont the little sines pours wnt his sulul tull carts

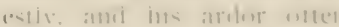

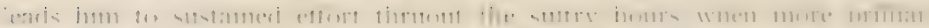

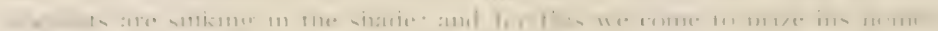

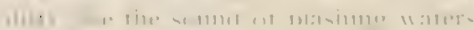

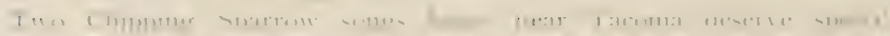

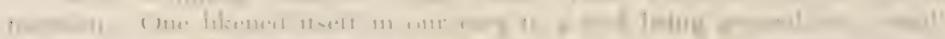

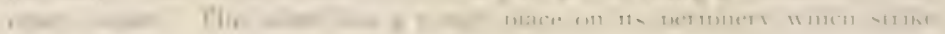


against the tool with additional force and serves to mark a single revolution, but the continuous burr which underlies the accented points, or trill-crests, is satisfied by this comparison alone. The other effort, a peculiar buzz of varying intensity, carries forward the same idea of continuous sound, but the comparison changes. In this the song appears to pour from the tiny throat withont effort, and its movement is as tho an monseen hand controlled an electric buzz, whose activity varies with the amount of "juice" turned on:

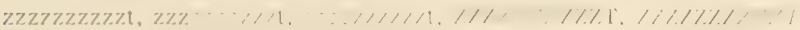

Chippy's nest is a frail affair at best, altho often elaborately constructed of fine twigs, rootlets and grasses with a plentiful lining of horse-hair. In some instances the last-named material is exclusively employed. A sagebush is the favorite situation on the planis of the Columbia, a horizontal fir branch in the wet comntry. Rose thickets are always poptuar, and where the bircl irankly forsakes the wilds, ormamental shrubbery and vines are

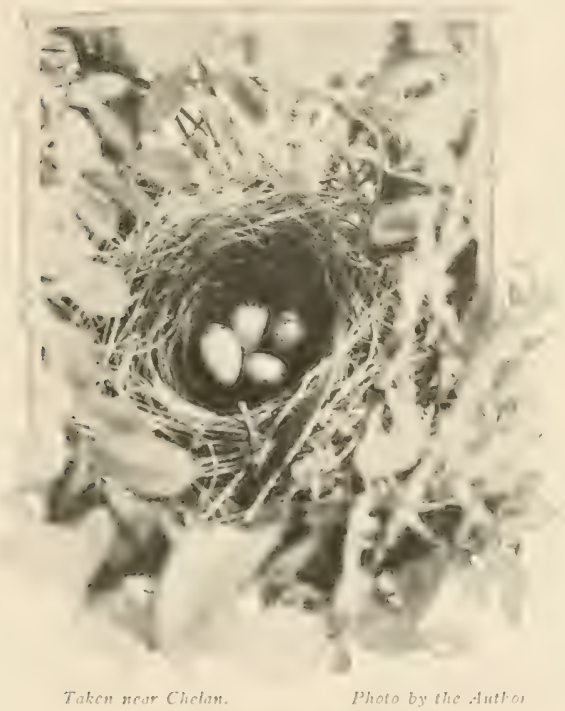

"IOCR OF THY: CTTESI chosen. 'l'he nests are often so loosely related to their inmediate surrotundings as to give the impression of having been constructed elsewhere. and then moved bodily to their present site. Some are set as lightly as feathers upon the tips of evergreen branches. and a heary storm in seasoni is sure to bring down a shower of Chippies' nests.

Eiggs are laid during the first or second week of Mlay in the vicinity of American Lake and from one to three weeks earlier in the sage country. They are among the most faniliar objects in Nature, and particular description of them ought to be mmecessary. But every person who knows that we are interested in birds las to stop as on the street to tell about the "cumningest little nest, you know, with four of the cutest __ "Hold on," we say: "were the egres blue?" "Yes," "With dots on them?" "Mhy, yes: how did you know?"

Incubation lasts only ten davs and two broods are raised in eacli season. 
Chifphing Sparrows are very devoted parents and the sitting fenale will seme-

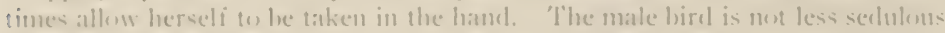
in the care of the young, and he smmetimes exercises a fatherly enersight of the lirst batch of ballies. While his mate is preparing for the funce crops.

No. 51 .

\section{BREWER'S SPARROW.}

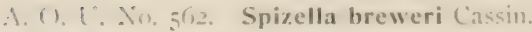

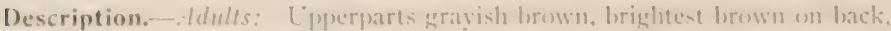
cverywhere (salve on remiges and rectrices) streaked with black or dnsky, narrow1y on crown, more hroally on lack and scapulars, less distinctly on rump: wingeoberts and tertials varied by edgings of brownish buff; fliglu-feathers and rectrices dark grayish brown or dusky with some edging of light grayish lorown; a broal gale lulfy superciliary stripe scarecty contrasting with surrombling - : underparts dult whitish tinged on siles and across hreast hy pale butiy eraty. [Bill pale

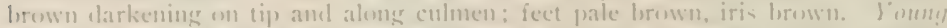
birels are less complemonsly streaked alowe: midelle and greater onverts broally tipped with buffy forming two distinct bambls: breast streaked with dor-ky.

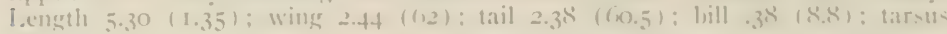
as $(17+4)$.

Recognition Marks.-Warbler size: eneral streakeel appearance: absom of distinguishing marks practically distinctive; sage-haunting habit:

Vesting.-. Yest: of small twigs and dried grasses, lined with horse-hair. set

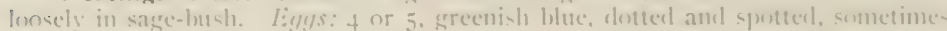

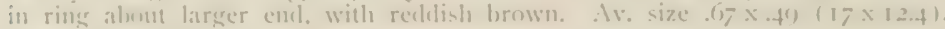
Seasun: Agril, Inne; two broods.

(ieneral Range.-Sage-brush plains of the 11 est, breeling iroms Arizona un

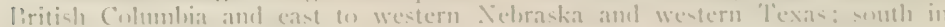
winter in .lexien and Iower California.

Range in Washington.-()pen country of the Liast-sile, abmulant - mmones resilent: ocensionally invales (ascalle. Tombants fonly in late smonner?).

Migrations. Sprim!: Vakima March 2i), lom,

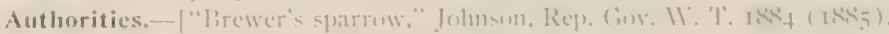

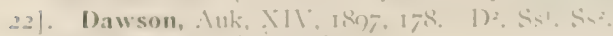

specimens.- (', if 11 . 1'. C.

I'l Is never quite bir to say that Xature produces a creature which harmenizes perfectly with its surromelings, for the moment we yield tribute uf arluniration to one ereature, we discoser andel the same circumstance anuther as nearly perfect hut entirely different. When we combicler the satge sparrow we think that dature cammot improve much mpun his aft grays hy was wi fitness for his desert enviromment: hut when we come upun the lirewer sparrow, we are rearly or wager that here the dame has dene her 
utmost to produce a bird of non-committal appearance. Mere brown might have been conspicuous by default, but brownish, broken up by liazy streakings of other brownish or dusky-call it what you will-las given us a bird which, so far as plumage is concerned, may he said to have no nark of distinction whatever-just hird.

The Sage Sparrow fits into the gray-green massy scheme of color har-

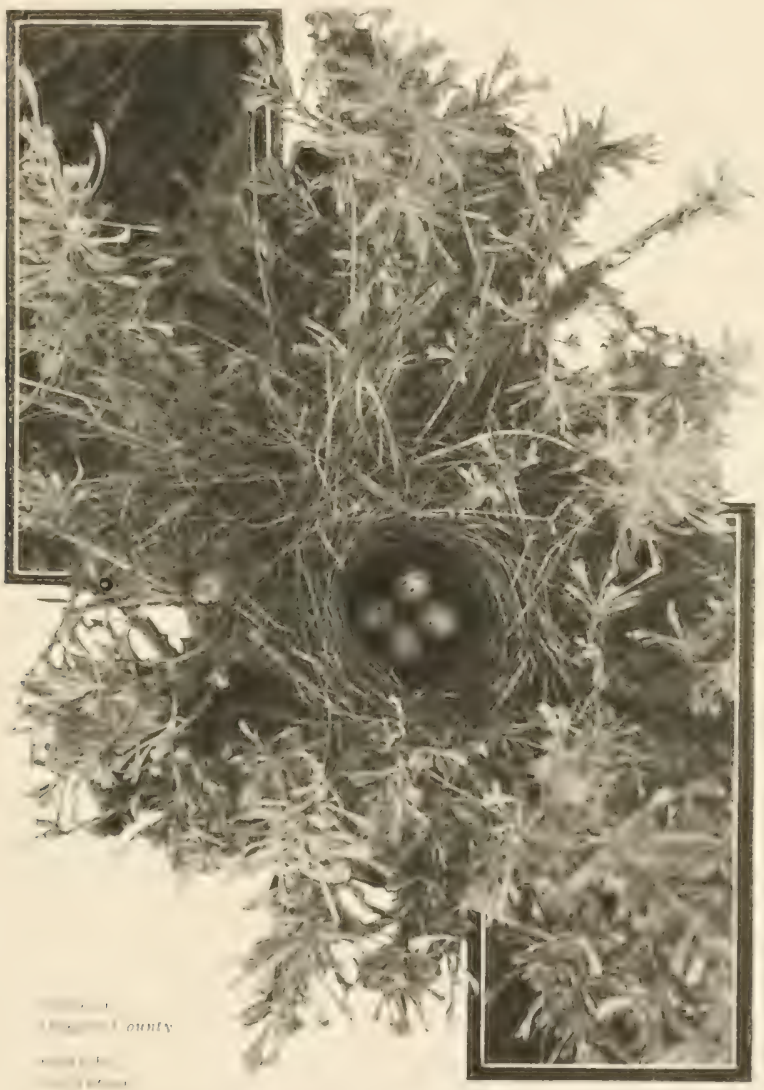

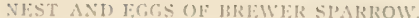


momy in the artemisia, while lirewer's tits inte the somber. brown-and-streaky

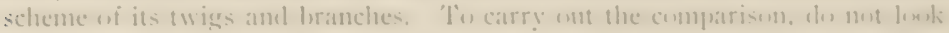

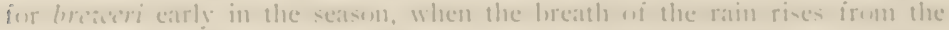

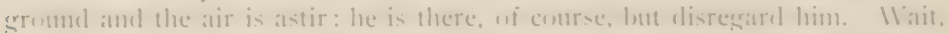
rather, until the seassm is alvanced, when the incomparalle sum eif latkinat

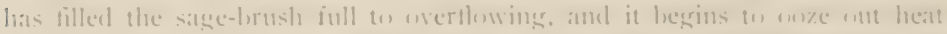

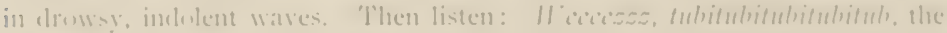
first part an inspired trill, amel the remanoler an expusisely modulated ex-

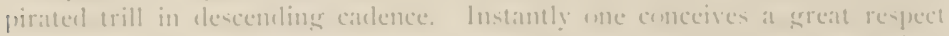

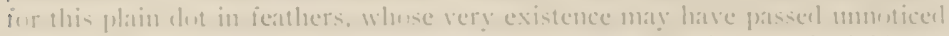

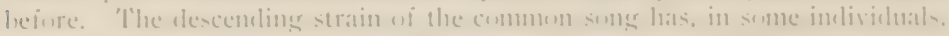
all the fine shather heard in certain imperted camaries. l'itch is concenterl In infinitesimal gratations. wherehe the singer, from some heaven w fancy.

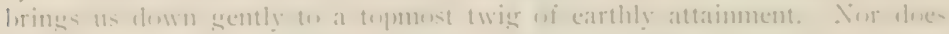

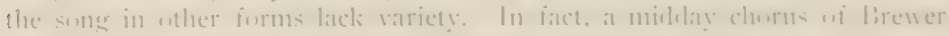
Spartmol is a treat which makes at tramp in the sage memmorable.

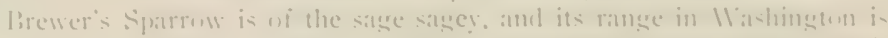

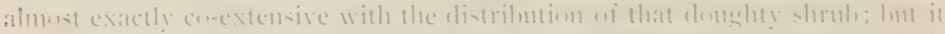

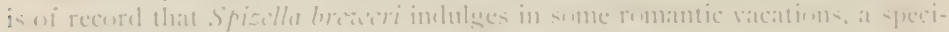

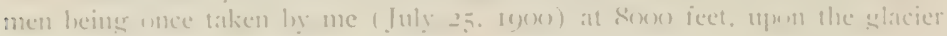
levels of 11 rightis l'enk.

Nio. 52.

\section{GOLDEN-CROII NED SPARROIV.}

1. (). [. Xin, 557. Zonotrichia coronata (I'all.)

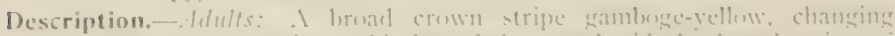

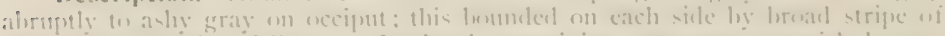

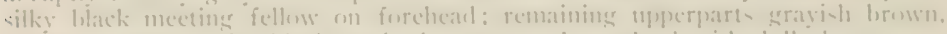

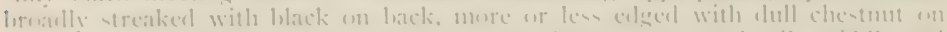

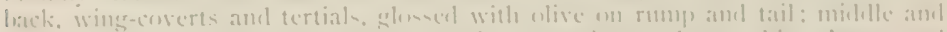

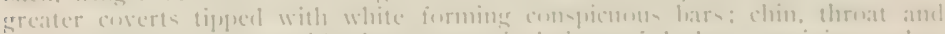

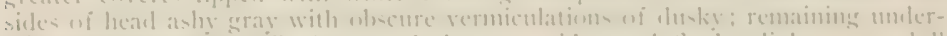

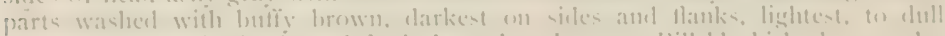

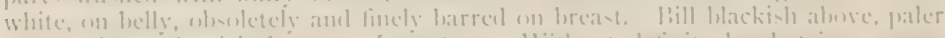

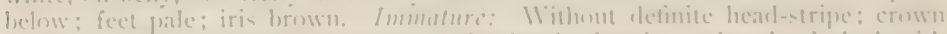

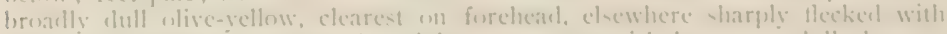
blacki-h in werlge-shaped narks, giving way fo grayish brown wr dull che-tume

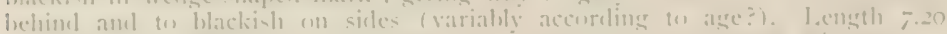

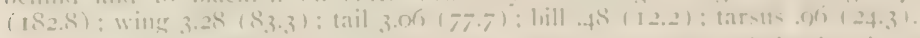

Recognition Marks.-Sparrow size: yellow of crown dintinctive in any plummge.

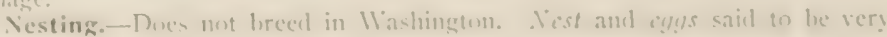
cinvilar to phose of \%. I. nuthalli. 
General Range.-Pacific Coast and Pering Sea districts of Alaska; south in winter thru the Pacific States to Lower California; occasionally straggles eastward.

Range in Washington.-Spring and fall migrant both sides of the Cascades, more common westerly.

Migrations.-Spring: c. April 2I (West-side); c. May 20 (Chelan).

Authorities. - Limberiza atricapilla Aud. Orn. Biog. I. I839, 47 ; pl. 394. Baird, Rey, I'ac. R. R. Surv. Vol. IX. I858, 462. CES. L2 . D. Ki. Ra. Kk. B. E. Specimens.-U. of 11 . Prov. E.

REG AL tho he be, this sparrow is discreet in the matter of appearances, and does not cultivate the public eye. Washington is only a way-station in lis travels, and the splendors and liberties of court life are reserved for Alaska. Appearing at 'Tacoma during the last week in April, demure companies of Golden-crowns may not infrequently be seen associated with migrating Nuttalls. 'They are in no hurry, or perhaps the haste of midniglit flight is over when we see them yawning sleepily in the bushes of a morning. 'They are languid too as they deploy upon the park lawns, always within reach of cover, in search of fallen seeds or lurking beetles. Their leisurely movements contrast strongly with the lunsting activities of the local Nuttalls: for the latter are burdened with the care of children, before the Maskan migrants have forsworn bachelorhood. East of the Cascade Motmintains the northward movement of this species is even more tardy, and May i $8-22$ are the dates at which I have recorded it at Chelan.

Migrating Zonotriclias are all coquettishly retiring, ancl the first lint of danger sends them scuttling into the bushes. If one presses up to the edge of the brusli, he may hear an uncanny rustling among the leaves and branches as the birds retreat, but not a single note is uttered. Left to themselves, the birds beenme sociable with many zinks common to the genus: and, if unusually merry, the Golden-crowns indulge a sweet, preparatory hoo hec which reminds one of both the White-crowned (Z. lencophrys) and Whitethroated (\%. albicollis) Sparrows of the East: but the song has never heen completed here to our knowledge.

Suckley said that Golken-crowned Sparrows were abundant in summer both at Fort Dalles and Fort Steilacoom, but this was undoubtedly a mistake, as the recorels of allegred nesting in Califormia proved to be. On the other hand they may winter with us to some extent, since Mr. Bowles took a specimen on December I6, 1907, in the Puyallup Valley: 
No. 5.3.

\section{(;AMBEL'S SPARROW'}

\section{A. (1. L. No. 55t a. Zonotrichia leucophrys gambelii (Nuttall).}

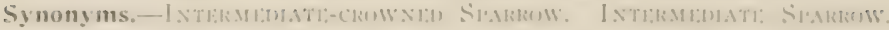

Description.- Julls: Crown pure white, lecoming graty lechinel; lateral crowestripes meeting in frome, and post-neular stripes, jet blick, separafed by white stripe contmusus with lore; rensameler of head, neck all around, and entire umberparts slaty gray, darkest on nape, whitening on chin and belly, with a tawny wash on tlanks and crissmm; hack and sapulars brown (burnt umber) eflgerl with gray: rump and upper tail-eoterts tawny olivacenus; wings and tail fuscous, the tertials dark-centered with edeinge uf las and white; middle and greater coverts tipped with white, forming two inconspicunts wing-hars; rectrices with brown shafts and tawm edgings, bill redilish bown alkese, saffron rellow bekws, with tip of maxilla black. Jumne of the vear loase the black of heat

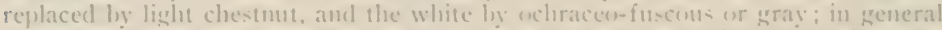

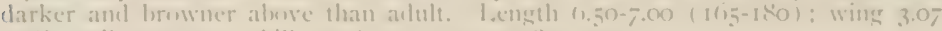

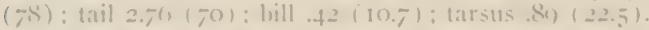

Recognition Marks.-Sparrow size: broal white crown amel jet lilack lateral strives stromgly commating: sightly lareer and general eoluration lighter than in Z. 1. mullalli: white crown-stripe irmater.

Nesting.- Is next; not known to brees is Washington but probalily does sn.

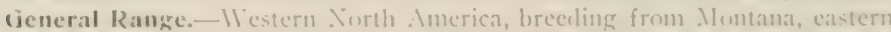
Oregotl, efe., morthward between const motntains of liritish columbia and . laska and the interios plains to the lower. Mackenzic and Anderson River Valleys thence westwarl thruout . Maska to the coast of liering Sea; in winter sunthward across western United States into Ifexien and Inwer California, straggling eastward acrous the (ireat I'lains.

Range in Washington. - Mumbant spring and fall migrant on the liast-side, pinsibily smmmer resident; cloubtless migrant west of Cascades, lut mo specinens taken.

Migrations.-Spring: April 20-11ay 20. Wallula, April 24, $14 x) 5$; Chelan, April 24. 18 fro: Brook lake, June 7 . Imps.

Authorities.-Frimgilla gumbelii Nuttall, Man. Orn. L. S. \& Camada, 21

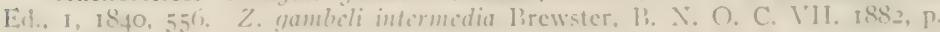
22\%. I)! Sr. 1): Kk. I

specimens.-U. of W. C. I?

I'T IS probably safe to say that during the height of their spring migratims, viz. April isth to May igth, these hirels exeeel in numbers all the nther sparrows of eastern Washington combined. Indeed, on certain occasions, it would seem that they are mure mumerons than all other birds comhined. Anel this altho they do not move in great foncks in the open, like lierlpulls, hut thit and skulk wherever there is show of cover. Wingside thicticts, spring traws, and the timbered banks of streams are fatorite places. The more ismlaterl the cover the more certain it is on he held as a \%nmotrichian 
stronghold, and they are sometimes so hard put to it for shelter that they resort in numbers to the sage-brush, where they affect great secretiveness.

These handsome and courtly gentlemen with their no less interesting, if somewhat plainer, wives are far more reserved than their talents would warrant. Our approach has sent a score of them scurrying into cover, a neglected rose-briar patch which screens a fence, and now we cannot sec one of them. An occasional sharp dink of warning or protest comes ont of the screen, or a suppressed titter of excitement, as two birds jostle in their effort to keep out of sight. We are being scrutinized, however, by twenty: pairs of sharp eyes, and when our probation is ended, now one bird and now another hops nip to an exposed branch to see and be seen.

What distinguished foreigners they are, indeed, with their white crowns, slightly raised and sharply offset by the black stripes which flank them,Russians, perhaps, with shakos of sable and ermine. 'The bird has an aristocratic air which is ummistakable; and, once he has deigned to show himself, appears to expect deference as his due. What a pity they will not make their homes with us, lut must needs go further north!

As diligently as I have searched for this species, I have never found a specimen in the summer montlis $\mathrm{s}^{\mathrm{a}}$, nor is there any record of the bird's nesting in Washington. 'This is the more remarkable in that the type form (Z. lencophrys) breeds extensively "thruout the high mountain districts of the western United States" (Ridgway), exclusive of WVashington and Oregon, southward to the San Francisco Mountains of Arizona, "northward to northern California (Momt Shasta, etc.)." In view of this, nne may feel free to suggest that the Camp Harney record ${ }^{b}$, referred to gambelii, is really referable to the typical form, and that as such it represents a northern extension of leucophyys, rather than a southern extension of gambelii.

No. 54 .

\section{NUTTALL'S SPARROW.}

A. O. [ : No. $55+$ b. Zonotrichia leucophrys nuttalli Ridgw.

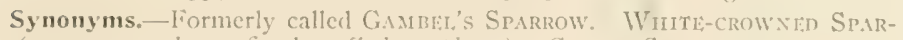
kow (name properly confined to Z. lencophry's). Crown SPArRow:

Description.-Adults: Like preceling but general tone of coloration much darker ; streaks of back and scapulars deepest brown or blackish; general groundcolor of upperparts light olive-gray; median crown-stripe narrower, dull white;

a. I'ntil the season of toos. See nute under "Migrations."

b. "(?) liendire, l'roc. liost. Sieg. X. II. XIX., 18\%, 118 (Camp IJarney, e. Oregon, brecding)" (Riligway). 


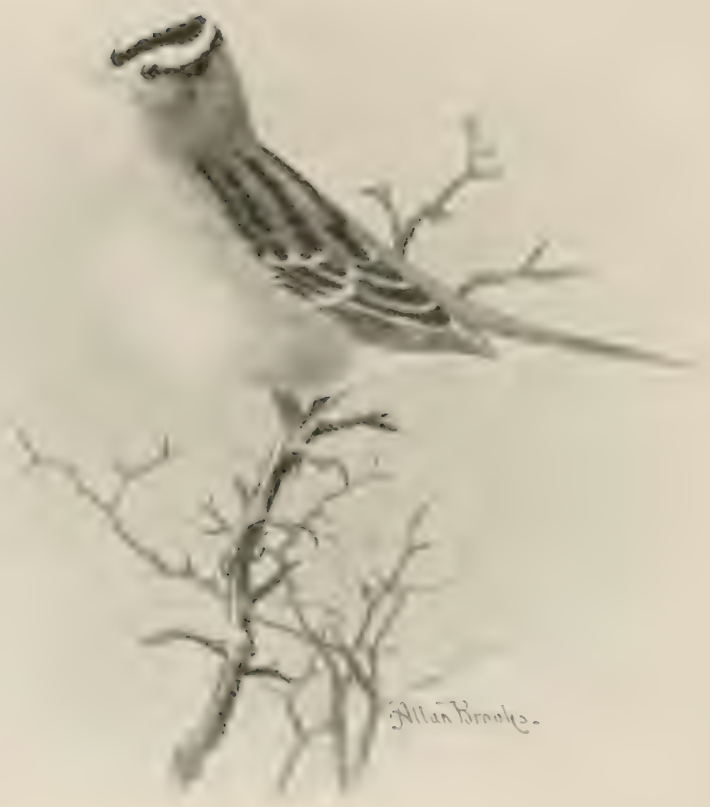

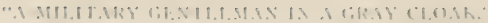

molemare more stromely wasleel with brownish gray: axillaries and bend of wing nure strongly yellow: bill yellewish with dark tip. Immalure: Somilar to that of preceling form, lut molerparts yellowish: upperparts light olive loufi: croma-stripe cimmamomeons, or gale clestnut. firy yeune lirels are more

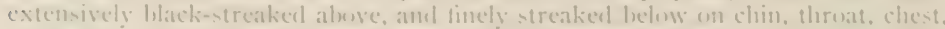
and sirles: bill hrighter yellow: feet paler. length of alult males, 5.80-6.70

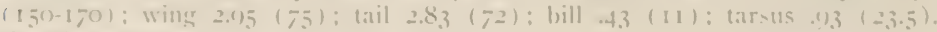
finmales maller.

Recognition Marks.-Sparrow size: black-amel-wlate striping of erown distinctive in range: much darlier than preceding.

Vesting.- list: on ground or low in husles: rarely in trees up to 25 feet : a mather pretentious structure of hark-strips, dead grass, and rootless. Wuth a 
lining of fine dead grass and horse-hair; measures externally 6 in. wide by 4 deep: internally $2 \frac{1}{2}$ wide by I deep. Liggs: 4 or 5 , pale bluish white, profusely dotted and spotted, or blotched, with varying shades of reddish brown. $\lambda \mathrm{v}$. size $.86 \times .64(21.8 \times 16.3)$. Season: Last week in April, and Nay 25-June 10; two brookls.

General Range.-Pacilic Coast district, breeding from Monterey, California, to Fort Simpson, [3ritish Columbia; south in winter to San l'cdro Martir Mountains, Lower California.

Range in Washington.-Of general distribution west of the Cascade . Nomntains at lower altitudes; casmally winter resident.

Migrations.-Spring: March 25-April 1.

Authorities.-Z. gambelii Gambel, Baird, Rep. Pac. R. R. Surv. IX. I858, 46r. (T.) C\&S. L (?) L2. Rh. Kb. Ra. Kk. B. E.

Specimens.- $\mathrm{U}$. of $\mathrm{IV}, \mathrm{I}$. B. BN. E.

WIEN you enter a lit of slumblery at the edge of town in May or Jume, your intrusion is almost sure to be questioned by a military gentleman in a sray cloak with black-and-white trimmings. Four business may be persomal, not public, but somelow you feel as if the atthority of the law had been invoked, and that you would better be careful how you conduct yourself in the presence of this military person. Usually retiring, the Nuttall Sparrow comrts exposure where the welfare of his family is in question, and a metallic scolding note, zink, or d $\approx$ ink, is made to do incessant service on such occasions. A thoroly aroused pair, worms in beak, and crests uplifted, may voice their stuspicions for half an hour from fir-tip and brush-pile, without once disclosing the whereabonts of their young.

Nuttall's Sparrow is the familiar spirit of brush-lots, fence tangles, herry patches, and half-open situations in general. He is among the last to quit the confines of the city before the advancing ranks of apartment houses and sky-scrapers, and he maintains stoutly any vantage ground of racant lot. clisordered hedge-row, or neglected swamplet left to him. After the Rusty Song Sparrow, he is perhaps the commonest Sparrow in western IVashington-munestionably so within the borders of settlement.

As a songster this Sparrow is not a conspicuous success, altho he works at his trade witl commendable diligence. He chooses a prominent station. sucli as the topmost sprig of a fir sapling, and holds forth at regular intervals in a prosy, iterative clitty, from which the slight musical quality vanishes

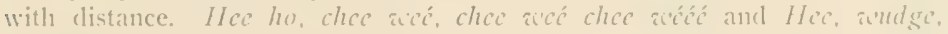

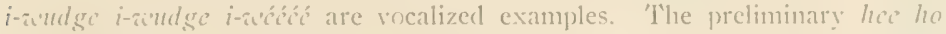
is sonetimes clear and sweet enougl to prepare one's ear for the Vesper Sparrow's strain, but the succeeding syllables are tasteless, and the trill with which the effort conclucles has a wooden quality which we may overlook in 


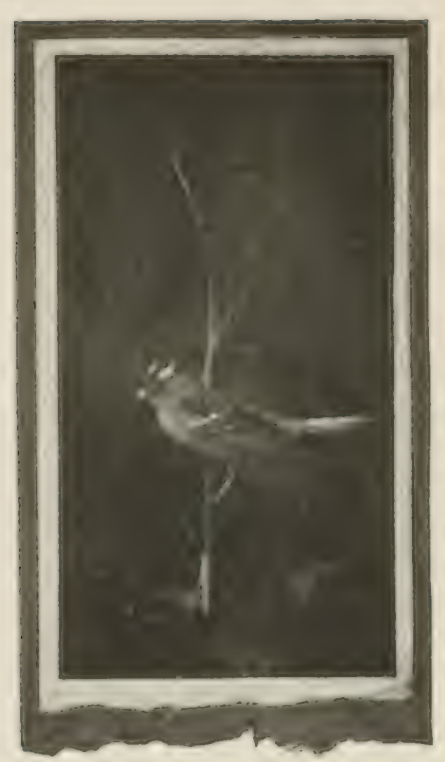

$+1$

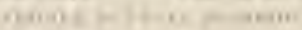

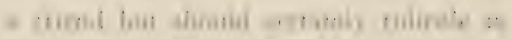

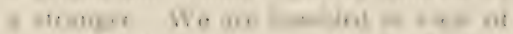

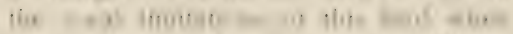

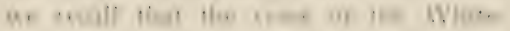

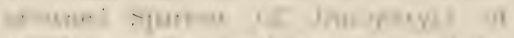

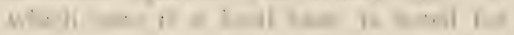

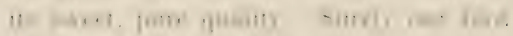

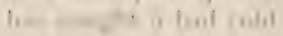

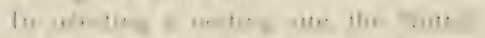

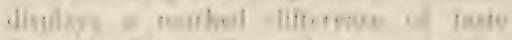

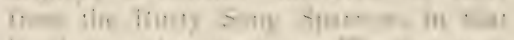

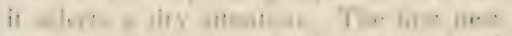

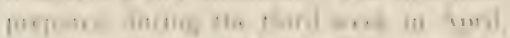

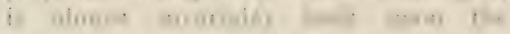

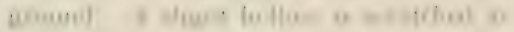

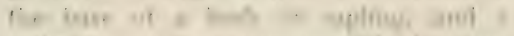

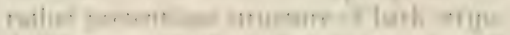

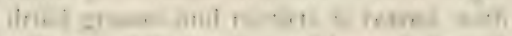

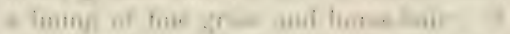

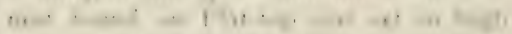

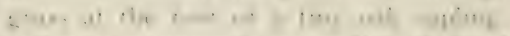

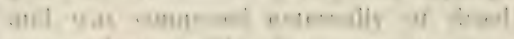

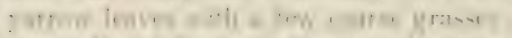

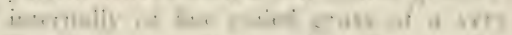

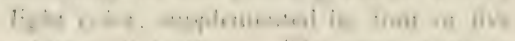

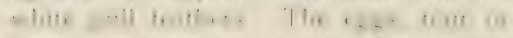

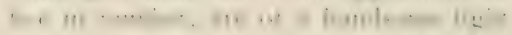

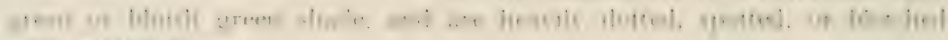

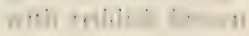

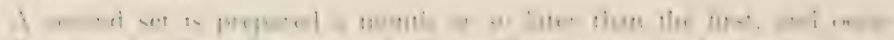

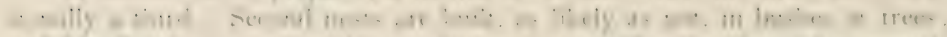

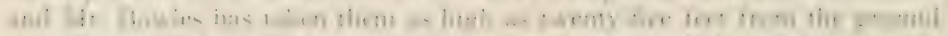

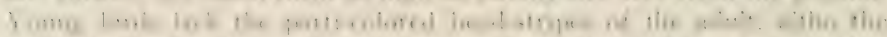

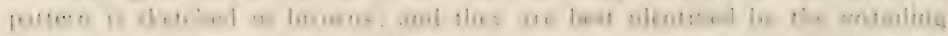

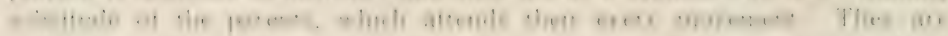

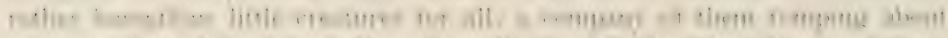

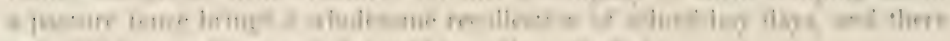

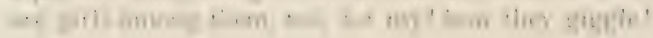


No. 55 .

\section{MOUNTAIN SONG SPARROW.}

A. (). L. . No. 58I b. Melospiza melodia montana (Henshaw).

Description? - Idults: Crown dull bay streaked with black and divided by asly-gray median stripe; rufous brown post-ocular and rictal stripes, enclosing erayish-brown auriculars; remaining upperparts ashy-gray varied by reddish brown, the gray due to broad edgings of feathers and occupying from one-half to two-thirds the total area according to season, feathers of back and scapulars sharply streaked with blackish centrally; wings and tail brown varied by minor markings and edgings of dusky, brownish gray and aslyy-gray; below white, or sordid, heavily strcaked on sides of throat, breast and sicles by blackish and rufous, markings wedge-shaped, tear-shaped or elongated, contluent on sides of throat as maxillary stripes and often on center of breast as indistinct blotch. 13ill horn-color above, lighter below; feet pale brown, toes darker; iris brown. Young: Like adults but duller, all markings less sharply defined, streaks of underparts narrower. Length of alult male (skins): 6.00 ( I 50); wings $2.73(60.3)$; tail $2.74(69.6)$ : bill . 48 (12.2) ; tarsus .88 (22.4).

Recognition Marks. - Sparrow size; heary streaking of breast and back, with saried houd markings, distinctive; lighter, grayer and more sharply streaked as compared with, $1 /$. m. merrilli.

Nesting.-As next.

General Range.--."Rocky Mommain district of the United States west to and inclucling the Sierra Nevala, in California; north to eastern Oregon, southern Idaho and southern . Montana: south in winter to western Texas and northern Mexico" (Ridgway). I'robably also north into British Columbia and southwestern Alberta.

Range in Washington.-Migrant and winter resident along eastern borders.

Authorities.-? Snorlgrass, Auk, XX. 1903, 207. IV. T. Shaw in cpist, Dec. 3т, 1008 . Sr?

Specimens.- I's $(32$ spec.).

WHE'THER or not the Song Spartows of northern Montana and eastern British Colmubia are typical montana, the doctors must settle; but certain it is that sparrows of a type decidedly lighter, that is, ashier, in coloration. than our merrilli, pass thru our eastern borders during migrations. Of such a bird, examined narrowly at Spokane on November 4, I905. my note-book says (comparing at every" point with merrilli): "Ashy gray and brown of head strongly contrasting: ashy of hack and scapulars very extensive, brown areas of feathers not exceeding one-third their total width: underparts clearer white: streaking lighter rusty and more sharply defined, more narow on sicles."

a. Based upon that of Melospiza melodis from which it differs slightly in proportions but chichly in

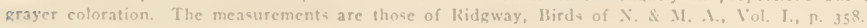




\section{No. $5 \%$. \\ MERRILL'S SONG SPARROW.}

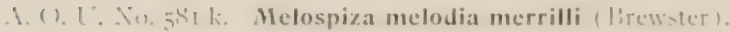

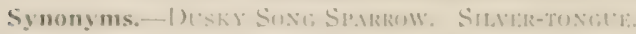

Description.-(hatacters intermediate letween thene of .16. m. monfeme and

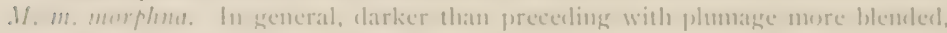
mopurtion of gray in lack abut one-third; lighter than nexe, not so brown. strakings mere distinet.

Nesting.- Vest: a subutantial structure of uwige, gratsess, eniled hark-strips.

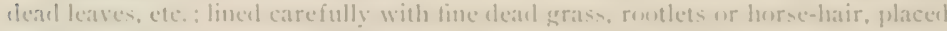

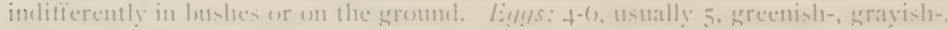
ur bluish-white, heavily spotterl and lilutched with redelish hrowns which some-

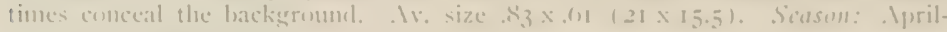
July: two ur three brouts.

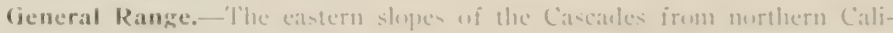

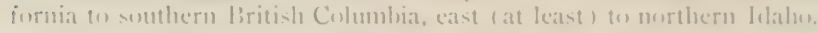

Range in Washington. - East-sile-theoretically inclusive. Sivecimens from the central valleys of the Cascacles may be called morphat and fhose from the P'alouse conutry montuma, at pleasure.

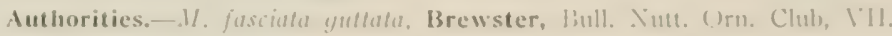

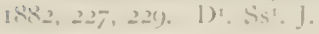

specimens.-I".

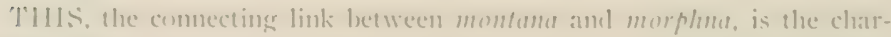
acteristic Somg Sparmw of eastern 1 atshingtom, and aboumels along timbered water courses and in all cultivated districts. While chosely resembling the Rusty song spartom of the Mest-sile, it maty be distinguished from it by the sharper coler jattern of its plumage: and the perints of diverenence from menhme are matntaned with substantial moifomity, at least alome the eatsern shopes of the Cascades, and in the mortern tier of counties.

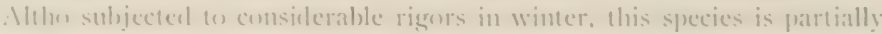

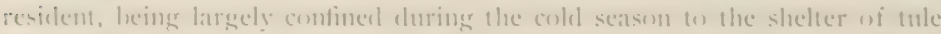

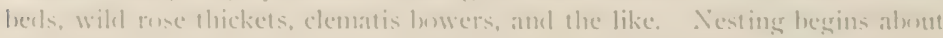
tice seconel week in April and contimes with undiminished arelor till July or Auguat. Inculation reguires ewelve days, and the young are reaty to lly in as many mure, so that a devoted pair is able (1) ratise there and somefimes funt lomels in a season.

Af this rate we shoukl he werrun with somg sparrows if there were nen sn many atgencies to hold the species in check. A young song sparrow 
is the choice morsel of everything that preys, - cats, skunks, wensels, chipmunks, Sharp-shimned Hawks, Crows, Magpies, Black-headed Jays, and garter snakes. How would this motley company fare were it not for the ammal crop of Song Sparrows? And the wonder of it is that the brave heart holds out and sings its song of trust and love with the ruins of three nesis behind it and the harvest not yet past.

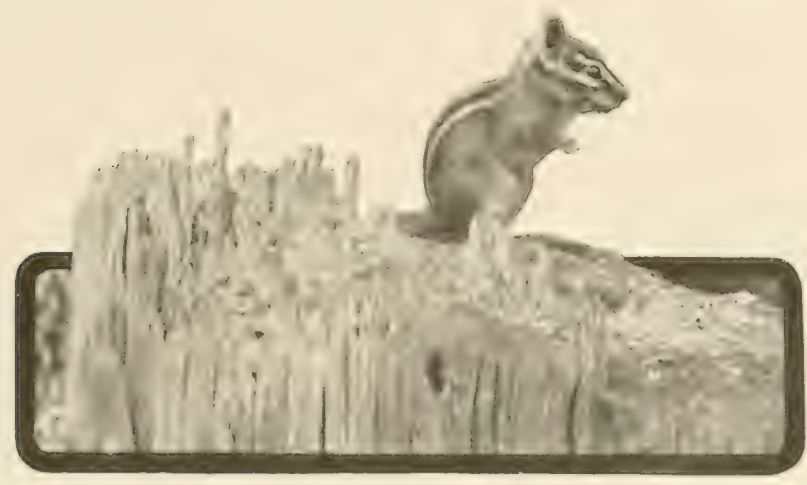

Taben in Oregon.

Whoto by A. W. Anthony.

. PRORIESIONM, OOLOGIST.

A litte glimpse of Nature's prodigality in this regard was afforded by a pair which nested on my grouncls in the Ahtanum Valley. On the fth of June I cance upon a nest in a rose bush, containing fotir young just latelexl, and these almost immediately disappeared-a seconcl. or possibly a thircl, attempt for the season. On July fth in an adjoining clump the same pair was discorered with three well-fledged young, which, for aught I know, reached days of self-elependence. On July $2 f^{\text {th }}$ a nest was foumd some twenty feet away containing four eggs, which I knew, both by the familiar notes and by elimination, to belong to this pair: but the nest was empty on the day following.

At the begimning of the senson nests are frequently made upon the ground uncler cover of old regetation, or at the lase of protecting bush clumps in swamps. Occasional ground nests may also be found thrunut the season. One seen at Stelekin on August. 30 was nestled loosely in a recumbent potato vine. At other times any situation in bush or tree, up to twenty feet, is acceptable, if only within convenient reach of water. A 
Bavorite building ste is amid the debris of last year's thoul water. camght

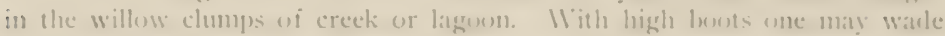
the beel of a brusly creck near lakinn ankl connt certanly on limeling a Merrill song spatrow's nest every five or ten rods.

No. 57.

\section{RUS'TY SONG SPARROW.}

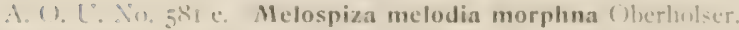

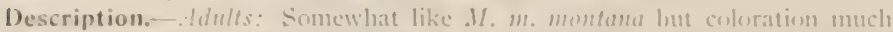

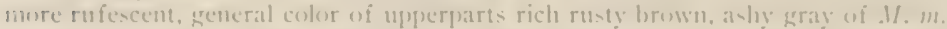

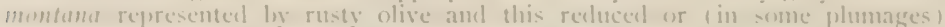
almost wanting; black mesial streaks of scapulars, efc., much refuecel, indistenct or sometimes wanting; underparts leavily and broally streatical with chestmut usually withent black shaft lines: sides and tlanks washed with ulivacens. "Youm, slightly rufesent bister brown aluse, the lack streaked with blackish. hemeatle dull whitish or very pale butiy gravish, the che-t, sides and thanks more or less tinged with buffy or pale fulvous and streaked with sooty brownish"

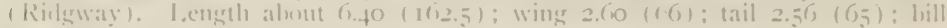
$.50(12.7)$ : tarsus $.17,(1,7)$.

Recognition Marks.-Sparrow size; rusty brown coloration; heavily spottinge of underparts distinctive save for the l'assirella iliaca group from which it is further distinguished by smaller size and varied head markings.

Vesting.-. Vest: Is in precerling. Eimgs: nsually 4. averaging tartier in chloration and larger than in $.1 \%$. m. merrilli. Av. size, $87 \times 6.63$ (22.1 $\times 16$ ). Sidsent: secomel week in April to July: two or three broods,

(ieneral Range.-"lireeding frem extreme sonthern portion of Alaska through liritish Columbia (including lancouver Island) to western Oregon soorth of Rengue River Mountains): in winter, sonth to southern (alifornia (Fort "Tejon, elc. )" (Rideway.

Range in Washington.-Common resilent west of the Cascarles: innmel elictly in vicinity of water.

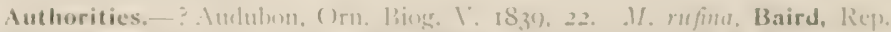

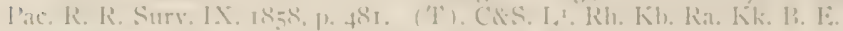

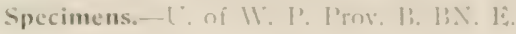

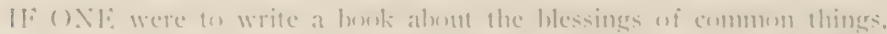

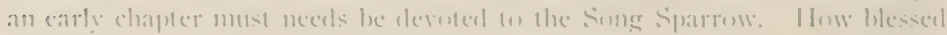

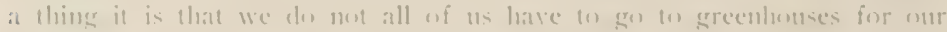

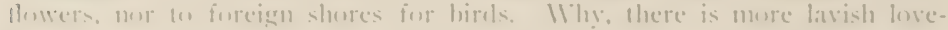

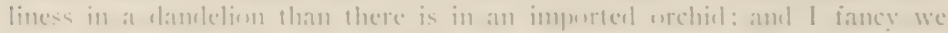
Gombl tire of the Nightingale, if we hat fo exchange for him une sweet

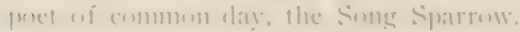


Familiar he certainly is; for while he las none of the vulgar obtrusiveness of Passer domesticus, nor confesses any love for mere bricks and mortar, there is not a weedy back lot ontside of the fire limits which he has not gladdened with his presence, nor a disordered wood-pile or brush-heap which he has not explored. Much lurking under cover in time of rain has darkened his plumage beyond that of the eastern bird, and close association with the fallen monarchs of the forest has reddened it, mutil he limself looks like a rusty fragment of a mouldering fir log.

It is as a songster, however, that we know this sparrow best. Silvertongue's melody is like stunsline, bountiful and free and ever grateful. Mounting some bush or upturned root, he greets his childish listeners with "Pcace, peace, peace be unto you, my children." And that is his message to all the world, "Peace, and good-will." Once we

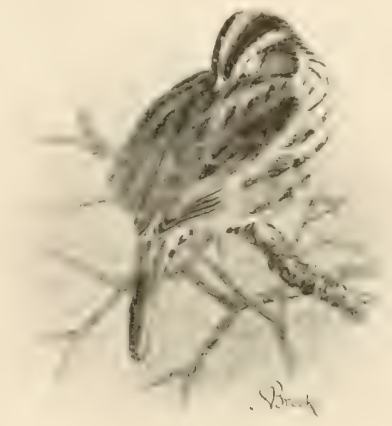

SONG SPARROIV ASTIFEP sat stombound at the mouth of our tent, and, mindful of the unnsed cameras, grumbled at the eternal drizzle. Wheretipon the local poet flitted to a favorite percli on a stump hard by, and, throwing back his head, sang, with sympathetic earnestness, "Cheer 11p! Cheer up! Count your many" mercies noz"." Of course he did say exactly that, and the childish emphasis he put upon the last word set us to laughing, my partner and me, until there was no more thought of complaint.

Even in winter the brave-hearted hircl avails himself of the slightest pretext - an hour of sunlight or a rise of temperature-to mount a bush and rehearse his cheerful lay. The song is not continums, but it is frefuently repeated thru periods of several minutes, and is followerl by little intervals of placid contemplation.

Bat no matter how gentle a bird's disposition may be, there is ample use. alack! for the note of warning and clistrust. When, therefore, the Song Sparrow's nesting haunts are invaded, the bird emits a chip or chirp. still musical, indeed, but very anxious. In winter the resident birds deny themselves even this characteristic cry: and, except for the occasional ontbursts of full song, they are limited to a high nasal t.ss, which seems to serve the purpose of a flocking, or recognition, call. Song Sparrows are mot really gregarious birds; nor are they even seen in close proximity save 


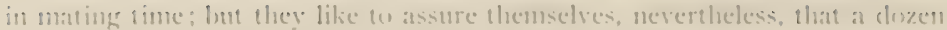
of their fellows are within call agatinst a time wi neerl.

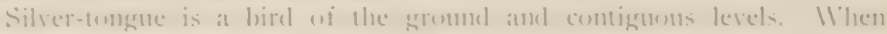

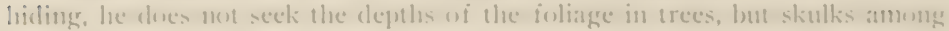

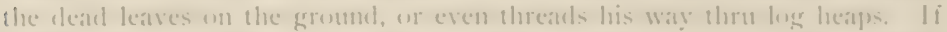

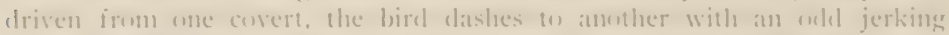
highn, working its tail like a pump-hanulle, as tho to alssist progress. (Jroli-

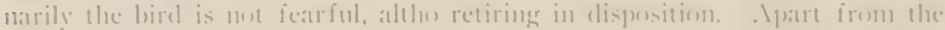

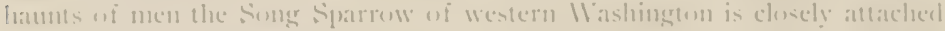

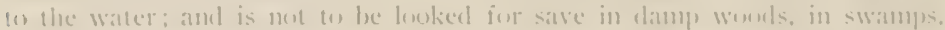

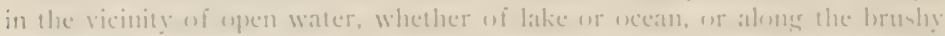
margins wi streams. Inelecel, its habits are beginning to assume a slighty

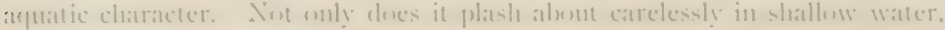

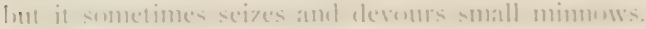

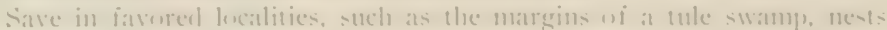

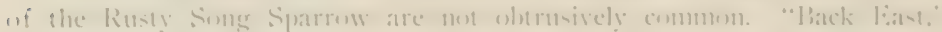

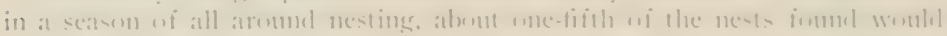

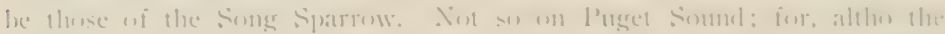

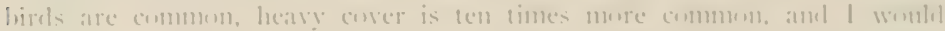

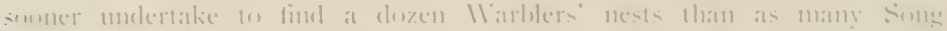

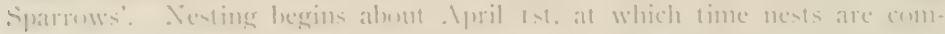

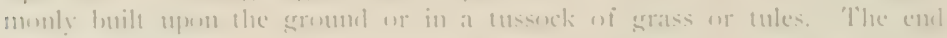

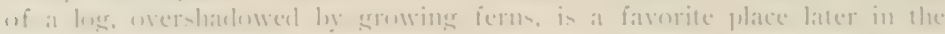

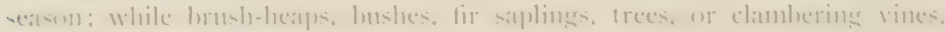
steh ats ive and clematis. are mot desprised.

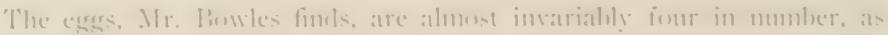

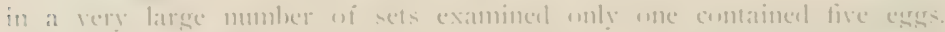

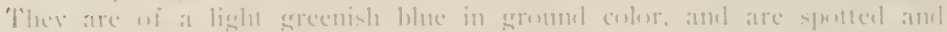

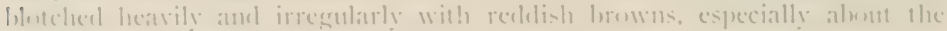
larerer emil. Sereral bromels are raiserl each seasom.

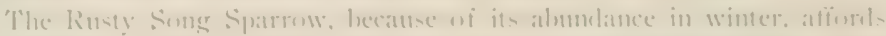

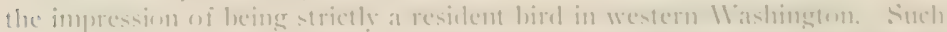
mav le the case with a majority of the individuals. lut there is still evielenee

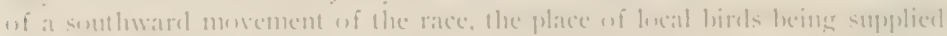

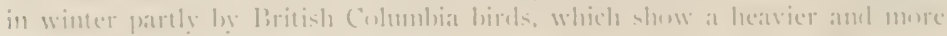

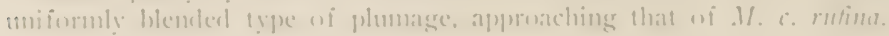


No. 58 .

\section{SOOTY SONG SPARROW.}

\section{A. O. U. No. 58 I f. Melospiza melodia rufina (Bonap.).}

Description.- Similat to $M$. $M$, morplna but larger and with coloration darker, more blended; general color of upperparts deep sooty brown or bister, brightening on greater wing-coverts and tertials; back obscurely streaked with darker; median crown-stripe obsolete or at least indistinct; streaking of mnderparts dark brown. Length 6.50 ( I 65$)$ or over; wing 2.75 (70); tail $2.64(67)$; bill .48 (12.3); tarsus .92 (23.5).

Recognition Marks. - Sparrow size; dark brown coloration; plumage of upperparts blended, almost uniform. Requires careful distinction from Passerclla but is smaller and variegation of head still traceable.

Nesting.-As in preceding. Does not breed in Washington.

General Range.- "Southern Alaska (islands and coast); north to Cross Sound, Glacier Bay, Lynn Canal, etc.; sonth to north side of Dixon Entrance, in winter to coast of British Columbia, Vanconver Island, and northwestern Washington (Olympic Mountains)" (Ridgway).

Range in Washington.-Winter resident in northwestern portion of Statenot common.

Authorities.-M. cinerea mfura (Brandt), Ridgway, Birds of North and Mirille America, Vol I. p. 374. E.

Specimens.-Prov. E.

THESE larger and darker birds reach our northern borders in winter only, having retired thus far from their home in southern Alaska. 'Their deneanor while with us is even more modest than that of the local Silvertongue; and when one is stalking the dank woods of Whatcon Comnty on the qui a'ir' $c^{\prime}$ for varieties, it reruires a second glance to distinguish this Song Sparrow, with its softy blended plumage, from a winter Fox Sparrow:

No. 59.

\section{LINCOLN'S SPARROIV.}

A. O. U. No. 583. Melospiza lincolnii (Atrl.).

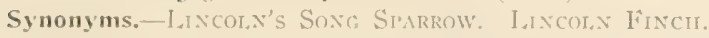

Description.- Idults: Alove, much like 1I. melodia montana, but crown brighter rnfous, and with more decieled black markings; back browner and more broadly and smartly streaked with black; the gray of back sometimes with a bluish and sometimes with an olivaceous tinge; below, throat aml belly white, the former never suite inmaculate, but with small arrow-shaped black marks; sides 
uf heal and nock and remaining underpars creamy lutf, everywhere marked by clongated and sharply delined black streaks: m-nally an alorupt dowky spot on

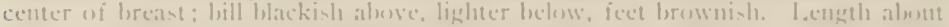

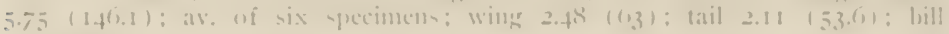
.f() $(10,2)$.

Recognition Marks,- Ilarbler size; bears general rencmblanec w Song

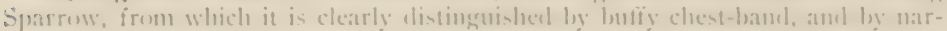
row, sliarp streaks of hreast and sides.

Vesting. - Vist: much like that of Kusty Song Syarrow, uf dricel grames.

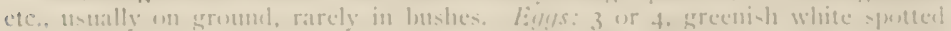

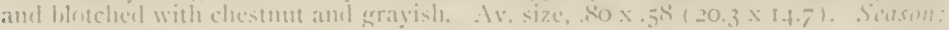
Junc, July; two (?) bromels.

General Range,- North Anerica at large breeling chefly merth wi the [nited States (at least ats far ats the lukon lalley) and in the higher parts of the lincky Momntains and the Cascate-Sierras; suth in winter to l'anama.

Range in Washington.-lmperfecty made out-probalsly not rare yoring

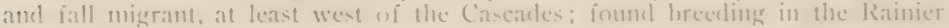
National l'ark.

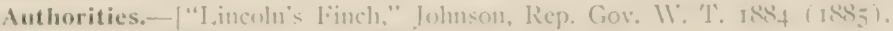
22.] Bowles and Dawson, Ank, XXI. ()et, 1908, p. 483.

specimens.-(1'. of II: ) l'rny. I'.

MOI)lis'l'I is a beatiful trat, and, I suppuse, if we hat always to chonese between the hrazen arrogance of the Linglish Sparrow and the shy timornusness of this hird-afraicl-of-his-sharlew, we slunuld feel obliged to aecept the latter. Put why should at hirel of such inconspicuous color steal silently thru our forests and slink alung our streams with baterl breath as if in mortal dreat of the human eye? Are we then such holgghblins:

Therice only have I seen this bird, and then in morthern ()hive. ()n the first necasion two of us followed a twinkling suspocion along a shadewy

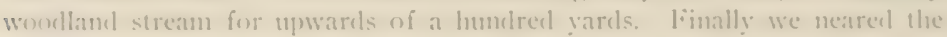
edge of the wools. 'There was light! exposture! recognition! IVtits an inwarel erroan the flitting shape quitted the list brush-pile and rose twenty feet des at tree-limb. Just an instant-lut ennugh for cur purpose-and he had whiskerl over our heads, hot-wing upun the dusky loack wail. 'That same Way day we came upon a litte comprany of these sparrows halted by the forbideling aspect of Latke lirie, and dallying for the mone in the dense thickets which skimerl a slugerish tributary. Here they skulked like moles, and it was only ly patient encleaver that we were able th cut nut a single birel and constman it in intermittent expmstre at the edge of the stream. Here, at intervals. from the npposite bank. we eagerly fork mote of its hearstripes, pale strealeerl brenst, and very demure airs, and listened to smatches ni a sweet hut very weak song, with which the hird fasored us in spite of 
our "persecution." Is it any wonder that the Lincoln Sparrow is so little known to fame?

While rated a regular summer resident of British America and Alaska, Lincoln's Sparrow has also been foumd breeding in the motntains of eastern Oregon, California, Utah, and Colorado. It ought, therefore to occur in Whashington; but we have only to shrug our shoulders and say with the lawer, non cst incentus. Indeed, the only positive record we have of the bird's occtrrence at any season is that of a specimen taken by A. Gorclon Bowles, Jr., in Wright's Park, Tacoma, May 22, I906.

So much penned in good faith in April, Igos. In June of the same year the good fairy of the bird-man piloted him to a spot where the Lincoln Sparrows were: so numerously and so thoroly at home, that he began to wonder whether he might not have been dreaming after all for the past quarter of a century. T'en or a dozen pairs were found occupying the wellknown swamp at Longnire's Springs. On the 3oth of Jume they were much more in evidence than the Rusty Song Sparrows, which occupied the same grassy fastnesses: and altho the females were not done waiting on overgrown babies, the males were loudly urging their second suits.

The song of the Lincoln

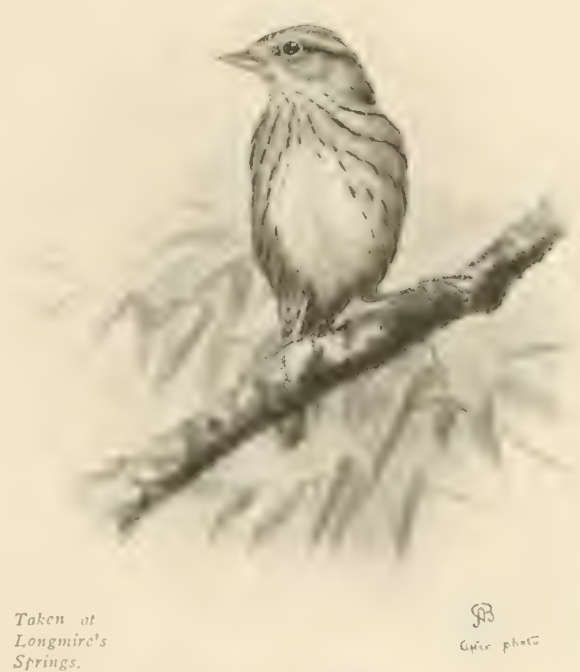

LINCOJA'S SONG STARLUIV.

ALLAN BROOKS AFTER PHOTO BY THE AUTHOR.

Sparrow is of a distinctly musical order, being gushing, vivacious, and wren-like in quality, rather than lisping and wooden, like so many of onr sparrow songs. Indeed, the bird shows a mucl stronger relationship in song to the Purple Fincl than to its immediate congeners, the Song Sparrows. 'The principal strain is gurgling, rolling, and spontatneous, and the bird has ever the trick of arlding two or three inconsequential notes at the end of his ditty; quite in approved Purple Finch fashion. "Linkup, 


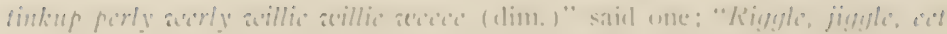

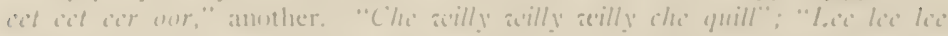
quilly ailly acilly:" and otluer such, came with full force and fresheses at at humbled vards to the listeners on the back purch at lomglnire's

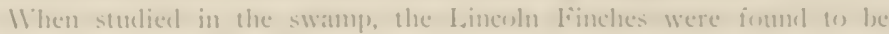
more reluctant than song sifarrows to expose themselves, but one pair, anxions for their young, sat ont against a clear sky again and again. 'The birl was seen excasionally to erect its comm feathers in infury or excite-

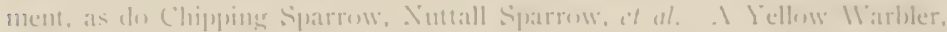

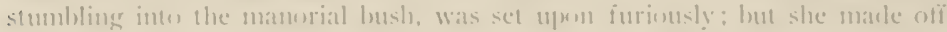
philosuphieally, linwwing that her punishment was after the accepted corle.

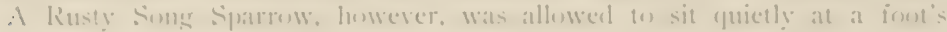

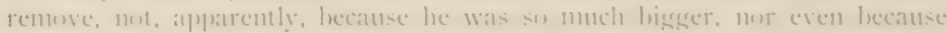
nearer of kin, lut rather lecatuse of common parental anxiety. The entrast

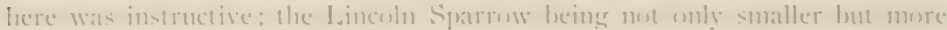
lighly colored and with a sharp-ent streakiness of plumage. I comparison uf many examples slomeed the smbitaty of leat pattern between the two

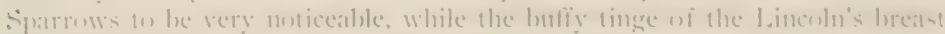
would appeat (n) he one of its least comstant marks.

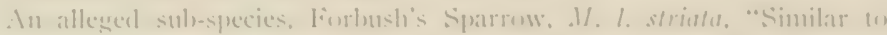
J. lincolni but superciliary stripes and upperparts mere strongly olivacens. and dark streaks especially on hack and upper tat-coverte conarser, blacker.

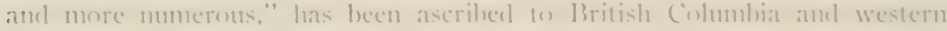
Ilashingtom, but the material at loanel is meager anel incenclusive, and the

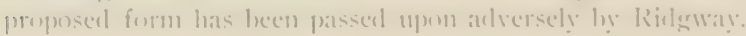

Nin. 60.

\section{KADIAK FOX SPARROW.}

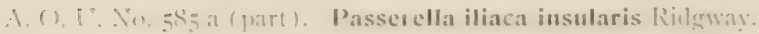

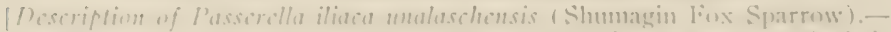
idults: "Pilem and himblneck hrownish erav or errayish lowwn fnearly hair hrown) pas-inge into clear sray (mouse gray or smelic gray) on superciliary

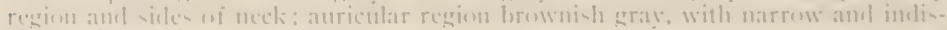

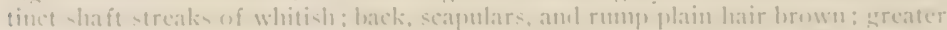

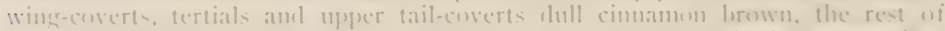

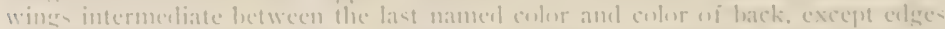
uf entermone prinbaries. which are pale hatr lorown: molerplarte white. the fore-

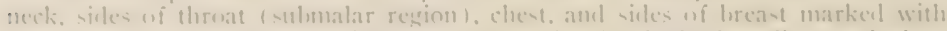

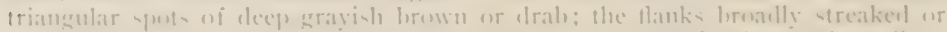

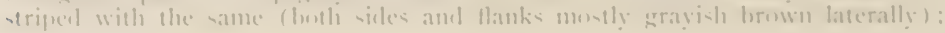


malar region white flecked with grayish brown; under tail-coverts grayish brown centrally; broadly margined with white or buffy white; midclle of throat and breast usually with a few small spots of brown; maxilla dusky on culmen, paler on tomia; mandibte pale colored (yellowish in winter, pinkish or liliaceous in summer); iris brown; legs and feet brown" (Ridgway). I

Description.- "Similar to $P$. i. malaschensis but much browner and more uniform in color above (back, etc., warm sepia brown insteat of grayish brown or brownish gray) ; spots on chest, etc., larger and deeper brown; under tail coverts more strongly tipped with luft" (Rilgway). Length of adult male (skins): 6.78 (172.5); wing $3.30(83.8)$; tail 2.92 (7. . I) ; bill .50 (I2.7) ; tarsus 1.02 (25.9).

Recognition Marks.-Sparrow size; uniform brownish coloration of back: nnderparts heavily spotted with brown; broancr than malaschensis but duller than tocinsendi; larger than annectens; color of crown unbroken as compared with Rusty Song Sparrow (Mclospiza melodia morplma), also bird larger.

General Range.- "Kacliak Island, Alaska, in summer; in winter south along the coast slope to sonthern California."

Range in Washington.-Winter resident and migrant west of Cascades.

Authorities.-P'asscrella tocinscndii Baird, Rep. Pac. R. R. Surv. IX. I 858 . 1). 489 part (Thitbeys Id., winter).-Fide Ridgway.

A singular fatality (or, more strictly, a'dant of fatality) has attended our efforts to secure a representative series of migrating Fox Sparrows on Puget Sound. The birds have only revealed themselves in city parks or otherwise in the absence of a gum. It is practically certain that all the Alaskan forms described by Mr. Ridgway occur here regularly in winter and during migrations but so mohtrusive are the birds and so dense the cover afforded that we have been completely baffled in our attempts, and find ourselves obliged, at the last moment, to fall back upon Mr. Ridgway's original descriptions in Lirds of North and Middle America, Vol. I. (p. 38 j ff $)$, and for the use of these we desire again to express our grateful obligations.

For additional remarks on the Shumagin Fox Sparrow ( $P . i$. malaschensis) and the lakutat Fox Sparrow (P. is annectens) see Hypothetical List in Volume II. of this work.

FIELD irlentification of the Fox Sparrows by means of binocular: may not command the respee of precise scientists. But there he sat, placid, at twenty fect, in a well-lighted grove on the Nisqually litats, on the roth day of February, roo6. See: twenty divided by eight (the magnifying power of the glasses) equals two and a half. At arm's length I held him, while I noted that the upperparts were dul! hair-lorown thruout, not noticeably brightening on wings and tail but perhaps a slade darker on the crown: anderparts heavily but clearly spotted with a wamer brown-so, olsviously and indisputably, neither a Sonty nor a Townsend. Slumagin (P. i. unalaschensis) perhaps; lut Riclgway enters all Puget Sound winter records as Kadiaks, and we must follow the gleam until we are able to perfect the light of our own little lanterns fyy the flash of a shot-gun.

a. Birds of North and Mid. Am., Vol. I., P. 391. 
No. (I)

\section{TOMVSLND'S SPARROW}

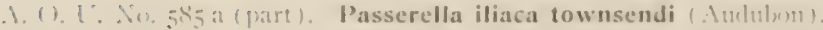

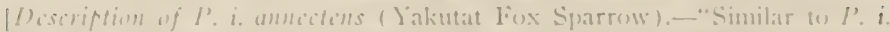
insularis but smaller (ele bill especially") and coloration shightly lormwer" (Rilgw:).

Description.- Idults: Similar to I’. i. amectens lont coluration darker anel

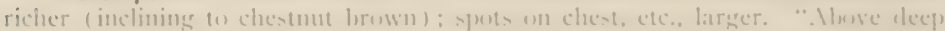

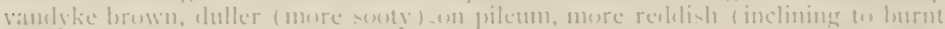
umber or dark chestmut brown) (ni upper tail-coverts and tail ; siles of heal deep sinty lorown, the lores ifoted, the aturicular region fincly streaked, with dull whitisla: general color of underparts white, but elerywhere spotterl or streaked with deep dhestute lorown or vandyke brown, the spets mu-tly of triamgular

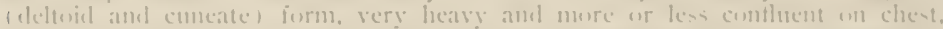

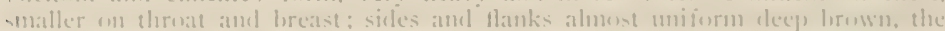
latter tingeel with butis or pale tawny, moler tail-coverts dece olive or olive-hrown

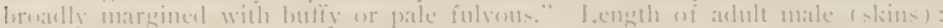

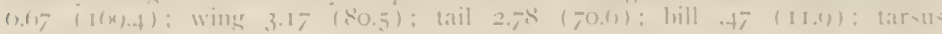
$1.00)(2,5) .4)$.

Recognition Marks. - Sartow size; warm brown (nearly migiom colora-

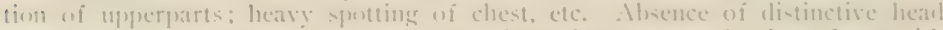
markings will dintinguish bird from leal Song Sparrows, and robust form with conical heak from migrating Hermit 'Thrushes.

Vesting.-. Is next. Denes not breed in Washington.

General Range.- - Coast district of sumthern . Mlaska (islands and cuant of mainlaud from southern side of Cross Sommd, I. ynu Canal, etc., to north sile of Dixon Eintrance) : in winter, sonth to northern California" ( Ridgway.

Range in Washington.-Common migrant and (posilbly) winter resident West af cilcaules.

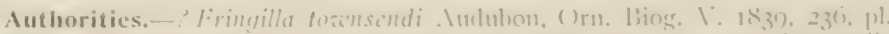

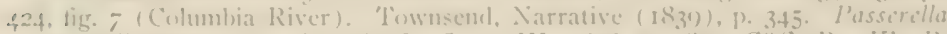

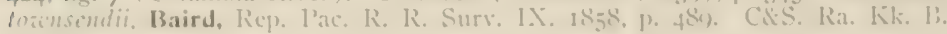
[i: 11$]$ ).

Specimens.-1 ( . of II:) Prov. H. C .

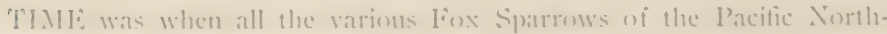
west were lumped together under the nane 'fownsemel's sparrow. A more

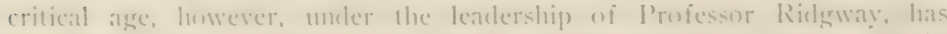
resolved the hewildering array of shifting browns inte five forms. or sub-pecies, assignings on each stmmer quarters accoreling on the desllness or brightness of its conte. The emel is mot yet, of enturse. but the distinctions alrealy matle are sufficiently atfenuated to catuse the public to yawn. Suffice it (o) say, that this is one of the plastic species long resident on the Pacific 
Coast : and that the varying conditions of rainfall and temperature, to which the birds have been stbjected thruout the greater portion of the year, have given rise to five recognizable forms of the 'lownsend Sparrow.

Probably all forms are migratory, but the northermmost menber of the group, the Shumagin liox Sparrow ( $P . i$. malaschensis) has not been taken except in its summer lome, the Naska Peninsula, Lnalaska, and the Shnmagins. The remaining four are known to retire in winter as far south as Califormia; but whether they preserve the $2,3,4,5$, arrangenent in winter, or whether the order is roughly reversed (as is true in the case of certain other species), so that number 2 goes farthest sonth, while number 5 , less anxious as to the severities of winter, migrates, as it were, half-heartedly, and becomes for a time the northermmost form, we cannot tell. However this may be, 'Iownsend's Sparrow proper ( $P$ '. i. tor'nsendi) appears to outnumber any of the renuter forms during at least the spring mierations; and becatuse it is ont next neighbor on the north, shoukl be entitled to more consideration than plain heathen birds.

It no time does the alssorptive power of our matchless P'uget Somnd cover appear to greater advantage than cluring the migration of the lox Sparrows. However they may choose to move at night, by day they frequent the clense tangles of salal and salmon brush, or skull about in cedar swamps. To search for them is useless, but if you are much out-of-doors the time will come, while vou are footing it softly along some woodland path, that a clemure brown bird will hop out in front of you and look unconcernerly for ticl-bits before your very eyes. The bird is a little larger than a Song Sparrow, but you will require a second glance to note that the colors of the upperparts are smoothly blencled, that the lead lacks the vague stripiness of Mclospiza, and that the underparts are spotted instead of streaked. Or. it may he, that you chance upon him as he is busily scratching anong the fallen alcler leaves. Sicratching is hardly the word tho, for the bird leaps forward and executes an extravagant double kick backward, landing invariably at the edge of the cleared space. Here, without a moment's delay, he proceeds to glean busily, whereas you rather expected him to pause at the end of his stunt, like the acrobat, awaiting the conventional burst of applause. If you must needs purste the path, he hops back into the thicket and you have seen, perhaps, your last Fox Sparrow for this year, altho his migrating kinsmen must number millions. 
No. 62.

\section{SOO'I FOA SIPARROIY}

\section{1. (1) L. Ao. $585 a$ (part). Passerella iliaca fuliginosa Ridgway.}

Description.- Tdults: Liperparts, sides of hearl, neck, and lateral underparts nearly uniform dark brown (sepia brown-"sonty" not inappropriate), warming slightly upon exposed surfaces of wings amel upon rump and ouster ederes of rectriecs: below white save for under tail-coverts, which have clear lutfy wash, crerywhere save on midelle lolly heavily marked with large, chietly triangular, spots of the color of lack or clarker-spotting heaviest on breast where nearly confluent. Bill black aloove shading on sides into yellow of lower matnlible: feet pale rudcly brown or wine-color. Length (of a single fresh speciment ) 7.45 (101.7); wing (av.) 3.21 (81.5); tail 2.98 (77); lill .48 (12.2); latr $\rightarrow 15$ 1.02 (25.7).

Recognition Marks. - Sparrow w Chewink size; unifurm sonty brown enluration of heal and mperparts; heavily spotted below with sepia or liackish: darker above and more heavily spoted lechw than any migrant form of the P. i. malasithensis group.

Nesting.- list: a bulky structure with a broad, flat brim, uf mosses, grasses, twigs, woody libers, weed-stalks, often heavily lined with hine dry grass of contrating color and with an inner mat of fur, hair or ienthers; placed at mexlerate heights in thickets or saplings: measures externally 6 inches across

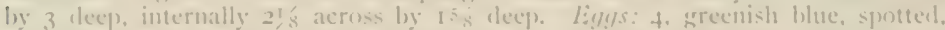

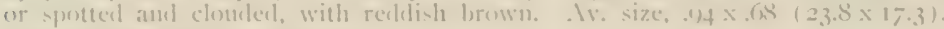
Sinsin: May-|uly: wo brouds.

(ieneral Range.-Sumuer resident in const region of liritiv Colmmbia amel merghwestern IVashington: in winter south along the coast to San lirancisen.

Range in Washington.-lireeding on tlue San Juan Islanels and upen the mosthern and western shores of the ()fympic l'eninstila not uncommen migrant (m) l'uget Sounul.

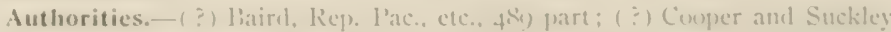

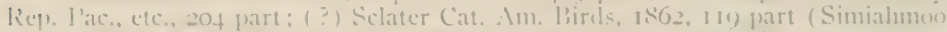

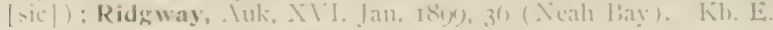

specimens.-T'rov. JiX. E.

THl: motery of the liox Sparrow clears a litte as we mowe morthward on l'nget simmel, and may even resoloce itself one day as we spend a lazy

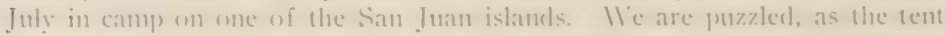
pees are being drisen, by certain sprightly songe lussing ont mow here, now binere, irom the copse. We labur muler a sence of avian surveillance as we gather fuel from the heach, but the somes are tou joyens and limpiel on make precise connections with anyhing in previnus experience. It is not till the coml of the erening. When we seck the spring hack in the deptls of the thicket, that we come upron a fair hirdmaiclen slyly regaling herself upun at 
luscions salnon-berry, flushed to the wine-red of perfection, while three of her suitors peal invitations to separate bowers in the neighboring tangles. She flees guiltily on detection, but the secret is ont; we know now where these shy wood nymphs leep themselves in summer.

The male bird is sometimes embolkened by the moment of song to venture into the tops of willows or alclers, but even here he hugs the screen of leaves and is ready in a trice to dive into the more familiar element of bushes. Once under cover of the protecting salal, or among the crowding ierns, the Fox Sparrows are excelled by none in their ability to get about with a moclicum of disturbance; and the longest journers, such as are made necessary in the time of clamoring young, appear to be made by slipping and slicling thru the maze of intersecting stens. The song is varied and riracious: but, save for the opening notes, is neither very strong nor very brilliant. The opening phrase, however, Porcit, hen, comes as, a tiny bugle call into which is distilled the essence of all dank hollows, of all rustling leaves, of all murmuring tides, and of all free-lolowing breezes. It is the antlientic voice of the little wild.

On a July day a trio of Inclian boys, Quillayntes, were showing the bird-man a roumd of belated nesters, while lie was looking for opportunities to photograph eggs, and also recording Quillaytuan bird names in passing. A Rusty Song Sparrow's nest held only. weanlings, miklly hiclenus,

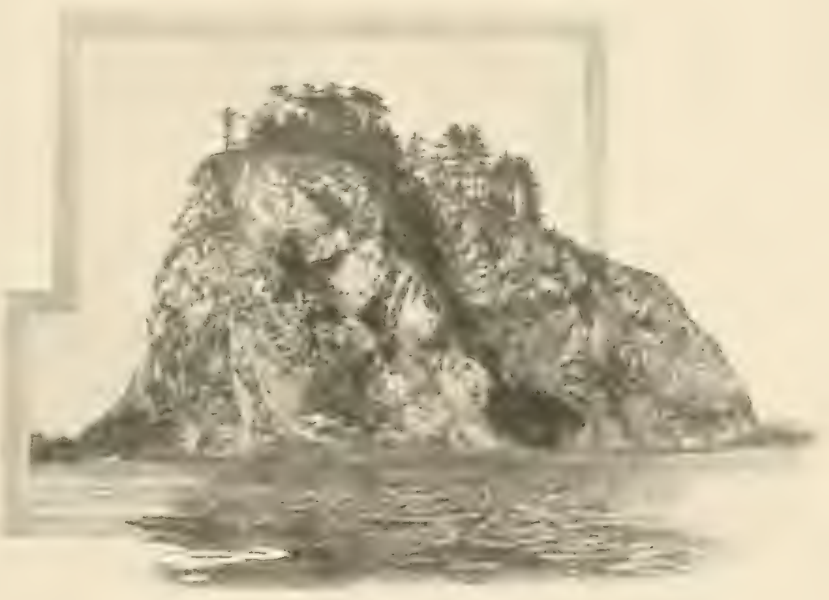

From a Pholograpl: Copyright, 1907, by JV. L. Lauson. C.ARROI,I, ISI,I.T-SUUTII F:XPOSURE.

WUERE THF IIRST SEST OF THE SOOTY FOX SPARROW WAS FOUND.

and the leader, a lad of ten, expressed regret that he conld not show me the nest of amother kind of Song Sparrow. With excess of Cancasian pride I assured him that there was only one species of Song Sparrow to be found locally, but my learned statements drew forth only puzzled and monconvicted glances. Some days later when I had taken a set of Sooty Fox Sprrow's eggs from a neighboring islet, the boys clanored in trimmp, "I'hat's it: 


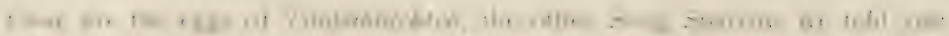

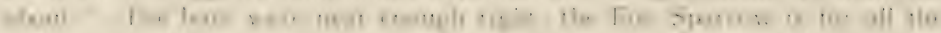

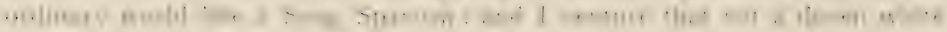

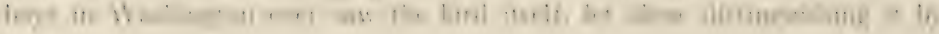
$n+\cdots$

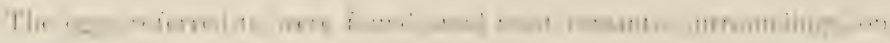

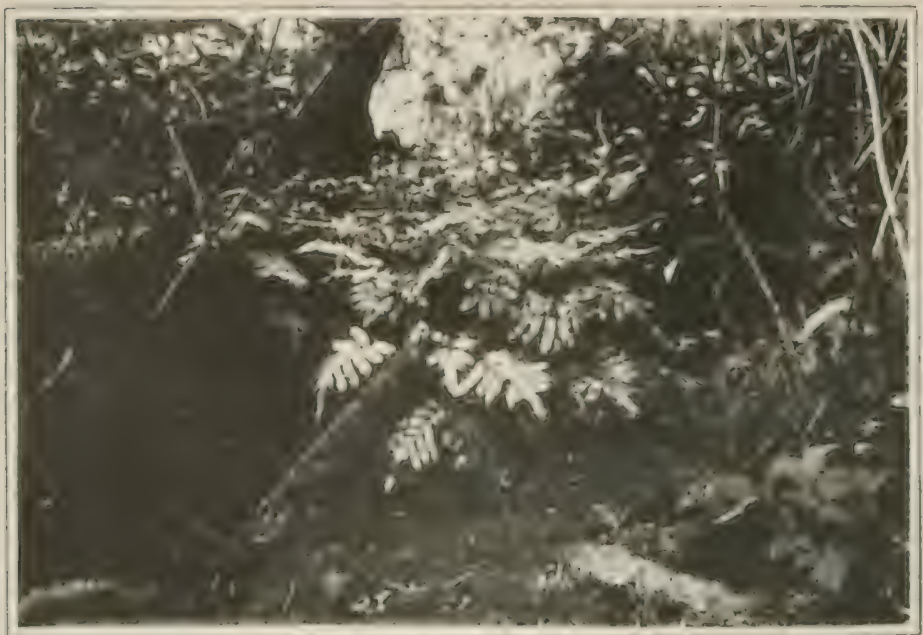

IR

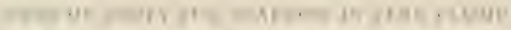

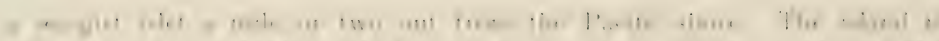

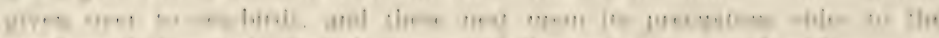

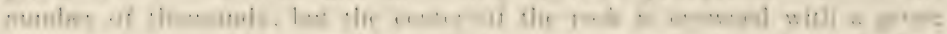

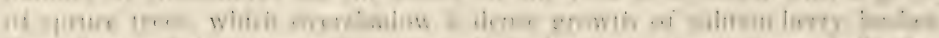

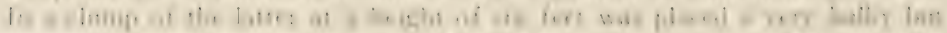

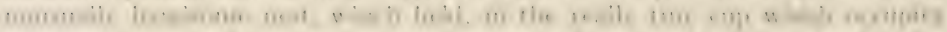

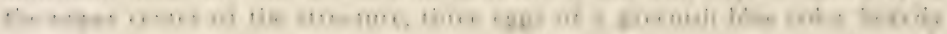

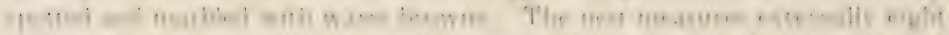

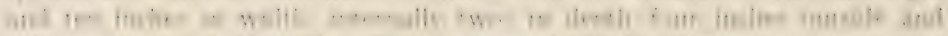

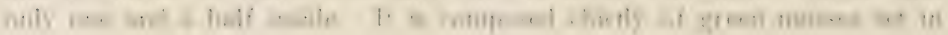


dead spruce twigs with a few twisted weed stalks; while the lining is of a light-colored, fine, dead grass, rery loosely arranged, and a few breastfeathers of the Glancous-winged Gull. A nestful of young Peregrine Falcons were conversing in screams with their doting parents in the spruce trees overhead, and terrorizing the island thereby; but the Sooty Fox Sparrows stepped forward modestly to claim ownership in the nest which "Science" tunfortunately required. The date was July 2I, Igo6, and the eggs were nearly upon the point of hatching.

Thus, the north and west slopes of the Olympic Momntains, together with the islands of lower Puget Sound, appear to mark the southern breeding range of the coastal Fox Sparrows. 'This form has not been reported breeding upon the mainland east of Puget Sound, but it is difficult to see why it should not do so. It is rather the commonest form during the spring and fall migrations, and there is no evidence as yet that it tarries with us in winter.

\section{No. 63.}

\section{SLATE-COLORED SPARROIV.}

A. O. U. No. $585 \mathrm{c}$. Passerella iliaca schistacea (I Baircl).

Synonym.-SLATH-COLORED FiOX SPARROW.

Description.-Flults: Upperparts slaty gray tinged with olivaceons, changing abruptly to russet brown on upper tail-coverts, and tail; wings brown brightening, more rusty, on edges of greater coverts and secondaries; some white feckings below eye, and supraloral spot dull whitish; underparts white shaded with color of back on sicles; the sides of throat, chest, and sicles of breast heavily and distinctly marked with triangular spots of sepia; lower breast (and sometimes middle of throat) flecked, and sides and flanks striped, with the same shade; moler tail-coverts grayish brown centrally edged broally with buffy. Young birds are tinged with brown above and are duller white helow with less distinct markings. Length of adult nuale $7.00-7.50$ ( $177.8-190.5)$ : wing 3.15 (80); tail 3.15 (80); bill .47 (12); tars11s .92 (23.3).

Recognition Marks.-Sparrow to Chewink size; slaty gray and brown coloration above with heavy spotting on breast distinctive; yray instead of brown on back as compared with the five members of the malaschensis gromp.

Nesting.-Nest: a bulky affair of twigs, weed-stalks, grasses, etc, placed on ground or low in bushes of thicket. Liggs: 3-5, usually 4 greenish brown sharply spotted or (rarcly) blotched with chestnut. Av. size $85 \times .65$ (21.6x 16.5). Scason: May-July; two broods.

General Range.-Rocky Momntain district of United States and British Coltumbia west 10 and including the Cascade Mountains, the White Mountains 
uf sutheastern Cillifurnia, and the mountains of northeasters Cislifurnia: semth in winter on - lew Mexien, Arizuna, ete.

Range in Washington.-Summer renident in the timbered dintricts of the

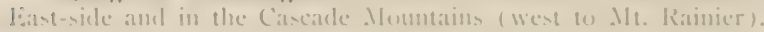

Authorities.-|"slate-colored sparrow," Johnson, kep. (;os. II. 'T. 18s'4

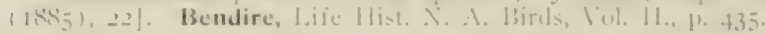

l'll1: resulents of (ammun Hill, in Sijukane, are (1) le congratulated,

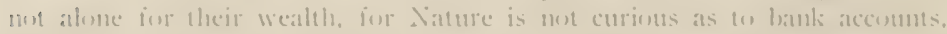
but for the rate gend taste which hats been clisplatyed in utilizing the largesess wi Sature. Inseanl of going in with axe and shosel and tire-framel, forst lu wbliterate the distinctive fealtures of Nature and then rear meclinge plati-

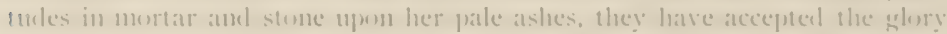
of her grim lavat hastions and the grace of her monewn pines ; nes have they eren despised the tangles of wild shrublery, thwse decem draperies without which lent tree and clifi would be werstark. 'Tu be sure the landscape artist with consummate skill has said to the ping semterel, "stambl here!" and to the onse, "Sit there!" lout he lats nut forgetlen withal the prineval rights of the feathered alourigines. Is a resule the hirds approat. What higher

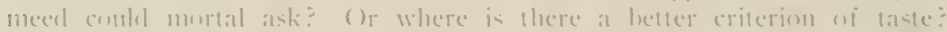
Taken all in all I douht if there is a more delightenl spot in Ilashingtum in which to sturly lirel life, certainly not within municipal bomels, than ('ammen llill allurds.

Here, for instance, is this womel sprite. the very genius of the umravished wild: no one would think of lomking for him in a city, yee of an early morn-

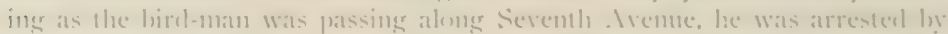

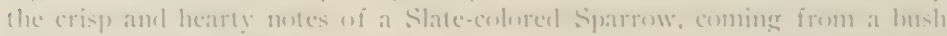
in an artistically unkempt corner of the adjoining yare. In the half lights. mothing in the puse and alpearance of this birel would have induced an

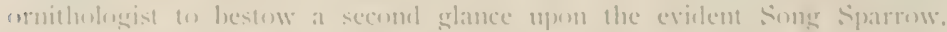
fard it not lecen for the sweet and powerful challenge which poured from lis earnest beak. (Jore, rickit, loupitier, it said, with varied caulence and minor change, which gave evielence of no mean ability. 'There is something sn forthright and winsume alont the song of this molest hirol. that the listener prompuly surremlers "at discretion," and lecgins to ask eager questions of his dainty captor.

A few yarels further on three of these sparrows were seen feeding on a well-kept lawn. isut ready on skurry at a breath of the sledter of hush.

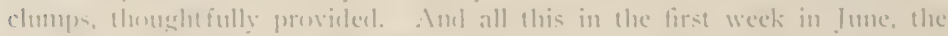
very height of nesting time! With this as an example, what need un speals

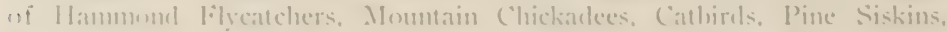

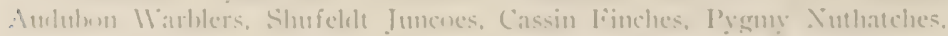
American ('rossbills. Cassin Virens, I.nuisiana 'Tanagers, liuby-crowned 
Kinglets, Olive-sided lilycatchers, Evening Grosbeaks, Violet-green Swallows, Black-chinned Hummingbirds, Bobwhites, and a host of commonet sorts, all residents of the same demesne? "Unto him that hath shall be given." Unto these who have shown appreciation and consideration, has been given the friendship of the birds, and they deserve their good fortume.

On the 5th of June we risited a nest which had been located a few days before in a little aspen grove beyond Garden Springs. The nest was placed mpon the gromnd at the base of a small tree, and it sat so high, without pre. tense of concealment, that it was plainly visible with all its contents two rods away.

'The female was brooling. but upon our approach she slipped quietly off and left her three callow young to the tender nercies of the bircl-nan and his big glass eye, set at four feet, while sle began searching for food mpon the groumel a yard or two away.

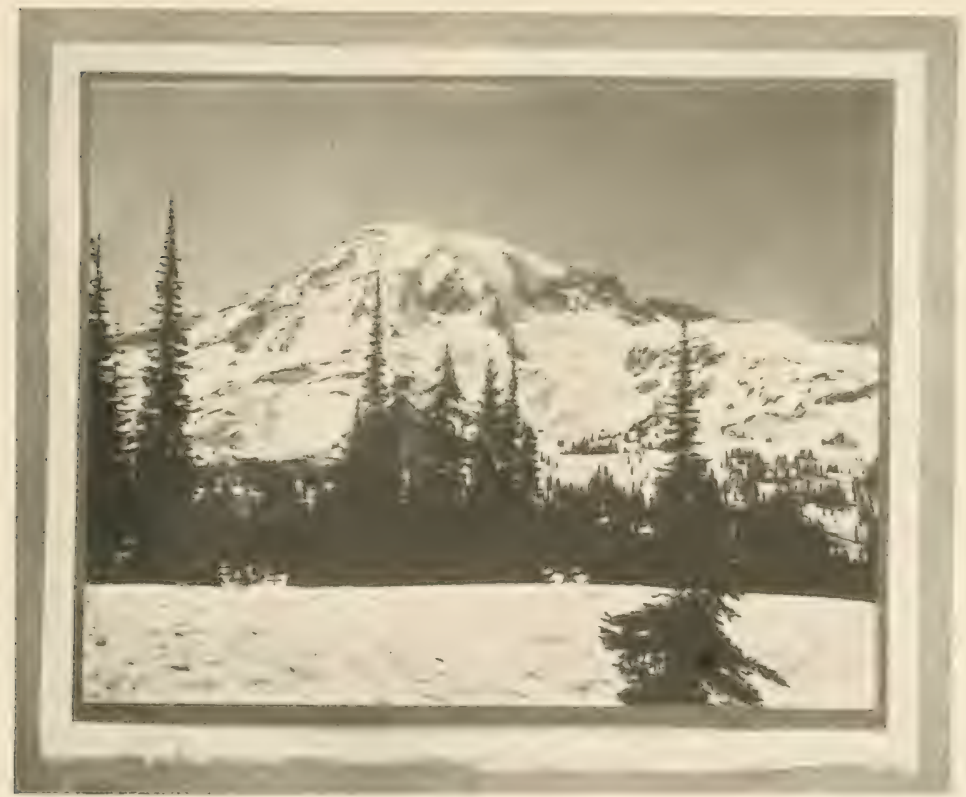

Faten in Ravicr Wational Parl.

From a Phopograph Copsight agus, by Wh. L. Minson

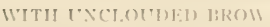




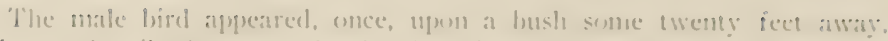
making mo lestile demumatration lont beaming rather a hearty confidence, as

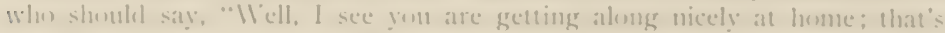
right, conjoy yourselves, and l'll finish up this bit of hoeing before supper."

l'he mother lirel, meanwhile, was tutering mo complaint of the strange presence, preferring insteat to ghleatn foul industriously from moler the carpet

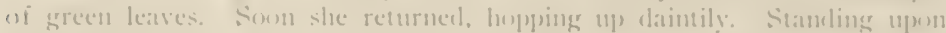
the clevaled hrim of her nest sle carefully survered her broul without

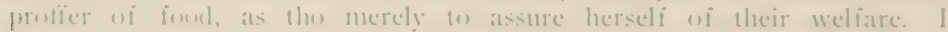
"smappeel" amb sle retreated, mot hastily, as tho irightened, lum quictly as matter of reasmable protence. Again ame again during the hour I hatel

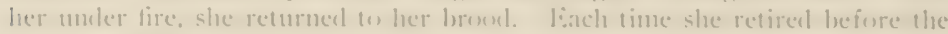

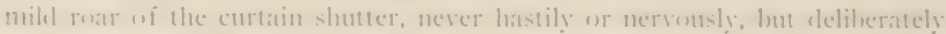

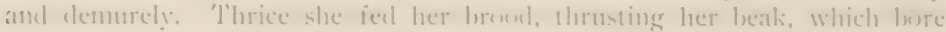

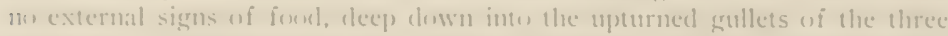
children. 'Thrice sle attempted fo broxt her bates, and very handsome and sery motherly she lowkerl, with thtfed feathers and mildly inguisitive eve: lut the necessary movemem following an exposure semt her atway for a seistsit.

When absent she neither moperl nur scolifed, but discreetly set alsout serateling for foud, always within a range of ten or fifteen feet of the nest. At such times sle would louk up trustfully aud unabashed. Upron the return she never flew. amb there was mething to advise the wating camerist of her

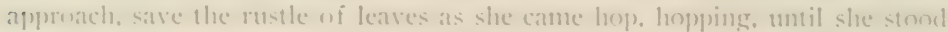
"1pun the familiar brin.

The opportunities for preture-making were simply unlimiterl, sate for the weakness of the leaf-diluterl ligrlt. Seldom have I been stirred to such achmiration as in the case of this gemtle mother Schistuced. So demure, so cren-tempereel, and so kindly a hird-jersnn, with streh a preserving air ni sentle breegling. I have nut oftens seen. It was an hour to he long remembereet.

No. 6.8 .

\section{GREEN-TALIED TOWHEE.}

1. ค. I. Nu, 502.t. Oreospiza chlorura (Aml.).

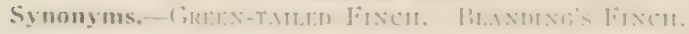

Description.- Idults: Crown and occiput rich clestnut ; foreheal hlackish

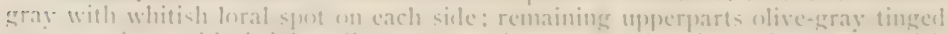
mere or lese with bright wlive-green: wings and tail with brighter greenish criginge: bend of wing, axillaries and umeler coverts yellow: chin and throat 
white bordered by dusky submaxillary stripe; sides of head and neck and remaining underparts ashy gray, clearing to white on abdomen, tinged with buffy or brownish on sides, flanks and crisstm. I3ill blackish above, paler below; legs brown, toes darker; irides cinnamon. Young birds are brown above tinged with greenish and streaked with (lusky but with wings and tail much as in adult. Length of adult about $7.00(177.8)$; wing $3.15(80)$; tail $3.30(84)$; bill .50 $(12.7)$; tarsus .9. (2.4).

Recognition Marks.-Sparrow size; rufous crown, white throat; greenish coloration of upperparts.

Nesting.- "Nest: in bush or on the ground. Eiggs: .90 x.68 (22.8 $\times 17.2)$ : pale greenish or grayish white, freckled all over with bright rechlish brown, ustally aggregating or wreathing at the larger end" (Coues).

General Range.-- MIomtain clistricts of western United States, from more castern Rocky Mountain ranges to coast range of California; north to central Montana and Idaho and eastern Washington" (Ridgway). Sonth in winter to Mexico and Lower California.

Range in Washington.-D'resumably summer resident in the blue Nountains,

Authorities.-["Green-tailed towhee," Johnson, Rep. Gov. IV. 'T'. I884 ( 1885,22 ]. Ridgway, Birds of North and Middle America, Part 1, 401. 'T(?).

NOT having ourselves encomtered this species we are not able to conment on Prof. Ridlgway's inclusion a of eastern Washington in the bird's breeding range. 'T'he Green-tailed Towhee appears to be essentially a mountain-loring species, and if it occurs within our borders, will be nearly confined to the Blue Monntains of the sontheastern cormer.

Mr. Trippe, writing from Idlaho Springs, Colorado, says of this bircl': "It arrives at Idaho early in May, and soon becomes abundant, remaining till the close of September or early part of October. It is a sprightly, active little bird with something wren-like in its movements and appearance. It is equally at home among the loose stones and rocks of a hill-side (where it hops about with all the agility of the Rock Wren), and the densest thickets of brambles and willows in the valleys, amidst which it loves to lide. It is rather shy, and prefers to keep at a good distance from any suspicious olject; and if a cat or dog approaches its nest, makes a great scolding, like the Cat-bird, and calls all the neighbors to its assistance: but if a person walks by, it steals away very quietly and remains silent till the danger is passed. It has a variety of notes which it is fond of uttering: one sounds like the mew of a kitten, but thinner and more wiry; its song is very fine, quite different from the 'Towhee's and vastly superior to it. It builds its nests in dense clumps of brambles, and raises two broods each season, the first being latched about the midclle of Inne."

a. Hirds of North and Milllie America, Vol, I., p. 401.

b. Coues, "Pirds of the Northwest" (1:d, 1874), p. 17\%. 
No. 6.5.

\section{SPURRED TOWHEE.}

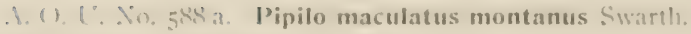

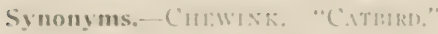

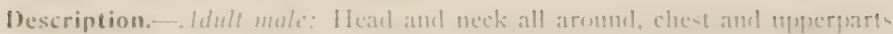
black. glums anteriorly, cluller on hack: chongated white spots on scapulars, on

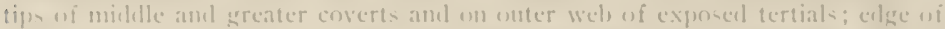

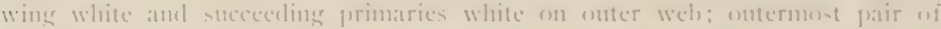
rectrices exterel with white on suter wels: the three ontermest fatirs ferminally bleteleet with white on inner wet and the fourth pair toncheal with sane near lig): loreabit and ledly white; sirles, flanks and erisum light cimanom rafoum,

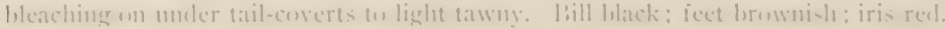
idult femule: Similar to male lut duller: black uf male replacesl hy -laty with an

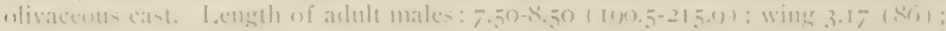

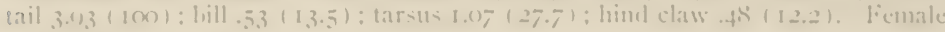
a linke lesis

Recognition Marks, Stambart of "L'lewink" size: black. white and cin-

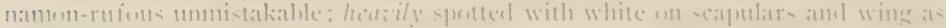
comparerl with $l$ '. Mt. (1)'!nmus.

Vesting.- Vist: on the grummel in thicket or at hase of small saplings, a

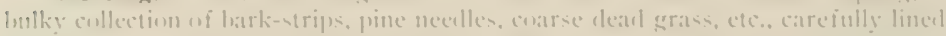

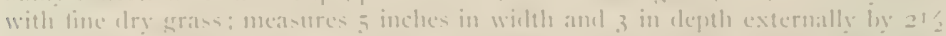

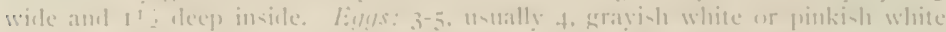

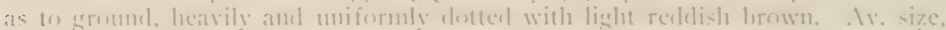

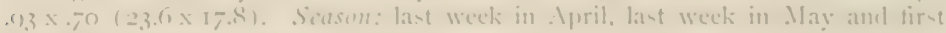
werk in lune: (wo) hronds.

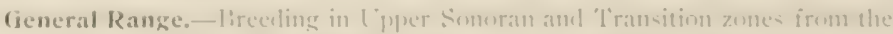

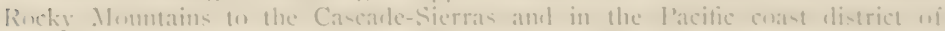

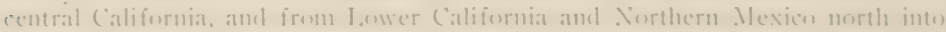
I:ritish Cinlumbia: retiring from morthern portion of range in winter.

Ramge in Washington.-Cimmon smmmer reviclent east wi the C'iscates,

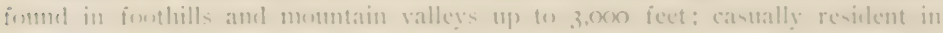
minler.

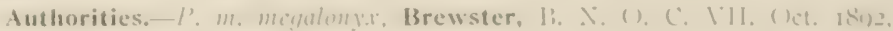

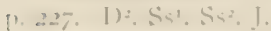

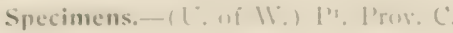

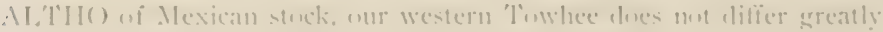

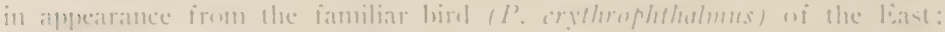

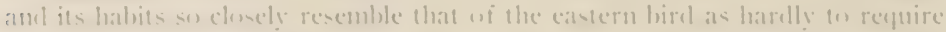

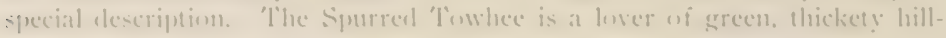

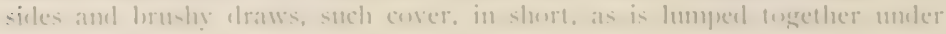


the term "chaparral" further south. It is, therefore, narrowly confined to the vicinity of streans in the more open comnty, but it abonnds along the foothills and follows up the deeper valleys of the Cascades nearly to the divide.

'low'hee, as a mame, is a manifest corruption of tow hec, or to-har', an innitative word, after the bird's most familiar note. Chewink is an attempt along the same line, but Marie is what the bird seems to me to say. It is on this account alone that the bird is said to "mew" and is callerl

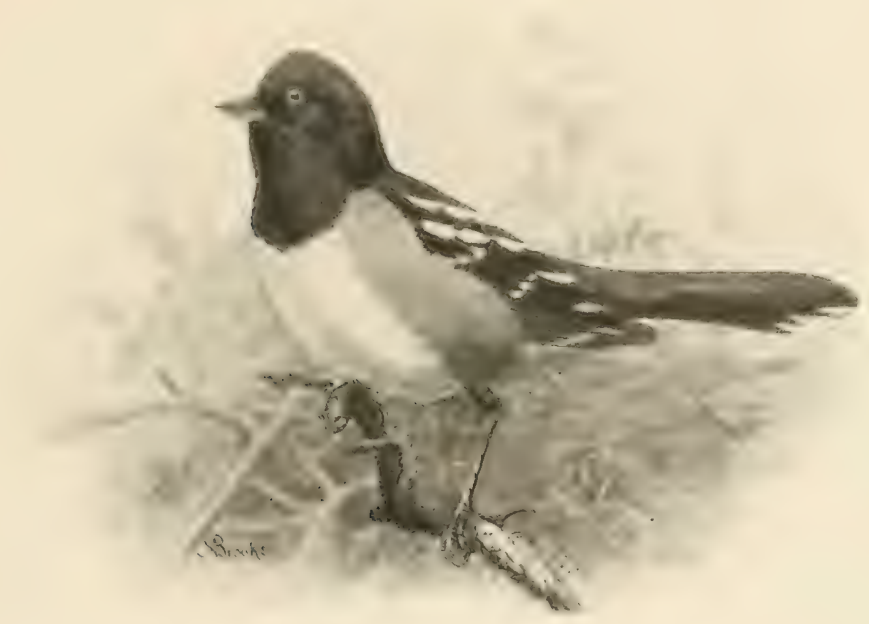

SIUKRED TOIHEL: MALE.

"Catbird." 'The true Catbird, however, always says Ma-á ry, and there is no cause for confusion. During excitement or alarm the 'Towhee's note is always shortened and sharpened to Wric, with a flirt and jet, and a flash of the eye. 'The song variously rendered as "Chec-terr, pilly, willy, willy," "Chip, ah, toat-hec-ce" and "Yang, kit-cr-cr," is delivered from the top of a bush or the low limb of a tree; and while monotonous and very simple, it retains the pleasing quality of that of the eastern bird. The singer will not stand for close inspection, for, as Jones says of its consinz: "He is a nerrous fellow, emplasizing his disturbance at your intrusion with a nervous

a. I.ynds Jones in Dawson's "The Itirds of Ohio," 8. 94. 


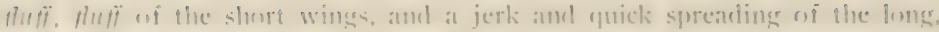

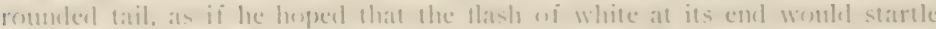
the intruter aw:at
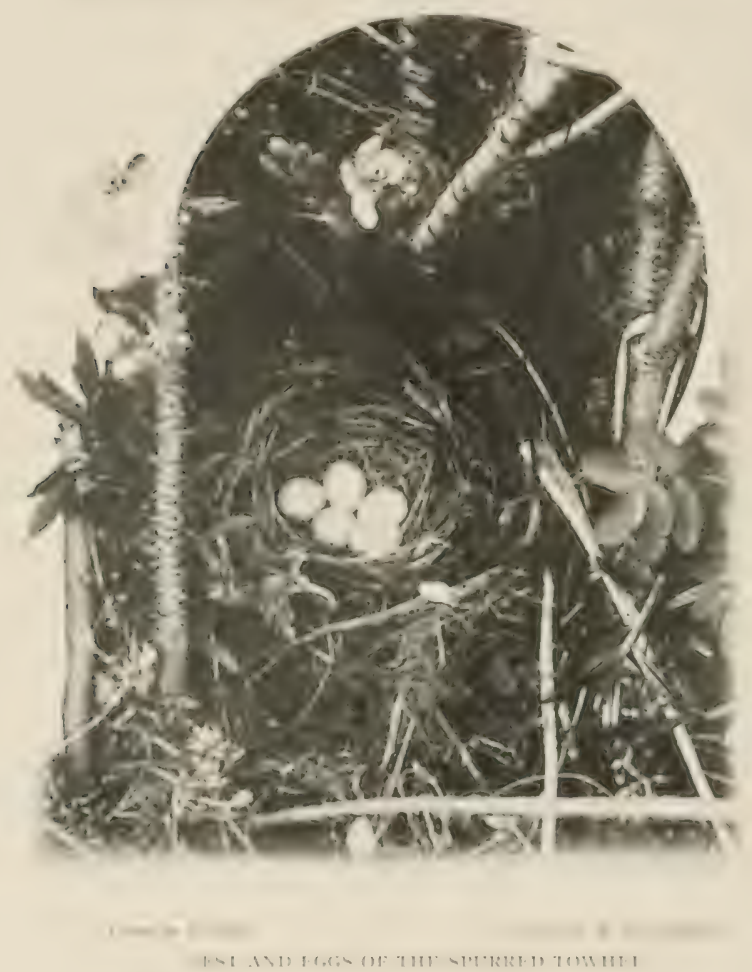

Fior at nest the simereal 'Towhe arateme it imii = it the bate of : bush or clump in

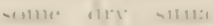
ticns. atnd line. Illic carcinlly lim with leaver lark-strims an flant +1en! Int with funce ermatises ur rutlets. 'T"<smiles>[AlH2]</smiles>
in all ringuile

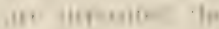
. 11 ni $(114)$ 11. $\quad$ Hiy ant the fental

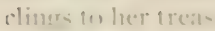
ane Int1lil th (rotrimer

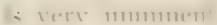
1 Hine : a crers sile keren h "ile batkerromur ecroleling inte pumen exills: amb slu will une returt metil lome att

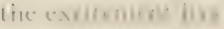
died domint

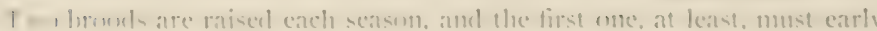

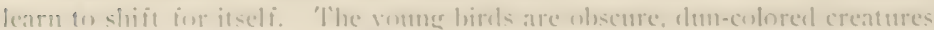

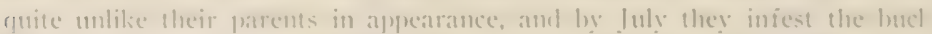

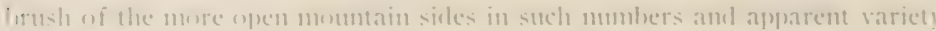

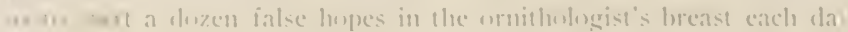


No. 66.

\section{OREGON TOWHEE.}

A. O. U. No. 588 b, Pipilo maculatus oregonus (Bell).

Synonyms.- "CATHRI)." CIIEWINK.

Description.-Idult male: Similar to P. m. montanus but darker, the white spotting of wing and blotelies on tail much reduced; two outer pairs of rectrices blotched and the third tonched with white near tip; cimnamon-rufous of sides. ctc., richer and deeper. Adult female: Like male but black veiled by deep redklish brown (clove brown) skirtings of feathers. Length about 8.50 (2I6); wing $3.33(8+.6)$; tail $3.60(9.3 .7)$; bill $.57(1+.5)$; tarsus $1.10(27.9)$; hind claw .$+3($ I 0.9$)$. Female a little smaller.

Recognition Marks.--"Chewink" size; black (with white spotting on wings) above; white of breast; deep reddish brown of sides; mewing cry.

Nesting.-Like that of preceding species. Eggs a little larger: Ar. size, I.0.4 $\times .74(26.4 \times 18.8)$.

General Range.-l'acific coast district from liritish Columbia (including Vancouver Id.) south to central California; chiefly resident thruout its range.

Range in Washington.-Of general occurrence, save at higher levels, west of the Cascarles: resiclent.

Authorities.-? Fringilla arctica, Aud. Orn. Biog. V. 1839, 49; pl. 394. P. oreyomus, Dell, Baird, Rep. Pac. R. R. Surv. IX. I858, 1p. 5I3, 5 I4. ('I'). C.S. I $2^{2}$. Rh. Kb. Ra. Kk. 13. E.

Specimens.- U. of WV. I'. I'rov. B. BN. E.

PlikHAPS no bird is better known by voice and less by plumage than this shy recluse of the under forest. Swampy thickets, brush-piles, loglieaps, and the elges of clearings are his special delight. Hence it is that the newcomer, taking up quarters at the edge of town, hears this mysterious, questioning voice, mc-ay' mcay uh? rising from the deptlis of the brush-lot opposite. He reports the somnd under the name of "Catbird," and asks the bird-man's opinion. Or, if the newcomer has been persistent enough, he has a glowing accomt to give of a handsome black bird with red on its sides, "like a Robin," and some white below. The bird would only show himself for a monent at a time, and then he flitted and flirted restlessly before he dived into cover again, so that the fine points of white spotting on the wing and white tips on the onter tail feathers were lost ont of account.

Of course it is the Oregon 'lowhee, and the half pleasant, half complaining notes will insure him notice forever after. The bird is strictly resiclent wherever found, and the ummistakable blackness of his plumage is clue rather to the age-long endurance of rain than to any chance association with blackened logs and stumps, as might be supposed. lowhee is prines 
of the underwerle, net, of course, in the Mephistophedian sense, lun as the

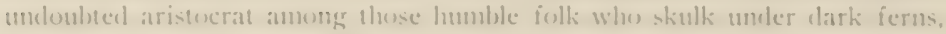
threat marvelous mazes of interlacing sticks and stalks, explure eavernems recesses of moss-cosered ronts, and molerstand the fomolations of things generally:

The lamesome birel is a litte impatient of ehe company of his own kind.

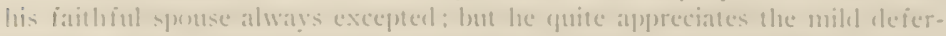

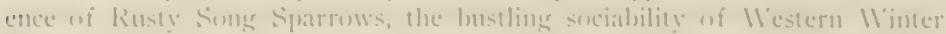
Il rens, or exen the intermitent homatge of seattle IV rens. In winter the

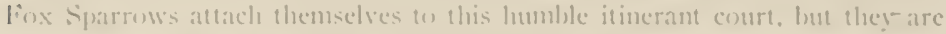
a dozen times more bashful than their chief even.

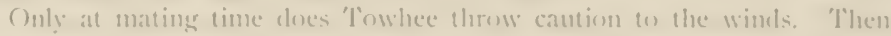
lie memonts a sapling amel drones away by the hour. 'l'he damps of ten thum-

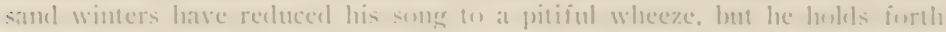

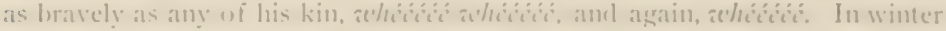

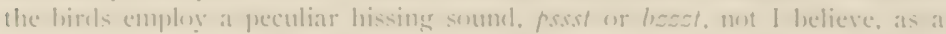

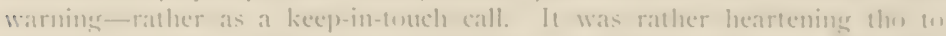

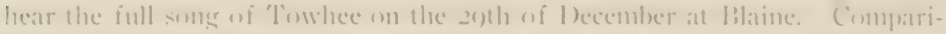
suns were munecessary, and the hemely trill stond ont like at heneeliction against the dripping silence.

In feceling. 'Tuwhees resort chicfly to the groumel. T'hey are mot careful (1) observe quict, and one may follow their mowements ly the attendant rusthus of leaves. Scratching for foul is a fasorite emplosment, and this elese

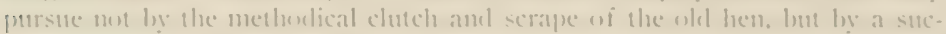

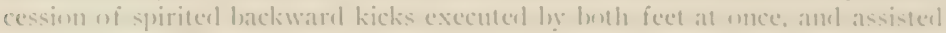

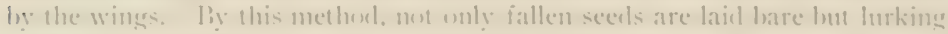
inseces af many sorts, which the hird swiftly devens.

No. 67.

\section{LAZULI BUNTING.}

\section{A. (). (1. Do, 5ix). Passerina amena (Say).}

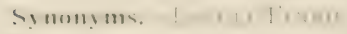

Descriptioss. - Adult mule: Heal and neck all aremel ecrulean blue: this

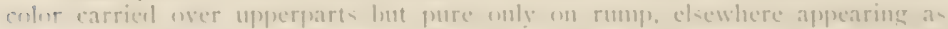
sirting of featlees: misklle coserts broally and greater conerts narrowly tipped

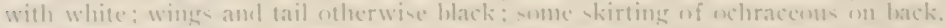

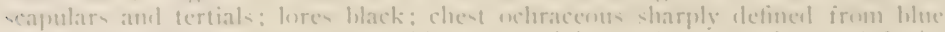

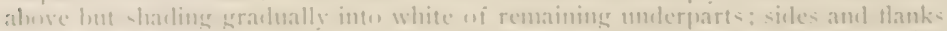

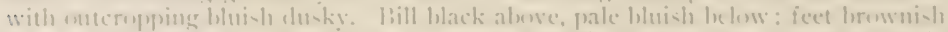

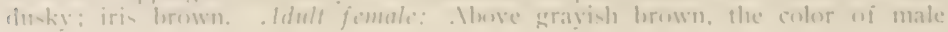


recalled by dull greenish bhe of rump and npper tail-coverts and by skirtings of wing- and tail-feathers; micllle and greater coverts tipged with light buffy: underparts washed with buffy, nost strongly on chest and sides, fading to whitish on belly and moler tail-coverts. Young birds resemble the female but lack the bluish-gray of rump and skirtings, and are nsually more or less streaked below on chest and sicles. Length of adult male: 5.25-5.50 (133.3-139.7): wing 2.87 (73) ; tail 2.08 (53); bill .39 (9.9); tarsus .67 (17). Female smaller.

Recognition Marks.- Warbler size; color pattern of male distinctive. female not so easy: in general clistinguishable by a softness and uniformity of the grayish brown.

Nesting.-. Vest: a loosely constructed, bulky structure made chicfly of dead grasses and strips of soft bark, with a heavy inner lining of hair; placed abont three fect up in fork of weed, bush or sapling; measures, outside, $4^{1 / 4}$ inches across by 3 in depth, insicle. $21 / 2$ wicle by $11 / 2$ deep. Eggs: 4 , very pale bluc mmarked or, rarely, dotted with reldish brown. Av. size .76x.56 (19.3 x I.4.2). Scason: first week in June; one brood.

General Range.-Western Linited States from eastern botder of Great I'lains to the Pacific (less common on Pacific slope) north to soutlern British Columbia (chiefly east of the Cascarles); south, in winter, to Cape St. Lucas and the Valley of Mexico.

Range in Washington.-Common summer resident east of Cascade Nountains; less common and of irregular distribution in the Puget Sound region; breeds in Cascades up to 3,000 feet.

Migrations.-Spring: Yakima County May 5, Ig06; Chelan May 2I, I896.

Authorities.-? Fringilla amana, Anclubon, Orn. Biog. V. 1839, 64. 230; plates 398. 424. Cyanospiza amana liairl. Baird, Rep Pac, R. R. Surv. IS. I858, p. 505. T. CXS. D'. Ra. D². Ss ${ }^{1}$. Ss 2 . I. B. E.

Specimens, - L. of IV. Pr. Prov. B. E.

ONE can scarcely believe his eyes as this jewel flashes from a thicket, crosses a space of common air, and disappears again all in a trice. Eithe: there has been some optical illusion, or Nature has grown careless to fling her turquoises about in stuch fashion. Vie must investigate. Lipon arrival. somewhere about the roth of May, and before the return of his dun-colored mate, the male Lazuli is quite conscious of his prominence in the landscape. He avoids notice and groes bounding away if closely pressed; but love soon makes him bold, and he will pursue the object of his affections into the very thicket where you stand. 'Then, while the female lurks timidly within, lee mounts a spray and yields an outburst of music, piercing and earnest, if not too sweet. WV e see that his blue is deep azure, or turcuoise, rather than that of the lapis lazuli from which he is maned. The red of his breast is nearly that of the Robin's, while the pure white of the remaining underparts completes a patrintic study in real, white, and blue. 'The female shows something of the color pattern of her mate, with the inmortant exception that dull brown supplants the royal blue of head and back. After all, then, they are fitted 


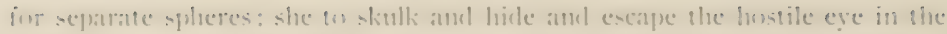
afischatere of her maternal duties: he to lose himself agatinst the blue of

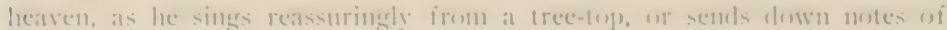
warning upess the approatch wi danget

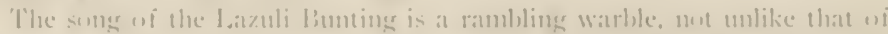

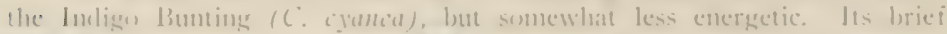

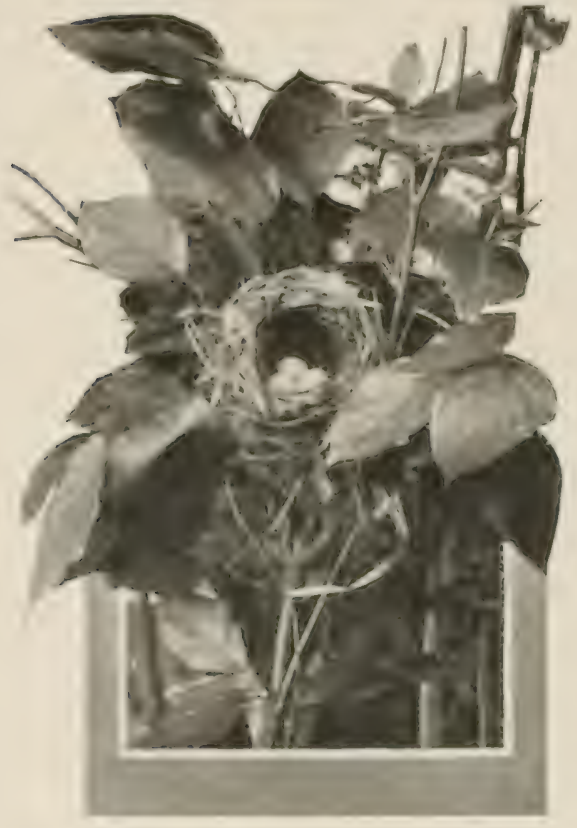

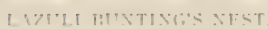
course rises and falls in short carlences and encls with at hasts immble wi monimberl moles, as thr the singer were ont of loreath. Morenser. the biril dies nest take his task lere serimusly, and he dres not burden the minl-rlas air with incessant soner. ats does his tireles: (i) $11<$ ill.

somewhere in the shrublery and langle, whether wi saplings, herr? fushes, roses, ferms, or weedse a mater bully nest is built abmot an upright intk, at at lecight of twe or there feet from the ermund. A nest ubserverl in lakina (inmenty

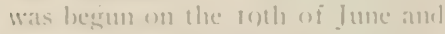
pratetically completed by the atternoxen of the followine dav.- The

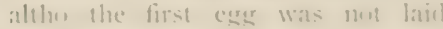
until the zhith. "Ilemp)," millsweed fibers, atul itried eqrasses were used in comblructions. ansel there was an claburate lining of lonrse-hair (p) dears: what will they (t) when the anomubile has fully supplanter the lurse?

Amente means pleasant. but the iemale amenity is amvthing else when fier fancied rights of malemity are assailed. Her vocabulary is

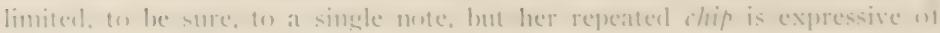
all worels in dis from distrust to distress and violeme disappundation 
No. 68.

\section{BLACK-HEADED GROSBEAK.}

\section{A. O. U. To. 506. Zamelodia melanocephala (Swains).}

Description.- Idult male: General coloration black and tawny varied with white and vellow: head glossy black, narrowly on chin, and with irregular invasion of tawny behind; back, scapulars, wings, and tail chiefly black; middle of back with much admixture of tawny; scapulars narrowly tipped with yellowish buffy or white, two conspicuous white wing patches formed by tips of midclle eoverts and basal portion of primaries: tonches of white on tips of greater coverts and secondaries, and on onter edge of primaries: touches of yellow (in ligglest plumage) bordering white of wing-coverts, etc.; terminal third of two outer pairs of rectrices white on imner webs: lining of wings and breast centrally rich lemon vellow: remaining plumage tawny, brightest on throat and clsest, with admixture if black on sides of neck; nearly as bright on rump, but veiled by lighter tips of

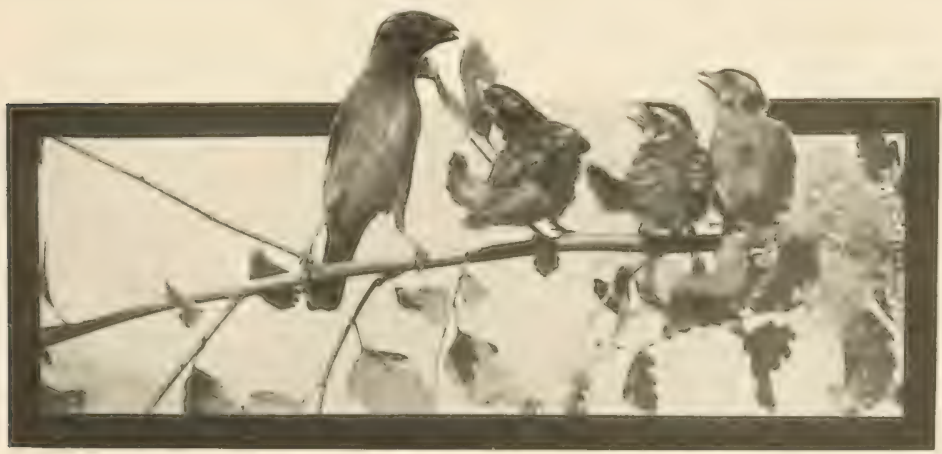

Tithen in Oregon

Whoto by lintery and Boliturn

.XTICIP.1TIOA

ieathers: lightening posteriorly on remaining underparts; nearly white on moler tail-coverts : bill bluish gray, darker above: feet plumbeous. Idult fimale: Like male, but tawny of unclerparts paler; upperparts dark olivaceous brown with admixture of white and pale tawny: head blackish with white or brownish median and superciliary stripes; wings and tail fuscous, white markings restricted, those on tail reduced or wanting: sicles and flanks streaked with dusky: Length $7.75-8.50(\operatorname{Ig} 5.85-215.90)$ : wing $3.9(90)$; tail $3.15(80)$; bill .7I (18); deptli of hill at hase .59 ( 15$)$ : tarstis $.95(24)$.

Recognition Marks.-Chewink size; black head and variegated plumage of male; large beak, with hannts, distinctive.

Vesting.-Vest: a careless lut often lunlky collection of twigs or weed- 
stalks, lined, ar not, with line dead gratseces set lesecly in branches of bush or

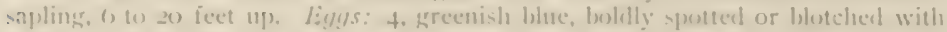
reddish lorewn, duaky lorown and lavender, most heavily alume larger end. Ar.

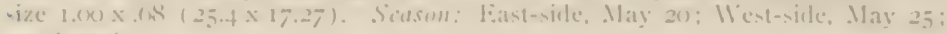
une. lirmorl.

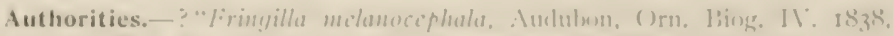

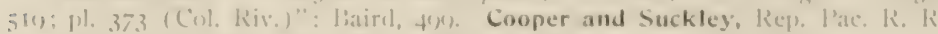

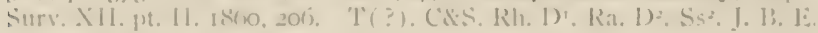

specimens.-1'. I', E.

THIOSl: whe complatin of our lack of song-lirels should make the acpuatintance of this really skilled musician. He will not often be fumel in the city garks, nor yet in the lir forests; but wherever there are deciclums frees, not (on) dense, or tall thickets of willow and alder besirle some latie

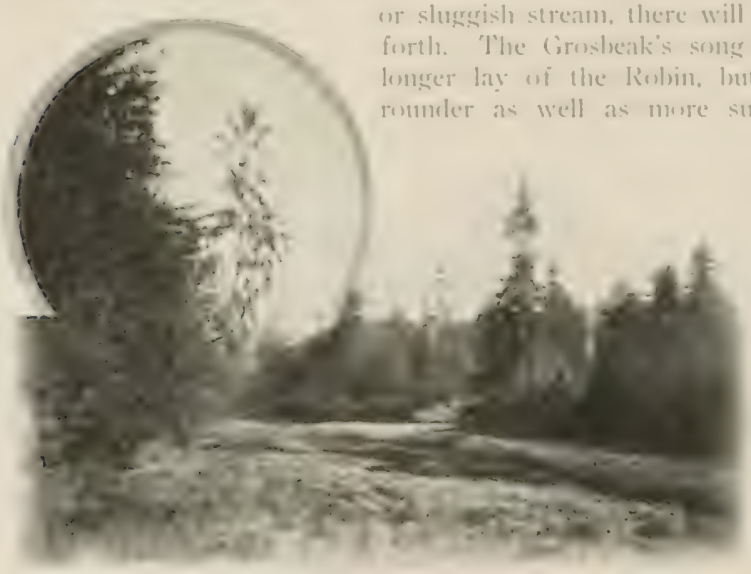

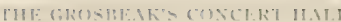

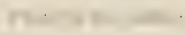

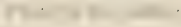

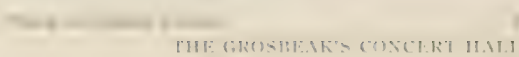

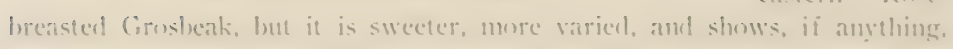
it still more strongly marked undertene of liepuid harmunice

The male cirosteak is, moreorer, an indefatigable singer, chmsing for

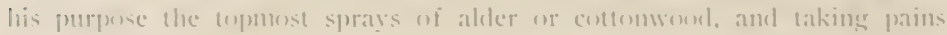

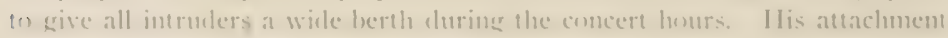
(1) a griven locality becomes apparent only after he has leen pursued from tree to tree in a wide circuit which brings up at the original station. And 
yet his shyness is not inspired by caution, for he will sing upon the nes? when he spells his wife at the hopeful task of incubation.

The more matter-of-fact female has no word of greeting for the stranger betond a sharp kimp, a beak-clearing note, not unlike that of a clicken with a crumb in its throat. This the male repeats also, with all slades of emphasis when the home is beset, or, as a last resort, he breaks into song at close quarters, - an ample price, surely, for the fullest immunity.

It is the nest which confirms the southern origin of these gentle birds. It is a flimsy affair of twigs, grassstems, or weed stalks carelessly interlaced, and caught in the crotch of a sapling at a height of from five to fifteen feet. The construction is so open, that the blue eggs with their dark brown and lavender spottings may be comted from below. The birrls, you see. have been accustomed to a warmer climate, to a tropical range, in fact, where warmtl of bedcling is no object.

If found upon the

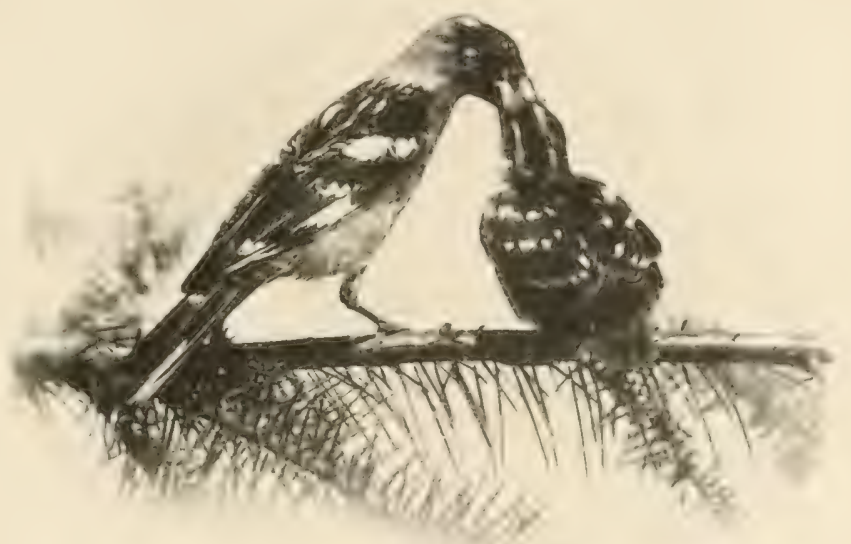

Taken in Oregon. nest, the brooding bird cannot think ill of you; or, if there is ground for misgiving, secks to disarm hostility by a display of gentle confidence. Instances are of record where the sitting bird has been stroked with the hand, and a little discretion will usually insure a lasting friendship.

This species enjoys a wirle range in Washington, being found from ticle-water to the upper reaches of the deeper mountain valleys: but it is nowhere common enough, let alone abundant. 
No. (\%).

\section{CRIMSON-HEADED TANAGER.}

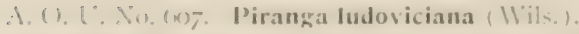

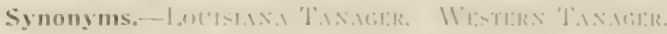

Description.- Mult male: liack, wings, aml tail black; milille coserts and tips of greater coserts yellow; remaining plumage rich gamboge vellow;

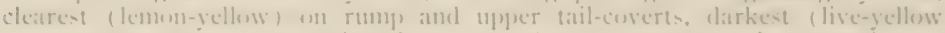

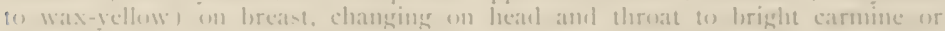

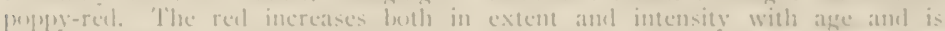

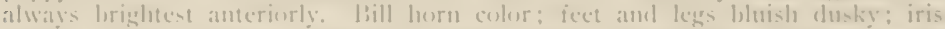

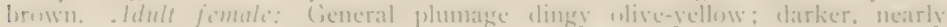
ulive, above; lighter and clearer on muler tail-ceserts; wings amel tail dusky with wlisaccons wing markings as in male but yellow paler. Jommen males rescmble the adule fembale amb only gradually acepure the elearer lorighter phumage

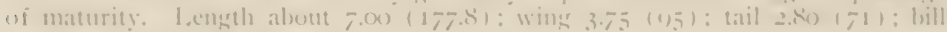
.5) $(15)$; iarsills . 80 (20.5).

Recognition Marks.-Sparrow size; sedate ways: pittic mote. 1Black and

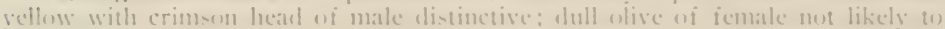
fue semfunest when size is diseriminated.

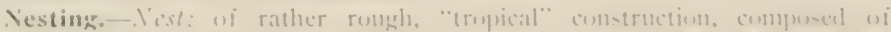
iwigs, roullets and mom, lined with lurse- or cow-hatr: measures externally

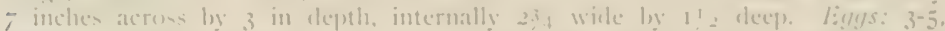

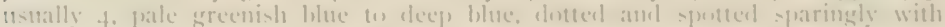
laventer and dark greenish slate, smuctimes in wreath almut lareer end: surface

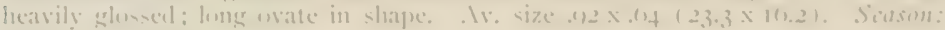
lune: ine liговl.

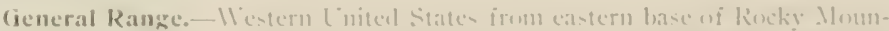

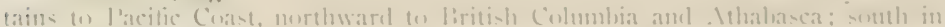

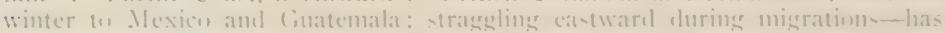
leen reveral times taken in Xew linglamel.

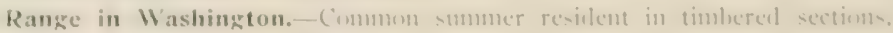
mierant in open comtery of liat-sile.

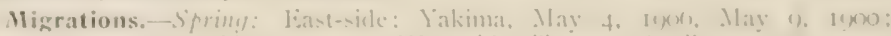

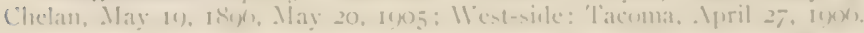

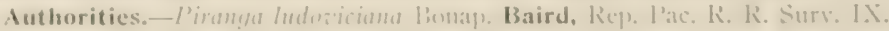

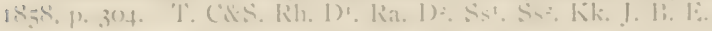

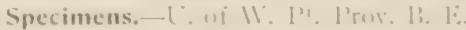

JIIS hambente Tanager is one of the mum characteristic birts of the more ofen forest areas of 11 ishingtem. whether east or west. It is me of

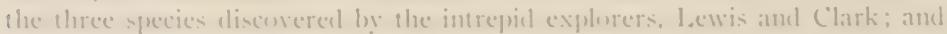

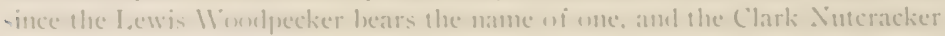
si the onlere, there was unthing for it hut to call the 'lanager after the region 
"lotisiana," whose further reaches they were then exploring. But we are no longer a part of Lonisiana, and we prefer a color-name for one of om few brilliant birds of plumage.

In the hand, the bright yellow of the male 'Tanager, shading into the bright crimson upon the head, wothl seem to assure a very conspicunus bird, but afield it is not so. Seen against the clinging green of maples, pines, or fir trees, these brilliant colors are lost to any but the most attentive eve. A resplendent male does not hesitate to stand quietly upon the end of a brancli and survey you until his curiosity is fully satisfied. This quiet attitude of genteel curiosity seens to be characteristic of all Tanagers. Apart from its psychological bearings, sedateness would seem to play an effective part in modifying the attractions of bright plumage.

The male bircls precele the dull-colored females by several days, and at such times only may be found in companies. One windy afternoon in May, the 2oth it was, while the Columbia River steamer doddered with its freight, I took a turn ashore and explored a tiny oasis of willows which lined a neighboring brook. I soon canght the pitic or pititic of newly-arrived 'Tanagers. Judge of my delight upon beholding, not one, but eight of these heaties, all old males, as they filed ont of a willow clmmp, where they had eviclently taken refuge for the clay. A week or so later I saw 'Tanagers at lome in the meager willow fringes of Crab Creek, in Lincoln Connty: and while we were in camp at Brook Lake in Douglas Connty, one came out thru the sage, lopping and flitting from bush to bush, to bring me friendly greetings. It was like meeting a king in a millet fiekd.

The song of the Lonisiana Tanager-pardon the lapse; habit is stronger than reason-the song of the Crimson-headed Tanager is an étude in $R$. "It is remotely comparable to that of the Robin, but it is more stereotyped in form. briefer, and uttered at intervals rather than continuonsly sustained. 'The notes are sharp-edged and rich in r's, while the movement of the whole, tin deliberate, is varied, and the tone cheerful"a. I can detect no constant flifference between the song of the Crimson-headed 'Tanager and that of the Scarlet 'Tamger ( $P$. crythromelas), save that that of the former is oftener

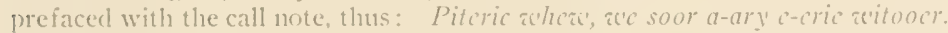
T'his song, lowever, is less frequently hearl than that of the Scarlet 'T'anager. liast. Its perfect renclition, moreover, argues the near presence of a clemure little lacly in olive, a person who looks like nobody in particular to our mfiscriminating gaze, but who exerts a strange fascination over our brilliant sytuire. Foung males of the second summer sing hopefully, but they are less often successful in love than their rucklier rivals.

It behooves the Tanager mailen to be exacting in her choice, for all

a. Applied to P'. crythronelos in "The Birds of Ohic," p. 109. and exactly applicable here. 


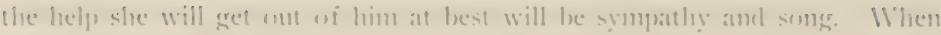

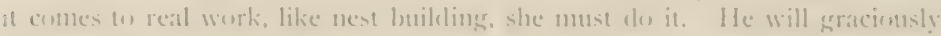
achise ats to the situation, some lowizontal branch wi fir or pine, from six w

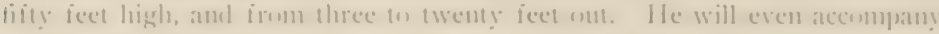

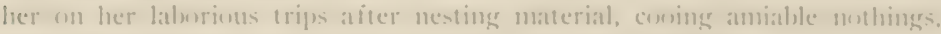

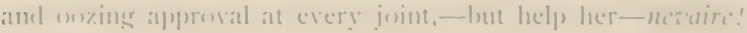

The nest is quite at substantial attair the rather roughly put together. of fir twigs, routlets, and moss, with a more or less heavy linisg uf hurse-

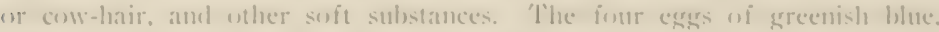
chetted and spotted with lavender and datr greenish slate, appear especially

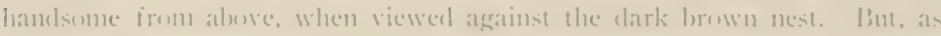

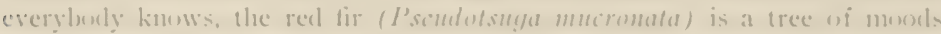
and tenses. Son may dangle with impunity from the very tips of the branches of some fir trees, while a step) from the trunk is fatal in wethers of the same genceal apprearabee. The l'amagers are quite as apt to patronize the britte kinel.

No. 70 .

\section{ORANGE-CROWNED WARBLER.}

1. (). 1'. . Sis, fuf), Helminthophila celata (Say).

Description. - thult male: . Wrove anly olive-greens, clearing and lorighter

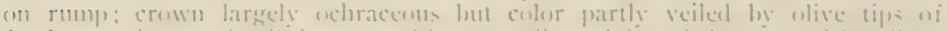

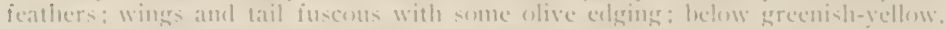
dinger, or vaguely streatied with blue on loreast and sicles. fdult fomale: similar

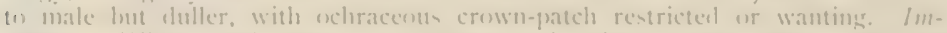

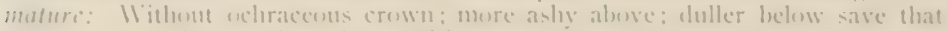

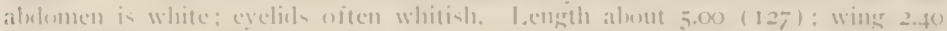

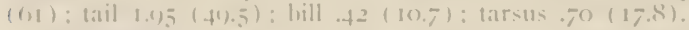

Recognition Marks.-Small warbler size; ochracenus ("orange") crown-

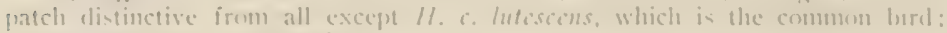
fluller. Siee next (sub) species.

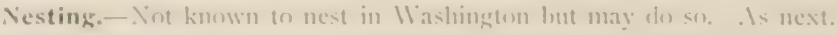

(ieneral Range.-Summer resident in western liritish . Mnerica and . Maska

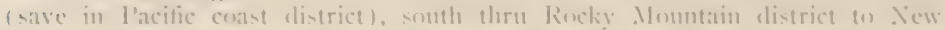

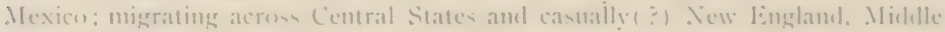

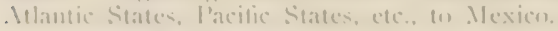

Range in Washington.-l'robably common migrant but passing undistinEminfeel among more alumulane lutesceris.

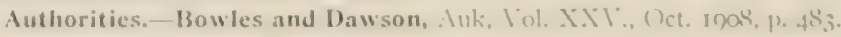

specimens.- liowles. I'rov. I'. 
MOST Alaskan species, even of those which retire in winter in Sotuth Carolina, Florida, and the Antilles, may be expected to drift thru our borders sooner or later. 'I'yical $H$. celata was first caught in the act by' Mr. Bowles in May, Igo\%, but we have no means of knowing that the northern form is not a frequent trespasser. Kermode gives it as a common summer resident east and west of the Cascades in British Columbia, and it is not impossible that ou northern Cascade records should be referred to this type.

No. 71 .

\section{LUTESCENT WARBLER.}

A. O. U. No. Gq6a. Helminthophila celata Iutescens Ridgway.

Description.--Adults:-Similar to H. celata but brighter. Above bright olive-green; below definitely yellow-olive-yellow, gamboge, or even canary (on tuncler tail-coverts). Immature: Above plain olive-green (not ashy, as in $I I$. colata); below buffy yellow tinged with olive on breast and sides. Measurements as in preceding.

Recognition Marks. - Small warbler size: perhaps the most abundant of the eight or nine "yellow" warblers of the State; ochraceous crown-patch, of course, distinctive; not so bright as the Pileolated IVarblers (IV.p. pilcolata and $W \mathrm{~W} . p$. chriscola).

Nesting.- - Vest: on the ground sunk in bed of moss, mnder protection of bush or weel, or in shelving bank, of coiled dry grasses, lined with finer; I $3 / 4$ inches wide by I inch deep inside. Ligys: 4. rarely 5. dull white marked with dots and a few small blotehes of yellowish brown and lavender; in shape long to short ovate, rarely oval. Av size $67 \times$.5 $(17 \times 12.9)$. Scason: May I and June I: two broods.

General Range.-Summer resident in Pacific Coast district from Cook Inlet to southern California, east to western ranges of Rocky Mountain System, where intergrading with $\mathrm{H}$. colata; sonth in winter to western Mexico and Guatemala.

Range in Washington.-Of general occurrence thruout the lower levels: abundant in Puget Sound region.

Migrations.-Spring: April $3,6,7$ (Seattle). April 24 (Chelan). Marcl 28, 1008 (Seattle).

Authorities.-( ?) 'Iownsend, Journ, Ac. Nat. Sci. Phila., VIII., 1839, I5.3 part (Columbia River). Cooper and Suckley, Rep. Pac. R. R. Surv. XII., pt.

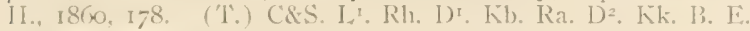

Specimens.-U. of II. I'rov. B. P3... E.

YliLLOIt appears to be the prevailing color among ont Washington Wood Warblers; and even of those which are not frankly all over yellow. 


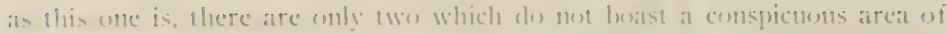
this fasliomalile shate. And wi all yellows, yellow-green, as represented by the hack of this lirel, is the commmonest, - st communt, indeed, as to merit the iacetions epithet "musem colner." It is all very well in the case of the

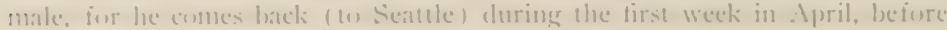
the leaves are fully ont: and lec is so full of combelence at this season that

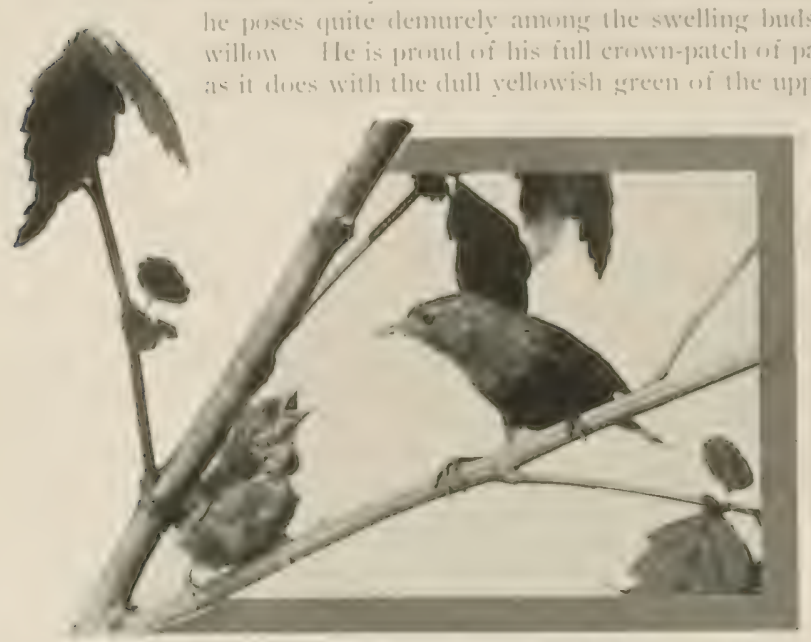

I IITNGRY CIICK

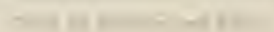

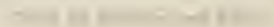

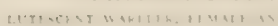
greenish yellow of the underparts, and lic lets your get a genol riew of it at twenty yards whth the glasses. Iiesiles hiate. he must stop? mow ind lluen in vent his ieclinge in ang. lint the catse if the iemale is al. most horpeless - ion the morice.

The sone of the lontescent 11 arbler ippears to have leeen very largely neer. lonked. lont it wanot the hirel's fault. While wating for his tardy mate, he fars rehearsed diligently from the taller hushes of the thicket, or else from some ligher vantage ponent of maple, clogwend, or fir trec. The burelen is intencled for fatiry cars, but he that hath ears tu leear let him hear a curious vowel seale, an inspirated rattle or trill, which rlescencls and emels in a simple wable of several notes. 'The trill, hrief as it is, lats three quatlities of change which make it quite monipue. Al the upening the metes are full and stow. Int in the instant necessary on the entire recital the pace aecelerates, the prited rises slightly. and the enmponem motes decrease in volume, or size It the dimax the tension breaks mexpectedly in the gente, musical catence uf the enncluding phrases, whose noses much resemble certats of the lellow llarbler's. The opening trill carries an a considerable distance. but the sweetnese of the chosing warble is lest fo any hut neat listeners. The whole 


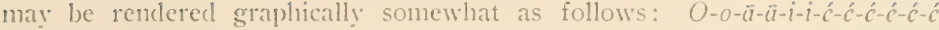
aichl, wichy, aichy:

In the brush and under alarm these bircls utter a brusque, metallic scolding note, which is perfectly distinctive locally; altho it much resembles that of the Oporormis gromp last. By this matk alone may the mere greenish female be certainly discemed.

Lutescent Warblers abound thruont western Washington, and easterly, when the Cascades are well passed, as upon the Pend d'Oreille. Jungle of any kind suits them. whether it be at thicket of roung firs at 'Tacoma, an overgrown burn al Snoqualmie, a willow swamp in Yakima County. or a salmon-berry tangle on Destruction Island. Nests are of clear? grasses well knitlecl and stmik tlusl with the gromukl. or below it. in some moss berl. at the base of a bush. or on some sloping hillside. Rarely the structure mav be taken

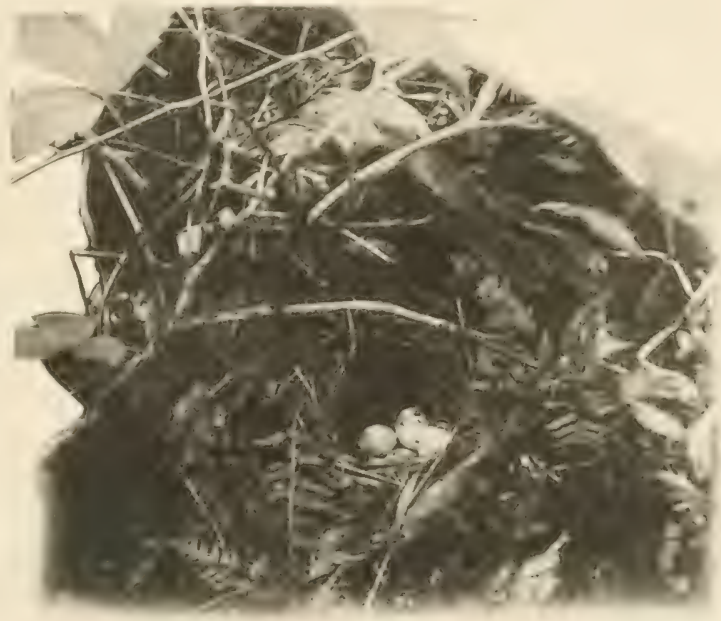

Tillon neir Tacoma

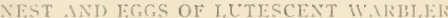

11i) 110 to a busl.

The female is a close sitter, but once flushed sluws implacalble resentment. She summons her mate to assist in the gentle art of exorcism, or else turns the tables and deserts outright. 'The latter, you understand, is quite the subtlest and most baftling fom of revenge which a bird may compass in the case of an oölogist anxious to iclentify his find. 
No. 72.

\section{CALAVERAS WARBLER.}

1. (). L. Ao, 645a. Helminthophila rubricapilla gutturalis (Rielgw.; .

Description,- fdull male: Heal aluwe and on sides bluish ash wels a partially concealed crown-patch of bright chestnut ; whitish cye-ring: remanuing upperparts bright olive-green leesming yellowish green on rump and upper tailcoverts; underparts including crissum, hright yelkw, but whtening on belly; bill smatl, short, acute, blackish above, lorownish below; feet brown. Adult fimale: l.ike male but someswat duller below: ashy of leat lesis pure, glosicel with wlivaceous and not so aloruptly contrasting with yellow of throat ; clestnut crownfatch less conspicusous or wanting. Immuture: ()live-green of upperparts cluller: head and neck grayish brown instcal of aslyy: helow dull olive-yellow, clearing (n) belly and crisstum. I.ength of male (skins) 4.05-4.75 (10.3-121) ; wing 2.35 $((x)$ ) tail $1.75(4,5)$; bill . $38(0.6)$ : tarsus $.63(16)$. Female smaller.

Recognition Marks.-Smaller: hright yellow of throat (and unclergarts). contrasting with ashy of head, distinctive.

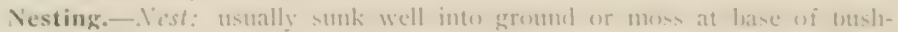

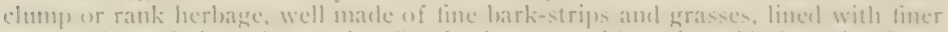
grasses, lurse-latir aud, oecasionally, feathers: outside, 3 in. wide le 2 in. deep:

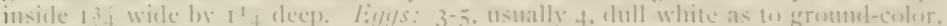
lut showing two distinct types of markings: one leavily sprinkled with fine dorts of redelish brown, nearly uniform in dissribution, or gathered mure thickly alust larger end; the other sparingly dotted, and with latge blenches or "llowers" of

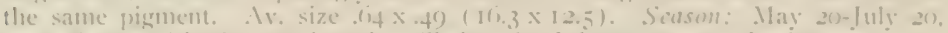
according to altitude: two lirends. Chelan (o. July 22, leno, 3 fresil egges.

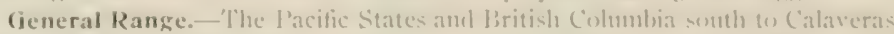
Connty, California, and east (at least) on morthern folaho: found chietly in the higher mountains; in migrations to I.ower (alifornia and western . Mexico.

Range in Washington. - Summer resileme on brusly slopes and in simbered valleys of the bigher ranges thruout the state, and irregularly at lower levels, at least on l'uget Sommel (Tacoma).

Migrations.-Sprin!: Wallula, April 23. I105: liemtom County, May f.

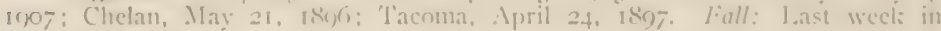
August (Blaine).

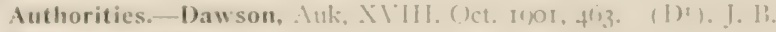

specimens.-1:

'7ll:Ll: is something distinct and well-bred alunt this temure exquisite, and the day which discovers one searching the willow topls with sentect alonfmess is sure on le monerseosed in the mote-lumk. 'The marks of the spring male are as mmistakiable as they are rexal: a hright yellow breast and throat contrasting with the ashy of checks and head, the latter shate

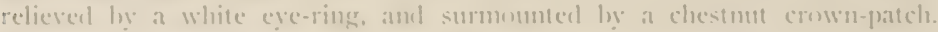
If you stumble upun a company of them at play among the therm bushes. 
you are seized, as like as not, with a sense of low birtl, and feel like retiring in confusion lest you offend royalty.

These gentle despots are bound for the mountains; and since their realms are not prepared for them till June, they have ample leisure to cliscuss the fare of waysicle stations. They enter the State from the South during the last week in April-WVallula, April $23 \mathrm{~d}$, is my earliest record; but May 21 st records an manxious company at the foot of Lake Chelan. As the season advances they take up quarters on brushy momntain sides, or in the deciduons skirts of fierce momntain torrents. Here while the female skmrries about thru the buck-brush or vine-maple thickets in search of a suitable nesting site, the male mounts a fir tree and occupies limself with song.

If you are spying on this sacred function, the bird first peers down at you nneasily, then throws his head back and sings with great animation: Choopy', choop 1', choopy churr ("tr). T'he trill is composed of a dozen or so of large notes which the ear can easily distinguish, but which because of the vivacious utterance one cammot quite count. The pitch of the finale is sustained, but there is a slight decrease in volume. If forced to descend. the singer will join his mate in sharp chips of protest. somewhat similar to those of the Auchlon Warbler, altho not yuite so clear-cut or inflexible.

While the Calaveras Warbler is a bird of the monntains and lives at any height where stitable cover is afforded, it is a curions fact that it sometimes prefers the timbered lowlands of l'uget Somnd, and may be found in some seasons in considerable numbers about the southern prairies. Mr. Bowles has foumd them commonly in scrub-oak patches which border the fir groves and timbered lakes: and yet during some years they lave been nuacemutably absent from the entire region.

Near Tacoma this Warbler places its nest at the base of a young oak or fir tree, where the spreading branches have protected the grass and gathered weeds. The nest is sunk well into the gromel or moss, and is so well concealed as to defy discovery unless the bird is flusherl. When frightened from the nest the female instantly disappears, and returns only after some considerable interval. Then she approaches with the greatest cantion, ready to dart away again upon the first sign of movement on the part of the intrucler. The male, if he happens to be about at all, neither joins the defense nor consoles his mate in misfortune, but sets upon her furiously and drives her from bush to bush, as tho she had wilfully deserted their treasures.

At sea-level two sets of eggs are laid in a season, one fresh about May i 8 th, the other alout June 25 th. In the mountains, however, the second nesting. if inclulged in at all, is thrown very late. I took a set of three fresh eggs from a carelessly constructed nest placed in the top) of an elk-weed (Echinopanar horridum) at a height of three feet, on the $22 x$ day of July, Inoo. 
No. 73.

\section{YELLOW WARBLER.}

1. (). (:. No, (152, Dendroica aestiva (cmel.).

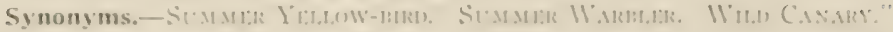

Description.-. Idult male: Forchead and fore-crown bright yellow with

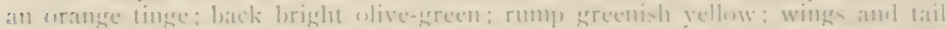

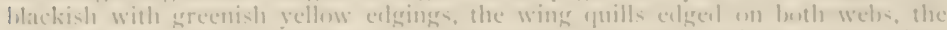

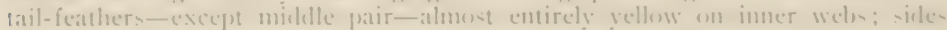

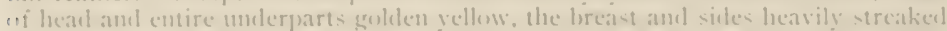

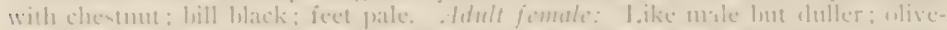

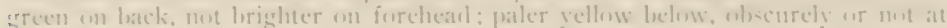

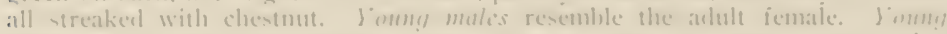

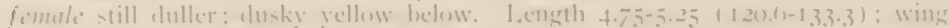

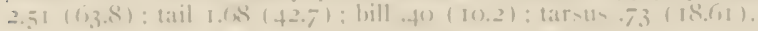

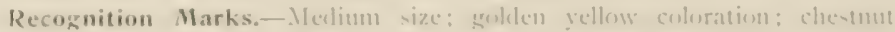

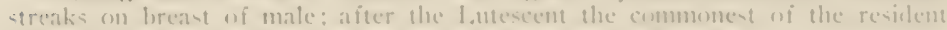
IVarbless: chichlo comfined to the lanke of streams and pumbls.

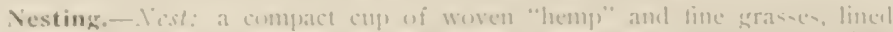
heavily with plant-ilown, erasees, and, occasionally, horse-hair. fastencel to npright

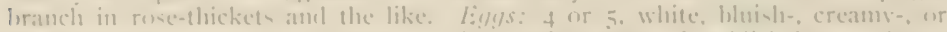
srayi-h-white. speckleal and marked with larginh youte of redelinh brewn. hurnt

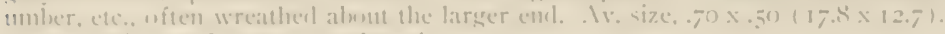

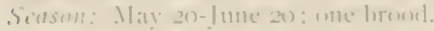

(ieneral Range.- Vurth Inerical at large, except southwesern part, ghving place on /). of ruhiginese in extreme nerthwest. Sunth in winter to central

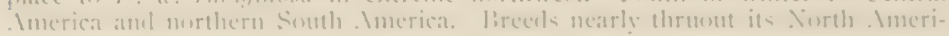
(at) ratuse.

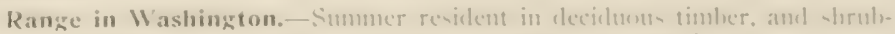

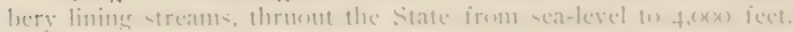

Migrations,-Sprin!: 'Tacmma, Ipril 2f-30: Yakima, Ipril 30. umo:

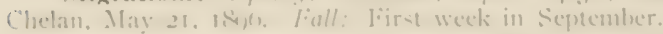

Authorities.-Cooper and Suckley, Rep. l'ac. K. K. Surv., XII., Jt. II.

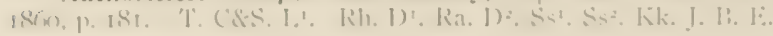

Specimens.-1:. IIN. I: I't.

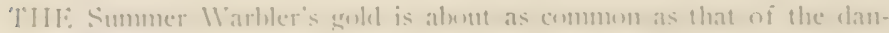
feliom, but it trim little form has mot achieved any such distinctness in the

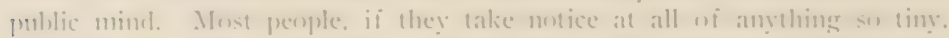

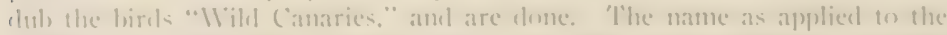
(indellind may le barely tolerated. hut in the case wi the llarbler it is quite inappropriate, sone the hial has mothing in common with the camary exeept

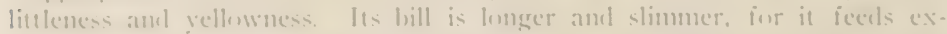
chasiely on insects insteat of exeds: and its pure yellow and olive-green 
plumage knows no admixture, save for the tasty but inconspicuons chestnut stripes on the breast of the adult male. These stripes are lacking in males of the second year, whence Audubon was once led to elaborate a supposed new species, which he called the "Children's Warbler." 'The name is not ill-fitting, even tho we know that it applies only to the Warbler"s children.

The Yellow IVarbler is peculiarly a bird of sunshine, and is to be found chiefly in open situations. It swarms thru the orcharcls and gardens, frequents the wayside thickets. and in town takes possession of the shrub. bery in lawn or park. It is abundant in swampy places, and is invariably present in season along the banks of streams which are lined with willows, alclers, and wild rose bushes.

The song is sunny, too. ancl while not elaborate, makes substantial contribution to the good cheer of spring. Heard in the boskage it sounds absurdly as if some wag were shaking an attic salt-cellar on a great green salarl. The notes are almost piercing. and sound better perhaps irom across the river than they do in the same tree. Individual variation in song is considerable, but

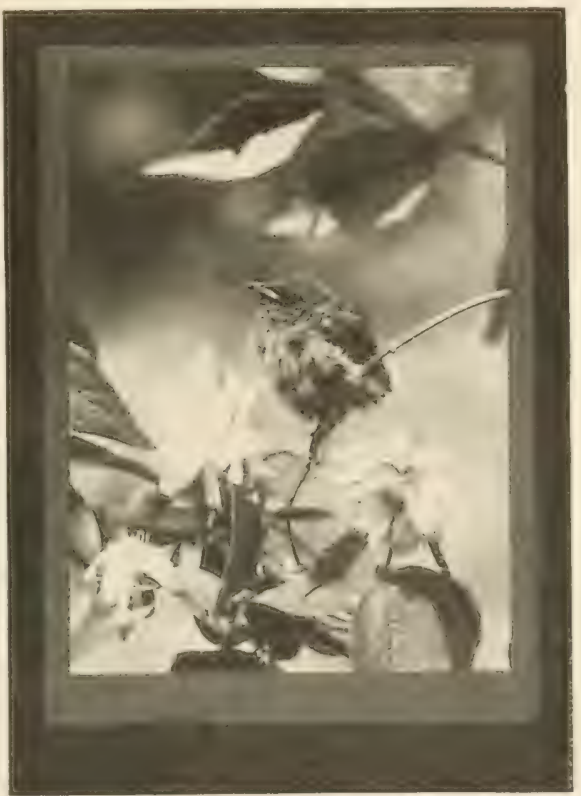

Taken in Orezon.

I CONTENTED B.IIS

the high pitch and vigor of delivery are distinctive. Certain common types

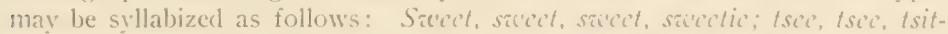

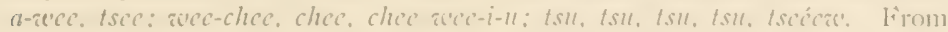
its arrival sometime during the last week in April, until near the close of its second nesting, late in July, the bird may be found singing thruout the stunlit hours.

'The date of this bird's ammal arvent in Washington is far less nearly 


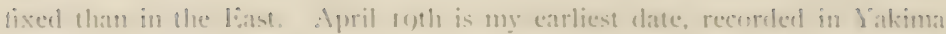

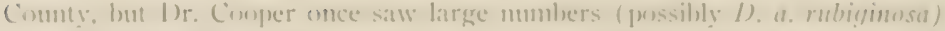
"at the stmats of l)e leuca," on April \&. On the west side of the mountans

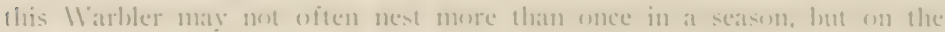
liast-sile it usually raises (wi) loriments.

The nest of the le llow IItrabler is yule commum. especially casferly, where its conete is more re utricterl; atul nue special patins is laken all conceal ment. Dests maty de phlaced at amy levergh is urchard trees, alders, wil lows, or even fir saplenes lont. withme foulde. Ihe most atcecptathle sitce is that alfureled be demse thickets ui the wiln rose kesal pismatpal where

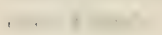

The cratle of this lomel is uf expulsite filbrica tim. 'The toush inter lark of ertain weerls called indiccriminalel! "hempip" - merether witl erasises amel other librous materials in various pro. protions, is woren into at

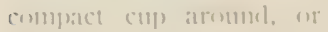
setelect inte. some stom furizontal ar ascemeling burli of lnusle or trees. Is a result the buslese are inll of llarblers neits

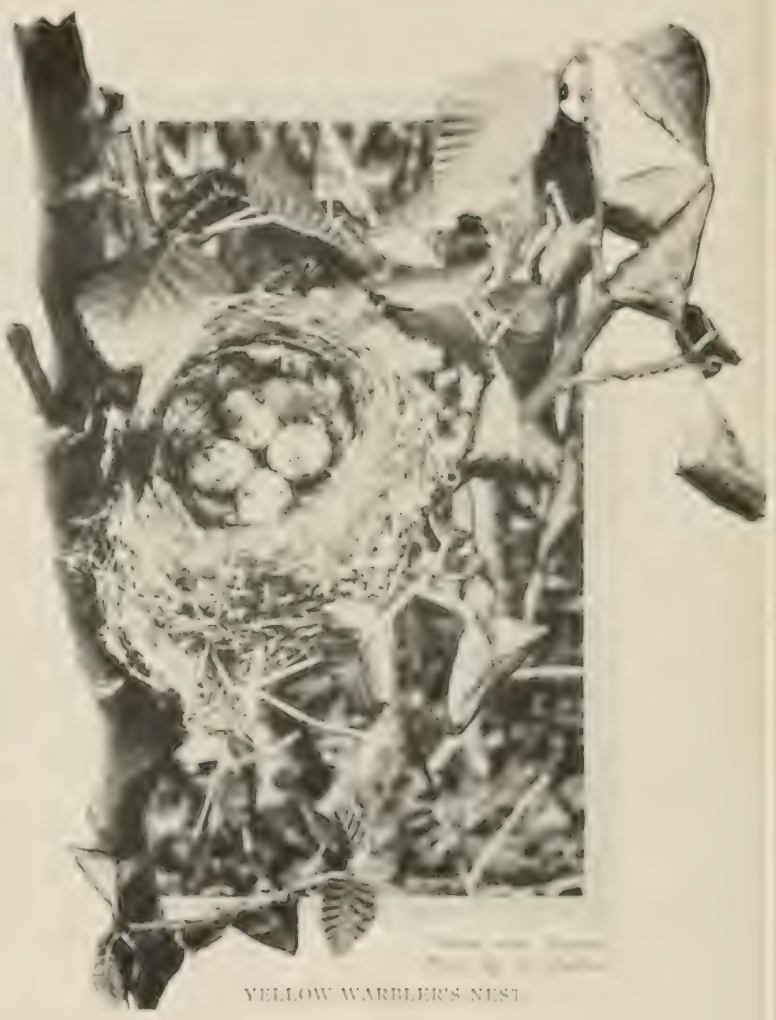

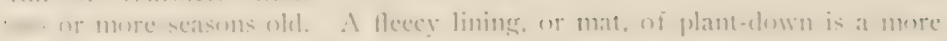

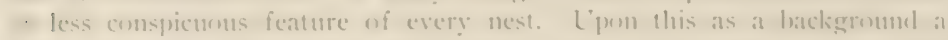

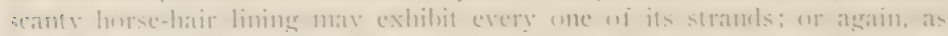
in the case of a mest taken on the Chelan River, the exgs themselses mas le thrown inen high relief he a coiled black mattress. 
'The male Jellow is very domestic in his tastes, insomuch that, quite unlike other Warblers, he will often venture to sing from the very bush in which his mate is sitting. Unless well accustomed to the presence of humans, the female will not sit patiently uncler the threat of close approach. She slips off quickly and her vigorous complaints serve to summon her husband, when both Hit about close to the intruder, and scold rombly in fierce, accusing notes, which yet have a baby lisp about them.

\section{No. 74 .}

\section{MYRTLE WARBLER .}

\section{A. O. U. . సo. 655. Dendroica coronata (Linn.).}

Synonym.- YBLOW-RUMIPD WARLLER.

Description.- - dult male in spring: Above slaty blue with black streaks, smaller on sides of crown and nape, broader on back; below white, with black on upper breast. sides of middle breast, and sirles in endless variety of patterns; a large patch on each side of breast, a partially concealed patch in center of crown, and rump, bright yellow (lemon or canary) : superciliary line white; a deep black patch on side of head; wings fuscous; tail darker; middle and greater coverts narrowly tipped with white, forming two rather conspicuous bars; three onter pairs of tail-feathers with white blotches on inner webs, decreasing centrally; bill black: feet dark. licmale in spring, and both seres in fall: Duller; the biue of upperparts overlaid with brownish; a brownish wash on sides of breast and llanks: black of breast obscure,-restricted to centers of feathers; yellow of breast-spots pale or wanting. Immature: Brownish above; whitish below with a few obscure clusky streaks. Length $5.25-5.75$ (I $33.3-1+6.1$ ) ; av. of five ma!es: wing $2.98(75.7)$ : tail $2.22(56.4)$; bill . $38(9.7)$; tarsus .78 (20).

Recognition Marks.-Larger; aihite throat as clistinguished from $D$. anduboni, which it otherwise closely rescmbles.

Nesting.-Not known to breed in Washington. Nest as in next species. Eggs indistinguishable.

General Range.- "liastern North America chiefly, straggling more or less commonly to the P'acific; breeds from the northern United States northward, and winters from southern New Lingland and the Ohio Valley southward to the West Indies, and througl Mexico to Panama" (A. O. U. '95). "An abmulant summer resident on Vanconver Island and mainland (B. C.), chiefly west of Cascardes" (Kermode).

Range in Washington.-Spring and fall migrant, probably of regular occurrence east and west of the Cascades.

Migrations.-Spring: Tacoma, Apr. 27, I006, Ino7; Seattle, May 3, ryo8; Chelan, Nay 22, 1005; Yakima, Apr. 30, 1801.

Authorities.-Baird, Rep. Pac. R. R. Surv. IX. pt. II., I858, 272, 273. C\&S. Rh, Ra, 1)². Kk, P. Ki.

Specimens.-U. of W. I'rov. C. 


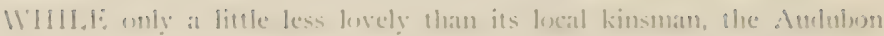

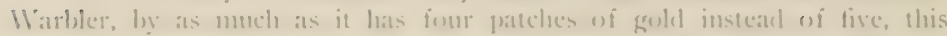
beatuiful migrant appears un have been very largely lost (1) sight in the throner of its more brilliant relatives. Kathlum, writing from seattle, sass

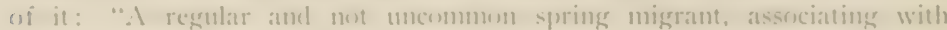

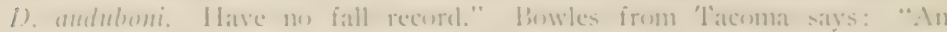
irregular fall migrant, very numeroms smme vears, the fall uf 100 for for

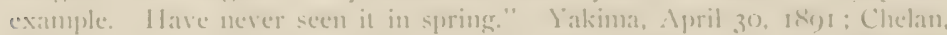
Maty 22, log 5 : 'lacoma, April 27, 1007, are some of my own records. fitmmin gives the species as "An abumelant summer resident, chictly west of lhe Cascarles," in liritisl Cohmulsia, and it should aceur regularly within our Ixorelers dluring migration.

The thip mote of the Myrtle Marbler is indistinguishable irm that of 1). andulumi, lut a single glimpse of the white throat is sufficient to establish identity. 'Thuse seen have necessarily been at close quarters and ranging how, in willow thickets, along the margins of pronds, ete., but it is altogether prssible for a migrant troop to lowlel ow the tree-tops in passing and so cincle (s) servation from "lourly-nine" on the Colmmbia.

No. 75.

\section{AUDUBON'S WARBLER.}

1. (). ['. Ni, 65̧6. Dendroica auduboni ('l'owns.)

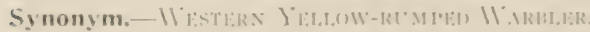

Description.- Idult male: Similar to /). commafa lut throat rich gambnge vellow; auriculars bluish gray insteat of hlack: a large white wing patel formed

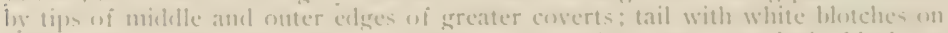
imer webs of four or five outer icathers: nsually more extensively black on

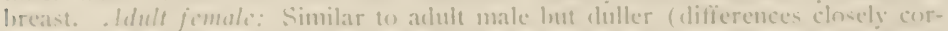
respombling with those in /). coromaful): the white of wing patch nearly colsolete: the vellow of throat praler and often, especially on chin, more or less displaced low white (youms females even of the secombl summer are sometmes absolutely withent velfow on throat but the more aloundant white on rectrices is clistinctive as comprareal with /). coromata). Suamal changes follow very closely those ni I). commote lut yellom of throat is nsually retained in winter sate in young

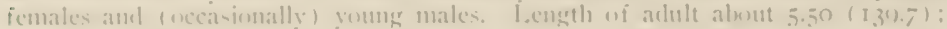

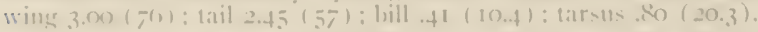

Recognition Marks. - Warbler size: fiat yots of yellow: exten-ive white

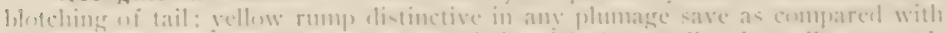

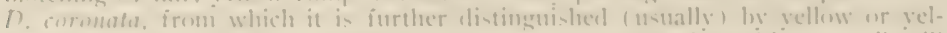
lowish of throat if this character fails, the mere extencive white on tail will alwats hull|.

Vesting.- list: a well huilt, lnulky structure of lir twigs, weet stems. 



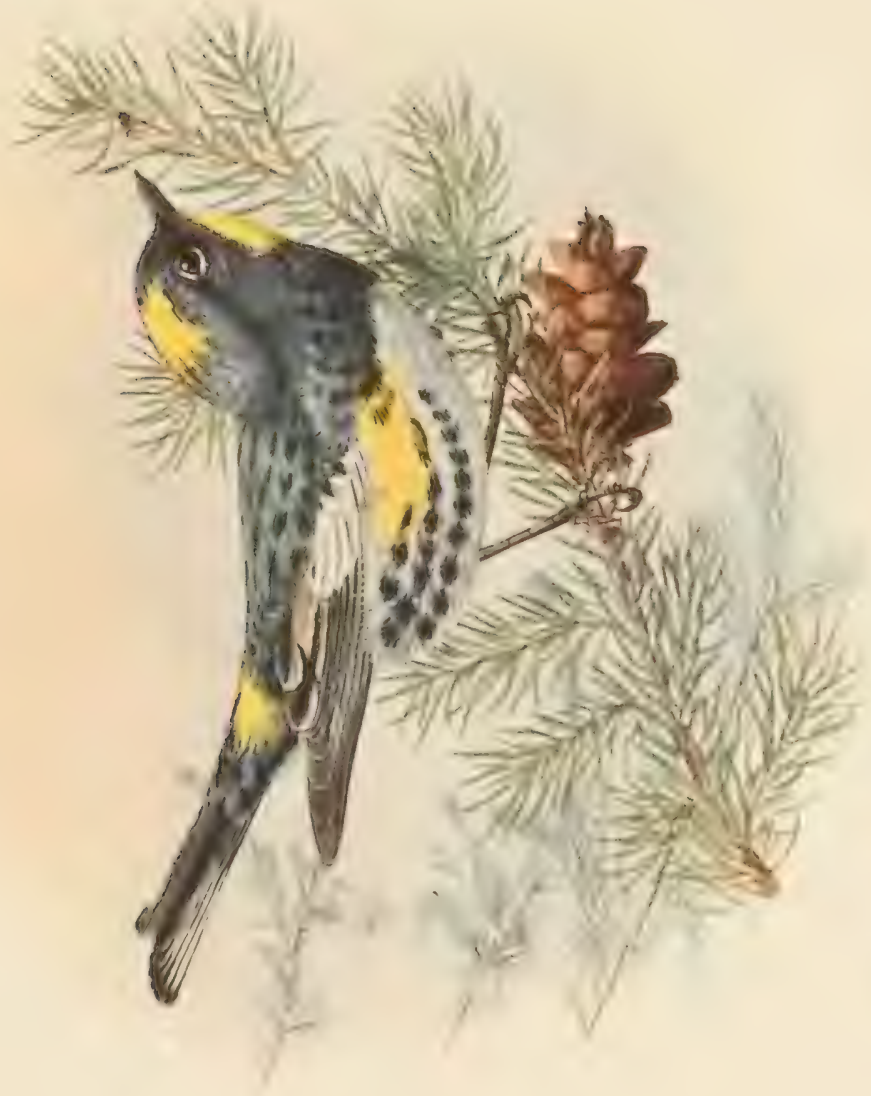



rootlets, etc., heavily lined with horse-lair and feathers; placed usually on branch of conifer from four to fifty feet up, sometimes in small tree close against trunk, measures 4 inches in width outside by $23 / 4$ in depth; inside 2 by $1 / 2$. Eggs: 3-5, usually 4 , dull greenish white sparingly dotted with blackish or handsomely ringed, spotted and blotched with reddish brown, black and lavender. $A \mathrm{r}$. size, .7 $\times 54$ ( $18 \times 13.7)$. Scason: April-June; two broods. 'I'acoma, April 9, 1905, 4 eggs lialf incubated.

General Range.-Western North America, north to British Columbia, east to western border of the Great Plains, breeding thruont its range (in higher coniferons forests of California, northern Arizona, etc.), wintering in lower ralleys and sonthward thruout Mexico. Accidental in Massachusetts and in I'ennsylvania.

Range in Washington.-Common resident and migrant on West-side from tidewater to limit of trees; less common migrant and rare winter resiclent (?) east of the Cascarles.

Migrations,-Spring: East-side: Yakima, March II, Igoo (probably winter resiclent); Lakima, April I3, I900; Chelan, April 20-2.4, 1806. West-side: I'acoma, April 24, 1906.

Authorities.-Sylvia auduboni Townsend, Journ. Ac. Nat. Sci. Phila. VII. 1837, I9I ("forests of the Columbia River"). Cis. L. Rh. Dt. Kb. Ra. D'. Kk. B. I.

Specimens.-U. of IV. P Prov. B. BN. E.

AS one considers the Thrushes, Wrens, and Sparrows of our northern clime, he is apt to grumble a little at the niggardliness of Mother Nature in the matter of providing party clothes. 'The dark mood is instantly dispelled, however, at the sight of this vision of loveliness. Black, white, and gray-blue make a very tasty mixture in themselves, as the Black-throated Gray WVarbler can testify, but when to these is added the splendor of five golden garnishes, crown, gorget, epaulets, and culet, you have a costume which Pan must notice. And for all he is so bedecked, auduboni is neither proud nor vain,-properly modest and companionable withal.

Westerly; at least, he is among the first voices of springtime, and by the Ioth of March, while all other W Warblers are still skulking silently in the Southland, this brave spirit is making the fir groves echo to his melody. 'The song is brief and its theme nearly invariable, as is the case with most IVarblers: but there is about it a joyous, racy quality, which flicks the admiration and calls time on Spring. The singer posts in a high fir tree, that all may hear, and the notes pour out rapidly, crow ling close mpon each other, till the whole company. is lost in a cloud of spray at the end of the ditty. At close guarters, the "filling" is exquisite, but if one is a little way removed, where he catches only the crests of the sound waves, it is natural to call the effort a trill. At a good distance it is even comprable to the pure, monotonous tinkling of Junco.

I once heard these two dissimilar birds in a song contest. The Warbler stond upon a farorite perch of his, a spindling, solitary fir some hundred feet 


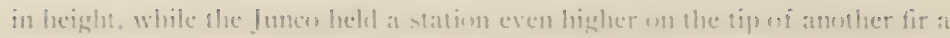
bleck awaty: Here fhey hat it hack and forth, with homors surprisingly even.

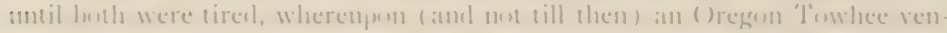
tured to loring iorth his prosy rattle. It was like simbes and his "lenes" atfer ati ipretrit.

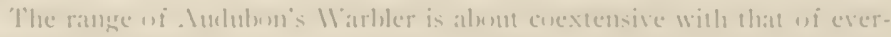

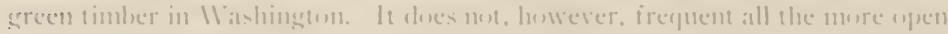

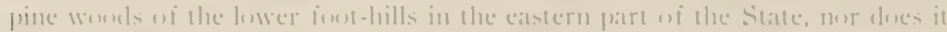
eceur lathitually in the deeper solitueles uf the western forests. Cinnsilered altitulinally, its range extents from sea-level tu timber-line. Inulalth it is at home in the highest mumutins, it is expally so in the city park and in the shate

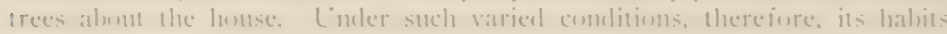
must vary wielely.

11 e de non know to what extent it is resiclent, that is, present the yeas

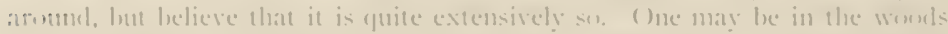

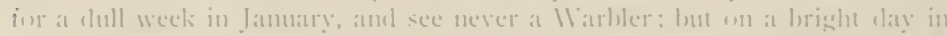
the same reginn lee may encenter mumbers uf them. I have seen them playing

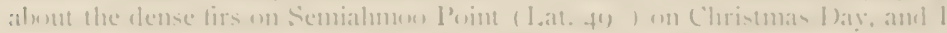

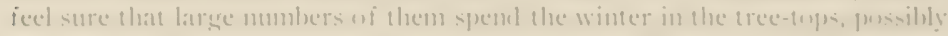

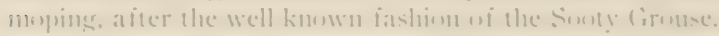

It is these winter resielents which heerme atetive in early spring. In the

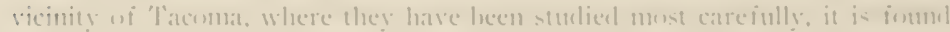

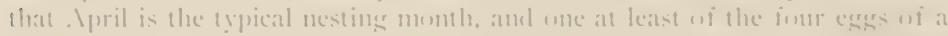

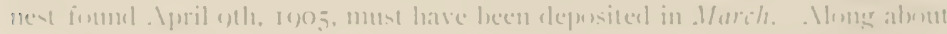

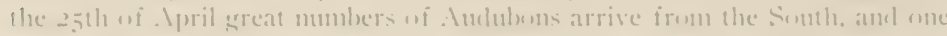
maty see indelent companies of them lonmering thro the trees. while resident birds are lusy feeding yomes. These migrants may te destined for our own moumans as well as british Colmmbia. latst-side hirels atre likewise tardy in arrival. for pine trees are inalepuate sleder for wintry experiments.

The alberbing desty of springtime is nesting, and th this ant the . Iudubons sive themselves with lecoming artor. 'The female thes the werk. while the male cheers ler with somg. amel not infrequently trails alunt afeer her, useless lut sympatletic. Inte a certain tiely growe near taermat the hirel-man entered me crisp morning in April. 'The trees stemel alum like decoroms candlesticks, but the place hummed with linglets and clattered with Junces and . Imlubons. () ne Aulubun, a female, aldertised her business on all emmers. I saw her, upon the grouml, wrestling with a larese white chicken-feather, and spmbering ex-

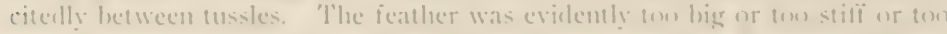
wet for her proper tatste: Int linally stre flew away across the growe with it. ehirping merrily. Amb since she repented her precise course three times, it was an easy matter to trace her some fifleen rouls straight to her nest. forly feet up (n) an ascencling fir branch. 
When the nest was presumed to be ripe, I ascended. It was found settled into the foliage and steadied by diverging twigs at a point some six or seven feet ont along the limb. None of the branches in the vicinity were individually safe, but by dint of standing on one, sitting on another, and clinging to a third. I made an equitable distribution of avoirdupois and grasped the treasure. Perhaps in justice the supporting branches should have broken just here, but how could you enjoy the rare beaty of this landsone structure unless we brought it to you?

The nest is deeply cup-shaped, with a brim slightly turned in, composed externally of fir twigs, weel - tops, flowerpeclicels, rootlets, catkins, etc., while the interior is heavily lined with feathers which in turn are bound and helel in place by an innermost lining of horselairs. Onc feather was left to curl claintily over the edge, and so partially conceal the eggs,-font spotted beatities.

These Warblers are connoisseurs in teathers, and if one

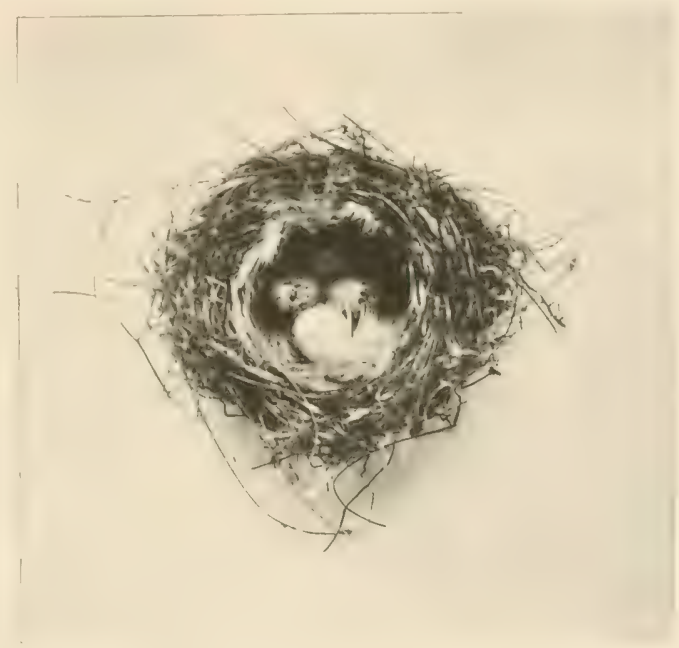

Taken in Tacoma.

Photo by lie Author.

had all their nests submitted to him, he conkl make a rough assigmment of locality for each according to whether feathers of Oregon Ruffed Grouse, Franklin Grouse, Ptarmigan, or clomestic fowls were usecl.

In the wet region the birds appear to nest in fir trees only, and they are as likely to use the lowermost linal, as any. 'There is little attempt at concealment, and Bowles reports a nest only ten feet high over a path used daily by hundreds of people in 'Tacoma. On the dry side of the mountains the IVarblers avail themselves freely of deciduous trees and bushes for nesting sites. A nest on Cannon Hill in Spokane was placed at the lowermost available crotch of a young elm tree near the sidewalk and not ten feet up-as bold as a Robin! 


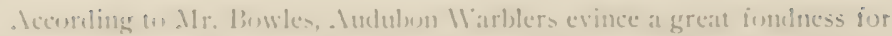
their clusen nestiug lammts, and will return on them year atfer year, biten to she sanc tree, and sometimes th the same branch. "Whey are the must solicituns of all the Il ashington IVarblers concerning their egge, sumetimes coming

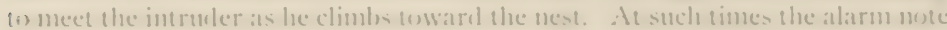
"if the ienale sen brings the male, when, slosuld the nest contain inculsated eggs or yenng, benth hinels crawl among the branches, frequently within reach, with wings and tail spreat, in absolute iorgetfulness of their own safety."

Inculation is accomplished in twelve days; and one or two lorouls are mased, according to lecality and length of seasum.

$1 / \mathrm{e}$ lose sighte of most of the bircls, especially the smaller ones, after the inevlay wi springtime, hut here is one who, lecatuse he las iorsworn wander-

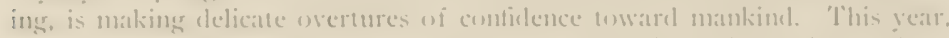
especially, mow that the dense trace of wonds nerth of the Liversity has been

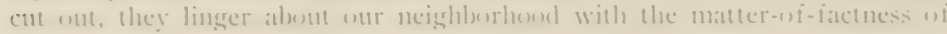

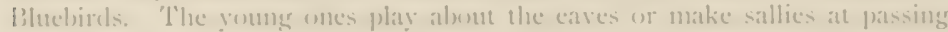
flies fom the windew-sills, and yawn with childish insonciance if mammat surerests, ly a shatp thip, that enemics may lurk hehind the curtatus. 'They kmow it's only habit with her, and she doesn't helieve it herself. 'The aluht antire is duller now, and only the rethes rumpepatteh remains for recognition he a friend. 'The year is waning, mo dentu of that, but Oetober sunshine is end enough for us- or Sorember ratins. Let them flit whe will! IVashinston is genol enungle for us. you in your fir house and I in mine.

\section{No. 76 .}

\section{BLACK-THROATED GRAY WARBLER.}

1. (). L. Xon. G6.5. Dendroica nigrescens I'lomms.).

Description.- Hilult mule in sprimy und summer: I supraloral spout of yellow: remaining plumbere black, white and lifue-gray ; heal, throat and dreat lifack interrupted by superciliary stripes and loroal malar striges of white: remaining mpperparts blue-gray, markerl with hlack in inverted weelge-shapent yosts on back, scapulars and upper tail-eoserte: wings and tail black edgeel with blui-h

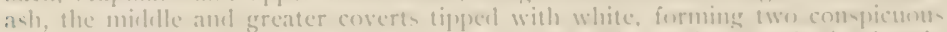

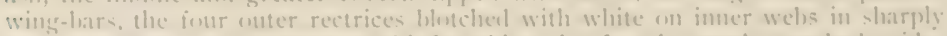

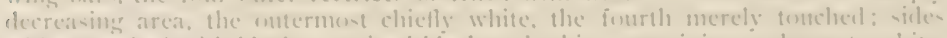
white streaked with black or striped black-and-white: remaining inderparts white. didult femole: I,ike male but duller, the black of erown partly veiled by lilneeray stirting, that of thruat reclueed loy white tipe of fenthers. Jommi hirds

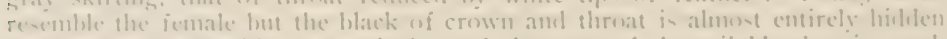
by hlue-gray and white revpetively, and the area of the tail bifuches is mueh

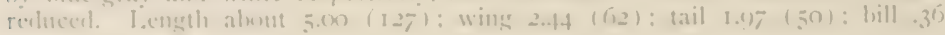
(1).2): tar-11: (x) $(1,7,5)$. 
Recognition Marks.-Warbler size; black and white and blue-gray coloration distinctive.

Nesting.-Nest: a rather loosely built structure of dead grasses, silky plant fibers, moss, etc., placed midway on horizontal limb of conifer $25-50$ feet from grotund; measures, externally, 3 inches wide by 2 (leep, internally $13 / 4$ wide by 1 deep. Egys: t, creamy white, marked, chicfly about the larger end with spots and small blotches of varving shades of brown, lavender and black. Av. size. $.83 \times .63(21 \times 16)$. Season: last week in Nay and first week in June; one brood.

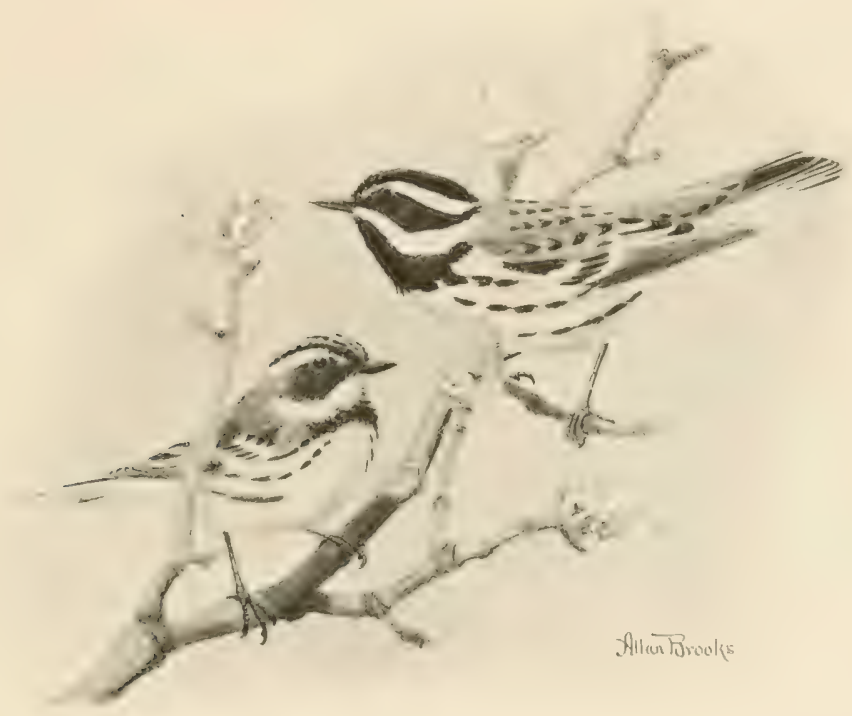

DTACK-THROATED GRAY W.MRLLIES, MAI: INI FEMALE.

General Range.-Western United States (north to Colorado, Utah and Washington), and Britisl Columbia west of the Cascades; breeding southward to Sonthern California, southern Arizona and I.ower California; south in winter thru Mexico and States of Oaxaca and Vera Cruz.

Range in Washington.- Summer resident and migrant west of the Cascade Mlotuntains.

Migrations.-Spring: Seattle-Tacoma c. April I2. Fall: c. Sept. I (Blaine).

Authorities.-Sylita nigrescens Townsend, Jomrn. Ac. Nat. Sci. Phila. VII. 18.37, 19I ("forests of the Columbia River"). CiS.S. L. D' (?). Ra. Kik. B. Es.

Specimens.-U. of WV. Prov. I3. IE. 


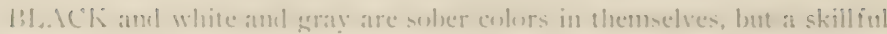

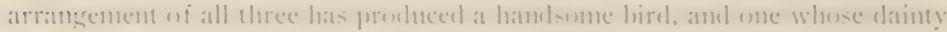
dignity repuires me meretricions display of gatuly reds and yellows. Warlsers are stuch timy ereatures at hest that Xature has given litte thenght to their pros-

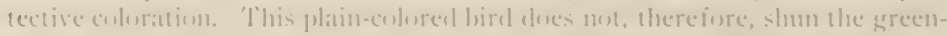

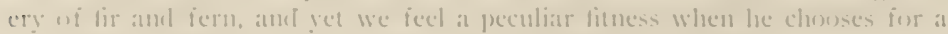

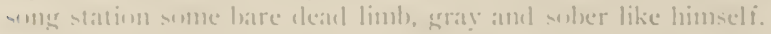

Lats year the first arribal in Seattle seated himseli upun it projecting limb

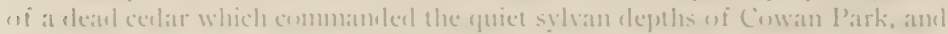

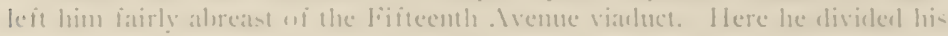
time letween song and enjoyment of the seene, sparing a friendly glance nuw ambl then for the almiring lirel-man. His mamer was complatisant amb selfcontainet, and I felt that his little veat wlierings were a tribute to the perfect morning ratleer than a hid for applatuse.

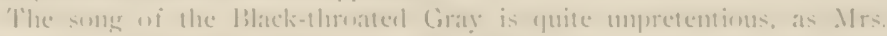

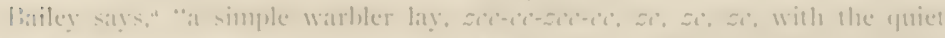

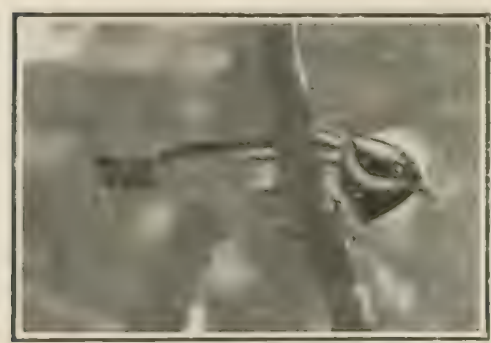

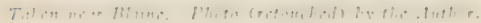

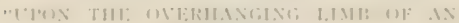
11.1+1.1: Ti1:1: wanklsy quality of aroms and ine

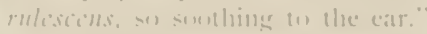
It is this clrominge womelsy quality alene which must endide the car eis a listener in a forest, which may be resomeling at the same time to the metes of the llermit. J'ownsent. Indulmon, Jutescems, ansel T'nlmic Ilathlers. Oecasionally eren this bisls. In early songer which came irmon at young male feeding partiently amone the catkins of some 1all, fresli-imeleling alders, had some of the airy qualities of the King-

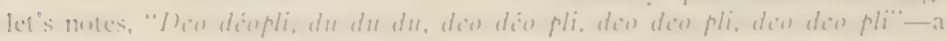

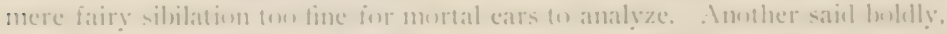

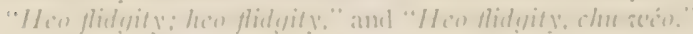

This 11 arbler is of rather irregular distrilution in the western part wi the

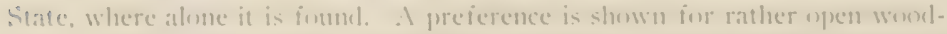

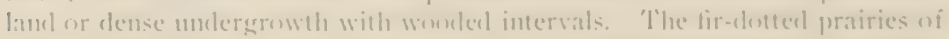
the steilacomm area ase approsed, and the oak groves have their patronage. Doring the Angust migration I have foumel the birel almost abumlant at Blaine.

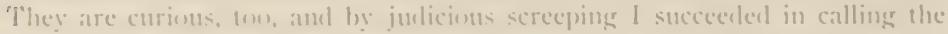

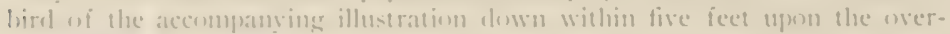
inangimg limblo of an apple tree.

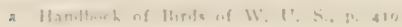


Of their nesting Mr. Bowles says: "In IVashington these Warblers are strictly confined to the large coniferous timber of the prairie cotntry, during the breeding season placing their nests nirlway ont on a fir limb, at from 25 to 50 feet above the gromel. Strangely enough, luwever, in Oregon they almost always nest low down in the deciluous trees, sometimes only three or four feet up in a bush. In Washington the nests are always placed directly on a limb), while in Oregon my brother, Mr. C. II. Bowles, found then mostly in upright crotches.

"'l'he nest is ratlee a loosely-lunilt little struc ture, measturing external 1y three inches wide bs two inches (leep, internal fy one and three-guarter: incles wide ly one deep. It is composed of dead grass. silky plant fileres. moss, etc. with an ampl lining of clifferent kinclof hair and feathers:-a pretty little nest, tho scarcely as artistic as that of the Itrlubon IV arbler

"The eggs are laid clur ing the last week in Mat ancl the first week in June. ancl are invariably font in mumber. They are cream! white in color, marked chiefly aromel the larger end, with spots and small

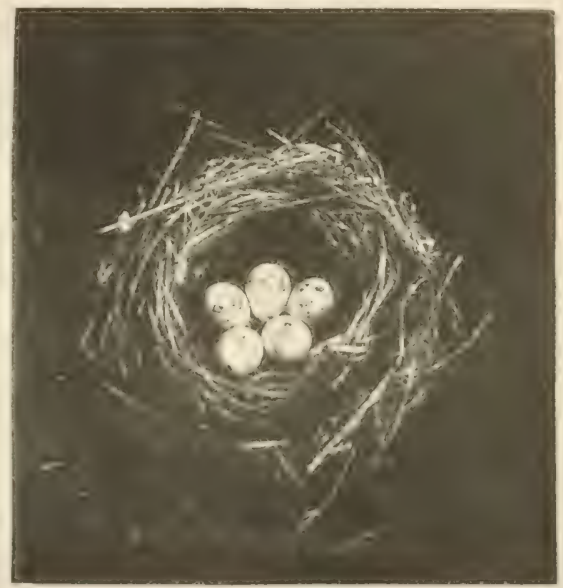

Taken in Ticomit. Plate b. $y, \pi$

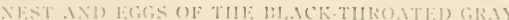
II: IRISI. IIS

blotches of varving shacles of brown, lavender, and black. Liges in my collec tion from 11 ashington average $.83 \times .63$ inches in dinensions, while exgs from Oregon average . $6-x .50$ inches, the laresest egg from Oregon being snlalle than the smallest Washington egg. In shape the eggs vary from long to short orate, and only one set is laid in a seasnu.

"The parent birls are very shy in the vicinity of the nest. the female leaving at the first sign of danger and kecping out of sight.

"In Oregon, my brother noted that the male often acomunatied the female while she was collecting building material, continuously senleling, but never assisting her in any way. In that section the nests were greatly preved upon by that prince of egg-robluers, the California Jay 
No. 77.

\section{TOIVNSEND'S WARBLER.}

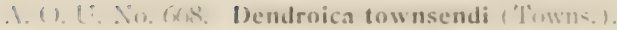

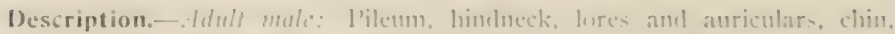
threat and upper clest black: supraloral region contimums with loroal superciliary: a spet under eye and a malar stripe broadening bethind fand nearly meeting end of supereiliary on sicke of neck) yellew, breast yellow heavily -treaked on siles with black, the black streaks thickening and nuerging wieh late of chest in front, seattering on llanks and reappearing on moler tail-coverts: np)er siles and thanks and remaining underparts fumteriorly white at to gromul:

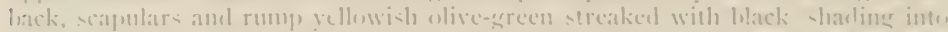
black of leacl on himbeck: upper tail-cowerts abruptly hluish gray: wings and pail blacki-l witl sme edgings of light gray: two white wing-bars formed hy tip-

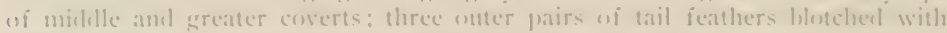
white on inner wets in deseeneling ratios. lsill hlack with paler tronia; feet and lews hrown: iris brown. . ldult mak in foll and winfer: Ireas and intensity of black much reclucerl, pilem and lindneck with much shirting of clive green thru which black appears mesially on feathers: aturiculars entircly concealeal ly whe green feather-tips: black of chin and throat nearly enoncealed hy yellow amil streaks of siles reducel : black streaks of upperparts more or less concealeal: mpper tail-coserts color of back. Idult fimale: Very similar in coluration on arlult male in fall: throat often more or less black, pilentm somethes more extensiscly black but lifack streaking of upperparts still further reduced. Jommel hirils in first autummal plumate: have no clear hack, and the yellow of throat and

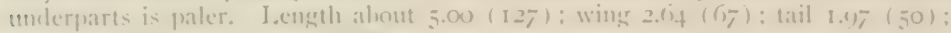
lill $.34(8.6)$; tarstis . 74 ( 18.8$)$.

Recognition Marks. - Ilarbler size: black on erown, checks and throat in

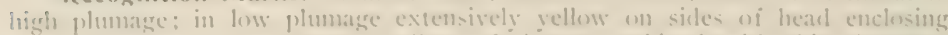
area of darker (olive-sreent)-yellow of throat combined with this character mas afforal clew to identilication of winter specimens.

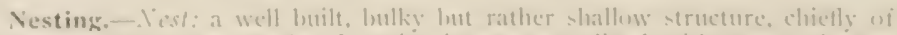

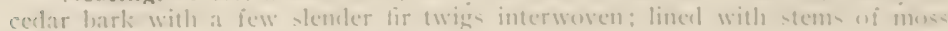
flowers: placed at mederate lecights in yenug tir trees well ont on limb or settled

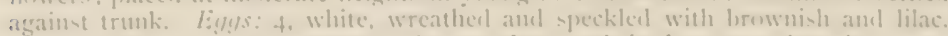

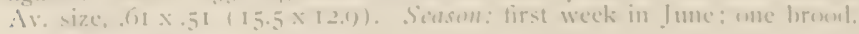

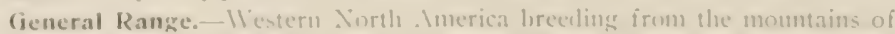
smulsern California morth to . Maska and eas to habu: during migrations cast-

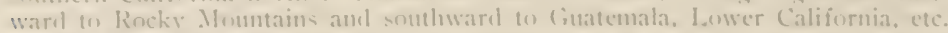

Range in Washington.- - Xot unemmon sprimg and fall migrant on both sifles of the Cancale. Ifountains, sumuner resilent in coniferous timber, probalily thruwt the State: partially resirlent in winter on l'uget Somml.

Migrations.-Sprin!: Seaute April 20, 140;: Ahtanum (Yakima Co.)

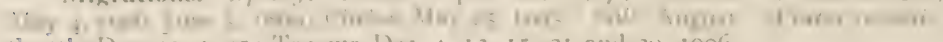

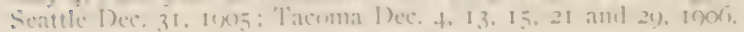




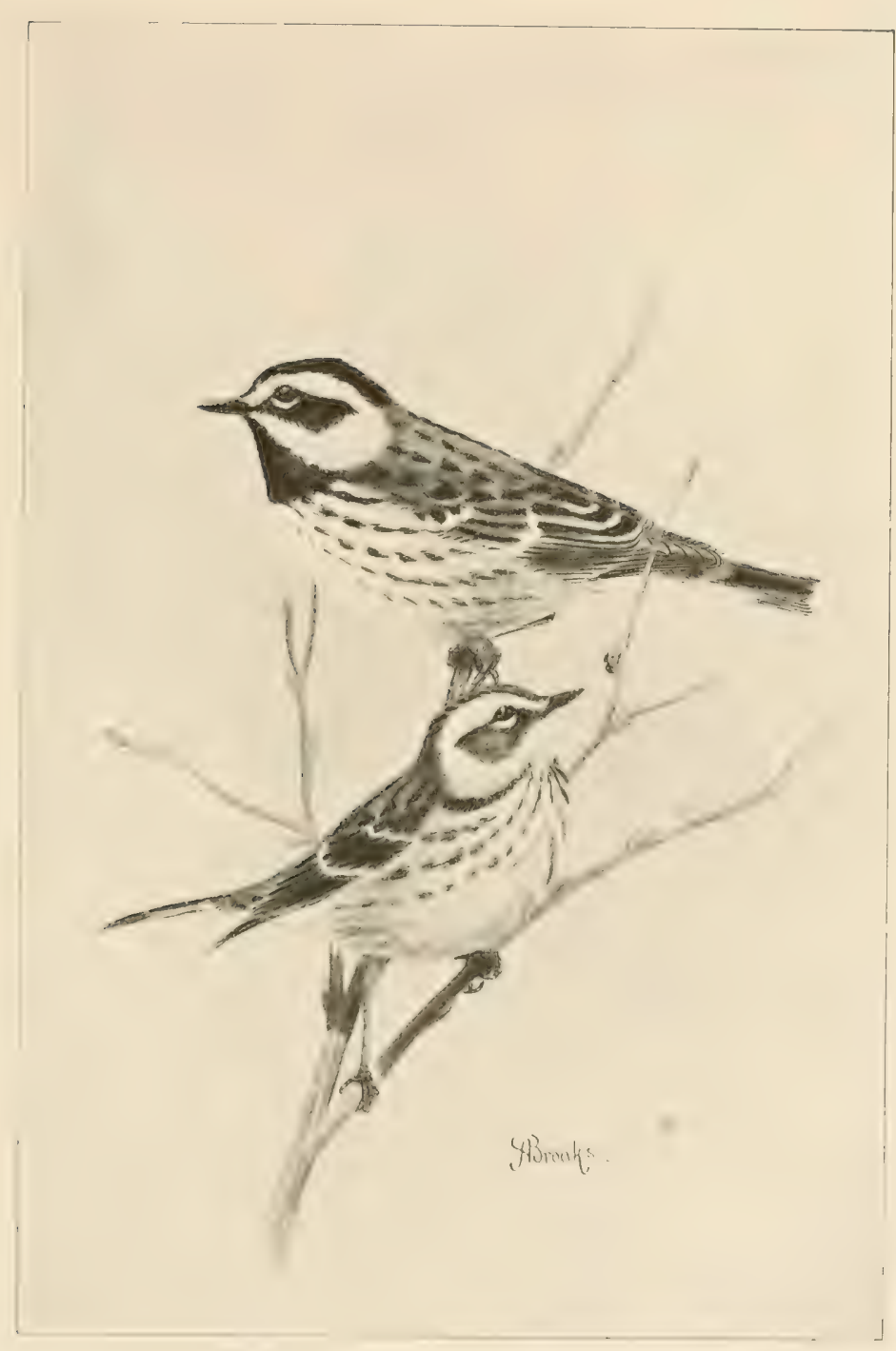

TOWNSEND WARBLERS, MAII AND FFMII.F. 
Authorities, - Sylitu tuiensemfi "(Nuttall)," Townsend, fomrn. Ac. Nat.

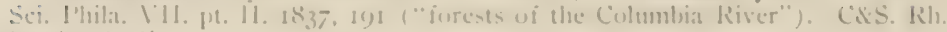
(ia, 1): 1: 1:

specimens.- L'. wi II: I'rov. C. I:.

IIIX'l' a meminge that wats at the ohle parsonage in the Ahtamum salley. when the shate trees of the live acre enchsure were lit up hy the presence of at fozen wi these fairies! Waste acres of sage lay aromel, or fielels of allatiat and growing wheat, latrolly mere inviting. but the eye of the leanler, winging

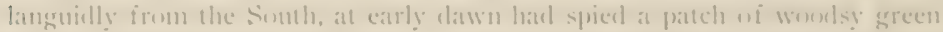

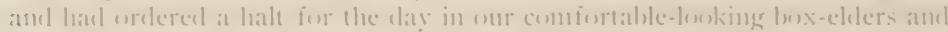

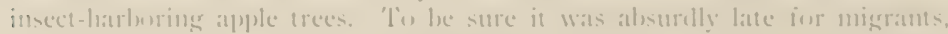

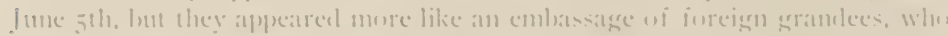

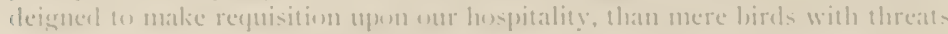

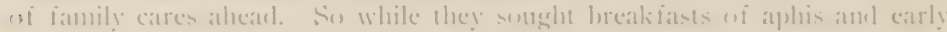

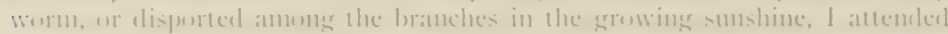
their mesements in rustic womber. Sim and then a member of the party

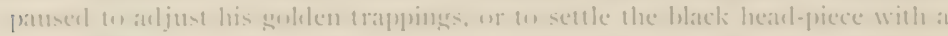

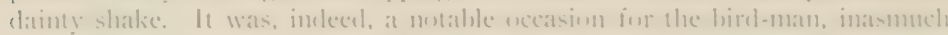

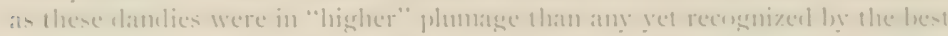

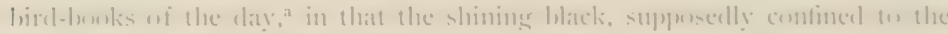
fower throat. mow acempied the very chin as well.

'l'here was a litte comsersational lisping in a foreign tomgte, in which the

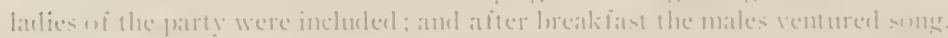

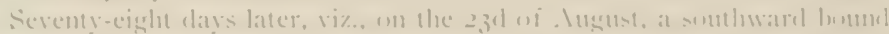

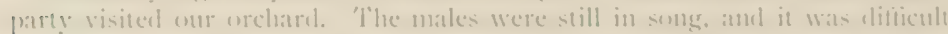

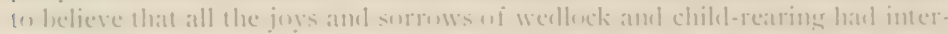
venerl: yet stuch wats jurobably the casce.

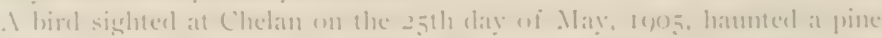
and at balm tree at the fout of the latice, singing comstantly. 'l'he simes rats.

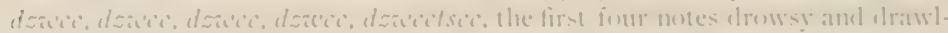

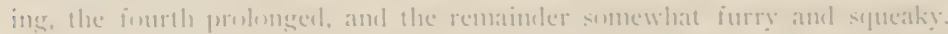

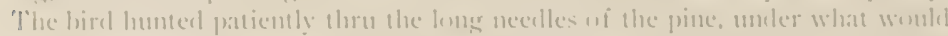

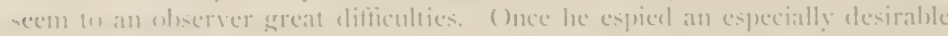

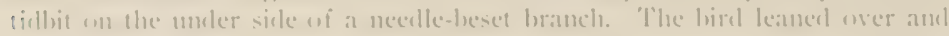

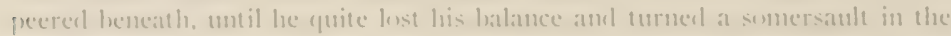

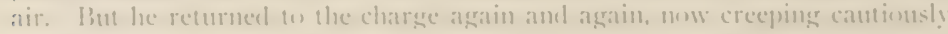
around on the under sile. now clinging on the prine needles thensedses and

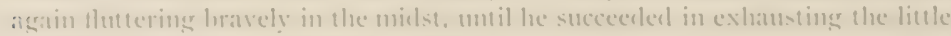
packet wi provemeler. Whatever it was.

In June, regno, we foumd these bircls in the valley of the sitehetin, and

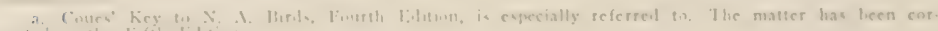
ireicil int tir lifih filition. 
again in the valley of the Cascade River, near Marblemount, breeding, undoubtedly, in botli places. Here we allowed the notes, oozi, woozi leooli to pass for some time, unchallenged, as those of the Hermit IVarbler, but finally caught a tow'nsendi in the act at fifteen feet. 'There is, to be sure, a lisping, drawling, obstructed quality in the opening notes not found in the typical Hermit song, and possibly not at all, but the lilt at the end, lchooli, is inseparable from the Hermit Warbler, and I do not take it kindly of tocunsendi to mix up the game so.

Upon returning to the valley of the Stehekin in June, I908, Mr. Bowles found the Townsend Warbler a not uncommon breeder. On the 20 h of that month he discovered two nests, each containing four newly latched young. Both were placed about twelve feet up in young fir trees, one about fire feet out on a limb, the other close against the main trunk. In each instance the brooding female allowed a close approach ; then dropped straight to the ground and disappeared. 'The birds were extremely shy at first but after an hour or so became sufficiently accustomed to the human presence to return to their duties within a few minutes after being flushed. But repeated visits failed to discover the males in the vicinity of their nests, and, indeed, they seened to be wholly occupied with minstrelsy in the tree-tops.

On the 3 Ist of December, I905, I saw a Townsend Varbler in the pale winter plumage in Madrona Park, on the border of Lake Washington. He was with a group of Auclubon Warblers feeding in the alclers, but attention was instantly attracted to the $t$ sip note, which was sharper and more clear-cut than that of the Audubon; and it had, moreover, a sort of double quality, or central turn, tsiip or chiip. This record of winter residence was further confirmed by specimens taken at 'Tacoma by Mr. Bowles the following December

\section{No. 78 .}

\section{HERMIT WARBLER.}

\section{A. O. U. No. 660. Dendroica occidentalis ('Townsenc1).}

Synonym.-IVFSTERX WARBLER.

Description.- Idult male in breeding plumage: Forehead, crown and sides of head and neck, broadly, rich lemon yellow, sharply defined helow hy black of chin, throat and upper chest, less sharply above by black of occiput or hindneck; this in turn shading thru mingled olive and black into gray of remaining "1pperparts; upper plumage more or less tinged with olive-green and streaked more or less broadly with black; wings and tail black with gravish edgings; midlle and greater coverts tipped with white forming two conspicuous wingbars, - outermost part of tail-feathers chicfly white on both webs, next pair white on terminal half of inner web and third pair marked with longitudinal spot near tip; black of chest with convex posterior outline sharply defined from white of remaining underparts. IBill black; legs and feet dark brown; iris brown. Adult 
male in joll and winter: Yellow of crown veiled by olive green; black of throat veiled hy whitish tips: hlack streaking of npperpars les comspicusts. . Idult

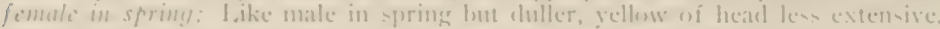

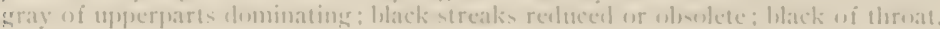

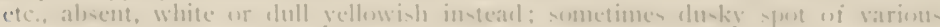

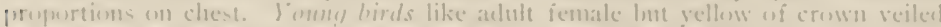

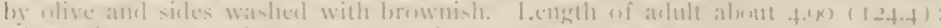
wing $2.65(6,-3)$ : tail $2.20(5,5))$ : lill fo (10.2) : tarsus off (11.3)

Recognition Marks. - Smaller Warbles size; vellow mak of male ondined

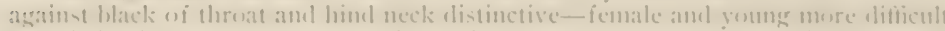

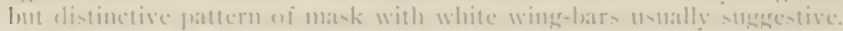

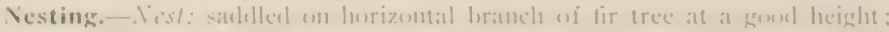

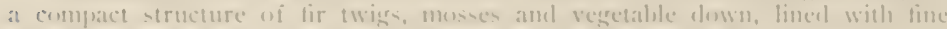

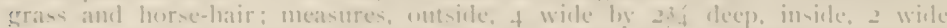

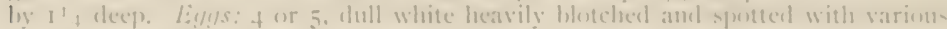

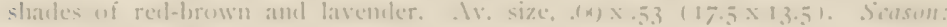

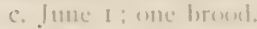

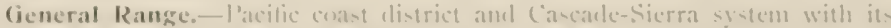

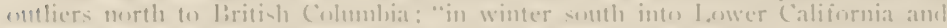
through . Irizona orer . Mexican platean to highlamels of (inatemala."

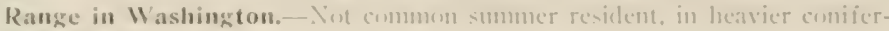
ons timber onls:

Authorities, - Sylid occidmhalis Townsend, Inurn. Ac. Nat. Sci. I'hila.

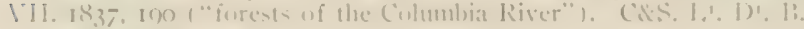

\section{specimens.-C}

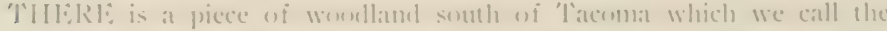
Hermit Ifomels, lecause here on any May day may he heatrel the voree of the

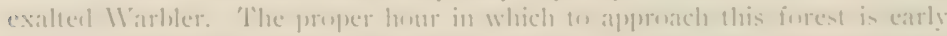

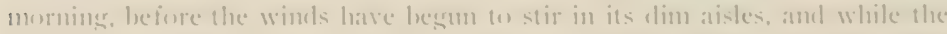

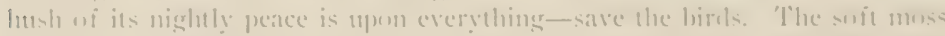

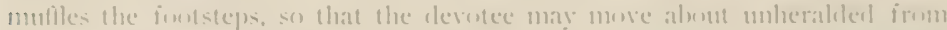

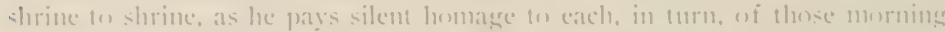

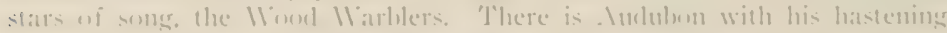

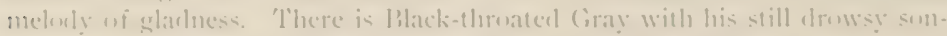

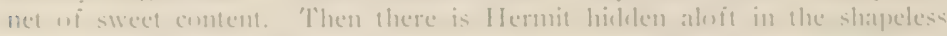

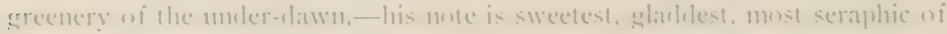

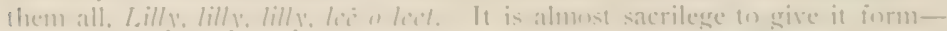

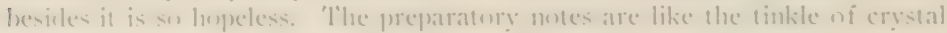

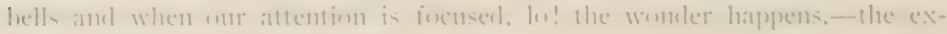

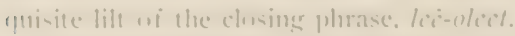

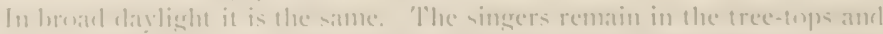
fease the imagination with thoughts af at demestic life lived mpon a higher

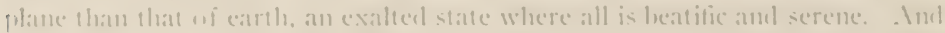

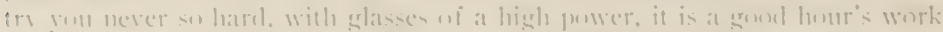
for aldatin a satisfactory sight uf ane of the mplifted creatures 
In despair, one day, I determined to penetrate this supramundane region where the Hermit is at home, and selected for the purpose a well branched tree in the center of the forest and some hundred and fifty feet in height. The tree was, fortumately, of the tougher sort, and permitted ascent to a point where the stem might be grasped with the finger and thumb of one hand. It was a treat to see the for. est as a bird does. 'The surface riewed from alone was surprisingly uneven. Here and there strong young trees. green and full of sap, rose to the level of mine, but the majority were lower. and some appeared like green rosettes set in a well of green. Others still, rugged and uneven as to limb). towered aloove my station by fifty or seventy-five feet. My. first discovery upon reach. ing the top was that the bulk of the bird chorus now someled from below: I3ut a few singing Hermits dicl occupy stations more lofty than mine. One I marked down-rather, up-

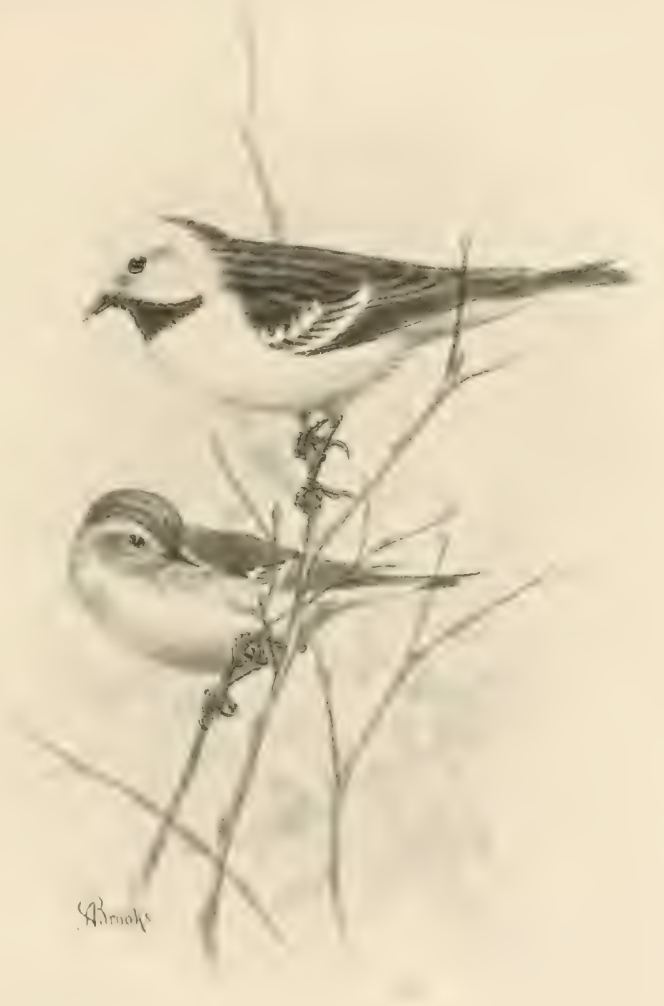

IIFMMT W:IRBI,ERS

fifty feet above and a lumbled yards away. He sang away like a contented eremite from a single twig, and I was reverently constructing his high bingraphy and trying to pick out his clomicile from the neighboring branches, when flaslt! he pitched headlong two hundred feet and was seen no more. 


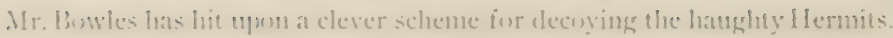
He resents to the vicinity of sume Cassin liren's nest containing young, and studies the throng wi smath hirds, which the masterly scolding of the Vireos invariably attracts. Ljen one snch occasion, having lured down an ingusitive

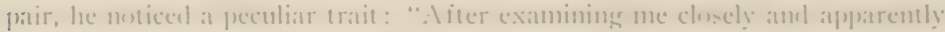
deciding that I was a new kind of stump, the fentale commeneed feeding: but her attention wats som attracted on a last vear's nest of a liusset-backed

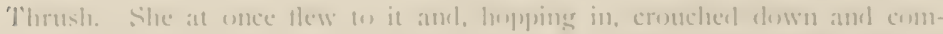

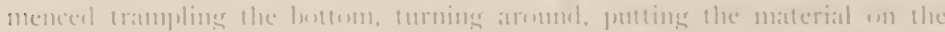
sinles into shape with her bill, atme altegether acting ats the she hat nest-huilding

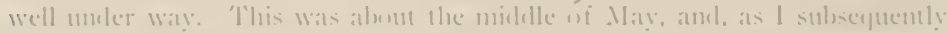

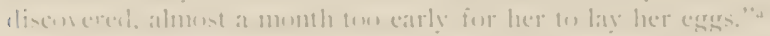

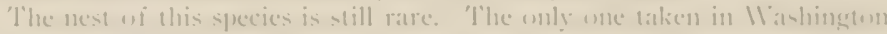

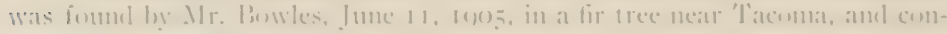

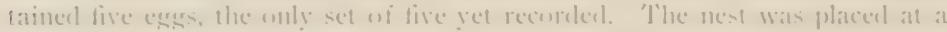

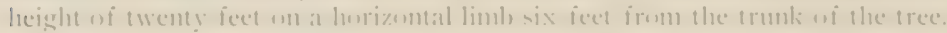

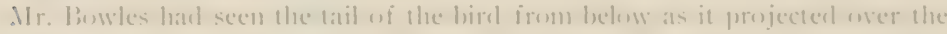

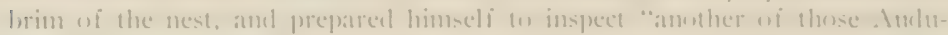

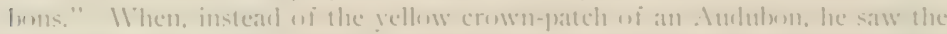

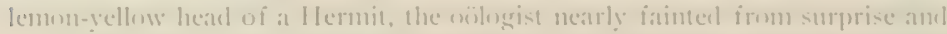

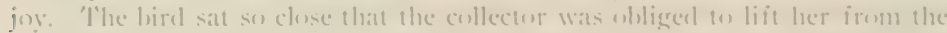
nest, amb she then thew only a few feet, where she remained, chippling and spreating her wings and tail. 'l'he male at no time put in an appearance.

'lle nesting range of this species is still imperfectly male ont. Ile fomm it commen at Newport in Sterens Comnty, and among the pines and latedes of the Calispell range. Ile comnecl them commun in the valley of the siteleckin

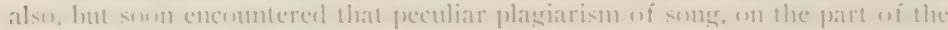

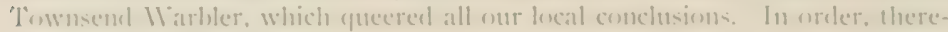

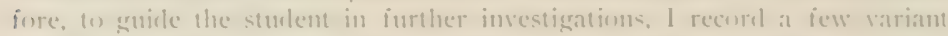
somer forms which I have clearly traced to the Hermit llambles: \%ergli:

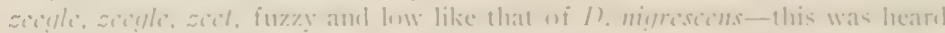

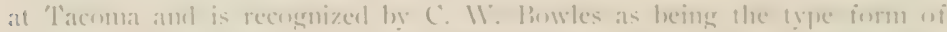

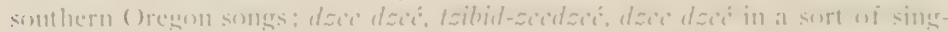

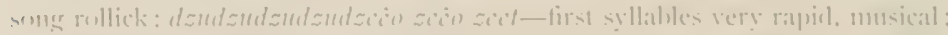

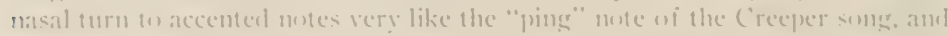

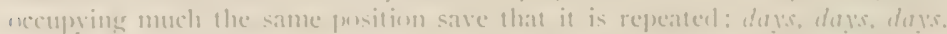

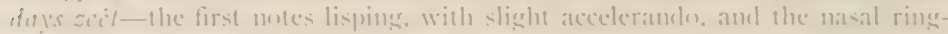
iner quality reserved for the lase

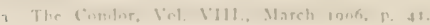




\section{No. 79.}

\section{TOLMIE'S WARBLER.}

\section{A. O. U. Nंo. 680. Oporornis tolmiei ('T'ownsend).}

Synonym.-MACGILTITR.AY'S WTARBLER.

Description.- Adult male in spring and summer: Fore-parts in general, including head and neck all around and chest, blackish slate or slate gray; extreme forehead and lores jet black; feathers of lower chest slate-black narrowly fringed with ashy gray; extreme chin usually white: a sharp touch of white on upper eyelicl behind and a longer one on lower licl: remaining plumage bright greenish yellow to olive-green, clearest yellow, canary to olive-yellow, on breast and remaining underparts, centrally, and on bend of wing, shading thru yellowish olive green on sides to olive-green of upperparts; onter primary edged with white on outer web. Bill dusky brown above, paler below; feet and legs light brown; iris brown. Adult male in fall and winter: Similar but feathers of auriculars and hincheck and sometimes crown tipped with dull brown; ashy skirtings of throat and chest more extensive, sometimes nearly concealing the black. Adult fomale in spring: Like male but slate of hood replaced by dull brownish gray (mouse sray) above and by pale brownish gray on chin, throat and chest. In fall plumage still more extensively gray below. I om fencles lack the hood altogether being simply olive green on crown, yellow on throat, etc. Length about 5.50 ( 1.39 .7$)$; wing 2.4 (62); tail 2.16 ( 55 ) ; bill.+5 (II.4) ; tarsus .85 (2I.6).

Recognition Marks. - IVarbler size; slaty hoorl of male clistinctive; contrast of color between chest and breast wstually apparent. I frequenter of thickets, with a sharp tsick or chuck note of alarm.

Nesting.-Nest: in thickets in upriglat crotch of bush from six inches to three feet from gromul; a bulky affair of coarse lead grass, rootlets and trash, lined with fine black rontlets and horse-hair; measures, outside, $4^{1 / 2}$ wide by $21 / 2$ deep, inside, $21 / 2$ wide by I $^{1 / 4}$ deep. Liggs: $3-5$. 11sually +. dull white, heavily marked around larger end with redklish browns and lavender. Av. size, $70 \times .54$ $($ I $7.8 \times 13.7)$. Scason: first week in June: one brood.

General Range.-- Vestern United States ankl Iiritish Columbia lreeding sonth to Arizona and western 'lexas; east cluring migrations to western Nebraska, etc.; south in winter to Cape St. Lucas and over whole of Mexico and Central America to Colombia (IBosota).

Range in Washington.--Summer resident in dense thickets thruont the State from sea level to alrout 2,000 feet elevation.

Authorities.-Syliti tolmici Townsend, Narrative, $\Lambda$ pril I839. 343 (Colum-

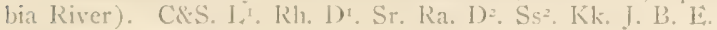

Specimens.-L. of W. P. Prov. I3. E.

WV I slall have to import the worl "chaparral" if we are to characterize with any brevity the sort of cover this Warbler loves. A great confusion of willow, alcler, dogwood, syringa, ocean-spray, and huckleberry is his delight. 


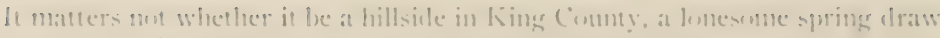

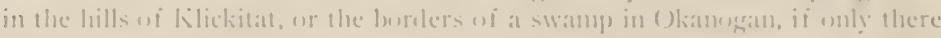

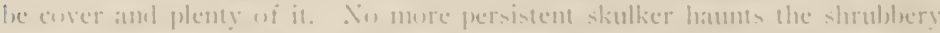

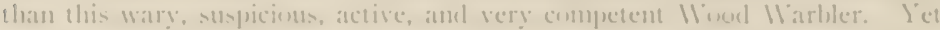

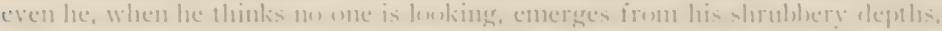

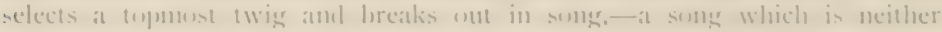

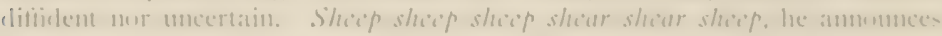
in at brisk, husiness-like tome, totally devoid of musical quality. And when you

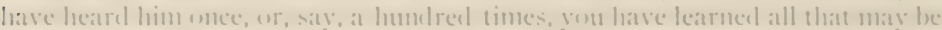

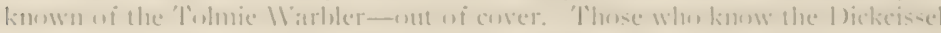
uf the midelle Il est will at mee be struck with the chese similarity uf its song. altho it must be atmited that the 11 arbler's is lighter in yoality and less wonden. P'atetically, the only variety is in the number of syllables and in the

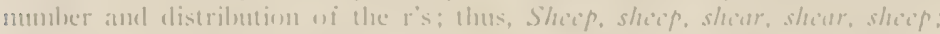

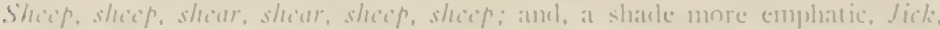
jick. jick, jick, shitur, shiep.

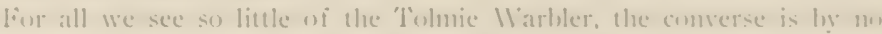
means true. 'That is to say, the bird deses see a great deal of us if we frepuemt the thickets. Ithenever there is amblhing eloing in his vicinity, the llarbler prompty and silenty threats the intervening mazes, takes mbervations of the

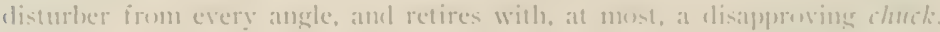
In the fall of the year discipline is somewhat relaxed, and a litule juelicions

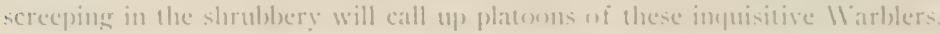

Owing partly to the catut inn of the sitting female, and mere to the densits

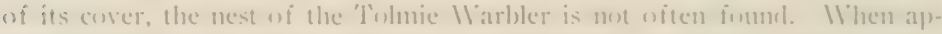
probled the hird glicles away silemely irom her nest, and legens feeding osten-

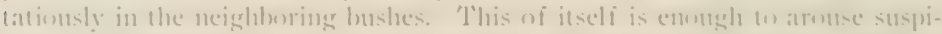

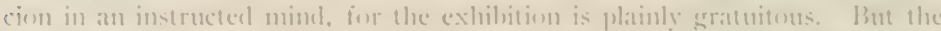

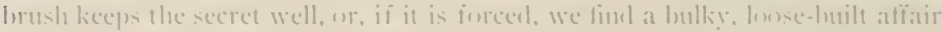

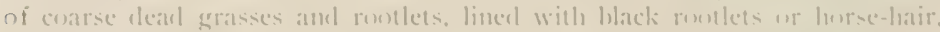

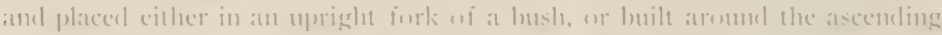
stems of rank lectage at a few incless or at mest 1 wo or three feet irom the

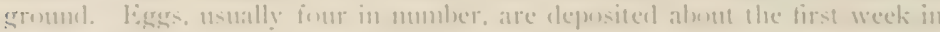

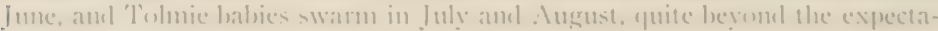
timu of our soilesgical fore sestson.

1 worel of explanation regrating the clange of mame from . Macgillivray

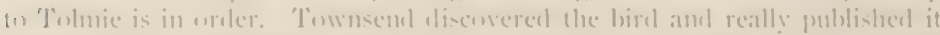

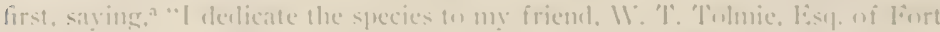

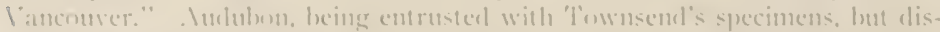
regarding the uwner's pror rights, published the birel independertly, and tardi-

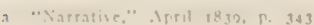




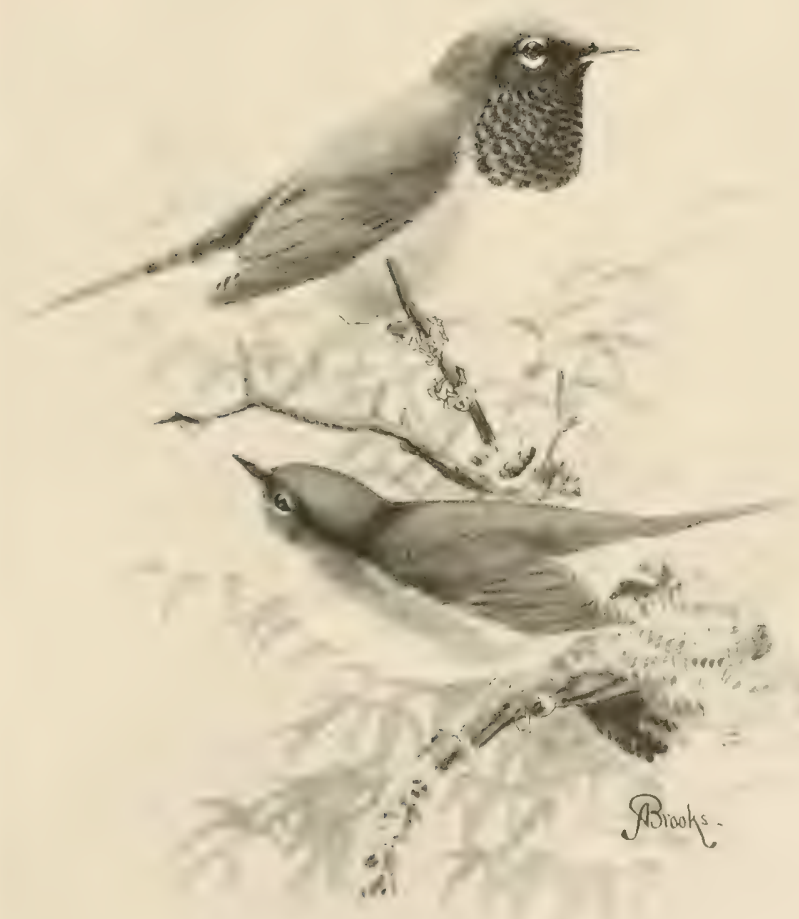

TOI.MIF, WARIITIRS 
Iy, as it happened, as Sylia musyillis rayi, hy which specitic name it was long known to ornithelogists. Macgillivray was a sentch naturalist who never saw America, but Tolmie was at that time a surgeon and later a factur of "the Honorable the Hudson bay. Comprany," and lie clearly deserves remembrance at our latuds for the friendly hospitality and coüperation which he invariably. extenrled in men of science.

\section{No. So. \\ GRINNELL'S WATER-THRLSH.}

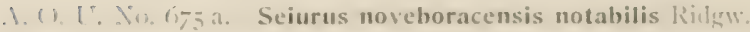

Description,- tdults: Abowe sonty olive-brown, singularly miform: felow while or tinged with pale yellow, everywhere (save on ablenten, centrally, under tail-coverts and extreme chin) streaked with sumty olive, the streaks small and weelge-shaperl on throat, increasing in size posteriorly on brea-t, sifles and flanks (where nearly comfluent on luffy gromul); a smperciliary stripe comtumens in nostril pale bully ; a cresecnt-shapesl mark of same shate on lower eyelisl : checks and aturicular region linely streaked with pale buffy and ooke wi lack. Thill clark

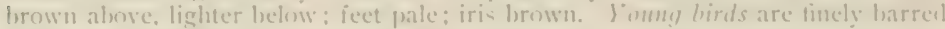
with bufy alove and have two luffy wing-hars: wnelerparts leavily and inlis-

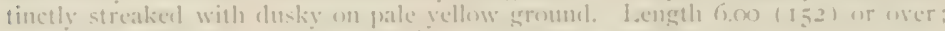

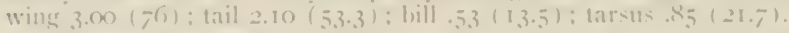

Recognition Marks.-IVarloler size: plain lorown abowe: white for pale

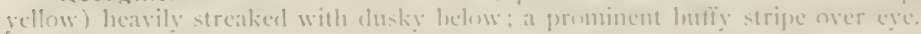

Vesting.-Does not breed in Whashingtom. Xist: an the gromuml or in ronte

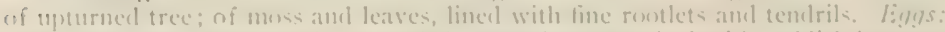
for 5 . white or creany white, speckled, spetted or wreathed with redklish hrown-

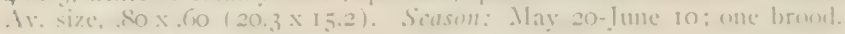

General Range,-llestern North America; breeding from Minne-rta, we-t-

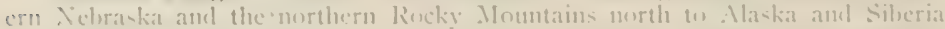
(liast (alfe) : southward during migrations over Western States and Misissippi Valley, Jess commonlyothru . Mantic const States, on lleet Indies, Mexion, Central America and ('inhombia.

Range in Washington.-Conjectural-should he mut uncommkn migrant.

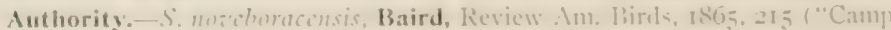
Mrumic, Washington").

specimens.-I'( Maskan). I'rus:

IVIIJIE we have only one recorel, and that an old one, there is every

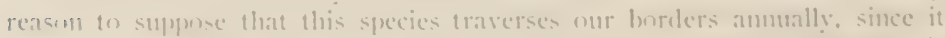
breeds in the midelle momtain districts of liritish Colmulnia (Rlinads). is abumclant in . Maska (Xelsmm), and migrates sombwarel tloru the western

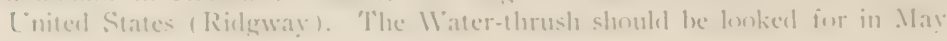

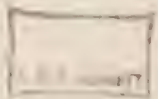


along the shaded banks of streams, but may possibly be found along more open margins, consorting with Pipits, with which it shares a restless habit of julting, or curtseying, whimsically:

\section{No. $8 \mathbf{I}$.}

\section{WESTERN YELLOW-THROAT.}

A. O. U. No. 68t a. Geothlypis trichas occidentalis Brewster.

Description.- Adult male in spring and summer: Alove grayish olive-green, brighter (less gray) on upjer tail-coverts and tail, inclinimg to brownish on crown and hindneck; an obliquely descending facial mask of black involving forchead, lores, space about eyes, cheeks and (more narrowly) sides of neck; along the posterior margin of this mask a narrow sharply contrasting area of clear ash or white; chin, throat and breast rich yellow (inclining to gamboge); sides of brcast and sides heavily shaded with olive-gray and breast more or less wasled with same; lower breast and below between vellow and palest olive-gray : under tail-coverts and bend of wing clear yellow. Adult male in autumn. Occiput more decidedly brown; upperparts clearer olive-green. Founy male in first autumn: Mask of adult merely indicated by black underlying sooty-brown on sides of head ; coloration of underparts cluller. Idult female in spring: Like adult male but without black mask and ashy edging; crown and sides of head olive sray; forehead tinged with brown; region above and abont eye notably paler; coloration of underparts duller and paler, sometimes clearly yellow on under tail-coverts alone. Young female in first autumu: Similar to adult but underparts still duller and dingier, breast and sides heavily washed with brownish olive. Length of adult about 5.00 (127); wing 2.26 (57.5); tail 2.19 ( 55.8$)$; bill .4. (I I.3) ; tarsus .83 (2I).

Recognition Marks.- Ifarbler size: black mask and white fillet of male distinctive. 'I'he female is a much more difficult bird to recognize-perhaps best known by peculiar sordicl olive-brownish-yellow shade of underparts. 'The palc orbital area also assists, but one must live with these birds to know them infallibly,

Nesting.-Nest: of coarse grasses lined with fine grass and horse-hair: placed I-2 feet high in tussock of grass or rank herbage, ustally near water: outside $4^{T / 2}$ wide iy $3^{1 / 2}$ deep, inside $2^{1} / 4$ by $11 / 2$. Eggs: 4 or 5 . dotted and spotted or, rarely, streaked with blackish and lavender. Av. Size, $70 x .50$ $(17.8 \times 14.2)$. Season: May 20-June Io; one brood.

General Range.-Western United States and British Columbia, except l'acific coast district, east to western portions of the Great Plains; breeding southward into. Mexico and northern Lower California; in winter south to Cape St. Lucas and western Mexico.

Range in Washington.-Summer resident cast of the Cascade Mountains; found chiefy in rye-grass districts and in vicinity of water. 
Migrations.-Sprint: Mhamum ( Vakima (io, March 21) 1(xk).

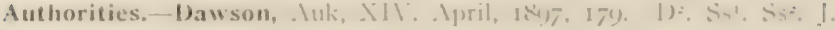

Specimens.-1', wi II: I'. I'ros:

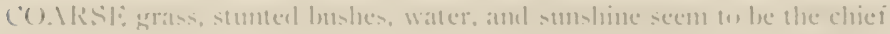

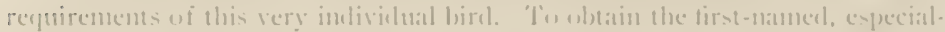

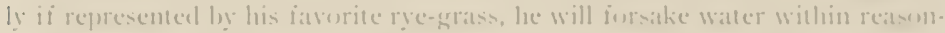

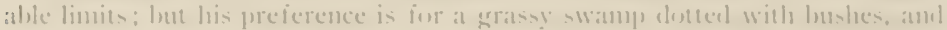

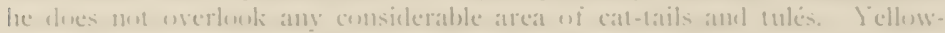

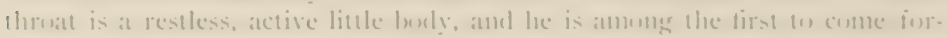
wart when you enter the swamy). His methent is liele-and-seck amel the game wenld all be his, if lee diel met reveal his presence from time to lime by at harsh

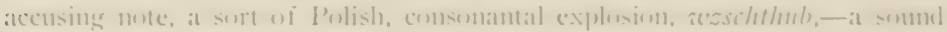
nes unlike that mate be a suitar string when struck aldese the stop. If you at-

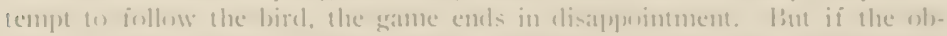

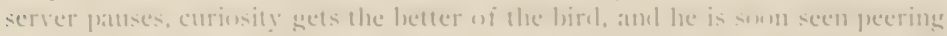

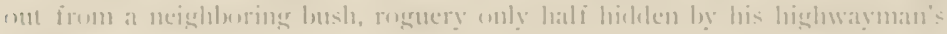
miask.

The female, having me mask, keeps to the backgromel, but sle is mot les: interesterl than her mate in the progress of erents. When the (c)ult returns to report, there is uflen a corrous muthreak of elis(ulsison, in which the hushande ats like as nut, lints it necessary (n) rejenel his opminon with at periece forremt of azschlhuhs.

lellow-throat's some is me wi the ien explicit things in the swammp. Monmting at weerl-stalls.

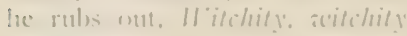

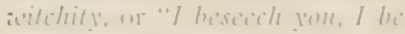

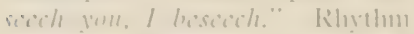
is the che charateristis af this roug, and althe a given birel ap peats to le comfineel on a single ype, the mariety of "feet" nffereel lw a swanly is nume entertaining

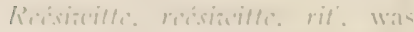

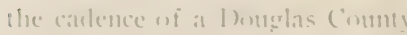

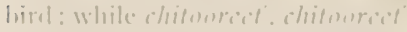
ihitumert. rhe learel at ("helan.

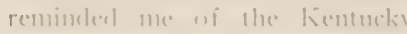

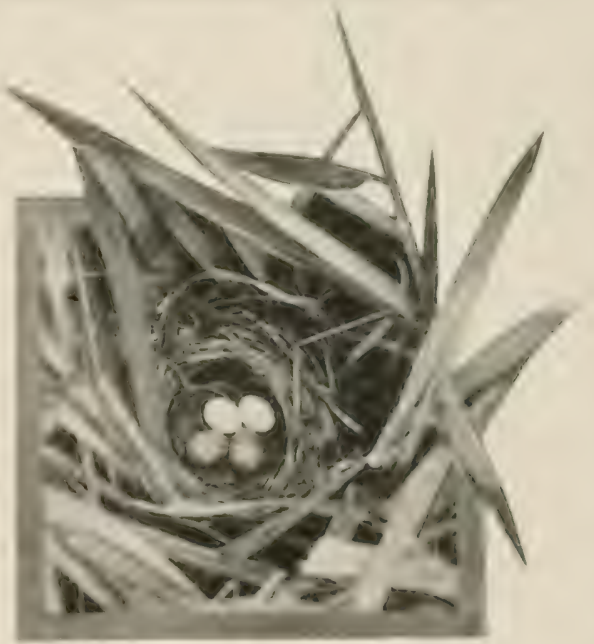

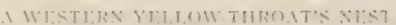

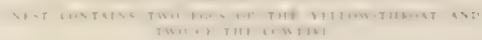


Warbler (Oporomis formosa). 'The bird has also an ecstacy song, "a confused stuttering jumble of notes" poured out in lhot laste in micl-air.

Like an echo from "the different world" cane the song of a bird at Brook Lake. We had just been listening to the muwonted notes of a Desert Sparrow (Amphispiza bilineata deserticola) some humalreals of miles out of its usual range, and were not unprepared for shocks, when Hoo hec, chink i woo chu tip fell upon the ear. What! a Slate-colored sparrow here in the sage brush! Or is it, mayle, a Vesper, grown precise? Again and again came the neasured accents, clear, strong, and sweet. Not till I had seen the manclibles of a Vestern Yellow-throat, and that repeatedly, moving in perfect rhythm to the music, conld I believe so small a bircl the author of this song. For fifteen minutes the Warbler brought forth this alien strain, Hec-o chiti aro, chu tip or Ho oo chitivere clu tipere withont once lapsing into ordinary dialect. Wherever did he get it?

My nests have nearly all been found in June and, I guess, they may have contained second sets, for the bird sometimes reaches Yakina Connty as early. as March 29th. One was sunk in a tussock of grass within eight inclies of the swamp water, and I nearly stepped on the female before she flew. Another was lashed at a height of two feet to a group of rank weeds, some forty feet removed from a lazy brook. A third, shown in the illustration, we found while dragging over a dense patch of rye-grass, some three humbed yards from water. 'The nest was composed entirely oi the flattened and macerated leaves of old rye-grass gleaned from the gromnd, with a scanty lining of horse-hair. It was simply set, or wedged, in between the stiff, upgrowing stalks of grass at the height of a foot, and was not attached in any mamner to its supports. The male bircl, strange to say, was covering the eggs, of which two belonged to that contemptible shirk, the Cowbircl.

No. 82.

\section{THE PACIFIC YELLOW-THROAT.}

A. (). [. No. 68r c. Geothlypis trichas arizela Oberholser.

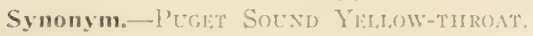

Description.- Adults: Very similar to G. t. occidentalis and with corresponding changes but throat, etc., rich lemon yellow (inclining to greenish, whereas occidcufulis inclines to orange); more yellow in grayish olive green of upperparts: ashy border of mask saicl to average more narrow (very doubtful). Alleged differences in measurenents are inconsecunential.

Recognition Marks. - Is in preceding.

Nesting.-Muclu as in preceling form but bircls more nearly confined to 


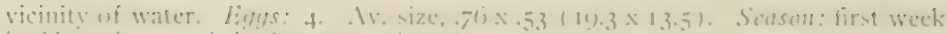
in . May, tirst week in June; two broukl.

General Range.-"l'acitic coast dintrict, irom British Cinhunbia southward:

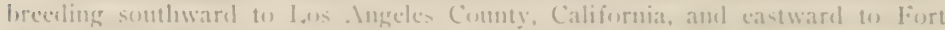

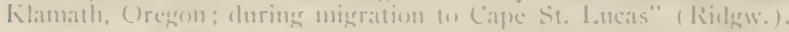

Range in Washington.-Summer resilent in fresh and salt water marshes west of the Catscates.

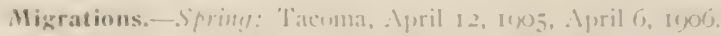

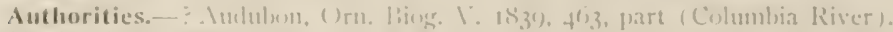

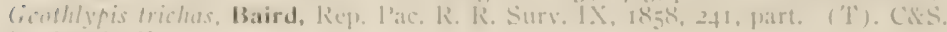
1.… R. I: I:

specimens.-I'rox: 13. F:

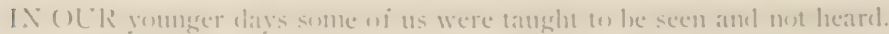

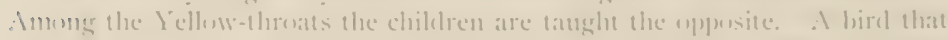
can call "Ilitch-ce-y! II itch-et-y! Witch-ct-y!" in a dezen diflerent places thru the swate and in the meantime can leep ont of sight while you are loseleing for him, is a well brought-mp Vellow-throat. Nie were tatught to tedl the

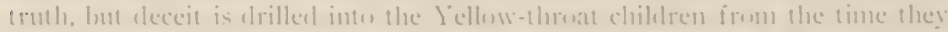

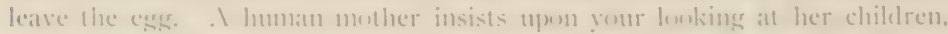

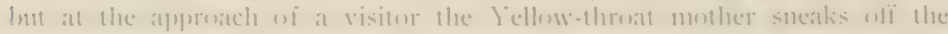
nest and away thru the lushes for the sole purpuse of persuading you the heme is in the reels on the entere sicle of the creck. 'This may be wong

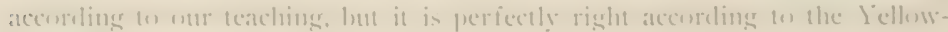
lhwat"s cosle of morals.

If you wamt to see Jellww-throut, you must gut down along the swate or risit some damp thicket or swamp). He likes the rushes and the recels

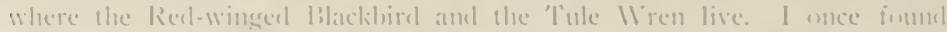
at hed-wing's nest and at lellow-throal's home withen a few feet of each

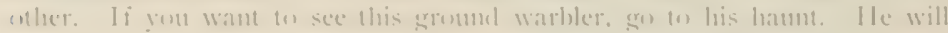
see you first but lic down putetly amoner the bushes. He will likely get

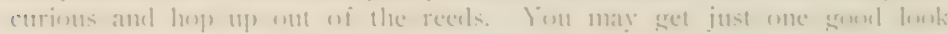
before he darts away indo the hushes again.

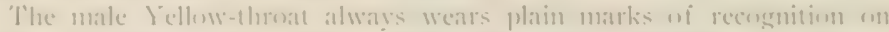
his face. Jle has a hlack matk expeneling across his forchead anwl back on

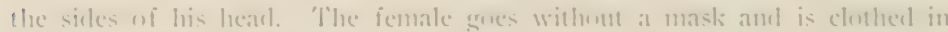
stuluelnerl tints wi vellow and hrown.

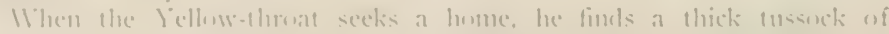
erases amel hivles his nest well in the mirlolle. It is my experience that

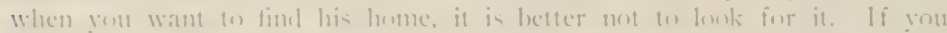
keep on tramping thru the smampes and swales, some daty you will stmmble ent one when you least expect it Onee I hunterl for several days almout at swampy flace where I hearel the Veflow-threats singing. Din a sign of a nest diel I find. Whenever I appeared the hirels were on hand as if 


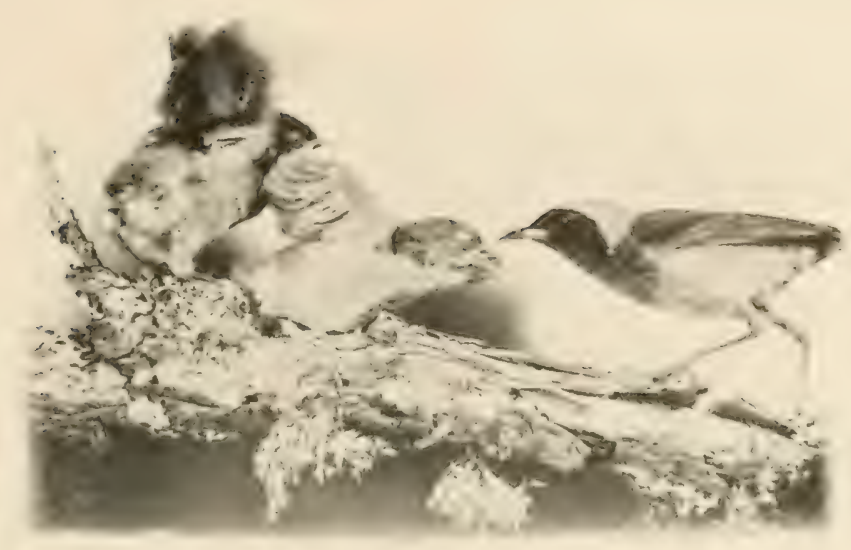

Taken in Oregon

Photo by H. T. Bohlutan and W. L. Fintey.

1N T:NTILSIASTIC RECI:PTION

YALE PACHFIC YELLOW-THROAT FEEDING YOLNG.

very anxions to aid me in funding their home. After tiring me with their deceit, they sneaked away fifty yards to the nest. A little later in the season I happened to see the father carrying woms and cliscovered the roung Yellow-throats just about to leave home.

$11,1,1,1,11$ I. Fin |.1.1.

No. 83 .

\section{WESTERN CHAT.}

A. O. ¿: Nंก. $188_{3}$ a. Icteria virens Iongicauda (I awrence).

Synonym.-Loxi-TAILED C'HA'T.

Description.-Adult male: Above grayish olive-green; fuscous on exposed inner webs of wings and tail a prominent line above lores and eye, a short malar stripe, and eye-ring, white: enclosed space black on lores, less pure hehind; throat. breast, lining of wings, and upper sides rich ganloge vellow: lower belly and

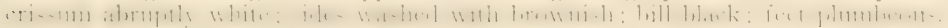
Adult female: Very similar: bill lighter: lores and check-patch clusky rather

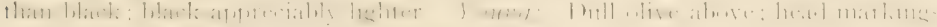
of adult faintly indicated; below gravish white, darker on breast, buffier behind. 


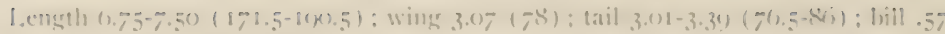
$(1+.5)$; tarsas $1.0+(26.5)$.

Recognition Marks. - Strictly "sigarrow" size, lut hecanse of hright color laving nearer the size value of chewink;- - the largest of the llarblers. Bright yellow breast with contratsing white ledew, with size, distmetive.

Yesting. - list: a lublsy and witen casreless structure, 7 inches wiele and 4

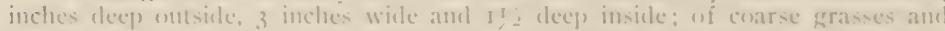

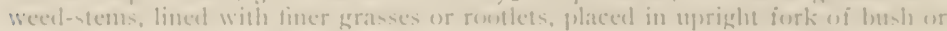
small tree in thicket. Emss: t. white, semewhat glossed and marked irregularly with spots and dote of lasesuler and rufous, mont heavily, or mot, alonst larger

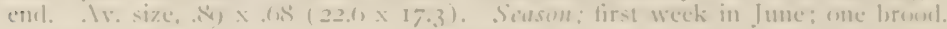

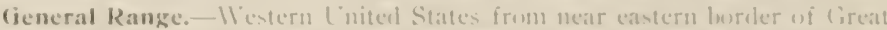
I'lains west to the l'acific Coast, hrecting north inte somblecemtral liritish (i)

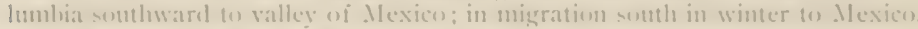

Range in Washington.-Summer resiclent in thickets alnut springs and

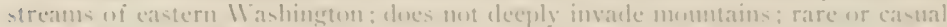

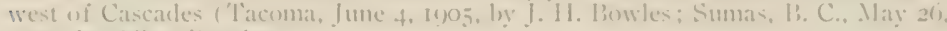
t(i) 7 , ly . Man lirenks).

Migrations,-Gprin!: May is, mon (Yakima county.

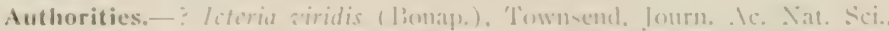

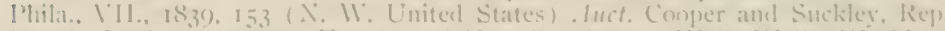

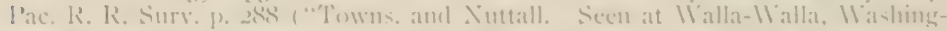

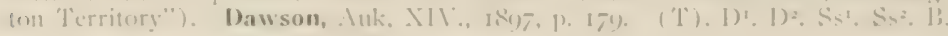

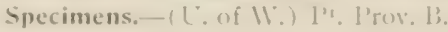

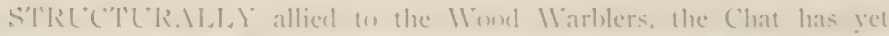

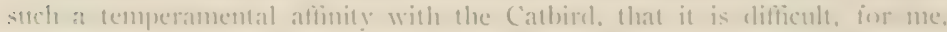
at least. to dissociate the two birels in thonght. Jonth love the thickets:

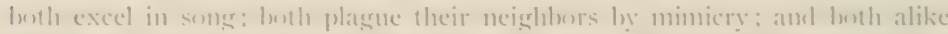
are dearly powoling bundles of comtralictsuns. The Chat is, perhaps, the ereater buffom, as lice is certainly the more haudsomely dressed of the two. lievond this we must comsiler him on his own merits.

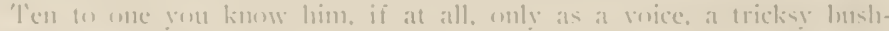

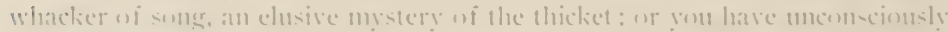

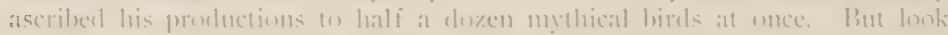

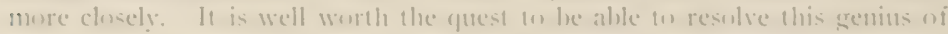
menery. He assured he knows you well enough hy sight. for he dees mot protie and pry and spe for mothing, in the intervals of songe. He has still the proserbial curiosity of woman, Seat yourself in the thicket, and when yom

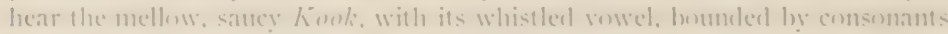

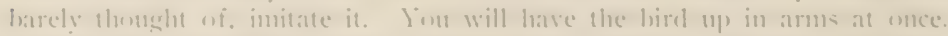

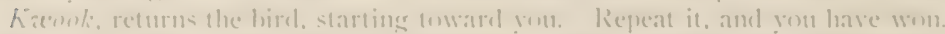

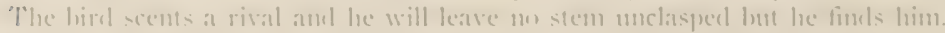
Is the hirel alternately spuints and stares from the hrush, mete the rich

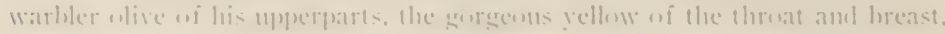


the white brow-stripe and the malar dash, offset by black and darker olive. It is a warbler in color-pattern, a lellow-throat done larger, but waggish, furtive, impudent, and resourceful beyond any other of his kind.

'The full song of the Chat is ustally delivered from some elevation, a solitary tree rearing itself above clense cover. The nusic almost defies analysis, for it is full of surprises, vocal somersaults, and whimsy turns. Its cadence is ragtime, and its richest phrases are punctuated by flipjoant jests and clroll parentheses. Eiven in the tree-top the singer clings closely. to the protecting greenery, whence he pitches headlong into the thicket at the slightest intimation of approach.

The love song of the Chat, the so-called "dropping song," is one of the choicest of avian comedies, for it is acted as well as sung. The performer flings himself into mid-air, flutters tpward for an instant with head upraised ancl legs abjectly dangling, then slowly sinks on hovering wing, with tail swinging tip) and (lown like a mad pump-handle. Punch, as Cupid, smitten with the mortal sickness. And all this while the zany pours ont a flood of tumultuous and heart-rending song. He manages to recover as he nears the brush, and his fincee evidently approves of this sort of buffoonery.

The Chat is a skilled minic. I have traced the notes of stich diverse species as Bullock Oriole, Slender-billed Nuthatch, and Magpie to his door: Once, clown on the Rio Grancle, we rapjed on a vine-covered cottonwood stump to dislodge a Flicker that had been shrieking $K / y^{\prime}$ k at us for some minutes past, and we flushed a snickering Chat.

The IV estern Chat, like the eastern bircl, has small taste for architecture. $A$ carcless mass of dead leaves and coarse grasses is assembled in a bush at a height of three or four feet, and a lining of finer grasses, when present at all, is so clistinct as to permit of removal without injury to the bulk of the structure. I'rom three to five eggs are laid and so jealonsly guarded that the birkls are said to destroy the eggs once risited by man. So cautious are the Chats that even after the young have hatched ont, they take care not to be seen in the vicinity of their nest. hut a low, anxions clunck sometimes escapes from the harassed mother in a neighboring thicket.

Chats will follow stuitable cover into most desolate places. On the other land they do not discriminate against civilization per se, and the Chats of Camon Fiil, in Spokane, are as grateful to the good sense of its citizens as are the Catbirds and two score other resiclent species of songsters. 'They are, howerer, birds of the sumshine belt, and IVest-side records ate very few. 
No. 84.

\section{PILEOLATED IVARBLER.}

\section{A. U. L. No. (S5at. Wilsonia pusilla pileolata (l'allan).}

Description.- Idult male: Aluse loright olive gureen; ioreleaul, sides of beal, and underparts bright greenish yellow, tinged on sides with olive-green; crown, or "calp," lu-trous black; wings and tail iusents and olive-edgeel withome

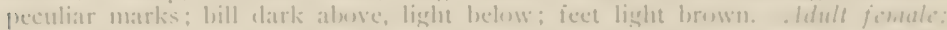
similar, lust the lnlack cap wantiner, or, if prenent, less distinct. Immature; like

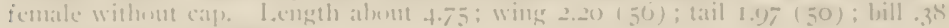
(8.5): tarsun $-75(18.8)$.

Recognition Marks,-1.cast,-pynm size: black cap of male distimetive;

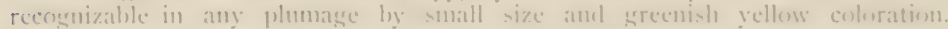

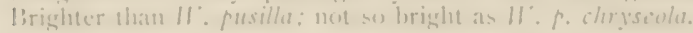

Nesting.-.. Is next.

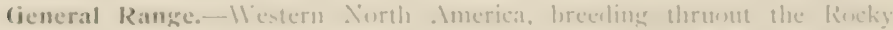

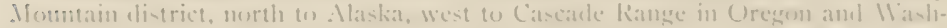
ingtom and (1) Vinconver lsland; during migratiom over the entire western

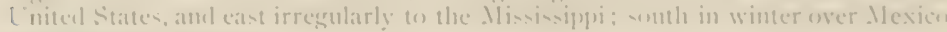
anul central America.

Range in Washington.- - Vot common re-jelent and aldunclant migrant on liast-side: migramt only west of Cascarles.

Migrations.-Sprin!l: May 1-15.

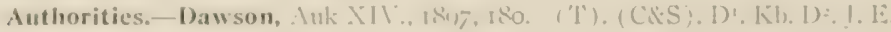

specimens.-13. II, I: 1'.

'Tll: persading yelhwones of this little bush-ranger will harelly serve to distongruisle it from the expally commun l,utescent llarbler, muless you are able of eatch sight of its timy silken crown-patel of hlack, the "little cap)"

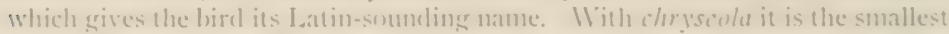
uf our warblers, and it is one of the commonest, during mignatens, an the liast-side. The thickets have taken on full leat hefore the hirel arrives from the sinuth, aloug alout the roth of .lay. and the northwarl mareh is witen probunged till the first of Jume. Suexpert is the little lilack-cayp at threacling hriary taneles, that at meeting here depenels upon the hirel's caprice ratler than the astutenes of the observer. Willow trees are fatwrite stations during the spring moxement, and these hecanse of their seantier folliage atford the best opportunitices for sturly.

My impressine is that the Pilenlated 11 arbler must hreed spangly in

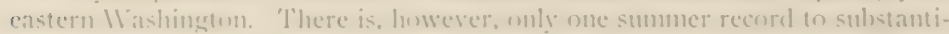

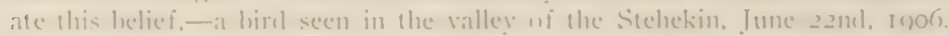
The only sumer I have heard differed from the alormsty erminated erescendo

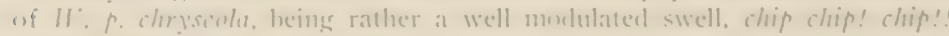
clip!!! chip!!! chip!! chip! chip. 
GOLDIDN WARIBI,EIR

MAT,IL, +/5 LTFL $\$ 1 \% I$

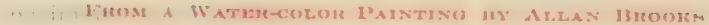




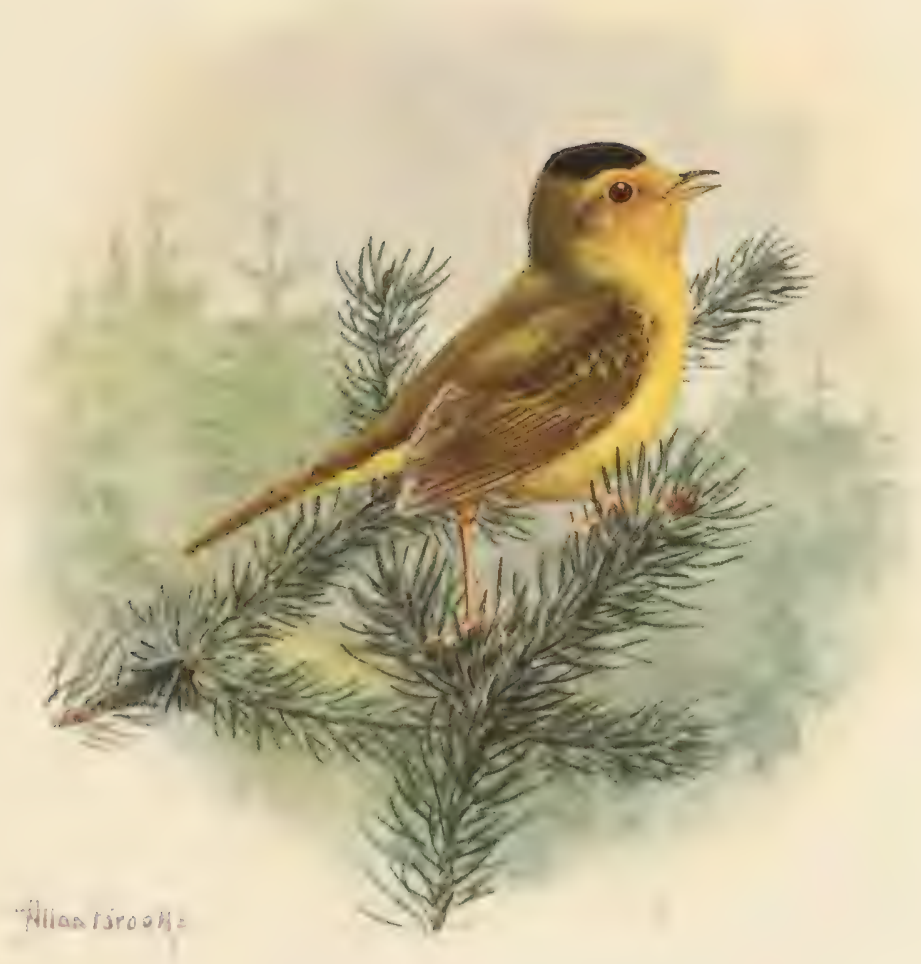



No. 85 .

\section{GOLDEN WARBLER .}

A. O. L. No. 685 b. Wilsonia pusilla chryseola RidgW:

Synonym.-GOLDE.N I'ILROLATED IVARIBLER (properly so-called, but the bird, because of its local abundance deserves the shorter name. Moreover, altho "golden" is the commonest color among the Warblers, the name has not been pre-empted).

Description.-" Similar to $\mathrm{W}$. p. pileolata, but slightiy smaller and much more brightly colored; olive-green of upperparts much more yellowish, almost olive-yellow in extreme examples; yellow of forehead and superciliary region (especially the former) inclining more or less to orange; yellow of underparts purer, more intense" (Ridgway). Length of adult males (skins) 4.35 (IIO); wing 2.18 (55.4) tail 1.93 (49.1); lill .33 (8.3); tarsus .72 (18.2).

Recognition Marks. As in preceding; brighter.

Vesting.-. Vest: a shapely and thick-walled mass of dead leaves, grasses and vegetable fibers, lined with coiled grasses or hair, on the ground or concealed at moclerate heights in weeds, bushes, evergreen saplings, etc. Ëgys: 3-5, white or creamy white, speckled and spotted with reddish brown markings, well distributed or gathered about larger end. Av. size .59 $\times$.48 (I5 x 12.2 ). Scason: May I 5-30; one brood.

General Range.-Pacific Coast district from southern California to southern British Columbia.

Range in Washington.-Summer resident in western 1 ashington; common in well-watered forcsts at lower levels and in thickets from sea-level to higher mountain valleys.

Migrations.-Spring: Arrives I'uget Sound April 25-Mlay 5. Fall: Blaine, Sept. I5.

Authorities.-Myiodioctes pusillus Bonap., Baird, Rep. I'ac. R. R. Surv. IX. pt. II., I858, 1). 294 (part). C\&S. L'. Ra. H. E.

Specimens, - U. of 11 . E.

'THIS dainty little Warbler is one of the most characteristic and well distributed birds of western Washington. Its summer range entbraces all sluady and moist woods having varied undergrowth; and it is at home alike on the sicles of the western Cascades, in the swampy bottoms tributary to Pugret Sotund, or under the dense spruce forests of the Pacific slope. It is certainly one of the most abundant birds in the last-named section, and its golden flittings not only dominate the fern levels but extend upward into the mossy arms of the evergreens. A brilliant dress does not appear to endanger the life of this little despot, for he is quite ton insignificant for notice among the Kinghts of Claw and Jaw, and so he flasles in and ont, scolcls, sings, and meditates, by turns, withont molestation. 
Dor is there any lack of interest in the life of this gelden midget. Have you never wished that you were tiny-oh, fery-with leaty lyack eyes, that you might explore the mysteries of a muss forest? that ederleerries might lowk un you like great blue pippins? and mastrone berries like luscions liery pumpkins? that you might pluck a thousand sappid meats at first land where now

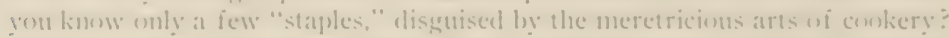
'llhat you might - Ih, here I hate you!- that yeu might pantingly pursue a gublen matelen down dim forest aisles, over plumging billows of spireat blossems, past corrielers of giant sword-fern, inte-()h, where is that madelening creature! Slle's given me the slip again! Never minel; l'll pause and sing:

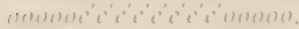

Truhlo to tell, the sumg just recorted is one of the rarest. a pertectly

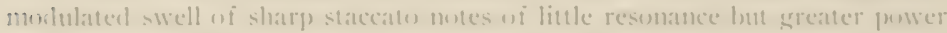

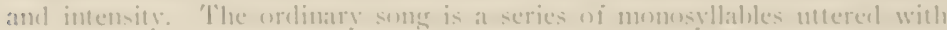

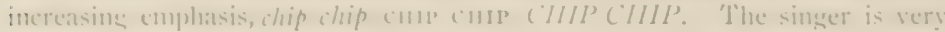
much in earnest, and compels attention in spite of his utler lack of musical

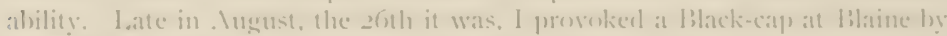

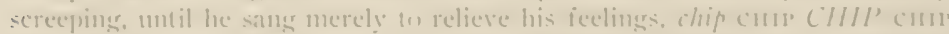

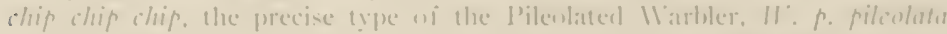

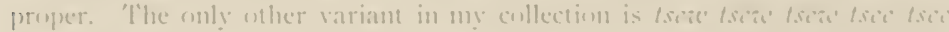

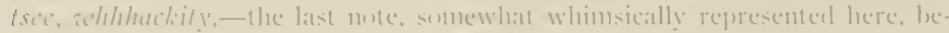
ing an intense guttural trill very difficult to characterize.

Messs. Rathbum and Renick, of Seattle, have mate a special sturly wi

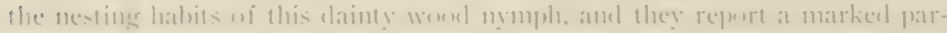

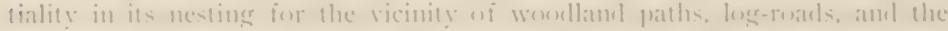

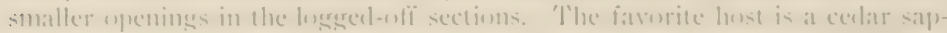
ling, a mere batoy tree with stem enly half an inch or se in diameter. () nine nests examined only one, in a bracken. was mere than two feet alsue the errentul, and nume were less than ten incles. 'The nest is quite a bulky atfair.

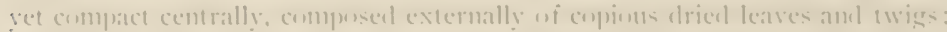

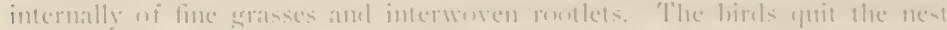

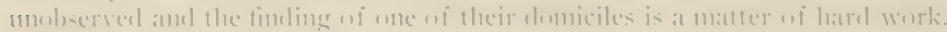

No. 86.

\section{AMERICAN REIDSTART.}

1. (). [?. Xin. (S-. Setophaga ruticilla (I,inn.).

Description.-- Idult mole: lleal and neck all around and breast shining hack; remaining mperparts dull black with ghesy patches, changing to browash hlack or fuecous on wings: a large -almem-eolored patch at hase of secomblarics: a -maller, nearly concealeal patch uf same color at bace of primaries: the nuter 
web of the onter primary salmon nearly thruont its length; the tail feathers, except the two middle pairs, salmon-colored on both webs for the basal twothirds; two large patches of reddish salmon on the sides of the breast; the lining of the wings and the sides extensively tinged with the same color, occasionally a few touches across the chest below the black; lower breast, belly, and crisstm, white; bill black; feet dark brown; black in variable amounts on sides of breast between the orange red spots; lower tail-coverts sometimes broadly tipped with blackish. Adult femalc: Above, brownish ash with an ochraceous or olive tinge on back; salmon parts of male replaced by yellow (Naples yellow), and the reddish salmon of sides by chrome yellow; remaining underparts dull whitish, sometimes buffy across chest. Immature male: Similar to adult female, but duller the first year; the second year mottled with black; does not attain full plumage until third season. Length 5.00-5.75 (127-146.I); av. of five males: wing $2.59(6.8)$; tail 2.17 (55.1); bill .36 (9.1) ; tarsus .70 (18).

Recognition Marks.-Medium Warbler size; black with salmon-red and salmon patches of male; similar pattern and duller colors of female and young; tail usually half open and prominently displayed, whether in sport or in ordinary flight.

Nesting.-Nest, in the fork of a sapling from five to fifteen feet up, of hemp and other vegetable fibers, fine bark, and grasses, lined with fine grasses, plant-down and horse-hair. Eggs, 4 or 5, greenish, bluish, or grayish-white, dotted and spotted, chiefly about larger end, with cinnamon-rufous or olive-brown. Av. size. $68 \times 5$ I (I7.3 $\times$ I3). Scason: June; one brood.

General Range-C'lemperate North America in general, regularly north to Nova Scotia, the Ilackenzie River (Fort Simpson), etc, west to sonthern Alaska, British Columbia, eastern Washington, Utah, etc., casual in eastern Uregon, northern California, and in the southeastern states; breeding from the middle portion of the United States northward; south in winter thrtiont West Indies, Dexico and Central America to northem South America.

Range in Washington.--Rare but regular stmmer resident in northern portion of State east of Cascades ( Nethow Valley, (irand Coulee, etc.), casual(?) in the Blue Mominains.

Authorities.-[J. K. Lord in "Nat. in Vanconver Id. and I?. C.", I866, p. I62 (Colville Valley).] Brewer, Bull. Nutt. Orn. Club. V., i880, 50 (Ft. Walla Uitllit. 1) $\therefore$. I.

Specimens.-C. P'.

THE "start" of Redstart is from the old Anglo-Saxon steort, a tail; hence, Redstart means Redtail ; but the name would hardly have been applied to the American bird had it not been for a chance resenblance which it bears to the structurally different Redstart of Europe. Ruticilla phoenicurus. In nur bird the red of the tail is not so noticeable as is the tail itself, which is handled rery much as a copuette handles a fan, being opened or shut, or shaken haughtily, to express the owner's varied emotions.

'The Redstart is the presiling genius of woodland and grove. He is a bit of a tyrant among the bircls, and among his omn kind is exceelingly 
sensitive mpon the subject of metes and bounds. As for the inseet world he

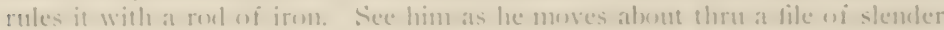
poplars. He flits restlessly irom branch to branch, mow peering mp att the

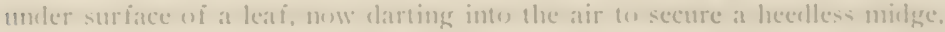
and closing npon it with an emphatic snap), now sprealing the tail in parclenable vanity or from sheer exulderance of spirits: but ever and anon patusing

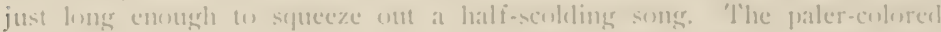
female, contrary fo the mstral went, is mot less atetive nor less noticeable than the male, execpt ats she is restratined for at seasen by the duties of incubation.

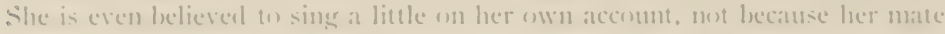

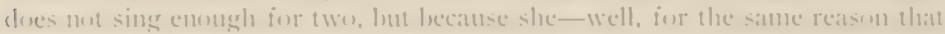
a woman whistles, - and gext luck on luer?

Doring the mating season great rivalries spring 10 , and males will chatse each enther alont in most hewildering mazes, like a patir of great fire-flies,

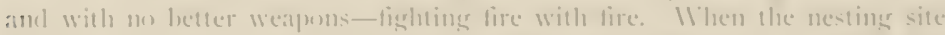
is chosent the mite is very jealous of intruders, and bustles up in at theatening fashon, which quite overawes most hirels uf gruleless intent.

Reelstart's song is sometimes little hetter than an empluateseent spueak. At mber times lis emention farles a fiter the mterance of two or three notes ane? the last one dlies nut. A more pretentions elfort is represented log . Mr. Chapp-

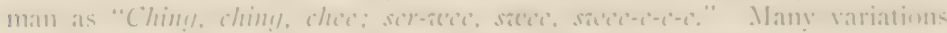

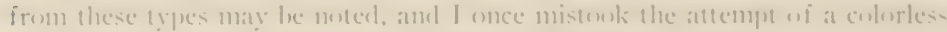

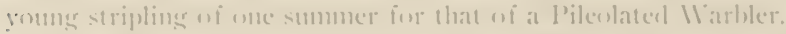

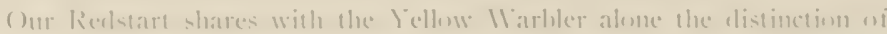

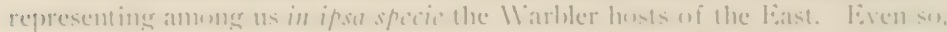

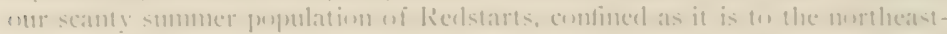

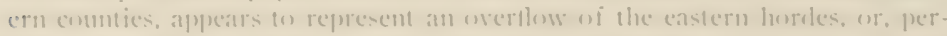

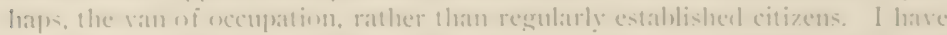

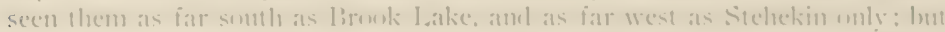

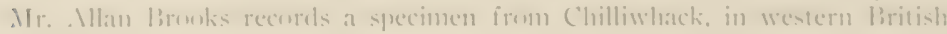
(i)lumbiat

No. 87.

\section{ALASKA HORNED LARK.}

A. (1) I: No, 47ta. Otocoris alpestris arcticola Oherholser. I. $\leftrightarrow k:$

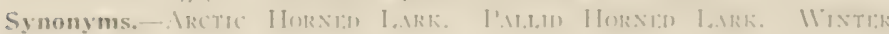

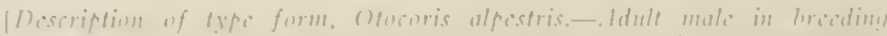

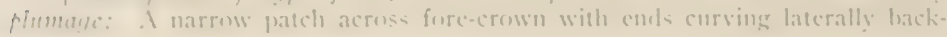


ward and produced into a feather-tuft or "lorn," black; a broad bar from nostril to eye thence curving downward and expanding to involve hinder portion of cheeks and auriculars anteriorly, black; a crescentic patch across upper chest black: forehead and superciliaries pale yellow (printose yellow) paling posteriorly: anriculars yellow continuons with and deepening into straw yellow of chin, throat and malar region; remaining underparts white, the sicles and flanks dull vinaceous streaked with dusky; upperparts in general warm grayish brown, the midlle of crown, occiput, nape, lesser wing-coverts and upper tail-coverts vinacens-cimamon; back, scapulars and rump grayish brown, each feather edged with paler and having dusky center; wings hair-brown with paler edgings, the outermost primary edged with white: tail chiefly black, the middle pair of feathers dusky, edged with whitish, the two lateral pairs edged with white. Bill black lightening below (basally); legs and feet black; iris (lark brown. Adult fomale in summer: Like male but duller and paler, the black areas reduced in extent and obscured by brownish or buffy tips; yellow of superciliary stripe, etc., (duller and paler; upjerparts more noticeably streaked and with less of vinaceous tint on hind neck and upper tail-coverts. Both sexes in fall and ainter are somewlat more heavily and more uniformly colored save on black areas which are overcast by buffy or brownish tips; also forebreast dusky or obscurely spotted. Foung birds are licavily speckled above with yellowish white on brownish and dusky ground. Length of adult male: 7.00-7.50 (I77-190); Wing 4.37 ( I I I ) : tail 2.83 ( 72 ) ; bill .48 ( 12.2$)$; tarsus .94 (2.4). Adult female: $6.75-7.25$ (I7I-184); wing 4.09 (104); tafl $2.48(63)$; bill 4.3 (II.I) : tarsus $\therefore \quad-3.2+1$

Description.-Adults: Similar to 0 . alpestris but upperparts paler and grayer, less warmed by vinaceous; no yellow (or merest tinge on head and throat - white instead : size about the same.

Recognition Marks.-Sparrow size; black crescent on upper clrest: black cheek and crown patches; feather-tufts or "horns" directed backward. "l'o be distinguished from $O$. a. merrilli and $O$. a. strigata by larger size and absence of yellow:

Nesting.-Not certainly known to breed in Washington but possibly does so above timber-line. Vest: a cup-shaped depression in the surface of the ground. plentifully lined with tine grasses, moss, grouse feathers, etc. Egyg: 3 or 4. greenish- or grayish-white, profusely and minutely dotted with olive-buff, greenish-brown and lavender. Ax. size $.95 \times .66$ (27 x i6.7).

General Range.- "lireeding in Alaska (exeept P'ncific coast district) and walley of the Lpper Yukon River, Northwest 'l'erritory; migrating southward to Oregon, Ltal, Montana, etc." (Riclgway).

Range in Washington.-Common winter resident and migrant east of the Cascales. librls breeling on the ligher mountains are doubtfully referable to this form. $D^{2} . J$

Authorities.-O. a. lencolcma (Cones), Dawson, Auk, XIV. I897, 176.

Specimens.-Irov:

'Tlli: Horned Lark bears the reputation of being the most plastic of American species-the Song Sparrow (Mclospiza melodia) being a close sec- 


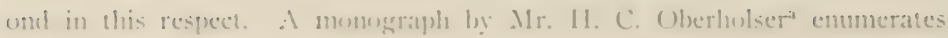
twenty-three forms, of which seventeen atre described ats Dorth Anerican, and

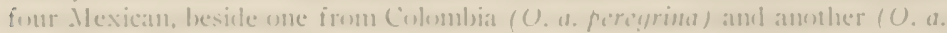
flara) from linasia. ()i this mumber the majority accur west of the Mississippi River, where clinatic comditions are more sharply dilferentiated, and where, especially in the sonthwest, the situation allows of that permanemt residence which is conducive to the development of subspecitic forms.

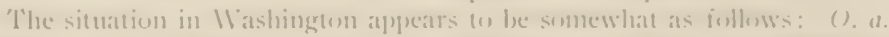
strigah, strongly matied, but showing relationship) (e mirrilli, and likeness io

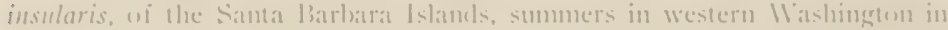
upen pratries, and at low altitules only. In winter it retires somthware, or strageles irregulaty eastwarel". (). (1) morrilli is related to strigsha on the one

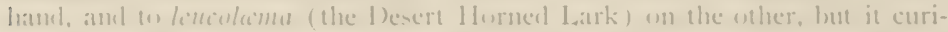

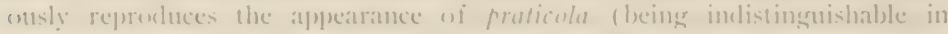

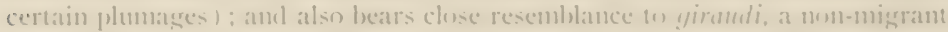
form of the (iulf shore of l'exas. It smmmers thrusul eastern IVashington,

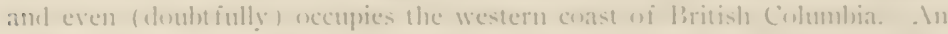

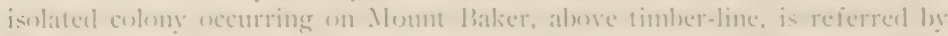
Oberholser in this form, but I slumbl prefer $w$ eall it an intererate witi arclicolu. In winter merrilli retires completely from its 11 asthingtom range. amd its platee is talien by articolu, sweepher down from the highlands of British Columbiat and Alaska in consirleralile mumbers.

It is not at all dificule for one whe is acenstomerl to the appeatrance of

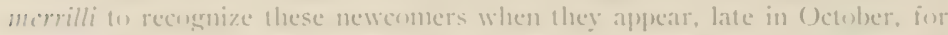
they are decidedly larger, more lightly colored, and show me slightest trace of vellow: They are much griven of wandering alust in straggling flocks. and the mild eries which they scatter freely have a sublused and plaintise tone. lomrowerl, mo dimbe. from the chastened character of the seasent. A sitting

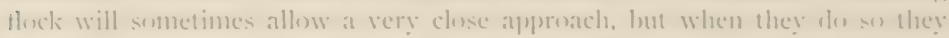
"freeze," su perfectly that the eye can scarcely find thems. The inly thing in

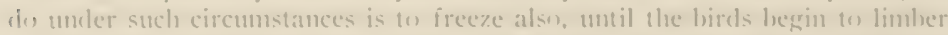
m) ancl steal cantionsly away, laking athantage, for concealment. of every tuit of gratss or depression of the eround, and giving necasional atmonitory vips to their fellows.

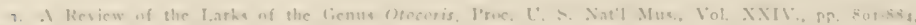
19: $:$

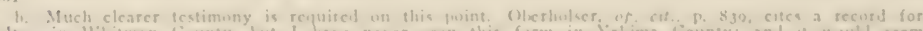

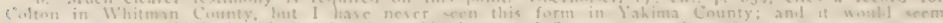

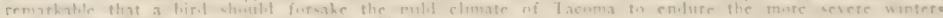

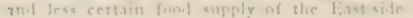


No. 88 .

\section{COLUMBIAN HORNED LARK.}

\section{A. O. U. No. 474 i. Otocoris alpestris merrilli Dwight.}

Synonyms.-DUsk: HorNid) LARK. MERRILL's HORNED LARK.

Description.-Similar to $O$. a. strigata but somewhat larger and decidedly: grayer above, streaks narrower and dusky rather than black; mulerparts not suffused with yellowish and yellow of head, especially superciliary, not so strong as in 0 . a. strigatu. Length (skins) 6.25 (159); wing 4.05 (I03); tail 2.32 (59); bill.+3 (II) ; tarsus .85 (2I.6).

Recognition Marks.-As in preceding; smaller, clarker and more yellow than $O$. a. arcticola; larger, grayer and less yellow than $O$. a. strigata.

Nesting.- Vest and cygs as in preceding. Av. size of eggs .03 ×.6 ( $23.6 \times$ I5.5). Scason: April-July; two or three broods.

General Range.-Breeding in northwestern interior district of the United States from northwestern Nevada and northeastern Califormia north thru Oregon and Vashington well up into british Columbia, east to Idaho; sonth in winter (at least) to central California.

Range in Washington.-Common summer resident and migrant cast of the Cascades. Hreeding birds of the high Cascades may possibly be of this form.

Authorities.-Ercmoplila alpestris, Brewster, I3. N. O. C. VII. Oct. IS92.

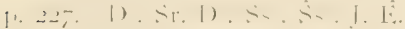

Specimens,-I'. I'rov. E'(?).

$\therefore$ MODIS'l birt is the Columbian Horned Lark, for lis hone is on the gromul, and he lungs its tiny shelters when disturbed, as tho quite assured that its browmess matches the tint of his back. If attentively pursued, he patters away half trustfully, or if he takes to wing, he does so with a deprecating cry of apology, as if the fattl were his insteat of yours. If his business lieeps him in the same field, he will reappear presently, picking from the ground with affected nonchalance at a rod's remove, or else pausing to face you frankly. with those interesting feather-tufts of inquiry, supported by black moustachios and jetty gorget on a gromel of palest primrose.

Iline unseeing class the Horned Larks among "brown birds" and miss the vaulting spirit beneath the modest mien. Yet our gentle Lark is of noble blood and ancient lineage. 'The Skylark, of peerless fane, is his own cousin; and. while he camnot hope to vie with the foreign bird in song, the same poet sonl is in him. Whether in the pasture, upon the hiliside, or in the desert, the coming of spring proclaims him laureate; and the clief vocal interest of nestingtime centers in the song-flight of the male Horned Lark.

The song itself is, perhaps, nothing remarkable, a little ditty or stuccession of sprightly syllables which have no considerable resonance or 


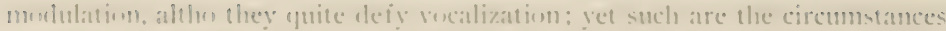
atlembling its delivery that it is ses thwn ly exeryone as "pleasing," while

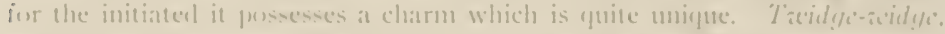

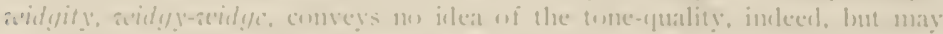
serve to indicate the proportion ame temponf the common song : while Treviles,

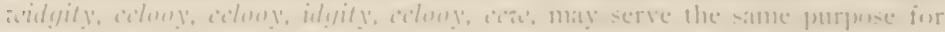

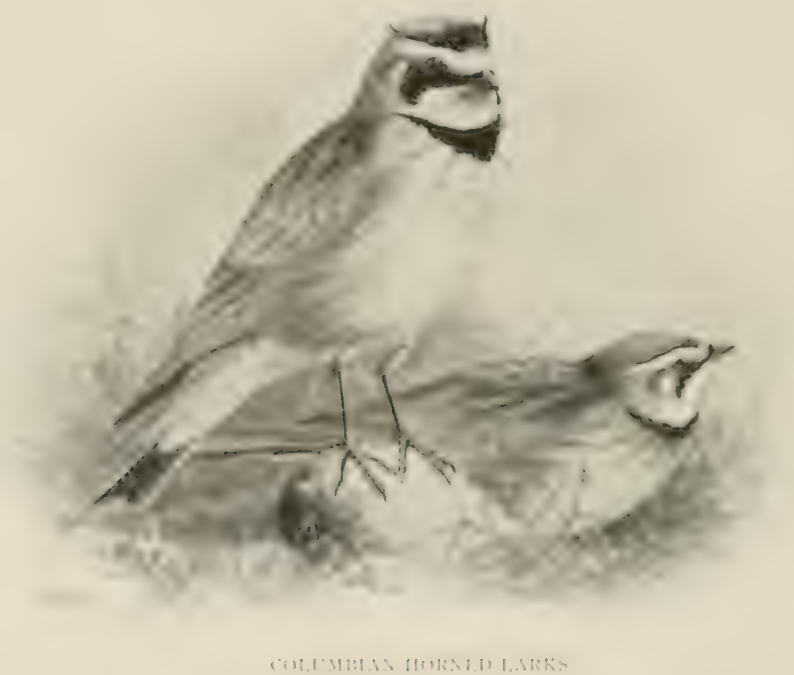

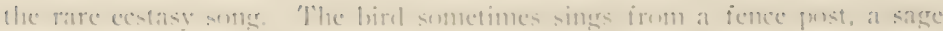

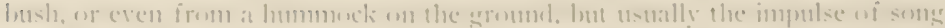

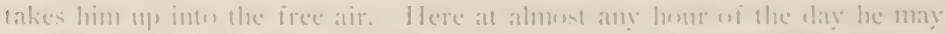

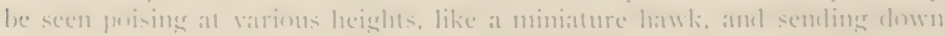

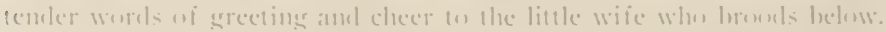

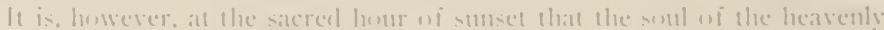

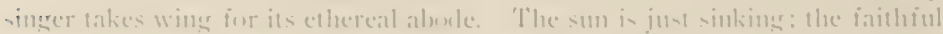

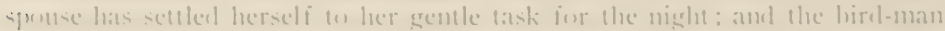

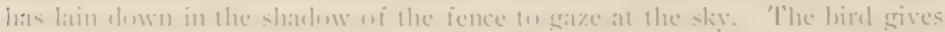
himedi to the humant inflences of the trembling air and mounts alenft by casy gratations. As be rises le swings rouml in a wicle, fouse circle, singing 
softly the while. At the end of every little height he pauses and hovers and sends down the full roiced song. Up and up he goes, the song becoming tenderer, sweeter, more refined and subtly suggestive of all a bird may seek in the lofty blue. As he fades from the maided sight I train my glasses on hin and still witness the heavenward spirals. I lower the glasses. Ah! I have lost him now! Still there float down to us, the enraptured wife and me, those most ethereal strains, strblimated past all taint of earth, beatific. elysian. Ah! surely, we have lost him! He has gone to join the angels. "Chirriquita, on the nest, we have lost him." "Never fear," she answers: "Lark!" Stronger grows the dainty music once again. Stronger! Stronger! Dropping out of the boundless darkening blue, still by easy flights, a song for every step of Jacob's ladkler, our messenger is coming down. But the ladder does not rest on earth. When about two hundred feet high the singer suddenly folds his wings and drops like a plummet to the ground. Within the last dozen feet he cliecks himself and lights gracefully near his nest. The bird-man steals softly away to dream of love and God, and to waken on the morrow of earth, refreshecl.

The Columbian Horned Lark enjoys a wide distribution thruont eastern Washington during the nesting season, the only requirement of the bircl being open commey. 'The convenience of water is no object, and the bird favors the undifferentiated wastes of sage, rather than the cultivated fields. Elevated situations are especially attractive, and thousands of these Horned Larks nest along barren, wind-swept rirlges and on the smaller mountains where no other species can be found.

No. 89.

\section{PACIFIC HORNED LARK.}

A. O. U. No. $47+\mathrm{g}$. Otocoris alpestris strigata IIenshaw.

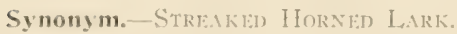

Description.- Similar to $O$. alpestris but darker and much smaller, above streaked broadly with black and tinged with buffy; nape, runp and bend of wing more rufescent : underparts usually more or less suffused with yellowish. Adult female more strongly and handsonely marked than that of any other form. Length of adult male (skins) 5.98 ( 52 ); wing 3.85 (98) ; tail 2.59 (65.8) ; bill .4 (II.3): tarsus .82 (20.8).

Recognition Marks.-As in preceding; smaller, clarker and more yellow than other local forms.

Nesting.- Vest and cggs as in preceling. Season: second week in May, second week in June; two broods.

General Range,-lirecling in Pacific Coast district of Oregon, Washington 
amel British Columbia: "migrating 4 enstern ()regon and IVashinglon, and nerthern (alifurna (Red lilunf; San Franciseo)" (Rielgway).

Range in Washington.-Fomel breeding only on praties weat of Cascaules,

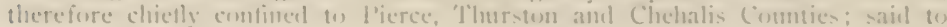
winter (18) liatst-side.

Migrations.-Sfrin!: last weck in Feluruary: 'Tacoma, Fichruary 25, 1105. liveruary 10, lyos.

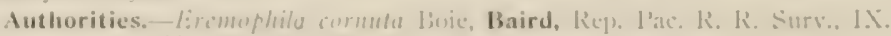

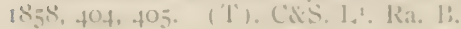

specimens.-1 L', of II.) l'rus. li.

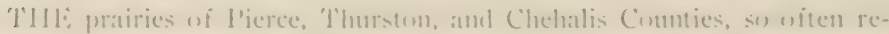
ferred to in these patges, are of comparatively recent formation-mere grated beds leveleal off he the action of at retreating seat-and s) theroly wathed thru

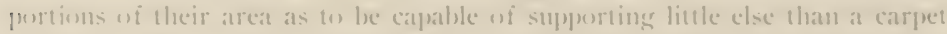
ui nuss. 'llhe wanton recklessness of the Pacitic Morned latks, which inhabil these ofen stretches, is really but one degree removed fonn the nurlesty

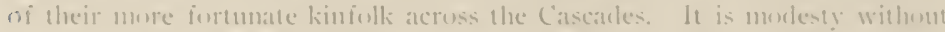

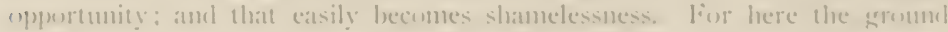
is of an mucompromising ereen, and the "coser," alforeded lo slight depressituss in the moss, is ustatly momothy wi the name.

The perfection of gereen batrenness was attained in the grolf-links of simtl ' lacomat, lefore they were surrendered to the demands of the groming city. Je this was the very place where the Hormed Larks appeared to the lest alvantage. Returninge ats they diel, alunt the 25 th of lichruary, in sumel seasons, they disported themselves like mal l'ixies for a month or so, engaging in amorous purstit and frepuent somg-tlight; mol in some way, late in April, domestic oreler began an emerege from the chaos of rival claims, and

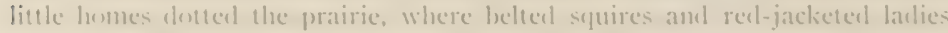
pursterl the eninkling grttat-percha. The contlice of inferests, avian and human.

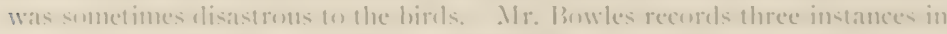
which larks were killed hy tlying gonlf halls: and anmler gentleman, himseli a devotee of the game, tells me lec once saw a birel struck deal in midl-air.

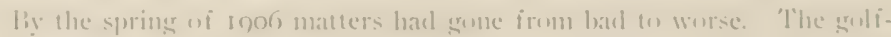
links became a sort of emmmen, elespairingly resorted w by a few enthusiasts and a motley laity. 'lhe northwest portion wi the section was staked out into luts, and the whole area was criss-crossed hy roals and paths, wherely work-

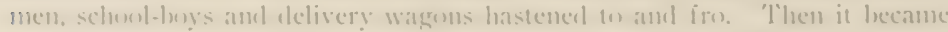
the special pasture of a hand uf lify cows, the lean kine of lharanlis tream

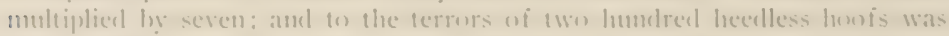

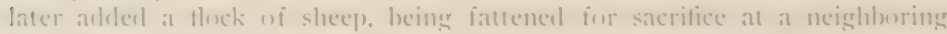
slatughter-lunse. 'This common was alse a faverite romping gromul for children, while doges smply went crazy upon it. I saw one rabid beast in a 
delirim of unfettered bliss do off about six miles in twice as many minutes, with a Horned Lark, tlying low, as the invariable object of his chase. When to such conditions as these was adderl the scantiness of cover. one marveled incleed that the daffy Horned Lark still persisted upon his ancient heritage.

Iet on the I th of April (the earliest record by far), in the barest of it, we marked a deep romkled carity which Mr. Bowles declared belonged to the Streaked Horned Lark. Returning on the 27 th, we found that the hole in the ground had become a bump insteacl. The birel. grown callons amid the impending evils, or else frankly intencling to warn off trespassers, had filled the cavity full to overtlowing, and had erected upon its site a monumental pile visible at in huncled yards. So zealons harl the bird's efforts been that the crest of the nest stuck up) two and a half inches above the closecropped landscape. and the bottom of the nest was above the grotnd. This creation was quite ten inches across. while it included mpon its skirts bits
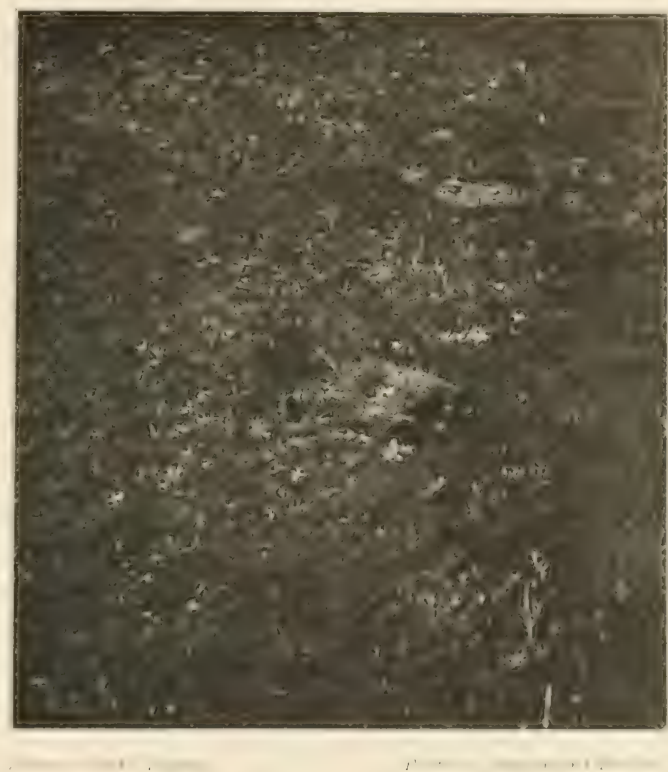

TIIE NEST ON THE GOI.I I.IXKS of sod, cou-clijes and pebbles, - a motley arrar, possibly designed to distract attention from the dun-colored eggs which the nest contained. 'l'lie most lavish clisplay of this sort of brtmagem marked a rtmway of approach, offset by a corresponding depression upon the other side. 'The nest was composed chiefly of dried grasses and weed-stalks with soft dead leaves, and was lined. not very carefully, with grass, dried leaves, and a single white clricken-feather. 


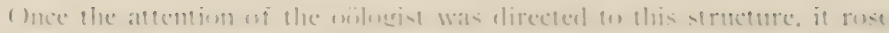

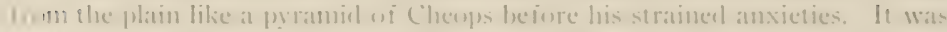

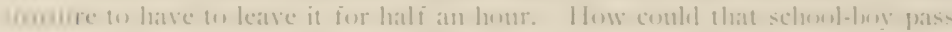

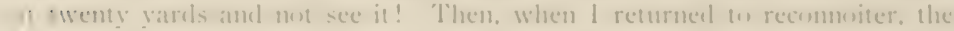

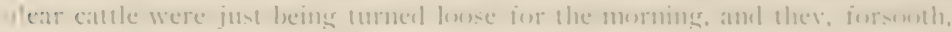

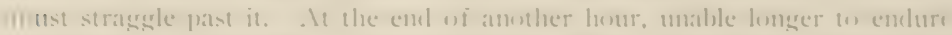

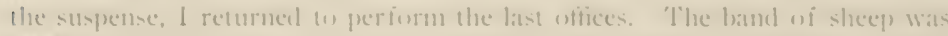
wat ilen, and they were drifting sn perilously close, that I ran the last humbet

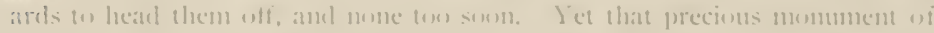

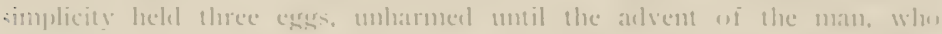

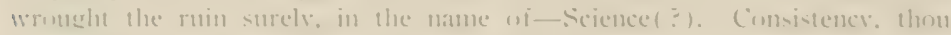

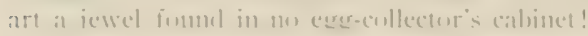

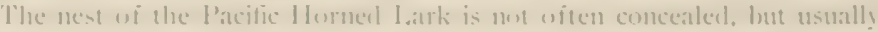
- deres met mure than fill the hollow of some cavity, natural on artificial,

Whecl-rut, a foutprimt of horse ur cow, a cavity left by an upturnet stone, or.

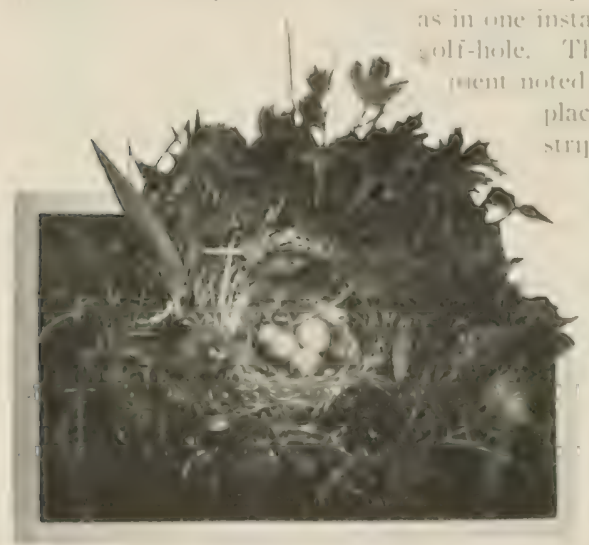

$-1$

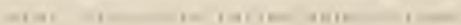

The placest meler the fold of a large

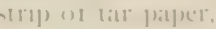

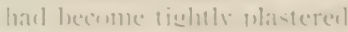
iin fire eroum

In spite of the enmulatal tencly milel weather urevail

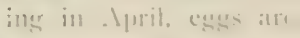

bften laibl lefiore the seromel week in Mals. and a secomel set is deprented afmule tum secontel weeti in Inne. The mumbler of exes in at is

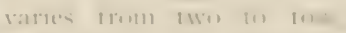
viece beines most commmonl fimml. In color the errotmel is eravish white, while dore

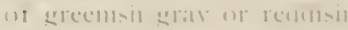

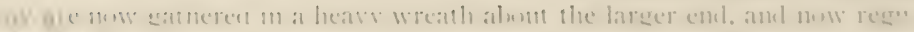

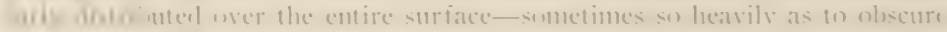

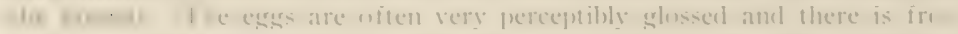
moently a latumling ereenish or yellowish linge which diftuses itself oner the

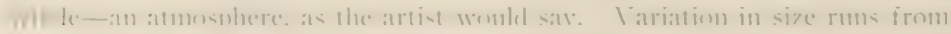

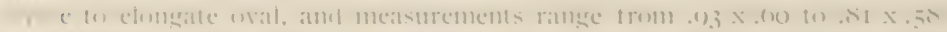
flaried Jarks owe their preservation chefly to the wariness of the female. 
for she flushes at long distances. Either she will slip off quietly and sneak at thirty yards, or else flush straight at a hundred. When the nest is cliscovered she is quite as likely to ignore the intruder, and seldom ventures near enough to betray ownership. On the other hand, given patience and a pair of strong binoculars, "tracking" is not a difficult accomplislment.

No. 90 .

\section{AMERICAN PIPIT.}

A. O. U. No. 697. Anthus rubescens (T'unstall).

Synonyms.-AMFricax 'T'itLARK. Brown LARK. LOUISIANA P'IPTT.

Description.-Adult in spring: Above soft and dark grayish brown witl an olive shade; feathers of crown and back with clarker centers; wings and tail disky with paler edging, the pale tips of coverts forming two indistinct bars: outer pair of tail-eathers extensively white; next pair white-tipped ; superciliary line, eye-ring and underparts light grayish brown or buffy, the latter streaked with dusky exeept on middle of throat and lower belly,-. heavily on sides of throat and across breast, marrowly on lower breast and sides. If inter plumage: Above, browner; below, duller lntfiy; more broally streaked on breast. Length $6.00-7.00$ (152.4-177.8); wing 3.37 (85.6); tail 2.53 (64.3); bill .46 (1 .7 ) . tarsus . ()0 (22.9).

Recognition Marks.-Sparrow size; brown aloove; luffy or brownish with diskly spots below: best known by thip-yip notes repeated when rising from eround or thing overlical.

Nesting.-West: at high altiturles, a thick-walled structure of grasses and moss set into deep excavation in sloping hillsicle or in cranny of cliff. liggs: 4-6, usually 5, so heavily speckled and spotted with reddish or dark brown as almost entircly to obscure the whitish gromel color. Often, except upon close examination, the effect is of a uniform chocolate-colored egg. Av. size .77 $x .57$ (19.6 $\times 14.5)$. Season: June I5-July 25: one broorl.

General Range.-North America at large, lorecling in the higher parts of the Rocky and Cascade Mlonntains and in sub-Aretic regions: wintering in the Gulf States, Mexico, and Central America. Accidental in Europe.

Range in Washington.-Abundant during migrations; common summer resiclent in Cascacle Momntains above timber-line; winters sparingly west of mountains.

Migrations.-Nomadic; retires from momtains early in September: moves solsthward across State Oct. I5-I)ec. I5; northward April I-May I5.

Authorities.-.? '́ownsend, Journ, Ac. Nat. Sci., Mhila., TIII., I839, I5t (Columbia River). Anthus ludoricianus, Ticht. Baird, Rep. Tac. R. R. Strv. IX. pt. II., I858, p. 233. 'T'. C\&S. I. . Rh. D:. Sr. Ra. D², J. B'. E.

Specimens.-U. of IV. I'. H'rov. 13. IE.

'THE: American Pipit does not sustain the hathitual clignity of the boreal breed. Ile is no clown, indeed, like our Chat, nor does he quite belong to the 
amkwarel symat with youmg lilackibirls: a trim form and a matey suit oflen save him irom well merited derision, but all chse olsersers will agree that there is a screw horse in lis make-up sumewhere. 'The whole Piphit race

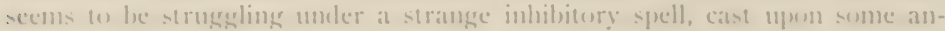

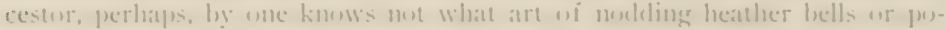

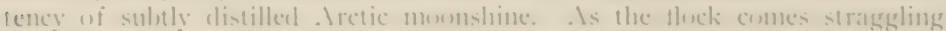
rown from the nombland they utter unceasing yifs of mild astonishment and seli-reproach at their apparent inability to decile what an do next. T'heir innecision is especially exasperateng as one riles along at trail which is closely nankeal by a primitive mil fence, ats I hase often dene in (Jkanegan County.

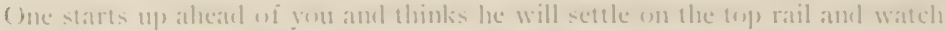
you gu hy. As his feet near the rail he deciles he wont, atfer all, but that

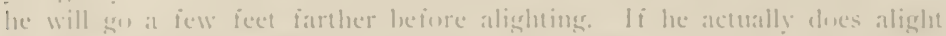
he instamty tmmbles wit with at started yip as thes the rail were hot and he

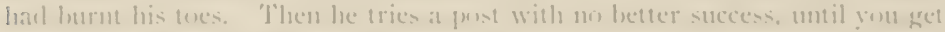

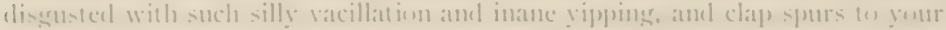

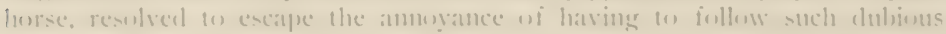
fortune:

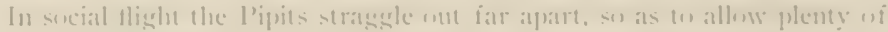

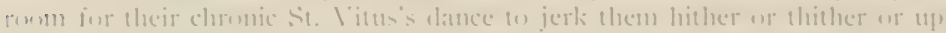
or deman, withent clashing with their fellows. ()nly a small pereentage of

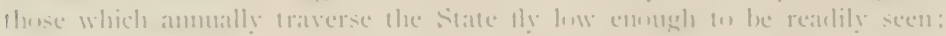
lunt when they de they are joltings alengs user the landscape and complatining at every ofler step). 'The mote is hest remelered llip-yip. less acematedy pip-if (whence wi course the name) : and a shower uf these petulant sumbls comes

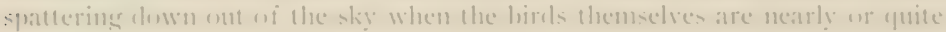
invisilule.

The fall migrations of this species appeal to have a compremml clatracter.

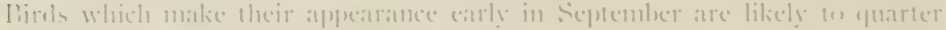

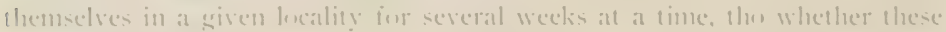

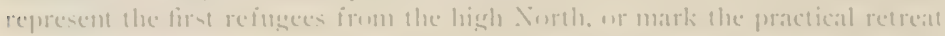

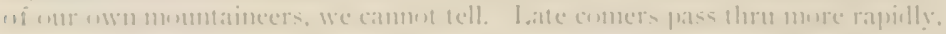

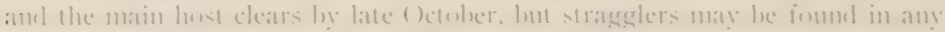

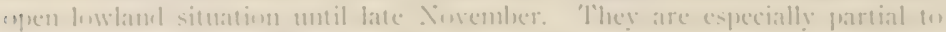

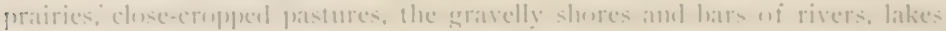
and pomels, and the shingle of sea-heaches. At semiahmes the great ricks of

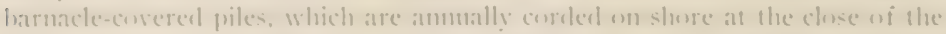

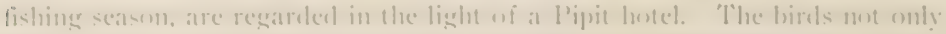

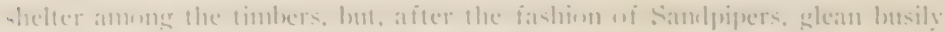
irum their surfaces where the marine creatures, thru expesture to the air, are dying a iragram death.

The return mosement of springs sets in carly, and the main thight is more 
direct. But here there is suspicion of destitory wintering on the one hand (I have a record of forty birds seen on the Nisqually Filats, Fel). Io, Igo6; and Fannin says they sometimes winter on Vanconver lsland) and there is alwavs a small percentage of loiterers who linger into May. Spring flocks may be looked for in freshly-plowed fields, where they feed attentively, often in absolute silence, moring abont with "graceful, glicling walk, tilting the body and wagging the tail at each step, much in the manner of a Seimrus.

Pipits are boreal breeders: but inasmucl as our own stiperb) Alps claim kinship with the Aretic, there is no more favorable spot to sturly the nesting of the Pipits than upon the Cascacles of northern W'ashington. At home the Pipit is a very different creature from the straggler of the long trail. On his mative heather, strrounded by dwarfed fir trees. melting snow-fields. and splendid vistas of peak and cloutl. he linows exactly what he wants and is quite capable of flying in a straiglit line.

All is bustle and stin along Ptarmigan Ridge,the transicrse rock-ril) of Cascarle Pass which divides the waters of Steliekin. Chelan, and the Columbia from those of the Cascarle.

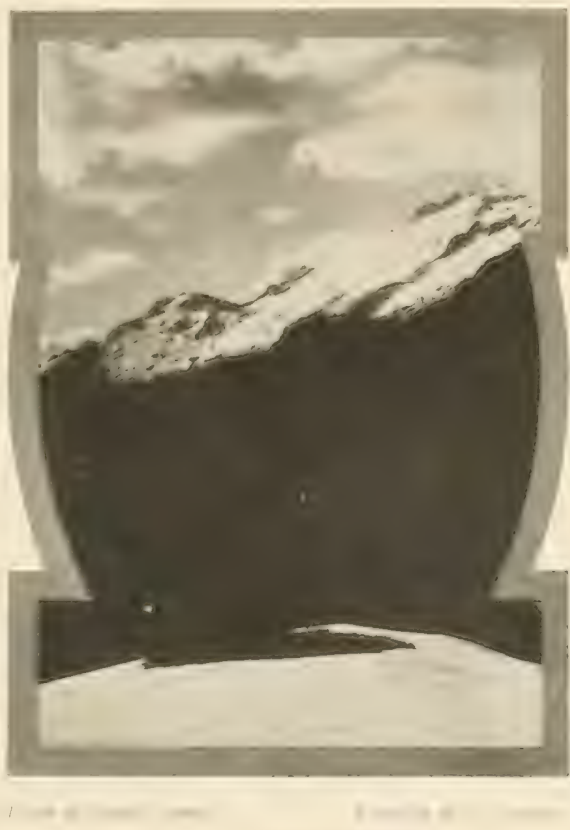

OLR 1. M1) Y OF TH1: $\$$ TOIIS

A CILUACTIRTSTC SUMMTIR HAUXT OF THI PINTT Skagit, and Puget Sound.

The season is late, June 23. I006, and the snows have only just released the ridge at 6000 feet elevation. Slate-colored sparrows are carolling tenderly from the thickets of stumted fir. Sierra Ifermit Thrushes, those minstrels of heaven, flit elusively from clump to clump or pause to rehearse from their depths some spiritual strain. Leuenstictes look in uyon the scene in passing. lut they hasten at a prudent thought to their loftier ramparts. 'lihe real 


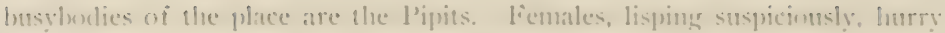
10 and fro, discussing locations, matching straws, platy fully refulking ower|xold swatins, and lastily gulpoing insects ont the sicle. 'The male birels hover atrout their mates solicitusly-never helping. wi course-er else sing lustily. irom prominent kimolls and rocks.

The Pipit song in many of its phases is strikingly like that of the liock

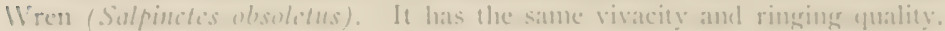
thu perhaps less puwer, and the similarity extends to the very phrasing. An alarm mote runs pichere pichene pichene, given six or seven times, raphilly and

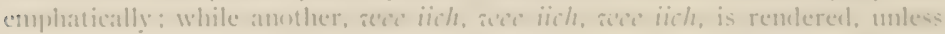
my eyes deceive me, with the same springing motion which characterizes the

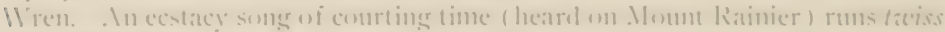

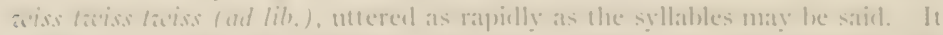
is alelivered as the bird descriles erreat stow cireles in mid-air: and when the singer is exlatused by his effurts, he balls like a spent rocket to the wround.

liof all this activite, however, the nests are hard we linel. limalle, as we

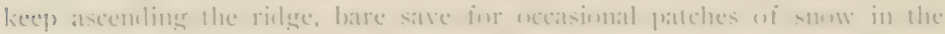

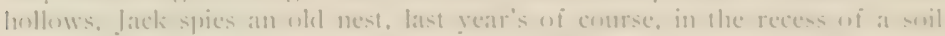
tassenck, completely merarcherl ly earth. The secret is ant, and we can

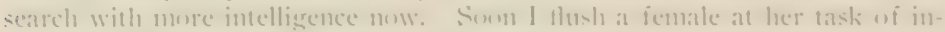

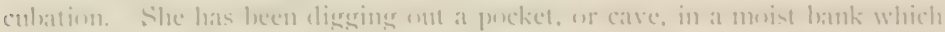
the smow has set free mot aldue three dass lefore. The earth remosed from the interior is piled up for the lower rim, or wall, amel a few rontlets, denthtlese those secureel in the process of excanation, have been culled ont and latil

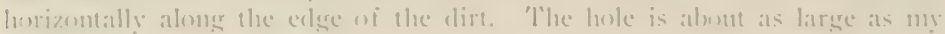
dimble lists, and the nest. when completerl. evidently camtun he injured he Pallinger smow:

In luly of the following year. work was carriced on in the Lpper llorse-

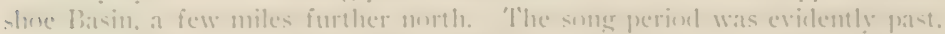
Inte a nest of five esess slightly inculated, was talien from a heather slope on the zoth of the month. P'le sitting birel flusherl from umeler the heating stick, lout only after 1 had passerl.

() In the izth, a venturesome climh ower the rock-wall which fromts the

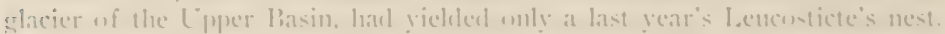
As I was nearly down the clifi and hreathing ensier, at I'ipit flew umannomeed

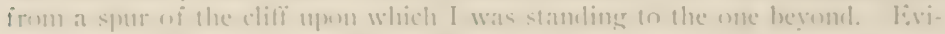
elently she havl heaml the call of here male, for the instant she lighted upon the

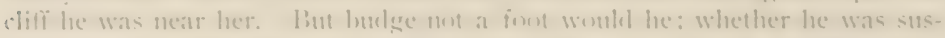

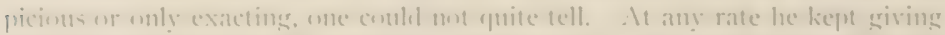
rent in a ringing metallic note of apprelension. 'lhe female conxerl with Autering wings, and moverl slowly forware as she did so, linally securing the worm from leer reluctant lurl, when-whisk! slue was lack again and ont 
of sight around the cliff on which I stood. I hastened forward to the furthest ontstanding point which gave a partial view of the wall's face. No bircl was in sight. Then I tossed pebbles against the cliff-side, and from beneath the second summons fluttered the frightened Pipit. Five beatiful eggs, of a warm weathered oak, rather than "mahogany" shade, lay in a niche of rock. $\Lambda$ tussock of grass clung just below, and a dwarf shrub afforded a touch of drapery above; while from the outstretched liand a flint-1lake might have fallen clean of the wall to the ice, a hundred feet below. The male bird continued his outcries from the distant cliff, but the female at no time reappeared.

With the advance of summer, the Pipits lead their broods about the disrobed peaks, even to the very summits, as do the noble Lencostictes. Knowing this, we may readily excuse any little eccentricities which appear in our friends during the duller seasons. 'The Pipit has redeemed limself.

No. 91 .

\section{TOIVNSEND'S SOLITAIRE.}

\section{A. O. U. \о. 754. Myadestes townsendi (Aud.).}

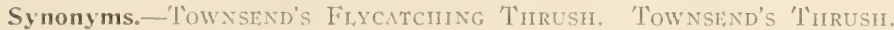
'D'OWNSEXI'S FILCATCHER.

Description.-Adults: General color smoky gray, lighter below, bleaching on throat. lower belly and under tail-coverts; a prominent white orbital ring; wings and tail dusky; wing quills crossed by extensive tawny area originating at

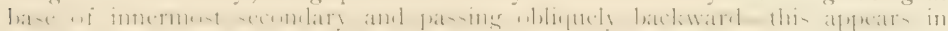
the closed wing as a spot at the base of the exposed primaries but does not reach nearer the edge of the wing than the fifth or sixth printary; another obscure tawny or whitish patch formed by subterminal elging on outer webs of seventh and eighth (sometimes ninth) primaries; greater coverts and tertials tipped with white of varying prominence; a blotch of white on each sicle of tail involving distal third of half of outermost reetrix, tip of second and sometimes tip of third. Iill and fect hlack; irides brown. Young birds are heavily spotted with buff above and below (showing therelyy 'T'mrline affinities), -above, each feather has a

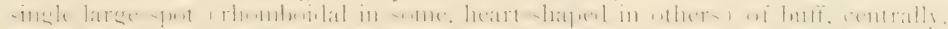
and is edged with blackish, thus producing a scaled appearance; below, the grouncl color is a pale buff or buffy gray with blackish edgings to feathers. I.cngth about 8.00 (203.2) ; wing 4.60 (i I 7 ); tail 4.05 (103); bill .49 (12.4); tarsus .79 (20).

Recognition Marks. - Chewink size; brownish gray coloration with spots of white (or pale tawny) on tail and wings. No black, as compared with a Shrike.

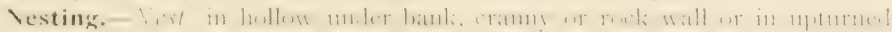
roots of tree, of sticks, coarse weels and trash, lined with rootlets. Liggs: 4 . grayish white spotted with pale brown, chiefly about larger end. Av. size, $.96 \times 70(24.4 \times 17.8)$. Season: .ay or June; one brood.

General Range.-Western North America, breeding chiefly in monntainous districts, from northwestern Mexico to Alaska and Yukon 'I'erritory, wintering 


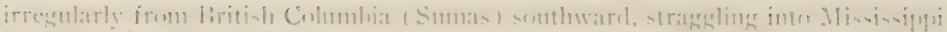
lalley during migrations.

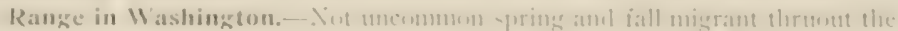

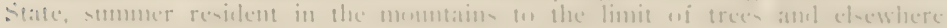

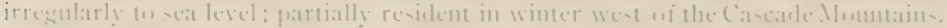

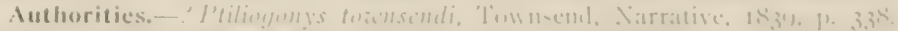

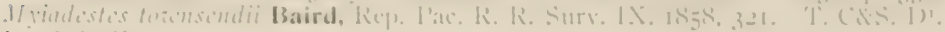
Ki. I. I: li.

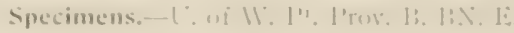

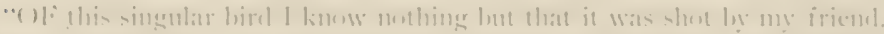

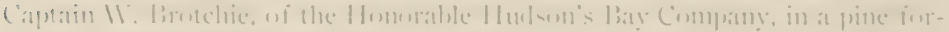
en near lint licorge, 1. Istoriat) It wat the only yecimens seen," In these

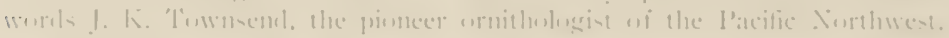

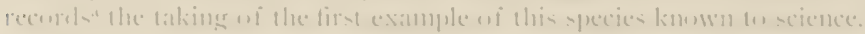

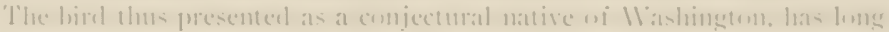

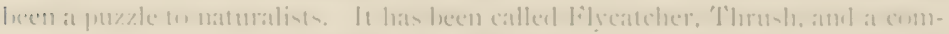

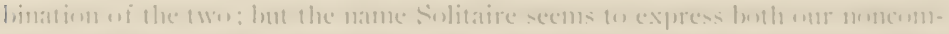

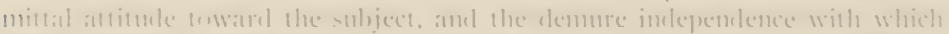

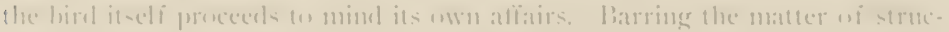

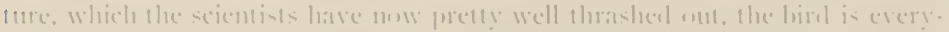

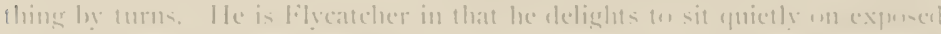

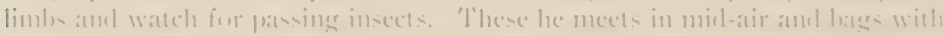

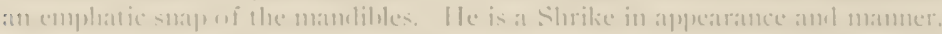

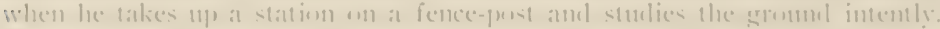

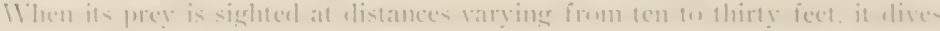

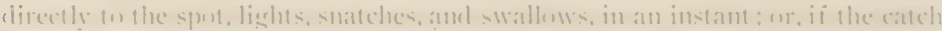

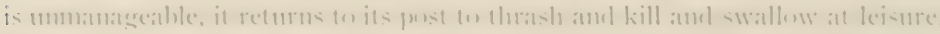

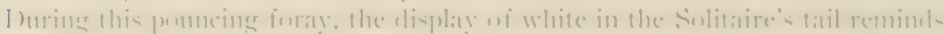

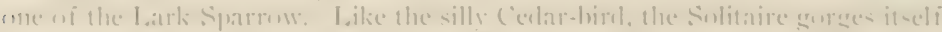

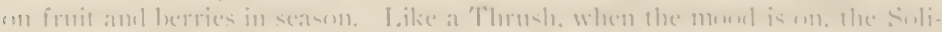

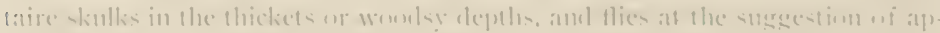

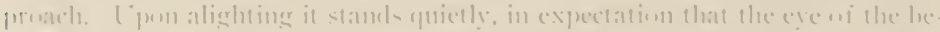

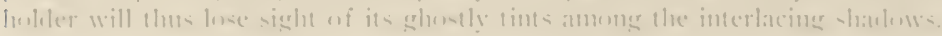

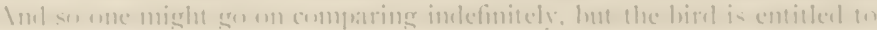

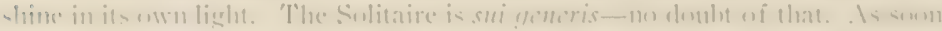

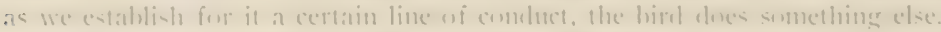

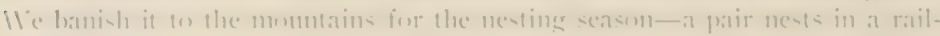

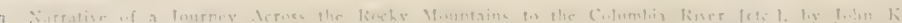
7 ....en

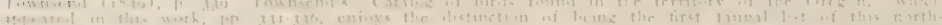

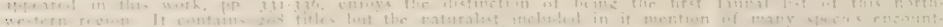

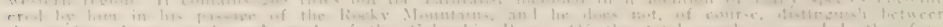

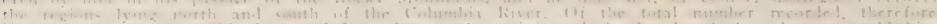

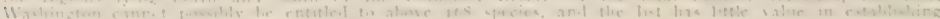

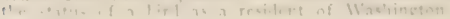


road cut near Renton, altitude 200 feet. We describe to our friends the benuts of its song-they go to its sanctuaries and the bird is silent. A hird of such dainty monkd shonld winter in the Sontli. It does,-at times. It atso winters at Sumas on our northern borler. 'This poet of the solitules, he should aroicl the liamuts of men. He does. mstally. But anotluer time lic may be seen hopping from bush to $\log$ in a suburban swamp), on moping ancler the erlege of a new sidewalk. Indeed, I nnee saw at Solitaite flutter up from muler a passenger coach, as it lay in station. He had happened to spy some bread crumbs and there was nothing to hincler save the comkluctor"s brisk "all aboarcl." Surely such at buncile of contradictions you never did see-and all belied by an expression of lamblike artlessness and doler far mionte, which would do creelit to a rag-4loll.

All observers testify to the rocal powers of the Solitaire. and some are most extravagant in the birl's pratises. My own notes are very meager. A song heard on Church .Inontain, in Whateon County, May I2. I005, is characterized ats "a dulect strain of varied notes. It reminels one strongly of the Sage Thmasher, but it is somewhat less impetunus." In view. of this meagerness, I venture to guote at length two oleler accoumts, now hidelen away in

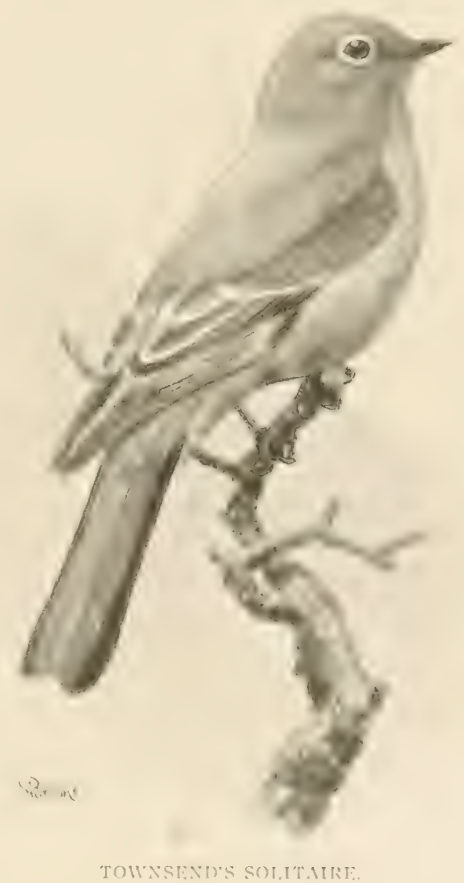
volumes not easily accessible. 1)r. J. S. Newberry first encomntered the Solitaire in the canon of the Mptolyas River, at the base of Mount Jefferson (Or.).

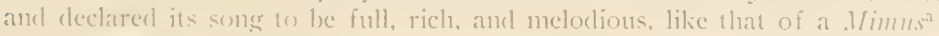




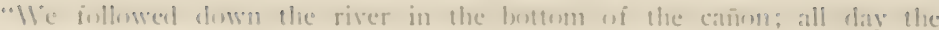
grurge was filled with a churus of sweet somme from humlreds and themsands of these hirels, which from their monotonous coler, and their hahit of sitting (n) the bramch wi at tree projecting into the void abue the stream, or hanging from some leetling crag, and flying out in narrow circles after insects precisely in the matmer of the lifycattelers I was dispresed to associate with them.

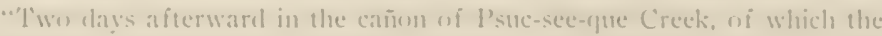
erraced hankis were sparsely set with hw trees of the western ceelar / J acti-

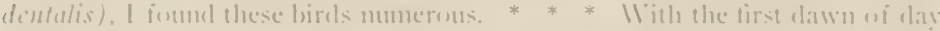
they began their songes, and at sumise the valley was perfectly veal with their motes. Never, anywliere, have I heard a more elelight ful chorus uf hirol music. Their song is mot greatly varied, lout all the nutes are particularly clear and

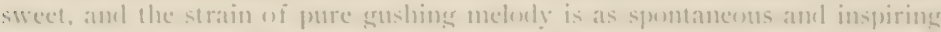
as that of the Somg Sparmos. At this time. September 30 , these birls were feeding on the berries of the eedar: they were very shy, and combl only be whtaineal by lying conceated in the vicinity ni the trees which they ireguented."

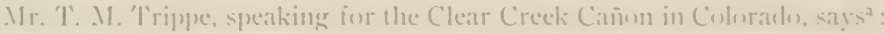
"In smmmer and fall its wice is rarely leard: but as winter comes on, and the wouls are well-nigh deserted by all save a few 'lindece and Nuthatehes, it begins to utter oceasionally a single hell-like nute that can he hearal at a great distance. The hirel is nuw very sly ; and the author of the cleatr, loud call, that I heard nearly every morning from the valley wi Clear Creek, was long a mys-

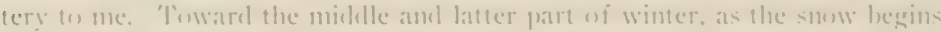
to fall. the lelyeatching Thrush delights to sing. chusesing for its rostrum a pine iree in some elevated gusitim, high up aluwe the valleys : and unt all the fielels and growes, and hills and valleys of the Fitstern Sitates, can luast a more exrquisite song : a somg in which the metes of the Purple lincls, the Mind Thrush. and the 11 inter 11 ren are blemeded inte as silvery cascale of medurly, that ripples amel dances down the menutain sides as clear and sparkling ats the mentam brom, filling the woorls and valleys with ringing music. It first it sings unly

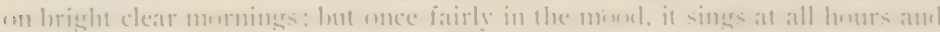
during the most inclement weather. ( ) iten while travelling oner the narrow.

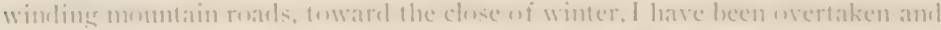

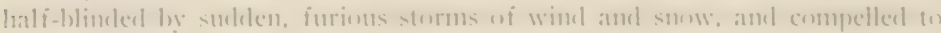
seck the nearest tree or projecting rock for shelter. In such situations I lave

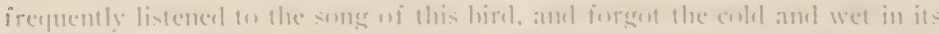

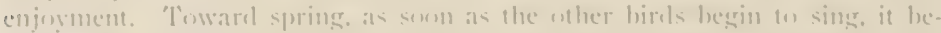

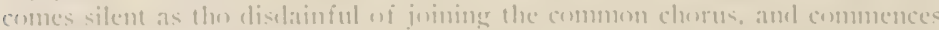

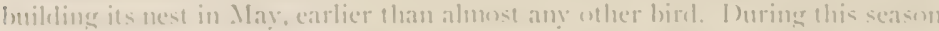
it reserts the valleys, and confines itseli to partially wouleel hill-tops."

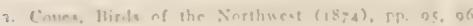


No. 92.

\section{WILLOW THRUSH.}

A. O. U. No. 556 a. Hylocichla fuscescens salicicola Ridgway.

Synonym.-Westikn WILSON 'TiIRUSH.

Description.-Idult: Above, dull tawny-brown, miform; wing-quilis shading to brownish fuscous on inner webs; below white, the throat, except in the upper micldle, and the breast, tinged with cream-butf, and spotted narrowly and sparingly with wedge-shaped marks of the color of the back; sides and flanks more or less tinged with brownish gray; sides of head buffy-tinged, with mixed brown, save on whitish lores; bill dark above, light below; feet light brown. Adult male, length $7.25-7.75$ (I8+.2-196.9) ; wing 3.93 ( 100$)$; tail 2.95 (75); bill .55 (I. 4 ); tarsus I.IS (30).

Recognition Marks.-Sparrow to Chewink size: dull cimamon brown above; breast buffy, lightly spotted.

Nesting. - N'est: of leaves, bark-strips, weed-stems and trash, lined with rootlets; placed at height of two or three feet in thickets or, rarely, on ground. Eiggs: 3-5, plain greenish blue, not unlike those of the Robin. Av. size, .90 x.65 (22.8 $\times$ I6.5). Season: first or second week in June; one brood.

General Range.- Vestern interior districts of United States and Canada: breeding from North Dakota and Manitoba west to interior of British Columbia and southward to Nevada, Utah and Colorado; sonthward during migrations thru Arizona, etc., to Lirazil, also thru the Mississippi Valley and, casually, castward.

Range in Washington. - Summer resident in the hilly districts of northwestern WVashington,-Bluc Mountains(?).

Authorities.-Howe, Auk, XliI. Jan. Igoo, P. I9 (Spokane). 'I'(?). J. Specimens.-Prov:

THE Willow 'Thrush shares with its even more retiring cousin, the Olive-back, the forests of the northwestern portion of the State. Here it may. be found in the seclusion of spring draws and alder bottoms, or in the miscellaneons cover which lines the banks of the larger streams. It is confmed almost entirely to the vicinity of water, and spends much of its time on the damp ground poking anong the fallen leaves and searching the nooks and corners of tree-roots. Since the birel is lut a flitting slade, one camnot easily determine its color-pattern, and must learn rather the range and quality of its notes. 'The bird is, rather than has, a roice, an elusive voice, a weird and wonderful roice. And only after one has heard the song, with its reverberant, sweet thunder, and its exfuisitely climinishing cadences, as it wells up at erentide from some low thicket, may one be said to know the IVillow 'Thrush.

For the most part the bircl betrays interest in vour movements by a sub)dued yca'i, a mote of complaint and admonition, varionsly likened to a grunt, a bleat, or a masal interjection. Not infreruently this becomes a clearly 


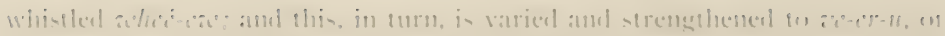

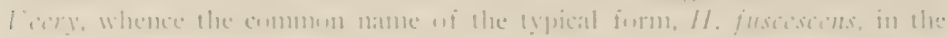

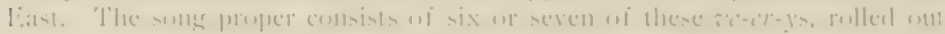

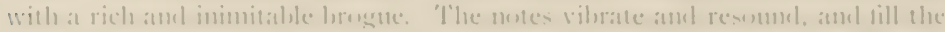
itir so full wi music that me is led to stspect the multiple elastacter wi each.

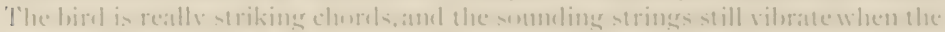

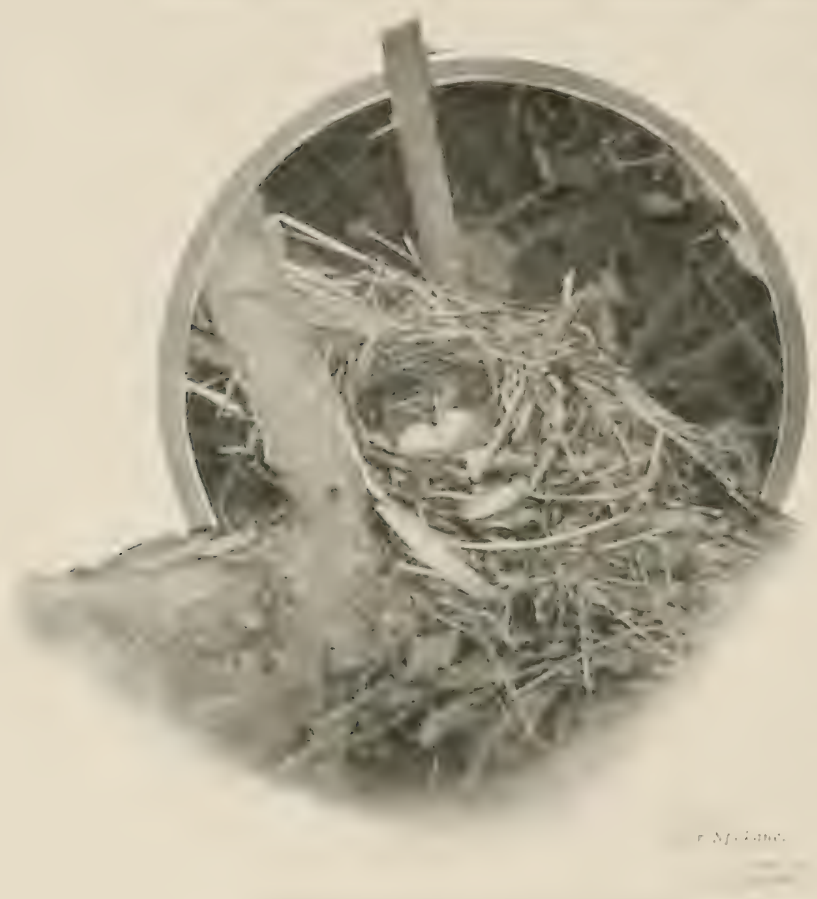

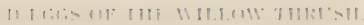
mext is struck. 'There is. merensers, in the whinle perimmance. a musical (reverenule) (inlulerl with it -tre econtive lowerials of prich, which in tatrl! ravishing in it im. presalon uf my-tert amel pumer.

The distrilution of this spectere is al yet imperfectly mate tut. Havine mate is acyuamutanee at simkatue and alems the valley wi the l'oml d'(i)reille. we were able to recong nize it later il (lue lim arul sichelin, the latter unyuestinmably the we-termment res-

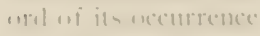
in the I niteel stalle IVhellew it maty alon extemel imrlieer womb athere the eats froms uf the Ciscoules, rematime fu le -

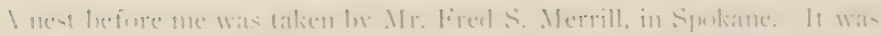

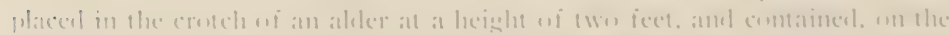

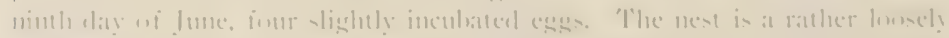

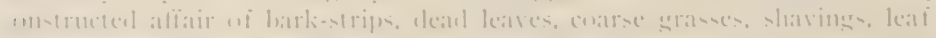

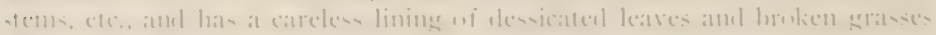

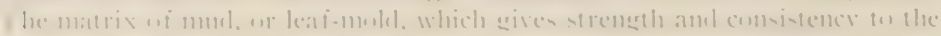


nests of certain other thrushes, is conspictnously lacking in this one. J'he brooding hollow is only three inches from brim to brim, by one and threeyturters in depth. 'I'he eggs are in every way miniature Robins', being withont spots, and representing only three-fifths or two-thircls the bulk of those of the larger birel.

No. 93.

\section{RUSSET-BACKED THRUSH.}

\section{O. L. No. 758. Hylocichla ustulata (Nutt.).}

Synonym.- "WoOI) 'T'uRt'sil" (name properly restricted to $I /$. mustclina of the East).

Description.- Idults: Above olive-lorown, substantially miform : a conspicuous orbital ring of pale lutt: sicles of head buffy mingled or streaked with oliveirown: chin, throat and chest bufl (or lightening to buffy white toward chin); sides of throat and entire chest with triangular marks of deep olive-lurown, smaller and narrower on throat, larger and broader (sector-shaped) posteriorly; breast. especially on sides, transversely spotted with light brown; sides and flanks heavily marked with brownish: remaining underparts white. Bill blackish, paling basally on manclible; feet and legs brown; iris brown. Winter specimens are brighter, more deeply tinged with buff before and with under tail-coverts buffy. Foung birds are more or less narked and streaked with buffy and tawny above and the markings of underparts are mostly transverse. Length 6.50-7.50 ( $66_{5} .1-$ I 00.5$)$ : wing $3.83(07)$; tail $2.87(7.3)$; bill .54 ( 13.7$)$; tarsts 1.10 ( 28 ).

Recognition Marks. - Sparrow size; miform olive-brown above; heavy spotting and buffy wash on clest: sides of head and eye-ring buffy; brown aloove as compared with $/ 1$. u. sachinsentii.

Nesting.-. lest: of hark-strips, moss and srasses, with a heavy inner mat on monld of dead leaves, lined with rootlets and fine grasses: placed usually at moderate heights in bushes or saplings of thickets, sometimes 30 -6o feet high in trees. Lings: 3-5. nstally + greenish blue or clull grayish blue dotted and spotted. rather sparingly, with various shades of brown. Av. size, $93 \times 37(23.6 \times 17)$. Season: June, July: one or two broods.

General Range.- Pacilic coast district from southern California to Alaska (Juneat1). breeding thruout its range; south in winter thru Mexico to Central and northern South imerica.

Range in Washington.-Common summer resilent and migrant west of the Carcarle Mountains: probably orertlows thru momam passes to at least the eastern slopes of the Ciscades.

Authorities. - Turdus ustulatus Nuttall, Man. ()rn. L. S. and Cianala, Land

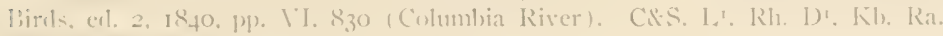
$1-\therefore i$

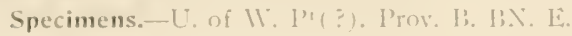




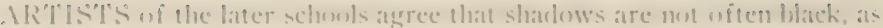

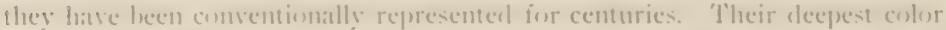
note is alwass thate of the gromel, or sereen, which bears them. The Thormsh. therefore, is the truest embetiment of woxlland slated for the shifting rusiets of its upगerparts melt and hlent with the tints of fille'n leaves, dum romts. and the sharluw: of tree-bules cast on the hrown aslees of fallen comrames. Vint content, either, with such prosective guarantere, this arentle spirit clings to coser. and reveale itseli aniv ats a tlitting sharle ancl a ha $1101 \mathrm{i} n g$ vories. Som and then a brown gleam does eross sume uxen sparce in the forrest. lunt the action is lateIV and the necessits. much regretterl.

The linseet-inatied 'l"hrash is ment much griven (n) soner, allow un aceasion the wombliste maty ringe with the simple melwly of its atite low

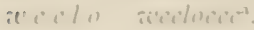
e Mher motes are more monalsle and clatrace feristic: and by the ene mas trace the

biral's every move.

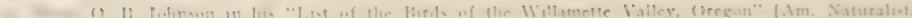

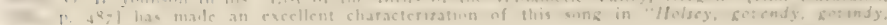


ment without recourse to sight. Quit, or havit, is a soft whistled note of inquiry and greeting, by which the birds keep in constant touch with each other, and which they are nowise disinclined to use in conversations with strangers. Hatootaylyochtyl is the name which the Quillaytute lad gives the bird, the first syllable being whistled rather than spoken, in initation of the bird's note. At the friendly call the Thrush comes sidling over toward you thru the brush, until you feel that you could put your hand on it if you would; but the bird remains invisible, and says, quit, quit, with some asperity, if you disregard the conconances.

A longer call-note, of sharper quality, quece, may be as readily initated, altho its meaning in the bush is uncertain. The bird has also a spoken note, a sort of hapy purring, which I call the coordaddy cry. In this the daddy' notes are given in from one to six syllables, and are spoken "trippingly on the tongue."

Recalling again the quce note, we are surprised to find that it is the commonest sound heard during migrations. At midnight when a solemn hush is vver all besides, this weird note comes down from the sky at any height, from every angle, a greeting on passunt from the voyagems, the tenclerest, the most pathetic, the most mysterious voice of Nature. There are a dozen variations of pitch and tone, quéé, quec, kooo, etc., but the thene is one, and the quality is that of the Russet-backed 'llurush. Now it is incredible that any. one species should so abound to the exclusion of all others, or that one alone should speak, while others flit by silently. Moreover, the intermittent utterance of a single bird proclaims the rate at which that bird is moving, and oftener argues for the passing of the smaller species. Varblers and the like. Repeaterl observation would make it appear certain that this quec note is the common possession of many, pertaps of all species of migrant song bircls, a sort of Esperanto for "Ho, Commale!" loy which the flying legions of the night are bound together in a great fellowship.

Much of the apparent difference in the call-notes of these night-birds is explained when we remember that they are reaching us from different angles. Thus, the quec of a rapidly approaching bird is raised sharply and shortened. quěc; while the same voice, in passing, falls to a ghostly kroo, at least a musical third below: It is, perhajs, needless to add that practiced lips may join this mystic chorus and hold delightful converse with these brothers of the air-may, indeed, provoke them to trebled ntterance in passing.

But only the Russet-backed 'Thrush may repeat this cabalistic note, by day. He is the bugler in that greatest of all armies and he must needs keep in practice while on furlough.

Russet-laacks are tarly migrants, seldom arriving before the first week in Nay; and they are off again for the Southland by the first week in Septemher. 'I'wo instances are on record, however, of the bircl's wintering here- 


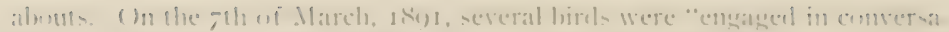

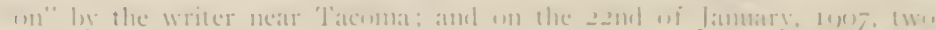

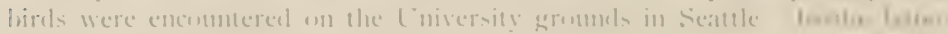

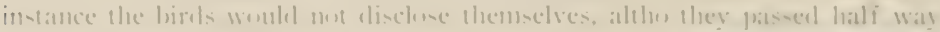
arromel me in the thicket. utterine their charas

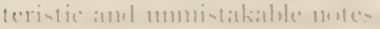

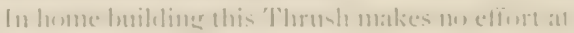

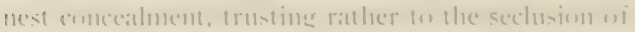
it a latums. 'The materials which enter inter the cons

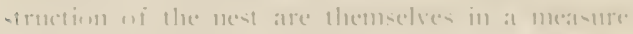
protective, cenectially in these mumerome inntaneres in which the exterion is compusent en

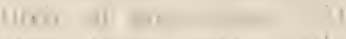

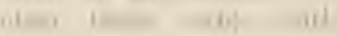
-qripe, amel granses atre used: lunt the ewo thines which ive ehamater tos the nest wi alis Throte are the mund (211), w matrix, wi muel anel leai-muld, amel the linings wi drienl leari-skeletenta. I hase empriserl a mother huseet al her latsk wi (my)-mmuleling, aund verily laer loils wats ats Mith as that wi ams child making mul pies. lior allhw The beak serves ior lond amel

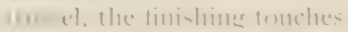

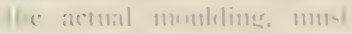

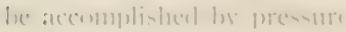
i the limal - bre:an

1)mrine a seationt

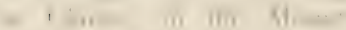 Heb, ane $45 \geqslant 1$}

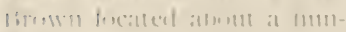
aled sele wi lle kimsed

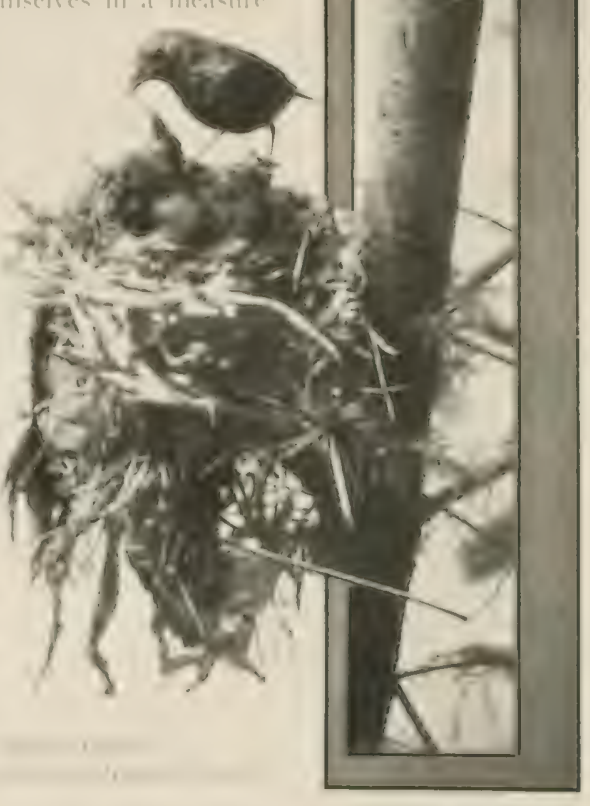

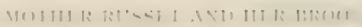

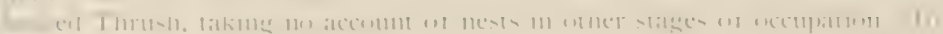

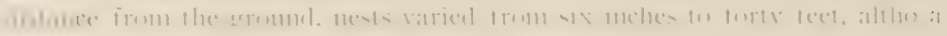

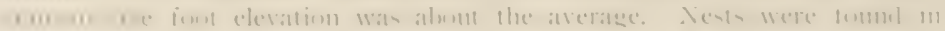

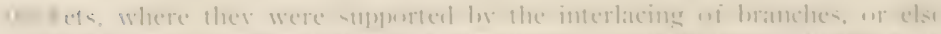

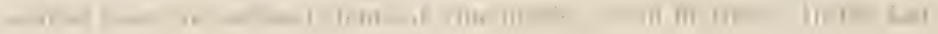


named places, nests might be set against the trumk on a horizontal limb, but were more often at some distance from it. 'The birds were very sensitive about molestation before eggs were laid, and would desert a nest in process of construction on the merest suspicion that a stranger had looked into it. After deposition, however, the mother 'l'hrush was found to be very devoted 10) her charges, and great confidence was often engendered by carefully consiclered advances.

At Glacier, nest-buikling averaged to commence abont the 25 th of May, and the first eggs were foumd on the ist of June. The last set was fomnd July 15th. All nests examined in the earlier part of the season contaned fotm eges: those found later, presumably second efforts, never had more than three.

As a curions example of the utse of the imagination on the part of early writers, take this from our venerated Cooper" : "The eggs, mulike those of most thrushes, are white, spotted thickly with brown, and font or five in number." The brown spotting is all right and an mpipmented shell is not an impossibility, but deviations from the characteristic greenish blue of the gromnd-color lave not since been reported.

No. 94 .

\section{OLIVE-BACKED THRUSH.}

1. O. L. No. 758 a. Hylocichla ustulata swainsonii (Cab.).

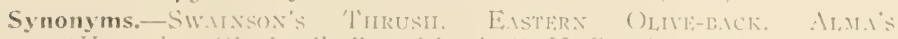
Phinesil (H. u, alme ()berh., disallowed by A. (). L. Com.).

Description.-Idults: Similar to $/ 1$. wstulato but grayer and more olivaceots: " color of upperparts varying from olive to grayish hair brown in sumuer. irom deep olive to slightly brownish olive in winter"; gromel color of tmelerparts lighter buffy (yellowish buff or creamy lufï) : sides and Hanks grayish-insteacl of brownisli-olive. Size of last.

Recognition Marks. - Is in preceding: grayer above, lighter luffy below: ustuluta.

Nesting.--. lest and Iigys indistinguishable from those of typical form. $H$.

General Range.-North America in general except l'acific const district sonth of Cross Sound and Lym Canal; breeling from the monntainous districts of the United States (especially northerly) north to linit of trees: south in winter thruout . Wexico and Central America to l'erw. Bolivia, ete.

Range in Washington.-Imperfectly made ont as regarcls that of $I /$. ustulater. liomed breeding in the valley of the Stehelin hence presumably smmmer resident in timbered elistricts of eastern II as shington.

Authorities.-Bowles and Dawson, Auk, Inl. AXY. ()et. Ig)o\$, p. 48.3.

Specimens.-l'rov. 1'.

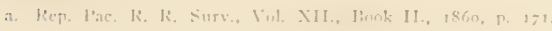




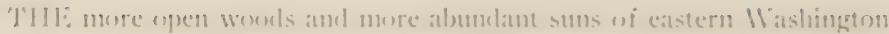

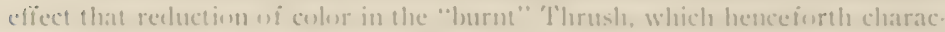
terizes the species clear thru to the Allantic. It weshld be idle to trace in detail all acompanying clamges uf manner and habit, lout we can latrolly fail to mote

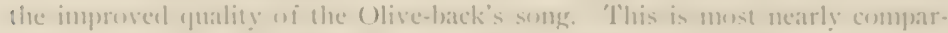

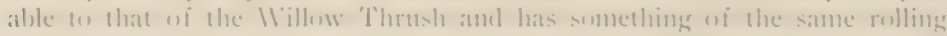

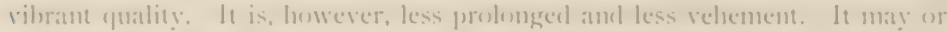
may not retain the liepuid l's, hut it discarels asutright the rich r's, which the leery rolls maler his enngue like sweet morsels; and the piteh of the whole rises slightly, pertiaps a mosical throl, as the volume of somel diminishe:

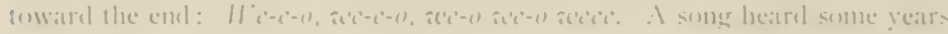

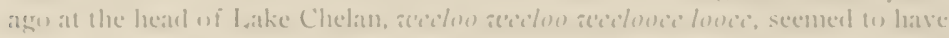

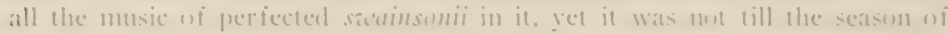
mos that . Mr. Lawles established the fact of the ()live-back s presence and the

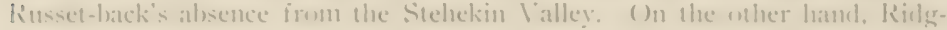
way finds that fouth forms sometimes encur together. even during the breedin: seasons: so we are nut yet prepated in malie generalizations ats to the relative distribution of these lials in 11 ashington.

No. 95.

\section{ALASKA HERMIT THRLSH.}

1. (). ( . N(1, 75 (). Hylocichla guttata (l'allas).

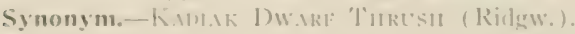

Description.- Idult: Liperparts phain srayich brown (hair hrown en near

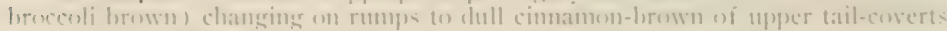
and tail: a prominemt whitish orlital ring: sides of head mingled gratyish brown

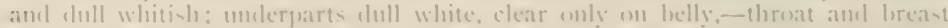
tinged with pale creany luffï; siles and tlanks washed with pale grayish brown:

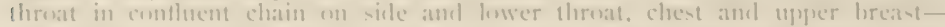

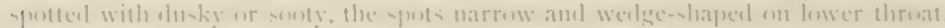
breadening and deequening on clest. fading and beeoming roumderl on breast.

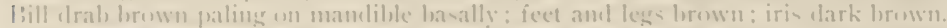
Il inter specinens are brighter and more strongly colored throut. Joung hirds are -treaked with hufiy aluse and the spetting of mulerparts inclines on hars on

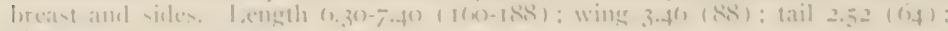

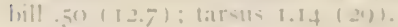

Recognition Marks.-Sparrow ize; cimamon of tail land mpper-eoverts comprasing more or lem with duller lormwn of remaining upperparts.

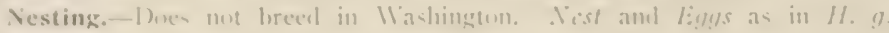
simunimsis:

(ieneral Range.-Cinst district of . Maska loreeling northward and westward 
from Cross Sound; sonthward in winter as far as Texas and western Mexico. migrating cliefly coastwisc.

Range in Washington.-Spring and fall migrant west of the Cascades.

Migrations, - Spring: 'Tacoma, April I 5, 1905 (J. H. Ilowles). Iall: Seattie Sept. 21, 1907 (Jennie V. Getty).

Authorities.-Bowles and Dawson, Auk, XXV. Oct. I908, P. 48.3.

Specimens.-P(Nlaskan). Prov, B.

ABOU'T' all we can certify to, so far, is that there are two varieties of the Hermit 'Thrush which may be seen on Puget Sound during the migrations: a lighter and grayer form, presmmably from northwestern. Alaska ; and a darker, more warmly-tinted bird, H. g. nana, which may or may not summer to some extent in western Washington. Specimens so far encountered in eastern Washington are probably $/ 1$. g. scquoicnsis, en route to or from their breeding hamts in the high Cascades: while if any are ever captured in the mountains of Sterens County, they will probably prove to be of the $H$. g. anuluboni type, which prevails in the eastern portion of British Columbia.

No. 96.

\section{SIERRA HERMIT THRUSH.}

A. O. U. No. 759 part. Hylocichla guttata sequoiensis (Belding).

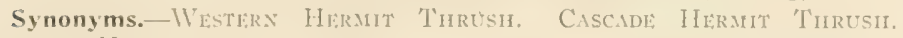
IoUNTAIN HYRMTT.

Description.- Similar in coloration to $H$. guttata but larger, paler and grayer. Adult male: wing 3.65 (92.8) ; tail 2.83 ( 71.8$)$; bill .53 (13.5); tarsus 1.12 (28.4).

Recognition Marks. - Is in 11 . guttata.

Nesting.-Iest: of bark-strips, grasses, leaves and moss, lined with fine rootlets, placed on gromnd in thickets or at moderate heights in fir trees. Liggs: 3 or 4, greenish blue mmarked-not certainly distinguishable from those of the ivillow 'Ihurush. Av. size, $85 \times .65$ (21.6x 16.5). Scason: Jume, July: one broosl.

General Range.-Monntains of the Cascade-Sicrra system and from Mt. Whitncy north thru central British Columbia, etc., to the Yukon River; south in winter to Lower California. Sonora, etc.

Range in Washington.-Common summer resident in the Cascade Mountains-further distinetion undetermined.

Authorities,-Dawson, Auk, Vol, XXV. Oct. Ig08, P. 483.

Specimens.--D. 


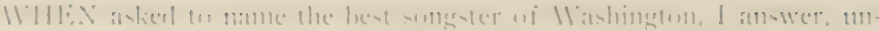

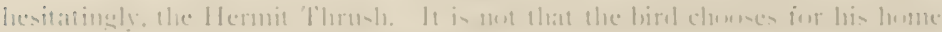

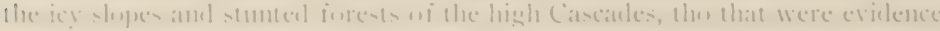

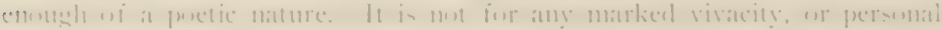

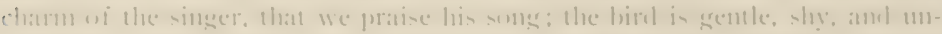

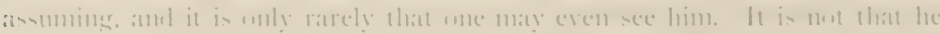

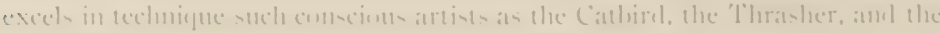
Morkinglirit: 1 he mere complativnt is

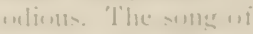

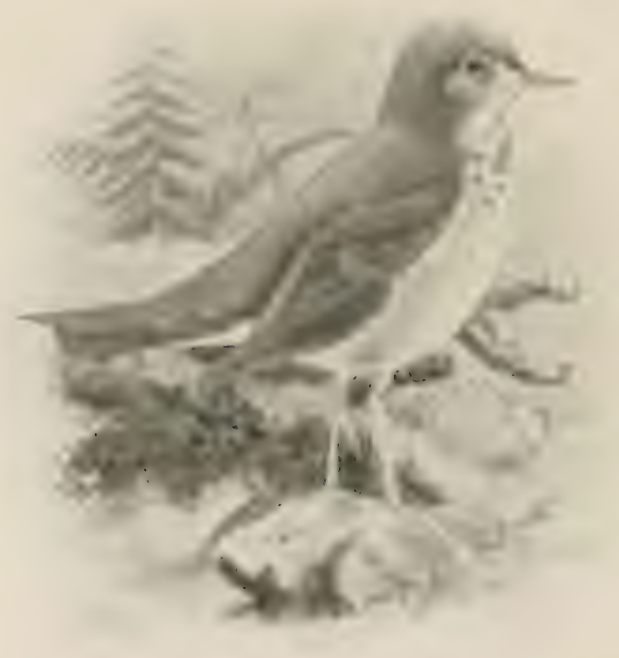

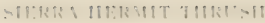

the Hemit Thmo-h is a thines aptamt. It in -atreal mun-ie. mat -coulat. 11 : a 1 i 11 " mothinger wi line dian

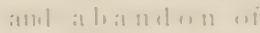

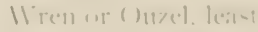
wi all the sputive moker o wi the lank-tasiled Clate it is the pure entering uf a shrien stul. bubling aceeprable etmoerse with light heavens. Din vinge wi solemun-pealines $\quad$ msim ir catluetral chonir al veyers exer hymme the partine daty more littingh than this apprintert churister wi the e.termal lills. Mommerl ant the ehancel ai

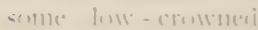

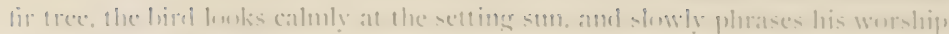

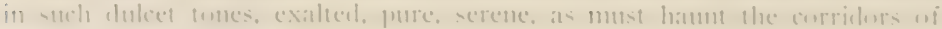
mement forever atter.

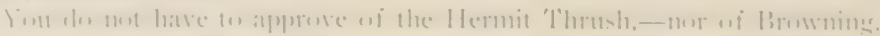

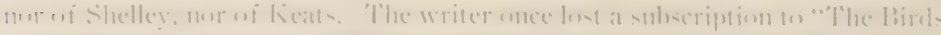

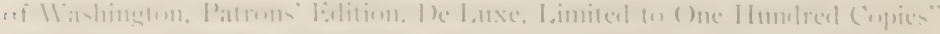

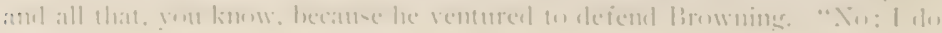



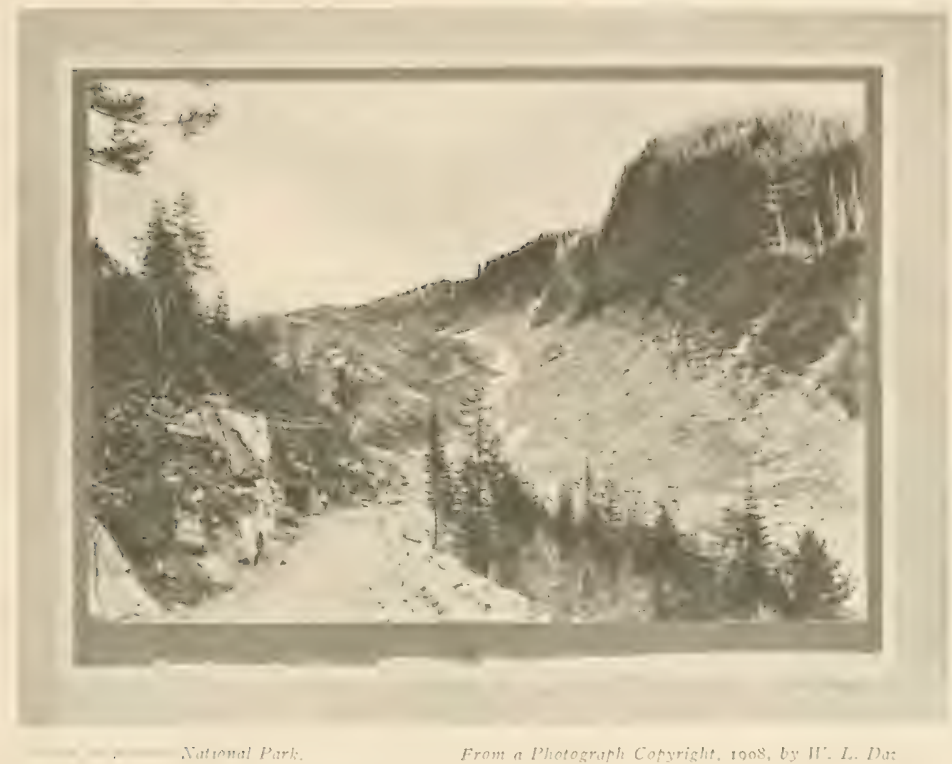

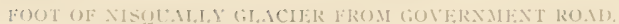

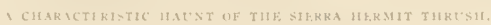

not want your litel-bonk." (Quite right, Maklame, it woukl have been a waste of mones-for you. But I hase heard the Hermit Thrush.

*-Ah, dicl you once see Shelley, plain.

And clicl he stop and speak to you.

And did you speak to him again?

Iow strange it seems, and new!

"But you were living before that.

And also you are living after;

And the memory I started at-

Iy starting moves your latugher!

"I crosserl a mone witl a nasme of its ompl.

Ancl a certain use in the world. no toubt.

Yet a handl's brearlth of it shines alone

'Mid the blank miles arouncl abust: 
"liur there I picked up on the heather, Ancl ihere I put inside my breas?.

A moulted feather, an eagle ieat!er!

llell, I fureset the rest."

No. 97.

\section{DIVARF HERMIIT THRUSH.}

A. (). (‥ No, 750) (Hylocichla guttata nana (Aucl.).

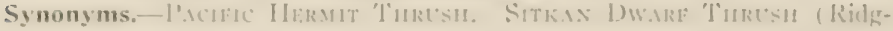
wa? $)$

Description.-."Similar (o) H. y. (Iuthafu lut coloration darker and browner. the color of back, ete. more sepia brown. upper tail-eoverts more russet, tail more chestnut, and y pots on chest larger and elarker" (Ridgway'. Adult male:

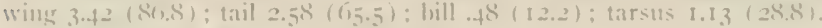

Recognition Marks. As in H. unlfatu.

Nesting. - Is in /I. (\%. sequnichsis.

General Range.-l'acilic coast district, breeding from western (.)regon (preummably) north to Cross Somnd, Alaska; south in winter to Sinuthwestern States.

Range in Washington.-l'robably common lut litele knoww, during migrations. l'resmalsly resilent in sumuner west of the Ciscales.

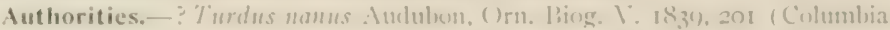
R.) ?'I'ownsend, Inurn. Ac. Nat. Sci. I'hila. VIIJ. I\&37, 153 (Col. R.) Befding.

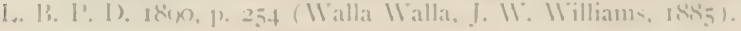

Specimens.- [*, of IV. I'row. I:

AS one gatses thru the wourls in mieldle April while the vine maples are still leafless, and the forest flow is not yet fully recosered from the browmess

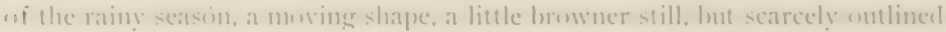

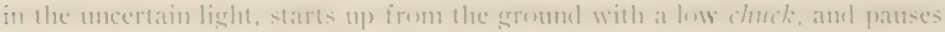
for a moment on a messy lose. liefore you have mate ont definite characters. the birel thits an a banch a litele higher up and mere remoweel, to stant montionless for a minute or so, or else fo chuckle softly with each twinkle of the reaty

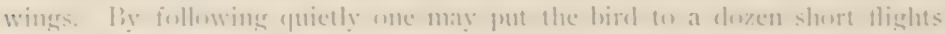
withut once drivines it ent of range: and in so dome he may learn that the tail is abruptly rufous in contrast with the olive-lorown of the back, and that the lueast is more lublly and distinctly spotted than is the case with the Remsicel-hacked 'Thrush.

'This hirel will mot tarry with us, unless it may cheose th haunt the solimales of the ()lympics. In the vicinity of Sitka, however. Mr. J. (irinnell re- 
ports the species as "very common everywhere, especially on the small wooded ; i lit11,k.

When clisturbed in its nesting haunts the Hermit 'Thush has a nasal scolding cry, not unlike that of the Oregon Towhee. This note lacks the cmphasis of 'l'owhee's, tho its clual claracter is still apparent-Wurry or Murre. But one forgets all trivial things as he listens to the angelic requiem of the Hermit at eventicle. Not Orphens in all his glory conld match that,for he was a pagan.

No. 98.

\section{AMERICAN ROBIN.}

A. O. U. No. .76r. Planesticus migratorius (Linn.).

Synonym.--EASTERX RORIX.

Description.- Adult male: Head black, interrupted by white of chin and white with black stripes of throat: eyclids and a supraloral spot white: tail blackish with white terminal spots on inner webs of onter pair of rectrices; wings dusky except on external edges; remaining upperparts grayish slate; helow,breast, sides, upper belly and lining of wings cinnanon-rufous; lower belly and crissmm white, tonched irregularly with slate; bill yellow with blackish tip; feet

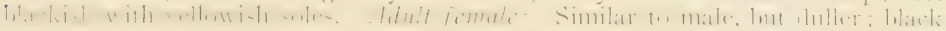
of hearl veiled by brownish. Adults in ainter: Upperparts tinged with brown, the rufous feathers, especially on belly, with white skirtings. Immature: Sinilar to adult, but head about the color of hack; rufous of underparts paler or more ochracens. T'ry young birds are black spotted, above and below. I.ength abont 10.00 (254) ; wing 5.08 ( I 29) ; tail $3.75(95.3)$; bill . 78 (I0.8).

Recognition Marks.- "Roluin" size; cimnamon-rufous breast: the "corners" of the tail conspicunously white-tipped, as distinguished from $P$. m. propinquzs.

Nesting.-Does not breed in Wrashington. Nest and eggs as in next (sul)) species, save that eges + or 5 . sometimes 6.

General Range,- Eastern and northern North America westward nearly to the Rocky Xomtains and northwestward to valley of Kowak River in Alaska; breeds from the southern Alleghenies, Pennsylvania, Ohio, Iowa, ete, northward; winters in Gulf States; south irregularly across the Western States during migration.

Range in Washington.-An carly spring (and late fall?) migrant, both sides of the Cascacles. Winters sparingly on Puget Sound.

Authorities.-Thrdus migratorius Brewster, B. N. O. C. VII., Oct. ISS2. P. 227. B. E.

Specimens.-13. E.

a. Auk, Vol. XV., April, 1898, p. $\times 30$. 


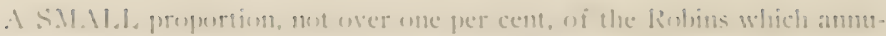

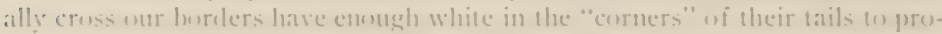
clain them true "Americans." 'The difference is striking and mmonistakable, and we feel sure that we hase here, not a chance sariation, but an alien element, at slender strean of migration diverted from the ateustomed channels

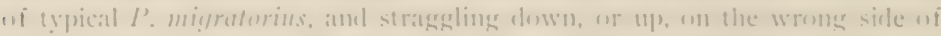
the kockies. When it is remembered that the American lowhin winters in fioriela ame the bulf States, and that its sprime migrations take it ats far west as the Kemak kiver, in . Maskat, that is, due northwest from . Mantat, it is less

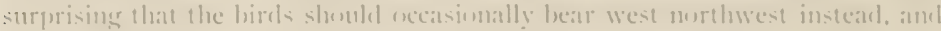

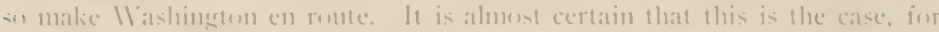

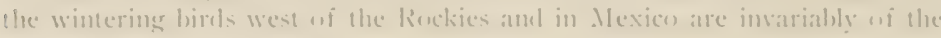
western type, propintums.

No. (9).

\section{IVESTERN ROBIN.}

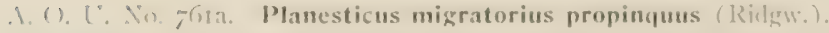

Description,--Similar 10 I'. mintotorius, hut white on inner wels of onter rectrices much reduced or wanting: gray of upperparts paler and sunte olivacenns, more sharply comtrasting with hlack of heasl: cimmamon-rufoum uf umelerparte averaging paler: wing, tail, and tarsus slightly lenger. 1,ength of males

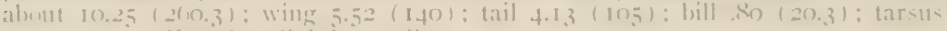
1.3+ (34.1). Females slightly smaller.

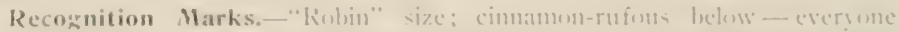

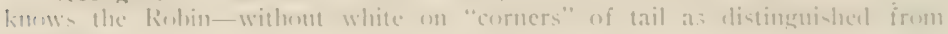
precerling.

Vesting.- Vist: a thick-walled hut shapely lowel of mul trarcly icted

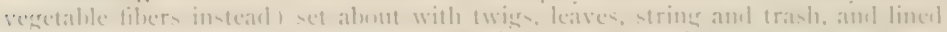
with line grass-stems: placesl anywhere in trees or vatrimsly, hut w-bally at

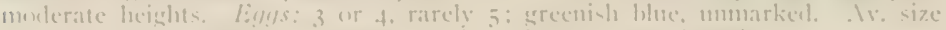

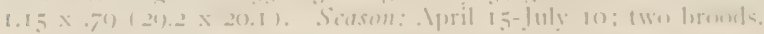

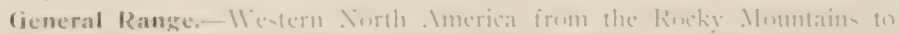

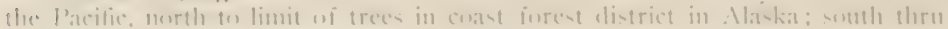

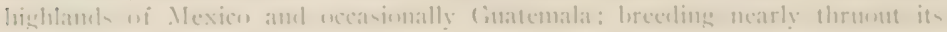
ramse.

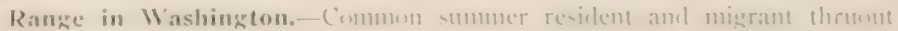

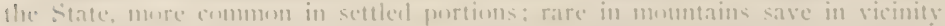

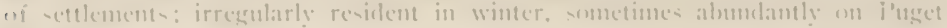
Srominl.

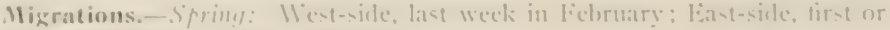

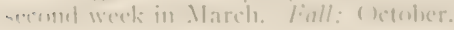


Authorities.-[Lewis and Clark, Hist. Ex. I8I4 Ed, Biddle: Cones, Tol. II. p. I85.] Turdus (planesticus) mignatorius, Limn, Baird, Rep. 1'ac. R. R. Surv.

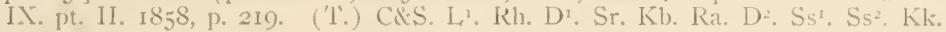
I. I. 1 .

Specimens.-U. of IV. I' . Prov, BN. B. E.

THERE are, it may be, a thousand fruits, sweet, acicl or spicy, which delight the palate of man, yet if we were forced to choose among them, not many of us would fail to reserve the apple. In like mamer, we could perhaps least afford to spare our tried and trusted, old, familiar friend, the Robin. $\mathrm{He}$ is a staple.

Everybody knows Robin. He is part and parcel of springtime, chief herakl, chief poet, and lord high reveller of that joyful season. It is a merry day when the first flock of Robins turns itself lonse on the home lanclscape. There is great bustle and stir of activity: Some scurry about to note the changes wrought by winter, some wrestle with the early and unsophisticated worm, while others voice their gladness from the fencepost, the gable, the tree-top, anywhere. Everywhere are heard interjections of delight, squeechings and pipings of ardent souls, and no end of congratulations over the lome-coming.

Robin las cast in his lot with nurs, for better or for worse. Our lawns are his lawns, nur sharle-trees were set on purpose to loold his homely mud-cup, and he has undertaken with liearty good will the musical instruction of our children.

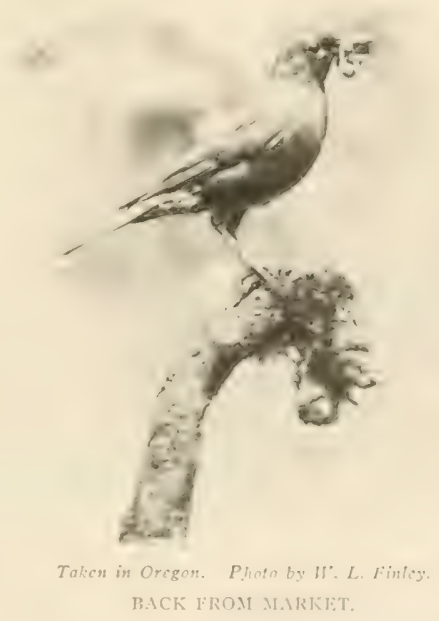
He serves without pay-Oh, a cherry now and then, but what of that? 'The fruit-grower never had a more useful hirerl man: and it is written: "Thou shalt not muzzle the ox that treadeth out the corm." I wonder if we realize luw much of life's good cheer and fond enspiriting we owe to this familiar birel.

Near the close of a burning day in the desert. we drew near to a litte ranch where a bravery of green, smpported by a windmill and a tiny trickle of water, defied the engulfing waste of sand and sage. It seened to me that I 


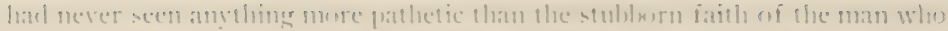

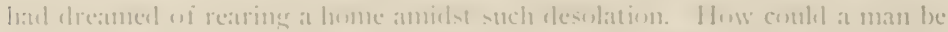

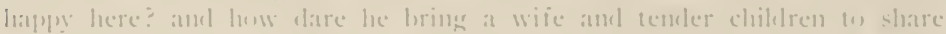

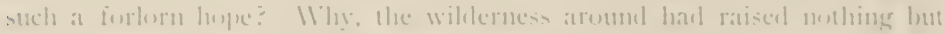

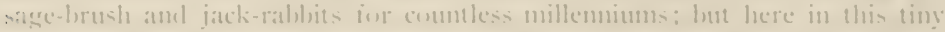

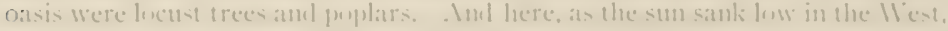

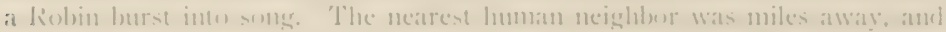

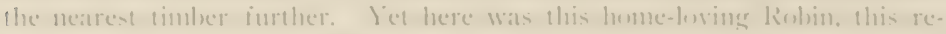

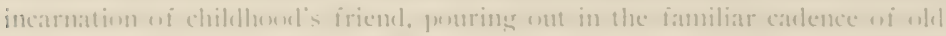

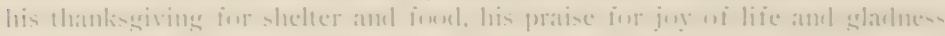

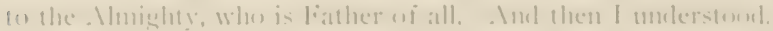

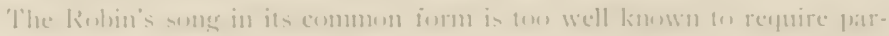

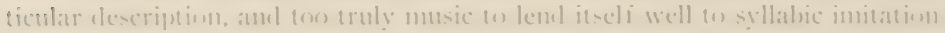

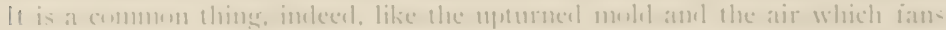

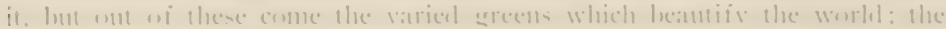
lumely pipines oi the kishin has given hirth 10 man 11 y

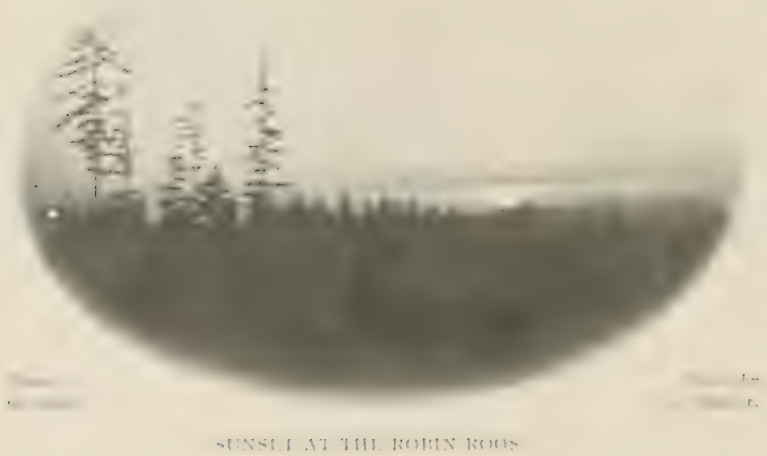

hearenterlirected aspimatim, amel pureed mam : soul of enilu intent. Ruhin conceives mans pat-sages which are tom high for lime. : anel theses he lomme in andills: w inl. Inw: in silent elinught, like : fersor with a (a)lsl. Whe+1 the

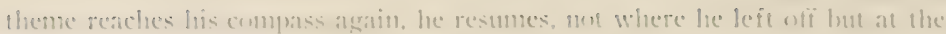

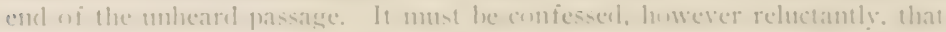
the song of the Western kehom is a litsle more sublued in character than that

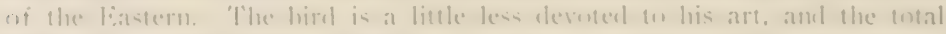

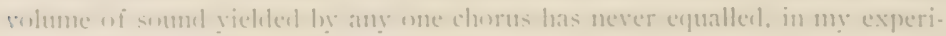
ence. that of a similat eform in the liast

IVlen the liobin is much given to hali-whispered motes and strains unnsmally temler, me mas suspect the near presence of his liancie. If you are 
willing to waive the propricties for a few noments you will hear low murmurs of affection and soft blandishments, which it would tax the art of a Crockett to reproduce. And again, nothing can exceed the sadness of a Robin's lament over a lost mate. Nll the virtues of the deceased are set forth in a coronach of smpassing woe, and the widower declares himself forever comfortless. It is not well, of course, to inquire too particularly as to the cluration of this bereaved state-we are all human.

In spite of his fondness for human society, there are two periods of retirement in Robin's year. 'The first occurs in Marcl and early April, and may be denominated the season of cotrtship. After the first arelent greeting of the home folks, Robins gather in loose companies and keep to the seclusion of the woods, following the sun from east to south and west, ransacking the roots of trees and the edges of standing water for food, and, above all, sketching in the matrimonial plans of the season. Wthen Robins lave become common about the streets and yards of village and town, partners lave ustrally: been selected, but there still remain for many of the cocks hard-contested battles before peaceful possession is assured. These are not slam fights cither: a Robin will fight a hated rival, beak and claw, till he is either thoroly winded or killed outright.

In late July and August Robins again forsake their familiar haunts, and spend the moulfing season in the woods, moving about like ghosts in great straggling, silent companies. When the moult is completed, as attumn admances, they return in merry bevies to clain their share of the ripening fruits-no longer begruklged now, for they prefer such harmless viands as momtain-ash berries, and the insipid clusters of the madrone tree.

Robins occasionally winter on the east side of the monntains: and they are hard put to it unless they find a sufficient supply of ungathered fruit, preferably apples, left ont to freeze or rot as the season dictates. West of the momtains they winter irregularly but quite extensively. There is nothing in the climate to forbid their staying all the time lont I am inclined to think that their abundance in winter depends upon the berry crop, and especially that of the Matrona (Arbutus mensiesii). 'The fall of Inot was mutalsle in this regatel. The trees were in splendid bearing, and a certain patch on the bluff south of latunteroy Park was a gorgents blaze of red, to which Rohins resorted in humelrerls.

Linder sncl circumstances the bircls establish winter rousts in convenient thickets, and repair to them at niglitfall in great mumbers. (One stuch ronst has been maintaned on the outskirts of Seattle, just east of Ravenna Park. and in the winter of $1907-08$ I estimated its poptulation at some four thousand. 'l'he winter, it will be remenbered, was a milsl one, and every one in Seattle rematied the alumklance of Robins.

In nesting, the Robin rlisplans little caution, its homely mul-walled (unp) 


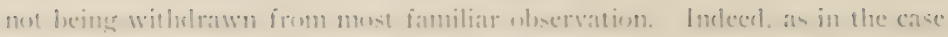

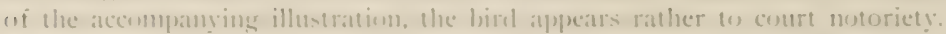

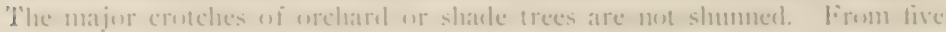
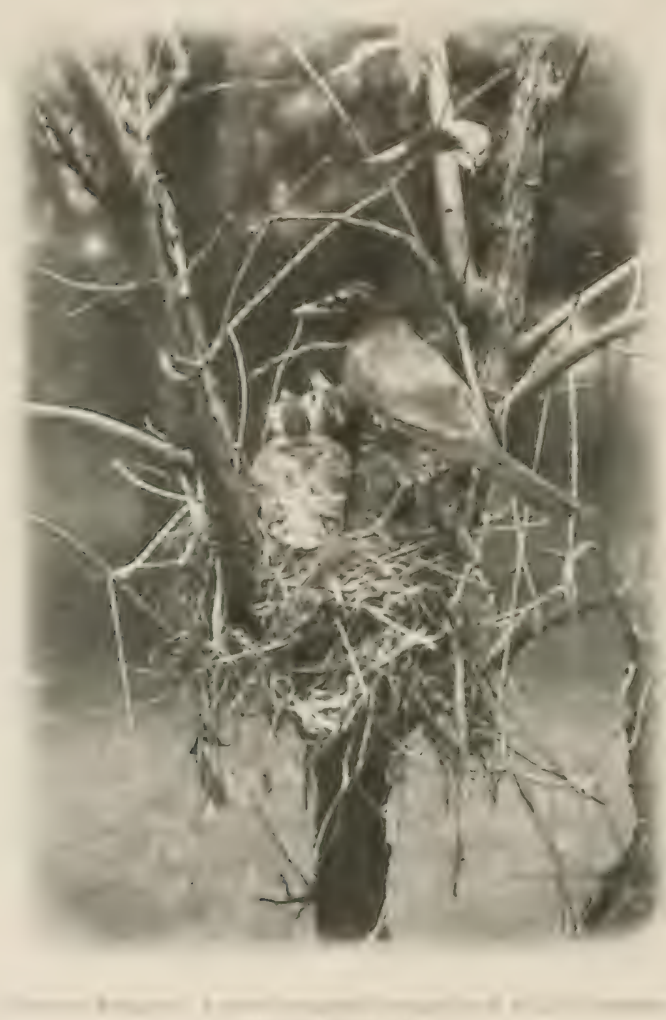

in $\min (\mathrm{in}$

(1) tifteen ieet is the usual elevation, but nests are sometimes iumil at fifty feet: and again, tho rare. I1: on the erommi II imluw silli and beams of purcles. larms. anul onthuilat iness are iatorite places, and, in de iatult of these, lormsle. piles or logr-heapl: will do.

The matr $\mid 1-(x)$ in comstructions is. of comrse, carried in the leak. Arriverl at the nest with a heakiusl uf mul. $1 / x$ muther biral strops her Joanl. of plasters it lomsely on the in sirle of the cup 'llhen slue hops inte the nest. settles ats lum ats ponsilale, and beerins (n) kick or trample vicurousls with leer ieet. From tirne to time she leys the smom thloles or romulaness of the job by senting on it with laer hreast. Inu

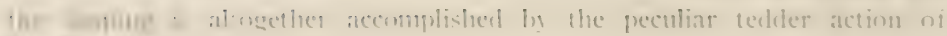
$\therefore$. $\quad \cdots$

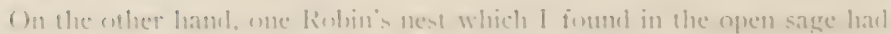

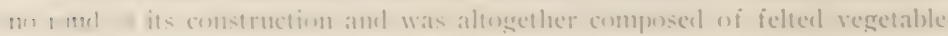


materials. Another freak nest, in Spokane, showed a hatchet handle firmly imbedded in its foundation and projecting from it a distance of six inches. The presence of the landle was not adventitions, for the nest was saddled on a pine branch, but it is difficult to conceive how the bircls could have placed it in position at a height of fifteen fect.

Three eggs is the rule for the Western Robin; four is not unusual: but five is rare, and I have never seen six. In this respect, therefore, the IVestern Rolin falls a little behind her eastern consin.

Young Robins are darling creatures; that is conceded by everyone,-even by the cat. And linnsry! Oli, so humgry! It is estimated that if the appetite of a man were jroportioned to that of a young Robin, le woukl consume daily the equivalent of a satusage four inclies in rl i a m e t e r and twelve feet long!

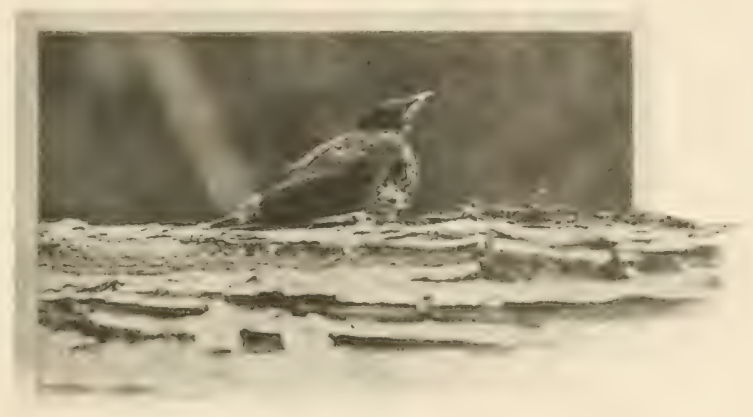

A ROBIN BABY

In spite of the law-makers, who knew exactly what they were doing in declaring the Robin worthy of protection, thonsands of these hirds are annually slaughtered by unthinking people because of a munored fondness for cherrics and other small frtits. And yet we are assured by competent atuthorities that cultivated fruit forms only four per cent of the Robin's food thruont the year, while injurious insects constitute more than one-thirel. Robins in the cherry trees are provoking, especially when they bring the whole family and camp out; but there is one way to limit their depredations without clestroying. these most distinguished helpers; plant a row of mulberry trees, preferably the Russian Mulberry, along the orchard fence, and the birds will seek no further. I have seen a mulberry tree swaming with Robins. while neigluboring fruit trees were alnost untouched. The plan is simple, humane, and efficacious. 
No. 100.

\section{VARIEI) THRUSH.}

1. (). L. No. -013. Ixoreus navius (Cimelin).

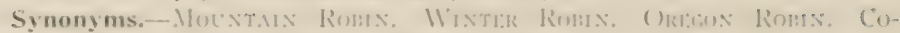

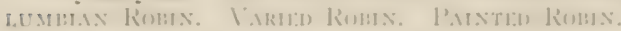

Description.-Idwh male: Above dark slate-color (plumbens slate on blackish slate), sometimes, especially in winter, tinged with olivaceous; wings dusky colged more or less with slaty, the llight-feathers varied by ochraceons-

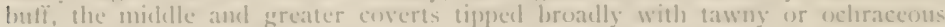
forming two conspictuous hars; tail blackish, the ontermust or several lateral rectrices tipped with white on inner web; a conspicmous lateral lead-stripe uriginating aldove eye and passing backward to nape veliraceuns or exhraceonsbulf: area on sife of head, inclucling lores, suborbital space and auriculars, black or slaty-lilack connected narrowly on siele of neck with a conspicunss pectoral collar of the same shate; chin, thront and remainine molerparts tawny for oeluracenus-tawny to oderacenus-lufft), paling on sides and danks where feathers broally margined with slaty-gray, changing to white on aledomen: under tailcoverts mingled white, slaty and ochraceous: axillars amb under wing-eoverts white hasally lowatly tipped with slaty-zray and under sturface of tlighto-feathers crosicel hasally by hand of white or buffish. Bill brownish black paling basally

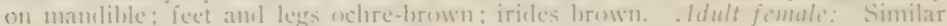
to adult male but paler and duller: upperparts olive-slaty to olive brownish: tawny of underjarts much paler and pectoral collar narrower, of the shate of back or a litgle darker: more extensively white on abromen: Joumy lideds: J.ike adult jemale lot more vellowish ofliraceous leelow: pectoral hand indistinct compresed of ochraceous feathers laving darker exlges; other feathers of throat

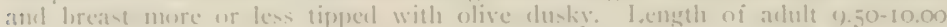

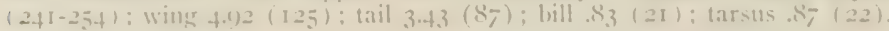

Recognition Marks.-Rohin size: blackish collar distinctive; wings conspicumsly varjed loy tawny markings: head pattern distmetive-etherwiec very Robin-like in bearimg and ileportment.

Vesting.- list: of sticks, whirs, statsies and roten womel smothered in moses, at bulky, hanclsome structure placed in saplinse or trees at molerate lecighes withont attempt at concealment. Lims: usually 3. rarcly \& greenish blue spar-

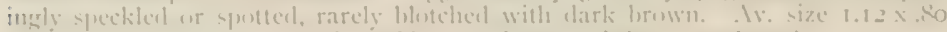

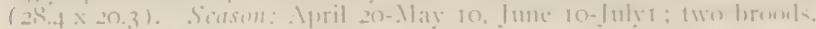

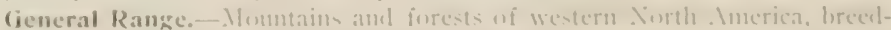

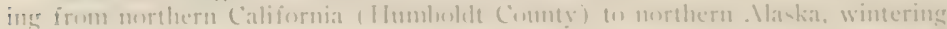

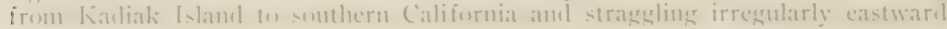
iluring migrations.

Range in Washington.- Revident in eoniferoms forests thrment the sitate from seat-lesel on limit if trees: retires to valleys and lowlands in winter: lese

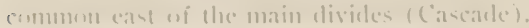

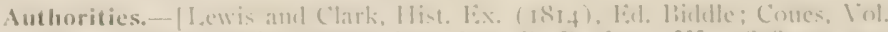

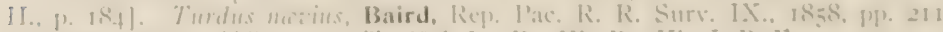

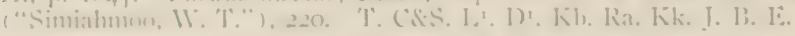

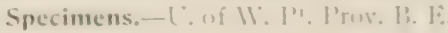


$\mathrm{NO}$; it does not always rain in western Washington. So far is this from being the case, that we will match our liebruaries against all comers, and especially invite the attention of "native sons" of California. Our summers, 100, are just a little dry latterly, and we begin to wonder with a vague uneasiness whether we are to be condemned to mediocrity after all. 'T'his paves the way for a declaration that the true web-footer, nevertheless, loves the rain, and will exchange a garish sky for a gentle drizzle any clay in the year. The Varied 'Ihrush is a true Web-footer. He loves rain as a fish loves water. It is his native element and vital air. He endures dry weather, incleed, as all of us should, with calm stoicismu. Lehrne au leiden olne zu Klagen, as poor Emperor Frederick II, the beloved "Unser Fritz." used to say. But the Varied 'Thrusl is not the poet of sturshine. Dust motes have no clarm for his eyes, and he will not misuse his vocal powers in praise of the crackling leaf. lingo, he sits silent in the thickets while avian poet-asters slirill the notes of common day. But let the sum once veil his splendors, let the clouds shed their gentle tears of self-pity, let the benison of the rain-drops filter thru the forest. and let the leafage begin to utter that myriad soft sigh which is clearer than silence. and our poet 'Thrush wakes 11 \%. He mounts the cliancel of some fir tree and utters at intervals a single long-clrawn note of brooding melancholy and exalted beanty,

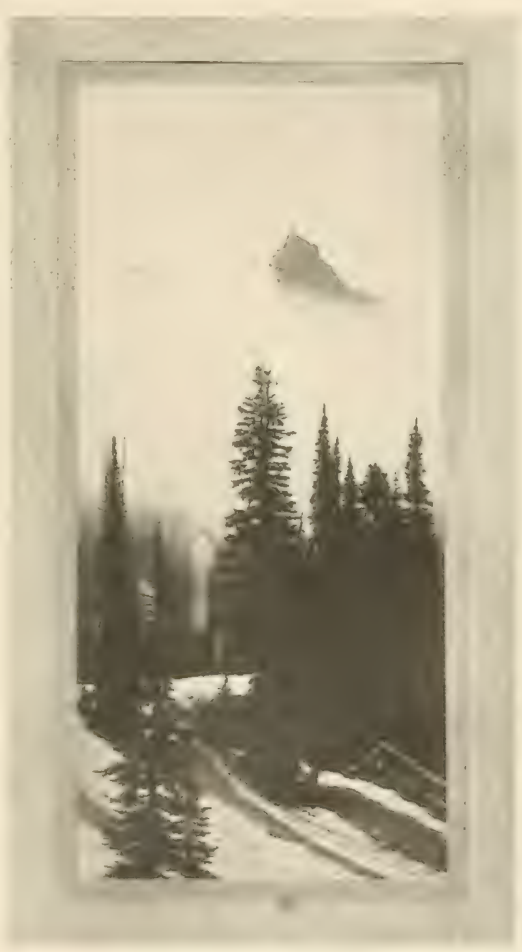

Taken in Rativir National Pay

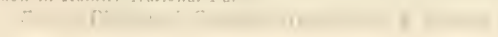

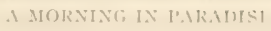
a voice stranger than the sound of any instrument, a waif echo stranding on the shores of time. 
There is no somed of the western womels more subtle, more mesterions, mure

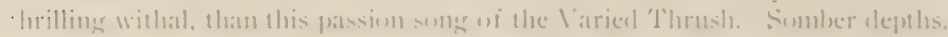
dripping foliage, and the elistatut grurgling of dark brown waters are its fitting

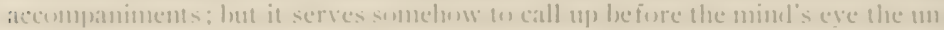
waled heights and the untrieal deeps of experience. It is sugerestive, chusive, and

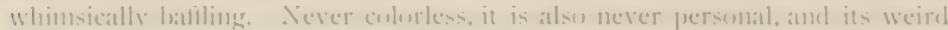

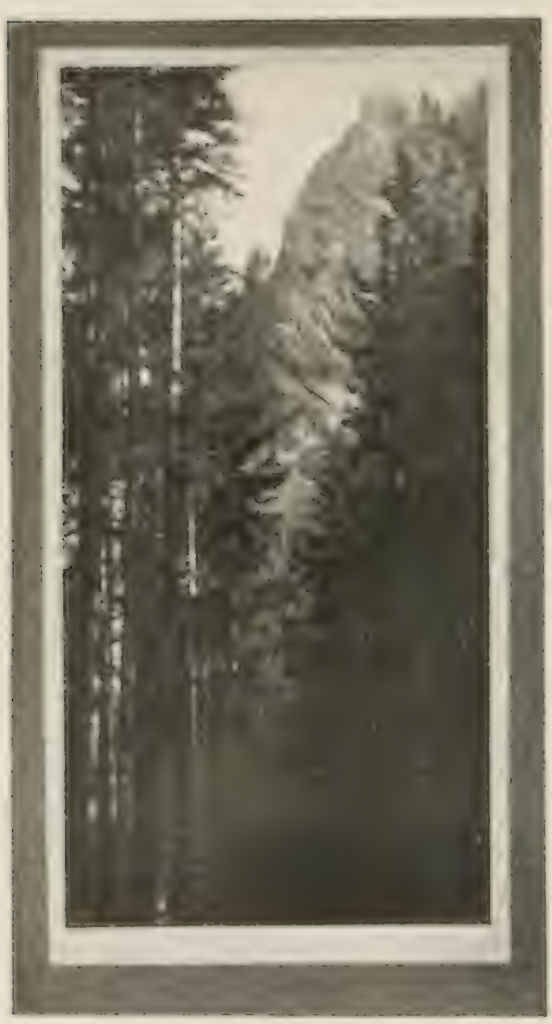

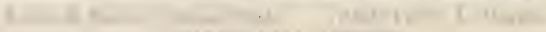
extra-mundane (matios reminds une of antirue clina redk, ur recalle the sululued luridnew wi certain ancient fresomes. Mfrat mere this hirel can thing his verice at vents alsell frem the

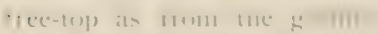
"um rielnt. now leit. the while he sitsmenticnless upen a bram la met fifteen feet aluse we

fontastic and varteel an 1 lhis single mole whell on the

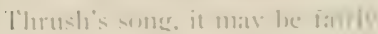
eprodecel by at high-prteter whistle comblinel with at visal

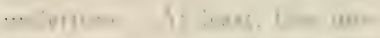
- tirm salielies the hirel. alta on is pussible on engage one afted mustrer of them in at wrt 11

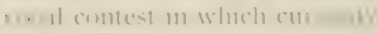

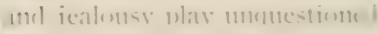
parts. Somsetimes the Thrusli:

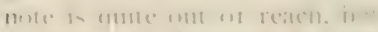

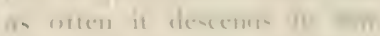
pitcless, whale mow and the is Hatferl and the resomatuet crowrleel ont of it. weit $n$ on

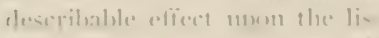
foner, smewhere leetwer at

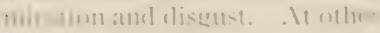
numes at trill is introduce Wheh can le taken care of he I ravimed malate. in arlationt to the ural sommel and the whiste

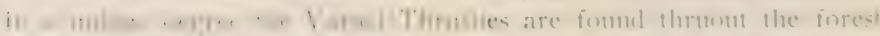

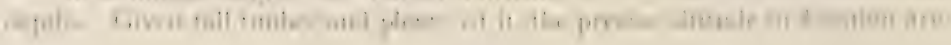


matiers of 110 consequence. 'The prettiest compliment that X゙ature can pay to the genuine wildness of Ravenna Park, in Seattle, or Defiance Park, in 'l'acoma. is the continted presence of the Varied 'Thrush in nesting time. Rum a survey. line across any timbered valley of western Washington, or up any timbered slope of the Cascales or Olympics, and the bird most certainly encountered, without reference to local topography or presumed preference, will be the laried 'Thrush. The bird may likewise be found among the latrohes and ceclars of the Calispell Range.

'lhe laried 'Thush is known by a variety of names, none more persistent or fitting than Winter Robin. It is a Robin in size, prevailing color, and sencral make-up; and it appears in the lowlands in large numbers only in the winter time, when the deep snow's have driven it out of the hills. T'he T'hrush is much more shy than the Robin, and altho it moves about in straggling companies, and does not shm city parks, it keeps more to cover. It also feeds largely upon the ground, and when startled by a passer-by it flutters up sharply. into the trees with a wing-sound whose quality may soon be recognized as clisinctive. At such times the bird makes off thru the branches with a low chuck. or tsook, or else tries the air by low notes which are like the song, only very mucl more subdued. This is manifestly an attenupt to keep in touch with companions, while at the same time attracting as little lostile attention as possible. 'This note is, therefore, barely audible, and has rery little musical qutality, aaruc, or iïir.

The nesting of the Varied 'Thurush was most fully brought to light by Mr. D. E. Brown, at Glacier, in the season of 1905. Like some tireless retriever, this ardent naturalist guartered the mazes of the dense sprtice forest which covers the floor of the North Fork of the Nooksack, and in a range of some fifteen miles up and down that stream stcceeded in locating forty-five nests of this, till then, litule-molerstood species. Of these, twentr-five contained full sets of eggs, while the remainder fell before such accidents as resertion, robbing by Jay's, Owls, etc. 'The first set taken was on May 5 th, and the eggs were slightly inculbted. The last, with fresh eggs, was taken Jume igth,-probably the second nesting of some bird robber earlier in the season. Annong the nests examined. three contained sets of fonr each, and the remainclet three. Of the entire number, all were placed in evergreen trees, save two. Of these last, one was set in the splinters in the broken top of a willom, alontt fifteen feet up: and the other was placed in an upriglte crotch of atn elelerberry bush at four feet from the grouncl.

Here are the wools that abound in moss-bunches, - great balls of thriftr sreen which grow, withont apparent excuse, alike from the thinsiest and from the most substantial supports. It is in view of the abundance of these, that the laried 'Jhrush builds as it does, right out in the open of the underwood. near the top), or at least well wp, in a small fir tree. The searcher has only the 


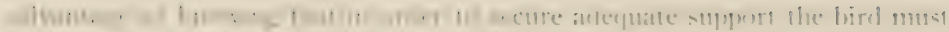

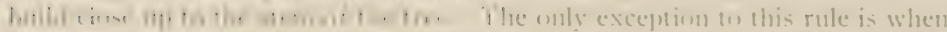

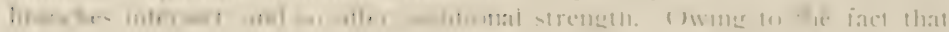

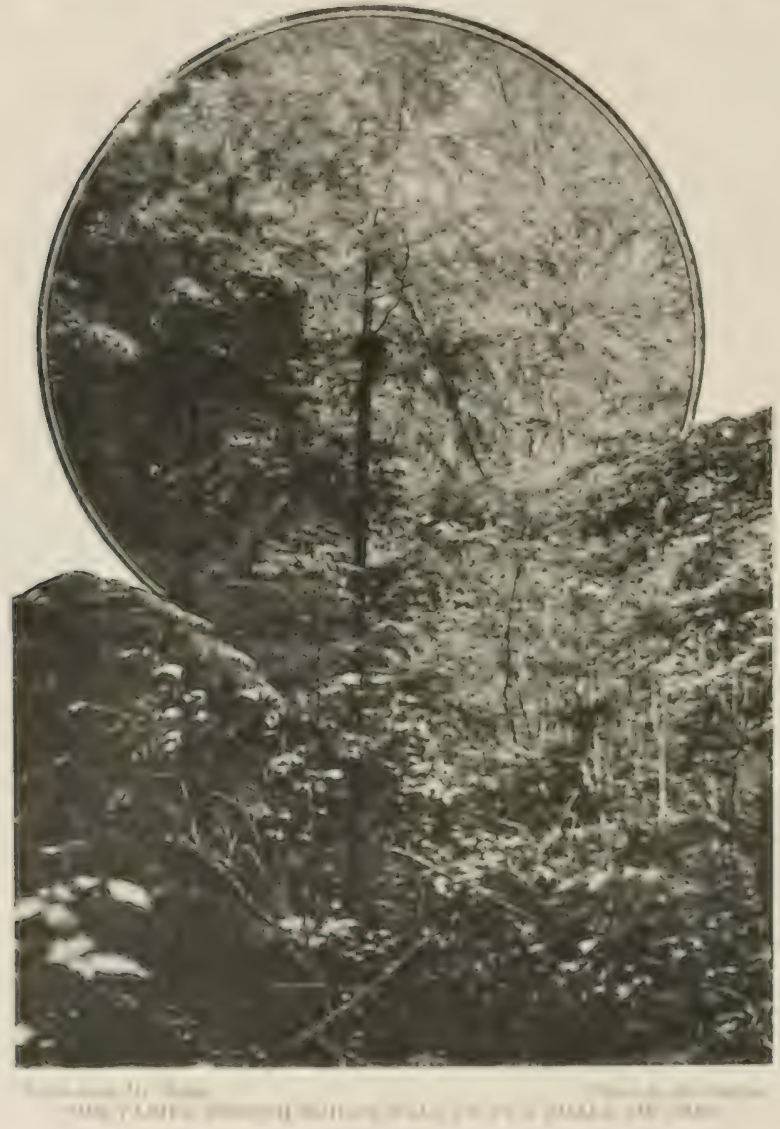

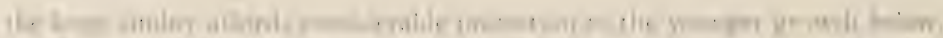

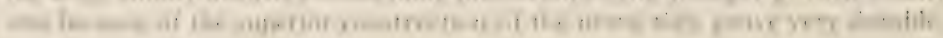


Old nests are common; and groups of half a dozen in the space of a single acre are evidently the consecutive product of a single pair of bircls.

There is a notable clivision of territory among these 'Thrushes. As a rule. they maintain a distance of half a mile or so from any other nesting pair In two instances, however. Mr. Brown found nests within three hundred yards of neighhors.

IV hen one alyproaches the center of a reserve. the brooding i emale slips quictly from the nest and joins her mate in denouncing the intruder. 'The birds flit restlessly from branch to branch, or from $\log$ to $\log$, nuttering repeatedly it stern tsook. which is almost their sole recourse. If the nest is discovered and exammerl. the birrls will disappear silently; and the chances are that they will never again be seen in that locality.

A nest foturd on

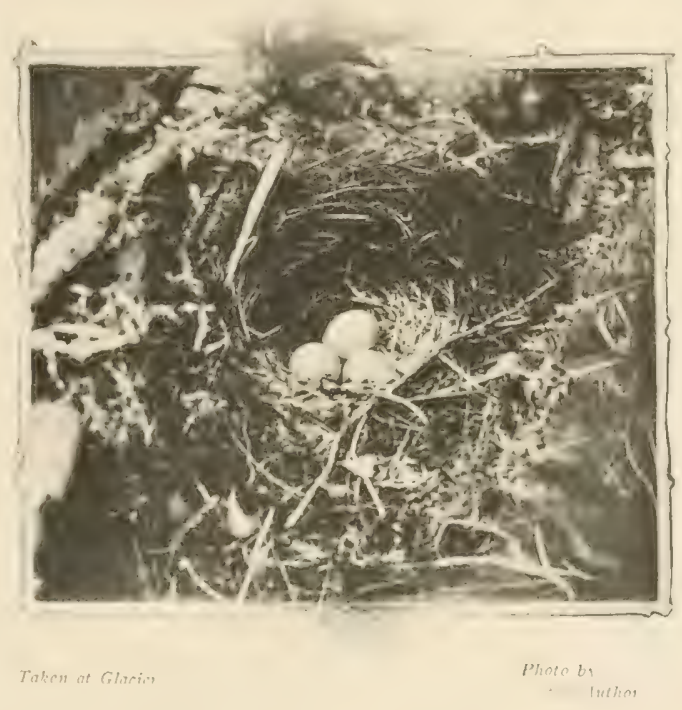

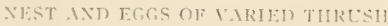

May Ioth, with two exges, was revisited on the I 2 th. It was sadelled at a point ten feet ont on a leaning hemlock, which jutted from the riven bank orer the roaring Nooksack. The proninence of the situation. in this instance, proved the owner's muloing. An ()wl harl eviclently snatched her up on the previous might, the first of her maternal cluty: for the nest and the neighboring foliage were strewn with feathers. Yet so suity liad the marauler executed his first conp that mot an egg was broken. 'l'he eggs were three in number, subovate, of a slightly greenish blue, beanti fully and heavily spotterl-one might almost suy blotched-with rafous. the handsomest, Irr. Brown says, ever seen. 


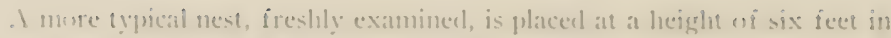
the fepe of a timy lir sapling, which required the support of a chance armstul of leaning vine-matple poles. 'The nest proper is an immense affair, eight and a hatf incles deep and welve inches by eight in dianeter ontside, and two and at half in depth and four in wills insicle. It wonld weigh about three promels. amel is, therefore, quite compact, althe the mess, which is the largest element in its compusition, hohls a large puantity of mosoture. 'l'wigs from six inches (1) at font in length enter inte the exterior construetion, and these are themsedves mess-learing. Siripping ofi the onter mess-coat, one comes to the matrix or crucible-shaped vessel of rotten woul, an incls or more in thickness thrust, and solklen with musture. W'ithin this receptack, in turn, appears another cup with wallis thece-ruarters of an incir in thichess, and compresed sulely of dried gratses and moss, neatly woven and turned. 'The innermust lining comprises the same materials, nut very carefully smouthed, but antazingly dry, consiclering the chancter of their surroumlings. The lorim of the nest is strengthened by bark-strips, the inner fiber of cedar bark being exclusively empleyed for this purpose: while the finishing cont comsists of muss, compaced and thwess. 'There are, in fact, few nests to compare with that uf the laried 'llorush in strength, elaburateness, and elegance.

in. 801.

\section{IVESTLRN BI,LEBIRI).}

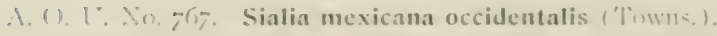

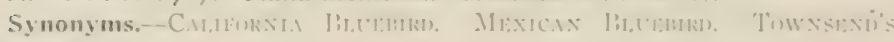
iitipituti).

Description.- Mdult mak: Ilead and meck all armund and mpgerparts rich

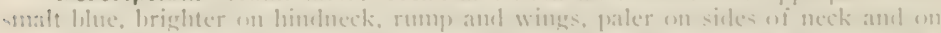

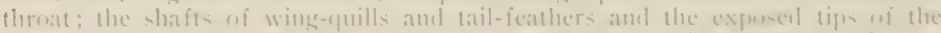

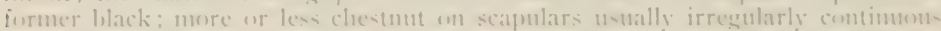

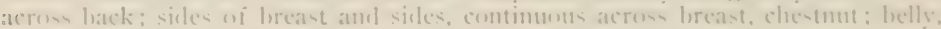
Hanke, crissum and under tail-coserts dull gravish hlue (campanula blue to pearl

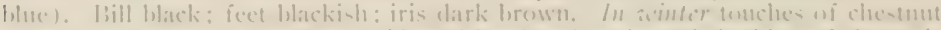
appear on crown, hindneck and sides of heal and neck, and the blue of throan is

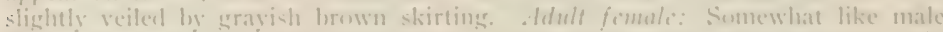
lut everywhere paler ame duller: blue of uprerparts clear only on rump, tail. feser and midelfe wing-eoverts and onter enges uf primares, there lighter than in male (campanula hlue to flax-flower blue : tiret primary and motemenet rectrices

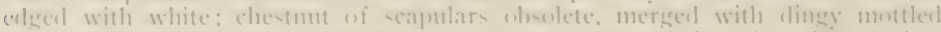

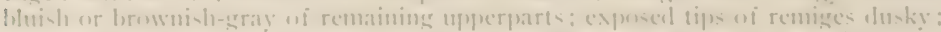

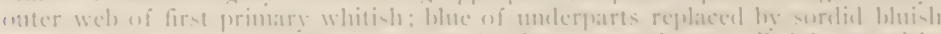

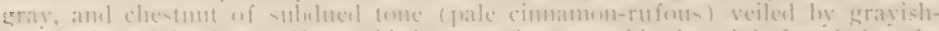

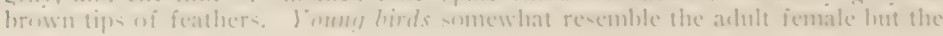


bluc is restricted to flight-fenthers and rectrices, that of the male being brighter and biver, that of the female duller and greener. In both sexes the back and scapular areas are brownish heavily and sharply streaked with white and the breast (jugulum, sides of breast, and sides) is clark sepia brown so heavily streaked with white as to appear "skeletonized." Length of atults $6.50-7.00$ $(165-177.8$ ) ; wing +.13 ( 105 ); tail 2.80 ( $7 \mathrm{I}$ ) ; bill .49 (12.5); tarsus .85 (2I.5).

Recognition Marks.-Sparrow size; rich blue and chestnut coloring of male; darker blue coloration of wings in female distinctive as compared with that of $S$. currucoides.

Nesting.-Nest: in cavitics, natural or artificial, old woodpecker holes, hollow trecs, stumps, posts, bird-hoxes, etc., lined with grasses and, occasionally, string, feathers and the like. liggs: $f^{-6}$, miform pale blue. Av. size, $.82 \times .62(20.8 \times$ 15.7). Scason: May-July; two broods.

General Range.-P'acific coast district from L.os Angeles County, California, to British Columbia, extending irregularly eastward in Oregon, Washington and liritish Columbia, and to Idaho and western Montana; sonth irregularly in winter as far as San P'edro Martir Monntains, L. C.

Range in Washington.-Summer resident, of general distribution west of the Cascades, rare and local clistribution (chiefly in heavily timbered sections) east of the monntains; casually resilent in winter.

Migrations.-Spring: c. March I; Ëast-side: Chelan, March 9. ISg6: Conconnully, March I5, I896; West-side: Seattle, Narch 6, I889; March 5, I89I; T'acoma, Feb. 25, I905. Fiall: October.

Authorities.-Sialia occidcntalis, Townsend, Journ. Ac. Nat. Sci. Phila. lol. VII. pt. II. I837, is8. CiS. L. Rh. D'. K1), Ra. D². Kk. J. L3. E.

Specimens, - U. of IV. I'rov. I3. BN.

$.1 / L^{*}-1 / 1 U-. M U U$ - munte you are, or next thing to it, you natighty little heanties! Why don't you sing, as do your cousins across the Rockies? You bring spring with you, but you do not cone shifting your "light load of song from post to post along the cheerless fence." Is your beauty, then, so burdensome that you find it task enongh to shift that?

Alack-a-day! our Bluebird does not sing! You see, he comes from Mexican stock, Sialia mericana, and since we will not let him talk Spanish, or Aztecan, or Zampeyan. he flits about silent in seven languages. Eir-butwhat's this? Can we be mistaken? Here is what Dr. J. K. 'Townsenda says of the Western Bluehird: "Common on the Columbia River in the spring. It arrives from the sonth early in April, and about the first week in . Iay commences butilling. * * * I flock of eight or ten of these bircls visited the liritish fort on the Columbia, on a fine day in the winter of 183.5 . They confined themselves chiefly to the fences, occasionally flying to the gromml and scratching among the snow for minte insects, the fragments of which were foumd in the stomachs of several which I lilled. After procuring an insect

A. Narrative $(18.39)$, ก. 3.14 
the male ustally requmed of the fence again, and warbled for a minute most delightiully: This mote althe somewhat like that of our common /l'ilsmii

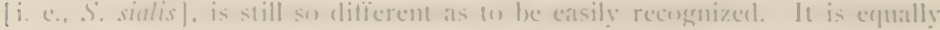

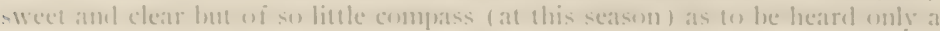
short distance. In the spring it is lubeler, lout it is att all times much less strong than that of the commmn species."

1)r. Prewer, comelensing Nutall, says : "He [Nutall] squalss of its

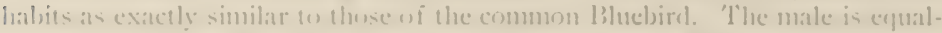
Iy tumeinl thruent the hreeling-season, and his somge is alse very similar. like the enmmen species lee is very devoted to his mate, altermately ieeding amel artessing her and entertaining ler with his song. 'This is a litule more

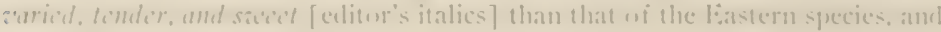
differs in its expressions."

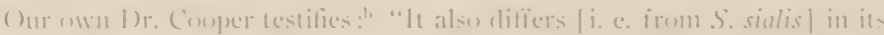

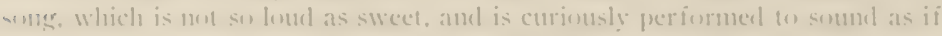
two hirals were singring at unce and in dilferent keys." Here the tratition

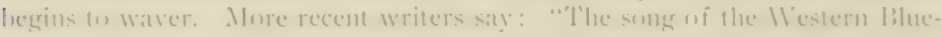
birel is mot inll lut is, like his mamers, gentle and sweet" (1,urd); and. "It

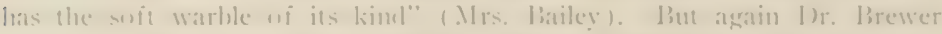

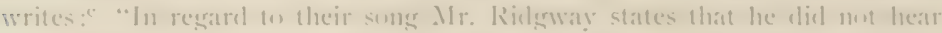

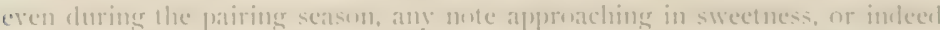

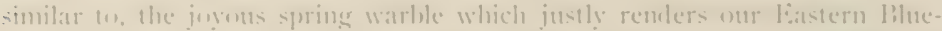

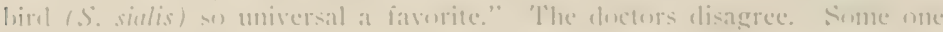
hats leech olrcaminger!

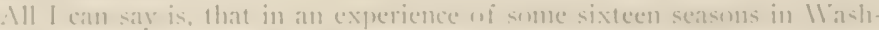

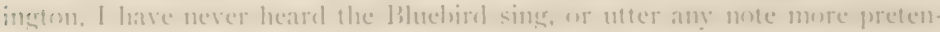
tims than the plaintive min alrealy referret to. It has hesile, however, a

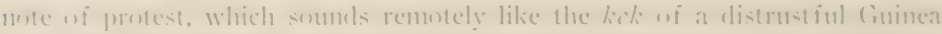

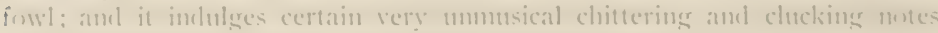
when encleavering to attract the attention of its youms.

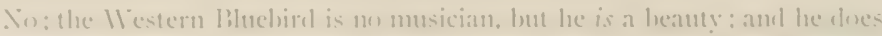
have the same gentle contesy of hearing which has endeared the Ibluebirel

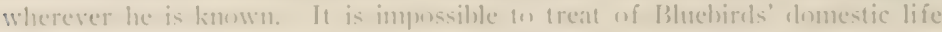

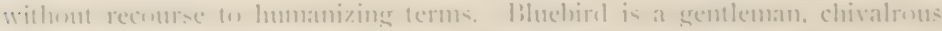

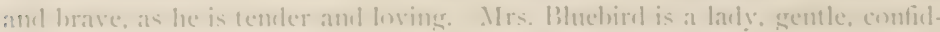

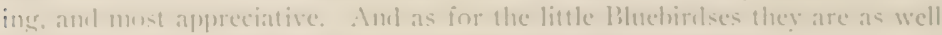

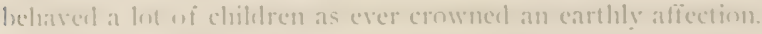

Fonth parents are unsparing in their lewention to the rising genematim, and si) thuroly is this unselfish spirit reflected in the conduct of the children that it

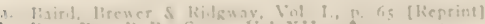

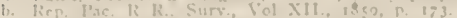

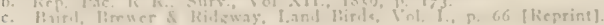




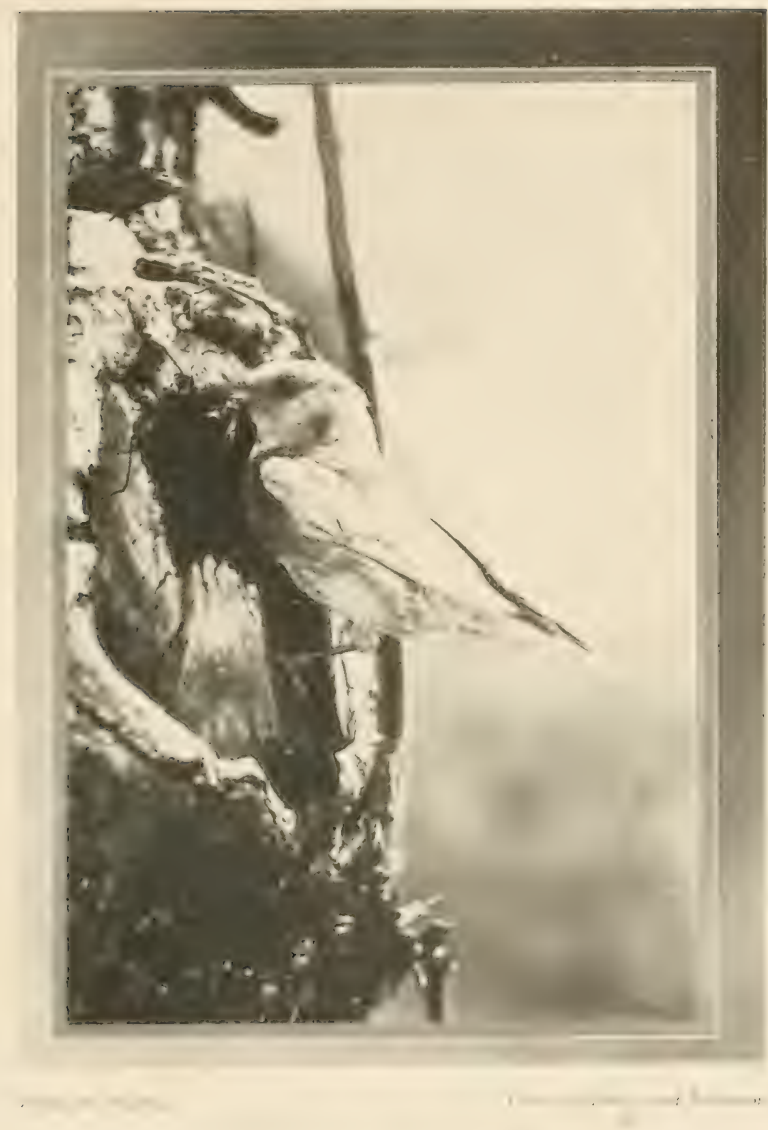

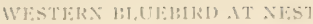

is the subject of freepuent remark. Mr. Hinley tells of an instance in which a first brond, just ont of pinafores, tmoned to and helped their parents provide iond for another batch of babies, and this not once, nor twice, nor castally. 

fast to the apple-trees or lodged at considerable intervals along the intersecting fences. 'l'he experimenter finds that more than half of the boxes are occupied each season, and he comnts the birds of inestimable value in helping to save the grapes and apples from the ravages of worms.

In providing for Bluebird's comfort, care must be taken to expel cats from the prenises; or at least to place the box in an inaccessible position. Linglish Sparrows, also, must be shot at sight, for the Bluebird, however valorous, is no match for a mob. 'l'ree Swallows or Violet-greens may coret the nesting-box-your affections are sure to be divided when these last appear upon the scene-but the Bluebirds can take care of thenuselves here. For the rest, clo not make the box too nice; and above all, clo not make it of new lumber. Nesting birds do not care to be the observed of all observers, and the more natural their surroundings, the more at ease your tenants will be. An occasional inspection will not be resented, if the Bluebirds know their landlord well. There may be some untoward conclition to correct,-an overerowded nestling: or the like. At the end of the season the box should be enptied. cleaned, and if possible sterilized.

Two broods are raised in a season, and the species appears to be on the increase in the more thickly settled portion of the State. Occidentalis avoids the dry sections, and is nowhere common on the east sicle of the nommans, save during migrations. It is, however, regularly found on the timbered slopes of the Cascades, the Kalispell Range, and the Blue Motntains, where its range inosculates with that of the Mountain Bluebird. There is reason to suppose that its range will extend with the increase of irrigated territory. West of the mountains, per contra, the Bluebird affects the more open conntry, and especially that which bas been prepared by fire and the double-bitted axe.

\section{No. 102 .}

\section{MOUNTAIN BLUEBIRD.}

\section{O. L. No. 768. Sialia currucoides (Bechstein).}

Synonym.-ARCTIC IBLTERIRD.

Description.-Idult male in summer: Anove rich cerulcan hine, palest (turcjuoise blue) on forehead, brightest on upper tail-enverts, darkest (sevres blue) on leseer wing-enverts: below pale blue (deepest turrpunise) on chest, shading on siles of hearl and neck to color of back, paling on lower belly, crissum and under tail-coverts to whitish: exposed tips of tlight feathers dusky. [Bill and feet black: iris dark brown. Adult mole in ainter: Blue somewhat duller and feathers skirted more or less with brownish above and ledow, notably on linel-neck, upper hack, breast and sides. Idult female: I, ike male but paler lilue, clear on rump. tail and wings only, elsewhere quenched in gray; pilemm. hindneck, back and 


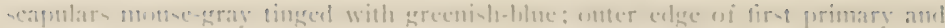

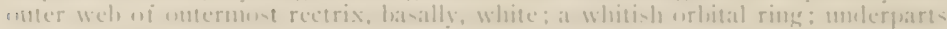

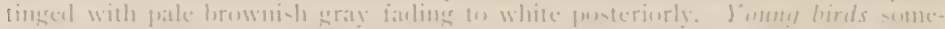

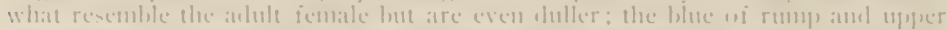

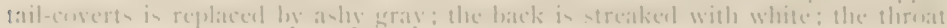

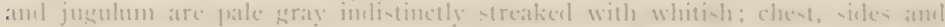

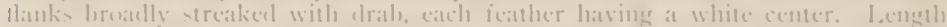

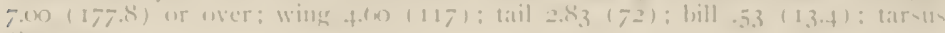
ii) $(22,1)$.

Recognition Marks.-Siparrow -ize: azure blue colnration of male and whi-h-egray and azure of fenale ummi-takablike.

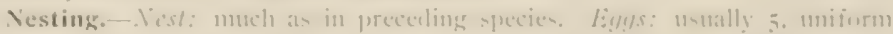

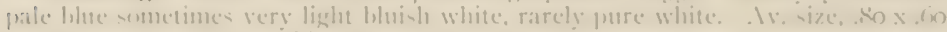

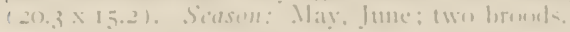

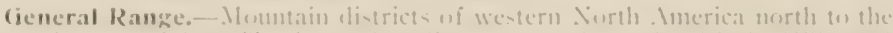

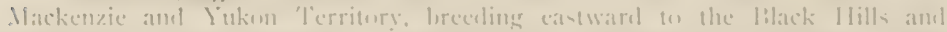

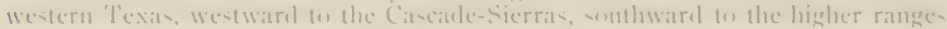

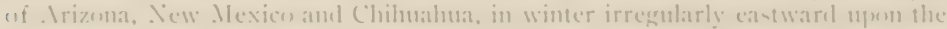

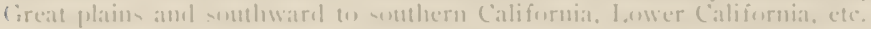

Range in Washington.--Sinnmer resilent in the Carcale. Monntain- chictly

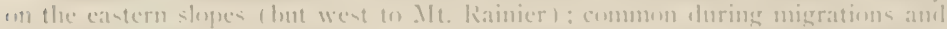

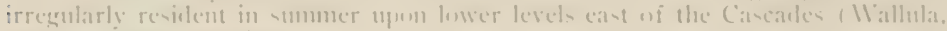
Alay 15. ino-, hrowlings).

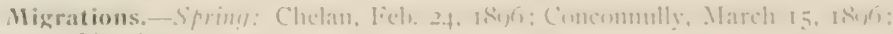
Mhamum, Yatrch 1,3. I1,mo.

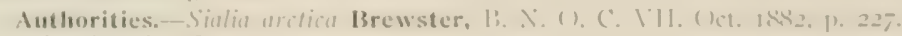
T. I. 101,1$) \div$. Sis'. J.

specimens.- l't. I'rny. C.

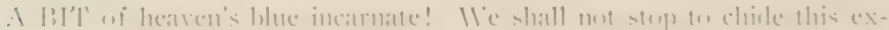

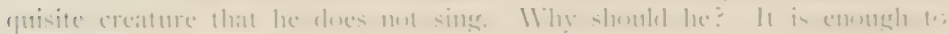
in>

The sky has net fillen lhis lecautiful mom,

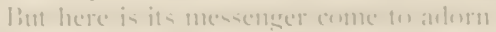

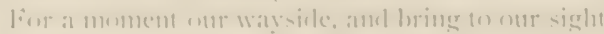

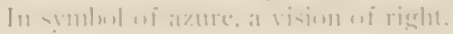

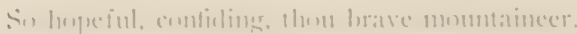

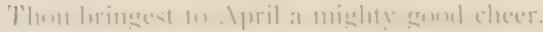

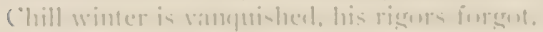

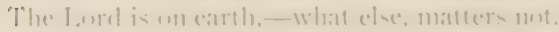

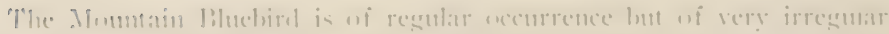

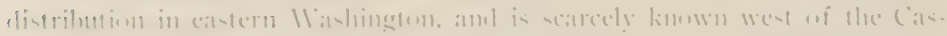

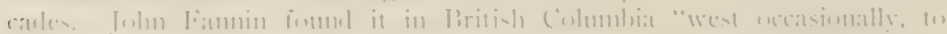

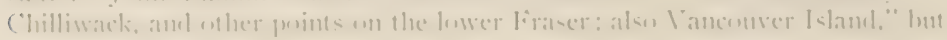


We have only two records of its occurrence on the Pacific slope in IVashington $1^{3}$. 'The bircl manges up) to the highest peaks of the central divicle, but it is not at all common in the mountains. It seems to prefer more open situations ancl. so far from being exclusively boreal in its tastes, has been fonnd nesting at as low an altitucle as IVallula, on the banks of the Colunibia River.

At Chelan in a typical seasun ( 1806 ) the migrations opened with the ap)pearance, on the afth day of February, of seren males of most perfect beauty. 'They deployed upon the townsite in search of insects, and nttered plantive notes of Sialian quality, varied by dainty, thrush-like tsooks of alarm when too closely pressed. 'T'hey dicl not at any time attempt song, and the entire song traclition, includling the "lelight ful warble" of Townsend, apjears to be guite withont foundation, as in the case of S. m. occidentulis. On the i 5 th of March a tlock of fifty Blucbircls, all males, were sighted flying in close order orer the monntain-sicle, a vision of loveliness which was enhanced by the presence of a dozen or more IVesterns. Several Hocks were observed at this season in which the two species mingled freely. On the $27^{\text {th }}$ of the same month the last great wave of migration was noted, and some two hundred birds, all "Arctics" now, and at least a third of them females, quartered themselves mpon us for a day,--with what delighted appreciation wpon our part may best he inngineci. The males are practically all azure; but the females luve a much more modest garl) of redclish gray, or stone-olive, which flashes into blue on wings and tail, only as the bird flits from post to post.

In nesting, Mountain Blueloirds sometimes display the same conficlence show'n by the darker species; and their adoption into urban, or at least village life, would seem to be only a matter of time. T'hey are a gentle breed, and it is an honor of which we may well strive to prove wortly, to be closen as hosts by these distinguished gentlefolk.

"Gentle," as applied to Bluebirds, has always the older sense of noble,noble becanse brave. My attention was first called to a nest in the timbered fonthills of lakina County, because its valiant owner furiously besct a Filicker of twice his size, a clumsy villain who had lighted by mistake on the I3hebird's nesting stub. The gallant defender dicl not use these tactics on the bird-man, but his accents were sternly accusing as the man proceeded to investigate a clean-cut losle eiglut feet up) in a pine stub four feet thru. Five dainty eggs of the palest possible blue rested at the bottom of the eavity on at soft cushion of fine grasses.

'This must have been a typical structure, but near ( Trelan I found the hirds nesting at the end of a tumel driven into a perpendicular bank nuch fre-

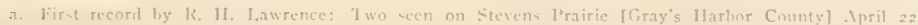

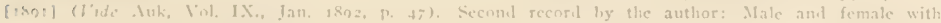

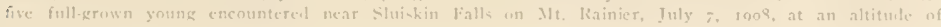
6500 feer.
} 


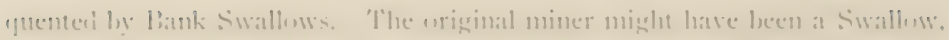

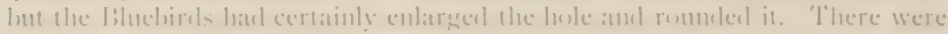

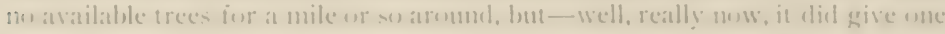

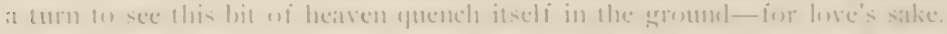

No. 103.

\section{WESTERN GOLDEN-CROWNED KINGLET.}

\section{1. (1. [". Nis, fiti. Regulus satrapa olivaceus lasirel.}

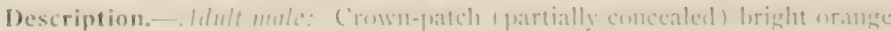

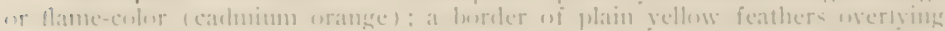

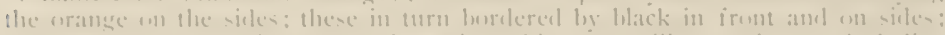
evtreme furdeat white, connecting with white superciliary tripe: a dark line

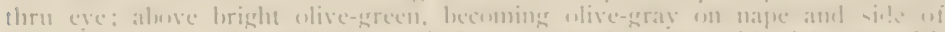

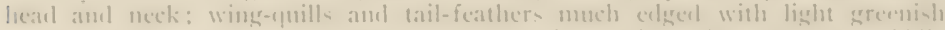

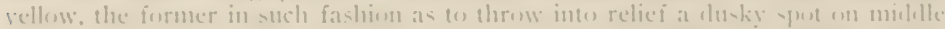

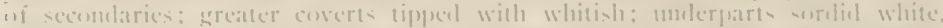

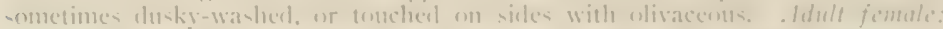
similar, lut with crown-patch plain yeflow insteat of orange. lmmature:

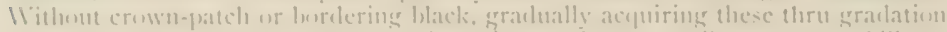

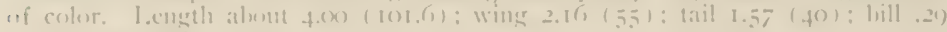

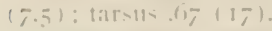

Recognition Marks. - l'ymeny size: nrange, or yellow, and hlack of crows iliminctive:

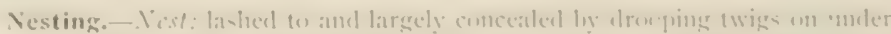

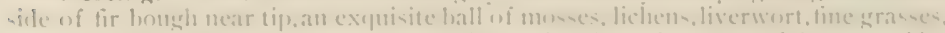

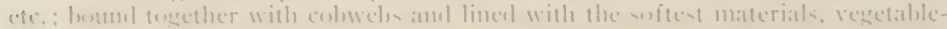

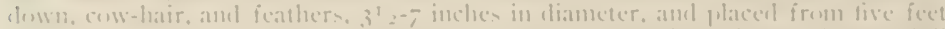

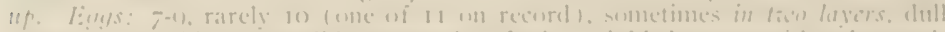

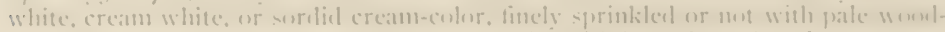

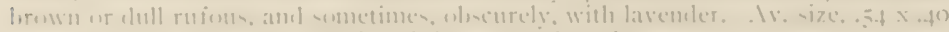

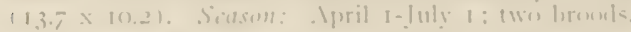

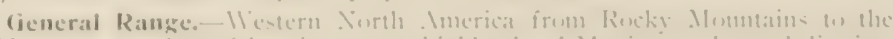

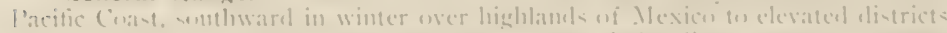

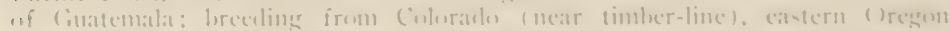

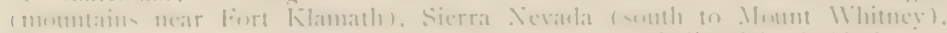

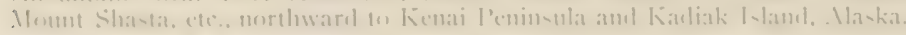

Range in Washingten.-Cimmen revilent in coniferme timber fexcopt

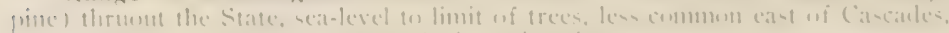

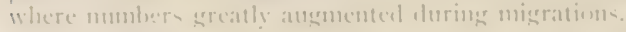

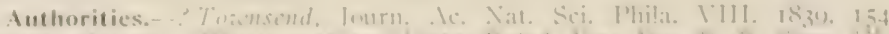

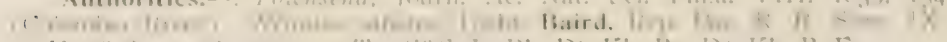

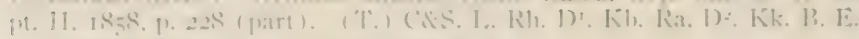

specimens.-1', of II. I'. I'row. I., I.. 
"COOH) things come (lone up in small packages," ny college chum used to say (speaking, of course, of la fommo petite), and that was before lie knew the Golden-crowned Kinglet. Indeed, it is surprising low few people do know this amiable little momarch; and yet, I suppose, he is by all ofkls the most abundant bird in $1 \mathrm{~V}$ ashington. 'To one who seeks the honor of his acquantance, he proves a most delightinl friend; but he has his little modesties and reserves, becoming to a potentate, so that a thousand of him would never be "common," nor pall upon the senses.

Kinglets go in trompes, family parties, which keep a little to themselves ordinarily ; altho Chickarlees a nd Anthatches. or ere 11

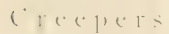
and IVrens, are welome messmates, in the friend. ly winter tinle. Fiverstreen trees, exclusively, are frecpuented, except during migrations upon the liastsirle where

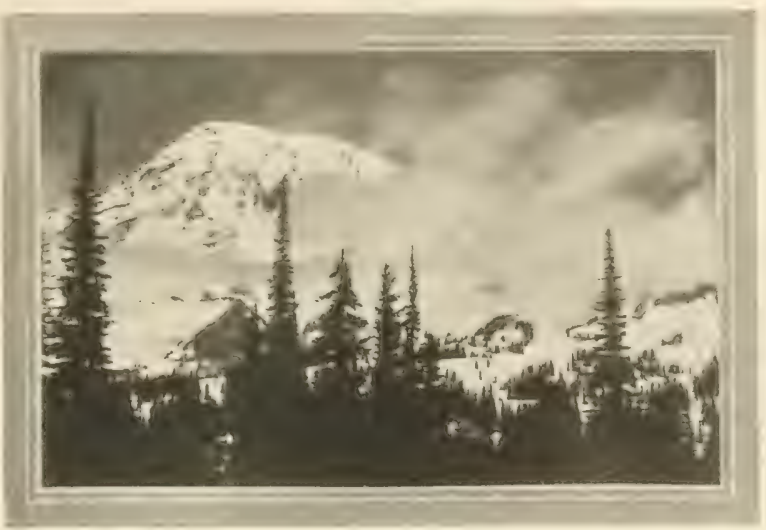
Taken in Ruinicy National Park.

From o Plotograph Copyright, 1008, by IV. L. Duason TIIF: UXVFIIIXC

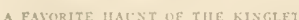

\section{the favorite}

cover is lacking. and the real abundance of the birds at all seasons is coexemsive with that of the Douglas Spruce (P'sendotsuge douglasi). With tireless energy they search both bark and branches for insects' egges and larrae scarce visible to the human eye. They peer about incessantly, bencling and darting and twisting and squirming, now hanging head downward, if need be, now fluttering prettily against the uncler side of the branch alowe: but always on the go, until freptently one despairs of eatching fair sight of the crown for the necessary fraction of a second. Of course it's a Golden-crown: but, then. we want to see it.

And all the thme Cutikins is earrying on an amiable ennersation with his 


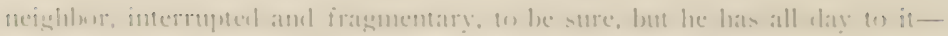

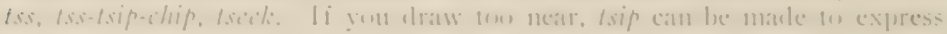
viguru disalpum

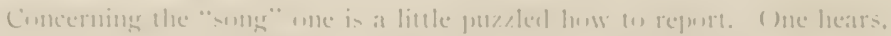

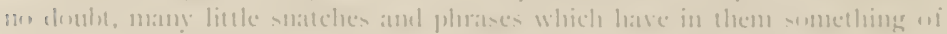

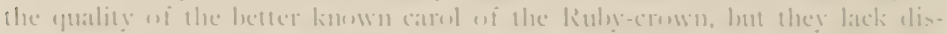

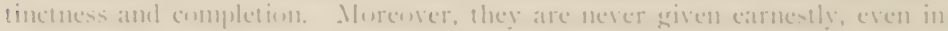
the height of the mathes seatsul, but, ats it were, reminisecutly, mere by=

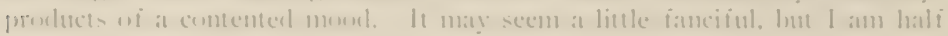

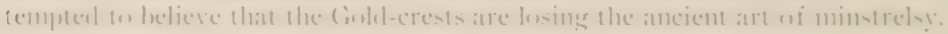

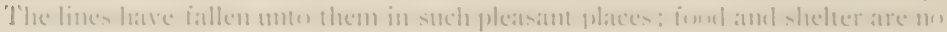

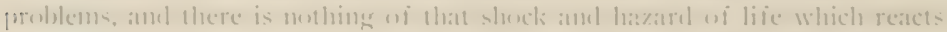

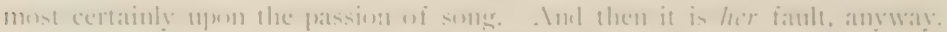

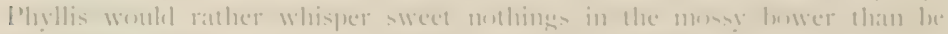

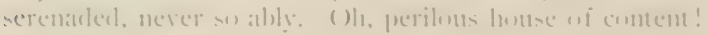

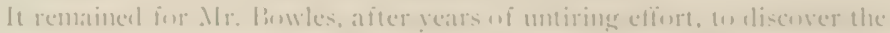
lirst nest of this western sariets. Int then it came le waty of revelation-at

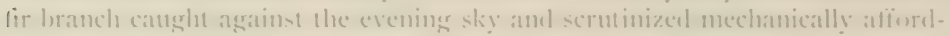

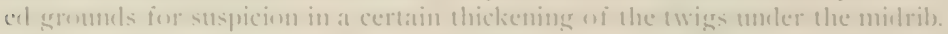
Investigation revealed a hall of mose natcheel on a nicety of green with the

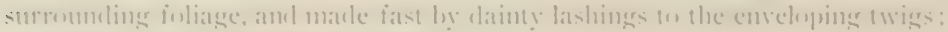

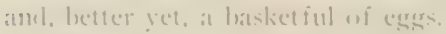

These hirkts probably nest at any heighe in the heaviest lir timber: hut.

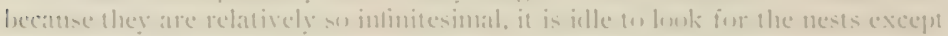

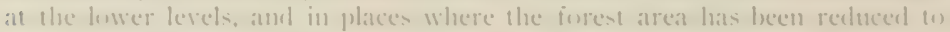

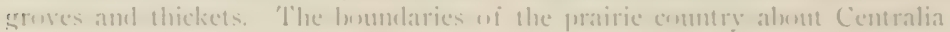

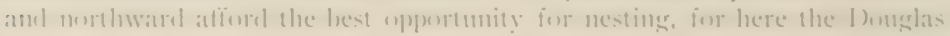

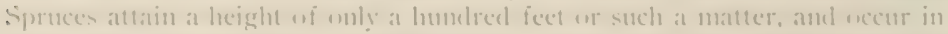

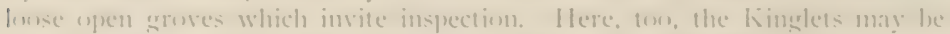

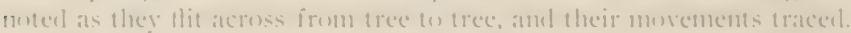

The binglet and queenlet ate a devonted pair in nesting time. Ithether sathering materials for the nest of lumbers for fous after the habies are

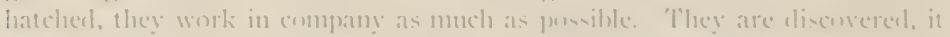

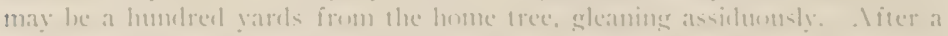

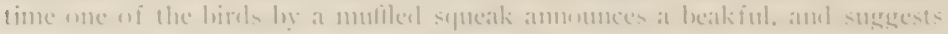

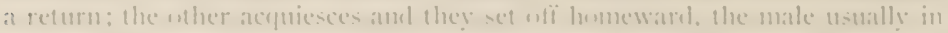

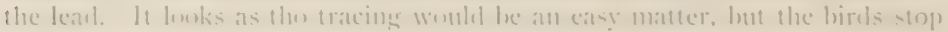

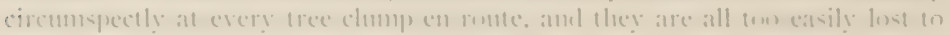
sight longe lic fore the lume tree is reacleed.

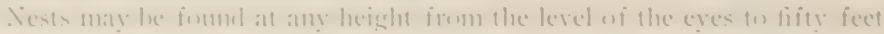

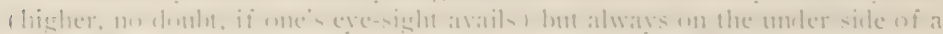

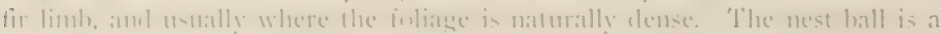


wonclefully compacted affair of noss, both green and pray, interspersed with liverworts, dried grasses, soft weed fibers, and cow-hair The deep depression of the nest cup scarcely mats the sphericity of the whole, for the edges are brought well in: so much so, in fact, that a eontaining branch overloardet witl: foliage upen one sicle, once tipperl half way over without spilling the exe the cleep cavity is heavily lined with cow-hatr and abmolant feathers of

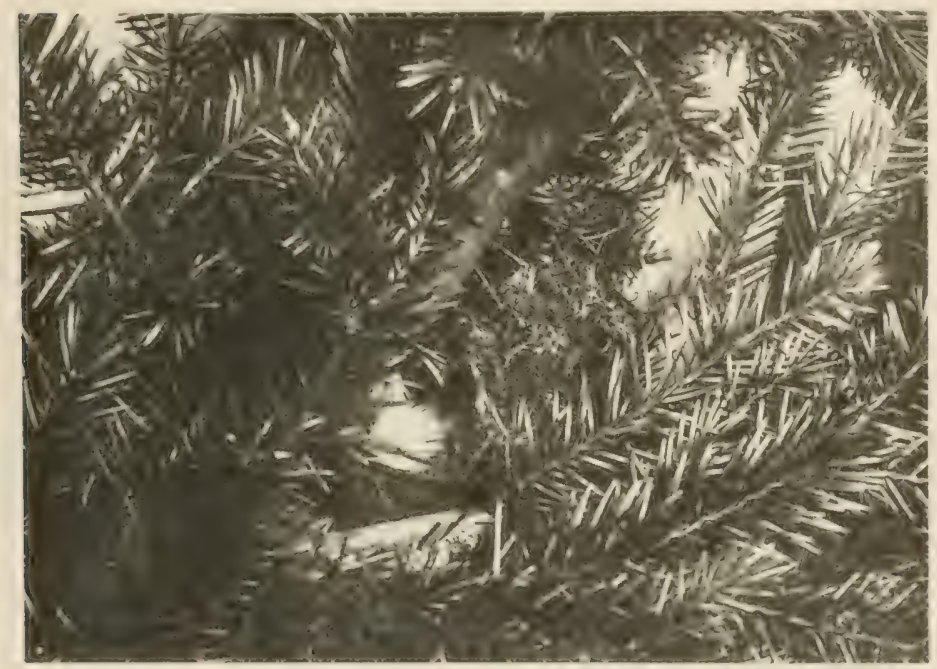

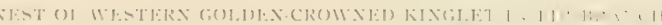

wrouse or elonestic foml. These feathers are placed with their soft ends pro truding. and they curl over the entrance in such fashion as alnost or quite to conceal the eggs. One would like to particularize at great length, for no fervors of description can orerstate the beatutes of this Kinglet palace

ligs vary in mumber from five to nine, seven and eight being the rulc I once $u(x)$ a a nest with eleven-one too many at the least, for it had to rest on

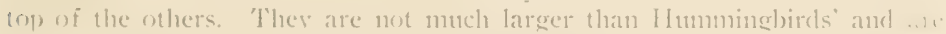
quite as fragile. Mr. Bowles consumed twenty minutes in remeong the on $\because$ its of the big nest to the collecting box athout a break. 'The eges vary in 


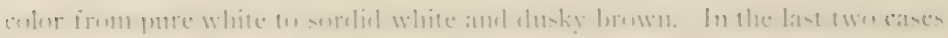

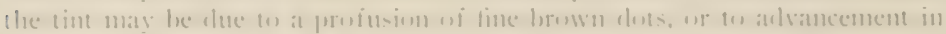

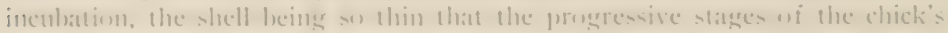
develepment are dimly shatuserl that it

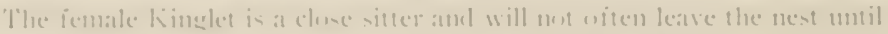

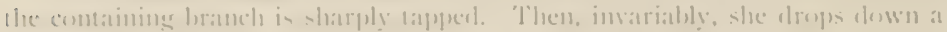

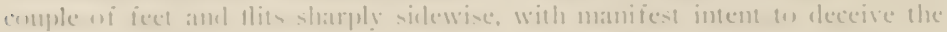

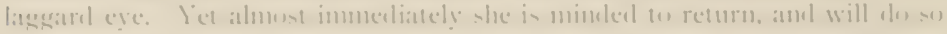

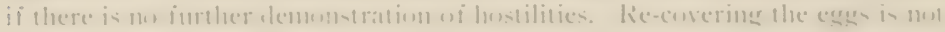
alwatys an ealy matter, for the well is teep and the muth natrow. () ne dame

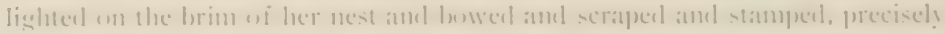

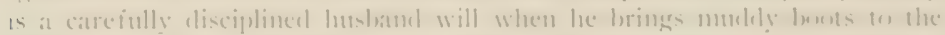

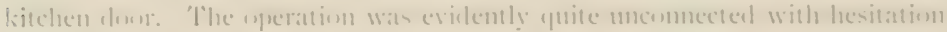

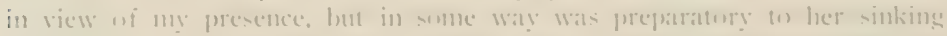

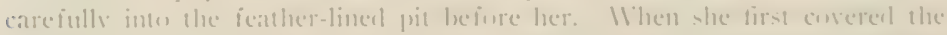

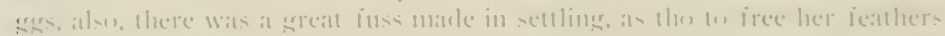

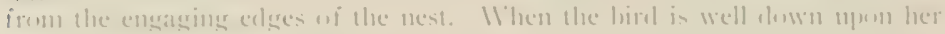
eeres there is mothines visible but the top of her hesel and the tip of her tatil.

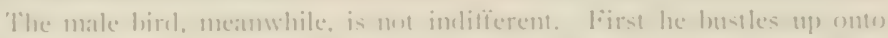
the nesting branch and thasles his fiery erest in platin tolien wi anger. fun

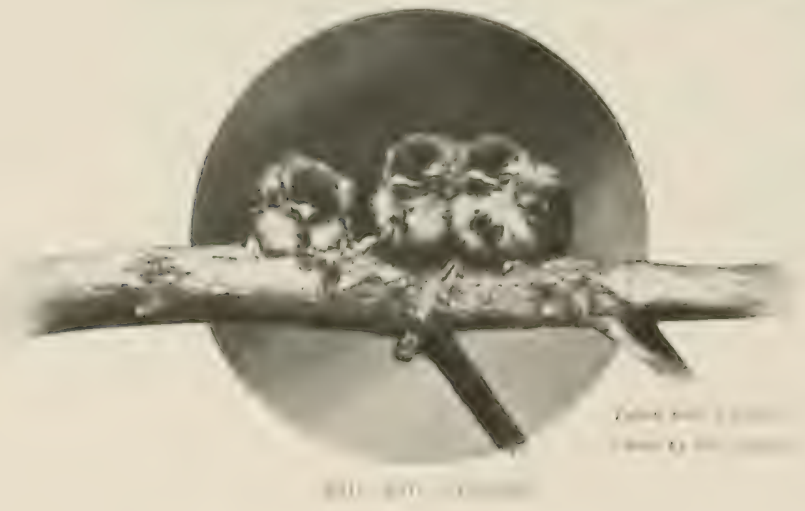
later he is centent

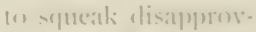
ati from a prition mwere remencel

IItrike the muther limal is sittines. the male lemels her iatils. fulle, lust les spenels lis spatre muments. accorrliner (o) Mr linwles in enm-trutetinte "unck nests." or decons in the neigh. berine trees. 'These' -eem to serse ne prurperac locerumel that of a mervmas relief un

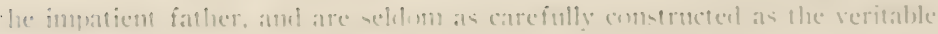

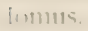

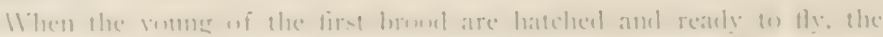
hief eare of them falls on the father. while the iemale prepares for a secome

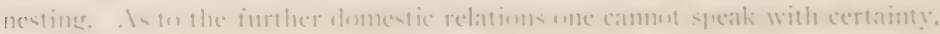


but it would seem at least possible that fall bird troops consist of the combinee families of Mr. and Mrs. Ouiverful.

As to the time of home-making, the Kinglets are not very particular. Nor is it necessary that they shottl be. It is always spring here after the first of ['ebruary. Besides that, a fir tree is both forest and store-house at any: season. In the vicinity of l'acoma, the ustral nesting time is the last week in April for the first set, and the second week in Jume for the second. 'The earliest record is April gth, that of a nest containing half-grown young. 'T'le first egg of this set must, therefore, have been rleposited about March isth.

So far as we can make ont, this bird is strictly resident in western Washington, but it is much less common on the east side of the Cascades, and is there largely migratory. Not only does the species retire in winter from the mountains to the lower foot-hills, but considerable mumbers pass over the State to and from Britisly Columbia. At such times they appear wherever timber or watered shrubbery is to be fomd. With mamers so engaging and lives so sheltered, to say mothing of families so blessed in the yearly increase, is it any woncler that the gentle tribe of Regulus prevails thruont the giant forests of this western slope, and spills over in blessing wherever trees abound?

\title{
No. 10.4 .
}

\section{RUBY-CROWNED KINGLET.}

\author{
A. (). L. No. 7 49. Regulus calendula (Linn, ).
}

Description.- Idult male: Ahove olive-green, duller anteriorly, brightening to erreenish yellow on edgings of quills and tail-feathers: a partly concealed crest of searlet (flame-scarlet to scarlet-rermilion); two narrow, whitish wing-bars formerl by tips of mirlde and greater coverts: some whitish eclging on tertials: a dusky interval separating greenish yellow exlges on outer vels of secontaries; a whitish eye-ring and whitish skirtings aromel base of bill: muler parts soiled white, heavily tinged with buffy and olivaceous buff. Adult female and immature: similar lut without crown-patch. I.ength $4.00-4.50 \quad($ IOI.6-11 +.3$)$; wing 2.33 $(59.2)$; tail $1.72(4.3 .7)$; bill from nostril .25 (6.4).

Recognition Marks.-I'ygmy size; scarlet crest distinctive. Note wing-bars and whitish eye-ring of female and young. I, ighter than $R$. i. grimelli.

Nesting.-. Vest: a hall of moss, lichens, etc., bound together with coluwelss, and lashed to drooping twigs beneath branch of conifer, lined with vegetabledown, catkins, hair, and feathers, and placerl at moderate heishts. E:yls: 5-9), dull white, or pale buffy, faintly or sharply lust sparingly speckled with reddish brown, chiefly about larger encl. Ax. size, $.55 \times .43(14 \times 10.9)$. Season: Jume: one brondi(?).

General Range.-Worth America at large in wooded districts, north to imit 


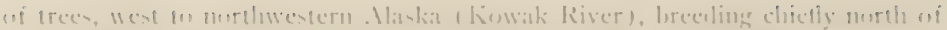

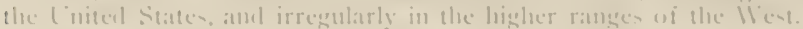

Range in Washington.-Cimmon spring and fall migram: summer reselent in mortheasern purtion of state unly(?).

Migrations.-Sprin!: April, Maly. Fall: ()etuler.

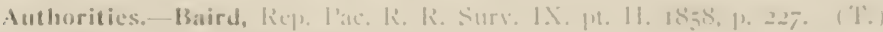

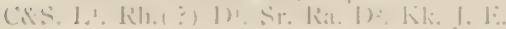

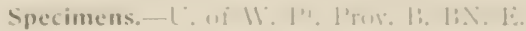

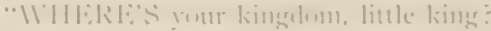

llhere's the latud you call vout uwn?

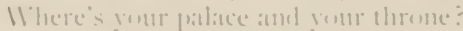

lilutteriner lightly an the wing

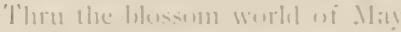

Whither lies your rewall way?

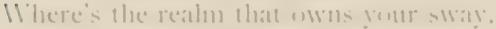

I.ittle Kine :"

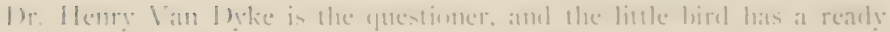

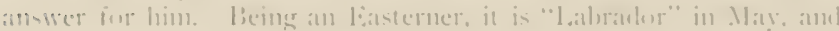

"Where the copress" viviel green

Anel tlec lark magnedia's sheen

Ileave as slefter romul mu lome"

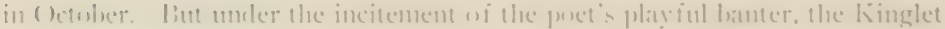
enlarges lis claim:

Never ling la right disine

Rulect a richer realun than mine!

llhat are lands and guhlen crowns.

Armies, fortresses and lowns,

Jewels, secpters, polues and rings.

Il hat are these to sulle and wings?

Eivervaliete that I call th

There I mon the earth amel sky:

liverywhere that I can sing

"lhere l'm happe at al kine."

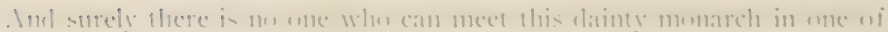

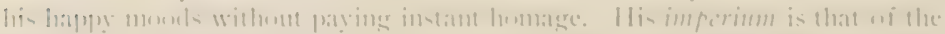

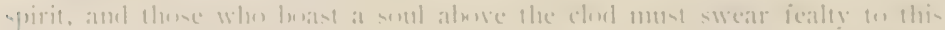

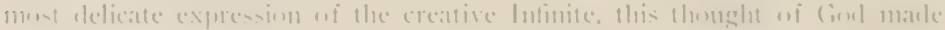

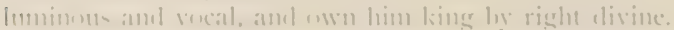

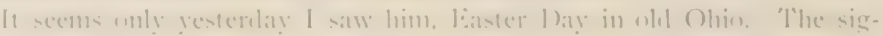


nificant dawn was struggling with great masses of heapecl-tup clouts, - the incredulities and fears of the world's night; but now and again the invincible sun found some tiny rift and poured a flood of tender gold mon a favored spot where stood some solitary tree or expectant sylyan company. Along the river ban': all was still. 'There were no signs of spring, save for the morlest springing violet and the pions buckeye, shaking its late-prisoned fronds to the morning air, and tarlily setting in order its manifold array of liaster canclles. The oak trees were gray and hushed, and the swamp elns held their pence tutil the fortunes of the morning should be clecided. Suddenly from flown the river path there came a tiny burst of angel music, the peerless song of the Ruby-crown. Pure, ethereal, without hint of earthly dross or sadness. came those limpid welling notes, the sweetest and the gladdest ever sung-at least by those who have not suffered. It was not indeed the greeting of the earth to the risen Lord, but rather the ammunciation of the glorious fact by heaven's own appointed herald.

The Ruby-crowned Kinglet has something of the nervousness and rivacity of the typical wren. It moves restlessly from twig to twig, flirting its wings with a motion too quick for the eyes to follow, and frequently uttering a titter of alarm, chit-tit or chit-it-it. During migrations the bircls swarm thrut the tree-tops like WVarblers, but are often found singly or in small companies in thickets or open clusters of saplings. In such situations they exhibit more or less curiosity, and if one keeps reasonably still he is almost sure to be inspected from a distance not exceeling four or five feet. It is lere too that the males are fomd singing in spring. The bird often begins sotfo ance with two or three high squeaks as tho trying to get the pitch down to the range of mortal ears before he gives his full roice. The core of the song is something like ter', te's', teri, tea', titoored', titoorect, the last phrases being given with a rising inflection, and with an accent of ravishing sweetness. The tones are so prute that they may reaclily be whistled by the human listener. and a musical contest provokerl in which one is glad to come ont seconcl hest.

Having heard only the preparatory spring song for years, it was a matter of consirlerable rejoicing to enme upon the bircls at lone in Sterens Counts: They were especially common in the neighborhoof of Newport, and they sang incessantly and lombly from the depths of the giant larches, which alommel there. It appears that the full-fleclged breeling song is quite different from the delicate migratory carol. 'The preliminary notes are of much the same quality, but instead of accenting the fimal syllable of the titoored pluase, ancl repeating this, the plurase is given only once. with a sort of tittering, tremolos effect, ambl the emphasis is thrown upon a series of strong, slarp temunal notes. four of five in mumber, and of a miform character-the whole some-

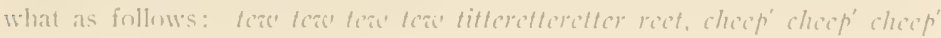




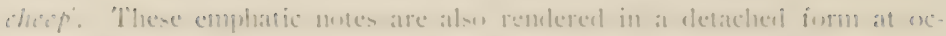

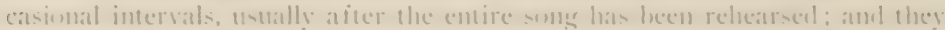

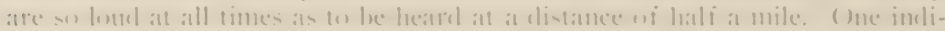

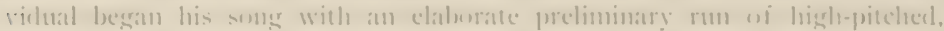

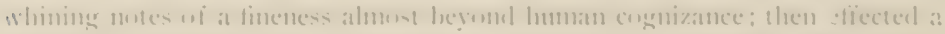

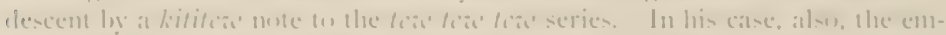

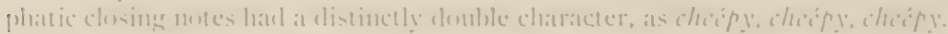

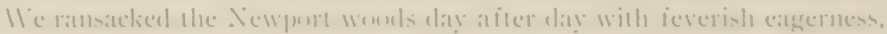
allureel and gotaled ly the music, but tilled also with that stratsege the of

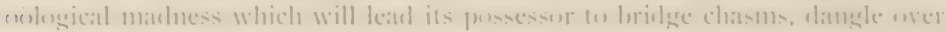

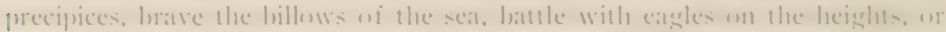

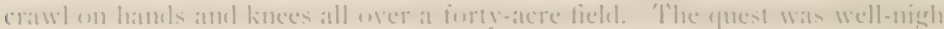
hopeless, for the womels were dense and the tamarackis were heavily drapeel

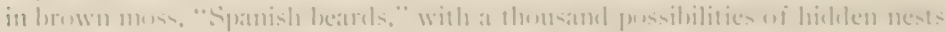

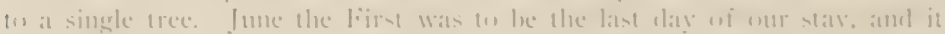

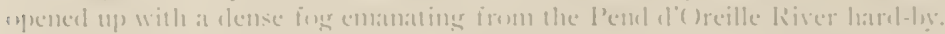

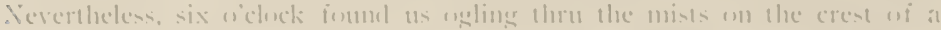

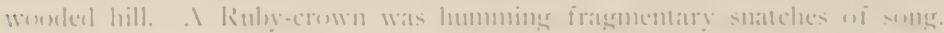

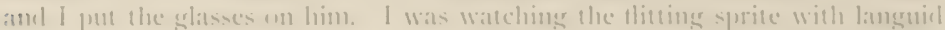
interest when Jack exclatmed petulantly. "Now, why wont that him visit his

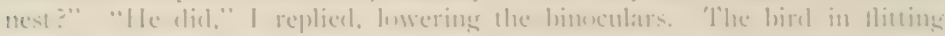

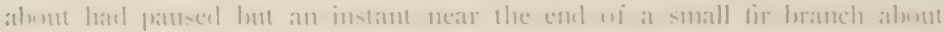

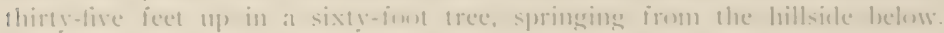

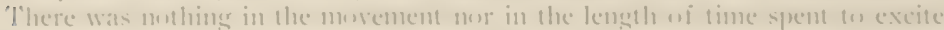

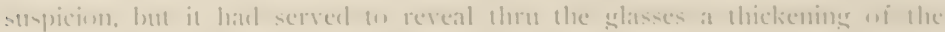

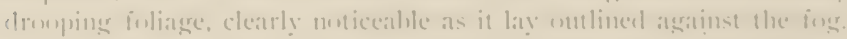

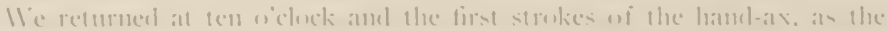

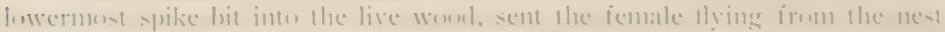

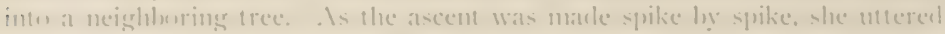

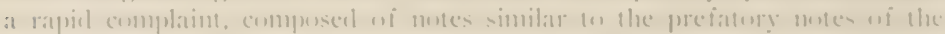

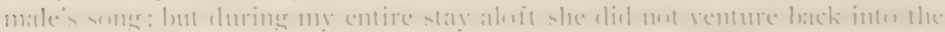

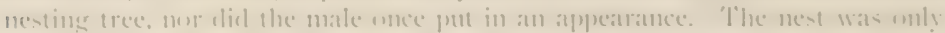

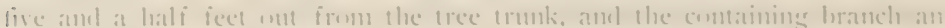

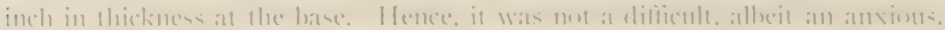

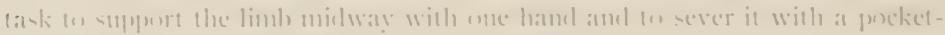

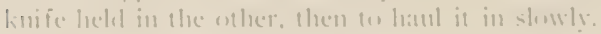

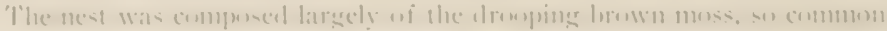

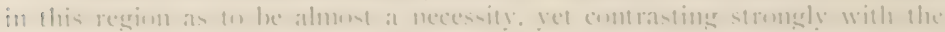

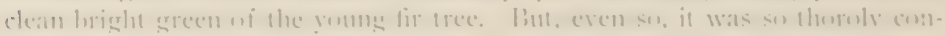

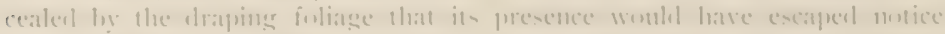

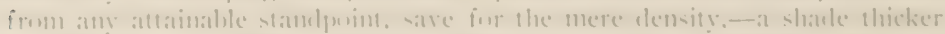

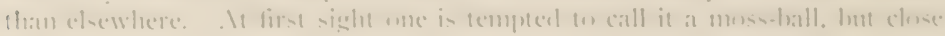


exanination slows it to be rather an assemblage of all sorts of soft substances vegetable clowns. cottons from the pussy willows and cottonwond trees. weathered aments, hair, fine grass (in abundance), wilh occasional strangc inclusions, such as spider-egg cases, dried flower-stalks, and the like. 'l'ho lining is exclusively of feathers, those from the breast of the liolon being

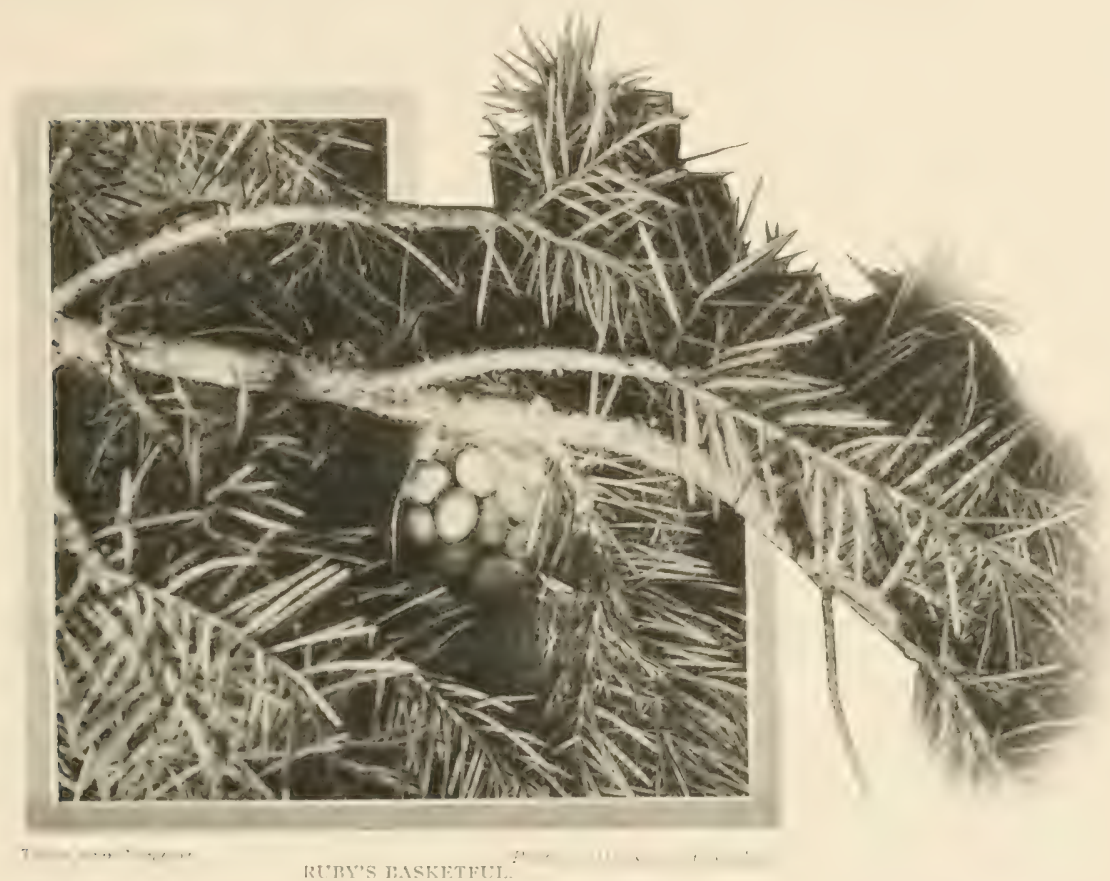

most in evidence. A few of these curled up from under the neatly umed brim, so as to partly conceal the contents: but only a litule effort was required to obtain a perfect view of the ege = from alure

i comber the glowing pile, slowly. calmly, ats a miser eounts his golel when the bolts are shot-twice to make sme-one, 1wo, three. * * * nime the last one being thrown in on top of the heap for gool meatsure

The exess were marvelously fresh, insomuch that in bowing them Mr

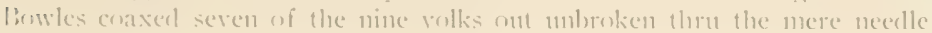




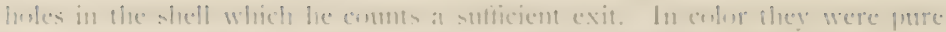

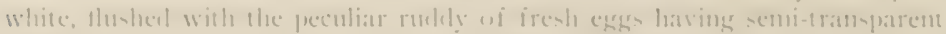

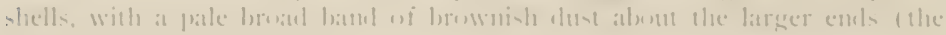
-maller une in une calse).

Il hen I laul desconderl, - singing and whisling right merrily snatches wi

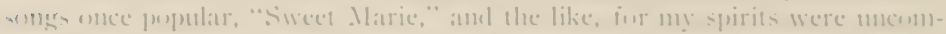

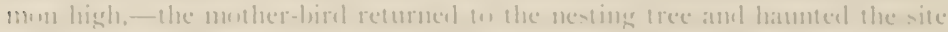

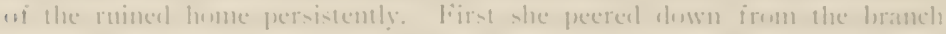

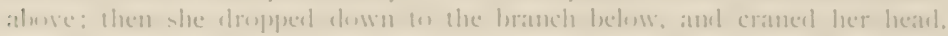

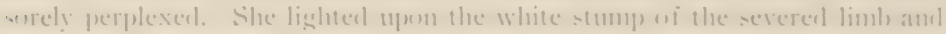

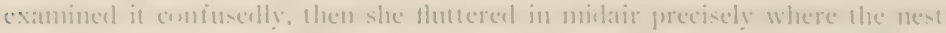

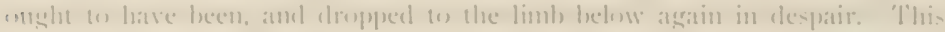

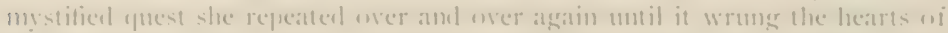

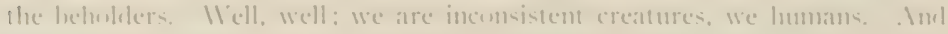

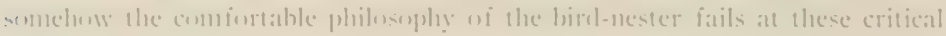
puints.

\section{ํo. 805.}

\section{SITKAN KINGILT.}

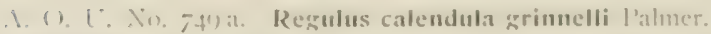

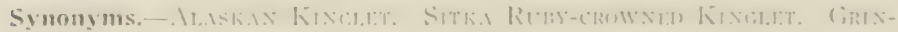

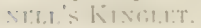

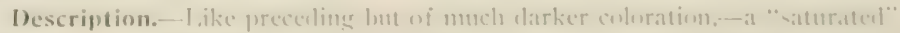
form: alen wing ermewhat shorter, hill larger, etc. Av, measurement of male-

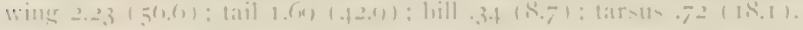

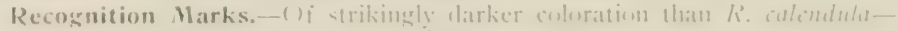
- "lppuned to lee the exelusive form in winter.

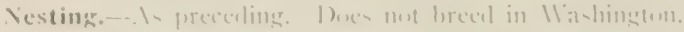

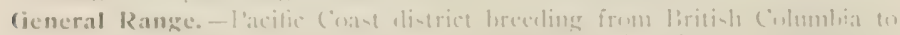

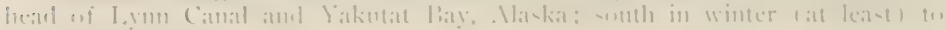
mirlelle ('alifomia.

Range in Washington,-- Farly -pring amel late fall migant, comment winter revilent on fruget sinuml.

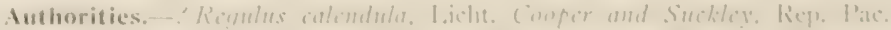

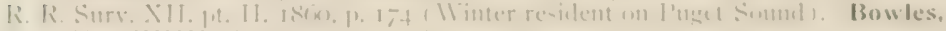

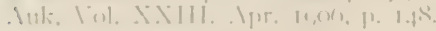

Specimens.-1:. I: I'( 1$)$.

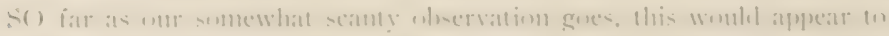

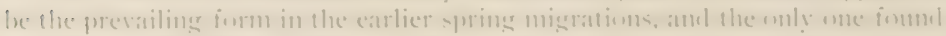

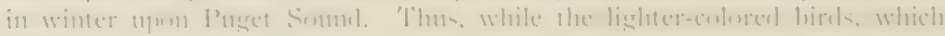

1 Kithay: $\rightarrow x$ premenax 
summer in our mommains and in British Columbia, are enjoying sumshine in Mexico, this Maskan coast dweller is re-rlyemg his plumage moler the dull skies of the P'acific watersherl.

The Sitkan Kinglet is not abundant in winter, altho it enjoys a general distribution, It does not associate in focks of its own lincl to any large extent. but oftener two or three individuals join thenselves to winter bird troops consisting of Chickadees, Scattle Wrens, Western Golden-crowned Kinglets, Ptuget Sound Bush-Tits, etc. It such times it is noticeable that they keep) largely to the lower levels, for they hunt and titter among the spirat thickets. salal hushes, hos and evergreen saplings, while their cousins only occasionally venture within five or ten feet of the gromul, and range from there to the tops of the tallest firs.

The notes, too, of the Sithan Kinglet are low-pitched and explosive, as compared with the fairy sibilations of the Golden-crowns. The neighborloos of "Seattle" Wrens and IVestern Winter Wrens will serve also to throw a certain wren-like quality of the Alaskan's note into fine relief.

\section{No. 106.}

\section{CHICKADEE.}

\section{O. L. No. T35. Penthestes atricapillus (I_inn.).}

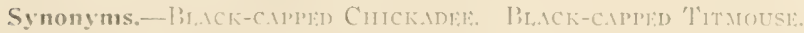

Description.-. Wult: 'fop of head and mape shining latack; throat deart black with whitish skirting posteriorly: a white band on side of head and neck, increasing in width ledhind: back and scapulars wrat with an olivacons cast and more or less ardmixture of buffy at the edges and as skirting: wings and tail cluski: more or less eflecel, especially on greater coverts and tertials, with anshy or whitish : breast and belly white; sicles, flanks and crissum washed with buffy or light "uste (nearly whitisli in summer) ; bill and feet clark. Rather variable in size; one aduh specinen measures: wing 2.27 (57.7) : tail $2.10(5.3 .3)$ : bill $.3+(8.6)$. Another:

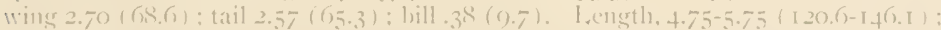
average of ejght specimens of medimm size: wing $2.60(66)$ : tail $2.4+(62)$ : lill

Recognition Marks. - Warbler size: of lighter colomation but not cortainly

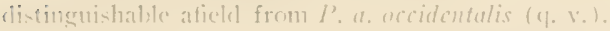

Nestimx.- lest: a heary mat of moss, grasses, and plant-down, linerl with

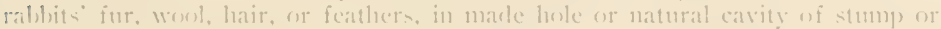
tree, w-mally not oser ten feet from the grommel, and near water. lings: $5-8$. white, marked sparingly with redelish Jorown, in small sponts, tending to gather

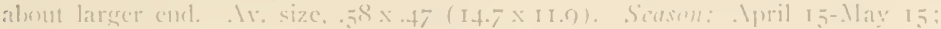
rime larood. 


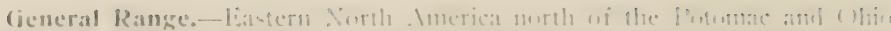

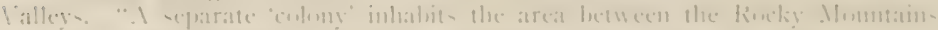

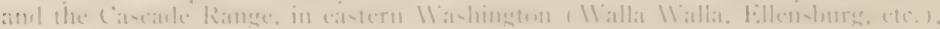

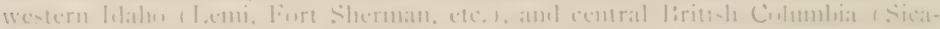

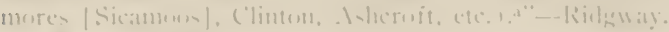

Range in Washington.- - I aluse.

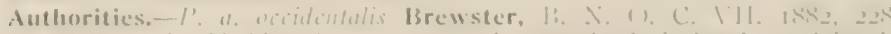

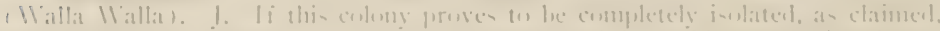

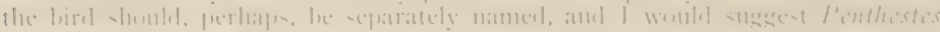
etricupillus fortuitus.

specimens.-1H. I'!

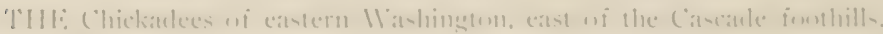

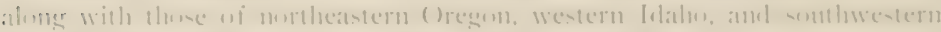

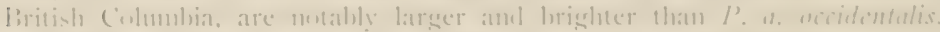

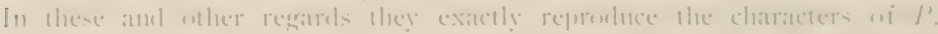

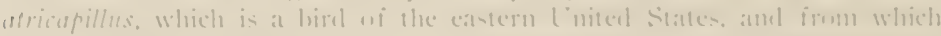

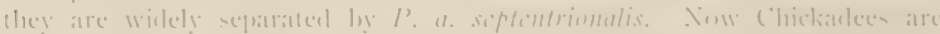

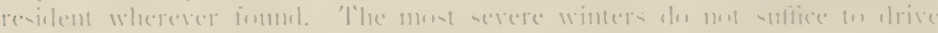

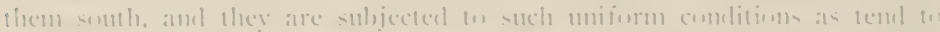

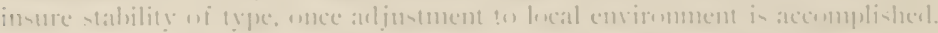

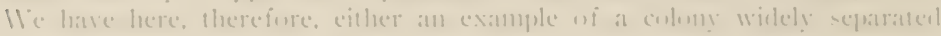

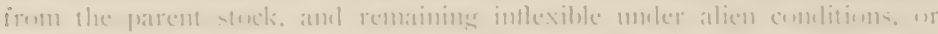

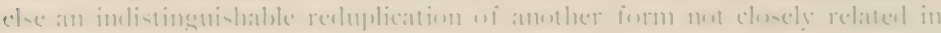

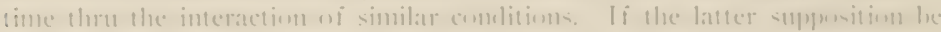

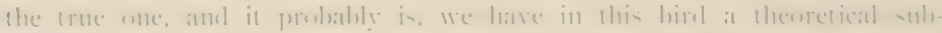

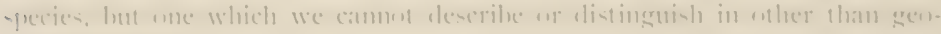
ermiplixial termis:

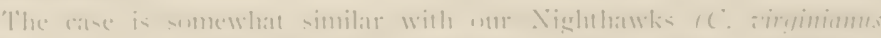

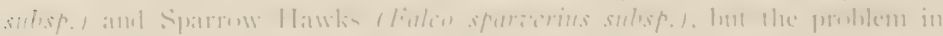

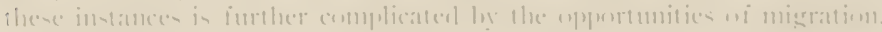

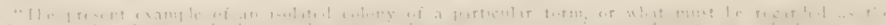

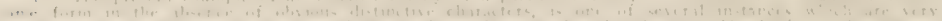

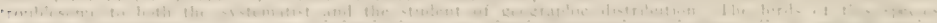

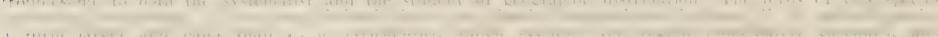

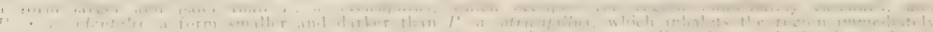

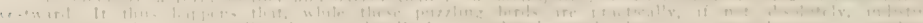

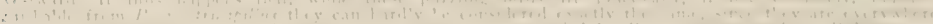

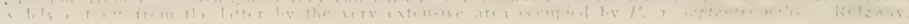


No. 107.

\section{OREGON CHICKADEE.}

\section{A. O. L. . Do. 735 b. Penthestes atricapillus occidentalis (Ihatirl).}

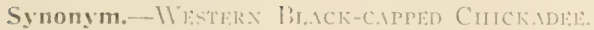

Description.- - dults: Similar to I'. atricapillus but smaller and coloration mucl darker: whitisl colging on wings and tail much reduced in area: "back varying from deep motse-gray or very slight buffy slate-gray in spring and stmmer to sleep hair-brown or light olive in fall and winter plumase" : sirles and flanks pale bufiy in spring, strong brownish buff or pale wookl-brown in fall plumage. I, ength $4.50-5.25$ (I $\left.+4.3^{-1} 33.3\right)$ : wing $2.44(62)$; tail $2.20(56)$; bill $.37(9.5)$ : tarsus .66 (16.8).

Recognition Marks.- Marbler size: no white stripe over ere as distingruished from $P$. yambcli; back gray as distinguished from $P$. mufescens.

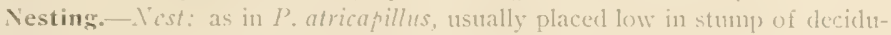
ous tree. Eggs: as in foregoing. Scason: April i 5 -May i 5 ; one brood.

General Range,--l'acific Coast district from northern California to liritish Columbia ( Port Moocly).

Range in Washington,--Resident west of Cascades; characteristic of wet lowlands and borders of streams; intergrades with typicus on east slopes of Cascacle Range.

Authorities,-I'urus occidcntalis l'aird, Baird, Rep. l'ac. R. R. Surr. IX.

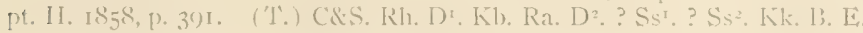

Specimens.-U. of IV. I'. T'rov. I3, E,

CIICK.\DELS: abound in Washington; and, because for the life of you you cannot surely tell whose notes you hear, there is a perennial necessity for levelling the glatses to make sure which is passing. Oregon or the chestnutbackerl. There are differences-Oh, bless you, yes-but then you alwars want to make certain, if only to pat yourself on the back and saty, when you liappen to have guesserl correctly. "There, I knew it was an Oregon; I can always tell by its squeak."

(hickarlees are friendly little foll (and this remark applies, irrespective of species), so that wherever they go except in the busy nesting season, they inm the nuclens of a merry batnel. Western Golklen-crowned Kinglets, Sitkail Kinglets, (reepers, Juncoes, Thwhees maybe, and a Seattle Mren or two (o) gratal the terrestrial passage and to furmish sport for the ferlerated farries. The ('lrickaclees are melisputed leaclers, tho their name be legion. While thes rematin aloft we may mistake their dainty sepueakings and minikin wass for forse of Kinglets, but if we can only determine what direction the flock is

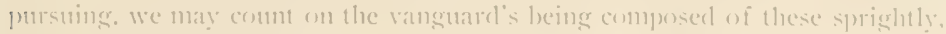
vancy litte lilack-caps. 


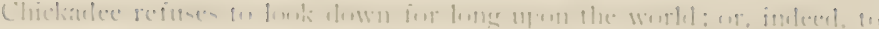

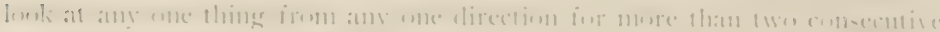

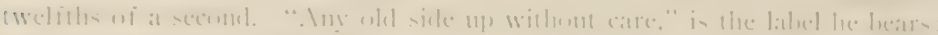

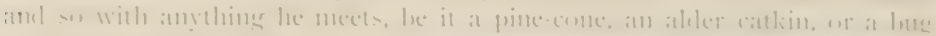
beringes loranchlet. (up)

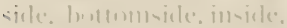
onsiste, all is rights siele tot the nimble ('liteliat slee. lamits! their litule.

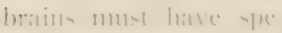

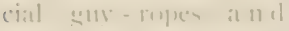
stats- elec they woulel hiave leens spillesl lomen ace, the wa: the

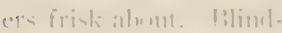
manti lntif. hivke-amel seck, and taer are merrs ammes cmolngh when plaver ente ont (m) plane. but when staterel in there dimensions. with a laburineh wi in terlacines bounderes fon latzatre mole the lilithe biral whese pration we siner anthe pusibile. master the ir intrisosie

lint Chickateler is as confielinger andel at com ticlence-insitiner :14 lec is capalile. It is precisel heratree wom habhle al

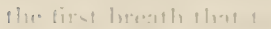

wlute wew

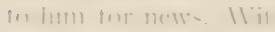

a. 1:1101115 W1 11+101

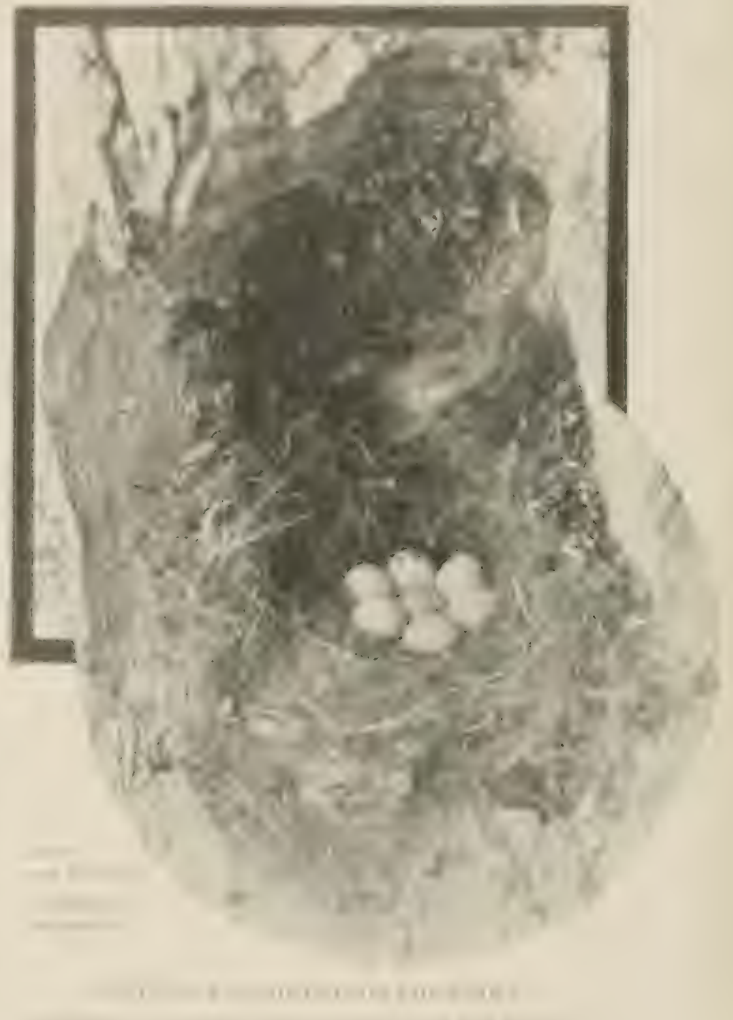

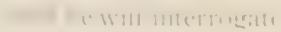

e

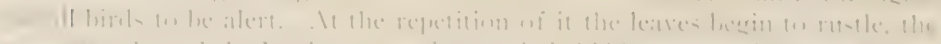

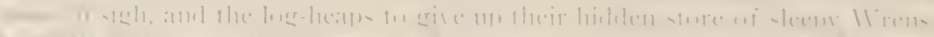


symenk were the strange discorery: the Steller far takes notice and sidles orer (1) spy mon the performance: while the distant-faring (row swerres fron his

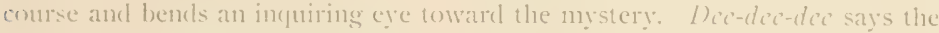
black-cap). A humelred bealy eyes are bent upon you, trying to resolve your domino of corduroy or khaki. Ciñ says the Cirow in comprehension, and ron know that the gane is mp,- - wp for all but the Chickadee. He will staty and talk with you at long as you may enclure to pucker your lips to his farry lispings.

It is no exageration to say that the "Sree-tee" note of the Chickadee. passibly inntated, is the quickest stmmons in the bird-worlel. It is the open sesame to all woolland secrets. One drawlack, lowever, attends its use: you cannot compass it when the air is chilly and the lips thick. Xinm: the eastern bird. (I'. atricapillus) las a clear, high-pitched call-note,

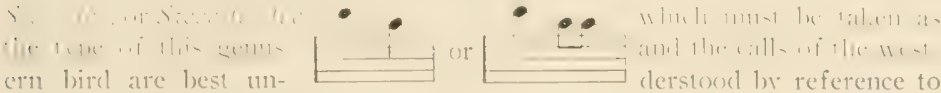
this nom. In the song of occitentalis the first note of the type, "high C," is ofterest repeated three or four times, and has a double character impossible (1) represent on palper: while the whole ends. or most, with the lower nute of atricapilins. These notes mav be called the deo deo deo day series. In rare instances thes become a ravishing trifl on high ('. befoncl innitation or amalesis.

Fior the rest. Chickindee's motes rlivide themseleses inter spuealss, vocai noles, and whis 1 les () f 1 he apuenks one is il wer hish-pitcherl. wh h w in w nole. which closedy re.

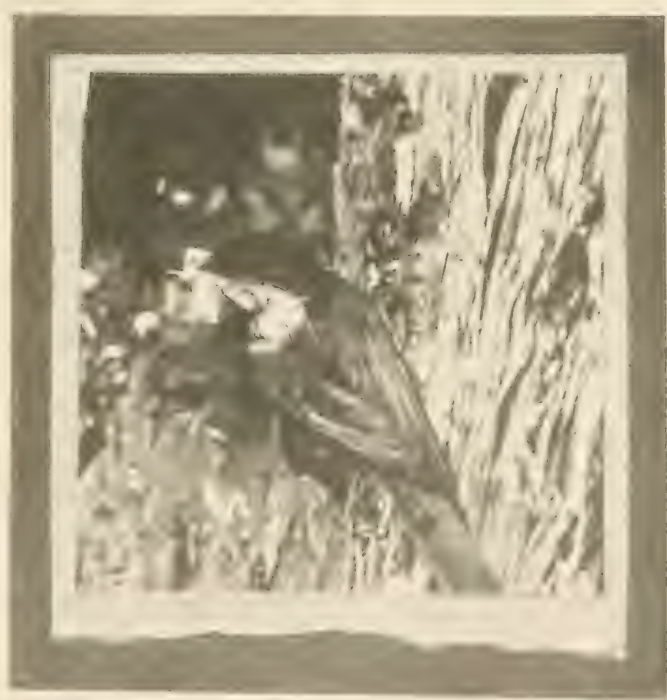

Fit 2 sit on Oxon.

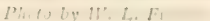

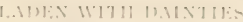




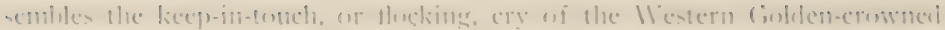
kinglet. 'The chiclatulees emplesy this when in compram with kingh

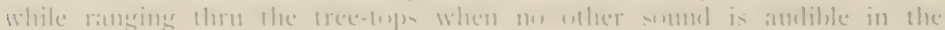

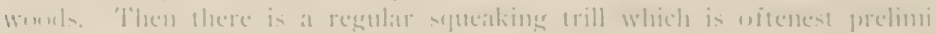

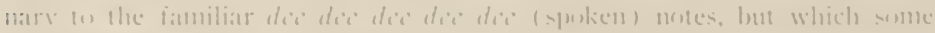

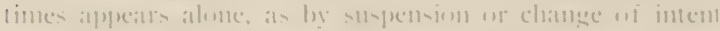

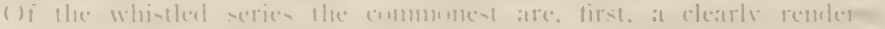

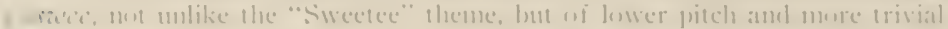
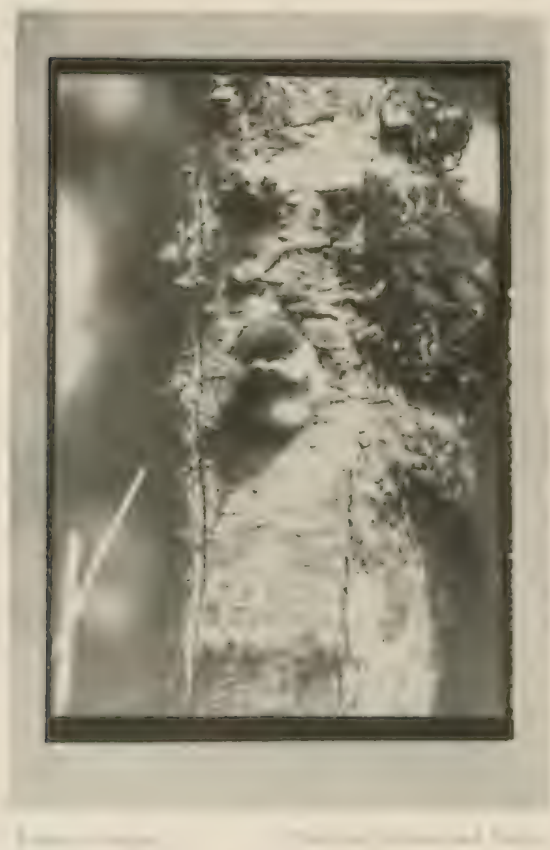

Y $\quad 41 \mathrm{Y}$ characler: amkl. secombl the di

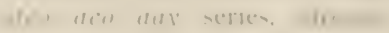
recorrenl. 'Tlere in a sriking renemblanee letween the whin lled amel the ymolien serien The day dety warel- enrespond (1) the dion dew whister. althe they are offenest precerlest b a fairs sneere. Which we lats comventionalizerl in "("hicl

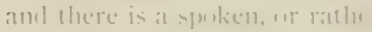

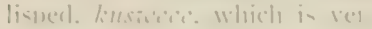
elammine amel delicalle. 1 sjuken trill accors infre quently, amel offers ils analug -w hush whistle and siluesti

'lowe mats seem like lim flum distinetions. Thes are

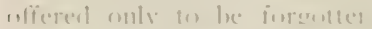
but the entomeneme of the me ("hickatere trones) bous conconmentes

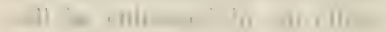

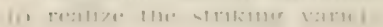
if the theses learel

comtrare on the went at

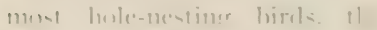
chiskarleer tedieves in wars

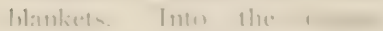
avisy whether nac.....

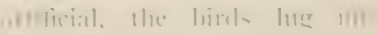

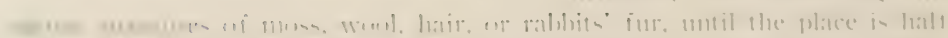

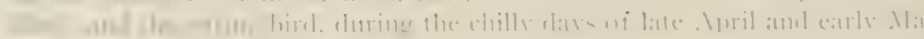
anti!

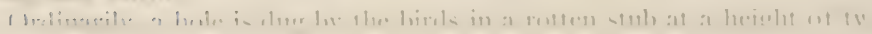


wr three feet. 'T'he near presence of water is a prime repuisite, and a low swampy woods is the farorite location. Sometimes a deserted nest of a Gairdner lloodpecker may be used: but, on the other hand, excavations may be mate in green wood at no little cost of exertion on the part of the midgets. Sereral nests I have seen in willow and poplar trees, and at a height of fifteen or twenty feet.

lommg Chickadees are such cuming little creatures that the temptation to fonclle them is sometimes irresistible. 'The parents may have very clecicled views ats to the propriety of such action, or they may regard you as some benevolent giant whose ways are above suspicion. Not infrequently; if the young are kindly treated, the parent bird will venture upon the hand or shoukler to pursuc its necessary offices.

\section{No. 108 .}

\section{MOUN'TAIN CHICKADEE.}

\section{O. L. No. 738. Penthestes gambeli (Ridgrvay).}

Description.-Idults in sprine and summer: Sonnewhat as in I'. atricapillus. heas and throat sinilar but black intermpted by strong white superciliary stripe nearly or quite mecting fellow on forchead: upperparts plain deep asliy gray, or mouse-gray; wings and tail deeper sray with some pale grayish edging: sicles of head and neck white; molerparts (except throat) dull white more or less washerl on sisles, lianks, and moler tail-coverts with gray. Adults in fall and winter: Lpperparts washed with buffy; brownish on sides: some white erlging on forchead and superciliary stripe broaler. Young birds are duller as to black of hearl and neck, and have a less distinct superciliary. Length about 5.00 ( 127 ) : wing $2.75(70)$; tail 2.35 ( $(10)$; bill .40 (10.2); tarsus .70 (I8).

Recognition Marks.-11arbler size; much like ()regon Chickaclee, but white superciliary distinctive: range higher (on the average) than other species.

Nesting. - Vest: yuite as in atricapillus and similarly situated. linys: $5-8$. fure ahite, or only faintly marked with redelish brown. Av size, 60 $\times 4.45(15.2 \times$ II.fl. Sedson: Ilay: one brond.

General Range.-Momntains of western Lnited States from the Rockies to the I'acilic Coast : north to british Columbia (chiefly east of the Cascades); south to morthern I, Inwer Califormia.

Range in Washington.--Resident in the mountains and timbered foonlibls, chiefly east of the (Calscarle) divicle: catsual at Seattle.

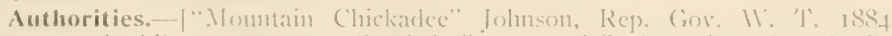

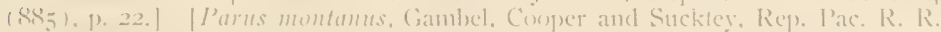

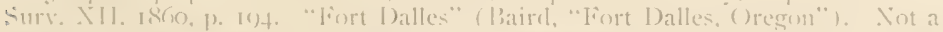

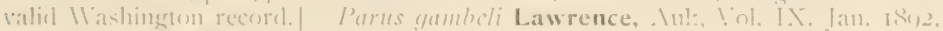

Specimens, - I'. of 11 . I'rox: (' 


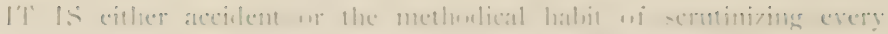

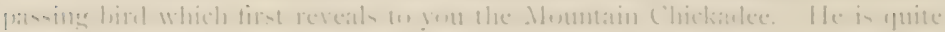

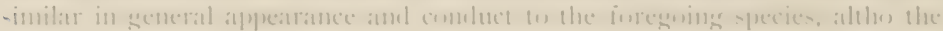

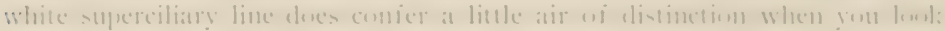

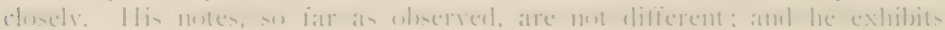

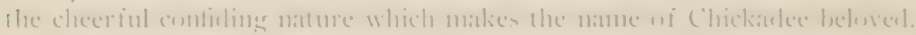

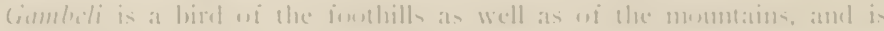

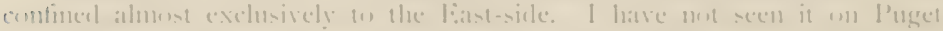

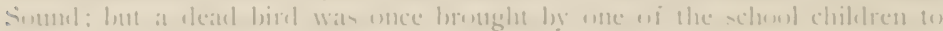

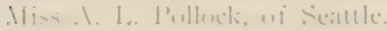

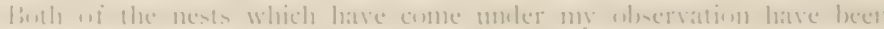

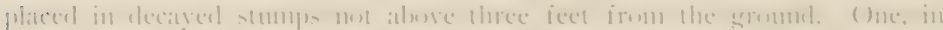

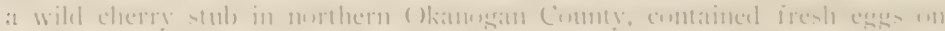

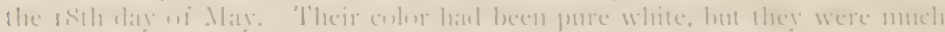

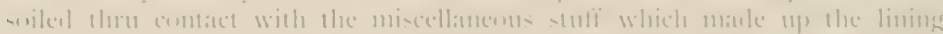

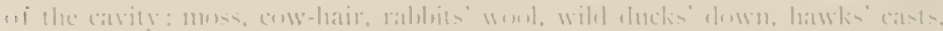

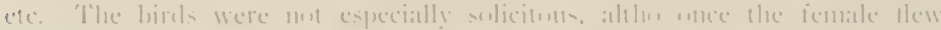

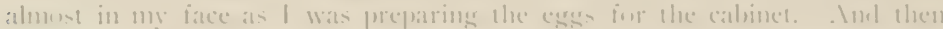

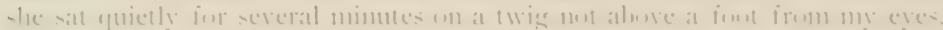

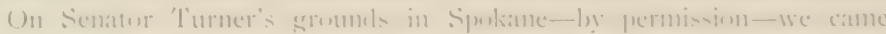

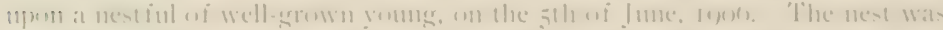

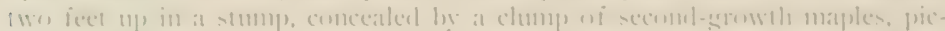

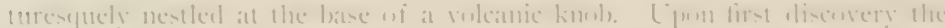

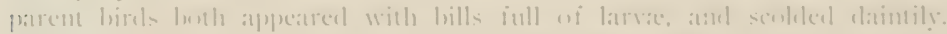

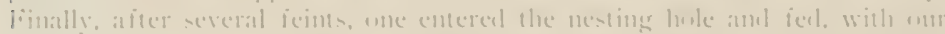

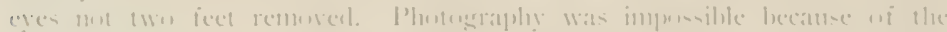

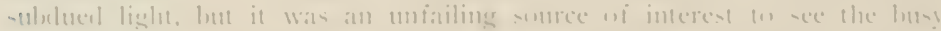

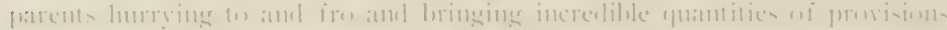

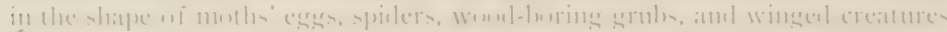

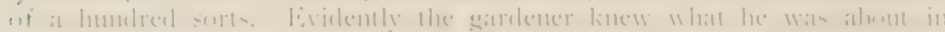

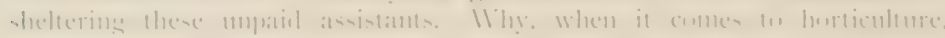

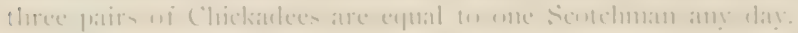

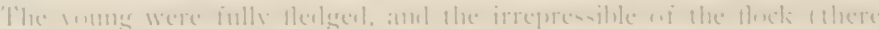

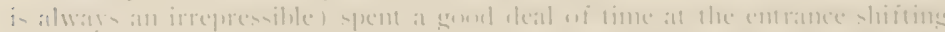

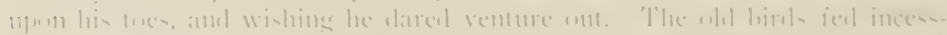

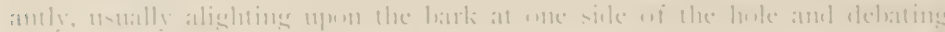

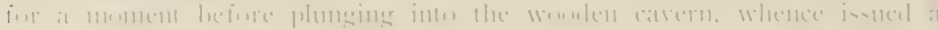

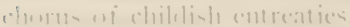

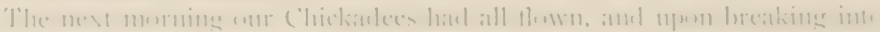

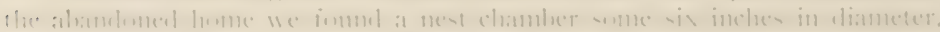

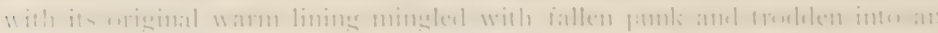

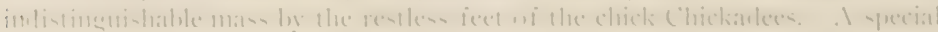


feature of the interior construction wats a knot, which had persisted ats a harel core when the surromeding punk had been removed. 'This hat evidently been no end of annsement to the young bircls and of service to the parents as well, for its surface was polished by the friction of many. Penthestine toes.

\section{No. 109.}

\section{CHESTNUT-BACKED CHICKADEE.}

\section{A. (). [:. No. 7 1. Penthestes rufescens T'owns.}

Description.-idults: Crown and nape dull sepia brown becoming sooty tmarel lateral border-black before and behmel cye, separated from sooty black throat patch by large white areat broadening posteriorly on sides of neck: back, sapulars, rump, and sides of boxly rich chestnut; lesser wing-coverts grayish brown: upper tail-coverts hair-brown or more or less tinged with chestmut ; wings and tail deeper grayish brown eclged with paler gray; remaining molerparts (centrally) white; muler tail-eoverts washed with brownish: bill black; feet brownisli dusky; iris brown. The brown of crown and hind-neck deepens in winter. Jomng bircls are duller in coloration, especially as to the chestnut of back and sides. Length about +.75 (120.1)); wing 2.35 (60); tail $1.00(48.3)$; bill .37 10.5): tarsis . 65 (16.5).

Recognition Marks. - I'ygmy size ; chestnut of back and siles distinctiveotherwise not easily distinguished in the tree-tops from $l^{2}$. u. occidentalis. I'requents thicker timber ankl, usually, drier situations.

Nesting.-Yest: in hrole of dead stub, usually some natural carity enlargecl and customarily at moderate heights, I0-20 feet, a couch of fine bark-shreds, sreen moss, etc., heavily felted with syuirret-, rabbit-, or com-lair, and other soft substances. Ligys: $7^{-9}$, pure white as to gromel and sparingly sprinkled with redelish brewn dots, chiefly about larger encl. Ar. size, of $x .+7$ ( $15.5 \times$ I I.9) ) Siasun: April 25-June I5 (according to altitucle); one brood.

General Range.- I'acific Coast district, from northern California to Alaska (I'rince IIillian Sound and head of I, ynn Canal), east to Montana.

Range in Washington.-Resilent; abundant and thoroly distributed thru iorests of ()fynupic I'eninsula and l'uget Sound region, decreasing in mumbers from Cascacle clivide eastward (in lienvier coniferous timber only). (Whe have no records of its occurrence east of Stehekin.)

Authorities.-Pams mescoms Townsend, Joum. Ac. Nat. Sci. I'hila. VIIT.

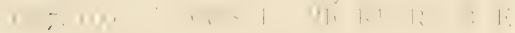

specimens.- U. of 11: P'. I'rov. 13. E.

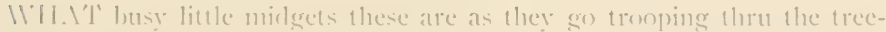
wops intent on plunder! Inel what a merry wat they wage on heete and wit as they acrutinize ererr crevice of bark and bract! 'The bircl eats insects at 


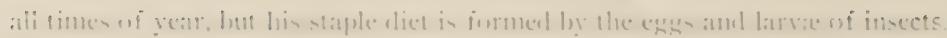

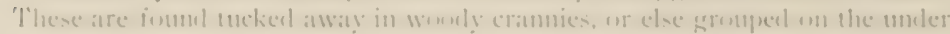

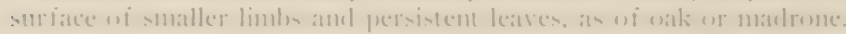

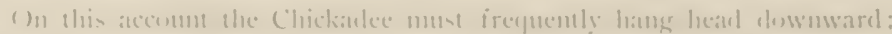

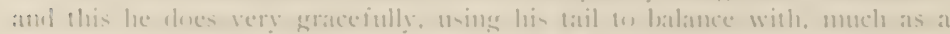

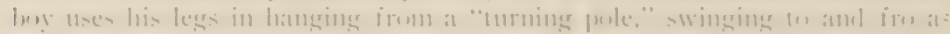
llue lo thomly enjoyed it.

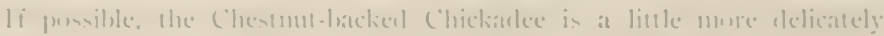

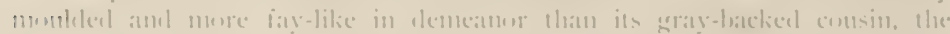

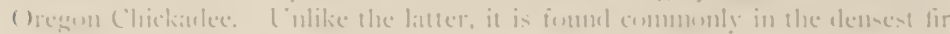

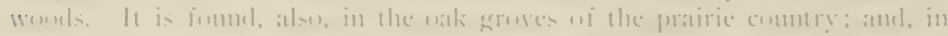

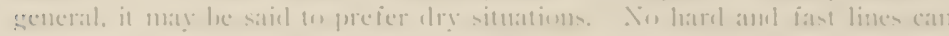

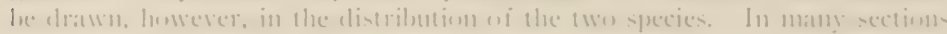

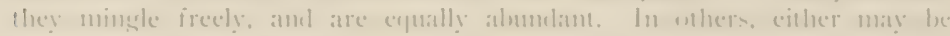

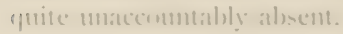

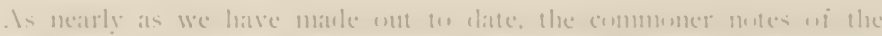

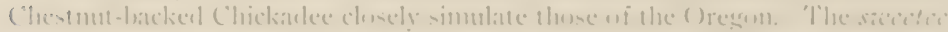

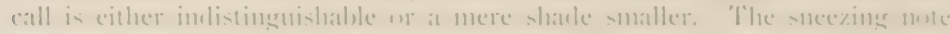

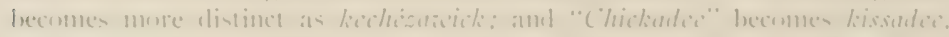

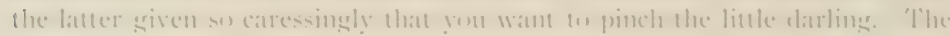

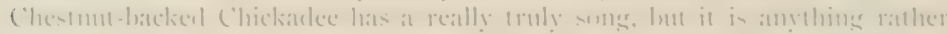

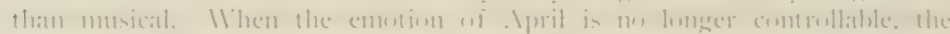

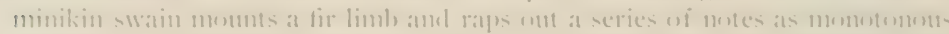

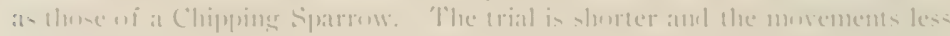

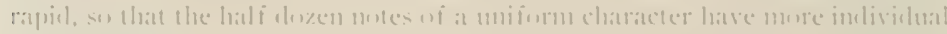

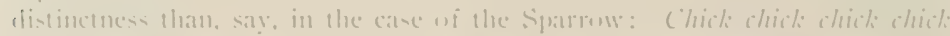

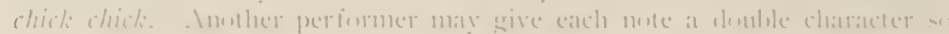

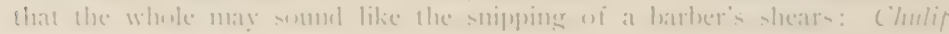
inulip shulip ilumlip chulip.

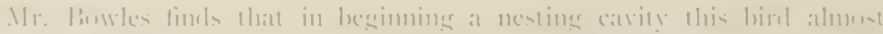

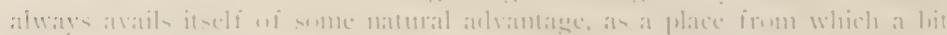

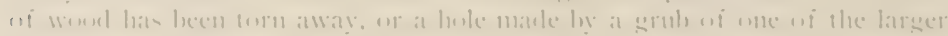

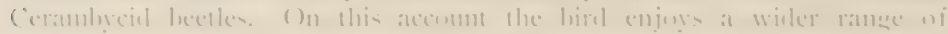

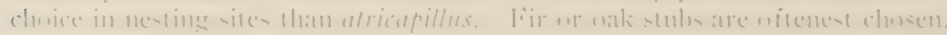

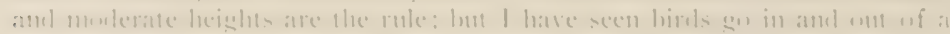

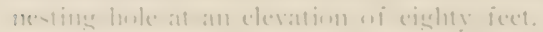

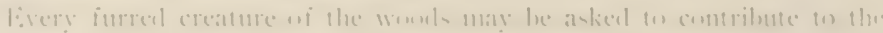

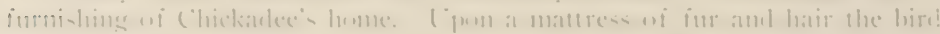

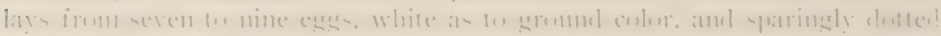

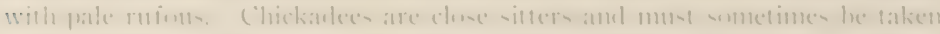

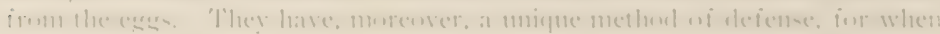




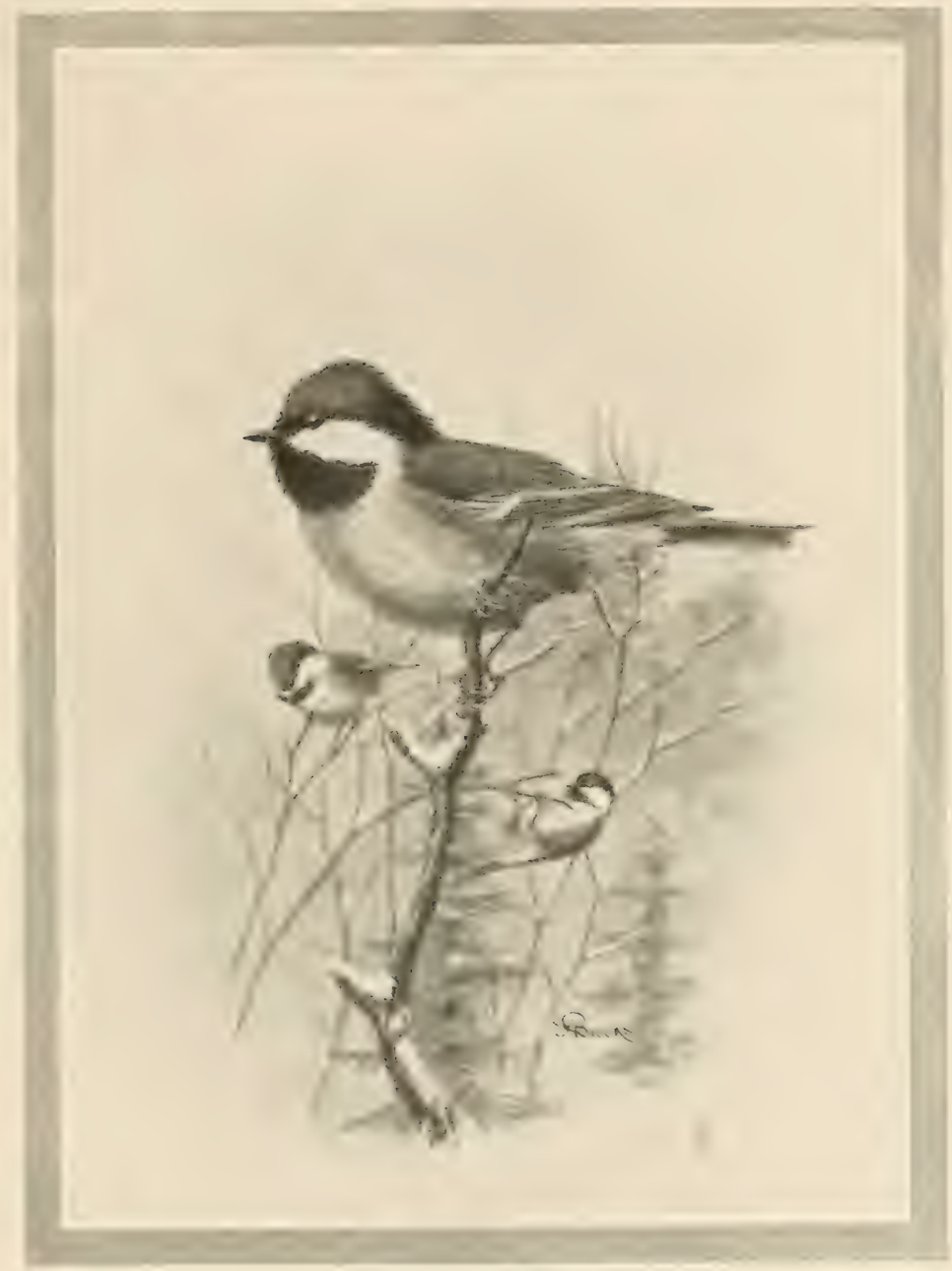

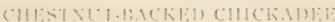




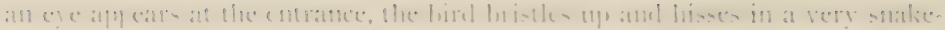

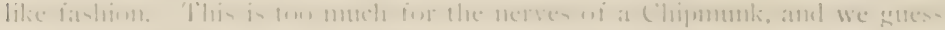

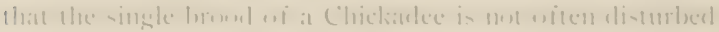

Vin. 1213

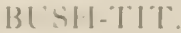

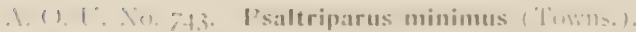

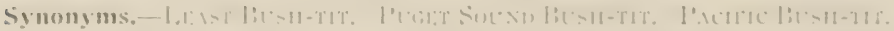

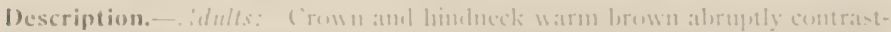

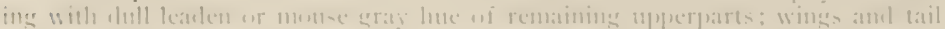

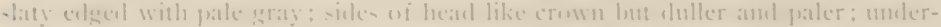

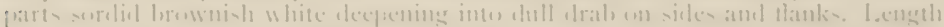

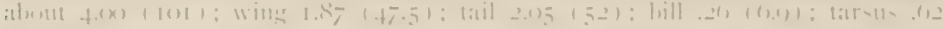

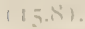

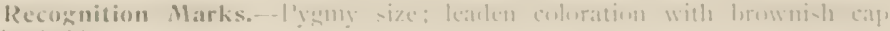
mmini-takialile.

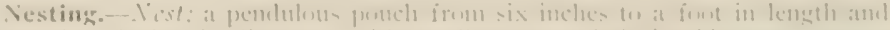

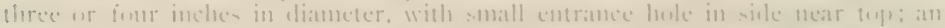

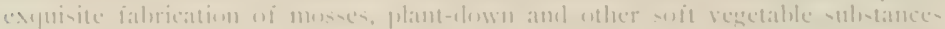

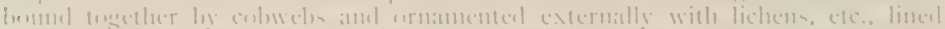

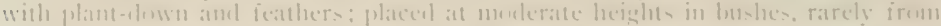

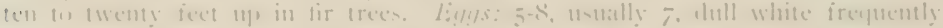

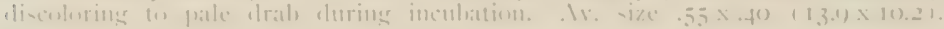

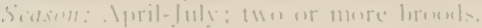

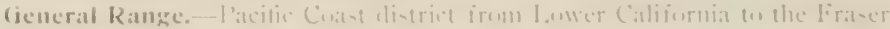
Kiver

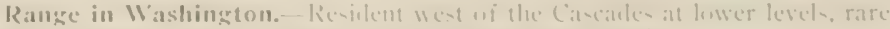

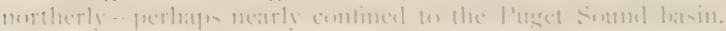

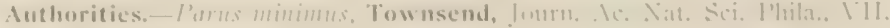

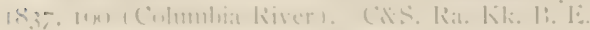

specimens, -1 , wi 11 . I'ros. 1:

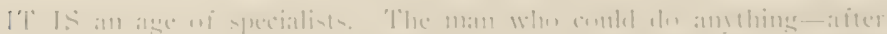

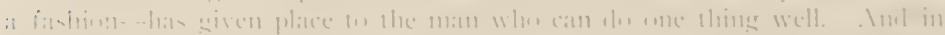

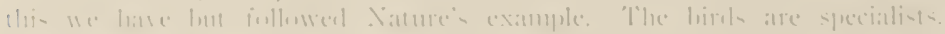

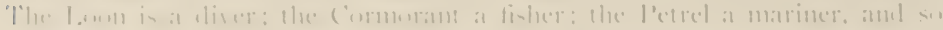

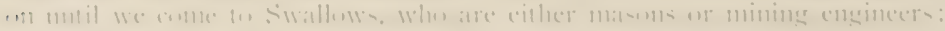

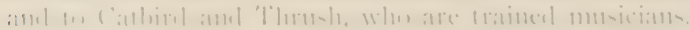

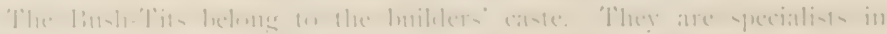

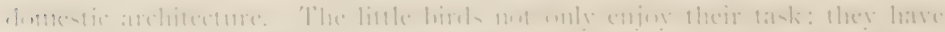

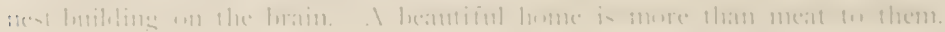




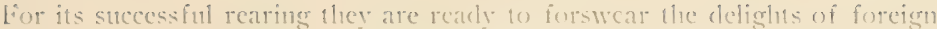
tratel, and to its embellishment they devote every sumplus energy, even after the children have come.

If there were time it would he interesting to trace the genesis of this architectural passion. Sufice it to say that the Bush-lit comes of a ratee of builders. 'They call him 'T'it, at name shated in common with all the Chickatdees: and Chickatee he is in structure and belavior. in his alosolute indiffer ence to position or halance, in his claintiness and sprightliness. Now Clickatdees, altho they have lost the art of building, arc specialists in nestlining. (A nest lined with rabbitfiur means as mutcli to a Chickadee ns floes a sealskin jacket to you, nuy lady!) Hence the Chickarlee strain is not lost upon our subject. 'llye 'T'it. further, shows his affinity with the Ninglets in a habit of restlessly. Airting the wines: and the Kinglets. as we knom: are master buiklers Pitte it is 10 the IVtrens that the Busle - Tit ones most of all. and? especially in the Tule llren. fn: tie Jias taken the seneral concepinn of a com pietely encloserl nest and worked

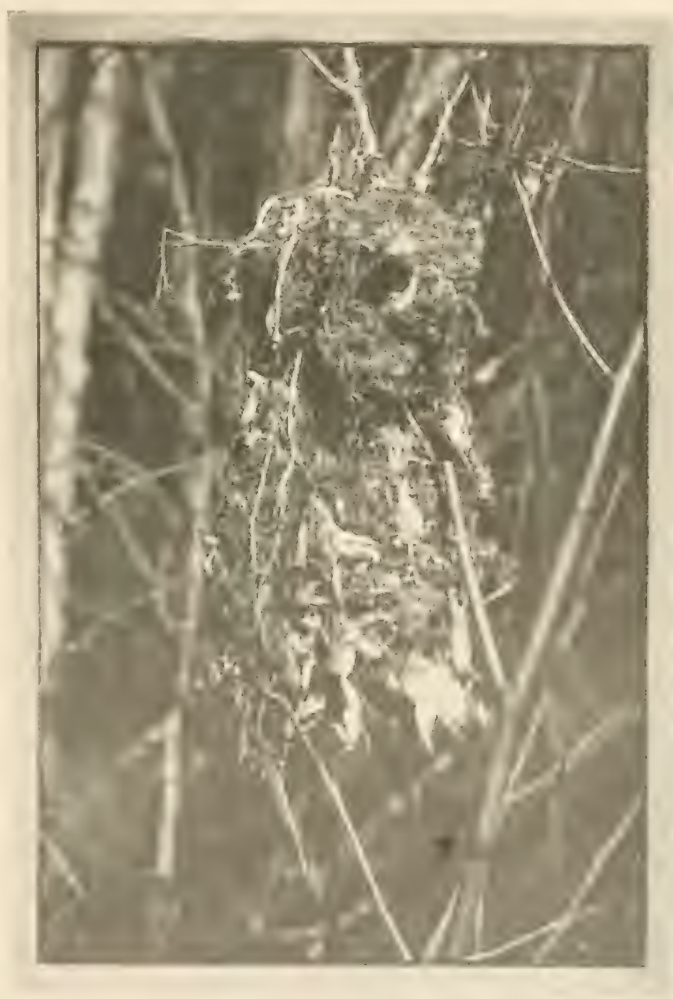

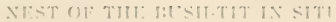




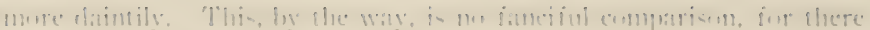

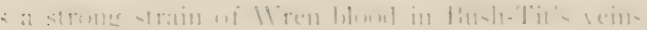

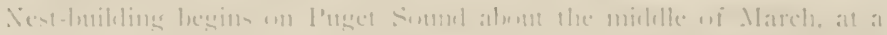

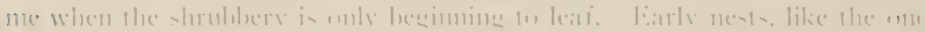

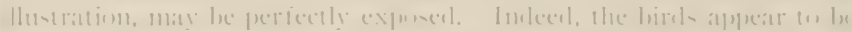

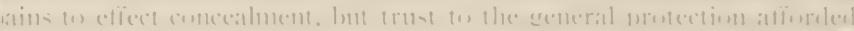

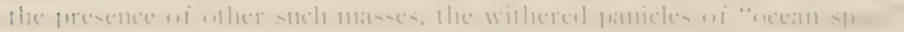

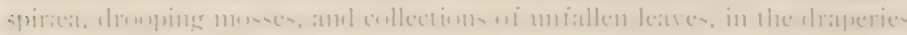

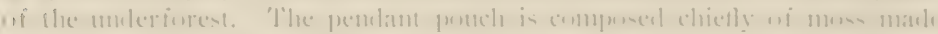

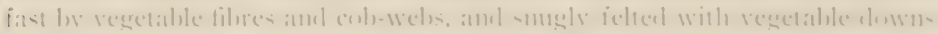

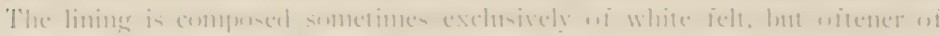

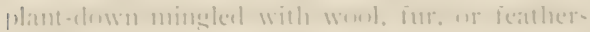

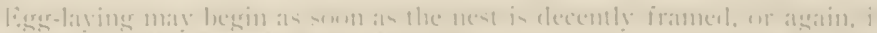

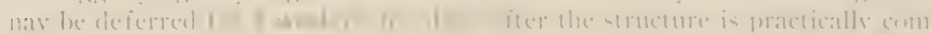

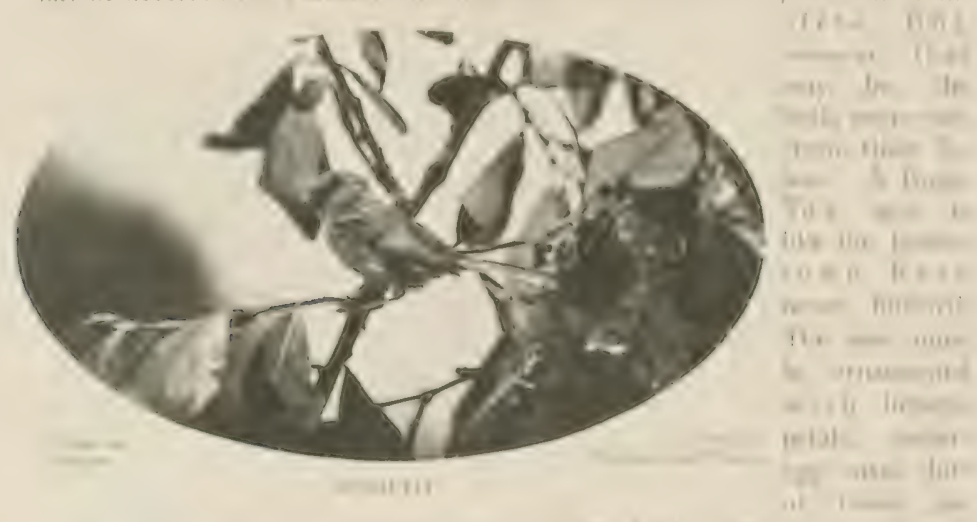

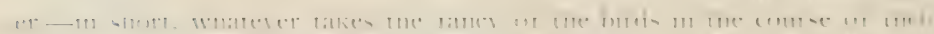

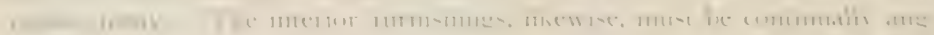

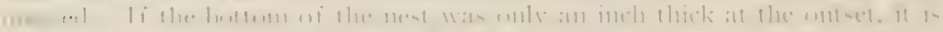

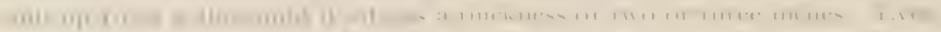

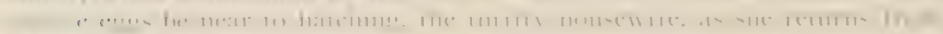

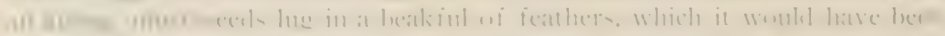

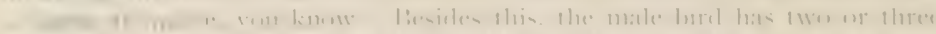

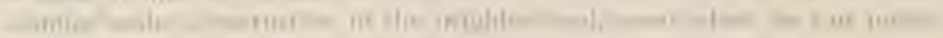

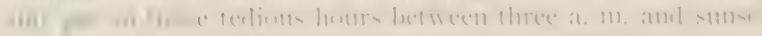

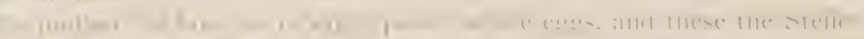

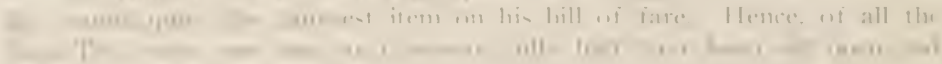


sobbed by the blue-conted thug. One stuch tragedy, with its human interest.

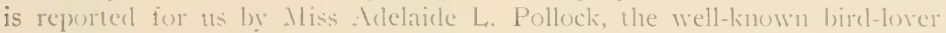
of Seatlice as follows:

"Ne fotnd the long purse-slaped nest swinging from the lower branclies of a giant red fir July sth, and every day thereatier for two weeks some member of our class in ornithology visited the castle in the air. It was woven with a silken fomblation greaned in the cobvelos of the forest, lined with the

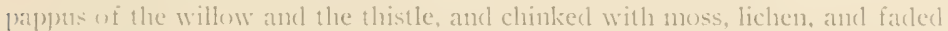
latzel blossonns. IV ith an eye to man-fashion, the architects had papered the home, but only in spots on the outsicle. Il hat a delight it wats to watch the parent bircls light on the dorstep with a worn and plunge insicle. Isy the wriggling and swaying of the nest we knew there was something doing there. but we ladel to guess at the gaping mouths. July i gth was a clreadful clay for the nestlings. Ife heard the pitiful notes of birds in distress as we approacherl and found the nest was gone. Searching the gromul it appeared with a great gapping hole in one sirle. which told of the work of jay, crow, or chipmunk. On investigation a tiny eleal bunch of feathers was drawn out: and then something mored. 'The nest was tied to a hazel branch and quick as a thought the parents went in at the fromt and out at the new back loor. Gaining conrage they triest again, this time with food, and within the hour had apparently forgotten their tragedy and settled down with the one wee chick. IVthile the parents were foraging we opened the slit and the way that baby birel turned tail-nu and buried its head in the lining of the nest reminderl us of the nstricls.

"July 2oth we saw the youngster scramble up the sicles of his home on

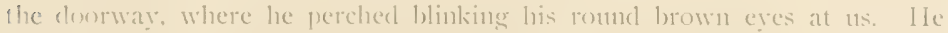
seeneel to enjoy having his throat and hack scratched and clicl not resent ont presence, but his parents dicl. for the nest was deserted at sumblown of July:

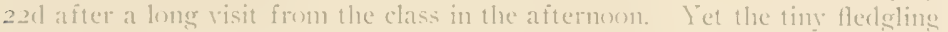
condel scarcely leap from twig to twige of the tangled undergrowth into which ine rlisappeared. 'Two days later we lancied we recognized the same fandily by a peculiar white iris of one parent birel, as they flitted from loranch io brancle of an alder forty feet above the sionund."

\section{No. I I.}

\section{SLINIER-BILLED NUTHATCH.}

A. (). 1:. Ln. 727 a. Sitta carolinensis aculeata (Cassin).

Description.- Idult mete: 'lop of heacl, nape and upper boundary of hack bining hack, with a slight greenish reflections: remaining mpperparts ashy blue: 


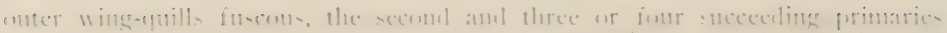

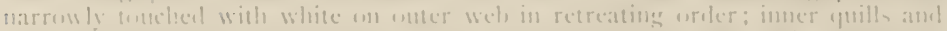

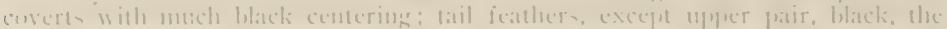

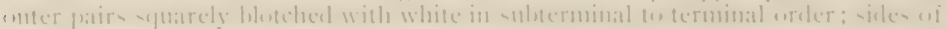

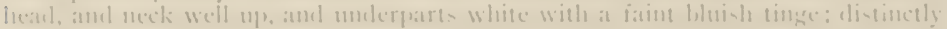

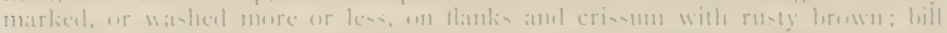

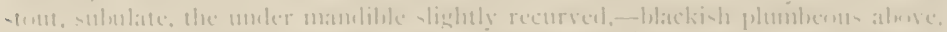

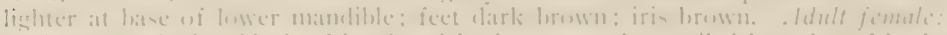

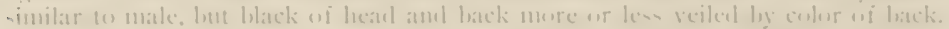

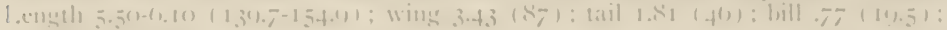

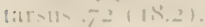

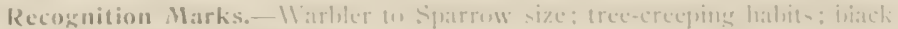
amel athe lilue allowe; white helows:

Sesting.-. Vist: a deserted llinelpecter lwhe, wr newly-mate cavity in

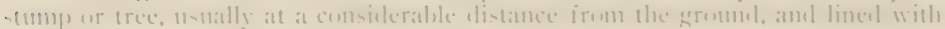

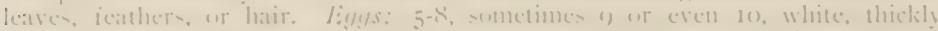

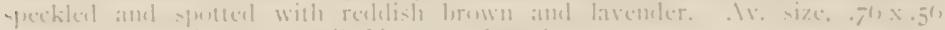

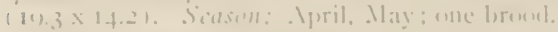

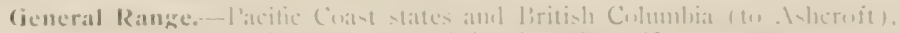

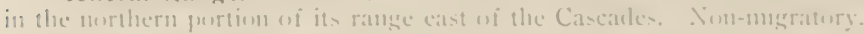

Range in Washisgton.- lecielent, of regular ocenrrence in pine timler cat uf Cancaules; rare and lecal in l'meet somml region,

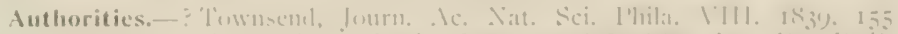

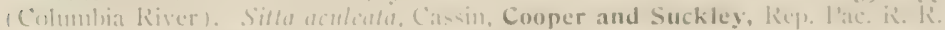

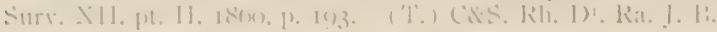

specimens.-1 (l'. wi 11 ., l'row: C'.

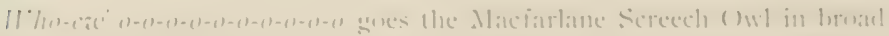

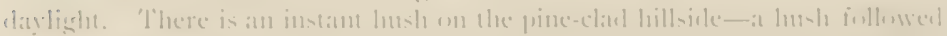

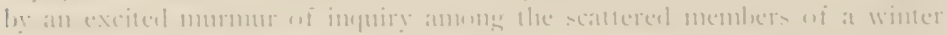

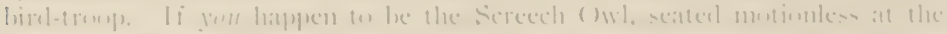

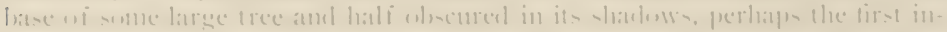

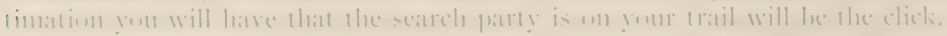

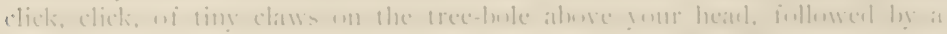

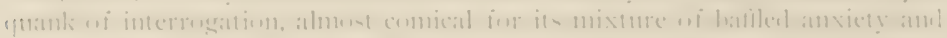

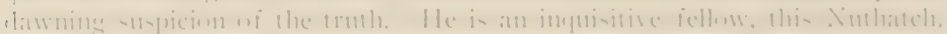
fin, s.

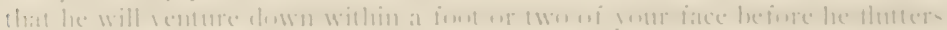

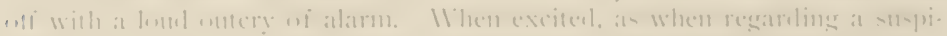

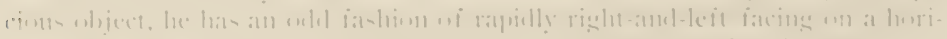

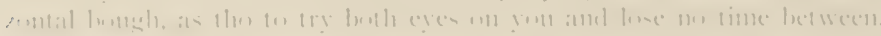

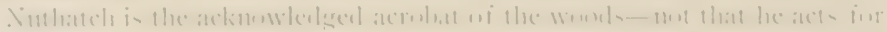

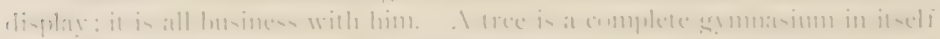

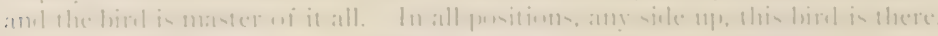

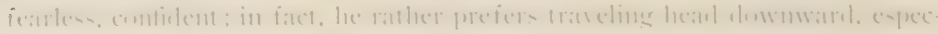


ially on the main trunk route. He pries under bark-scales and lichens, peers into crevices and explores cavities in his search for tiny insects, larve, and insects' eggs, especially the latter. 'I'he value of the service which this bird and his associates perform for the horticulturist is simply incalculable. 'There should be as heary a penalty imposed upon one who wantonly kills a Nuthatch or a Chickadee, as upon one who enters an enclosure and cuts down an orchard or a sliade tree.

The Nuthatch has a variety of notes, all distinguished by a peculiar nasal guality. When hunting with the troop he gives an occasional softly resonant tut or tut-tut, as if to remind his fellows that all's well. 'l'he halloo note is more decided, tin, pronounced à la francaisc. By means of this note and by using it in combination, they seem to be able to carry on quite an animated comersation, calling across from tree to tree. During the mating season, and often at other times, they lave an even more decided and distinctive note, quonk, quonk, quonk, or ho-onk, ho-onk, in moderate pitch, and with deliberation. They have also a sort of trumpeting song, but this is rarely heard in Washington; and, indeed, all the notes of the Slender-billed Nuthatch liave a softened and subdued character as compared with those of the eastern bird, typical $S$. carolinensis.

The nest of this Nuthatch is placed in a cavity carefully chiselled out, ustrally at a considerable height, in a pine stub, dead fir, or cottonwood. Both sexes share the labor of excavation, and when the cavity is somewhat deepened one bird renoves the chips while the other delves. Like all the holenesting species of this family, hut unlike the Woodpeckers, the Nuthatches provirle for their home an abundant lining of moss, fur, feathers, and the like. 'This precatution is justified from the fact that they are early nesters-complete sets of eggs being found no later than the second week in April.

The male is a devoted husband and father, feeding the female incessantly during incubation, and slaring with her in the care of the large fanily long after many birds have forgotten their young. The young bircls early learn in creep up to the montly of the nesting hole to receive food when their turn comes: and they are said in crawl alont the parental tree for some days hefore they attempt flight.

The Slender-billed Xuthateh is of rare oecurrence west of the Cascates. being chiefly confined to the wooded edges of the prairies. In the eastem half of the state it may be rare locally but increases in alumdance in the northeastern section. Wherever fomd, this bird associates frecly with the related species and is especially fond of the society of the Pygmies. A winter bird tronj encomtered near Spokane inclucled, beside a half dozen Slender-bills. as mamy Rerl-freasted Nuthatches, a score of P'ygmies, a dozen Mountain Clickarlees, four or five Patcheleler Wrondpeckers, a few Clark Nutcrackers. and twenty Red-shafterl Flickers. 


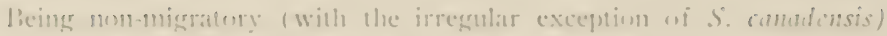

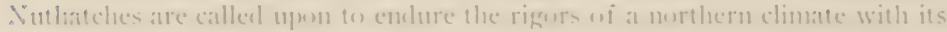

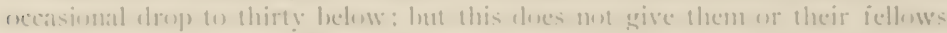

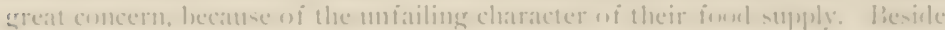
that, please remember that feathers and fat afford the warmest protection kituwn.

No. 112.

\section{RED-BREASTED NUTHATCH.}

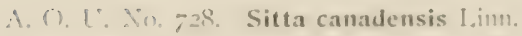

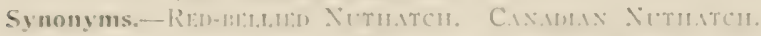

Description.- Halt mole: ('rown and nape shinine black: white superciliary lines meeting on extrene forchead: a black hand thru eye: remaining upperparts grayisls hilue: wings fusents, ummarked: tail feathers, except upper

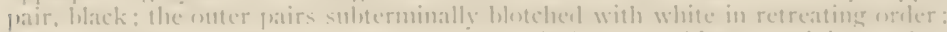
chin, and sides of heal, and neck betew the black. pure white: remainine umerer-

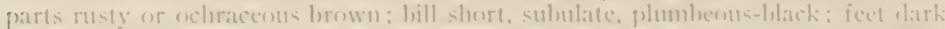

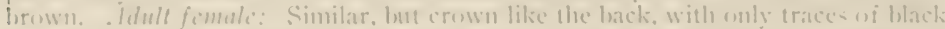
beneath: lateral hend-stripe blackish: usually paler rusly helow. Immaluri:

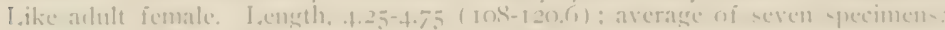

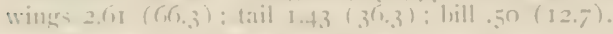

Recognition Marks. I'ygmy size: lilack and grayinh bluce aluse: ru-ty fecholl : tree-crecping hallit:

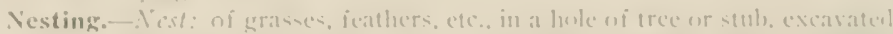

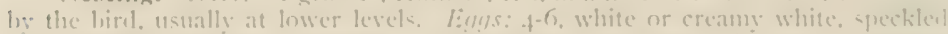

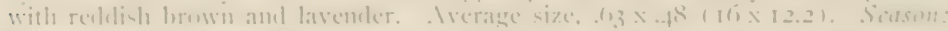
fir-l week in . Vay: me lirnoil.

General Range- North America at laree, breceling from morthern New

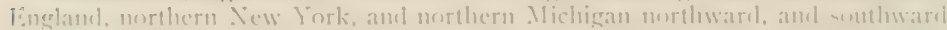

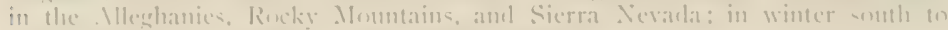

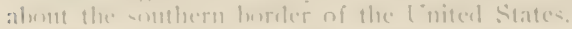

Range in Washisgton.-Commen resilent and migrant in timberent -ectmol

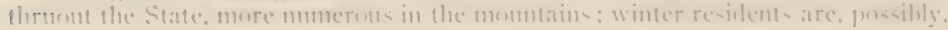
Alackin hirkls.

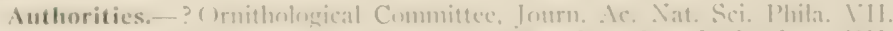

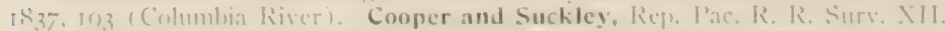

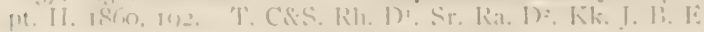

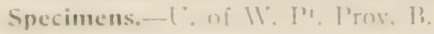

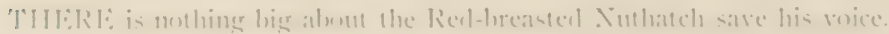

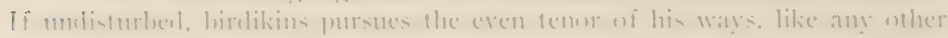

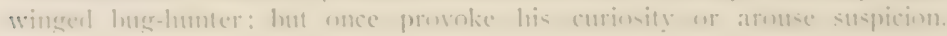


and he publishes forthwith a broadside of sensational editorial matter which no thoughtful reader of the woods can overlook. 'l'he full war-lance song of the Recl-breasted Nuthatch, executed, for instance, when he hears the false notes of the Screech Owl, is something like this:

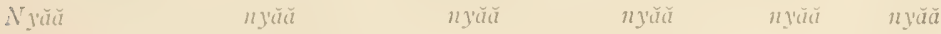

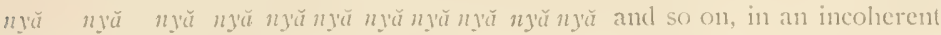
strain of will excitencnt, until he runs clean out of breath and (juits, exhausted. The early notes of this orgic rhapsody are interrogative and penetrating; the succeeling notes are a sort of trumpeting challenge for the intruder to show himself: failing which. the irate Creeper drops into a lower, non-resonant series, of rloubtful meaning and more doubt ful morals. But the bircl is not always angry, and the masal call sounding on migration has a fricndly quality about it which lrings one hastening ont-of-loors to greet the traveler again. Contrary to an early report, the liedbreast is ruite at home in on rleeper forests. Inrleerl, his is nne of the most characteristic roices of the solemu fir woorls. He still claims an interest however. in decirlunus timber. in botton lancls, and in the nak trees which borier the prairies. In western $1 \mathrm{~T}$ ashington, it is quite impossible to trace or to estimate the birl's

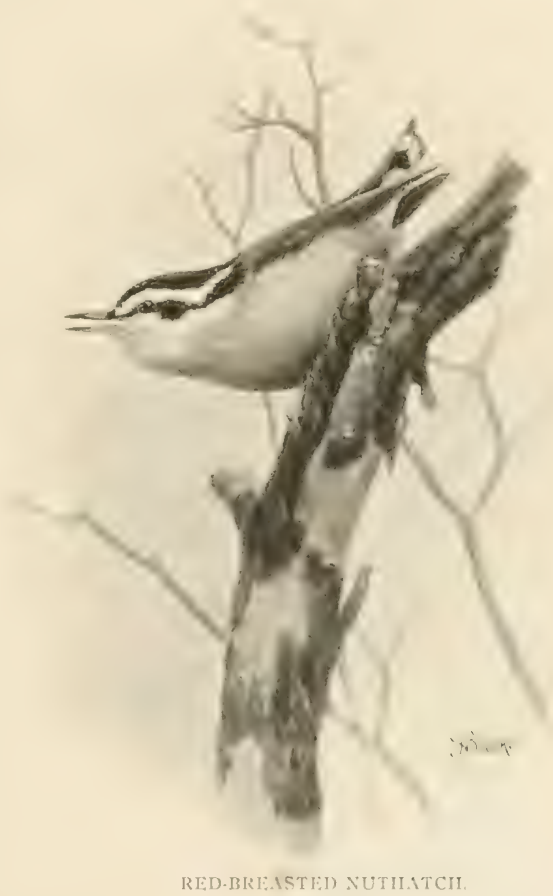

migrations, since it is present everywhere at all seasons: but it is probalbly much less abunclant with us in winter. In eastern llashington, it is confuned for the most part to the region of pine timber in summer. and altho it also winters here irregularly. the numbers in this part of the State are largely angmented by migrants during May and September. 


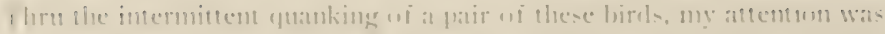

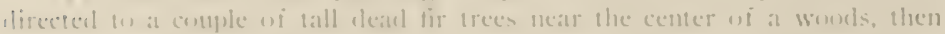

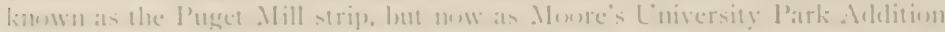

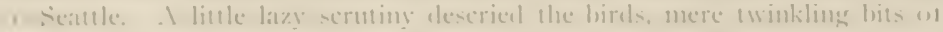

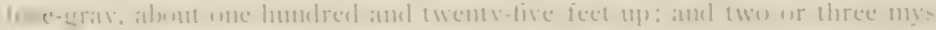

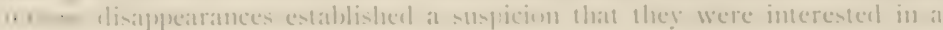

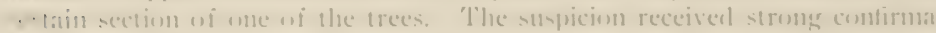

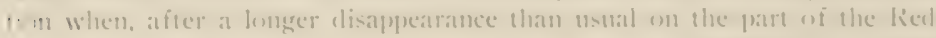

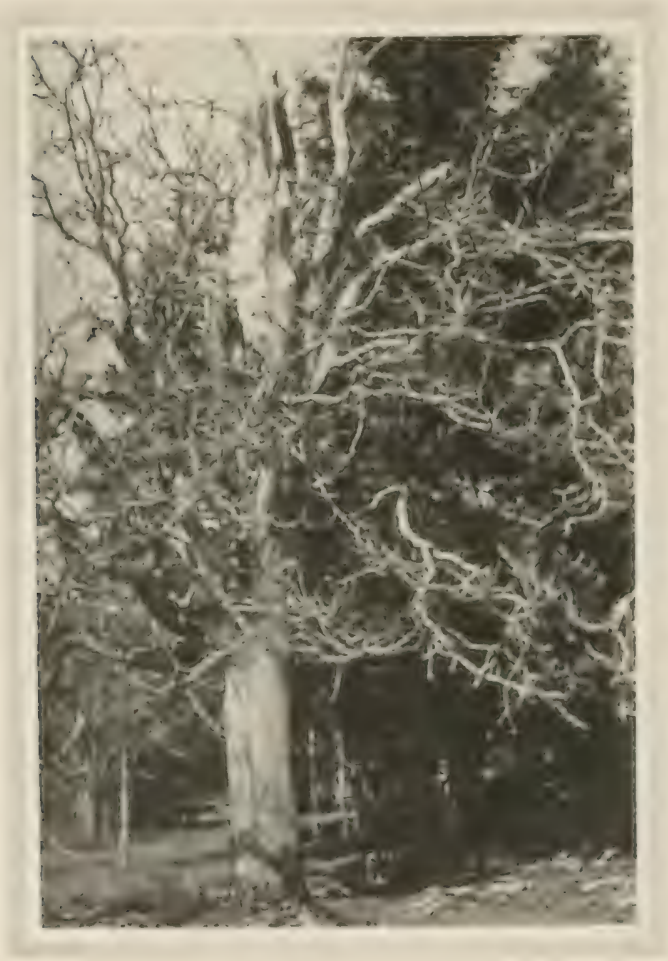

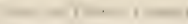

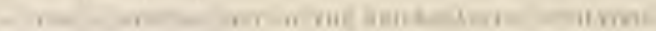

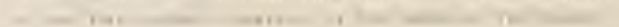

breasts. a Harric llomelpecker alight cel further up in the sa 111 e si 11 h, Tlue Sintlatches immerli. atcly swarmerl om ancl set nyen the llatric with vetur ancl language. 'llye IVimulpeelecr was dis poserl to stanel his eronmel, whereat the Ninlateleses lecame hithle emraterl and chatresel mon the in truter so viguramals

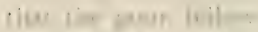
we romi shes

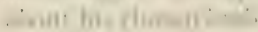

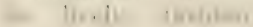
'lin fiwh. in'

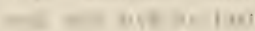

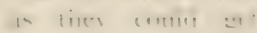
lowente and flimel theor wanes letween - ir erl iecline Harric maturally als sirlerl hefore lome - lat the gatme wa-nit sarth the turtu.

T'ime and atrain

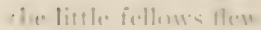
. Pirr ris 
iree, but only to come back as often to the same fascinating belt. Lrinally. from a new vantage point I mate out the hole, a very fresh one in an open stretch of bark about one hundred and twenty feet inp. As I looked, one bird entered the excation and remained, while the other monnted guard at the entrance. After about five mintites of this the tiny miner emerged and the other, the male, I think, took her place. His cluty appeared io be to remove the chips, for he stuck his head ont at the entrance momentarily, and one imagined, rather than saw at that height, the tiny flashes of falling white. All very romantic, but not a gool "risk" from the insurance man's standpoint.

'These Nuthatches must deliglt in work. They will spend a week in laborious excavation, and then abandon the clain for no apparent reason. Perlaps it is an outcropping of that same instinct of restlessness which makes Wrens build "decoy" nests. One such finished nest we found to be slraped not unlike a mursing bottle, a bottle with a bent neck. The entrance was one and three-eighths inches across, the cavity three inches wirle, one and a half cleep, and eight long (keeping in mind the analogy of the bottle resting on its flat side).

'T'he birds do not always nest at nngetatable heights. A nest taken near 'l'acoma on the Sth of Jume, 1006 , was found at a height of only seren feet in a small fir stump. 'The wood was very rotten, and the eggs resterl only fonr incles below the entrance. The nest-lining in this instance was a heary mat an inch in thickness, and was composed of regetable matter-wood fiber, soft grasses, exc.-without hair of any sort, as would surely have been the case with that of a Chestnut-hackerl Chickadee, for which it was at first haken.

The Nuthatches appear to leave their eggs during the wamer hours of the day, and one must await the return of the truant owners if he would be sure of iclentification. One mark, but not infallible, is the presence of pitch. smeared all arotmd and especially below the nesting lole. The use of this is not quite certain, hut Mr. Bowles's hazard is a good one; riz., that it serves to ward off the ants. which are often a pest to hole-nesting bircls. These ants not only anoy the sitting birl, who is presumably able to defend herself, but they sometimes destroy unguarded eggs, or young bircls.

No. 113.

\section{PYG.IY NUTHATCH.}

A. O. L. No. 730, Sitta pygmae ligors.

Synonym.-C.Mr.tForsis Xituritcit (carly name).

Description.- - Atults: Crown, nape, and sides of loead to below cye grayish rive or olive-hrown, a bufiy white spot on hind-neck (nearly concealed in fresh plumage): lores and region behind eve (bounding the olive) blackisls; remaining upperparts plumbeous, browning (brownish slate) on flight feathers. etc., hesom- 


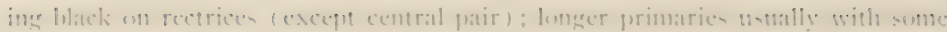

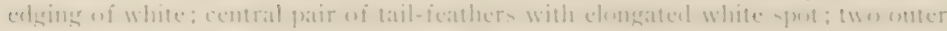
pairs crosed oblicuety with white, and the three onter tipjeed with slate; moler-

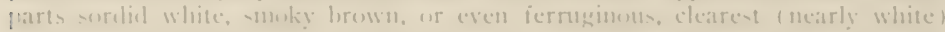
on chin amul checke: shles, flanks, and crissm washed with color of hack: bill

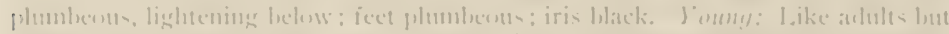

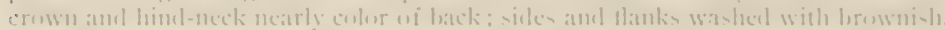

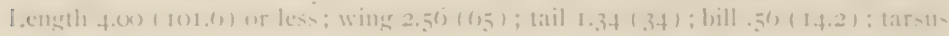
(5) $(15)$.

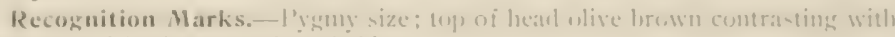
plombente wi hack: enregarious halsits.

Vesting.-. Vist: a frole in dead top of pine tece, excavated hy hirds, smeared alent entrance witl pitch, and lineel with ssit subtances, irass, loair, and

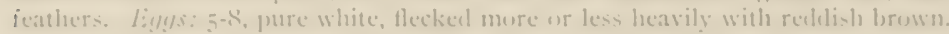

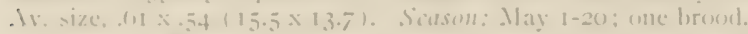

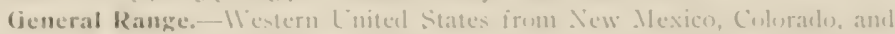
Nemtanat on southern Californiat, Mashingten, and castern liritish Columbia:

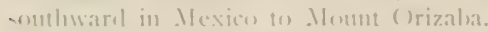

Range in Washington.- liesilent in nortern and eastern purtions of the

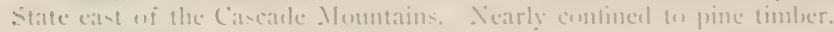
11

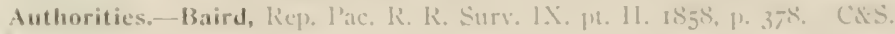

Specimens.-l'rov. C.

As for the l'yemy, the pine tree is his lomese. It is mot quite proper, inserer, to speak of this Nuthatch in the singulas. Lilligutians must lumt in trunpe and make up in mumbers what they lack in strength. P'ygmy Nuthatches are mot merely seciable: they are almone gregarious. Where a company of Kinglets would be comtent fo straggle thru it dozen trees, a pack of P'ymies prefers to atsemble in anc. let there is nu fluck impulse here, as with siskins, liath litule elf is his own naster, and at company of them is more like a combel of merry schoulluys than anything else. It's "comle an fellers." when me of the luss tires af a given tree.

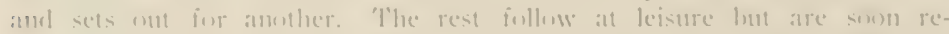

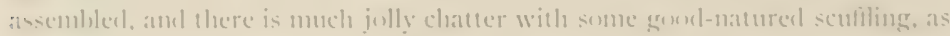

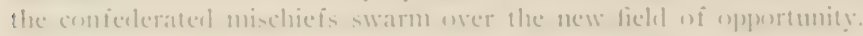

Nuthatches are mot methesleat, like Creepers, in their searels for insects, - they are haphazarel and latply. 'lle hranches are more ateractive wh Hem than the tree lute, and the deat top of the tree is most atluring

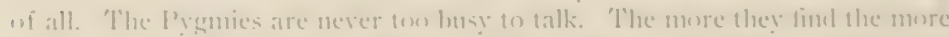
excited their chatter grows pretty lispings and chirpinge quite $(0)$ danty for

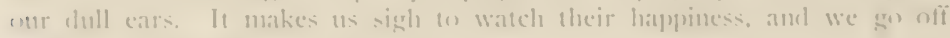

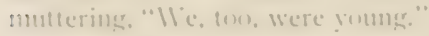

Again, it shocks us when we find these yumgsters in knickerbockers 
and braids paired off for nesting time. 'Iut, tut! children, so eager to taste life's heavior joys? A nest is chiselled out with infinite labor on the part of these timy lyeaks, in the dead portion of some pine tree. The cavity is from font to twelve inclies in depth, with an entrance a trifle over an inch in diameter. The owners share the taste of the Chickadees, and prepare an claborate layette of soft regetable fibers, fur, hair, and feathers, in which the eggs are sometimes quite smothered.

The parents are as prond as peacocks, and well they may be, of their six or eight oval treasures, crystal white, with rufous frecklings, lavish or scant. When the babies are hatched, the mother goes in and out fearlessly under your very nose; and you feel such an interest in the little family that you pluck instinctively-but alas! with what futility-at the fastenings of your purse.

No. 114 .

\section{SIERRA CREEPER.}

A. O. U. No. $726 \mathrm{~d}$. Certhia familiaris zelotes Osgood.

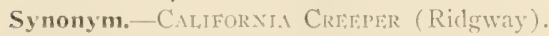

Description.-Idults: Above rusty brown, broadly and loosely streaked with ashy white; more fincly and narrowly streaked on crown; rump bright russet; wing-quills crossed by two whitish bars, one on both webs near base, the other on onter webs alone; greater coverts, secondaries and tertials tipped with whitish or grayish buff; a narrow superciliary stripe dull whitish or brownish gray: mulerparts sordid white or pale buffy, tinged on sides and flanks with stronger buffy: libll slender, decurved, brownish black above paler below: feet and legs brown; iris dark brown. Length of adult male about 5.50 (139.7); wing $2.50(63.5)$; tail 2.39 (60.8) ; bill .63 (16); tarsus .59 (15). Female a little smaller.

Recognition Marks. - Warlsler size; singularly variegated in modest colors above; the only brosen creeper in its range. Lighter colored than the next.

Vesting.--Nest: of twigs, bark-strips, moss, plant-down, etc., crowded behind a warping scale of bark whether of cedar, pine or fir. Eigys: usually 5 or 6 , sometimes 7 or 8 , white or creany white speckled and spotted with cimnamon brown or hazel, chicfly in wreath about larger end. Av. Size .6I x.47 (I5.5 x $1+1$,

General Range.-The Cascade-Sierra mountain system from Mt. IIhitney nortli to central Pritish Columbia, east to Idaho; displaced by succeeding form on l'acilic Coast slope save from Marin Connty, California, southward.

Range in Washington.-Resident in the Cascade Monntains, east in coniferous timber to Idaho where intergrading with C. $f$. montana.

Authorities. - Certhia familiaris montana folmson (Roswell H.), Condor. Vol. VIII., Jan. Ino6, p. 27.

Specimens.- U. of $1 \mathrm{~V}$. B. 


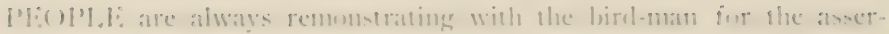

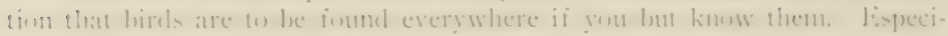
ally de they talli of the great silent forests in the western shoes af the

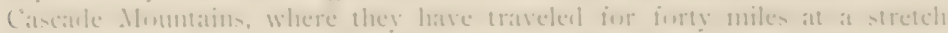

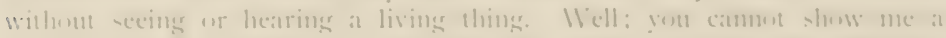
spuare mile of momellamel in atl that atreat where an least the follewing

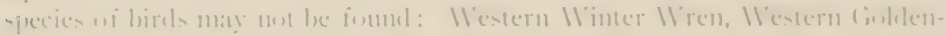

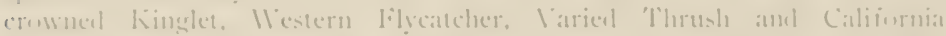

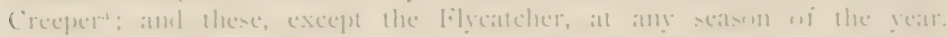

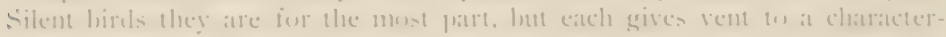
istic ery ly which it maty le known.

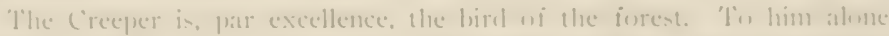

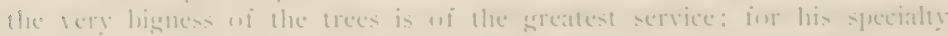

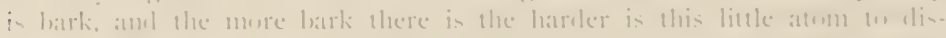

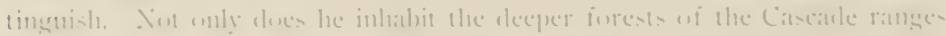

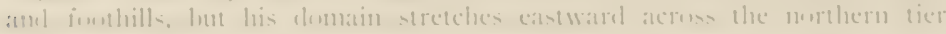

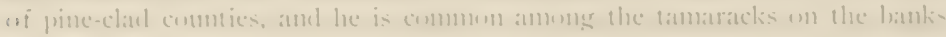
wi the l'enel d'()reille.

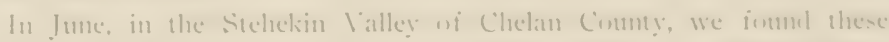

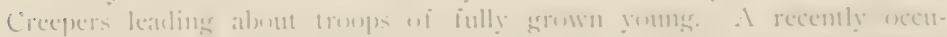

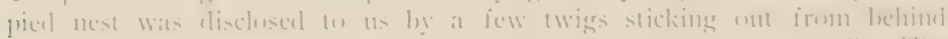

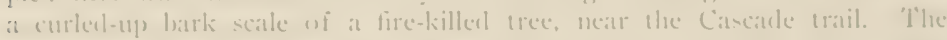

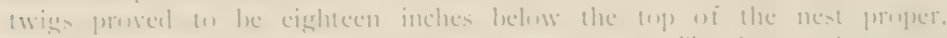

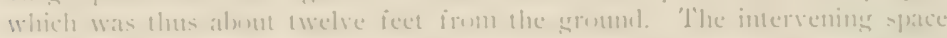
wats fillexl in lensely with twigrs, hatk-strips, muss, cottem, and every ofher

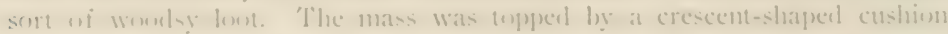

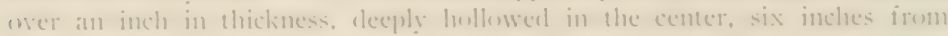

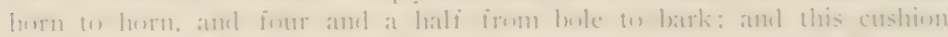
was compusent entirely of soft immer lark-strips anel a vegetable tiber resembling flax in quality-altugether a splemelid creatum.

No. 115.

\section{TAWNY CREEPLR.}

1. (). U. Nit. Ffoc. Certhia familiaris occidentalis Ridgway.

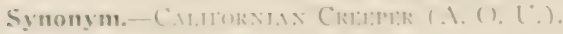

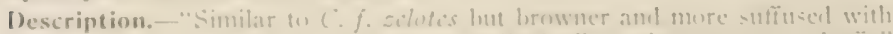

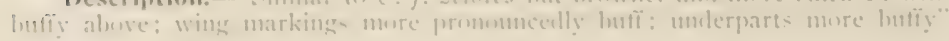

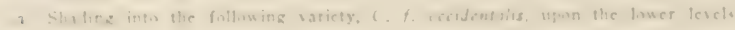


(Ridgway), Length of male: wing $2.4+$ (61.9); tail 2.41 (61.2); bill .60 (15.2); tarsus .6I (15.5).

Recognition Marks.-As in preceding; darker.

Nesting.-Vicst: as in preceding; placed behind sprung bark scale nsmally at moderate heights, 3-20 feet up (one record of 60). Immer (liameter of one nest $13 / 4$ inches, depth $21 / 2$. Eggs: 5 or 6 , as in C. $f$. zelotes. Ar. size $.58 x+47$ (If.7 X II.9). Season: May, Jane; two broods.

General Range, - 'acific Coast district from Northern California to Sithá.

Range in Washington.- Resident thruont the Wlest-side from tidewater up.

Authorities.-? Certhiu familiaris Orn. Com. Jomm. Ac. Nat. Sci. Phila., 111. 1837, 193 (Columbia River). Certhia americana Baird, Rep. l'ac. R. R. Surv. IX. is 58 , p. 372, part. ('T). C\&S. L. Rl. Ra. B. L..

Specimens,-U. of WI. l'rov. IiN.

IO one who loves bircls with an all inclusive passion-such as the uncleciled bachelor is wont to confess for the fair sex-the temptation (1) use superlatives upon each successive species as it is brought under review is very strong. But here perlaps we nay be partoned for relaxing our attention, or, it may be, for being caught in the act of stithing a little yawn. Certhia is a prosy (lrab, and all the beatuty she possesses is in the eyes of her little lubby-dear, deroted creature.

'l'his clerkling (lumby, of course, I mean) was brought into the world behind a bit of bark. His first steps, or creeps, were taken along the bask of the home tree. When the little wings got stronger and when the litlle claws had carried him uj) to the top of tree number One, he fluttered and spilled thru the air until he pulled up somelow, with heart leating fiercely; at the base and on the bark of tree number Two. Since then lie has climbed an atmost infinity of trees (but I dare say he has kept count). Summers and winters have gone over his head, but never a waking hour in which lie has not climbed and tmmbled in this worse than Sysiphaean task of gleaning nits and eggs and grulbs from the neverencling bark. Why, it gets upon the nerves! I pray you think, has not this anmate brown spot traveled more relative niles of riclgy brown bark in his wee lifetime than ever mariner on billowy sea! Work, work, work! With the industry of an Oriental he seeks to shame the rollicking caprice of Chickadee, and to be a "living example" to such spendthrifts as Colclikins, the Kinglet.

IBut wait! I am not sure. Could anyone live in these majestic forests, conkl anyone breathe this incense of perpetual balsam, could anyone mount trimmphantly these aspiring tree-boles, way, way up into the blue, without growing the soul of a poet? Hark! "Tere, terey, tere'y, Ping, terì,"-an 


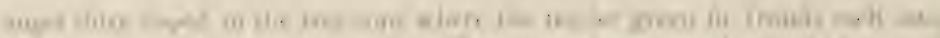

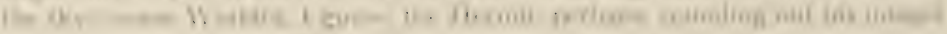

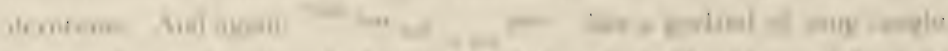

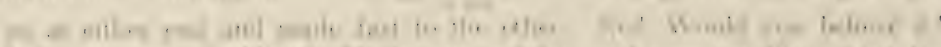

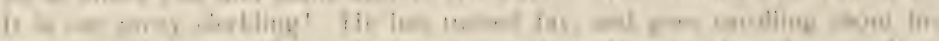

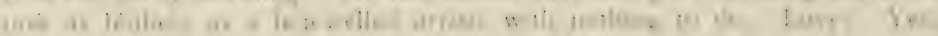

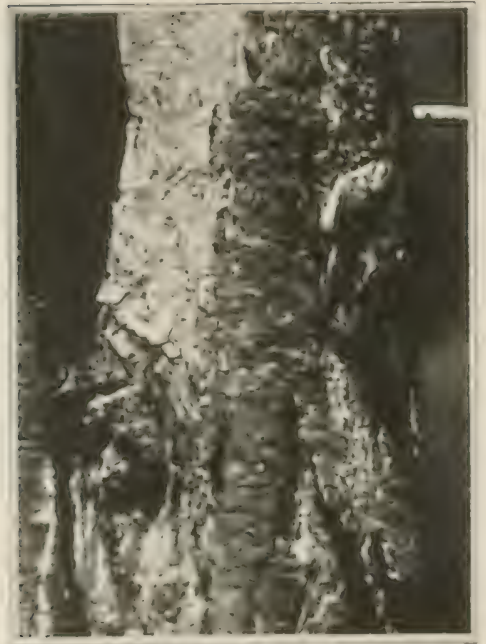

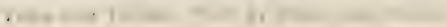

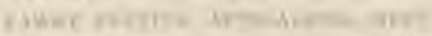

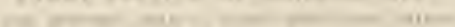

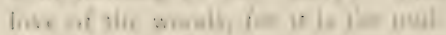
111. $11-1,2$.

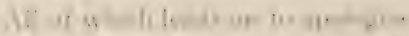

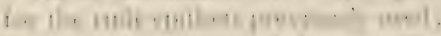

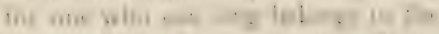

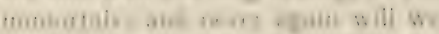

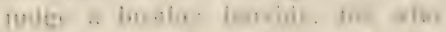

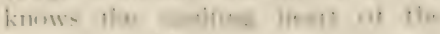
... ane ' the.

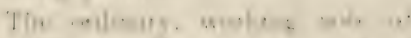

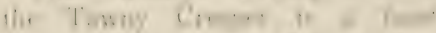

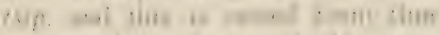

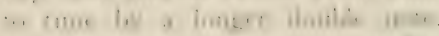

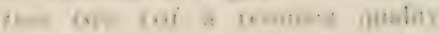

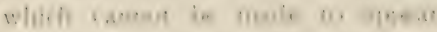

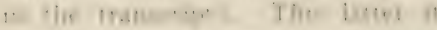

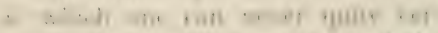

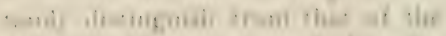

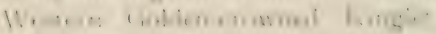

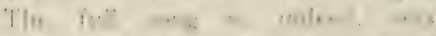

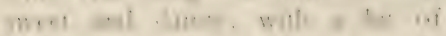

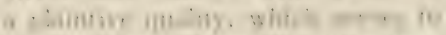

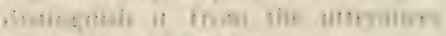

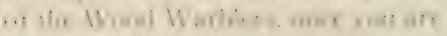
11...... $681+1$

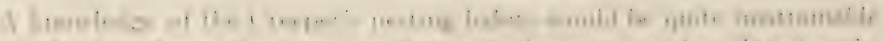

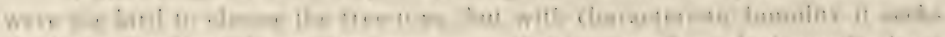

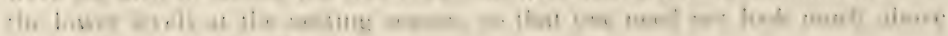

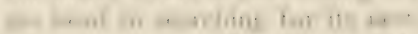

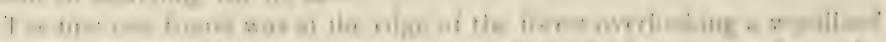

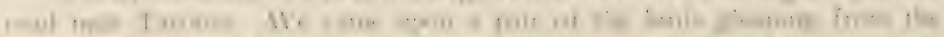

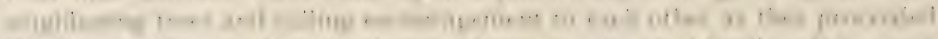

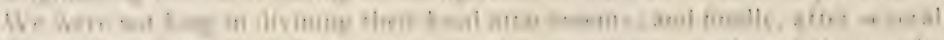

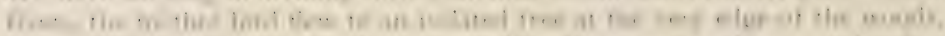

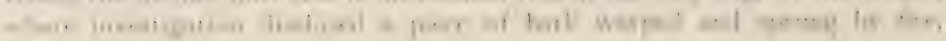




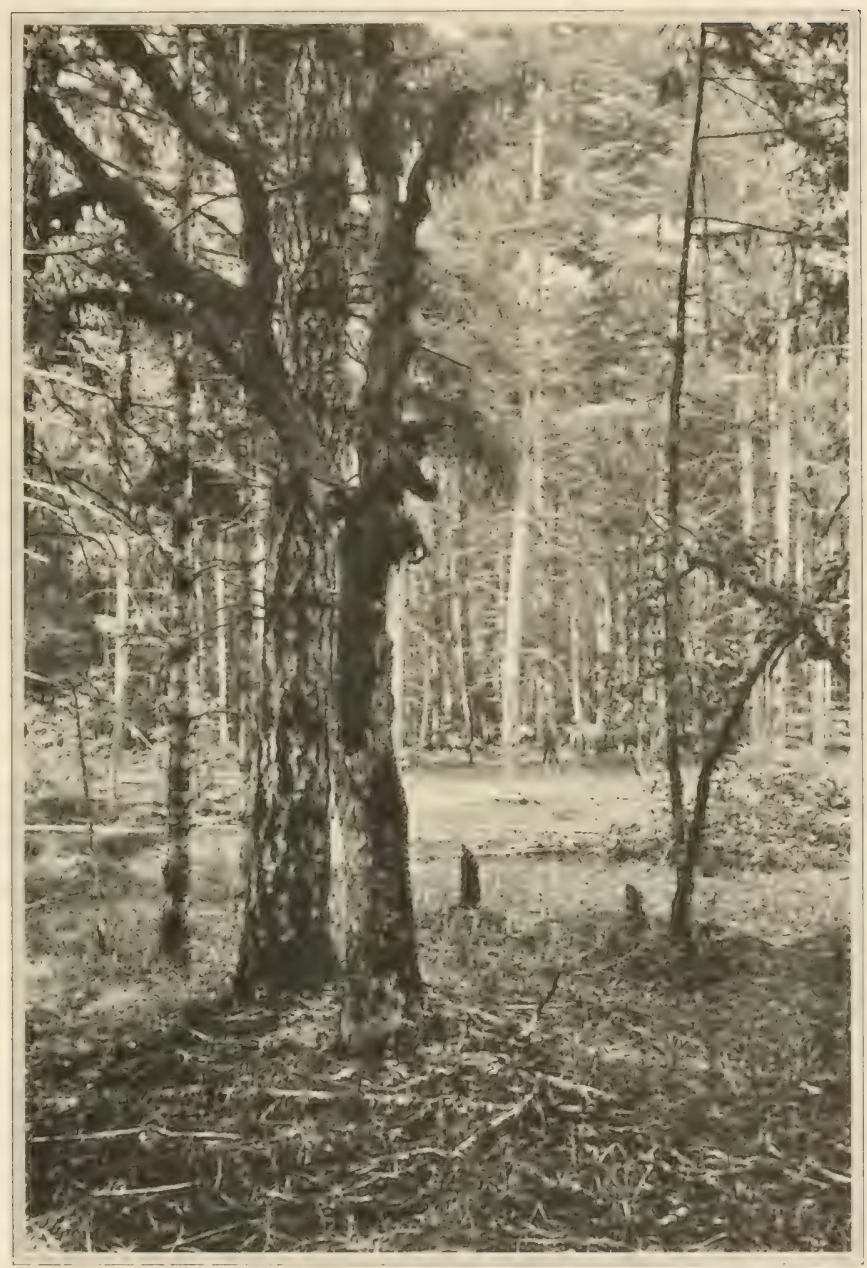

Taken $r \quad r$ Tacomo

Eive by $I W$, Leon Dateson. 

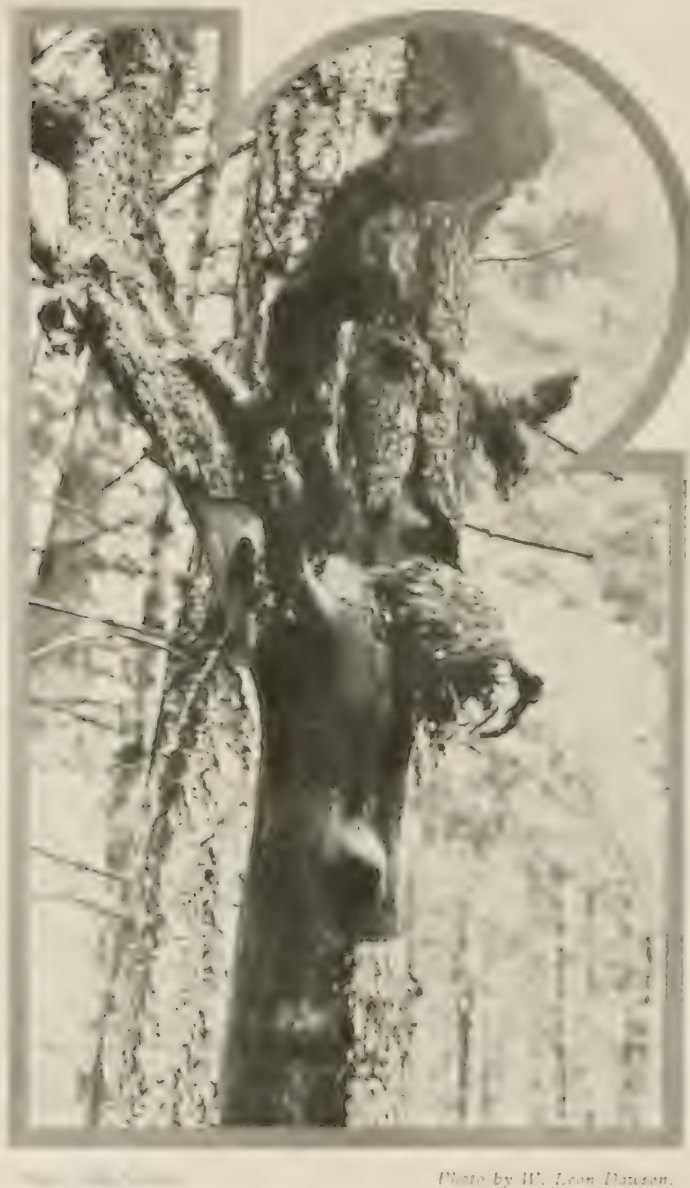

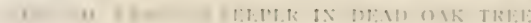

leefime which six alluw habies rese. (x) on an snft cusly ion of moses, hati amel bark-filuer.

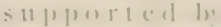

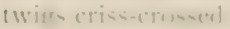

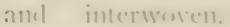
(1) litke 11 ill itailable space lo lew

l'his lonticil catre: Int 1he mum liligent scatrili int followine seas

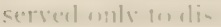
coner the recomb of patse yeats amel mefueful prospects liark sales of ind tha rierht di n1e+11-14m) (ii) 11$)$ it 1 m which de l 10 l

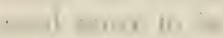
i til +1 or else to have re erived the scams cmmpliment if iew eriss-erossed sticks which mentn. "lle wemlel ae muile lerese if we had not likes snme other place terwh

Nint nmetil Mas 511, I1)(3), divl Mr lowwles discoser the firet eners. five inecklenl beatuties 
No. 16.

\section{IVESTERN MARSH WREN.}

A. O. L. No. $725 \mathrm{C}$. Telmatodytes palustris plesius (-iberholser).

Synonym.-IXTERIOR MARSI MREX.

Description.-Idult: Crown blachish; forehead light brown centrally,color sometimes spreading superlicially over entire crown; lund neck and scaptilars light brown (raw umber, nearly); rump warm russet; a triangular patch on back blackish, with prominent white stripes and some admixture of russet; wings and tail fuscous or blackish on inner webs, brown with black bars on exposed surfaces; upper and under tail-coverts usually and more or less distinctly barred with dusky; sides of head whitish before, plain brown or ptunctate behind: a white superciliary line: unclerparts white, tinged with ochraceous buff across breast, and with pale brown or isabella color on sides, flanks, and crissum; bill and feet as nstal. Length $+50-5.75\left(11+.3^{-1} 46\right)$; av of ten males: wing 2.12 (54); tail $1.82(46.4)$ : bill .56 ( I 4.2$)$ : tarsus .79) (20.1).

Recognition Marks.- Warbler size; brown and black pattern of back with white stripes distinctive: white superciliary stripe and long bill distinctive in haunts. Strictly contined to bulrushes and long grass of marshes. Lighter and larger than T. P. paludicola.

Vesting.-Y Nest: a ball of reeds and grasses, chinked and lined with cat-tail fown, witl entrance in side, and suspended in growing cat-tails, bulrushes or bushes. Liggs: $5-7$, so lieavily speckled with olive brown or sepia as to appear almost uniform brown. Av size, .05 $\times .52(16.5 \times 13.2)$. Season: May, July: iwo broods.

General Range.-IIestern Linited States and sonthern liritish Columbia between the Rocky Mountains and the Cascacle-Sierra Range, breeding from New Mexico northward: south during migrations to Cape district of Lower California and II estern . Mexico.

Range in Washington.-Summer resident in all stitable localities cast of the Cascalles.

Authorities.-Tchufodyles palustris paludicola Brewster, B. X. (1. C. III 1882,227 (Ft. Nalla IIalla). D2. Ss?. I.

Specimens.-C. P.

"TO the Conts and kails belong the ooze-infesting morsels of the swamp. but all the litule erawling things which venture into the upper story of the watring cat-tail forest, belong to the Long-billed Marsh 11 ren. somewhat less catutions than the waterfowl, he is the presiding genius of thowing acres, which sften have no other interest for the ormitholegist. 'There are only two necasions when the Marsh II ren woluntarily leaves the shelter of the cat-tails or of the closely related matraliales. One of these is when he is chiven somth by the migrating instinct. Then he may be seen sliulking about the borelers of the streams, shelering in the weerls or clambering abut the drift. 'The other' 


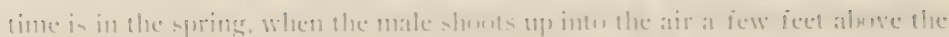

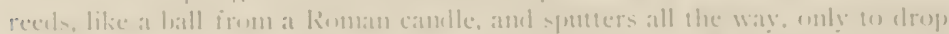

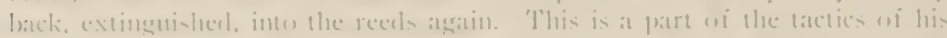

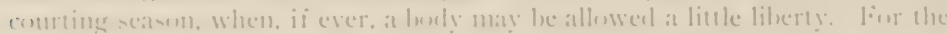

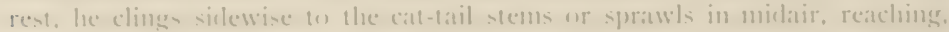

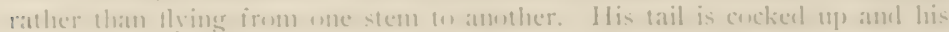

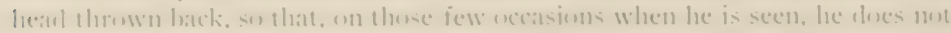

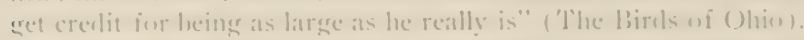

since his splere of activity is so limited. we maty proceed at onee en the

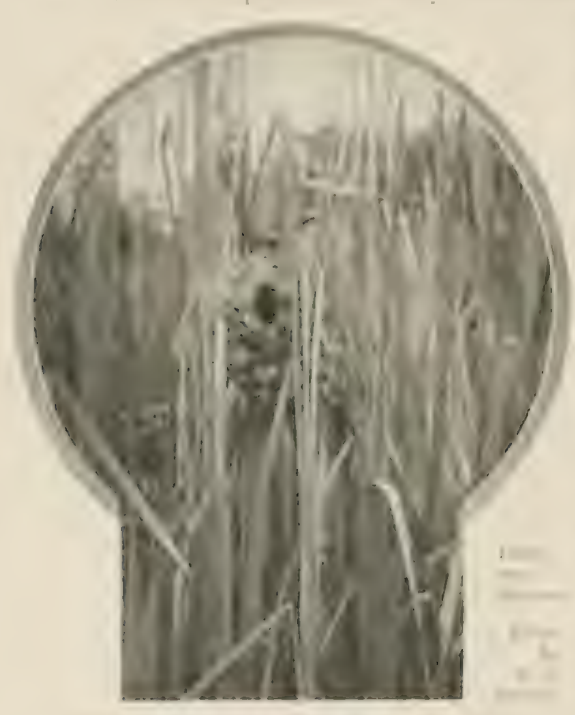

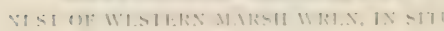
main interest. that of nest-puilding. Anct this is precisely as the Marsh Mren womld have it. else why does lue speeml the livelung rlay making extra nests, which are uf uo possible use on anyme. sive as examples of 'Pelmatodytine architecture: It is possible that the female is compettish. and repuires these many mansiome as evirlenee that the arrlent swain will be alole (n support leer becomimgly after marriagere. ()r, it may lec, that the suitor delights on afforel lis lady lowe a wiele ranere uf elutece in the matter of homes.

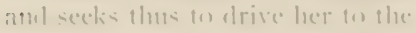
inevitable conchesim that there is (m)ly ence lome-matier for leer I Iowerey this may he, it is ertain

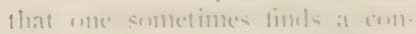
-irleralsle gromp of neet latll- catch "1i apparent stritability. lecine ans atre mectupierl.

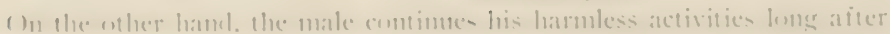

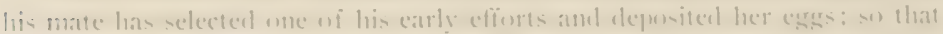

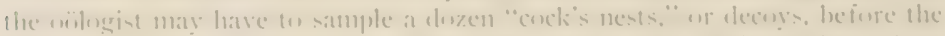

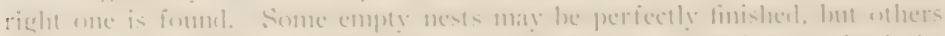
are apt to lack the wh lining: while still onhers, and having received the

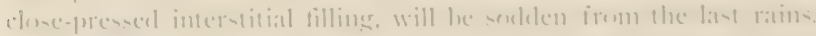

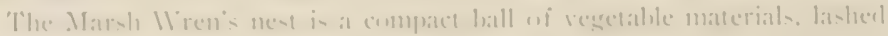

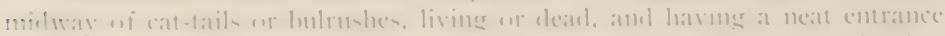

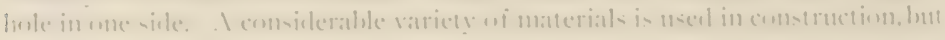


in any given nest only one textile substance will preponderate. Dead cat-tail leaves may be employed, in which case the numerous loopholes will be filled with matted down from the same plant. Fine clry grasses may be utilized, and these so closely woren as practically to exclucle the rain. On Moses Lake. where rankly growing hulrushes predominate in the nesting areas, spirogyra is the material most largely nsed. 'This, the familiar, scum-like plant which masses under water in quiet places, is plucked out by the venturesone birds in great wet hanks and plastered about the nest until the required thickness is attained. While wet, the substance matches its surroundings aclmirably; but as it dries out it slurinks considerably and fades to a sickly light green, or greenish gray, which advertises itself among the obstinately green bulrushes. Where this fashion prevails, one finds it possible to pick ont immerliately the olkest member of the gromp, and it is more than likely to prove the occupied nest.

The nest-linings are of the softest cat-tail down, feathers of wild fowl, or dried spirogyra teased to a point of enduring fluffiness. It appears, also, that the Wrens often cover their eggs mon leaving the nest. Thus, in one we found on the I 7 th of May, which contained seven eggs, the eggs were completely buried under a loose blanket of soft regetable fibers. The nest was by no menns deserted, for the eggs were warm and the mother bird very solicitous, insomuch that she repeatedly rentured within a foot of my land while I was engaged with the nest.

The Marsh Wrens regard themselves as the right ful owners of the reedy fastnesses which they occupy, ancl are evidently jealous of avian, as well as lumman, intruters. In one instance a Wren had constructed a sham nest hard against a completed stracture of the Yellow-headed Blackbird, and to the evident retirement of its owner. Another had luilt squarely on top of a landsome Blackbircl nest of the current season's. construction, and with a spiteful purpose all too evident.

No. 117.

\section{TULE WREN.}

A. O. U. No. 725a. Telmatodytes palustris paludicola (Baird).

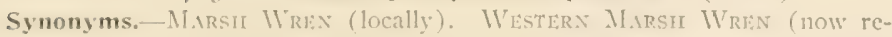

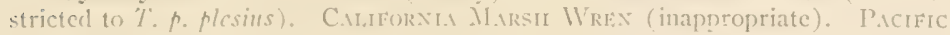
MAKSIT IIRL:

Description.- Idult: Similar to $\%$. p. plesius, but smaller and with coloration iecicledly darker. I.ength abnut 4.75 (120.6): wing 1.97 (50): tail 1.73 (44): bill .52 (13.2): tarsiss . -8 (20). 
Recognition Marks. -l'ygnuy size; brownisle coloration; recel-hannsing habits and squttering motes distinctive.

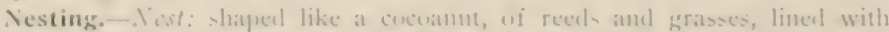
fulant-down, and with entrance in sile; placed two or three feet high in reeds, rarcly, high in bushes of swamp. Egys: 5 or 6, groumel-color grayish brown but

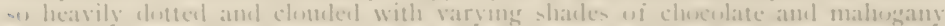

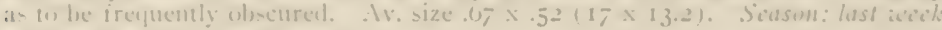

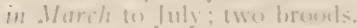

General Range- - l'acific Coase district from liritish Cilumbia south during migration to month of Colurasto River and extremity uf lower California.

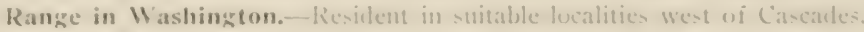

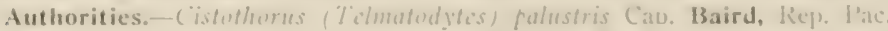

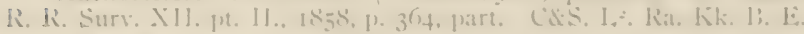

Specimens,- l', uf 11 . li. l'ruv.

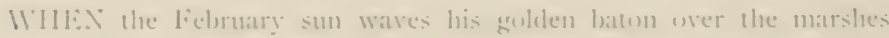
uf western 11 ashington, they yield up a chorus of wren song which is

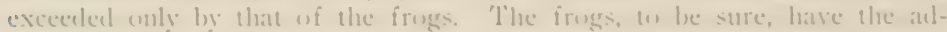

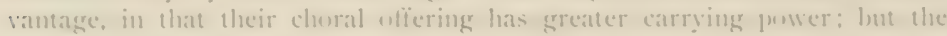

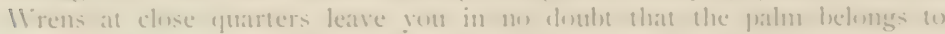
them. ()ne hesitates on call the medley of elicking. huzzing, and sputterins, which welects in the reeds, music: hut if one sucecels in catching sight

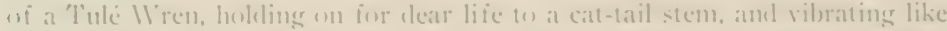
it drill-chuck with the cliort of his impatsinued utlerance, he feels sure that musio is all least intendecl.

Mrens are ever lousy luxlies, and if they combl mot sing or chatter, or at

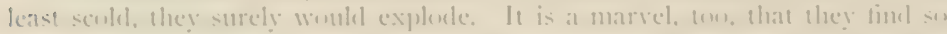

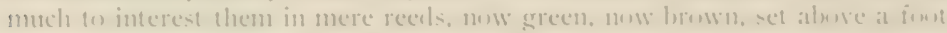

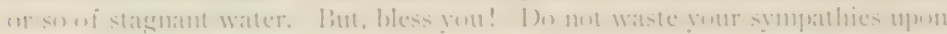

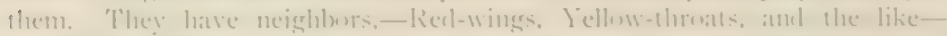

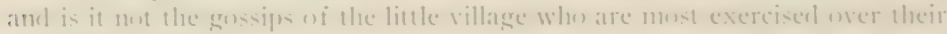
neighlous allatirs:

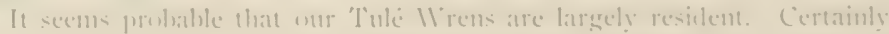

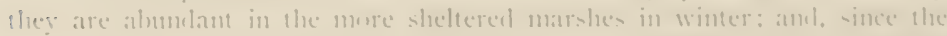

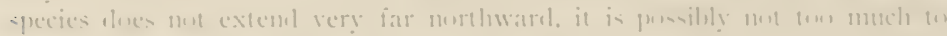

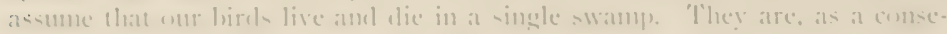

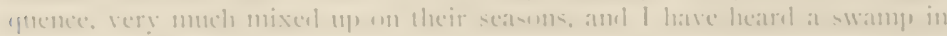
full wing in Niwember.

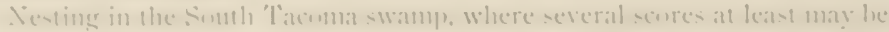

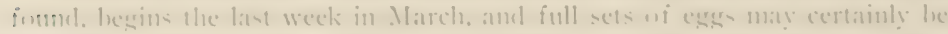

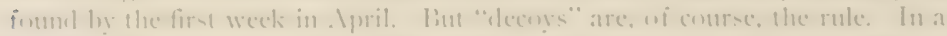

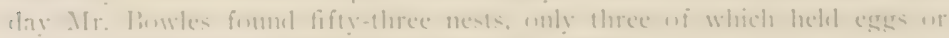

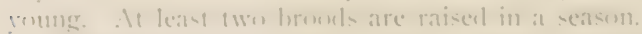

The eges manally five or six in mumber, are so werlavel will timy donts as 
to appear of an almost miform hair brown in color, very dark, except occasionally in the case of the last laid ege. 'The sitting bircl must subject her eggs to frequent turning in the nest, for they become lighly polished during incubation.

\section{No. 118.}

\section{SEATTLE WREN.}

A. O. L. No.719 c. Thryomanes bewickii calophonus ()herholser.

Description.-Alulfs: Above, dark olive-brown, or warm sepia hrown with an olive tinge: the rump with downy, concealed, white spots: wings showing at least traces of dusky barring,-sometimes complete on tertials; tail blackish on concealed portions, distinctly and finely barred with black on exposed portions: the outer pairs of feathers white-tipped and slowing white harring, incipient or complete on terminal thirel; a narrow white superciliary stripe, and an indistinct rlark stripe thrit cye: miderparts grayish white, tinged on sides and flanks with hrown: muder tail-coverts heavily harres wihl blackish; bill dark brown ahove, lighter below: culnen slishtly iecurved. I,ength: $5.00-5.50$ ( I27-139.7); wing 2.08 $(52.8)$ : tail 2.01 ( 52.3$)$; bill .50) (15): tarsus .70) (20).

Recognition Marks. - Warbler size: known from Western I Ionse Wren lyy superciliary stripe and whiter melerparts, mostly unbarred: a little larger ancl more deliberate in moventents.

Nesting.-N'Nest: in holes or cramines about stmmps, upturned roots, brushheaps, etc., or in builklings ; a rather slight affair of clried grasses, skeleton leaves. mosses, ancl waste, marely twigs, lined with wool, hair, or feathers, leggs: f $^{-6 .}$ usually 5. white, speckled or spotted, rather sparingly, with recklish lorown or purplish, uniformly or clicfly in wreath about larger encl. Ar. size, . $28 \times .54$ $(17.3 \times 13.7)$. Scason: April 15-June $15:$ two bronds.

General Range. - Pacific Coast district from Oregon to southern liritish Columbia and laneonver lsland; resident.

Range in Washington.--Resident west of the Cascades, chicfly at lower levels and in valleys.

Authorities.-?'T'ownsend, Ionrn. Ac. Nat. Sci. Mhila. VII. I8,37, I,54

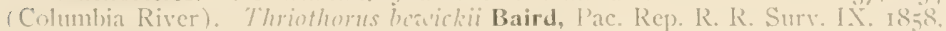
p. 363 part. ('T), (C\&S), I,2. Rh. Kh, Ra. Kk, ls. E.

Specimens.-L' of II. I'. I'rox. I3. B., E.

'Th those who are acquainted only with the typical Pewick IVren of the Last, the added rocal acemplishments of our western representative come in the nature of a surprise. For to the characteristic clity of berickii proper. culophomus has introltucel so many trills and flourishes that the original motif is almost lost to sight. Colophomus means having a beatiful roice, no sweetly sounding. and right well deses the hird deserve the nane, in a region which is all ton conspicunus for jts lack of untable songsters. 


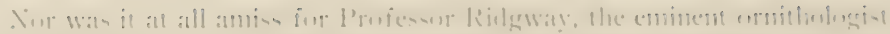

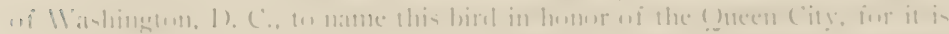

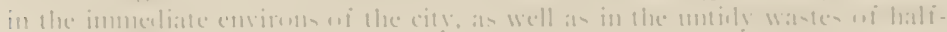

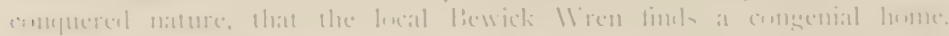

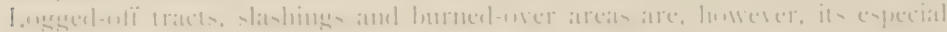

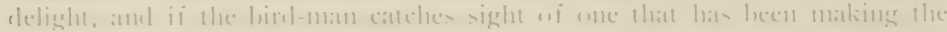

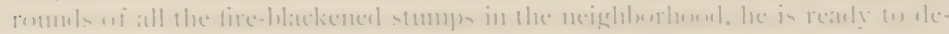

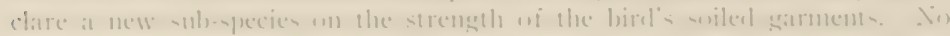

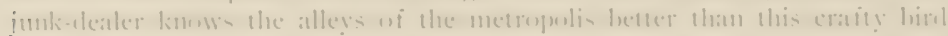

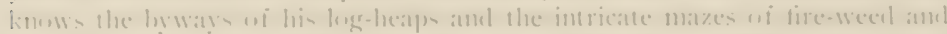

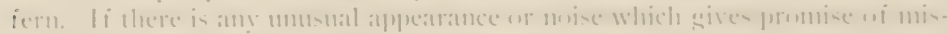

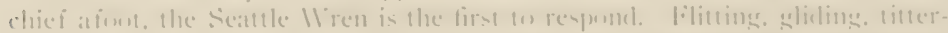

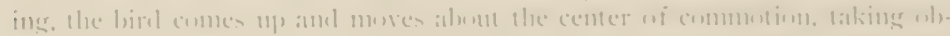

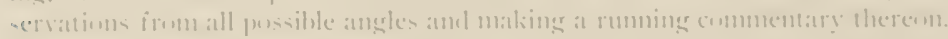

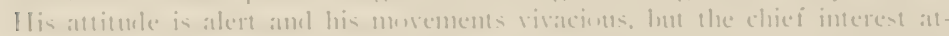

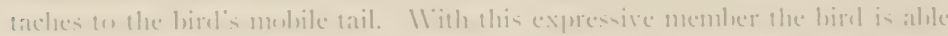

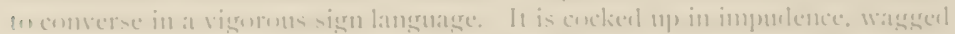

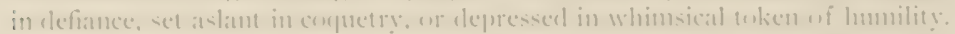

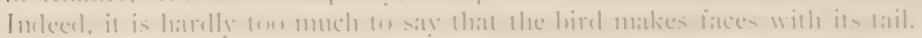

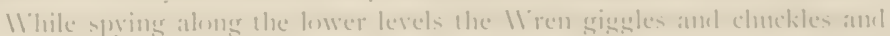

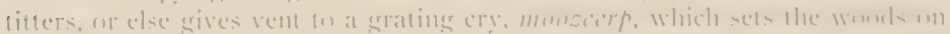

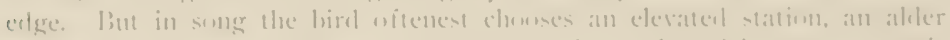

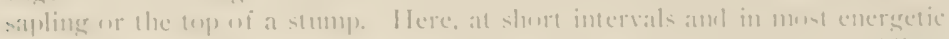

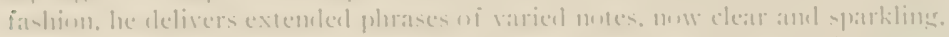

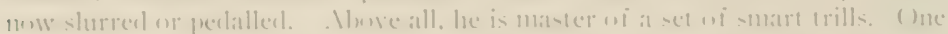

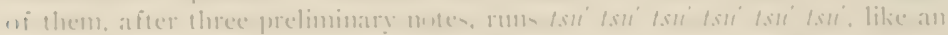

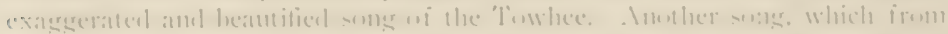

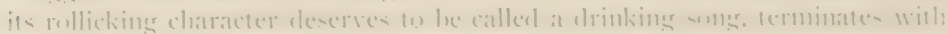

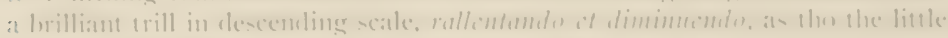
min-lrel were atetually alraming a leaker of dew:

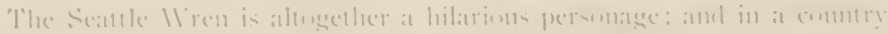

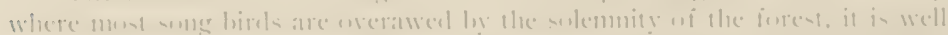

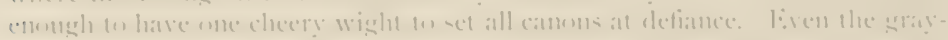

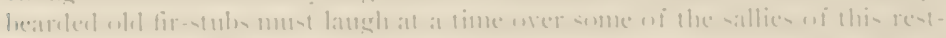

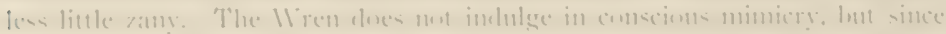

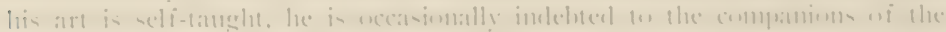

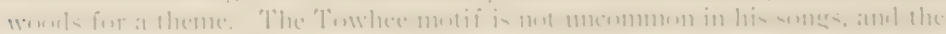

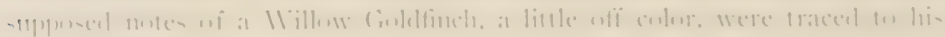
firme, at lilinime.

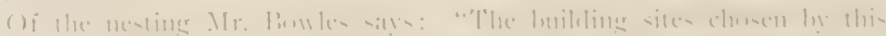

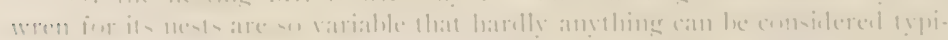

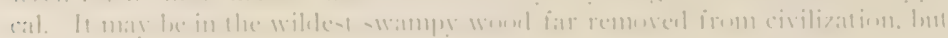


it is quite as likely to be found in a house in the heart of a city: A few of the nesting sites I have recorded are in uptumed roots of fallen trees, deserted woulpecker holes, in birl boxes in the city, in a fishing creel hanging on a proch, under a slab of hatk that has scaled away a few inches from the body. of a tree. or an open nest built on a bean meler a briclge.

"A very complete stuly of this wren has conrinced me that it never builds any nests except those used in raising the young. In other worls, it is the only wen in the Forthwest that is positively guiltless of using '(lecoys'.

"In constructing the nest these bircls do not often take over ten tays, in which proceeling the female does all the work. One pair, howerer, that I visited occasionally: Were over a month in completing a small nest in the natural cavity of a stump. No explanation of this seems possible, except that the female was not ready to lay her eggs any sooner.

"'The nest is a rather slight affair, as a rule, the arerage nest containing much less material than that of any other wren that I have seen. It is composed of fine dried grass, skeleton leaves, green moss, wool, and very rarely has a basis of twigs, with a lining of hair, the cast skins of snakes, and many feathers.

"A set contains from four to six eggs, most commonly five. These are prire white in ground color, marked with fine dots of reclclish brown. 'The markings are variable in clistribution, some specimens being marked rery sparingly over all, while in others the markings are largely concentrated around the larger end in the form of a more or less confluent ring. The eggs are rather short ovate oval in shaje, and average in measurenents . $8 \times 5.5+$ inches.

"Tho broods are reared in a season: or perhaps it would be more correct to say that fresh eggs maty be fomml at any time between the micllle of April and the mirklle of June.

" Ittho rather timicl in the vicinity of her nest, the iemale generally remains on her eggs meil disturber by a jar or some loud noise. She then disappears and neither bird appears nor makes any complaint in olojection in the intrurler."

No. II9.

\section{IVESTERN HOUSE IVREN.}

A. ค. I . No, 721 a. Troglodytes aedon parkmanii (Aucl.).

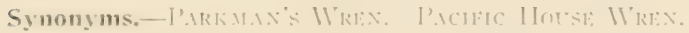

Description,- Idult: Alove, gravish rufons-lyown, duller and lighter on forcparts: lerighter and more rufous on rump, which has conceales clowny white 
quats: hack and scapulars harred (rarely indistinctly) with dusky: wings on

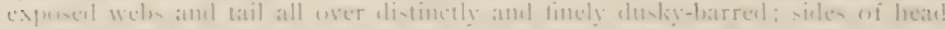

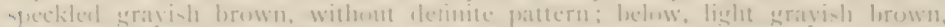

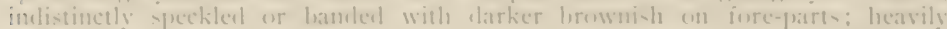

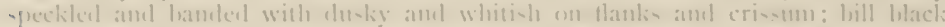

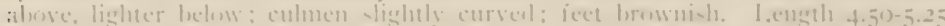

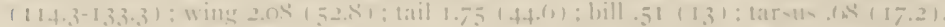

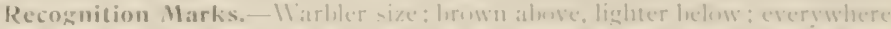

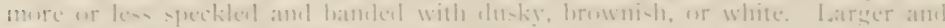
with honger tail than 11 eetern 11 inter 11 ren.

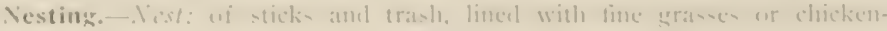

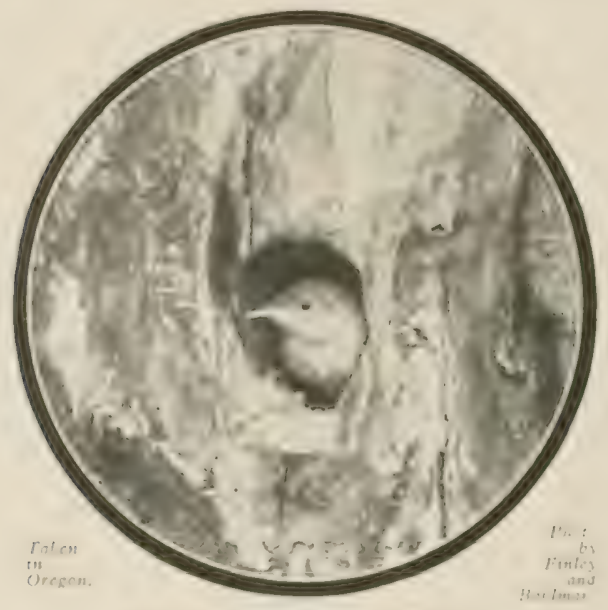

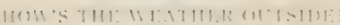

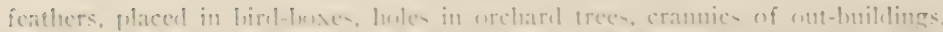

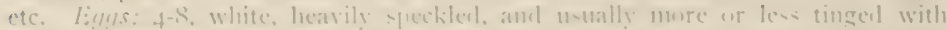

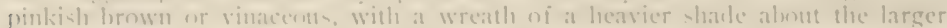

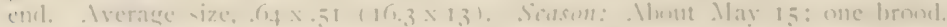

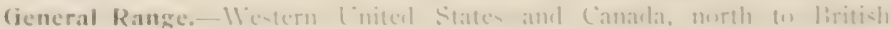

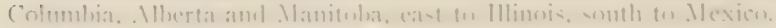

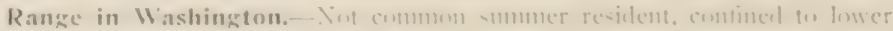

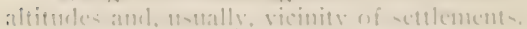

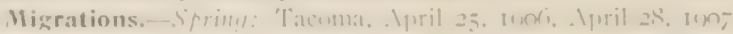

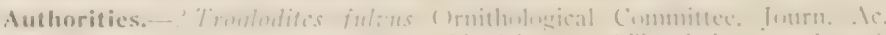

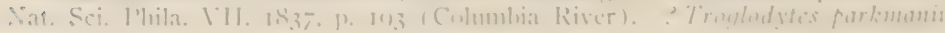


Audubon, Orn. Biog. 1. 1839 , 310 (Columbia River). Troglodytes parkmanit. Auk. Baird, Rep. Pac. R. R. Surr. XII. pt. II. I858, p. 368 . (T.) C\&S. D'. Ra. $D^{2}$. Ss $s^{2}$. Kk, J. B. E.

Specimens,-U. of 11 . I'rov. H'. B'.

SIXCE our country is pretty well supplied with 11 rens, and those too which are content with our clinate the year around, this bustling down-Liaster, arriving at what he considers the proper season, does not figure so largely in local bircl society as across the Rockies. Altho original1. described by Audubon from material secured by 'ownsencl, at l'anconver, in the 'Thirties, parkmanii gives evirlence of leing a newcomer, comparatively speaking. In the first place, the late arrival. April $25^{\text {th }}$ at P'uget sound points, marks the species in which the tratdition of a hard climate is still strong. And, in the second place, the slightly paler plumage acyured while crossing the desert has not yet been inst, altho it is very certain that it could not long withstancl onnsecutive centuries of resirlence in our hmmicl clinate. It is not surprising. therefore, that the IIntse IVren is not abmulant nor well distribut. ed in western W/ashington. On the last-sirle it is neither common $n$ r rare, being found about long-established ranches and wherever the

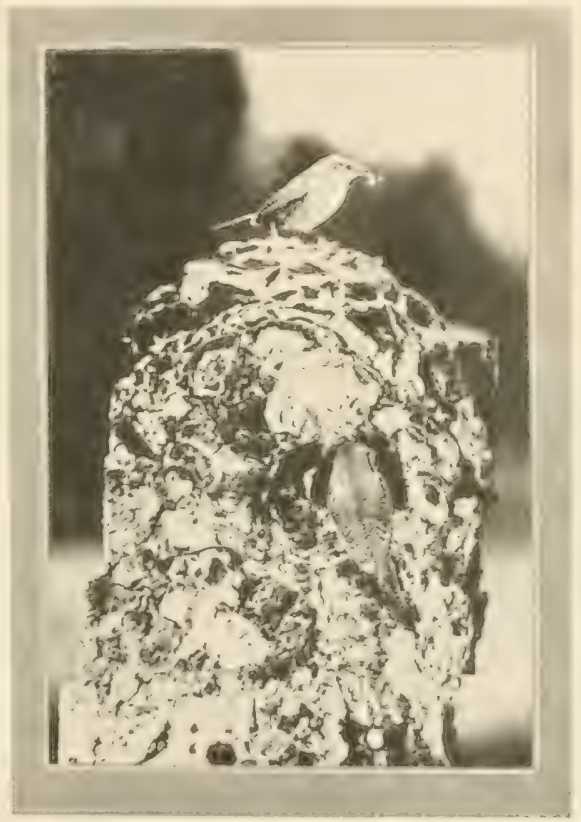

iaken th uregon. FHoto oy H. L. Fenticy. A VEKL BCSY WTF,

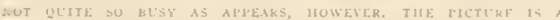
COMPOSITE AND RRFSENTS THE SAME PIRE TWICH presence of a little timber affords the variety of cover which is essential to its lappiness.

Once tupn the scence howerer, a litte Hotwe IV ren goes a great ways He is bursting with energy, and music escapes from his busy mandibles like steam from a safety valve. 'The first task is to removate last year's quarters 


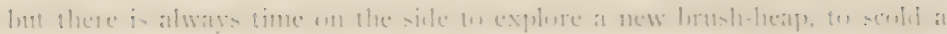

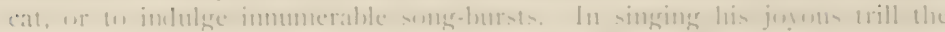

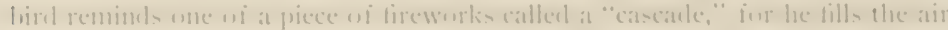

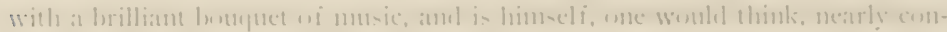

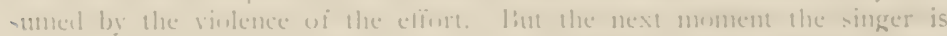

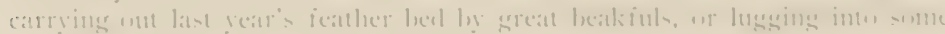

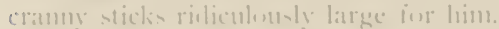

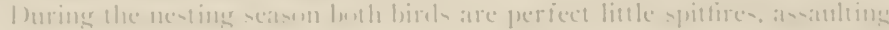

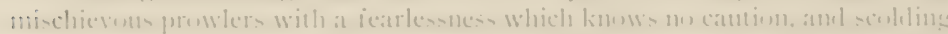

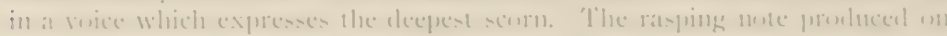

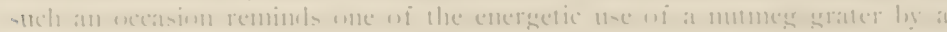

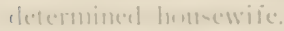

In newting, the Il rens malie iree of the hambls wi men, lnut are in mowi-e

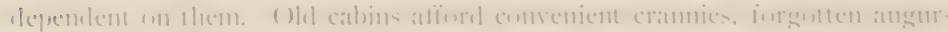

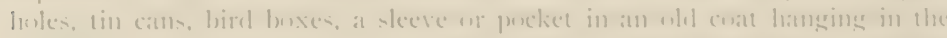

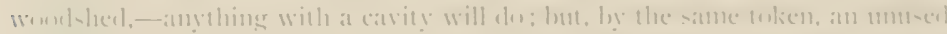

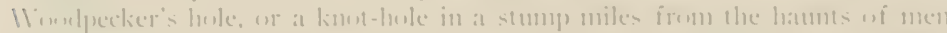

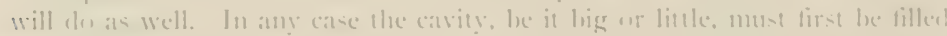

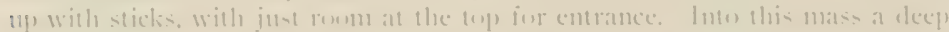

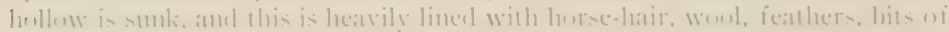
smake-skin, anylhing wh and "comfy".

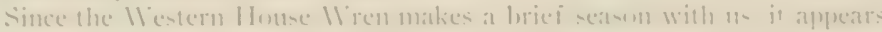
(1) raise lout wne lmasl ammally.

No. 120.

\section{WESTERN WINTER WREN.}

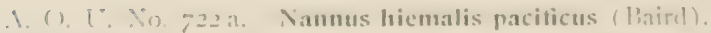

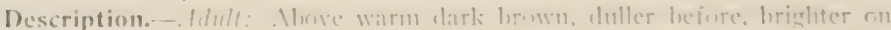

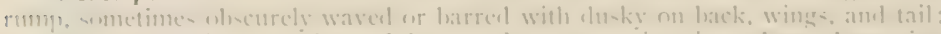

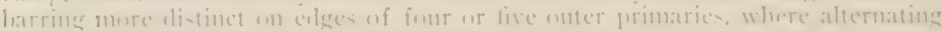

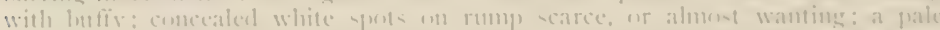

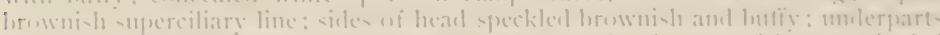

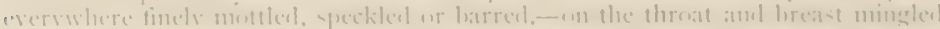

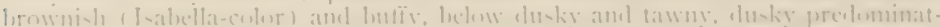

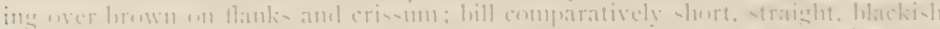

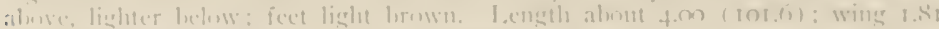

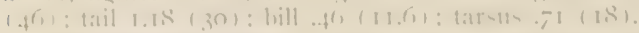

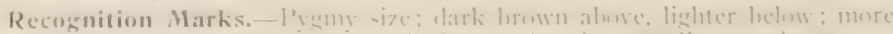

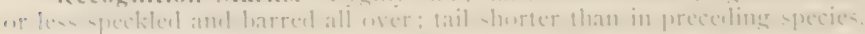

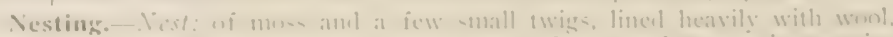

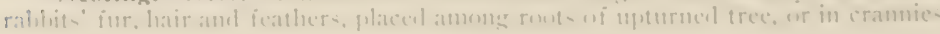


of decayed stumps, brush-heaps, etc. Liggs: $4-7$, usually 5 , white or creamy-uhite, dotted finely but sparingly with redelish brown: occasionally blotehed with the

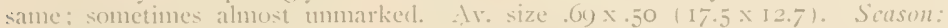
first weck in Ipril to first week in July according to altitude: two brookls.

General Range.-Western Vorth America, breeding from sunthern California to southern : laska, cast to western Montana. Chiefly resiclent, but soutls irregularly in Cireat liasin States and California in winter.

Range in Washington.- Resilent in coniferous timber from sea level to limit of trees: less common east of the Cascade Mlountains; of irregular occurrence in afen eotuntry during migrations.

Authorities.-I.ewis and Clark, Ilist. (ISry) Lid. Biddle: Cones. Vol, II. 1) I\&6.] Orn. Com, Journ. Ac. Nat. Sci. Phila. VII. 1837, 193 (Colmubia River). Troylodyfes (Inorthura) hyemalis Baird, Rej, l'ac. R. R. Surv. IA. I858. p. $3(10)$ ('T). C\&S. L. Rh. I) Kh. Ra. Kk. I. B. E.

Specimens. - L. of II. I'. I'rov. II, I3: E.

Chick - chick chick - chick chick; it is the Winter Wren's way of saying Ifow-(l)-yon-che? when you invade his domain in the dany) forest. The voice is a size too large for such a mite of a bircl, and one does not understand its circumbexed suality umil he sees its possessor making an emplnatic curtsey with each utterence. It is mot every day that the reche beholds a man, and it may be that he has stolen a march nucler cover of the ferms and salal brusli before touching off his little mine of interrogatives at your knees. If so, his brusque little being is softened by a friendly twinkle, as le notes your smprise and then darts back clutckling to the cover of a fallen log.

Igain, if rour entrance into the wookls las been munoticed, so that the little huntsman comes noon you in the regular way of business, it is antusing (o) watch with what ruses of circumvention he seeks to inspect you. Now he appears alowe a root on your right gawking on tiptoe: then clrops at at dhash behind its shelter to reprove himseli in uphraiding chick chick s for his rashness. 'Tlhen, after a minute of apprehensive silence on your part, a chuckle at your other ellow amounces that the inspection is satisfactorily. completer on that sirle. The Lilliputian has you at his mercy. Mr. Culliver.

Dr. Conper. Writing fifty years ago, considered this the commonest species in the forests of "the Territory" With the possible exception of the folden-erowned Kinglet, this is probably still true, since it is found not merely alomg streams and in romantic dells, but thruont the smmber depths of the fir and spruce forests from sea level to the linit of trees. It is fond of the wilderness and has as yet learned no necessity of clependence moun man, but it by no means slums the exleges of town. if only sufticient slensity of onser be grovided. Because of the more open character of pine timber, the llinter IVren is less common and is allengether local in its distribution east of the motuntains, lecing confuned for the most part to those forest areats which hoast an infusion of fir ancl tamarack. 


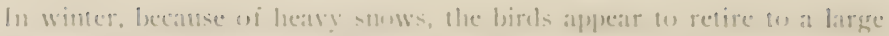

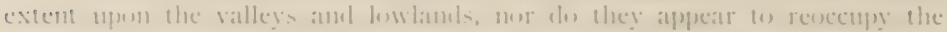

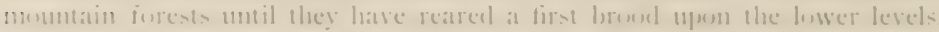

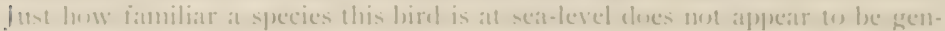
erally realizal. In the spring wi log I estimated that ferty gatirs were nest.

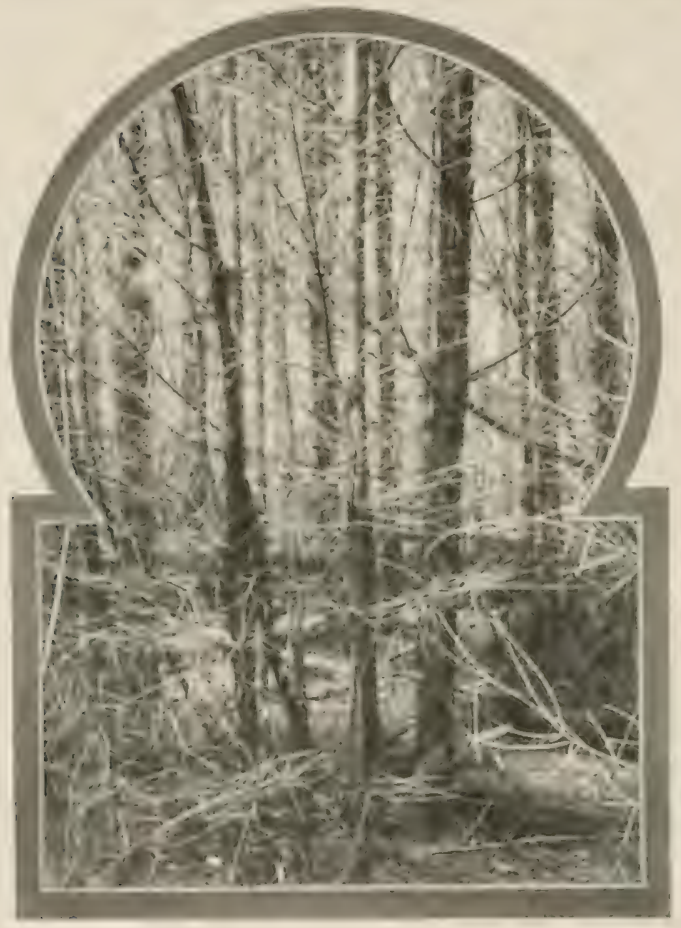

Tithen in siantle

I't., t, by the , luti, t

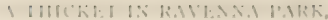
ing in litsenuna l'ark athere. Nior do they by any means desert the lowlands in totn in stmmer, inr they are secen recularly at that seasent thrmut l'uget Somme, the islatuls of 11 ash ingum sound, and u1) mu the llest Loast.

It is the IVinter Wren, chiclly, which gratilens the depuths of the ancient forest with music, Partly because of its unique ismlations. lout more becattse of the joymus alsomelem of the little singer, the sung of the II inter 11 ren etrikes the birl-huer as leing one of the must refreshing in the Virmburest It consists wi a rapul series of entraling notes and wanton trills, not vers lomel nor of ereat variets: but having all the spontaneity of $\mid$ ubl). bline water, at time eascarle of sumer in a waste of silence. The songe

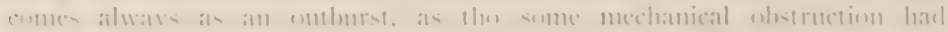

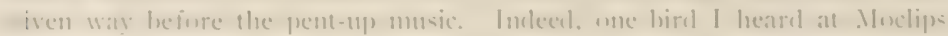
presederl his song with a series of titterines motes, which struck me 
absurdly as being the clicking of the ratchet in a music-box being wound up for action.

Heard at close (quarters the bird will occasionally employ a ventriloquial trick, clropping sudclenly to sotto soce, so that the song appears to conne from a clistance. Again, it will move crescendo and diminuendo, as tho the supply pipe of this musical cascarle were sul)mitted to varying pressure at the fountain liead.

A singing bird is the best evidence available of the proximity of the nest. Usually the male bircl posts himself near the sitting female and publishes his domestic happiness in musica! numblers. But again, le may only be patsing to congratulate himself upon the successful com pletion of another decoy, and the case is hopeless ine the nonce.

for nesting sites the IIrens avail themselves of culbby-lioles and cran nies in upturned roots or fallen logs, and fire-holes in half-burned stumps. $\therefore$ favorite situation is one of the crevices

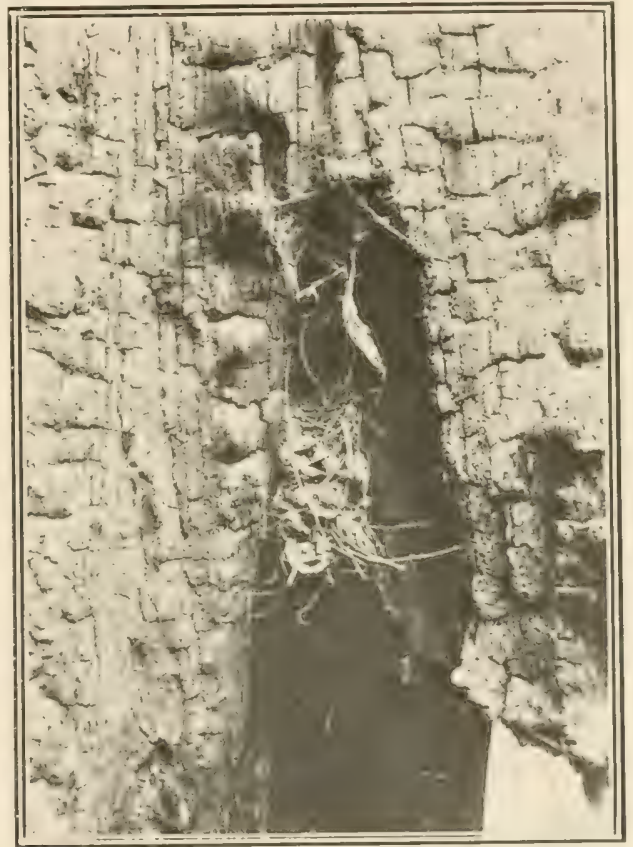

Taben in Siatelo.

Thoto by the fiuther

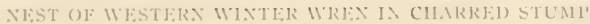
SOTE IHAT A SPLDK WIB APOVE, CLOSHLY SIMULATES THE NIS? FSTRASCE. WHICH IS RLALIYY AROLT MIIWAY which occur in a latge fir tree when it falls and splits open. Or the nest is sometimes fommd muler the bark of a decaving log, or in a crevice of earth in an unused mine-shaft. If the site selected has a wide entrance, this is walled up by the nesting ma terial and only a smonth rouml apenture an inch and a suarter in cliameter is left to admit to the nest projer. In default of any such shelter, hirds have been known to construct their nests at the center of some baby fir, or in the 
a)

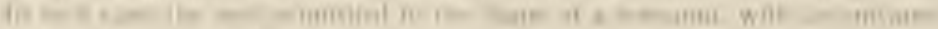

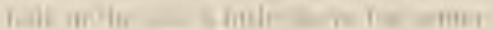

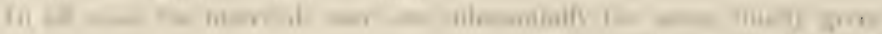
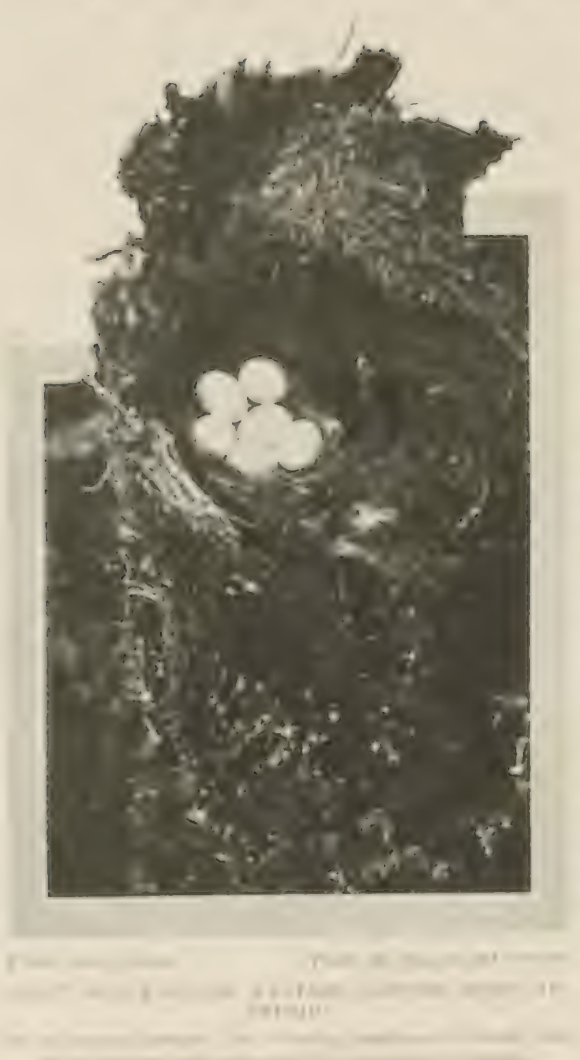

,

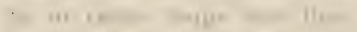

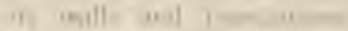
ine loil a nith lin

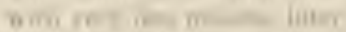

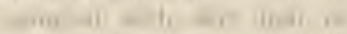
ine ar ale ire, liti

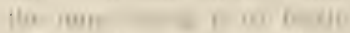
in whil li at Ian in in air |

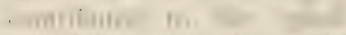

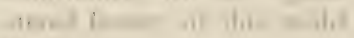
I..

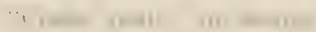

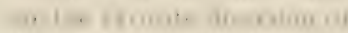

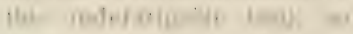
i. 11 11 11 | तi

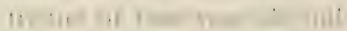

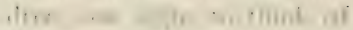

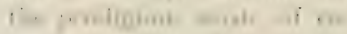

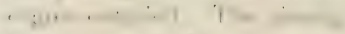

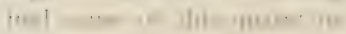

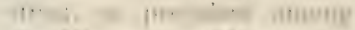

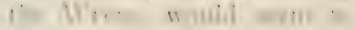
1. the $\because$ In th ile ine on. allewile, enime in i. r mi lin MYwer. Wwa

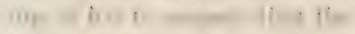

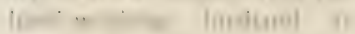

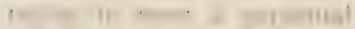
risilimer i n a n ail $\cdots$

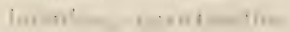

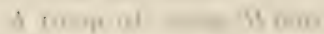

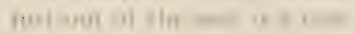

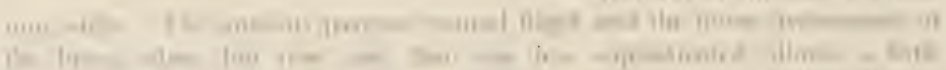

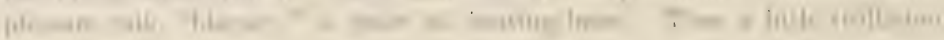


of the crown featlers will quite win him orer, so that he will aceept a gently insistent finger in place of the twig which has been his support. The unfaltering trust of childhorel has sublued many a savage heart, but when it is exemplified in a baby. Wren one feels the ultimate appeal to tenclerness.

Mr. Bromn, of Glacier, coming mon an old Russet-backed Thmsh nest at dusk, thrust an explomatory finger oter its brim. Judge of his surprise when out swarmed seven young 11 inter Wrens. Mr. Brown feels reatsonably sure, however, that the birds were hatched elsewhere, and that they were only roosting temporarily in the larger nest, in view of its ampler accommodations.

\section{No. $12 \mathrm{I}$.}

\section{ROCK WREN.}

\section{A. (). U. No. 715. Salpinctes obsoletus (Say).}

Description.- - teluls: Alove brownish gray clanging on rump to cinnamonbrown, most of the surface speckled by arrow-shaped marks containing, or contiguous to, rouncled spots of whitish: wing-cuills color of back, larred with clusky: on onter wels; micklle pair of tail-feathers color of back barred with dusky: remaining rectrices barred with dtsky on outer webs only, each with broad sul)terminal bar of blackish and tipped broadly with cinnamon-buff area varied by dusky marluling; outermost pair broadly blackish-and cinnamon-barred on both webs: a superciliary stripe of whitish: a broad post-ocular stripe of grayish brown; sides of head and unclerparts elull white slading into pale cintamon or vinacenns buff on flanks and under tail-coverts; sides of head, throat and upjper breast spotted, motted or streaked obseurely with grayish brown or dusky; under tail-coverts barred or transversely spotted with dusky. Bill clark horn-color above. paling below; fect and legs brownish clusky; iris brown. Jomng birds are more or less harred or vermiculated above, without white speckling, and are ummarked below: Length : 5.50-6.00 (139.7-152.4); wing 2.76 (70); tail 2.09 (53); bill .70 $(17.7)$; $\operatorname{tarst1} .83$ (21).

Recognition Marks. - IIarbler size; variegated tail with broad bulfy tips distinctive: rock-liamnting habits.

Nesting.- - lest: in crannies of cliffs. of twigs, grasses, wool, hair and other wft substances, approached loy rumway of rock-chips or pebbles. Eigys: $5-7$, white or pinkish white, sprinkled somewhat sparingly with pale cimnamon, chiehly alont

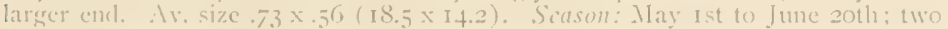
bromils.

General Range, - IVestern Linited States, northern and central Jexies, and

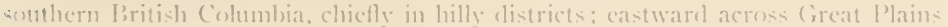
to Kansas, Nebraska, ete. : retires from northern portion of range in winter.

Range in Washington.-Summer resident and migrant in open comntry eant 


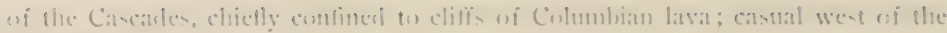
canciale-

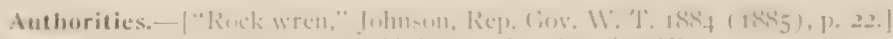

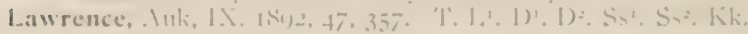

specimens.-1'. C:

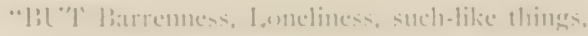

l'hatt gall amel grate on the White Man's nerves.

IV:s the rangers that campeel be the bitter springs

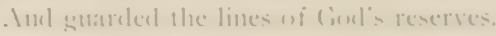

su dee folks all she irom the desem lamel.

"cent meblex a bew that kin mulersame."-Clark.

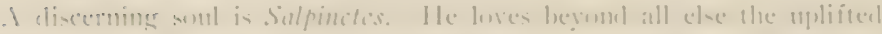

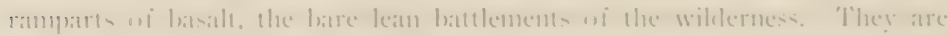

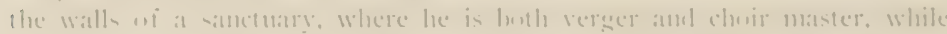

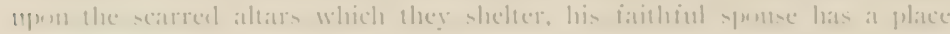
"where she maty lay liete yumb."

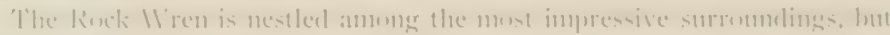

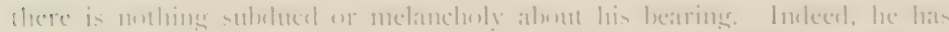

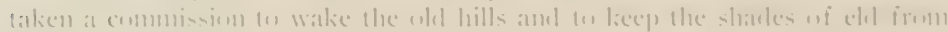

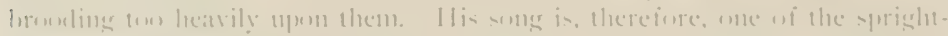

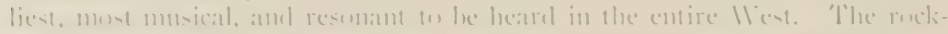

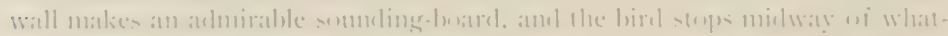

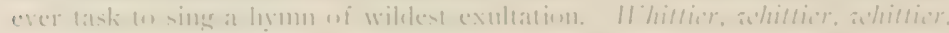

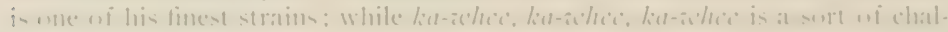

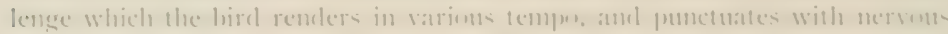

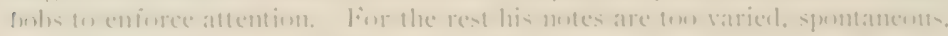

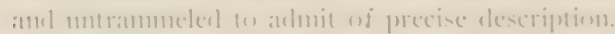

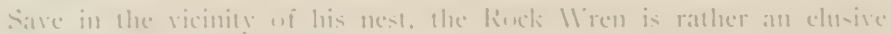

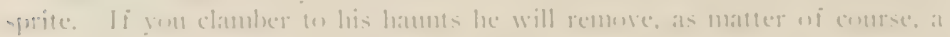

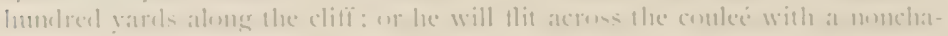

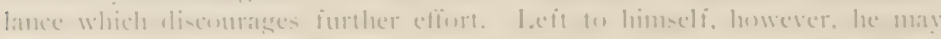
whimsically return-near enemgh perhaps for you to catch the click, clich

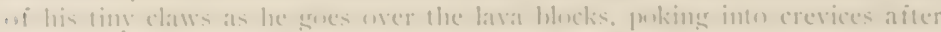

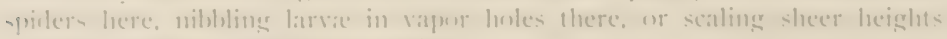
inder. without a tlusught of vertigne

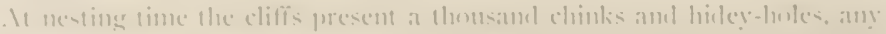

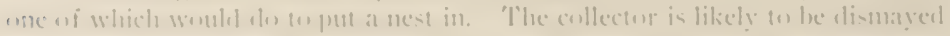

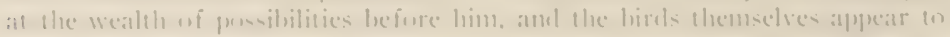

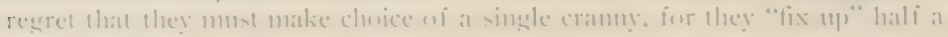


dozen of the likeliest. And when it comes to lining the ajproaches of the chosen carity, what do you suppose they use? Why, rocks, of course; not latge ones this time, but flakes and pebbles of basalt, which rattle pleasantly every time the bircl goes in and out. 'These rock chips are sometimes an inch or nore in cliameter. and it is rlifficult to conceive how a bircl with such a delicate beak can compass their removal. Here they are, however, to the quantity of half a pint or more, ankl they are just as much a necessity to every well-regulated salpinctean houseloli. as marble steps are to Philaclelphians.

The nest itself is rather at bulky affair. comprosed of weedstalks, clried grasses. ancl fine rontets. with a scanty lining of liair or wool (all Fast-side bircls are enthusiastic advocates of sheep-rais. ing ). "lwo loroods are raised in a sea. son. the first set of eggs appearing early in May, the second alont the miclalle of June. It is persible

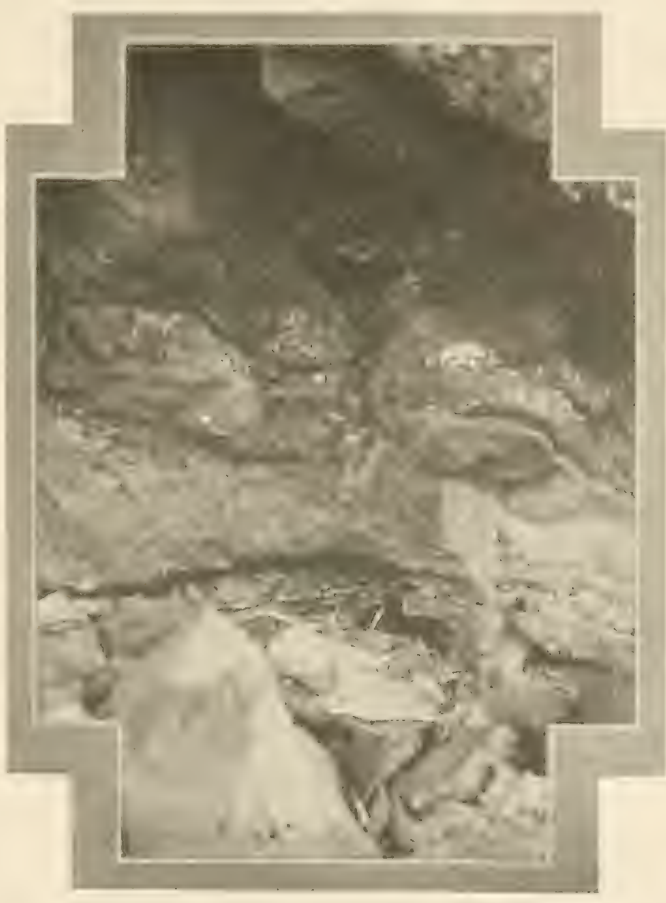

Taken in Douglas County.

Photo by the Author. that eren a third se:

may sometines be latid still later in the season, but these late sets are more apt to be due to the breaking aij) of the first or second. 'The eggs vary from five in seven, and are ptre white in color. sprinkled rather sparingly oser the surface with olnts of a faint brownish red, most heavily alont the larerer "uil" (Bowles). 


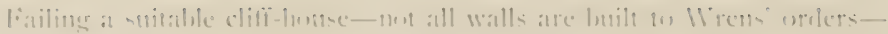

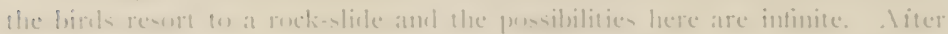

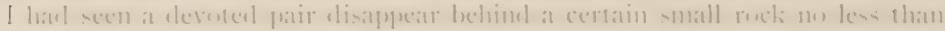

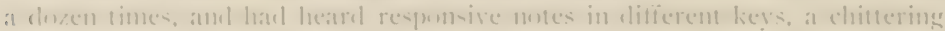

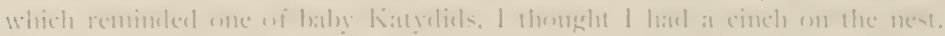

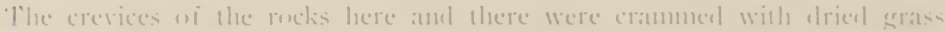

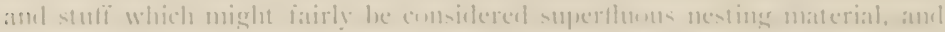

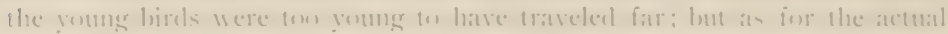

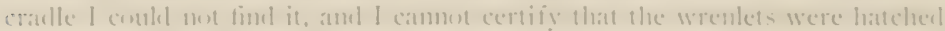

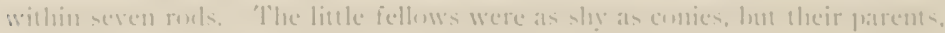

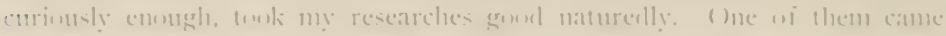

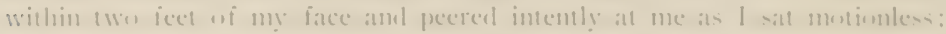

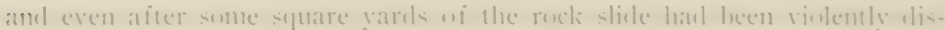

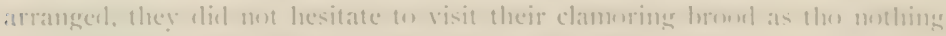

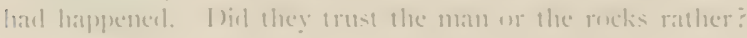

No. 122.

\section{CANYON WREN.}

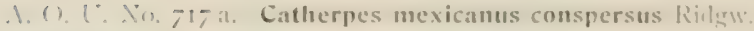

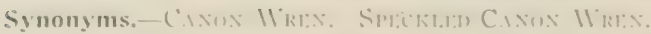

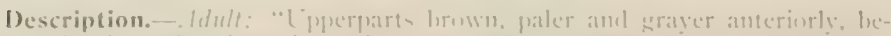

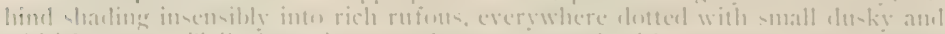

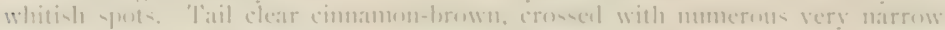

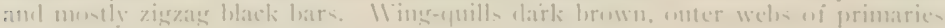

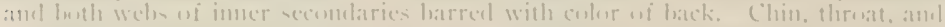

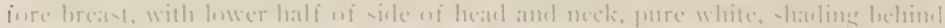

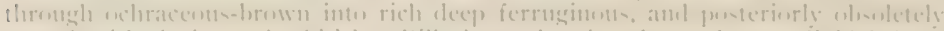

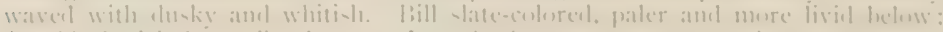

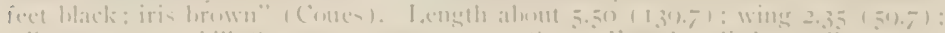

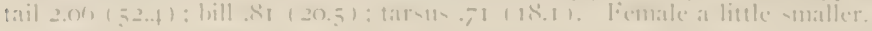

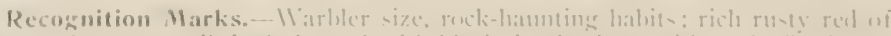

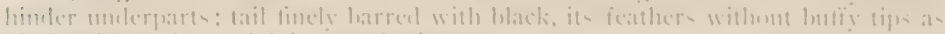

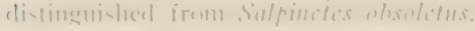

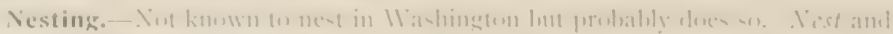

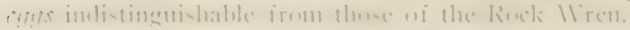

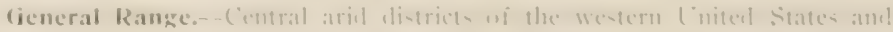

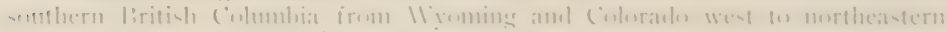
falifornia and woth lo Irizona.

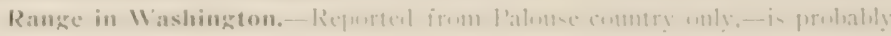


extending range into Lipjer Sonoran and Arid 'l'ransition zones of eastern Ilashington.

Authorities.-C. mericunns punctulatus, Snodgrass, Ank, Iol. XXl. Apr. [1) 04 . [1. 232. J.

specimens. I'.

I'O Mr. Robert E. Snodgrass belongs the honor of first reporting this species as a bird of IVashington. Ile encomntered it in the Simke kirer C'añon at Almota in the summer of 1903 , and mentions that it occurred also at IV awawai lierry, a few miles up the river. Roswell H. Johnson also refers (o) it castally in the preface to his list of the birds of Cheney ats vecuring "where conditions were favorable to the south and east."

It has long been supposed that the Canon Wrens were confined to a much more sontlem range. Riclgwarb assigns the northern linits of this species to 11 yoming and Nevala. Its appearance in $/ 1$ ashington, therefore, is matter of congratulation and may, perhaps, be taken as an instance of that northated trond of specis which undouldedly affects many of the l'asserine forms, and none more notalbly than the IV rens.

The Canon Wren frequents much the same situations as the Rock IV ren and lias the same sprigltly ways. In the southern part of its range it is saicl to be a familiar resiclent of towns, and nests as frequently in crannies and biril-boxes as cloes our House Wren (Troglodytes adon parkmanii). Its alarm note is a "peculiarly ringing dink," and its song is saicl to excel, if possible, that of the IInuse IVren. "What joyous notes! * * * His song comes tripping (lown the scale growing so fast it seems as if the songster could only stop by giving his odd little flourish back up the scale again at the encl. The ordinary song has seven clesecunding notes, but often, as if ont of pure exuberance of happiness, the $/ V^{*}$ en begins with a rum of grace notes, encling with the same little flomrish. The rare character of the song is its rhapsondy and the rich vibrant quality which has suggested the name of hugler for himand a glorions little bugler he strely is" (Mrs. Bailey ).

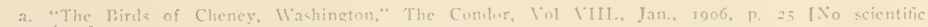
name given].

b. "The Jirits of X. and M. Imerica," Vol. 1II., P. 650 
No. 12.5.

\section{SAGE THRASHER.}

1. (1. 1'. Xin, g02. Oroscoptes montanus 'Tinm-ent.

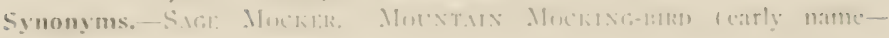
inipmipus)

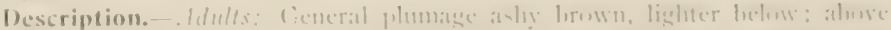

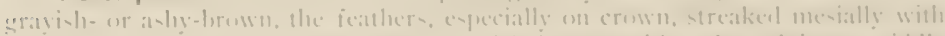

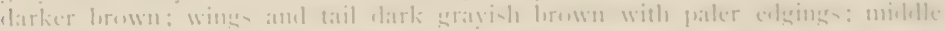

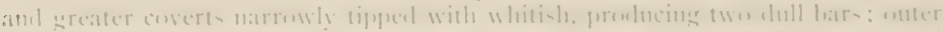

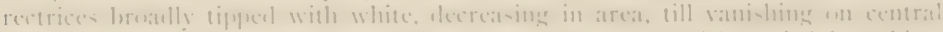

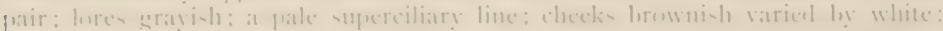

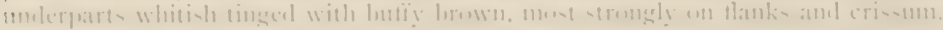

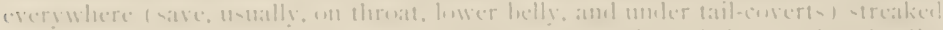

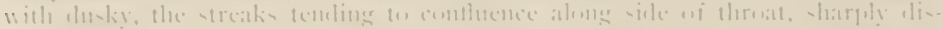

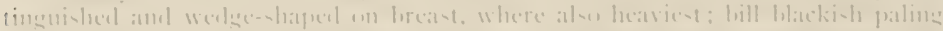

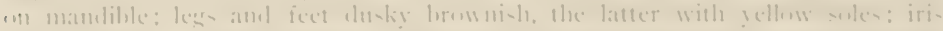

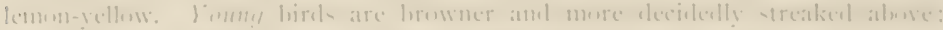

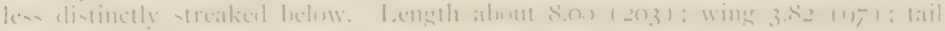

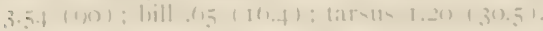

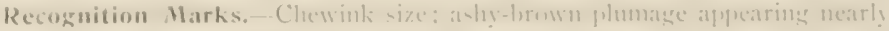

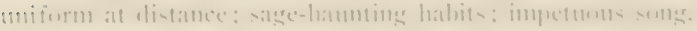

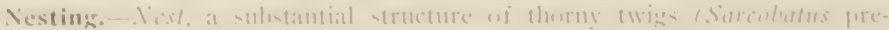

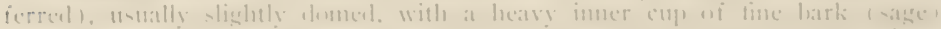

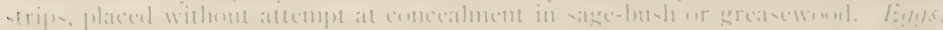

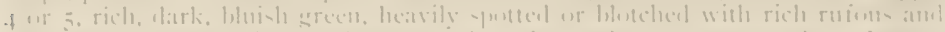

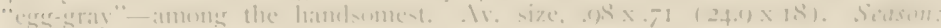
Mats 1-lime 15: I

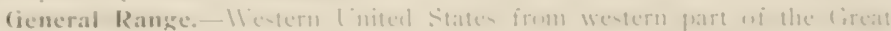

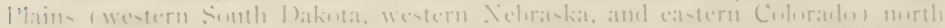

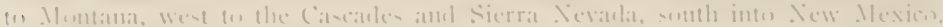

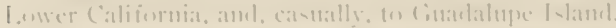

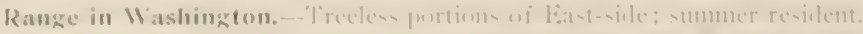

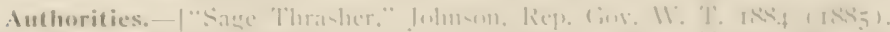

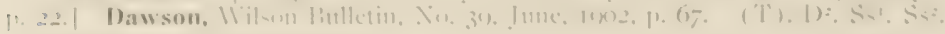
specimens.-1', of 11 . I'. C.

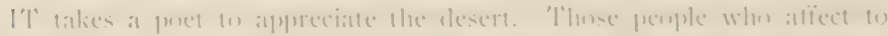

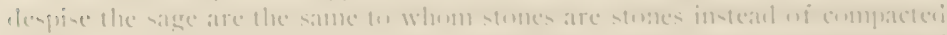

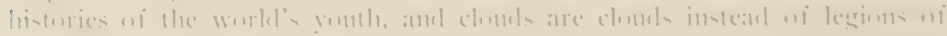

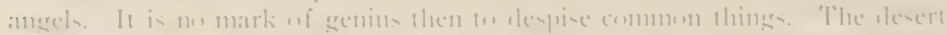

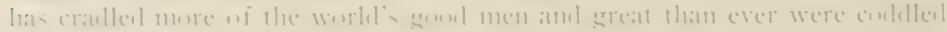

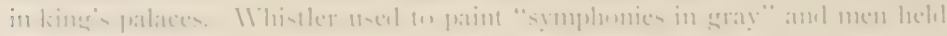

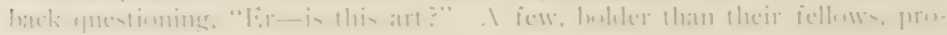


nomeed favorably mon it, and it is allowable now to admit that Whistler was a great artist-that is, a great discoverer and revealer of Nature.

Nature has painted mpon our eastern hills a symphony in gray greens, a canvas of artemisia, simple, ample, insistent. And still the people stand before it lesitating - it is so common-is it consiclered beatufinl, pray? $\mathbb{V}$ ell, at least a bircl thinks so, a bird whose whole life has been spent in the sage. Listen! The hour is smmrise. As we face the east, heary shadows still huddle about us and blend with the ill-defined realities. 'The stretching sage-tops tremble with oblation before the expectant sm. 'The pale dews are taking comnsel for tlight, lout the opalescent haze, pregnant with sunfire, yet tender with conl greens and stibtle azures, lovers over the altar wating the concomitance of the morning hymn before ascent. Sudkenly, from a distant sage-bush bursts a geyser of song, a torrent of tuneful waters, gusling, as it would seem, from the bowels of the wilclerness in an ecstacy of greeting and gratitule and praise. It is from the throat of the Sage 'Thrasher, poet of the bitter weed, that the tumult comes. Himself but a gray shadow, scarce visible in the early light, he pours out his soul and the soul of the sage in a rhapsoxly of holy joy. Impetuous, impassioned, compelling. rises this matchless music of the desert. 'l'o the silence of the gray-green canvas, beatiful but incomplete, has come the throb and thrill of life,-life brimful, delirions, exultant. The freshness and the gladness of it tonch the soul as with a magic. 'The heart of the listener glows, his veins tingle, his face beams. Ife cammot wait to analyze. He must dance and shout for joy. The wine of the wilderness is henceforth in his reins, and clrunk with ecstacy he reels across the enclianerl scene forever more.

And all this inspiration the birel draws from common sage and the rising of the common sum. How does he do it? I do not know. Ask IInmer. Milton, lieats.

No. 124 .

\section{(A'TBIRD.}

\section{A. O. [". Nn. 704. Dumetella carolinensis (I,imm.)}

Description.-. Idult: Slate-color, lightening almost inperceptibly below: black on top of hearl and on tail: moler tail-coserts chestmut, sometimes spotterl with slaty: bill and feet black. I.ength $8.00-1) .35 \quad(203.2-237.5)$ : wing 3.50 (6)1.2): tail 3.65 (02.7) : bill . 2 (15.8).

Recognition Marks.-Cluewink size: almost mniform slaty coloration with thicket-hannting habits distinctive; lithe and sleneler as compared with Water O) $112(\cdot)$ 


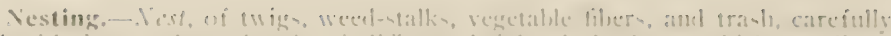

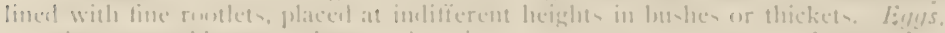

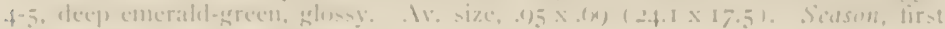
ewar week in lune: one bresel.

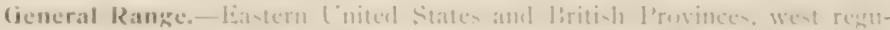

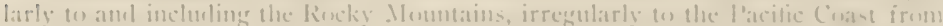

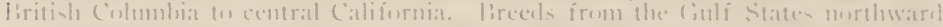

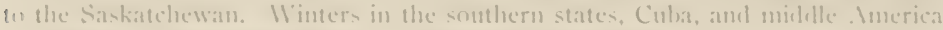
tu I'anama. Liermula, revilent. Aecilental in Europe.

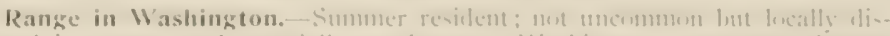

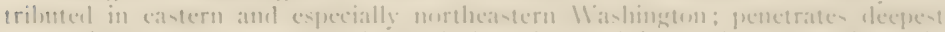

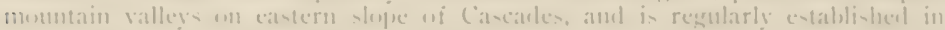

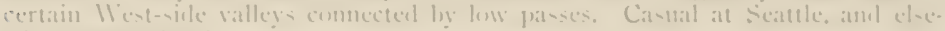
where at ita-level.

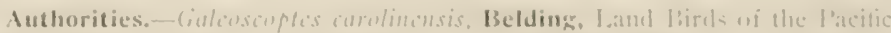

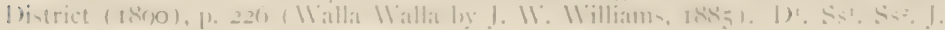

specimens.- (', of II. I'rux, I'. C.

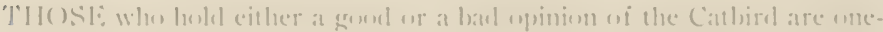

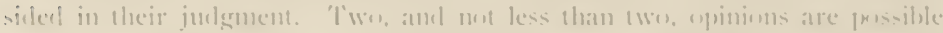

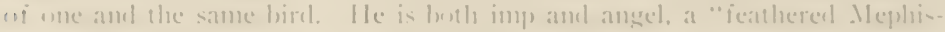

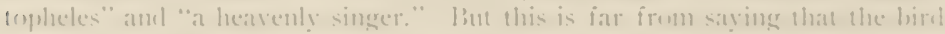

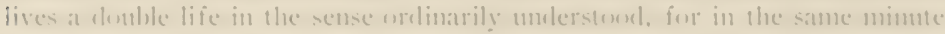
he is erave, saty pensive and elownish. Sature mate him huth at wats and at puet. and it is mo womeler if the mengishess and high philosuphy lecome inextricably entangled. ()ne monemt he steps forth hefore you at sleck at

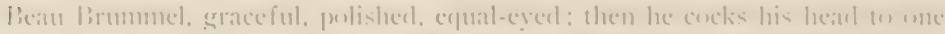

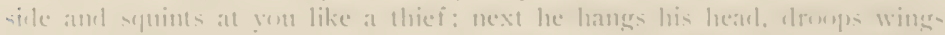
amel tail, amel lomks like a dog leeing lectured for killing sheep:- l'restes.

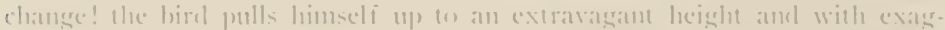

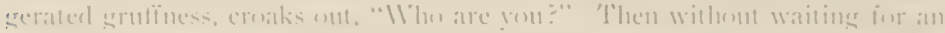

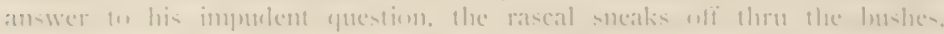

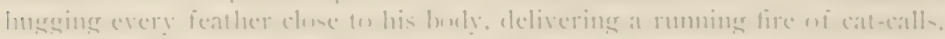

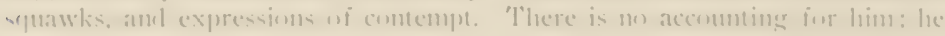
in an irrepressille-ant a genius.

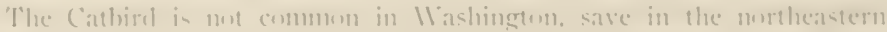

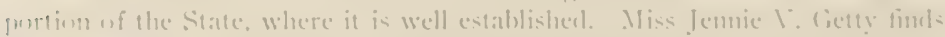
llem regulatrly at Sorth Pend, and there is a seattle record: so that there is reatum to believe that the Catbirel is one of these few species which are exfending their range be enconachenent from neighloring territury. There can

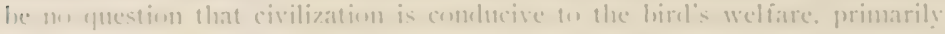

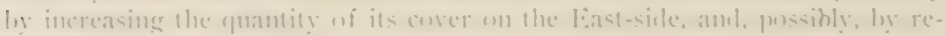

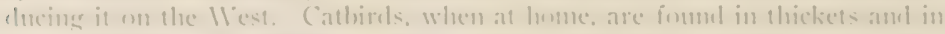

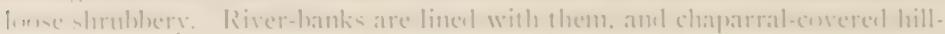


sides lave their share; but they also display a decided preference for the vicinage of man, and, if allowed to, will frequent the orchards and the raspberry bushes. They help themselves pretty freely to the fruit of the latter, but their services in insect-eating compensate for their keep, a lumdred-fold. Nests are placed almost anywhere at moderate heights, but thickety places are preferred, and the wilk rosebush is acknowledged to be the ideal spot. 'T'he birls exhibit the greatest distress when their nest is disturbed, and the entire neighborhood is aroused to expressions of sympatly by their pitiful cries.

My friend, Dr. James Ball Naylor, of Malta, Olio, tells the following story in answer to the oft-repeated question, Do animals reason? 'The poet's house nestles against the base of a wooded hill and looks out upon a spacions well-kept lawn which is studeled with elm trees. The place is famous for bircls and the neigliborhood is equally famous for cats. Robins occasionally venture to glean angle worms upon the inviting expanses of this lawn, but for a bird to attempt to cross it maided by wing would be to invite destruction as in the case of a lone soldier climbing San Juan hill. One day, howerer, a fledgling Catbird, overweening and clisobedient, we fear, fell from its nest overhead and sat helpless on the dreaded slopes. The parents were beside themselves with anxiety: The birdie conld not fly and would not flutter to any purpose. There was no enemy in sight but it was only by the sufferance of fate, and moments were precions. In the midst of it all the mother disappeared and returned presently with a fat green worm, which she held uj) to haby at a foot's remove. Baby hopped and floundered forward to the juicy morsel, but when he had covered the first foot, the dainty was still six inches away. Mama promised it to him with a flood of encouragement for every effort, but as often as the infant advanced the mother retreated, renewing her blandislments. In this way she coaxed her baby across the lawn and up. wwig by twig, to the top of an osage-orange herlge which bomeled it. Here, accorling to Dr. Naylor, she fed her chi'd the worm.

Comparing the scolding and call notes of the Catbird with the newing of a cat has perlaps been a little overdone, but the likeness is strong enough to lorge in the mind and to fasten the birl's "trivial name" upon it forever. Besicles a mellow phut, phut in the bush, the bircl has an aggravating mee-a-a. and a petulant call note which is nothing less than . Ma-a-ry. Cautious to a degree and timid, the bird is oftener heard in the depth of the thicket than elsewhere, but he sometimes mounts the tree-top), and the opening "l'hut, phut. coquillicot"-as Velt je Planchan hears it-is the promise of a treat.

Generalizations are apt to be inadequate when applied to singers of such brilliant and varied gifts as the Catbird's It would be impertinent to say: fromo sapiens has a cultivated roice and produces music of the highest order. Some of us do and some of us do mot. Similarly some Catbirds are "selfconscious ankl affected," "pause after each phrase to mark its effect upon the 


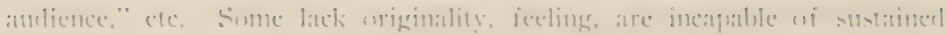

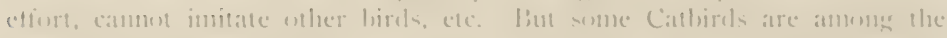

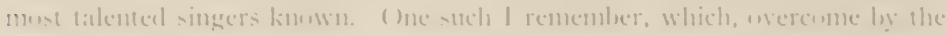

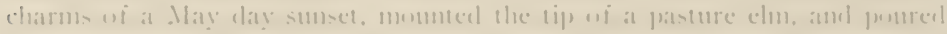

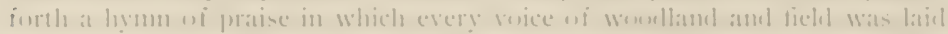

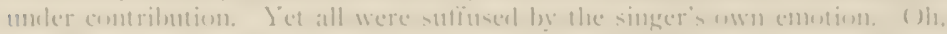

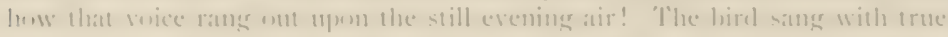

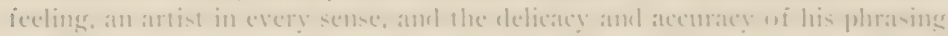

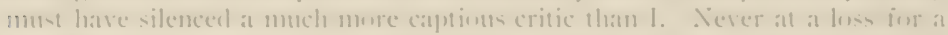
mete, never pamsing to ask limseli what le slumbl sing next, lee went searlily

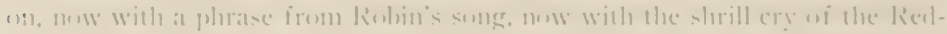

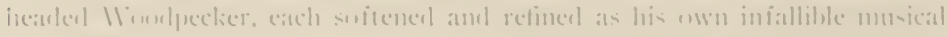

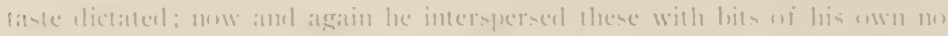

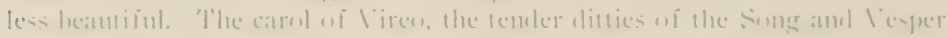

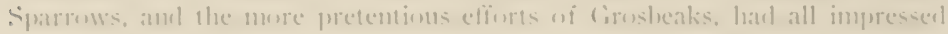
themselves mpon this musician's ear, and he repeated them, met slavishly, hut

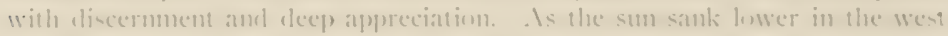

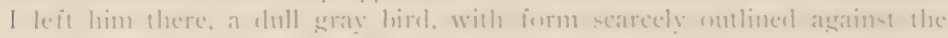

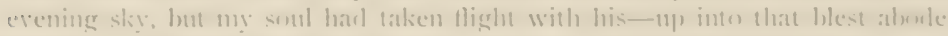

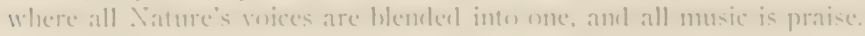

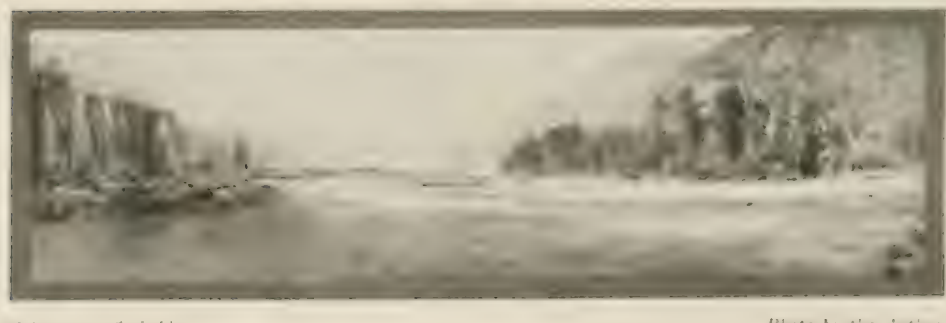




\section{No. 125.}

\section{AMERICAN WATER OUZEL.}

\section{A. O. U. No. 7оr. Cinclus mexicanus unicolor (Bonap.).}

Synonym.-AMricix DIréR.

Description.- Idults in spring and summer: General plumage slaty gray paling below; tinged with brown on head and neck; wings and tail darker, blackish slate; evelids touched with white; bill black: feet yellowish. Adults in full and ainter, and immature: Feathers of underparts margined with whitish and some whitish edging on wings: bill lighter, brownish. Joung birds are much lighter below; the throat is nearly white and the feathers of remaining under plumage are loroally tipped with white and have wash of rufous posteriorly-tips of wing-feathers and, occasionally; tail-feathers extensively white; bill yellow. l.ength of adult $6.00-7.00$ (152-178); wing $3.5+(00)$; tail 1.97 (50); bill .08

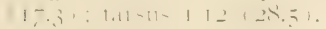

Recognition Marks.-Sparrow size but chunky, giving impression of a "better" bircl. Slaty coloration and water-hannting habits distinctive.

Nesting.- Vest: a large ball of green moss lined with tine grasses, and with entrance on sicle: lodged among rocks, fallen timber, roots, etc., near water. Eyys: + or 5. pure white. Ar. size, $1.02 \times 70(25.9 \times 17.8)$. Scuson: AprilJune: one or two brooks.

General Range. - The momtains of western North Anerica from the northem boundary of Mexico and northern Lower California to northern Alaska. Resirlent.

Range in Washington.-Of regular occurrence along all mountain streams. Retires to lower levels, even, rarely, to sen-coast in winter.

Authorities.-Cinclus mortoni, Townsend, Narrative, April, I839, p. 330.

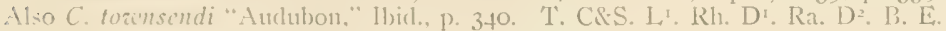

Specimens.-['rov. B. E.

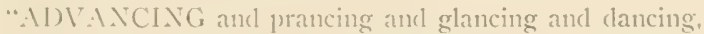

And dashing and tlashing and splashing and clashing;

Ancl so never encling. but always descending.

Sounds and motions forever and ever are blending.

All at once and all o'er, with a mighty uproar:

And this way the Water comes clown at Lodore."

But the seene of aqueous confusion was incomplete unless a leaden shape emerged from the spray, took station on a jutting rock, and proceeded to rub) (ont certain gruff notes of greeting. jigic, jüjic, jigic. These motes manage somehow to domimate or to pierce the roar of the cataract, and they symbolize henceforth the turbulence of all the motntain torrents of the $1 V^{r}$ est.

The IVater Onzel bobs must absurdly as he repeats his inquiry after your 


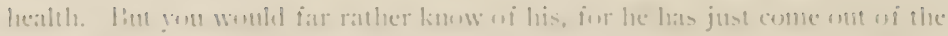

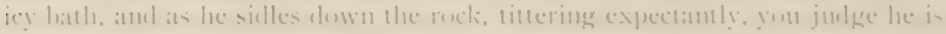

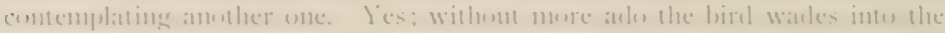

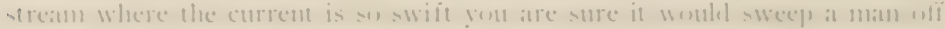

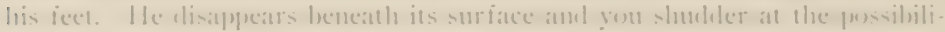

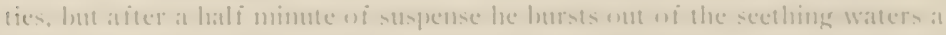

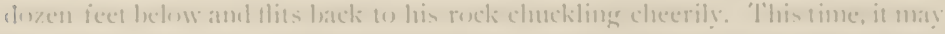

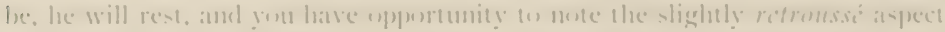

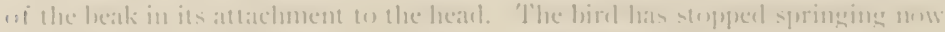

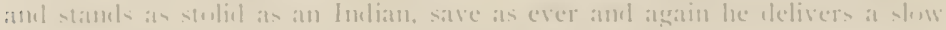

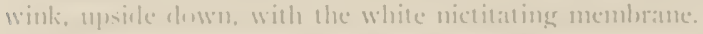

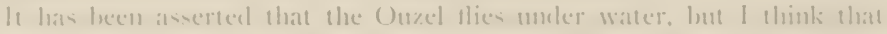

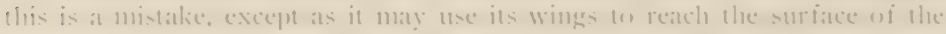

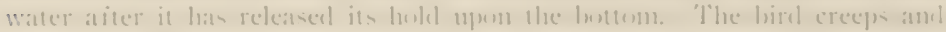

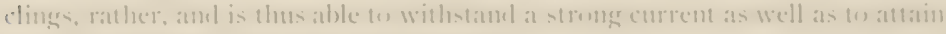
a vepula uf seremal feet in quicter waters.

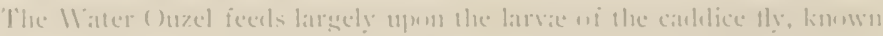

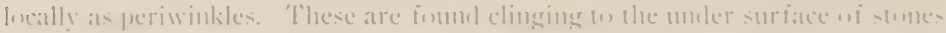

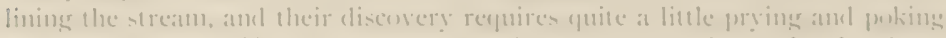

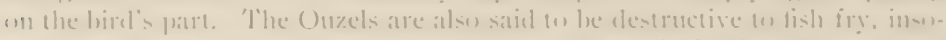

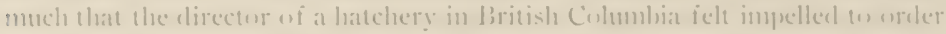

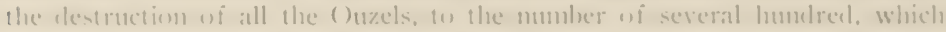

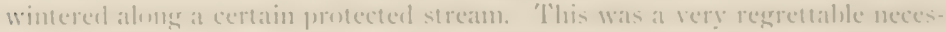
-ity, if necessity it was, and one which might easily lead en mismulerstanding

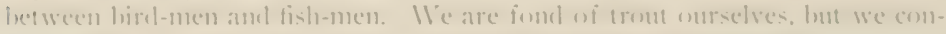
fess of being at great ileal fonder of this alventuresume water-sprite.

l'he ()uacl is non-migratury, but the stmumer hamms of the hirels in the mometains are largely chosed to them in winter, su that they fime it necessary at

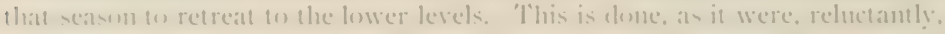
and mulhing shore of the actual blanketing of stus of ice will drive them to borsalie the higher watters. The birel is essentially solitary att this seasons, ats in summer, anul when it repairs to a fower station, alonge late in Povember.

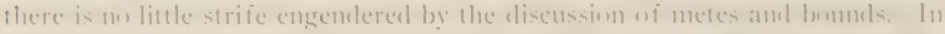

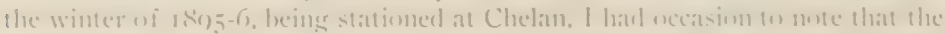

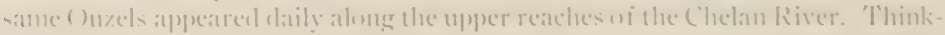

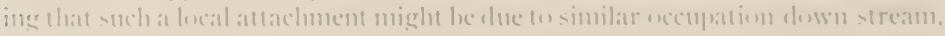

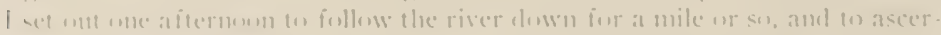

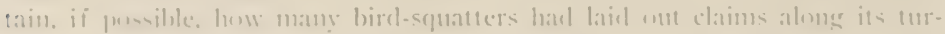

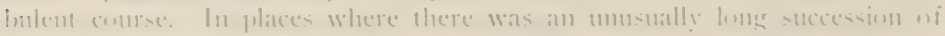

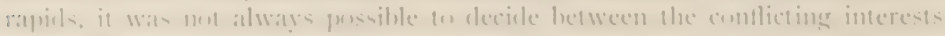

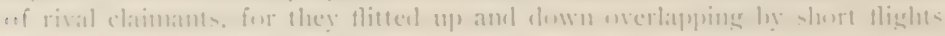

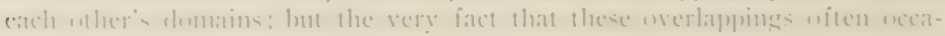


sioned sharp passages at arms served to confirm the conclusion that the territory had been divided, and that each bird was expected to dive and bob and surgle on his own beat. T'lus, twenty-seven bircls were found to occupy a stretch of two miles.

Here in winter quarters, the first courting songs were heard. As early as Christmas the bircls began to tume 11 ), and that quite irrespective of weatler. But their utterances were as rare in time as they are in quality. In fact, it does not appear to be senerally known that the Ilater Otweel is a beantiful singer. and none of those who have been so fortunate as to hear its song. have heard enougla to pass final judgmeni on it. $\mathrm{We}$ know. at least. that it is clear and strong and vivacinus. and that in its ntterance the bird recalls its affinity to both 'l'hrushes and 'Thrashers.

The Ouzel places its nest beside some brawling stream, or near or behind some small cascate. In cloing so, the chief soliciturle seems to be that the living mosses, of which the bulky globe

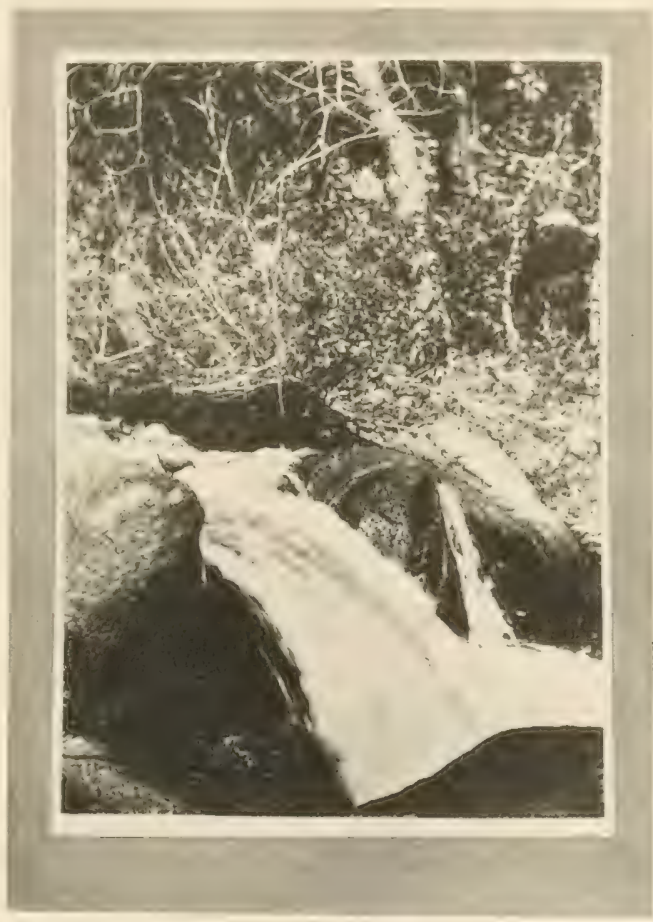

Taken in Caluforma.
Photo by Fredirick Badc.

THE I. AST STATION

is composed, shall be lept moist by the flying spray, and so retain their greenness. Indeed, one observer reports that in default of rearly-made conveniences, the birel itself turns sprinkler, not only alighting upon the dome of its house after returning from a trip, lout visiting the water 


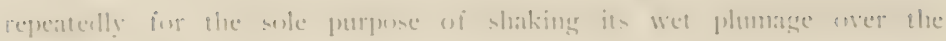
mon- mest

Lolem we mistake, the biral in the tirst pieture is athme the vist at thes

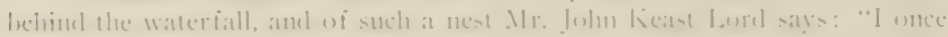

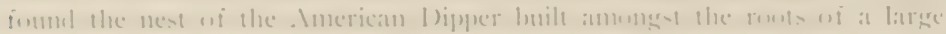

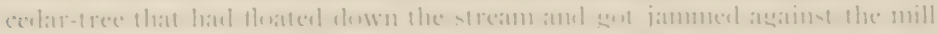

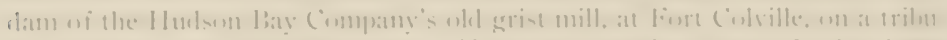

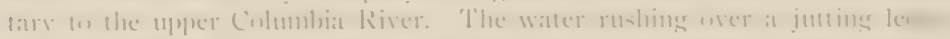

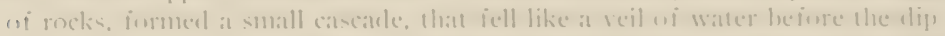

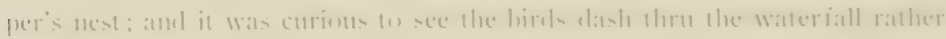
thatl ert in at the silles, and in that wat eqe lechinel it. For homes I hatre sat and watclecel the lusey parir, patas ine in amb ont thrte the fall, with :1 much applatemt earec ats an equecotram

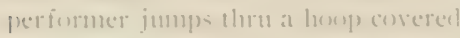
with tisste paper. 'The nest was in erenionsty comstructerl on prevent the snaty from wetling the interior. the moxes leeines so worked arer the ent france as of form and almirable ver amilal."

() f the nest sheswn in the aceoms

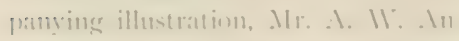
thrmy says that it wate completerl mo

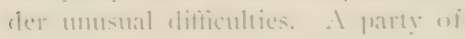
strvevers, requiring to brielese at

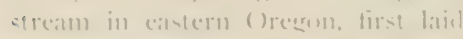
it syumerl stringer. This an ()uzel prompuly seizert t1рнm, and in tolicen 11 proprictership legean to heap) up mess.

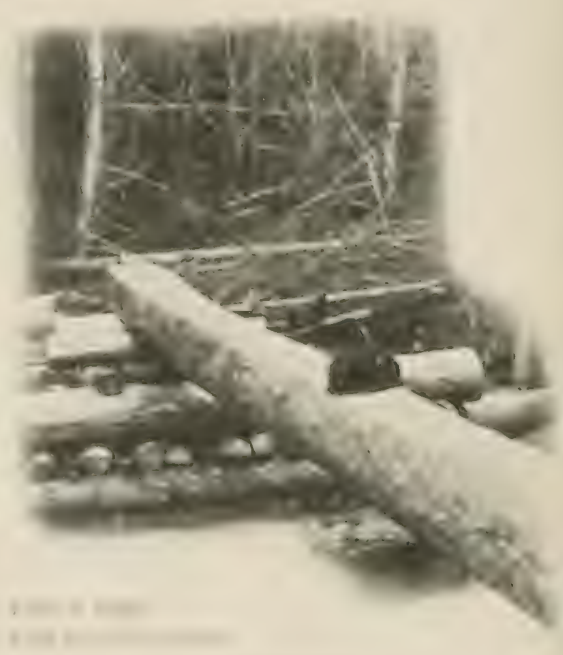

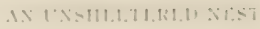
This arrangenseme thel nust compum

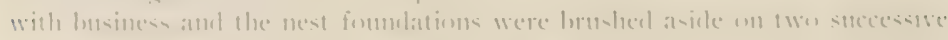

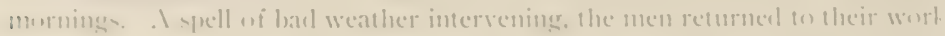

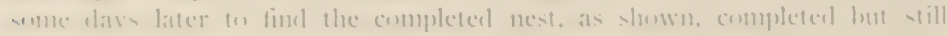

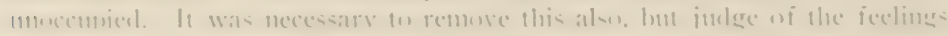

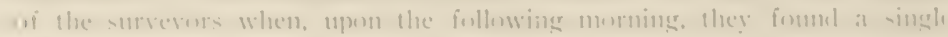

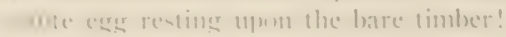


No. 126.

\section{PURPLE MARTIN.}

A. O. U. No. Gri. Progne subis (Limn.).

Description.- Adult male: Rich, purplish black, glossy and metallic: wings and tail dead black. Idult female: Similar to male, but blue-black of upperparts restricted and duller; forehead, hind-neck, and lower parts sooty gray, paler on belly and crisstm. Bill black, stout, and broad at the base, decurved near tip; nostrils exposed, circular, opening ujward; feet moderately stont. Jomng males: resenble adult female but are somewhat darker, the steely bluc appearing at first in patches. L,ength 7.25-8.50 (184.2-215.9); av. of eight specinens: wing 5.75 ( I $46 . \mathrm{I})$; tail 2.72 (60.I) ; bill, breadth at base .73 ( 18.5 ) ; length from nostril $3.3(8.4)$.

Recognition Marks.-Chewink size; the largest of the Swallows; blue-1)lack, or blue-black and sooty-gray coloration.

Vesting.-Xest, of leaves, grass, and trash, in some cavity, msually artilicial-birl-hoxes, gourds, etc. Eigys, +-5 rarcly 6, pure, glossy white. $d v$. size, .08 $\times .73$ (24.9 $\times 18.5)$. Season, first week in June; one brood.

General Range-Temperate North America, except southern portion of I'acific Coast district, north to Ontario and the Saskatcliewan, south to the higher parts of Mexico, wintering in South Anerica.

Range in Washington.-.Not common summer resident-nearly confined to business sections of the larger cities.

Migrations.-Spring: c. April I5; Tacoma, April I, 1005. Fiall: c. Sejt. Ist.

Authorities.-Cooper and Suckley, Rep. Iac. R. R. Surv. AII. pt. II. IS60, 1) I36. ('I'). C\&S. $\mid$ L $\mid$. Rh. Ra. Kk. B. E.

Specimens.-l'rov. L. E.

'THIS virtually rare bird appears to be strictly confined dering its stmmer residence with us to the business districts of our larger 11 est-side cities. Records are in from Seattle, 'Tacona, Olympia, Iiellingham, I ancomver, and Victoria only. Really, if this favoritism continues, we shall begin to think of imposing a new test for cities of the first class; riz., Do the Martins nest with you?

Suckley remembers a time when, in the early Fifties, a few Martins were to be seen alonut the scrub oaks of the Nisqually Plains, in whose hollows and recesses they undoubterlly nested : lont all Washington bircls lave long since aclopted the ways of civilization. April Ist is the earliest retmin I have noted. and we are not strpurised if they fatil to put in an appearance before the ist of May: 'Their movements depend largely upon the weather. and even if they have come back earlier they are likely in mope indorst when the weather is colrl and cisagrecable. The birls feed exclusively t1pon insects, and are thus quite at the mercy of a backward spring. Not only flies and nits are 


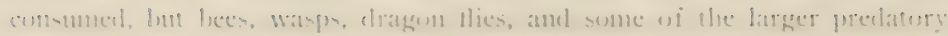
lecetlen in well.

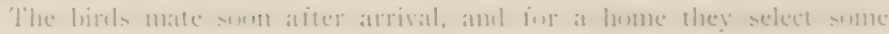

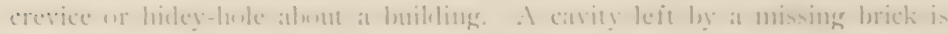

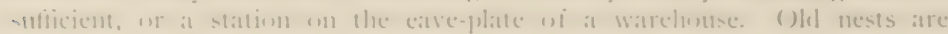

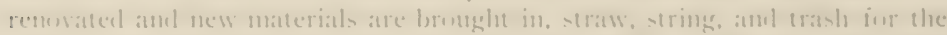

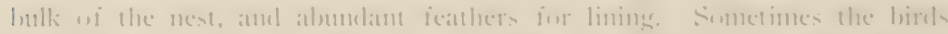

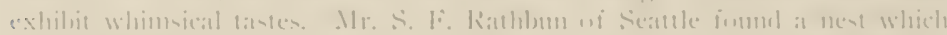

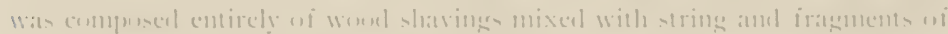

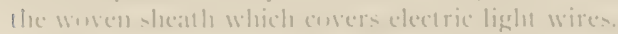

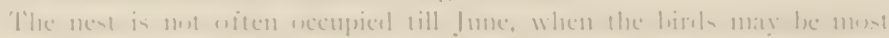

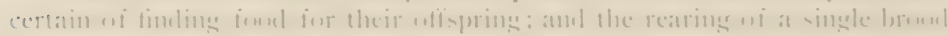

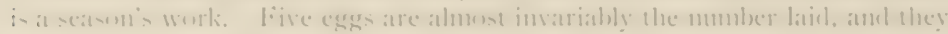

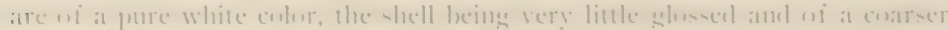

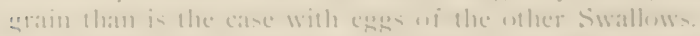

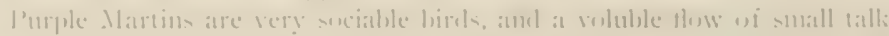

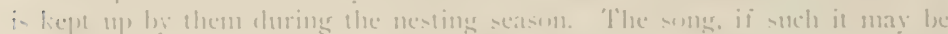

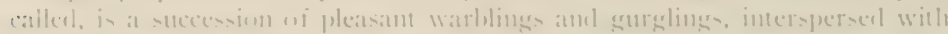

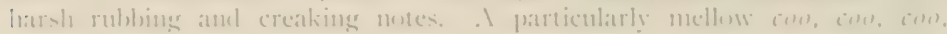

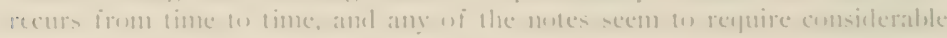
erfort ins the part of the periormer.

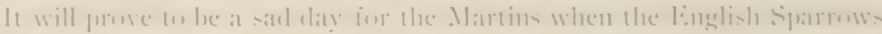

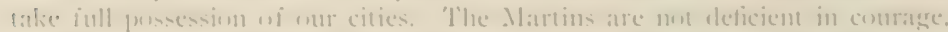

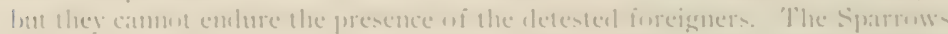
are tiltily creatures, and it may he that the burelen of the vermin, which

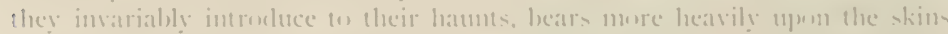

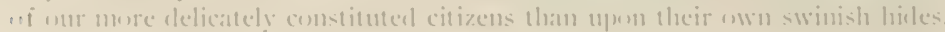

\section{No. 127.}

\section{CLIFF: SW MII.O)W:}

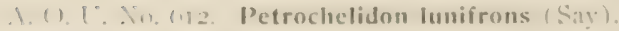

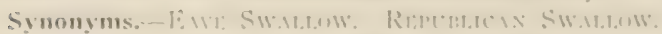

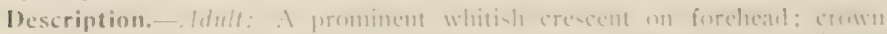

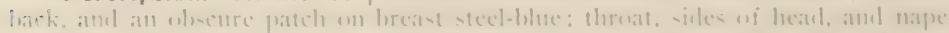

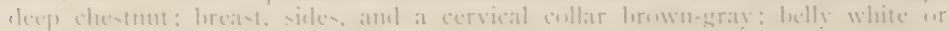

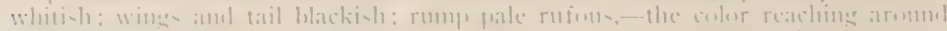

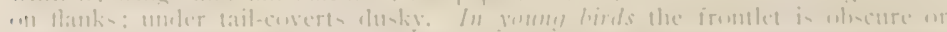

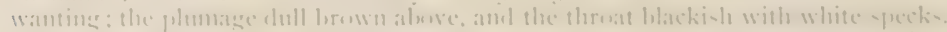

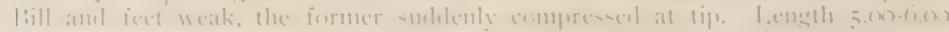

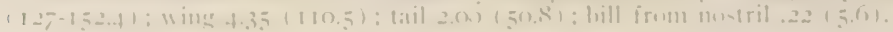


Recognition Marks. - "Warbler size," but comparison inappropriate,-better say "Swallow size"; white forchead and rufons rump. Fonnd in colonies.

Nesting. - I est, an inverted stack-shaped, or declined retort-shaped structure of mud, scantily or well lined with grass, and depending from the walls of cliffs. sides of barns under the eaves, and the like. Egys, 4-5, white, spotted, sometimes scantily, with cinnamon- and rufous-brown. Av. size, $82 \times .55$ (20.8 $\times$ if). Season, May 25-June 25.

General Range.-. North America, north to the limit of trees, breeding south. ward to the Valley of the l'otomac and the Ohio, southern 'l'exas, southern Arizona. and California: Central and South America in winter. Not found in liloricla.

Range in Washington.-Sumuer resilent, abundant but locally distributed cast of Cascarles; much less common in l'uget Sound region. 4. Inos.

Migrations.-Spring: April 15-30. Fall: first week in Sept. 'Tacona, April

Authorities.-Mimudo lmifrons, Say, Cooper and Suckley, Rep. I'ac. R. R. Surv, XII. $1860,184$. T. CiS. D). Kb. Ra. D2. $\mathrm{Ss}^{1} \cdot \mathrm{S}^{2}$. I. B. E.

Specimens.-I'rov. ['. C.

[ifill bircls serve $(0$ recall more accurately a picture of sequestered syandentr and prineval peace than do these amiable tenants of Washington's

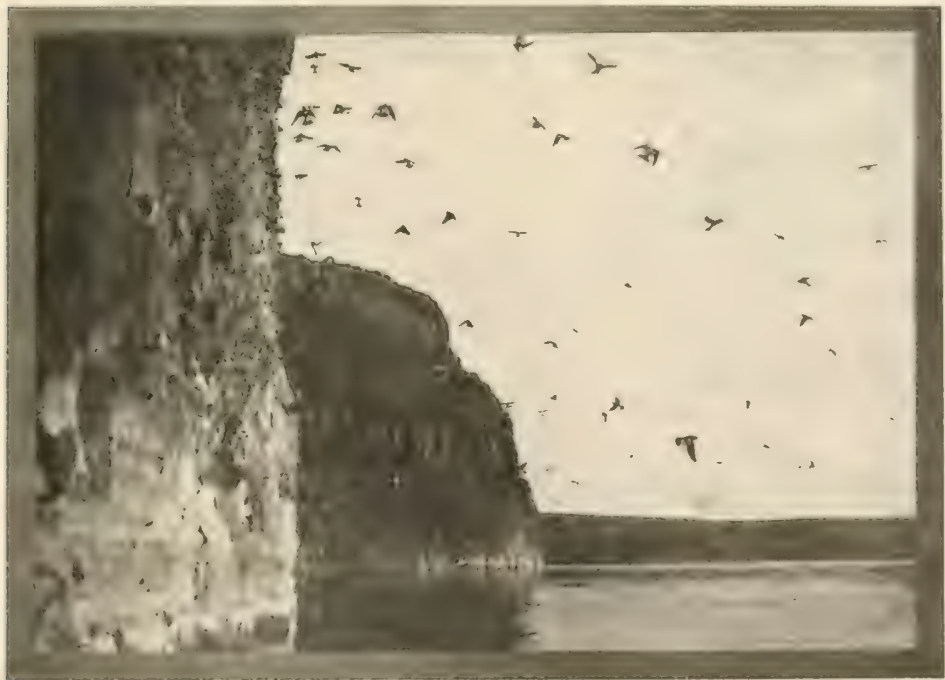


very linited scal, lands. It is true that certain Cliti swallews, following the example wi their wealier eatsersu brethem, have taken lo nesting murles the cares uf churches and barns and outhilelings, but they are a negligible quante in comprarison with the swatms which still resort on the ancestral

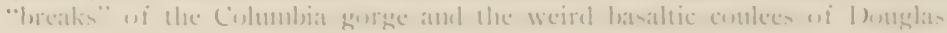
Cinuty:

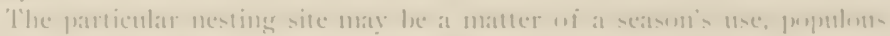
this year amb abankloned the next; Int smmewhere alomg this frowning tiace wi

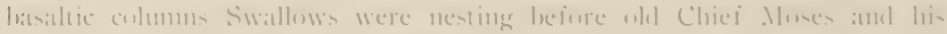

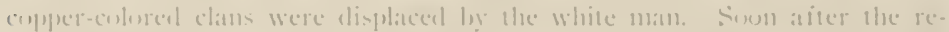

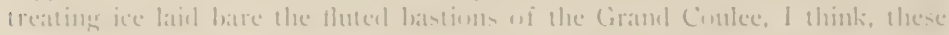

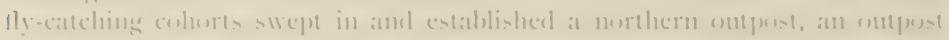

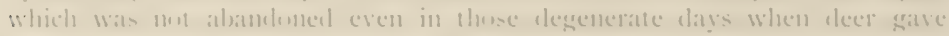

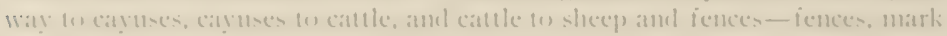
yent, win the Swallew's demmatin!

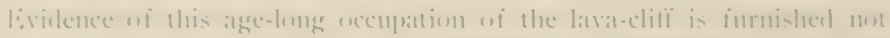

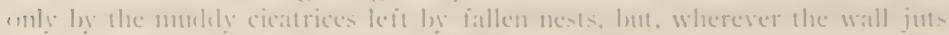

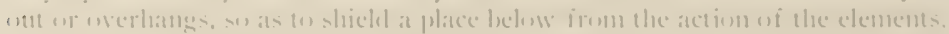

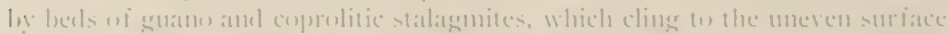

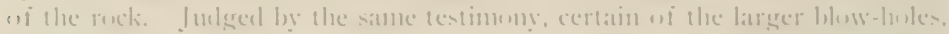

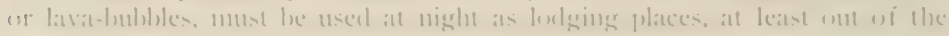
nestimes seasun.

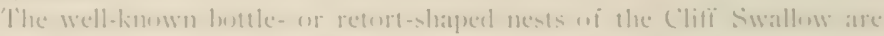

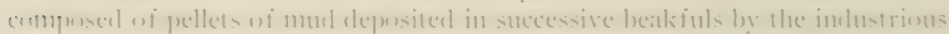
birds. It is always interesting to sece at twittering complate of these linte

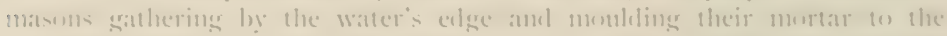

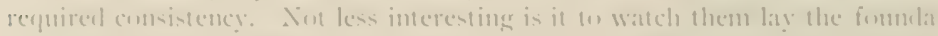

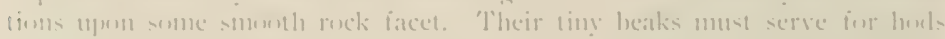

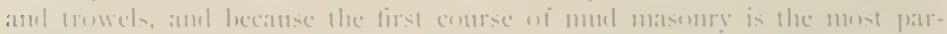

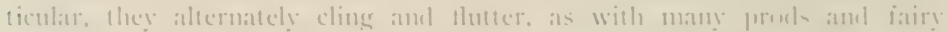
thumps they force the putty-like material on lay lowh of the ineliferent wall

'Tlene is usually much passing to and for in the case wi these cliftdwellers, and we ean nexer hepe he steal mpen them manwares. Il hem one

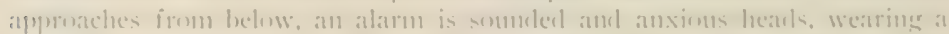

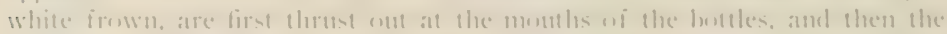

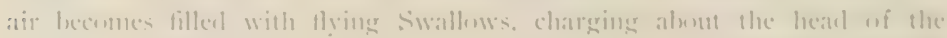
intruler in lewilering mazes and misine a habble of strange frangible

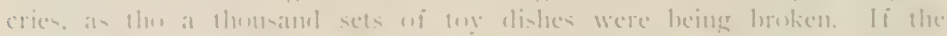

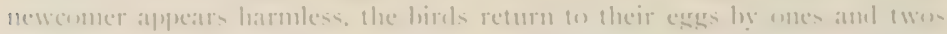

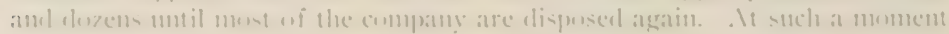

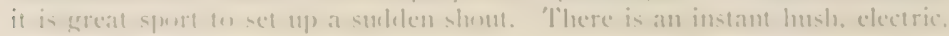
mminus. While every little Injun of them is making for the denor of his 
wigwam. 'Then they are dislodged from the cliff like an avalanche of missiles. a silent, down-sweeping cloud: but immediately they gain assurance in the open and bedlam begins all over again.

The Cliff Swallows are, of course, beyond the reach of all four-footed enemies, but now and asain a June rain-storm comes at the cliff from an unexpected quarter and plays sad havoc with their frail tenements. Besides

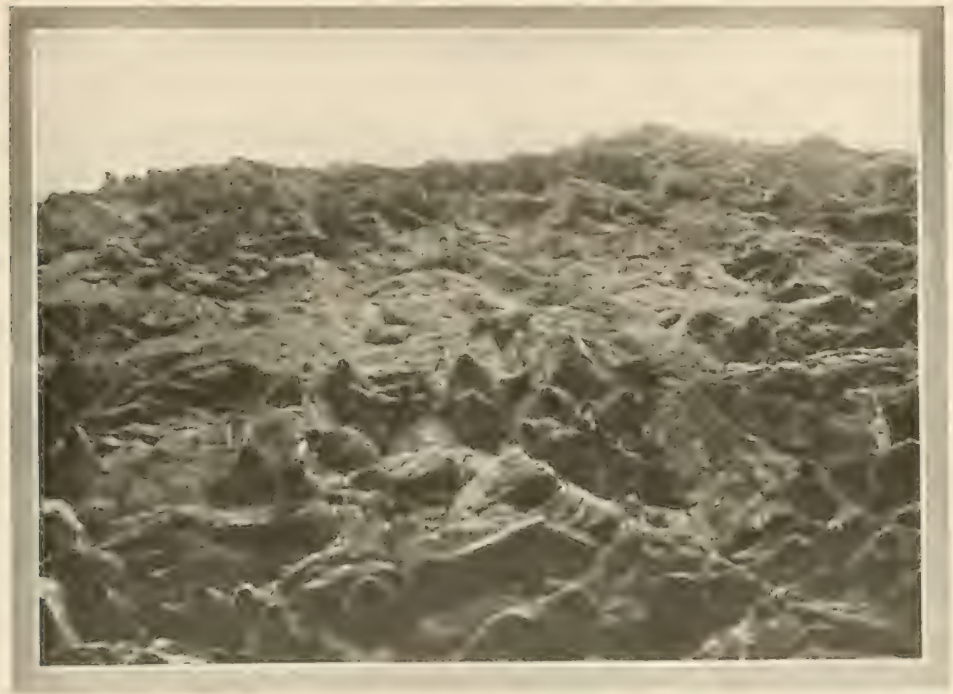

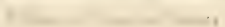

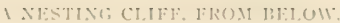

Lhis (in strictest confidence: one dislikes to pass an ill worl of al sulfering brother) the nests are likely to be infested with berl-bugs. Not all, of conrse. are so aftlicted, but in some cases the scourge becomes so severe that the nest is abandoned ontright, and eggs or young are left to their fate. In spite of this compromising weakness. the presence of these swallows comfers an incalculable benefit upon the famer of eastern 1 ashington, in that they alone are able to erope with a host of winged insect pests. They race tirelessly to and fro across the landscape, wearing a magic tapestry of search, unti] it would seem that not a cubic inch of atmosphere rematns without its invisible thread of flight. 
Nio. 128.

\section{ROLGH-WINGEDSWALLOW'}

\section{1. (1. L. No. 61\%. Stelgidopteryx serripennis (.|mel.).}

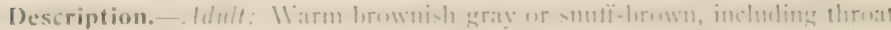

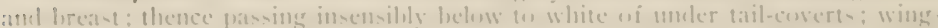

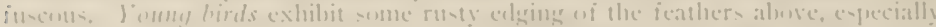

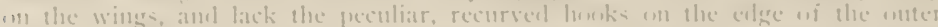

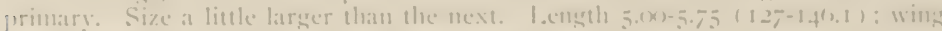

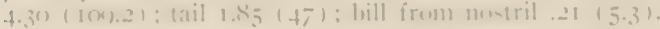

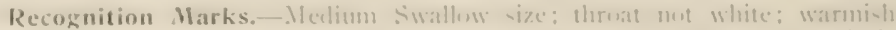

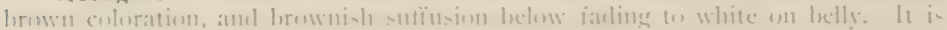

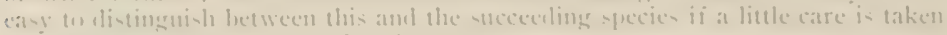
(1) inte the eqeneral pattern of molerparth.

Nesting.- Vest, in crevice of clift- at end of emmels in sand hanken or in

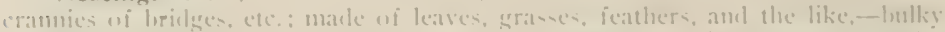

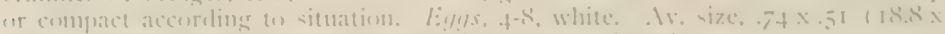

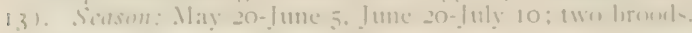

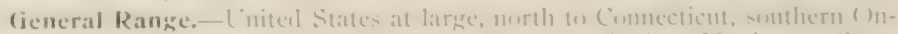

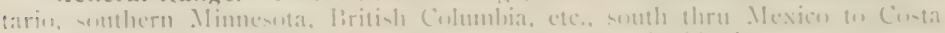
Rica. lireels thrunut (nited States range and south in .Mexien.

Range in Washington.-Sumner resilent, wi general distribntion, -ave in

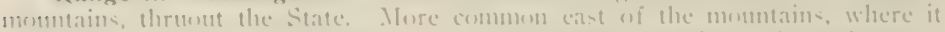
has taken at ereat fancy to banke of irrigating ditches enecially where abrupt.

Migrations.-Sprimel: Tïrst week in . Ipril: 'Tacoma, Ipril 3. 14x)5. Ipril ci. lescri and renes. liull: c. Sept. 1.

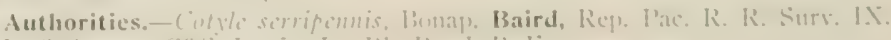

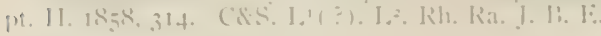

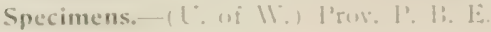

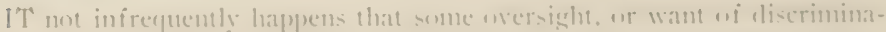

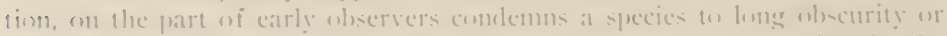

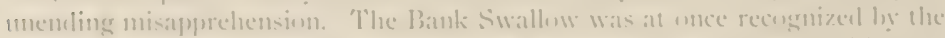

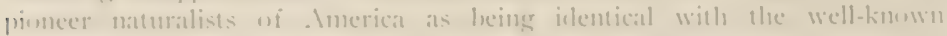

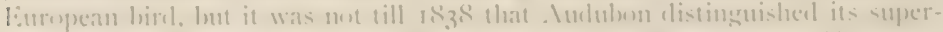

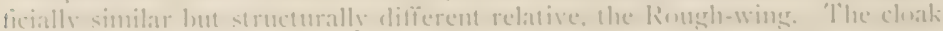

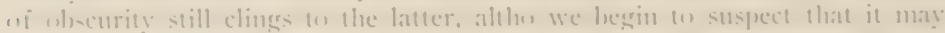

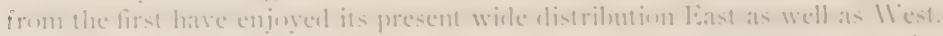

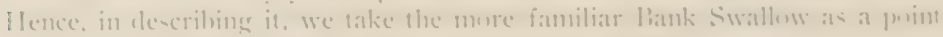
af eleparture, and say that it fiffers thus and so and sin.

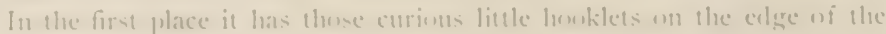

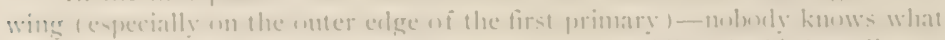

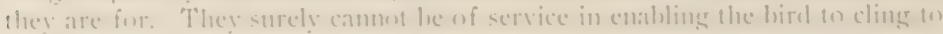


perpendicular surfaces, for they are bent forward, and the bird is not known to cling head-downward. It is easy to see how the bird might brace its wings against the sicles of its nesting tumnel to prevent forcible alyluction, but no one knows of a possible enemy which might be circumvented in this way.

Again, the Rough-winged Swallow has a steadier, rather nore labored llight than that of its foil. Its acrial contse is more dignified, leisurely, less impulsive and erratic. In nesting, altho it may include the range of the Sand Martin, or even nest sicle by side with it, it has a wider latitude for choice and

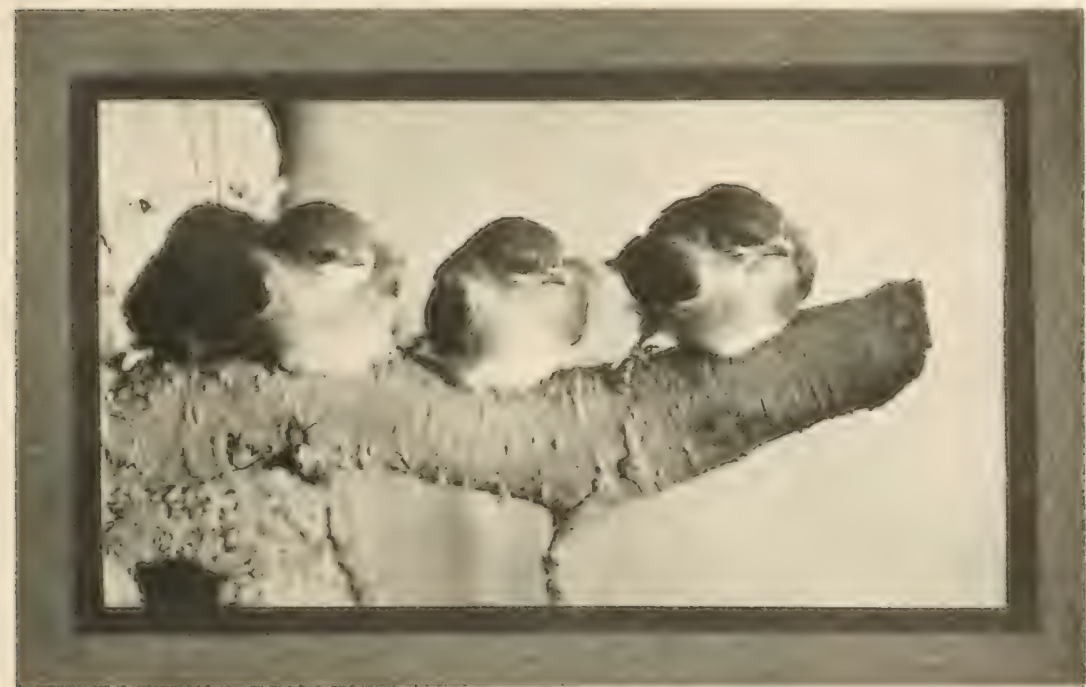

BAHY ROLGH-WTHC:S

is mot hampered by local tradition. If it burrows in a bank it is (quite as likely in dig near the bottom as the top). Crevices in masomry or stone quarries. crannies and aluntments of bridges or even holes in trees, are utilized. In Lincoln county where cover is searce and the food supply attractive. I fomel them nesting along irrigating ditches with banks not ower two feet high. One guileless pair I knew excavated a nest in the gravelly bank of an ungrated lot nnly three feet above the sidewalk of a prominemt street. Benmy II ay, in seattle. These bircls were unsuccesful, but another pair, which enjoved the 


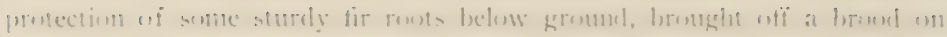
loifly-lith sireet, near my hume.

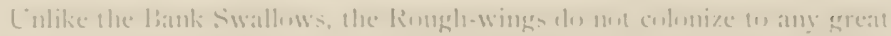

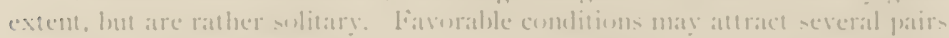

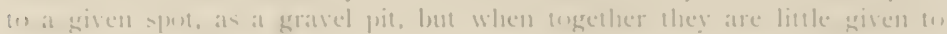
(2)

These swallows are pretly evenly distributerl thrume the length amb breathe wi the state, satse that they do mot venture inte high altitules. Since

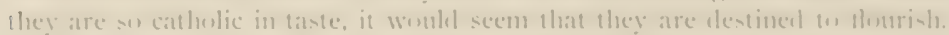

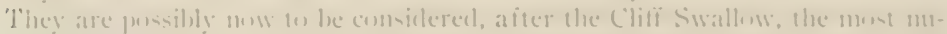

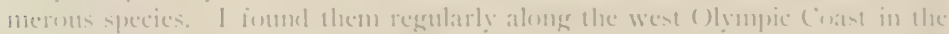

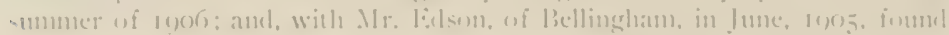

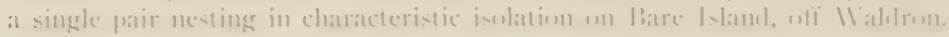

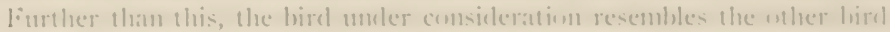
quite chosty in moles, in habits, and in general appearance, and requites sharp

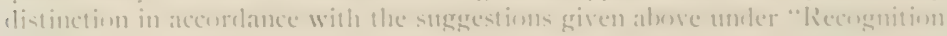
Marke,"

No. 129.

\section{BANK SIVALIOW.}

\section{1. (). [". To. 6rf, Riparia riparia (l,imm).}

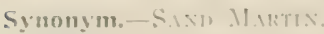

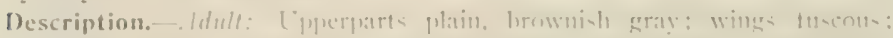

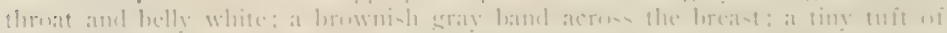
feathers alone the hind toe. There is some variation in the extent of the peetoral

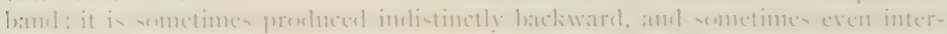

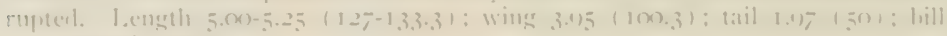
irom mutril .20 i 5.1 ).

Recognition Marks.-Smalle- of the swalluws: throat white: hrommi-h teray pectoral hatml on white groumrl.

Vesting. - Vest, at end of tumuels in hanke, I wo or three fect in: at irail

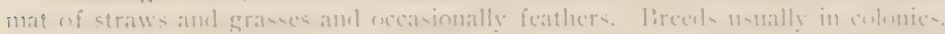

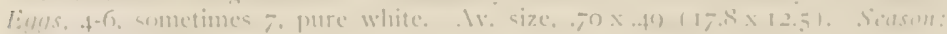
June: ane hrond.

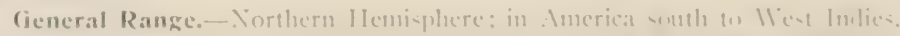

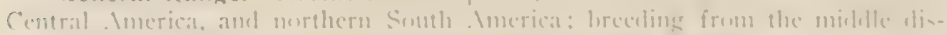
trict of the I nited State northwarel tu alume the limit uf erees.

Range in Washington.-Summer revilent: not commons. I few laree

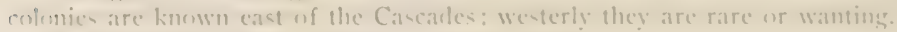

Migrations.-Sprin!l: May 11, Isifn, Cliclan. 
Authorities.-Clivicola riparia, Dawson, Auk, Vol. XIV. April, IS97, 1). 179.

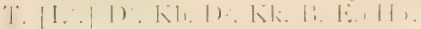

Specimens.-l'rov. C.

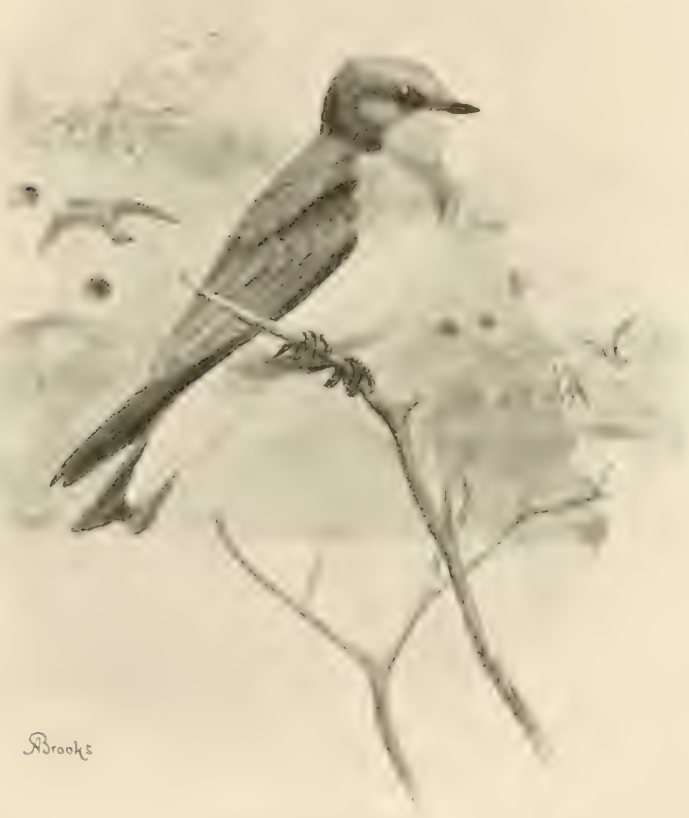

BAXK SII:M.I.OI:

'I'IOSSE, who hnow, conceive a regarl for this plain-colored bird which is quite out of teeping with its humble garl) and its confessedly prosy ways. The fact is, we have no other bircl so nearly cosmopolitan, and we of the 11 est, who are being eternally reminder of our newness. and who are, indeed. upon the alert for some new shate of color mont the feather of a hird for each added degree of longitude, take comfort in the fact that lere at least is an un- 


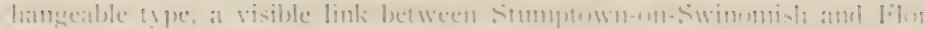

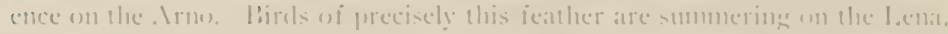

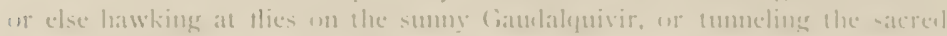

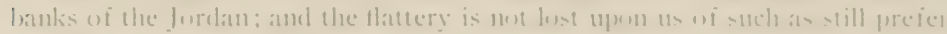
the Nespilems and the l'ilchuck.

The life of a swallow is as largely spent atwing, that ent interest in

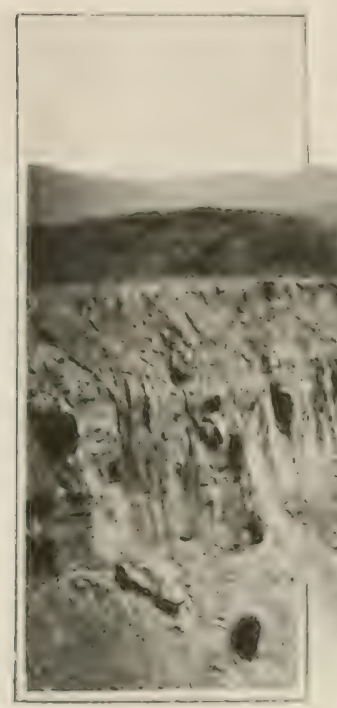

centers (even more than

in the erace wi uther

birls upon the time

when it is |x)mule to

1.

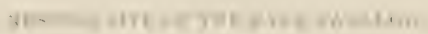

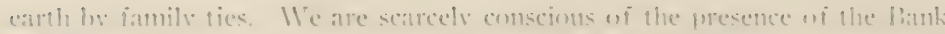
swallesw unt one dity we see at great company of them fluttering abum a samel

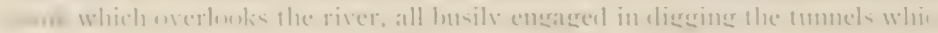

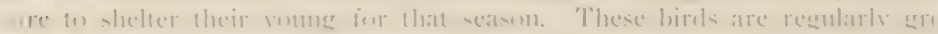

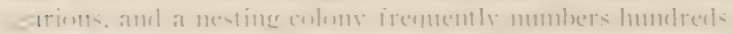

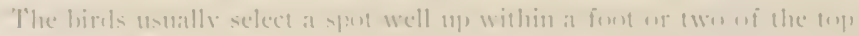

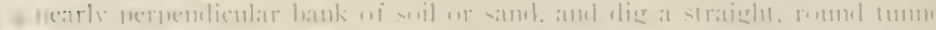

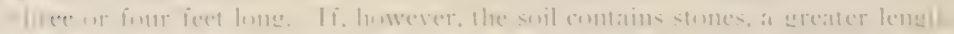

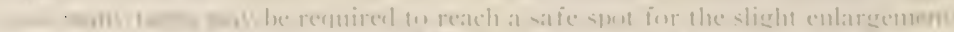

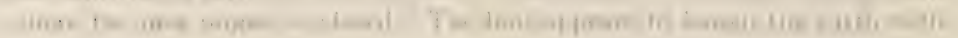


its closed beak, swaying from side to sicle the while; and, of course, fallen dirt or sand is carried out in the month. Sometimes the little miner finds a lens-shaped tumnel more convenient, and I have seen them as much as seven inclies in width and only two in height. While the members of a colony, especially if it be a small one, ustally occupy a straggling, horizontal line of holes, their burrows are not infrequently to be seen in loose tiers, so that the bank presents a honey-comberl appearance.

Communal life seems a pleasant thing to these Swallows, and there is usually a consiclerable stir of activity about the quarters. A good deal of social twittering also attends the mending gyrations. The wonder is that the rapidy moving parts of this aerial kaleidoscope never collide, and that the cases of turning up at the wrong number are either so few or so amicably adjusted. The nesting season is, however, beset with dangers. Weasels and their ilk sometimes find entrance to the nesting burows, and they are an easy prey to underbred small boys as well. The undermining of the nesting cliff by the swirling river sometimes precipitates an entire colony-at least its real and personal property-to destruction.

A certain populous bank near Chelan faced west, and whenever the west wind blew, the fine volcanic ash, which composed the cliff, was whirled into the montlis of the burrows, so rapidly, indeed, that the inmates required to be frequently at work in order to maintain an exit. A few dessicated carcasses. which I came across in old, filled-up burrows, I attributed to misfortme in this regard.

Pank Swallows are the least musical of the Swallow kind,- - unless, perhaps, we except the Rough-winged species, which is naturally associated in mind with this. They have, nevertheless, a characteristic twitter, an mmelodious sound like the rubbing together of two pebbles. An odd effect is produced when the excited birds are describing renonstrant parabolas at an intrucler's head. The heightened pitch in the tones of the rapidly approaching bird, followed instantly by the lower tone of full retreat, is enough to startle a slumbering conscience in one who meditates mischief on a Swallow's hone.

\section{No. I30.}

\section{AMERICAN BARN SWALLOIV.}

A. ก. U. No. fis. Hirundo erythrogastra Todkl.

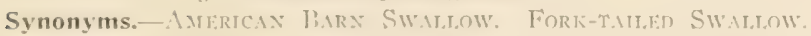

Description.-Idult: Whowe lustrous stcel-bluc: in front an imperfect collar of the same hue: forchearl chestuut: Inres black; throat and breast rufous: the renaining underparts, including lining of wings, more or less tinged with 


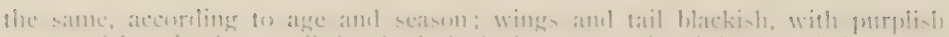

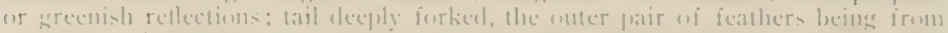

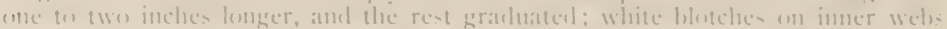

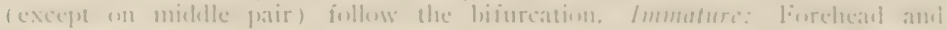

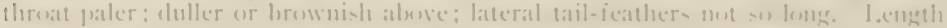

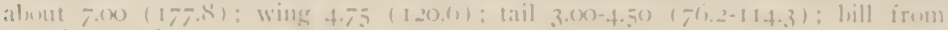
ne-iril $2 .+4(6.1)$.

Recognition Marks. - Sirial habit; rujous of throat and mmlerparte: fortici twil: nest llstlally inside the harn.

Vesting.- list: at neat braclict or hatf-howl of mud, Insuriou-ly lincel with grans and featlers, amel cemented to a heams of harn or hrislge. In llatshingtom

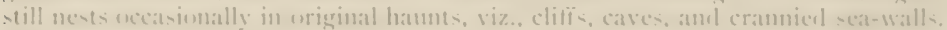

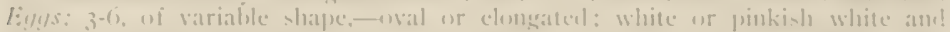

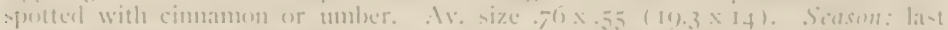

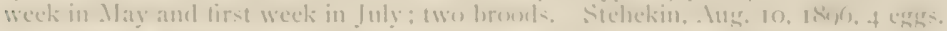

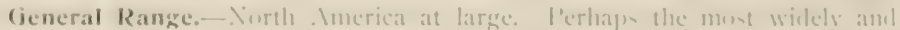
senerally distributed of any. Inserican hirel. Il inters in contral and somels Inerica.

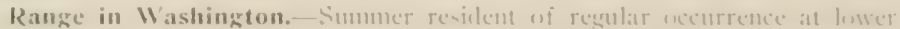

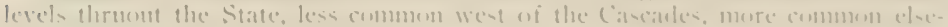
where in the whler setterl vallers.

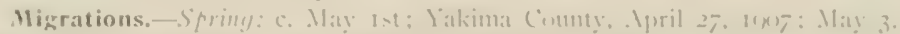

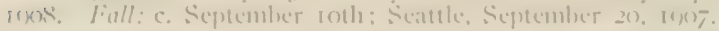

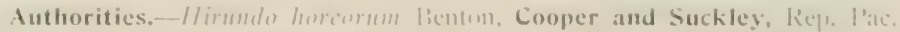

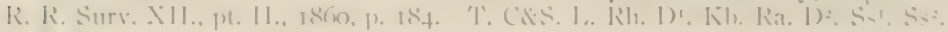
I. I., E.

Specimens.-I'ros: 1't. (C. I.

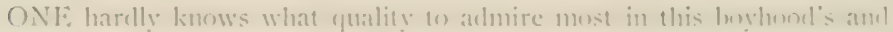
life-fone frienel, the liarn swallow. Sll the dear assuciations of life at the ofil farm come throngringe up at sight of him. Jou think of him sometom as a part of the sacred past: yet here he is turlaty as young and as fresh as ever. bubbling over with springtime laughter, realy for a frolic over the lee-haunted meaclows, or willing on settle down on the nearest fence-wire ambl recoum on you with sparkline eyes and eloxpent gesture the adventures of that ghorious (rip) up) from Mexico.

Perhaps it is his childlike enthusiasm which stirs us. He has come many

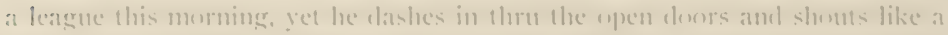

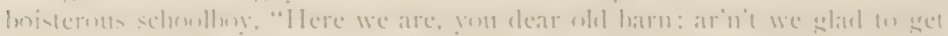

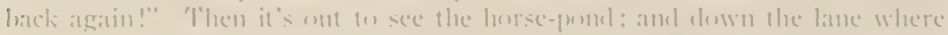

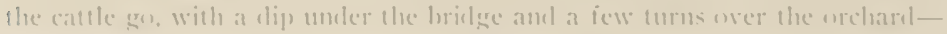

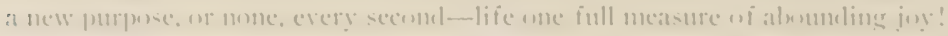

Or is it the apentheosis of mulum which talies the eve? See them as they

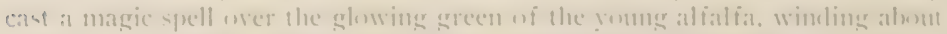

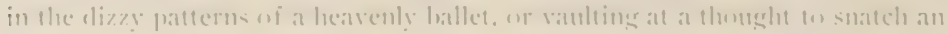


insect from the sky. Back again, in again, out again, away, anywhere, ererywhere, with two-mile a minute speed and effortless grace.

But it is the sweet contidingness of this dainty Swallow which wins tus. With all the face of Nature before him he yet prefers the vicinage of men, and comes out of his hilly fastnesses as soon as we provide him shelter. IVe all like to be trusted whether we deserve it or not. And if we don't cleserve it: well. we will, that's all.

'lise Barn Swallow is not a common birl with as as it is east of the Rockies, nor is it evenly distributed thruont onr State. Wherever the country is well settled it is likely, lutt not certain, to be found; while for the rest it is confined to such lower altitules as afford it suitable shelter cares and nesting cliffs.

It the head of Lake Chelan in I805 1 found such a primitive nesting hatmin. 'The shores of the lake near its head are very precipitons, since Castle Momntain rises 10 a lreight of over 8.000 feet within a distance of two miles. Along the shore-line in the siele of the difls, which continue several hundred iect below the water, the waves have hollowed ont ramnies and caves. In one of these latter. wh ic henctrates the granite wall to a dentli of some twenty feet. I fommet four or five Parn Simallows' nests. some containing vemeng, and two, altho it wass so late in the seatson ( July o. זト95), containing egas. Other nests were fomml in neigliburing crannies ontsirle the catre. I visit paid to this same spot on August roth, 1806 . disconered nne nest still necupjerl, and this enntatined four eerers.

Mr. I* S. Merrill,

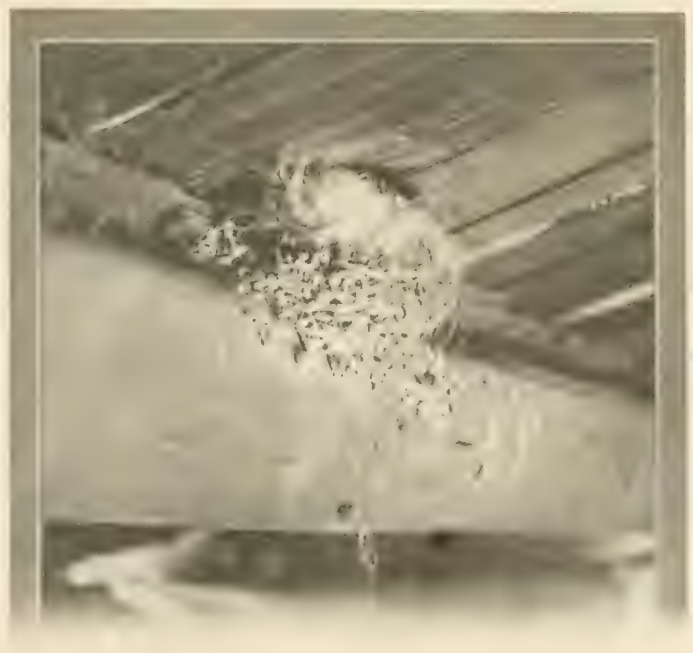
of Spokanc, reports Tratien near spotane. W\%oro by F. S. Merrit. CISST OF H.IRA SWAITUW. 


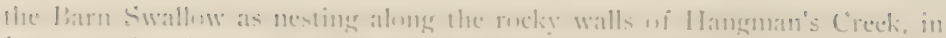

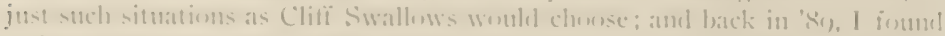

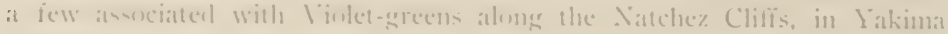
Cinumty.

A colemy of smme twenty pairs maty be fontme yearly nesting on I estrac-

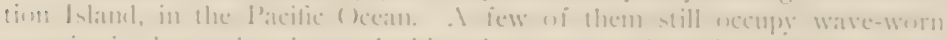

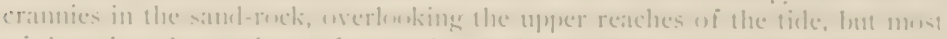

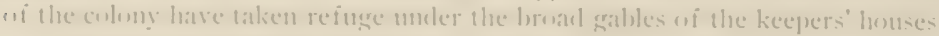

Jhe nest wi the liarn Swallew is qualrispherical, or bracket-slapecl, with

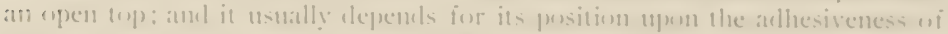
the mat used in construtents. Dr. Brewer silys wi thems: "The nests are constructerl of distinct latyers of mul, from ten to twelve in mumber, and each separancel by strata of line dry grasses. These layers atre each marle mp of
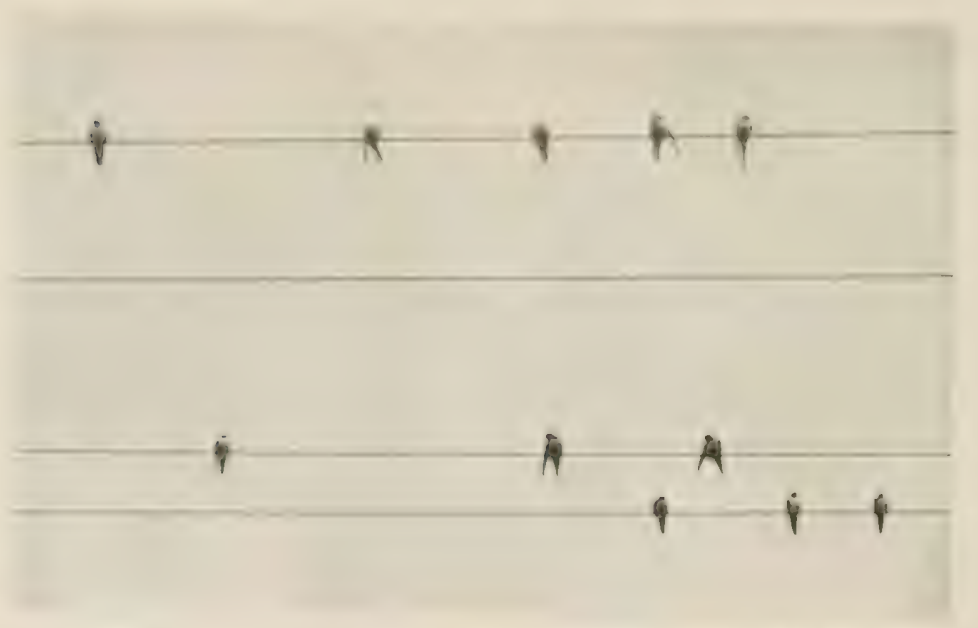

Iath in hione

From s Phoperopt Copgright, 1908, by WI. L. Dastsen TH1: Nitsisis

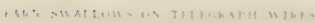

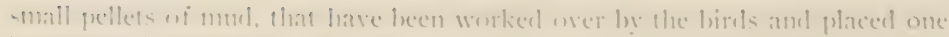

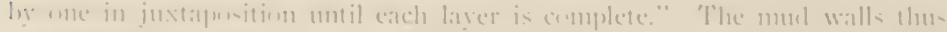

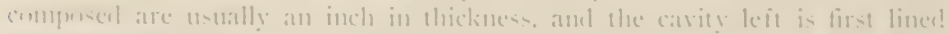

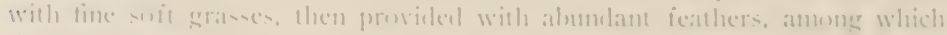

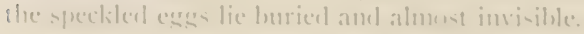


Bringing off the brood is an event which may well arrest the attention of the human householel. 'There is much stir of excitenent about the barn. 'The anxious parents rush to and fro shouting tisic, tisic, now in encouragenent. now in cattion, while baby number one launches for the nearest bean. 'The pace is set, and babies number two to four follow hotly after, now lighting sat fely, now landing in the hay-mow, or compromising on a plow-handle. Upon the last-named the agonized parents urge another effort, for 'Tablby may appear at any moment. He tries, therefore, for old Nellic's back, to the mili astonishment of that placid mare, who presently shakes him off. Number five tumbles ontright and requires to be replaced by hand, if you will be so kind. And so the tragi-comedy wears on, duplicating lnuman years in half as many days, mntil at last we see our Swallows among their twittering fellow: strung like notes of music on the far-flung staff of Western Union.

If birds really mean anything more to us than so many Japanese kites Hown without strings, we may surely join with Dr. Brewer in his whole-sonled appreciation of these friendly Swallows: "Innocent and blaneless in their lives, there is no evil blenderl with the many benefits they confer on man. 'They are his ever constant benefactor and friend, and are never known even indirectly to do an injury. For their daily food and for that of their offspring, they destroy the insects that annoy his cattle, injure his fruit trees. sting his fruit, or molest his person. Social, affectionate and kind in their intercourse with each other; faithful and devoted in the discharge of their conjugal and parental cluties; exemplary, watchful, and tender alike to their own family and to all their race; sympathizing and benevolent when their fellows are in any trouble,-these lovely and beantiful birds are bright examples to all, in their blameless and useful lives."

\section{No. 131 .}

\section{TREE SWALLOW.}

\section{A. O. L. No. 6rł. Iridoprocne bicolor (Vicill.).}

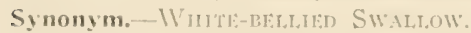

Description.-. dult male: Dhove, lustrous stecl-blute or stecl-green: below. pure white: lores black; wings and tail black, slowing some bluish or greenish luster; tail slightly forked. Ficmale: Similar to male, but duller. Immature: Eper parts montse-gray instead of metallic; below whitislı. T.ength about foon (I52.4); wing 4.57 (II6.I) ; tail 2. In $(5.5 .6)$ : bill from nostril .25 (6.4).

Recognition Marks. - Aërial hahits: steel-hlue or greenish above: pure white below: a little larerer than the next species.

Nesting.-Nest: in holes in trees or, latterly, in bird houses, plentifully lined 


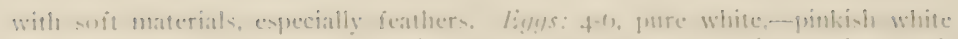

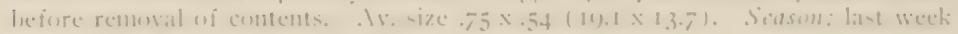
in . Maly, lirst weeti in luly; two brents.

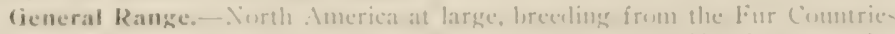

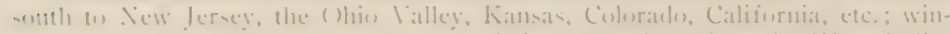

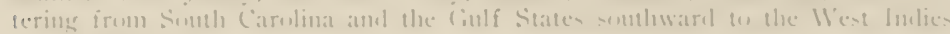
ambl Cinatemala.

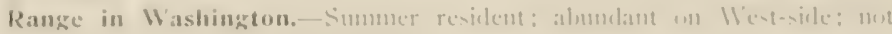

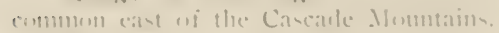

Migrations - Sprity: Jirst week in March or carlicr: Scattle, March 4.

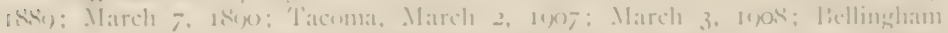

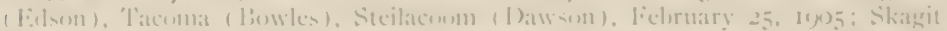

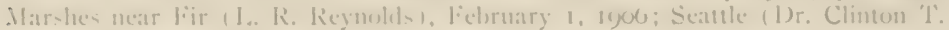
(intic), lamuary 21, Iyor.

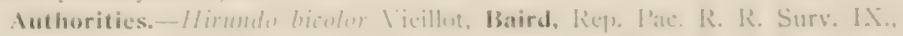

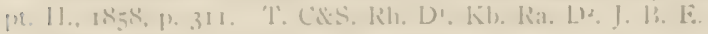

specimens. - L'. af II. I'. I'rus. C.

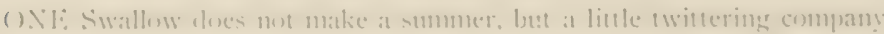
uf then faring morthward maties the heart glaul, and lills it with a sense wi exaltation at it respuncls th the call of these care-free children of the atir.

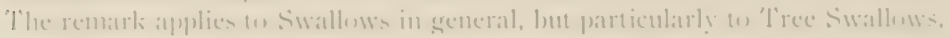

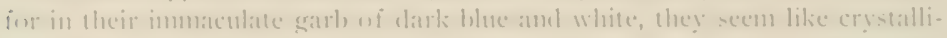

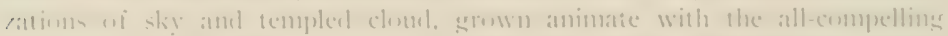

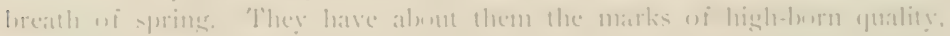

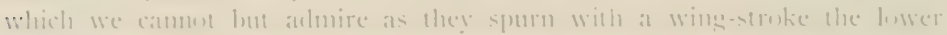

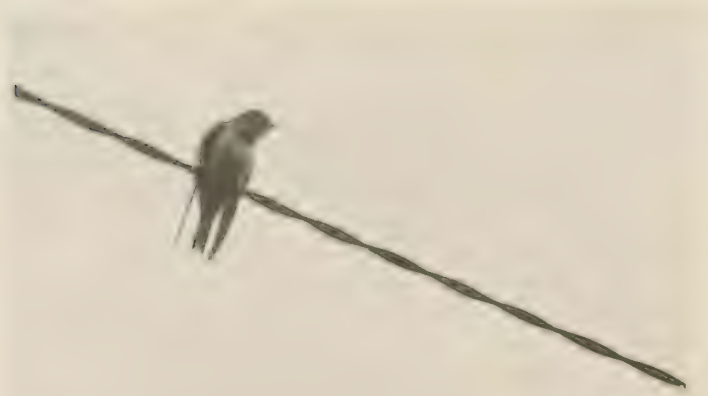

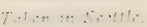

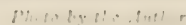

TRFY SW $17.5,1 \mathrm{M}$ -trital, antel rise in accept we know not w/ant daintien wi the und atr

Il hile nent so latraly ats Rubin and likmelirel. sine it mun-1 matnutain a11 exclusive alie? wi incerts. 'l'ree swallum is a matsimalls, rerre ven-

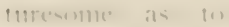
the seasom of its mortlowarel tlicht. Inderel a stucession of mild win- 
ters might induce it to become a permanent resident of the Puget Sound country, and it is not certain that it has not already clone so in some instances. It often reaches Seattle during the first week in March; while it wats simulaneonsly observed at 'l'acoma (Bowles), and Bellingham (Eidson) on the 2 th sceing it in numbers on the Skagit marshes near Fir, on the ist of liebruary; and I)r. Clinton 'T. Cooke, looking from his office window in the Alaska Building, saw a large specimen, apparently an adult male, soaring about over the Grancl Opera House, in Seattle, on the 2 ist day of January.

The Tree Swallow is a lover of the water and is selclon to be founcl at a great distance from it. It is close to the surface of ponds and lakes that the earliest insects are to be found in spring, and it is here that the hird may maintain the spotlessness of its plumage by frequent dips. Hence a favorite nesting site for these birds is one of the partially submerged forests which are so characteristic of western 1 ashington lakes. The birds are not themsclves able to make excavations in the wood, but they have no difficulty in possessing themselves of the results of other hirds' labors. Old holes will (lo if not too old?, but I once knew a pair of these Swallows to drive awaty a pair of Northwest lilickers from a brand new nesting-hole, on the banks of Iake Lnion, and to ocenpy it themselves.

'The nesting cavity is copionsly lined with clead grass and feathers; and sometime during the last week of May from four to six white eggs are deposited. 'llhe female sits very closely and it is sometimes necessary to renove her by hand in order to examine the nest. Both parents are very solicitous on such occasions, and should a featler from the nest be tossed inte the air, one of them will at once catch it and fly about atwating a chance (n) replace it. Or if there are other Swallows about, some neighlor will smatch it first and make off with it to ackl to her own collection.

'lree Swallows atre slowly arailing thenselves of artificial nesting sites. In fact. several species of our birels have become quite civilized, so that mowarlaty tur carciully constructed and quietly situated bird-box need be witlust its spring tenant. A pair once built their nest in a sort of tower attic, just insicle a hole which a IFlicker had pierced in the ceiling of an open belfry of a country clunch in Yakima. When in service the mouth of the swinging bell canc within two feet of the broseling bircl. One would suppose that the Swallows would have been crazed with fright to find themselves in the miclst of such a tumult of somal; but their enterprise fared successully; as I can testify, for at the proper time I saw the voungsters rangerl in a happy, twittering row along the unper rim of the bell-wheel. 
ㄱo. 132.

\section{VIOLET-GREEN SWALLOM.}

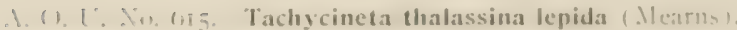

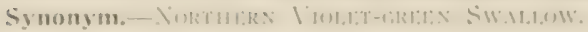

Description.- . idult male: (puerpatrts, including pilem, hind-neck, back.

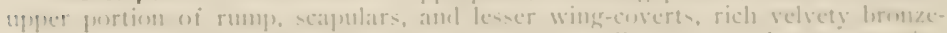

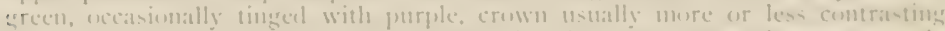
with color of back, urechish-brown rather than bronze-green, and more -trongly

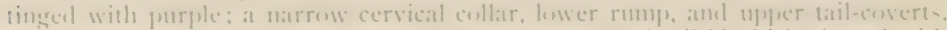

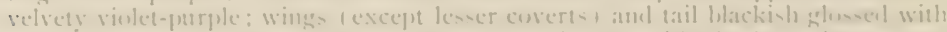

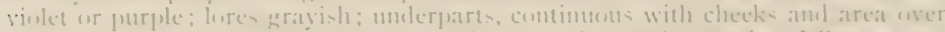

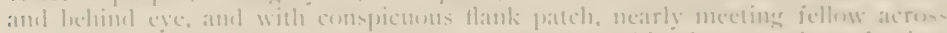
rump, pure white: under wing-coserts pale graty, whitening on exlge uf wing.

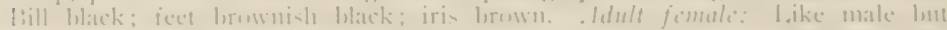

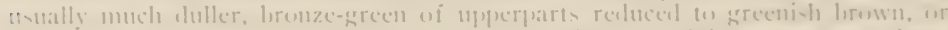

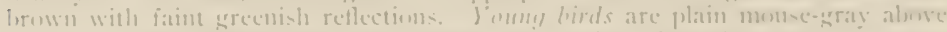

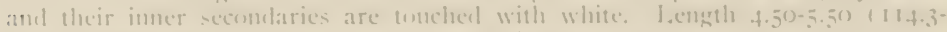

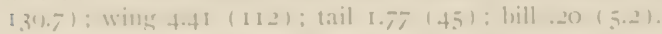

Recognition Marks. - Smaller: ereen amb violet alose, white hetow: white-

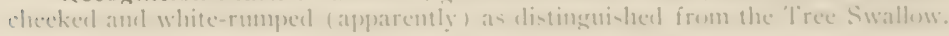

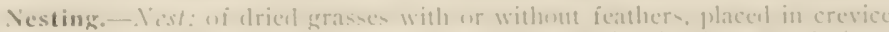

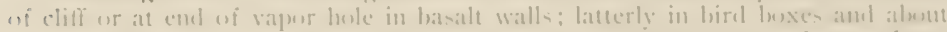

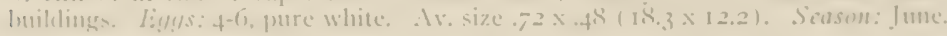

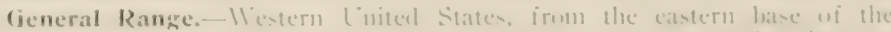

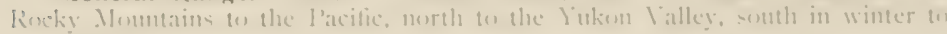
(imlil Ricit.

Range in Washington.-Summer resilent, of regular oceurrence in monmtam valleys and among the fonthills: rare or local clsewhere; hecoming common in the lareer cities.

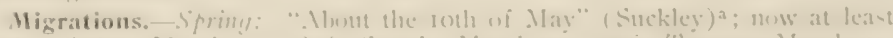

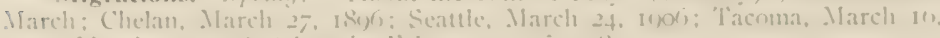

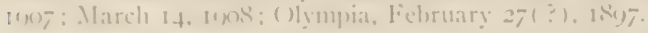

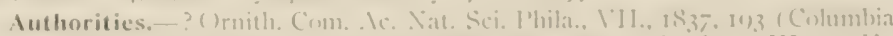

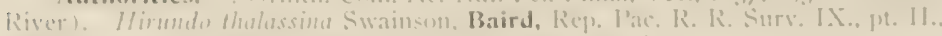

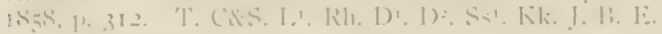

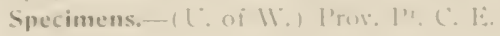

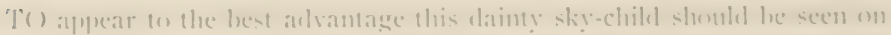

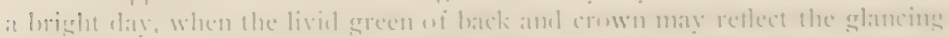

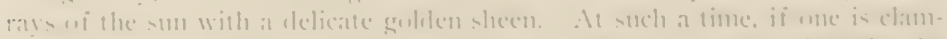
luring almont the walls +1

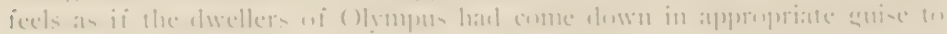

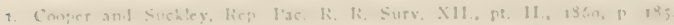





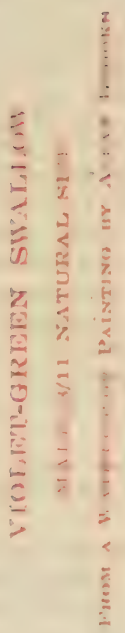




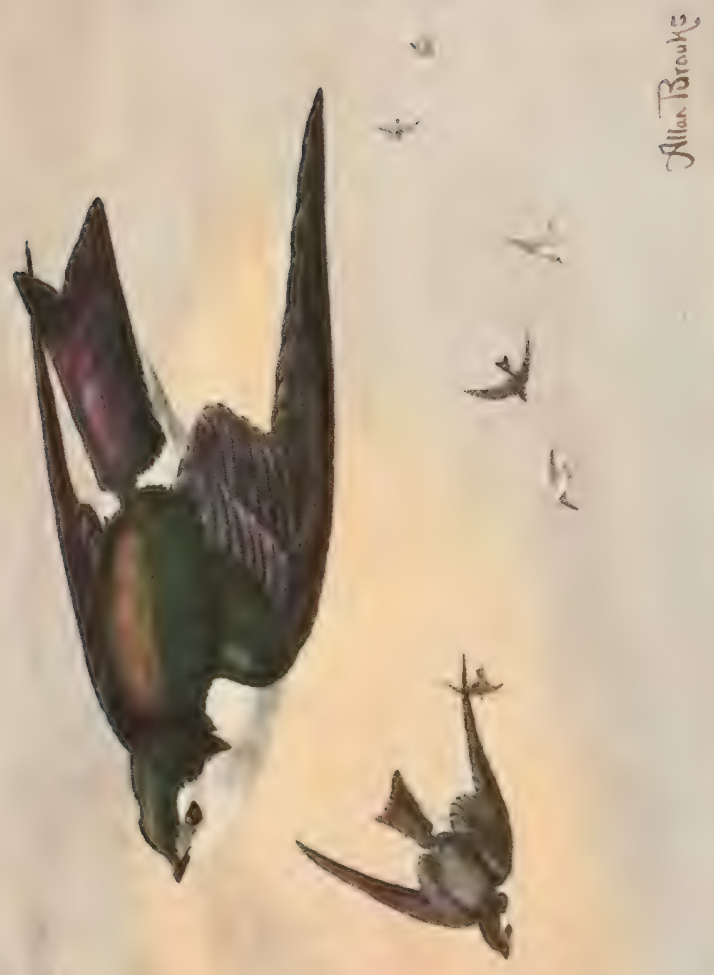



inquire his business. Not, however, that these lovely creatures are either medcllesome or shrewish. Eiven when the nest is threatened by the strange presence, the bircls seem unable to form any conception of harm, and pursuc their way in sumy disregard. Especially pleasing to the eye is the pure white

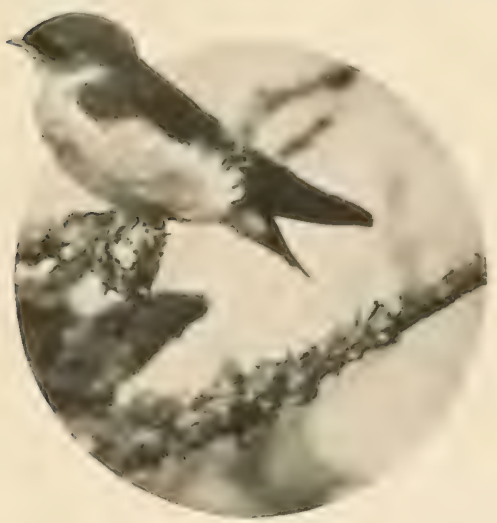

Taten in Orison. Photo by Finley and Boliman. YOUXG VIOI.ET.GREEN SWAI.I.OW: of the bird's underparts, rising high on flanks and checks and sharply. contrasting with the pattern of violet and green, in such fashion that, if Nature lad invited us 10 "remold it nearer to the heart's desire." we must lave declined the task.

Before the advent of the white man upon Puget Sound, these birds commonly nested in deserted woodpecker holes and in natural carities of trees, while upon the liast-side ther nested (and still clo to a large extent) upon the granite or lava cliffs. In the last-1amed situations they utilize the rocky clefts and in accessible crannies, ancl are especially fond of the smaller vapor holes which characterize the basaltic formations. Favorable circumstances may attract a consiclerable colony, to the number of a hundred pairs or more. but even so it is not easy to find a getatable nest. If one is able to reach the actual nesting site, the moutly of the ancient gas-vent which the birds lave chosen for a lome may prove too small to admit the hand.

Thrumt the State, however, and especially tipon the West-side, these expuisite birds are forsaking their ancient haunts and claiming protection of men. Already they have become common in larger cities, where they occupy bircl-boxes and crannies of buildings. South 'Tacoma, being nearest to their old oak museries, is quite given over to them, and it is a pretty sight on a sumny day in April to see them fluttering abont the cottages inspecting knotholes and recessed galsles or, in default of such conveniences, daintily roicing their disapproval of such neglect nu the part of careless humans.

In these birls and in the liarn Swallows, the well known twittering and creaking notes of Swallows most nearly approach the dignity of song Incleed. Nir. Kathbun contends that the song heard at close quarters is a really creclitable affair, varied, vivacious, and musical.

The Vinlet-ereens are somewhat less hardy or venturesome than the Tree Swallows, arriving ustally cluring the last week in Marcl. Last year's 


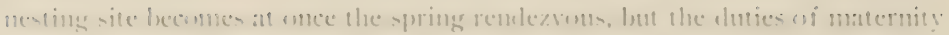

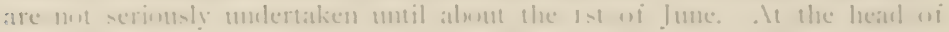

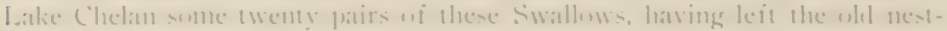

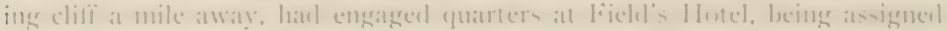

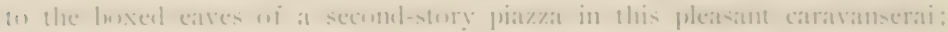

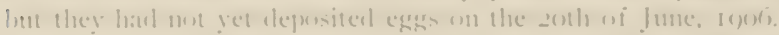

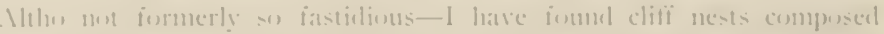

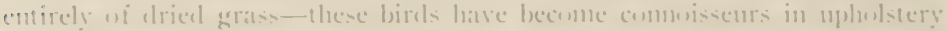

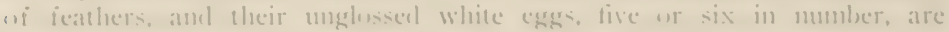

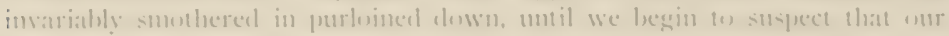

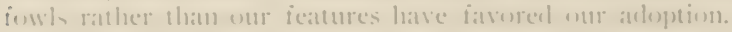

No. $1,3.3$.

\section{BOHEMIIN WIXWING}

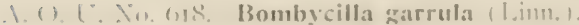

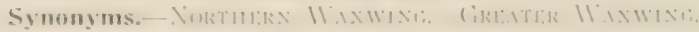

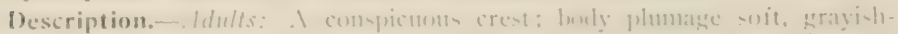

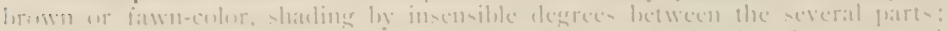

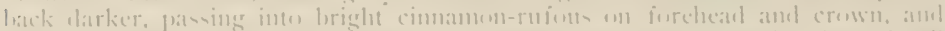
thru slark and of rumps and upper tail-coverts into black wi tail: tiph wi tail

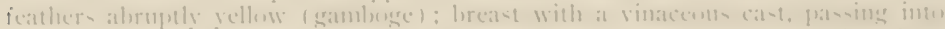

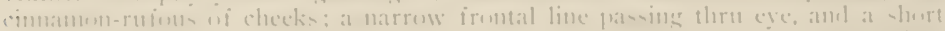

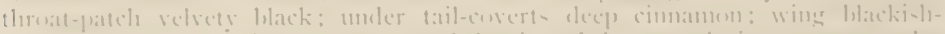

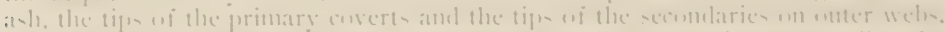

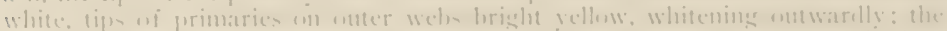

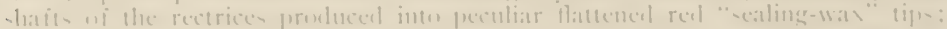

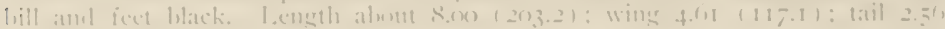

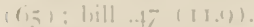

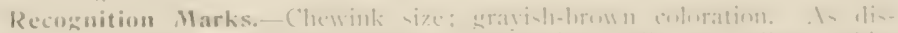

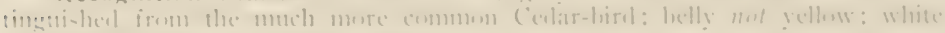

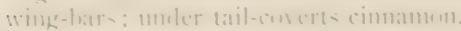

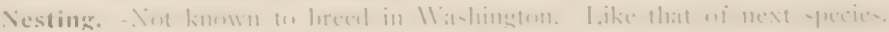

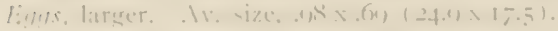

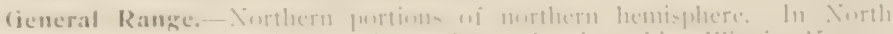

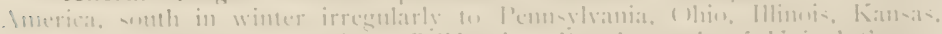

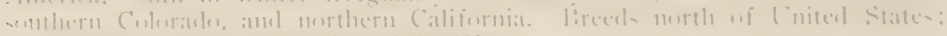

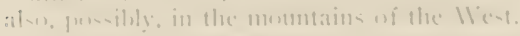

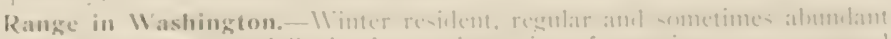

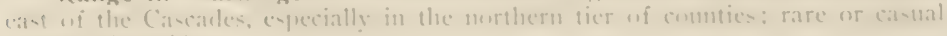

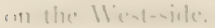

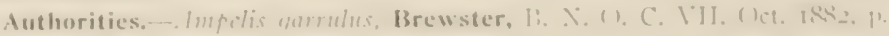
23 . 1). 1. 1:

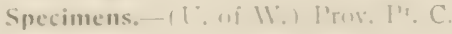


NO'THIXG can exceed the refined elegance of these "gentlenen in feathers" who visit us vearly in winter, rarely on Puget Sound, but alumdantly in the northeastern portion of the State. Đenure, gentle, courteons to a fault, and guileless to the danger point, and beyond, these lovely creatures exeed in beaty, if possible, their more familiar consin, the Ceclarbird. 'They move abont in flocks, sometimes to the number of lumdreds, and as the rigors of winter come on they search the orchard and berry-patch for ungarnered fruit, or divicle with hungry Robins the largess of rowan trees. Nuch time is spent in amiable converse, but it is not at all fair to call them "chatterers," or yommlus, as tho they were monkeys. Dignity is of the very essence of their being, and, as fond as they are of good living, they would starve rather than do anything rucle or unseenly.

An observer in Utala relates how an ill-mannered Robin, jealons of the good behavior of a company of these visitors, in an apple tree, set about to abuse them. "He would bluster and scream out his denumciations till he scemed unable longer to restrain himself, when, to all appearances, absolutely beside himself witl rage because the objects of his wrath paid no attention to his railings, he did the catapult act-hurling himself straight at the intruders. Several of the W/axwings, in order to avoid an actual collision, left the places where they were feeding, and alighting on twigs near by paused for a moment. as if to observe the antics of the furious Robin, when they would resume their feecling. 'T'heir indifference to the lond bullying protests of the Robin, and their persistence in remaining on the premises after he had ordered them oft so exasperated Mr. Redbreast that with screams of defiance he dashed from group to group without stopping to alight, milil, exhausted quite as much by the lieat of anger as by the umusual exertions he was making. he was glad to drop to a brancl and pant for breath"-While the IVaxwings continued to ignore the churl, as gentlemen shoukl.

Concerning the nesting range of this bird there has been much sumise. For many years the single eggs taken by Kennicott at Fort Yukon on July f. rS6I, remained minque; but latterly we are learning that it also nests much further south. Mr. Brooks took four sets, one from a Murray pine and three from Douglas firs, at is 8 -Mile House, I3. C., in June, igor ${ }^{b}$. Dr. C. S. Wonlyc reports the taking of a set of five eggs at Sandpoint, Itlalon, July 5. roof. On June 26, 1904. Robert (x. Bee, of Prow City, fomd a nest near Stumyside, [tah" ${ }^{3}$. With such examples before us it is practically certain that the species will be found nesting in this State. Indeed, Mr. I: S. Merrill. of Spokane, helieves that he once foumd a nest of the bohemian IVaxwing on the hearlwaters of the Jittle Spokane River near Milan. The nest he de-

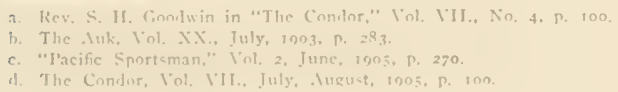




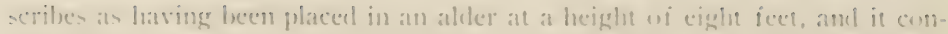

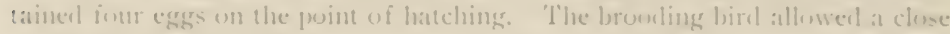
approach white tapm the nest, but was mot seen again ater lecing ance flusherl.

No. 1.31.

\section{CEDAR WAXWING.}

A. (1. L. An. G10. Bombycilla cedrorum Vicill.

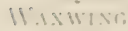

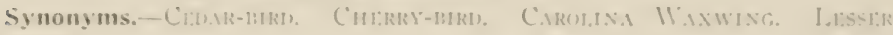

Description.- Idults: I cumspicums crest; extreme forcheat, lores, and line thru eye velvety-hlack; chin hlackish, fading raphelly inte the rich grayishhown of remainimg fore-parts and heal ; a narrow whitish line leorelering the black on the furchead and the blackish of the chin: back darker, shading thru

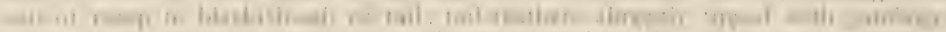
Vellow; belly sorelid yellow; muler tail-cuserts white; wings slaty-gray, primatres

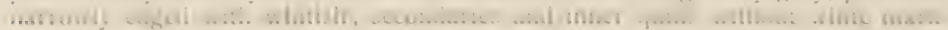
ings, but bearing tips of red "sealing-wax": the tail-featler are occasionally

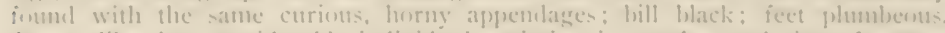
sexes alike, but ennsiderable inclivilual variation in mumber and size of waxen

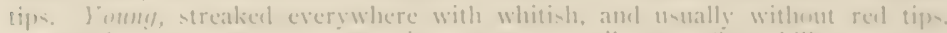

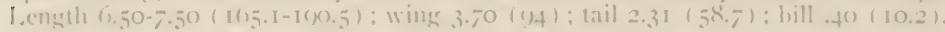

Recognition Marks. - Sparrow size: suft grayish-brown plumage: crest: reel sealing-wax tifn on secondaries: lolly yellow: wings withont white hars or -juth. ats distimgrisiseal from preecelinge species.

Vesting.- Vest, a bulky allair of leaves, grasses, hark-strip and tra-h, well

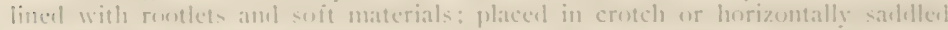

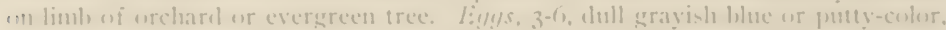

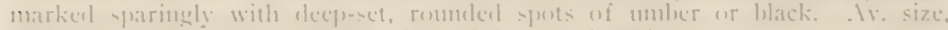

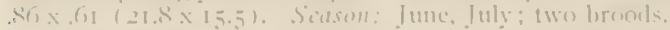

(ieneral Range-- Dorth . Inerica at large, from the liur Commeries smuth-

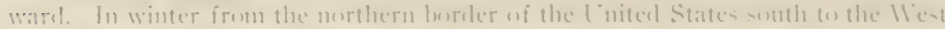

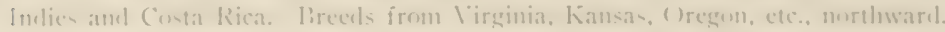

Range in Washington.-() f regular cecurrence in the state, hut irregular

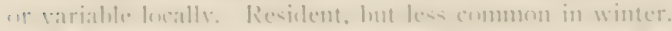

Authorities, Impilis cedrumm liairel, Cooper and Suckley, Rep. I'ne.

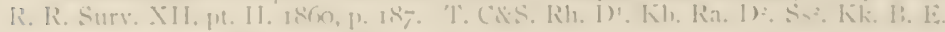

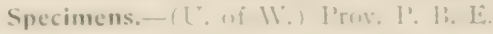

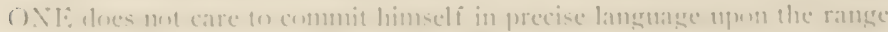

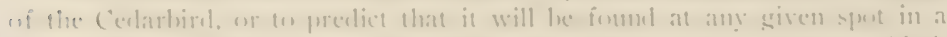

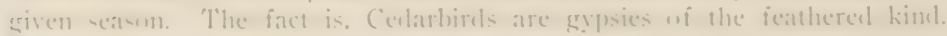

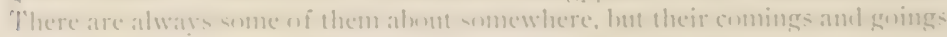

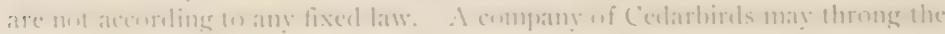


rowan trees in your front yard some bleak day in Decenber; they may nest in your orchard the following July; and you may not see them on your prenises again for years - mless you keep cherry trees. It must be confessed (since the shade of the cherry tree is ever sacred to 'T'ruth) that the Cedarbircl, or "Cherrybircl," has a single passion, a consuming clesire for cherries. But don't kill him for that. You like cherries yourself. All the more reason, then. why you should be charitable toward a brother's weakness. Besides, he is so handsome,-handsomer himself than a luscions cherry even. Feast your eyes upon him, those marvelous melting browns, those shifting saffrons and ( ) naker drabs, those red sealing-wax tips on the wing-quills (he is camning cherries, you see, and comes provicled). l'east your eyes, I say, and carry the vision to the table with you-and a few less cherries. Or, if there are not enongh for you both. draw a decent breadth of mosquito-netting orer the tree, and absolve your soul of murderous intent. Remember, too, if you require selfjustification, that earlier in the season he diligently devoured noxious roms and insect pests, so that he has a clear right to a share in the fruit of his labors.

Cherries are by no neans the only kind of fruit eaten by these birds. Like most orchard-hamnting species, they are very fond of mulherries, while the red berries of the mountain asl are a staple ration in fall and winter. 'Truth to tell, these beauties are sad gluttons, and they will gorge themselves at times till the very effort of swallowing becones a delicious pain.

The Ceclarbird, being so singularly enclowed with the gift of beatuty, is renied the gift of song. Ile is, in fact, the most nearly voiceless of any of the American Oscines, his sole note being a high-pitched sibilant squeak. Indeed, so high-pitched is this extraordinary note that many people, and they trained bird-men, camnot hear them at all, even when the W'axwings are sfueaking all about them. It is an amost uncamy spectacle, that of a company nf $1 /$ axwings sitting aloft in some leatless tree early in spring, erect, immosable, like soldiers on parade, but complaining to each other in that faint, penetrating monotone. It is as tho you had come upon a company of the Immortals, high-removed, conversing of matters too recondite for human ken, and strvering you the while with Olympian disclain. You steal away from the foot of the tree with a chastened sense of having encomintered something nost quite understandable.

The dilatory habits of these hirds are well shown in their nesting, which they put off until late Jume or July, for no apparent reason. In constructing the nest the bircls nse anything soft and pliable which happens to eatch the eve. Some specinens are composed entirely of the green hanging mosses. while others are a complicated mixtme of twigs, leaves, rootlets, fibers. grasses, rags, string. paper, and what not. The nest may be placed at any

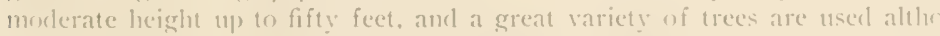
orchard trees are favorites. The birds are half gregarions, even in the nest- 


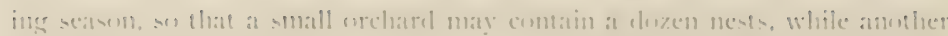
as gen

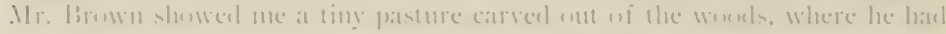

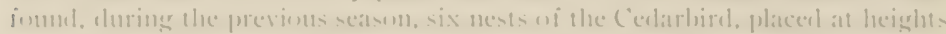

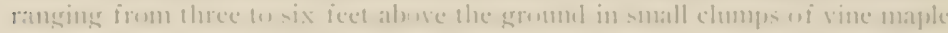

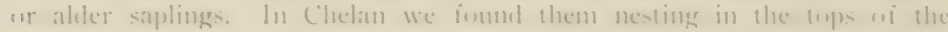
erditary jume trees which line the stream.

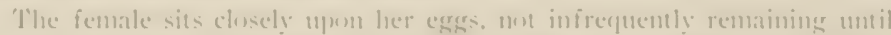

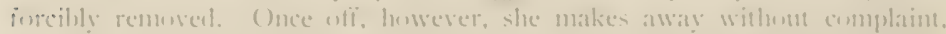
and pays no further attention on the incislent until the intrubler has departerl.

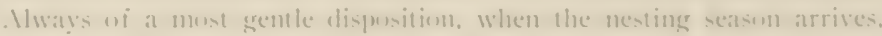

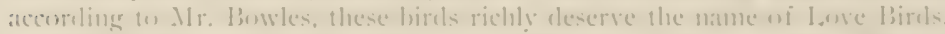

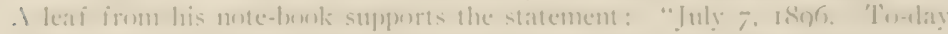

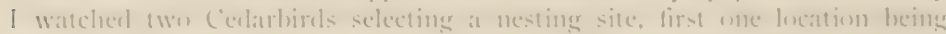

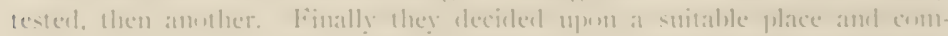
menced picking huth dry and green leaves from the surromeling trees, placines

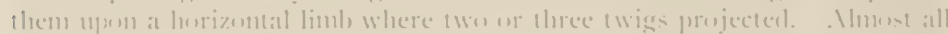

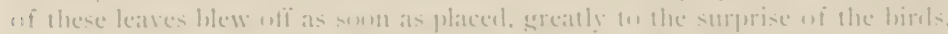

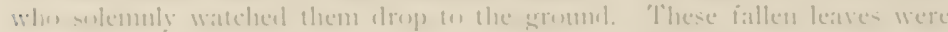

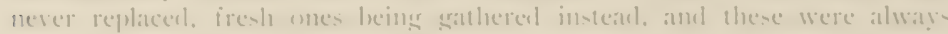

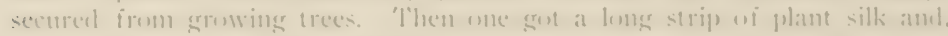

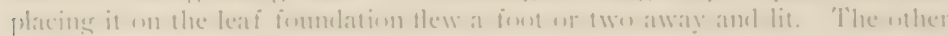

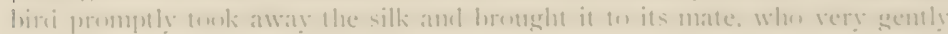
fmok it and put it back. 'lhis uperation was rejeateal again and again. . It

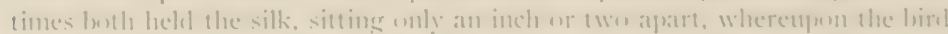

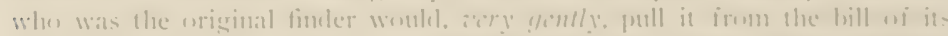

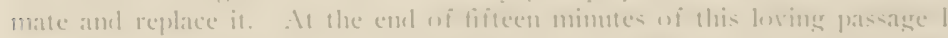
was obligeef on retire, and I shall never linow whether the plant filuer wats arecessully placed or merely wern onte."

Nio. 1.3 .5

\section{NORTHERN SHRIKE.}

A. (1) U. In fiz?. Lanius lorealis lieill.

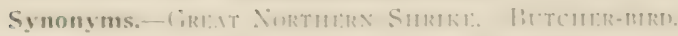

Description.- Idult: Cpperparts chas, hluish gray, lightest-almo-t white-

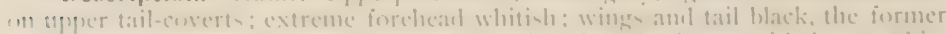

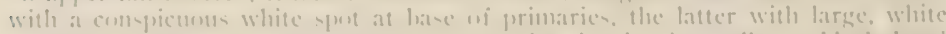

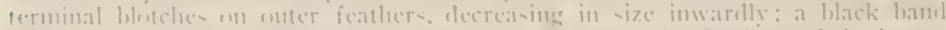

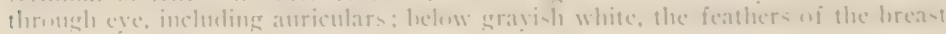


and sides narrowly tipped with dusky, producing a uniform, fine vermiculation which is always present ; bill blackish, lightening at base of lower mandible: feet black. Joung bircls are barred or washed with grayish brown. 'The plumage of adult is sometimes orercast above with a faint olivaceous tinge. Lengtl 9.25 $10.75(235-273.1)$; wing $4.50(114.3)$; tail $4.19(106.4)$; bill .72 (18.3); tarsus $1,1,-,-3,3$.

Recognition Marks.-Robin size; gray and black coloring; slatrply hooked bill; breast vermiculated with dusky; as distinguished from next species.

Vesting.-Does not breed in IVashington. Vest: a well constructed bowl of sticks, thorn-twigs, grasses, and trash, heavily lined with plant-down and feathers; in bushes or low trees. Eiggs: $3-7$, dull white or greenish gray, thickly dotted and spotted with olive-green, brown, or lavender. Av, size, I.07 $\times .78$ (27.2x 19.8).

General Range.-Northern North America; south in winter to the middle and sonthern portions of the Lnited States. Breeds north of the United States except sparingly in northern New England.

Range in Washington.-Spring and fall migrant and not common winter resident thruout the State, chicfly at lower levels.

Authorities.-?'T'omnsend, Jonrn. Ac. Nat. Sci. I'hila. VIII. I839, I52 (Columbia River). Baird, Rep. Pac. R. R. Surv. IX. I858, 325. C\&S. D'. Ra. (1) I: I:

Specimens.-(U. of 11 .) P'. I'rov. B. E.

FLI'T'T'ING like a gray ghost in the wake of the cheerful hosts of Juncoes and Reclpolls, comes this butcher of the North in search of his accustomed prey. If $i t$ is lis first visit sonth he posts himself upon the tip of a tree and rasps ont an inquiry of the man with the gin. Those that survive these indiscretions are thereafter faintly descried in the distance, either in the act of diving from some anxions summit, or else winging swifty orer the inequalities of the ground.

All times are killing time for this bloolthirsty fellow, and even in winter he "jerks" the meat not necessary for present consumption-be it chillyfooted mouse or palpitating Sparrow-upon some convenient thorn or splinter. In spring the north-bound bird is somewhat more amiable, being better fed, and he pauses from time to time during the advance to sing a strange medley, which at a little remove somnds like a big electric buzz. 'T'his is meant for a love song, and is doubtless so accepted by the proper critics, lut its rendition sometimes produces about the same effect mpon a troop of Finches, which a cougar's serenade does upon a cowering deer.

lixperts try to make ont that this creature is beneficial. on the whole. because of the insects he derours, but I have seen ton much good red blood on this butcher's beak myself. My gun is loarled!

suckley writing in the rifties remarks the scarcity of all Shrikes in Oregon or llashington "T'erritories," and this is fortunately still true, especially west of the Cascarles. The probable explanation is that the mild climate of the l'acific slope of Aaska retarls or prevents the southward movement of the more hardy species. 


\section{WHITE-RUMIPIS SHRIKL.}

\section{1. (). [ . Vi, (122 it. Lanius ludovicianus excubitorides (Swain-, ).}

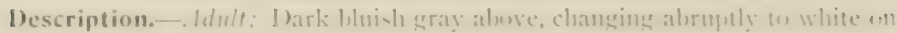

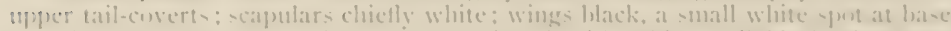
of prinaries: the inner yulls marrowly tipped with white; tail black, the enter pair of feathers chietly white, and the steceeding broally tipped with white in

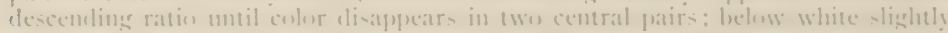
sofled on breast, hut evervwhere strongly contrasting with upperparta : narrons

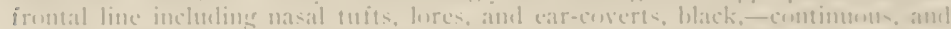

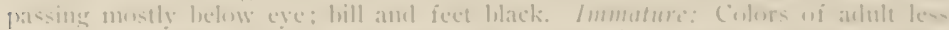

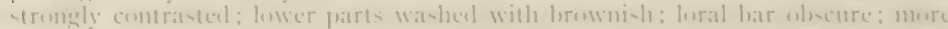

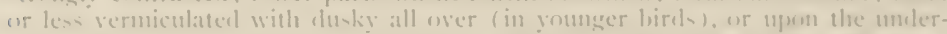
parts alome: ends of wing-epuills, coserts, and tail-featlers often with wehracents

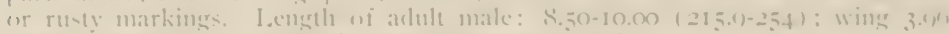

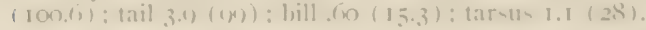

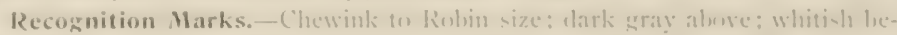

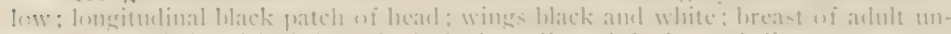

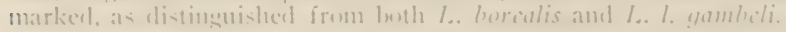

Vesting.--Vist: a bulky hut well-huilt structure of steks, lhum-twige, sagelark, drichl leaves, cte., heavily linel with wewl. hair, and feathers; placed at

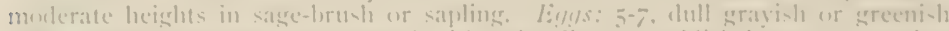

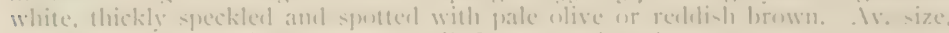

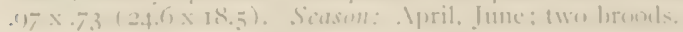

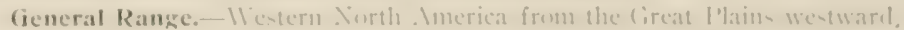

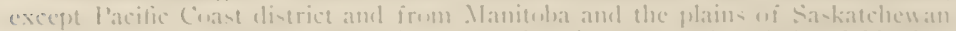

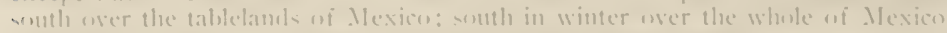
intereranling with 1. . l. miendens in region of the cireat lakes.

Range in Washington.-Cimmon smmmer resilent east of the Ciacarles. dirctly in sace-brtshli comutry:

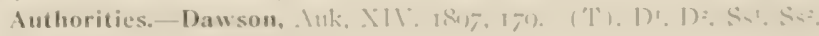

Specimens.-(L: of II:) I?. C.

Trll: bustw draws of the hu lava ranges and the open sage stretclues of the Fast-sile com-titute the favorite preserse of this lesser hire af prey. He arrives from the Simtle early in March when his potehy plumage harmonizes

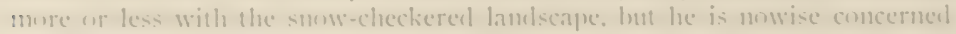
with problems of profective entoration. Seeking ont some promineme perch.

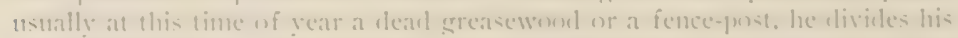

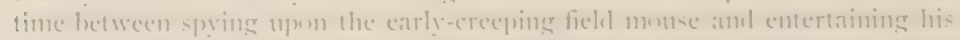

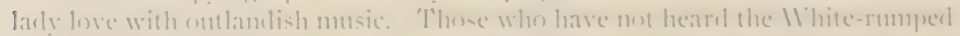
Slirike sime. have miscel a treat. He hegins with a series of raspines sumels,

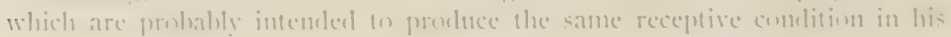


atudience which Olc Ibull secured by awkwarlly breaking one string after another on his violin, till only one wats left. 'l'here, however, the resemblance ceases, for where the virtuoso could extract a melody of marvelous variety and sweetness from his single string, the bircl produces the sole note of a struck anvil. This pours forth in successive three-syllabled phrases like the metallic and reiterative clink of a freely falling hammer. The clief difference which

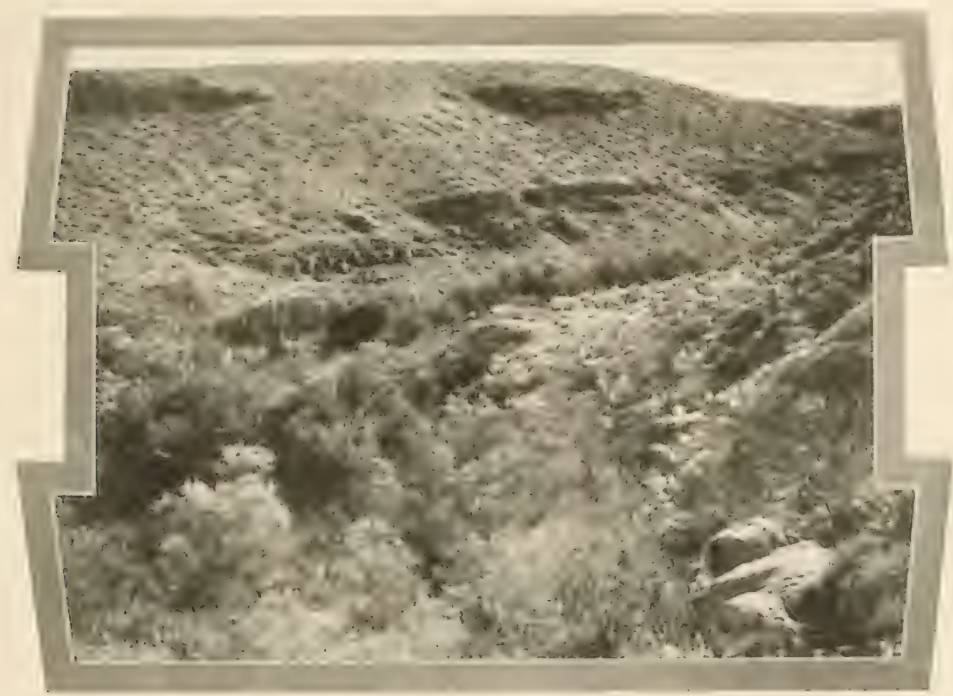

Taken in Douglas County

Photo by the Aluthor.

TIE SHRLE'S PRISSRRY

appears between this love song and the orlinary call of warning or excitement is that in the latter case the less tender passions have weighted the clanging anvil with scrap iron and destroyed its resonance.

'The Slurike is a bircl of prey but he is no restless prowler or hoverer. weatring out his wings with incessant flight-1nt he. Choosing rather a commaneling position on a telegraph wire, or exposed bush top, he searches the ground with his eve until he detects some suspicious movement of insect, monse, or birel Then he dives down amongst the sage, and if successful returns to his post to revour at leisure. 'The bird does not remain long enotiglo at one station to inspire a permanemt dread in the local poptulation of comestibles; lut rathermoves on from post to post at short intervals and in methodical fashion. In dight the 


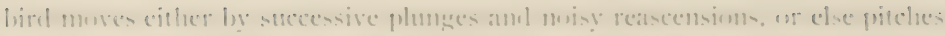

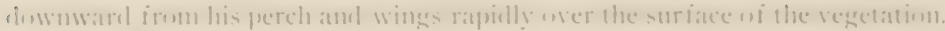

The Sage shrikes are prolific and attentive hreeslers. 'The first lorenl is

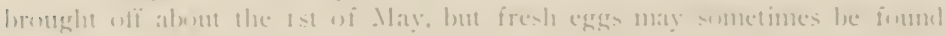
as early as the last week in March in the somblerm patrt ni the statese. I

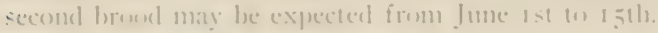

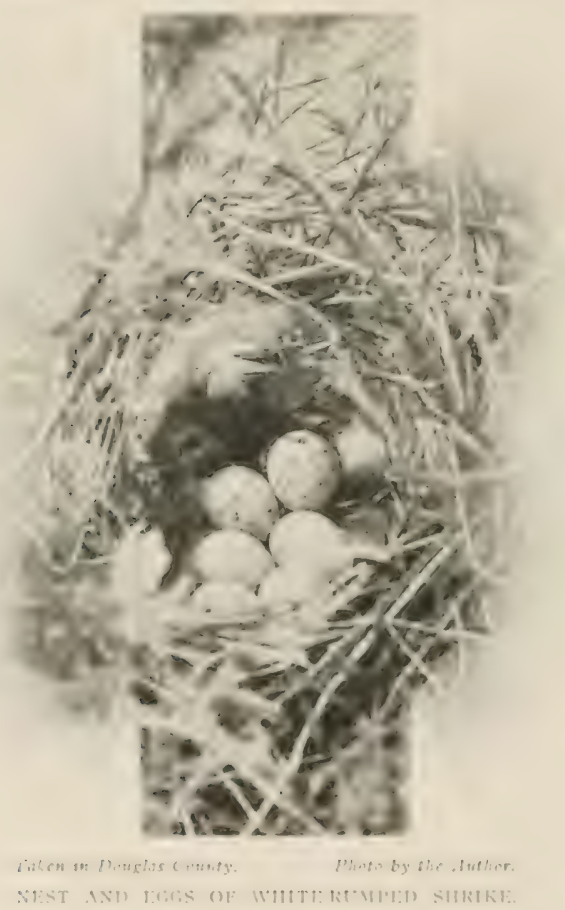

The nest is at loulkit but usuatly well-lusiti atïair. plateerl habitually in a sage lushe or it greiscwerel clump, with wilsl chematio for thirel clerice. 'The structure is designed for warmoth and comforst, so that. whenever pussilhle. tos the thickened walls ni plant tilsers. cowhair, ur sheep's woml, is adeled an inner lining of ieathers. and these mo infiequemty curl nuer the erlge sis ats completely to ennceal the nees inntents. One nest examinerl in IValla IIatla cinunty contained the follewwes materials: 11 illow twigs. hrom-sitge twigs, sage bark, weed stemls, drient yarrem leaves. Alriesl ange leatres. lempl, woml, rabluit fur. lowse-fatir. cow-hair. dhicken fenthers, string, rags, amel sanrl. hesibles a thick mmi

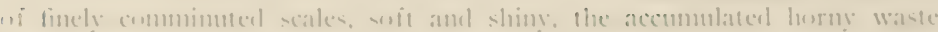

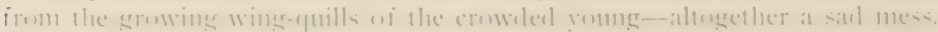

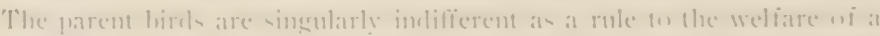

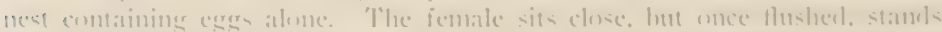

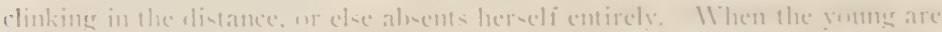

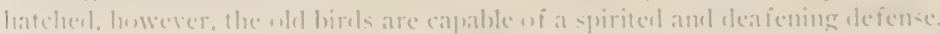


It is curions that in 1 ashington we have seen no signs of the ont-cloor larder, consisting of grasshoppers, mice, garter-snakes, etc., impaled on thorns, which the eastern birds of this species are usually careful to maintain somewhere in the vicinity of the nest. It may be simply that the lack of convenient thorns accounts for this absence, or for the failure of the labit.

Altho this bird belongs to a bad breed, one containing, among others, the notorious "Niuntöter," or Ninekiller, of northern Lurope, concerning which tradition mantains that it is never satisfied nntil it has made a kill of nine birds hand-rmming, the exidence seems to be overwhelningly in its favor. birds are found to constitute only eight per cent of this bird's food thruout the year, while, on accomt of its services in riclding the land of undoubted remin, its presence is to be considered highly beneficial.

\section{No. 137 .}

\section{CALIFORNIA SHRIKE.}

\section{A. O. [. . No. 622 b. Lanius ludovicianus gambeli Ridgway.}

Description.-Similar to L. l. c.rcubitorides but decidedly darker, duller gray above; underparts more sordid, tinged with brownish or with more or less distinct transverse vermiculation of pale brownish gray on chest and sides of breast; averaging slightly smaller.

Recognition Marks.-As in preceding-duller. ington.

Nesting.-Is in L. l. creubitorides-has not yet been reported from Wash-

General Range.-I'acific Coast district from southwestern british Columbia to northern Lower California; south in winter to Cape St. Lucas and western Mexico.

Range in Washington.--Rare summer resident west of the Cascales.

Authorities.-? Orn. Com., Journ. Ac. Nat. Sci. I’hila. VII. I $8_{37}$, I93 (Columbia River). Lanius Indoricianus crcubitorides Lawrence, Auk, IA. I $802,46$.

RESIDENT Shrikes, presumably referable to this recently elaborated sulspecies, are exceedingly rare in western Washington. Mr. Bowles has not seen any near Tacoma, ancl neither Mr. Rathbun nor myself liave encountered them in Seattle. Mr. R. H. Lawrence, however, notes having seen three "Il"hite-r"muped Shrikes" on June IO, I890, in a small clearing on the Humptullips Rivera.

'The smaller Shrikes are birds of the open country, and they should be fomml in at least Iewis, 'Thurston, and Pierce Counties.

2. Jirds of Cray's Ilarhor, Wash., Auk, Vol. 1X., Jan., J892, p. 46. 
No. 138.

\section{RED-EYIII) VIRIE().}

\section{1. (). L". (i) (1).4. Vireosylva olivacea (l.im1.).}

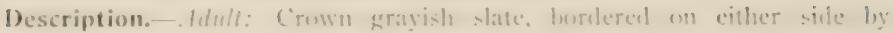

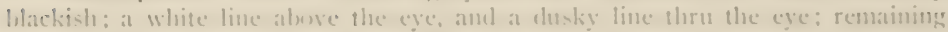
mperparts light grayish olive-green: wings and tail dunty with narrow olive-green

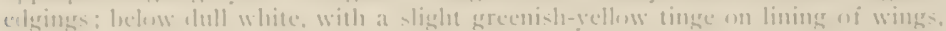

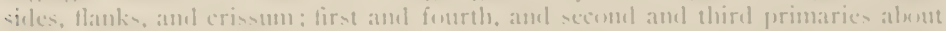
erpual, the latter pair forming the tip of wing; bill blacki-h at base absece, thence

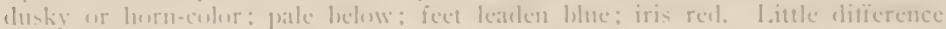

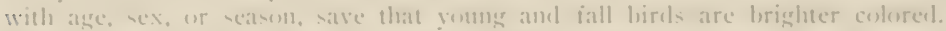

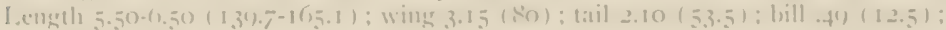
tarsis . 70 (18).

Recognition Marks. - llarbler size: largent; white superciliary line contrasting with hlacki-h amel slate of erown; red eye. Note smenther, and utteranee a litele mere rapiel than in l.. s. cussinit.

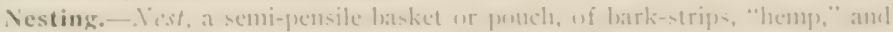

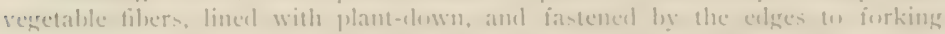
qwigrs near enul of horizontal loranch, five te twenty feet up. LEms. 3 or 4 . white, with hlack or umber spectis and spots, few in mumber. and chichly near larger

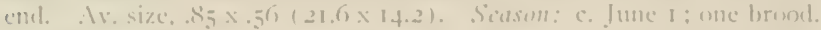

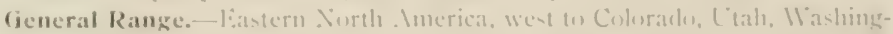
Inn and liritish coltumbia; north to the . Iretic regions: somble in winter from

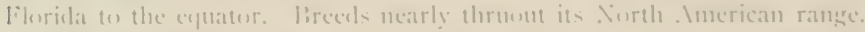

Range in Washongton.-Imperiectly male ont. Smmoner resident on luth

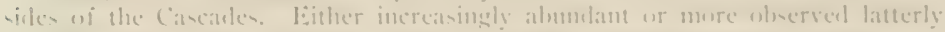

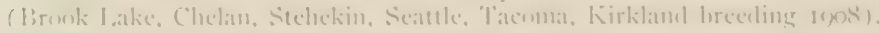

Migrations.- Sprimy: Scattle, May 3. I mos.

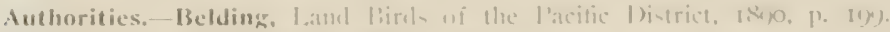

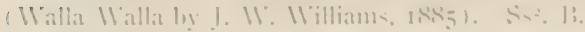

specimens.-C:

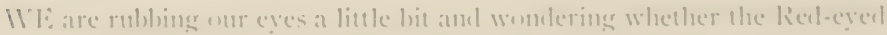

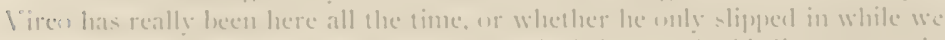

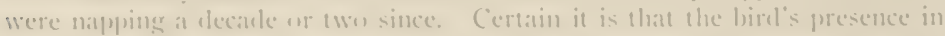

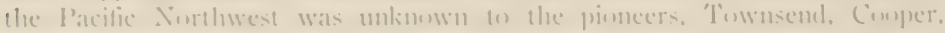
sincleley, and the rest: and the first intination we hat wi the recurrence of

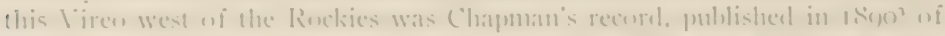

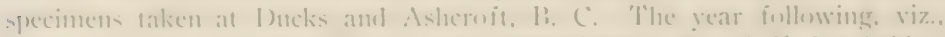

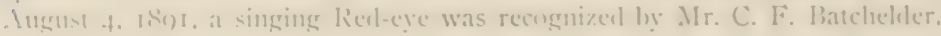


of Cambridge, Mass, at the Little Dalles, in this State ${ }^{a}$ Mr. Lyman Belding, the veteran ornithologist, of Stockton, Call, advises me, however, that this Vireo was first seen by his friend, Dr. J. W. Williams, of Walla Walla, on June + and 24,1885 , and that six specinens were tahen. Dr. Merrill, writing in $1897^{-6}$, records then as abunclant stmmer visitors at Liort Sherman, Idaho; and Fannin notes their occurrence upon Vanconver Island. Messis. C. IV. and I. H. Bowles met with this species in the Puyallup, Valley on June 23, I899, when they saw and heard at least half a dozen. Mr. Bowles and 1 were constantly on the lookout for this bird kluring our lisat-side trip in May and June, 1006, but we failed to observe it in either Spokane or Stevens Counties. We found it first in a wooded spur of the Grand Coulee on June I 3 th; then commonly at Chelan, where it nested; and also at the head of Lake Chelan with Cassin Vireos right alongside. And now comes the annonncenent of its breeding at Kirkland where Miss Jemine $V$. Getty took two sets in the season of 1908 .

The truth is, the Cassin Vireo has so long occupied the center of the stage here in the Northwest, that we may never know whether his consin, Rerleye, stole a march on us from over the Rockies, or was here for a century grieving at our dullness of perception. In habit the two species are not unlike, and their ordinary notes do not advertise differences, even to the nildly observant. Those of the Red-eye are, however, higher in pitch, less mellow and soft in quality, and are rendered with more sprightliness of manner. Its soliloptuzing notes are often nttered-always in single phrases of from two to four svllables each-while the bircl is busily hunting, and serve to mark an overflow of good spirits rather than a studied attempt at song. His best efforts are griven to the entertaining of his gentle spouse when she is brooding upon the nest. A bird to which I once listened at micklay, in Ohio, had chosen for his station the topmost bare twig of a beech tree a hundred feet from the ground, and from this elevated position he poured out his soul at the rate of some fifty plurases per minute, and without intermission during the half hour he was mucler olservation.

So thoroly possessed (loes our little hero become with the spirit of poesy, that when he takes a tum upon the nest he indulges, all mmind ful of the danger, in frequent outbursts of song. Both bircls are closely attaclied to the home, alontt which center their fears and their hopes and well they may be, for it is a beatiful structure in itself. The nest is a semipensile cup), bound firmly by its exlges to a small fork near the end of sone horizontal branch of tree or bush. and usually at a leeight not exceeding five or ten feet. It is composed largely of fibers from weed-stalks, and fine strips of cerlar or clematis bark, which also inrms what little lining there is. A curious characteristic of the entire Viren

a. The luk, Vol, IX., Oct., 1802, 0. 396

b. The Auk, Viel. XY., Jan., 18ge, P. 18. 


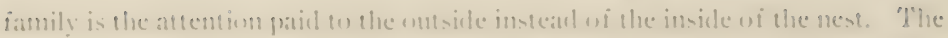

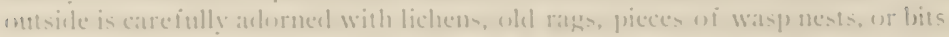

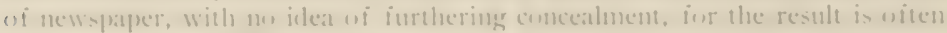

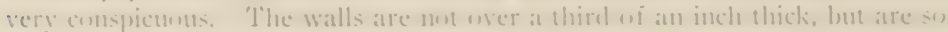

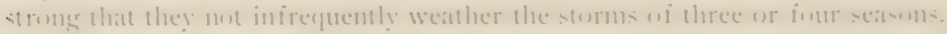

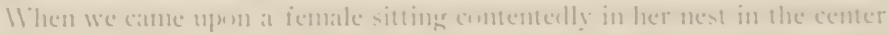

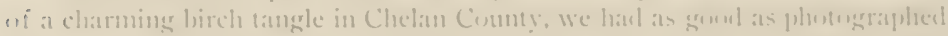

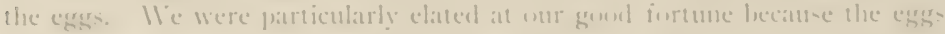

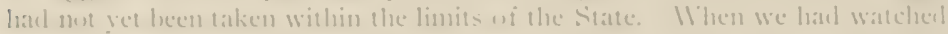

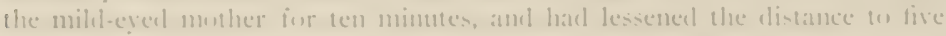

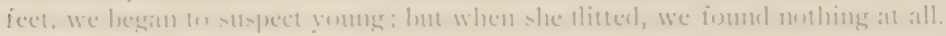
sile wais only fouling.

No. 13\%.

\section{WESTIER WARBLING IIREO).}

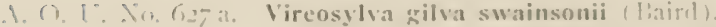

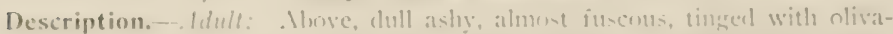

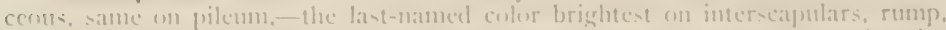
and colgings of secomblaries and rectrices: wings and tail fusecus, the primarice

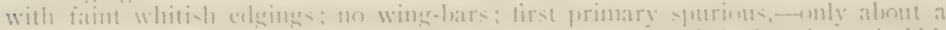

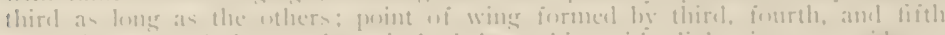

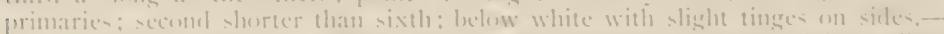

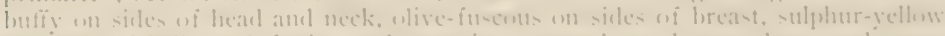

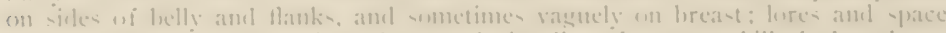

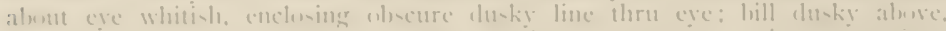

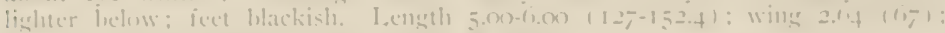

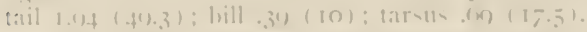

Recognition Marks. - IVarlbler size: general alsence of pestive characterio-

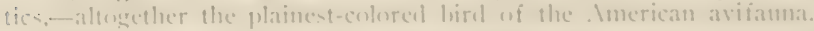

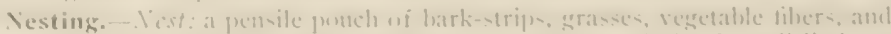
tra-h, carcinlly linesl with plamtelown: lumg usually from fork wi small limb, at

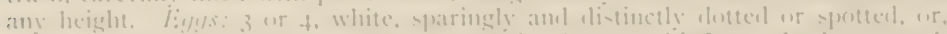

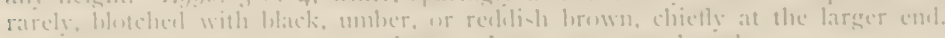

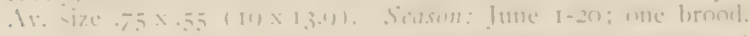

(ieneral Range-- ll wern I nited States amel Camala (Litish Columbia.

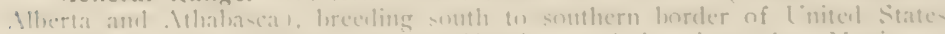

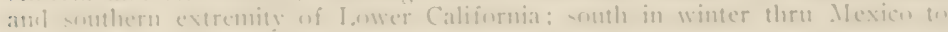
letal ('ruy and ( laxicat.

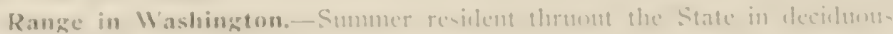
timber, chictly at lower levels.

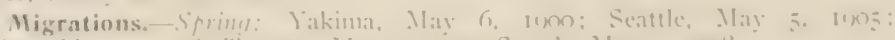

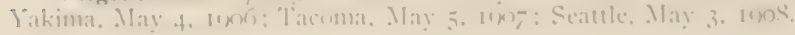


Authorities.-? T'irco gilzus, 'lownsencl, Journ. Ac. Nat. Sci. I'hila., VIII. 1839, p. 153 (Columbia River). T'ireo gilens (swainsonii proposed), Baird, Rep. Pac. R. R. Surv, 1X. pt. II. 1858, 336. 'T. C\&S. L. Rh. D'. Ra. D2. I. B. E.

Specimens.-U. of 11 . I'ror. L. I3N. E.

'HE old-fashioned name "Greenlet," as applied to the Vireos, was a misnomer, if a description of plumage was intended; but if it was intended to memorialize the bird's fondness for greenery, nothing conkl have been more apt. 'The $\mid l$ arbling Vireo's surromelings must be not only green, but freshly green, for it freguents only deciduous trees in groves and riverside copses. It is not an abundant bircl, therefore, in Washington, altho ecpually (istributed, whether in the willows and birches which gather about some lonesonre spring in the bunch-grass country, or among the croweled alders and maples of the turbicl Nooksachk. Noreover, the bird is not so frequently found about parks and shate trees as in the loast, altho it looks with strong favor upon the advent of orchards. And the orchardist may welcome him with open ams, for there is not anong all his tenants a more inclefatigable gleaner of lugs and worms.

Because lie is clad in ()uaker gray there is little need for the Vireo to show himself as he sings, and he remains for the nost part concealed in the dense foliage, a rocal embodiment of the living green. Unlike the disconnected fragments which the Red-eye furnishes, the song of this bird is gushing and continuous, a rapid excursion over pleasant hills and valleys. Continums, that is, unless the bright-eyed singer happens to spy a worm in medias res, in which crent the song is instantly suspended, to be resumed a moment later when the wriggling tid-bit has heen dispatched.

'J'he notes are flute-like, tencler, and melodinus, having, as Cliamman says, "a singular alto undertone." Nil hours of the rlay are recognized as approfriate to melody: and the song period lasts from the time of the bircl's arrival, early in May, mntil its cleparture in September, with only at brief hiatus in July:

In sharp contrast witl the heantiful canzonettes which the birel showers down from the treetops. come the harsh, wren-like

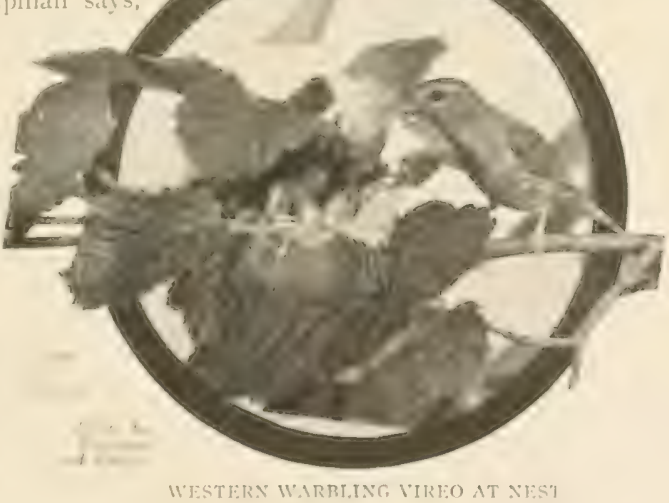




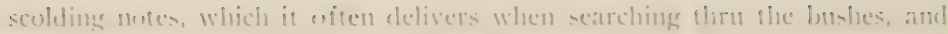
especially if it comese across al lurking cat.

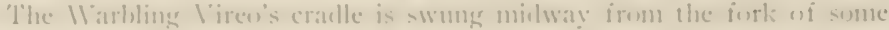

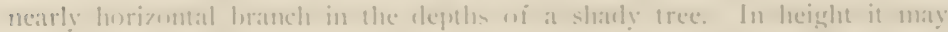

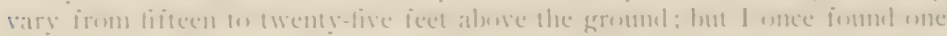

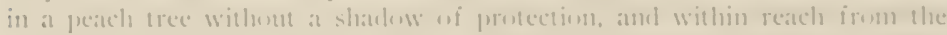

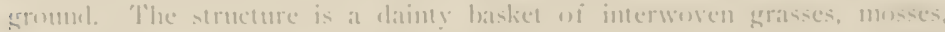

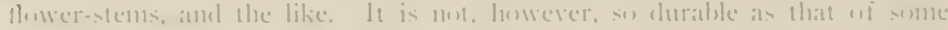

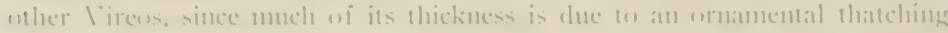

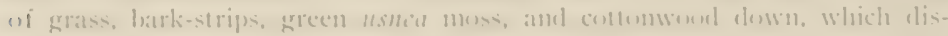
solves before wimer is oner. 'The female is a close sitter, siching we her pest even tho nearly paralyzenl with fear. The male is mstually in close

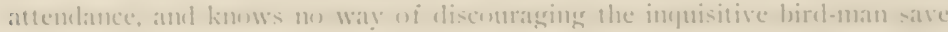
by singing with retenthled energy. He takes his turn at the egres when his wife neerls at hit of an airing. anel eren, it is said, carries his song with him (1) the nest.

No. 140.

\section{CASSIN'S VIREO.}

\section{1. (). 1". Nin, (62) a. Lamivireo solitarius cassinii (Xantus).}

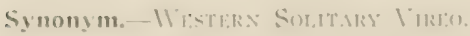

Description. - Hult mule: ('rown and sile of leand ambl neck deep olive-

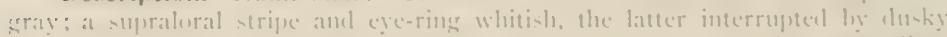
of lore: remainime upperparts olive-ereen owercast with gray, clearing. pure oliveErecn on rump and npper tail-coserts: winge and tail blacki-h with ealging of

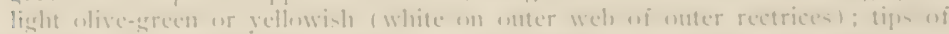

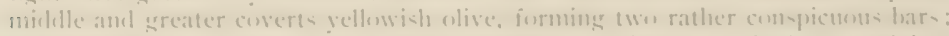

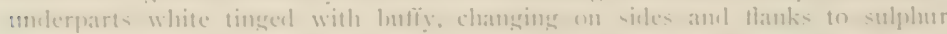

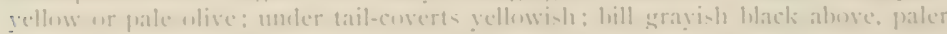

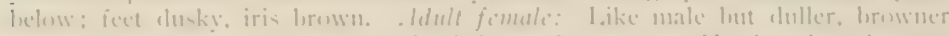

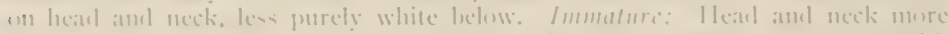
nearly like lack: supraloral streak, orlutal rimg. and molerparts wa-locel wish

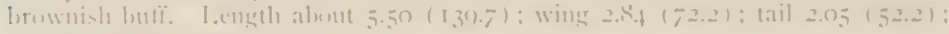
lill .311 (10): tarsilis 75 ( II)).

Recognition Marks.- II:arliler size: saty gray heal contra-ting with olivaconth latk: whitish eve-ring di-finctive: voice has mure wi an erge than that ui 1: alianciul.

Nesting,--Vial: a remi-pen-ile las-ket of wewen hark-strips, grasses, and

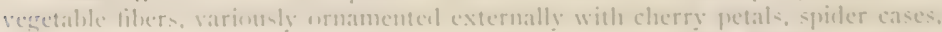

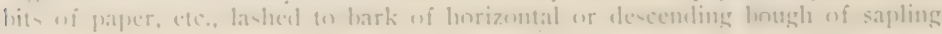


(oak, vine-maple, fir, etc.) at a height of from five to thirty feet; bulkier and of looser construction than that of other lireos; measures $2^{1 / 4}$ inches across by $I^{1 / 2}$ inches deep inside; walls often $3 / 4$ of an inch in thickness. Egys: $3-5$, usually 4 , white or creamy white, sparingly marked with spots, which vary from rich red brown to almost black-but ummarked specimens are of record. Av. size $75 \times .55$ (I9 $\times$ I3.9). Seasom: May 15-June 5; one brood.

General Range.-P'acific Coast district north to Iritish Colmmbia, cast to Idaho (Ft. Sherman; It. Lapwai), breeding from Los Angeles County, California, northward thruout its range: south in winter to western Mexico.

Range in Washington.-Common stmmer resident on both sides of the Cascades, found cliefly in timbered areas.

Migrations.-Spring: Seattle-'́acoma, c. April I5.

Authorities. - ? Virco solitarius, Ornithological Committee, Journ. Ac. Nat. Sci. Plila., VII. I837, 193 (Columbia River). $\quad$. solitarius Vieillot, Baird, Rep. I'ac. R. R. Surv, IX. pt. II I858, p. 340, part. ('I'). C\&S. Rlı. D1, Ra. D2. Ss². I. B. E.

Specimens,- (U. of $\mathbb{W}^{\mathrm{T}}$.) B. Prov. $\mathrm{P}^{1}$.

NOTHIXG so endears a bird to a human admirer as a frank exhibition of confidence. Overtures of friendship on the birl's part may. traverse all rules of caution and previous procedure, but henceforth there is a new relation established between them, bird and man, and the man. at least, is bound to live up to it. At the oncoming of a smart shower on Capitol Hill (before the "lior Sale" (lays) the bird-man put into a fir-covered nook for shelter, and had not been there two minutes before a pair of Cassin Vireos entered for the same reason. 'They were not in the least disturbed by the man's presence, but cheerfully accepted lim as part of 'I'hings as 'They Are. 'T'herefore, they proceeded to preen their dampened feathers at ristances of four or five feet.

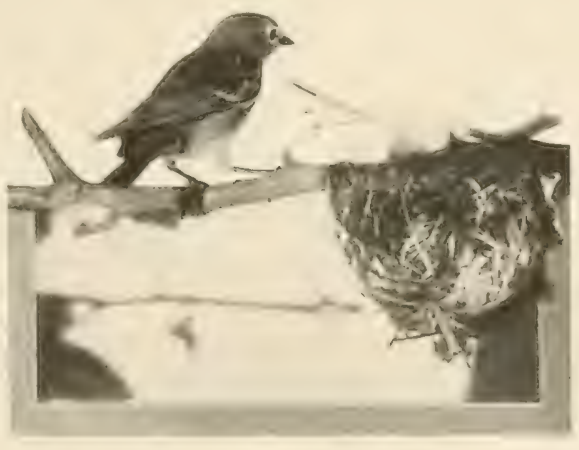

Takes in Oreran.
Phofo by Finky and Bohlmitn. C.ISSIN VIREO IT XIST.

While the bircl-man sat with bated breath and glowing eyes. 'l'he birch roamed freely about the nook and once, I think, he made a grimace behind the bircl-man's back; for when they came around in front again, I juclged she was saying. "Arn't you the wag!" while he tittered in troll recollection. 


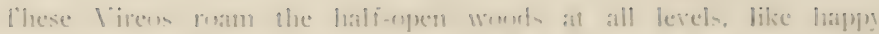
(thenel children: and their childish currimity is as little w be resented. If

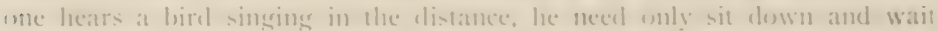
curiusity will get the letter wi the bird, and unter pretense wi chasing huges it will exlge aver, singring carelessly mow and then, ly way wi

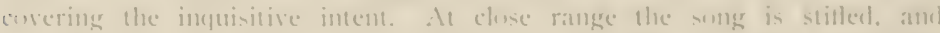

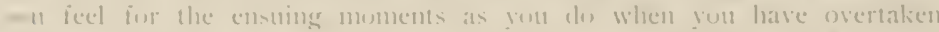

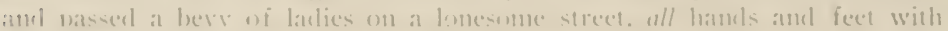
mome altruetulls smitgerer: Inspectimen done: the bivil smblents re stmenes the dis carreerl melext. :1114 अ111 limere latre to

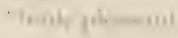

I.ike ment $\mathrm{Yi}$ rees. (a-1n) smess to he works: ancl. ar he works a [youl deal of this cime. allueit in levertely faslacen he sines in tim phrases, segatated he mentharrassed

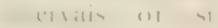
iencee a sm al abiar crome. mentary on lifi yert nleasant to

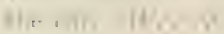

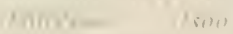
romi nitiacer. In li nil

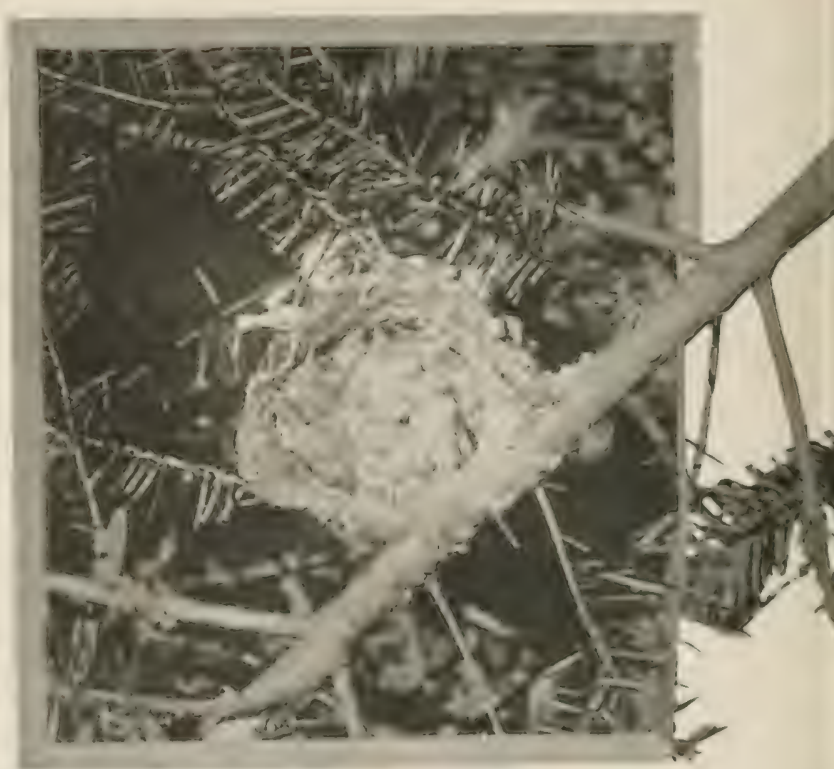

Whata by Doresen ard isontion

11:1 M1:

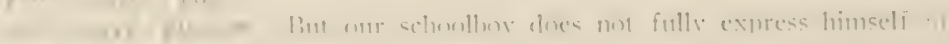

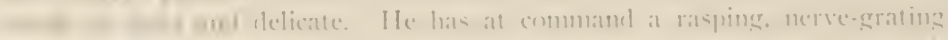

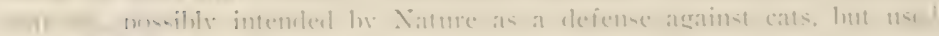

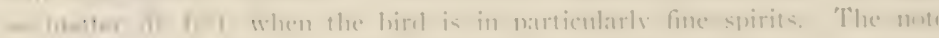

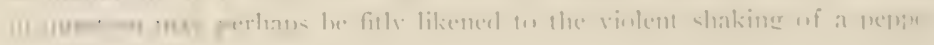


box, a rattling, rubbing, shaking note, of three or more vibrations, ending in a little vocal flourish.

'These Vireos swing a bulky basket from the lower or micklle heights of oak trees, fir trees, alders, or saplings of various sorts. Lsually no dependence is placed in cover, save that the ormanented nest corresponds roughly with its general surroundings of leaf, moss and lichen. In sheltered places, the texture of the nest is so well preserved that it may require close inspection the second season to distinguish it from a new nest. One such I examined, green with growing moss, and stark at the

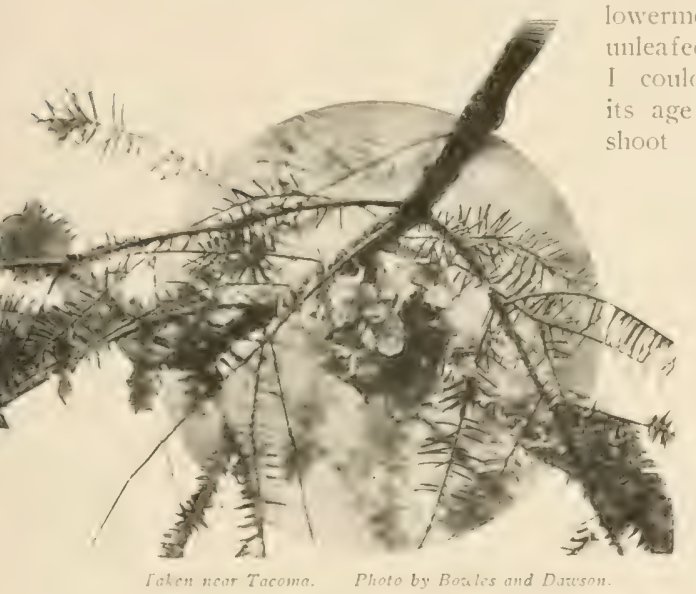

A DECOR.AT1:1) XEST

lowermost branch-tip of an unleafed cornel sapling, and I could not have determined its age save for a tiny weerlshoot germinating from the bottom of the cup,

Further Mr. Bowles says of their nesting habits: "Both bircls assist in the cluties of incubation. the male singing most assiduonsly while on the nest, and nsually singing close to his mate while she is sitting. His turn at sitting scems to come between nine o'clock in the morning and noon, and the nest is not hard to find if his song can be traced. The hird student must work quietly, however, as the song at once ceases shmuld any munsual noise necur. They are most courageons while on the nest, seldom leaving until removed by hand, when both birds remain within a few feet of the intruder, scolling vigurously. So much noise (lo they make that all the birds in the vicinity are attracted-incleed this is about the only sure method of ascertaining the presence of some of our rarer Warblers On nne such occasinn a female Conper Hawk left her nest, which was seventy-five yards clistant, and sat on a branch orerhead, screaning att me.

"They are the quickest as well as the slowest birls in com pleting their nests that have come muler my notice. One pair huilt a 


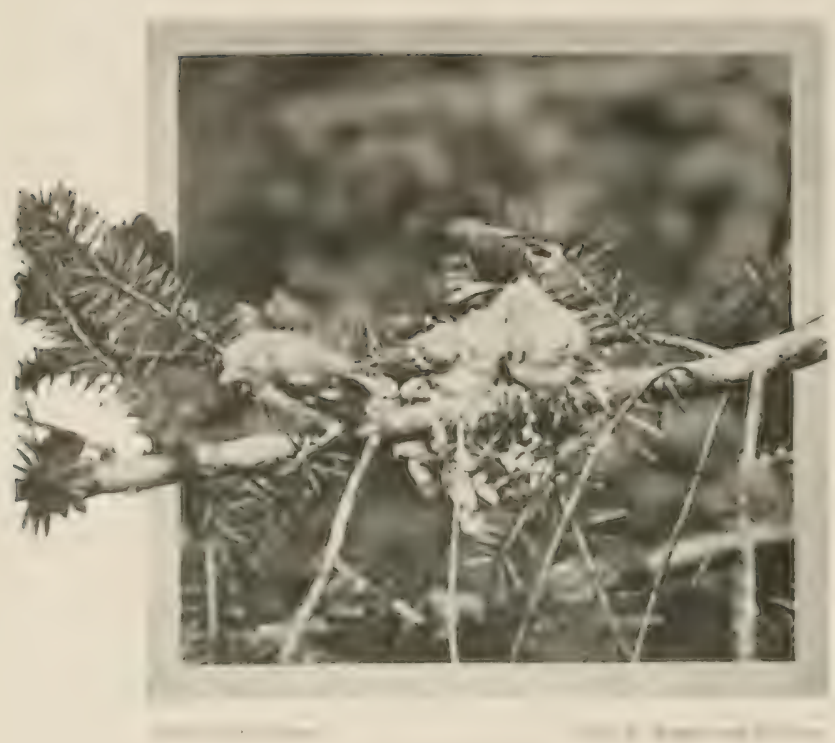

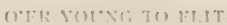

lamplomene nest ancl laid four egess in precisely ten dass: while amother patir were mure than three weetso from the line: the nes: was starterl mutil the exges were laiel

"l'hey are the mole Ireers that 1 have exer kmown on nest in (e)mumunities Single pairs atre il. whe. ! lime.. finisel as many as six occupierl nest: insirle of a very maill area. the mests lecing whly a few yaris apart

Nin. 1.41.

\section{ANTHONYS VIRLO.}

\section{1. ก. I . Xin. 63z c. Vireo huttoni obscurus Anthom}

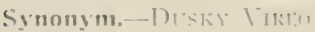

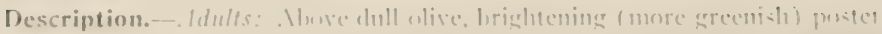

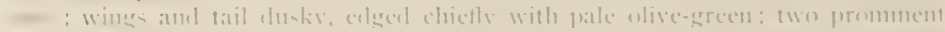

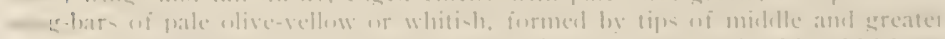

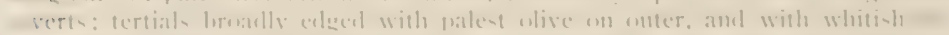

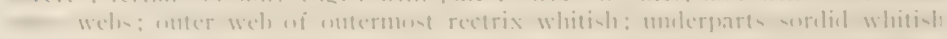

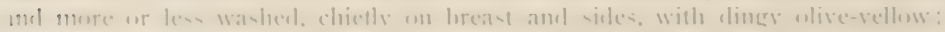

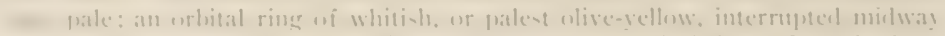

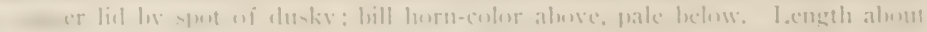

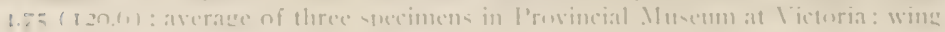

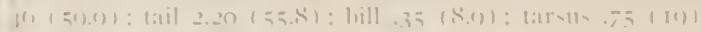


Recognition Marks. - P'ygny to warbler size; dingy coloration; whitish wing-bars serve to distinguish bird from Vircosylia g. sainsonii, but throw it into confusion in summer with the IVestern Flycatcher (Empidona. difficilis), which it otherwise closely resembles, and in winter with the Sitkan Kingle (Regulus c. grimuclli). From the Filycatcher it may be distinguished by its shorter. narrower and yet thicker bill, and by its more restrained yellowness; from the Kinglet by its greater size and much stonter bill, more prominent wing-bars, and rather less prominent cye-ring; and from both by its demure ways.

Nesting. - Y est: a semipensile basket of interwoven mosses lined with grasses (nine feet ligh in fir tree-one example known). Eiggs: 2-5(?); .72 x.52 (18 x 12.9). Scason: June (probably also earlier).

General Range.-Pacific Coast district from western Oregon to southwestern liritish Columbia at lower levels (not at all confined to oak wooks as variously reported).

Range in Washington.-West-sicle, as above; strictly resident.

Authorities.-?'Tommencl, Jonrn. Ac. Nat. Sci, Phila, V111, I839, I53 (Colmmlia River). Bowles (C. W. and J. H.), Auk, XV. I898, izs. Ra. L. E

Specimens- - U. of IV. Prov. B. E.

IN approaching the study of Anthony's Vireo one must forget all he knows or thinks he knows about Vireos in general. This bird is sui generis. and deviations from all known rules are its clelight. It las been, in fact, until (nuite recently, a sort of woodland spluinx, an ornithological mystery, the sur)ject of much inquiry and hazard. Its presence in VWashington was quite overinoked by Cooper and Suckley, and XIr. Rathbun's appears to be the record ${ }^{a}$ of first occurrence, that of a bird taken May It. I895. I took a specinen on Capitol Hill on the third day of Jume of the same year: and since that time appearances have become a matter of course to the initiated. Samuel $N$. Rhoads ${ }^{b}$, writing in 1893 . considered $\lambda$ nthony's Vireo a rare visitor to Vanconver Island, where he secured a specimen in 1892 near Victoria. Fanninc recorls it as "a stummer resident nn Vancomer Island." As matter of fact. the birl is resident the vear roumd wherever it occurs. I saw it near Victoria during the coldest weather of $1905-6$, and fund it regularly at Seattle and 'Tacoma during the winter season. J. H. Bowles secured a specinen, a male in full song, at American Lake on January the $260 \mathrm{~h}$, rgo\%. Moreover, this bircl had a bare belly as tho it might have been assisting with incubation.

The very fact that these bircls winter with us argues that they have been here for always and always, and the darkening of plumage (as compared with the type form, $Y$. Initoni) testifies further to their long residence.

Inthony's Viren is leisurely, almost sluggislu at times, in its movements.

a. Suk, Inl, Xix., Ipr., 1002 , p. 138 .

h. Prnc. Acarl. Xat. Sci. Phila., t8n3. P. 54

c. Cat. 13. C. Biriss Ptov. Mus., Victoria, yond, P. $5 z$ 


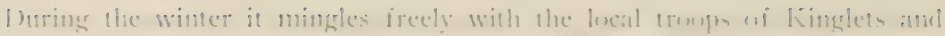

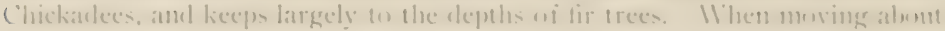
-ilently, it beats at striking resemblance to the linly-ernomet kinglet. It is. wi comse, slightly larger and much more deliberate, lacking enpecially the

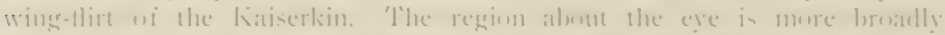

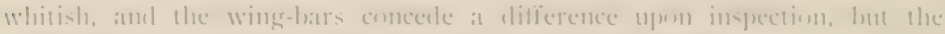
resemblance is su chese ats altergether to decerive the mowary

In spring the birel separates itself from its latte compranions, amel leggins fon

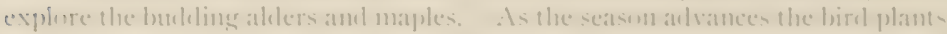

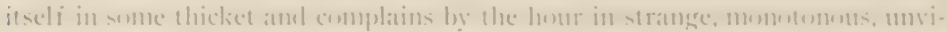

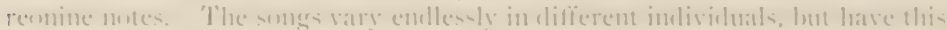

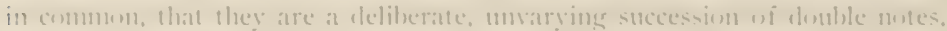

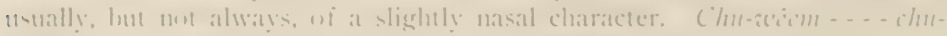

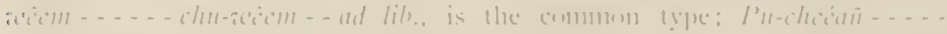

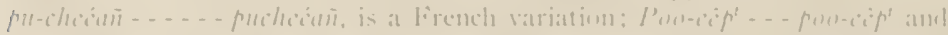

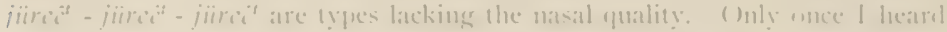

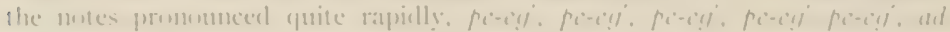

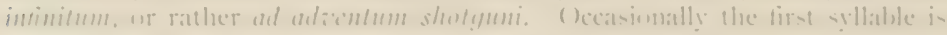

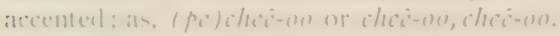

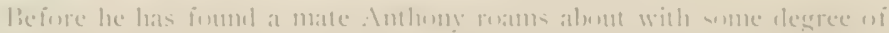

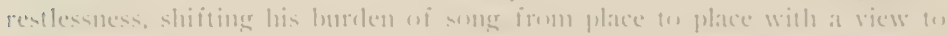

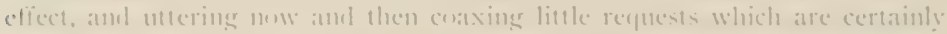

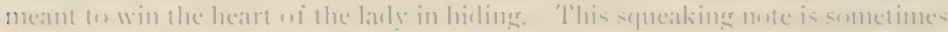

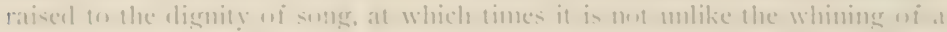

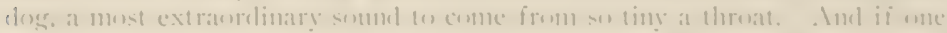

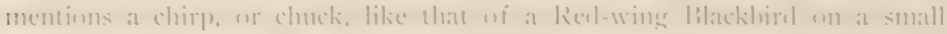
realle, we lanve must of the represemtative efforts of this eccentric genius.

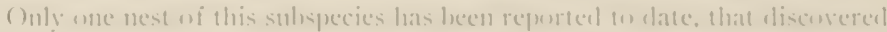

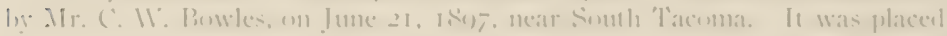

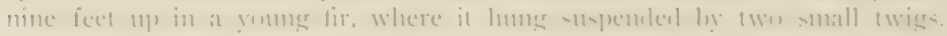

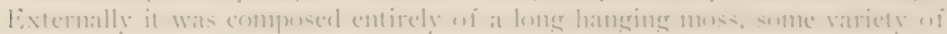

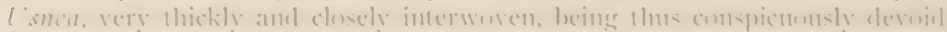

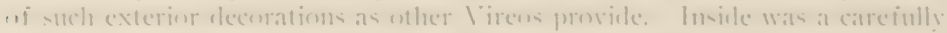

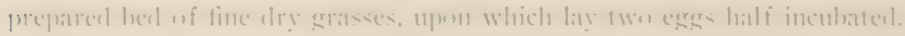

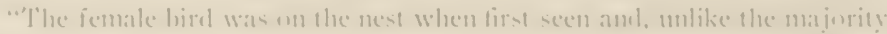

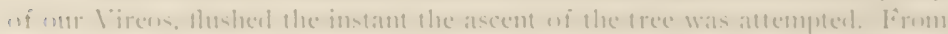

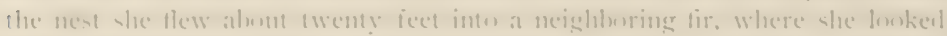

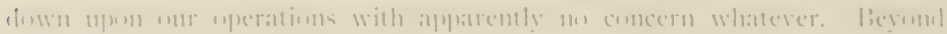
rearranging laer feathers from time to times there was mothing to indicate

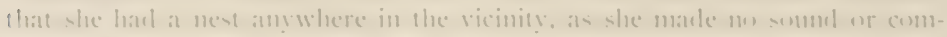

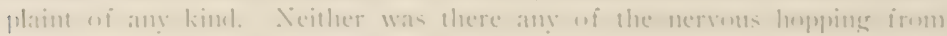


twig to twig in the mamer by which so many of the smaller birds as clearly display their anxiety as they clo by their notes of clistress." a

\section{No. 142. \\ KINGBIRD.}

A. O. U. No. 444. Tyrannus tyrannus (Linn.).

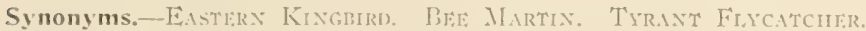

Description.-Idult: Ahove ashy black changing to pure black on head, and fuscons on wings; crown with a concealed orange-red (cadmitum orange) patch or "crest," the orange feathers black-tipped and overlying others broadly white at base; wings with whitish and brownish ash edgings; tail black, all the feathers broally white-tipped, and the ontermost pair often white-edged; below white, washed with grayish on breast; bill and feet black. Immature birds lack the crown-patch, and are more or less tinged with fulvous or buffy on the parts which are light-colored in the adult. Length 8.00-9.00 (203-228.6); wing 4.60 (I 16.8) : tail 3.3I (8.4.I) ; bill from nostril .52 (I 3.2).

Recognition Marks.-Chewink size: blackish ash above; relrite below; black tail conspicuonsly tipped with white; noisy and quarrelsome.

Nesting.-Nest: at moderate heights in trees, wswally over water, of weedstalks, plant-filores and trash, with a felted mat of plant-down or wool, and an inmer lining of tine grasses, feathers, rootlets, etc. Eggs: 3 or 4 , sometimes 5 , white or cream-white, distinctly but sparingly spotted with dark number and occasional chestnut. Av. size .98 x.73 (24.9x I8.5). Season: first week in June; one brood.

General Range.- North Anerica from the liritish Provinces south: in winter thru eastern Mexico. Central and Sonth America. Less common west of the Rocky Mountains. Not recorded from northern Mexico and Arizona.

Range in Washington.- - Vot uncommon summer resident on East-side: not common, lut of regular oceurrence in certain localities west of the Cascades; nearly confined to vicinity of water in lake or pond.

Authorities.-Tyanmus carolincnsis Baird, Baird, Rep. Pac. R. R. Surv..

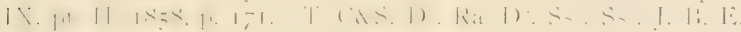

Specimens.-(L. of II:) P'rov. Pi. C. E.

NO one has cone forward witl a thenry to accomt for the testiness of this bird's temper, nor for the domineering qualities which distinguish him above all others: but I hazard that it is hecause his glowing crown is partially concealed by butreois black. Those whose regal marks are more patent are wont to receive homase as matter of course, but the scion of an unacknowl-

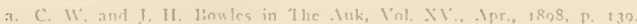




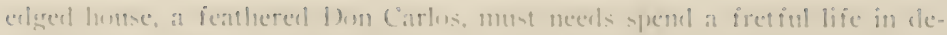

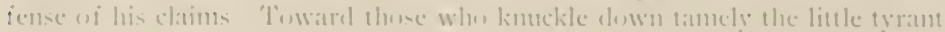
is often very gracions, and it maty he enteceled that he dees perform at real

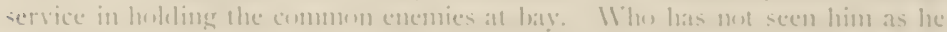

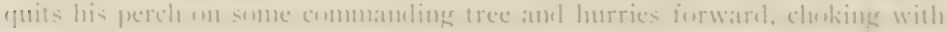

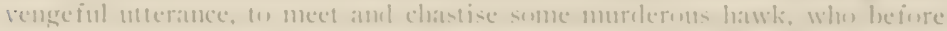

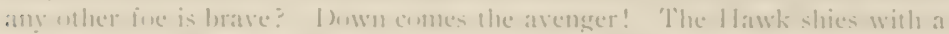

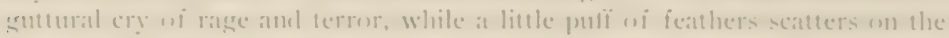
air to tell of the tyrant's stecess. Again and agatin the quick punishment falls. until the timy scourge desists, and returns, shaking with shrill laughter.

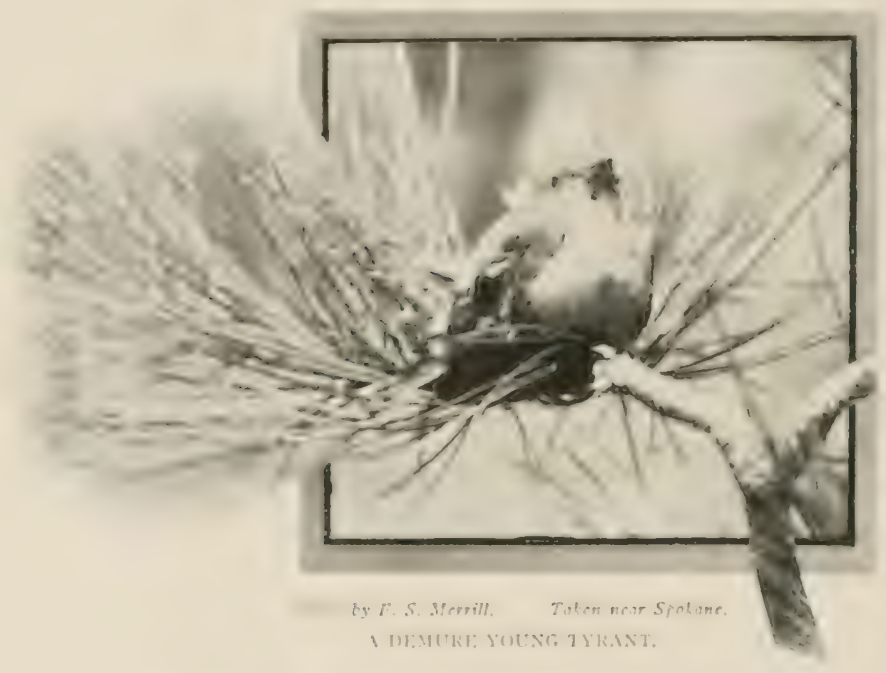
to give his mate an accontum wi his arlienture.

It is eilsily poscible, lowever, (1) exilsgerate the jutgmacity wi the kinglirel, or to infer from extreme examples that all are rjuarrelsume: It is not momemal for linghirds in lee on the ixist of termes with lleit immerliate neighbors, theeves always excejuterl. I nnee found in

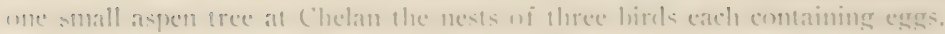

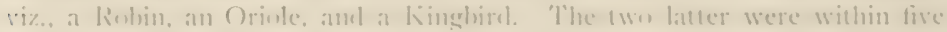

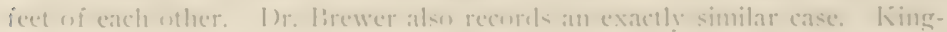

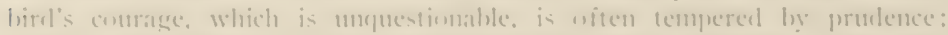

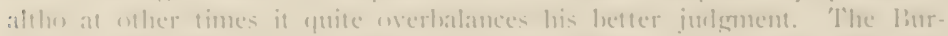

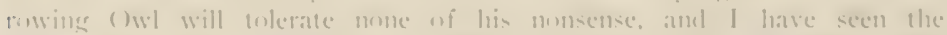

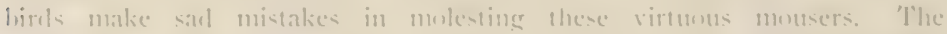

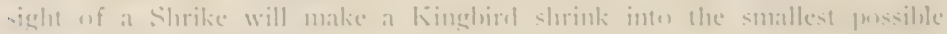

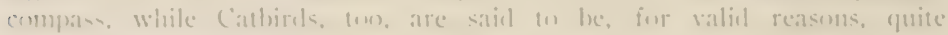
exempt from mulestation 
The food of the Kingbird consists entirely of insects, canglit on the wing for the most part, by sallies from some favorite perch. His eyesight must be very good, as he not infrequently spies his prey at distances of from twenty to fifty yards. Honey bees form an occasional but inconsiclerable article of diet. Grasshoppers are not orerlooked, and they sometimes capture, not without a scuftle, those big brown locusts (Mclanoplus sp.) which make Hippant exposure of their persons on a summer day. Both in the taking of food and in the discharge of police duties the Kingbird exhibits great strength and swiftness, as well as grace in flight. Once, when passing in a canoe thru a quiet, weed-bound chamnel, I was quite deceived for a time by the sight of distant white-breasted birds dashing down to take insects near the surface of the water, and even, occasionally dipping under it. They had all the ease and grace of 'Tree Swallows, but proved to be Kinglurds practising in a new role.

This fondness for water is often exhibited in the birds' choice of a nesting site. Where accustomed to civilization, orchard or shade trees are preferred, but on many occasions nests are found on low-swinging horizontal branclues overhanging the water; and, as often, in tiny willow clumps or isolated trees entirely surromeled by it. The nest of the Kinghird sometimes presents that studied disarray which is considered the height of art. Now and then a nest has such a (lisheveled ap)pearance as 10 ruite discotrage investigation, unless the owners' presence betravs the secret of occupance: On the shore of $\mathrm{Colk}$ Spring Lake. in Douglas County, we moterl a last vear"s Bullock Orinle's nest. which woukl not have attracterl a second glance, with the newer nest lonrel

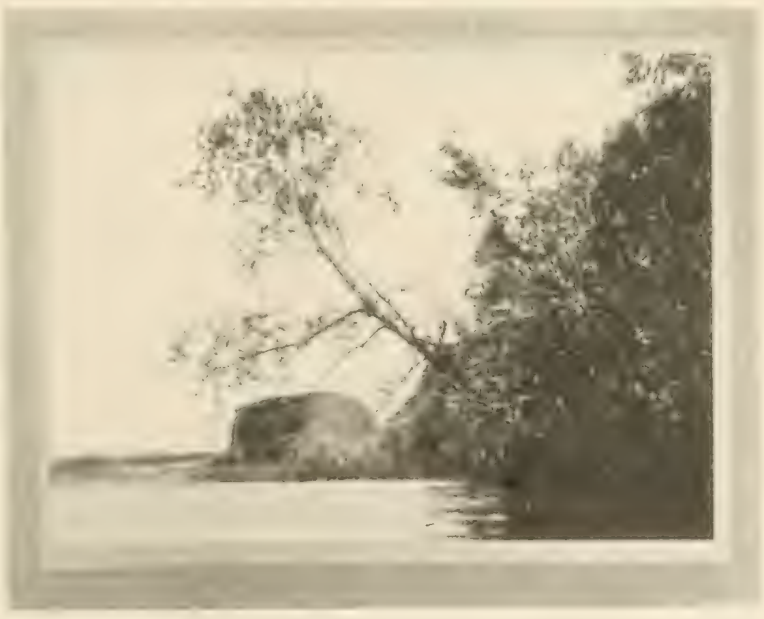

Takn't in Douglas Comty.
Plinto by II'. T. Darison

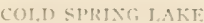

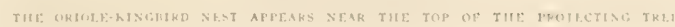




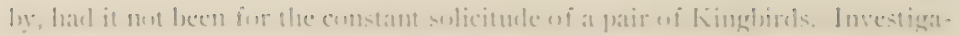

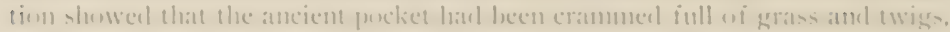

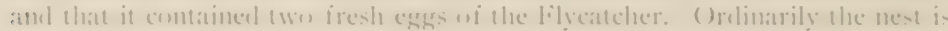
placed in an upright of lemizntal fork of a tree at a lecight of from three to

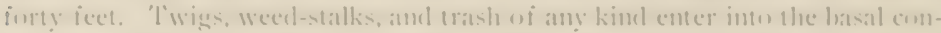

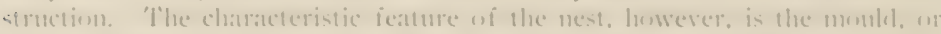

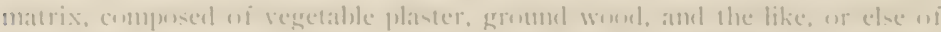

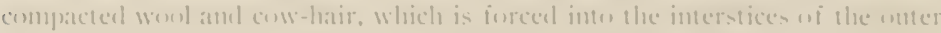

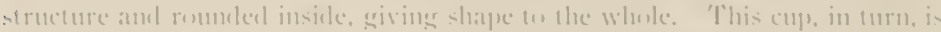

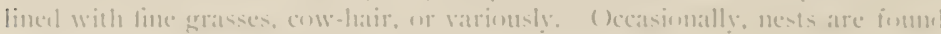

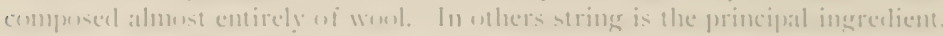

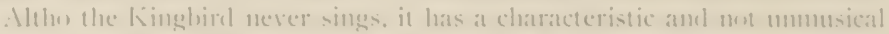

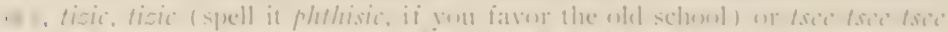

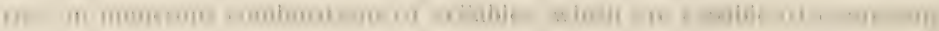
various degrees of excitenteme and emmotions.

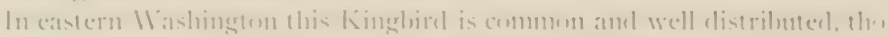

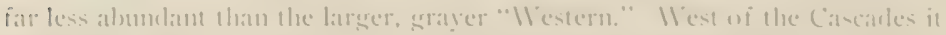

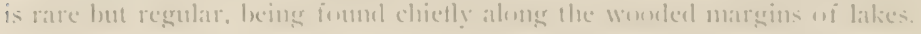

No. 1.3.

\section{WESTERN KINGBIRD.}

1. (). [1. No. 447. Tyramus verticalis Say:

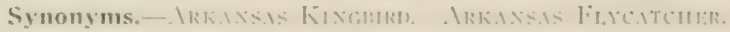

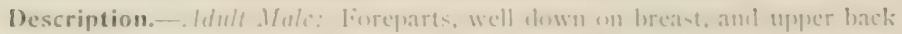
aube eray, lightening, nearly whine, wn chin and unger thenat, darker on lores and? hehimel eye; a partially encealed erown-patele of urange-red (Chinese urange):

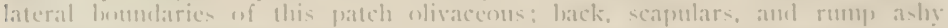

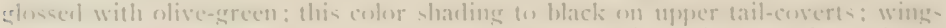
furents: tail black, the onter weh of entermost rectrix white, or iantly theed with vellow: molerpart helow hreas rich canary yellow, paler on wing-lising

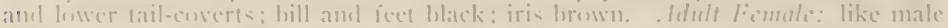
lut crown-patch m-ually semewhat restricted, and primarice much le's attemuated. boun! lirds are duller ambl hrowner witheut crown-pateh, and with little or no olivacens on hack: the yellow of unlerparts is paler (sulphury or even whitioh). and llac primaries are searecly or mot at all attentated. Length of adult male-

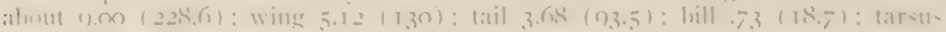

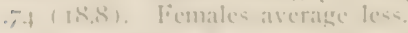

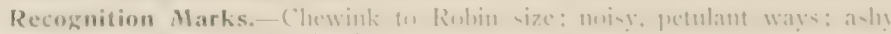
turepartic and yellew helly distinctive.

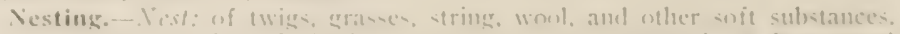

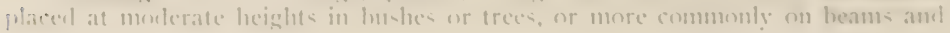


leelges of barn or outbuillings. Eigys: $3-5$, like those of 7 , tyrannus, but averaging smaller, $.93 \times .08(23.6 \times 17.3)$. Season: first week in Jume; one brood.

General Range.- Ilestern Lnited States, north regularly to southern Lritish Colmmbia, occasionally to Alberta, Assiniboia, and Manitola, north to western Jinnesota, eastern Nebraska, and western l'exas, lyreeding thruont range, and south to Chilumbua, Mexico; south in winter thru Mexico to highlands of Ginatemala.

Range in Washington.-Common summer resiclent east of the Cascacles, rare or casual on the 11 est-side.

Migrations.-Spring: c May Ist; IVallua April 20, I905; Yakima April 30, 1000: Chelan May 1I, 1806.

Authorities.-Baird, Rep. I'ac. R. R. Surv. 14. 1858, p. 174. T. C\&S. D'. $D^{2} . S_{s}^{t} \cdot S_{s}^{2}$. J. B. E.

Specimens,-U. of W. I's, I'rov. B. E.

HERE is the presiding genins of all properly conducted ranches upon the summy side of the. Cascarle Mommains. Guest he is not, host rather; and before you have had time to dismount from your panting cayuse this bird bustles forth from the locust trees and hovers over you with noisy effusive-

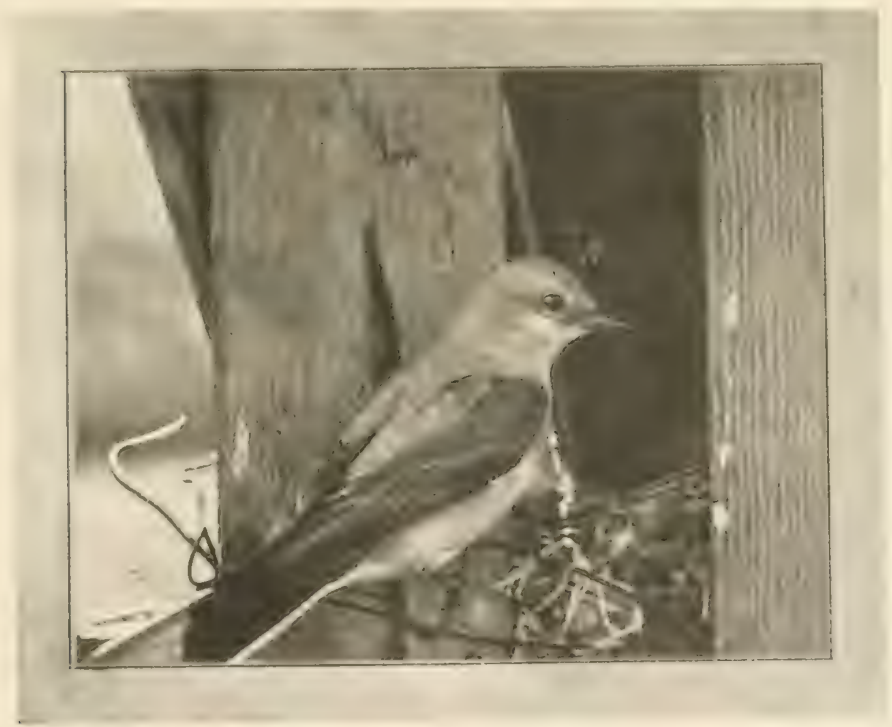




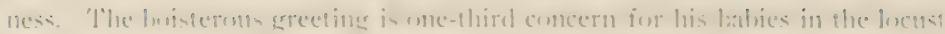

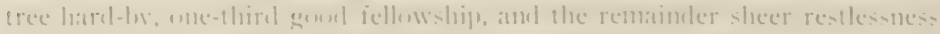

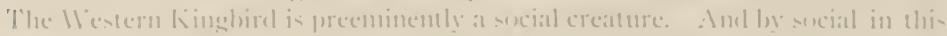
calse we meatn, wi course, inclined to human society. For, althe the hird nuay start
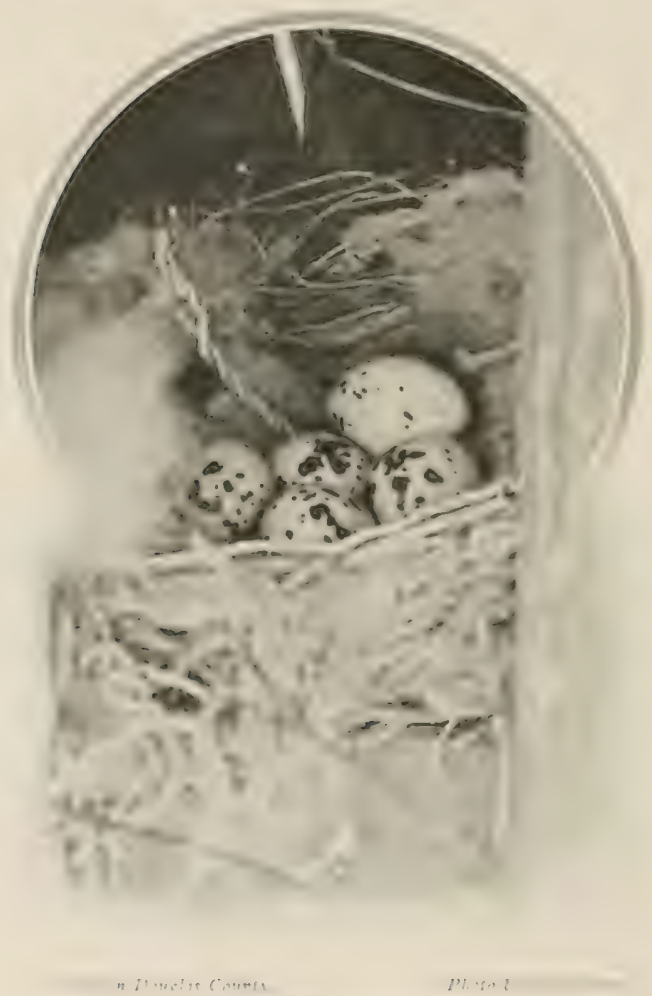

IV:,+ :

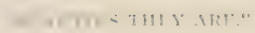

(1) with vecierating crose every mase a member of the lxe ijeged honselmikl sets ferst ont wi dewr mene is reminuled in these attentinus ratl (2) of a frolicomme puppy than wi a zeat. mes guturdian of 1 pertce. 'Those when have |xeen mu-t hanored by their pres ence year afler year claim that the hirel become fond of certain members of the family, and allow a familiarity in nesi inspection which would be slrielsingh resenterl in the case of strangers.

One can realils gutess a muitamat enncileration in ia vor wi manch life.

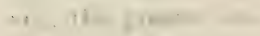
riets ancl almulanee of inserts affordert

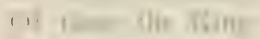
Pabis rains a sme!

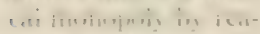
r wi lie mon.

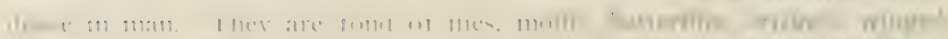

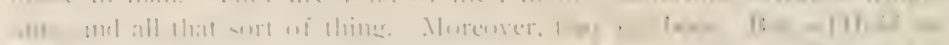

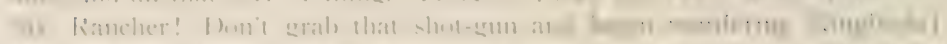

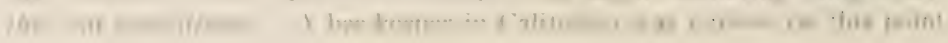


and dissected orer a hundred specinens of IVestern Kingbirds and Plowbes, using a microscope in the examination of stomach contents. 'The birds had been shot abont the apiaries, where they had been seen darting upon and catching bees. Nitho many of the birds were gorged, no working bees were found, only drones. 'This is an important distinction to bear in mind, for the reduction of drones is unqualifiedly beneficial. And when one stops to think of it, it is absurd to suppose that a bird could swallow bees, stings and all. with impunity:

But the real secret of Kinghird's attachment for mankind is not discorered until we see his nest. It is our strings which have won his heart. Whatever else the nest may or may not contain, it is sure to have string,string in strands, string in coils, string in lunches, lanks, and tangles, drug store string of a dissipated crimson lute, white string that came around the sugar, greasy string that you lad tied around your finger to remind you to feed the chickens, string of every length and size and use and hue.

Those II estern Kinglirds which have not yet adopted men manage to stulsist somewhat after the fashion of their easterin consins. and build a nest of twigs, grass, weed-stalks, bark strips, and cottonwood down, placing it against the trunk, or saddling it mpon a horizontal fork of willow, poplar, cottomwood, or pine, usually near water. One we found in Douglas County built in a small willow which emerged from a shallow lake, a hundred feet from shore.

But, more commonly, nests are placed about crannies and projections of fam buildings, fences, nunsed wagon-ricks, or upon the house itself. If no such conveniences offer, a shade tree is second choice. and the nest inclucles a 11 the soft waste wh icli the farme afforcls, bits of cloth. wo o l, cowhair. feathers, and string.

Eings to the number of 4 or 5 are deposited from the Ist in the istli of June.

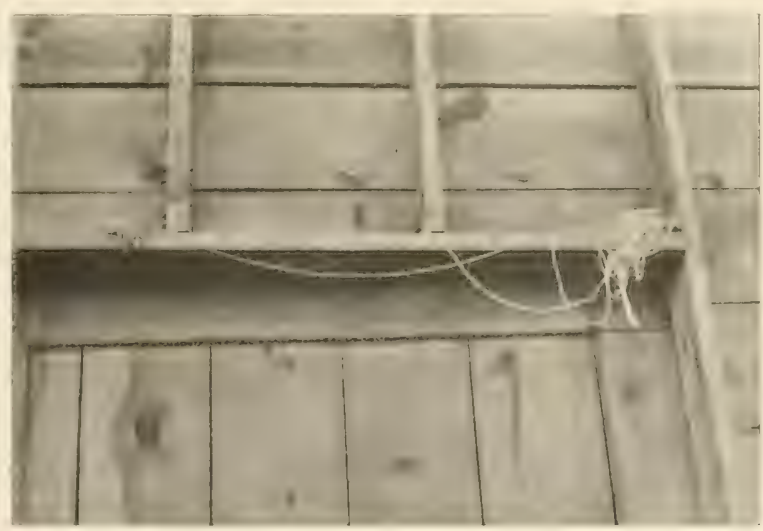

Tinten at Stratford.

Photo by the Autior. A DIII):I HOUSI: 


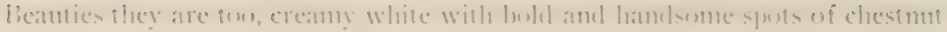

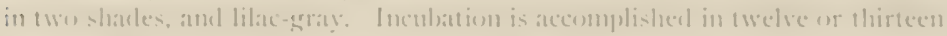
datys and the youmgsters tly in at matter af two weeks.

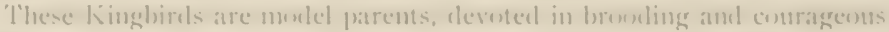

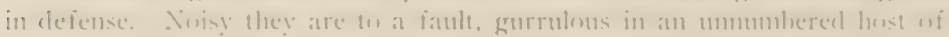
ajulatives and ecsatics, ats well ats expletives. Linlike the members of

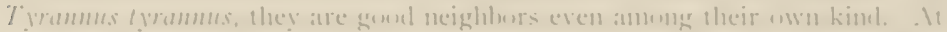

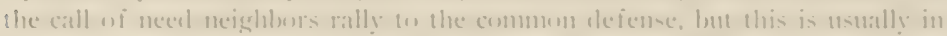

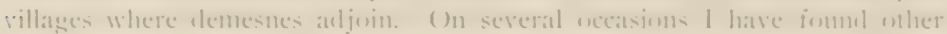

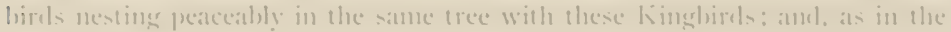

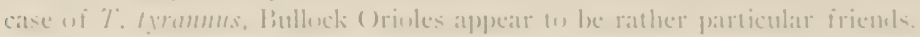

The nests shewn in the cut on precerling prage are the work wi one pair wi hirels. Embarratsed he a wealth uf string amb mable to decible which of

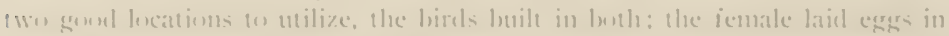

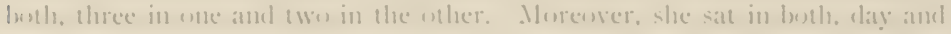
day albute a birel uf a clivicleel minel.

No. 144

\section{ASH-THROATED FLYCATCHER.}

\section{1. (1). (". Nin fift. Myiarchus cinerascens (I.awrence).}

Description.- Adults: Vhose dull grayish hrown changing to clear hros:a:

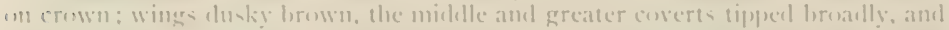

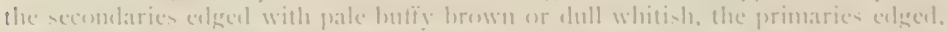
except suwarel tips, with cimmanom-rufous: atil clarker than hack, with paler

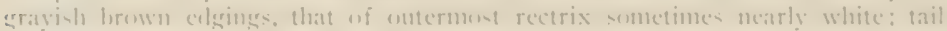

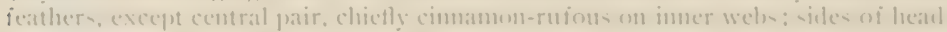
and necte gray (slightly tinged with brown facling inte much paler wray on chin. throat, and chest, changing to pale yellowish on breast amb remaining melerparte; yellow of moleparts strengthening pusteriorly, and axillars and moler wing-

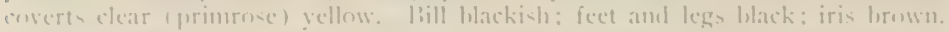

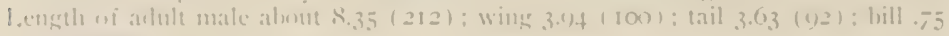
(II)): tarsin- (1)1 (23).

Recognition Marks.-Chewink size: lrownish grạy alowe: ashy throat viacling inte pale yellow of remaining melerparth.

Nesting.- lest: a natural cavity or eleserted lilicker hole, coppounly linesi

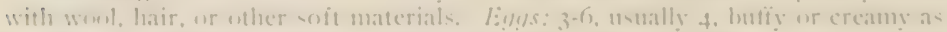

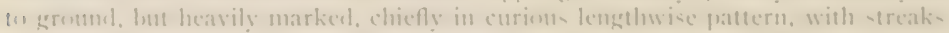

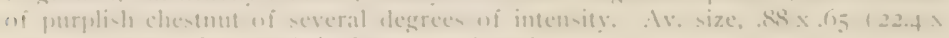

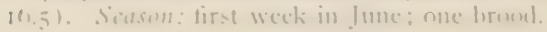


General Range-- llestern United States and northern Mexico, north irregularly to 17 ashington; south in winter thru Mexico to Guatemala.

Range in Washington.- lireeding near Jorth Yakina in summer of I003; one other record, Tacoma Mlay 24, 1905.

Authorities.-Snodgrass (R. E.), Auk, Vol. XXI, Apr. I904, p. 220. B. Specimens.--I'? C.

FI, YC Y'TCHIiS are somewhat given to wandering, or at least exploring. on their own acount, regarlless of traditions. A Gray Kingbird ('Tyrannus dominicensis), normally contined to the Gulf of Mexico, is of record for Cape Beate on laneoner lsland: and that dashing gallant, the Scissor-tailed Flycatcher, of Texas, has rentured as far north as Hudson Bay. The Ashthroated Flycatcher is trpically a bird of the sonth-western Linited States: lunt it is not altogether surprising that it should have extended its northern range into the Upper Sonoran belt of eastern Wrashington, as it dicl in the seasun of 1903 . When it was observed at North Yakima by Mr. [oowles, and, inclependenty, by Mr. Robert E. Snorlgrass, the latter collecting for Pullman College. Ilithout precedent or excuse, however, was the appearance of at handsome pair near Tacoma, as recorded hy Mr. Bowles, on the 24 th day of May, I905.

"The Ash-throated filvatcher is quite expert upon the wing but never molulges in protracted flight if it can help it. It seems to be rather guarrelsome and intolerant in its disposition toward other birds, and will not allow anv to nest in close proximity: in fact. I an inclined to believe that it mot infrequently dispossesses some of the smaller Woodpeckers of their nesting sites.

"Its fool consists mainly of beetles, lutterflies, grasshoppers, flies, moths, and necasionally of berries, especially those of a species of mistletoe.

"By the begiming of May most of the birds are mated, and nidification begins shortly afterwarl. The nests are ustrally placed in knot-holes of mesquite, asli, oak, sycamore, juniper, and cottomwood trees, as well as in cavities of old stumps, in Woodpeckers holes, and occasionally belnind loose pieces of hark, in the manner of the Creepers.

"'llhe Ash-throated libcatcher nests at varjous heights from the ground, rarely, however, at greater distances than twenty feet. The nest varies considerably in bulk accorling to the size of the cavity usecl. Where this is latge the buttom is filled up witl small weed-stems, rootlets, grass, and bits of diy cow-or horse-nanure, and on this fommlation the nest proper is luilt. This consists principally of a felted mass of hair and fur from different animals. and oceasionally of exurie of smakes and small lizarels: but these materials are not nearly as generally used as in the nests of nur ertstern ('rested [*ilycatcherit fact, it is the exception and not the rule to find such remains in their nests" (lienclire). 
No. 1.45 .

\section{SAY'S PEIYEE.}

1. (1. (5. No. 4.5\% Sayornis saya (limapr).

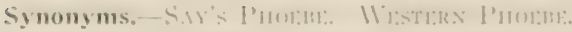

Description.- Idults: Cieneral color drals (grayisls brown to dark lairbrown , rlarker en pilem and auriculars, lighter on throat, shading thru upper

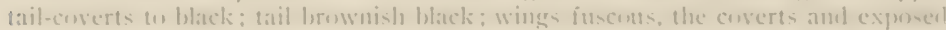

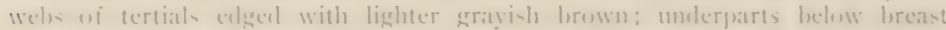

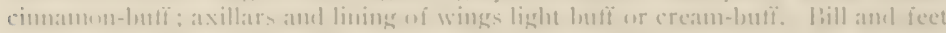
hlack: iri- lorewn. Jeneme birds are more extensively fulsens, and are marked ly two cinnamumem batnd on wings f formed by tips of midelle and greater

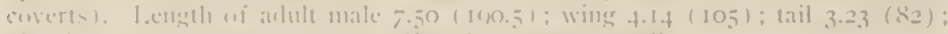

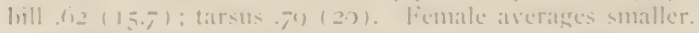

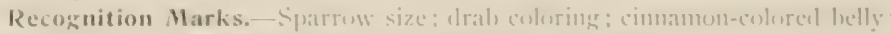
medanclubly motes; frepuents larme amel outhuildinge or clifis.

Vesting. - Vest: compuseal of dricel grasses, mons, plant-filers, woully matterials of all sorts, and hair: plated on lecleses, under eaves of enthuildings, under

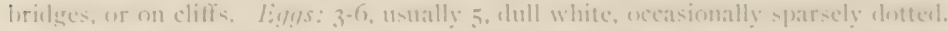

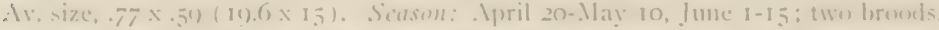

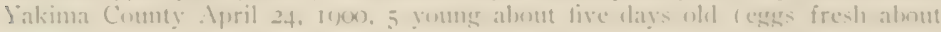
April zth).

(ieneral Range.-Western Xorth American north to the Aretic Circle in

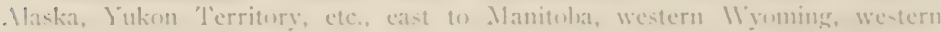
Kinn-is. ete., loreceling thruont range, south to Arizona and northern lower Califurnial somblawaril in winter over northern and central .lexico.

Range in Washington.-Common summer resident east wi the Cascade:

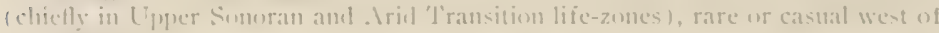
the monntains.

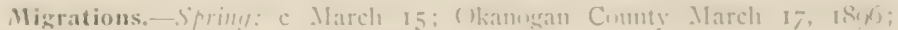

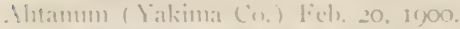

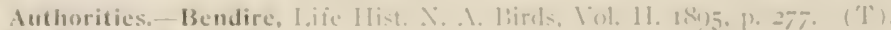
(1) W 1 .

Specimens.-l"t. I'row. (c.

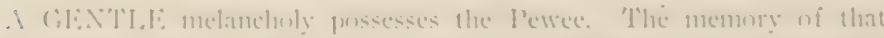

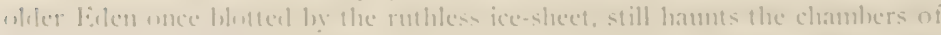

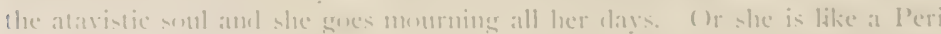

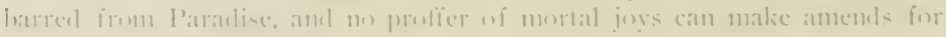

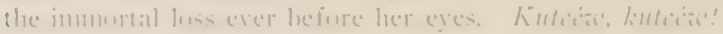

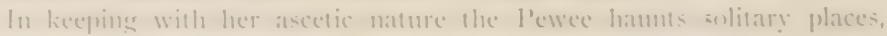

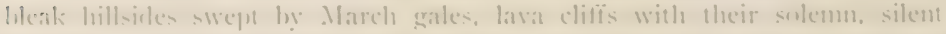

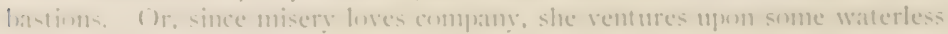


townsite and roices in mexpectant cadences the universal yearning for green things and cessation of wind.

A part of the drear impression made by this bird is occasioned by the time of year when it puts in an appearance, March at the latest, and, once at least, as early as Fiebruary 20 h (in Iakima County). Filies are an uncertain (rop at this season, and it is doubtless rather from a desire for shelter than from inclination to society, that the species has so largely of late years resorted to stables and outbuildings. 'T'wenty years ago Say's Pewee was unknown as a tenant of buildings in Yakima County. Now, there are few well-established farms in that part of the State which do not boast a pair somewhere about the premises: while hop-houses are recognized as provicling just that degree of isolation which the bircl really prefers.

Say's Pewee, for all its clepressed spirits, is an active bird, and makes frequent sallies at passing insects. These constitute its exclusive diet save in early spring when, under the spell of adverse weather, dried berries are sought. Butterfties and moths are favorite food, but grasshoppers and beetles are captured as well: and the bird, in common witl certain other theatchers, has the power of ejecting indigestible elyta and leg-sheathings in the form of pellets.

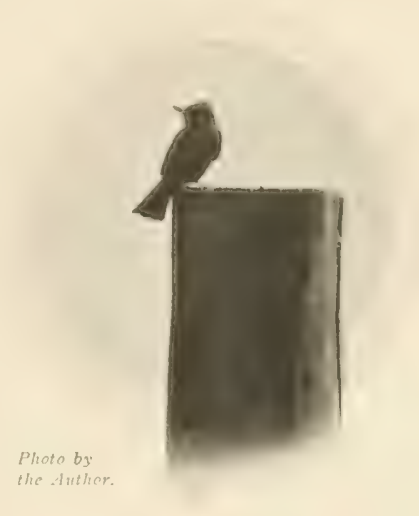

SAL"S PI:WEE.

The males arrive in spring some days in advance of the females. Conrtship is animated in spite of the melancholy proclivities of the bird: and the male achieves a sort of song by repeating ku-tea's rapidly, on fluttering wing: besicles this, in moments of excitement, both birds cry Look at 'or', with great distinctness.

liggs are laid by the roth of April and nsually at least wo brooxls are ratsed, in this latitule. In the natural state these Pewees nest about clifis. at moderate heiglits, and in shallow caves. In selecting a site, they show a decided preference for a clifi which enjoys the protection of nesting I'rairie lialcons. A stout bracket of twigs, weed-fibers, lichens, and nther soft sub stances, is constructed, and a luxurious lining of wool and hair is supplied: but the whole must be partially slielded by some projecting tooth or face of stone. or artificial construction.

The anthor in taking his first (ancl only) set of Say Pewee eggs selected a nest on the south wall of Brook Lake, reached only by canoe. 'The floor of an 


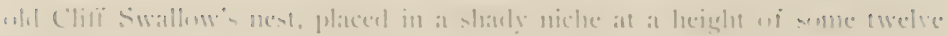

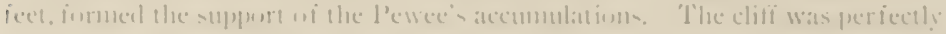

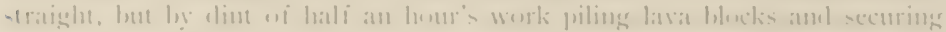

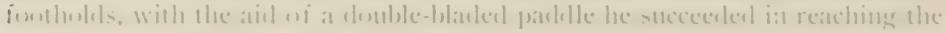

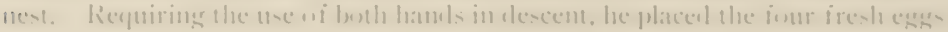
in his hatl, and the hat in his teeth, reaching the gromml sately and depusting

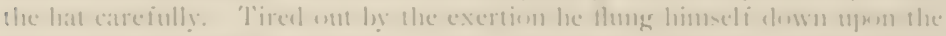

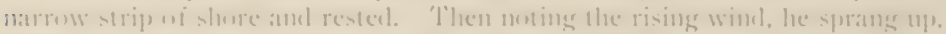

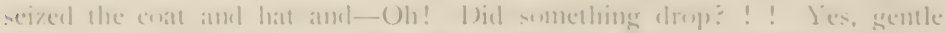

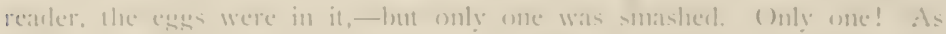

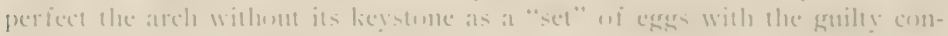

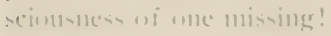

No. 1.10.

\section{()I,IVE-SIDEI) FIYCATCHER.}

1. (1) L. Xin, $45 \%$. Nuttaltornis borealis (Swatim.)

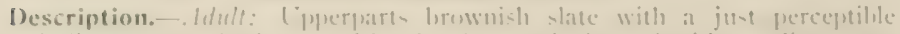

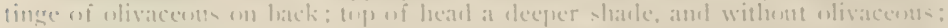

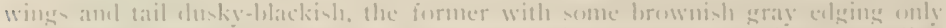

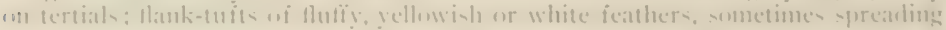

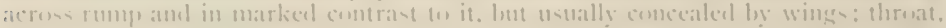

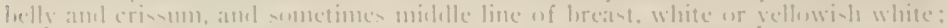

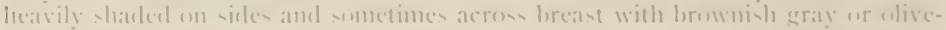

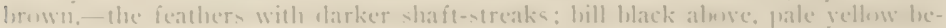

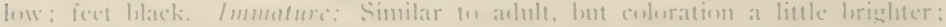

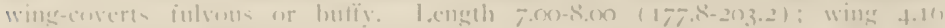

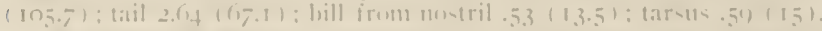

Recognition Marks.-Spartum to (hewink -ize: leaty - haterl -irle : bill

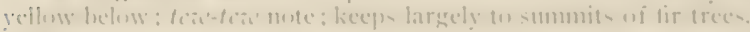

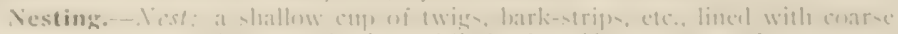

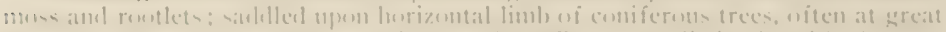

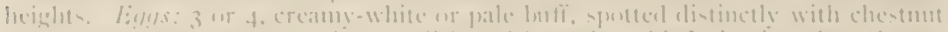

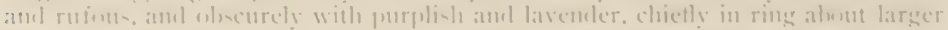
(mol. . Is -

(ieneral Range,- Vurth . Imerica, loreceling irom the mortleren ame the higher

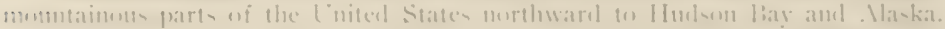

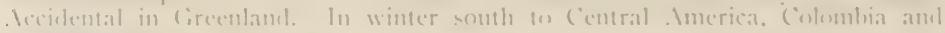
morluern l'ern.

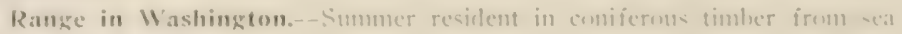
lewel to limit ui trees.

Migrations,--Sprimel: $<$. May 15.

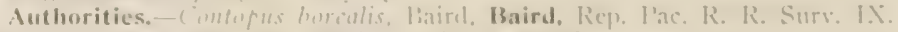

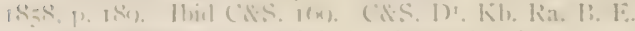

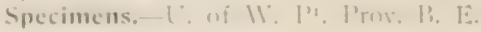


FLICA'TCCHLRS belong to the sub-order Clamatores, that is to say, Shouters. Some few of our American Filycatchers lisp and sigh rather than cry aloud, but of those which shout the Olire-sicled lifycatcher is easily dean. And it is as an elocutionist only that most of ns know this bird, even tho nur opportunities may have stretcled along for decades. On a morning in micl May, as surely as the season comes aromel, one hears a strong insistent voice slronting. "Sec here!" There is not much to see, save

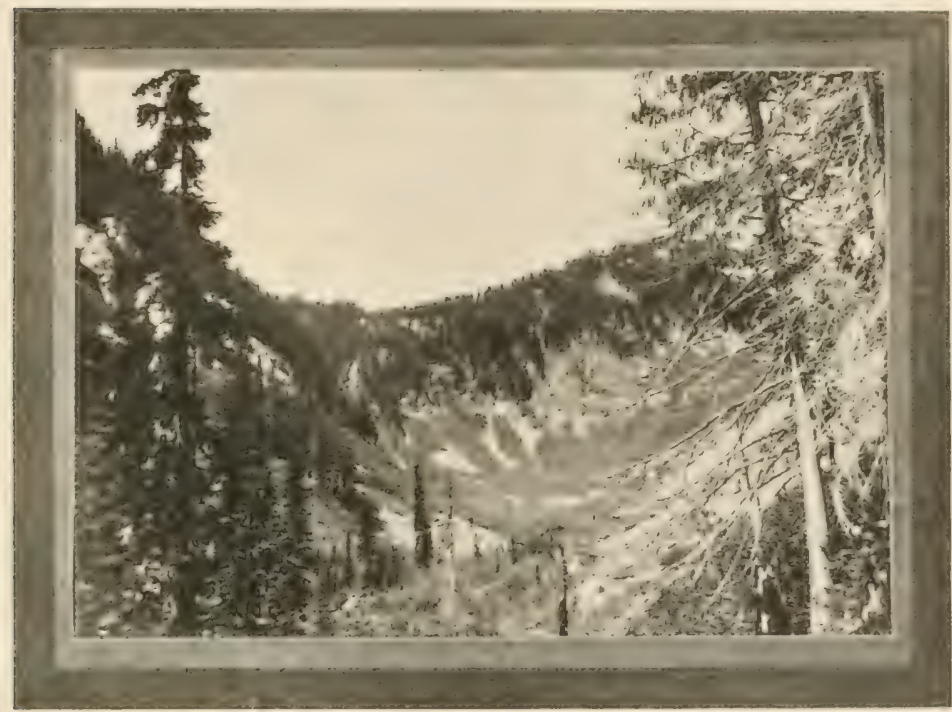

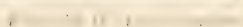

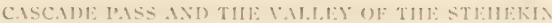

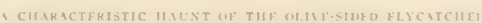

a dum-colored birel seated at an impossible lieiglu on the summit of a tall fir tree. Its pusture is that easy hali-slonch which with the lilycatchers hetohens instant readiness for action. While we are ogling. the birl launches from his post, seizes an insect sonne thirty feet distant, and is lack again hefore we have recosered from surprise. "See here!" the bird repeats, bul its accent is melanged and there is really mothing more to sec.

In intmate acquaintance with the Olive-sirled Filveatcher is not easily attainerl: but its claracteristic cry carries to a distance of half a mile or 


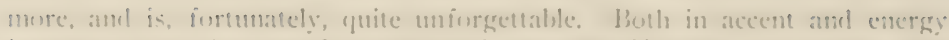
it secms to set the pate for several of the lesser 'Tyrants. Oi course, like many annther wi the voices of Sature, its interpretation depends a grmel deal tum the moxi of the listener. Heard on a dull day at seatevel it may somel dismal enough, hut hearel in the slarp air of the momntans it becontes an exultant note. 'lhere are miners in the heart of the Cascarles who regard the brisk evening greeting of this filyenteher as one of the

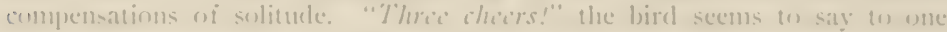
whon returns from the silemt howels of the earth and grasps agrain the fancts wi oner life.

lioralis is a birel of the tree-tups and nearer you cammut come, sive in enesting seatsun, when caution is thrown to the winds ancl at sturly in

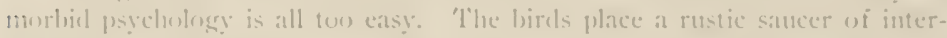
weren black romelets and mosses on the appere sicle of a horizontal branch. whether wi lectuleck, fir, or eetat, and, as oflen as otherwise, at mulerate leverhts. 'l'hey are very unealsy at the presence of strangers and thit almut

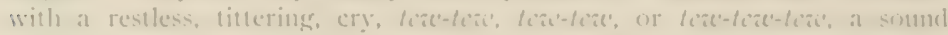
which strangely excites the blend of the soibgrist. Once the nesting tree is make ont and the ascent leegun, the hirds are besiele themselves with rage, amb dash at the intruler with angry eries, which really stimulate emeleater where they are inteneled on disconrage it.

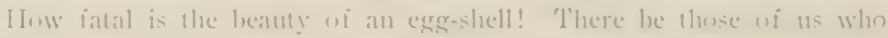
have atrunk so wit wi this suble potion that the hamel gocs ont instinctively

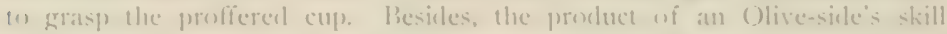
is af a very special kind-a rich cream-costeresl wat, wamed hy a hint of living flesh and spleteleel with sancy chestnut. It is irresistible! lint. luys, don't do it! We are old topers nurselves: public sentiment is agramet 11s, and ond diss are numbered. It is right that it slosuld be ses. liesides that, and spealing in all serinusuess now, while it is desirable and necessary flat a few representative collections of matural history should le built

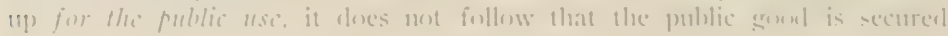

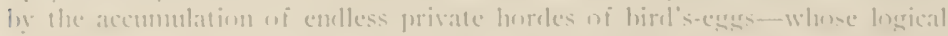

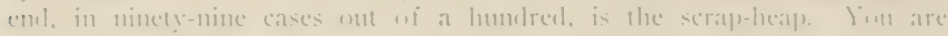

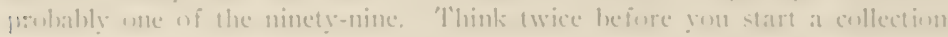
and then-ilonit! 
No. $14 \%$.

\section{IVESTERN IVOOD PEWEE.}

A. O. U. No. 462 . Myiochanes richardsonii (Swains.).

Synonyms.-SHORT-L, licilin PFWEE. RICHARDSON'S P'EWEE.

Description.-Adults: - thove deep grayish brown or grayish olive-brown: a lighter slade of same continued around sides and across breast, lightening on chin and throat, on remaining underparts becoming white or yellowish white; miclde and greater coverts tipped with grayish ; outer webs of tertials edged with grayish white. Bill black above, dlusky (never light) below. Young birds have the midllle and greater coverts tipperl with buffy (forming two not inconspicuous hars), and some buffy edging on rump and upper tail-coverts. This species bears a curionsly close resemblance to $M$. itrens of the East, insomuch that it is not always possible to separate specimens in the cabinent; yet the two are perfectly distinct in note and habit and are not suspected of intergradation. Length of adult males 6.00-6.50 (152.4-I65.I) ; wing $3.43(87)$; tail 2.60 (66) : bill .5I (13): tarsus .53 (I3.4). Females a little smaller.

Recognition Marks.-Sparrow size; (lark coloration (appearing blackish). - but much darker and a little larger than any of the Limpidonaces. Ifeeneer note of animated melancholy clistinctive.

Nesting.-Nest: a shallow cup of compacted moss, grasses, rootlets, etc, lined with fine grasses and wool or hair, and decorated externally, or not, witls lichens: saddled midway or in fork of horizontal limb, chiefly at moderate heights. Iigys: usually 3, sometines t, creamy white, marked by largish spots of distinct and obscure rufous brown or tmber, chiefly in open wreath about larger

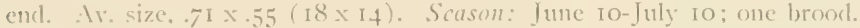

General Range.-Ilestern North America; breeding north to Alaska and Dorthwest l'erritory, east to Ilanitola and western portion of (ireat l'hains to 'I'exas, south to northern Mexico: south in winter over Mexien and Central America to Ėquador. P'eru, and Bolivia.

Range in Washington.-Common stmmer resident and migrant east of the Cascarles, chiefy in coniferous forests. occasionally in open sage; less common west of the mointains.

Migrations. - Spring: c. May is; 'T'acoma May 5, I907: Yakina May if. 1805. May 15, 1900; Newport May 20, I006: Conconnully May 27. I896. Fall: c. Sept. I.

Authorities.- "Western IVood ['ewee," Johnson, Rep. Gov. IV. 'T'. IS84 (I8S5), 22.] ?.Muscicapa richardsonii. Aud. Onn. Biog. I. I839, pl. 434. [Contopus richardsonii, IBairl, Rep. Fac. R. R. SurT. IX. I858, 189, I90. "Columbia River O. 'T. I. K. 'Townsend."'] Contopus richardsonii(?) Belding, I. B. I'.

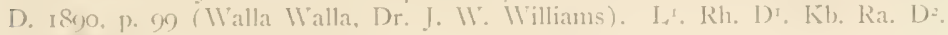
I I: I:

Specimens.-U. of $\mathrm{IV}$. Pr. Prov. IB. E. 


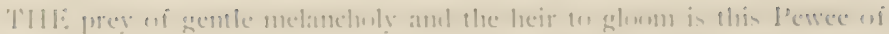

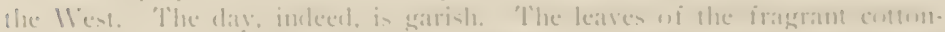

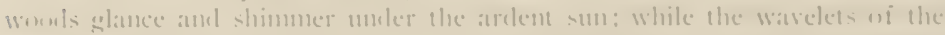

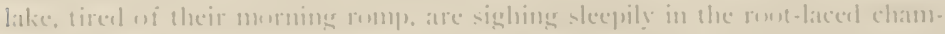

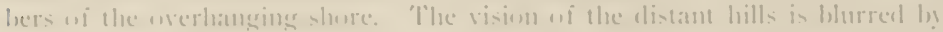

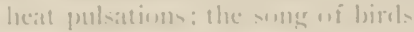
lats ceaseel atsul the very cathlisflice are takinger reinge irom the

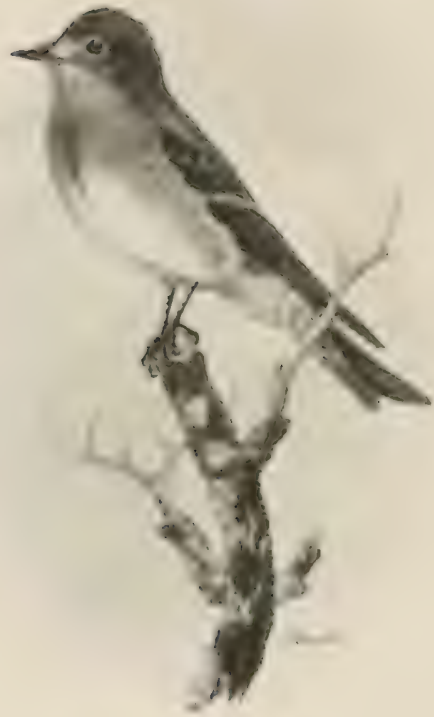

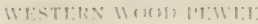
glare. 'T'tse sum is demomant amel all ditture yiedels drums allegri. ance to his swat: . III hut l'ewee. He avoirls the - - inn. inelecel. lont frum a sheftereal perch he lifts : visue of protest. "/) iar . Me $\because "$

it secems amealled-ior. 'l’he bird does not alpear to be min-

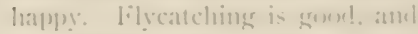
the l'eswee cuets his head ruite cheerfully as lae returas (1) his ferch affer a stecessiul ioray lint, trace to some hidelen impulse. as you gaze 1 gem him, he swells with approschine effort, his matldibles part. and be wters that deleful, apprinteal sommel. dear me. His mflematere has all the precision anel tumality of an as signerl part in an mreluestra. It is as if we were watching it single plaver in a symplum of . Cature whose other strams were lews sub. lle for on cars. The player secms inatfentive to the music, he

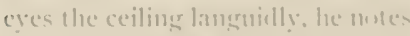

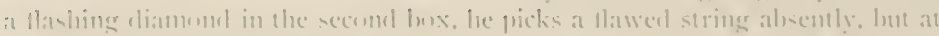

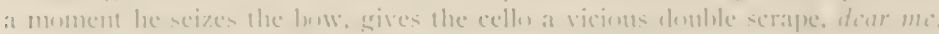

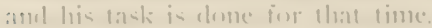

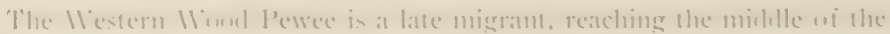

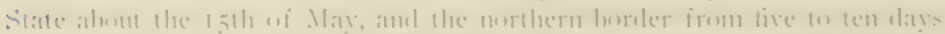

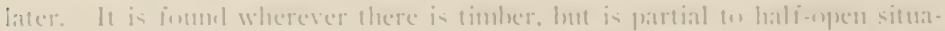

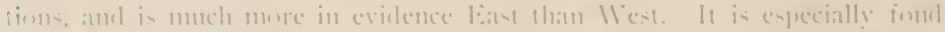

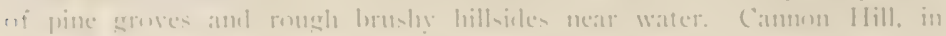


Spokane, is a typical resort and a mere tyro can see three or four nests there on a June dlay:

The Pewee takes the public quite into her conficlence in nest building: Not only does she build in the open. without a vestige of leafy cover, but when she is fully freighted with nesting naterial, she flies straight to the nest and proceeds to arrange it with perfect nonchalance. If a nest with egres is cliscovered in the bird's absence, she is guite likely to return and settle to her eggs withont a troubled thouglit.

The nest is a molerately (leep, well-made cup of lremp, fine bark-strip)s, grasses, and similar soft stibstances; and it is ustrally sacldled upon a horizontal limb of pine, larch, maple, alkler, oak, aspen, cottonwood, etc. But, occasionally, the nest is set in an upright crotch of a willow or some deal sapling. Nests having such support are naturally deeper than saddled nests. but the characteristic feature of both sorts is the choice of a site, quite removed from the protection of leaves. The grayish tone of the bark in the lost tree is always accurately matched in the choice of nesting materials and, if the result can be secured in no other way, the exterior of the nest is elaborately dratped with cobvelos.

All eggs appear beatufift to the seasoned oölogist, but few surpass in lainty elegance the three creany ovals of the Pewee, with their spotting of guaint old browns and subdued lavenders. They are gentume antigues, and the commoissem must patse on enjoy them even tho he homors the prior rights of Mr. ankl Mrs. M. Richardsonii.

\section{No. 148 .}

\section{IVESTERN FLYCATCHER.}

\section{O. U. No. ff4. Empidonax difticilis liaird.}

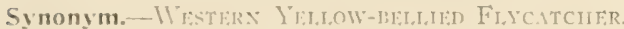

Description.-. Idults: Nhove aticl on sides of breast olive or olive-creen: a lighter shade of same color continued across breast : remaining underparts vellow (between sulphur and primrose), sordid on throat and silles, clearest on abxlomen : bend of wing sulplutr-yellow; a faint yellowish eye-ring; axillaries and lining of wings paler yellow: midelle coverts and tips of greater coverts, connintot1s with elging of exposed seconclaries, vellowish gray, forming two more or less comspicunous wing-bars. bill brownish black above. vellow lolow: feet anel legs brownish dusky: iris brown. Jomng birds are browner above and paler below: wing-bar cinnamon-buffy, (and not certainly clistinguishable in color from young of li. traillii). I enerth $5.50-6.00(1.39 .7-152.4)$ : wing $2.64(6,5)$ : tail 2.24 $(57)$ : bill .47 (12): tarsus . 37 ( 17 ) .

Recognition Marks.-Warbler size: characterized ly pervaling yellownes: 


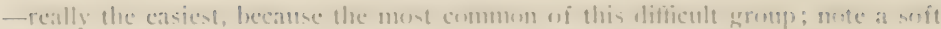

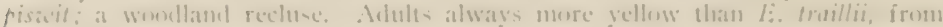

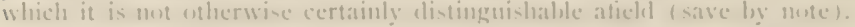

Nesting.-. Vist: placed anywhere in forest or alunt shated clifils, chiefly an

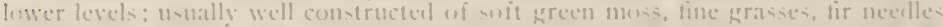
and hemp. latys: 3 or 4 d lull creamy white, sparingly spotted and dotted or

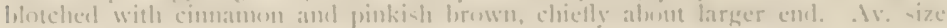

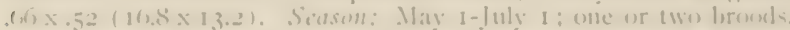

(jeneral Range- - Ilecetern North Americal from the easterm hate of the

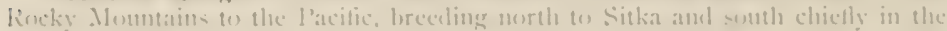

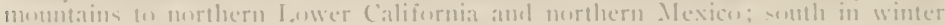
intor Xlexicos.

Range in Washington.-Common smmuner resident in timberesl sections throment the siate.

Migrations.-Sprime: Seattle-Jácuma, April 15. Fall: c. Segte. 1.

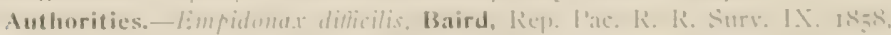

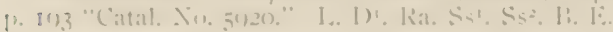

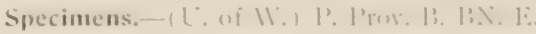

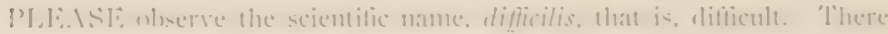
is a delicate irome aloout the use of this term ats a distimetive appellation fur

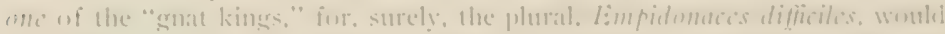

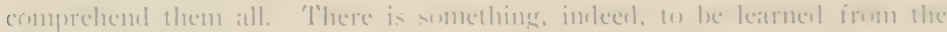

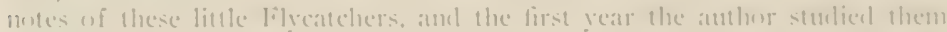

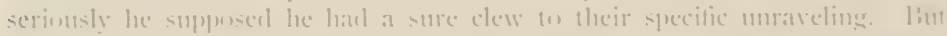

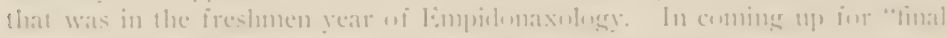

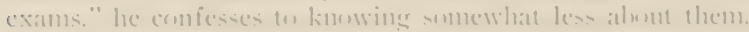

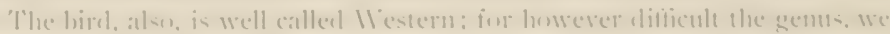

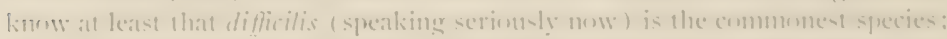

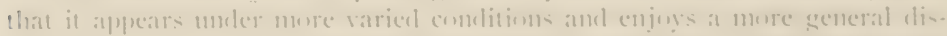

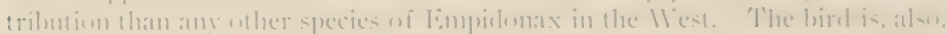

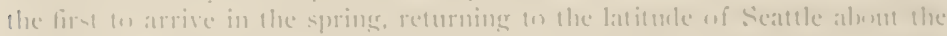

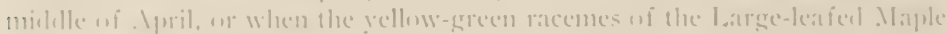

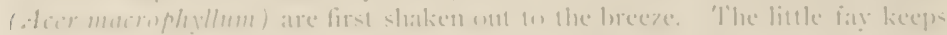

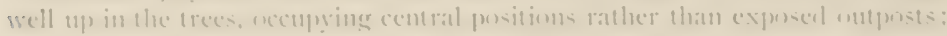
and so perfectly do his colors bleme in with the eneler hues of the new inliage that we leat him twents times in once we see him.

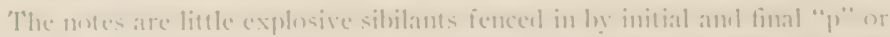

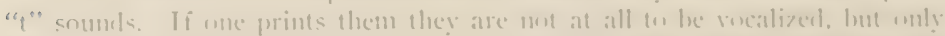

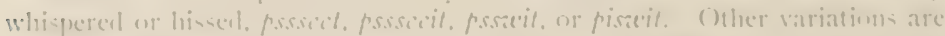

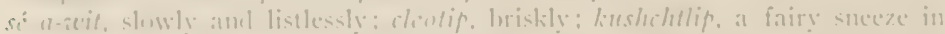

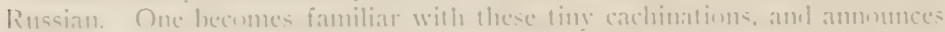
the IVestern Filyeatcher moseen with some tegree of confielence. Ihut the way is beset with dangers and surprises. ()uee, in June, at at pont on I atke (Chelan. 
after an hour's discriminating study, I shot from practically the sante stand, three birds which said sicht, piscit, and pisoo respectively, and picked up a Wright's Flycatcher (E. arightii), a Western Flycatcher (E. difficilis) and a Trail Flycatcher (E.traillii). The same woods contained Hammond's F'lycatcher (E. hammondi), while the IVestern Wrood Pewee (Myochun's richurdsonii), which has the same general economy, was abundant also. Difficilis? I:tiam!

The Western Flycatcher inhabits the deepest woods and occurs thruout the State wherever sufficient shade is offered. It is rather partial to wellwatered valleys, and will follow these well up into the mountains, but does not occur on the mountain-sicles proper at any consiclerable altitude. Nor (loes it appear to visit, save during migrations, those green oases in the dry comntry which are the delight of E. traillii. It mingles with traillii in summer along the banks of streams and at the edges of swamps: with hammondi in the more open woods and along the lower hillsicles: with arrightii along the margin of mountain lakes and streans: but in the forests moper it is easily dominant

The Western Flycatcher is a catholic nester. It builds almost always a substantial cup of twigs, grasses, and hemp, lined witl grass, hair or feathers. The outside is usually plentifully hedecked with moss, or else the whole structure is cliefly composed of this substance-not, however, umless the color-tone of the immerliate surromelings will permit of it. In position it varies without limit. Te fund nests sunk like a Solitaire's in a mossy bank, or set in a niche of a rocky cliff, on logs, stumus, or leams, in a clump of ferms, or securely Ioriged in a fir tree at a height of forty feet. One 1 foumd in a swamp was sadclled on the stem of a slanting vine maple without a vestige of cover other than that afforeded by the general gloont.

Eiggs to the number of three or four. rarely five, are deposited late in May or early

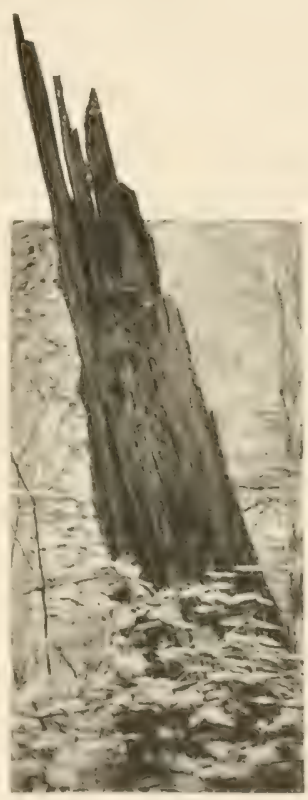

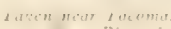
Phote by I. Y XEST OF WRSTIR.

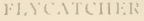

in June, and only one brond is raised in a season. 'Jle eggs are of a dull creamy white color, spotted and blotched rather lightly with cimnamon brown and pinkish buff, easily distinguishable from all others save those of the 'Traill Flycatcher. 


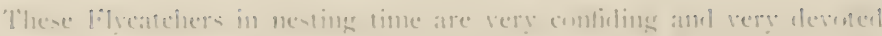

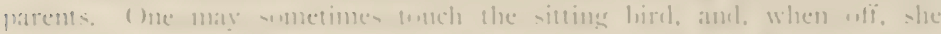

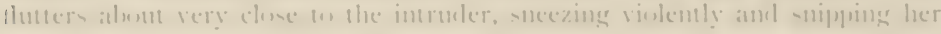

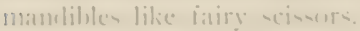

No. 1.19.

\section{TRAILL'S FITCATCHLR.}

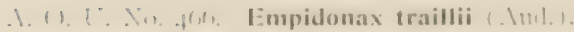

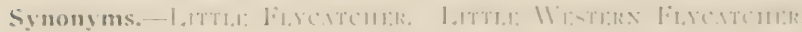

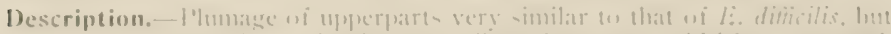

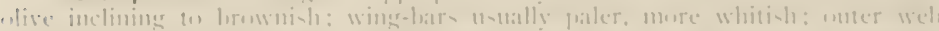

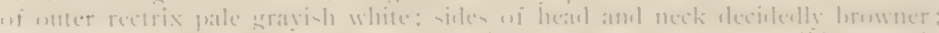

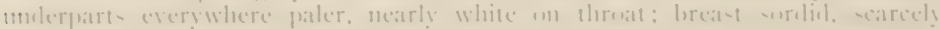

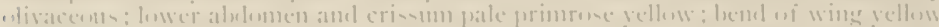

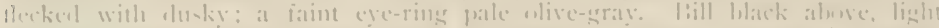

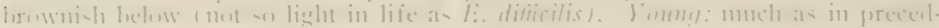

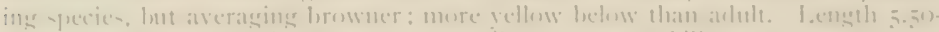

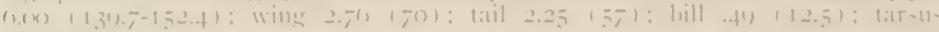
$1,5(11,5)$

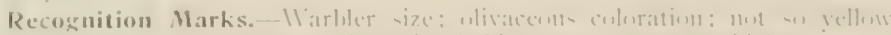

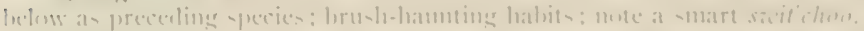

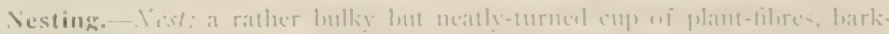

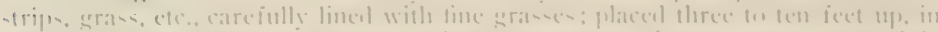

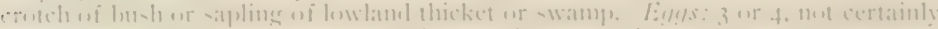

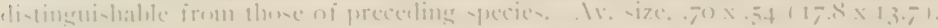
Siosint: Jume: ane loremel.

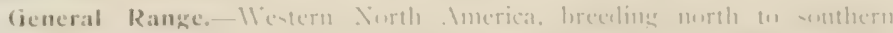

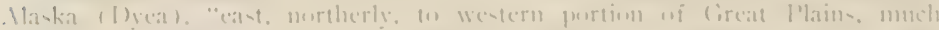

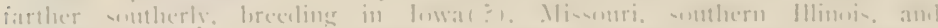

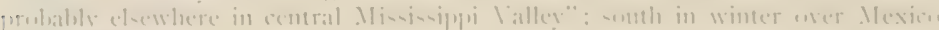
16) (inlumbiat, cto

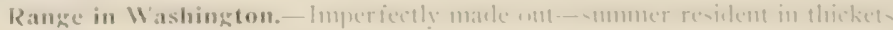

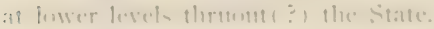

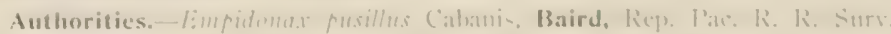
1.8. 1

specimens. $-11^{\circ}$, ni 11 ., I'ron: It. 1:

1)

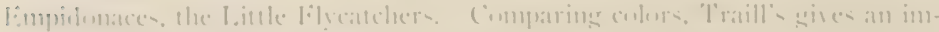

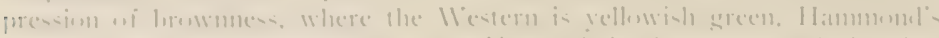

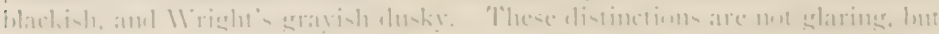


Whey obtain roughly alield, in a gromp where every thating mote of clifierence is gladly welcomed. The 'Tatill lilycatcher, moreoser, is at lover of the halfopen simations, bushy rather than timbered, of clearings, low thickets, and river banks. Lnlike its congeners, it will follow a stream ont 11 ) m a desert; and a spring, which glatelens a few hundred yards of willows and crategi in some nook of the bunch-gratss hills, is sure 10 number anong its smmmer hoarders at least one pair of 'Taill f'lycatchers. 'T'his partiality for watercourses does not, however, prevent its frequenting dry hillsides in western IVashington and the borclers of momntain meaclows in the Cascades.

Traill's Filseatcher is a tarly migrant, for it arrives not earlier than the zoth of May, and frepuently not before June ist. In 1899 , the bird dicl not appear at Ditanmm, in Yakima Comnty, until the I fth of June: and it became common immediately thereafter. 'l'his bird is restless, energetic, and pugnacions to a fanlt. It posts on conspicuous places, the onpmost twig of a syringa bush, a willow, on an aspen, making freftent ontcries, if the moxd is on, and clarting nimbly after passing insects. During the nesting scason it pounces on passing bircls of whatever size and drives them ont of bonnds. It is not always so hardy in the presence of man, and if pressed too closely will whisk out of sight for good and all.

The notes of the Little Flycatcher, as it used to be called, are rarious and not always distinctive. Particulary, there is one style which cannot be distinguisherl from the commonest note of the Hanmond Flycatcher, satithoo.

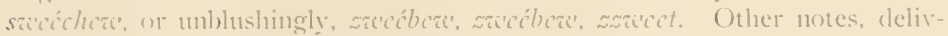
ereel sometimes singly and sometimes in groups, are pisos; saitoo, satect.

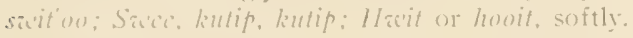

Jesting begins late in Junc and fresh eggs may be expected about the fth of July. Jests are placed claracteristically in upright forks of willows. akler-berry buslues, roses, etc. 'They are usually compact and atristic structures of clried smasses, hemp) (the inner bark of dead willows and plantdown, lined with fine grases, horse-latir, feathers and other soft substances. Aist inferpuently the nests are placed over water; and low elevations of. say. two of three feet form the gromel appent in prevail westerly. I Yakima (onnty nest, taken July roth, containing two eggs. was hali saddled upon. balf smo into the twigs of a horizontal willow branch one and a half feet aldeve rumning water, and had to be reaclued by wading.

Incubation lasts twelve days, and the babies repuire as much more time

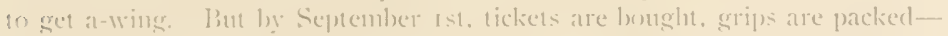

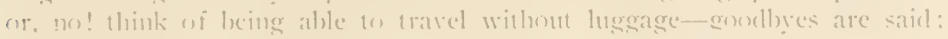
and it's "Ileighlue! for Mexion!" 
o. 150.

\section{HAMMONIS' FLYCATCHER.}

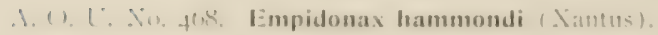

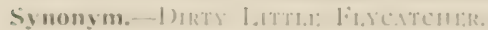

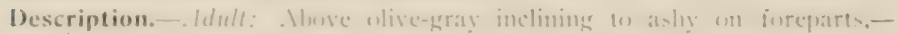

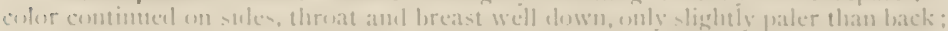

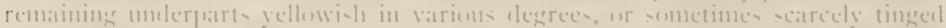

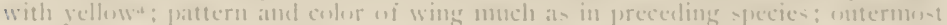
rectrix celged with whitish un onter wels; hill comparatedy small ambl marrow,

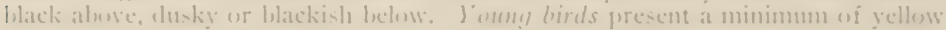
heluw and their wing-markings are lndïy in-teal of whiti-h. 1.ength almut 5.50

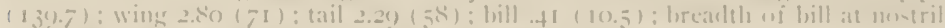

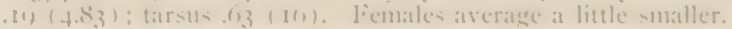

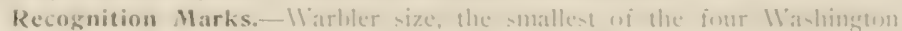

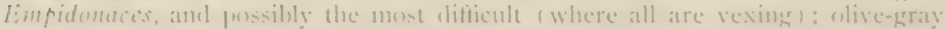

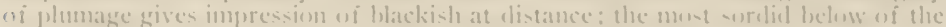

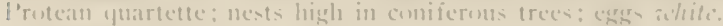

Nesting.- list: of lir-twigs, gratsecs and mums, lined with fine granes,

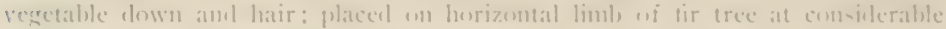

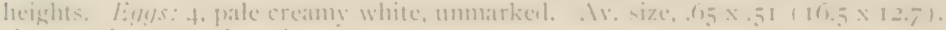
Sictson: lune: anc loruml.

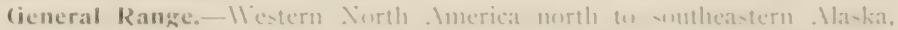

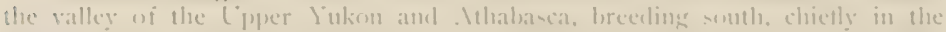

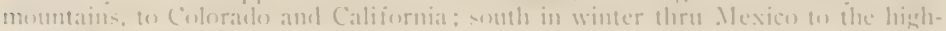
lanck uf (inatemala.

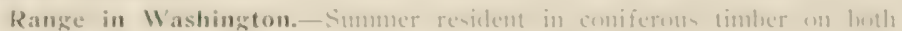
-ides of the cancaules, irsegularly ahumbant and lecal in distribution.

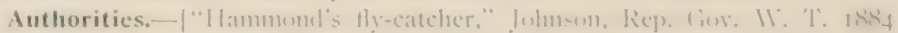

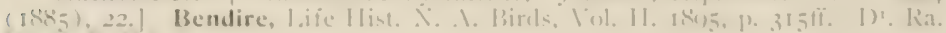
(1) I inili

\section{Specimens:-C:}

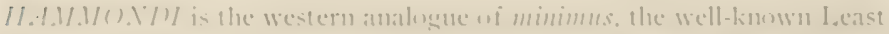

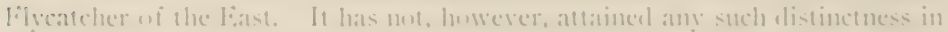

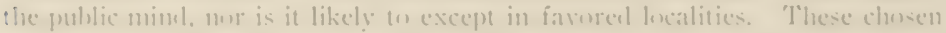

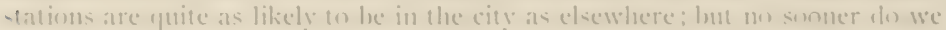

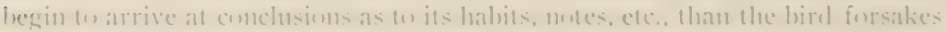

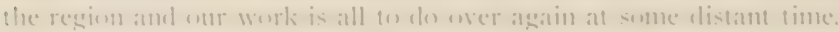

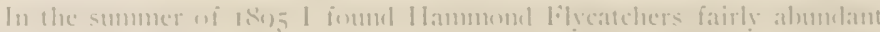
un captesl Ilill (which was then in its pin-feather stage). 'Twenty or thirty

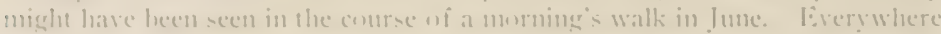

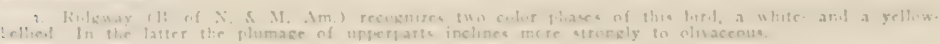


were to be hearcl brisk Servick's in the precise fashion of eastern minimus; and at rarer intervals a more intense but still harsh and unresonant Savé-chece'. These observations were confirmed by the taking of several specinens; but elsewhere and in other seasons I have found the bird most unaccomntably silent, and lave been able to add little to its repertory of speech.

In the summer of 1906 we found these Flycatchers preparing nests on Camon Hill in Spokane. In both instances the bircls were building out in the open after the fashion of the Western Wood Pewee ( M liochanes richardsonii): one on the bare limb of a horse-chestnut tree some ten feet from the ground: the other upon an exposed elbow of a picturespue horizontal limb of a pine tree at a height of some sixty feet. Near Nervort, in Stevens County, we located a nearly completed nest of this species on the zoth of May, and retumed on the Ist of June to complete accounts. The nest was placed seven feet from the trunk of a tall fir tree, and at a height of forty feet. The bird was sitting, and when frightened dived heallong into the nearest thicket, where slue skulked silently cluring our entire stav. The nest proved to be a delicate creation of the finest vegetable matcrials, weathered leaves, fibers, grasses, etc., carefully inwrought, and a considerable quantity of the orangecolored bracts of young fir trees. The lining was of hair, fine grass, bracts, and a single feather. In position the nest might well have been that of a IVood Pewee; but, altho it was (leeply cupped, it was much broader, and so relatively flatter. The fontr fresh eggs which it contaned were of a delicate cream-color, changing to pure white upon blowing.

The Hammond Flycatcher was also found to be a conmon breeder in the vallev of the Steliekin, where Mr. I3owles lats taken several sets in very similar situations, viz., upon horizontal branches of fir trees at consiclerable heights.

\section{No. $15 \mathrm{I}$.}

\section{WVIGHT'S FLYCATCHER.}

A. (). L. No. 460 . Empidonax wrightii baircl.

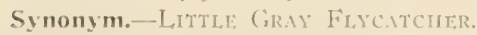

Description.-Adult (yray phase): Above dull bluish gray or faintly olivaceous on back and sides; throat and breast pale gray to whitish with admixture of ill-concealed clusky; remaining parts, posteriorly, faintly tinged with pale primrose; a whitish eye-ring; wing-markings, of the same pattern as in other species, or more extensive on secondaries and onter webs of tertials, delinitely white; outer web of ontermost rectrix pale whitish. Adult (yclloni-bellicet phase): As in graty phase, but underparts strongly tinged with yellow and upperparts faintly tingerl with olive-green; wing-markings less purely white. IBill blackish above, 


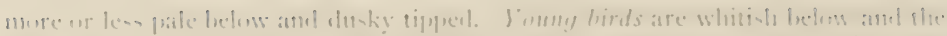

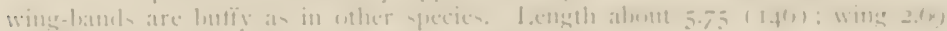
1f

Recognition Marks. - Ilarliler ize: prevalinge krat coloration: whiti-le eyering: execentively retirimer lablits.

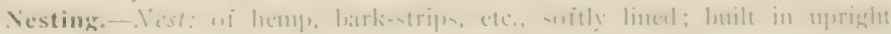

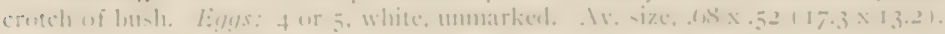

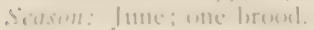

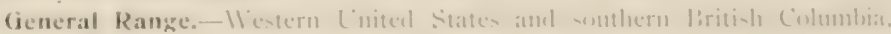

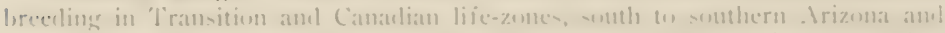

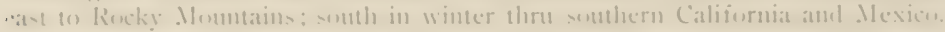

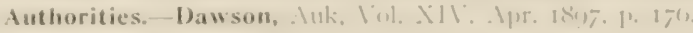

Specimens.-1'rux. (C)

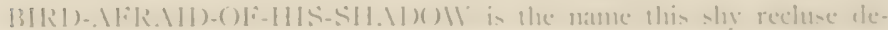

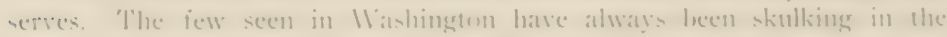

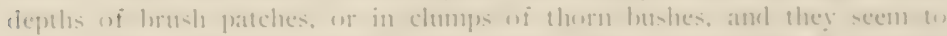

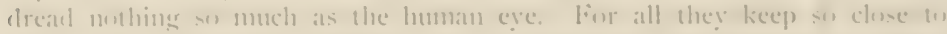

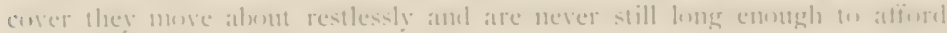
ans satisfaction to the behokler.

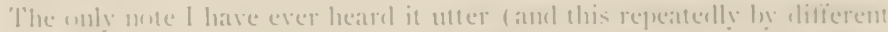

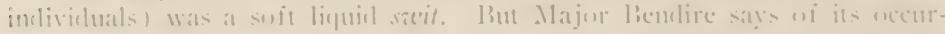

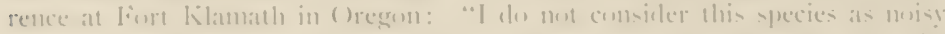

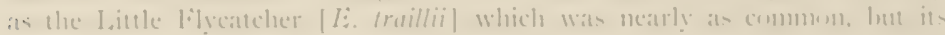

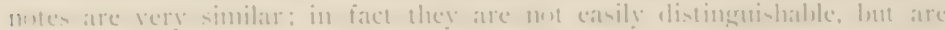

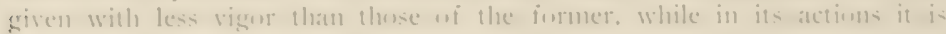

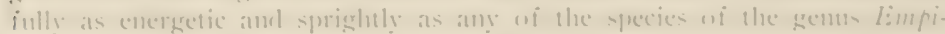

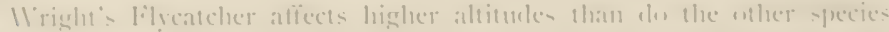

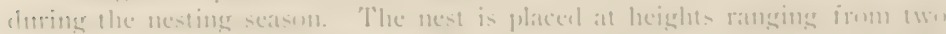

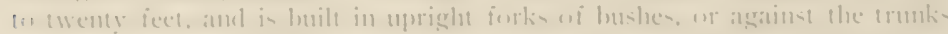

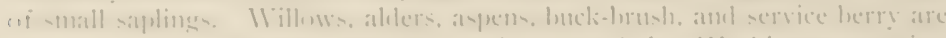

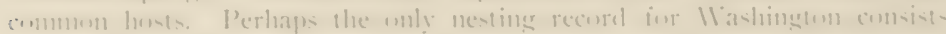

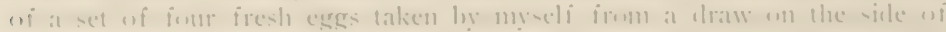

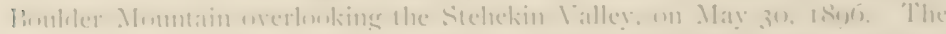

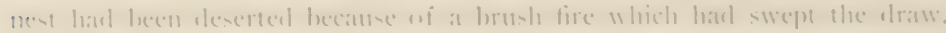

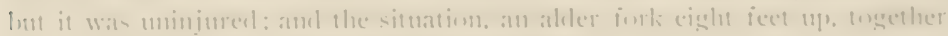

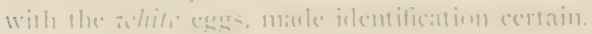


No. 152.

\section{BLACK-CHINNED HUMMINGBIRD.}

A. O. L. No. 429. Trochilus alexandri liourc. \& Muls.

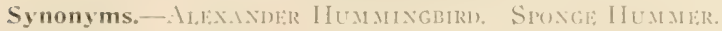

Description.- - Idult male: Upperparts including miclelle pair of tail-featlers: shining bronzy green; wing-quills and remaining rectrices fuscotts with purplish reflections; tail ilouble-rounded, its feathers broadly acuminate, and central pair of feathers about .12 shorter than the thircl pair, the ontermost pair shorter than micldle pair: the gorget chiefly oparue velvety black, on each side of the median line a small irregular patch of metallic orange, or else with various jewelled iridescence posteriorly; remaining underparts white, heavily tinged with greenish on sicles, elsewhere lightly tinged with dusky and dull rufous; bill slender, straight. Idult female: Similar to male in coloration but without gorget, a few dusky specks instead; tail different, single-rounded, central feathers like back in coloration, and scarcely shorter than succeeding pairs, remaining feathers with broad stubterminal space of purplish black, and tipped with white, lateral feathers: scarcely acuminate, the outermost barely emarginate on inner web. Length of aclult male: about $3.50(88.9)$; wing $1.75(4.5)$ : tail 1.25 (3I.8) : bill .75 (19.1). Female, length about +.00 ( Ior.6): wing $1.95(+9.5)$.

Recognition Marks.-I'ygmy size; black gorget of male clistinctive: female larger than in Stcllula calliope, with which alone it is likely to come into comparison.

Nesting.-. Iest: Of plant down secured by cobwehs. saddled upon small descending branch at moxlerate height, or lashed to twigs of small fork. Eiggs: 2 or, rarely, 3. pure white, elliptical oval in shape. Av. size. .50 $x .33$ ( $12.7 \times 8.3$ ). Scason: May or I tune according to altitude; onc brood.

General Range. - Ilestern L"nited States, except the northern Pacific coast clistrict, north in the interior into liritish Columbia, loreeling sonth to northern Lower California and east to the Kocky Mountains: sont? in winter into . Nexico. only:

Range in Washington.-. - Not conmon summer resident east of the Cascate-

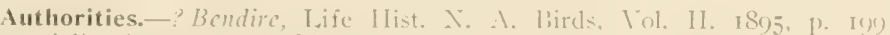
(inferential). Dawson, Auk, Vol. XIT. Apr. 18)7. 1) 175. Sr. S:2. I.

Specimens.-(Li. of II.) P. C.

'IIOOSE of us, who as children were taught to call lady-bugs "lacly-lireds," might have been pardoned some uncertainty as to the whereabouts of the dividing line between insects and birds, especially if, to the vision of the "IInnbird's" wings shimmering by day above the flower berl. was atded the twilight visits of the hawk-1moths not a whit smaller. 'The Hummer is painted like a butterfly; its flight is direct and buzzing like a lece's; it secks its foorl at the flower's brim by poising on rapidly vibrating wing like the hawk-moth: but there the resemblances cease. For the rest it is a birl, migrating, mating. and nesting quite like grown folks. 


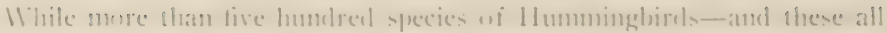

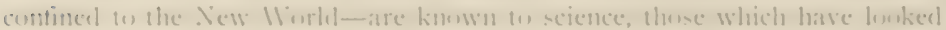
merthwarl at all hase shown a deciled preference for the l'acific Cinast. 'Thus.

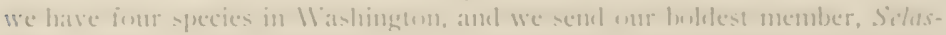

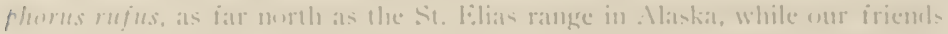

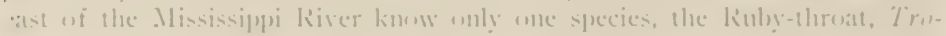

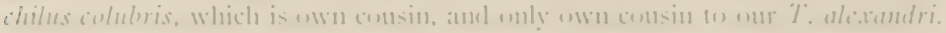

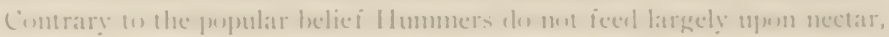

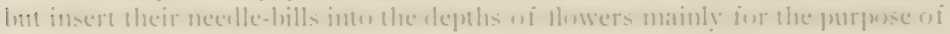

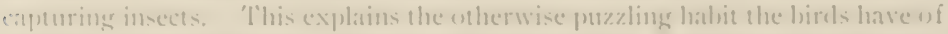
revisiting the same fluwer leels at frequent intervals. It is mot th grather new-

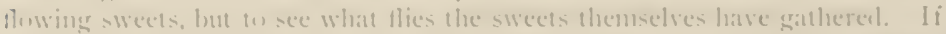

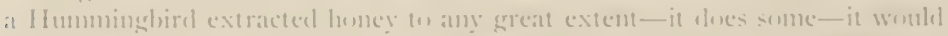

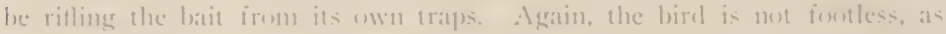

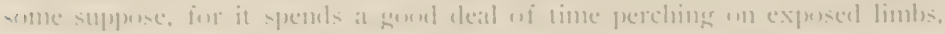
from which it may dart. lifeatelee fashion, after passing insects.

Vur is the hirel quite smagless. It lat Clatre's, on the banks wi the

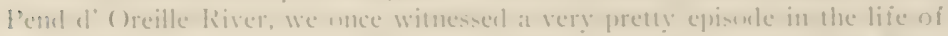

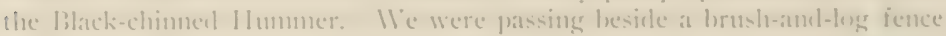
in a clearing, when we moticent the locking somg-flight of a male black-chin

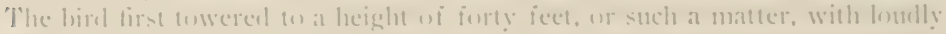

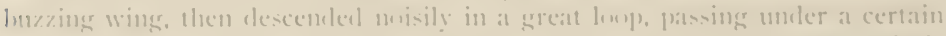

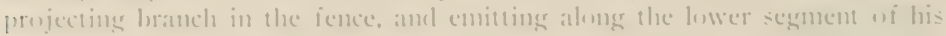

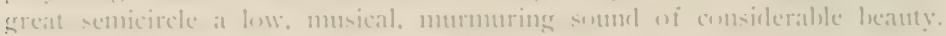

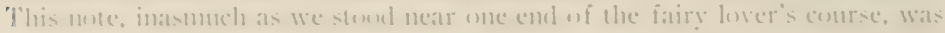

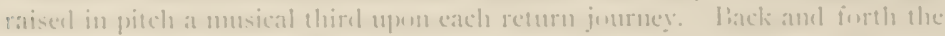

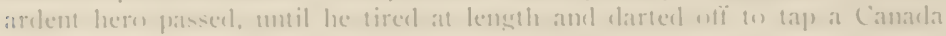
lily for monishment, or the pretense wi it. Then he perelecel on a twig at ien feet amel sulmitted to a must axhmiring inspections.

The Hummer's back, well up on the neck, was of a dull green shate. the

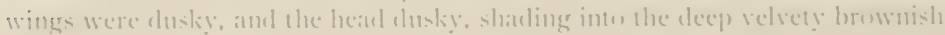

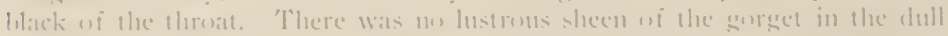
light, Int on each sisle of the median line of the throat lay an irregular pated

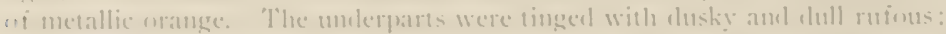

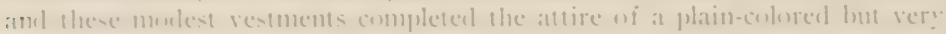
d:aints birel.

ipen the paseimate resmuption ai his conting dance we orelered an

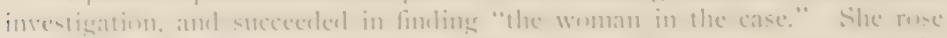

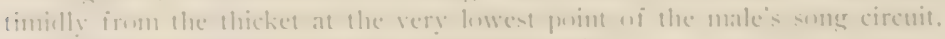

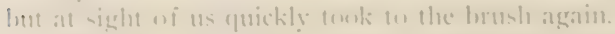

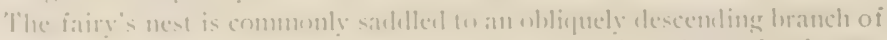

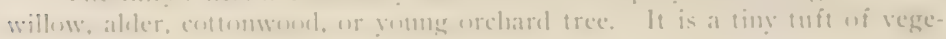


table down, bound together and lashed to its support by a wealth of spiderwebbing. Linlike the nest of colubris, the nest of alcrandri is not decorated with lichens: and it not infrexuently resembles some small fine sponge, not only in its yellow-brown tint, but in the elastic texture of its walls, which regain their shape after being lightly sfueezed. The eggs, two in number (but sometimes three in this species alone), look like lomeopathic pills-so dainty, incleed, that the owner herself must needs dart off the nest every now and then and hoyer at some distance to admire them. 'The male deserts his mate as soon as she is well established, and the entire care of the little family falls upon her shotillers. The young are fed by regurgitation, "a frighteful looking act," as Bradford Torrey says.

\section{No. 153.}

\section{RUFOUS HUMMER.}

\section{A. O. L. No. 433. Selasphorus rufus (Gmel.).}

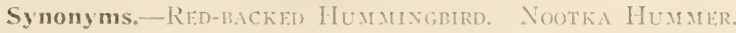

Description.- Idult male: In general above and below bright rufous or cimnamon-red, changing to bronzy green on crown, fading to white on belly and on chest, where sharply contrasting with gorget; wing-(uills purplish-dusky on tips; the central pair of tail-feathers broadened and broadiy acuminate: the succeeding pair with a (leep notch on the imner wel) and a slighter emargination on the onter IIel); goret somewhat produced laterally; of close-set rounded metallic scales, shining coppery-red, liery red, or (varying with individuals) rich ruly-red. Bill slender and straight. Adult female: Alyove rufons overlaid with bronzy green, clear rufous on rump) and tail-coverts: pattern of tail as in male but less deciled; central tail-feathers green tipped with black; lateral feathers chiefly rufous, clanging to black subterminally, and tipped with white; underparts whitish, shaded with rufous on sides: gorget wanting or represented by a small central patch. Yonny males: like adult female but more extensively rufous above and throat flecked with redelish metallic scales. Youny femoles: I, ike adult fenale but rump green and throat flecked with greenish scales. I,ength of adult male about $3.50(88.9)$; wing 1.65 (41.0) I) ; tail $1.30(3.3)$; bill .65 (16.5). Female: 3.70 (94); wing $1.75(44.5)$; tail $1.28(32.5)$; bill . $08(17.3)$.

Recognition Marks.-I'ygmy size; almmelant rufous of male clistinctive: female requites careful cliscrimination from that of S. alleni and may be known certainly from it by notclung of next central tail-feather, and by outer tail-feather more than . Io wide.

Nesting.--Yest: Of plant down and line mosses bound together with cohwebs, and ornamented with licliens, placed on horizontal or declining stem of bush or tree. IEgys: 2, pure white, elliptical oval. Av. size, .50 5.33 (12.7 x 8.3). Scason: April 15-July 10; two lurookls. 


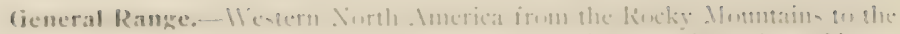

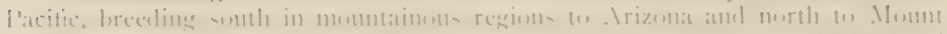

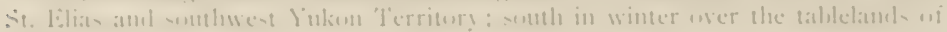
Ilexion.

Range in Washington. - Cimmunn smmoner revilent on the Ilest-sile irom

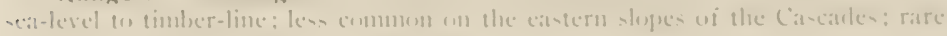
in the musntain of castern llathingtun.

Migrations.-Sprine: March 15--1pril 15.

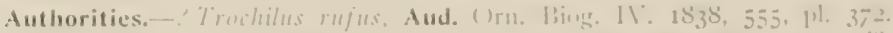

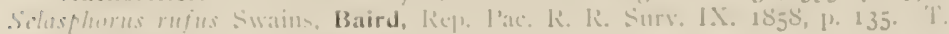

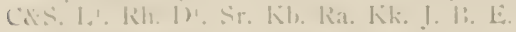

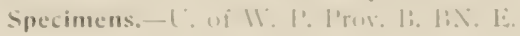

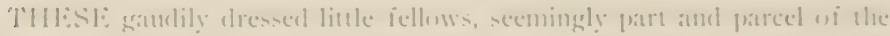

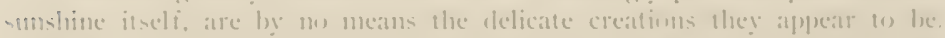

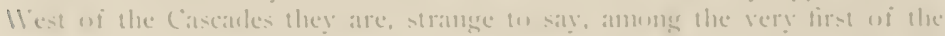
yrimg arrivals from ile sumb. 'The vanguarel alwalys arrioes log the lat

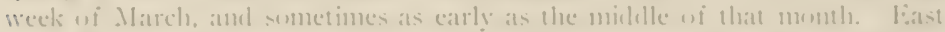
of the Calscales they are considerably later, and are mo fomml in nearly st

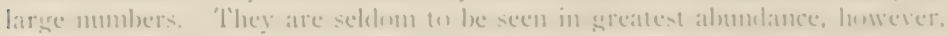

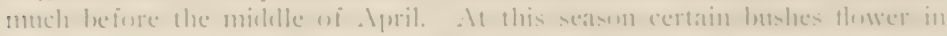

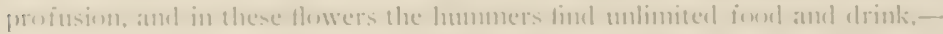

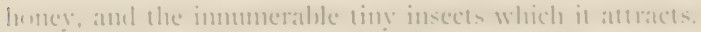

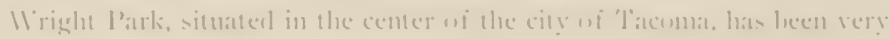
exeensively planted with the decorative wild currant : and it is here that loum-

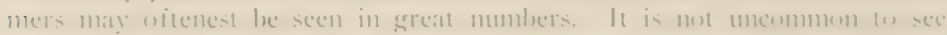

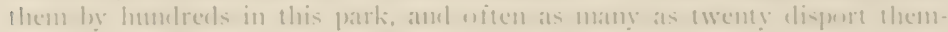

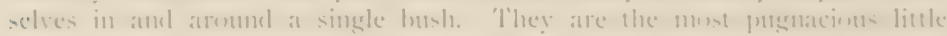

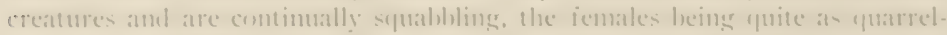

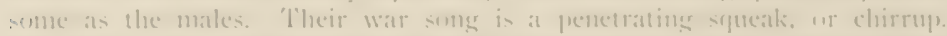

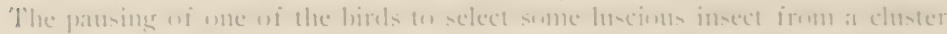

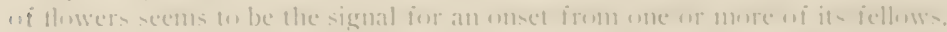

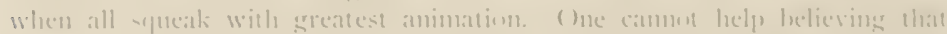

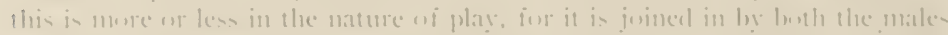

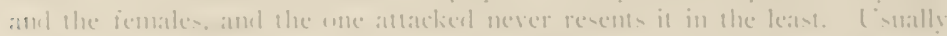

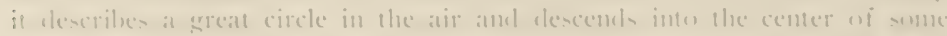

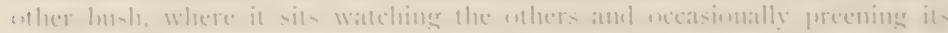

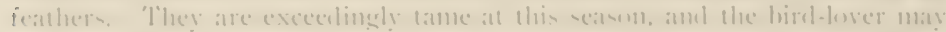

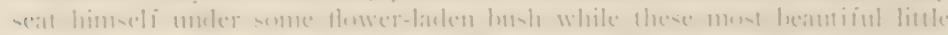

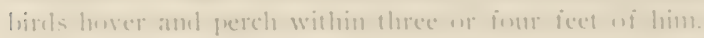

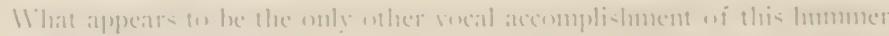

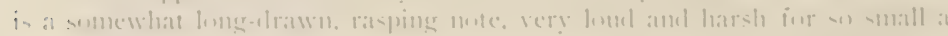

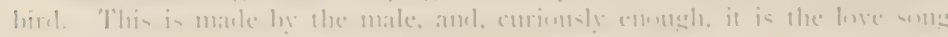


nttered while wooing his mate. She perches quietly in the center of some small tree, apparently quite insensible to his frenzied actions. 'lhese consist in flying t1p to a very considerable height, and then dropping in a circular course to within a few feet of where she sits. It is on the iowntarel conrse that he makes his cleclaration of love, ancl if it is tome to arumse her lic ought to be successful. Ceraninly it is a son1110l 1110 st startling to a luman being. when it expholes umexpecterlly witl in a fell feet of his heril.

It is almost umnecessary to say that the nesting lualsits of these little: bircls are of un nsilal interest. The male is a

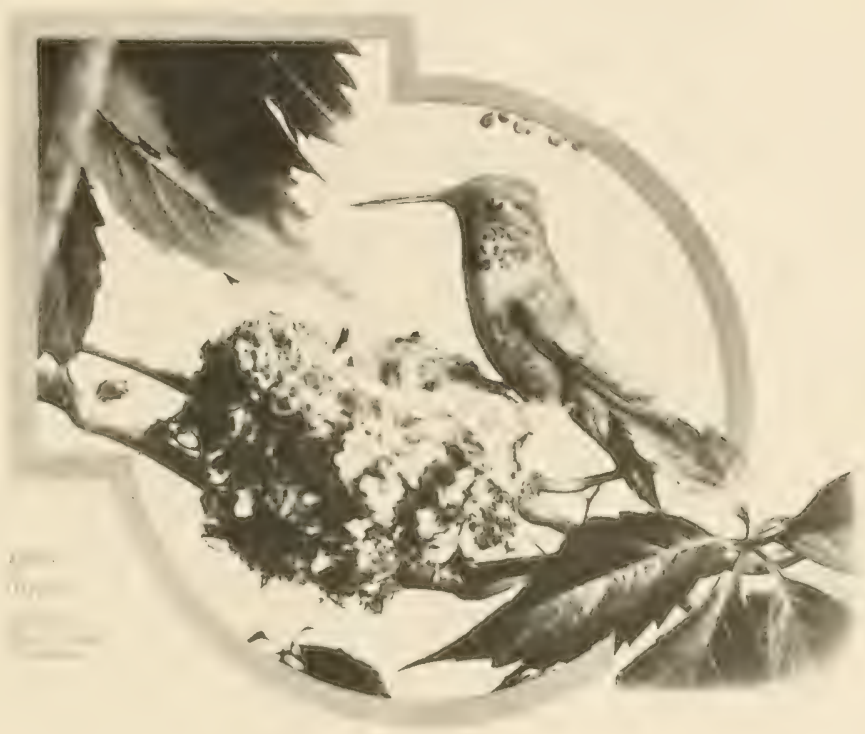

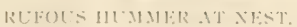

discracefully irlle iellow, never cloing a stroke of work while the female is building the nest, and leaving her as sonn ats the exgs are lairl. It seens that at least he might feet her while she sits so patiently upon her eggs: but 110 . he retires on some warm, stmmy gnteh and spends his time in selfish enjurment.

Strange to say. the first nest-building occurs during the first week in Ipril, at which season sleet and cold rains are of not infrefuent occurrence. This is long before the majority of the species have arrived from the south. amel it would leat one to think that the first comers are already paired when they arrive. I nest containing two fresh eggs was fombl on the Ifth of Ipril, the egess hatching on the zoth. On this last rate it was raming in intrents wrth a bitter onlel wind, yet the tiny young did nen secm to sulfer in the least, altho frerguenty left for as long ats fifteen or twenty minutes be 
thes mother. Indecel it was a mystery where she condel pressibly have fomm

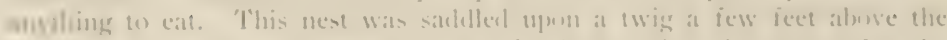

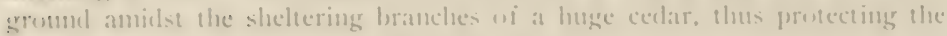
voung irom any direet contact with the ram

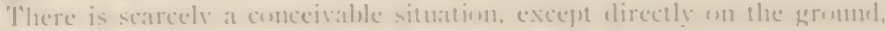

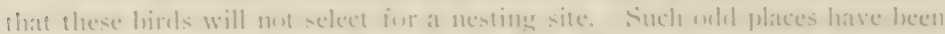

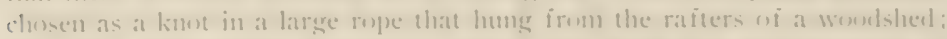
and agrin, ammengt the wires of an electric light glole that was strspended in the fromt prorch of at rits resiclence. It mis Ix iumel lify feet up in some louge fir in the

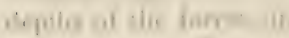

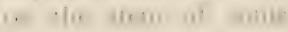
hitakluerr bush growwer in al city lon.

ton witen the

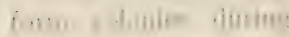

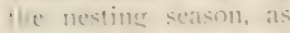
mank a a twents mests levine luile in at smatl alra. Sime latrece th

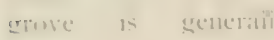
roment ion the colom bint at $1110 \mathrm{~m}$ meterentuse mene was leaterl on a min met m fomb Simmel. 'This islamel has

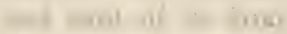

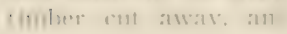

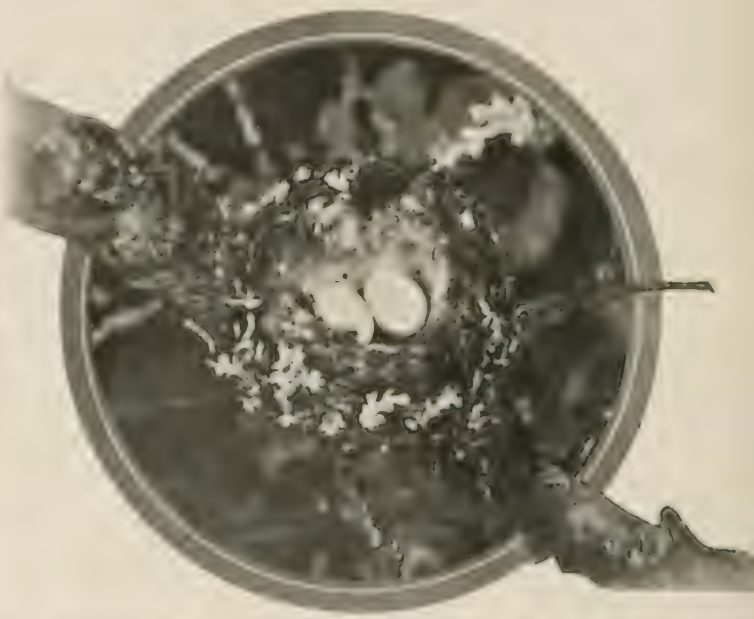

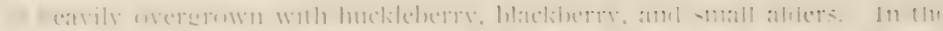

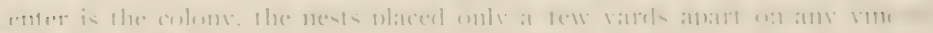

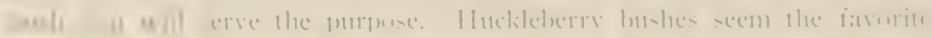

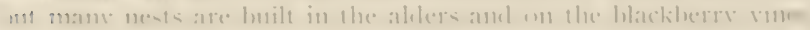

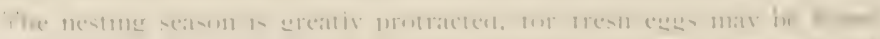

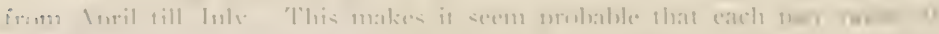

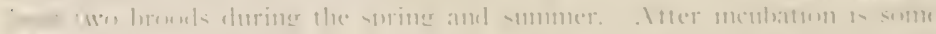

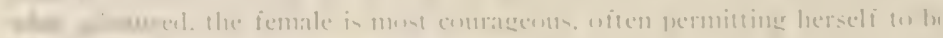

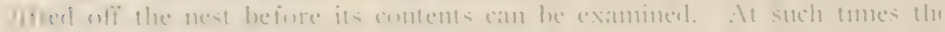

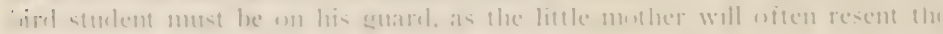
untusion. and her attack is alwavs mate all the eves 
The eggs, so far as has ever been recordecl, are invariably two in number. They are immaculate nilky white in color; and when freshly laid the yolk makes them look like little pink moonstones. such ats one finds on the beach. In shape they are elliptical, and seem large for so small a bird, measuring .50 $\times .33$ inclies.

The young are fed by regurgitation. For several days after hatching their bills are little longer than those of any other young bird; but by the time they leave the nest. their sword-like beaks are nearly as Iong as those of their parents.

I. H. Bow.r.s.

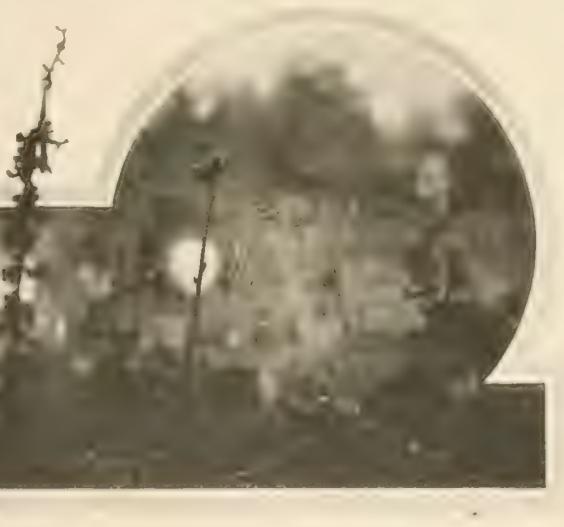

Taken new Tacoma.

Photo by II I oon $\Omega$.

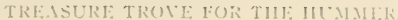

COBWEAS ARE LARGELY LTIIIZFD IS TIIE, BTIIDISG OF A HCMMIXGRIRT'S NFST

No. 154.

\section{ALLEN'S HUMMINGBIRD.}

A. O. L. No. 4.34. Selasphorus alleni IJensh.

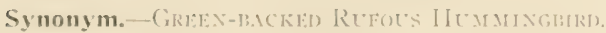

Description.-Idult male: Similar to adult male of S. mefus, lut upperparts shining bronzy green (duller on crown); underparts, including lefly, cinnamon. rufous, changing to white on clest only: tail-feathers without notching or emargination, the two outer pairs smaller and rery narrow, the outermost acicular. Idult female: Very similar to adult male of 5 . mujus. but with tail as in male S. allcrit. Length of arlult male: $3.25(82.6)$ : wing $1.52(38.6)$ : tail r.17 (20.7) : bill .63 ( 16 ). liemale a little larger.

Recognition Marks.-I'yemy size: ficry gerget with arecu back of malc nmmistakable: female indistmguishable out of hand from that of S. mefus: onter most tail-feathers less than . In wide.

Nesting.-Is in prececling.

General Range.- Pacific Coast district north to southwestern British Colum 


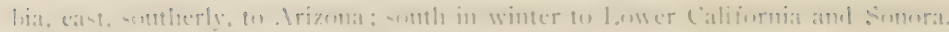

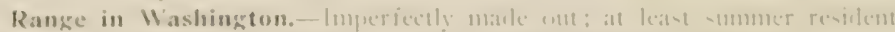

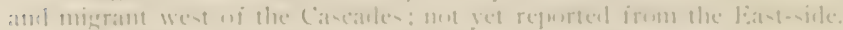

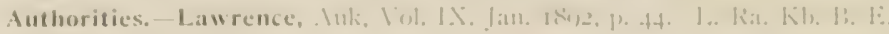
Specimens.- - L. E.

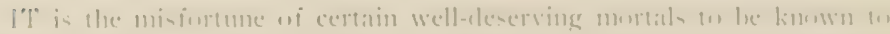

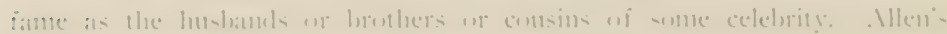

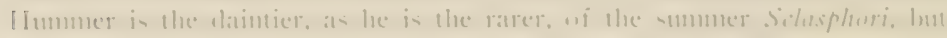

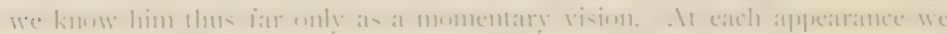

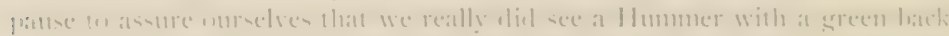

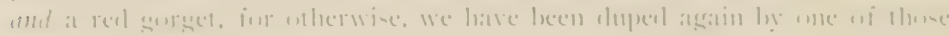

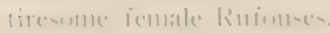

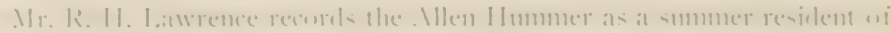

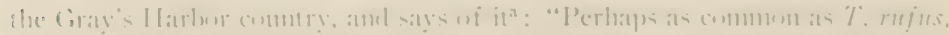

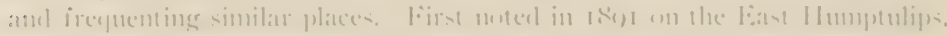

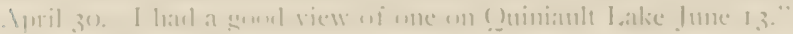

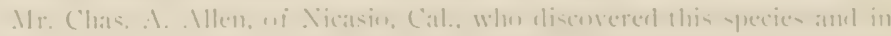

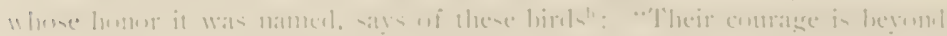

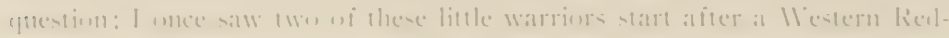

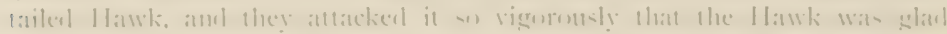

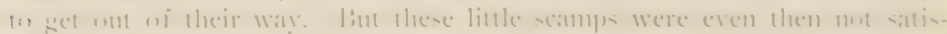

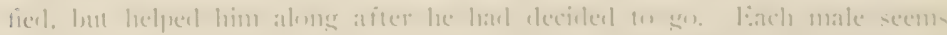

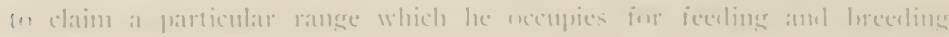

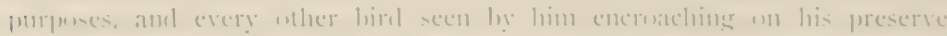

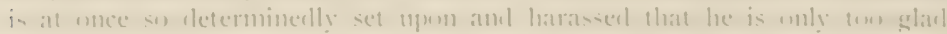

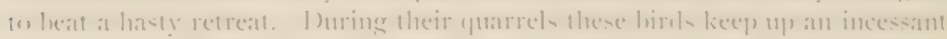

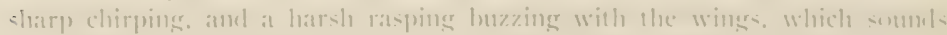

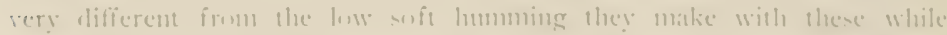

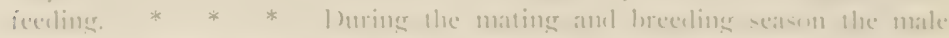

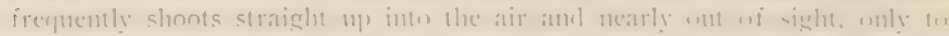

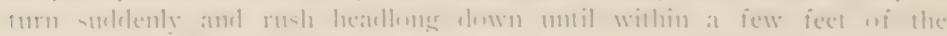

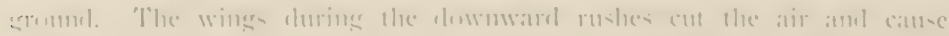

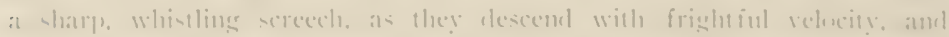

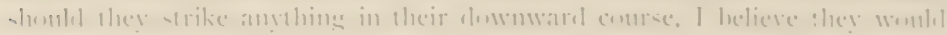
le in-lamly killerl,"

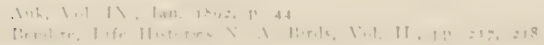





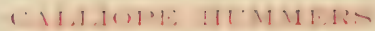

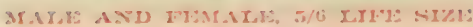

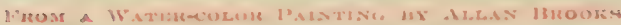




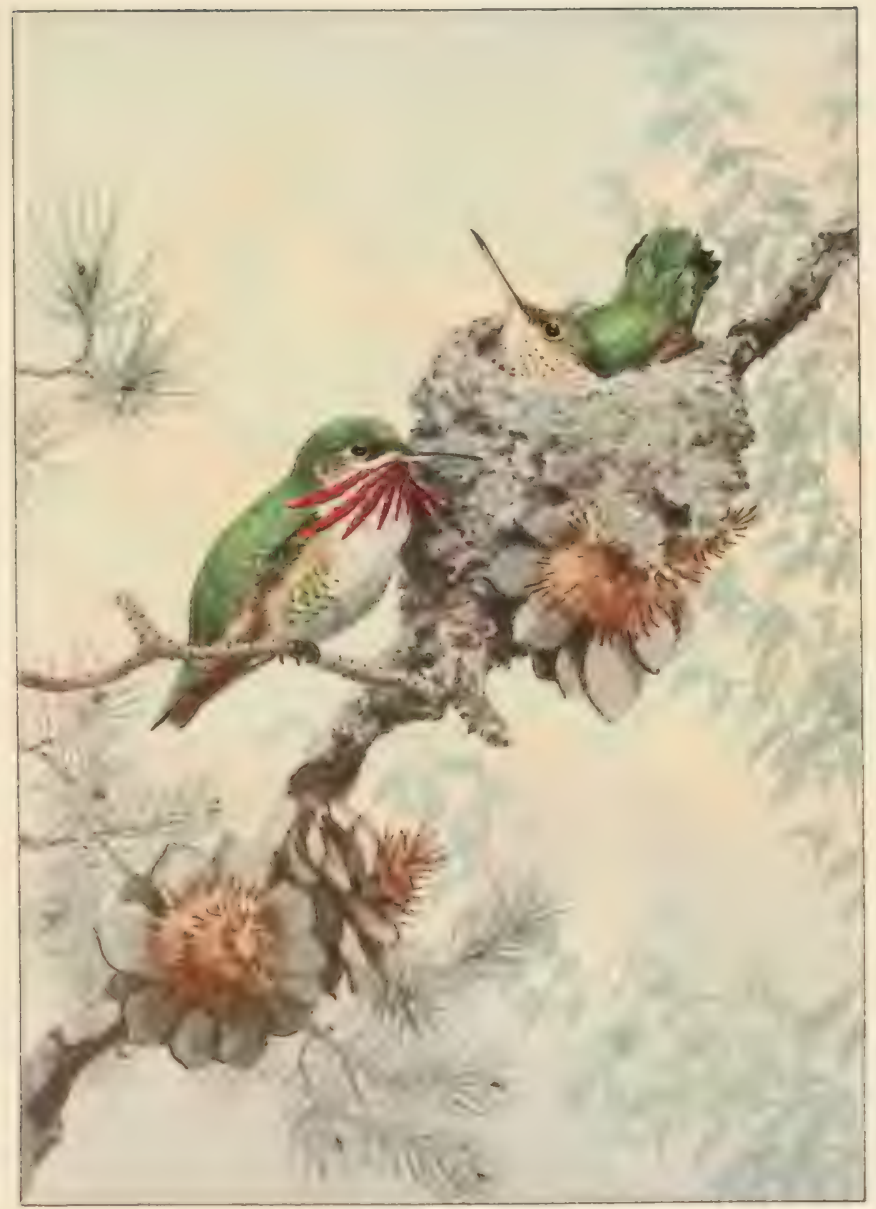



No. 155.

\section{CALLIOPE HUMMINGBIRD.}

A. (). U. No. 436 . Stellula calliope Gould.

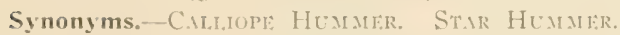

Description.-Adult male: Upperparts goklen-green; tail chiefly dusky. mfous at base, paler on tips, slightly (louble-rounded, its feathers broadening distally and nearly round at tips: sicles of throat and underparts white, washed with greenish and brownish on sicles; gorget somewhat produced laterally, of lengthened acuminate feathers having white hases, rose-purple, or violet. with lilac reflections. Bill straight, black above, yellowish below. Idult female: Coloration of upperparts, save tail, as in male: central tail-feathers green tipped with dusky; remaining rectrices greenish gray mingled with rufons basally, crosied with black, and tipped with white. Jinng birds resemble adult female but are lieavily washed with rufous below and have throat more or less specked with dusky. Length of adult male: $2.75-3.00(60.9-70.2)$ : wing 1.55 (39.4): tail $1.00(25.4)$; bill $.57(1+.5)$. Finale much larger-11p to 3.50 (88.9).

Recognition Marks.- l'ygmy size; the smallest of the northern ranging species: gorget of male with radiating feathers of rose-purple hue distinctive, but female hard to cliscrimbinate afielel.

Nesting.-Nuch as in other species. Ar, size of Ey/g: .47 x.30 (II.9x 7.fi). Season: June or July aceording to altitude: one brood.

General Range.- lireeding in the momntains of the llest, north to central IBritish Columbia: south in winter to the mountains of Mexico.

Range in Washington.-Sumner resident, chiefly in Transition and Canadian zones, east of the Cascaics, and in these mountains to the limit of trees. Mr.

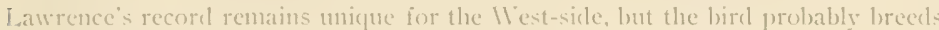
in the ()lympics also.

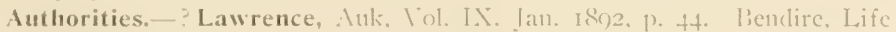

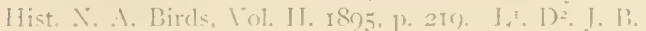

Specimens, - I's. C.

ORNITHOI.OGIS'T'S have been hard put to it to provicle names for these most expuisite of birds, the Hummers. 'T'he realuns of callilithology, chromatics, esthetics, astromomy. history, classical mythology, and a score besicle, lave been laid under tribute to secure such fanciful and high-sounding litles as the Fiery 'Iopaz, Ruby-and-T'opaz. Allied Enerald, Red-throated Sapplire, Sparkling-tail, White-bunted Racket-tail, lork-tailed Ratinbuw, the Sapplus Comet, the Circe, Rivoli and Incifer Hummers, the Aclorable Coquette, and, last but not least, the truly. Marvelous Humminghird / Loddigesia mirabilis). IIhat wotnder, then, that with so many children w provide for, Contel, the great monographer of the Trochilide. should have named 


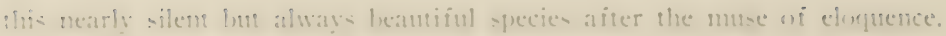
Calline?

While it is true that the -pecies mat be intme in alumelane thromen

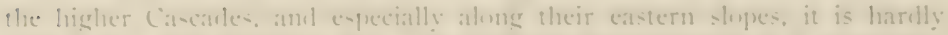

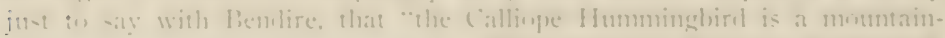

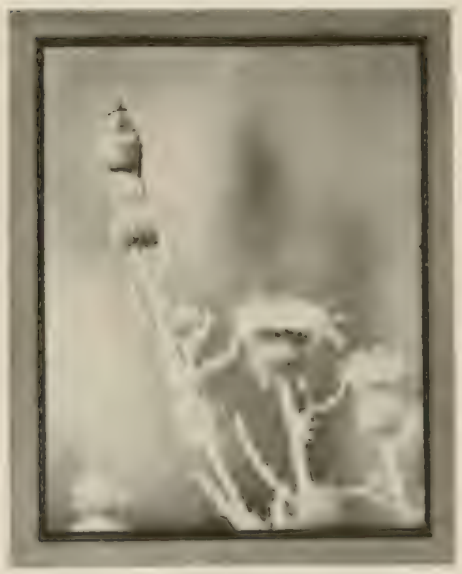

T:isen in is : :

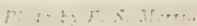

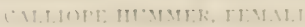
foring species ame during the breeding -cas in is rarely met with below altimules wi forme fect. and much more iretuenty between b. icet." 11 e lave jutmul it commsmonly in the nurthern and easern pertionwi 11 as hingurn at much liswer altiturles. and have taken it nest in the

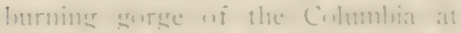
an altitule wi unly six lomelres ieet. In the mostutains the hirel kinnte nos restrietion wi ranere. save that it

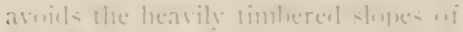
the lleet-miele: ant it is at leats ats commonen along the rlivile as iv the kinimss Hommer.

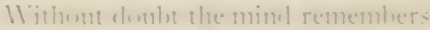

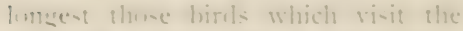

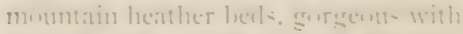

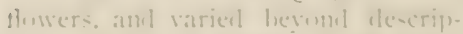
tiun. A hit wi heather um 11 right Peak at an elevation uf s.mon ieet.

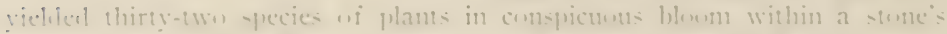

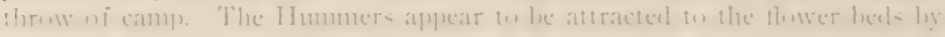

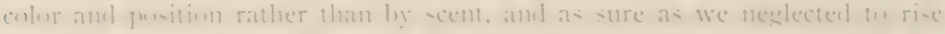

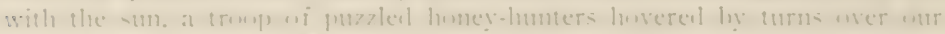
farti-entered blankets. Onee a limmer minutely inspected a resl handama

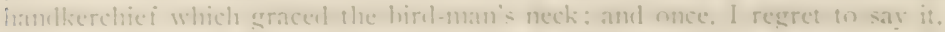

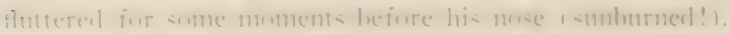

The tower and dive wi the callinge Hummer produces at its climax a selneak wi the tiniest and shrilles quality. It is a sight well worth seeing

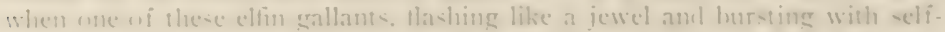

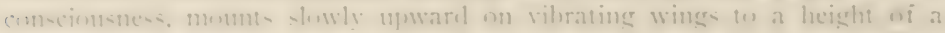

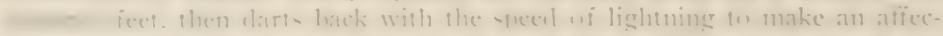

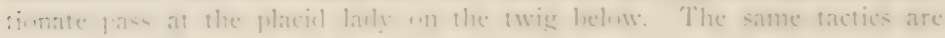

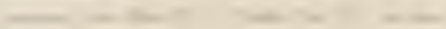


pursued when the cat or a snooping chipmunk is the object of attention. but the cliange in temper is unnistakable. I do not feel sure that the spitfire will strike an enemy, but the suclden explosions of winged fury hatrd about the ears are quite sufficient to put a prowler in a panic.

'The secret of nest-finding in the case of Hummingbirds lies in the tell-tale wing-buzz of the female as she quits her nest. In this way, on the I th of June, I906, we found the first Washington nest of the Calliope, in the dense greenery of La Chapelle's Springs, on the Columbia River, near Chelan Falls. The nest was saddlerl on a slender descending branch of a red birch sree, at a point seven feet ont from the trunk and twelve feet from the grouncl. It was overshadowed by a little canopy of leaves, and was held in place not only by its lashings of cobwehs, but by a drooping filament from a Inftier iranch.

In eastern Oregon Bendire found these birds nesting extensirely in the pine trees. The nests were usually settled upon a cluster of pine

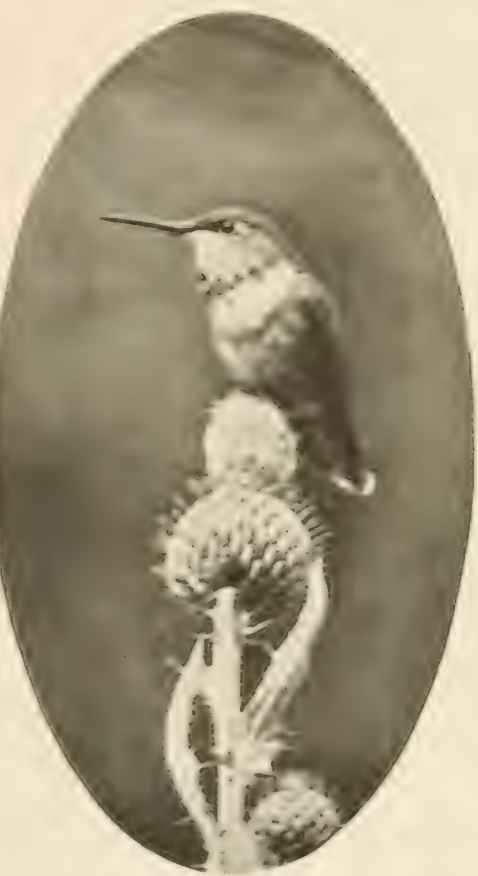

Taken in Spolare.

A XEARER VIFW. cones, and so closely simulated their surroundings that detection would have heen impossible save for the visits of their owners. Riclgway figures a fourstory nest taken at Baird. Califormia, and believed to represent the occupation of successive seasons.

2. The Humminebirds (Kep. Nat, Mus, I 890, fr. $253 \cdot 3^{83}$, plate I) 


\section{o. 850 . \\ POORWILL.}

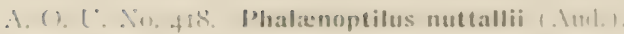

Description.-1dult: I narrow hame of pure white arese thenat: ledow this

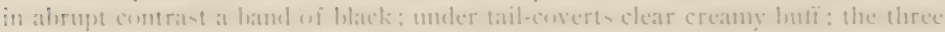

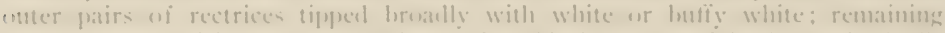

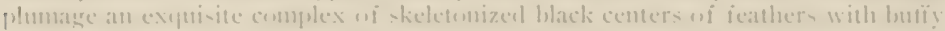

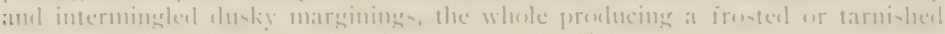

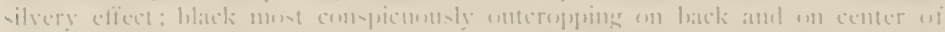

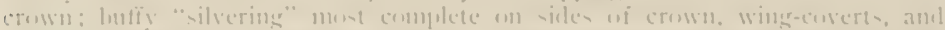

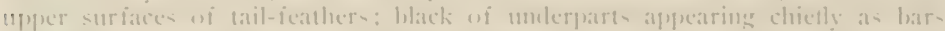

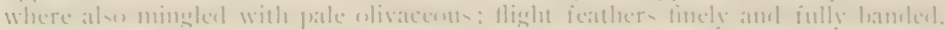

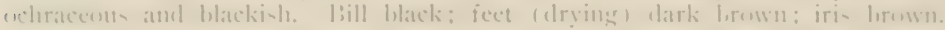

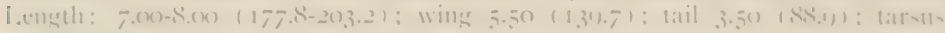
(1) $111(1,5)$.

Recognition Marks.-Siricly Clewink -ike hut appearinge larger: -maller

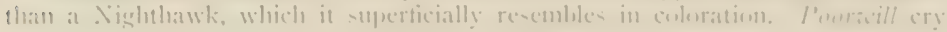

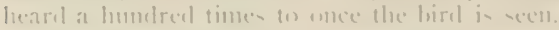

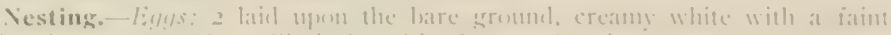

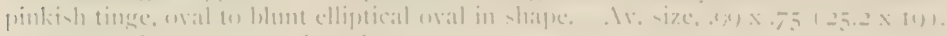

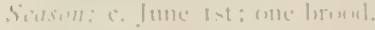

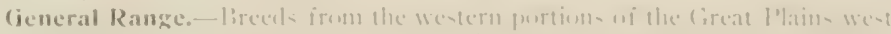

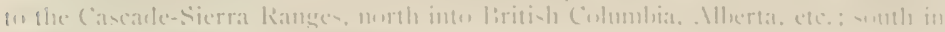
winter thra . Mexien to limatematia.

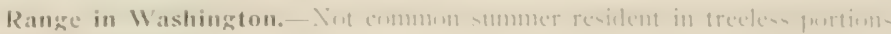

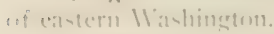

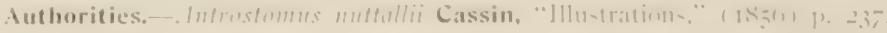

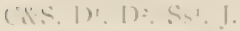

specimens.-l'ros: (:

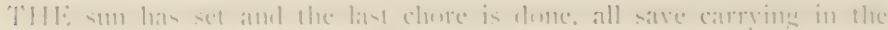

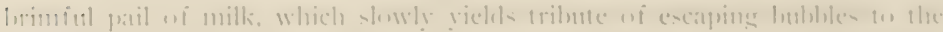

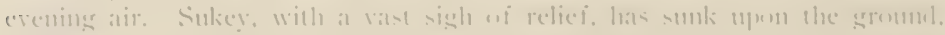

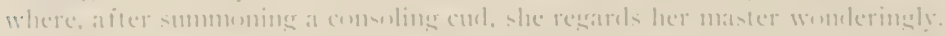

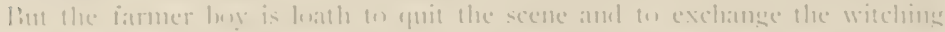
awilight for the homely glate wi the wather keronene: so he lingers an his

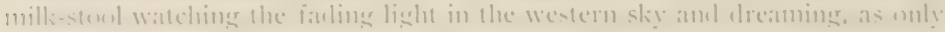

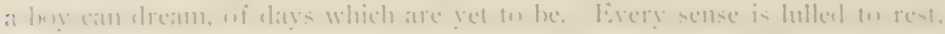

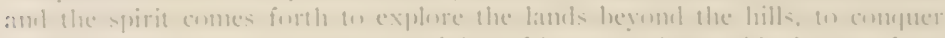

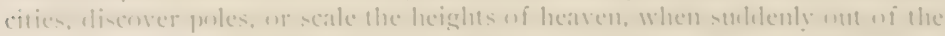

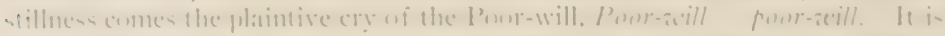

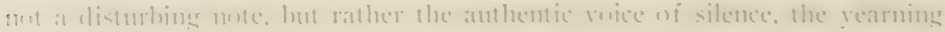


of the bordering wilderness mate veal in appeal to the romantic spirit of youth. Poor /f ill! Poor /l' ill! you think upon cities, actions, achievements; think rather upon solitude, mpon fuietness, upon lonely devotions. Conse, oh, conne to the wilklerness, to the mystic, silent, fateful wastes! Ancl ever after, cren tho duty call him to the city, to the stupid, stifling. roaring. (and glori(nts) cits, the roice of the Poor-will has wrought its work within the heart of the exiled farmer boy, and he owns a reverence for the silent places, a loyalty of affection for the wiklerness, which not all the forced subservience of things which creak or blare or shrick may fully efface.

The Poor-will spents the (hy sleeping on the gromel muler the shelter of a sage-bush, or close besicle sone lichen-covered rock, to which its intricate pattern of plumage marvelously assimilates. When startled, by day, the bircl flits a few rarels over the sage-tops and plumps down at haphazard. If it chances to settle in the full sumlight, it appears to be blinded and may allow a conse approach : hut if in the sharle, one is not likely to smprise it again. Liven atter night fall these fairy moth-catchers are much more terrestrial in their habits than are the Nighthawks. 'They alight apon the ground upon the slightest pretext and, indeed, appear most frecpuently to attain their object by leap)mg up at passing insects. 'They are more strictly noctmol in habit, also, than the Night Jars, and we know of their later novements only thru the intermittent exercise of song. Heard in some starlit canon, the passing of a Poorwill in full cry is an indescribalule experience, producing feelings sonewhere hetween pleasure and fear,--pleatsure in the lelight ful melancholy of the notes hearl in the clim clistance, but something akin to terror at the near approach and thrilling climax of the portentoms sommls.

T'aken in the hand, one sees what a ruiet, inoffensive fay the Poor-will is. all feathers and itself a mere featherweight. The silken sheen and delicate wacery of the frost-work upon the plumage it were hopeless to describe. It is as tho sone fair suowhall harl struck the bird full on the forehead, and from thence gune shivering with ever lessening traces all over the upperparts. Or. perhaps. to allow another fancy, the dust of the inmunerable moth-millers. with which the bird is always wrestling. gets powdered orer its garments. The lare bristles which line the upjer mandible. and which increase the catching capacity of the extensive gape by half, are seen to be really modified feath. ers. and not hatirs, as might he stipposed, for in younger specinens they are protected by little bormy hasal sheaths. It ith this equipment, and wings, our melanchuly hern easily lecomes the eny of mere luman entomologists. 
No. 157 .

\section{PACIFIC NIGHTHAWK}

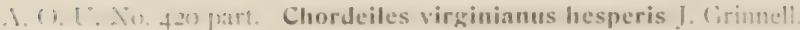

\section{simmm. 1. At}

Description.- Wull mule: Mettled, black, graty amel uchracens, and with whice in patches abowe black predeminates, eypecially on forehead and hack, moteling falling into indistinct hars on upper tail-coserts and tail anterior edge of wing white: the wing-pull, dasky; a large, white, tranciverse patch alust midway on the liret five primaries, save on the onter web wi the lirst; a larese l-shapeel throat-patels white: remaining underparts distincty and finely harred. dusky and whitish with some iams ochracens, - the latter found especially on the parts aljacent to the white throat-pateh: the crisum sometimes pure white, Innally larreel, at greater intervals than on hreast; a white band crosing tail near tip, execpt an central feathers. Litl without evident bristes, the borny part very small, but length of gape alout an inch. 'larsus very short; the midelle claw enlargerl, and with a curious, hormy, comb-like process on the inner exlge. ddult fomale: Similar, hut without white banel on tail, and with white spote un primaries often much reduced ; throat-patch tinged with (echracesus, and suffu-

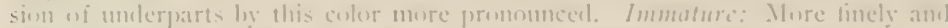
heavily mottled than adults, and with uperparts more heavily marked, or even sulfuserl with exhracens-butf. I.ength n.mo-10.00 (228.6-25f): wing 4.85

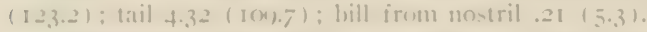

Recognition Marks.-'T"n appearance "l,ittle llawk" sze-really smaller: central white spont in longe wing distinctive.

Vesting.-lings: 2, depusited on the bare ground, often amumg rocks, snme-

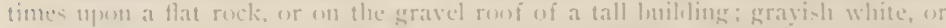

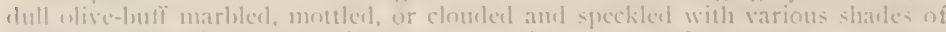

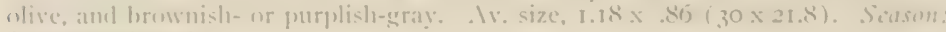
Jume: one liroml.

(ieneral Range,-I'acitic cuant slope north ow liritish Columbial.

Range in Washington.-West-sile, summer resilent in open situations.

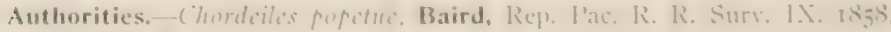

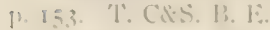

Specimens.-I'rov.

'TIl: Nighthawk arrives st tarlily-never lefore the micklle of May and from that date in the miklle of Jume- hat he reminds us wi the manghty

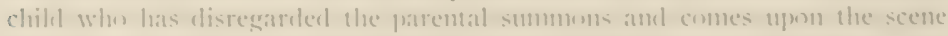

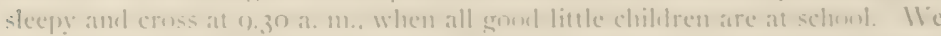
are sure, tom, that it must be something like the neecesity of eating cosld rictuals

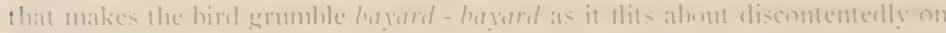

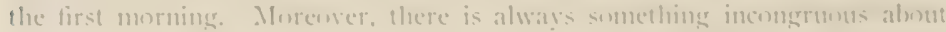
the appearane of this pratrie species in the land wi tall tmoler. He is like the 
man from Kansas. He has a perfect right here and he is a very good fellow. Oh, to be sure!

The Pacific Nighthawk differs by scarcely assignalble characters from the twpical form of the eastern United States, but it is separated from it in distri-

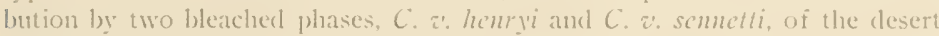
and plain respectively; so we feel conficlent that it represents a resaturation of the intermediate stock rather tham a division or colony of $C$. eirginimms proper. Bircl of the platins tho it be, it is pushing its way determinedly on the IV est-side wherever openings offer, and is as likely to occur nupon the San Juan Islands or in some little clearing of the mountain valleys as mon the ampler reaches of the (helalis praties. Latterly, also, it has accommodated itself to the life of the city, and from the fearless way in which it appears orer Pacific Arente in Tacoma, or Second Arentue in Seattle, we judge that it must be following the well established eastem custom of lating its eggs on the that roofs of down-town buildings.

No. 158 .

\section{WESTERN NIGHTHAWK.}

\section{A. O. U. No. 420 a. Chordeiles virginianus henryi (Cass.).}

Description.- Similar to C. $:$. hesperis, but paler thruout areas of black reduced, white patches of throat, wing, and tail averaging larger; below more extensively tawny whitish.

Recognition Marks. - As in preceding.

Nesting. - Vest and Eggs not distinguishable from those of C. z'. hesperis.

General Range.-Arid 'Transition and Canadian life-zones of the IVestern United States from the eastern slopes of the Rocky Mommains to the CascadeSierra ranges, north into British Columbia: south in winter to northern South America.

Range in Washington.-Common summer resiclent in open situations east of the Cascade .lountains.

Migrations.-Spring: Moses Lake, May 13, Igo6: Chelan, May 20, Ino5: Oro, May 29, iso6.

Authorities. - "Westem Nighthawk," Iohmson, Kep. Gox. II. 'T. I884

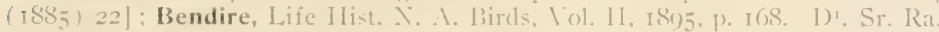

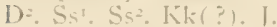

Specimens.-( L of IV.) I'r. I'rov. Is

THIS:SE Xighthawks are perfectly harmless except to moths, mideses, and their ilk: and their uplifted wings half careened by the evening lreeze furmish 


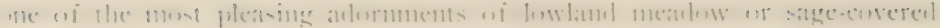

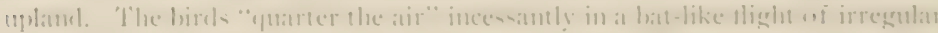

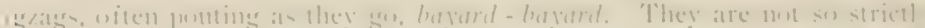

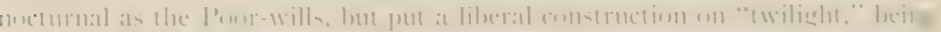

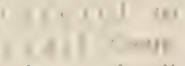
wives wi all Fumly dias, ancl, in liact. musing allout ati will when (ever the sint slants jatits The miallo thume wit the daty are spout n1 pon th the erroment, where their nemtral timts serve a motectile pur prose and are alnow immplic

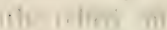
in: 10 ne contion stomen

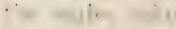
«थ Indic heaclers II 1 iो : औil $r(11 \% \| 1111 \%$ Clemgin are

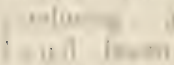

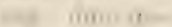
4. .) . 16. in I care if at!

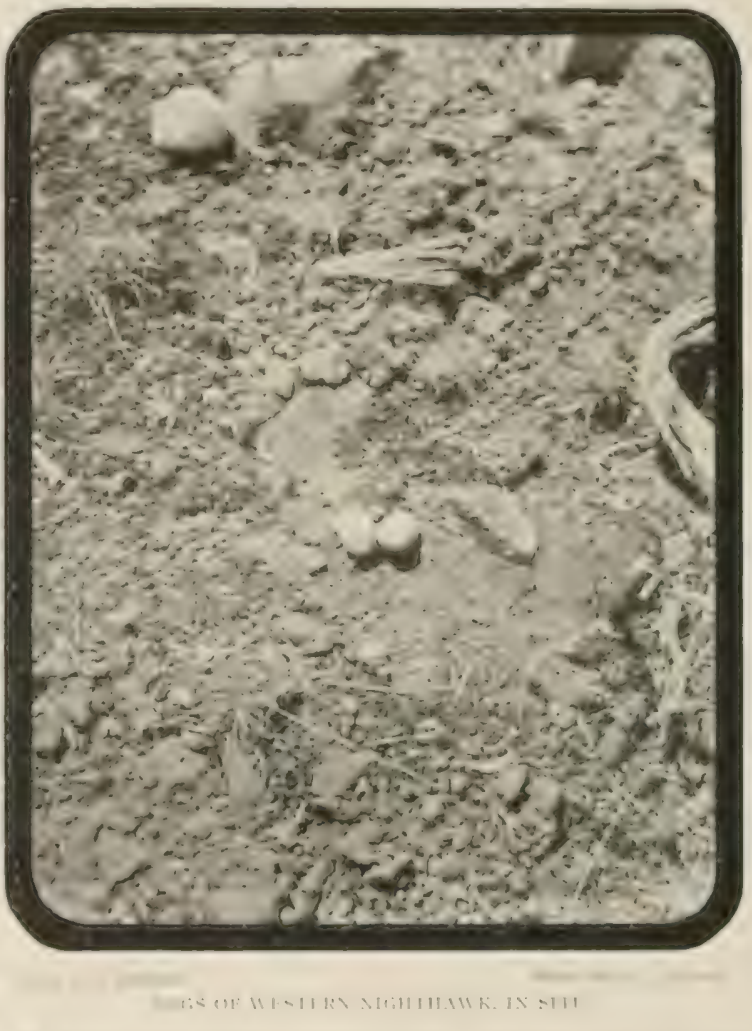

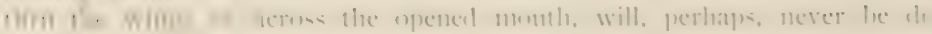
1. momates

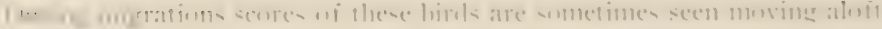

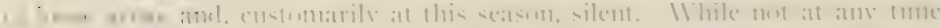

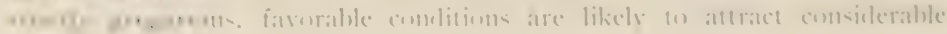


numbers 20 at given spot. I have seen scores at a time winging noiselessiy to and fro over the trancuil waters of bronk Lake, and once 1 saw a company of not less than two hundred executing a grand march with bewildering erolutions, in a lakima pasture. The clate in the last-mentioned instance was Angust Ioth, and it is more likely that the birds had discovered some notable erent in the insect workl, than that they thenselves were preparing (1) migrate.

The eggs of the Nighthawk are heavily nottled with slaty and other (ints, which rencler them practically invisible to the searching eve, eren tho they rest upon the bare ground or, as oftener, upon an exposed lata ledge. Except during the very wamest hours (when the sums rays might addle them) and the coolest (when they might becone chilled), the sitting bird is likely to rest besicle her egess instead of on them. The young birds when hatcherl place sreat reliance $n$ won their protective coloration, and eren permit the fondling of the hand rather than confess the defect of their fancied

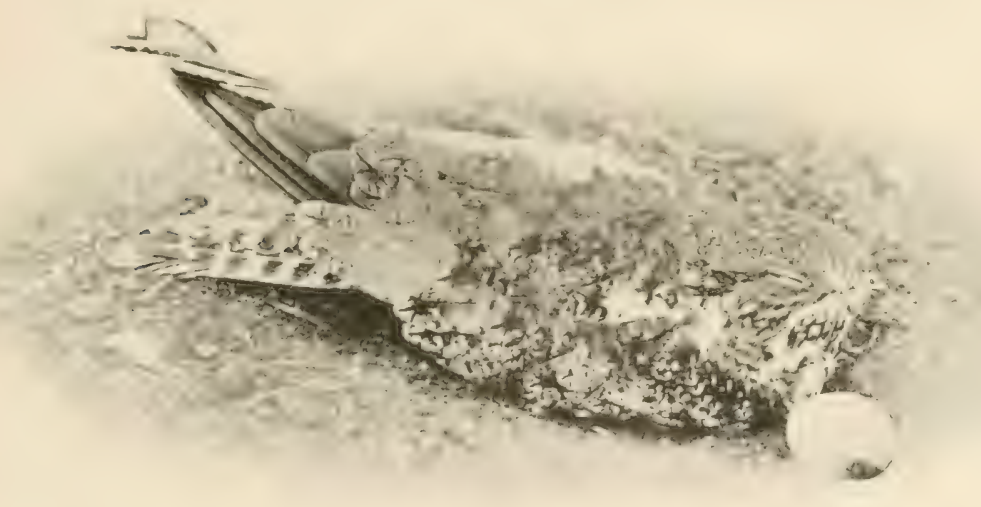

Figien ant Srobanc.

Telephoso by 15: H. High

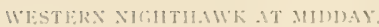

security: Phe old bird, meanwhile has flutered away over the sromel with moncertain wing and dronping tail (o (lrop) at last on the very point of cleath. Or fating in this ruse, she is charging about in misl air with plantive cries. Look upon the babies in the latst tine. for they will he spirited away before your return,-borne olf, it is sairl. between the thighs of the parent hirel. 
ํ. 159 .

\section{BLACK SWIFT.}

1. (1. [. . Vo. 423. Cypsefoides niger borealis (Kenmerly).

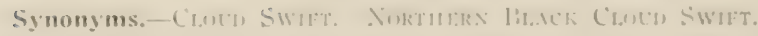

Description.-.-Idults: sinty black; featlers of extreme chin, anterior por-

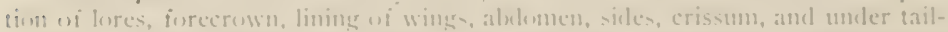

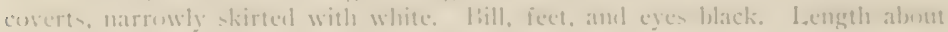
$7 .(x)(17-3)$; wing $(1.50(165.1)$; tail 2.08$)(5.3)$.

Recognition Marks. - Sparrow -ize lnt appearing larger: long wings and raphiel thight, clomel-hatunting hathits with onher and size distinctive.

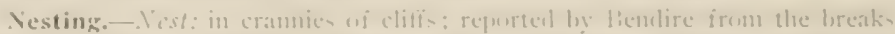

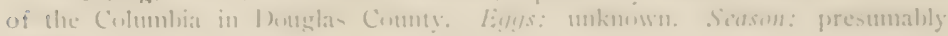
Junc.

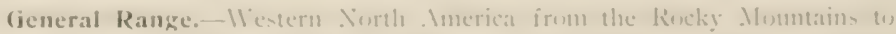
the l'acilic, merth thru liritish (inlumbia to southwestern Diaska partially nomatic, etratic, and far-ranging: winters suth to contral Anericat.

Range in Washington.-_ummer resielent in the higher Cascades and epresomably) the (Blympice: appears yporalically at lower levele, chicfly west of the caveate Menmenims.

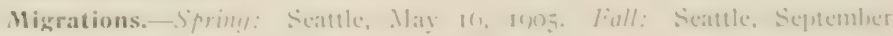

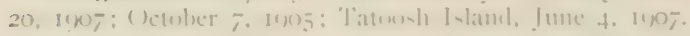

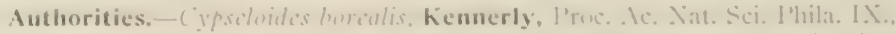

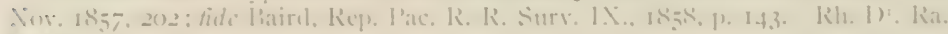
a. 1 .

Specimens.-I'ros: C. 1:

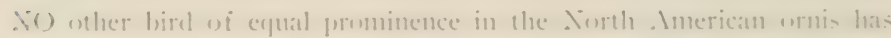

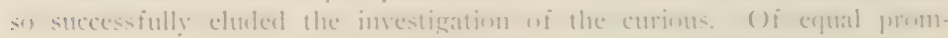

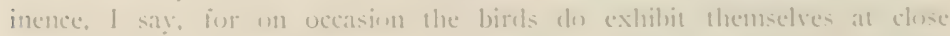

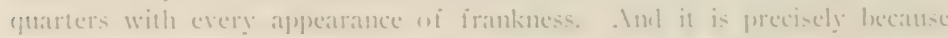
they fos ereasionally stoup to our level, that we lome to follow them as

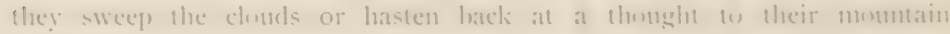
fiatmesses.

Clomel swift hunt in great straggling companies, and when one of them has attracterl attention he swanging near the ground, and the eyen

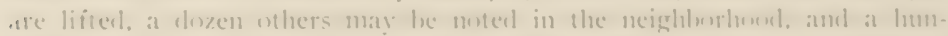

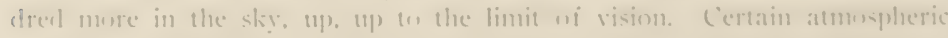

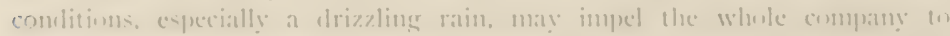

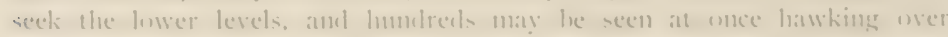

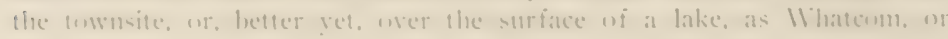


Wrashington. But on brighter class, and ordinarily, the passing throng occupies the whole heavens, and at bird seen clarting across a distant cloud may in another instant clescend to the tree-tops. Nhtho not quite so speedy as the White-throated Swift, there is no bird whose aerial evolutions convey such a sense of power and tunfettered freedom as to those of this veritable sky-scraper.

'The extraurlinary wolitatorial powers possessed loy the Cloud Swifts permit a breacth of claily range ummatched in the case of any other species. II suppose that the flocks which appear here and there at sea-level thruout

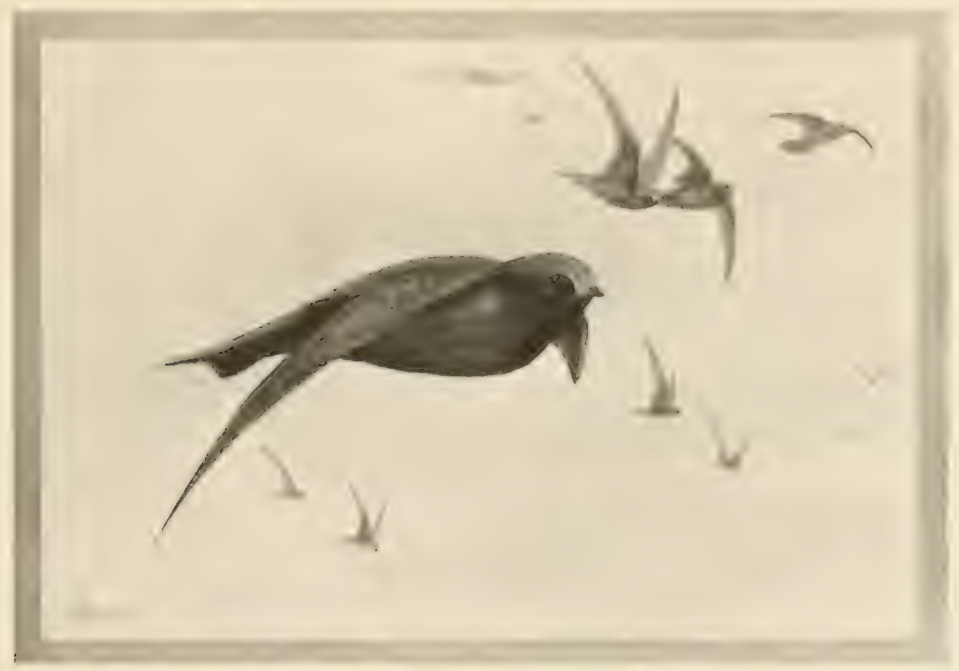

BI.1CK SIIRTS

the summer nest only in the Cascalc Mountains: and it is easy to see that a hundred mile dash before loreakfast would hardly figure in the rlay's work. On this account, we may fatrly prestme that the Cloud Swifts are really less numerous than might he stupposed from the analogy of other birds. Perhaps half a dowen moving bands would comprise the entire population of the State. A company nesting on Glacier Peak might elect to spend one day hawking oter Gray's Harbur. and the next in the Palouse country: Sonne stuch dimmal shifting does exist, for at Chelan I have seen the Swifts in Itue passing down the valley at early morning, and returning in the 


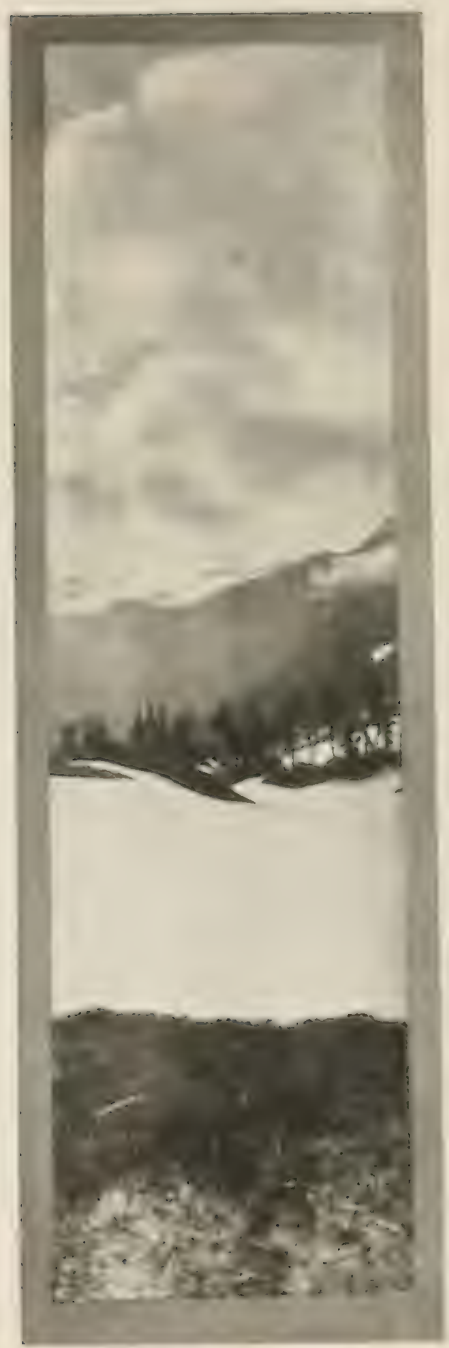

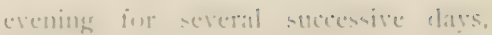

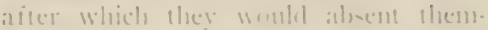

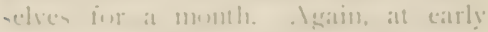
merninge we hate secm them tiling thru

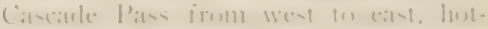
winge as the there latul business in latitur.

J'here bilack swits nest chefly in the mutumtains upen the fatce of inace

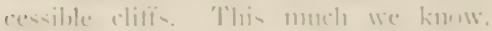
lute the nese amel egers atre still แm-

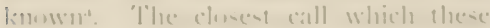

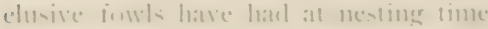

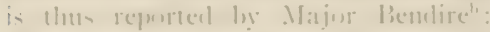

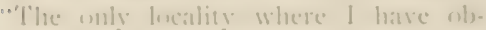
enverl this species was ont the uppes

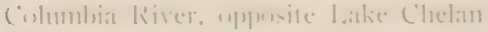
Mishingtom, in July, 18-r). Here quite a colomy mesterl in al high perpumelicular clifi m lhe mile batk from the river, and mumbere uf thems tlew to amel imme the valley ledow, where they were feceling the

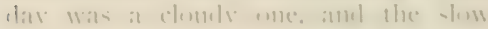

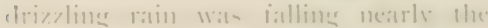

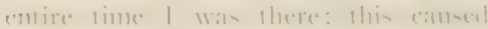

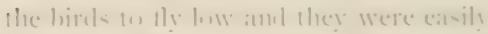

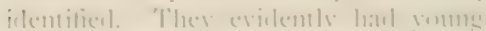

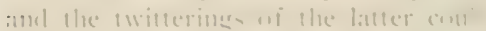

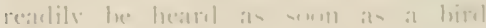

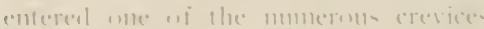
in the rlifi aluse. This was mers

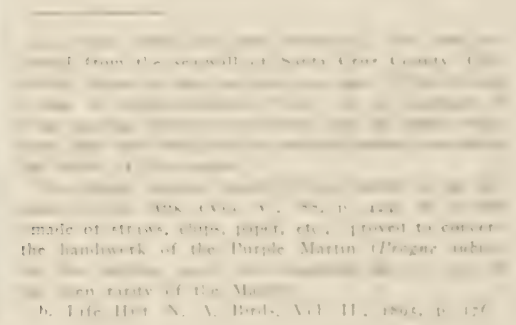


inaccessible, heing fully 300 feet high and almost perpendicular: and without suitable ropes to lower one from abure it was both useless and impracticable to make an attempt to reach the nests. These were eviclently placed well back in the fissures, as nothing bearing a resemblance to one was visible from either above or below. In this locality I believe fresh egess maty he looked for about June 25. "

I had word of the nesting of these birds in the summer of 1006 t1pon a majestic rock wall overlooking the Sahale Giacier in the Upper Horseshoe Basin of Chelan Comnty. Dut a visit paicl to this scene the following season failed to discorer either nests or birds, altho local miners were ready to confurm the report of their presence the previous season. Dr. Eirlwarl Hasell, of lictoria, informs me that they have nested about a certain cliff overtorking Cowiclan Irake on Vanconver Islankl. The cliff referred to is alout 1,600 icet higlt, and access was, therefore, out of the question. Mr. M. M. Mright. the well-known nature student and guide, of Sipokane, tells me that he once saw these bircls nesting among some cliffs called "The Chimneys," which are five or six miles distant from Priest. Idaho. He saw the Swifts carrying twigs to the cliffs. but clid mot take further notice of their actions. He visited 'The Chimneys at the same time of year on each of two succeeding seasons, but saw nothing of the Swifts. From these reports, and from the fact that the comntry referred to by Benclire has been ransacked in vain, I conclucle that the black Swifts are contintally slrifting the scene of their ammual nestings, being. in fact, as erratic in this regard as they are in the matter of their local appearances at the lower levels.

No. 160.

\section{VAUX'S SWIFT.}

\section{A. O. U. .To, 424. Chatura vauxi ('Townent).}

Description.-Idults: Move, sooty brown, lightening, nearly hair-browm. on rump and upper tail-cowerts; below, light sooty gray, lightening, nearly white. on chin and throat: lores velvety black; slafts of tail-feathers denueled at tips a thirel of an inch. Lecngth ahout $+.50(1+4.3)$ : wing $+.50(1+4.3)$ : tail $1.59(40)$.

Recognition Marks. - Strictly "pygmy size," but comparison misleaslingto appearance, swallow size: rajpid erratic flight and how-and-arrow-shaped position in flight distinctive. Mtho this species is only half the size of the preceding. careful discrimination is necessary while the birds are atwing.

Nesting.-Vest: a shallow half-saucer of short twigs, glted together with 


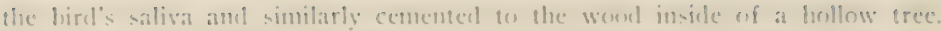

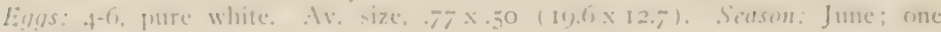
liroust.

General Range-- l'acific Cinat states and Litioh Columbiato locecling throent its range ; enth in winter to ('ontral Anerica.

Range in Washington.- Not commun smmer rewilent in timbered sections and in monntain valleys; locally distrituted.

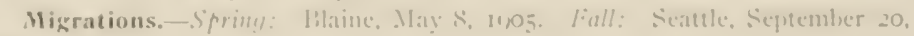
$1(x) \div$.

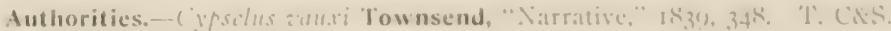

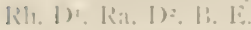

specimens.-I'ros: (’. l:

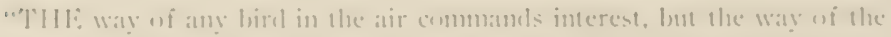

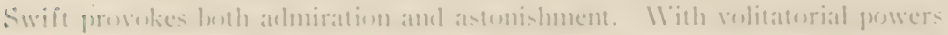
which are unepuated hy any othere lanel hirel, this avian missile geres lumrting

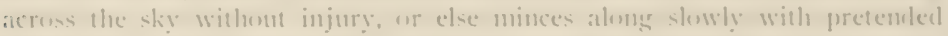
difficults. Suw it wathlles to anul iro in strange zigzags. picking wp a grath at every angle, and agean it "lighlus out" with sulden aceess wi chergy and altermate wing strukes, intent on hawking in heaven's upper story. At famrite seasons the hirels cross and rechess cach wher's pands in lawless mazes and fill the atr with their strident ereakinge, while here and there comples and exen

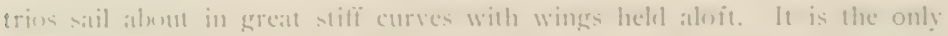

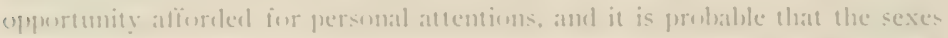
bave mo further acepuantance execpl as they pass and replats in minstering (1) the youmg

"In nesting the Chimmey 'siveeps' seek out the smaller chimmeys of dwelling houses, and usually only one pair occuples a single shast. Short twigs are seizerl and snapjed off by the bird's beak in midtight, and these, affer being rolled about in the enpions saliva, are mate lats to the bricks, a neat and homegeneons loracket heing thus formerl. 'This will he sufficient to suppore the half fomen erystal white egres and the hissing spuals which follow. molese a premalure fire or a fongecontinued rain dissolves the glue and tumbles the iabric inte the grate.

"sitting hirels, when disconered. oftenest drop lee!ow the nest and hivle, clinging easily with the tiny feet supported hy the spim tail. 'The male hirel seldem patys any attention moless there are yomes. in which case he even bruslues past the intrueler and enters the nest in lis eager-

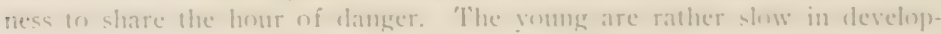

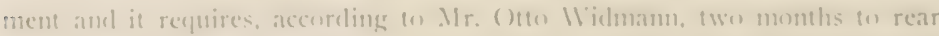
a family of them. ["sually only one broml is raised, hut a second nesting 
is undertaken even as late as August if the first has proven unsuccessful" (Bircls of Ohio).

Save in the matter of nesting, the Vatix Swift does not differ essentially in liabit or appearance from the well-known Chinney Sivift, referred to in the preceding paragraphs. It is, however, very much less common and is only of local distribution, chiefly in the lower mountain valleys. Local attachments are doubtless largely determined by the presence of large cottonwond timber, but the bircls descend to the lowlands, especially after the close of the nesting season, in small roving parties, somewhat after the fashion of the Clourl Swifts, with which indeed they frequently associate. They have thus been regularly reported by West-side observers at T'acoma, Seattle, and Bellingham, and I have seen them at Blaine, and in the valleys of the Nooksack (at Cilacier), Skagit, Nisqunally (in Rainier National Park), and (Duillaytute Rivers. 'The only East-sirle records appear (1) be those from the north fork of the Ahtanmo, in Yakima County, and the valley of the Stehekin, in Chelan County.

Vaux's Swift with tis nests only in the hollow recesses of tall dead cottomwond trees. where they glue a shallow bracket of broken twigs, cemented with hardened saliva, to the curving inner wall. In California, however, they are said to be adopting the ways of civilization, and are beginuing to nest in chimneys, after the fashion of $C$. pelagica.

\section{No. I6I.}

\section{WHITE-THROATED SWIFT.}

\section{A. O. [T. No. 425. Aeronautes melanoleucus (Baird).}

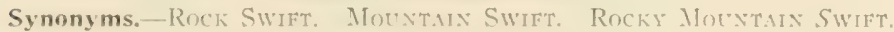
WHTE-THROATHI) Rock SWIFT.

Description.- - Idults: I'lumage black (variable, sooty brown to glossy black) ; forehead and line over eye paler; lore velvety black; chin, throat, breast. and belly, centrally, white-also onter eclge of otter primary, tips of secondaries. lateral tail-feathers, and a conspicuous patch on flank, sometimes nearly meeting fellow across rump; bill black. I,ength 7.00 (I77.8) or under: wing 6.50-7.00 (I65.I-177.8); tail $2.65(67.3)$.

Recognition Marks.-Sparrow size but larger to appearance; exceedingly rapid flight with flashing white underparts and flank patches listinctive.

Nesting.- "The nest is sccurcly placed far in holes or crevices of rocks or indurated earths, usually at a great height; it is a saucer-like structure, about $5 \times 2$ inclues, with a shallow cavity, made of various vegetable materials well glned together with saliva, and lined with feathers. Egggs several, in one instance 


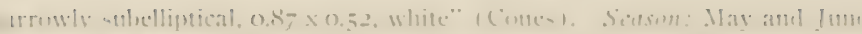

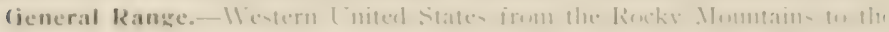

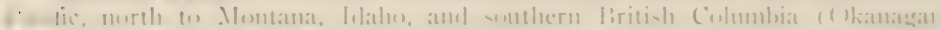
Cinatemala

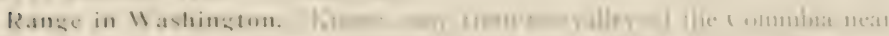

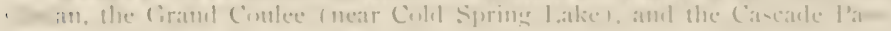

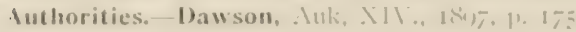

specimens.-C

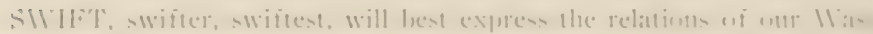

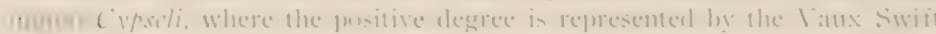

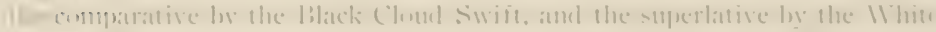

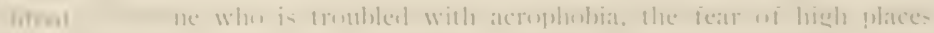

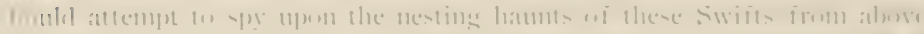

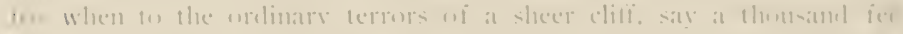

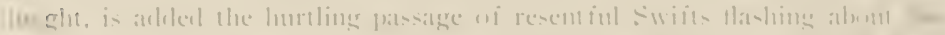

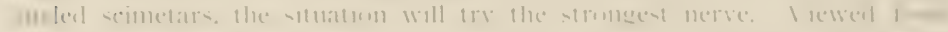

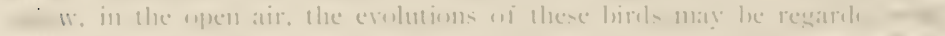

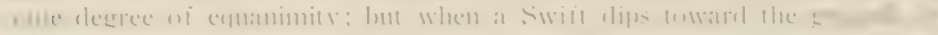

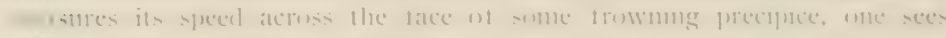
alle a really frierletul velecil

1 teined. There is mes exact

.. In i measuring this, but an

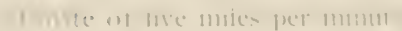

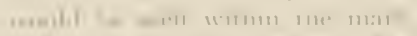

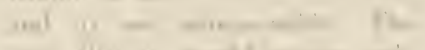

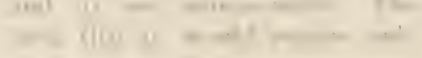

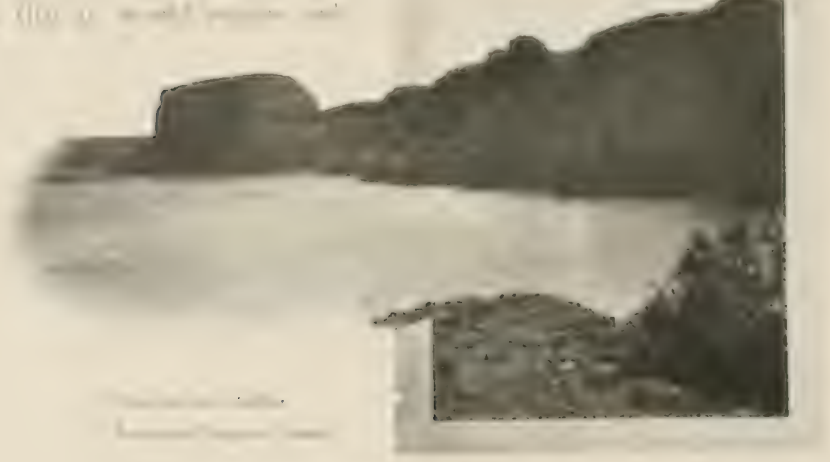

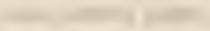


an hour to flit from Spokane to Aberdeen; or, it might breakfast at Osooyoos on the Forty-ninth Parallel, lunch in Chihuahua, and dine, a trifle late, in Panama.

This Rock Swift nests only in crevices and cates of the most inaccessible cliffs. Most of its lumting, however, is clone in the upper air, where its lighter colors soon render it indistinguishable. It appears also to be less sociable than the other species upon the hunt, so that almost the only opportunities for careful study of it are afforded near the cliffs. Here there is much anorous pursuit, and the frequent sound of thrilling notes. The characteristic notes constitute a sort of war-cry, rather than song, and consist of a liputicl descending scale of musical chuckling, or rubbing tones. The noise produced is much as if two pebbles were being fiercely rubbed together in a rapidly-filling jar of water.

The birds exlubit a preternatural cunning in the selection of nesting sites. Jot only do they choose sheer walls, but those which, because of the fissures so afforded, are crumbling and dangerous to a degree. The butte shown in the illustration consists of a hard lava capping over a clisintegrating bed of tufa, impossible of ascent and impracticable of descent. Here in some remotest crevice the bircls affix a narrow shelf. of straws, bits of weedstalks, and miscellaneous trash, agglutinated with saliva; and in this four or five narrowly elliptical white eggs are deposited late in June or early in July.

T'hese interesting birds are newcomers within our borders, and their comings and goings are as yet little known. Bendire in 1895 remarked $^{\mathrm{a}}$ their utter absence from Oregon and VVashington. In I896 I saw a single bird in the gorge of the Columbia near Chelan, and npon revisiting this scene in May, Igo6, found that quite a colony of them were haunting a granite wall some 800 feet in height. Iate in the same season, and in each succeeding year I liave found them in the vicinity of Cold Spring Butte in Douglas County; and have every reason to suppose that other such colonies exist in the Grand Coulec. In the summer of I906 Mr. Bowles and myself observed them crossing the Cascade Pass in company with Black Swifts: while still more recently. Mr. Charles De Blois Green amounces ${ }^{b}$ that they have extended their range up the valley of the Okanogan into British Columbia.

a. Life Hist. X゙, A. Birds, Vol. II., ก. 185.

b. Allan Brooks in The Auk, I'ol. XXIl., Jan. 1909. 
Nin. 16,2

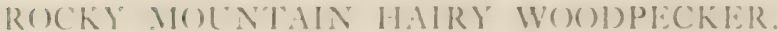

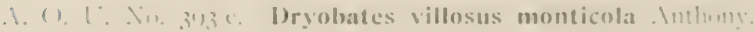

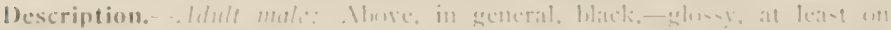

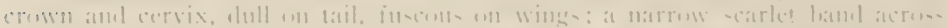

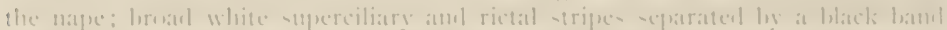

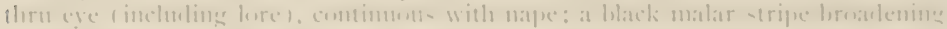

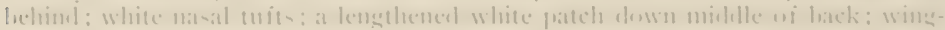

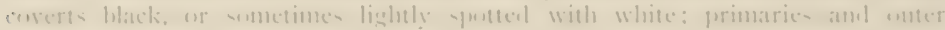

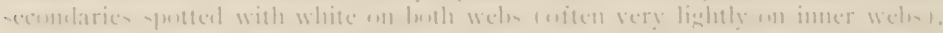

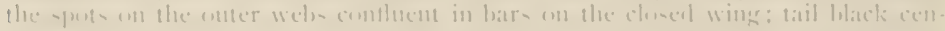

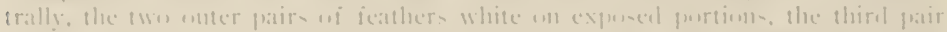

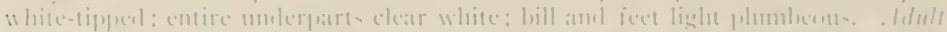

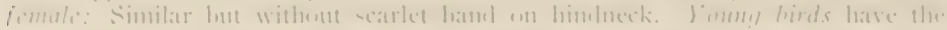

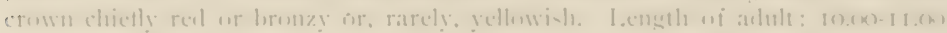

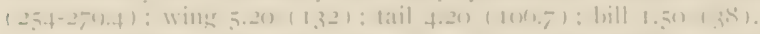

Recognition Marks. - knhin -ize: litack-ind-white pattern wi leanl 1 o

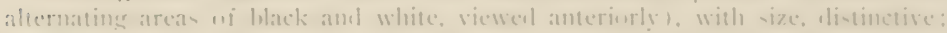

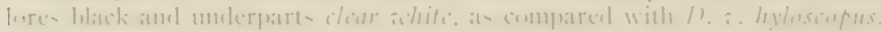

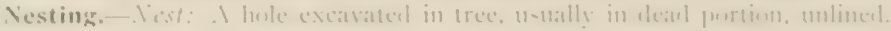

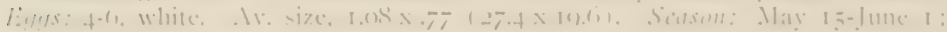
aine liтиниl.

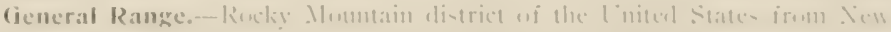

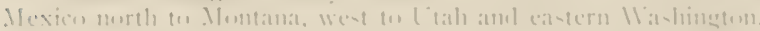

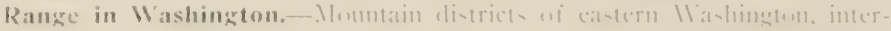

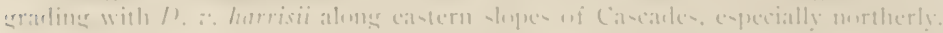

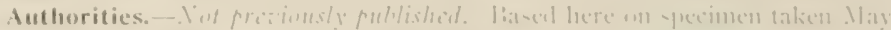

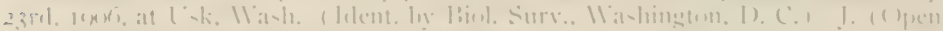

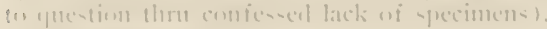

\section{specimens.-1:}

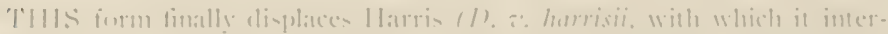

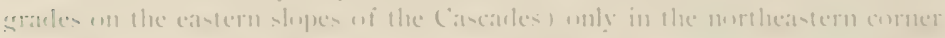

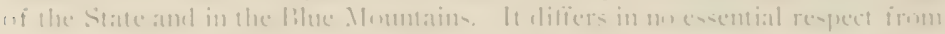

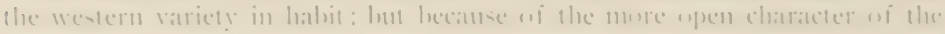
simber. in mather more in evistence thrment is range.

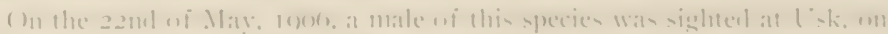

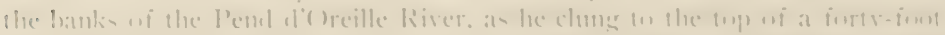

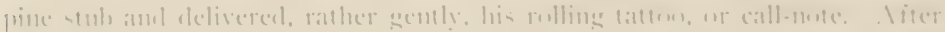

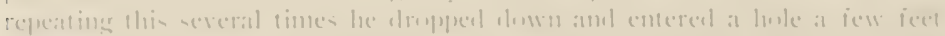

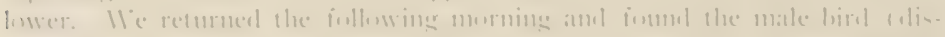

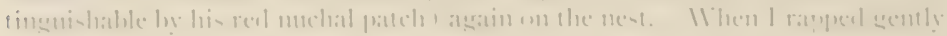


on the stub lie emerged: and proceeding to lis drumming gromel alsore, he rolled repeatedly. I3y and by the female answered in the distance with the plimp or plick note. Soon she arrived upon the nesting stub. wherempon Mr. Hairy took himself off prompty, and Mrs. Hairy entered the nesi and settled to her egers. Or Sor you would have supposed. wouklnt you? lisy the aicl of sixteen spikes, " $600^{\circ}$ ", and a rope, I climber to the nest. thirty-five feet 11]). II ith a small hand-axe I en. larged the entrance (sacrilicing inciclentally at thunt)nail, and giving sad evidence of the swaty of "mortal mincl") to fincl onle one fresh egre. inurteen incles rlomin

Of contrse it was rlisap perinting. but the ege was a pearl, so transparent that one could see the rery outlines of the imprisoned yolk.

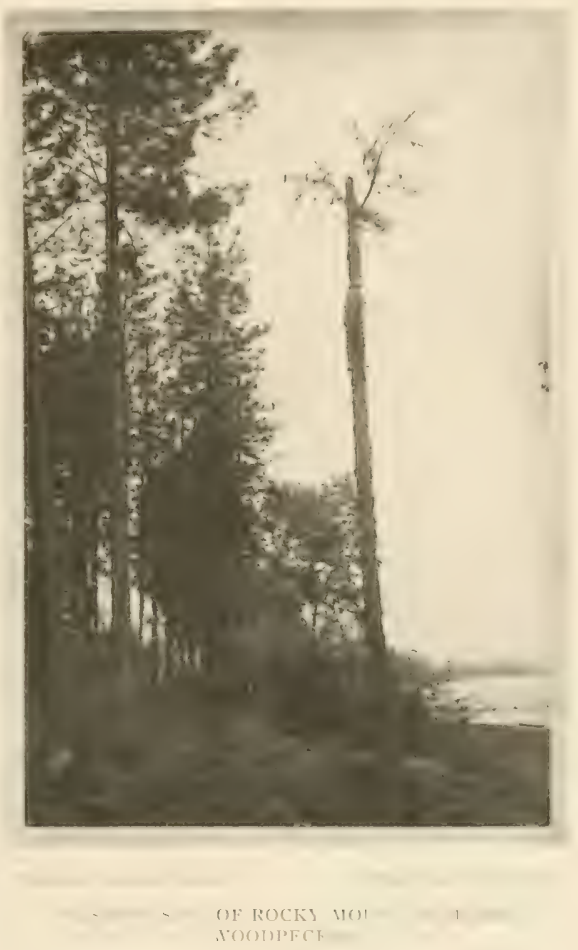

Nin. 10.2.

\section{CABANIS'S WOODPECKER.}

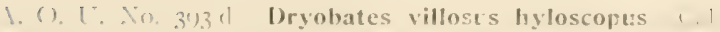

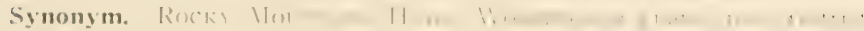
to prececline form)

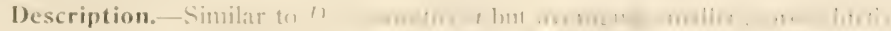

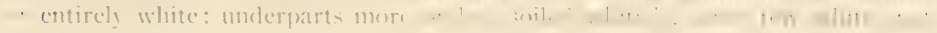




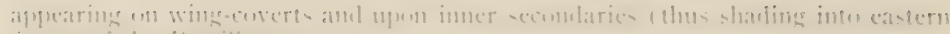

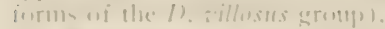

Recognition Marks.-. I in precteline.

Vesting.-1- in 1 . . - menticulu.

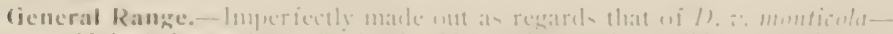

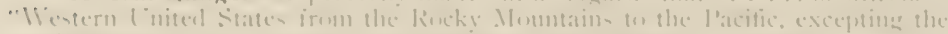

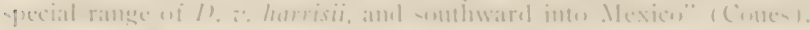

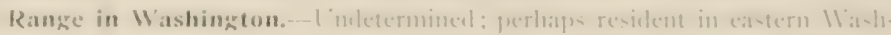

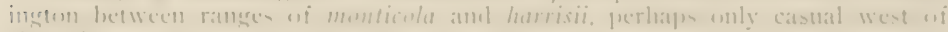
(':inciules.

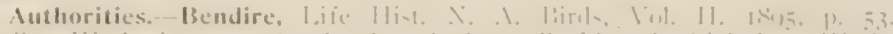

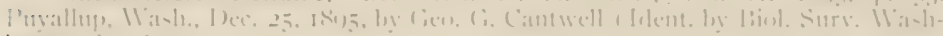
ington, 1). ('.).

\section{Specimens.- $C^{\prime}$}

H()

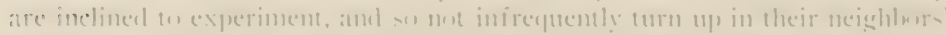

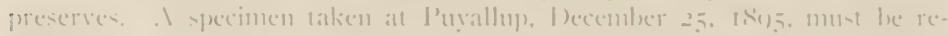

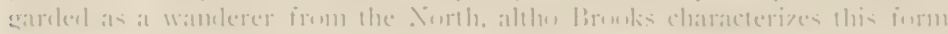
as remular at Smmatc. li. ('.

\section{ํ. 164. \\ HARRIS'S WOODPECKER.}

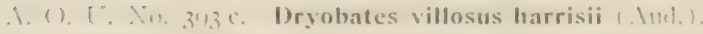

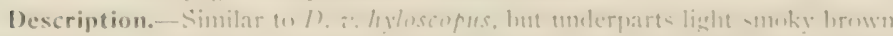

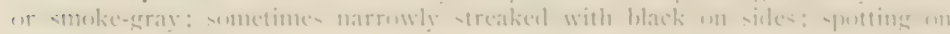

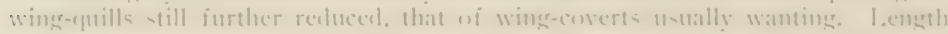

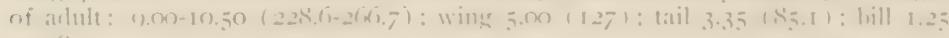
( $31, \mathrm{~s})$.

Recognition Marks.-Konbin -ize: black-and-white pattern of head ( with

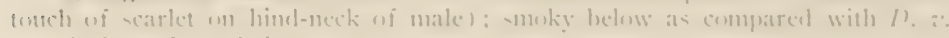

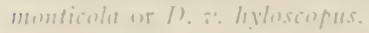

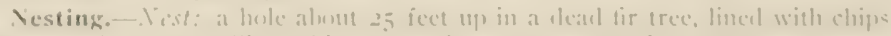

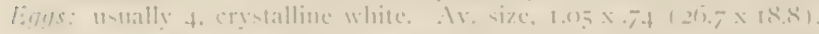

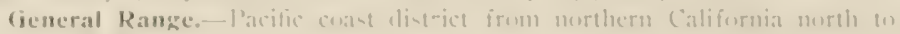
whthern Mlaska.

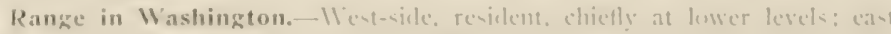

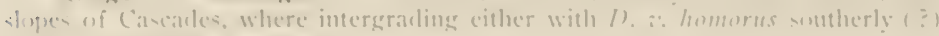
(1) I). a munficola moreherly.

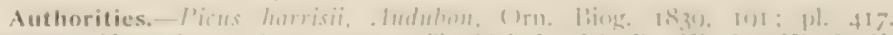

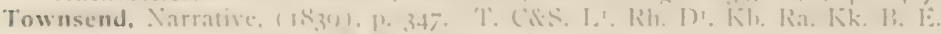

Specimens.- [', wi II: I'. H'row. H. II: 
DR. COOPER judged the Harris to be the most abundant Noodpecker in Viestern Washington: and this, with the possible exception of the Filicken (Colaptes cafor saturatior), is still true. The bird ventures well out tipon the eastern slopes of the Cascacle Mommains, and is found sparingly in the higler mountain vallers; but his farorite resonts are burns and the edges of clearings, rather than the depths of the wools. Altho he is resiclent the year around we are quite likely to orerlook his presence until onld weather appears to quick('n lis pulses. and to send him careering noisily over the tree-tops. He has spent the night. it may be, in the heart of a fir stul) at the end of his winter tummel. and now lie covers at half-woder! pasture with great boumels of tlight. shouting. plick, plick, from time to lime: and lie gives a buul rolline call-a domen of these notes in swift surcession-as he pulls (11) in the top of a dead tree to legegin the day"s work.

He is an active fellow. hitcling up) er droppling elown the tree trumk with brusque ease, and publisling his proge ress now and then in cheerful tones. Inut he knows low on be patient too. In the search for hirlden worme and burrowing larve it seens not in probable that the 1 roodpecter depends largely mpon the sense of hearing-that he

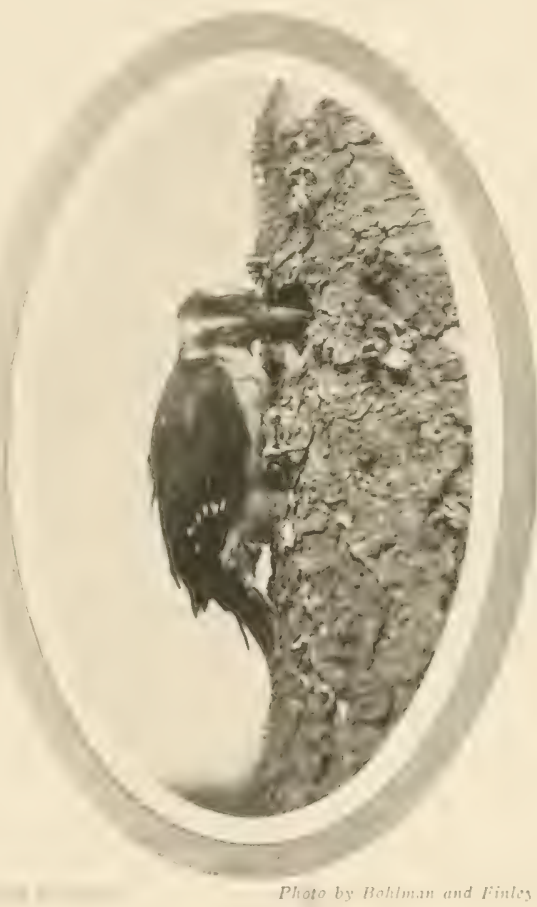

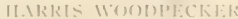
practices anscultation, in fact. I meditative tap, taps, is followed by a pause. fluring which the hirel apparently mats the effect of his strokes, noting the rustle of apprelension or attempted escape on the pant of the hidelen morsel. It is not musual for the bird to spenel a half hour tumneling for a single taste. ancl even then the wary game may withelatw along some tumel of its own. even levond the reach of the birt's extensible tongue. But hesiles that which 


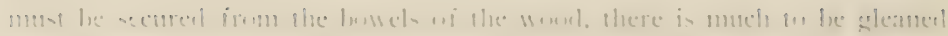

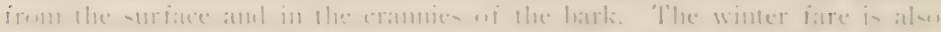

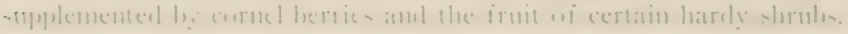

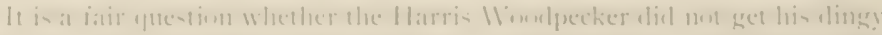

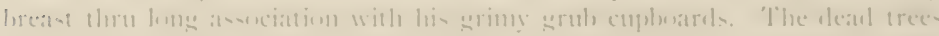

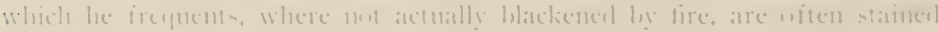

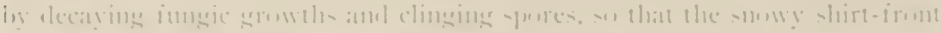

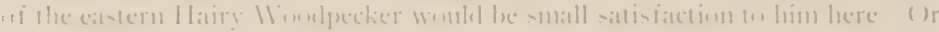

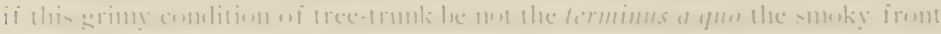

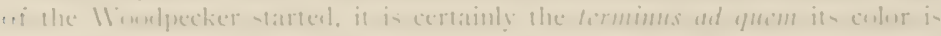

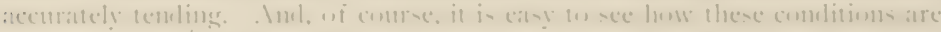

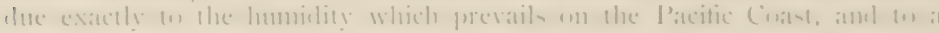

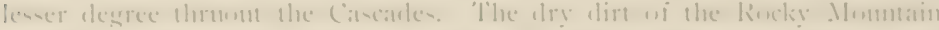

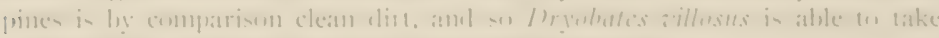

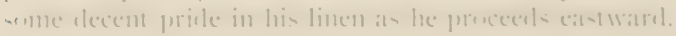

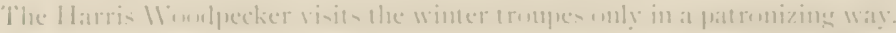

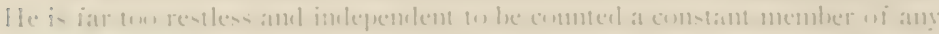

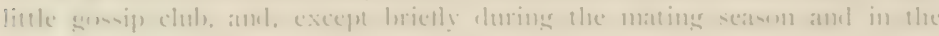

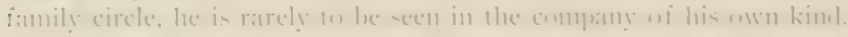

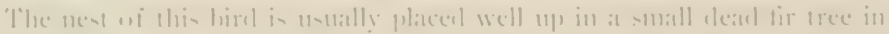

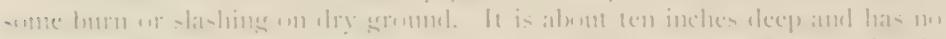

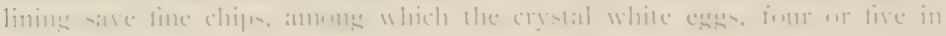

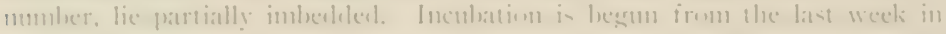

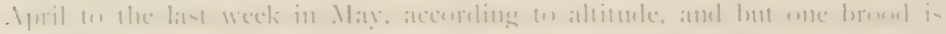

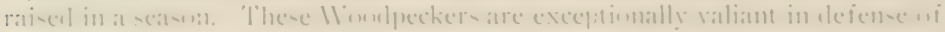

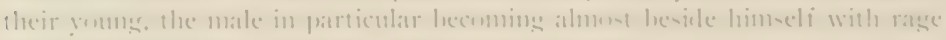
at the alpeatratece af an enemy neat the heme ne-t.

\section{No. 16.5.}

\section{IOONY W(O)IPECKIR.}

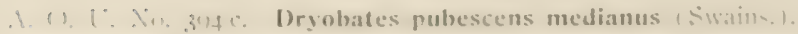

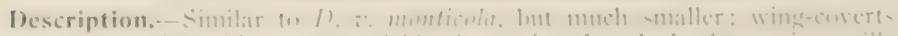

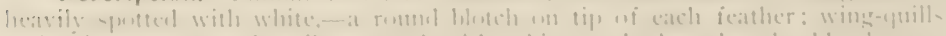

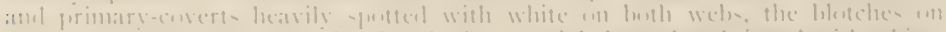

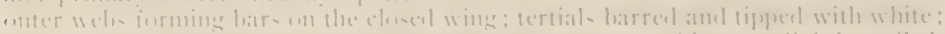

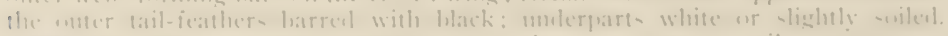

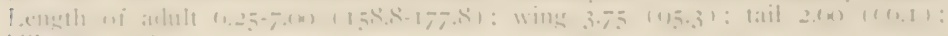

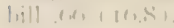

Recognition Marks.- Sparrou -ize: liak-and-white coler pattern with 
small size distinctive: red nape of male; heavily white-spotted on wings as compared with D. P. homorus; white helow as compared with D. P. yenirdnerit.

Nesting.-Does not breed in II ashington. . Vest: A loole in stub or decayed limb of tree, ustally at moderate height, unlined. Eggs: $f^{-6}$, white. Ar. size, $.75 \times .50(19) .1 \times 15)$.

General Range.- Micklle and northern portions of Lnited States and northwarl: of castral occurrence in the Pacilic Northwest.

Range in Washington.-One example, Seattle, Fich, 20, ISo2, by S. F. Rathbon1.

Authorities.-Dryobates pubescons (I,inn.), Bendire, I.ife Hist. N. A. Lirds, Iol. II. Iso5. Pp). 55. 56. Ra.

Specimens. $-\mathrm{P}^{1}(?)$. C. Eे.

ON the 20 h of February, ISo2, Mr. S. F. Rathbun took what is consirlered to be a typical specimen, a female, of this species, near seattle: and on the $23 \mathrm{rel}$ of March, I 896 , I took one at Chelan which belongs either to this or to the more recently elaborated $D$. P. nclsoni. Apart from $D$. ynimerii, whose center of distribution, at least, is pretty well known, great confusion exists in our knowledge of I probales pubescens and its rarieties in the Northwest. Downy Woulpeckers are not migratory, but they rove consiclerably in winter, and the most we can say of these IVashington specimens is that they point (o) the presence of $\mathrm{D}$ ). pubescens or D. P. nelsoni, or both, as resiclent bircls in British Colmmbiat.

No. 166.

\section{BATCHELDER'S WOODPECKER.}

A. (). I . No, $39+$ 1). Dryobates pubescens homorus (Cab.).

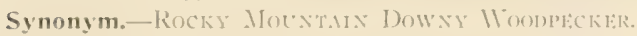

Description.-Similar to D. P. medianus, but larerer, clearer white below, and with less white spotting on wing, that of midklle and greater coverts reduced or wanting. Length : 6.75-7.50 (171.5-100.5) wing $4.00(101.6)$; tail $2.65(67.3)$; bill .73 ( 18.5$)$.

Recognition Marks. - Is in preceling; white spotting of wing recluced as compared with I). p. mediante: molerparts clear white as compared with D). P. ycuirdncrii.

Nesting.-. Viest and Legeps as in preceding. Seuson: May: one brood.

General Range.-Rocky Mountain region of western Linited States and British Columbia, west to castern slopes of Cascade-Sierra Range.

Range in Washington.- lisat-side, not uncommon resilent, especially in 
valleys of mere leavily timberel section; intererale will nexs furm on castern: slopes of ciavcarles.

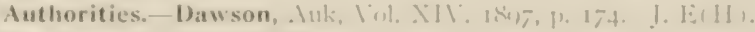
specimens.- (', ai 11'. I'ros:

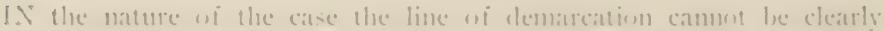

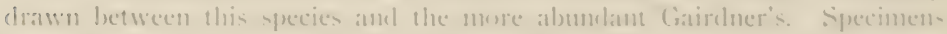

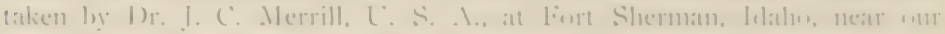

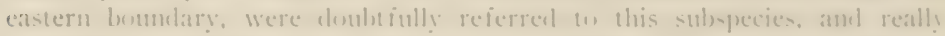

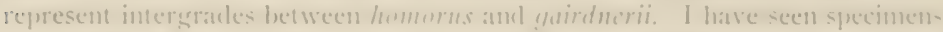

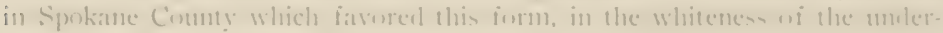
parts, much more strongly than gaindmerii.

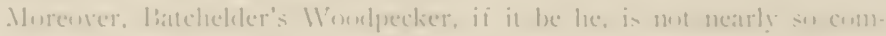

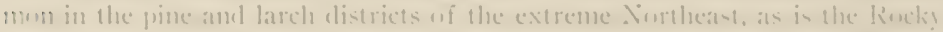

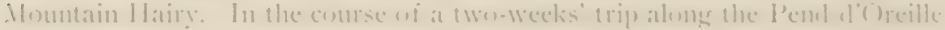

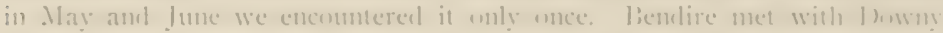

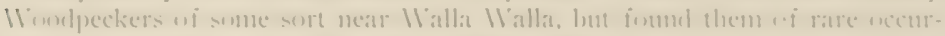

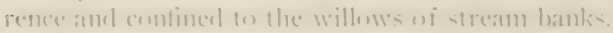

No. $16 \%$

\section{GAIRIONER'S IVOOIDPCKER.}

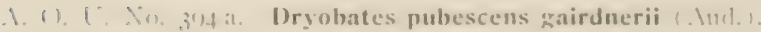

Description. - Similar to $/ 1$. $f$. homorms, hut white ymuthes of wing still

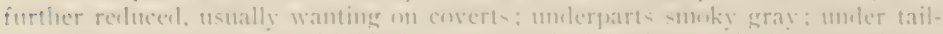

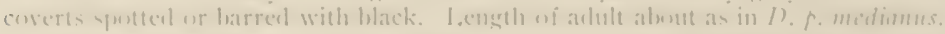

Recognition Marks.-Sparrow size; black-and-white pattern of heaul: white late contractime with hlack seapulars, etc: much the commenest womprecter: wing searecty spotled as compared with II. r. midimus: molerpars- muky as complared with l). r. homortus.

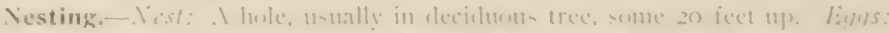

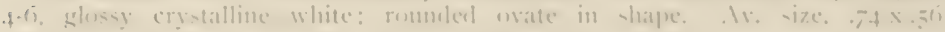

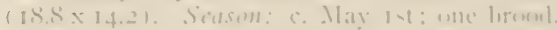

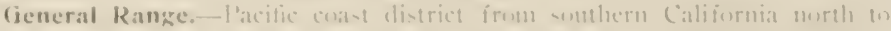

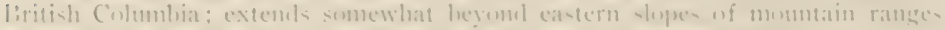

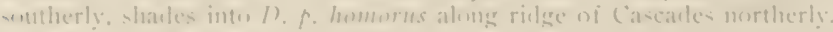

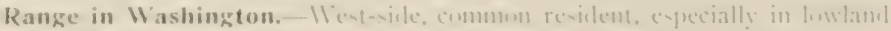

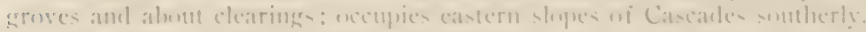

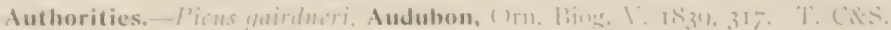

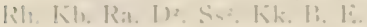

Specimens.-Ii of II: l'ros. It. IS. 


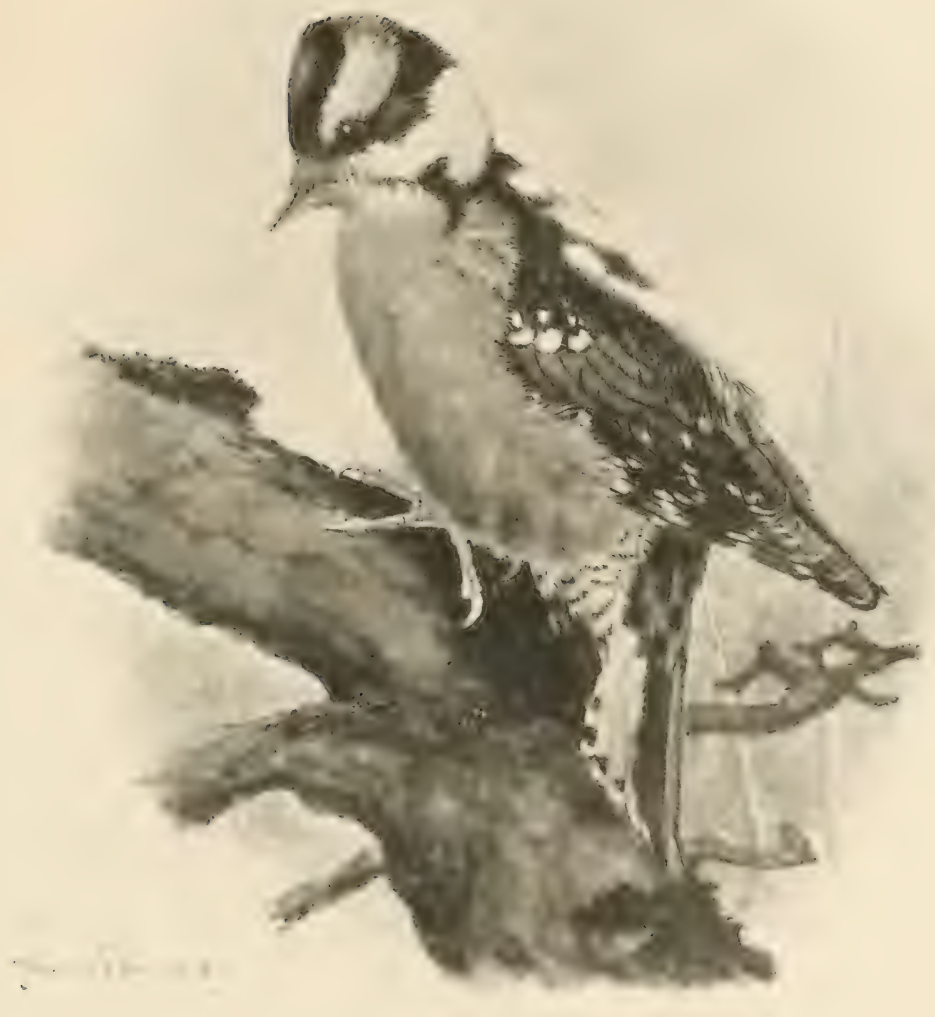

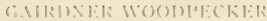




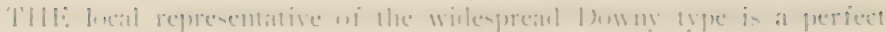

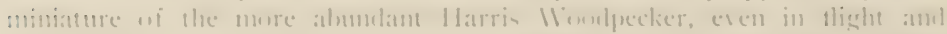

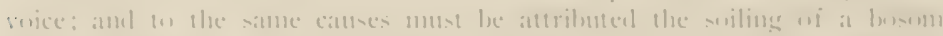

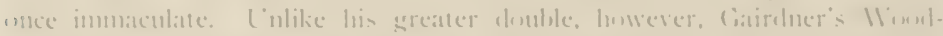

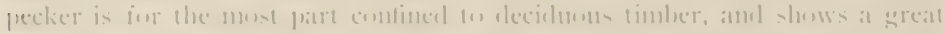

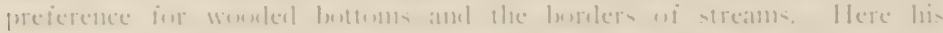

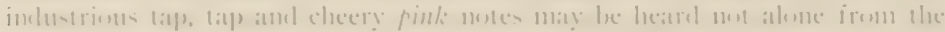

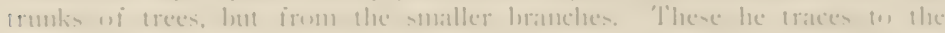
lery cuel in a search fur lurking smols ar nit.

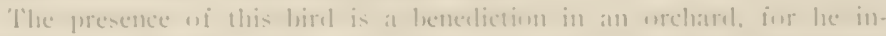

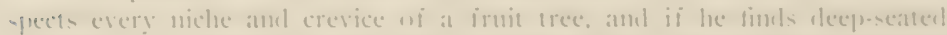

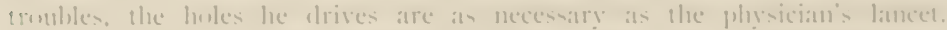

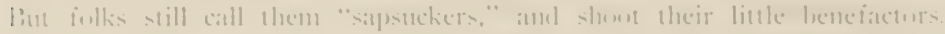

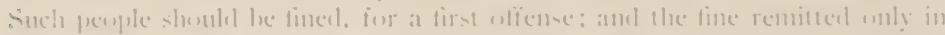

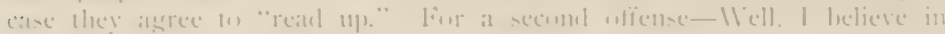
anvital punislment mescli.

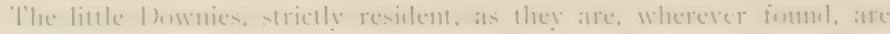

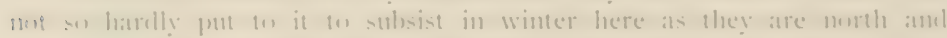

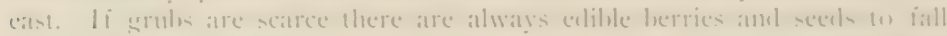

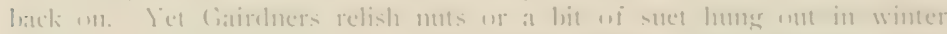

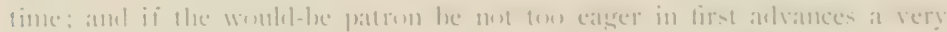

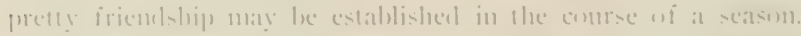

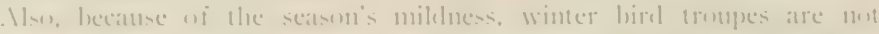

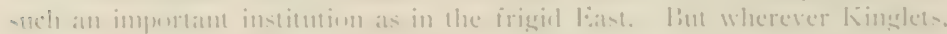

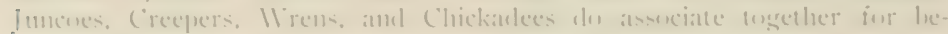

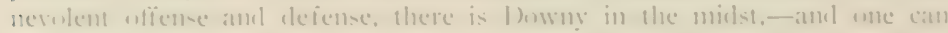

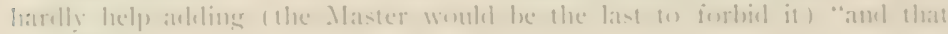
1.. hilew.

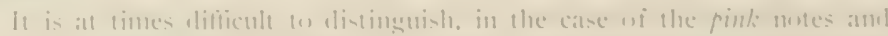

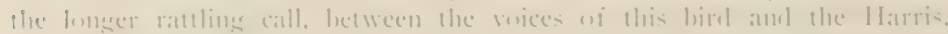

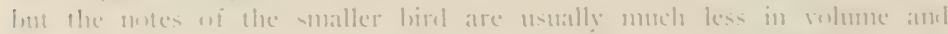

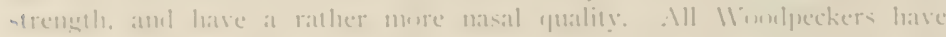

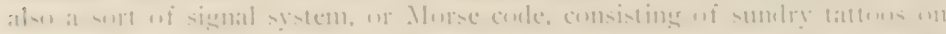

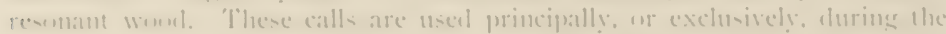

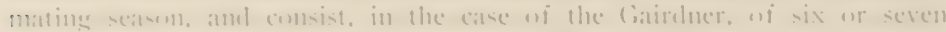

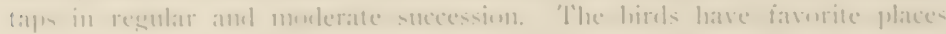

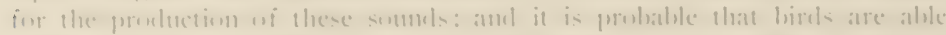

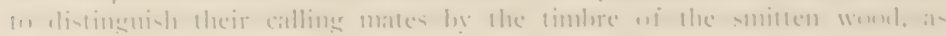

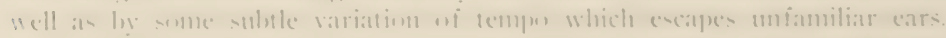

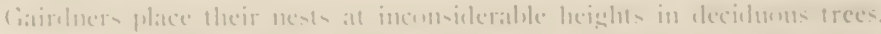

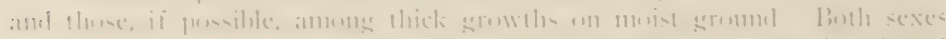

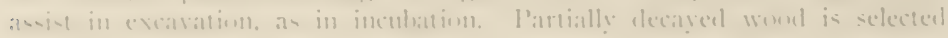


and an opening made about an inch and a quarter in diancter. After driving straight in an inch or two, the passage turns down and widens two or three diameters. At a depth of a foot or so the crystal white eggs are deposited on a neat bed of fine chips. Incubation lasts twelve days and the young are hatclied alout the ist of Jume.

Ir. Bowles asserts that when a tree containing eges is rapped the sitting birl will try, sometimes stccessfully, to deceive the incuirer by coming to the entrance and dropping ont a nouthful of chippings, thus conveying the impression that she is still building. It's a shame to give it away.

No. 168.

\section{IVHITE-HEADED IVOODPECKER.}

1. O. L. No. 304. Xenopicus albolarvatus (Cass.).

Description.-Adult mule: Body plumage and tail ghosig black; wings dull back with large blotel of white on median portion of inner prinaries and secondaries, and sone discomnected white spotting distally; throat and entire head (not (leeply) white; a scarlet patch on naye. libll and feet shty black: iris red. Fomale: Exactly as male without scarlet muchal band. Length: 9.00-0.50 (228.6$2+1.3)$ : wing $5.15(130.8)$ : tail $3.50(88.9)$.

Recognition Marks.-Chewink to Robin size; white heal mipue.

Nesting.-. Nest: A hole in live pine tree at moderate height. Eygys: 3-7.

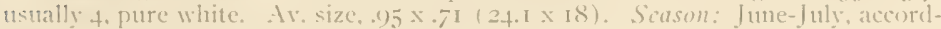
ing to altitude; one brood.

General Range.-Nomtains of the I'acific Coast States north into liritish Colmmlia, east to Irlaho and Litah.

Range in Washington.-Resiclent in the monntains, chicfly cast of the Cascacle summit.

Authorities.-l'icus albolureatus, Baird, Rep. I'ac. R. R. Surv. 11. I\&58, p. 97. (X). D. D) D . J.

Specimens.-l'rov. C.

THERlis is a Gray's Harbor record for this birl, but the ocenrence is unique west of the Cascalles. So far as onm experience goses, the llhitehearl is to be looked for only in the pine limber which clothes the eastern slopes of the Cascades and their ontlers. The range of the species extends catsually northward into liritish Columbia, hut the southern bumelary of (oregon is nearer its center of distribution, and the birds recrease rapilly in numbers north of the Peshastin Range in IV ashingtom.

At first glance we would saty that this bird eschews protective coldoration alongetler, but Mrs. Ihailey argues that even black and white are not very 


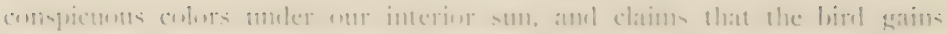

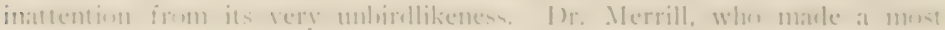

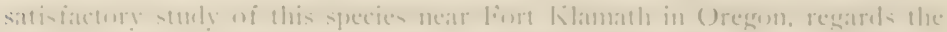

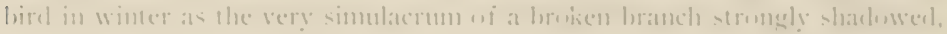

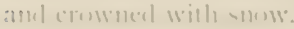

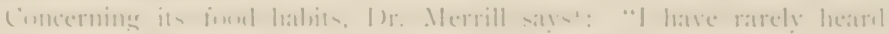

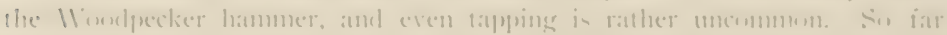

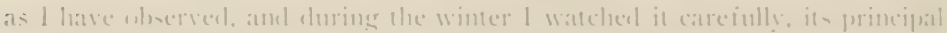

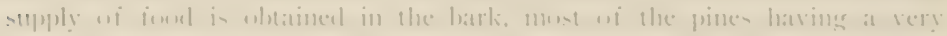

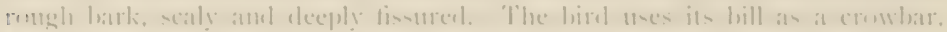

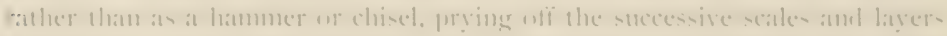

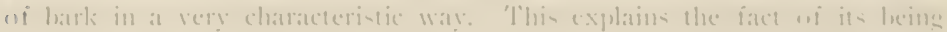

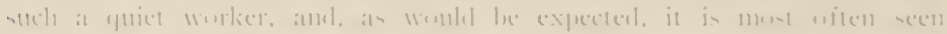

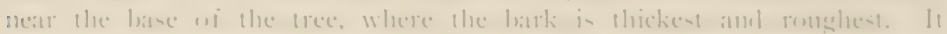

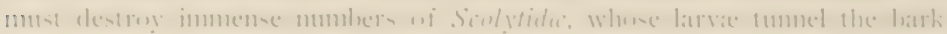

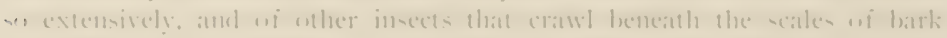

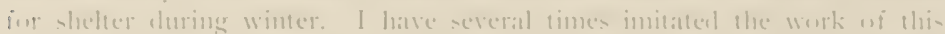

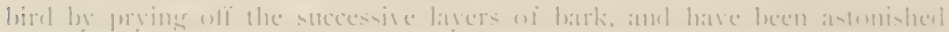

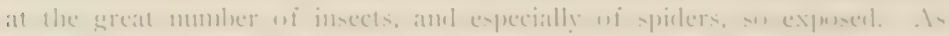

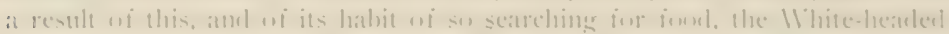

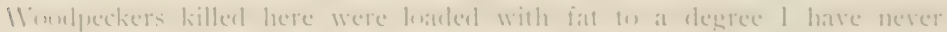

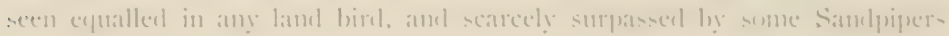
in :แ1tumun."

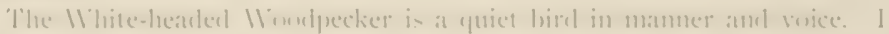

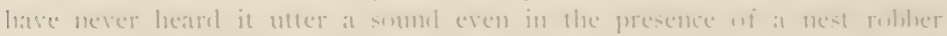

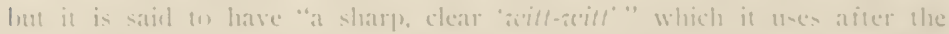

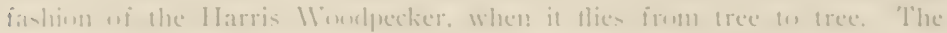

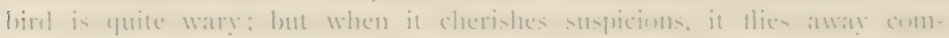

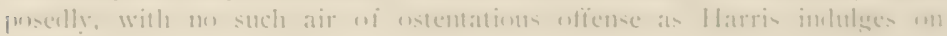
me:asint

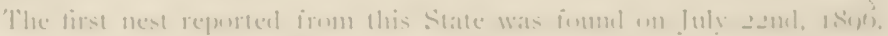

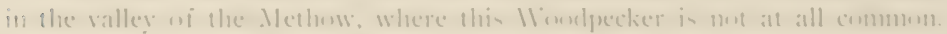

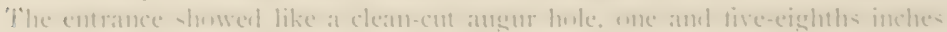

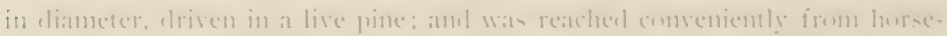

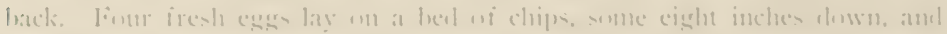

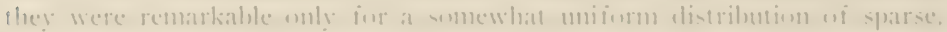

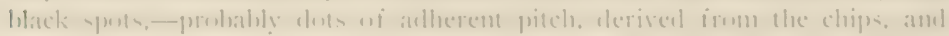
soleel to hlacknes he contact with the -itting hirel. 
No. 169 .

\title{
ARC'TIC 'THREE-TOED WOODPECKER.
}

\author{
1. O. L. No 400. Picoides arcticus Swains.
}

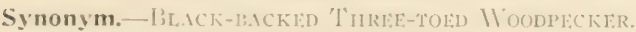

Description.-Idult male: Upperparts glossy blue-black, duller on flight feathers; primaries and onter secondaries with paired spots of white on edges of outer and imer wels: a squarish crown-patch of yellow (carlmim orange); a small post-ocular spot of white, a transverse white cheek-stripe meeting fellow on forchead and cut off by black malar stripe from white of throat and remaining underparts: sides hearily barred or mingled with blue-black. Pill and feet plumbens black: iris brown. Adult female: I.ike male, without yellow crownpatch. Length 9.00-10.25 (228.6-260.4) ; wing 5.25 (133.3) ; tail 3.50-4.00 (88.0101.6); bill $1.25(31.7)$.

Recognition Marks.-Chewink to Robin size: yellow crown-patch of male; back without white as compared with $P$. americamus fasciatus; and black of heacl continuons with that of back as compared with the Drlobates zillosus group.

Nesting.--Not known to breed in Washington, but probably does so. Nest: hole in pine or fir stuh, IO-I8 inches deep. Liggs: $4^{-6}$, white, moderately glossed. Ar. size, .96 $5.72(24.4 \times 18.3)$. Scason: last week in May, June; one brood.

General Range.-Northern North America from the Arctic regions south to northern tier of states, and in the Sierra Vievarla to Lake l'ahoe, south in New England and in Mlleghany. Mountains in winter, but breeding thruout western range.

Range in Washington,- Rare resiclent in confiferous forests of the central Cascades.

Authorities.-["Black-backed three-toed wookpecker," Johnson, Rep. Gox. 11. '1'. I884 (1885), 22.] Bendire. Life Hist. . . A. Pirds, Vol. II. I895. p. 7t. E.

Specimens.- L. of II. I'ror. C. E.

'JHE: Plack-backed 11 roodpecker should occur in all our mountains. and especially rpon the pine-timbered slopes of the eastem Cascades and in the Blue Mountains. It must, however, be considered rather rare, for we have never met with it afield, and have records of only two specimens. one taken at Glacier and the other near I ake Kichelas. 'The species is practically non-migratory and should breed wherever it occurs. It is ordinarily a very quiet bird, devoting itself assidunusly to its search for treeboring insects and their larve, chiefly Buprestide and Cormblecide; and at other than breeding seasons appears stoliclly to ignore the presence of strangers. Its note is described as a sharp, slurill "chirk, chirk"; and it is besicles a most persistent clrummer, rattling awaty at a single station for 


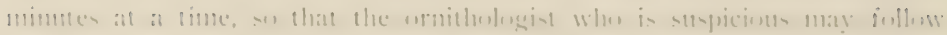

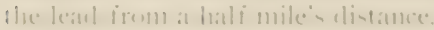

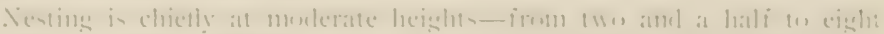

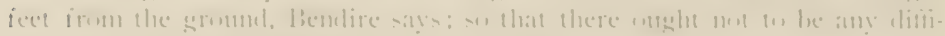

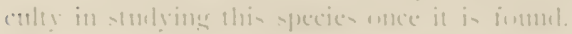

\section{No. 170 .}

\section{AIASKAN THREE-TOIED WOOIPIEKKR.}

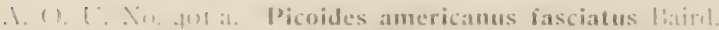

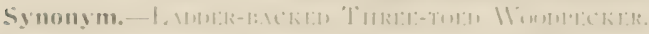

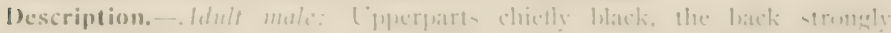

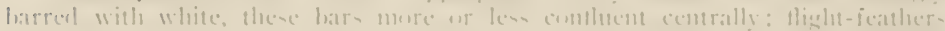

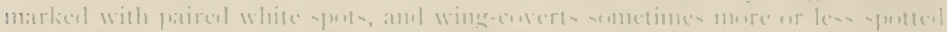

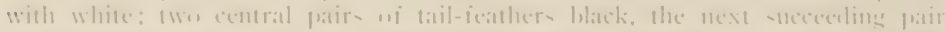

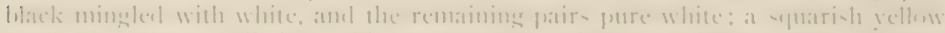

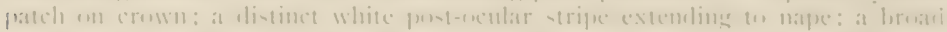

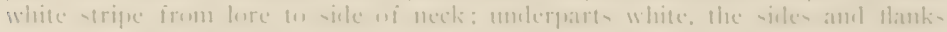

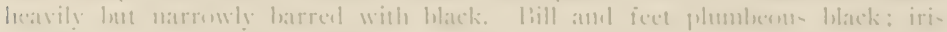

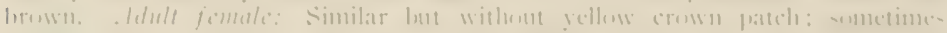

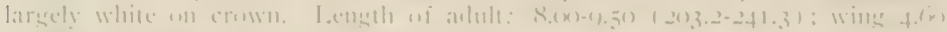

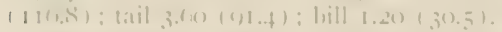

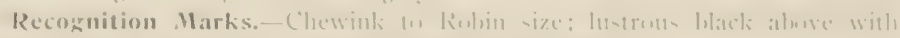

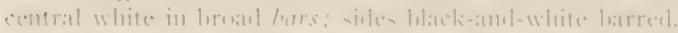

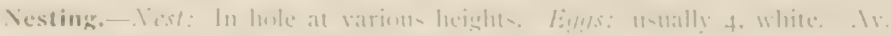

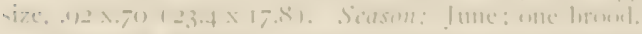

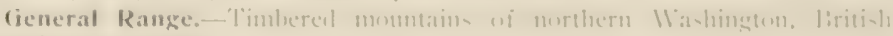
Cilumbia and Mlaka.

Range in Washington.- sparingly revilent in mertherm ca-carlen.

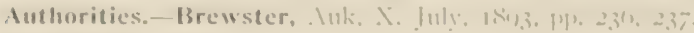

Specimens.-I'rus: (')

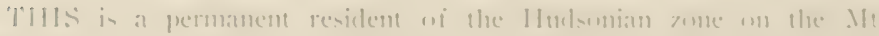

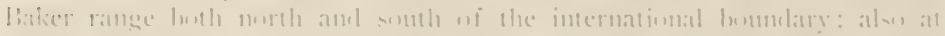

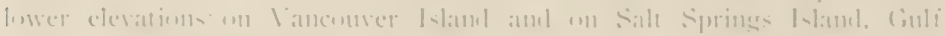

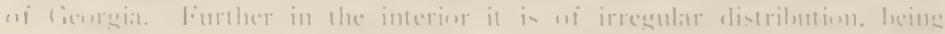

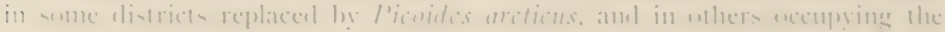

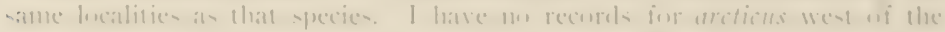

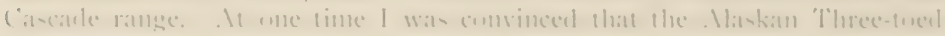

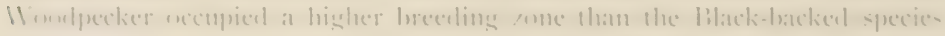

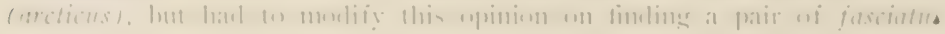


breeling in the low hills back of Clinton, where one would hardly expect to find any thee-toed woodpectier. Lstaliy the species is found in the gloomy forests of balsam, spruce, and hemlock, and up to timber line Here it is a silent bircl, its tapping being nsually the only sign es its presince.

'The cry is a slarp cluck withont the insistent ring of its allies of the Dyrobates group). In spring the usual chattering cry, common to so many woolpeckers, is heard, but this is more sublued and guttural than that of the Hairy 11 oodpecker. The males will also hang for hours on some dead spire beating the regular rattling tattoo of all true woolpeckers.

When shot, even if instantly killed, three-toed woolpeckers of both species have a marvelous faculty of remaining clinging to the tree in death. Where the tranks are draped with Lsnea moss, it is impossible to bring one clown, except when winged-then they attempt to fly, and fall to earth: but when killed ontright they remain securely fastened by their strong curred claws. Repeated shots fail to dislorlge them, and it is no joke to (lrop) a big tree with a camp axe, as I have done, only to find at the finish that you cannot disonser the object of your quest in the tangle of broken branches and dense rhododendron scrub. The only clance is to leave the bircl and to visit the font of the tree when the relaxing muscles have at length permitted the boxly to drop-ustally within two days. Once I was fortunate enough to observe the exact position that enabled the bire to maintain its srip. I had slot and killed an Arctic Three-toed IVoofpecker on a low stmmp. On going ups I found the bird's feet to be three inclues apart by measurement; the tail was firmly braced, and the further the body was tilted back the more firmly the claws held in the bark.

\section{AI,INA BROOKS}

No. 171 .

\section{RED-NAPED SAPSUCKER.}

\section{A. O. [. . .0. 402 a. Sphyrapicus varius muchalis Iharcl.}

Description.-. Idult mule: I'ilemm. throat, and nuchal hancl carmine for poppy-red to crimsons): crown and throat patches delined hy liack, narrowly on sirles, broadly behind, the black border of throat below forming a conspicuons crescentic chest-band : a white streak orer and behind eve, more or less continunus with black-and-white mottling of 11 prer-lack: a transverse stripe from nostrif around throat and chest, and continutous with white of underparts: remaining

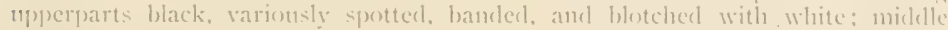
coverts and upper tail-coverts nearly pure white, the lirst-naned forming with the exposed eclees of the greater coverts a broad white wing-band: underparts centrally pure white or flusherl with sulphur-yellow: sicles, flanks, and under tail- 


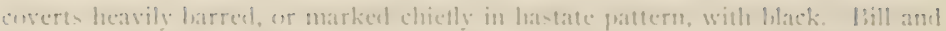

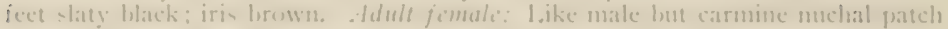

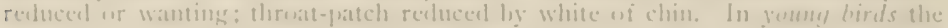

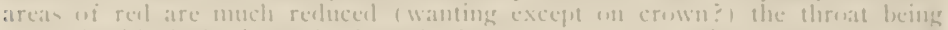

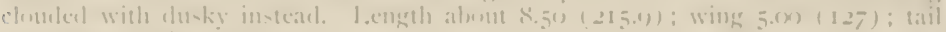
3.20 181.31: hill 1.(x) 125.41 .

Recoguition Marks. - Chewink sze: lighly variegated hlack, white, and red

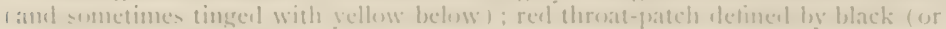
white alduse in iemale, distinctive.

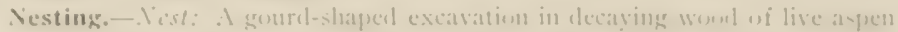

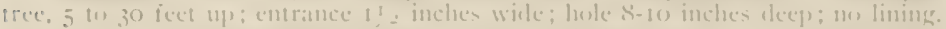

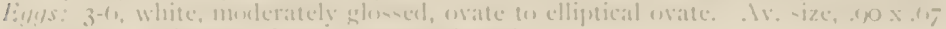

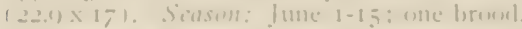

(jeneral Range.-Recky Mommtain and adjacent ramgen irom . Irizona and

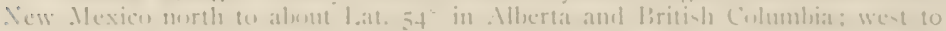

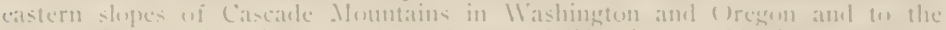

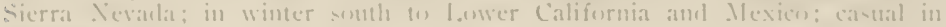
Kiancils.

Range in Washington.-In general, in the hilly constery wi the mortheantern

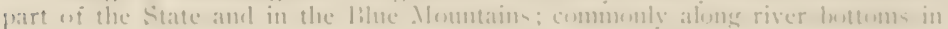

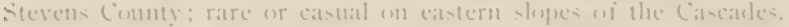

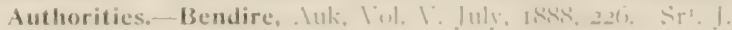

Specimens.-I'rov. C.

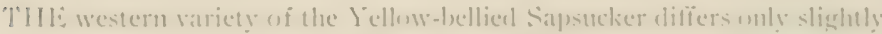
from the eastern hirl in appearance, and met at all in clisposition. () f anrins I have alreaty saicla :

liefore the maple sap has ceased rumbug, our words are imbaled from the sonth lo a small army uf humgry Sapsuckers. 'The hirds are rather unsuspicions, quiet, and sluggish in their movemems. 'l'heir commen mote is a clrawling and petulant lice-d, like that wi a distant llawk lut they use it rather on vent their feclings than wo call their fellows, for atiho there may lec twenty in a given grove, they are only chance associates and hate nu, dealings one with another. Starting near the lentenm of a iree, one goes hitching his way up the trunk, turns at lazy back-somersault is reinspect some neglected erevice, or leaps ont intu the air to capture a passing insect. The huth of this bird's foxel, huwever, at least during the migration, is secured at the expense of the tree itself. The rough exterior lark laver, or cortex of. say, a maple, is strippeel wif. and then the bircl drills it transwerse series of owal or roughly rectangular holes through which the sap is sementhwing. The immer loark is eaten ats remused and

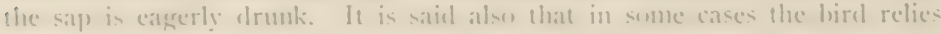
mpen this smgar-bush on attract insects which it likes, anel thus makes its 
little wells do triple service. Aconding to Professor Butler, an observer 11 Indiana, Mrs. J. L. Hine, once watched a Sapsucker in early spring for seven hours at a stretch, and during this time the bird did not move above a vard from a certain maple tap from which it drank at intervals.

Orchard trees suffer occasionally from this bird's depredations, Dut the sap of pine or fir trees is its favorite diet and available the year around.

In nesting the Red-naped Sapsucker shows a marked preference for aspen trees and its summer range is practically confmed to their vicinity. $\therefore$ nest found on the banks of the Pend d'Oreille, opposite lone, was placed twenty-five feet ny in an aspen tree some sixteen inches in diameter. The tree was dead at the heart but there was an onter shell of live wood two inches in thickness. The bird had penetrated this outer shell with a tummel as rouncl as an augur-lole, and an inch and a half in clianeter, and had excavated in the soft heart-wook a chamber ten inches (leep vertically; five and a half horizontally, and three from front to back. Here five eggs, "as fresh as paint," reposed on the rotten chips. Like all, or most, Moodpecker eggs, these were beatifully transparent, with the position of the contained yolk clearly indicated. One egg was broken with a snall round hole, as tho a careless claw had been stuck into it.

The parent birds, especially the male. who was canght on the egrgs as tho inspecting the latest achievement, were very attentive, flying back and forth in neighboring trees, and giving utterance to the kos all and other notes. After my descent from the ruined home, the male alighted beside the hole and tapped at the edges, as tho seeking in the sound of the wood explanation of the clisaster.

No. 172.

\section{RED-BREASTED SAPSUCKER.}

A. O. U. No. 403. Splyrapicus ruber (Gmel.).

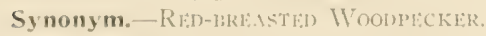

Description.- Idult male: Somewhat as in preceding but distinctive markings of head and neck and chest nearly obliterated by all-prevailing carnine which reaches well rlown on lureast: marks alluded to most persistent in anterior portion ni transverse (white) check-stripe and in black of lores: breast (posterior to carmine) and remaining underparts strongly suffused with yellow; white spotting

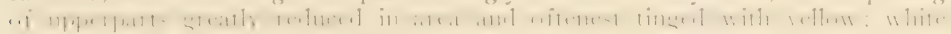
wing-bar fully persistent but often yellow-tinged-thus an evolved form of $S$. . 


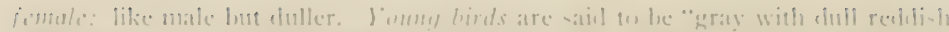

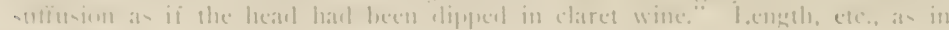
frecerling:

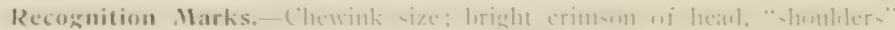

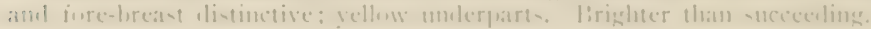

Vesting. - Vest and limes an in st. r. metlinsis.

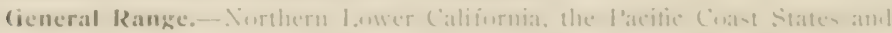

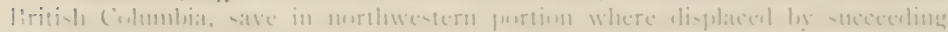
furms: retire irtom merthern purtion wi range in winter.

Range in Washington.-Summer revilent ant migrant cheth alonge the

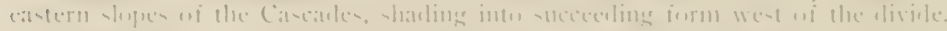

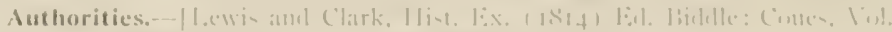

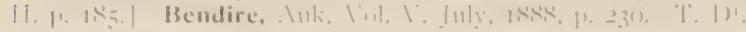

specimens, - 1', ni 11 .

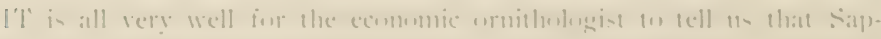

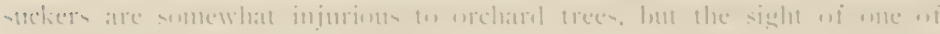

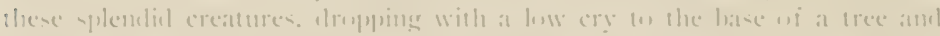

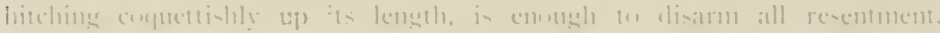

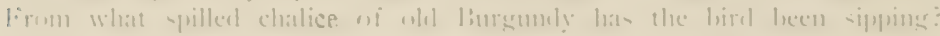

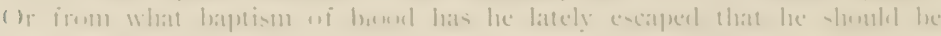

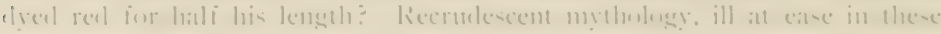

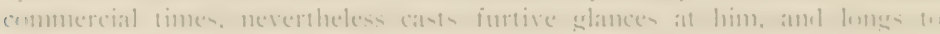

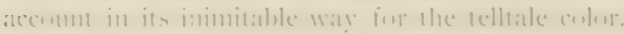

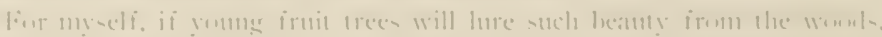

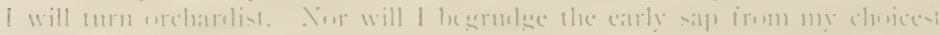

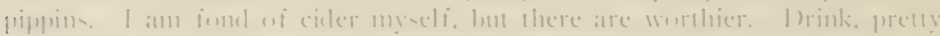
creature, drink!

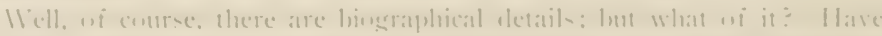

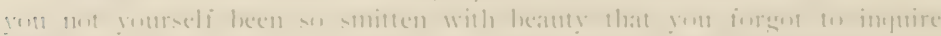

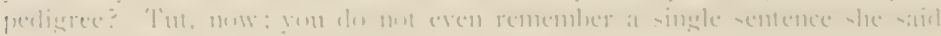
that rlas: lint you rememher her. Fimmsht

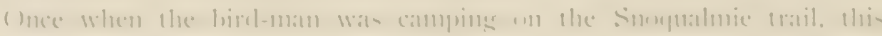

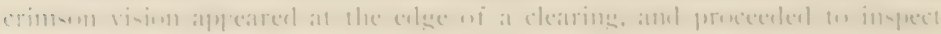

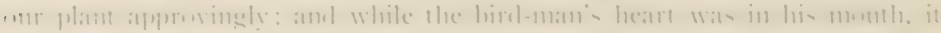

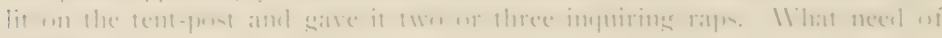
letails! 



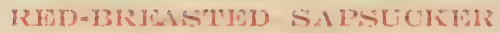

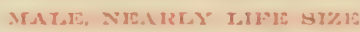

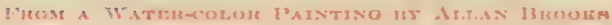




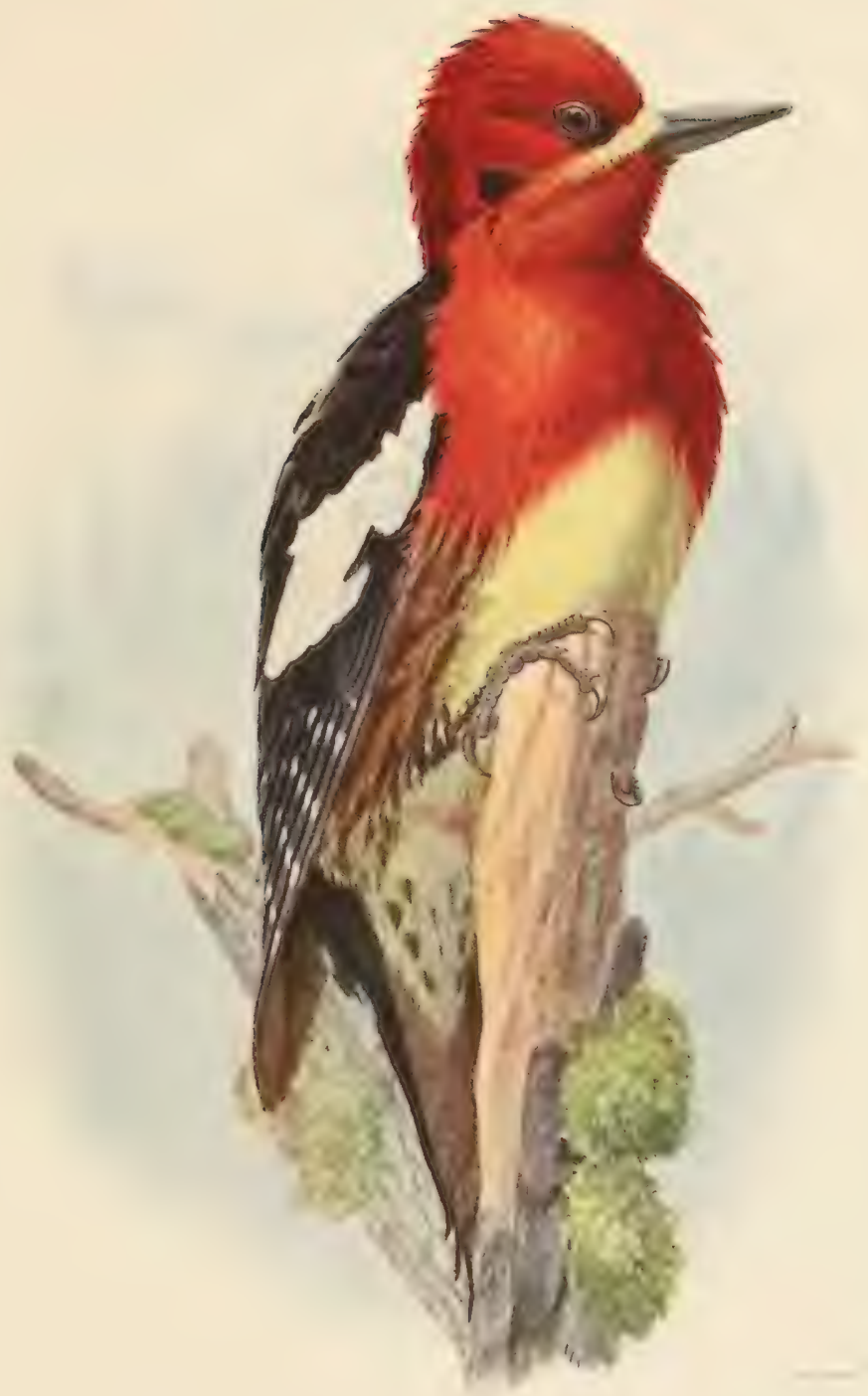



No. 173

\section{NORTHWEST SAPSUCKER.}

A. O. L. No. 403 a. Sphyrapicus ruber notkensis Suckow.

Synonyms.-NORTILIRX RED- BREASTII) SIPSTCKER. CRIMSON-IIF.ADED IIVOMIPECKFR.

Description.-Like preceding but clarker, red a deep crimson or maroon purple. Original markings of $S$. íarius muchulis still further effaced. Av. measnrements of two atdults from Glacier: 1.ength, 0.94 (252.5); wing 5.2. (133.1); tail $3.40(86 .+)$; bill 1.03 (26.2).

Recognition Marks.-Chewink size; clark crimson of head, neck, and breast distinctive.

Nesting. - Vest: in unlined carity excavated in dead fir or living deciduous tree, ustally at considerable height. Liggs: 5-7, white. Ar. size, .92 $\times .69(23.4 \times$ I7.5). Seuson: May or Jume; one brood.

General Range.-Breeding in Northwest coast district of North America from ()regon to Sitka. Alaska; south in winter to southern California.

Range in Washington.-Summer resiclent west of the Cascacles; also partially resiklent in winter.

Authorities.-Shyrapicus mocr Baird, Baird, Rep), Pac. R. R. Smr. 1A. $1858,[1), 104.105$. C\&S. Rh, Ra. B. E.

Specimens.-P. I'rox. I3. E.

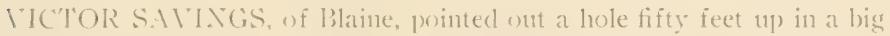
fir stul, as the Salpsucker's nest. Soon the fenale flew to the entrance: wherempon the male birel emereed, gorgeous in crimson panoply, and flew away, the female taking lis place on the eggs. After a bit Victor pounderl on the tree to raise a pussible Ilarris further up. for the tree above is riddled with nesting froles. 'The female Sapsucker promptly thrust out her head and sturlied the situation fur five mimutes or so, after which slie (lropped back content. The only motable thing alout the nest exterually was a round smooth patch, the size of a chllar, upen the tree about four inches below the nest, wom and polislued by the tail-feathers of the alighting birds. Judged by this mark of ictentification, only one of the untsed holes above belonged to the Sapsucker: the remainder to the IIarris Woolpecker.

The stub commands at view of the Sarings's orchard, where. Victor says. the Sapsuckers ro immense dimage, especially to the pear trees. 'T'his nesting tree was sixteen feet aromel at the hase, above the root bulge, and perfectly resolate of limbs. fortumately, also, it had long since disposed of its shagey cratt of bark, - iortumately. I say. for when a fir stuls sherls its lir coat it deres so sucklenly. and great is the fall thereof.

It was a far (ry up that barren shaft with one knew not what possihilities of 


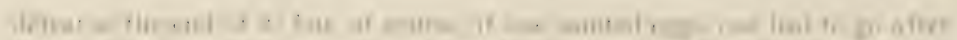

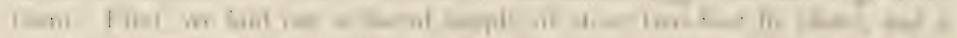

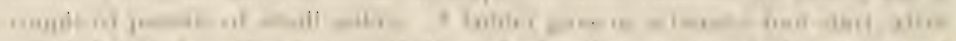

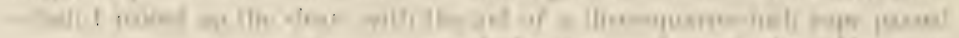

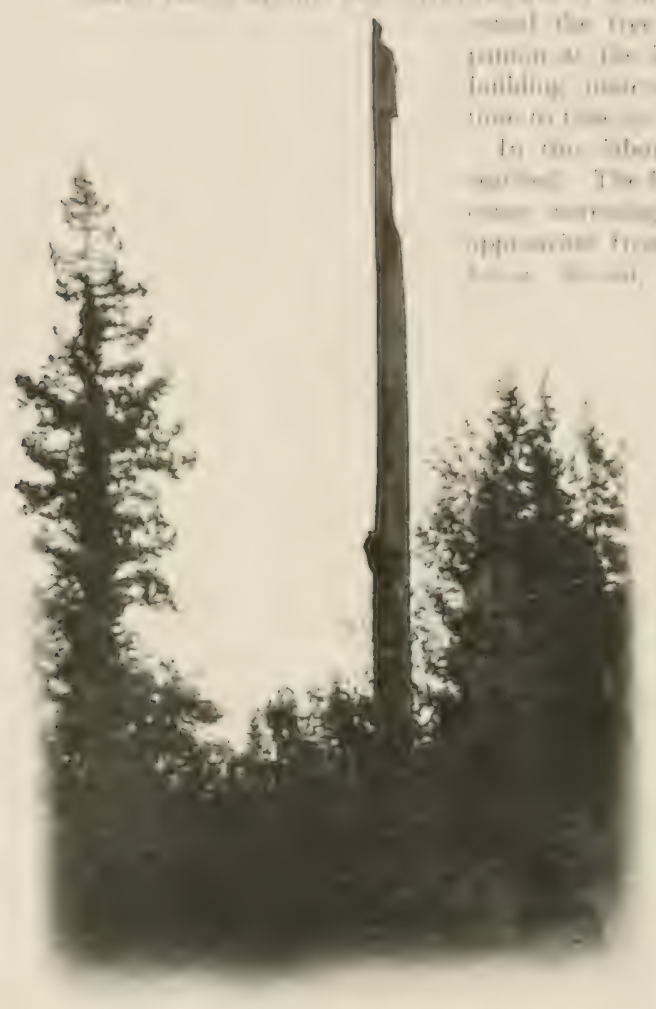

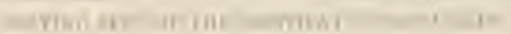

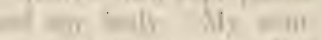

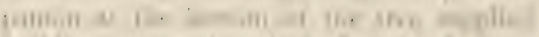

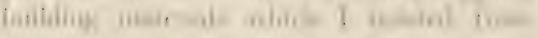

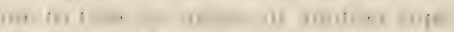

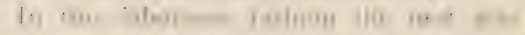

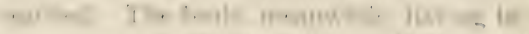

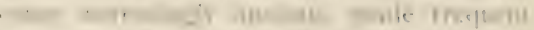

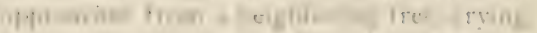

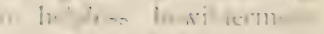
$\rightarrow+i$ inmes $1=$ lis + I theit die at ni rair. an 11 m irithine l til lis le

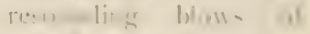
Ilu ins: 1-anc. 11 ill the avi , disy ritse a literle siring 1/11 : $\quad-y^{2}-4$, III Ir lecise learel. mal mix in whe as:me all: wi h R, l-tue o 11 niflen lis 10 lo ilit:

(b) h ance I lies a luce las ge ex mult on lisu it tis linus tise ex: ane nise limint iii liffe, काi : ve

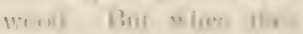

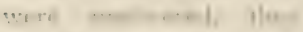
wro at in : n 11. S sur in twat an

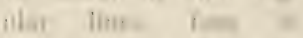
il in an an at

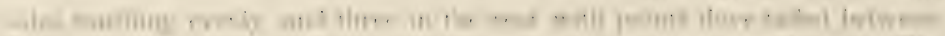

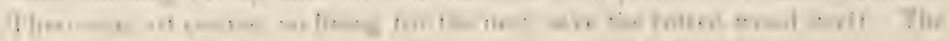

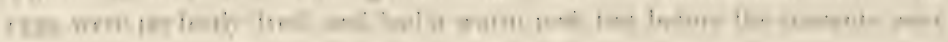


renover?. 'l'heir surface is highly polished, and their texture varied, giving an effect as of water-marked linen paper, in heary branching lines and coarse frost-work patterns.

\section{No. 174 .}

\section{WILLIAMSON'S SAPSUCKER.}

\section{A. (). [. . Io. 404. Sphyrapicus thyroideus (Cass.).}

Synonyms.--WILLIMASON'S WOODPECKER. RED-THROITED WOODPECKER (nale). Browx-mEADER IVOODPlickLR (female). BLACK-MREASTLD WOODMLCKR (female),

Description. - Idult male: In general glossy black including wings and tail; throat, narrowly, scarlet; belly gamboge yellow; sides, flanks, lining of wings and

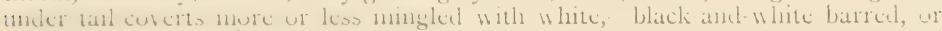
marked with black on white ground; a broad oblique bar on wing-coverts and small more or less paired spots on wing-cuills and upper tail-coverts, white: a white post-ocular stripe and a transverse stripe from extreme forehead passing below ere to side of neck. Dill slaty; feet greenish gray with black nails; iris clark brown. Adult fenale: Very clifferent: in general, closely barred black-and-white,

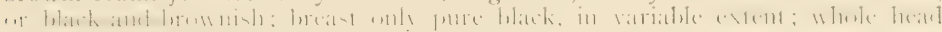
nearly uniform hair-brown, but showing traces of irrupting black; post-ocular stripe of male faintly inclicated and occasionally with touch of red on throat; some intermediate rectrices black but exposed surfaces of central and outer tailfeathers black-and-white barred; white spots of wing-quills larger, paired, and changing to bars on inner quills. Foung male: Like adult male, but black not slossy: belly paler: throat white. Yomny female: Like adult female but barring carried across head, neck, throat, and breast. Length of adlult: 9.00-9.75 (228.6$2.47 .6)$ : wing $5.25($ I3.3.3) : tail .3.80 (y) (.5) ; bill .yo-1.15 (22.9-29.2).

Recognition Marks.-Small Robin size; fine barring of female distinctive; extensive black of male with white head-stripes, white rump (upper tail-coserts) and white wing-bar: pattern of molerparts (in male) clearly a moditication of

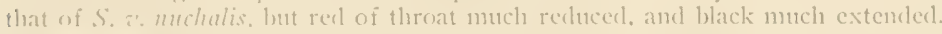

Nesting. - Iest: I hole excavated ly birds at any height in live deciduous

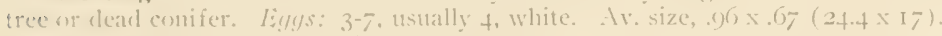
Sectson: May-June; one brood.

(ieneral Range,- Ilestern United States chictly in mountains and foothills from castern slopes of the Recky . Mountains to western slopes of Sierra-Cascades, breeling from mountains of Arizona and Xew Mexico north to British Colmubia fin the valley of the ()kanterun): south in winter to Southwestern States and Mexico.

Range in Washington.-Simmer resident chiefly on eastern slopes of the Ciaciules.

Authorities.-Bendire, I, ife Hist. .1. A. Bircls, Vol. 11. 1895, 1). 97. 1)2.

Specimens,-C: 


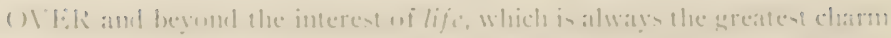

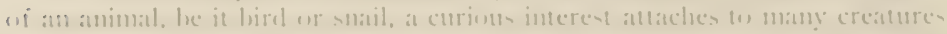

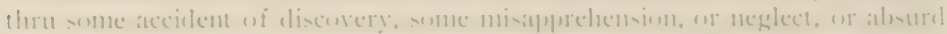

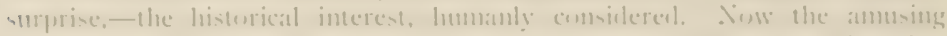

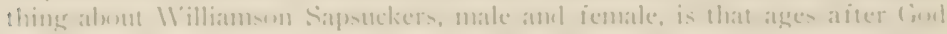

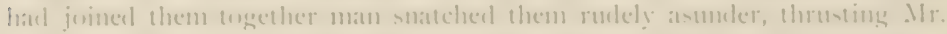

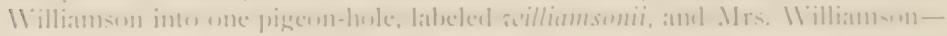

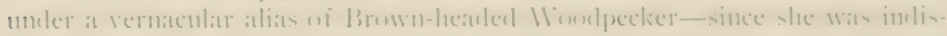

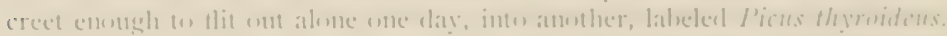

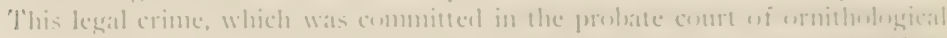

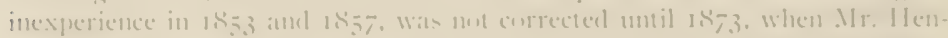

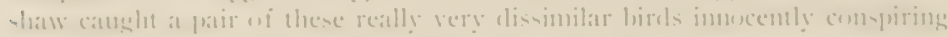

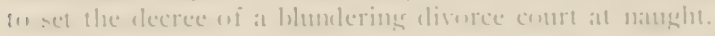

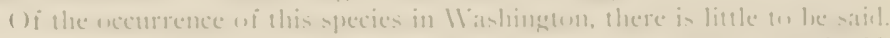

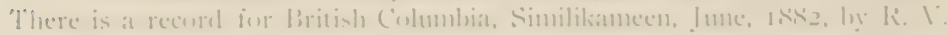

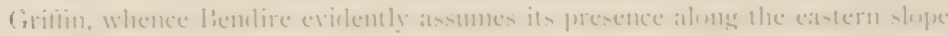

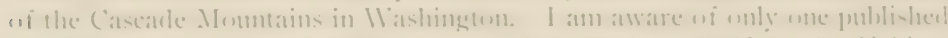

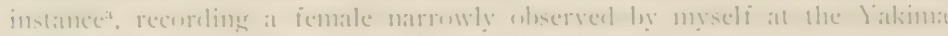

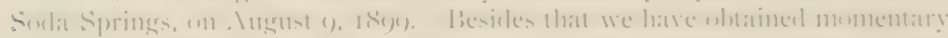

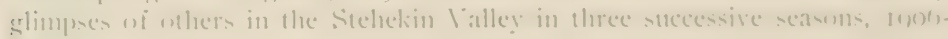
irpos.

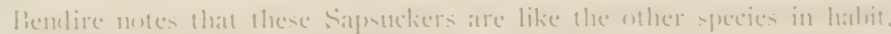

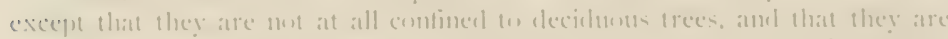

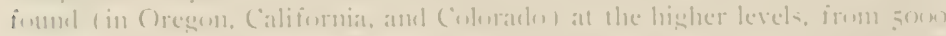

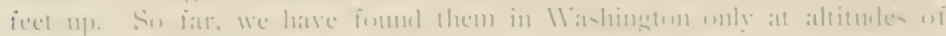

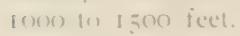

\section{No. $17 \overline{5}$.}

\section{NORTHERN PILEATED WOUDPECKIR.}

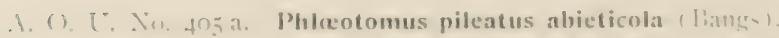

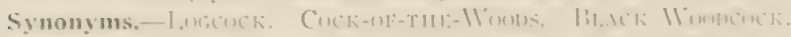

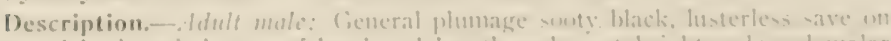

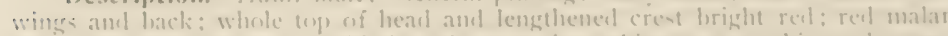

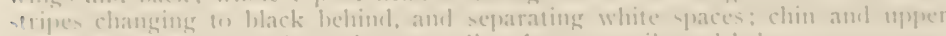

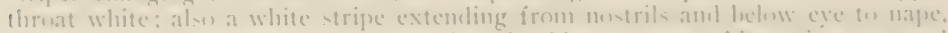

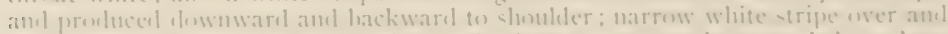

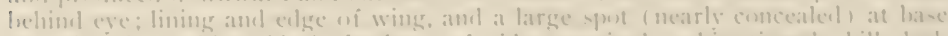

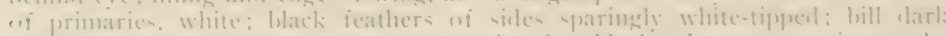

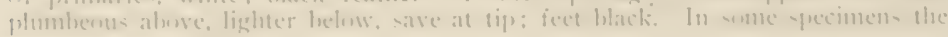

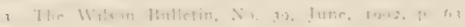


whites are everyhere tingerl with pale sulphur-yellow; the color being especially noticeable in the axillaries and lining of wings. Fdult femele: Similar, lut black on forehead, and black instead of red malar stripes. Length $15.50-19.00$ (39)3.7$482.6)$; wing 8.50-10.00 (215.9-254) : tail 5.85-7.40 ( I $48.6-1.88)$ : head $4.50-5.50$ $(1+1+.3-1.39) \cdot 7)$ : bill $1.75-2.65(+4.5-(1,-3)$.

Recognition Marks. - I argest size: black, white and red on lead in stripes: hocly mainly black.

Nesting.- - Vest: high in dead trees. Eygs: $4^{-6}$, white. Ar. size, 1.29 x.94 $(32.8 \times 23.0)$. Scuson: Day: one brond.

General Range.-Formerly the heavily wooked regions of North America sonth of about latitucle $63^{\circ}$. except in the sonthern locky Monntains. Now rare or extirpated in the more settled parts of the liastern States.

Range in Washington.- Not suncommon resiclent in larger coniferous forests thrunut the State.

Authorities.-|Lewis and Clark, I list. Ex. (I8I+) Lid. lichlle: Cones, Vol.

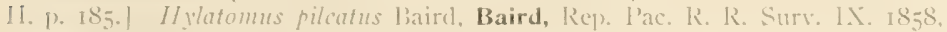

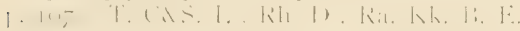

Specimens.- L. of 11 . I'. I'rov. I3, I3X.

ONE"S first acputhintance with this huge black fowl matks a red-letter flay in woulcraft, and it is pernitted the serious student to examine the bird amatomically just once in a life-time. 'The scarlet crest attracts first altention, not only because of its brilliancy, lut because its presence comterlatances the bill, and imparts to the head its hammer-like atspect. 'This crest wats much sought after by the Indians of our coast, and figured prominently as a personal decoration in their medicine danees, as dirl the hird itselt in their meelicine hre. A measurement of twenty-eight inches from wing-tip to wing-tip marks the size of this "Plack Woodorck," while the stiffened tatil-feathers with \{heir downtumed banes show what alefuate support is given the clinging claws when the bird (lelivers me of its powerful strolies. The bill is the marel. Narle ap)parently of hrm. like other birds hills, it has some of the attributes of tempered steel. 'l'he hird uses it recklessly as both axe and crowloar, for it hews its way thut the bark of our largest dead fir trees, in its efforts to get at the gruls, which have their greatest fiekl of activity between the bark and the wornl. It pries ofi great chips and llakes by a siclewise wrench of its lead. A carpenter is known by his clips, but no carpenter would put his chisels to such hard service as the bird does his. As a result there is no mistaking the bark pile which smromels the base of certain old stulgs in the forest for the work of any other agency:

Possibly the most interesting of all is the Ione-cock's tongue, which it is able to protrucle sudelenly to a clistance of four or five inches beyond the tip) of its beak. 'l'his provision enalues the bird wecomomize labor in the tracking of buried sweets. and the arangement is marle possible by the great 


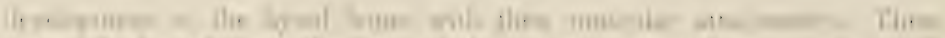

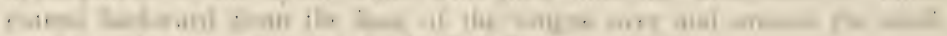

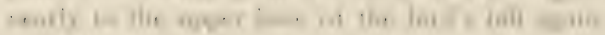

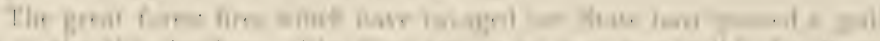

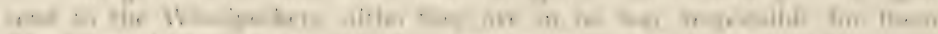

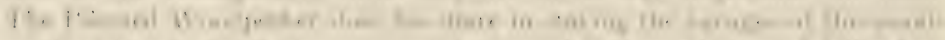

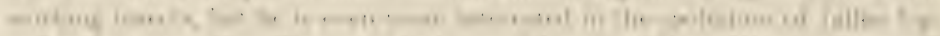

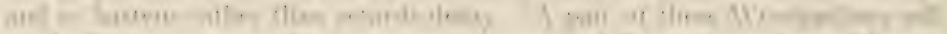

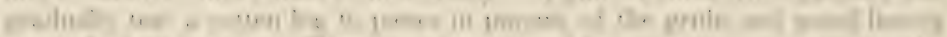

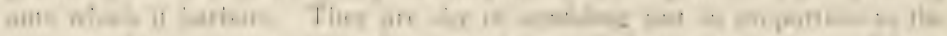

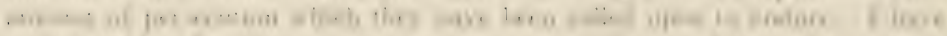

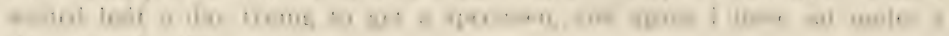
Ine in it r :

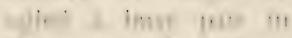

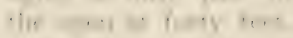

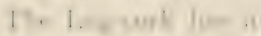

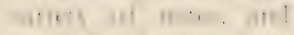

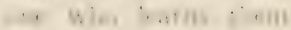

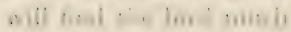

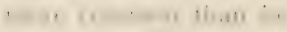

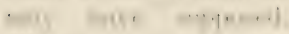

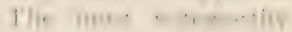

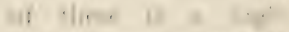

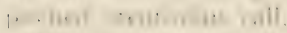
whit $\mathrm{t}$, soll

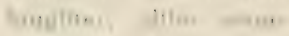
- Hilhe if is . inth mith he I.

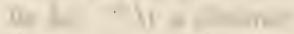
the saitial a. Imas fir ar im

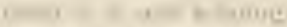
ilis ile yer is is

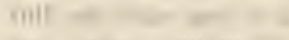
matamiso,

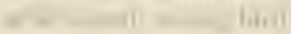
n-16
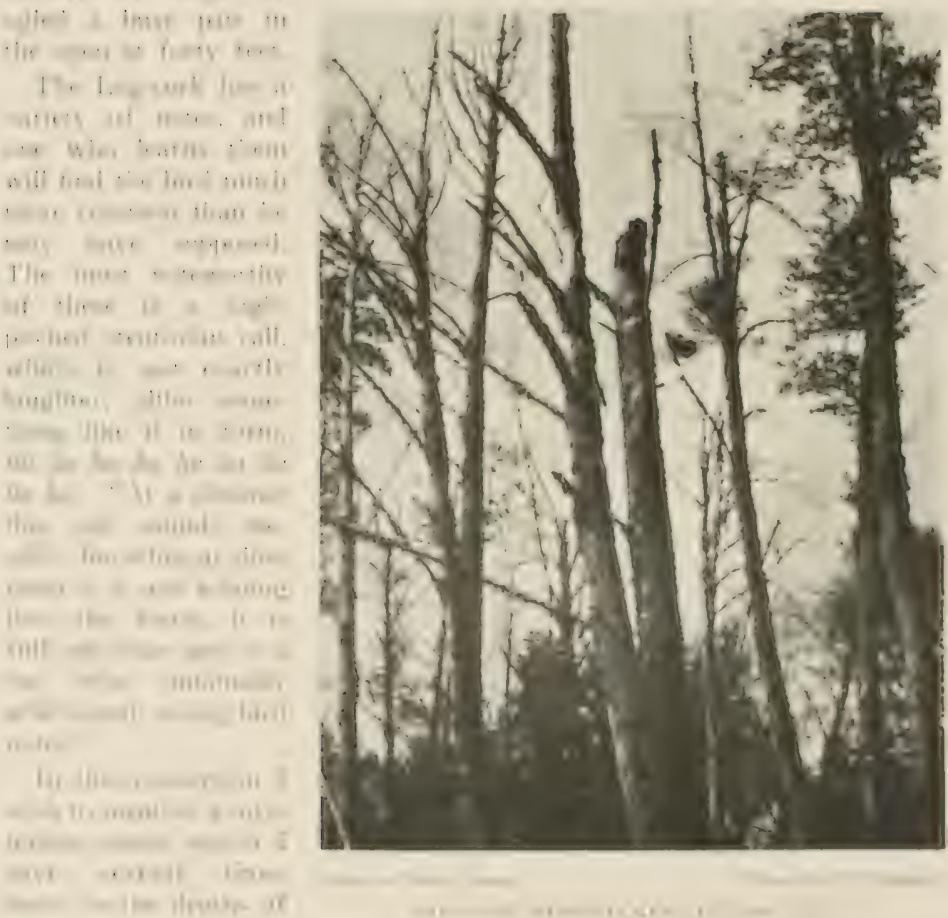
the western forest, hut to whose authorship I have no clew unless it proceeds from this bird. 'The note comes from well up in the trees, and is repeated slowly, after little intervals, and with a sort of funereal solenunity. If I renture to literate it, the letters are to be thought rather than said.or better still, thenght while whistled in al low key (si) poolk (ng) - - (si)poolk(ng) - - (si)poolk(ng). Who will "riddle me this mystery"?

The Pileated IVoodpecker chisels out its nesting hole at any height in cleal timber. whether of fir, pine, spruce, or other. It nests regularly in this State, but the taking of its eggs is something of a feat; so, in defatult of muchcoreted "luck," we fall back on Benclirea: "lirom three to five exgs are usually laid to a set, but I have seen it stated that the Pileated Woodpectier nften lairl six, and that a nest found near Famville. Virginia, contained eight. An egg is deposited claily, and inculation begrins occasionally before the set is completed, and lasts about eighteen clays, both sexes assisting in the duty, as well as in caring for the young. L,ike all 11 oodpeckers the Pileated are rery deroted parents, and the young follow them for some weeks after leaving the nest, tuntil fully capable of caring for themselves. Only one brood is raised in a season. The egas of the Pileated Woodpecker are pure clima-white in color, mostly orate in shape: the sliell is exceedingly fine-grained and very glossy, as if enamelecl."

No. 176.

\section{LEWIS'S WOODPECKER.}

1. (). L. To. foS. Asyndesmus lewisi Riley.

Synonym.-lí.ick WOOHPCKI:R.

Description.- - dults: Alowe shining black with a greenish bronzy luster: "race," including extreme foreheal, space alout eve, checks, and chin, rich crimson; a collar around neck continuous with breast hoary ash : this ashy mingled intimately with carmine, or carmine-lake, on rentaning unclerparts, save flanks. thighs and crissum, which are black: feathers of nape and underparts black and compact at base but finely dissected on colored portion of tips, each harb lenstlienexl and hristly in character. Bill and feet black: iris brown. Jomug birds lack the crimson mask and hoary collar: the underpats are eray mingled with dusky helow, with skirtings of reel in increasing ahumbance accoreling to age. Length of adtult : $10.00-11.00(254-279)+4)$ : wing $6.75(171.5)$; tail $4.50(1+4.3)$ : bill 1.20 $1,30.5)$

Recognition Marks. - Robin size; shining black above, hoary collar ancl breast: red mingled with hary ash on unclerparts distinctive. 


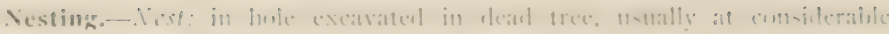

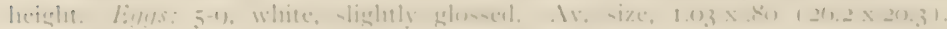

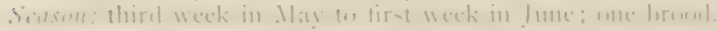

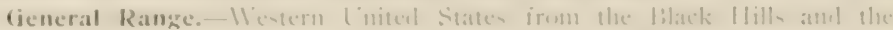

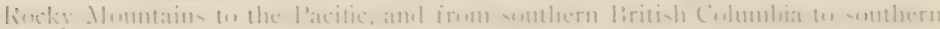

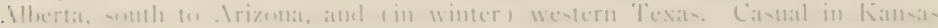
(.1. (1). ( . .)

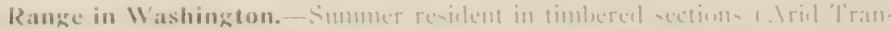

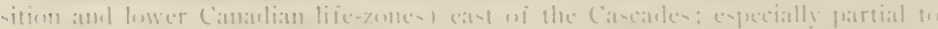

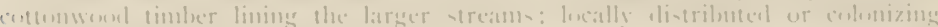

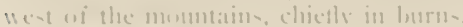

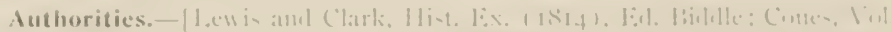

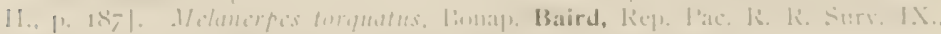

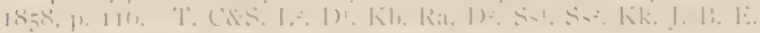

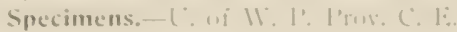

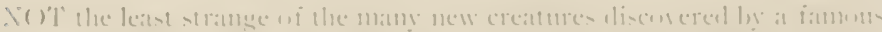

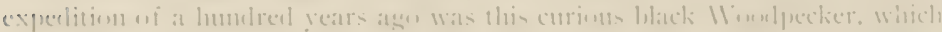

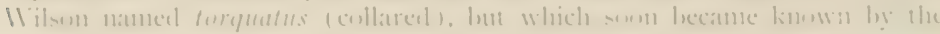

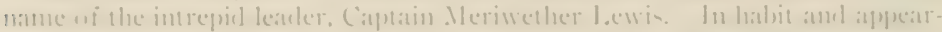

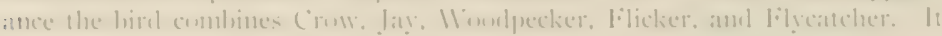

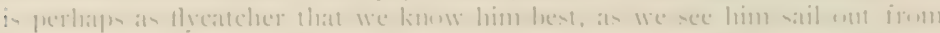

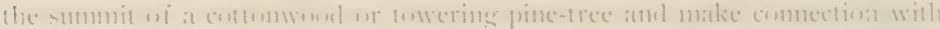

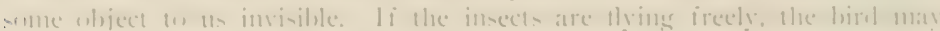

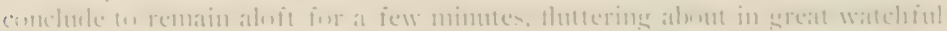

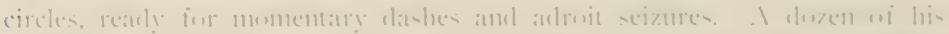

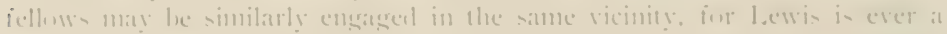

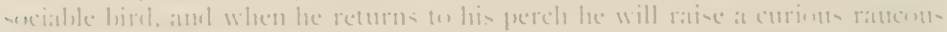

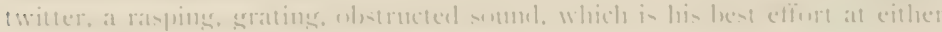

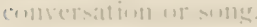

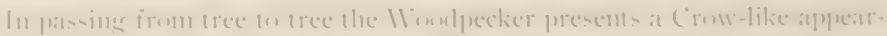

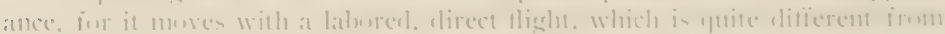

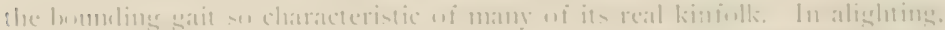

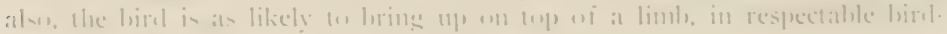

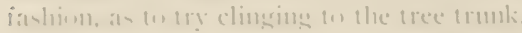

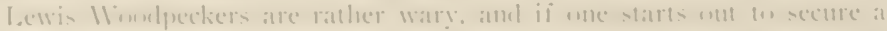

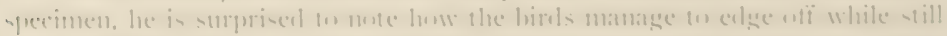

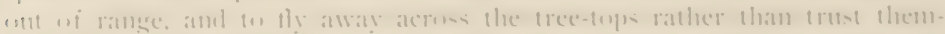

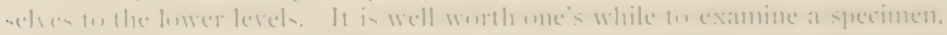

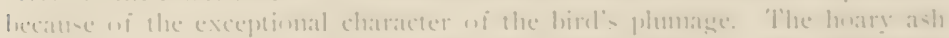

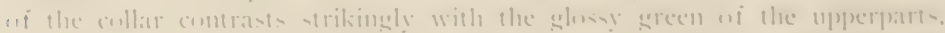

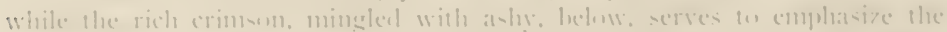

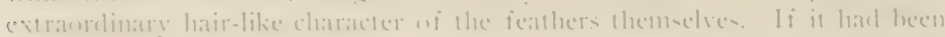


a Sapsucker, now, or a 11 arris. We could realily mulerstank how the abcominal plumage might hate been teased to rags thrt constant friction with rough bark: but this lazy Jack-of-all-tracles, whos is more thycatcher than true wondpecker, how did he get his under-plumage so fearfully mussed?

For all the liack IV oudpecker keeps largely to the tops of trees, it is not averse to ground-meats, a 11 d where ummolested. will rescent to feerl with Cousin Flicker upon crickets, geotic beetles, or fallen acorns. (irasshoppers are a farorite food. and cluring the season of their sreatest abumlance the hind requires little else. Service-berries are a staple in seasom. wikl strawberries are not often neglected, and the bird has been known to fild a cherry now and then. Indeed, it is noteworthy that in certain irnitsrowing sections, such as the lakima Valley. [3 lack lloodpeckers lave increased in numhers of late. It must not be hastily conclusted on this accomut that the 11 oodpecker is a menace to the orcharel. He earns what he eats. Orcharels attract in-

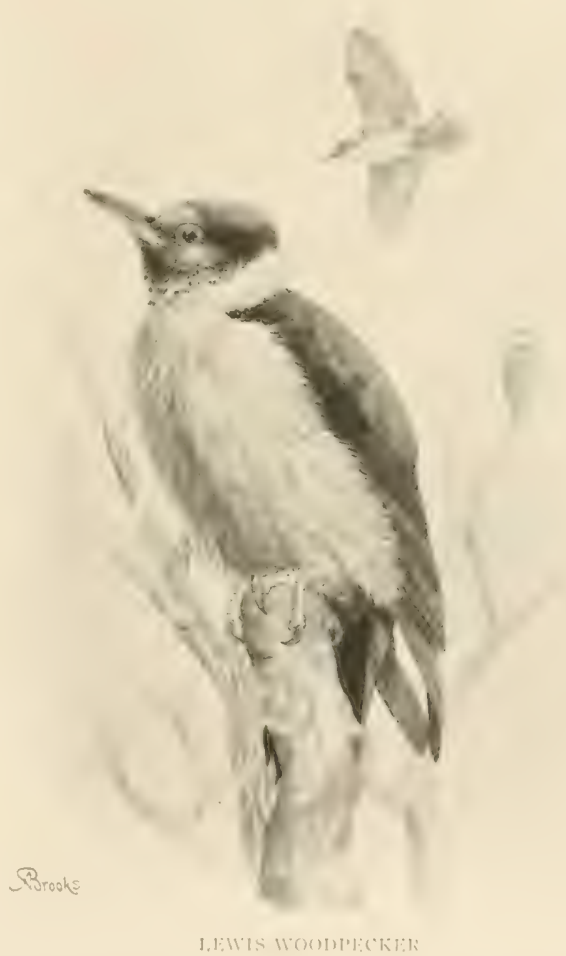

sects, and insects athact birds. Which will you hate, no birels, more insects, and so, eventually, mo fruit? or more birels, fewer insects, and enough iruit for all:

The occurrence of the Blick Woodpecter west of the Casciules is 


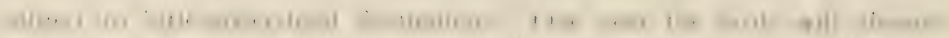

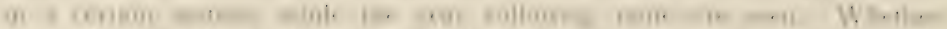

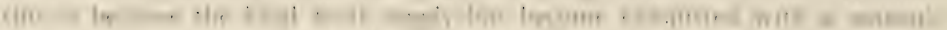

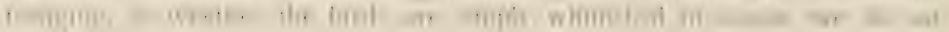
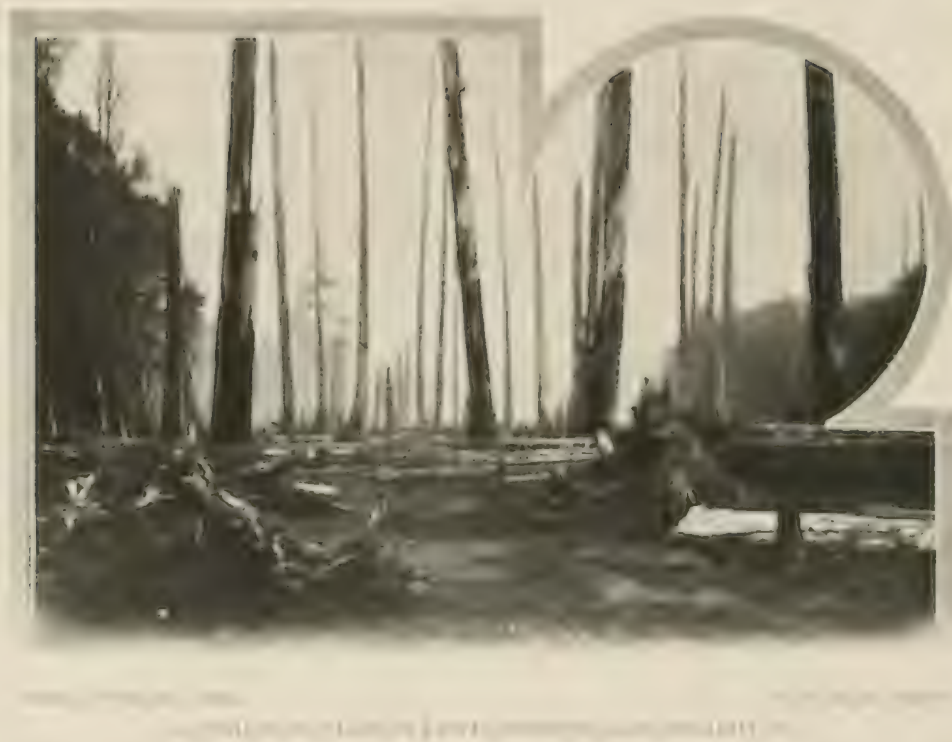

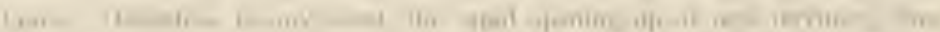

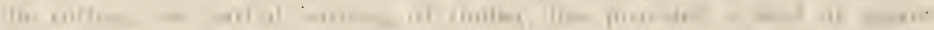

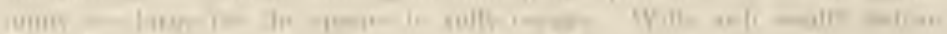

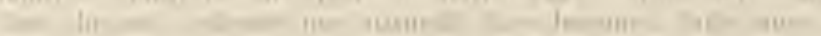


No. 177.

\section{YELLOW-SHAFTED FLICKER.}

A. O. L. No. fiza. Colaptes auratus luteus Bangs.

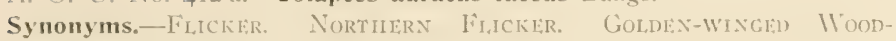

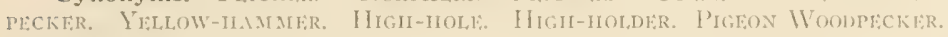
IVAKE-UT.

Description.-- - dult male: 'T'op of head and cervix ashy gray, wikh a vinaceous tinge on forehead; a bright scarlet band on the back of the neck: back, scapulars, and wings vinaceous gray with conspicuous black bars, brace-shaped, crescentic or various : primaries plain dusky on exposed webs; lining of the wing and shafts of the wing-quills yellow: rump broadly white; upper tail-coverts white, black-barred in broad, "herring-bone" pattern; tail double-pointed, black, and with black shafts on exposed upper surface; feathers sharply acuminate; tail below, golden-yellow and with yellow shafts, save on black tips; chin, sides of head, and throat vinaceons, enclosing two broad, black, malar stripes, or moustaches; a broad, black, pectoral crescent; remaining molerparts white with heavy vinaceons shading on breast and sides, everywhere marked with sharply defined and handsone round, or cordate, spots of black. Bill and feet dark plumbeons. Adult female: Similar, but without black moustache. Sexes about equal in size. Length I 2.00-1 2.75 (304.8-323.9) ; ax: of thirteen specimens: wing 6.13 ( I 55.7); tail $4.34(110.2)$; bill $1.3+(34)$.

Recognition Marks. - Size not comparable to that of any better known bird; scarlet muchal hand; ycllow "flickerings" in flight : pectoral cresecnt; white rump); black-spotted breast, etc.

Nesting.-Does not breed in II ashington. Nest: an excavation in a tree or stump, ustrally made by the birkl, at moderate heights; mlined, save by chips.

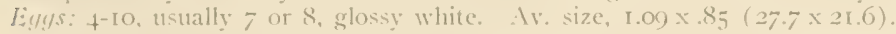

General Range.- Northern and castern Nortl Anerica, west to the eastern slope of the Rocky. Momntains and dlaska. ()ecasional on the l'acific slope from California northward. Acciclental in liturope.

Range in Washington.-Casual cluring migrations-a straggle' from Mlaska.

Authorities.-Dawson, Auk, Vol. XXY., Oct. I908, p. 484.

Specimens.-Prov. E.

'THE true Yellow-shafted Ficker, the familiar bird of the liastem States, is nccasionally taken as a straggler cluring the fall migrations. Mr. D). Fi. Brown took a typical specimen at Glacier, in I004, and Mr. Victor Savings, of Blaine, lass slont one and seen several others. A specimen in Mr. Rathlum's collection wats taken by Mr. Matr. II. Commley, on Orcas Islank. October I5. ino3. The birl is a male and is typical save for the iantest possible tinge nf salmon in the yellow: which marks him as a border-line specimen, probably a british Colmubian bird which did not deflect eastward sulficiently in the antumun retreat. 


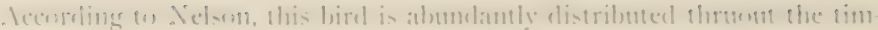

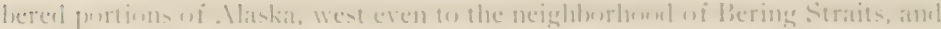

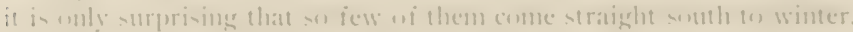

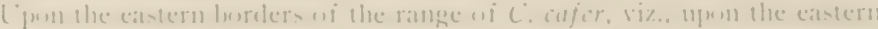

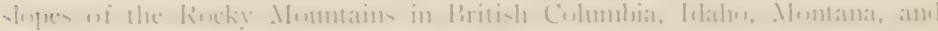

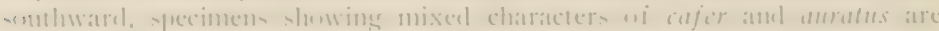

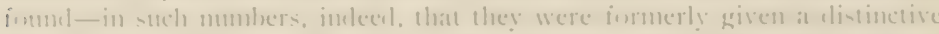

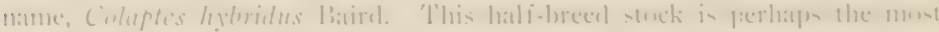

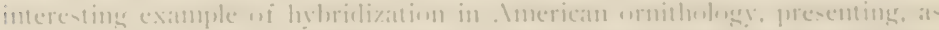

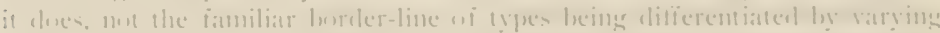

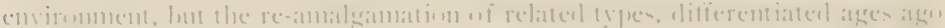

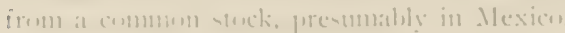

No. $1 \rightarrow x$.

\section{RED-SHAFTED FILICKER.}

1. (1) (1. Die +13. Colaptes mexicanus collaris 1 ligut-1.

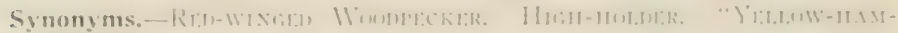

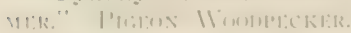

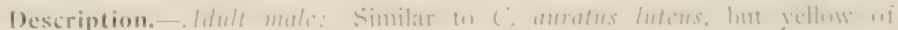

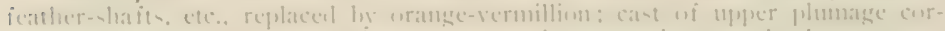

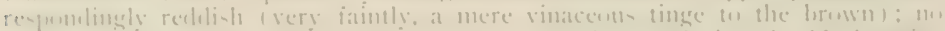

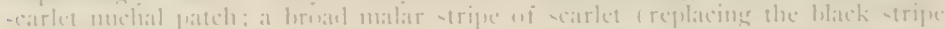

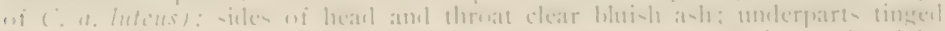

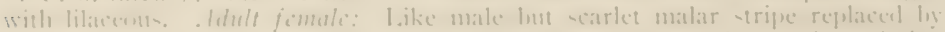

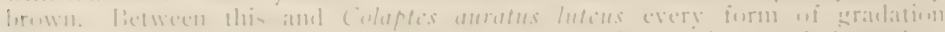

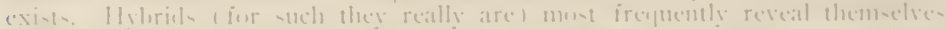

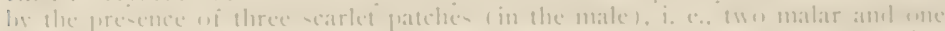

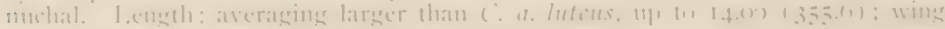

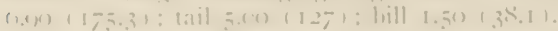

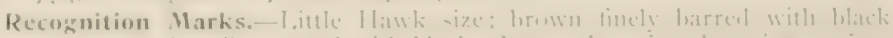

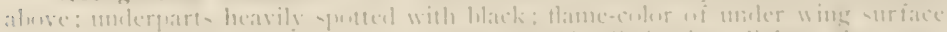

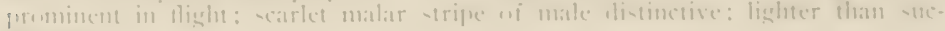
recrling

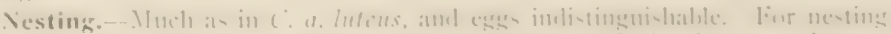

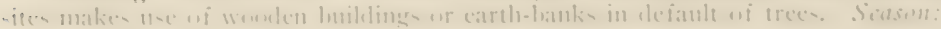
Mas : ame lirenul, rarels $\{$ wo

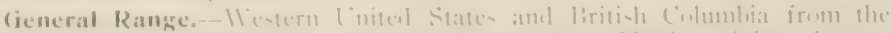

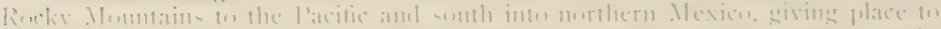

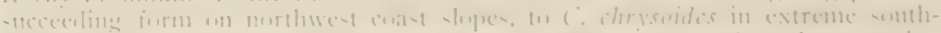

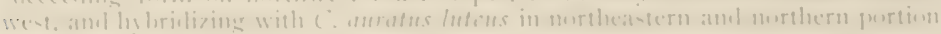
wi rallues.

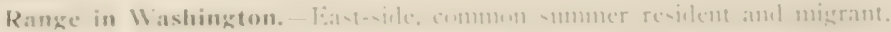


foumel to timber-line in the Cascarles, where shading into next; partially resirlent in winter.

Authorities.- Lewis and Clark, I list. Lx. (ISIf) Eid. Lichlle: Cones, Iol.

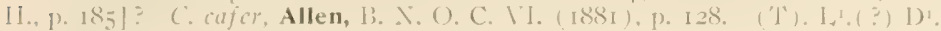

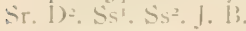

Specimens.-(L. of 11.) I'. Hrov. B. IiN.

I.I'LRE has nut dealt justly with the fiast-sicle ficker in the matter of provirling an abundance of dead timber for nesting sites. What more natural. then, than that the stinted bircl should joyfuly fall upon the first "frame" heuses and ricklle them with holes? The front door of a certain commery parsonage nea . North lakina testifies (o) at least one pastoral vacation, hy the presence of three large filicker holes in its panels. 'The church hard by is dotted with tin patches which conceal this bird's handiwork: and the mind recalls with stee how the irreverent Flicker on a summer Sunday replied to the parson's fiftly, by a mighty rat-at-at-at-at on the weather siding. 'l'he clistrict schoolhouse of a neighboring township is worst served of all, for fortyone Iilicher holes punctuate its weather-beaten sicles-reason enough, surely: for teaching the young idea of that clistrict how to shoot. Indeed, the schoul directors became so incensed at the conduct of these naughty fowls that they offered a bounty of ten cents a lead for their destruction. IBut it is to laugh to sec the fierce energy with which these bircls of the plains, lomg deprived of legitimate exercise, fall to and perforate such neglected ontposts of leaming. The bird hecomes obsessed by the iclea of filling a particular wall full of holes. and no ingenuity of man cam deter him. If work during mon hours is aliscommereel, the hirel returns stealthily to his task at fotr a. m., ancl chisels ont a masterpiece before hreak fast. If the gum speaks, and one birct falls a martyr to the sated catuse, another comes forward promptly to take his place, and there is always some patriotic lilicker of uphold the rights of acalemic research.

()f comse the situation is much relieved in the timbered foothills and along the worded bauks of streams, where rotten stubs abound. 'T'he lílicker is at home, also, to the very limit of trees in the Cascade Mlomuans. Nests atre orlinarily excalated late in April, and any tree or stump may serve as host. In ()kanogan (inunty I saw a lilicker's nest in a stumponly two feet high, and its egess rested virtually mon the gromel. Others ocent in live willows, cottonwimels, and apple trees, as well as in clead pines- the last named oncasionally at at height of sixty or serenty feet. They nest also in the walls of buildings, in which case they lug in the chips to lay on heam or sill, and so prevent the exges imon rolling. In Chelan County a nest was foumel in a bank of fine earth among

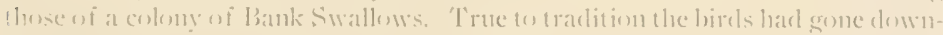
marrl after entering this hank. Faxcatsation prosed to he such a pleasant task

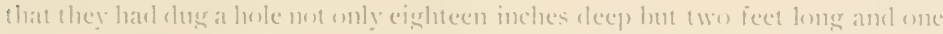
wirle, measurerl horimontally. Three cubic feet of carth these industri- 


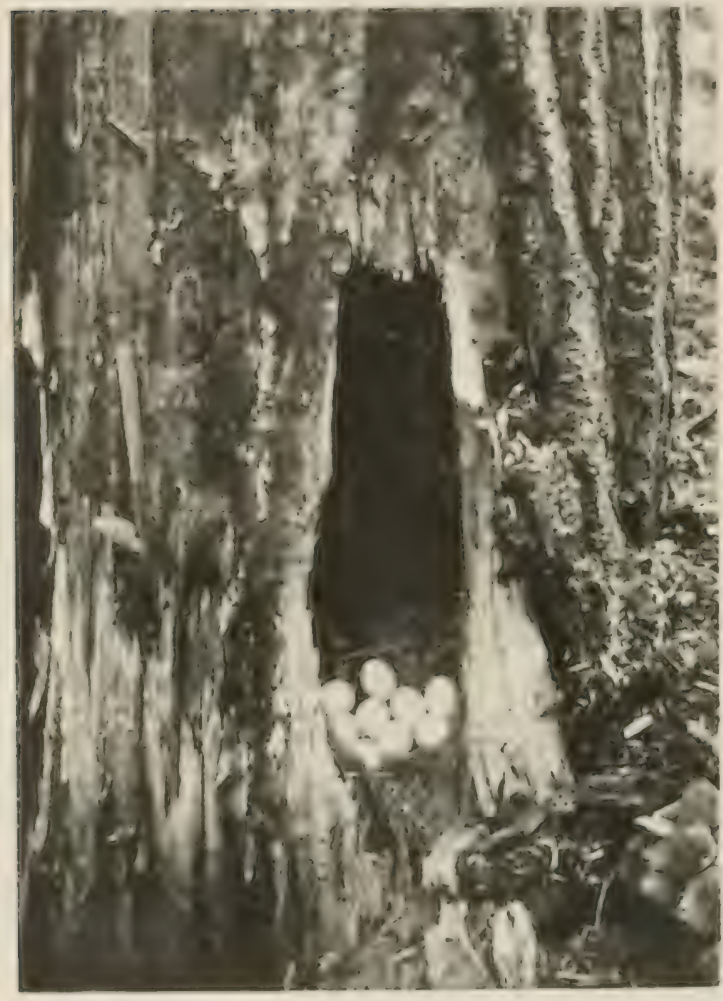

1.

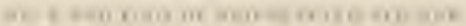

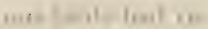
(m). Dhe hamilias perh ant Gahe Pathom i.: nis Iand Whing 20. $\lim { }^{2}$ die 16. 1. an it at mithen wh

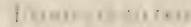

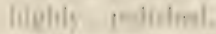
- me Inamary.. aline , and are

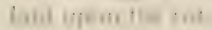
Pig and in

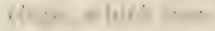
ally $\mid 1 \cdot \ldots+2$, . ant I1 $\because$ itust

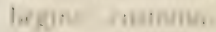
ar win. in i $\ldots+1=1,2.1$ $\therefore$ rent, 4 ... II + II

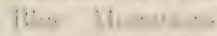
wi 114 . nit It in as vilali andaime

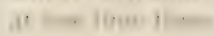

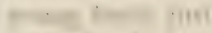
inir al wh …int exty nat

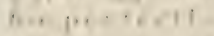
in il we ne 4. . ' 1 itim:

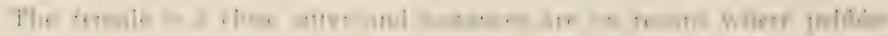

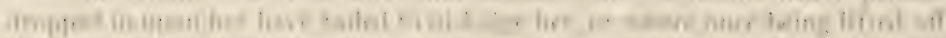

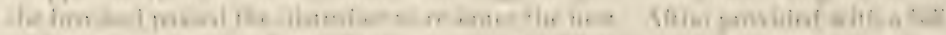

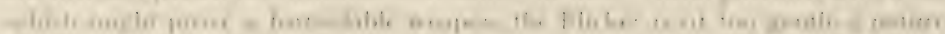

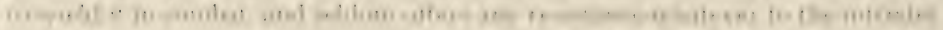

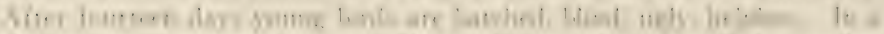

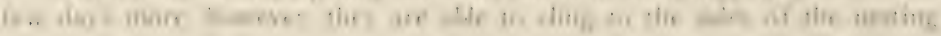


hollow, and are ready to set up a clamor upon the appearance of food. 'This noise has been conpared to the hissing of a nest of snakes, but as the fledglings grow it becomes an uproar equal to the best efforts of a telephone pole on a frosty morning.

The young are fecl entirely by regurgitation, not an attractive process, but one admirably suited to the necessities of long foraging expecitions and varying fare. When able to leave the nest the fledglings usually clamber about the parental roof-tree for a day or two before taking flight. 'l'heir first efforts at obtaining food for themselves are usually made upon the ground, where ants are abmulant. 'These with grasshoppers and other groundhaunting insects make up) a large percentage of food, both of the young and adults. It will appear from this that the Red-shafted licker is not only harmless but decidedly beneficial-save in the matter of hostility to school boards, above mentioned,

\section{No. 179 .}

\section{NORTHWESTERN FLICKER.}

\section{A. O. U. No. 413 a. Colaptes mexicanus saturatior Ridgway.}

Description,-Like C. m. collaris but clarker; ground color of upperparts burnt umber with a purplish tinge; ground color of underparts vinaceous buff to color of back: sides of head and throat deep smoke-gray; pilem cinnamomeous. Specimens in the Provincial Museum at Victoria inclicate lwbriclization between this form and $C$. antatus luteus. Of twenty-seven males from Vanconver Island nine possess in whole or in part the scarlet nuchal patch characteristic of auratus. Length up to I $4.00(3.55 .6)$ : as: of tive Glacier specinens: wing 6.55 (166.4); tail 5.13 ( 1.30 .3$)$; bill 1.55 (39.4).

Recognition Marks.- As in preceling: darker.

Vesting.-Vest: muclu as in prececling. but usually higher up. IEgys: usually 6, somewhat less glossy than those of C. m. collaris.

(ieneral Range.-Northwest coast from northern California to Sitka. hybridizing with C. a. luteus northerly:

Range in Washington.-Common resident west of Cascades, breeding from tide-water to timber-line, migrating irregularly to liast-side in winter; probalbly some substitution of northern bircls for local smmmer residents on l'uget Sonnel in winter.

Authorities. $\quad: \quad$ :

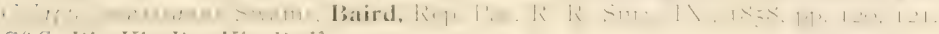
Cis. Rh. Kh, Ra. Kk, li, lis.

Specimens.-C. of 11. I'. I'rov. I3. BN. L. 


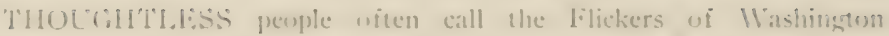
"leflow-hammers," quite regardless of the fact that the western lilicher is nu) longer yellow, but orange-reel. Such an oversight is unpardonable, bus it would require a nice ere to distinguish out of hand this really deeply-tinted hird from its lighter brother, the lied-shafted, across the Cascates. 'The Cascade Momtans smark the gromnd of intergradation between mexicmus

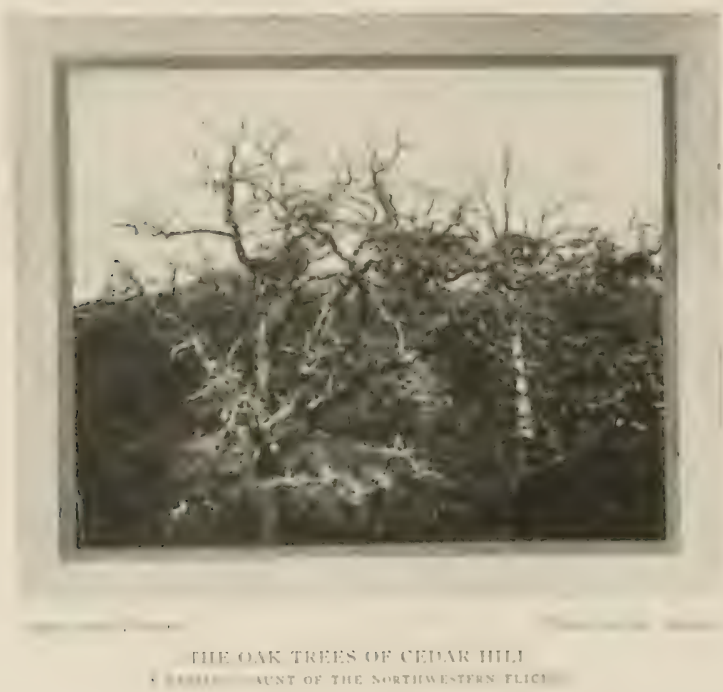
and solfuratior. intel it wumbl iceun probable t liat specindens iaken in winter in 11 ล 5 e 11 II ashingtum and dubleed solurah or. are realls hirels which sum mer on the easterm slopes of the liacarles. a 11 rl which approach the saturated type of plumage. rat lier than mierants irom merose the momains, as has heen assumed. 'T'hese' are mere stolstleties. It is more

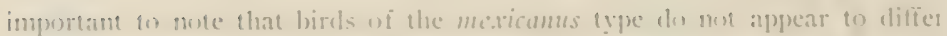
in song or in pstchology from the familiar Coldples andus of the liast. I lherefore transcribe three paragraphs from "The Birols of Ohion" without

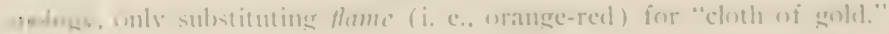

It is fuchaye as at musician that the Flicker is lest known. 'The word mmsian is used in an aceommolated sense, for the bird is mo professional

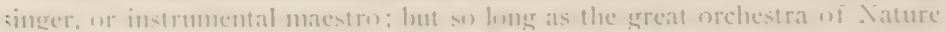

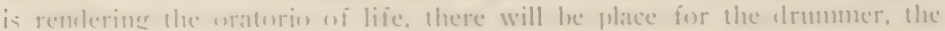
icreamer. and the ullerer of stranee sounds, as well as for the human obligato?

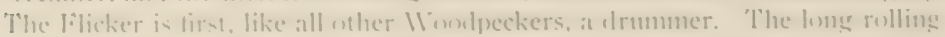
faften wi early - mrinetime is elecited from smme dry limb or luard where the ereatest resmatue mav he secturerl, and it is intemeled buth as a musical pet

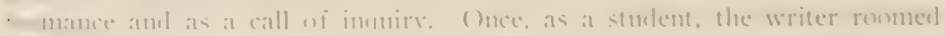


in a large building. whose unused chinneys were covered with sheet-iron. A Flicker had learned the acoustic value of these elerated drums, and the sound of this bird's reveille at 4:00 a. m. was a regular feature of life at "Combil Hall."

The most characteristic of the bird's vocal efforts is a piercing call clelivered from an elevated situation, clape or kly-ak, and cheer or kec-yer. The scrthewhetting song is used for greeting, coaxing or argumentation, and runs from a low acec-co, ace-co-thru acakc-up, acake-up, acakc-up-to an empliatic ii'y-lile, i'y-kle, i'y-kile, or, in another mood somals like flicker, flicker, flicker.

In the early days of April courtship is in progress, and the $10 \mathrm{ve}-$ making of the Flicker is both the most curious and the most conspicuous of anything in that order. An infatuated Flicker is a very soft and foolishlooking bird, but it must be arlmitted that he thoroly understands the

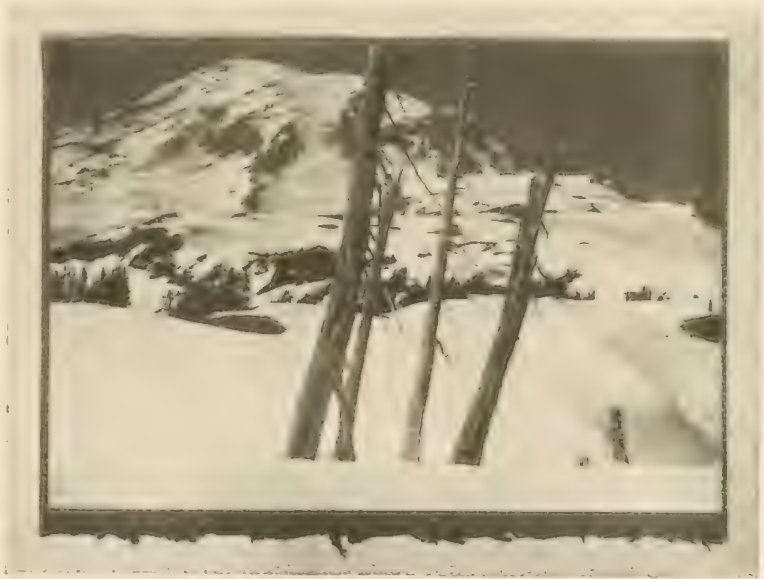

Token in Rainicr National Park.

Photo by W. Lcon Dawson. A NESTING SITE OF THE NORTHWFST FI.ICKER.

THE LARGEST STUB CONTAINED SIX EGGS ON THE POINT OF IIATCIING TULY 7, 1908 , WHE, TIIS PICTURE, WAS TAKEN

feminine heart and streceeds in love beyond the luck of most. A bery of suitors will lay siege to the affections of a fair lady, say in the top of a sycamore tree. Altho the rivalry is fierce, one gallant at a time will be allowed to display his charnus. 'This he does by advancing toward the female along a horizontal limb, bowing, scraping, pirottetting, and swaying his head from side to side with a rythmical motion. Now and then the swain pretends to lose his balance, being quite blinded, you see, by the luster of milarly's eves, lut in reality he does it that lee may have an excuse to throw up his wings and display the dazzling flame which lines 
disem. The lady is dispused on he eritical at tirst, and backs anaty in appareme imlitference or thes oft to amother limb in the same eree. This is

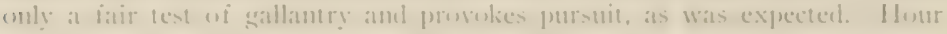
afeer lour, and it may be day alter day, the suit is presseal be one and another mol the maiden imlieates her preference, and hegins for respond in

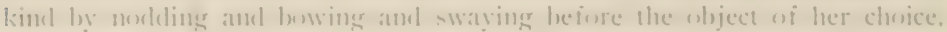

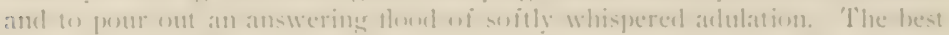

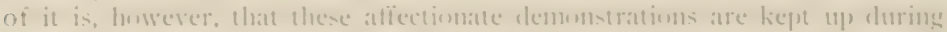
die nesting seasent, an that even when one hirel relieses its mate upon the

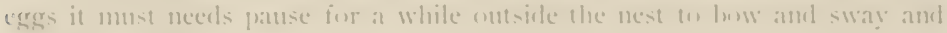
sivilp compliments.

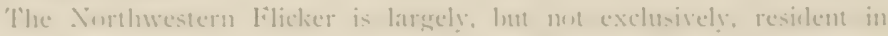

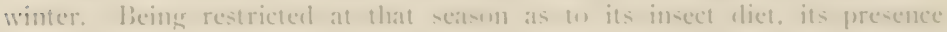
appears (o depend more of less upm the abmolance of iroits and muts. It

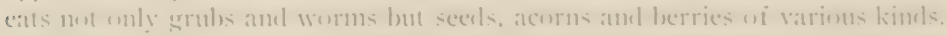

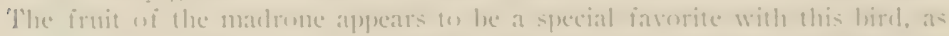

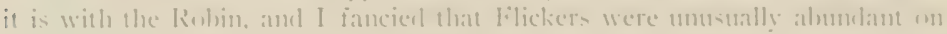

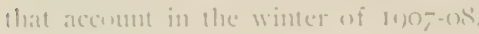

\section{No. 18 in.}

\section{CALIFORNIA CLCKOO.}

1. (1. [. Xi. 30- a. Coccyzus americanus occidentalis Rilguay.

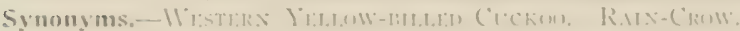

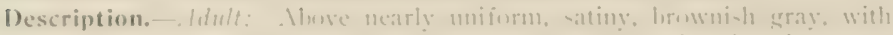

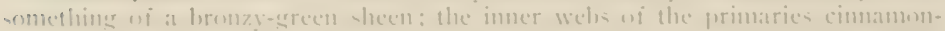

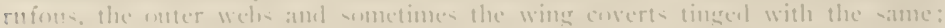
central pair wi tail-ienthers like the hack am completely onering the nthers during

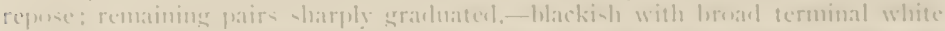

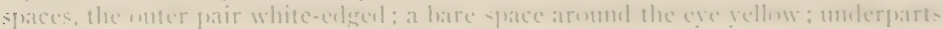

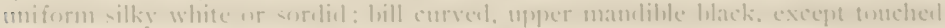

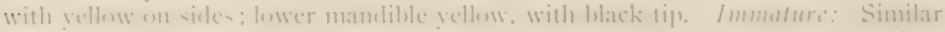

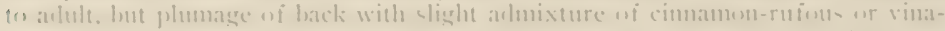

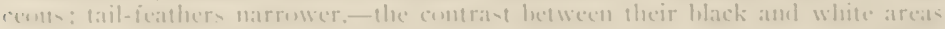

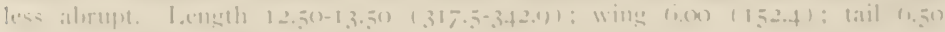

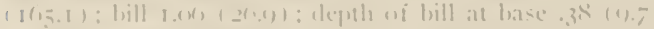

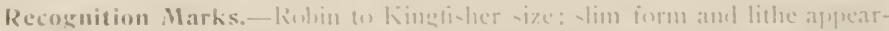

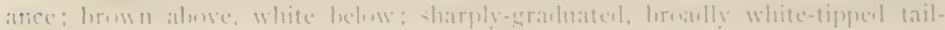
ientleers

Nesting. - Vest: a careles strueture of twis- lark-strips, and catkins, placerl

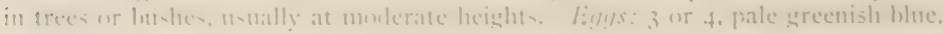


becoming lighter on continued exposure. Ar. size, 1.3I x.94 $(33.3 \times 2.3 .9)$. Scason: June-August; one brood.

General Range.-IVestern temperate North America from northern Lower California north to sonthern British Columbia, east to Vew Mexico and western T'exas, and sonth over tablelands of Mexico.

Range in Washington.--Kare stmmer resident, chictly west of Cascakles.

Authorities.-["Jellow-billed cuckoo" Johnson, Rep. Gov. 11. 'T.., I884

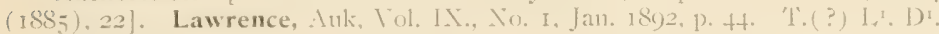
Ra. B., E.

\section{Specimens.-( L. of. 11.) l'rov. I:}

IT IS possible that these bircls are really more numerous in V'ashington, west of the Cascades, than is generally supposed. 'Whey are, hotvever, extremely shy and retiring in their habits, and rery local in clistribution. The latter characteristic is carried to such an extent that they mat almost be said to colonize. For example, the only place they may be found with certainty, near Tacoma, is in a small area well within the city limits and surrounded by houses. In this small space four or five pairs may be found at any time during the summer.

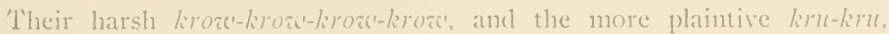
kru-kru, is most often heard along the ontskirts of some swamp encircled by a heavy growth of brush and small conifers nixed with deciduous trees. From the kroateleroa note the bircls lave gained the name Rain Crow, poptalar stuperstition pointing out the fact that it ustally rains soon afterward (an occurrence not at all mnlikely to happen in western llashington, irrespective of the suggestion of the Cuckino).

'I'heir food consists entirely of caterpillars, spiclers, and other insects, this being perhaps the only bircl to make war extensively upon the tentcaterpillar. The poem, "II sucks little bircls' eggs to make his roice clear," etc., applies only to the Cuckoo of Europe. Small bircls, it is true. are very often seen in purstit of a Cuckoo. but this must be purely on account of its close resemblance in form to that of their areh-enemy, the Sharp-shinned Hawk.

The nest is rather a frail structure, tho much more bulliy than nests of the Plack-billed or Vellow-billed Cuckoo. It is placed from four to ten feet from the ground, usually nearer ten, and is most often built against the trunk of a baby fir. The materials used consist of coarse dead twigs. heavily lined with coarse tree-moss and sprays of dead fir nectles.

The eggs are two or three in number, most often three, and are laid from the second week in June to the first of July. They are a pale bluish sreen in color, overlaid with a light chalky deposit. somewhat like that fomel on Comorant egers. In shape they vary from long to rounded nval, and 
average in measurement if $60 x .(x)$ inches. A week often elapses between the laying of the first and the last eggr.

lipun one occasion 1 moticeal a most interesting trait in these birrs. which I never ulserved in any other species. W'hile standing in an open woolland listening to a pair of Cucknos calling to each other, I saw the male sudelenly tly past with a large green worm in his bill. He tlew directly to the female, wh was percherl in a tree a few yards clistant, and for a moment or two sley sat motionless a iew inches apart looking at each other. The male then lowered lighty over his mate and, settling gently upon her shoulders, gracefully bent over and placed the worm in her hill. It was a pretty and daintily performed piece of lnve-making.

\section{J. II. HowLI:S.}

\section{No. 181.}

\section{BELTED KINGFISHER.}

\section{A. (1) [ . An, 37o. Ceryle alcyon (Linn.).}

Synonym.-Commonly called plain Kixorismik.

Description.- Idult male: Alove, hright bluish gray, feathers with blackish shafts or slaft-lines; fonsely crested ; edge of wing white; primaries dusky, whitespotsed on otter web, sarriwly white-tipped, broadly white on inner wel, coverts often delicately tipped or tonched with white: tail blush gray ahove, the central feathers with herring-lone pattern of dusky: remaining featlers only blue-edged. duky, finely and incompletely harred with white: lower erelid white, and a white spont in iront of ere: throat and sicles of neek, nearly meeting behind, pure white: a broat loaml of bluish gray across the breast; remaining underparts white, sides meler wing, and tlanks, heavily shated with blue-gray; bill flack, pale at base below: ieet dark. Idult fimale: Similar, but witla a chestmut banul across lower breast, and with heavy shading of the same colne on sides. Immature: I like adlults, excent that the plumbeous hand of breast is heavily mixed with rusty. (suggesting chestnut of fenale). I,ength 12.00-1 4.0n $(304.3-3.5 .6)$; wing li.2i

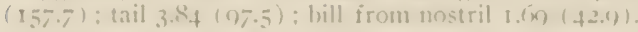

Recognition Marks. -Kingfisher" size; blue-gray and white coloration: piscaturial halnits; rattling cry:

Nesting.- Vest: at end of tumnel in hank, four to six feet in, unlined. Eigys,

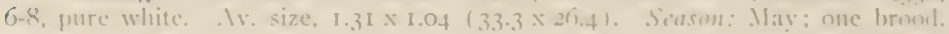

General Range.-Dorth America from the Iretic ()eens sunth to Panama

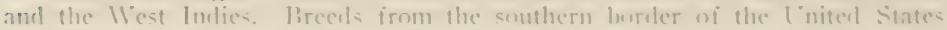
northward.

Range in Washington,-Summer revilent, chietly at lower levels: partially resident west of the Cascaules, and casually resident on the East-side.

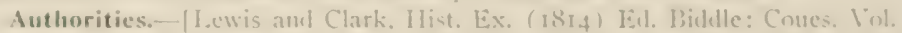

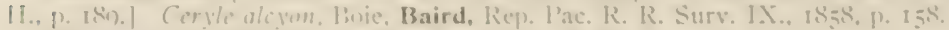

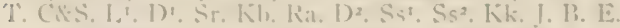

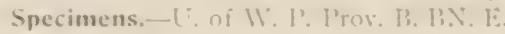


IIHEN we were small boys and had successfully teased our fathers or big brothers to let us go fishing with them, we were repeatedly admonished not to "holler" for fear of scaring the. fish. 'T'his gratuitous and frequently emphatic advice would have been discredited if the example of the Kingfisher had been followed. Either because noise doesn't matter to fish, or because he is moved by the same generous impulse which prompts the cougar to give fair and frightful warning of his presence at the beginning of an intended foray, the bird makes a dreadful racket as lie moves

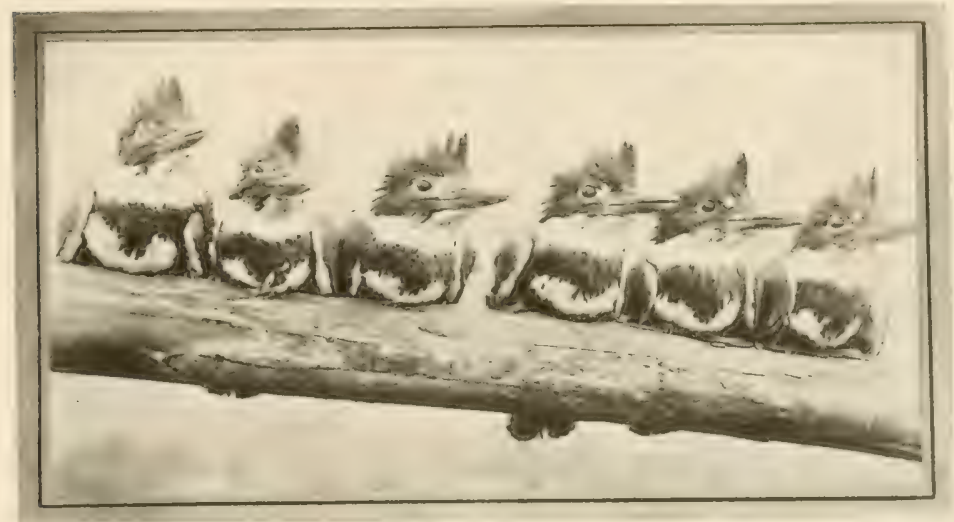

Taten near Portland

thoto by \&. H'. Anthony.

THE KI:C RO R

up stream and settles mpon his favorite perch, a bare branch overlooking a quiet pool. Here, altho he waits long and patiently, he not infrepuently varies the monotony of incessant scrutiny by breaking out with his weird rattle-like a watchman's call, some have saicl; but there is nothing metallic about it, only worlen. Again, when gane is sighterl, he rattles with excitement before he makes a plunge; and when lie bursts out of the water with a wriggling minnow in his heak, he clatters in high glee. If, as rarely happens, the bird misses the stroke, the sputtering notes which follow speak plainly of disgust, and we are glad for the moment that Kingfisher talk is not exactly translatable.

It is not quite clear whether the bird usually seizes or spears its prey, aitho it is certain that it sometimes does the latter. The story is told of 


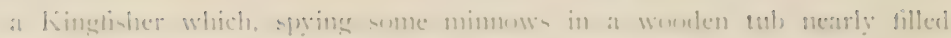

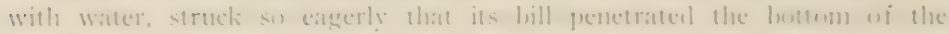

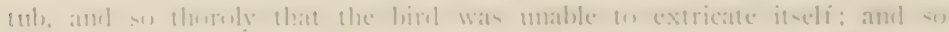

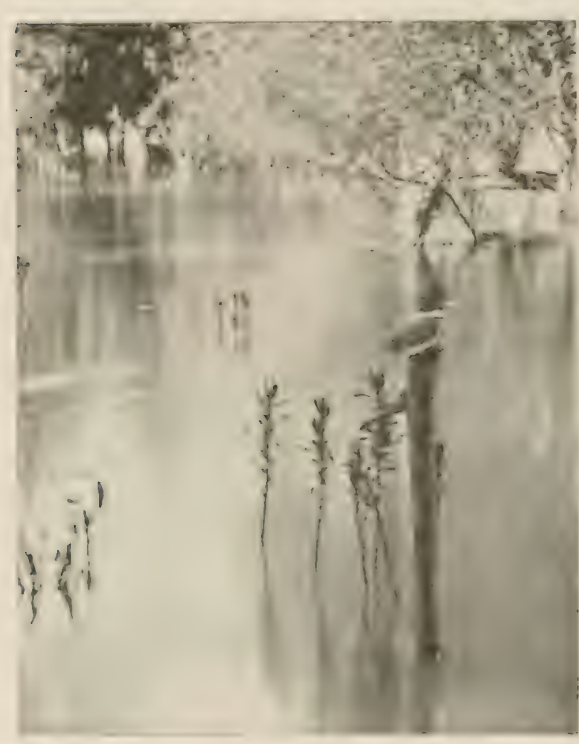

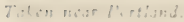

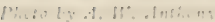

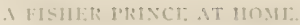
diecl-ar deatli almost as ingumimus at that wi the linger whe was drownerl in at lutt wi Malmsey wine.

Illen a finls in takion the

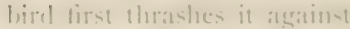
its perch to make sure it is deatrl. and thess swallows it inearl firrenteris. li the fish is at latrece onse its catptom witen finds it necessary (1) sou thare the mose rielionlune comturtions, gasysines, writhing- chokings. regurgitatims, and renewerl attempts. in oreley to encomprass its sate delisery within.

kingfislects hate the reputatton of hemes vere unsocial lirels . lpart from their timily life. which is irlyllice this reputation is well smitatinet. (ionsl tishing is sol saree that the hircls clecem it best on purtion wh the eerritury with others of their 1mwn kind, and they are vers punctilions about the observance of hemblaries asm allotments. For the

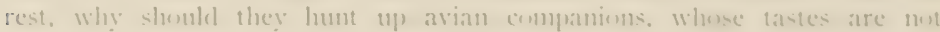

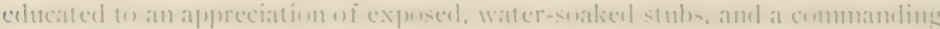

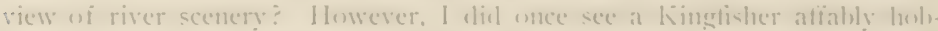

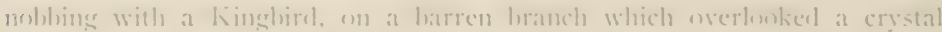
stream in Jdahos. I wombler if they recognized a mutual kimeliness. this fumble fisherman and this petulamt latwk-triver:

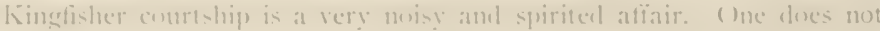
know just how mane miles up and demas stream it is comsidered proper for the gallant wo pursue hic enamurata lefore she vielels a coy aceeptance: and

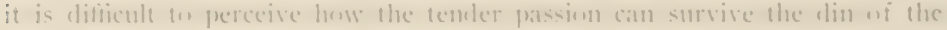


actual proposal, where both vociferate in wooden concert to a distracted workl. But la! love is mighty and doth mightily prevail.

The nesting tumel is driven laterally into the face of a steep bank, preferably of sand or loam, usually directly over the water, but occasionally at a considerable distance from it. Dr. Brewer reports one in a gravel pit at least a mile from water. The birds are not so particular as are the Bank Swallows about digging near the top of the lank, but. especially if the bank is small, usually select a point about midway. The tumel goes straight in or turns shary)ly to suit an occasional whim, until a convenient deptl, say five or six feet, is reached, when a considerable enlargement is made for the nest clamber. Here, early in May, six or seven white eggs are laid, usually upon the bare earth, but sometimes upon a lining of grass, straw and trash. From time to time the bircls eject pellets containing fisl scales, the broken testre of crawfisly and other indigestible substances and these are added to the accumulating nest material. Sanitary regulations are not very strict in Kingfisher's hone, and by the time the yoming are ready to fly we comld not blame them for being glad to get away. The female is a proverbially close sitter, often permitting herself to be taken with the lrand. lont not montil after she has made a vigorous defense with her sharp beak. If a stick he introduced into the nest she will sometimes

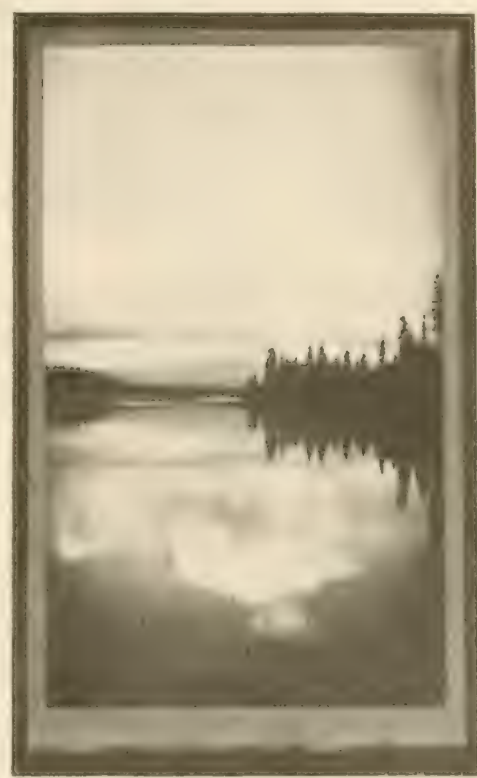

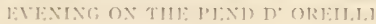
seize it so tightly that she can be lifted from the egess, turtle fashion.

The parents are very busy bircls after the young have broken shell, and it takes many a cuintal of fish to prepare six, or mavbe seven, lusty fisher princes for the battle of life. It this season the birels hunt and wait upon their young principaliy at night, in oreler not to attract hostile attention to them by dayliglut risits. Only one lonoxl is ratised in a season, and since fishing is mupuestionably at fine art, the youngsters require constant supervision and instruction for several montls. A troop 


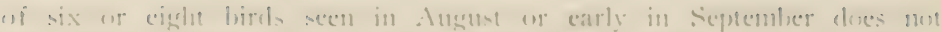
mean that kinglisher is indulging in mil-eummer gatitice with his follows. lut only that the iamily group of that seamen has not vet heen hroken up.

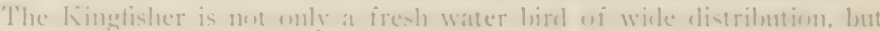

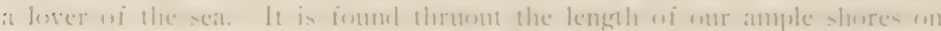

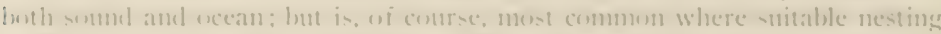

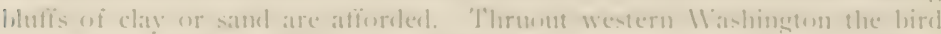
is largely resiflent, and if this very stable species ever doe begin th shom varation, it will lee in the l'acilic Northwest. 







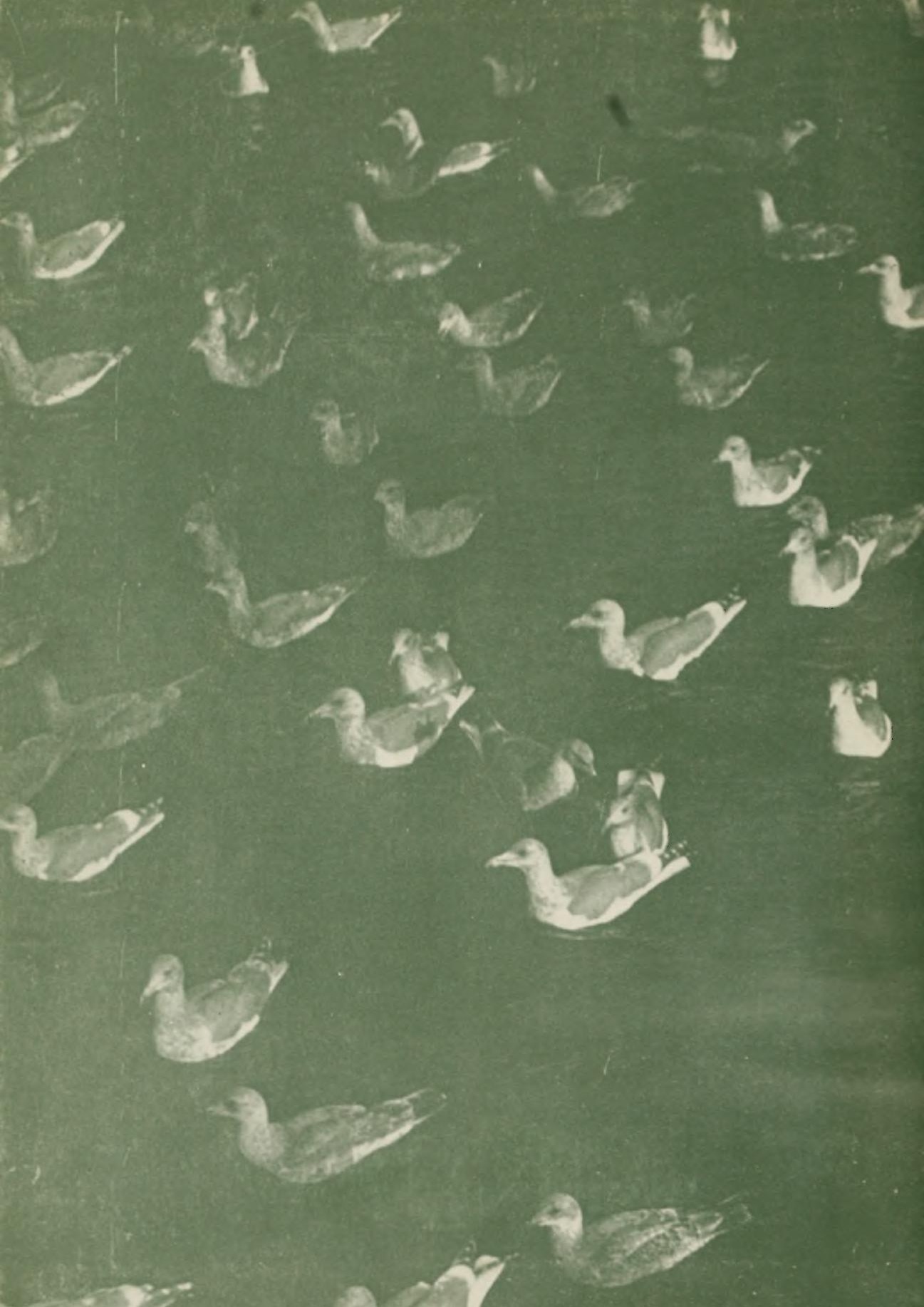




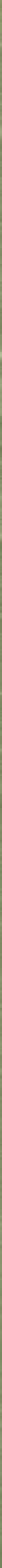

t 
